UNIVERSIDADE DE SÃO PAULO

FACULDADE DE FILOSOFIA, LETRAS E CIÊNCIAS HUMANAS DEPARTAMENTO DE LETRAS CLÁSSICAS E VERNÁCULAS PROGRAMA DE PÓS-GRADUAÇÃO EM FILOLOGIA E LÍNGUA PORTUGUESA

RENATA FERREIRA MUNHOZ

Correspondência oficial para o Morgado de Mateus: Transcrição semidiplomática do Livro № 170 do AESP (de 1767 a 1775)

SÃO PAULO

2009 


\section{UNIVERSIDADE DE SÃO PAULO}

FACULDADE DE FILOSOFIA, LETRAS E CIÊNCIAS HUMANAS

DEPARTAMENTO DE LETRAS CLÁSSICAS E VERNÁCULAS

PROGRAMA DE PÓS-GRADUAÇÃO EM FILOLOGIA E LÍNGUA

PORTUGUESA

Correspondência oficial para o Morgado de Mateus: Transcrição

semidiplomática do Livro № 170 do AESP (de 1767 a 1775)

Renata Ferreira Munhoz

Dissertação apresentada ao Programa de Pós-

Graduação em Filologia e Língua Portuguesa do

Departamento de Letras Clássicas e Vernáculas da

Faculdade de Filosofia, Letras e Ciências Humanas da

Universidade de São Paulo, para a obtenção do título de Mestre em Letras.

Orientador: Prof. Dr. Sílvio de Almeida Toledo Neto

SÃO PAULO

2009 
DEDICATÓRIA

A minha família, pelo apoio recebido em todas as fases de minha vida. 


\section{AGRADECIMENTOS}

Primeiramente agradeço a Jesus, o Mestre dos mestres, por auxiliar-me em mais uma conquista nesta existência.

Agradeço a todos que contribuíram para que este trabalho pudesse ser realizado.

De modo especial, agradeço:

Ao Prof. Sílvio de Almeida Toledo Neto, meu orientador, pelo apoio, atenção e paciência durante todas as etapas dessa dissertação.

Aos Profs. Manoel Mourivaldo Santiago Almeida e Marcelo Modolo pela participação na banca de qualificação, seus comentários e importantes sugestões.

Ao Professor Heitor Megale, por apresentar-me a Filologia.

À Professora Heloísa Liberalli Bellotto, por todas as úteis instruções a este trabalho.

À Paula Held Lombardi Araújo, por toda a ajuda e amizade.

À Solange Aparecida Malengo, pelas pacientes coordenadas da Língua Portuguesa.

A meu pai, Francisco Lopes Munhoz, pelo apoio incondicional e constante ajuda na tomada de decisões. A minha mãe, Denise Farto Ferreira Munhoz, pela fortaleza que me auxilia a superar barreiras. À Fernanda Ferreira Munhoz, irmã de todas as horas.

A meus avós, Nilse Farto Ferreira e José Ferreira de Almeida, pelo exemplo de conduta.

Às grandes amigas e conselheiras, Deise Farto Ferreira e Fabiana Sereno.

Ao Fábio Bueno Retta, meu noivo, pelo companheirismo e compreensão. 


\section{RESUMO}

Este trabalho apresenta a edição semidiplomática de 68 documentos manuscritos da segunda metade do século XVIII, entre os anos de $1767 \mathrm{e}$ 1775, referentes ao período de governo de Dom Luís Antonio de Sousa Botelho Mourão como Capitão General da Capitania de São Paulo. O conjunto desses documentos, originalmente avulsos, encontra-se reunido em um livro manuscrito de número 170 no Arquivo do Estado de São Paulo (AESP).

A fim de melhor estudar tal livro manuscrito, esse trabalho compõe-se de um capítulo acerca da descrição codicológica e paleográfica, seguido da classificação das espécies documentais existentes no corpus transcrito. Além de um capítulo sobre o momento histórico em que foram executados os documentos.

Após os capítulos de análise do corpus, há o núcleo do trabalho: a transcrição semidiplomática e justalinear face a face com a reprodução facsimilar de cada fólio dos documentos. No livro manuscrito há também páginas impressas, que foram anexadas após as transcrições, embora não façam parte do presente estudo. Uma vez que os documentos aqui publicados encontravam-se inéditos, a sua divulgação certamente contribuirá para os estudos filológicos, linguísticos e históricos da época.

Palavras-chaves: Filologia; Documentos manuscritos; Codicologia; Paleografia; Diplomática. 


\begin{abstract}
This essay presents the facsimilar copies and the semi diplomatic editions of 68 manuscripts from the second half of the eighteenth century, between the years 1767 and 1775, during the government of the General Captain of the São Paulo Captaincy, Dom Luis Antonio de Sousa Botelho Mourão. This corpus was selected in the "Arquivo do Estado de São Paulo" (AESP) and all of the documents are covered in the manuscript book number 170, where they follow the same order as presented here.

In order to study the manuscript book, this work is composed by a chapter about Codicology and Palaeography of the studied documents, followed by the classifications of the documental species of the corpus. Before the transcriptions, there is a chapter about the historical moment in which the documents were executed.

The transcription of the handwriting part of the codex is semi diplomatic, line by line and face to face with the respective facsimilar reproduction of each manuscript. There are also printed documents in the manuscript book, which were attached to this work, though they are not the object of study. Since the documents are not yet published, their divulgation can certainly contribute to the philological, linguistic and historical studies.
\end{abstract}

Keywords: Philology; Manuscript documents; Codicology; Palaeography; Diplomatic.

\title{
E-mail: renatamunhoz2000@yahoo.com.br
}




\section{LISTA DE ILUSTRAÇÕES}

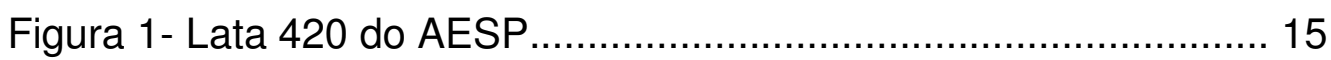

Figura 2- Livro fechado (capa)...................................................... 15

Figura 3- Primeira página do livro manuscrito....................................... 15

Figura 4- Lombada do livro manuscrito ............................................ 16

Figura 5- Livro número 170 aberto ………………......................... 17

Figura 6- Exemplo de página impressa ........................................... 18

Figura 7- Exemplo de documento manuscrito ................................... 19

Figura 8- Reprodução de marca d'água ….................................... 20

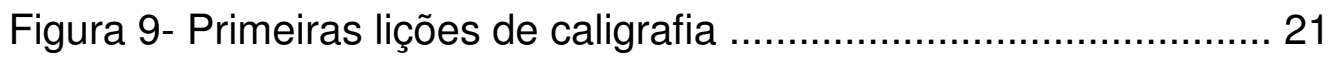

Figura 10- Página sobre exercício e louvor das letras ....................... 21

Figura 11- Exemplo da caligrafia de D. Luís....................................... 24

Figura 12- Diário de viagem de D. Luís .......................................... 27

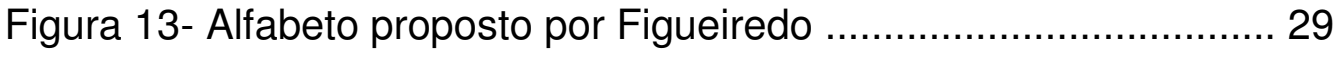

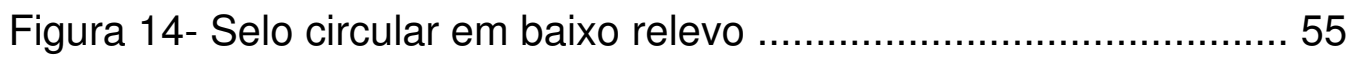

Figura 15- Selo moldado em cera vermelha …………………….......55

Figura 16- Assinatura comum a grande parte dos documentos............ 56

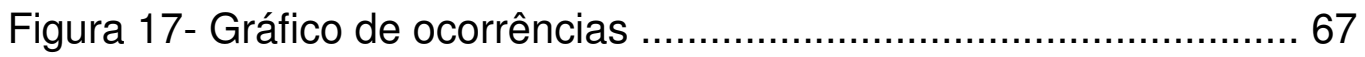

Figura 18- O termo "está conforme", seguido da assinatura ................. 73

Figura 19- Estado político da Capitania de São Paulo em 1766 ............ 76

Figura 20- Leituras Cartográficas, Históricas e Contemporâneas ......... 77

Figura 21- Convento do Carmo......................................................78

Figura 22- Brasão da Casa de Mateus ............................................... 80

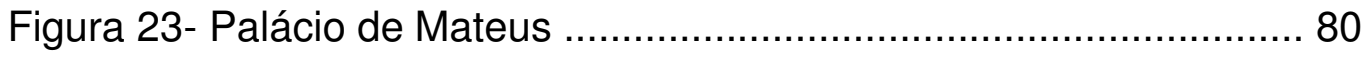

Figura 24- Retrato do Morgado de Mateus........................................... 80 
Figura 25- Morgado de Mateus, em Menezes.................................... 82

Figura 26- Página impressa de Figueiredo, sobre a escrita................. 492 


\section{LISTA DE QUADROS}

Quadro 1- Ocorrências de letras maiúsculas do punho 1........................30

Quadro 2- Ocorrências de letras minúsculas do punho 1 ......................... 33

Quadro 3- Ocorrências de letras maiúsculas do punho 2........................35

Quadro 4- Ocorrências de letras minúsculas do punho 2 .........................37

Quadro 5- Ocorrências de letras maiúsculas do punho 3........................40

Quadro 6- Ocorrências de letras minúsculas do punho 3........................42

Quadro 7- Ocorrências de letras maiúsculas do punho 4 ........................ 46

Quadro 8- Ocorrências de letras minúsculas do punho 4 .........................48

Quadro 9- Quadro sinóptico dos documentos manuscritos....................... 68

Quadro 10- Verbetes sinóptico dos documentos impressos....................494 


\section{SUMÁRIO}

1. Introdução 12

2. Capítulo 1: DESCRIÇÃO CODICOLÓGICA E PALEOGRÁFICA DO LIVRO № 170 DO AESP. 14

2.1. Descrição codicológica.................................................................14

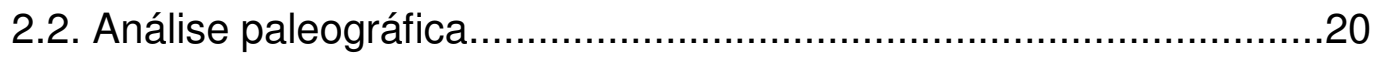

2.3. Em busca da identidade dos punhos...........................................23

3. Capítulo 2: DESCRIÇÃO DIPLOMÁTICA: IDENTIFICAÇÃO DAS ESPÉCIES

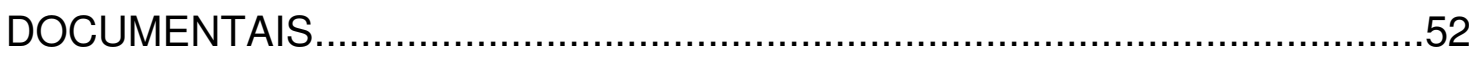

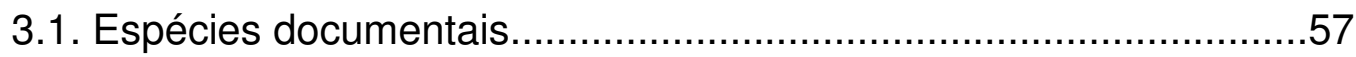

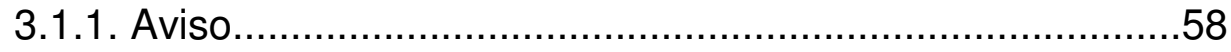

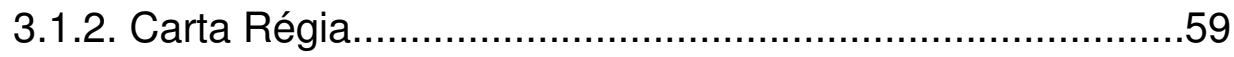

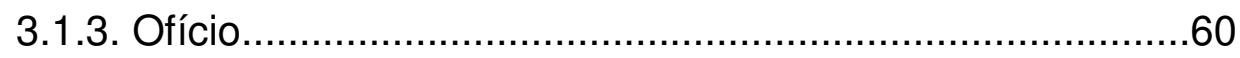

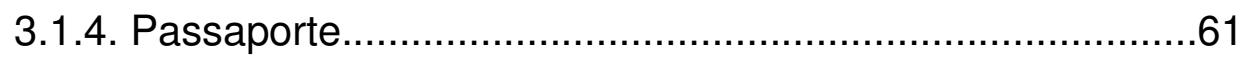

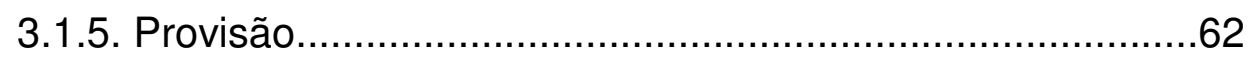

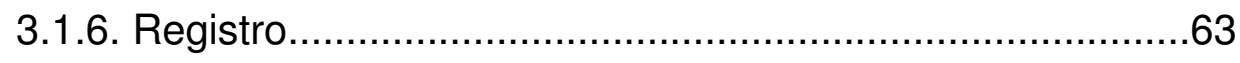

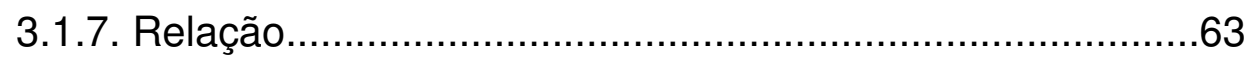

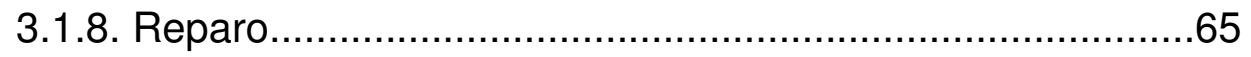

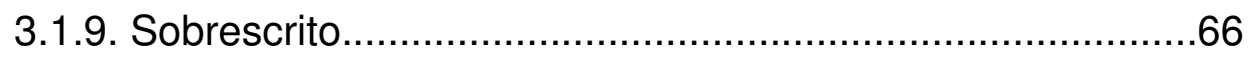

3.2. Documentos manuscritos..........................................................67

4. Capítulo 3: O MORGADO DE MATEUS: UM BREVE PERFIL BIOGRÁFICO. .74

5. Capítulo 4: TRANSCRIÇÃO SEMIDIPLOMÁTICA DO LIVRO № 170 DO

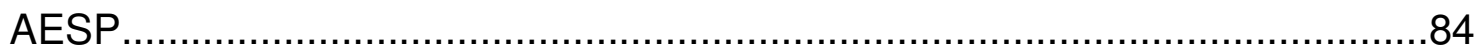

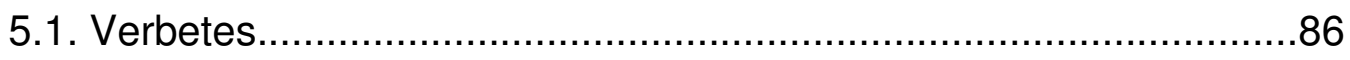


5.2. Edição fac-similar e semidiplomática justalinear.............................99

Edições semidiplomáticas (página de inclusão)........................100

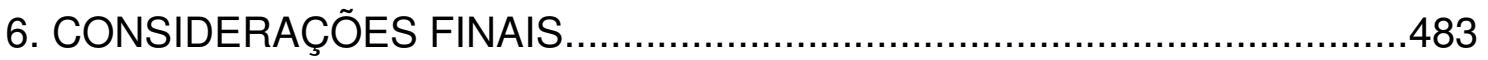

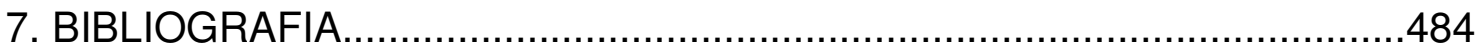

8. ANEXO: textos impressos contidos no livro no 170 do AESP......................491

8.1. Leitura dos documentos impressos...............................................

8.2. Verbetes dos documentos impressos..........................................493 


\section{INTRODUÇÃO}

Neste trabalho, apresenta-se a edição semidiplomática de 68 documentos setecentistas referentes ao governo de Dom Luís Antonio de Sousa Botelho Mourão, o Morgado de Mateus, que atuou como Capitão General da Capitania de São Paulo no período de 1765 a 1775. Embora seu governo tenha durado dez anos, o corpus aqui estudado apresenta documentos datados do período de 1767 a 1775.

Os documentos do século XVIII que compõem o corpus deste trabalho contam 191 páginas manuscritas intercaladas de forma aleatória com outras 111 em branco, totalizando 302 páginas ou 151 fólios. Este corpus foi selecionado no Arquivo do Estado de São Paulo e se encontra encadernado no Livro número 170, na mesma ordem em que os documentos são aqui apresentados.

Com o objetivo de contribuir com o estudo linguístico e filológico de documentos manuscritos lavrados na segunda metade do século XVIII, referentes à capitania de São Paulo, esse trabalho tem o intuito de, por meio do recorte sincrônico estabelecido pelo corpus, franquear acesso a textos da época em transcrição conservadora. Por preservar as características gráficas do período e facilitar a leitura a partir do desenvolvimento das abreviaturas, esta edição semidiplomática permite a um maior número de interessados e estudiosos a consulta direta a fontes primárias por vezes de difícil acesso e decifração.

Por serem os documentos manuscritos, segundo Silva (1989, p. 41), fiéis "informantes" para a depreensão de dados linguísticos e culturais de um determinado período, a publicação do presente corpus pode contribuir com estudos mais detalhados sobre a evolução da Língua Portuguesa no Brasil. Assim, a importante tarefa da Filologia, que visa à preservação de manuscritos originais ou em cópias por meio de sua edição filologicamente cuidada, é aqui empregada, uma vez que o objetivo central desta dissertação é, como já se referiu, a edição semidiplomática dos manuscritos selecionados que podem preencher possíveis lacunas nos estudos referentes ao estado da língua no século XVIII. 
Desta forma, este trabalho também abre espaço para futuros estudos de cunho histórico, visto que "[...] era em forma de correspondência que chegavam [a D. Luís] a legislação e as disposições da Coroa." (BELLOTTO, 2007b, p. 14).

Além disso, deve ser evidenciado o fato de os documentos aqui em exame não se encontrarem até o presente integralmente editados nem publicados: "O núcleo fundamental dessa correspondência acha-se no Arquivo do Estado de São Paulo, [...] com códices não publicados relativos a "Avisos e Cartas Régias" e a "Provisões Régias". (BELLOTTO, 2007b, p. 14)

Com o objetivo de melhor estudar o corpus deste trabalho, o Capítulo 1 apresenta a descrição codicológica, com abordagens sobre os aspectos materiais do livro manuscrito, e a análise paleográfica, com observações sobre a escrita dos principais manuscritos estudados. Contribuindo para uma melhor compreensão dos documentos, o Capítulo 2 traz a descrição diplomática das espécies documentais contidas no livro manuscrito e identifica cada manuscrito, apresentando quadro sinóptico acerca dos 68 documentos. Após identificar os aspectos anteriormente citados, o Capítulo 3 apresenta comentários sobre o período histórico de que tratam os manuscritos. $O$ Capítulo 4 traz as normas de transcrição, os verbetes explicativos e a transcrição semidiplomática das 191 páginas manuscritas. Há, após as Conclusões Finais e a Bibliografia, um Anexo, com a apresentação de todas as páginas impressas que se encontram encadernadas no livro manuscrito estudado junto aos manuscritos. 


\section{Capítulo 1: DESCRIÇÃO CODICOLÓGICA E PALEOGRÁFICA DO LIVRO № 170 DO AESP}

Este capítulo pretende descrever, embora não de forma exaustiva, aspectos codicológicos e paleográficos do corpus aqui estudado. Essa descrição contribui diretamente para compreender melhor a estrutura do livro manuscrito estudado, por ser a ciência da Codicologia responsável por examinar "a técnica do livro manuscrito" (CAMBRAIA, 2005, p. 26). A Paleografia, por sua vez, também segundo Cambraia (2005, p. 23), pode ser definida como o estudo das escritas antigas que visa a capacitar os leitores modernos a interpretarem adequadamente as escritas do passado. Encontrando-se todo o corpus desse trabalho encadernado em um livro manuscrito, torna-se válida a análise de aspectos codicológicos, enquanto a análise paleográfica justifica-se por serem manuscritos os documentos a seguir editados.

\subsection{Descrição codicológica}

Inicia-se a descrição codicológica com os aspectos materiais mais relevantes do livro identificado pela cota número 170 do AESP. Cabe mencionar que o livro em que todo o corpus está contido, fica guardado juntamente com o de número 169 na lata de referência 420, intitulada "Avisos e Cartas Régias", disponível no Arquivo do Estado de São Paulo. Não há referência explícita à data de encadernação do livro manuscrito, mas é possível deduzir que os fólios tenham sido encadernados após a última data cronológica encontrada no documento $34,12 / 05 / 1775$, uma vez que este documento não se encontra como o último da ordem. Quanto ao lugar de origem, pode-se inferir por hipótese que tenha sido a própria Capitania de São Paulo, porque os documentos encontram-se chancelados por D. Luís e datados no período de seu governo.

Apresentam-se, a seguir, ilustrações da lata onde está o livro manuscrito e da capa do livro. 


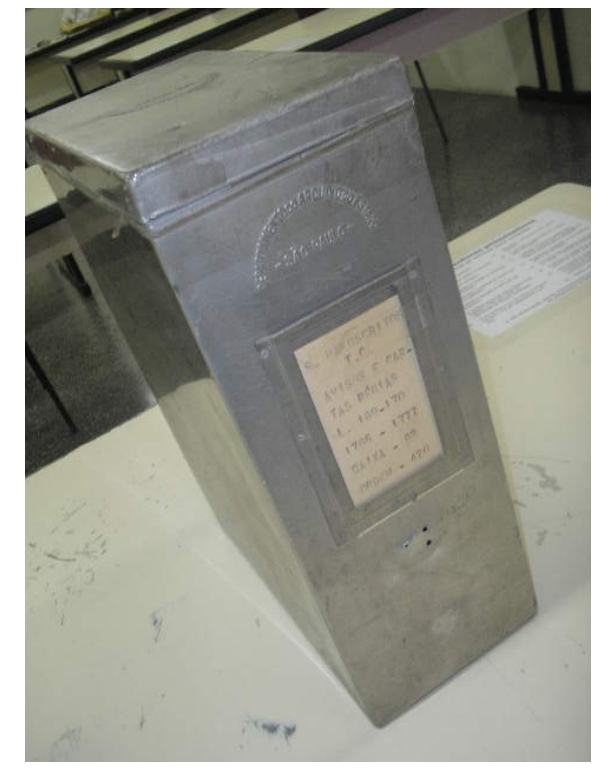

Figura 1: Lata 420 do AESP.

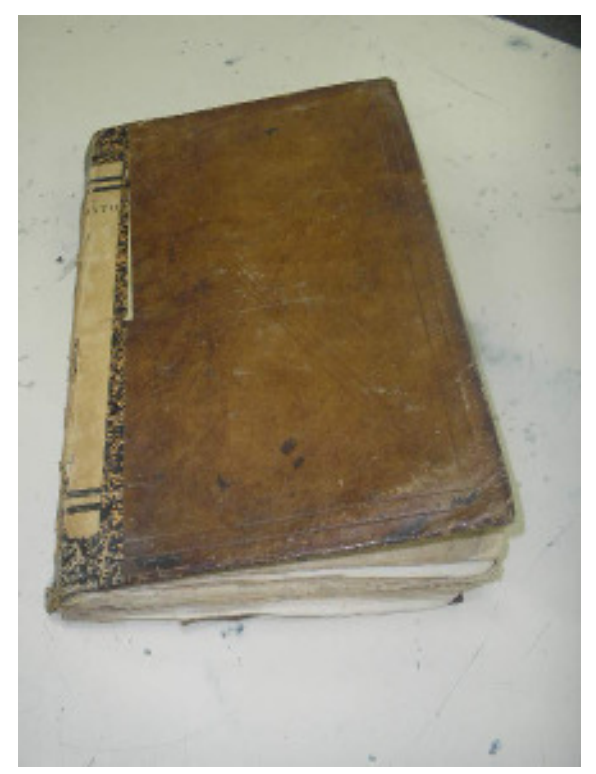

Figura 2: Livro fechado (capa).

Seguindo-se os itens propostos no Guia Básico de Descrição Codicológica de Cambraia (2005, p. 28), pode-se dizer inicialmente que o livro manuscrito em análise não possui folha de rosto, apresentando na primeira página o documento manuscrito número 1 , segundo nossa classificação. É possível, verificar que o livro manuscrito é composto por cadernos com quantidade de bifólios variáveis, de dois a quatro, com costura bastante resistente.

Na figura abaixo, pode-se ver a costura que une os cadernos.

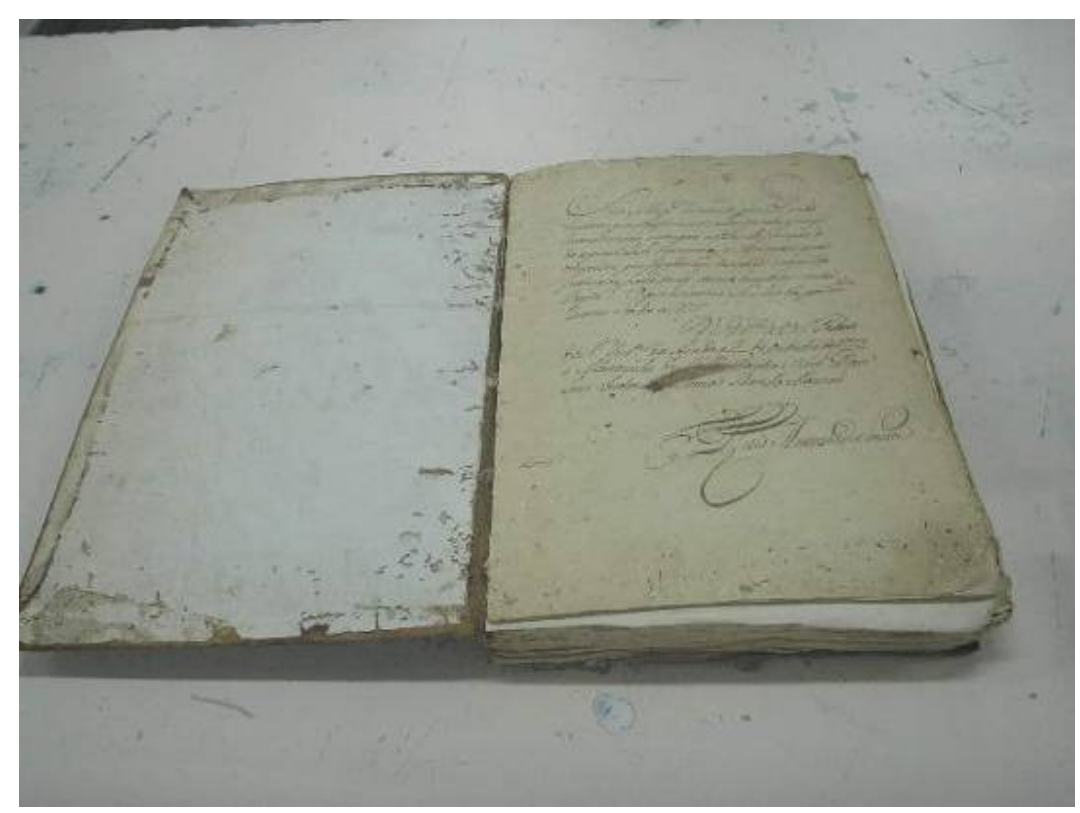

Figura 3: Primeira página do livro manuscrito. 
Por se tratar de encadernação que parece visar unicamente à organização de documentos anteriormente avulsos, não há colofão (inscrição que pode estar no fim ou início do livro e que contém a informação sobre título, autor, editor, gráfico, tipografia, local e data de impressão, por exemplo). Assim, a única referência encontrada diz respeito apenas ao arquivamento no próprio AESP e se localiza na lombada, de $3,5 \mathrm{~cm}$ de largura e $34 \mathrm{~cm}$ de altura, com os dizeres "Arquivo do Estado de São Paulo" impressos e o número 420 escrito à mão. É o que se vê na figura seguinte.

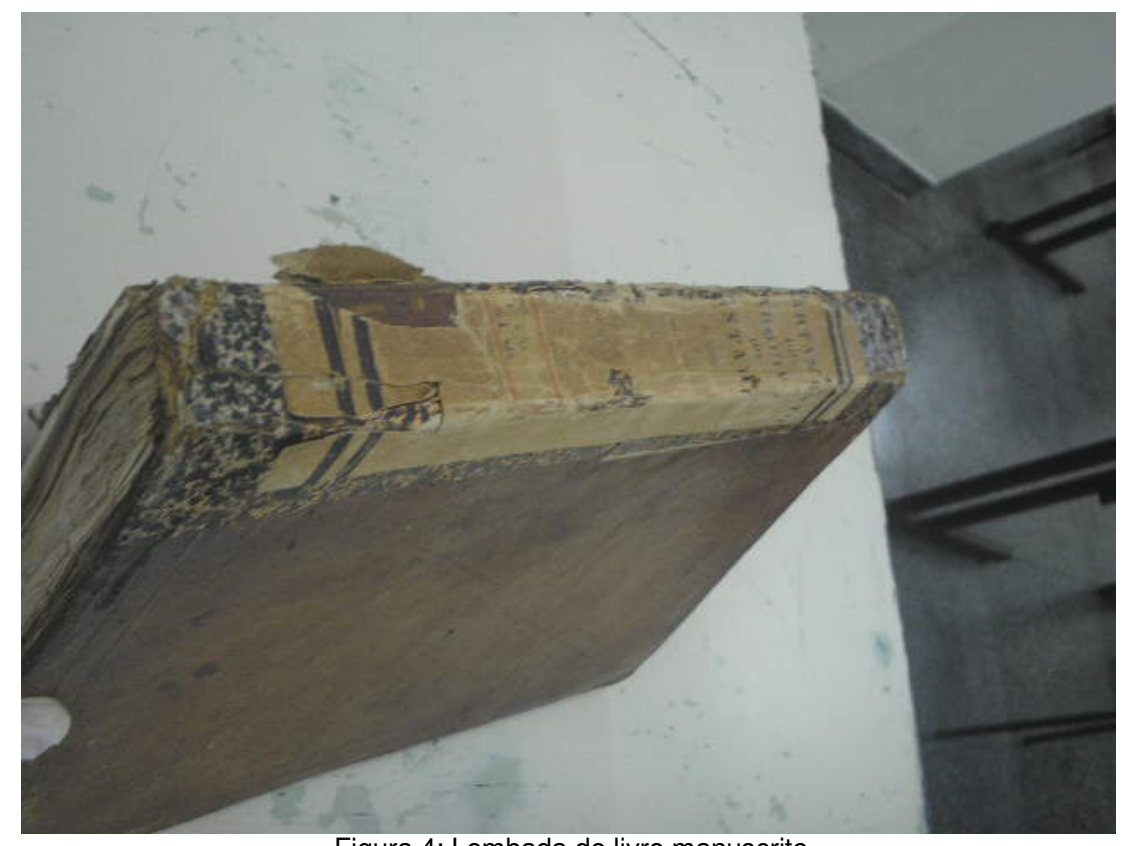

Figura 4: Lombada do livro manuscrito.

O livro manuscrito possui, além dos 191 fólios manuscritos, outros 66 fólios impressos com medida menor, de $21 \mathrm{~cm}$ de largura por $31 \mathrm{~cm}$ de altura, todos inseridos de forma aparentemente aleatória (conforme indicado no anexo). A encadernação compõe-se de capa feita em couro gofrado (couro trabalhado pelo processo de gofragem, que consiste em demarcar um relevo), a qual é melhor visualizada nas figuras 2 e 3 .

Quanto às medidas, o livro manuscrito possui $22 \mathrm{~cm}$ de largura e $34 \mathrm{~cm}$ de altura, seguindo o tamanho dos fólios manuscritos. Menciona Acioli (1994, p. 55) que as páginas manuscritas, normalmente, têm diversas larguras, mas elas são delimitadas muito uniformemente, dando uma fisionomia agradável à composição, o que é corroborado pelo livro em estudo, conforme ilustra a figura 5. 


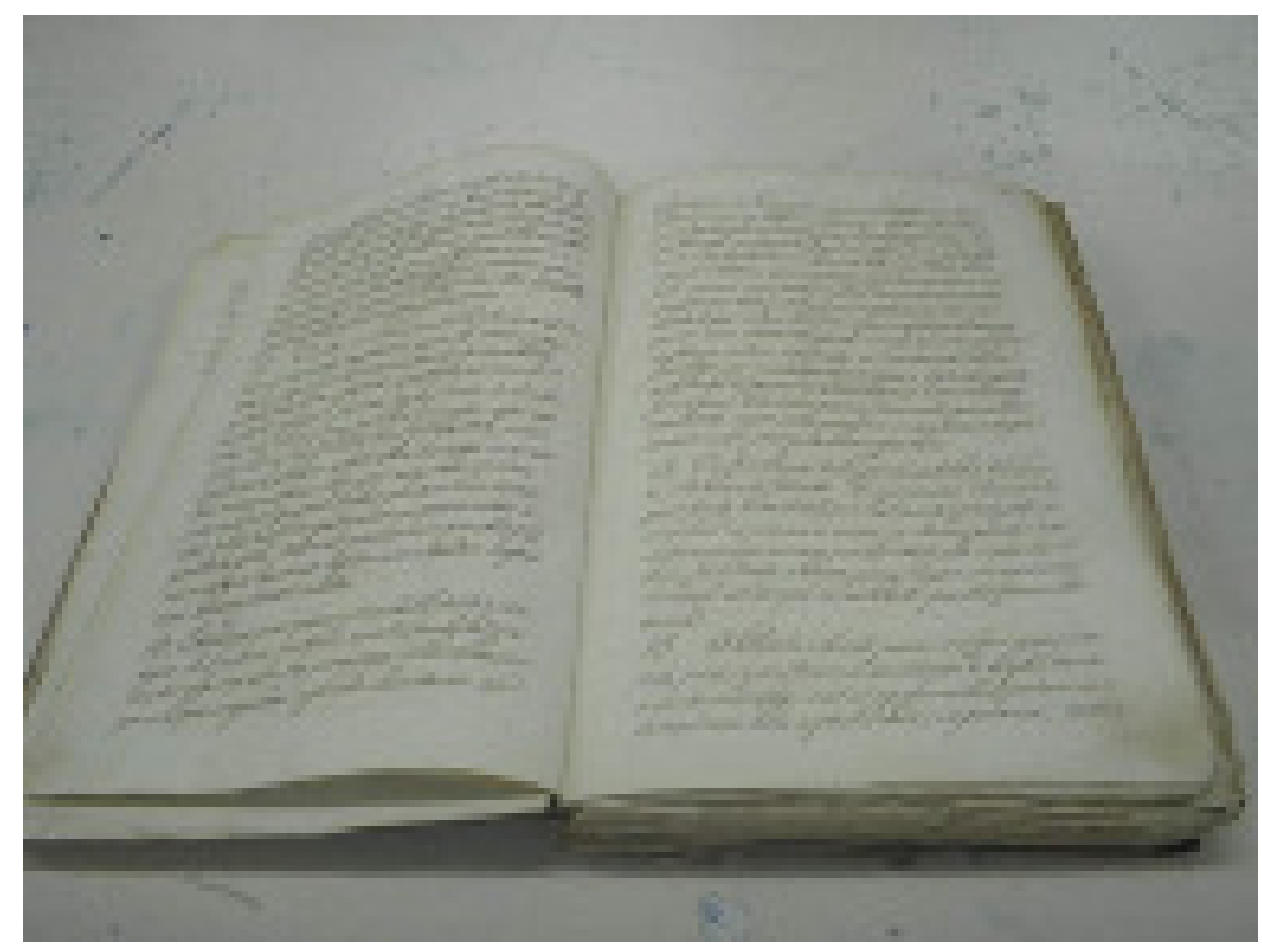

Figura 5: Livro número 170 aberto.

Os fólios impressos inseridos entre os manuscritos apresentam papel branco e mais fino que o dos manuscritos, semelhante ao papel de seda, e com tinta preta. Segundo o Departamento de Preservação do Arquivo do Estado de São Paulo, tanto os documentos manuscritos quanto os impressos empregam por suporte o papel de trapo. Conforme Melo (1926, p.16), a pasta de trapo foi o primeiro material usado para a fabricação do papel, sendo os trapos retirados de tecidos já usados, submetidos a um processo de maceração ou de fermentação com água e lixívia de potassa em recipientes de pedra. Tal processo durava de cinco a trinta dias até que os trapos pudessem ser desfibrados.

A diferença do estado de preservação pode ser consequência das diferentes grossuras dos papéis e possivelmente às condições de conservação. Embora esse livro esteja atualmente sob custódia do Arquivo do Estado, instituição de cultura tradicionalmente considerada responsável por sua preservação, não se sabe desde quando tais documentos estão encadernados em conjunto e onde estiveram arquivados anteriormente, pois, conforme lembra Acioli (1994, p. 15), "Arquivo morto, no Brasil, é sinônimo de porão, onde os documentos são jogados sem qualquer tratamento técnico." Abaixo, um exemplo de documento impresso. 


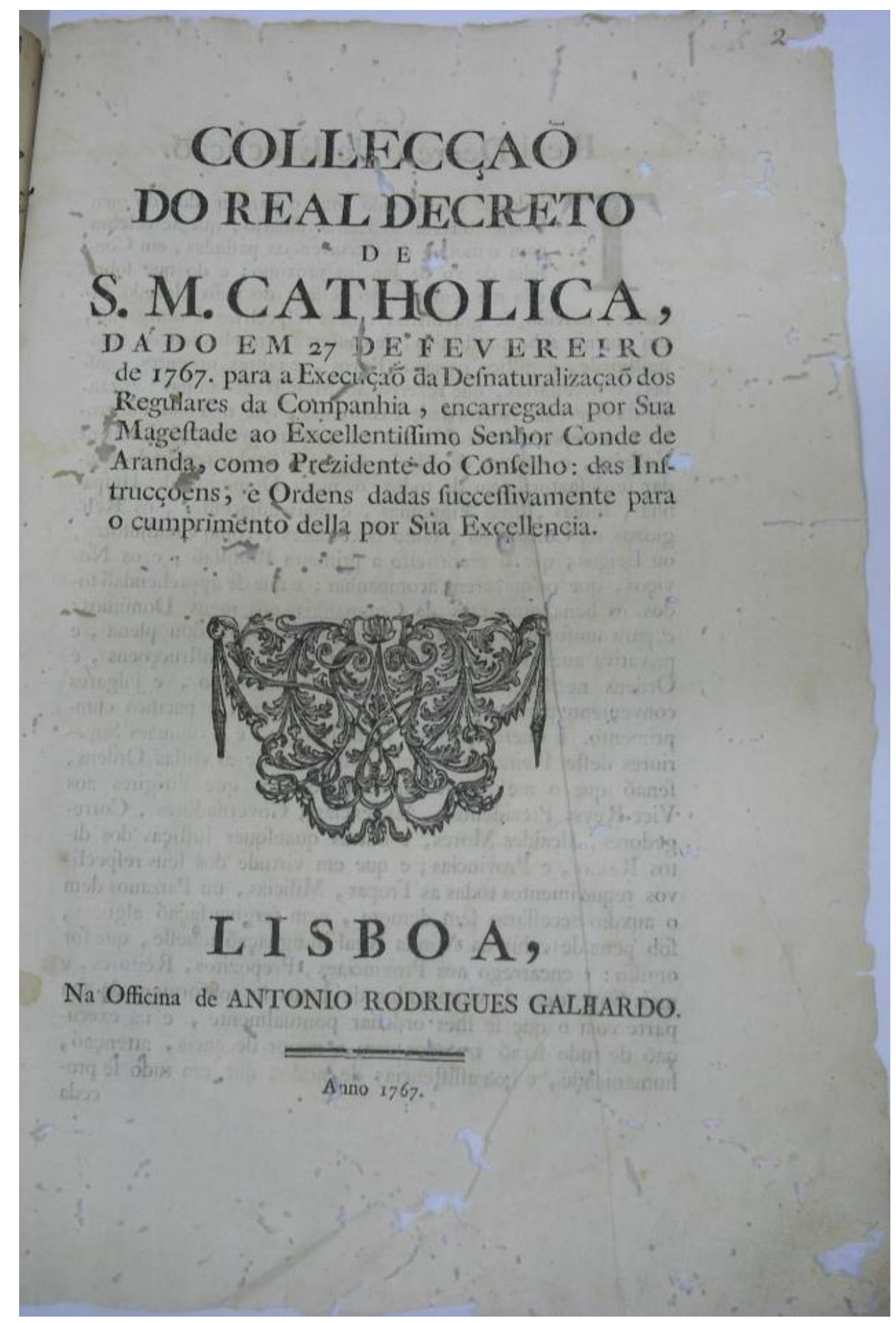

Figura 6: Exemplo de página impressa (Primeira página do anexo).

Os fólios manuscritos editados no capítulo 4 deste trabalho, encontramse bem conservados. Possuem suporte material cartáceo de trapo que se caracteriza como papel pardo, grosso, amarelado e resistente. Quanto à disposição do texto, os manuscritos estão organizados de forma regular: todos com a mancha em tamanho semelhante, seguindo medidas proporcionais de margens. É o que se vê na figura 7. 


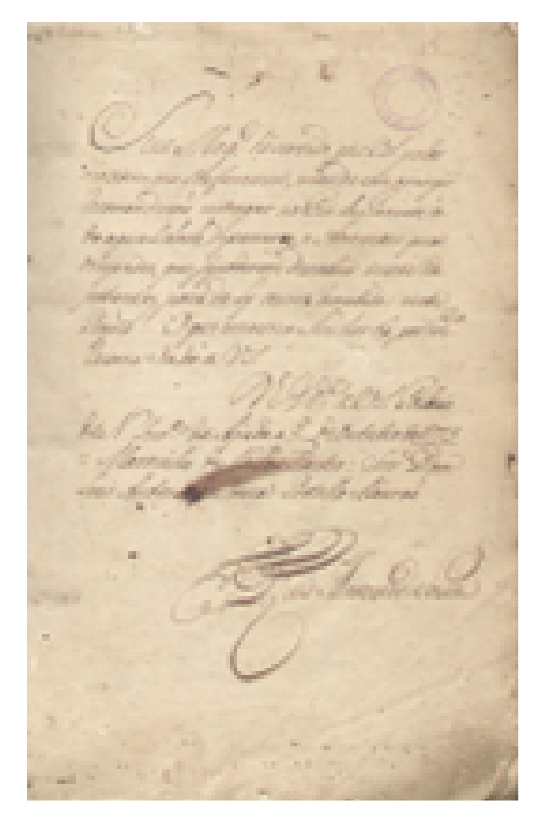

Figura 7: Exemplo de documento manuscrito (Doc. 1).

Percebe-se o mesmo em respeito à pauta e às margens, o que caracteriza um texto cuidadosamente elaborado.

Quanto à questão da fabricação do papel, pode-se dizer que, segundo Melo (1926, p. 11), os papéis eram produzidos em uma espécie de tear, cujo fundo era composto de numerosos fios metálicos que constituíam o tear das formas, marcavam o papel por linhas de água verticais e horizontais, respectivamente designadas por pontusais e vergaturas. Tal estrutura era coberta por um plano móvel de madeira, ficando entre eles apenas o suficiente para a espessura da folha de papel. Tal conjunto era submerso em uma espécie de tina com a pasta do papel e sujeitava-se à compressão. A seguir, retirava-se da vasilha e a pasta que secava era o papel que se endurecia com cola. Os espaços formados pelos fios metálicos eram as "raias". Alguns fios metálicos, na fieira em que era inserida a pasta, formavam um desenho intencional, com nome ou monograma, cuja impressão sobre o papel resultava na marca d'água. A importância das marcas d'água é a de representarem a identidade do papel, permitindo muitas vezes identificar a data e origem de muitos documentos antigos. A marca d'água encontrada nos manuscritos é a com brasão e inscrição da $D$ \& C Blauw, uma empresa holandesa que produziu o papel em amplo uso na Europa na segunda metade do século XVIII e, de acordo com Pires (1997, p. 32), está entre os principais papeleiros estrangeiros em Portugal da época, concorrendo com, por exemplo, Howned \& Zoonen, G. 
Magnani, Gattegasca e Vigo Giuseppe e os nacionais Góes, Louzã; Porto de Mós, Abelheira, Prado e Porta de Cavaleiros.

Nas figuras a seguir, pode-se ver uma cópia fac-similar de uma marca d'água e sua reprodução.

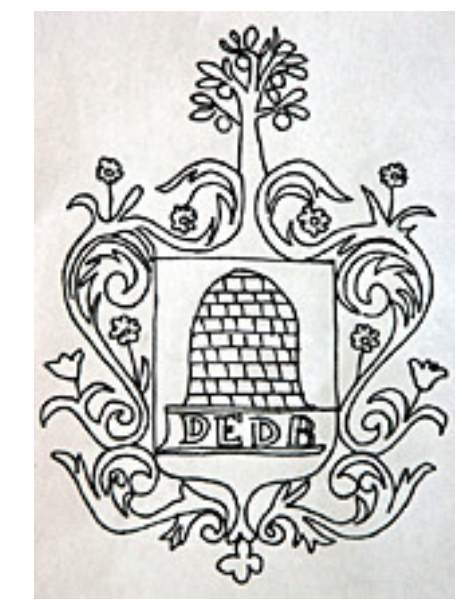

Figura 8: Reprodução de marca d'água'

\subsection{Análise paleográfica}

A análise paleográfica inicia-se com a menção de Higounet (2003, p.165), de que as escritas mecânicas não mataram as escritas manuscritas, embora as tenham feito retroceder. Com o passar do tempo, a tipografia eliminou-as do domínio do livro e, em parte, dos documentos oficiais. Esse recuo qualitativo foi compensado pelo crescimento constante do número de pessoas que passaram a servir-se da escrita. A partir do século $\mathrm{XVI}$, a rápida propagação da tipografia em substituição às caligrafias gótica e humanística acentuou a diminuição da escrita dos escribas e dos notários, inclusive em documentos. Com isso, a escrita gótica transformou-se mais e as abreviaturas já não serviam apenas para economizar o papel, menos caro e agora menos raro que o pergaminho, mas para permitir rapidez. Decorre desse aumento da produção escrita, uma das dificuldades de se estabelecerem regras que englobem a escrita do Brasil colonial, o que reforça o objetivo deste trabalho de facilitar o acesso aos documentos manuscritos do corpus.

Os documentos em análise têm caligrafia legível de mão hábil, ou seja, os copistas são conhecedores da língua e da caligrafia da época, pois a escrita

\footnotetext{
${ }^{1}$ A partir do site <http://www.forum-numismatica.com/viewtopic. php?f=32\&t=1521 >, com acesso em 20 mai, 2008.
} 
demonstra bastante habilidade. Apresentam escrita cursiva, que, de acordo com Acioli (1994, p. 13), caracteriza-se por letras corridas, traçadas de um só lance e sem descanso da mão, com palavras conectadas entre si por nexos ou ligações, o que dificulta o reconhecimento das fronteiras de palavras. $O$ emprego de caligrafia cursiva em documentos brasileiros é justificado por Acioli (1994, p. 55), que afirma ser a formação caligráfica dos colonos e colonizadores a mesma, sendo mais generalizado o uso da cursiva para a redação de documentos.

Como os manuscritos transcritos neste trabalho são bastante legíveis, pressupõe-se que todos os amanuenses responsáveis pelo trabalho de cópia ou redação dos documentos tenham sido profissionais ou, ao menos, tenham recebido um treinamento similar ao conhecido por meio de Figueiredo (1722), com interessantes páginas de exercícios para o bom desempenho da escrita. Apresentam-se, a seguir, a figura 10, com os primeiros exercícios a que um aluno que começava a aprender a escrever deveria ser submetido e a figura 11 com uma demonstração da habilidade manual possível a um calígrafo:

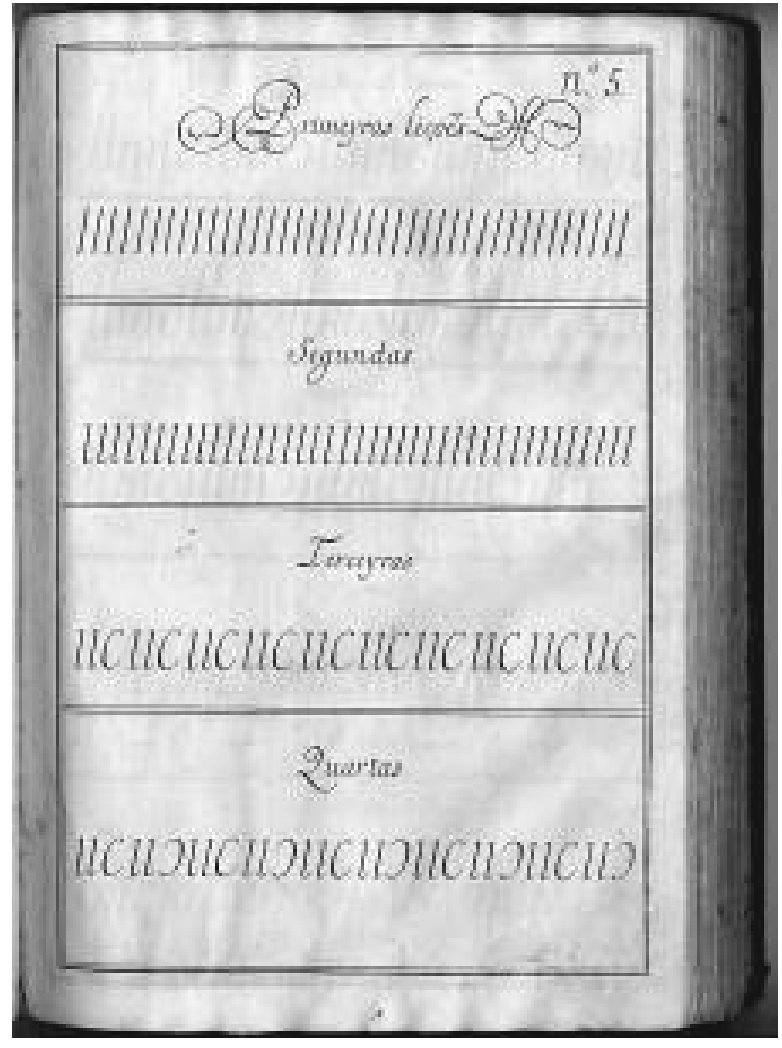

Figura 9: Primeiras lições de caligrafia.

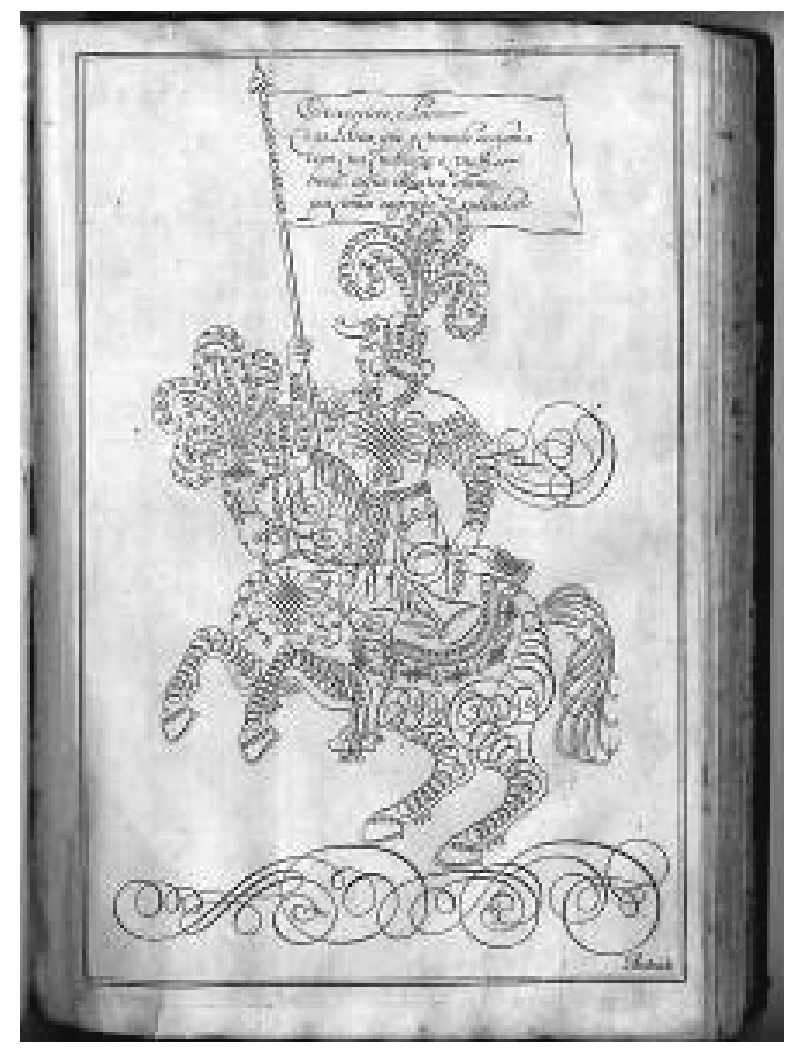

Figura 10: Página sobre "Exercício e louvor das Letras". 
O instrumento de escrita utilizado provavelmente tenha sido a pena de ave que, após ser colhida, deveria ser preparada, talhada e, segundo Santos (1994, p.33), deveria ser seca ao natural (o processo era muito lento, poderia levar de seis meses a um ano) ou artificialmente (consistia em levar as penas ao fogo ou remolhá-las, secá-las e enterrá-las em areia quente). A secagem concedia às penas uma dureza necessária à delicada ação que se seguia: 0 talhar. Com a pena nos primeiros dedos da mão esquerda e um canivete na direita, iam-se fazendo vários cortes até formar um bico que, finalmente, era preciso "dividir". Segundo se julga, era o ato mais difícil e felizmente chegaram até nós algumas das regras que se deviam observar. São nove e constam de um códice de origem alemã provavelmente do séc. XV ou mesmo anterior: 1.0 corte deve passar pelo meio da pena; 2. O aparo deve ter metade do comprimento do corte da pena; 3 . Deve ser tão largo de uma parte como da outra. 4. Os cortes devem ser iguais; 5 . Não deve fazer-se a incisão a direito mas obliquamente; 6 . O corte deve ser de meio a todo aparo; 7. Não deve ser aparada a direito mas obliquamente; 8 . A incisão deve ser feita principalmente no dorso; 9. O aparo deve condizer com a linha da pena. Figueiredo (1722, p. 31) explica ainda que "as pennas retiradas de ave são cruas, cheas de caspa, com alguma gordura, e para ficarem lisas, e rijas se cozem em cinza de pinho." Fornece, ainda, as seguintes informações sobre as boas penas:

\footnotetext{
As pennas para serem boas hão de ter os cannos compridos, grossos (não demasiadamente) lizos, brancos, rijos, e delgados na qualidade: o rijo se conhece apertandoa nos dedos, e o delgado em ser transparente; serão da aza direita por se accomodarem melhor aos dedos; conhecem-se tomandoas na mão em fórma de escrever cahir a mayor pluma para o peito, e a menor para fora. (FIGUEIREDO, 1722, p. 31)
}

A tinta empregada nos manuscritos em estudo é a ferrogálica, composta de sulfato de ferro, ácido galotânico (tanino extraído da noz de galha, formada no carvalho) e um aglutinante, em geral a goma-arábica dissolvida em água. Apresenta diversas tonalidades, variando de marrom a vermelho, e, seguindo o manual de Acioli (1994), pode ser também chamada de "tinta de noz gálica", de cor castanha. A preparação dessa tinta usada na época, conforme descrita por Bow (1999, p. 13), de acordo com recursos atualmente disponíveis, consiste em colocar $80 \mathrm{~g}$ de pedaços da madeira do carvalho em um jornal velho e amassar a madeira com um martelo. A seguir, a poeira da madeira deve ser 
colocada em um recipiente de vidro com água de chuva e tampada. Após dois dias sob o sol, a mistura recebe $50 \mathrm{~g}$ de cobre para que ganhe coloração mais escurecida e $25 \mathrm{~g}$ de borracha arábica para melhor aderir ao papel. Toda a receita deve ser deixada sob o sol por mais alguns dias e, por fim, deve ser coada com uma peneira de nylon. A durabilidade da cor da tinta está diretamente ligada ao seu tempo de exposição à luz.

\subsection{Em busca da identidade dos punhos}

A existência das diferentes caligrafias de diferentes punhos ou mãos observadas nos documentos prova que muitos terão sido cópias feitas na própria Capitania de São Paulo por ordem do Morgado de Mateus, a fim de serem arquivadas, ao mesmo tempo em que permaneceram outras cópias ou originais em Portugal. Há, em Bellotto (2007a, p. 205), referência ao excessivo espírito de organização de Dom Luís, uma vez que ele deixara em Mateus, sua residência no reino, "procuração feita, papéis organizados, identificados e classificados, inventários [...] Em lista separada, também existente no Arquivo de Mateus tudo o que levara para o Brasil"

Embora o livro manuscrito aqui estudado possa ter sido organizado a mando de D. Luís, é possível comprovar que não há documentos em que ele seja o autor material, ou seja, não há documentos redigidos por ele próprio. Não é tarefa fácil encontrar documentos comprovadamente autógrafos do autor, mas há em Belloto (2007a, p. 189) fac-símile de uma carta enviada a sua esposa, D. Leonor Ana Luísa José de Portugal, por D. Luís. Por se tratar de carta particular, tudo indica que D. Luís a tenha redigido de próprio punho. Além disso, a assinatura de D. Luís constante nos documentos do corpus é compatível com a que consta na carta reproduzida parcialmente a seguir. 


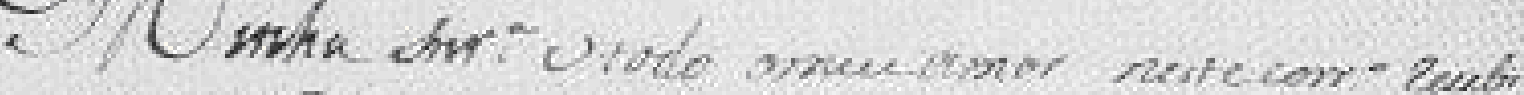

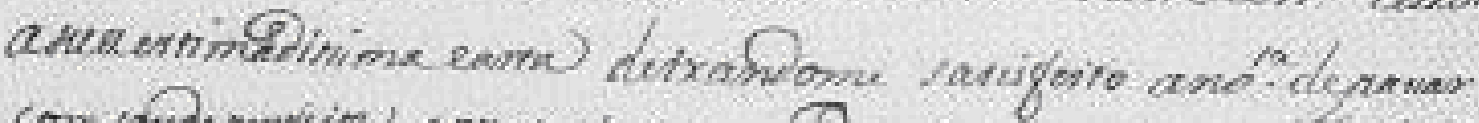

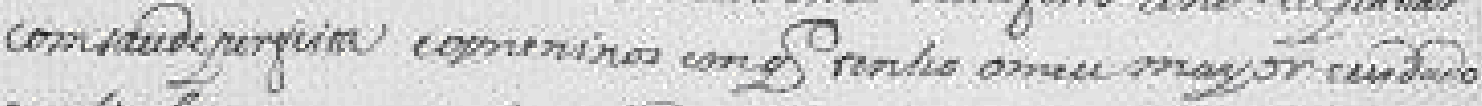

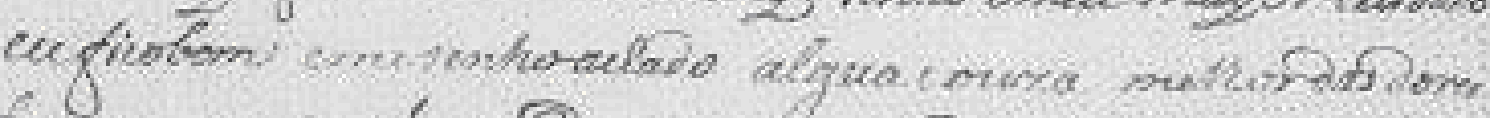

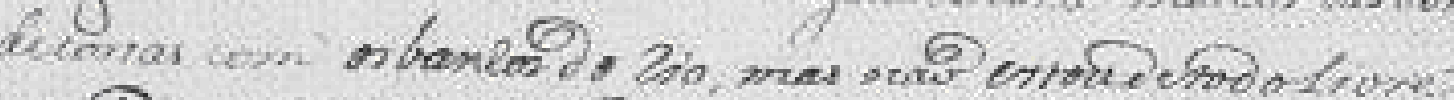

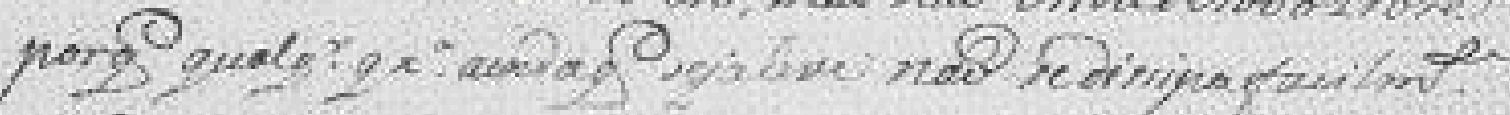

P. 0 ,

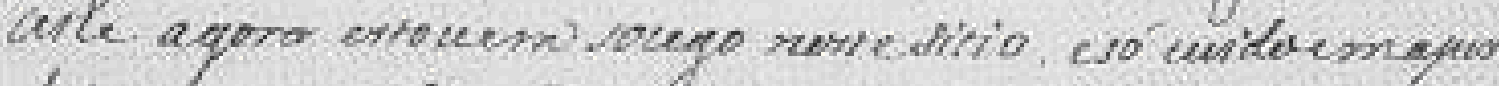

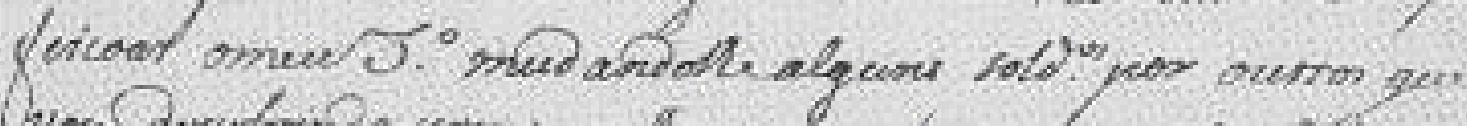

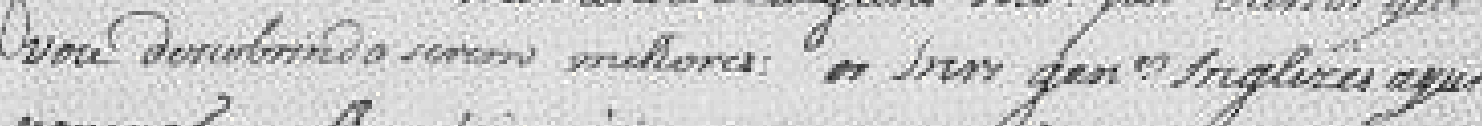

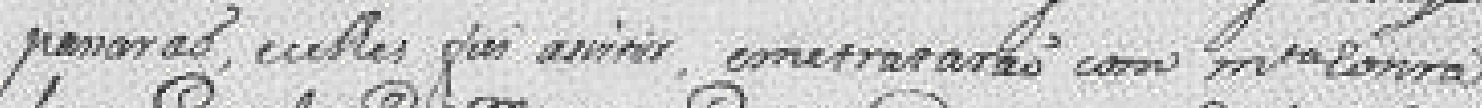

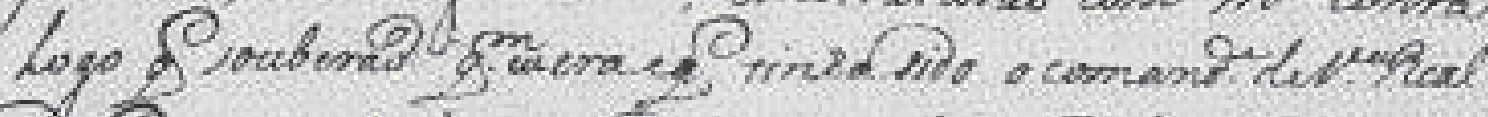

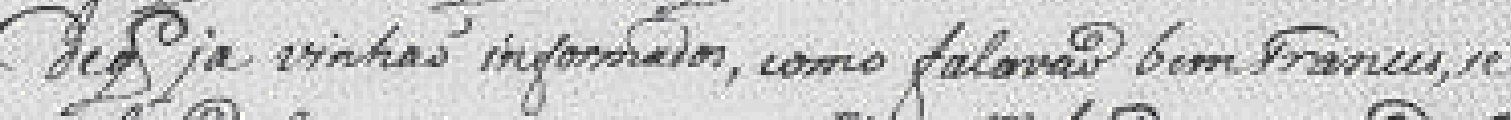

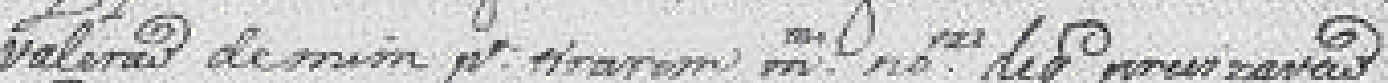

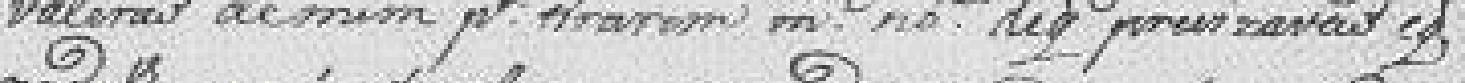

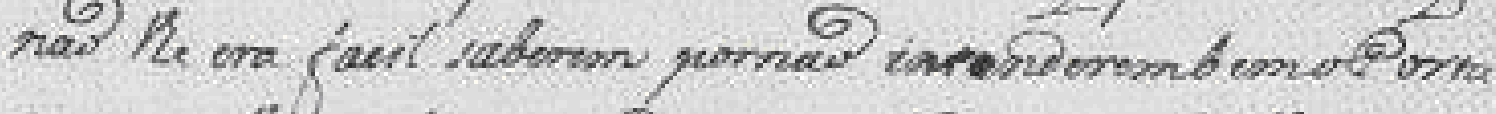

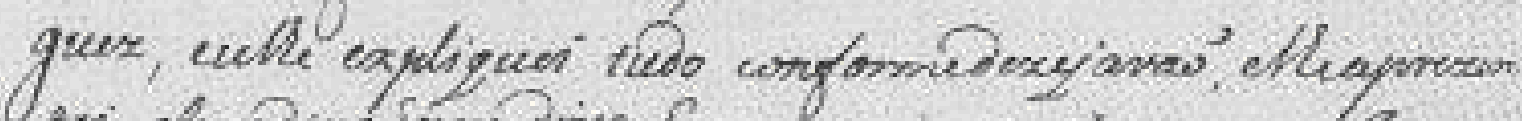

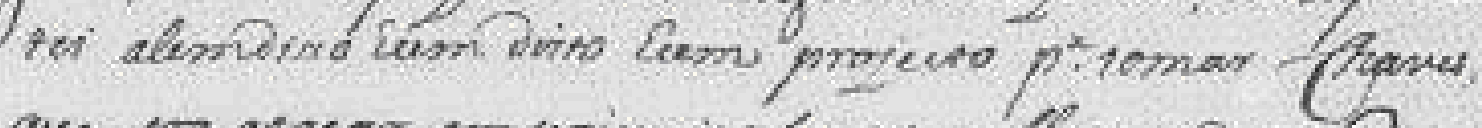

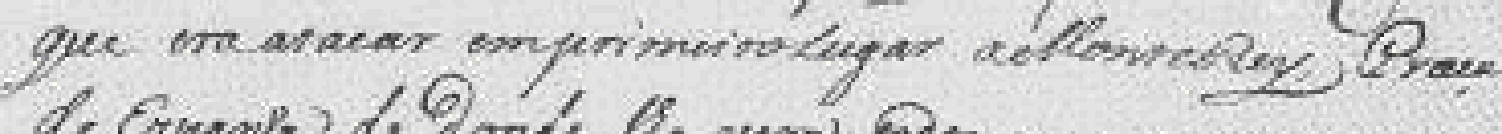

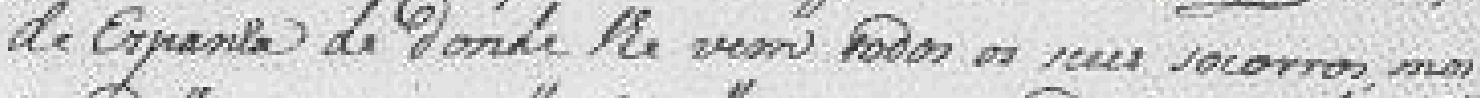

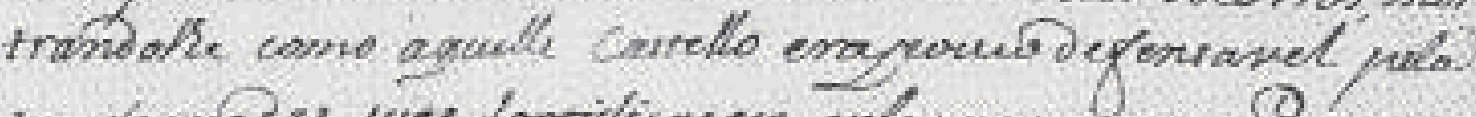

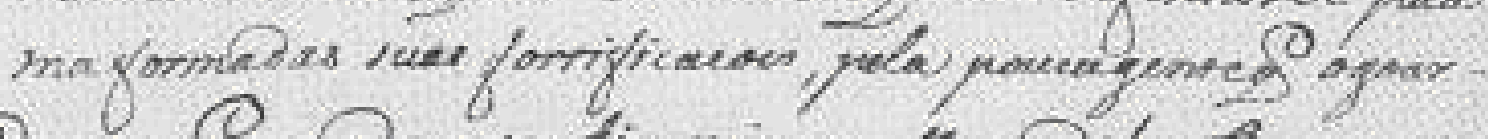

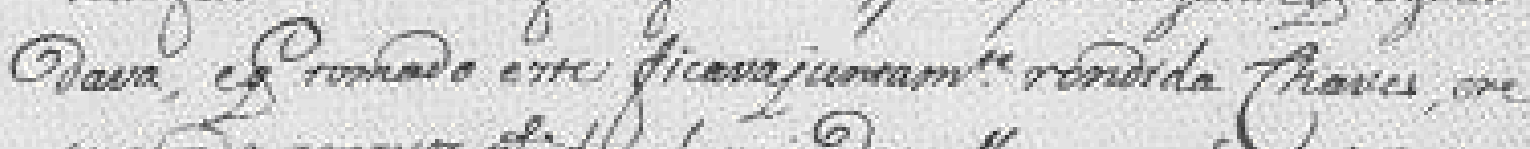

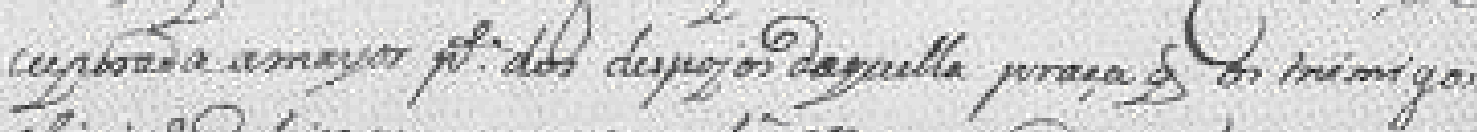

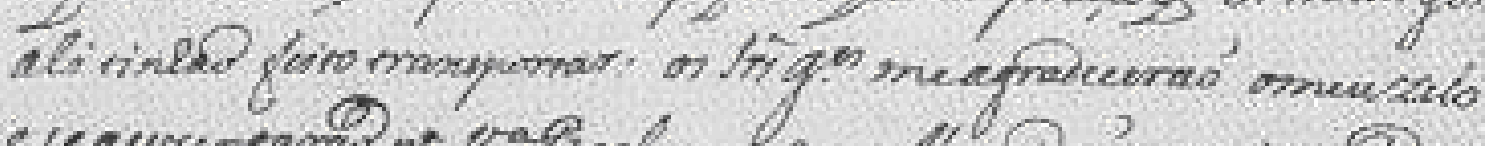

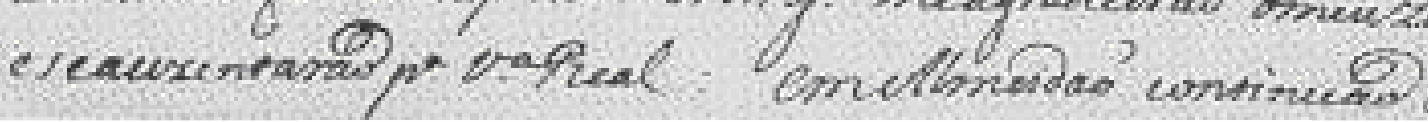

Carta recebida por D. Leonor Ana Luísa José de Portugal, enviada por seu marido, D Luís António de Sousa Botelho Mourão, 1762.

Figura 11: Exemplo da caligrafia de D. Luís. 
Para que a leitura do texto da figura 11 (carta de D. Luís a D. Leonor, sua esposa, em 1762, quando se encontrava em outra região de Portugal a trabalho, anos antes de seu embarque para o Brasil) seja facilitada, apresentase, abaixo, sua transcrição ${ }^{2}$ justalinear, seguindo as mesmas normas empregadas para a transcrição dos documentos manuscritos do corpus ${ }^{3}$.

\begin{abstract}
Minha Senhora etodo omeuAmor neste correio recebi
asuaestimadissimacarta deixandome satisfeito a noticia depassar

comsaudeperfeita eosmeninos emque tenho omeumayorcuidado

euficobem emetenhoachado alguacouza melhordasdores

decostas com os banhos do rio, mas naõ estoudetodoLivre

porque qualquer queixa aindaque sejaleve naõ sedissipafacilmente

athe agora estouem socego nestesitio, esó cuidoemaper

feicoar omeuterço mudandolhealguns soldados por outros que

vou descobrindo serem melhores: os Senhores generaes Inglezes aqui

passarão, eulhes fui asistir, emetrataraõ com muitahonra

Logo que souberaõ quem eu eraeque tinhasido o comandante deVilaReal

deque ja vinhaõ informados, como falavaõ bemFrances, se

valerão demim para tirarem muitas noticias deque precizavaõ eque

naõ the era facil saberem pornaõ intenderembemoPortu

guez, eulhe expliquei tudo conforme desejavaõ, elheparezen

tei alemdisso hum [doito] hum projecto para tomar Chaves,

que eraatacar emprimeiroLugar aMonteRey, Praça

de Espanha de donde the vem todos os seus socorros, mos

trandolhe como aquelle Castello erapouco defensavel pela

maformadas sua fortificações, pela poucagenteque agoar-

dava, eque tomado este ficavajuntamente rendida Chaves, ere

cuperada amayor parte dos despojos daquella praça que os inimigos

ali tinhaõ feito transportar: os Senhores Generaes meagradeceraõ omeuzelo

eseauzentaraõ para VilaReal: emAlmeidaõ continuaõ os
\end{abstract}

Tendo sido redigido pelo próprio $D$. Luís, temos aqui um documento autógrafo, com o registro de sua própria caligrafia. Tal caligrafia, por ser diferente de todas as encontradas nos documentos do livro manuscrito estudado, prova que não há no corpus deste trabalho nenhum documento autógrafo de D. Luís, apesar de sua assinatura estar, como já citado, na

\footnotetext{
${ }^{2}$ A fonte da carta reproduz apenas esta parte transcrita, por isso esta transcrição é parcial.

${ }^{3}$ As normas de transcrição podem ser consultadas na página 84 desse trabalho.
} 
maioria dos manuscritos. Uma vez que se trata de correspondência passiva, a assinatura comprova que muitos documentos a seguir transcritos são cópias, feitas provavelmente a mando de D. Luís na capitania de São Paulo, com o intuito de arquivamento.

Por ser o objetivo central deste trabalho a transcrição semidiplomática do corpus, ressalta-se aqui que as análises codicológicas e paleográficas são relevantes para a caracterização e melhor identificação dos documentos manuscritos que o compõem.

Pode-se supor que o trabalho de cópia dos documentos estivesse sob os cuidados de determinado profissional escolhido previamente no reino, mas há referências nos próprios documentos de que os amanuenses eram contratados na própria capitania conforme a necessidade e, do mesmo modo, demitidos quando o volume de trabalho diminuía. O secretário de governo, Tomás Pinto de Oliveira, do mesmo modo que D. Luís, não pode ser considerado o autor material de qualquer dos documentos em estudo. Prova disso é a figura apresentada por Bellotto (2007a:192), fac-símile de uma página do diário de viagem de D. Luís Antonio de Sousa Botelho Mourão, redigido por Tomás Pinto de Oliveira, que desde o embarque de Dom Luís ao Brasil redigiu tal diário. 


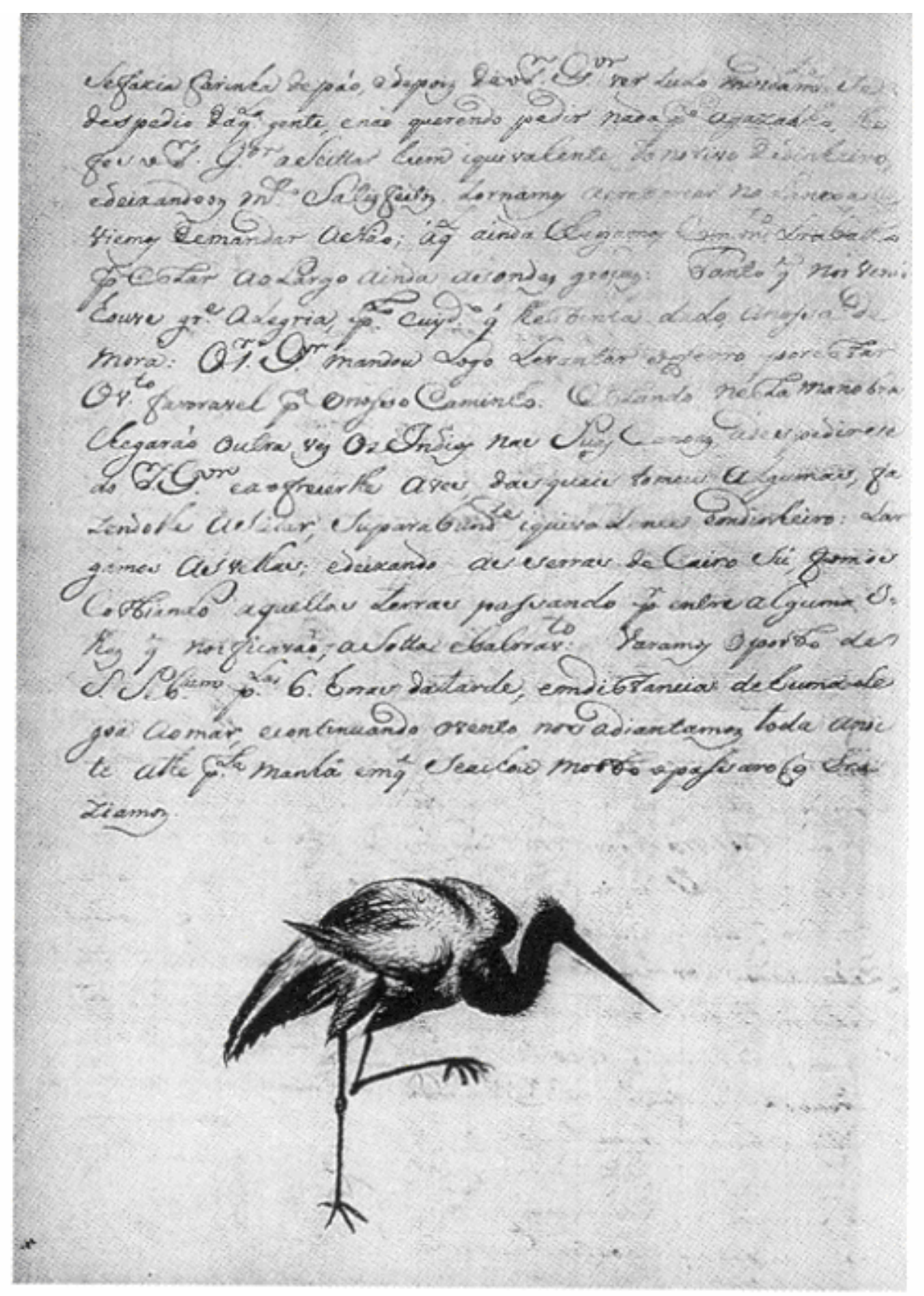

Desenho do diário de viagem de D. Luís António de Sousa Botelho Mourão, no qual relata a viagem do Porto até São Paulo, 1765/03/23-1768/12/31.

Figura 12: Diário de viagem de D. Luís. 
Segue abaixo a transcrição do fac-símile da figura 12.

Sefazia farinha depáo, e depoiz deo Senhor Governador ver tudo miudamente Se despedio daquela gente, e naõ querendo pedir nada pelo agazalho, the fes oSenhor Governador aSeittar hum iquivalente do nativo dedinheiro, edeixando oz muito Satisfeitoz, tornamos aembarcar na Lanxa e viemos demandar aNáo, aqual ainda Chegamos Com muito Trabalho por Estar ao Largo ainda das ondas groças: Tanto que Nos Verão houve grande Alegria, peLo cuydado que Ihetinha dado, anossa de mora: Osenhor Governador mandou Logo Levantar oferro por estar Ovento favoravel para Onosso Caminho: Estando nela manobra Chegarão Outra vez OsIndios nas Suas Canoas, a despedirse doSenhor Governador eaofrecerlhe a ves, das quais tomou Algumas, fa zendolhe ASeitar, Supor abundante iquivalente emdinheiro: Lar gamos AsVellas; edeixando as serras deCairo Sú, fomos Costhiando aquellas terras passando por entre alguma $\mathrm{I}=$ Ihaz, que nos ficavaõ, aSotta ebalrravento: Varamos O porto de São Sebastiam pelas 6 . horas datarde, em distancia dehumale goa Ao mar, econtinuando ovento nos adiantamoz toda anoi te athe pela manhã emque Seachou morto opassaro que tra | ziamos

Sem nenhuma intenção de análise exaustiva, apresentam-se, a seguir, oito quadros acerca do traçado de letras dos quatro punhos mais recorrentes no corpus. Do mesmo modo que a figura 13, em que Figueiredo (1722) no século XVIII arrolou as letras com o intuito de analisar seu traçado, os quadros pretendem mostrar ocorrências de traçados das caligrafias cursivas.

Para a breve análise sobre a forma das letras arroladas nos quadros, são empregados os termos determinados por Mallon (1952). São eles o "ângulo", referente à inclinação da letra, resultante da posição do instrumento e do suporte da escrita; o "peso", espessura do traço que depende do instrumento, do suporte e da mão e o "ductus", trajeto da sequência de traços das letras, que determina o "módulo", altura e largura da letra. 


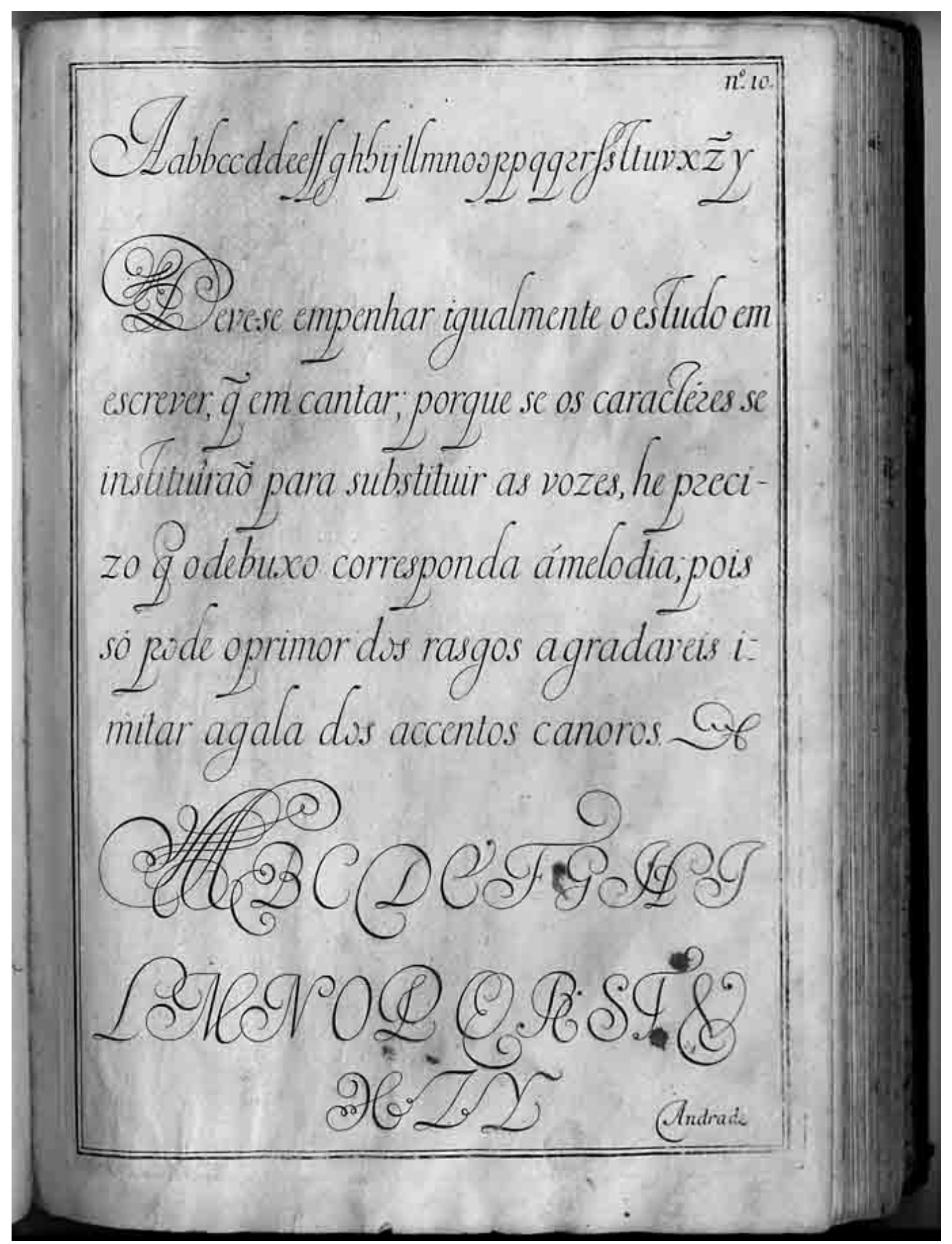

Figura 13: Alfabeto proposto por Figueiredo (1722) 
A forma das letras proposta por Figueiredo é a redigida de maneira cuidadosa e bem trabalhada, com ângulo sem muita inclinação; o peso é leve; o ductus indica um desenho cuidadoso, realizado para a esquerda, de baixo para cima, com módulo bastante regular.

O alfabeto proposto por Figueiredo servirá de parâmetro para uma análise geral dos traçados de letras dos quatro punhos observados por meio dos quadros. Para tanto, não serão consideradas as posições iniciais, mediais ou finais de cada letra dentro da palavra, mas a sua ocorrência de forma genérica.

O critério usado para numerar os punhos foi inicialmente o da comparação dos documentos manuscritos, em busca de semelhanças. Escolheram-se, para a montagem dos quadros, as caligrafias que apresentavam evidências de terem sido produzidas pela mesma mão, no caso dos seis primeiros quadros, e de ocorrência em maior número de fólios, no caso dos quadros 7 e 8 , montados a partir do maior documento do corpus, o de número 68. Vale ressaltar que quando não ocorre um dos grafemas no punho, retirou-se a linha referente à dada letra da tabela.

Quadro 1: Ocorrências de letras maiúsculas do punho 1, presentes nos documentos 4, 5, 6, 11 e 12 .

\begin{tabular}{|c|c|c|c|c|}
\hline Grafema & Letras & Palavras & Documento & Linha \\
\hline$<A>$ & & & 4 & 14 \\
\hline$<B>$ & & & 4 & 9 \\
\hline$<\mathrm{C}>$ & & & 4 & - \\
\hline$<\mathrm{D}>$ & & & 5 & 3 \\
\hline
\end{tabular}




\begin{tabular}{|r|r|r|r|}
\hline & & & \\
\hline & & & \\
\hline
\end{tabular}




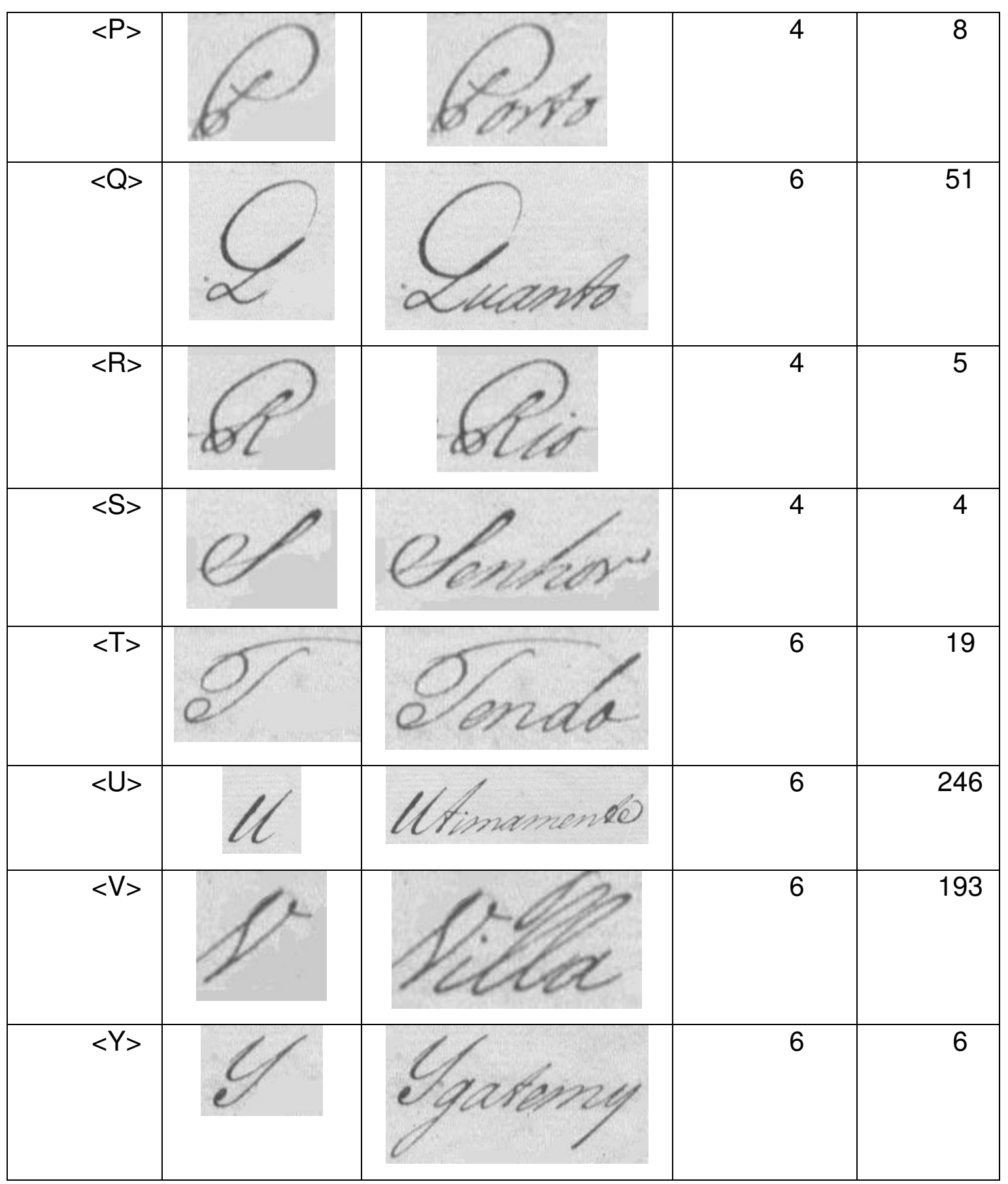


Quadro 2: Ocorrências de letras minúsculas do punho 1, presentes nos documentos 4, 5, 6, 11 e

\begin{tabular}{|c|c|c|c|c|}
\hline Grafema & Letras & Palavras & Documento & Linha \\
\hline$<a>$ & & & 4 & 4 \\
\hline$<b>$ & & & 4 & 6 \\
\hline$<\mathrm{C}>$ & & & 4 & 5 \\
\hline$<d\rangle$ & & & 4 & 5 \\
\hline$<\mathrm{e}>$ & & & 4 & 4 \\
\hline$<f>$ & & & 4 & 3 \\
\hline$<g>$ & & & 4 & 8 \\
\hline$<h>$ & & & 4 & 5 \\
\hline$<i>$ & & & 4 & 1 \\
\hline
\end{tabular}




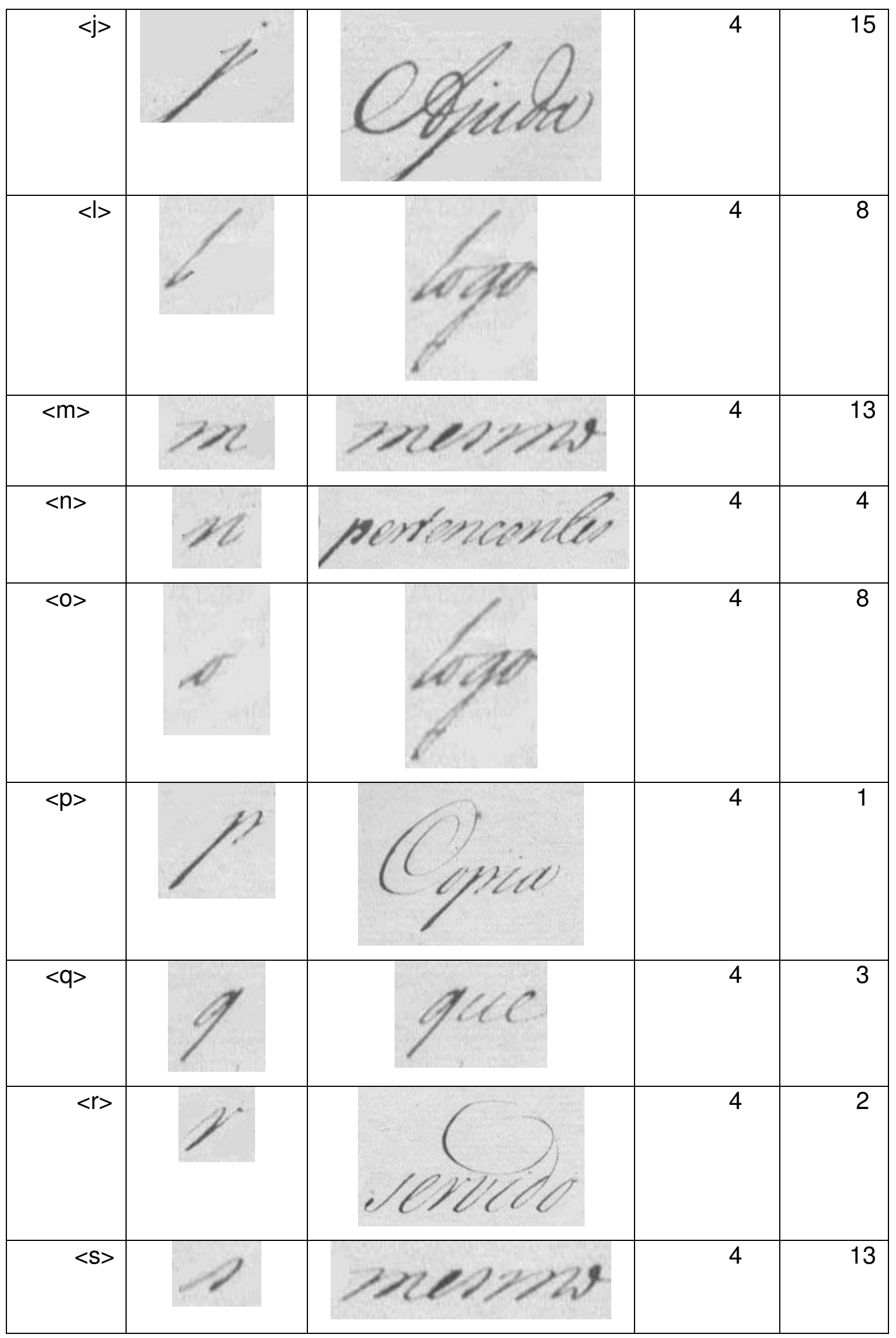




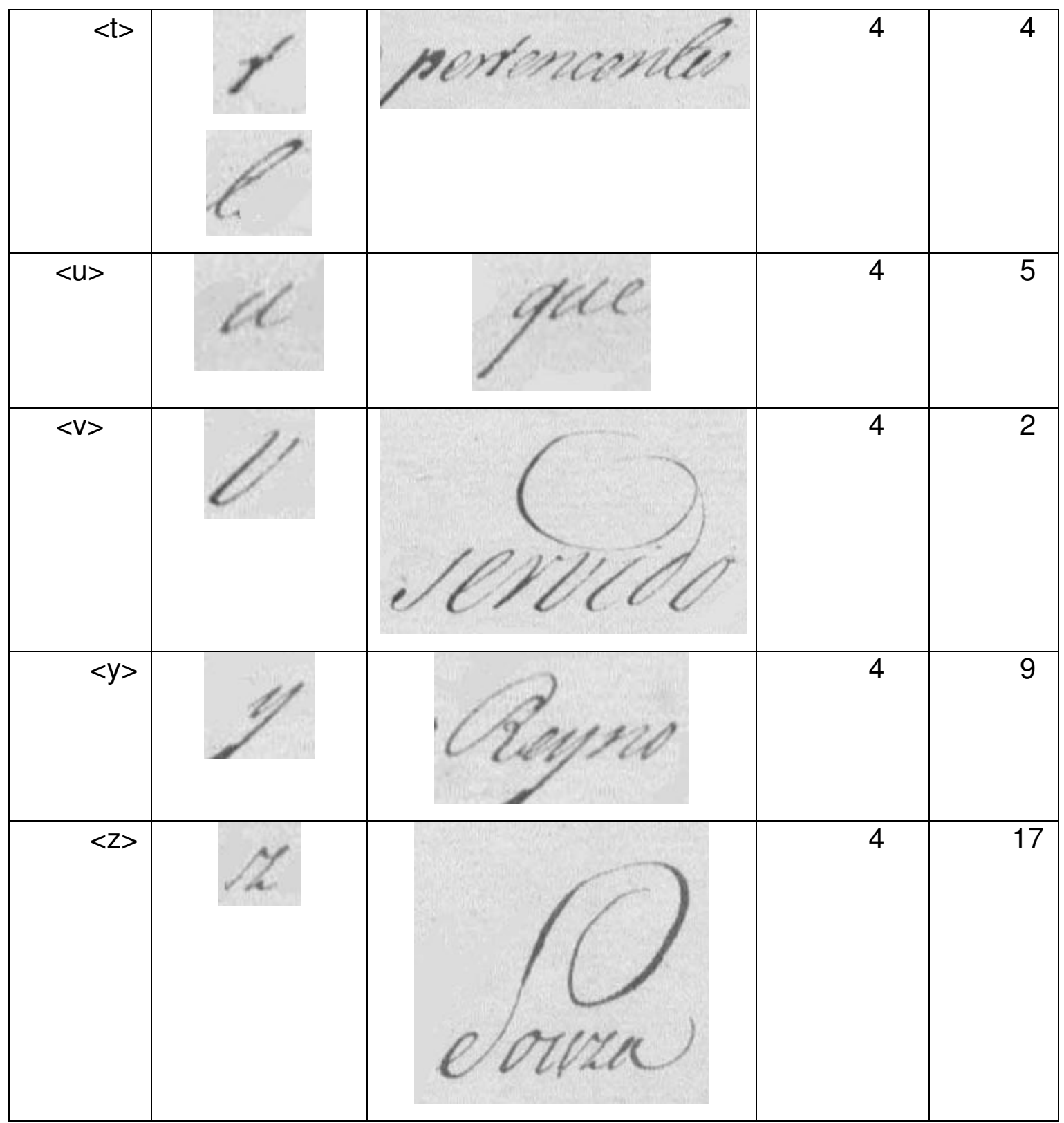

Quadro 3: Ocorrências de letras maiúsculas do punho 2, presentes nos documentos 18, 19, 20 e

\begin{tabular}{|c|c|c|c|c|}
\hline Grafema & Letras & Palavras & Documento & Linha \\
\hline$<\mathrm{A}>$ & & & 18 & 8 \\
\hline$<B>$ & & & 19 & 4 \\
\hline
\end{tabular}




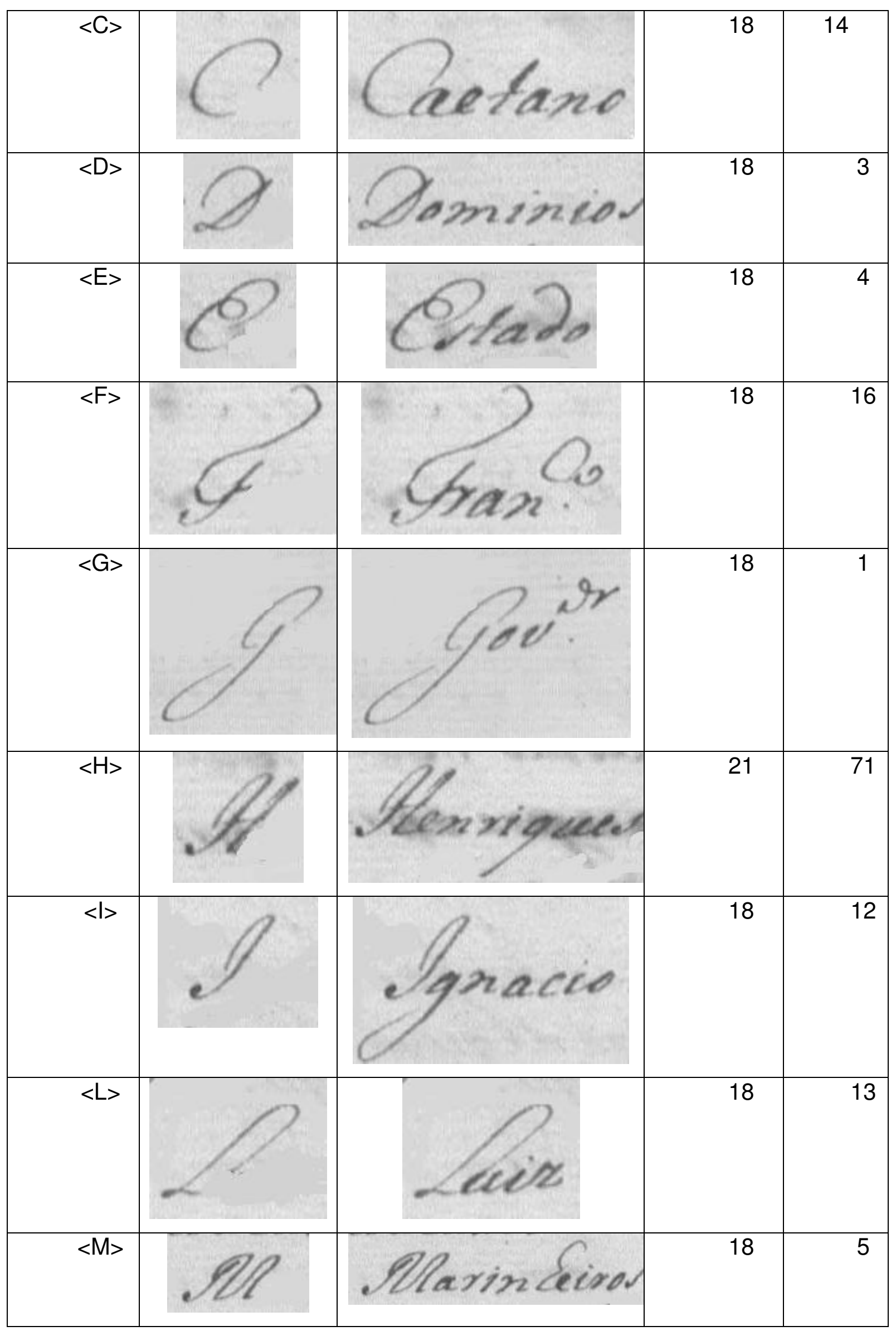




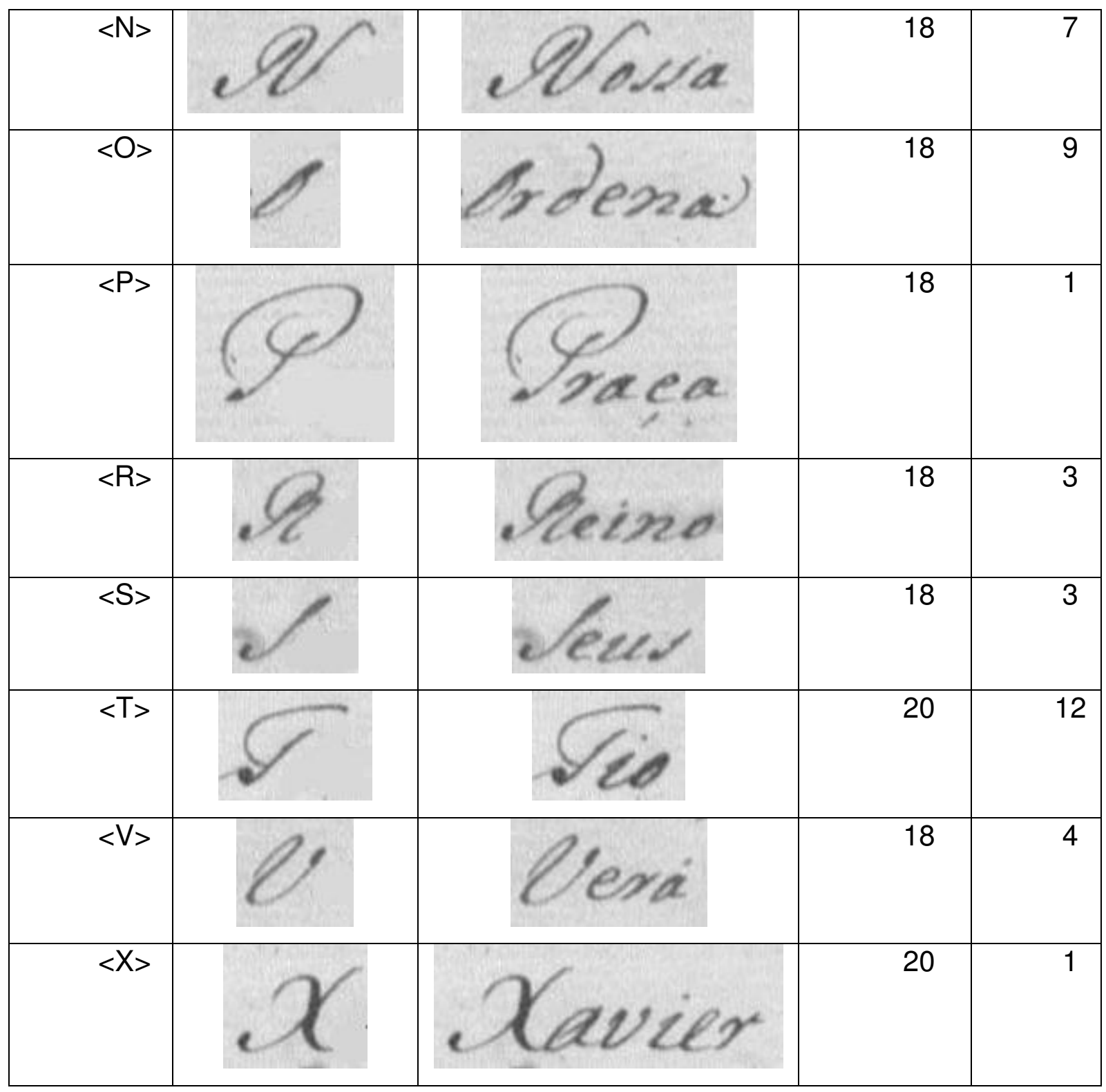

Quadro 4: Ocorrências de letras minúsculas do punho 2, presentes nos documentos 18, 19, 20 e 21.

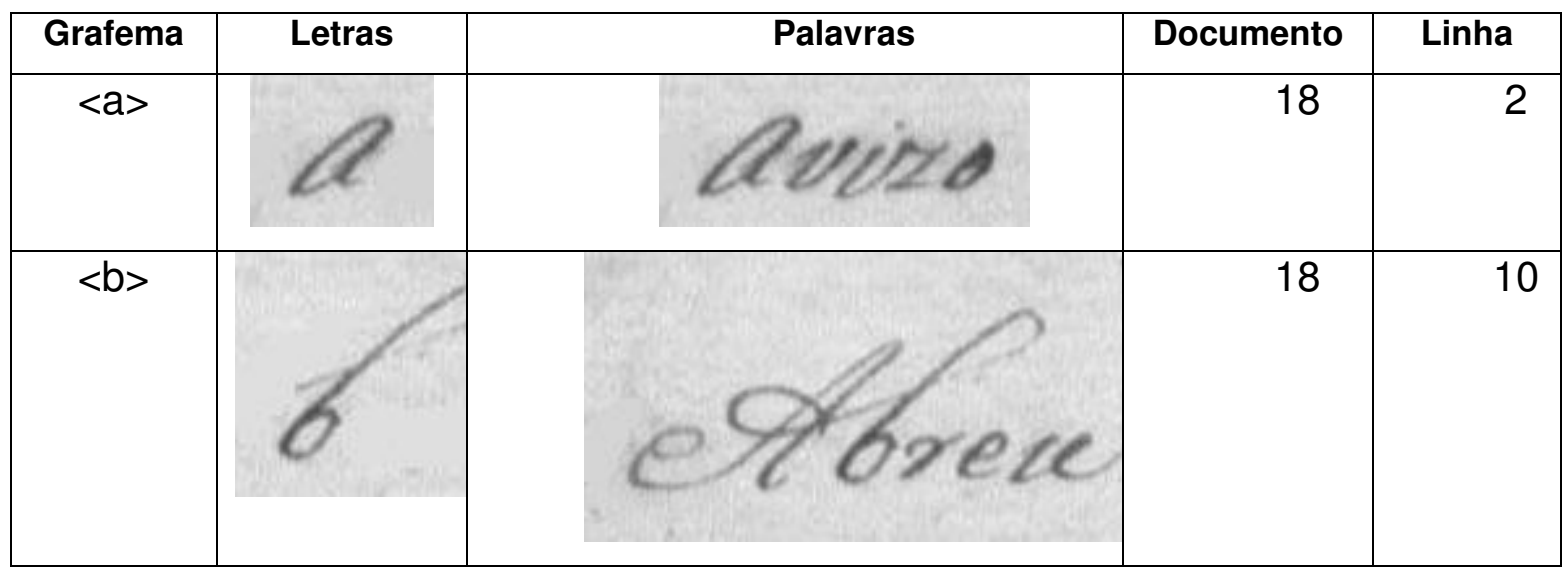

37 


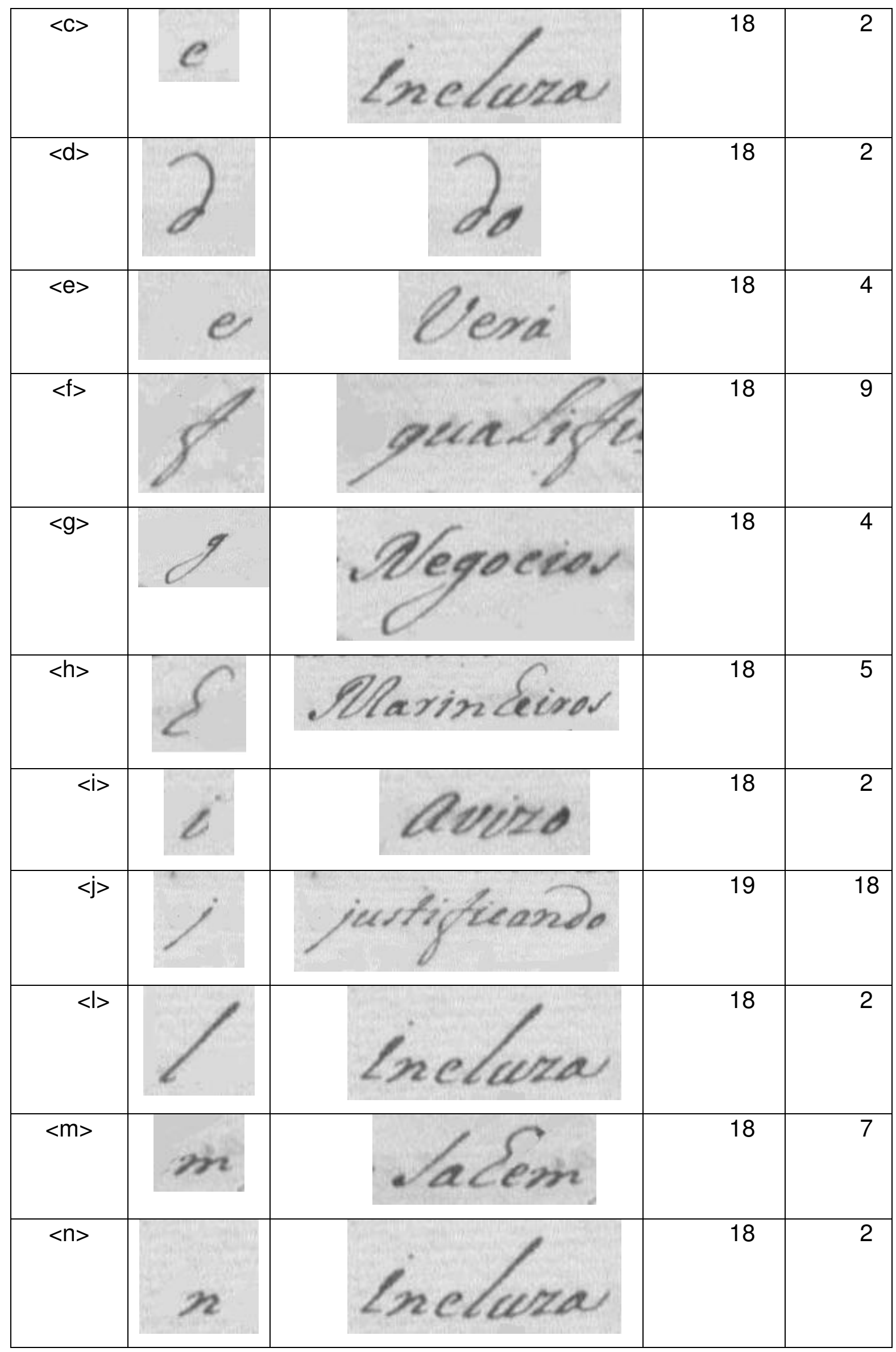

38 


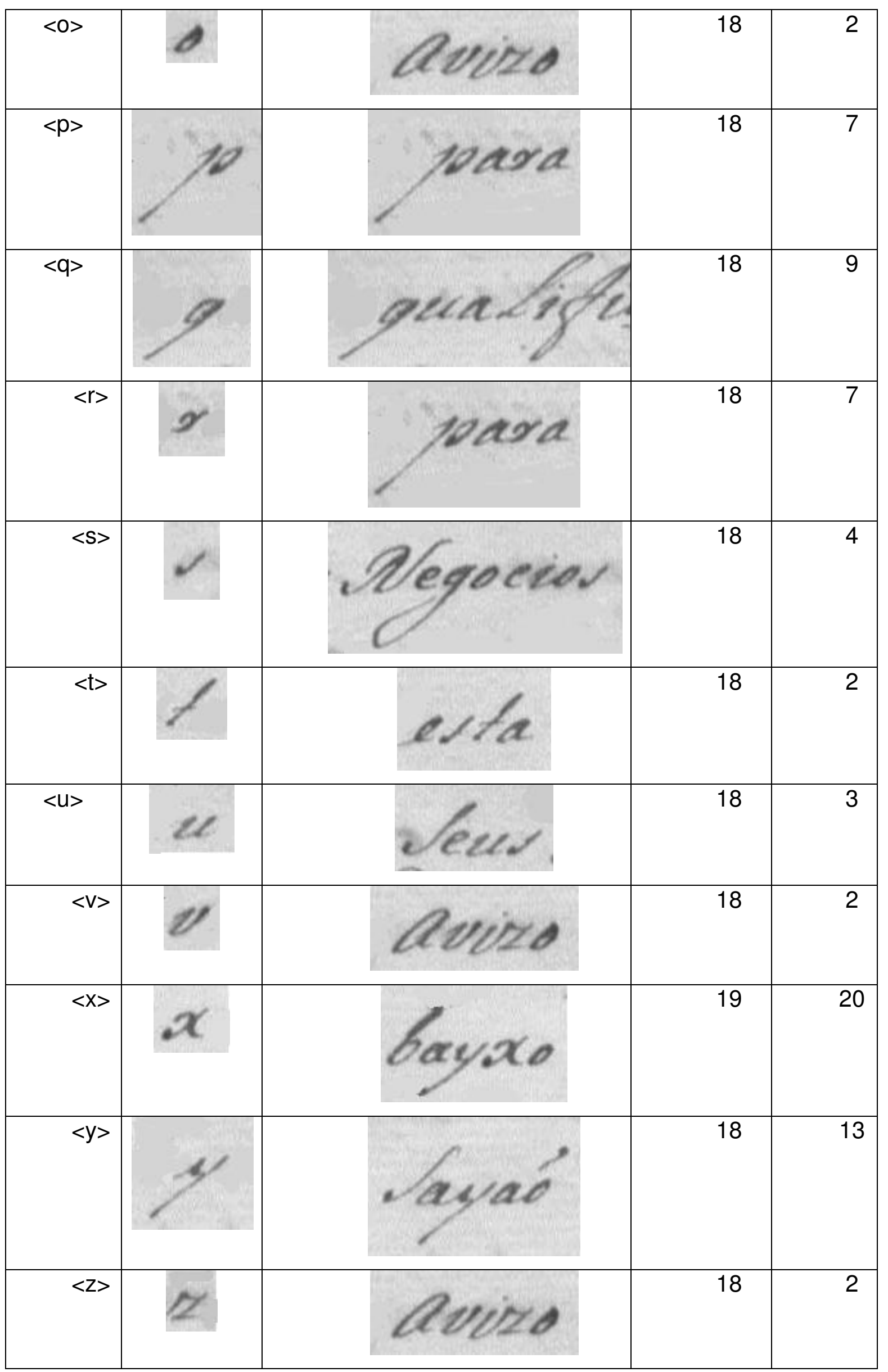


Quadro 5: Ocorrências de letras maiúsculas do punho 3, presentes nos documentos 40, 41, 42 e 43.

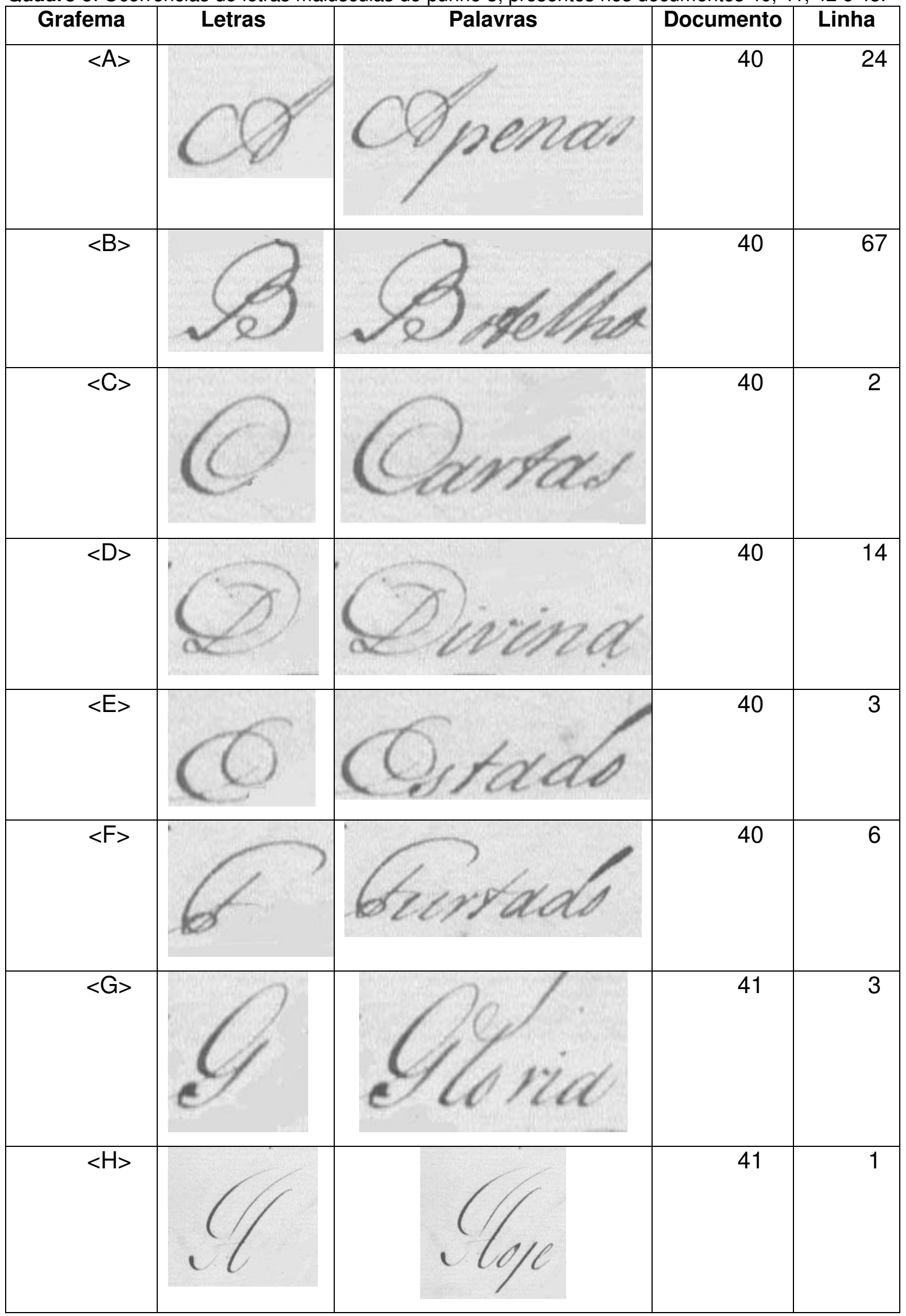




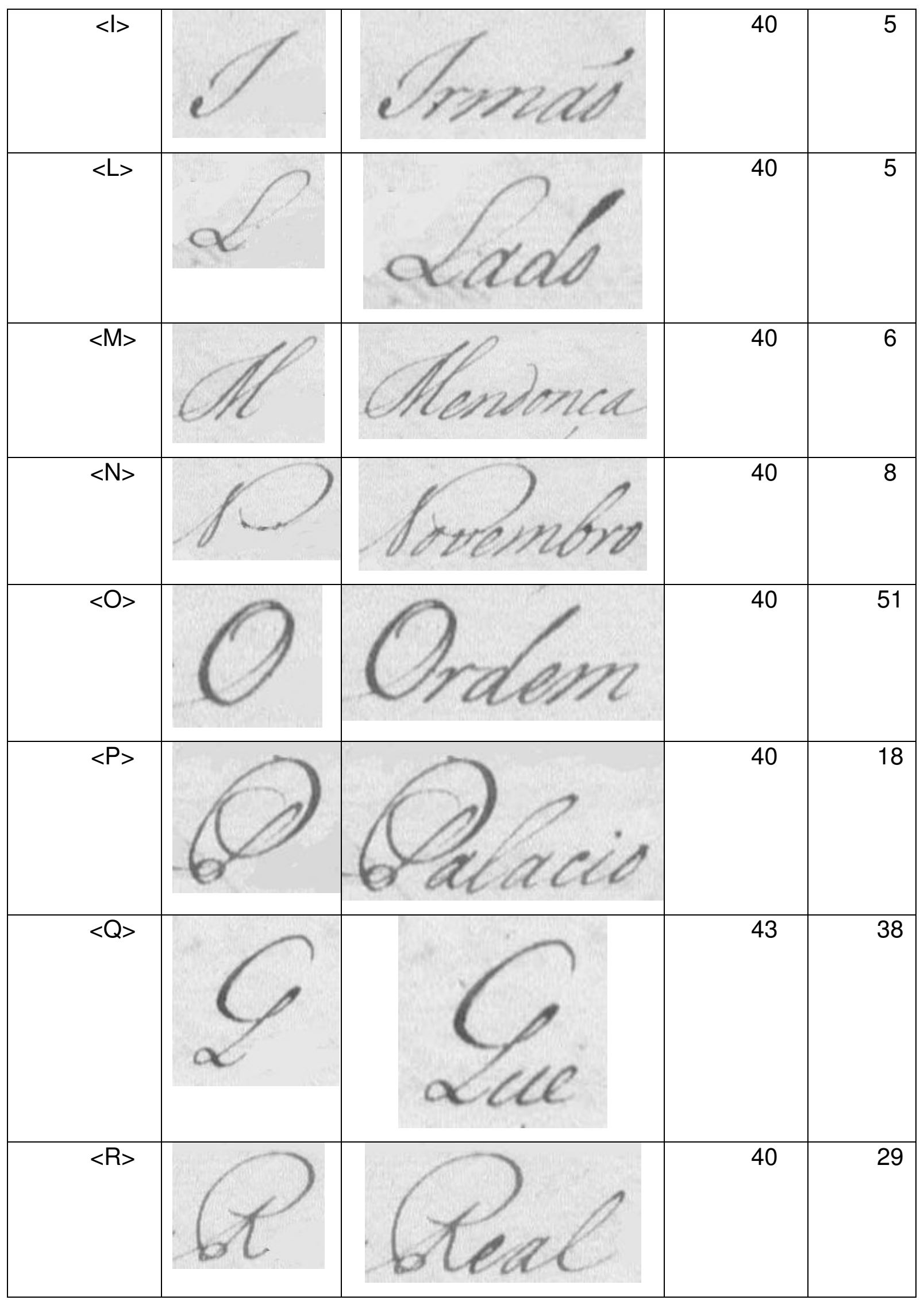




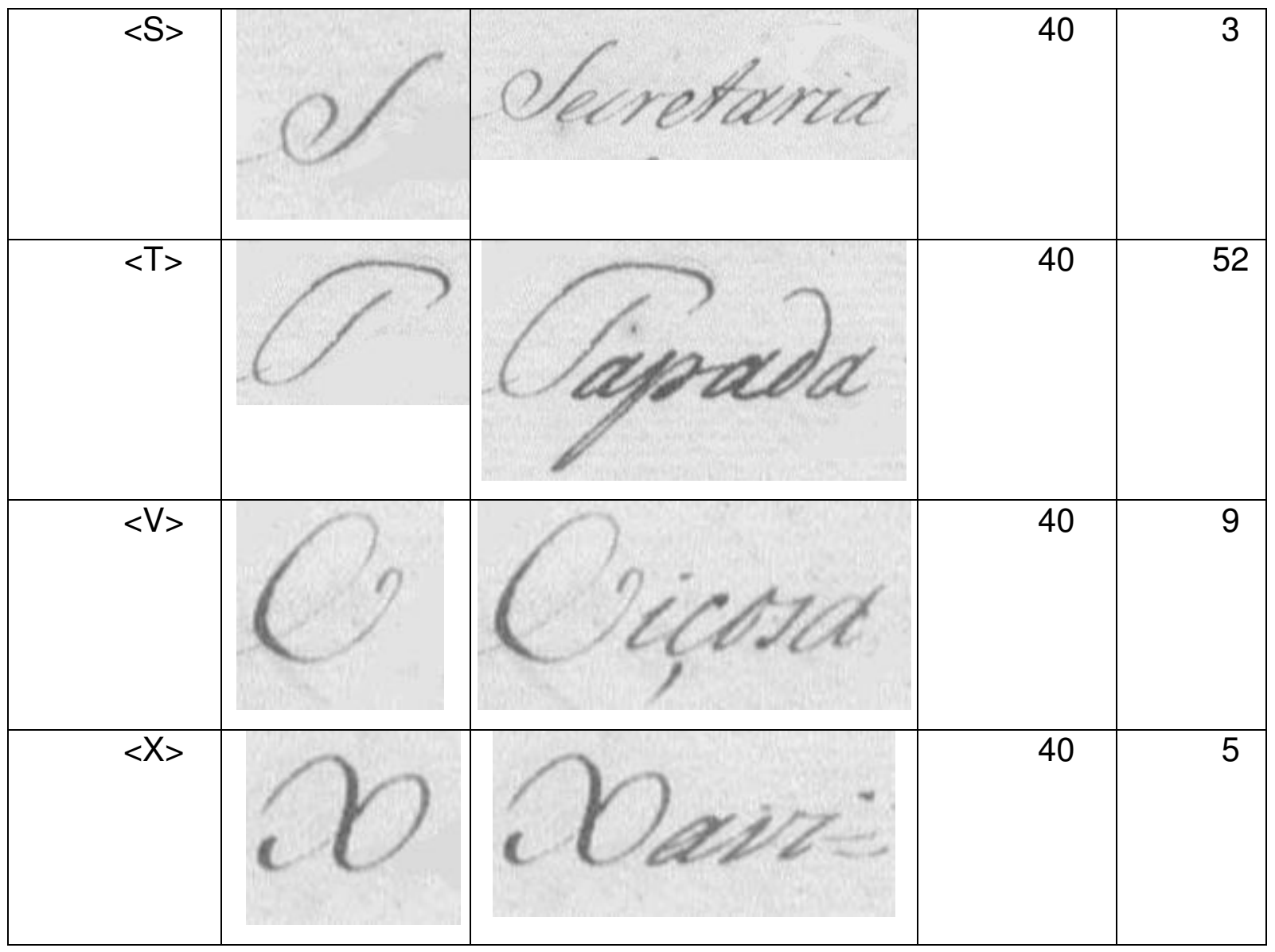

Quadro 6: Ocorrências de letras minúsculas do punho 3, presentes nos documentos 40, 41, 42 e 43.

\begin{tabular}{|c|c|c|c|c|}
\hline Grafema & Letras & Palavras & Documento & Linha \\
\hline$<a>$ & & & 40 & 1 \\
\hline$<b>$ & & & 40 & 1 \\
\hline$<\mathrm{C}>$ & & & 40 & 1 \\
\hline
\end{tabular}




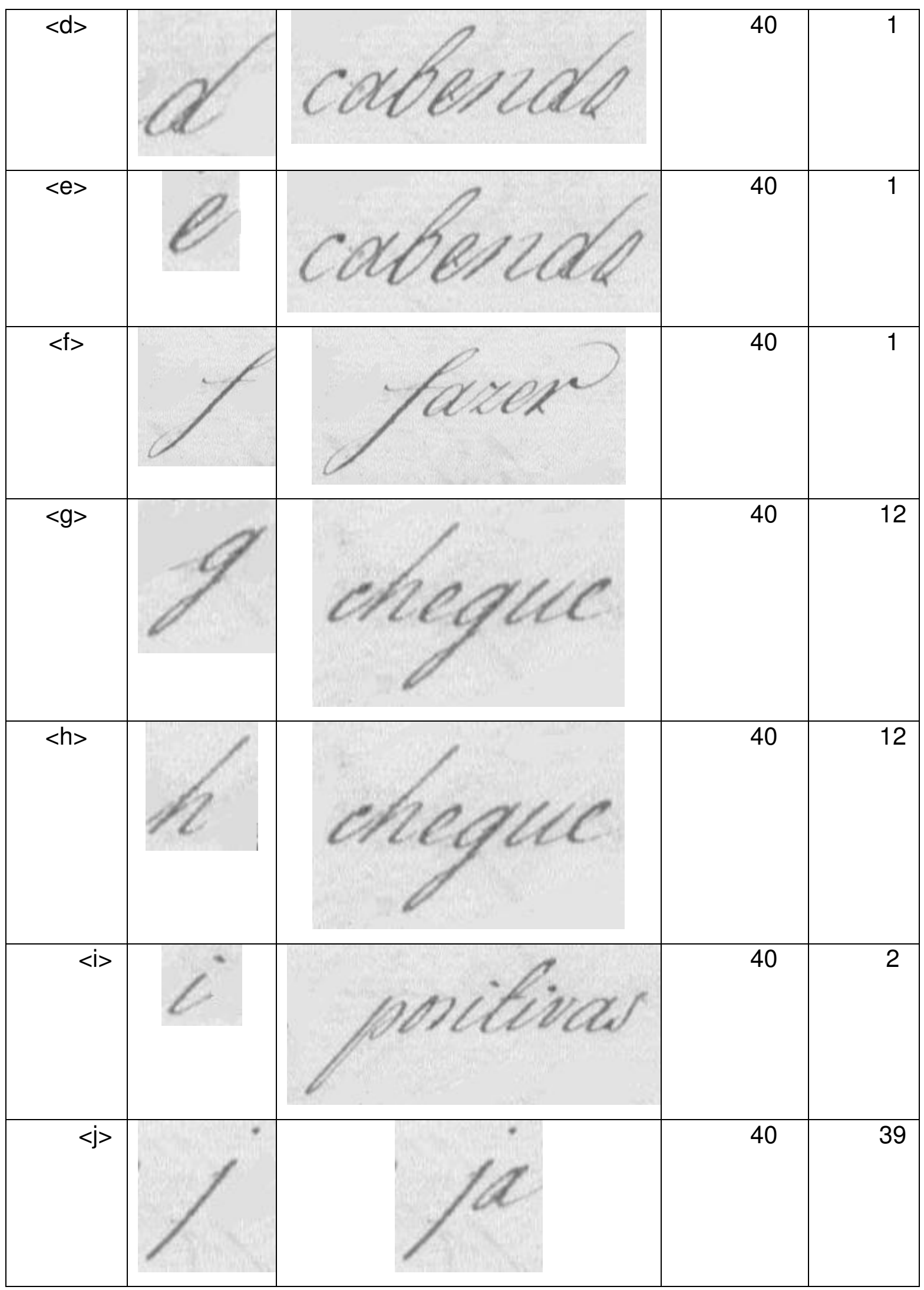




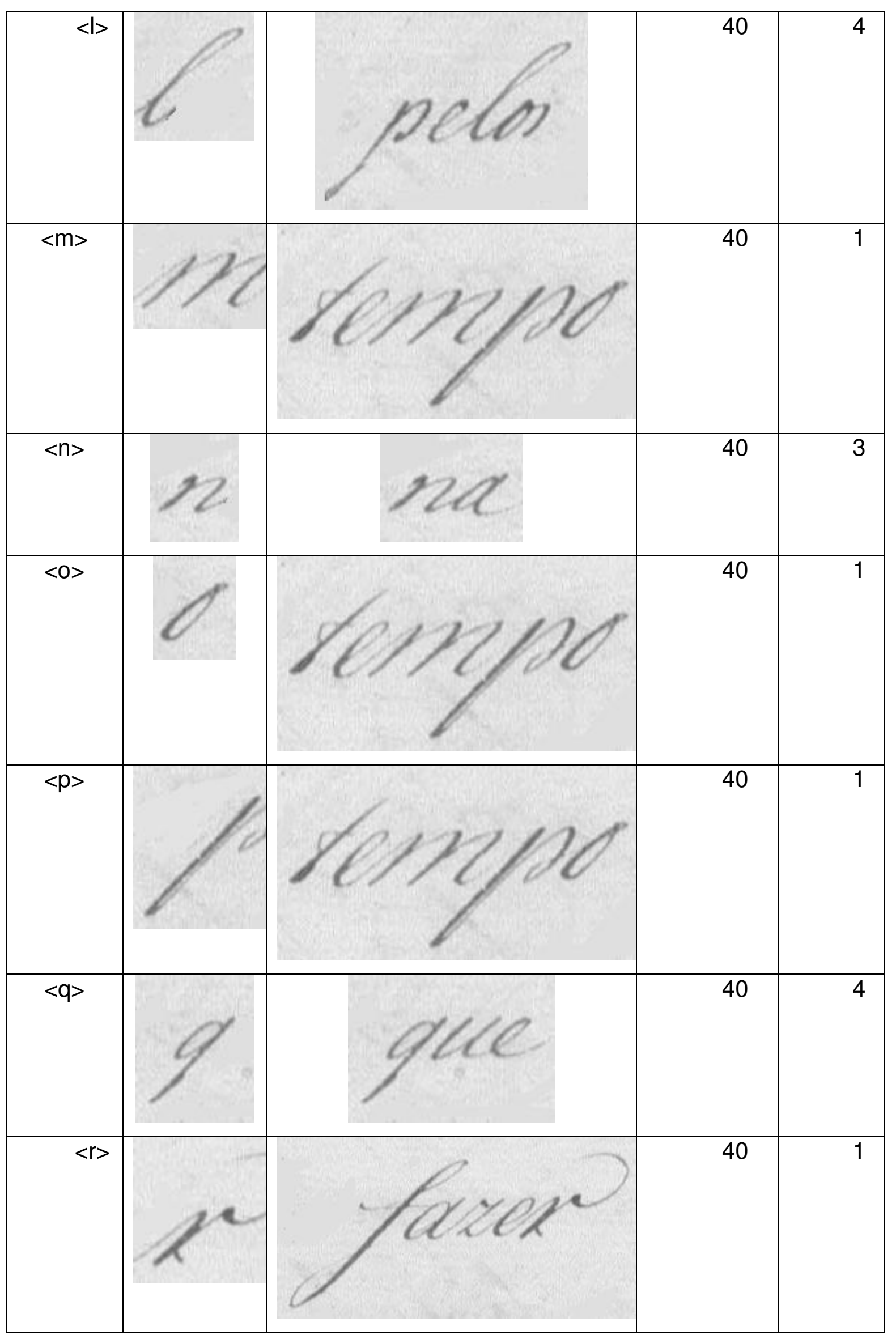




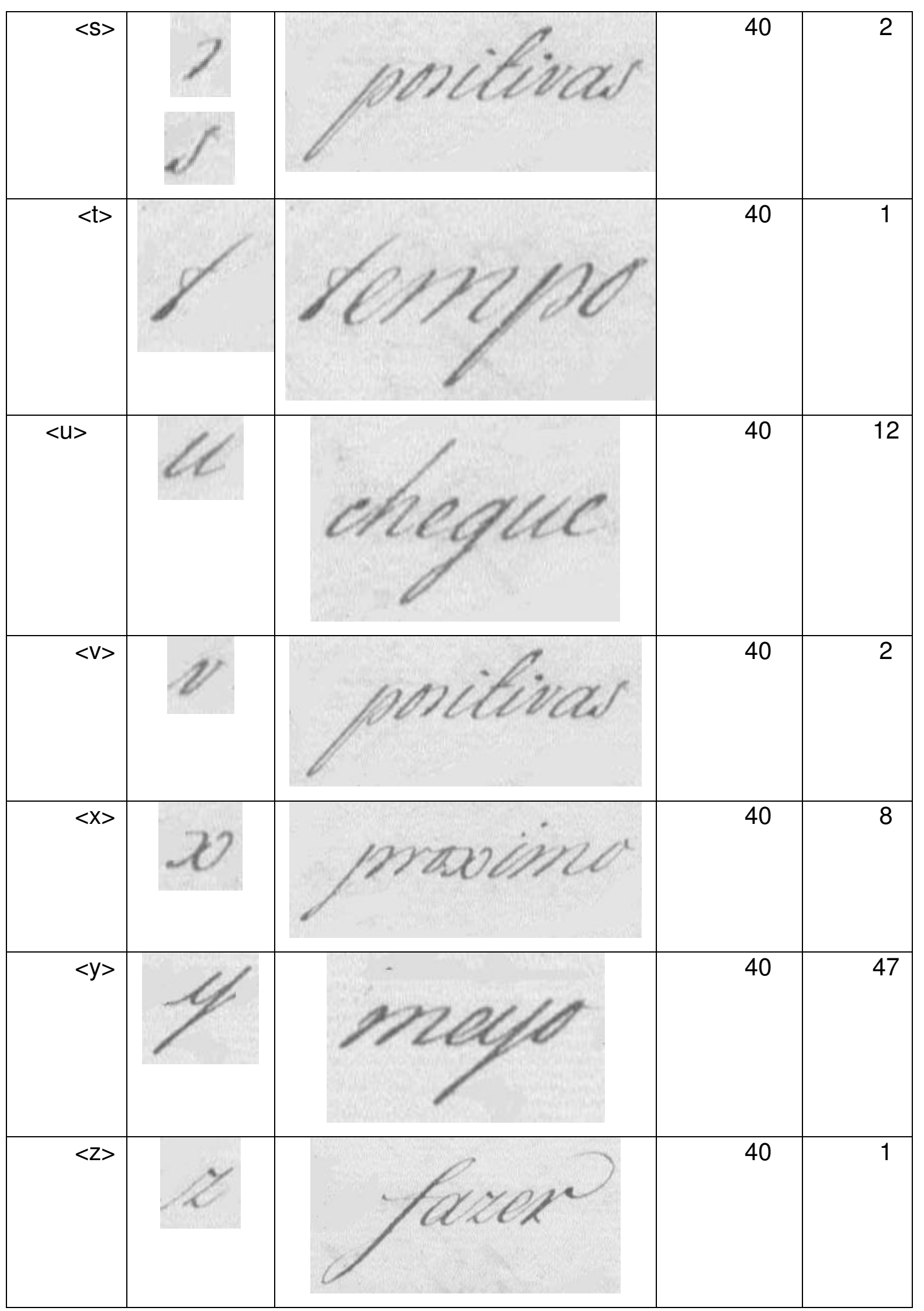


Quadro 7: Ocorrências de letras maiúsculas do punho 4, presentes no documento 68.

\begin{tabular}{|c|c|c|c|c|}
\hline Grafema & Letras & Palavras & Documento & Linha \\
\hline$<\mathrm{A}>$ & & & 68 & 27 \\
\hline$<B>$ & & & 68 & 20 \\
\hline$<\mathrm{C}>$ & & & 68 & 2 \\
\hline$<\mathrm{D}>$ & & & 68 & 2 \\
\hline$<\mathrm{E}>$ & & & 68 & 21 \\
\hline$<F>$ & & & 68 & 9 \\
\hline$<G>$ & & & 68 & 14 \\
\hline$<\mathrm{H}>$ & & & 68 & 26 \\
\hline$<1>$ & & & 68 & 10 \\
\hline$<L>$ & & & 68 & 15 \\
\hline$<\mathrm{M}>$ & & & 68 & 10 \\
\hline
\end{tabular}




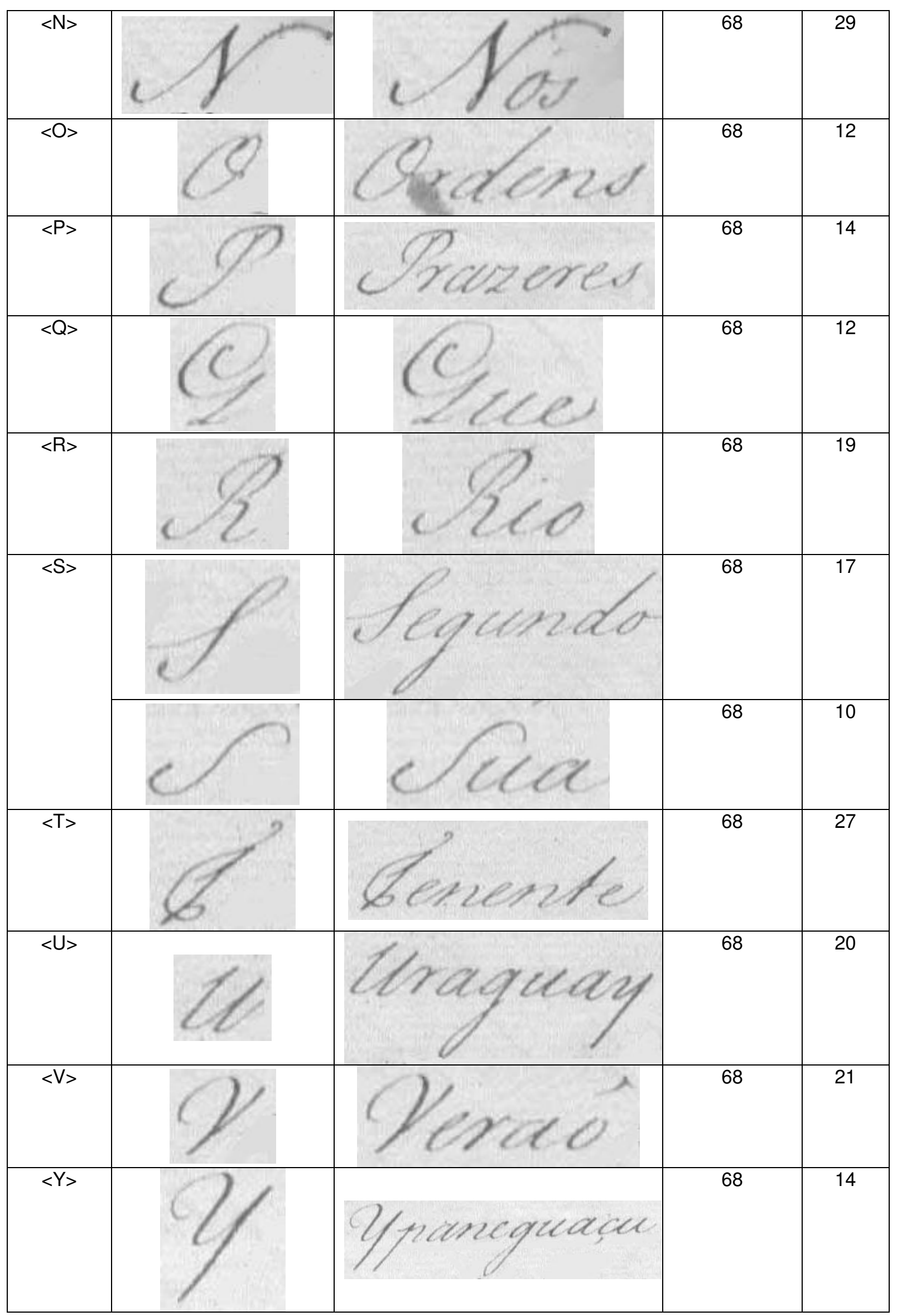




\begin{tabular}{|l|l|l|l|l|}
\hline$<\mathrm{Z}>$ & & & 68 & 15 \\
& $x>1$ & & & \\
\end{tabular}

Quadro 8: Ocorrências de letras minúsculas do punho 4, presentes no documento 68.

\begin{tabular}{|c|c|c|c|c|}
\hline Grafema & Letras & Palavras & Documento & Linha \\
\hline$<\mathrm{a}>$ & & & 68 & 1 \\
\hline$\langle b\rangle$ & & & 68 & 3 \\
\hline$<\mathrm{C}>$ & & & 68 & 11 \\
\hline$<d>$ & & & 68 & 12 \\
\hline$<e>$ & & & 68 & 12 \\
\hline$<f>$ & & & 68 & 10 \\
\hline$\langle g\rangle$ & & & 68 & 17 \\
\hline$<\mathrm{h}>$ & & & 68 & 12 \\
\hline$<i>$ & & & 68 & 11 \\
\hline$<j>$ & 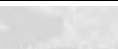 & & 68 & 9 \\
\hline
\end{tabular}




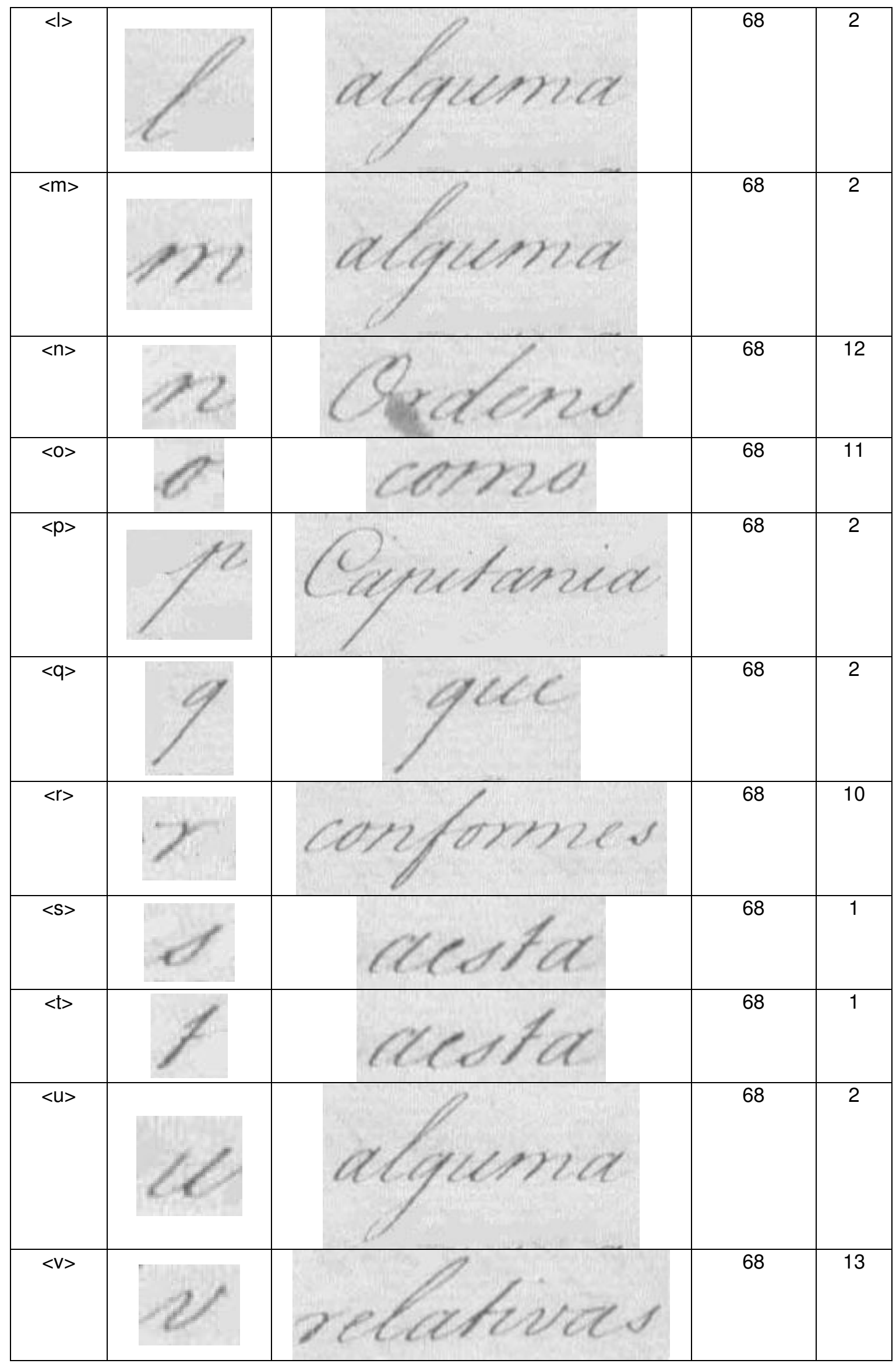

49 


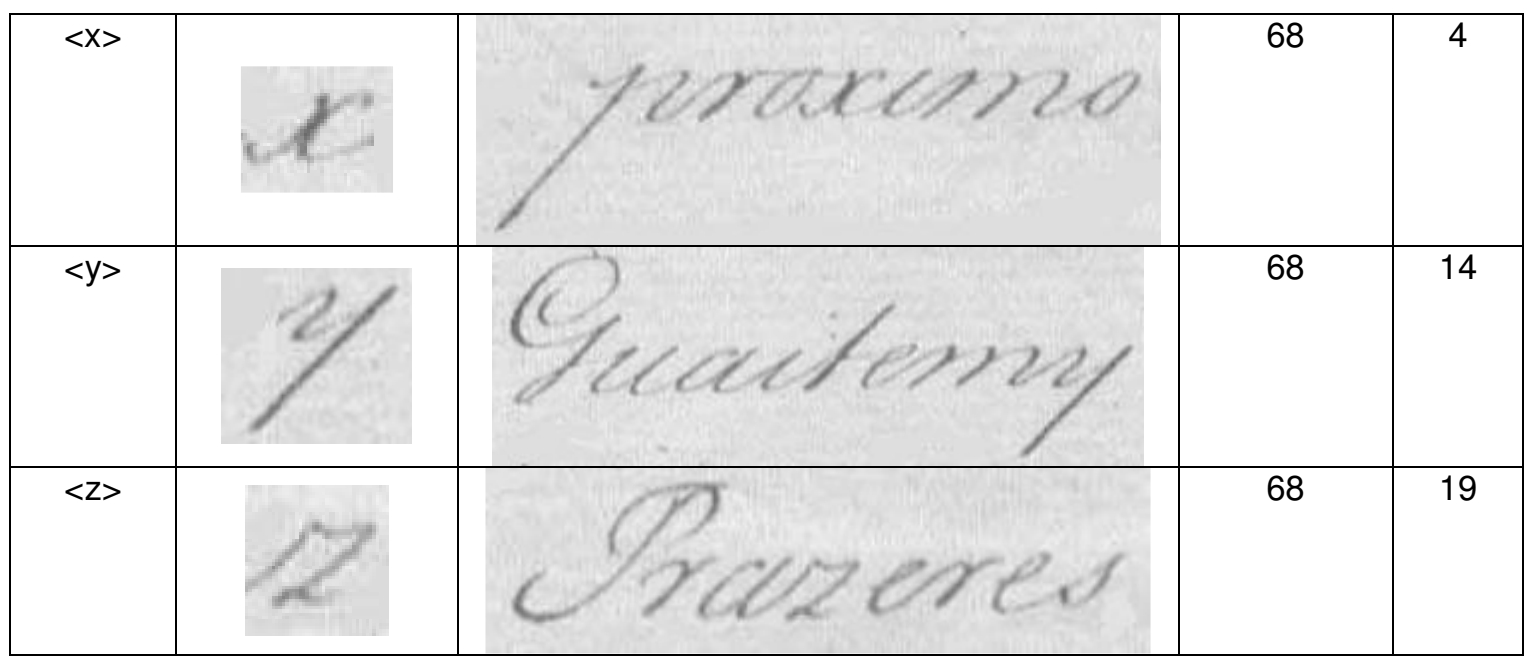

A partir da visualização das tabelas, verifica-se que os quatro punhos aqui retratados têm características distintas no que se refere ao ângulo, peso, ductus e módulo. Todas seguem o padrão de caligrafia cursiva proposto por Figueiredo (Figura 13), entretanto cada mão possui suas peculiaridades.

Seguindo-se a análise proposta por Megale (2006, p.116), de que existe um limite invisível no suporte, uma espécie de linha imaginária, que determina para cima o traçado de uma haste e para baixo, o traçado de uma cauda. E levando-se em conta os aspectos de ângulo, peso, ductus e módulo, apresentam-se exemplos que mais se diferem de letras com haste e cauda.

Os quadros 1 e 2 mostram uma caligrafia bastante regular, com ângulo inclinado para a direita e maiúsculas com traçado bem trabalhado. Conforme pode ser verificado, retornando-se aos quadros, as letras maiúsculas que apresentam traços peculiares são as maiúsculas $\langle\mathrm{F}\rangle$ e $\langle\mathrm{T}\rangle$ e as minúsculas $<\mathrm{d}>$ e $<\mathrm{l}>$. São também características desse punho as maiúsculas $\langle\mathrm{Q}>\mathrm{e}<\mathrm{Y}\rangle$ e as minúsculas $<\mathrm{y}>\mathrm{e}<\mathrm{f}>$.

Já os quadros 3 e 4, referentes ao punho 2, apontam a característica do peso bem carregado como distinção e letras pouco uniformes, com menos conexões entre si e pouco presas à linha imaginária inferior. No quadro 3 , encontram-se também características interessantes em $<\mathrm{F}>\mathrm{e}<\mathrm{T}>$. No quadro 4 , há as letras $<\mathrm{b}>\mathrm{e}<\mathrm{h}>$ com haste; $<\mathrm{p}>\mathrm{e}<\mathrm{y}>$ com cauda. 
Nos quadros 5 e 6, com palavras retiradas dos documentos 40, 41, 42 e 43, há maior proximidade da letra atual conhecida como "técnica" ou "bastão", embora conectadas entre si como a cursiva. No quadro 5 , as maiúsculas mais características são $\langle\mathrm{F}>$ e $\langle\mathrm{N}\rangle,\langle\mathrm{G}>\mathrm{e}<\mathrm{Q}>$. Enquanto no quadro 6, destacamse as minúsculas $<b>$ e $<\mathrm{d}>$ com haste; com cauda, $<\mathrm{f}>\mathrm{e}<\mathrm{j}>$.

Por sua vez, o punho 4 , exemplificado nos quadros 7 e 8 , tem letras robustas, regulares e bastante uniformes, com traçado pouco trabalhado nas maiúsculas, denotando rapidez e habilidade do escriba. No quadro $7,<\mathrm{L}>\mathrm{e}$ $\langle\mathrm{T}\rangle$ são as letras mais características, juntamente com $\langle\mathrm{S}\rangle \mathrm{e}\langle\mathrm{Y}\rangle$. Já no quadro 8 , encontram-se as minúsculas $\langle\mathrm{b}\rangle \mathrm{e}<\mathrm{t}\rangle$ com haste; $\langle\mathrm{p}\rangle \mathrm{e}<\mathrm{q}\rangle$ com cauda. 


\section{Capítulo 2: DESCRIÇÃO DIPLOMÁTICA: IDENTIFICAÇÃO DAS ESPÉCIES DOCUMENTAIS}

Dentre os vastos corpora de documentos brasileiros redigidos no século XVIII, foram selecionados os 68 documentos manuscritos encadernados no livro 170 e arquivados na lata $420^{4}$, sob o título "Avisos e Cartas Régias", no Arquivo do Estado de São Paulo. Esses documentos foram fac-similados em 191 fólios manuscritos que representam o corpus total, divididos em 68 documentos. Além disso, há outros 66 fólios impressos, em tamanho menor e encadernados em meio aos manuscritos ( $v$. anexo). A escolha dos 68 documentos para objeto de estudo deve-se, então, ao fato de comporem toda a parcela manuscrita do livro de número 170.

A seleção do corpus ter ocorrido no Arquivo do Estado de São Paulo deve-se ao fato de, Segundo Bellotto (2007, p. 18), lá estar arquivado o núcleo fundamental da correspondência ativa e passiva de Dom Luís Antonio de Souza, publicado em "Documentos Interessantes para a história e costumes de São Paulo" e nos livros manuscritos ainda não publicados, relativos a "Avisos e Cartas Régias" e "Provisões Régias". Entende-se aqui "correspondência" de um administrador colonial com seus superiores e com seus subordinados como a forma como se processa o receber e dar ordens. Era em forma de correspondência que chegavam a Morgado de Mateus a legislação e as disposições da Coroa; da mesma forma que fazia chegar a voz da Metrópole e a sua própria aos seus lugares-tenentes e aos órgãos de administração local.

De acordo com Silva (1989, p. 15), o corpus é sempre um corte intencional sobre a totalidade de uma língua, pois os documentos que retratam um estado de língua já passado determinam os limites de observação sobre documentações preexistentes. Por isso, o termo corpus é aqui empregado com

\footnotetext{
${ }^{4}$ O Arquivo do Estado de São Paulo, de acordo com Bellotto (2002, p. 7), tem sob a sua tutela um rico acervo e um grupo técnico capacitado para o desenvolvimento de suas atividades, o que the permite assumir o papel de relevo que the cabe historicamente na administração pública e entre os seus congêneres. Neste Arquivo, conforme afirma Menezes (1997, p.2) estão catalogados mais de 3.000 metros lineares de documentos produzidos ou acumulados pelo poder executivo de São Paulo desde o século XVI até 1980. A origem da acumulação do arquivo remonta ao ano de 1721, quando o Secretário de Governo Gervásio Leite Rabelo deu início ao inventário dos documentos de ordenança, para auxiliar o recém nomeado Capitão General Rodrigo César de Meneses na administração da Capitania de São Paulo. Hoje o arquivo conta com 10.000 latas ou caixas de documentos com cerca de 12.000 volumes de documentos encadernados.
} 
o mesmo significado daquele usado por Silva (1987, p. 16) em seu livro Estruturas Trecentistas, ou seja, designando o conjunto diversificado de documentos-informantes a serem analisados de forma fragmentada.

Os 68 manuscritos que compõem o corpus deste trabalho são documentos diplomáticos por se tratarem de registros legitimados de atos administrativos $^{5}$. Trata-se de atos escritos de origem governamental e/ou notarial que, emanados das autoridades supremas, delegadas ou legitimadoras, são submetidos, para efeito de validade, à sistematização imposta pelo Direito. A ciência responsável pelo estudo da estrutura formal dos documentos eivados de fé pública que lhes garanta a legitimidade de disposição e a obrigatoriedade da imposição é, segundo Bellotto (2002, p.13), a Diplomática. Como ciência afim da Filologia, a Diplomática concentra-se no estudo formal do documento diplomático, considerado individualmente, e no estudo de suas relações com o contexto orgânico de sua produção.

Este trabalho tem como base "documentos diplomáticos", de natureza jurídica, que refletem no ato escrito as relações políticas, legais, sociais e administrativas entre o Estado e os cidadãos, cujo conteúdo é submetido a tipologias textuais preestabelecidas. Sabendo-se que o discurso diplomático é aplicado a um quadro redacional no qual se insere o ato escrito, o documento diplomático é o testemunho escrito de um ato de natureza jurídica, redigido em observância a fórmulas estabelecidas que se destinam a dar-lhe fé e força de prova (Nuñez Contreras 1981, Apud Bellotto 2002).

Sendo o objeto da Diplomática a estrutura formal do documento, vale ressaltar que, segundo Bellotto (2002, p.13), um documento é formado por "estrutura" mais "substância", em que a estrutura corresponde a todo o substrato necessário à elaboração do documento, seja nos aspectos mais materiais, seja nos menos palpáveis; enquanto a substância é a essência, a razão de existir do documento, o conteúdo que o tornará único no seu contexto de produção e utilização. Assim, todo documento escrito implica: 1. um suporte ou veículo sustentador e transmissor da mensagem ou assunto (texto); 2. um

\footnotetext{
${ }^{5}$ Se é "ato jurídico todo aquele que tenha por fim imediato adquirir, resguardar, transferir, modificar ou extinguir direitos, $\mathrm{o}$ ato administrativo é $\mathrm{o}$ ato jurídico, porém, eivado pela finalidade pública; é toda manifestação unilateral de vontade da administração pública que, agindo nesta qualidade, tenha por fim imediato adquirir, resguardar, transferir, modificar, extinguir e declarar direitos ou impor obrigações aos administrados ou a si própria." (Ibid. 2002)
} 
conteúdo textual expresso com linguagem, vocabulário, escrita, estilo, fórmulas peculiares de acordo com a natureza e a importância do tema e em relação direta com a época, chancelaria, tabelionato, lugar, ambiente cultural, autor ou autores e destinatário; 3. determinada finalidade e ideologia; estruturação e formalidades variáveis e identificativas que the servem de garantia (PIQUERAS GARCÍA, 1999, Apud BELLOTTO 2002, p.18).

O texto do discurso diplomático, na realidade, é a união entre partes distintas: o protocolo inicial, o texto propriamente dito e o protocolo final. Nessas três partes evidenciam-se as coordenadas (representadas pelas fórmulas diplomáticas obrigatórias, próprias da espécie documental determinada pelo ato jurídico e seu objetivo) e as variantes (teor pontual e circunstancial relativo às especificidades do ato aplicado a um fato, pessoa ou assunto).

O protocolo inicial ou protocolo, na sequência dos dados, é constituído por: 1) invocação (invocatio) que, em geral, só ocorre nos atos dispositivos mais antigos (a expressão "Em nome de Deus" é um exemplo de invocação); 2) titulação (intitulatio), formada pelo nome próprio da autoridade (soberana ou delegada) de que emana $o$ ato e por seus títulos; 3) direção ou endereço (inscriptio), parte que nomeia a quem 0 ato se dirige, seja um destinatário individual ou coletivo; 4) saudação (salutatio), parte final do protocolo.

Já o texto constitui-se por: 1) preâmbulo (prologus ou exordium), no qual se justifica (por razões de ordem moral, jurídica ou material) a criação do ato; 2) notificação (notificatio ou promulgatio), que pode ser entendida na expressão "tenho a honra de comunicar a vós"; 3) exposição (narratio), na qual são explicitadas as causas do ato, o que o originou, quais as necessidades administrativas, políticas, jurídicas, econômicas, sociais ou culturais que 0 tornaram necessário; 4) dispositivo (dispositio), que é a substância do ato, seu "assunto" propriamente dito, em que se determina o que se quer (iniciado por um verbo na primeira pessoa, como "ordeno", "mando", "estabeleço", "sou servido..." etc; 5) sanção (sanctio ou minatio), na qual se assinalam as penalidades, no caso do não cumprimento do dispositivo; 6) corroboração ou cláusulas finais (valoratio ou corroboratio), em que se dispõe sobre os meios morais ou materiais que asseguram a execução do dispositivo (alguns autores 
classificam essa parte final do texto segundo suas variantes: cominatórias, que podem ser penais ou espirituais, de garantia, de renúncia ou de corroboração).

Enquanto o protocolo final ou escatocolo inicia-se após a corroboração ou cláusulas finais, com: 1) subscrição/assinatura (subscriptio), isto é, a assinatura do emissor/autor do documento ou quem o faça por sua ordem; 2) datação (datatio). É preciso distinguir a data tópica da data cronológica, ou o elemento topográfico do elemento cronológico. A primeira é referente à forma como está designado no documento o local onde ele foi assinado. Aí cabe, muitas vezes, não o nome de uma cidade, e sim a denominação de um palácio, de uma sala ou de um logradouro. Isto deve ser obedecido, sem que se acrescente a cidade na qual estejam situados. A segunda corresponde ao dia, mês e ano; 3) precação (apprecatio), onde, por meio de dois elementos (assinatura de testemunhas e sinais de validação, como carimbos e selos), reitera-se a legalidade do documento. (BELLOTTO 2002, p.39).

Há elementos de validação da autenticidade dos documentos, tais como assinaturas e o selo encontrado no documento 37, moldado sobre cera vermelha (Figura 15). Para a moldagem deste tipo de selo, é usado um sinete, pequeno objeto de metal como ouro ou prata (placa, coluna e até anel) usado como assinatura do proprietário para selar e autenticar documentos e cartas. Após a assinatura, a impressão é feita com um pouco de cera que é derramada sobre o papel no qual é pregado com o sinete, deixando um desenho pessoal, como um brasão ou um símbolo. Tal procedimento é usado desde a Grécia Antiga e teve larga utilização no século XVIII, servindo até hoje à Esfragística, ciência auxiliar da Diplomática que estuda o material e as figuras dos selos, como material de comprovação da autenticidade dos documentos. ${ }^{6}$

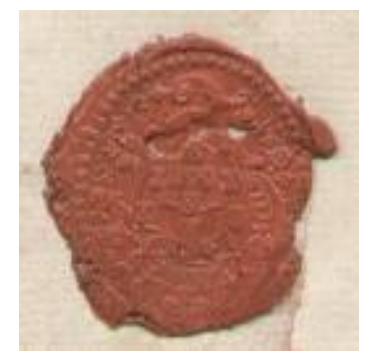

Figura 14: Selo circular em baixo relevo (Doc. 51).

Figura 15: Selo moldado em cera vermelha (Doc. 37)

\footnotetext{
${ }^{6}$ Acerca da Esfragística, há informações disponíveis no site: <http://www.arqnet.pt/portal/estudo/diplomat.html>
} 
Em oposição ao selo, que tem pouca recorrência no corpus, há a assinatura, bastante recorrente nos manuscritos. Tal assinatura parece ser autógrafa por apresentar o mesmo traçado de letras em todas as ocorrências. As assinaturas, segundo Acioli (1994, p. 57), vêm às vezes acompanhadas por cetras (traços supérfluos, laçaria caligráfica acrescentada a uma firma) que dificultam a interpretação quando o nome é desconhecido seria ou não o caso desta assinatura. Ao mesmo tempo em que se pode atribuir o traçado de letra ao próprio Morgado de Mateus, suas assinaturas corroboram que todos os documentos são cópias revistas e chanceladas por ele, com validade documental, portanto.

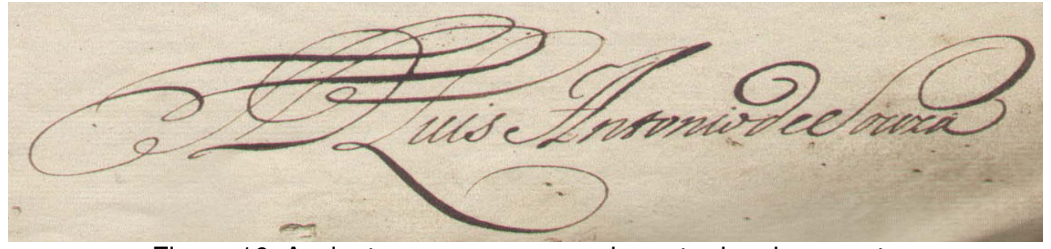

Figura 16: Assinatura comum a grande parte dos documentos.

Barbosa (2002) destaca a importância de se estudar o contexto de produção de fontes escritas para o estudo da história da língua portuguesa. Critica, em contrapartida, a adoção de tipologias que considerem apenas a situação e função da escritura. Diante disso, a análise das nove espécies documentais encontradas segue a classificação feita por Martinheira (1997), que apresenta uma tipologia de documentos produzidos pela Administração Central no Antigo Regime e contribuições de Faria (2008). Além disso, a análise leva em conta a teoria de que a tipologia documental visa aos objetivos da Diplomática, ciência que analisa a configuração interna e o estudo jurídico das partes para atingir a autenticidade do documento, conforme expõe Bellotto (2002, p.12). Assim, o documento deve ser estudado como parte constituinte de um conjunto de documentos, observando a relação desses textos com as atividades institucionais/pessoais.

Uma vez que os documentos do corpus encotram-se encadernados sem critérios claros de organização, o objetivo deste trabalho engloba a apresentação das espécies documentais e a catalogação de cada documento. Para tanto, foram empregados os manuais de Belloto (2002) e Martinheira (1997) e as valiosas observações da Professora Heloísa Liberali Belloto, a 
quem, sinceramente, agradecemos ${ }^{7}$. Torna-se importante ressaltar que embora a lata em que está arquivado o livro manuscrito seja intitulada "Avisos e Cartas Régias", há outras tipologias documentais, conforme o item 3.1 explicita a seguir.

\subsection{Espécies documentais}

Considerando-se que "espécie documental é a configuração que assume um documento de acordo com a disposição e a natureza das informações nele contidas." (BELLOTTO, 2002, p. 27), serão definidos alguns termos empregados na classificação de cada espécie documental encontrada no corpus.

Uma vez que o livro manuscrito apresenta os documentos encadernados de forma aleatória, o trabalho de organização do limite de cada documento, bem como a pesquisa para a classificação das espécies documentais, faz parte desse trabalho.

Para a melhor compreensão de cada espécie documental, vale definir que o termo "documento diplomático", segundo Bellotto (2002, p.35), refere-se aos documentos que têm natureza jurídica e refletem no ato escrito as relações políticas, sociais e administrativas entre o estado e os cidadãos. Ainda segundo Bellotto (2002, p. 29), os "documentos dipositivos" dividem-se em normativos (manifestações de vontade de autoridades supremas e que devem ser obrigatoriamente acatados pelos subordinados), de ajuste (são acordos de vontade entre duas ou mais partes) e correspondência (determinam a execução dos atos normativos no âmbito mais restrito da jurisdição). Os documentos informativos, por sua vez, são opinativos/enunciativos e esclarecem questões contidas em outros documentos, cujo conteúdo vai fundamentar uma resolução" (BELLOTTO, 2002, p.29)

Há, no corpus, espécies documentais ascendentes, que de acordo com Bellotto (2002, p.37) sobem dos súditos às instâncias superiores; descendentes, que descem do Rei e das autoridades superiores; e horizontais,

\footnotetext{
${ }^{7}$ Agradecemos o importante apoio da Professora Heloísa Liberalli Bellotto, que gentilmente emprestou materiais e, sobretudo, doou seu tempo em sua residência, contribuindo com suas valiosas orientações.
} 
que se distribuem entre autoridades/pessoas ou autoridades do mesmo nível. Em sua maioria, os documentos estudados são descendentes, sobretudo se considerarmos a afirmativa de Bellotto (2002, p. 37) de que o direcionamento dos papéis também ocorre do ponto de vista geográfico, descendo de Portugal ao Brasil.

Será apresentada, a seguir, uma breve descrição de cada espécie documental encontrada no corpus, com o intuito de contextualizar a classificação atribuída a cada documento, seguida de uma transcrição como modelo e dos números de documentos classificados em cada uma das espécies.

\subsubsection{Aviso}

Tido como "documento diplomático e/ou não-diplomático, informativo, descendente" (BELLOTTO, 2002, p.49), tem forma de ofício e foi empregado na administração colonial para que os secretários de Estado transmitissem ordens régias em nome do soberano.

Os avisos ou "cartas dos secretários" são, segundo Martinheira (1997, p. 15), ordens expedidas em nome do soberano pelos secretários de Estado a qualquer magristrado, pela qual se ordenava a execução das reais ordens.

Como exemplo, a seguir, encontra-se a estrutura da transcrição do Documento número 1:

\section{$\underline{\text { Texto }}$}

SuaMagestade [dispositivo] hêservido, queVossaSenhoria pelas*

ocazioens, queseoferecerem, mandecom amayor

recomendaçaõ entregar noRio delaneiro, to-

daaqualidadedepassaroz, eAnimaes qua

drupedes, quesepoderemdescobrir nessasCa

pitaniaz, para daLy serem remetidos aeste

Reyno: OqueomesmoSenhorha pormuito

\footnotetext{
* Acima há um carimbo circular do AESP.
} 
recomendadoaVossaSenhoria

[Protocolo final] DeosGuarde aVossaSenhoria [fecho de cortesia]Palacio deNossa Senhora daAjuda[data tópica] a $\underline{5}$ deOutubrode 1773 [data cronológica] = Martinho deMelloeCastro [subscrição]= Senhor Dom Luis AntoniodeSouza BotelhoMouraõ

DomLuis AntoniodeSouza

Nesta categoria, enquadram-se os documentos transcritos de número 1 , $2,4,10,19,39,43,44,46,54,55,65$ e 67.

\subsubsection{Carta Régia}

A "Carta Régia" segundo Bellotto (2002, p. 54), é de um documento diplomático, dispositivo normativo, descendente, uma ordem real, dirigida a uma determinada autoridade ou pessoa e iniciada pelo nome dela. É expedida imediatamente pelo soberano e por ele assinada como Rei (Rainha ou Príncipe Regente, se for o caso) ou por algum de seus representantes legais. Compõem-se da seguinte maneira (transcrição do documento 11):

\section{[Protocolo Inicial] Copia}

Dom Luis Antonio deSouza $\mathrm{Bo}=$ telho Mouraõ Governador eCapitaõ General daCa= pitania deSaõPaulo Amigo EU ELREY vos invio muitoSaudar: [direção, titulação, notificação] [Texto] Atendendo aos Servi= cos queManoel JozedaNobrega Botelho fes no Posto deCapitaõ deExtincto Regimento dos Volun= tarios Reaes: Hey porbem nomealoSargento Mor deInfantaria daLegiaõdePaulistas, Sertanejos,e 
Caçadores, que mandolevantar nessaCapitaniade Saõ

Paulo: [exposição] EvosOrdenoquelhe mandeis sentar Praça

dar posse, epagar osSoldos correspondentes ao referi-

doPosto, sem embargo de que naõaprezente $\mathrm{aPa}=$

tente naforma ordinaria. O quetudo executareis

naõ obstantes quaes querLeys Regimentos ou Dispo-

siçoens queSejaõ em contrario. [dispositivo]

[Protocolo final] Escrita no Palacio

deNossaSenhoradaAjuda [data tópica] emdes deSetembrode

mil sete centos Setenta equatro[data cronológica]. Rey[subscrição] com Guar= da Para Dom Luis AntoniodeSouza.

Dom Luis AntoniodeSouza

As cartas régias encontradas no livro manuscrito são os documentos de número $3,7,11,12,13,16,28,30,33,48,50$ e 68.

\subsubsection{Ofício}

Os ofícios são documentos não-diplomáticos, informativos, por meio dos quais se mantém o intercâmbio de informações de forma padronizada e em caráter oficial entre subalternos e autoridades e entre órgãos públicos e particulares. Segue, como modelo, a transcrição do documento 5:

Copia [Texto] Foraõ prezentes aSua Magesta= de as Relaçoens deVossaSenhoria comdatas de3,e 4 deDezembro de1772 emrepostadasCartas que Ihe dirigi com data doprimeiro deOutubrode1771: E igualmente vio omesmoSenhor as outras Rela= çoens deVossaSenhoria comdata de14 deAbril de1773 
e oPapel intitulado $=$ Notas $=$ emrepostadaCar

ta quetambemlhe escrevi com data de20 de $\mathrm{No}=$ vembro de1772: E reservando paraoutra ocasi= aõ dizeraVossaSenhoria ojuizo que aqui sefez sobre os ex= tensissimos, dispendiosos, eimpraticaveis Serviços de quetrataõ as ditas Relaçoens, Ihe voutaõ somenteparticipar as positivasOrdens deSuaMagestade, queVossaSenhoria achará noPapeljunto assignado daminhaLetra. [exposição]

Deos Guarde aVossaSenhoria Pala $=$ [fecho de cortesia] cio deNossaSenhoradaAjuda [data tópica] em21 de Abril de1774 [data cronológica $]=$ MartinhodeMelloeCas $=$ [assinatura do emitente] tro $=$ SenhorDomLuis Antonio deSouzaBotelho Mouraõ.

\section{DomLuis AntoniodeSouza}

Os ofícios encontrados no livro manuscrito são os de número 5, 6,15, 18, $23,24,27,29,32,35,36,38,40,41,42,52,53,56,57,58$ e 59.

\subsubsection{Passaporte}

Trata-se de um documento diplomático informativo que autorizava, na administração colonial, pessoas, viaturas ou embarcações a deslocarem-se de país a outro. Segue o único passaporte transcrito neste trabalho (documento 20):

[Texto] A Francisco Xavier de Araujo, filho de Theodozio de Araujo, ja defundo, e de sua Mulher Maria Luiza daSilva, Solteiro, e sem Officio, natural da 
Freguezia de Santiago de Lanhozo Comarca deGuimaraẽns

Arcebispado deBraga, eaSistente na rua Augusta, em

Caza do Capitaõ loaõ de Freitas Monteiro; de Estatura

menos que ordinaria, alvarinho, Com alguns Sinaes de be-

xigas, olhos pardos Cabello Castanho escuro, ealgum

tanto crespo: Sepassou atestaçaõ poresta junta do

Commercio destes Reynos, e Seus Dominios, para pas

Sar pela Villa de Santos, para a de Goyazes, para Caza

deSeuTio loze Antonio de Araujo [exposição] Lixboa [data tópica] ao primeiro de

lunho de 1767 [data cronológica]

loaõ Luiz de Souza Sayaõ [subsrição]

Apenas o documento 20 é um passaporte.

\subsubsection{Provisão}

Tal espécie é um documento diplomático dispositivo de correspondência, descendente, em que o rei conferia algum benefício ou cargo a alguém e emite ordem baseada em dispositivos anteriores. Encontra-se, a seguir, o documento de número 22, uma provisão:

[Texto] Domlozé porgraça de Deos Rey dePortugal edos Algarves daquem

edalem mar em Africa, Senhor deGuiné etcoetera [titulação]Faço saber avôs Governador, eCappitam

General daCapitania deSaõ Paulo, eSantos [direção]que lozê Alvares deMira rematou no meu Concelho VLtramarino paraSy, eparaSeo Socio loaõ Baptis[ta] deoLiveiraCosta o Contrato do Subsidio dos molhados, enovo [e]mposto daPraça deSantos dessaCappitania, portempo de tres annos, parater principio, emo primeiro delaneiro, demilSete centos Secenta, eouto, por preço emcada hum delles, de humConto, quinhentos etrintae Sinco mil reis, Livres pa- 
ra aminha realFazenda; como vereis do exemplar impreco dasCondiçoẽns,

eAlvará, quecomesta Sevos remete asignado pello Secretario domesmo Con-

selho; pelloque SouServido ordenarvos façaes cumprir odito Contrato e

suas Condiçoẽns como nellas Secontem. [exposição] EIRey Nosso Senhor omandou

pellosConcelheiros do SeoConcelho VLtramarino abaixo asignados Antonio

FerreiradeAzevedo afes em Lisboa [data tópica] adous delunho, demilSeteCentos

Secenta,eSete [data cronológica]epagoude feitio destatrezentos reis, edeasignaturaouto cen-

tos reis. Secretario loaquim [onnofre de farea] [ilegível]

DiogoRangeldeAlmeida[Cardozo]FranciscoMarcellinodeGouveia [subsrições]

Encontra-se uma provisão no documento 22.

\subsubsection{Registro}

Documento não-diplomático testemunhal de assentamento que consiste em inscrição ou transcrição de atos, fatos, títulos e documentos a fim de autenticá-los. Segue o registro de número 8:

Registada a folhas $\underline{135}$ do livro primeiro deregisto

deOrdensRegias. SaõPaulo a12

deMayo de $\underline{1775}$

lozeCarlosdosSantosBernardes

Os documentos de números 8 e 14 são classificados como registros.

\subsubsection{Relação}

Também chamada de "Lista" ou "Listagem", é um documento nãodiplomático informativo em que consta rol de nomes de pessoas, objetos, quantias, fatos, etc. Encontra-se, a seguir, o primeiro fólio do documento 21 : Relaçaõ detoda a Artilharia e Moniçoens pertencen= tes a mesma Artilharia.

Pessas debronze de calibre detres da 
nova invençaõ seis

6 Pessas debronze

Pessas debronze de calibre dehum seis 6 Pessas debronze

Reparos para as doze pessas com suas

rodas eferrage Doze................ 12 Reparos

Chapuzes comparafuzos e soleiras para

as pessas de calibre de tres, Seis

6 Chapuzes

Chapuzes de reparos dehuma libra

Seis

6 Chapuzes

Carros manxegos com suas rodas eferra=

ges, com quatro cauxas dentro, e dous

cadeados cadahum Doze

12 Carros man-

Tapas depaô com coleiras de coiro para xegos.

as bocas das pessas, Doze

12 Tapas de pau

Pranxadas de Chumbo, Doze

12 Pranxadas

Capas deOliado para cobrir as pessas, doze 12 Capas deOliado

Cartuxos debaetilha, dois mil e quatrocentos 2400 Cartuxos

Fundos de papel para os mesmos cartu= xos, dous mil equatro centos. 2400 Fundos de papel

Capas de papel curvado para os ditos cartu= xos, duas mil e quatro centas. $\quad 2400$ Capas depapel

Balas fixas atacos depao, seis centas 600 Balas com

Lanternetas cheyas de peloiro para as tacos

pessas dehumalibra trezentas. 300 Lanternetas

Lanternetas cheyas debala miuda deferro fixas atacos depao para as pessas detres; trezentas 300 Lanternetas 
São relações os documentos número 21, 60, 61, 62, 63, 64 e 66.

\subsubsection{Reparo}

Trata-se da apresentação escrita de um exame atento, análise ou observação. Não apresenta estrutura formalizada, não constando no manual de Martinheira (1997, p.10). Transcreve-se, a seguir, o primeiro fólio do documento 25:

Reparos Sobre a deffença doRio

Grande de Saõ Pedro, eSeus Territorios.

A Situaçaõ do Rio Grande he munto infe-

Lis para se Fortificar; oseu Terreno naõ tendo

solides nenhuma, sendo pura areya taõ miuda,

e fina, que naõ só entra por todas as Cazas, e Co=

zinhas por fichadas que estejam, nem basta $\mathrm{di}=$

Ligencia alguma para impedir, que naõ se in=

troduza no Comer, mas acada passo seve a

metamorphose / com os Ventos impetuozos que

nesta Paragem dominam / deachar os Montes

de Areya, onde o dia antes se havia deixado

o pLano, eeste onde estava o Monte: Demo-

do que a Sua Fortificaçaõ no estreito, que no-

anno de 53 quando por esta Paragem passou

o Conde de Bobadella com o Seu acompanha=

mento, indo a Castilhos Grandes para conferir

com o Marquez deVal deLirios, ainda sepo-

dia conhecer o deLiniamento da dita Fortefi= 
caçaõ, alguns Bastioens della, etodos os Seus $\mathrm{Pa}=$

rapeitos estavam descubertos; mas despois de

dous annos, ealguns Mezes, voltando ámes=

ma Paragem, sedesconheceu o Pais; porque

ja naõ aparecia nenhum vestigio daSobredi=

ta Fortificaçaõ, e amesma Caza do Comandante [exposição]

Apenas o documento número 25 é um reparo.

\subsubsection{Sobrescrito}

O "sobrescrito", segundo Faria (2008, p.65), é o

[...]recipiente plano usado para meter cartas e outros papéis, normalmente de forma retangular, conseguido a partir de uma folha de papel dobrada, de modo a obter um recto liso e um verso formado por quatro abas sobrepostas; geralmente três ou duas destas abas são coladas entre si, servindo a quarta aba, colada ou não, para fecho; o recto do sobrescrito pode conter uma janela transparente.

Consiste no nome e endereço escritos sobre envelope, capa ou invólucro de carta ou ofício e não aparece nos manuais de tipologia textual consultados. $\mathrm{O}$ documento 31 , transcrito a seguir, ilustra essa tipologia:

\section{Por ELREY}

A Dom Luis Antonio deSouza Bote= Iho Mouraõ do seu Conselho, Governador eCapitam General daCapitania de

Saõ Paulo. 
São sobrescritos os documentos número 9, 17, 26, 31, 34, 37, 45, 47, 49 e 51.

Nota-se que os documentos régios selecionados, embora apresentem diversos autores, obedecem a critérios recorrentes quanto à forma, periodicidade e destinatário, conforme se pode verificar no quadro 1.

Há, no total dos sessenta e oito documentos do livro: um passaporte, uma provisão, um reparo, dois registros, sete relações, dez sobrescritos, onze cartas régias, quatorze avisos e vinte e um ofícios, conforme mostra o gráfico a seguir:

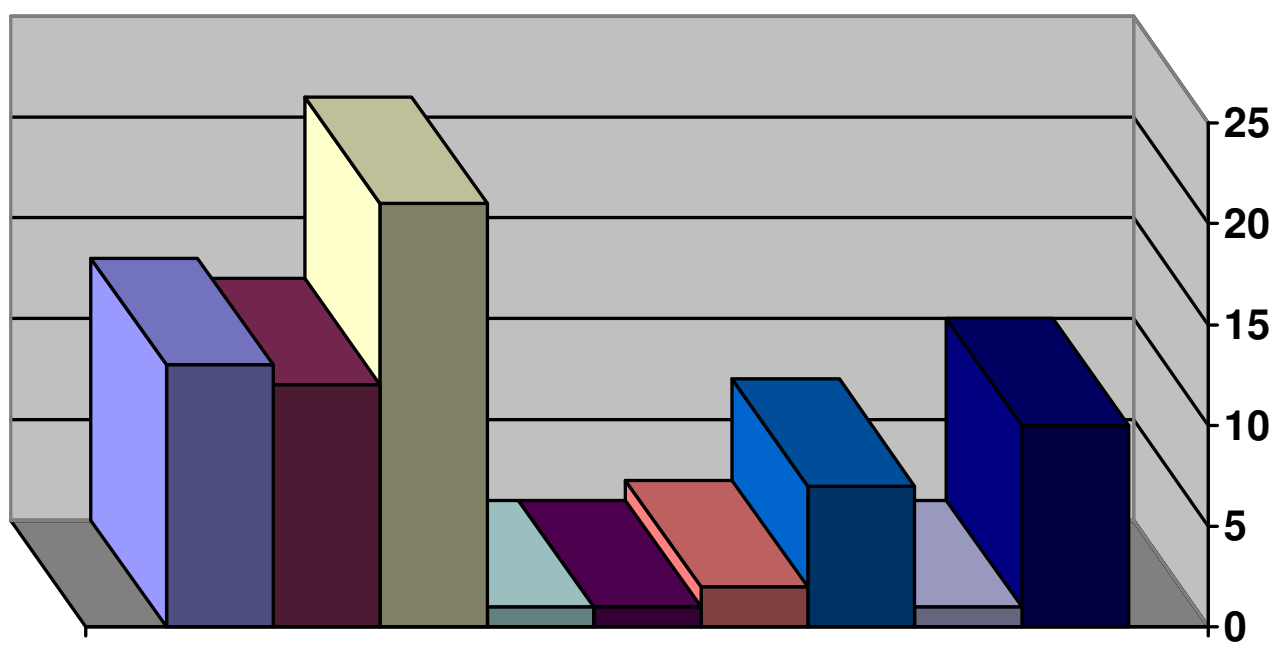

\begin{tabular}{|l|}
\hline Avisos \\
$\square$ Cartas Régias \\
$\square$ Ofícios \\
$\square$ Passaporte \\
$\square$ Provisão \\
$\square$ Registro \\
$\square$ Relação \\
$\square$ Reparo \\
$\square$ Sobrescrito \\
\hline
\end{tabular}

Ocorrências

Figura 17: Gráfico de ocorrências.

Tal gráfico serve para mostrar que, embora o título de catalogação do corpus no Arquivo Histórico do Estado de São Paulo seja "Avisos e cartas régias", a tipologia textual de maior recorrência é o ofício.

\subsection{Documentos manuscritos}

O quadro a seguir arrola a ordem de encadernação em que os fólios encontram-se no livro manuscrito, enquanto a numeração dos documentos foi organizada exclusivamente para este projeto. Os números dos fólios, apresentados entre parênteses, obedecem à sequência do livro e, 
consequentemente, dos fac-símiles. Há, entretanto, no canto superior de cada fólio recto, um número, provavelmente colocado após a montagem do livro; tais números, por nada influenciarem neste trabalho, não serão transcritos, conforme estabelecido nas Normas de transcrição (Capítulo 4).

Na primeira coluna, intitulada "Número do documento", há a numeração dos documentos determinada para este trabalho, de acordo com a sequência de encadernação do livro manuscrito. Essa numeração será usada como base para todas as análises nessa dissertação.

A coluna "Data cronológica" apresenta as datas escritas em cada manuscrito. Para uma melhor classificação, decidiu-se por apresentar a ordem de ano, mês e dia.

Os fólios foram, na terceira coluna, apresentados com a sequência exata em que aparecem no livro manuscrito, considerando-se na contagem as páginas em branco. Segue-se, entre parênteses, a quantidade de páginas redigidas para o referido documento.

Para facilitar a identificação dos manuscritos, a quarta coluna transcreve a primeira linha do documento.

Há a cópia da assinatura, na coluna "Subscrição" e do local apresentado no manuscrito na penúltima coluna "Data tópica".

A última coluna, por sua vez, apresenta a espécie documental atribuída a cada documento, seguindo a classificação anterior.

Quadro 9: Quadro sinóptico dos documentos manuscritos

\begin{tabular}{|c|c|c|c|c|c|c|}
\hline $\begin{array}{c}\text { Número } \\
\text { do } \\
\text { Documento }\end{array}$ & $\begin{array}{c}\text { Data } \\
\text { Cronológica } \\
\text { Ano-Mês-Dia }\end{array}$ & $\begin{array}{c}\text { Fólios } \\
\text { (Quantidade } \\
\text { de páginas) }\end{array}$ & $\begin{array}{c}\text { Primeira Linha } \\
\text { do Documento }\end{array}$ & Subscrição & Tópica & $\begin{array}{c}\text { Espécie } \\
\text { Documental }\end{array}$ \\
\hline 1 & $1773-10-05$ & $1 \mathrm{r}(1)$ & $\begin{array}{c}\text { SuaMagestade } \\
\text { hêservido, } \\
\text { queVossaSenhori } \\
\text { a pelas }\end{array}$ & $\begin{array}{c}\text { Martinho de Mello } \\
\text { e Castro }\end{array}$ & $\begin{array}{c}\text { Palácio de Nossa } \\
\text { Senhora da } \\
\text { Ajuda }\end{array}$ & Aviso \\
\hline 2 & $1773-10-14$ & $2 r(1)$ & $\begin{array}{c}\text { Sendo prezente } \\
\text { aSuaMagestade } \\
\text { peloBis= }\end{array}$ & $\begin{array}{c}\text { Martinho de Mello } \\
\text { e Castro }\end{array}$ & $\begin{array}{c}\text { Palácio de Nossa } \\
\text { Senhora da } \\
\text { Ajuda }\end{array}$ & Aviso \\
\hline 3 & $1773-17-10$ & $3 r$ a $4 \mathrm{r}(3)$ & $\begin{array}{c}\text { Dom Luis Antonio } \\
\text { de Souza } \\
\text { Governador, } \\
\text { eCapitaõ Gene= }\end{array}$ & Rei & $\begin{array}{c}\text { Palácio de Nossa } \\
\text { Senhora da } \\
\text { Ajuda }\end{array}$ & Carta régia \\
\hline 4 & $1773-11-09$ & $7 r(1)$ & $\begin{array}{c}\text { SuaMagestade } \\
\text { he servido, }\end{array}$ & $\begin{array}{c}\text { Martinho de Mello } \\
\text { e Castro }\end{array}$ & $\begin{array}{c}\text { Palácio de Nossa } \\
\text { Senhora da } \\
\text { Ajuda }\end{array}$ & Aviso \\
\hline
\end{tabular}




\begin{tabular}{|c|c|c|c|c|c|c|}
\hline 5 & $1774-04-21$ & $\operatorname{9r}(1)$ & $\begin{array}{l}\text { Foraõ prezentes } \\
\text { aSua Magesta= }\end{array}$ & $\begin{array}{c}\text { Martinho de Mello } \\
\text { e Castro }\end{array}$ & $\begin{array}{c}\text { Palácio de Nossa } \\
\text { Senhora da } \\
\text { Ajuda }\end{array}$ & Ofício \\
\hline 6 & $1774-04-21$ & 10r a $16 r(11)$ & $\begin{array}{c}\text { Copia } \mid \\
\text { Emprimeiro Lugar } \\
\text { reprova }\end{array}$ & $\begin{array}{c}\text { Martinho de Mello } \\
\text { e Castro }\end{array}$ & $\begin{array}{c}\text { Palácio de Nossa } \\
\text { Senhora da } \\
\text { Ajuda }\end{array}$ & Ofício \\
\hline 7 & $1774-09-10$ & $17 r(1)$ & $\begin{array}{l}\text { Dom Luis Antonio } \\
\text { deSouza Gover= }\end{array}$ & Rei & $\begin{array}{c}\text { Palácio de Nossa } \\
\text { Senhora da } \\
\text { Ajuda }\end{array}$ & Carta régia \\
\hline 8 & $1775-05-12$ & $18 r(1)$ & $\begin{array}{l}\text { Registrada a } \\
\text { folhas } 135 \text { do } \\
\text { livro primeiro } \\
\text { deregisto }\end{array}$ & $\begin{array}{c}\text { Joze dos Santos } \\
\text { Bernardes }\end{array}$ & São Paulo & Registro \\
\hline 9 & $\begin{array}{c}\text { Sem data } \\
\text { cronológica }\end{array}$ & $18 \mathrm{v}(1)$ & Por ELREY & Rei & São Paulo & Sobrescrito \\
\hline 10 & 1774-04-21 & 19r a 22 r (7) & $\begin{array}{c}\text { Para } \\
\text { lozêCostodio } \\
\text { deSâ eFaria }\end{array}$ & $\begin{array}{c}\text { Martinho de Mello } \\
\text { e Castro }\end{array}$ & $\begin{array}{c}\text { Palácio de Nossa } \\
\text { Senhora da } \\
\text { Ajuda }\end{array}$ & Aviso \\
\hline 11 & $1774-09-10$ & $23 r(1)$ & $\begin{array}{c}\text { Copia | Dom Luis } \\
\text { Antonio deSouza } \\
\text { Bo }=\end{array}$ & Rei & $\begin{array}{c}\text { Palácio de Nossa } \\
\text { Senhora da } \\
\text { Ajuda }\end{array}$ & Carta régia \\
\hline 12 & $1774-09-13$ & $24 r(1)$ & $\begin{array}{l}\text { Copia | Serve } \\
\text { esta deCuberta } \\
\text { aCartaRe- }\end{array}$ & $\begin{array}{c}\text { Martinho de Mello } \\
\text { e Castro }\end{array}$ & $\begin{array}{c}\text { Palácio de Nossa } \\
\text { Senhora da } \\
\text { Ajuda }\end{array}$ & Carta régia \\
\hline 13 & 1774-09-13 & $25 r(1)$ & $\begin{array}{c}\text { Serve esta de } \\
\text { Cuberta â Carta } \\
\text { Regia }\end{array}$ & $\begin{array}{c}\text { Martinho de Mello } \\
\text { e Castro }\end{array}$ & $\begin{array}{c}\text { Palácio de Nossa } \\
\text { Senhora da } \\
\text { Ajuda }\end{array}$ & Carta régia \\
\hline 14 & $1775-05-12$ & $26 r(1)$ & $\begin{array}{c}\text { Registrada } \\
\text { afolhas } 136 \text { do } \\
\text { livro primeiro } \\
\text { deregistro }\end{array}$ & $\begin{array}{c}\text { Joze dos Santos } \\
\text { Bernardes }\end{array}$ & São Paulo & Registro \\
\hline 15 & $1767-04-29$ & $29 r$ e $29 v(2)$ & $\begin{array}{c}\text { Constando aSua } \\
\text { Magestade por } \\
\text { certas } \\
\text { informaçoens, } \\
\text { que- }\end{array}$ & $\begin{array}{c}\text { Francisco Xavier } \\
\text { de Mendonça } \\
\text { Furtado }\end{array}$ & $\begin{array}{c}\text { Palácio de Nossa } \\
\text { Senhora da } \\
\text { Ajuda }\end{array}$ & Ofício \\
\hline 16 & $1767-05-13$ & $30 r(1)$ & $\begin{array}{l}\text { Dom Luiz Antonio } \\
\text { deSouza Bo- }\end{array}$ & Rei & $\begin{array}{c}\text { Palácio de Nossa } \\
\text { Senhora da } \\
\text { Ajuda }\end{array}$ & Carta régia \\
\hline 17 & $\begin{array}{l}\text { Sem data } \\
\text { cronológica }\end{array}$ & $31 \mathrm{v}(1)$ & Por EIREY & Rei & São Paulo & Sobrescrito \\
\hline 18 & $1767-06-01$ & $32 r(1)$ & $\begin{array}{c}\text { Senhor } \\
\text { Governador da } \\
\text { Praça de Santos }\end{array}$ & $\begin{array}{c}\text { Joaquim Ignácio } \\
\text { da Cruz }\end{array}$ & Lisboa & Ofício \\
\hline 19 & $1767-05-11$ & $32 v(1)$ & $\begin{array}{l}\text { Copia | Sua } \\
\text { Magestade he } \\
\text { servido que a } \\
\text { lunta do } \\
\text { Commerci- }\end{array}$ & $\begin{array}{l}\text { João Luiz de } \\
\text { Souza Saião }\end{array}$ & Paço & Aviso \\
\hline 20 & $1767-06-01$ & $33 r(1)$ & $\begin{array}{c}\text { A Francisco } \\
\text { Xavier de Araujo, } \\
\text { filho de }\end{array}$ & $\begin{array}{l}\text { João Luiz de } \\
\text { Souza Saião }\end{array}$ & Lisboa & Passaporte \\
\hline
\end{tabular}




\begin{tabular}{|c|c|c|c|c|c|c|}
\hline 21 & $\begin{array}{l}\text { Sem data } \\
\text { cronológica }\end{array}$ & $33 v$ a $34 v(3)$ & \begin{tabular}{|c|} 
Rellaçaõ das \\
Pessoas deque \\
Consta a Equipa-
\end{tabular} & $\begin{array}{l}\text { João Luiz de } \\
\text { Souza Saião }\end{array}$ & Sem data tópica & Relação \\
\hline 22 & $1767-06-02$ & $36 r(1)$ & $\begin{array}{c}\text { Domlozé } \\
\text { porgraça de Deos } \\
\text { Rey dePortugal } \\
\text { edos Algarves } \\
\text { daquem }\end{array}$ & $\begin{array}{l}\text { Francisco } \\
\text { Marcellino de } \\
\text { Gouveia }\end{array}$ & Lisboa & Provisão \\
\hline 23 & $1768-06-20$ & $37 r(1)$ & $\begin{array}{c}\text { Copia | } \\
\text { Abrevidade com } \\
\text { que partem } \\
\text { osNavios, que } \\
\text { de- }\end{array}$ & Conde de Oeiras & $\begin{array}{c}\text { Palácio de Nossa } \\
\text { Senhora da } \\
\text { Ajuda }\end{array}$ & Ofício \\
\hline 24 & $1767-06-20$ & $39 r$ a $41 v(6)$ & $\begin{array}{c}\text { Copia | } \\
\text { Illustríssimo e } \\
\text { Excelentíssimo } \\
\text { Senhor }\end{array}$ & Conde de Oeiras & $\begin{array}{c}\text { Palácio de Nossa } \\
\text { Senhora da } \\
\text { Ajuda }\end{array}$ & Ofício \\
\hline 25 & $\begin{array}{l}\text { Sem data } \\
\text { cronológica }\end{array}$ & $43 r$ a $49 v(14)$ & $\begin{array}{c}\text { Reparos Sobre a } \\
\text { deffença doRio } \\
\end{array}$ & Sem subscrição & Sem data tópica & Reparo \\
\hline 26 & $\begin{array}{l}\text { Sem data } \\
\text { cronológica }\end{array}$ & $50 r(1)$ & $\begin{array}{l}\text { AoSenhor Dom } \\
\text { Luiz Antonio de } \\
\text { Sou= }\end{array}$ & $\begin{array}{c}\text { Francisco Xavier } \\
\text { de Mendonça } \\
\text { Furtado }\end{array}$ & São Paulo & Sobrescrito \\
\hline 27 & $1767-06-23$ & $51 \mathrm{r}(1)$ & $\begin{array}{c}\text { Copia | Para que } \\
\text { VossaSenhoria } \\
\text { naõ ignore o que } \\
\text { se tem }\end{array}$ & $\begin{array}{c}\text { Francisco Xavier } \\
\text { de Mendonça } \\
\text { Furtado }\end{array}$ & Rio de Janeiro & Ofício \\
\hline 28 & $1767-06-14$ & $52 r$ a $53 r(3)$ & $\begin{array}{c}\text { Copia | } \\
\text { Illustríssimo e } \\
\text { Excelentíssimo } \\
\text { Senhor } \\
\end{array}$ & Conde vice-rei & $\begin{array}{c}\text { Palácio de Nossa } \\
\text { Senhora da } \\
\text { Ajuda }\end{array}$ & Carta régia \\
\hline 29 & $1767-03-22$ & $54 \mathrm{r}$ a $56 \mathrm{v}(6)$ & $\begin{array}{l}\text { Copia da Carta } \\
\text { do Illustríssimo e } \\
\text { Excelentíssimo } \\
\text { Senhor. }\end{array}$ & $\begin{array}{c}\text { Francisco Xavier } \\
\text { de Mendonça } \\
\text { Furtado }\end{array}$ & $\begin{array}{c}\text { Palácio de Nossa } \\
\text { Senhora da } \\
\text { Ajuda }\end{array}$ & Ofício \\
\hline 30 & $1767-08-21$ & $58 r(1)$ & $\begin{array}{c}\text { Dom Luiz Antonio } \\
\text { deSouza Botelho } \\
\text { Mou= }\end{array}$ & Rei & $\begin{array}{c}\text { Palácio de Nossa } \\
\text { Senhora da } \\
\text { Ajuda }\end{array}$ & Carta régia \\
\hline 31 & $\begin{array}{l}\text { Sem data } \\
\text { cronológica }\end{array}$ & $59 v(1)$ & Por EIRey & Rei & São Paulo & Sobrescrito \\
\hline 32 & $1767-10-20$ & $60 r(1)$ & $\begin{array}{c}\text { Copia | Depois } \\
\text { deter recebido as } \\
\text { se }\end{array}$ & Conde de Cunha & Rio de Janeiro & Ofício \\
\hline 33 & $1768-12-15$ & $62 r(1)$ & $\begin{array}{c}\text { DomLuiz Antonio } \\
\text { deSouza Botelho } \\
\text { Mou= }\end{array}$ & Rei & $\begin{array}{c}\text { Palácio de Nossa } \\
\text { Senhora da } \\
\text { Ajuda }\end{array}$ & Carta régia \\
\hline 34 & $\begin{array}{l}\text { Sem data } \\
\text { cronológica }\end{array}$ & $63 v(1)$ & PorEIRey & Rei & São Paulo & Sobrescrito \\
\hline 35 & $1769-03-02$ & $64 r(1)$ & $\begin{array}{c}\text { Copia I Com a } \\
\text { chegada daNao } \\
\text { deGuerra Nossa }\end{array}$ & $\begin{array}{c}\text { Francisco Xavier } \\
\text { de Mendonça } \\
\text { Furtado }\end{array}$ & Oeiras & Ofício \\
\hline 36 & $1769-04-04$ & $67 r$ e $67 v(2)$ & $\begin{array}{c}\text { Sendo prezentes } \\
\text { a Sua Magestade } \\
\text { alguns descuidos, } \\
\text { ede }=\end{array}$ & Conde de Oeiras & Lisboa & Ofício \\
\hline 37 & $\begin{array}{l}\text { Sem data } \\
\text { cronológica }\end{array}$ & $69 \mathrm{v}(1)$ & $\begin{array}{l}\text { Ao Illustríssimo } \\
\text { Senhor Dom Luis } \\
\text { Antonio deSouza }\end{array}$ & $\begin{array}{l}\text { Inspetor geral do } \\
\text { real erário }\end{array}$ & São Paulo & Sobrescrito \\
\hline
\end{tabular}




\begin{tabular}{|c|c|c|c|c|c|c|}
\hline & & & Gover- & & & \\
\hline 38 & $1769-04-22$ & 70r e 70v (2) & $\begin{array}{c}\text { Sendo prezente a } \\
\text { Sua Magestade } \\
\text { oreque- }\end{array}$ & $\begin{array}{c}\text { Francisco Xavier } \\
\text { de Mendonça } \\
\text { Furtado }\end{array}$ & $\begin{array}{c}\text { Palácio de Nossa } \\
\text { Senhora da } \\
\text { Ajuda }\end{array}$ & Ofício \\
\hline 39 & $1769-04-24$ & $71 r(1)$ & $\begin{array}{c}\text { Para Dom Luiz } \\
\text { Antonio deSouza }\end{array}$ & $\begin{array}{c}\text { Dom Luiz Antonio } \\
\text { deSouza }\end{array}$ & $\begin{array}{c}\text { Palácio de Nossa } \\
\text { Senhora da } \\
\text { Ajuda }\end{array}$ & Aviso \\
\hline 40 & $1769-05-20$ & $74 r(1)$ & $\begin{array}{l}\text { Para sepoderem } \\
\text { regular as remes- }\end{array}$ & $\begin{array}{c}\text { Francisco Xavier } \\
\text { de Mendonça } \\
\text { Furtado }\end{array}$ & $\begin{array}{c}\text { Palácio de Nossa } \\
\text { Senhora da } \\
\text { Ajuda }\end{array}$ & Ofício \\
\hline 41 & $1769-12-19$ & $75 r$ a $76 r(3)$ & $\begin{array}{l}\text { Naõ cabendo no } \\
\text { tempo poderfazer }\end{array}$ & Conde de Oeiras & $\begin{array}{c}\text { Palácio de Nossa } \\
\text { Senhora da } \\
\text { Ajuda }\end{array}$ & Ofício \\
\hline 42 & $1771-01-14$ & $78 r(1)$ & $\begin{array}{l}\text { Hoje pelas cinco } \\
\text { horas ehum }\end{array}$ & $\begin{array}{c}\text { Martinho de Mello } \\
\text { e Castro }\end{array}$ & $\begin{array}{c}\text { Palácio de Nossa } \\
\text { Senhora da } \\
\text { Ajuda }\end{array}$ & Ofício \\
\hline 43 & $1771-04-27$ & $79 r(1)$ & $\begin{array}{l}\text { Sendo prezente } \\
\text { aSuaMagestade }\end{array}$ & $\begin{array}{c}\text { Martinho de Mello } \\
\text { e Castro }\end{array}$ & $\begin{array}{c}\text { Palácio de Nossa } \\
\text { Senhora da } \\
\text { Ajuda }\end{array}$ & Aviso \\
\hline 44 & $1771-10-01$ & 80 r a $82 r(5)$ & $\begin{array}{l}\text { Copiaprimeira | } 1 \\
\text { ASua Magestade } \\
\text { foraõ }\end{array}$ & $\begin{array}{c}\text { Martinho de Mello } \\
\text { e Castro }\end{array}$ & $\begin{array}{c}\text { Palácio de Nossa } \\
\text { Senhora da } \\
\text { Ajuda }\end{array}$ & Aviso \\
\hline 45 & $\begin{array}{c}\text { Sem data } \\
\text { cronológica }\end{array}$ & $86 r(1)$ & Por El Rey & Rei & Sem data tópica & Sobrescrito \\
\hline 46 & $1770-08-23$ & $87 r(1)$ & $\begin{array}{c}\text { Sendo prezente } \\
\text { aSua Magestade } \\
\text { o grande }\end{array}$ & Conde de Oeiras & Lisboa & Aviso \\
\hline 47 & $\begin{array}{c}\text { Sem data } \\
\text { cronológica }\end{array}$ & $89 \mathrm{v}(1)$ & $\begin{array}{c}\text { Ao Senhor Dom } \\
\text { Luis Antonio } \\
\text { deSouza } \\
\text { Governador }\end{array}$ & $\begin{array}{c}\text { Inspetor geral do } \\
\text { Real Erário }\end{array}$ & São Paulo & Sobrescrito \\
\hline 48 & $1770-08-28$ & $90 r(1)$ & $\begin{array}{c}\text { Dom Luis Antonio } \\
\text { de Souza Botelho } \\
\text { Mou- }\end{array}$ & Rei & $\begin{array}{c}\text { Palácio de Nossa } \\
\text { Senhora da } \\
\text { Ajuda }\end{array}$ & Carta régia \\
\hline 49 & $\begin{array}{c}\text { Sem data } \\
\text { cronológica }\end{array}$ & $91 \mathrm{v}(1)$ & PorEIREY & Rei & São Paulo & Sobrescrito \\
\hline 50 & $1770-11-16$ & $92 \mathrm{r}$ e $92 \mathrm{v}(2)$ & $\begin{array}{l}\text { Dom Luiz Antonio } \\
\text { deSouza Botelho }\end{array}$ & Rei & $\begin{array}{c}\text { Palácio de Nossa } \\
\text { Senhora da } \\
\text { Ajuda }\end{array}$ & Carta régia \\
\hline 51 & $\begin{array}{c}\text { Sem data } \\
\text { cronológica }\end{array}$ & $93 v(1)$ & Por EIREY & Rei & São Paulo & Sobrescrito \\
\hline 52 & $1770-01-17$ & $94 r(1)$ & $\begin{array}{c}\text { Por Decreto de } \\
\text { quatro } \\
\text { doCorrente }\end{array}$ & $\begin{array}{c}\text { Martinho de Mello } \\
\text { e Castro }\end{array}$ & $\begin{array}{c}\text { Palácio de Nossa } \\
\text { Senhora da } \\
\text { Ajuda }\end{array}$ & Ofício \\
\hline 53 & $1770-04-20$ & $95 \mathrm{r} \mathrm{e} 95 \mathrm{v}(2)$ & $\begin{array}{c}\text { Receby tres } \\
\text { Cartas de } \\
\text { VossaSenhoria } \\
\text { escritas em cinco } \\
\text { de }\end{array}$ & Conde de Oeiras & Lisboa & Ofício \\
\hline 54 & $1770-07-30$ & $96 r(1)$ & $\begin{array}{l}\text { Sendo prezente } \\
\text { aSua Mages- }\end{array}$ & $\begin{array}{c}\text { Martinho de Mello } \\
\text { e Castro }\end{array}$ & $\begin{array}{c}\text { Palácio de Nossa } \\
\text { Senhora da } \\
\text { Ajuda }\end{array}$ & Aviso \\
\hline 55 & $1770-12-17$ & $100 r(1)$ & $\begin{array}{l}\text { Sua Magestade } \\
\text { manda remeter } \\
\text { aVossaSenhoria } \\
\text { alguns Exem= }\end{array}$ & $\begin{array}{c}\text { Martinho de Mello } \\
\text { e Castro }\end{array}$ & $\begin{array}{c}\text { Palácio de Nossa } \\
\text { Senhora da } \\
\text { Ajuda }\end{array}$ & Aviso \\
\hline 56 & $1771-10-01$ & $102 r$ a $103 r(3)$ & Carta segunda & $\begin{array}{c}\text { Martinho de Mello } \\
\text { e Castro }\end{array}$ & $\begin{array}{c}\text { Palácio de Nossa } \\
\text { Senhora da } \\
\text { Ajuda }\end{array}$ & Ofício \\
\hline
\end{tabular}




\begin{tabular}{|c|c|c|c|c|c|c|}
\hline 57 & $1771-10-01$ & $\begin{array}{c}104 \mathrm{r} \text { a } 112 \mathrm{v} \\
(18)\end{array}$ & Carta terceira & $\begin{array}{c}\text { Martinho de Mello } \\
\text { e Castro }\end{array}$ & $\begin{array}{c}\text { Palácio de Nossa } \\
\text { Senhora da } \\
\text { Ajuda }\end{array}$ & Ofício \\
\hline 58 & $1771-10-01$ & $\begin{array}{c}113 r \text { a } 115 v \\
(6)\end{array}$ & Carta quarta & Não mencionada & $\begin{array}{c}\text { Palácio de Nossa } \\
\text { Senhora da } \\
\text { Ajuda }\end{array}$ & Ofício \\
\hline 59 & $1771-10-01$ & $118 \mathrm{r}$ a $121 \mathrm{r}(7)$ & Carta quinta & $\begin{array}{c}\text { Martinho de Mello } \\
\text { e Castro }\end{array}$ & $\begin{array}{c}\text { Palácio de Nossa } \\
\text { Senhora da } \\
\text { Ajuda }\end{array}$ & Ofício \\
\hline 60 & $1771-09-07$ & $\begin{array}{c}122 \mathrm{r} \text { a } 124 \mathrm{v} \\
(6)\end{array}$ & $\begin{array}{l}\text { A. | Relaçaõ } \\
\text { detoda a } \mathrm{Ar}=\end{array}$ & $\begin{array}{c}\text { Manoel Gomes de } \\
\text { Carvalho e Silva }\end{array}$ & $\begin{array}{l}\text { Arsenal Real do } \\
\text { Exército }\end{array}$ & Relação \\
\hline 61 & $1771-09-07$ & $\begin{array}{c}126 r \text { a } 127 v \\
\text { (4) }\end{array}$ & $\begin{array}{l}\text { B. | Relaçaõ das } \\
\text { Moniçoens, }\end{array}$ & $\begin{array}{l}\text { Manoel Gomes de } \\
\text { Carvalho e Silva }\end{array}$ & $\begin{array}{l}\text { Arsenal Real do } \\
\text { Exército }\end{array}$ & Relação \\
\hline 62 & $1771-09-07$ & $\begin{array}{c}128 r \text { a } 129 v \\
\text { (4) }\end{array}$ & $\begin{array}{l}\text { C. | Relaçaõ das } \\
\text { moniçoens que }\end{array}$ & $\begin{array}{c}\text { Manoel Gomes de } \\
\text { Carvalho e Silva }\end{array}$ & $\begin{array}{l}\text { Arsenal Real do } \\
\text { Exército }\end{array}$ & Relação \\
\hline 63 & $1771-09-07$ & $\begin{array}{c}130 \mathrm{r} \text { e } 130 \mathrm{v} \\
\text { (2) }\end{array}$ & $\begin{array}{l}\text { D. | Relaçaõ das } \\
\text { Armas eMo= }\end{array}$ & $\begin{array}{l}\text { Manoel Gomes de } \\
\text { Carvalho e Silva }\end{array}$ & $\begin{array}{l}\text { Arsenal Real do } \\
\text { Exército }\end{array}$ & Relação \\
\hline 64 & $1771-09-12$ & 132 r a $135 r(7)$ & $\begin{array}{l}\text { E. | Relaçaõ das } \\
\text { Armas eMoniço= }\end{array}$ & $\begin{array}{c}\text { Manoel Gomes de } \\
\text { Carvalho e Silva }\end{array}$ & $\begin{array}{l}\text { Arsenal Real do } \\
\text { Exército }\end{array}$ & Relação \\
\hline 65 & $1771-10-01$ & $\begin{array}{c}136 \mathrm{r} \text { e } 136 \mathrm{v} \\
(2)\end{array}$ & $\begin{array}{c}\text { Fez prezente } \\
\text { aSuaMagestade }\end{array}$ & $\begin{array}{c}\text { Martinho de Mello } \\
\text { e Castro }\end{array}$ & $\begin{array}{c}\text { Palácio de Nossa } \\
\text { Senhora da } \\
\text { Ajuda }\end{array}$ & Aviso \\
\hline 66 & $1771-07-22$ & $137 r$ a $138 r(2)$ & $\begin{array}{l}\text { Relaçaõ dos } \\
\text { Paos depi= }\end{array}$ & Manoel Vicente & Ribeira das Naos & Relação \\
\hline 67 & $1771-10-07$ & 140r (1) & $\begin{array}{l}\text { SuaMagestade } \\
\text { manda re }=\end{array}$ & $\begin{array}{c}\text { Martinho de Mello } \\
\text { e Castro }\end{array}$ & $\begin{array}{c}\text { Palácio de Nossa } \\
\text { Senhora da } \\
\text { Ajuda }\end{array}$ & Aviso \\
\hline 68 & $1772-11-20$ & $\begin{array}{c}142 r \text { a } 150 r \\
\text { (17) }\end{array}$ & $\begin{array}{l}\text { 1. Naõ tendo } \\
\text { chegado aesta } \\
\text { Corte, noticia }\end{array}$ & $\begin{array}{c}\text { Martinho de Mello } \\
\text { e Castro }\end{array}$ & $\begin{array}{c}\text { Palácio de Nossa } \\
\text { Senhora da } \\
\text { Ajuda }\end{array}$ & Carta régia \\
\hline
\end{tabular}

Sendo todos os documentos relacionados à administração pública, há a vantagem de serem esses os meios mais usados em uma época em que o acesso à escrita era restrito a poucas pessoas, segundo Barbosa (2002, p. 425). Além disso, conforme Maia (1986, p. 48), os textos burocráticos trazem explicitamente onde, quando, para quem e por quem foram escritos, o que facilita o trabalho filológico.

Diante da ordem anteriormente apresentada e da observância das datas cronológicas, confirma-se que a organização dos fólios no livro não segue critério cronológico.

Do mesmo modo, as datas tópicas dos documentos são variáveis, porém a que apresenta maior ocorrência é a do "Palácio de Nossa Senhora da Ajuda" localizado em Lisboa, construído nos séculos XVIII e XIX, utilizado na época para fins residenciais e administrativos das autoridades portuguesas.

Para as classificações tanto da "data cronológica" (com dia, mês e ano), quanto da data tópica ou elemento topográfico, encontradas no protocolo final dos documentos, na parte denominada "datatio" ou "datação", segue-se 
Bellotto (2002, p. 40) respeitando o manuscrito, com a denominação de um palácio, sem que se acrescente a cidade na qual está situado. Por isso houve a escolha pela menção dos locais "Palácio de Nossa Senhora da Ajuda" e "Arsenal Real do Exército", sem ser citada Lisboa onde se localizam.

Embora não haja, em sua maioria, a menção explícita da palavra "Cópia", supõe-se que a natureza de tais documentos seja essa. Tal idéia pode ser corroborada com a análise dos diversos tipos de mãos, diferentes caligrafias, provavelmente de amanuenses do próprio governo da capitania de São Paulo, que copiavam os documentos no intuito de arquivá-los. A característica de organização do Morgado de Mateus e a sua proposta de montar um acervo de correspondências oficiais e pessoais encontra-se estudada na obra Nem o tempo Nem a distância de Bellotto (2007a), em que o gosto dele por literatura é atestado por inventário existente no Arquivo da Casa, em que consta terem saído, junto da comitiva que acompanharia D. Luís Antonio a São Paulo, em 25 de Janeiro de 1765, diversos baús. "Entre estes, iam manuais militares, escrituras sagradas, os poetas romanos: Tácito, Virgílio e Ovídio, além das cartas do Padre Vieira, e as crônicas de alguns reis antigos de Portugal." (BELLOTTO, 2007a, p. 30) Por meio de sua assinatura, recorrente na maioria dos manuscritos estudados, pode-se supor que algumas cópias tenham sido feitas de próprio punho pelo governador e capitão general. Todos os documentos são de comunicação passiva, tendo o Morgado de Mateus recebido e, ao que tudo indica, assinado para indicar que estava ciente do conteúdo lido. Essa suposição é reforçada pela nota "está conforme", encontrada no documento 27 .

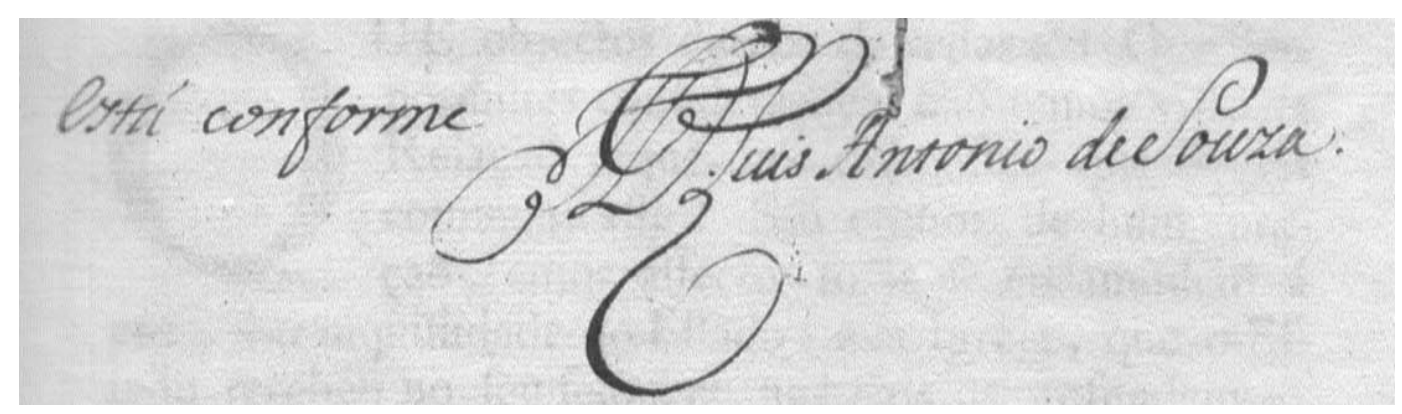

Figura 18: O termo "está conforme", seguido da assinatura (Doc. 27). 


\section{Capítulo 3: O MORGADO DE MATEUS: UM BREVE PERFIL BIOGRÁFICO}

Uma vez que este trabalho trata de documentos referentes ao governo português no Brasil colonial no período de 1767 a 1775, torna-se fundamental fazer um comentário histórico sobre a época. Para isso, cabe retomar a contextualização de Salgado (1985, p. 45) segundo a qual, na segunda metade do século XVIII, a economia portuguesa apresentava quadro de decadência desde 1762, com a crise do ouro brasileiro. À frente de um império grande demais para se sustentar, com um território metropolitano culturalmente organizado pelo jesuitismo, carente demográfica e economicamente, havia necessidade de se resolver a crise com o reforço do fisco, com reformas de toda ordem e com o aumento do poder central. Assim, durante o reinado de D. José I, Sebastião José de Carvalho e Melo, Marquês de Pombal, assumiu a administração colonial portuguesa em busca de fortalecer a estrutura militar e econômica colonial. Em território português, primava pelo crescimento da indústria, contra a mentalidade impregnada de jesuitismo, o domínio inglês no comércio externo e o abandono da terra. Na colônia, lutava contra o desleixo do fisco, o contrabando e pelo incentivo à agricultura, tópicos bastante recorrentes nos manuscritos do presente corpus.

Durante o período a que pertencem os documentos do livro manuscrito aqui estudado, de 1767 a 1775, Portugal mantinha o Brasil Colônia sob a ordem jurídico-institucional absolutista, governo no qual, de acordo com Salgado (1985, p.15), o monarca não se sujeita a qualquer tipo de limitação, dele demandando todo o poder, inclusive 0 de promulgar o ordenamento jurídico que submete o corpo social, mas não a autoridade régia. Nessa estrutura de dominação prevalece, assim, uma soberania calcada na vontade suprema do rei, que anula os direitos individuais em troca da garantia de segurança e de ordem aos seus súditos. Seu poder prolonga-se em delegações aos agentes de confiança para gerirem, em seu nome, o funcionamento dos negócios do Estado. Tal delegação régia de poderes manifesta-se, por excelência, no âmbito da ordem administrativa: às várias funções inerentes ao controle do Estado impõe-se uma extensa distribuição de 
competências a um vasto corpo de funcionários, encarregados imediatos da supervisão de inúmeras áreas administrativas.

Assim, as diversas funções do Estado, tais como segurança, defesa, ordem e gestão dos seus interesses financeiros, estão submetidas à gerência do monarca absoluto e por ele transmitidas aos seus agentes, configuravam diversas áreas em que se subdividia a administração. Esta recrutava os funcionários administrativos com base nos padrões da lealdade e da confiança, apesar de em alguns setores, como o judicial, passarem além desses valores um conhecimento específico indispensável à aplicação da lei.

Para a melhor compreensão dos fatos apresentados nos documentos, vale lembrar que, segundo menciona Bellotto (2007b, p. 24), São Paulo sobrevivia a um enfraquecimento demográfico, econômico e político, resultante, em grande parte, da perda das zonas mineiras. Para colocar a Capitania em condições de assumir o papel de participação efetiva no combate ao espanhol, propunha-se a militarização, a exploração territorial e o fomento patente na política econômica e na urbanização.

Consequentemente, São Paulo foi alvo de mudanças, em razão de sua localização estratégica próxima às colônias da Espanha, que serviria de barreira à penetração de estrangeiros na região das minas. Os mapas, a seguir, ilustram a situação demográfica da região encontrada pelo Morgado de Mateus no início de seu governo. 


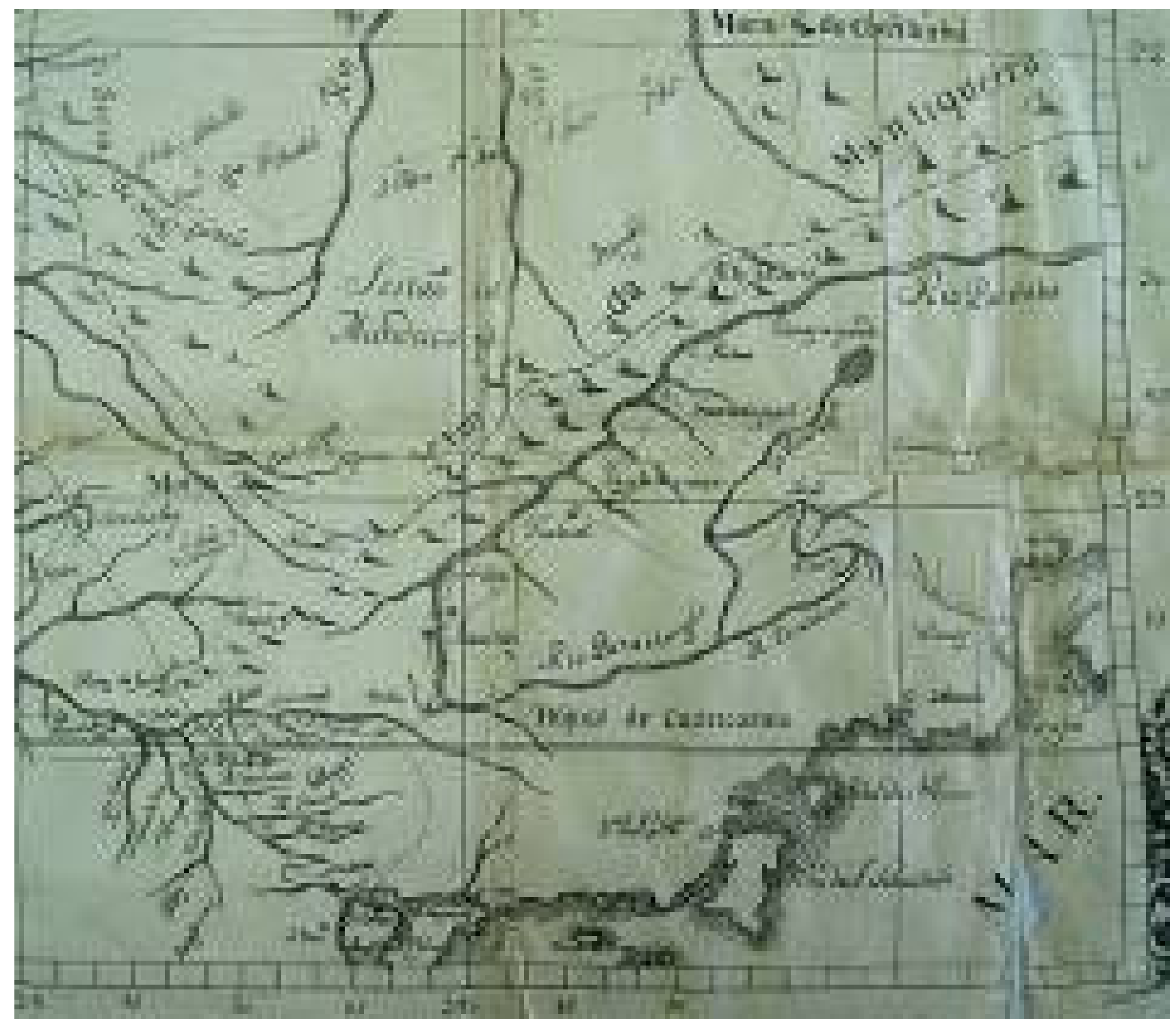

Figura 19 : Estado Político da Capitania de São Paulo em 1766. Reprodução da cópia conservada no Arquivo do Estado de São Paulo, São Paulo/SP

Referência de localização do documento: setor iconográfico/mapa 08.02.04 


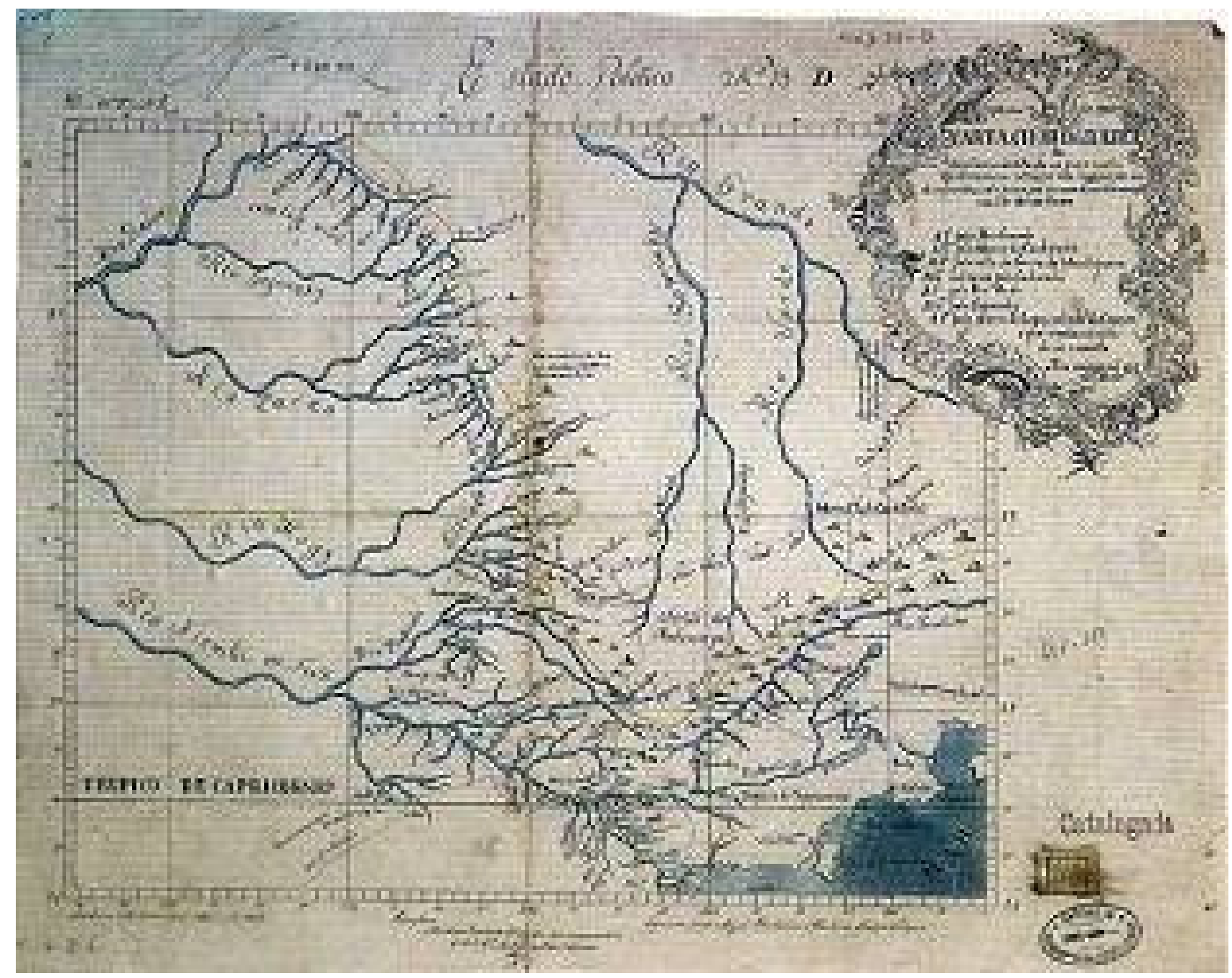

Figura 20 : Leituras Cartográficas Históricas e Contemporâneas, ed. conjunta BrasilConnects Cultura \& Ecologia, Museu de Arte Contemporânea da Universidade de São Paulo (MAC USP) e Exército Brasileiro, São Paulo/SP, março/2003 (acervo do historiador Waldir Rueda)

As mudanças em São Paulo iniciaram-se com a expulsão dos jesuítas, obrigados a desocuparem o colégio que fundaram. E, em 1765, a Capitania de São Paulo, que desde 1748 era subordinada à Capitania do Rio de Janeiro, teve restaurada sua autonomia com a nomeação para governador do nobre português D. Luís Antonio de Sousa Botelho e Mourão, o Morgado de Mateus, Fidalgo da Casa Real e militar de carreira. Pelo Decreto de 5 de janeiro de 1765, ele foi nomeado aos 43 anos para governar a Capitania de São Paulo. Entretanto, desde 14 de dezembro de 1764, já estava escolhido para o cargo de governador e capitão general da Capitania de São Paulo. Acerca disso, afirmou o Rei que:

Sendo presente a grande necessidade que há de se erigir governador e Capitão General na Capitania de São Paulo na mesma 
forma e com a mesma juresdição que já antecedente houve nella: Sou servido restabelecer a mesma Capitania a seu antigo estado: Hey por bem nomear para Capitão General do mesmo governo a D. Luís Antonio de Sousa Botelho Mourão que servirá por tempo de tres annos e o mais que decorra enquanto the não nomear sucessor e com o dito governo havera ordenado de vinte mil cruzados cada anno. (BELLOTTO, 2007b, p. 44)

O embarque do Morgado de Mateus para o Brasil só ocorreu, entretanto, a 23 de março de 1765 , sendo a partida só a 27 por conta do mau tempo. Depois da travessia cheia de reveses, a 20 de junho, a Nau de Guerra Nossa Senhora da Estrela chegou ao Rio de Janeiro. Nos dias que se seguiram, ele recebeu a bordo a visita do Vice-Rei e de outras autoridades. Só a primeiro de julho desembarcou em terras brasileiras.

A Igreja ou Convento do Carmo de São Paulo, fundada pelo frei Antônio de São Paulo Pinheiro em 1592, por ser um centro religioso importante no período colonial e com numerosos bens, serve como ilustração de um local de relevância ao governo de Morgado de Mateus, conforme indica um relatório do próprio século XVIII:

[...]uma fazenda denominada Caguaçu, situada na freguesia da Penha; uma dita no distrito da freguesia de Itaquaquecetuba, no lugar denominado Itaim; uma dita no distrito da vila de Santa Isabel, no lugar denominado Pontes; uma dita no distrito da cidade de São Roque, no lugar denominado Sorocamirim; uma dita no distrito da cidade de Curitiba; uma quinta na freguesia de Santa Efigênia; uma capela em Tamanduá, com terreno anexo; um terreno que cerca o convento; 32 prédios térreos e 3 ditos de sobrado e um andar na capital, e 435 escravos. (MARQUES, 1988, p.201)

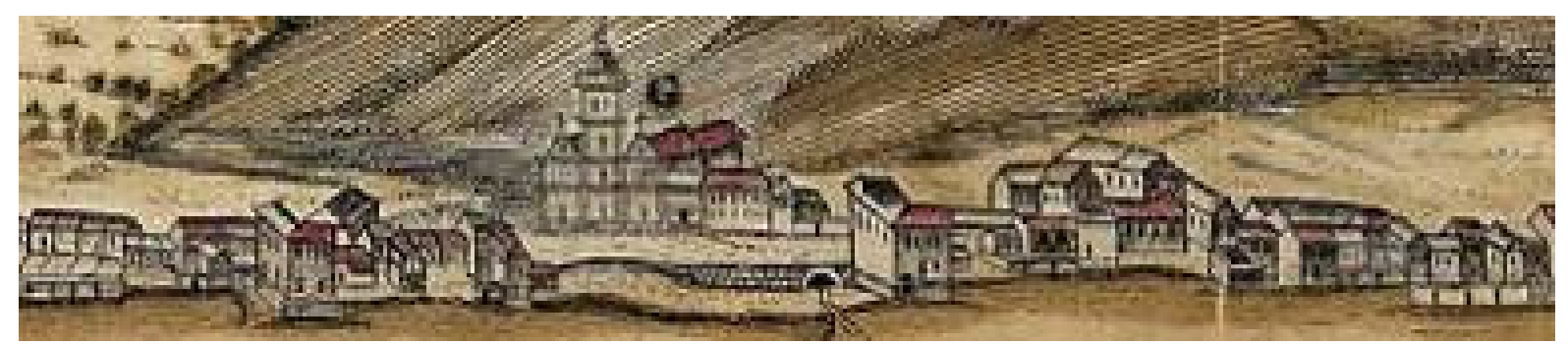

Figura 21: Convento do Carmo (sob a letra G). 
Quanto à biografia do Morgado de Mateus, vale mencionar que fora nascido em 21 de Fevereiro de 1722 e, segundo Bellotto (2007a, p. 22), passara a infância e adolescência com o avô materno, D. Luís Antonio de Sousa, governador do Castelo de Santiago da Barra da Vila de Viana, local onde vivera até os 23 anos. Era filho legítimo de Dona Joana Maria de Sousa, Senhora de Moroleiros, e de Antonio José Botelho Mourão, fidalgo da Casa Real e terceiro Morgado de Mateus, que serviu com distinção na guerra da Grande Aliança e aumentou consideravelmente o brilho de sua Casa, que edificou em Vila Real. A partir de 1751, pôde intitular-se "Dom", pois recebera a mercê real da Comenda de Santa Maria da Vermiosa. Importante ressaltar que o título "Morgado" é herdado por sucessão direta pelos primogênitos que recebem as propriedades da família. No ano de 1753, D. Luís Antonio tornouse Fidalgo da Casa Real, recebendo mercê da Honra da Ovelha, na Serra do Marão. Casou-se neste mesmo ano com sua parenta, D. Eleonor Ana José Luisa de Portugal, filha de Rodrigo de Souza Coutinho e de D. Maria Antonio de Meneses. Na cidade do Porto, onde residia o casal, nasceu o primogênito D. José Maria de Souza, que herdou o morgadio.

O Palácio de Mateus (hoje Fundação Casa de Mateus), uma das mais nobres residências portuguesas, a dos Condes de Vila Real, está situado na freguesia de Mateus, Distrito de Vila Real. O projeto desse palácio foi desenhado pelo arquiteto Nicolau Nasoni no século XVIII para António José Botelho Mourão (o primeiro Morgado de Mateus). Trata-se de uma edificação barroca de planta retangular, estruturada em dois corpos laterais ligados entre si por duas alas que the são perpendiculares, conferindo ao conjunto uma grandiosidade e beleza de raro efeito e arquitetônico ${ }^{8}$.

\footnotetext{
${ }^{8}$ Mais detalhes podem ser consultados no site da Casa de Mateus: $<\mathrm{http}: / /$ www.casademateus.com/home.htm>
} 


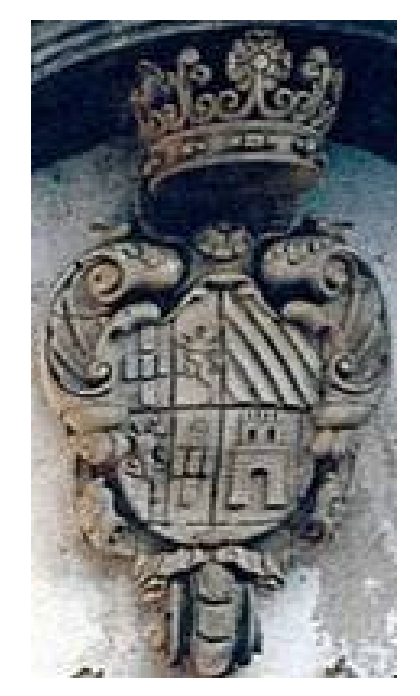

Figura 22: Brasão da Casa de Mateus

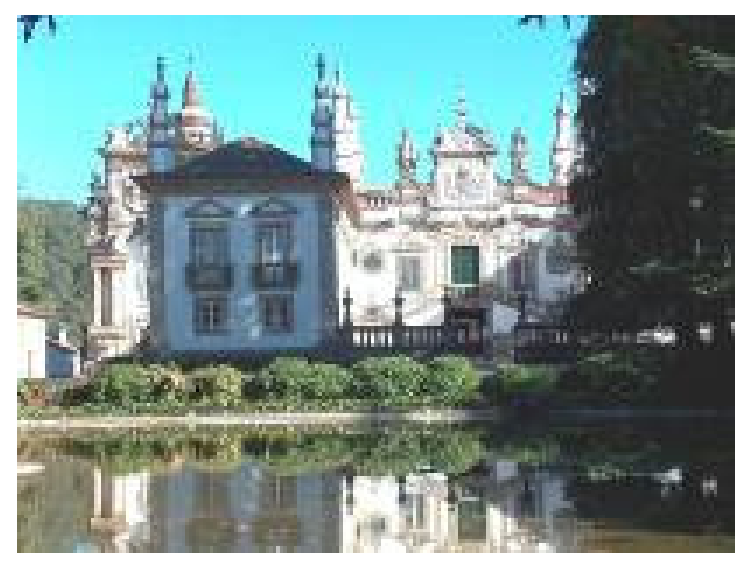

Figura 23: Palácio de Mateus

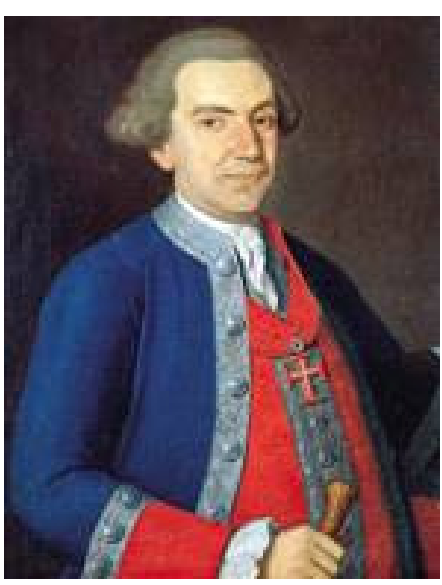

Figura 24: Retrato do Morgado de Mateus

Por sua ascendência ilustre, sempre apresentou conduta baseada no moralismo e na religião. Como "membro da pequena nobreza nortenha de Trás-os-Montes, D. Luís Antonio de Sousa Botelho Mourão, o quarto Morgado da Casa de Mateus" (BELLOTTO, 2007a, p. 8), que fez novas vinculações, ampliando os bens da referida Casa. Iniciou a organização dos documentos da Casa, existindo muitas capas de organização manuscritas pelo próprio D. Luís. Os documentos refletem o rigor com que D. Luís Antonio de Sousa Botelho Mourão e sua mulher conduziam os negócios da Casa, tendo sido a sua organização continuada por seu filho D. José Maria do Carmo de Sousa Botelho Mourão e Vasconcelos, que afirma ter sido a administração de sua mãe, D. Leonor, a melhor administração que teve a Casa, pois ela quitou todas as dívidas e conseguiu aumentar as fazendas existentes, concluindo a Capela, reformando e mobiliando as casas. Tais ações foram descritas nas cartas que Dona Leonor escrevia a seu marido, conforme comprovam os documentos transcritos por Bellotto (2007a, p. 9).

O Morgado de Mateus foi o mais ativo dos capitães generais que teve o Brasil na fase final do período pombalino: "[...] o objetivo de Pombal, naquele momento: que a capitania, tendo à frente um capitão general de ânimo empreendedor, pudesse constituir no Sul uma barreira defensiva e, talvez, uma força ofensiva contra os castelhanos." (BELLOTTO, 2007b, p. 73) Nesses dez anos de governo, fundou cerca de vinte freguesias e vilas. Conhecido como administrador, estadista e urbanizador, D. Luís Antonio era ainda um homem que valorizava a cultura, tendo fundado na Capitania a "Academia dos Felizes", 
homônima de outra do Rio de Janeiro. Por conta de sua devoção, mandou erigir uma Capela em louvor à Santa Ana, no templo jesuítico, a qual se inaugurou a 19 de agosto de 1770. Durante as festividades dessa inauguração, ele promoveu a primeira sessão literária paulistana, declamado o soneto "Em louvor da Gloriosa Santa Ana", de autoria do próprio Morgado de Mateus.

\begin{abstract}
Gloriosa Matrona, cujo emprego/ por dom de Deus Eterno Onipotente/ é socorrer o mísero inocente,/ que deste mundo surca o lar pego/ Neste mar proceloso, em que navego/ Conduzindo o destino a tanta gente,/ os votos vos consagro humildemente/ Quando a vós o governo todo entrego./ Vós sois do mar da graça norte, e guia,/ que ao humano baixei desamparado/ o socorro prestais de mais valia:/ Fazei que destes céus nos seja dado/ o ouro, que encha os povos de alegria/ a graça, que nos livre do pecado. ${ }^{9}$
\end{abstract}

Além de contribuições como essa para a cultura local, a 20 de novembro de 1772, o Morgado de Mateus assinou uma "Portaria sobre o divertimento das óperas" e preocupou-se com a abertura de escolas públicas de ler, escrever e contar e Estudos de Gramática, Grego. Havia, por conta da expulsão dos jesuítas, uma séria depressão no ensino do país, pois "as aulas dos jesuítas eram as únicas que então existiam no abandono completo em que nos deixava a metrópole, e os moços estudiosos encontravam neles mestres eruditos, que, sem pedantismo, abriam-Ihes as portas de templo da ciência" (TAUNAY, 1945: 143)

Houve contribuições efetivas à economia local, como, segundo Andrade (1935), em 1773, a edificação do primeiro mercado público da capitania, que contribuiria muito para o bem da população.

Somados a sua conduta, havia a disciplina e o autoritarismo, reflexos de sua notável carreira militar. Tais características foram determinantes para 0 bom desempenho de suas funções como governador e capitão general, ao mesmo tempo em que se chocaram com a maneira de ser dos paulistas.

Obrigou os paulistanos e paulistas a severo arrolamento nas fileiras das tropas auxiliares da Ordenança, criando seis unidades para toda a capitania, das quais duas caberiam à Cidade de São Paulo, de cavalaria e infantaria. Em 1767 tinha sob as bandeiras 1404 cavalarianos e 2600 infantes além das ordenanças, companhias de pardos e tropa de índios. Mais de 6000 homens mobilizados dentro de uma população que escassamente alcançaria cem mil almas! (TAUNAY, 1953, p.125)

\footnotetext{
${ }^{9}$ Retirado do site: <http://www.goiases.cnpm.embrapa.br/divida.html>
} 
Assim, o recrutamento forçado da população, forçou, segundo mostra o Diário de Navegação de Teotônio José Juzarte Souza (1999, p. 32), muitas famílias a fazerem a temerosa navegação do Tietê ao Paraná para viver nas paragens do Iguatemi. Do mesmo modo, a situação de penúria era geral:

[...]se ajuntaram à porta do Capitão Mor um número de homens povoadores que passavam de cinquenta, requeriam que tinham fome em nome de todos os daquela Praça, que padeciam eles, suas mulheres, e seus filhos... a este tempo já não havia sal, nem coisa alguma mais que algumas abóboras a que chamam quibebes, que se assando se sustentava a maior parte da gente... (SOUZA, 1999, p.95)

Conta Menezes (1954, p. 124), sob o título de "Caricata conspiração contra o Morgado de Mateus sacudiu a pequenina cidade de 1767.", que durante as festividades de comemoração do aniversário do rei $D$. José I na capitania de São Paulo, Dom Luís descobriu que estava sendo alvo de conspirações: soube que os paulistas planejavam assassiná-lo durante a queima de fogos e identificou o padre Garcia como autor de uma sátira, a respeito de sua pessoa e de seu governo, afixada na porta da Igreja de Santa Teresa. O padre foi, diante disso, preso na Fortaleza da Barra e acabou de lá fugindo um ano e meio depois.

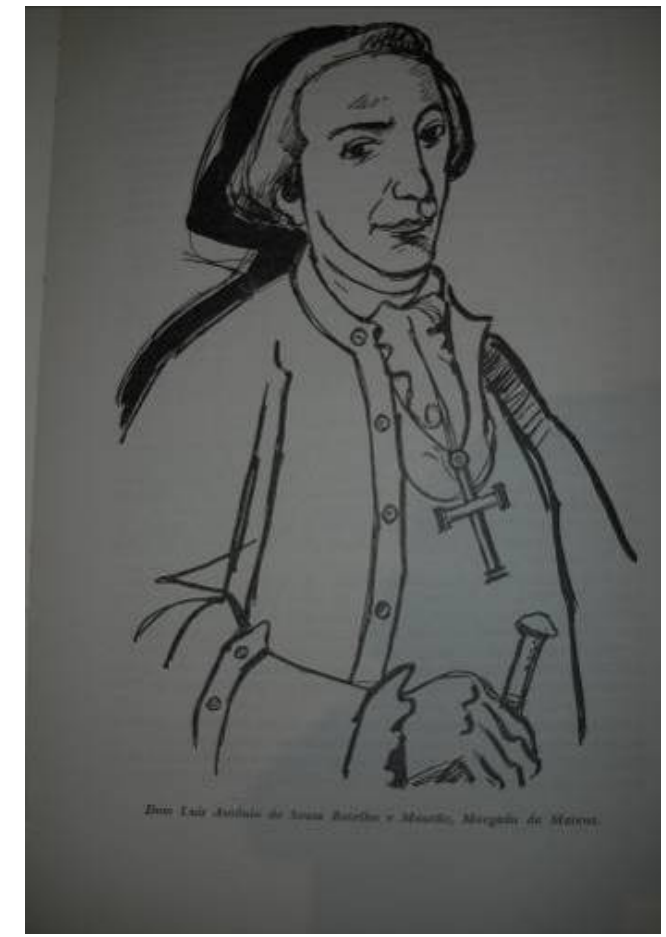

Figura 25 : Morgado de Mateus, em Menezes (1954, p. 118) 
Nesse contexto, Morgado de Mateus deixou como legado "[...] muito à Capitania de São Paulo, em termos de preparação da sua infra-estrutura para suportar o extremo desenvolvimento econômico que a arrancaria definitivamente da decadência [...]" (BELLOTTO, 2007a, p. 19)

Em 1775, receberia ordem para regressar, já que lhe mandavam sucessor. Partiria do Rio de Janeiro em fins de Janeiro de 1776, não sem que antes tivesse deixado uma longa carta a seu sucessor, Martim Lopes Lobo de Saldanha, na qual fazia um balanço do seu governo. (BELLOTTO, 2007a, p. 32)

Segundo BELLOTTO (2007a, p. 51), faleceu em 03 de Outubro de 1798, tendo sido sepultado na sua Capela de Nossa Senhora dos Prazeres em Mateus. 


\section{Capítulo 4: TRANSCRIÇÃO SEMIDIPLOMÁTICA DO LIVRO № 170 DO AESP}

No intuito de fornecer fontes de consulta dignas de confiança, seguem-se na transcrição dos manuscritos, as "Normas para Transcrição de Documentos Manuscritos", propostas durante o $2^{\circ}$. Seminário "Para a História do Português do Brasil", realizado em Campos do Jordão, em maio de 1998. Tais normas foram revistas e adaptadas segundo as necessidades deste trabalho.

1. A transcrição será conservadora.

2. As abreviaturas, alfabéticas ou não, serão desenvolvidas, marcando-se, em itálico, as letras omitidas na abreviatura, obedecendo os seguintes critérios:

a) respeitar, sempre que possível, a grafia do manuscrito, ainda que manifeste idiossincrasias ortográficas do escriba, como no caso da ocorrência "registo", que leva a abreviatura "rego" a ser transcrito "registo";

b) No caso de variação no próprio manuscrito ou em coetâneos, a opção será para a forma atual ou mais próxima da atual, como no caso de ocorrências "Deos" e "Deus", que levam a abreviatura "D.s", a ser transcrita "Deus".

3. Não será estabelecida fronteira de palavras que venham escritas juntas, nem se introduzirá hífen ou apóstrofo onde não houver. Exemplos: "deCuberta"; "nessaCapitania"; "Elogoque"; "mandarádarposse"; "deNossaSenhoradaAjuda";

4. A pontuação original será rigorosamente mantida. No caso de espaço maior intervalar deixado pelo escriba, será marcado: [espaço]. Exemplo: "naforma Ordinaria. [espaço] O que tudo exe=" 
5. A acentuação original será rigorosamente mantida, não se permitindo qualquer alteração. Exemplos: "dalingoa”; "Portuguez"; "Pallacio”;

6. Será respeitado o emprego de maiúsculas e minúsculas como se apresentam no original. No caso de alguma variação física dos sinais gráficos resultar de fatores cursivos, não será considerada relevante. Assim, a comparação do traçado da mesma letra deve propiciar a melhor solução.

7. Eventuais erros do escriba ou do copista serão remetidos para nota de rodapé, onde se deixará registrada a lição por sua respectiva correção. Exemplo: "nota 1. Rel por Real"

8. Inserções do escriba ou do copista na entrelinha ou nas margens superior, laterais ou inferior entram na edição entre os sinais $<>$ na localização indicada. Exemplo: $<$ Em todos estes se apontaõ seus sinais na forma que vão apontados nafolha antecedente, quepornaõ ser cousaessencial se não tresladaõ>.

9. Quando houver repetição de palavra(s) no início do fólio seguinte, indicando refrão, a segunda ocorrência aparecerá entre colchetes duplos [[ ]].

10. Intervenções do editor hão de ser raríssimas, permitindo-se apenas em caso de extrema necessidade, desde que elucidativas a ponto de não deixarem margem a dúvida, seja uma supressão feita pelo escriba ou pelo copista no original aparecerão entre colchetes. Exemplo: "esendo [o] mesmoCapitaõ".

11. A numeração dos fólios segue a ordem em que se encontram encadernados no livro manuscrito, incluindo páginas em branco na contagem. Por se tratar de numeração aleatória, os números escritos na margem superior direita dos fólios recto foram ignorados e, por motivo de economia, não aparecem em nota nas transcrições. 
12. Letras ou palavra não legível por deteriorização justificam intervenção do editor na forma do item anterior, com a indicação entre colchetes: [ilegível].

13. Trecho de maior extensão não legível por deteriorização receberá a

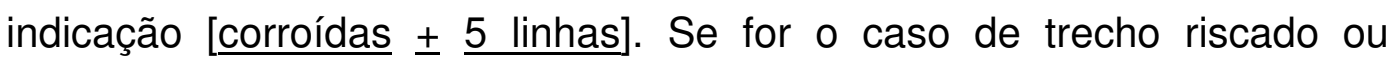
inteiramente anulado por borrão ou papel colado em cima, será registrada a informação pertinente entre colchetes e sublinhada.

13. A divisão das linhas do documento original será preservada, ao longo do texto, na edição, de forma justalinear; embora se use uma barra vertical | em alguns casos, por questões de editoração da página. A mudança de fólio receberá a marcação com respectivo número na seqüência de suas barras verticais: || 1v. || 2r. \| 2v.\|. Cada novo documento receberá 0 número: [1], [2] antecedendo o primeiro fólio fac-similar do documento. $A$ contagem de fólios considera todas as páginas do livro manuscrito, portanto os saltos na numeração representam fólios em branco.

14. Na edição, as linhas serão numeradas de cinco em cinco. Essa numeração será encontrada à margem direita da mancha, à esquerda do leitor. A contagem será iniciada a cada documento.

15.As assinaturas simples ou as rubricas serão sublinhadas. Exemplo: "DomLuis AntoniodeSouza" (doc. 23)

\subsection{Verbetes}

Do mesmo modo como não havia uma catalogação para os documentos, os verbetes explicativos de cada documento apresentados a seguir, foram elaborados para este trabalho e seguem o modelo das "ementas dos documentos editados" por Megale (2005, p.133) por apresentarem um resumo do conteúdo de cada documento. Entende-se aqui "verbete" como uma 
unidade estruturada de informações que organiza as entradas de uma obra a fim de facilitar a pesquisa dos leitores.

Tais verbetes encontram-se organizados, de acordo com o Quadro 1 ( $p$. 60 ), na ordem de numeração dos documentos manuscritos criada para este trabalho segundo a ordem de encadernação. Ao lado da numeração, que vai de 1 a 68, vem a data cronológica, seguida da data tópica. Na segunda linha de cada verbete foi colocada a espécie documental em caixa alta, acompanhada do emissor e do receptor (quando mencionados no documento) e do resumo do conteúdo de cada documento.

1 - 1773, Outubro, 05. Lisboa.

AVISO do Secretário de Estado da Marinha e do Ultramar, Martinho de Melo e Castro, ao Governador e Capitão General da Capitania de São Paulo, Dom Luís Antonio de Souza Botelho Mourão, pedindo o envio de pássaros e animais quadrúpedes a Portugal.

2 - 1773, Outubro, 10. Lisboa.

AVISO do Secretário de Estado da Marinha e do Ultramar, Martinho de Melo e Castro, ao Governador e Capitão General da Capitania de São Paulo, Dom Luís Antonio de Souza Botelho Mourão, transmitindo a ordem do rei para que se entregue ao bispo, para residência dos prelados, o edifício que fora 0 Colégio dos Jesuítas. Pede que se reserve, neste espaço, uma quadra para a formação de futuros professores à mocidade da capitania.

3 - 1773, Outubro, 17. Lisboa.

CARTA RÉGIA do Rei de Portugal, Dom José I, ao Governador e Capitão General da Capitania de São Paulo, Dom Luís Antonio de Souza Botelho Mourão, ordenando que seja cumprido o pagamento de imposto sobre as carnes e aguardentes produzidas na Capitania. O registro trimestral da arrecadação deveria resultar em um mapa do valor anual arrecadado e a quantia deveria ser usada para pagamento de salários e remetida à Junta da Fazenda. 
4 - 1773, Novembro, 09. Lisboa.

AVISO do Secretário de Estado da Marinha e do Ultramar, Martinho de Melo e Castro, ao Governador e Capitão General da Capitania de São Paulo, Dom Luís Antonio de Souza Botelho Mourão, transmitindo a ordem do rei para que se enviassem a Portugal os cabedais de rendimento da capitania, a fim de que, com base na declaração, os homens de negócio pudessem prevenir as remessas de seus cabedais.

5 - 1774, Abril, 21. Lisboa.

OFícIO do Secretário de Estado da Marinha e do Ultramar, Martinho de Melo e Castro, ao Governador e Capitão General da Capitania de São Paulo, Dom Luís Antonio de Souza Botelho Mourão, retomando correspondências anteriores e prevendo o envio de futuras ordens do rei.

6 - 1774, Abril, 21. Lisboa.

OFíCIO do Secretário de Estado da Marinha e do Ultramar, Martinho de Melo e Castro, ao Governador e Capitão General da Capitania de São Paulo, Dom Luís Antonio de Souza Botelho Mourão, em 23 itens, transmitindo ordens do rei de como dirigir operações militares na capitania e em locais como Viamão e Rio Grande de São Pedro.

7 - 1774, Setembro, 10. Lisboa.

CARTA RÉGIA do Rei de Portugal, Dom José I, ao Governador e Capitão General da Capitania de São Paulo, Dom Luís Antonio de Souza Botelho Mourão, promovendo Joseph Manoel da Nóbrega Botelho para o posto de Sargento Mor de Infantaria da Legião de Paulistas, Sertanejos e Caçadores que estava sendo criada na Capitania de São Paulo.

8 - 1775, Maio, 12. São Paulo.

REGISTRO de número 13 no primeiro livro de registro de ordens régias.

9 - Sem data cronológica. São Paulo.

SOBRESCRITO. Por El Rei, a Dom Luís Antonio de Sousa Botelho Mourão. 
10 - 1774, Abril, 21. Lisboa.

AVISO do Secretário de Estado da Marinha e do Ultramar, Martinho de Melo e Castro, ao Governador e Capitão General da Capitania de São Paulo, Dom Luís Antonio de Souza Botelho Mourão, a fim de que se defendam os territórios.

11 - 1774, Setembro, 10. Lisboa.

CARTA RÉGIA do Secretário de Estado da Marinha e do Ultramar, Martinho de Melo e Castro, ao Governador e Capitão General da Capitania de São Paulo, Dom Luís Antonio de Souza Botelho Mourão, promovendo Joseph Manoel da Nóbrega Botelho para o posto de Sargento Mor de Infantaria da Legião de Paulistas, Sertanejos e Caçadores que estava sendo criada na Capitania de São Paulo. Cópia do Documento 7.

12 - 1774, Setembro, 13. Lisboa.

ANEXO do Secretário de Estado da Marinha e do Ultramar, Martinho de Melo e Castro, ao Governador e Capitão General da Capitania de São Paulo, Dom Luís Antonio de Souza Botelho Mourão, acerca da promoção de Manoel José da Nobrega Botelho para o posto de sargento mor de infantaria da Legião dos paulistas, sertanejos e caçadores, conforme a ordem expedida em 21 de abril de 1774.

13 - 1774, Setembro, 13. Lisboa.

CARTA RÉGIA do Rei de Portugal, Dom José I, ao Governador e Capitão General da Capitania de São Paulo, Dom Luís Antonio de Souza Botelho Mourão, acerca da promoção de Manoel José da Nobrega Botelho para o posto de sargento mor de infantaria da Legião dos paulistas, sertanejos e caçadores, conforme a ordem expedida em 21 de abril de 1774.

14 - 1775, Maio, 12. São Paulo.

REGISTRO de número 13 no primeiro livro de registro de ordens régias. 
15 - 1767, Abril, 29. Lisboa.

OFícIO do Secretário de Estado da Marinha e do Ultramar, Martinho de Melo e Castro, ao Governador e Capitão General da Capitania de São Paulo, Dom Luís Antonio de Souza Botelho Mourão, pedindo que se verifiquem os passaportes dos estrangeiros a fim de se evitarem jesuítas na capitania.

16 - 1767, Maio, 13. Lisboa.

CARTA RÉGIA do Rei de Portugal, Dom José I, ao Governador e Capitão General da Capitania de São Paulo, Dom Luís Antonio de Souza Botelho Mourão, comunicando o nascimento do Infante.

17 - Sem data cronológica. São Paulo.

SOBRESCRITO. Por El Rei, a Dom Luís Antonio de Sousa Botelho Mourão.

18 - 1767, Junho, 01. Lisboa.

OFÍCIO de Joaquim Inácio da Cruz, José Sousa e Abreu, João Luís de Sousa Saião, Caetano Alberto Ferreira, Caetano José de Sousa, Francisco Nicolau Roncon e Antonio Álvares Aguiar, ao Governador da Praça de Santos, alertando sobre necessidade de verificação em determinados navios que chegariam ao porto de Santos.

19 - 1767, Novembro, 11. Lisboa.

AVISO de João Luís de Sousa Saião, ao membro do Conselho da Fazenda e tesoureiro do Real Erário, Joaquim Inácio da Cruz, pedindo maior controle na admissão de homens para as navegações.

20 - 1767, Junho, 01. Lisboa.

PASSAPORTE de Francisco Xavier de Araujo, com sua descrição física, autorizando sua passagem pela Vila de Santos para a Vila de Goyazes, onde residia seu tio José Antonio de Araujo. Assinado por João Luiz de Souza Sayão. 
21 - Sem data tópica e cronológica.

RELAÇÃO da tripulação do Navio Nossa Senhora do Rosário Santo Antonio e Almas, com destino a Santos. Consta o nome, profissão, idade e descrição física de cada um dos marinheiros. Assinado por João Luiz de Souza Sayão.

22 - 1767, Junho, 02. Lisboa.

PROVISÃO dos conselheiros do Conselho Ultramarino, Diogo Rangel de Almeida e Francisco Marcelino de Gouveia, para o Governador e Capitão General da Capitania de São Paulo, Dom Luís Antonio de Sousa Botelho Mourão, ordenando em nome do rei o cumprimento do Contrato do Subsídio dos Molhados.

23 - 1768, Junho, 20. Lisboa.

OFícIO do Conde de Oeiras, Sebastião José de Carvalho e Melo (Marquês de Pombal), ao Governador e Capitão General da Capitania de São Paulo, Dom Luís Antonio de Souza Botelho Mourão, informando que serão enviados reparos sobre os negócios pertencentes às capitanias do Brasil.

24 - 1767, Junho, 20. Lisboa.

OFíCIO do Conde de Oeiras, Sebastião José de Carvalho e Melo, ao Governador e Capitão General da Capitania de São Paulo, Dom Luís Antonio de Souza Botelho Mourão, em 13 itens que retomam assuntos tratados em documentos anteriores (tais como a necessidade de resistência e proteção do território contra os jesuítas e contra o domínio castelhano), bem como informa sobre o tópico das tentativas do rei de Portugal em manter boas relações com o monarca da Espanha

25 - Sem data tópica e cronológica.

REPARO sobre a defesa do Rio Grande de São Pedro e seus territórios. Tratase da descrição do local e argumentos que indicam a necessidade de serem construídas fortificações que afastem os inimigos. 
26 - Sem data cronológica. São Paulo.

SOBRESCRITO do Secretário de Estado, Francisco Xavier de Mendonça Furtado, ao Governador e Capitão General da Capitania de São Paulo, Dom Luís Antonio de Souza Botelho Mourão, provavelmente serviu de capa ao documento anterior.

27 - 1767, Junho, 23. Rio de Janeiro.

OFícIO do Secretário de Estado, Francisco Xavier de Mendonça Furtado, ao Governador e Capitão General da Capitania de São Paulo, Dom Luís Antonio de Souza Botelho Mourão, informando sobre a permanência dos jesuítas na França.

28 - 1767, Julho, 14. Lisboa.

OFíclO do Conde Vice Rei, ao Governador e Capitão General da Capitania de São Paulo, Dom Luís Antonio de Souza Botelho Mourão, informando sobre os problemas por que tem passado as tropas de Rio Grande, sob o comando de José Custódio de Sá e Faria e justificando o atraso da Nau Nossa Senhora da Graça.

29 - 1767, Março, 22. Lisboa.

OFíclO do Secretário de Estado, Francisco Xavier de Mendonça Furtado, ao Conde da Cunha, Dom Antonio Álvares da Cunha, pedindo que este trabalhe em conjunto com Dom Luís Antonio de Sousa, no que se refere à defesa e ampliação dos territórios; nunca, porém, declarando guerra contra os espanhóis.

30 - 1767, Agosto, 21. Lisboa.

CARTA RÉGIA do Rei de Portugal, Dom José I, ao Governador e Capitão General da Capitania de São Paulo, Dom Luís Antonio de Souza Botelho Mourão, ordenando que fossem pagos uma ajuda de custo e reembolso por investimentos do Provedor da Real Fazenda, José Honório de Valladares e Aboim. 
31 - Sem data cronológica. São Paulo.

SOBRESCRITO por El Rei a Dom Luís Antonio de Sousa.

32 - 1767, Outubro, 20. Rio de Janeiro.

OFíCIO do Conde da Cunha, Dom Antonio Álvares da Cunha, ao Governador e Capitão General da Capitania de São Paulo, Dom Luís Antonio de Souza Botelho Mourão, pedindo a manutenção das relações pacíficas com os vassalos do rei português.

33 - 1768, Dezembro, 15. São Paulo.

CARTA RÉGIA do Rei de Portugal, Dom José I, ao Governador e Capitão General da Capitania de São Paulo, Dom Luís Antonio de Souza Botelho Mourão, informando sobre o nascimento da Infanta, filha da princesa do Brasil.

34 - Sem data cronológica. São Paulo.

SOBRESCRITO por El Rei a Dom Luís Antonio de Sousa.

35 - 1769, Março, 02. Oeiras.

OFÍCIO do Secretário de Estado, Francisco Xavier de Mendonça Furtado, ao Governador e Capitão General da Capitania de São Paulo, Dom Luís Antonio de Souza Botelho Mourão, justificando que não poderia responder de imediato a uma correspondência recebida por encontrar-se doente.

36 - 1769, Abril, 04. Lisboa.

OFÍ́CIO do Conde de Oeiras, Sebastião José de Carvalho e Melo, ao Governador e Capitão General da Capitania de São Paulo, Dom Luís Antonio de Souza Botelho Mourão, indicando medidas que melhorem a arrecadação de impostos na capitania.

37 - Sem data cronológica. São Paulo.

SOBRESCRITO do Conde Inspetor Geral do Real Erário. 
38 - 1769, Abril, 22. Lisboa.

OFíclO do Secretário de Estado, Francisco Xavier de Mendonça Furtado, ao Governador e Capitão General da Capitania de São Paulo, Dom Luís Antonio de Souza Botelho Mourão, ordenando a restituição de uma quantia em dinheiro para o procurador dos herdeiros de Tomé de Godoi Moreira da Costa Corte Real.

39 - 1769, Maio, 20. Lisboa.

AVISO do Conde de Oeiras sobre a petição de Antonio Utra Ricardo, como procurador da Administração da Casa de Thomé Joaquim da Costa Corte Real. Pede-se a restituição a Antonio Utra Ricardo do pagamento indevido feito ao falecido José de Godoy Moreira, ex-provedor e contador da Capitania de Santos.

40 - 1769, Maio, 20. Lisboa.

OFíCIO do Governador da Capitania do Grão-Pará e Plenipotenciário das Demarcações, Francisco Xavier de Mendonça Furtado, ao Governador e Capitão General da Capitania de São Paulo, Dom Luís Antonio de Souza Botelho Mourão, pedindo o envio de um mapa das tropas e valor de desconto dos soldos disponível para compra de fardamentos.

41 - 1769, Dezembro, 19. Lisboa.

OFíCIO do Conde de Oeiras, ao Governador e Capitão General da Capitania de São Paulo, Dom Luís Antonio de Souza Botelho Mourão, informando sobre um ataque sofrido pelo Rei de Portugal.

42 - 1771, Janeiro, 14. Lisboa.

OfíclO de Martinho de Melo e Castro, ao Governador e Capitão General da Capitania de São Paulo, Dom Luís Antonio de Souza Botelho Mourão, informando sobre a morte da infanta Dona Maria Francisca Dorothea e sobre o luto de seis meses. 
43 - 1771, Abril, 27. Lisboa.

AVISO de Martinho de Melo e Castro, ao Governador e Capitão General da Capitania de São Paulo, Dom Luís Antonio de Souza Botelho Mourão, pedindo a prisão presbítero João de Bem Filgueiras.

44 - 1771, Outubro, 01. Lisboa.

AVISO de Martinho de Melo e Castro, ao Governador e Capitão General da Capitania de São Paulo, Dom Luís Antonio de Souza Botelho Mourão, sobre obstáculos aos descobrimentos.

45 - Sem data cronológica. São Paulo.

SOBRESCRITO por EI Rei, ao Governador e Capitão General da Capitania de São Paulo e Santos e do seu Conselho.

46 - 1770, Agosto, 23. Lisboa.

AVISO do Conde de Oeiras, ao Governador e Capitão General da Capitania de São Paulo, Dom Luís Antonio de Souza Botelho Mourão, ordenando que se fiscalizasse o trabalho dos oficiais da cobrança de impostos, isentando-os de obrigações que os desviassem de sua função principal.

47 - Sem data cronológica. São Paulo.

SOBRESCRITO do Conde Inspetor Geral do Real Erário, ao Governador e Capitão General da Capitania de São Paulo, Dom Luís Antonio de Souza Botelho Mourão.

48 - 1770, Agosto, 28. Lisboa.

CARTA RÉGIA do Rei de Portugal, Dom José I, ao Governador e Capitão General da Capitania de São Paulo, Dom Luís Antonio de Souza Botelho Mourão, sobre os bens confiscados dos jesuítas, pedindo um mapeamento das terras confiscadas para que se pudessem administrar os devidos impostos.

49 - Sem data cronológica. São Paulo.

SOBRESCRITO por El Rei, ao Governador e Capitão General da Capitania de São Paulo, Dom Luís Antonio de Souza Botelho Mourão. 
50 - 1770, Novembro, 16. Lisboa.

CARTA RÉGIA do Rei de Portugal, Dom José I, ao Governador e Capitão General da Capitania de São Paulo, Dom Luís Antonio de Souza Botelho Mourão, sobre os desvios de diamantes.

51 - Sem data cronológica. São Paulo.

SOBRESCRITO por El Rei, ao Governador e Capitão General da Capitania de São Paulo, Dom Luís Antonio de Souza Botelho Mourão.

52 - 1770, Janeiro, 17. Lisboa.

OFíclO de Martinho de Melo e Castro, ao Governador e Capitão General da Capitania de São Paulo, Dom Luís Antonio de Souza Botelho Mourão, informando sua nomeação como Secretário de Estado dos Negócios da Marinha e Domínios Ultramarinos.

53 - 1770, Abril, 20. Lisboa.

OFí́cIO do Conde de Oeiras, Sebastião José de Carvalho e Melo, ao Governador e Capitão General da Capitania de São Paulo, Dom Luís Antonio de Souza Botelho Mourão, anulando a arrematação do contrato dos meios direitos do registro de Curitiba a Leonardo de Araújo de Aguiar, ocorrido em 06 de março de 1769.

54 - 1770, Julho, 30. Lisboa.

AVISO de Martinho de Melo e Castro, ao Governador e Capitão General da Capitania de São Paulo, Dom Luís Antonio de Souza Botelho Mourão, pedindo que a lei seja cumprida no que se refere à proibição de serem fabricadas cartas de jogar.

55 - 1770, Dezembro, 17. Lisboa.

AVISO de Martinho de Melo e Castro, ao Governador e Capitão General da Capitania de São Paulo, Dom Luís Antonio de Souza Botelho Mourão, pedindo que os falecimentos sejam registrados. 
56 - 1771, Outubro, 01. Lisboa.

OFÍCIO de Martinho de Melo e Castro, ao Governador e Capitão General da Capitania de São Paulo, Dom Luís Antonio de Souza Botelho Mourão, sobre a oposição com os índios.

57 - 1771, Outubro, 01. Lisboa.

OFÍClO de Martinho de Melo e Castro, ao Governador e Capitão General da Capitania de São Paulo, Dom Luís Antonio de Souza Botelho Mourão, sobre oposição com os castelhanos.

58 - 1771, Outubro, 01. Lisboa.

OFÍClO de Martinho de Melo e Castro, ao Governador e Capitão General da Capitania de São Paulo, Dom Luís Antonio de Souza Botelho Mourão, apresentando planos para prevenir ataque castelhano.

59 - 1771, Outubro, 01. Lisboa.

OFÍclO do Secretário da Marinha e Ultramar, Martinho de Melo e Castro, ao Governador e Capitão General da Capitania de São Paulo, Dom Luís Antonio de Souza Botelho Mourão, sobre expedições.

60 - 1771, Setembro, 07. Arsenal Real do Exército.

RELAÇÃO A, feita por Manoel Gomes de Carvalho Silva, de toda a artilharia e munições.

61 - 1771, Setembro, 07. Arsenal Real do Exército.

RELAÇÃO B, feita por Manoel Gomes de Carvalho Silva, das munições destinadas a seis peças de artilharia.

62 - 1771, Setembro, 07. Arsenal Real do Exército.

RELAÇÃO C, feita por Manoel Gomes de Carvalho Silva, das munições destinadas a seis peças de artilharia. 
63 - 1771, Setembro, 07. Arsenal Real do Exército.

RELAÇÃO D, feita por Manoel Gomes de Carvalho Silva, das armas e munições que se remetem dos armazéns do Arsenal Real do Exército.

64 - 1771, Setembro, 12. Arsenal Real do Exército.

RELAÇÃO E, feita por Manoel Gomes de Carvalho Silva, das armas e munições que estão contidas em cada um dos caixões.

65 - 1771, Outubro, 01. Lisboa.

AVISO do Secretário da Marinha e Ultramar, Martinho de Melo e Castro, ao Governador e Capitão General da Capitania de São Paulo, Dom Luís Antonio de Souza Botelho Mourão, pedindo a extração de madeira da capitania.

66 - 1771, Julho, 22. Ribeira das Naos.

RELAÇÃO dos paus de pinho que são precisos para mastreações das naus, fragatas e embarcações miúdas fabricadas no Arsenal da Ribeira das Naos, feita por Manuel Vicente.

67 - 1771, Outubro, 07. Arsenal Real do Exército.

AVISO do Secretário da Marinha e Ultramar, Martinho de Melo e Castro, ao Governador e Capitão General da Capitania de São Paulo, Dom Luís Antonio de Souza Botelho Mourão, informando o envio do Compêndio Histórico de Estado da Universidade de Coimbra no tempo da invasão dos jesuítas.

68 - 1771, Novembro, 20. Lisboa.

OFÍCIO do Secretário da Marinha e Ultramar, Martinho de Melo e Castro, ao Governador e Capitão General da Capitania de São Paulo, Dom Luís Antonio de Souza Botelho Mourão, escrito em 38 itens sobre manutenção e expansão de territórios. 


\subsection{Edição fac-similar e semidiplomática justalinear}

As transcrições semidiplomáticas precedidas de suas respectivas imagens fac-similares encontram-se a seguir, na mesma sequência em que se encontram no livro manuscrito estudado e de acordo com a ordem apresentada pelo Quadro 1 e pelos verbetes descritivos anteriormente apontados.

O número de cada documento aparece antes da primeira cópia facsimilar entre colchetes, por exemplo, antes do documento 1, aparece [1]. Essa numeração vem centralizada na página, seguida do número do fólio entre barras duplas. As transcrições vêm sempre precedidas pelo número do fólio, na primeira linha da transcrição para não alterar a contagem de linhas. 


\section{Edições semidiplomáticas}


||1r||

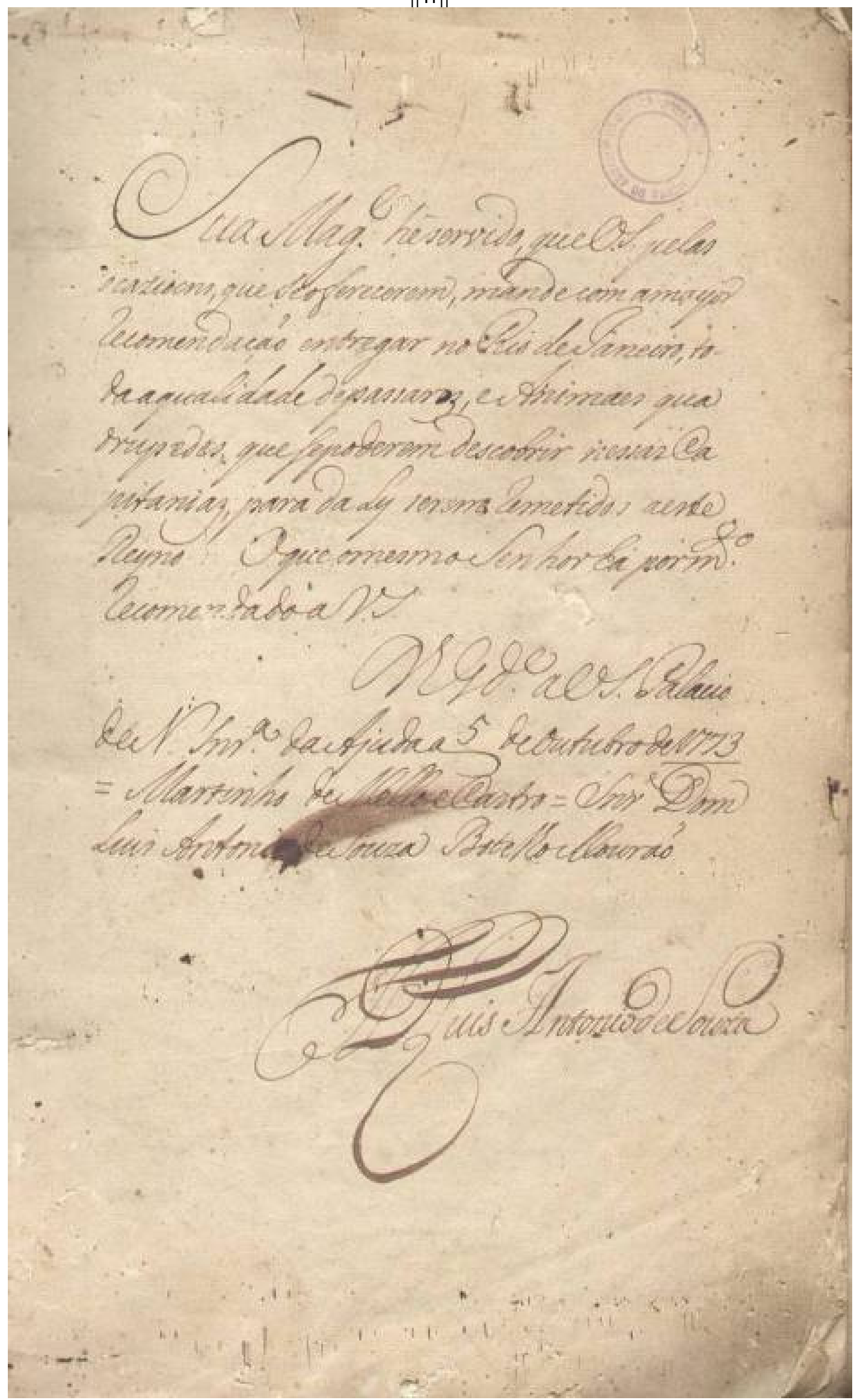


||1r|| SuaMagestade hêservido, queVossaSenhoria pelas*

ocazioens, queseoferecerem, mandecom amayor

recomendaçaõ entregar noRio delaneiro, to-

daaqualidadedepassaroz, eAnimaes qua

5 drupedes, quesepoderemdescobrir nessasCa

pitaniaz, para daLy serem remetidos aeste

Reyno: OqueomesmoSenhorha pormuito

recomendadoaVossaSenhoria

DeosGuarde aVossaSenhoria Palacio

10 deNossa Senhora daAjudaa $\underline{5}$ deOutubrode $\underline{1773}$

$=$ Martinho deMelloeCastro $=$ Senhor Dom

Luis AntoniodeSouza BotelhoMouraõ

DomLuis AntoniodeSouza

* Acima há um carimbo circular do AESP. 


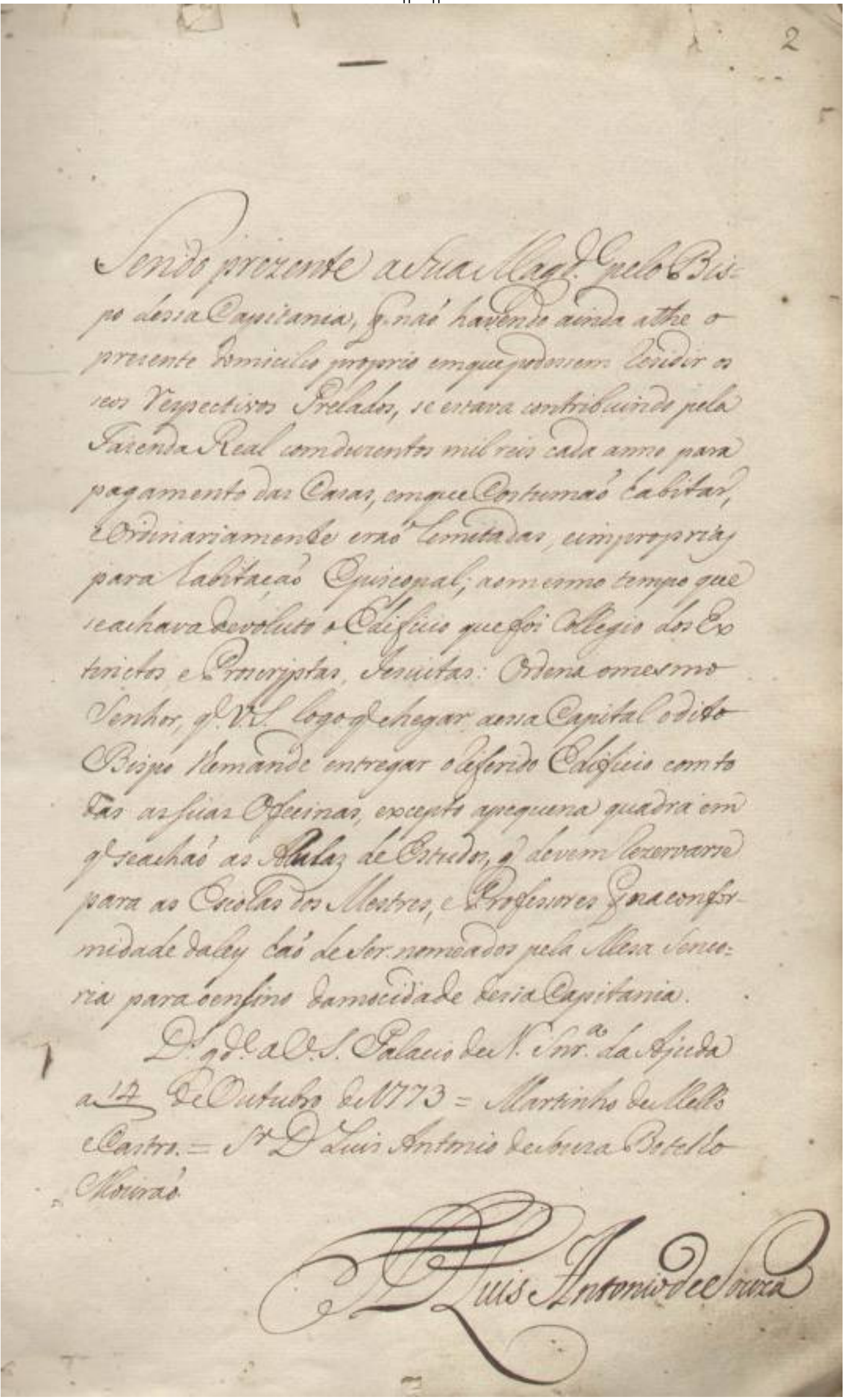


||2r|| Sendo prezente aSuaMagestade peloBis= po dessaCapitania, que naõ havendo ainda athe o prezente domicilio proprio emquepodessem residir os seos respectivos Prelados, se estava contribuindo pela

5 FazendaReal comduzentos mil reis cada anno para pagamento das Casas, emqueCostumaõ habitar, eOrdinariamente eraõ lemitadas, eimproprias parahabitaçaõ Episcopal; ao mesmo tempo que seachavadevoluto oEdificio quefoi Collegio dos Ex

10 tinctos eProscrjptas, lesuitas: Ordenaomesmo Senhor, queVossaSenhoria logoquechegar aessaCapital odito Bispo Ihemande entregar o referido Edificio com to das assuasOfecinas, excepto apequena quadra em queseachaõ as Aulaz deEstudos, que devemrezervarse

15 para as Escolas dos Mestres, eProfessores que naconformidade daley haõ deSer nomeados pela Mesa Senco= ria parao ensino damocidade dessaCapitania.

Deos guarde aVossaSenhoria Palacio deNossa Senhora daAjuda a14 deOutubro de1773 = Martinho deMello

20 eCastro. $=$ SenhorDomLuis Antonio deSouzaBotelho Mouraõ. 


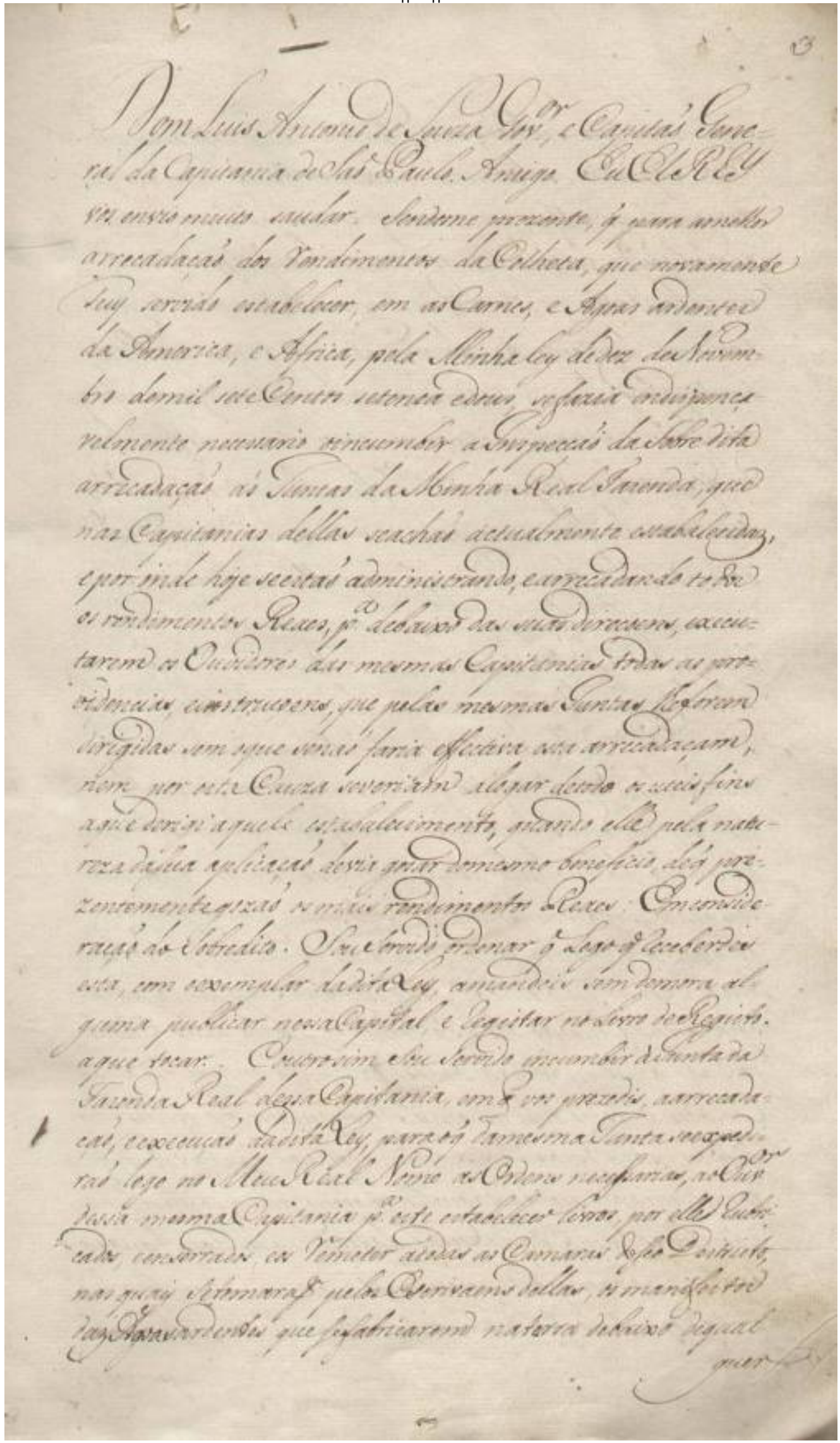


||3r|| Dom Luis Antonio de Souza Governador, eCapitaõ Gene= ral da Capitania deSaõ Paulo. Amigo. EuEIREY

vos envio muito saudar. Sendome prezente, que para amelhor arrecadaçaõ dos rendimentos daColheta, que novamente

5 Fuy servido estabelecer, em as Carnes, e Agoas ardentes da America, e Africa, pela Minhaley de dez deNovem= bro demil seteCentos setenta edous, sefazia indispençavelmente necessario oincumbir alnspecçaõ daSobre dita arrecadaçaõ ás luntas daMinha Real Fazenda, que

10 nas Capitanias dellas seachaõ actualmente estabelecidaz, e por onde hoje seestaõ administrando, earrecadando todos os rendimentos Reaes, para debaixo das suas direçoens, execu= tarem os Ouvidores das mesmas Capitanias todas as pro= videncias, einstruçoens, que pelas mesmas luntas Iheforem dirigidas sem oque senaõ faria effectiva esta arrecadaçam, nem por estaCauza severiam alogar detodo os uteis fins aque derigi aquele estabalecimento, quando elle pela natureza dasua aplicaçaõ devia gosar domesmo beneficio, deque pre= zentementegozaõ os mais rendimentos Reaes: Em consideraçaõ doSobredito. SouServido ordenar queLogoquereceberdes esta, com oexemplar daditaLey̆, amandeis semdemora al= guma publicar nessaCapital, e registar noLivro deRegisto a que tocar. Eoutrosim SouServido incumbir àluntada FazendaReal dessaCapitania, emque vos prezedis, aarrecada= çaõ, eexecuçaõ daditaLey, paraoque damesmaluntaseexpedi= raõ logo no MeuReal Nome asOrdens necessarias, aoOuvidor dessa mesmaCapitania para este estabelecerlivros, por elle rubricados, eenserrados, eos remeter atodas as Camaras doseo Destricto, nas quais setomaraõ pelosEscrivaens dellas, os manifestos

30 daz Agoasardentes quesefabricarem naterra debaixo dequal |quer 


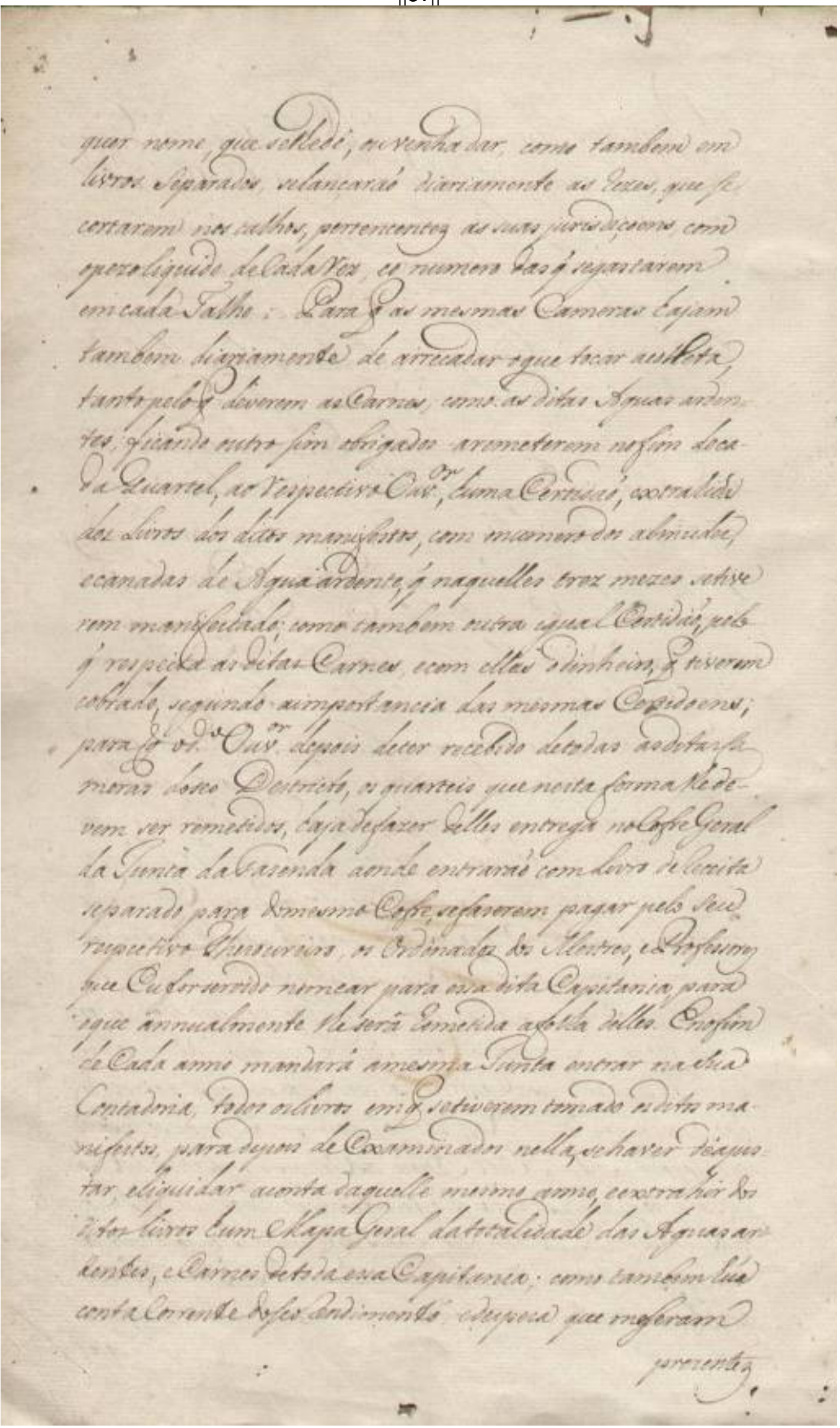


||3v || [[quer]] nome, queselhedê, ouvenha dar, como tambem em livros separados, Selançaraõ diariamente as rezes, quese cortarem nos talhos, pertencentez as suas jurisdiçoens, com opezoliquido deCadaVez, eo numero das que segastarem em cada Talho: Paraque as mesmas Cameras hajam tambem diariamente de arrecadaroquetocar acolleta, tantopeloque deverem asCarnes, como as ditas Aguas arden= tes; ficando outrosim obrigados aremeterem nofim decadaQuartel, aorespectivoOuvidor, humaCertidaõ, extrahida

40 dos Livros dos ditos manifestos, com onumerodos almudes, ecanadas de Aguaardente, que naquelles trez mezes setive rem manifestado; como tambem outra igualCertidaõ, pelo que respeita as ditasCarnes, ecom ellas o dinheiro, que tiverem cobrado, segundo aimportancia das mesmas Certidoens; paraqueoditoOuvidor depois deter recebido detodas as ditas $\mathrm{Ca}$ meras doseo Destricto, os quarteis quenestaformalhedevem ser remetidos, hajadefazer delles entrega noCofreGeral da lunta daFasenda aonde entraraõ comLivro dereceita separado, para domesmoCofre,sefaserem pagar pelo seu

50 respectivoThezoureiro, os Ordenados dos Mestres, eProfessores queEuforservidonomear para essa ditaCapitania, para o que annualmente Iheserâ remetida afolha delles. Enofim deCada anno mandará amesmalunta entrar nasua Contadoria, todos oslivros em que setiverem tomado os ditos manifestos, paradepois deexaminaods nella,sehaver deajustar, eliquidar aconta daquelle mesmo anno, e extrahir dos ditoslivros humMapaGeral datotalidade das Aguas ardentes, eCarnes detodaessaCapitania; como tambemhuã contaCorrentedoseorendimento, edespesa que meseram 


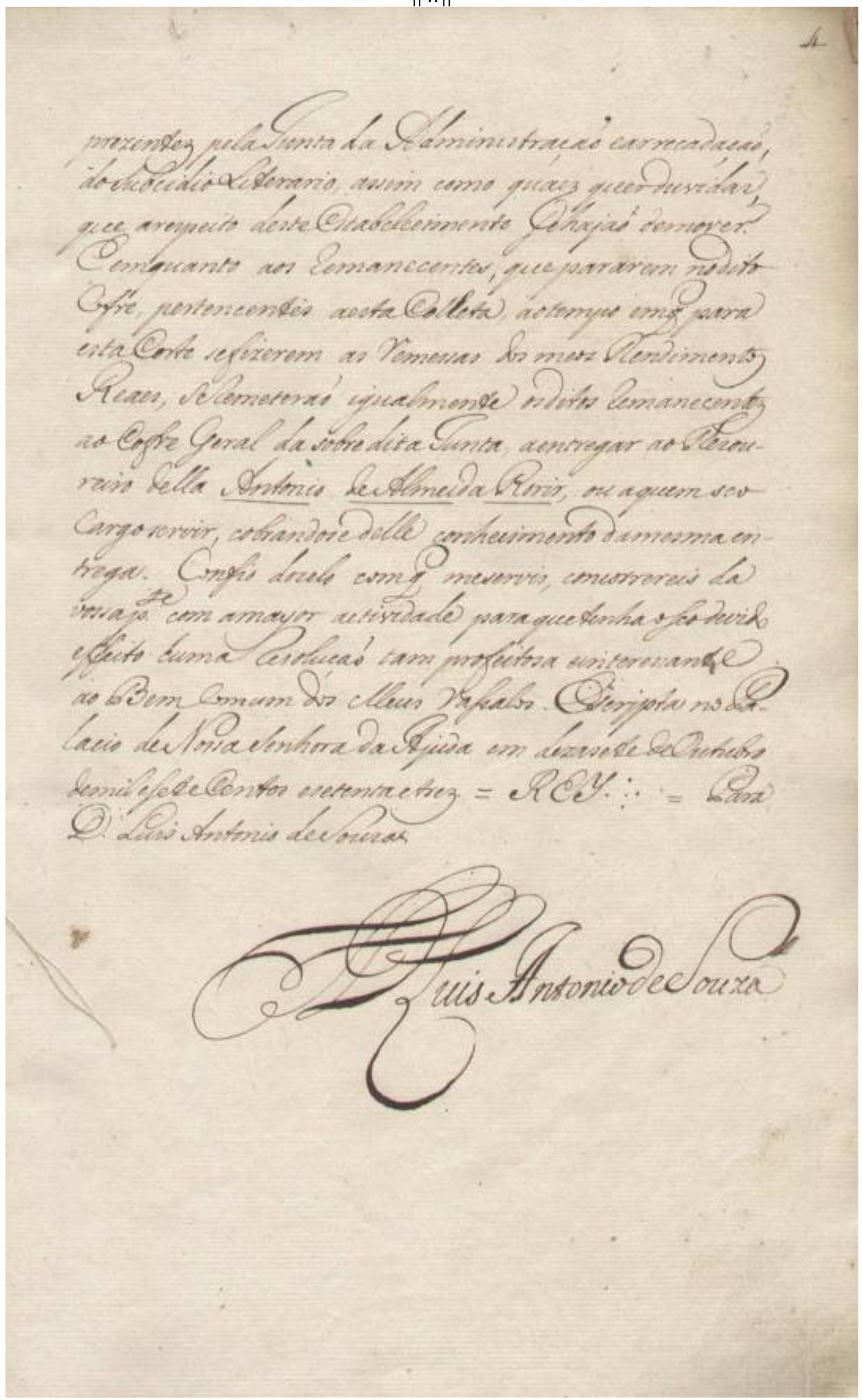


||4r|| [[prezentez]] pelalunta da Administraçaõ earrecadaçaõ, doSubcidioLiterario, assim como quaez querduvidas, que arespeito desteEstabelecimento sehajaõ demover. E emquanto aos remanecentes, quepararem no dito

65 Cofre, pertencentes aestaColleta, aotempo emque para estaCorte Sefizerem as remessas dos meos Rendimentos Reaes, seremeteraõ igualmente os ditos remanecentez aoCofre Geral da sobre dita lunta, aentregar aoThezou-

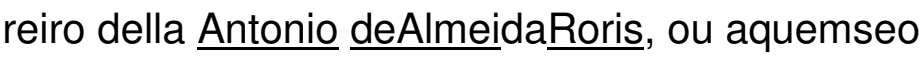

70 Cargoservir, cobrandosedelle conhecimento damesmaentrega. Confio dozelo comque meservis, concorrereis da vossaparte com amayor actividade paraquetenhaoseodevido effeito humaresoluçaõ tam profeitosa einteressante ao BemComum dos Meus Vassalos. Escripta no Pa-

75 lacio deNossaSenhoradaAjuda em dezasetedeOutubro demil eseteCentos esetentaetrez $=$ REY.$=$ Para Dom Luis Antonio deSouza. 
(C) vine

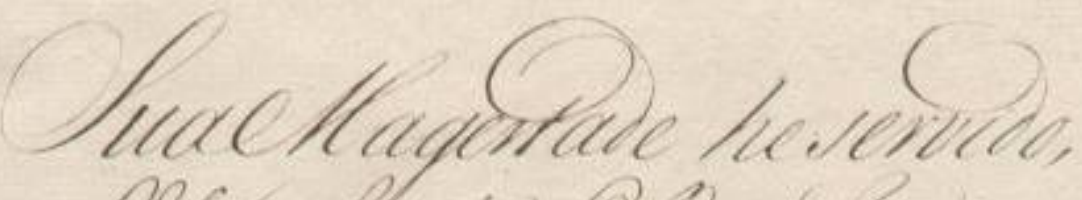

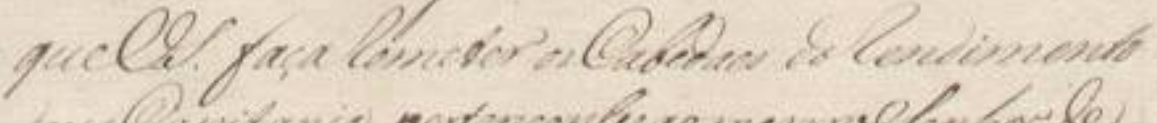

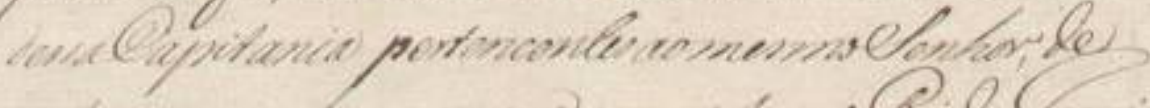

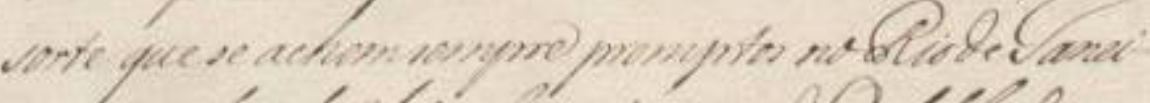

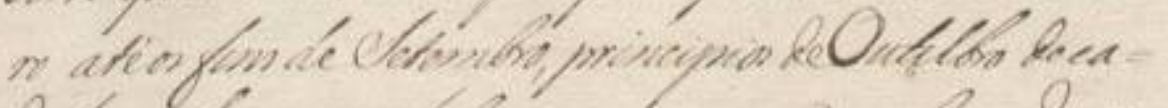

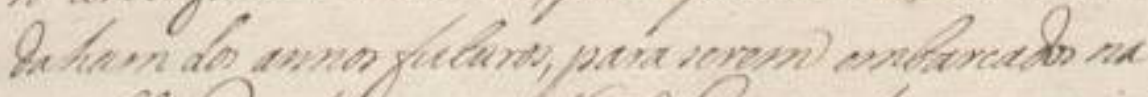

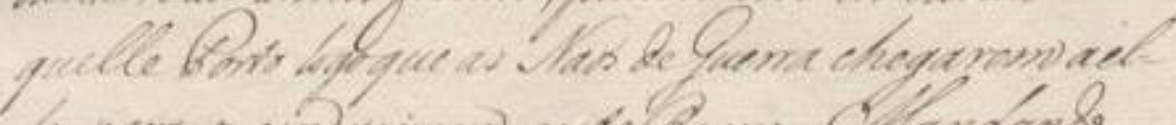

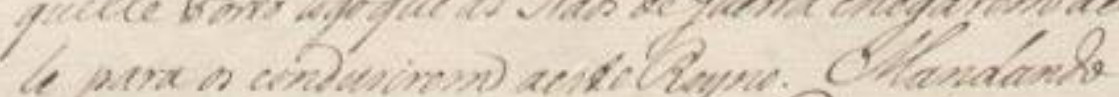

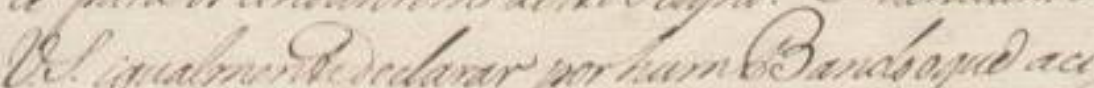
yive 18

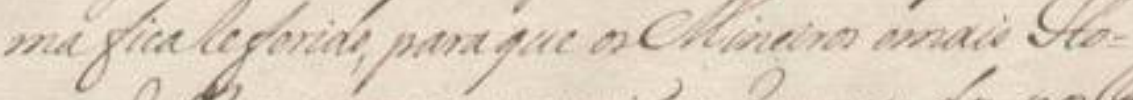

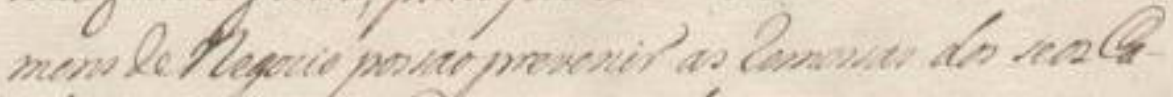

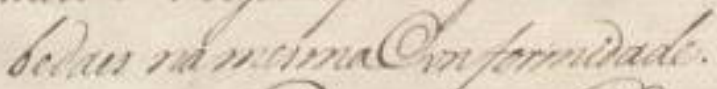

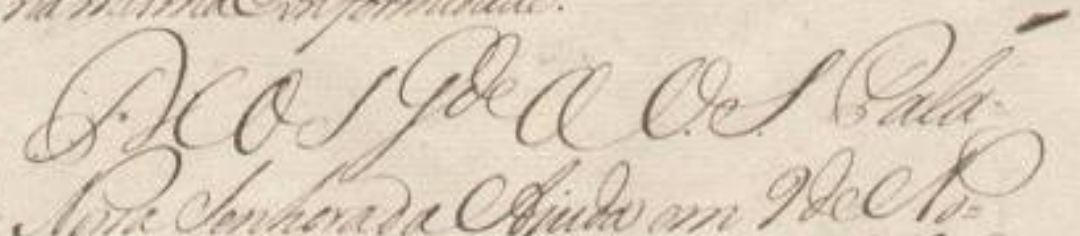

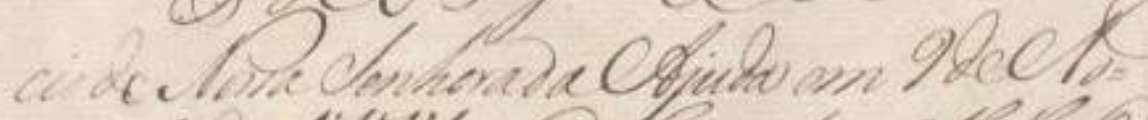

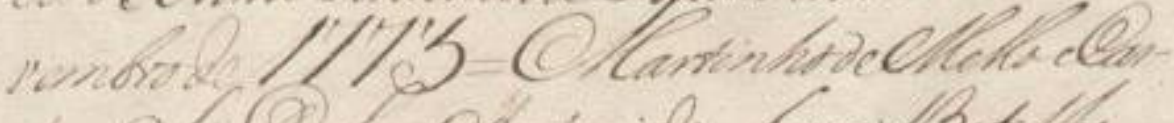

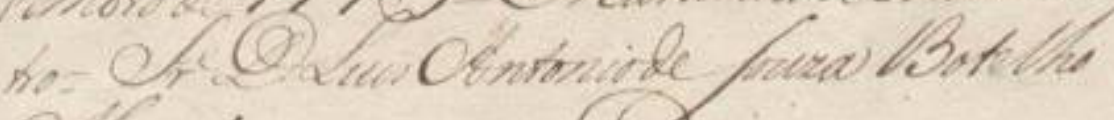
(ineret
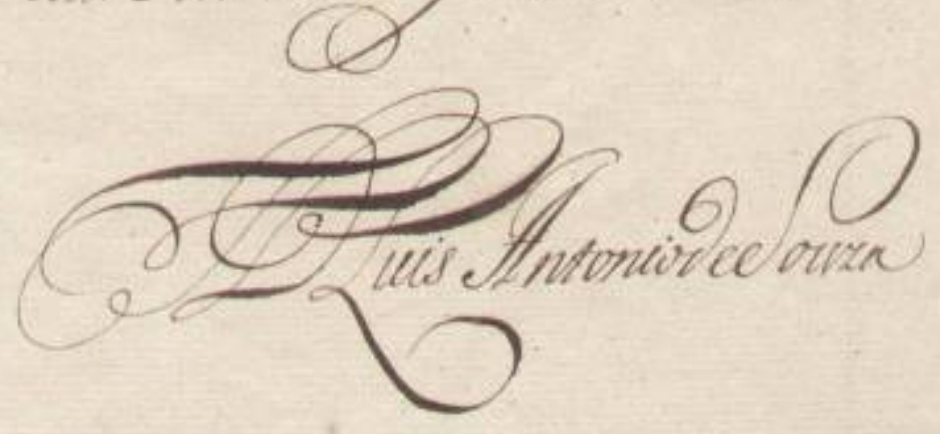


\section{$\| 7 r||$ Copia}

SuaMagestade he servido, queVossaSenhoria faça remeter osCabedaes dorendimento dessaCapitania pertencentes ao mesmoSenhor, de

5 sorte que se achem sempre promptos noRio de laneiro até os fins deSetembro, principios deOutubro deca= dahum dos annos futuros, para serem embarcados na quelle Porto logo que as Naos deGuerra chegarem aelle para os condusirem aeste Reyno. Mandando

10 VossaSenhoria igualmentedeclarar porhumBando oque acimaficareferido, para que osMineiros emais $\mathrm{Ho}=$ mens deNegocio possaoprevenir as remessas dos seosCabedaes namesmaConformidade.

Deos Guarde aVossaSenhoria Pala-

15 cio de Nossa SenhoradaAjuda em 9deNo= vembro de1773 $=$ Martinho deMello eCastro $=$ Senhor DomLuis Antoniode Souza Botelho Mouraõ 
(uide

320

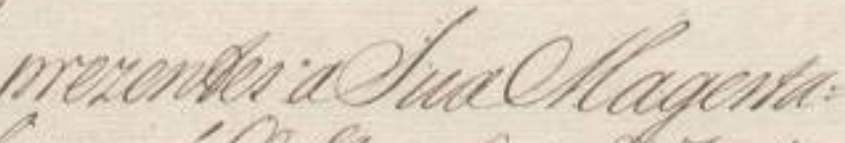

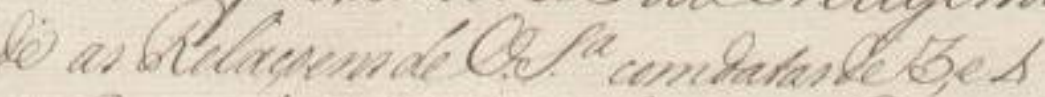

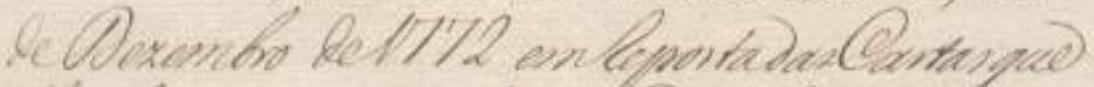

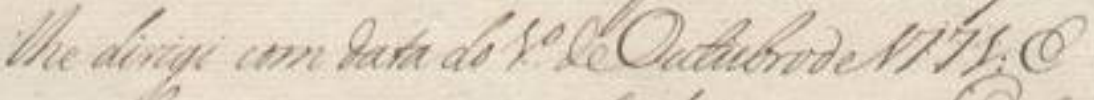

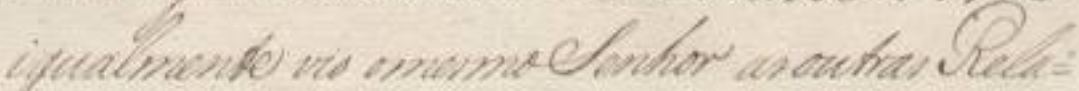

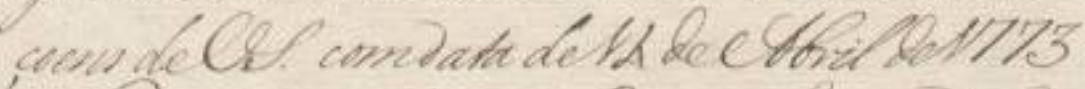

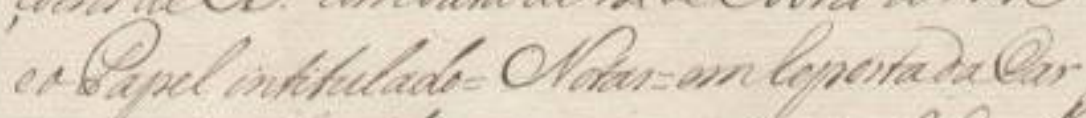

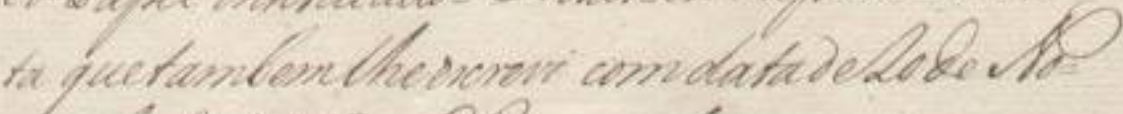

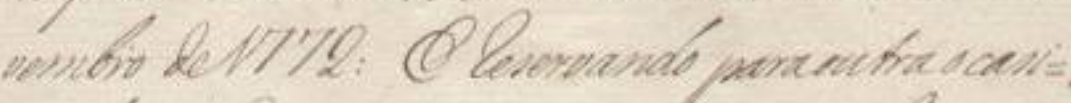

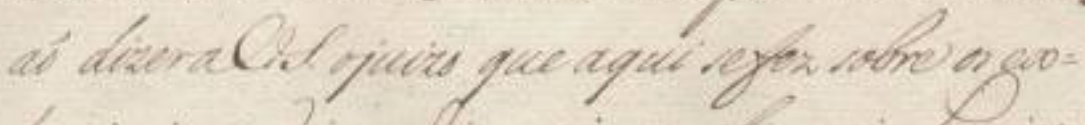

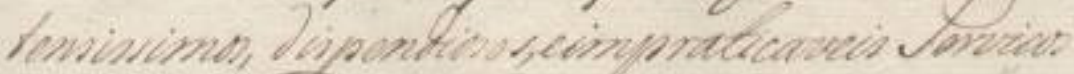

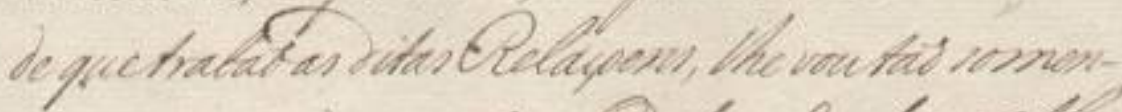

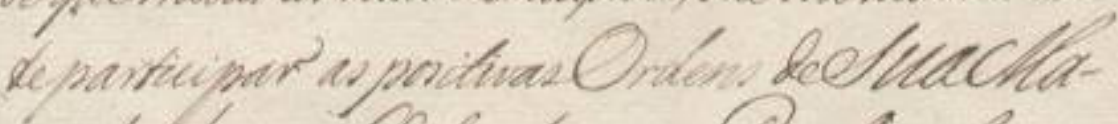

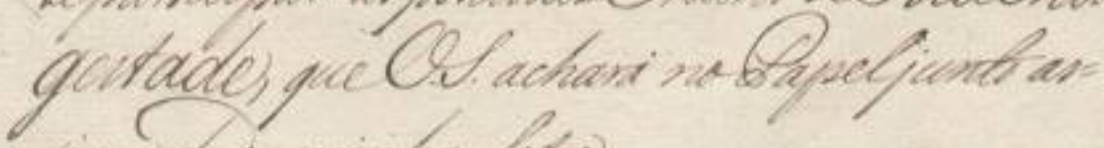
sigmadoreminia dess.

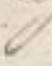

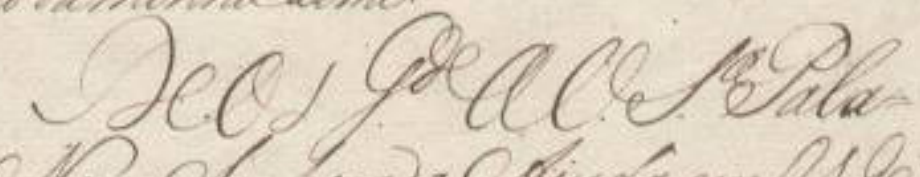

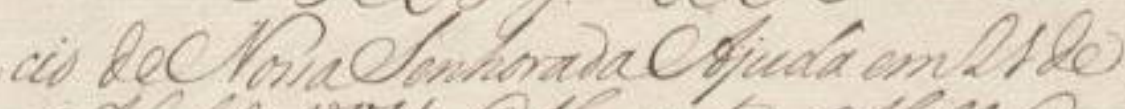

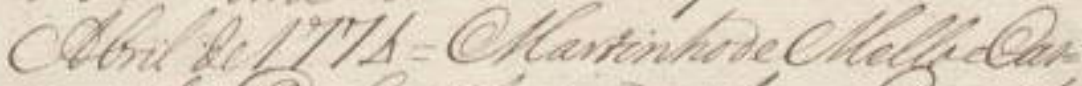

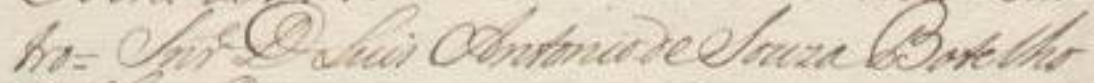
Cirang?

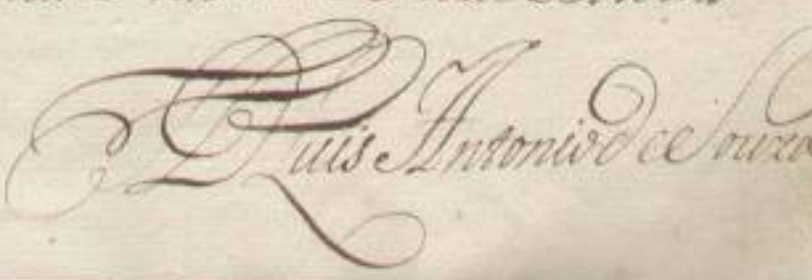


||9r|| Copia

Foraõ prezentes aSua Magesta=

de as Relaçoens deVossaSenhoria comdatas de3,e 4

deDezembro de1772 emrepostadasCartas que

5 Ihe dirigi com data doprimeiro deOutubrode1771: E

igualmente vio omesmoSenhor as outras Rela=

çoens deVossaSenhoria comdata de14 deAbril de1773

e oPapel intitulado $=$ Notas $=$ emrepostadaCar

ta quetambemlhe escrevi com data de20 de $\mathrm{No}=$

10 vembro de1772: $\mathrm{E}$ reservando paraoutra ocasi= aõ dizeraVossaSenhoria ojuizo que aqui sefez sobre os ex= tensissimos, dispendiosos, eimpraticaveis Serviços de quetrataõ as ditas Relaçoens, Ihe voutaõ somenteparticipar as positivasOrdens deSuaMa-

15 gestade, queVossaSenhoria achará noPapeljunto assignado daminhaLetra.

Deos Guarde aVossaSenhoria Pala= cio deNossaSenhoradaAjuda em21 de Abril de1774 $=$ MartinhodeMelloeCas=

20 tro $=$ SenhorDomLuis Antonio deSouzaBotelho Mouraõ.

DomLuis AntoniodeSouza 
||10r|

$$
\text { Cyia }
$$

(Q)

Gun aligar ceporita

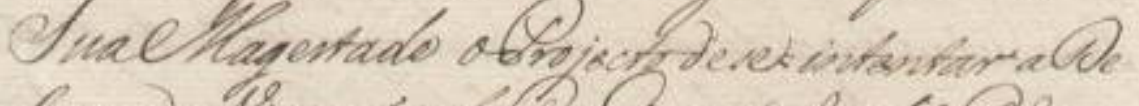

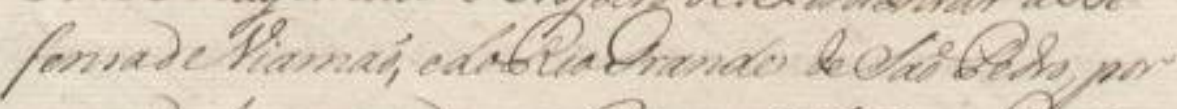

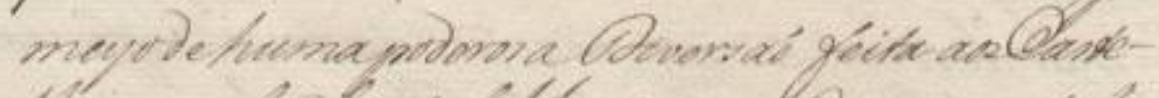

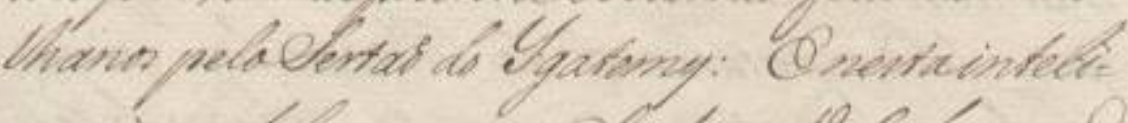

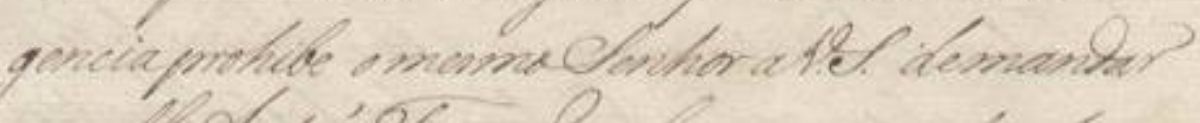

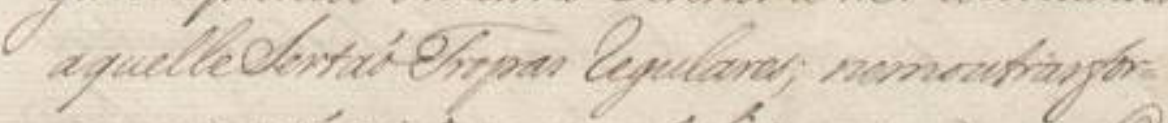

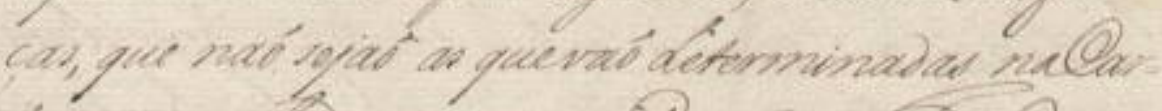

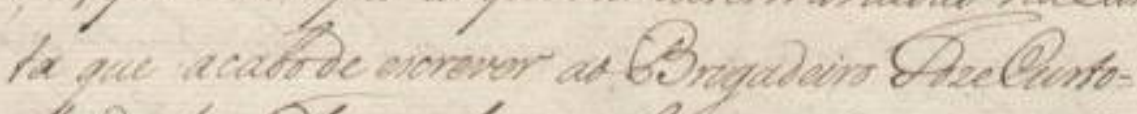

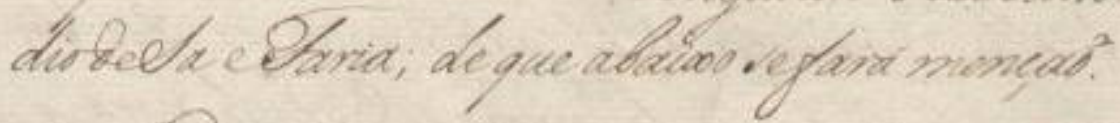

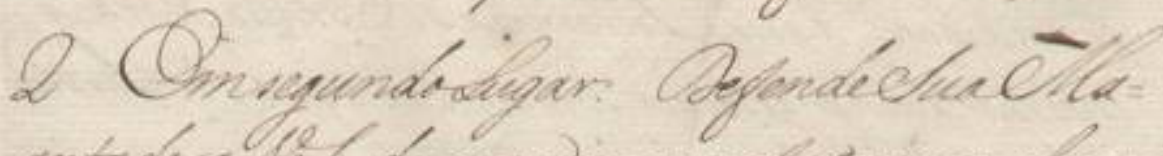

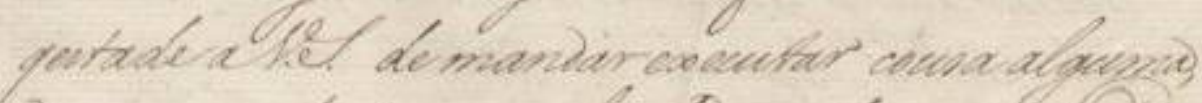

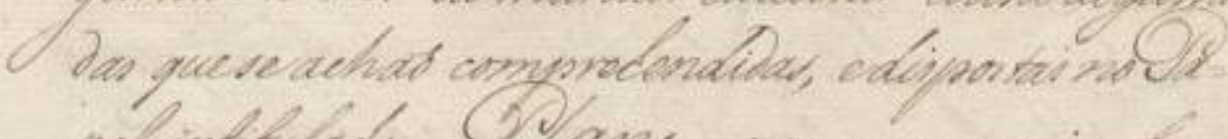

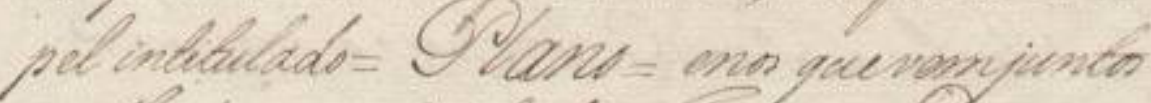

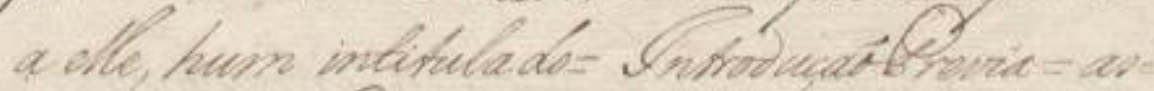

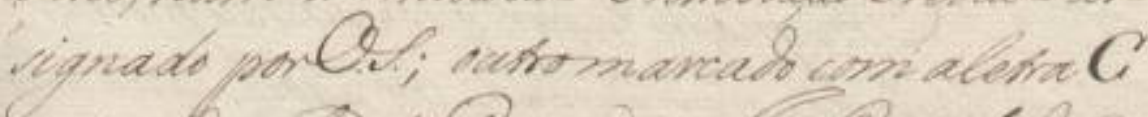

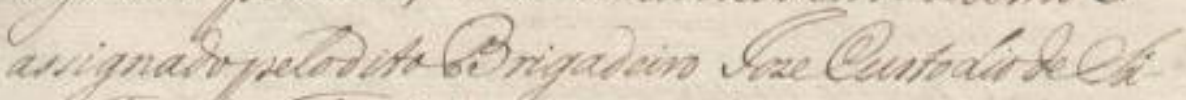

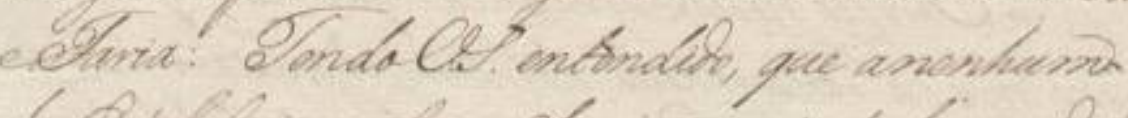

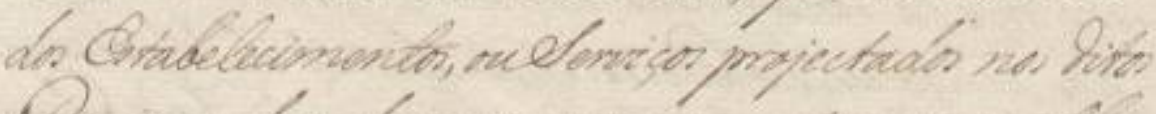

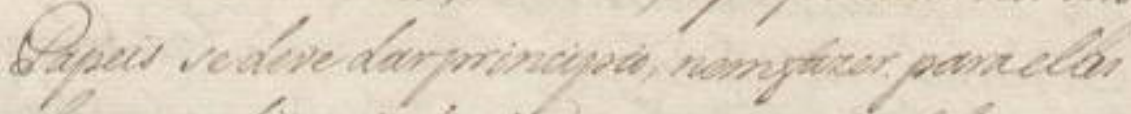

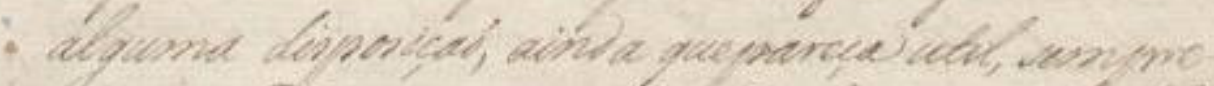

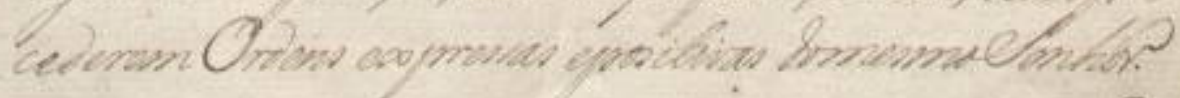


||10r|| Copia

1 Emprimeiro Lugar reprova

SuaMagestade oProjecto dese intentar $\mathrm{aDe}=$ fensadeViamaõ, edoRioGrande deSaõPedro, por

5 meyodehumapoderosaDiversaõ feita aosCasteIhanos peloSertaõ do Ygatemy: E nestainteli= genciaprohibe o mesmoSenhor aVossaSenhoria demandar aquelleSertaõTropas regulares; nemoutrasfor= ças, que naõ sejaõ as quevaõ determinadas naCar=

10 ta que acabode escrever aoBrigadeiro lozeCusto= diodeSa eFaria; de que abaixo sefará mençaõ.

2 EmsegundoLugar: DefendeSuaMa= gestade aVossaSenhoria de mandar executar cousa alguma, das quese achaõ comprehendidas, edispostas no $\mathrm{Pa}=$

15 pel intitulado $=$ Plano $=$ enos quevemjuntos

a elle, hum intitulado $=$ IntroduçaõPrevia $=$ as $=$ signado porVossaSenhoria; outromarcado com aletra C assignadopeloditoBrigadeiro lozeCustodiodeSâ eFaria: TendoVossaSenhoria entendido, que anenhum

20 dos Estabelecimentos, ouServiços projectados nos ditos Papeis sedeve darprincipio, nemfazer paraelles alguma disposiçaõ, ainda quepareça util, sempre cederem Ordens expressas epositivas domesmoSenhor. 


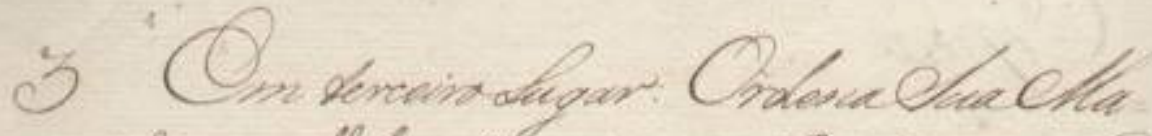

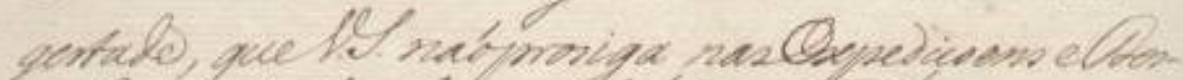

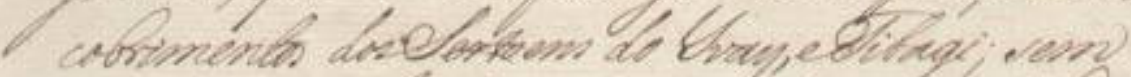

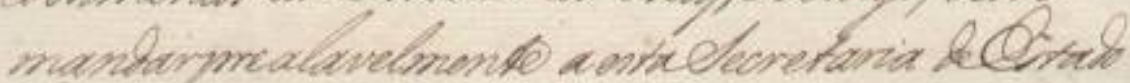

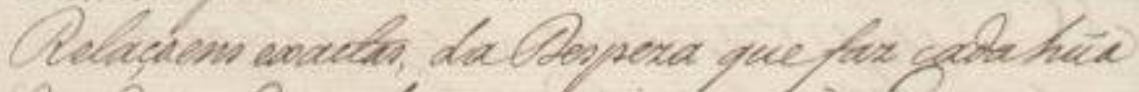

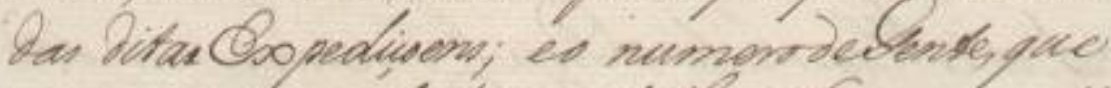

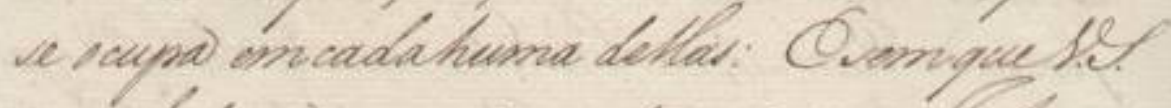
mande findr' as mais exactas, enigonsas leporne-

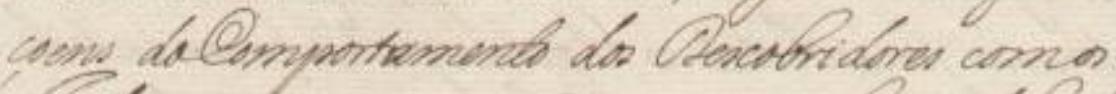

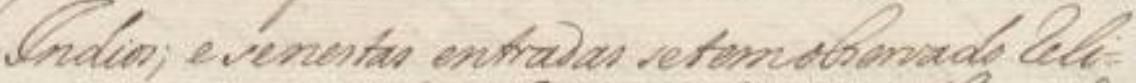

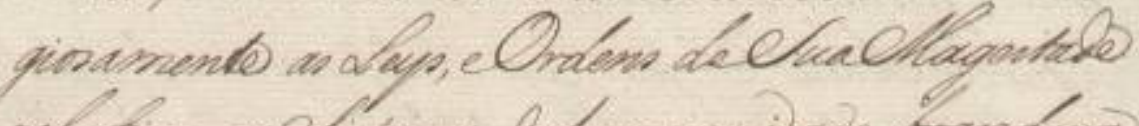

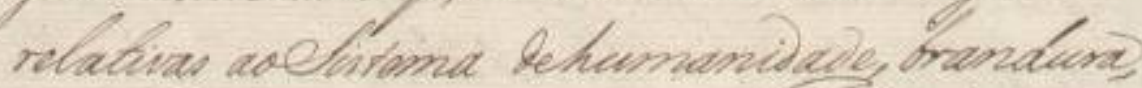

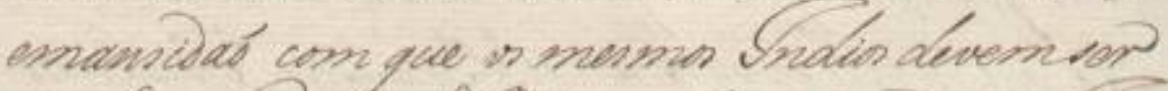

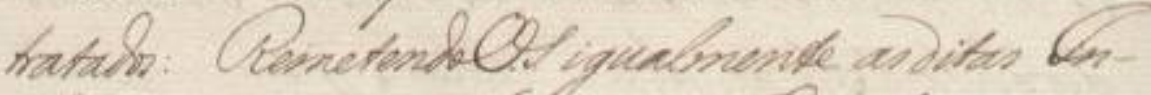

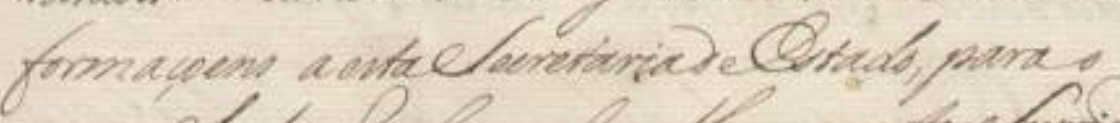

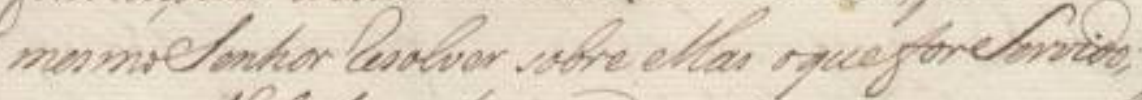

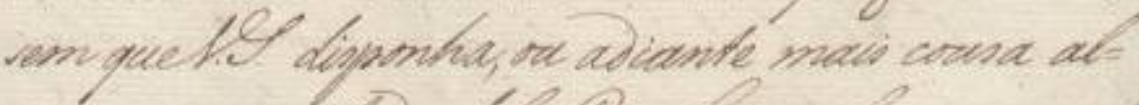

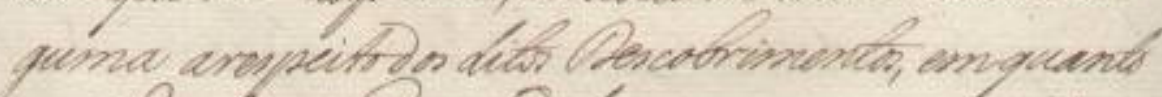

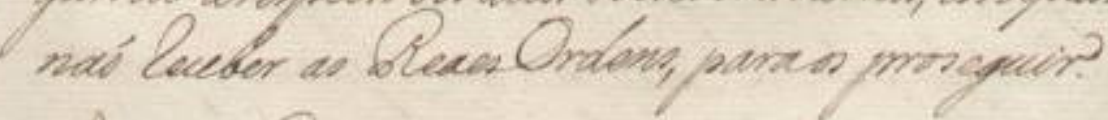

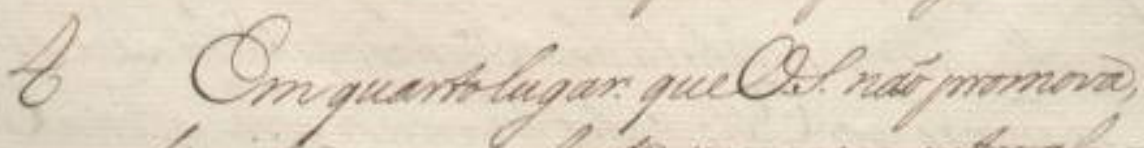

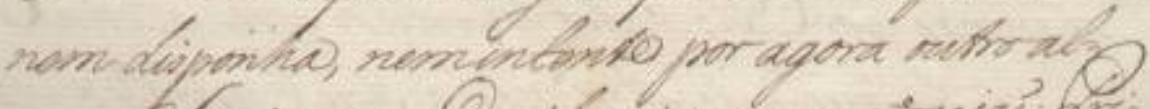

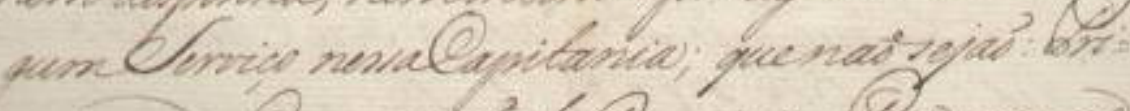
meingorda (Q)

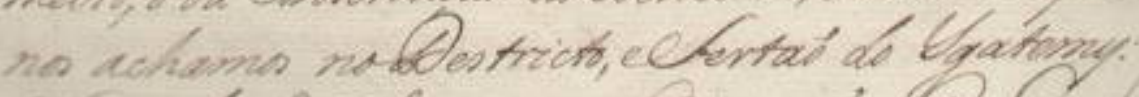

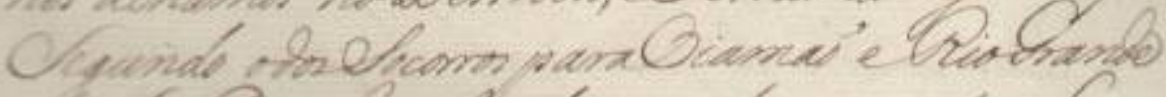

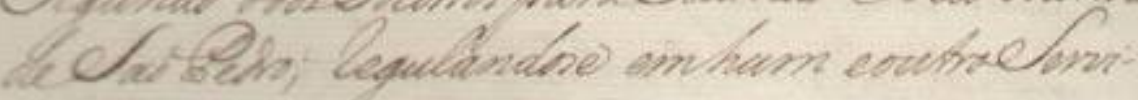
co nu phome numieral 
$\|10 v\|$ [[3]] Em terceiroLugar: OrdenaSuaMa= gestade, que VossaSenhoria naõprosiga nasExpediçoens eDescobrimentos dosSertoens doYvay, eTibagi; sem mandarprealavelmente a estaSecretaria deEstado Relaçoens exactas, daDespeza quefaz cadahũa das ditas Expediçoens; eo numerodeGente, que se ocupa em cadahuma dellas: E sem queVossaSenhoria mandetirar as mais exactas, erigorosas Informaçoens doComportamento dos Descobridores comos Indios; e senestas entradas setemobservado reli= giosamente as Leys, eOrdens deSuaMagestade relativas aoSistema dehumanidade, brandura, emansidaõ com que os mesmos Indios devemser tratados: RemetendoVossaSenhoria igualmente as ditas Informaçoens a estaSecretariadeEstado, parao mesmoSenhor resolver sobre ellas oqueforServido; sem queVossaSenhoria disponha, ou adiante mais cousa alguma arespeitodos ditos Descobrimentos, emquanto naõ receber as ReaesOrdens, paraos proseguir. 4 Em quartolugar: queVossaSenhoria naõ promova, nem disponha, nemintente por agora outroal= gumServiço nessaCapitania; quenaõsejaõ: Pri= meiro;o da Conservaçaõ doDominio, ePosse emque nos achamos noDestricto, eSertaõ do Ygatemy: Segundo odosSocorros paraViamaõ eRioGrande deSaõPedro; regulandose emhum eoutroServiço na forma seguinte. 5 


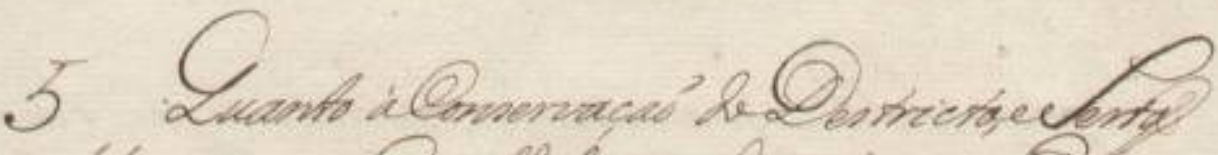

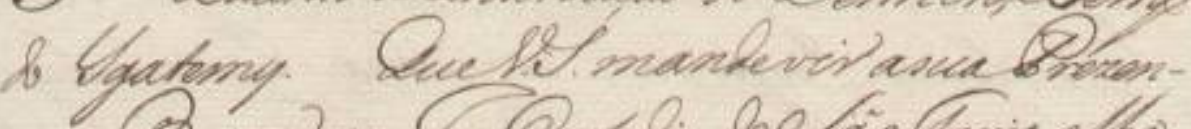

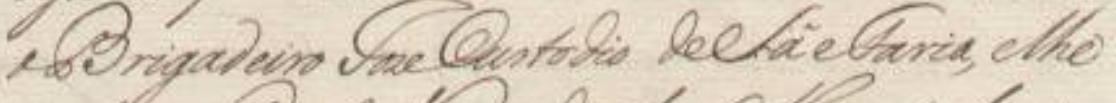

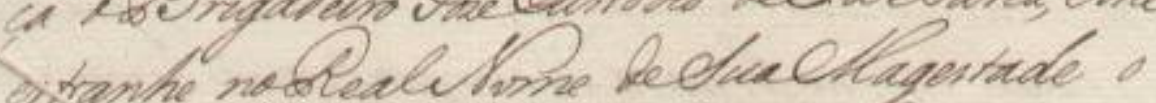

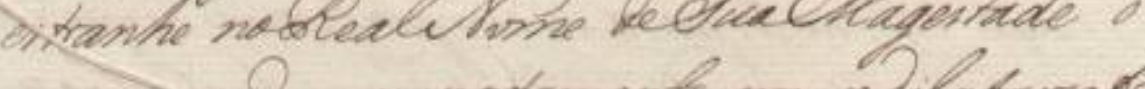
wimpine compmaments en sedilatarede

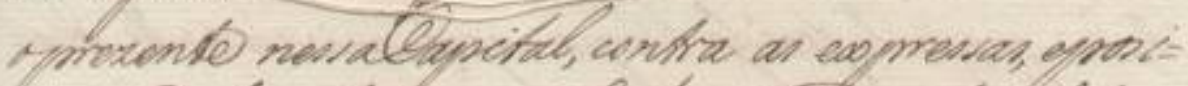

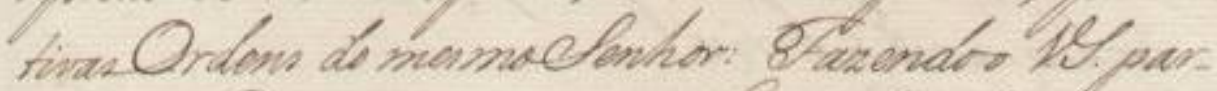

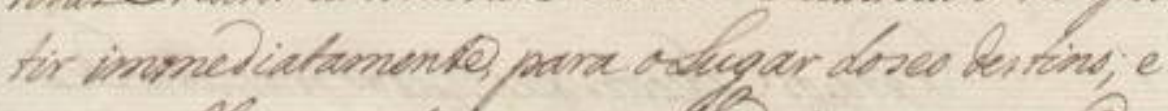

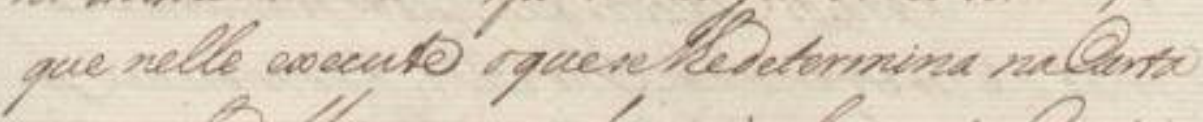

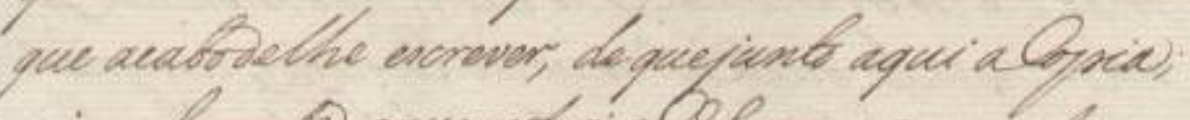
eiguabmente rquengen a Qu no nangrapos $\mathrm{x}=$

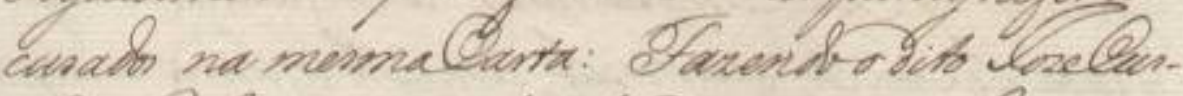

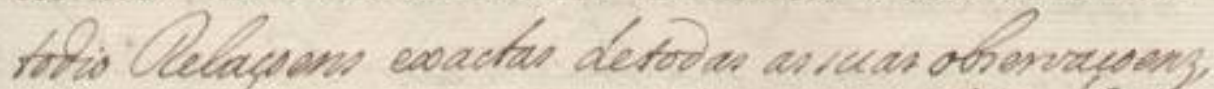

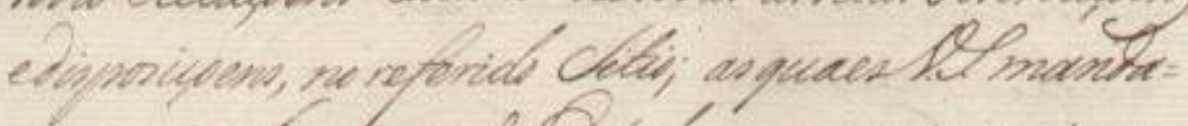

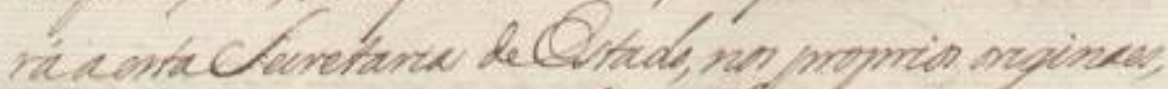

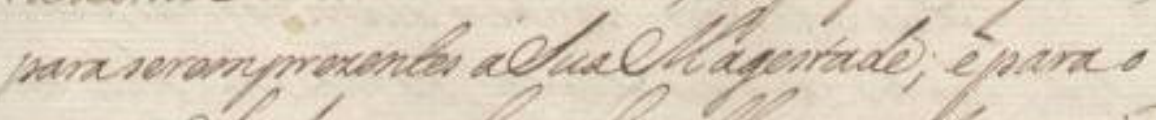

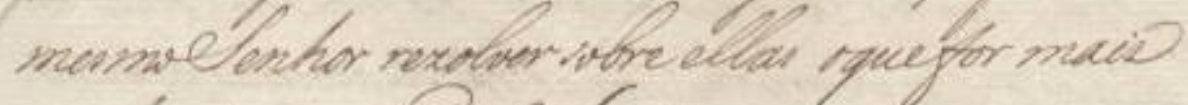

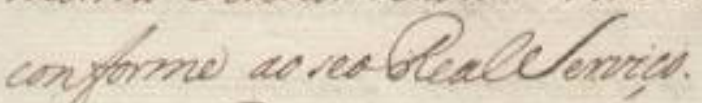

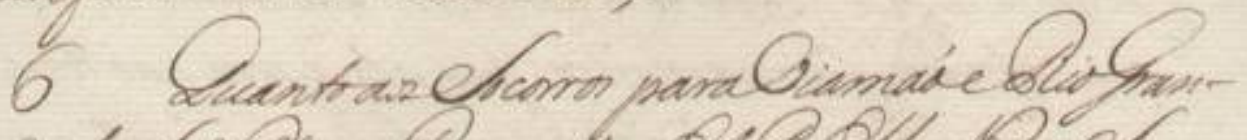

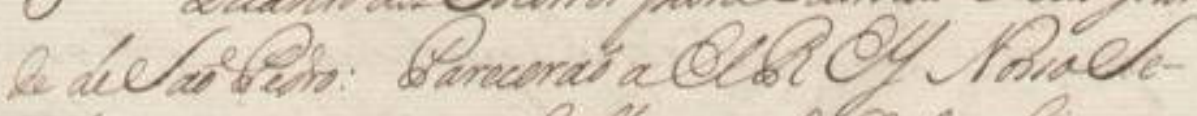

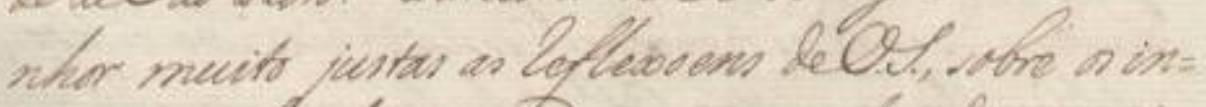
comenicutes dese mandanan manchar bus su pros

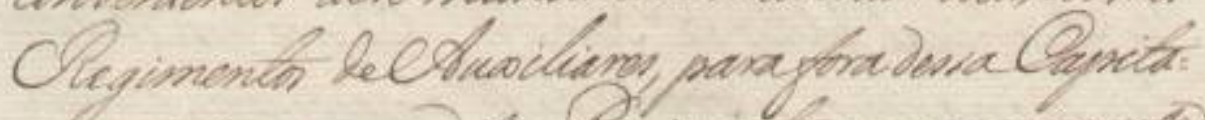

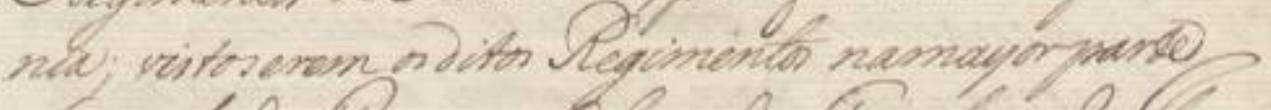

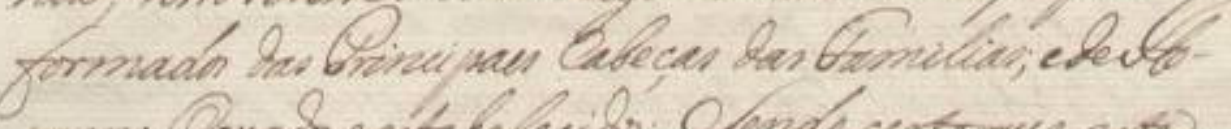

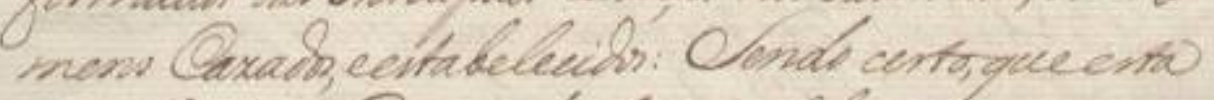

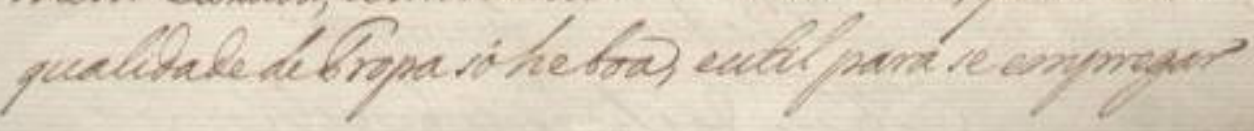


\|11r\| [[5]] Quanto àConservaçaõ doDestricto,eSertaõ

do Ygatemy. [espaço] QueVossaSenhoria mandevir asuaPrezen-

55 ça oBrigadeiro lozeCustodio deSâ eFaria, elhe

estranhe noRealNome deSuaMagestade o

seo reprovado comportamento, em sedilatar ate

oprezente nessaCapital, contra as expressas, eposi $=$

tivasOrdens do mesmoSenhor: Fazendoo VossaSenhoria par-

60 tir immediatamente, para oLugar doseo destino; e

que nelle execute oqueselhedetermina naCarta

que acabodelhe escrever, de quejunto aqui aCopia;

e igualmente oquereferi aVossaSenhoria nos paragrafos $\mathrm{a}=$

cusados na mesmaCarta: Fazendoo dito lozeCus-

65 todio Relaçoens exactas detodas as suas observaçoenz,

edisposiçoens, no referido Sitio; as quaesVossaSenhoria manda= rá aestaSecretaria deEstado, nos proprios originaes, paraseremprezentes aSuaMagestade; e para o mesmoSenhor rezolver sobre ellas oquefor mais

70 conforme ao seoRealServiço.

6 QuantoaosSocorros paraViamaõeRioGrande deSaõPedro: Pareceraõ aEIREY NossoSenhor muito justas as reflexoens deVossaSenhoria, sobre os in= convenientes dese mandarem marchar dous, outres

Regimentos deAuxiliares, parafora dessaCapita= nia; vistoserem os ditos Regimentos namayorparte formados das Principaes Cabeças das Familias; edeHomens Cazados, eestabelecidos: Sendo certo,queesta qualidadedeTropa sóheboa, eutil para se empregar 


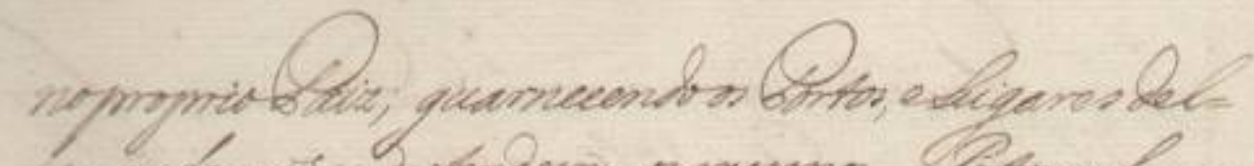

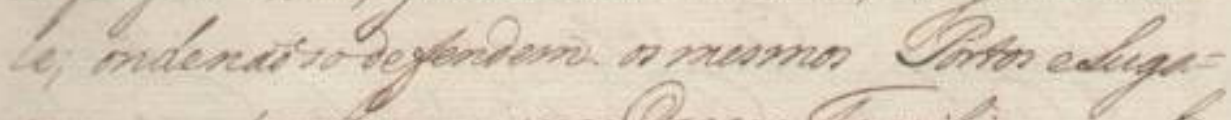

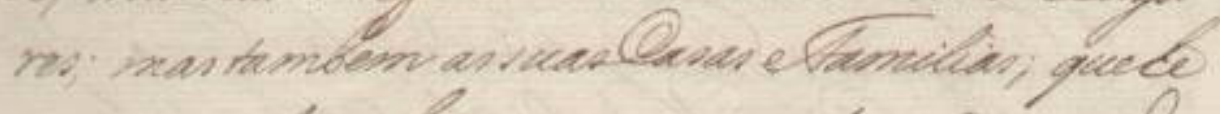

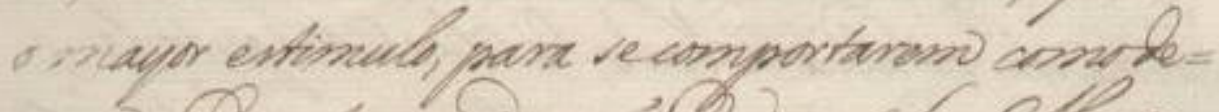

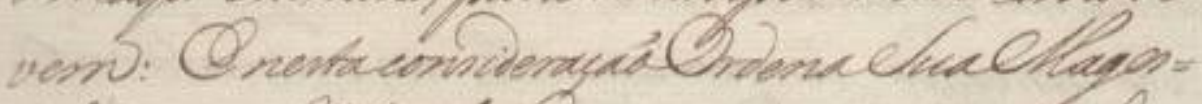

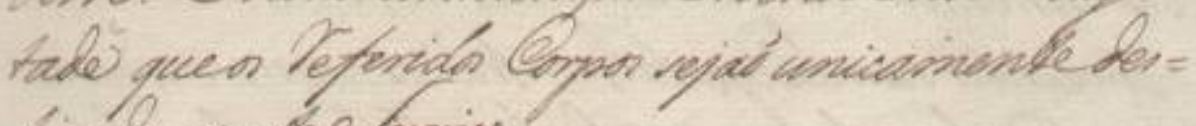

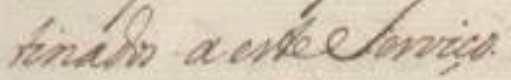

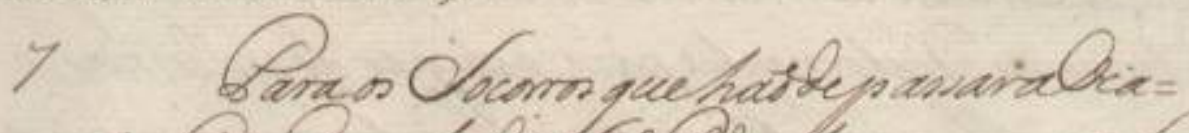

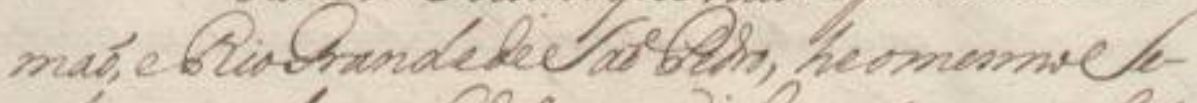

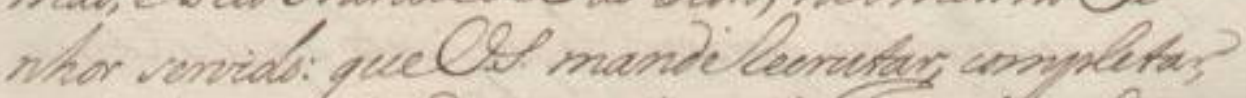

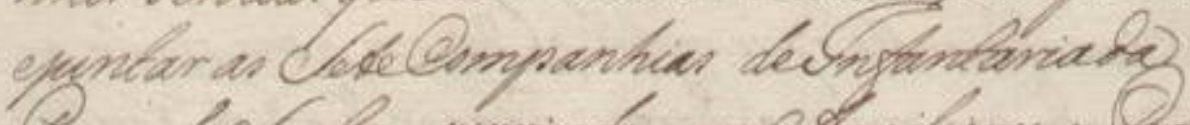

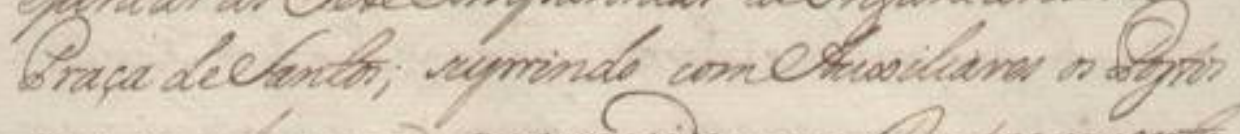

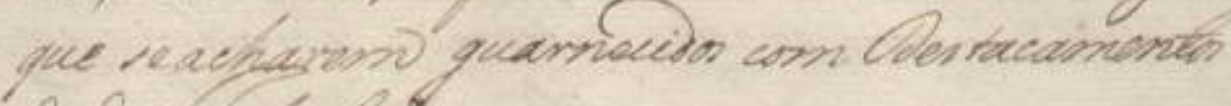

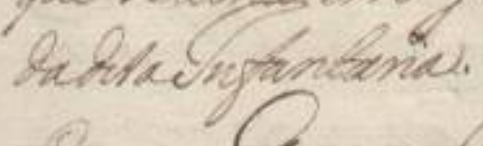

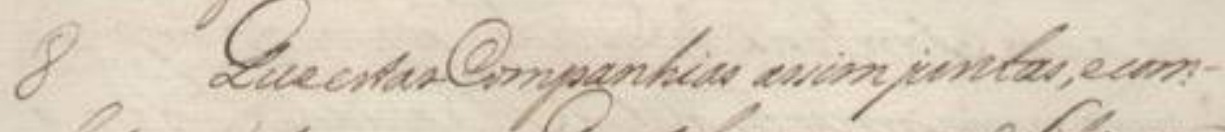

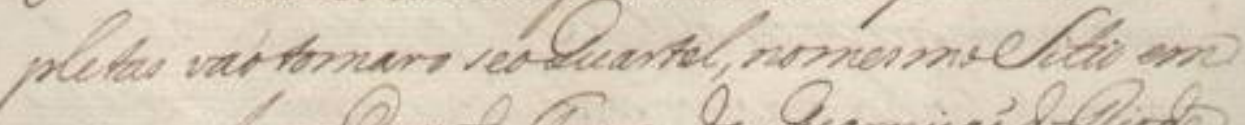

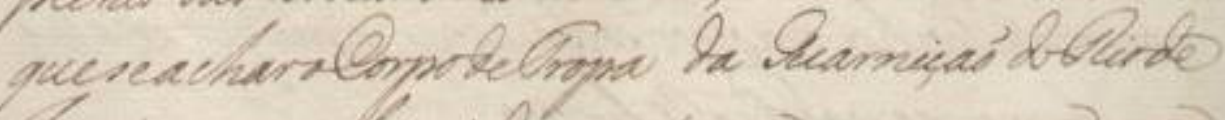
Anein; eque depori bievertenm camamm con

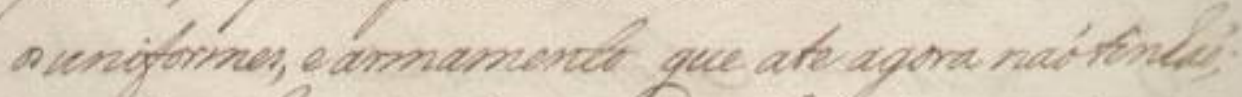

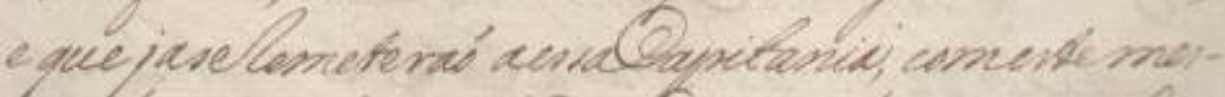

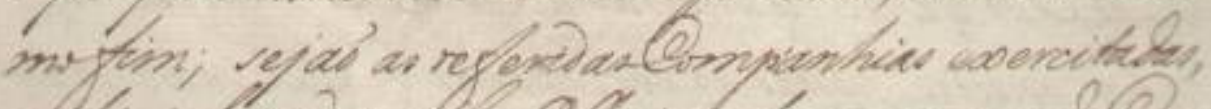

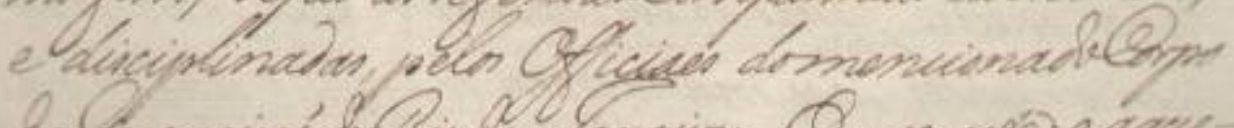

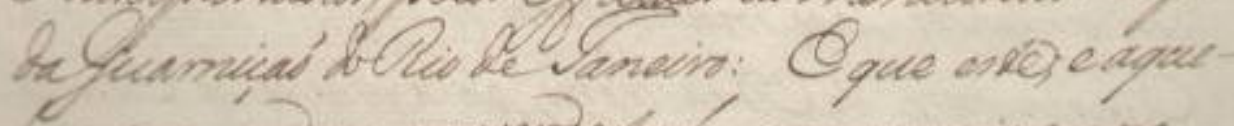

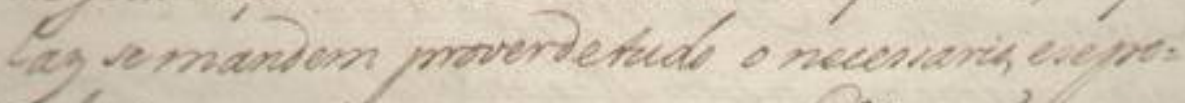

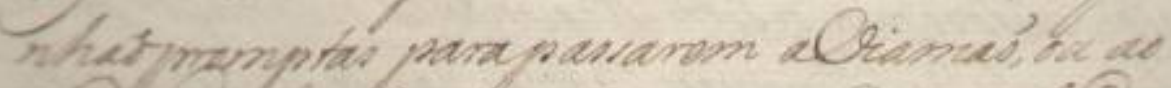

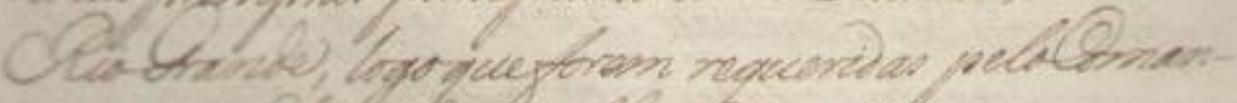

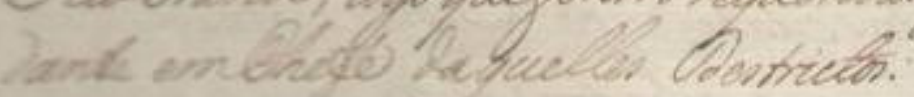

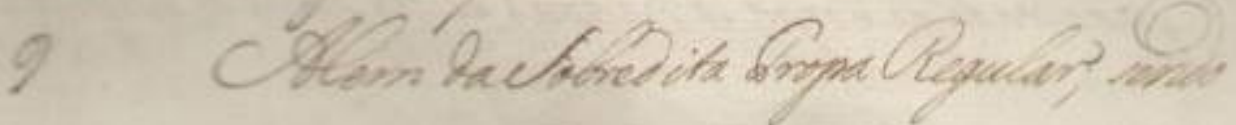


80 ||11v || noproprioPaiz; guarnecendoos Portos, eLugares del= le; ondenaõsodefendem os mesmos Portos eLuga= res; mas tambem as suasCasas eFamilias; quehe o mayor estimulo, para secomportarem comode= vem: E nestaconsideraçaõOrdenaSuaMages=

85 tade queos referidos Corpos sejaõ unicamente des= tinados a esteServiço.

7 Paraos Socorros quehaõdepassaraVia= maõ, eRioGrandedeSaõPedro, heomesmoSenhor servido: queVossaSenhoria manderecrutar, completar,

90 ejuntar as SeteCompanhias delnfantariada Praça deSantos; suprindo comAuxiliares os Postos que seacharem guarnecidos com Destacamentos daditalnfantaria.

8 QueestasCompanhias assim juntas, ecom-

95 pletas vaõtomaro seoQuartel, nomesmoSitio em queseacharoCorpodeTropa da Guarniçaõ doRiode Janeiro; e que depois desevestirem earmarem com os uniformes, e armamento que ate agora naõtinhaõ; e que jaseremeteraõ aessaCapitania, comestemes-

100 mofim; sejaõ as referidasCompanhias exercitadas, e disciplinadas, pelos Officiaes domencionadoCorpo daGuarniçaõ doRio delaneiro: E que este; e aquelaz se mandem proverdetudo o necessario, esepo= nhaõpromptas parapassarem aViamaõ, ou ao

105 RioGrande, logoqueforem requeridas peloComandante emChefe daquelles Destrictos.

$9 \quad$ Alem daSobredita Tropa Regular, sendo 
(2)

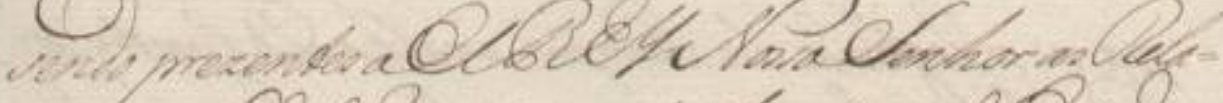

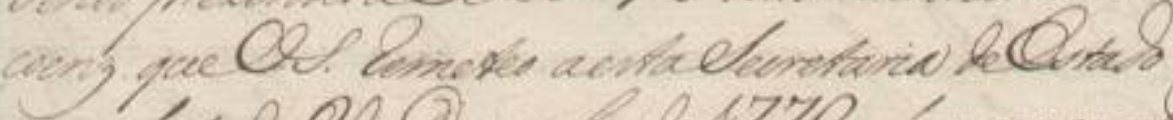

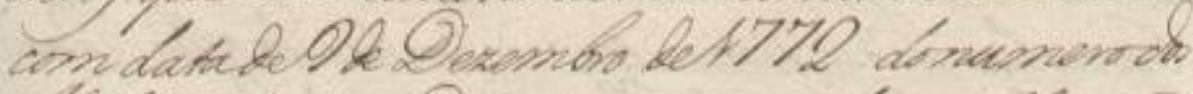

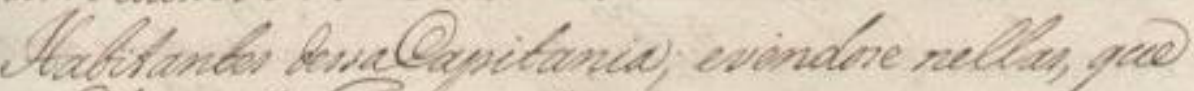

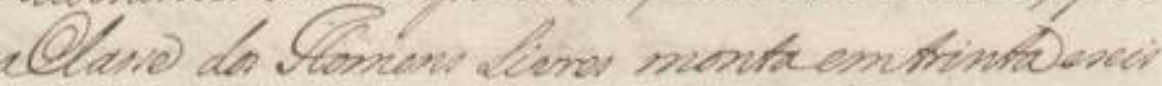

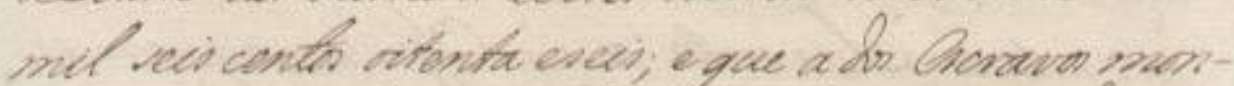
IA envinte etwen mil novecentes neventa edow:

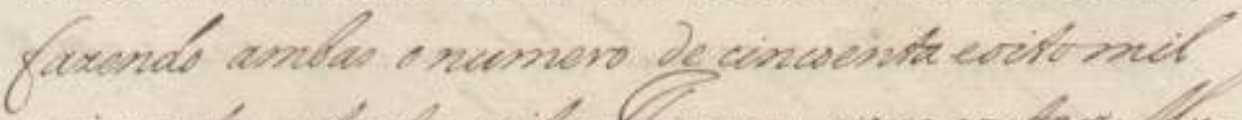

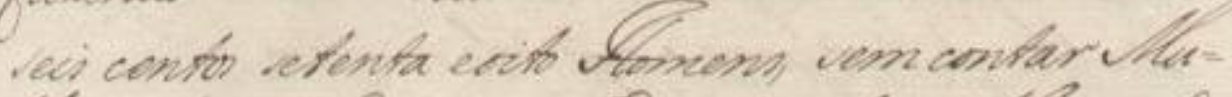

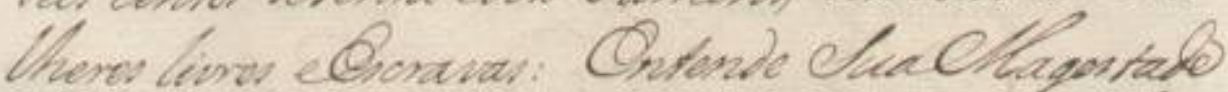

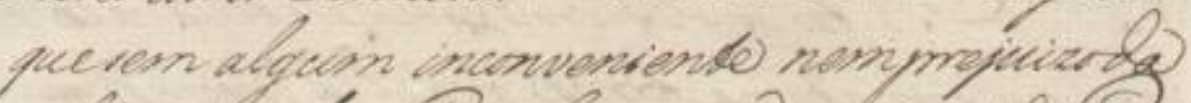

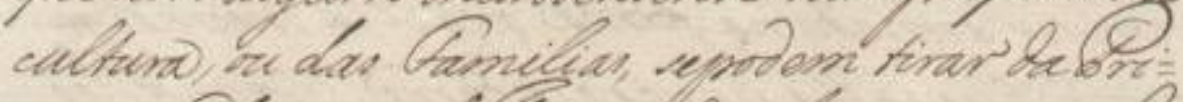

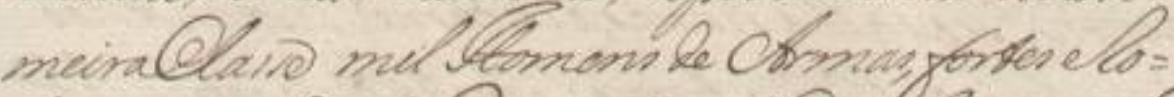

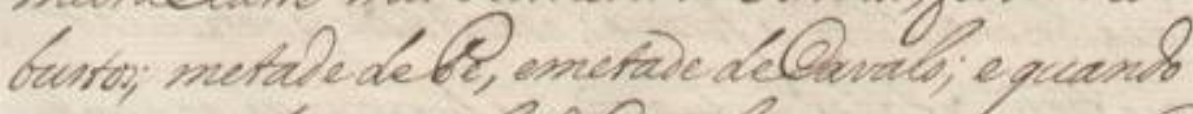

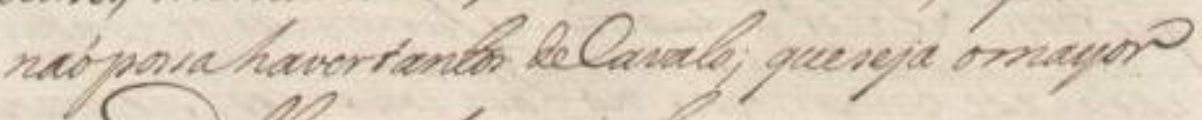
indondeles queporprover.

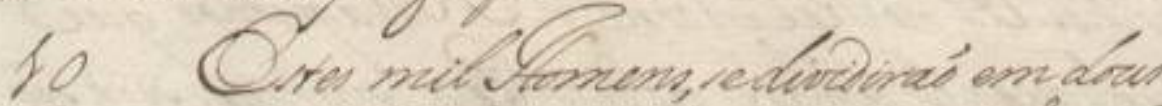

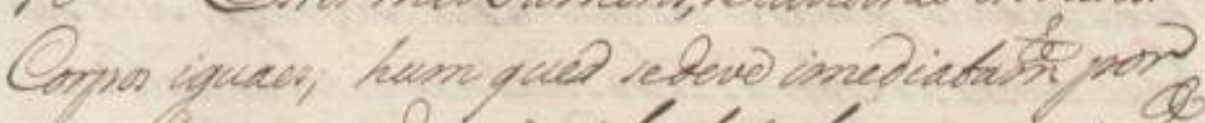

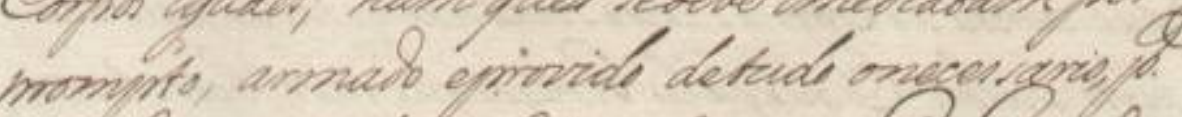

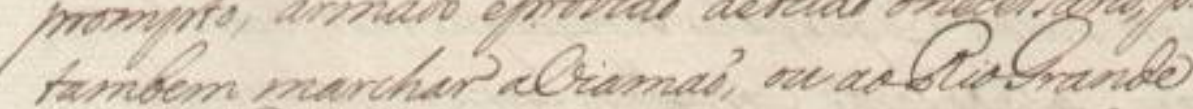

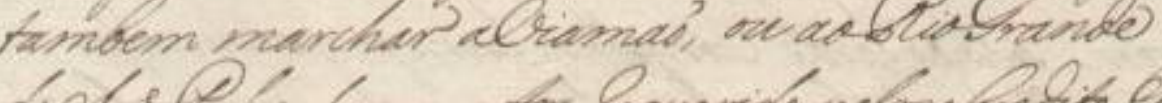

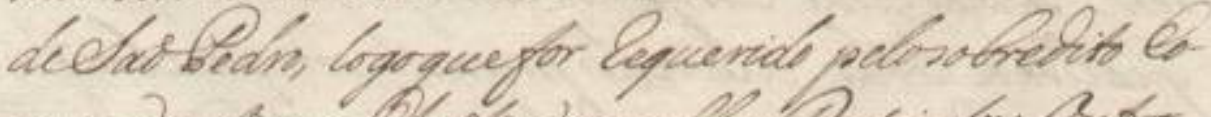

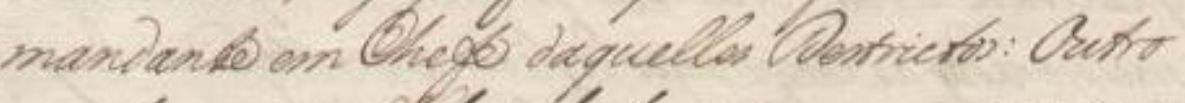

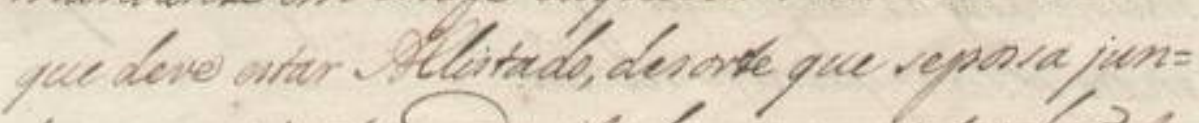

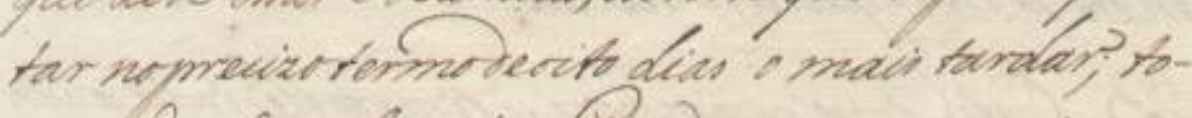

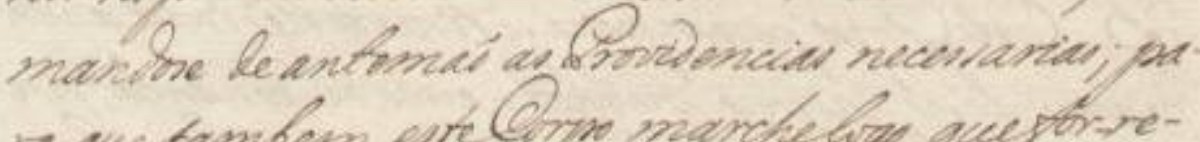

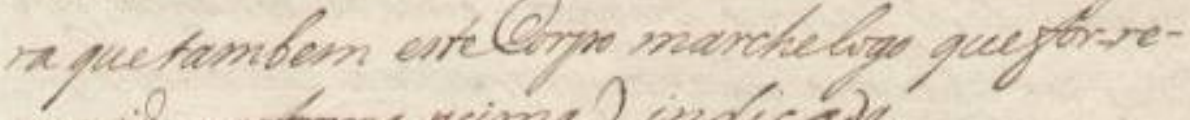
awios nagorna kainel indecade.

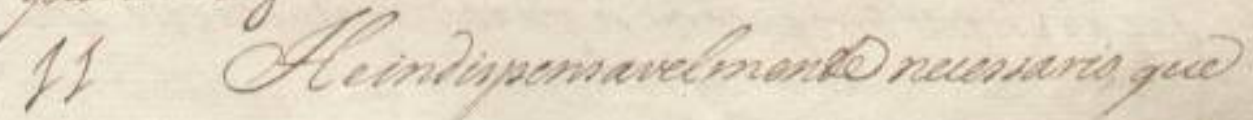


||13r||sendo prezentes aEIREYNossoSenhor as Rela= çoenz queVossaSenhoria remeteo aestaSecretaria deEstado com datade9 de Dezembro de1772 donumerodos Habitantes dessaCapitania; evendose nellas, que aClasse dos Homens Livres montaemtrintaeseis mil seis centos oitenta eseis; e que a dos escravos monta emvinte ehum mil novecentos noventa edous;

115 fazendo ambas o numero de cincoenta eoitomil seis centos setenta eoito Homens, sem contar $\mathrm{Mu}=$ Iheres livres eEscravas: Entende SuaMagestade quesem algum inconveniente nem prejuizoda cultura, ou das Familias, sepodem tirar da Pri=

120 meiraClasse mil Homens de Armas, fortes ero= bustos; metade dePe, emetade deCavalo; e quando naõpossahaver tantos deCavalo; queseja omayor numero delles queforpossivel. 10 Estes mil Homens, sedividiraõ em dous

125 Corpos iguaes; hum que sedeve imediatamente por prompto, armado eprovido detudo onecessario, para tambem marchar aViamaõ, ou aoRioGrande deSaõPedro, logoquefor requerido pelosobredito Comandante em Chefe daquelles Destrictos: Outro que deve estar Allistado, desorte que sepossa jun= tar noprecizo termodeoito dias o mais tardar; tomandose de antemaõ as Providencias necessarias; para quetambem esteCorpo marchelogo quefor requerido naforma acima indicada. 11 Heindispensavelmente necessario, que 


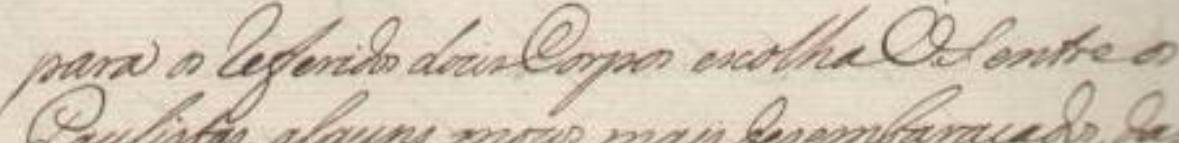

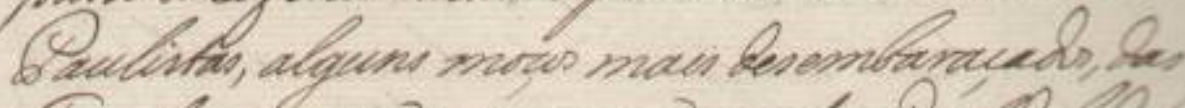

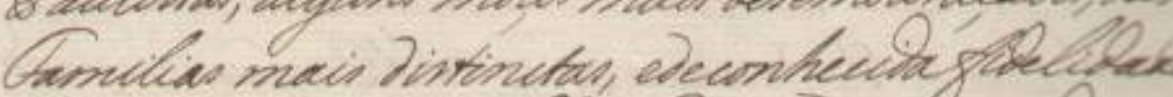

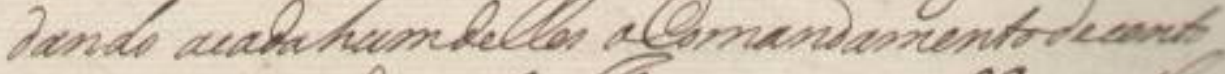

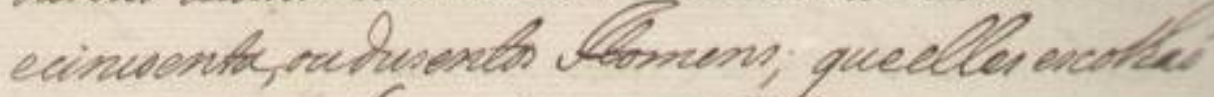
rorestaves Obrentes os res Oficials, equese on:

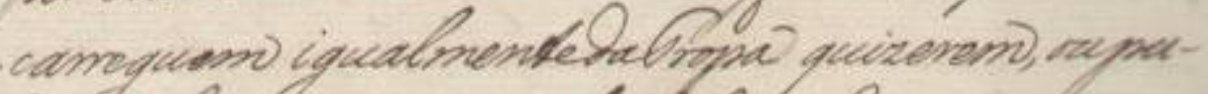

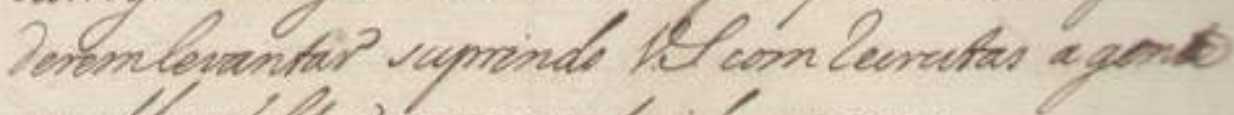
quel hes pulter para refenide numens.

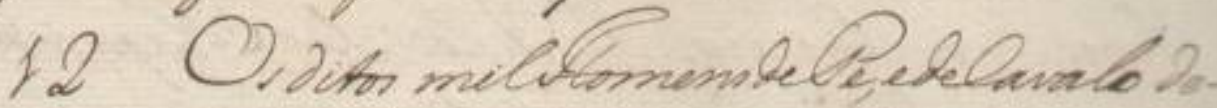
vemser amain nagtomo que elles memon wer:

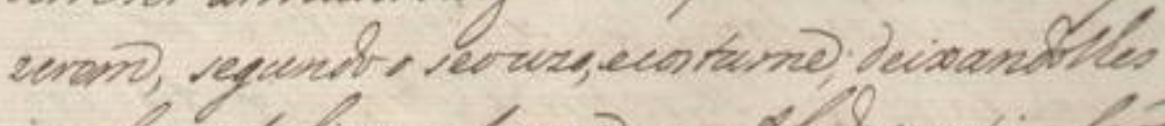
iquelmente live a pormo, eme thovparticular?

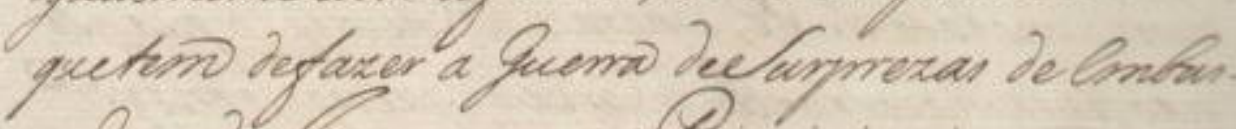
cabar ede dracinoeng nobaix

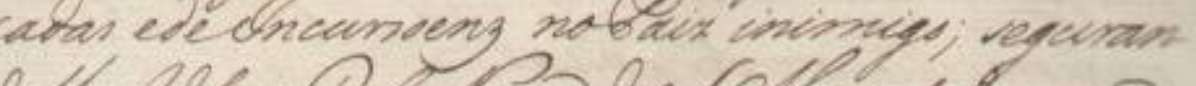

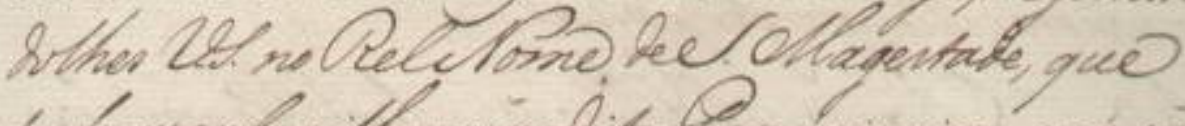

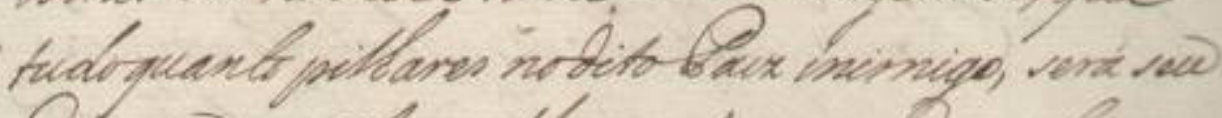

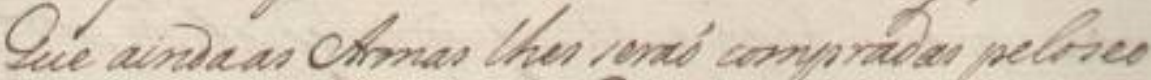

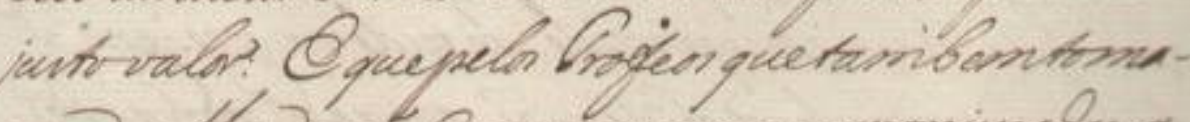

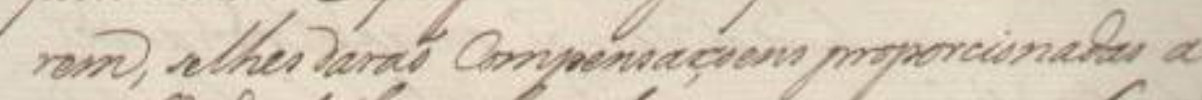

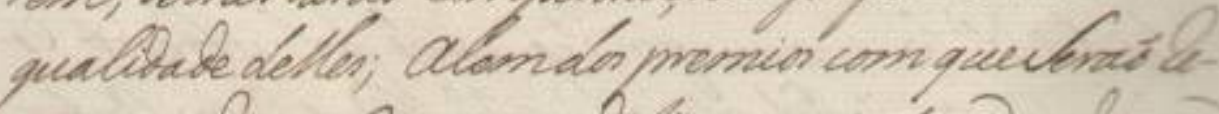

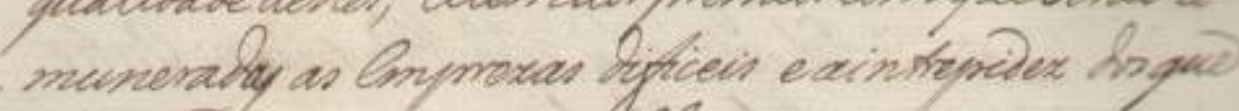
mai Reintinguinon nelas.

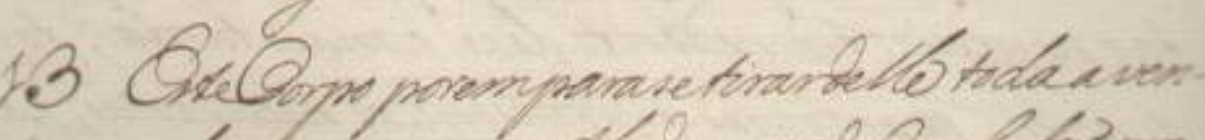

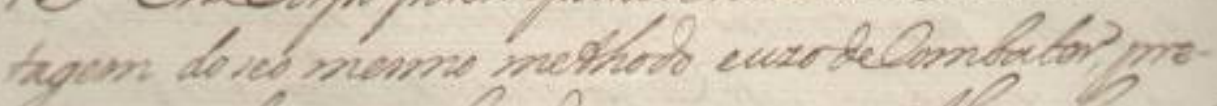

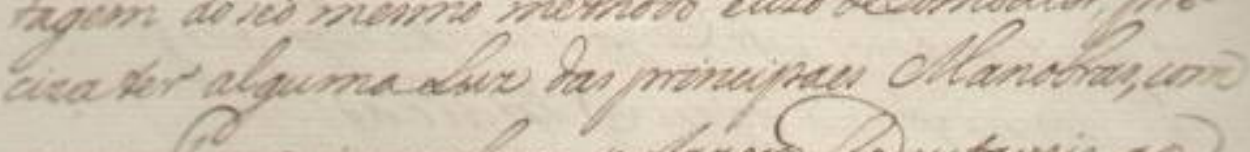

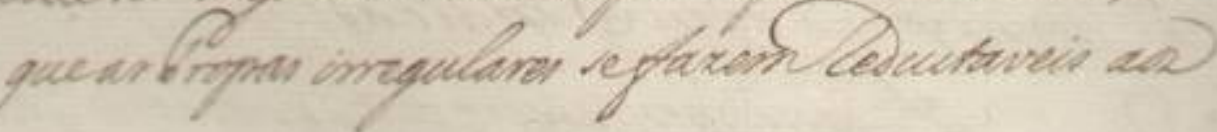


||13v|| para os referidos dousCorpos escolhaVossaSenhoria entreos

Paulistas, alguns moços mais desembaraçados, das

Familias mais distinctas, edeconhecidafidelidade;

dando acadahumdelles oComandamentodecento

140 ecincoenta, oudusentos Homens; queelles escolhaõ

por estaves Somente os seos Officiaes, equese en-

carreguem igualmentedaTropa quizerem, oupu-

deremlevantar suprindo VossaSenhoria com recrutas a gente

quelhes faltar parao referido numero.

14512 Os ditos milHomens dePe, edeCavalo de-

vemser armados naforma que elles mesmos qui-

zerem, segundo o seouzo, ecostume; deixandolhes

igualmentelivre aforma, emethodoparticular

quetem defazer a Guerra deSurprezas de Embus-

cadas edelncursoenz noPaiz inimigo; seguran-

dolhes VossaSenhoria no Rel"Nome deSua Magestade, que

tudoquanto pilhares noditoPaiz inimigo, será seu:

Que aindaas Armas Ihes seraõ compradas peloseo

justovalor: E quepelos Trofeos quetambemtoma-

rem, selhes daraõ compensaçoens proporcionadas a

qualidade delles; Alemdos premios com queSeraõ re-

muneradas as emprezas dificeis eaintrepidez dos que

mais sedistinguirem nellas.

13 EsteCorpo poremparasetirardelle todaaven-

tagem do seo mesmo methodo euzodeCombater, pre-

cizater algumaLuz das principaes Manobras, com

que as Tropas irregulares sefazemreductaveis aos

* "Rel" por "Real". 


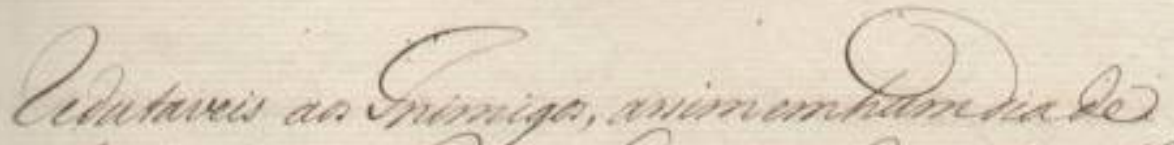

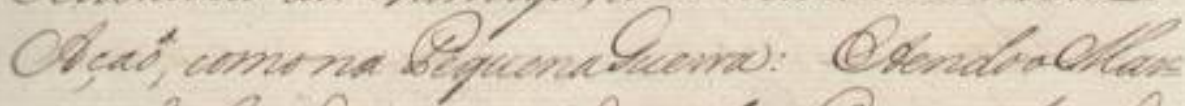

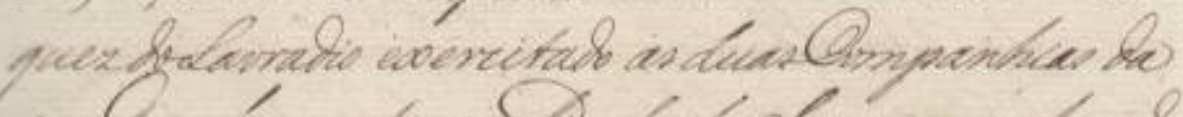

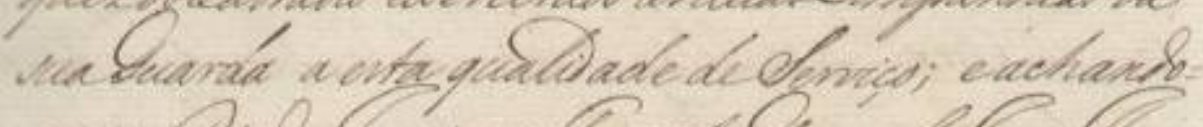

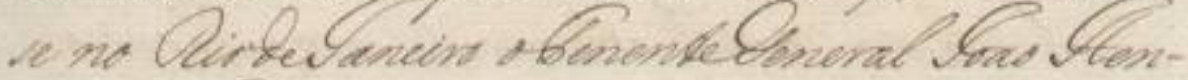

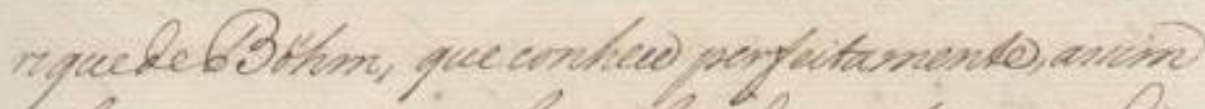

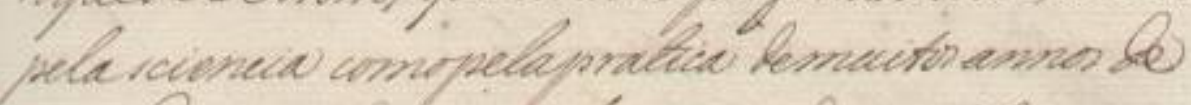

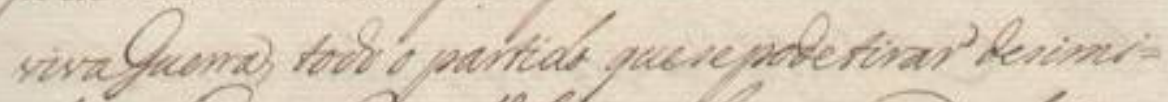

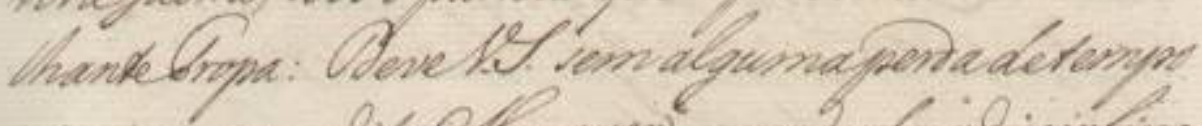

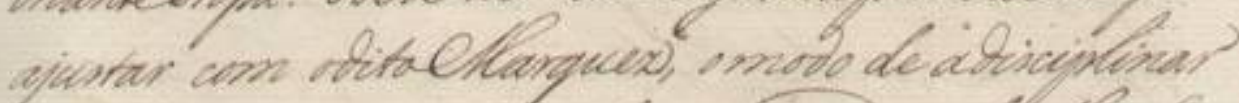
neporma acina inticada, m mandendi etleal:

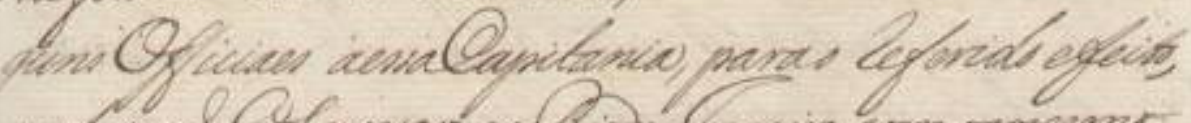

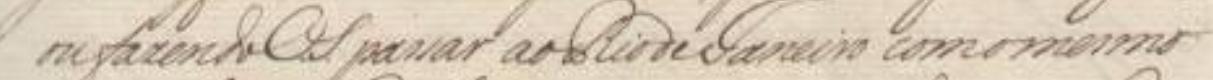
Gion, alquons baulistur quetiver dovinass para

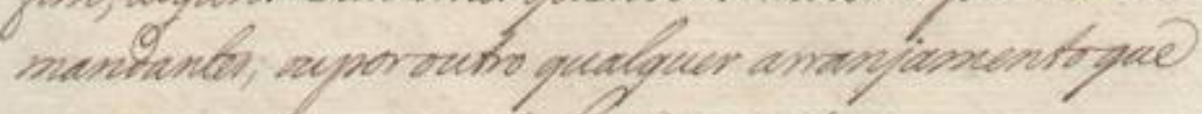

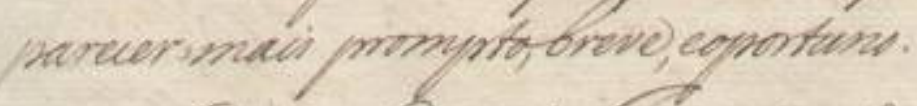

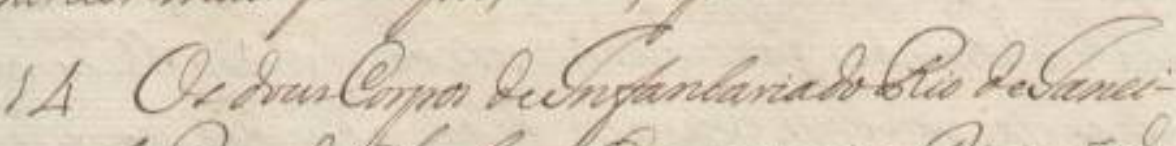
nedabracere blantas: Capmincina Divear do

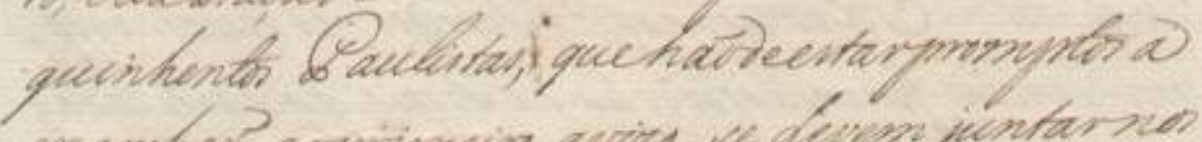
mantar aspimain avize, ve devem juntarnes

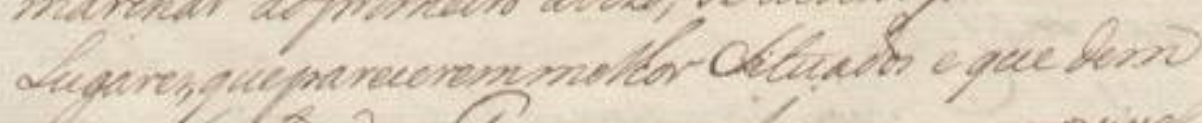

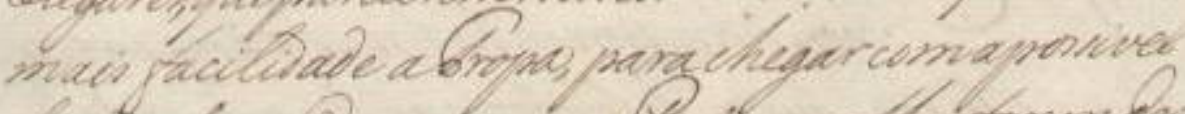

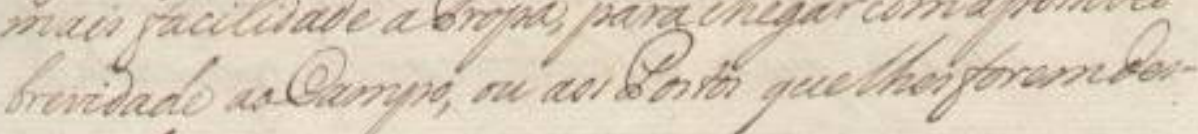
nimades.

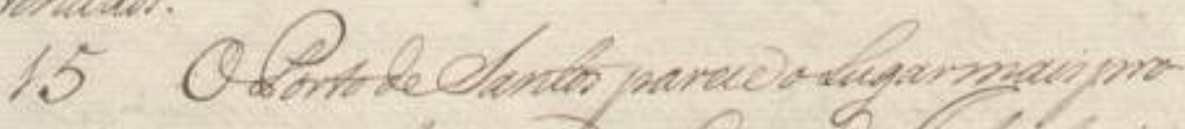

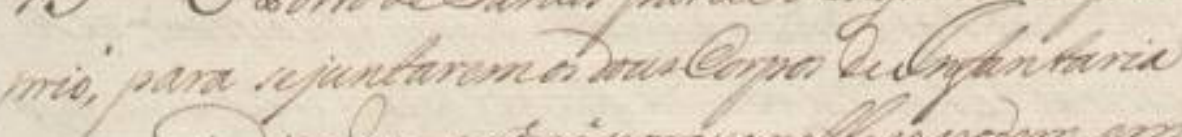

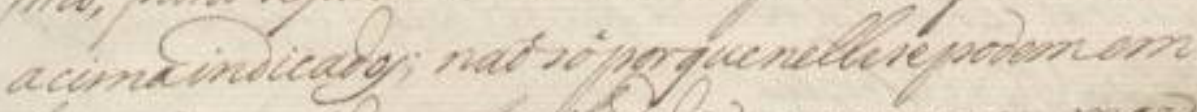

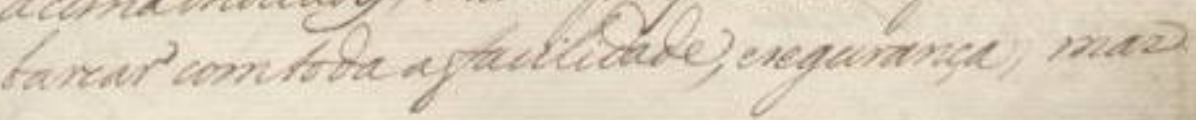


||14r|| [[redutaveis aos]] Inimigos, assim emhumdiade Açaõ, comona PequenaGuerra: EtendooMar= quezdoLavradio exercitado as duasCompanhias da suaGuarda a esta qualidade deServiço; eachando= se no Riodelaneiro oTenenteGeneral Joao HenriquedeBöhm, que conhece perfeitamente, assim pelasciencia comopelapratica demuitos annos de vivaGuerra, todo o partido quesepodetirar desimi= IhanteTropa: DeveVossaSenhoria sem algumaperda detempo ajustar com oditoMarquez, o modo de adisciplinar naforma acima indicada; ou mandando elleal= guns Officiaes aessaCapitania, parao referido efeito, oufazendoVossaSenhoria passar aoRiodelaneiro comomesmo fim, alguns Paulistas quetiverdestinado paraCommandantes; ouporoutro qualquer arranjamentoque parecer mais prompto,breve, eoportuno.

14 Os dousCorpos delnfantariadoRio delaneiro, e daPraçadeSantos: E aprimeira Divizaõ dos quinhentos Paulistas, quehaõdeestarpromptos a marchar aoprimeiro avizo, se devem juntarnos Lugares, quepareceremmelhor Situados e que dem mais facilidade aTropa, para chegar com apossivel brevidade aoCampo, ou aos Postos quelhes foremdestinados.

15 OPortodeSantos parece oLugarmais proprio, para sejuntaremos dousCorpos delnfantaria acimaindicados; naõsô porquenellesepodemem barcar comtoda afacilidade, esegurança; mas | 18 


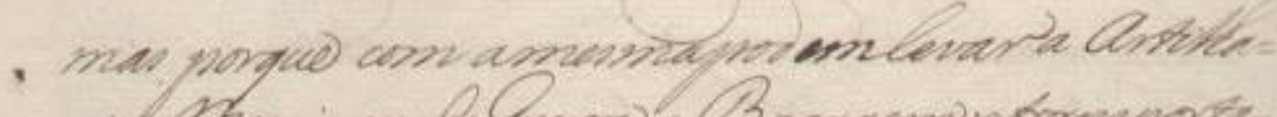

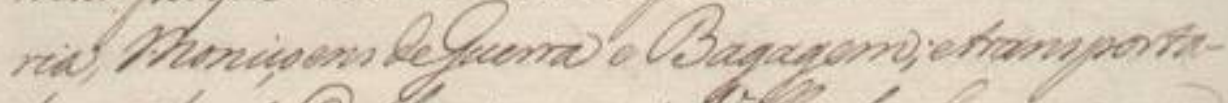

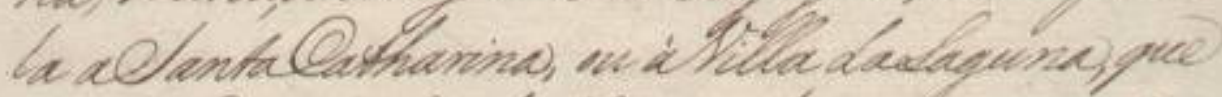

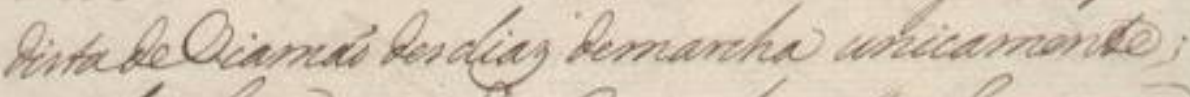

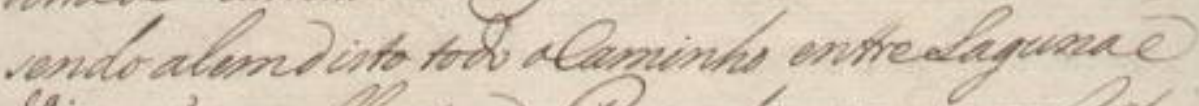

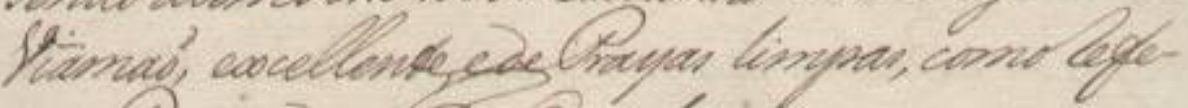
$r$ - bripain Dre castoras.

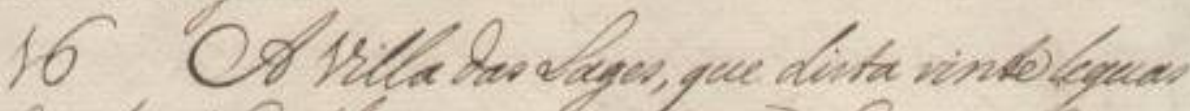

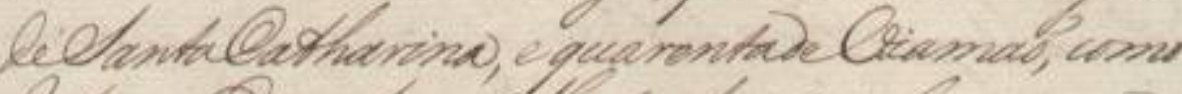

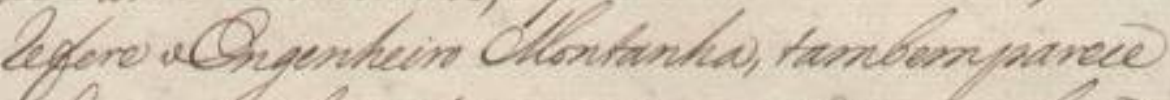

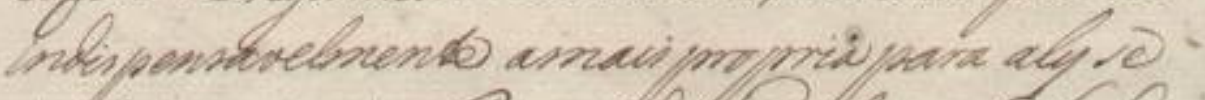

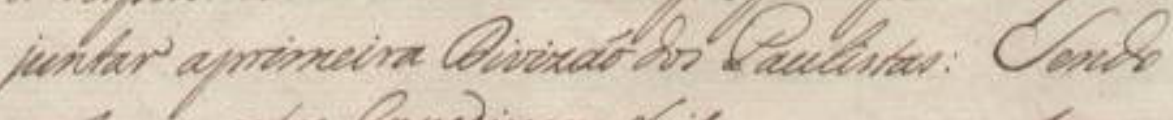

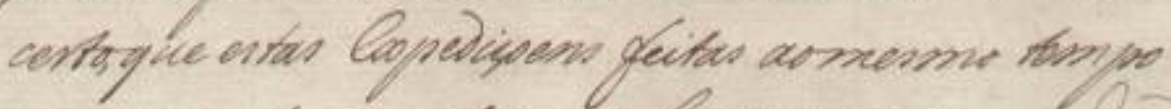

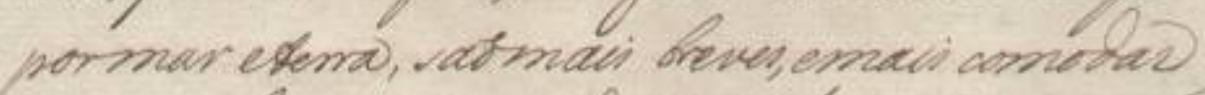

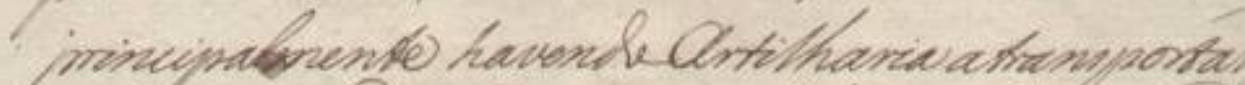
epoitenata Omanamkemenefedelemis

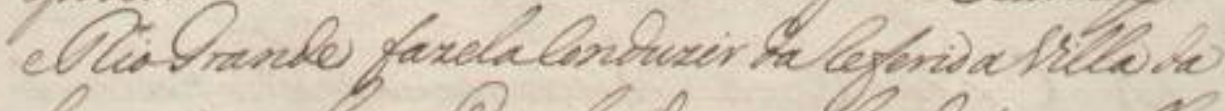

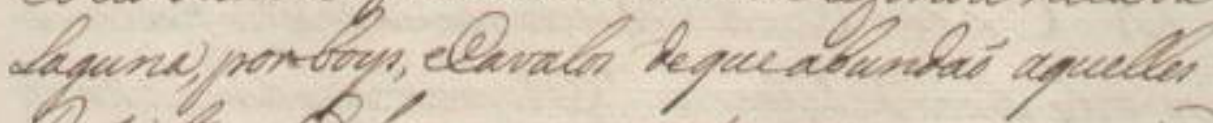

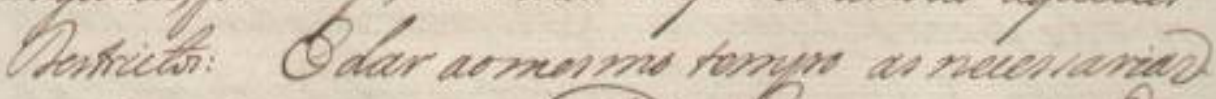

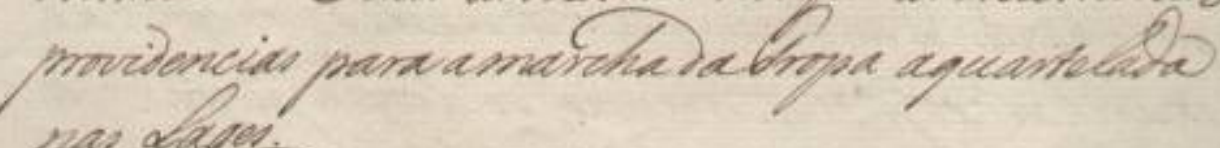
mar aryes.

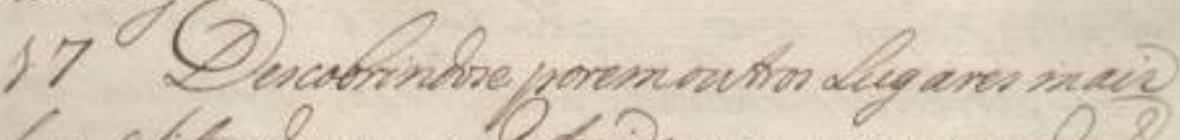

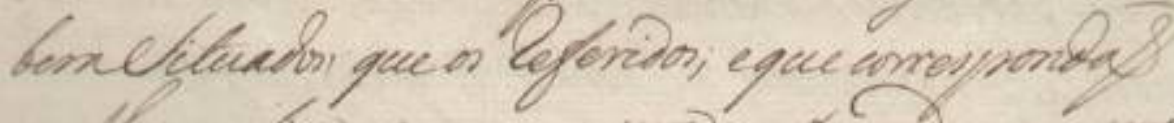

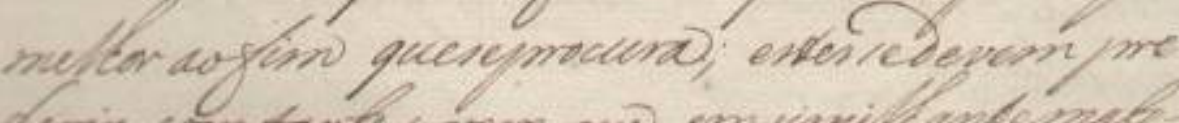

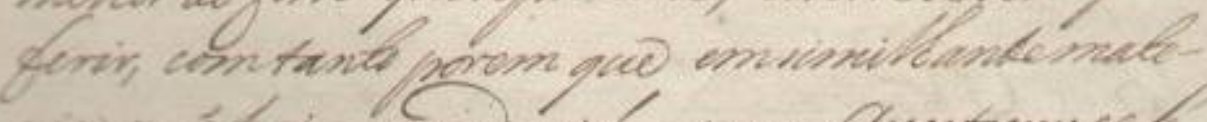

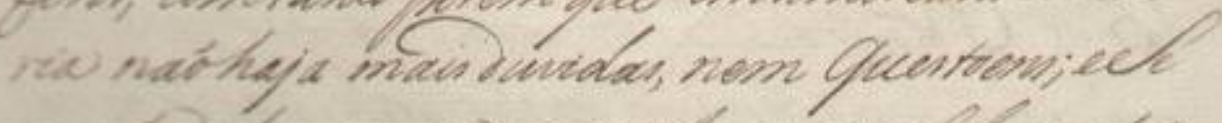

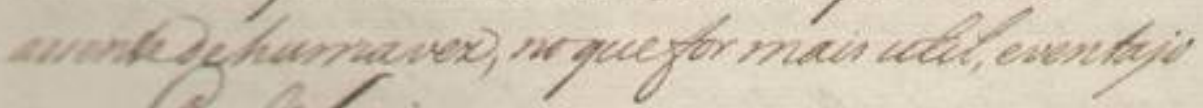
whe biselentise. 
||14v $\mid$ [[mas]] porque com amesmapodemlevar a Artilha=

ria, Moniçoens deGuerra e Bagagem; etransporta-

la aSantaCatharina, ou àVilla daLaguna, que

distadeViamaõ des diaz demarcha unicamente;

195 sendo alemdisto todo oCaminho entreLagunae

Viamaõ, excellente, edePrayas limpas, comorefe-

reoBrigadeirolozeCustodio.

16 A Villa das Lages, que dista vinte leguas

deSantaCatharina, e quarentadeViamaõ, como

200 refere oEngenheiro Montanha, tambemparece

indispensavelmente amais propria para aly se

juntar aprimeira Divizaõ dos Paulistas: Sendo

certo,que estas Expediçoens feitas aomesmo tempo

pormar eterra, saõmais breves, emais comodas

205 principalmente havendoArtilharia atransportar;

epodendo oComandante emChefedeViamaõ

eRioGrande fazelaConduzir dareferidaVilla da

Laguna, porboys, eCavalos dequeabundaõ aquelles

Destrictos: E dar aomesmo tempo as necessarias

210 providencias para amarcha daTropa aquartelada

nas Lages.

17 Descobrindose poremoutros Lugares mais

bemSituados, queos referidos; eque correspondaõ

melhor aofim queseprocura; estes sedevem pre

215 ferir, comtanto porem que emsimilhantemate-

ria naõhaja mais duvidas, nem Questoens; eSe

assentedehumavez, noquefor mais util, eventajo so aoRealServiço. 


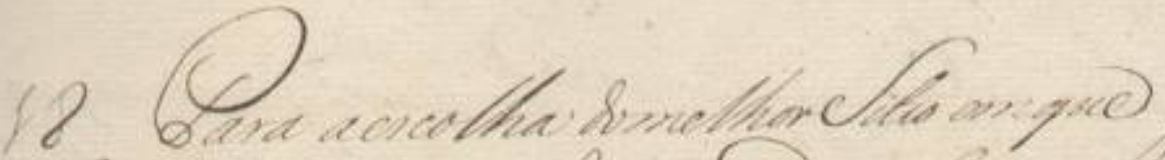

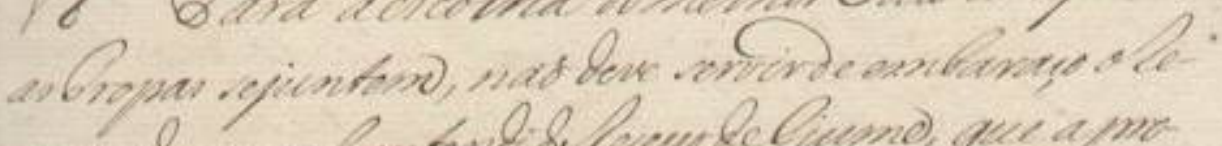

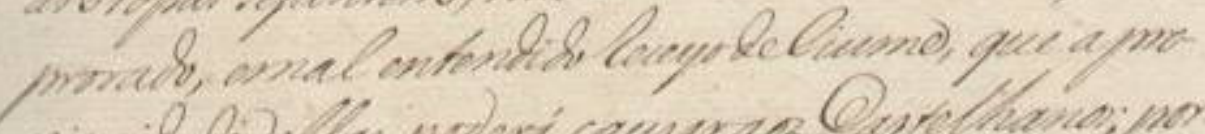

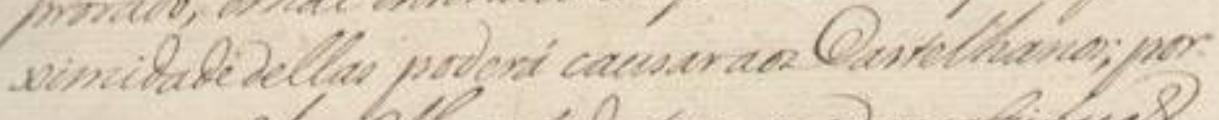

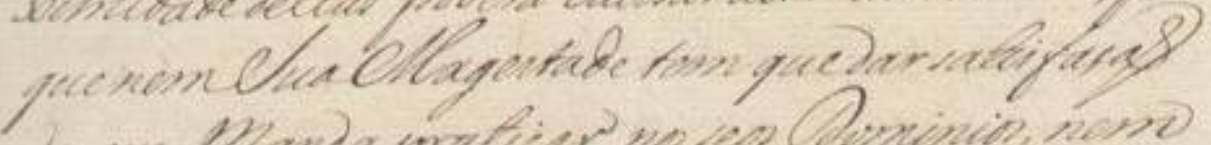

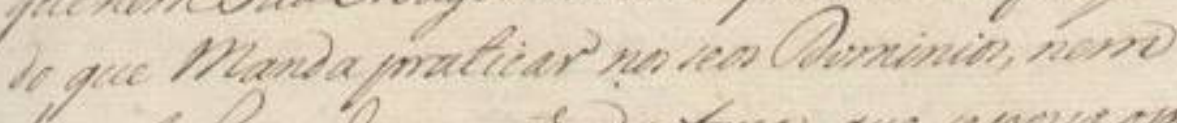

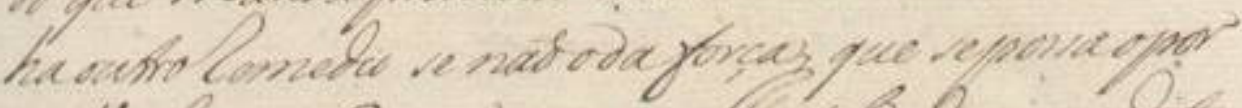

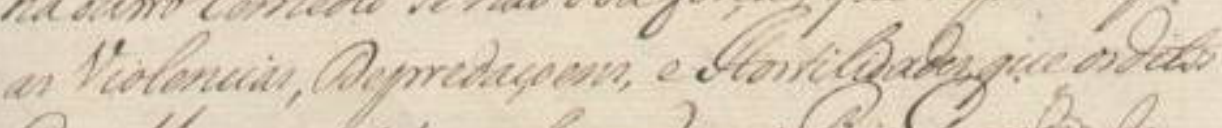

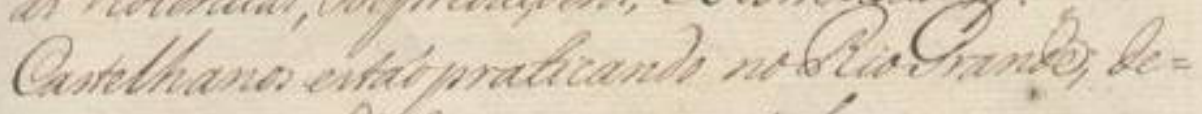

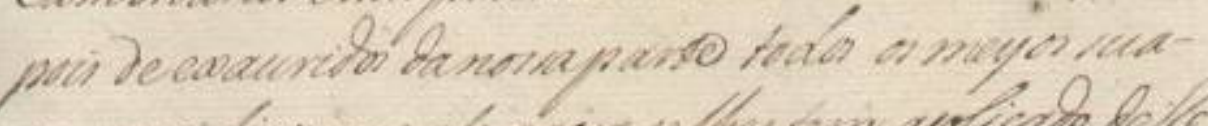

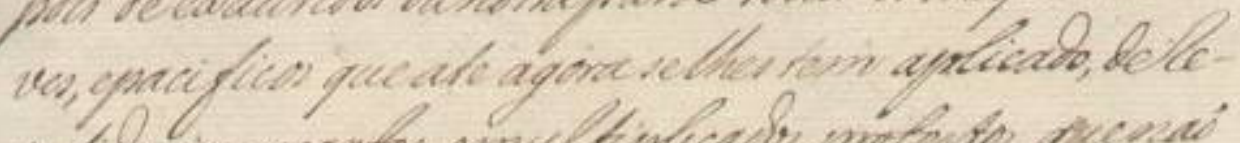

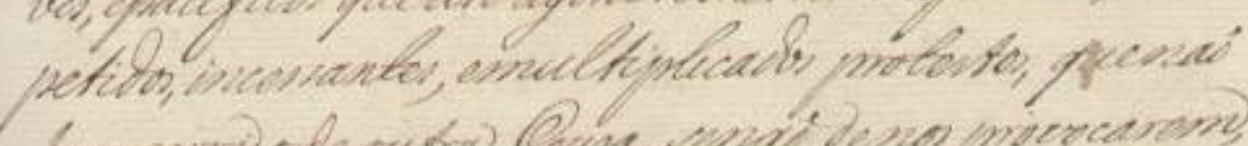

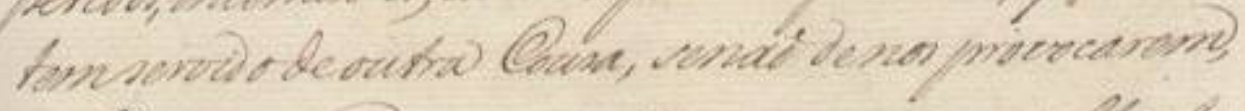

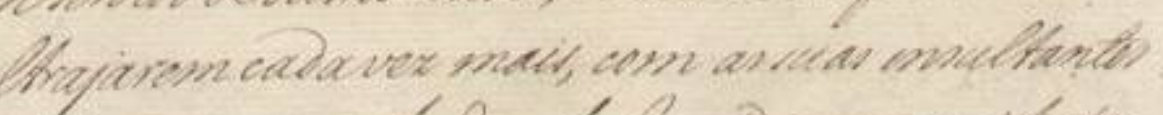

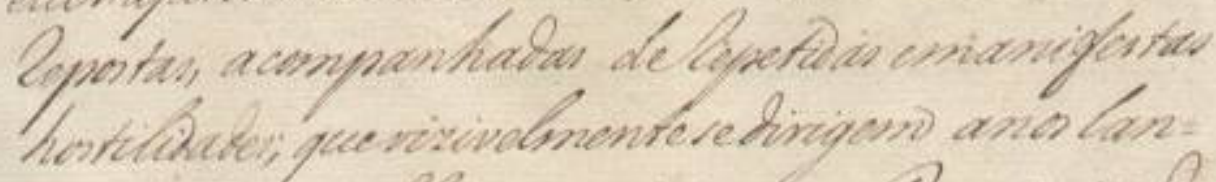

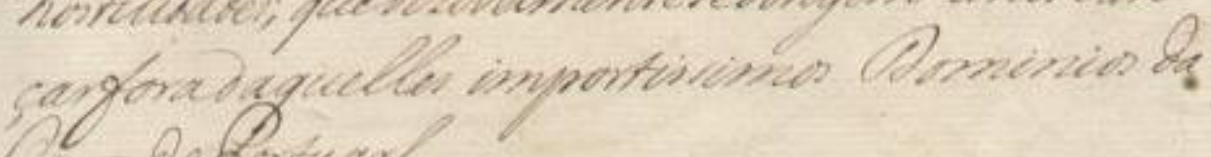

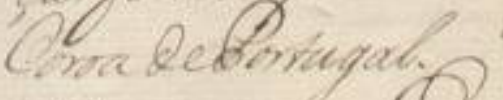
10
(1)

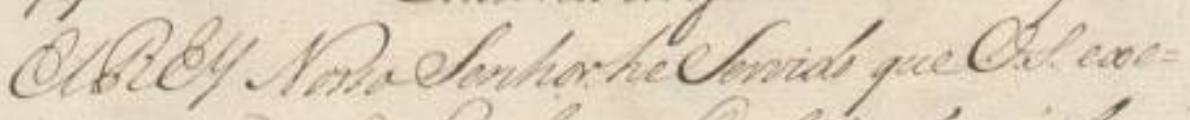

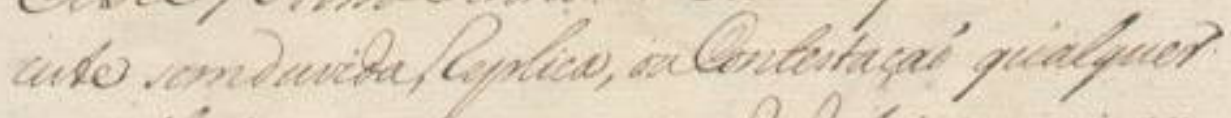

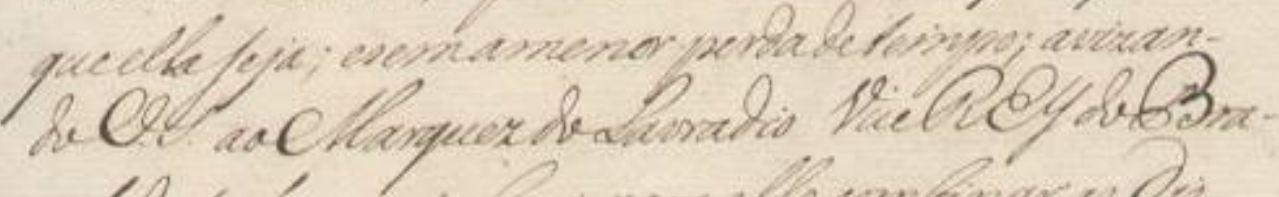

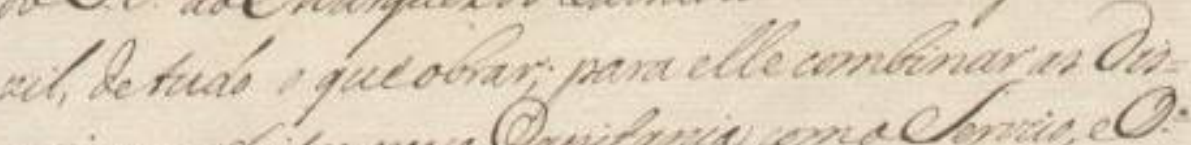

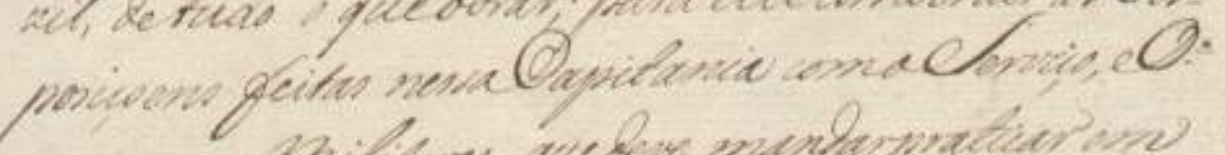

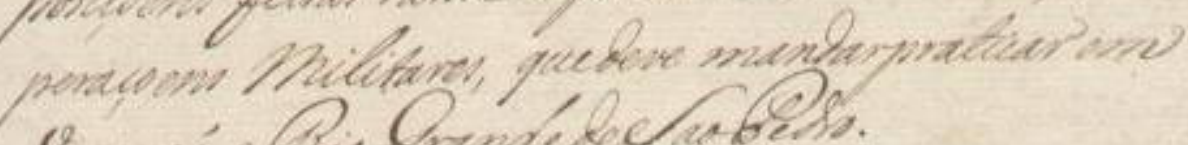

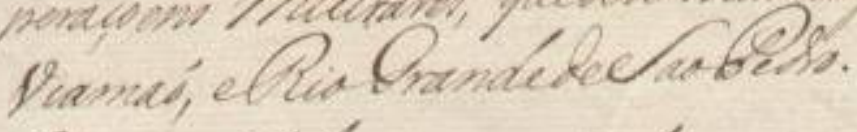

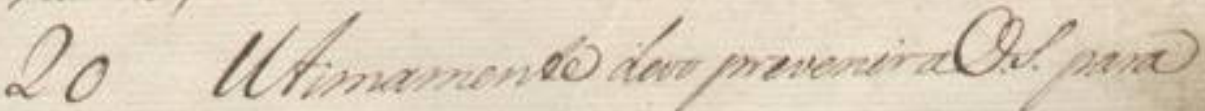


asTropas sejuntem, naõ deve servirde embaraço oreprovado, emal entendidoreceyo deCiume, que aproximidade dellas poderá causaraosCastelhanos; por quenemSuaMagestade tem quedar satisfaçaõ do que Manda praticar nos seos Dominios, nem ha outroremedio se naõodaforça, que sepossaopor as Violencias, Depredaçoens, e Hostilidades, que os ditos Castelhanos estaõpraticando noRioGrande; de= pois de exauridos danossaparte todos os meyos sua-

230 ves, epacificos queate agoraselhes tem aplicado, derepetidos, incessantes, emultiplicados protestos, quenaõ temservido deoutra Cousa, senaõ denos provocarem, eultrajarem cadavez mais, com as suas insultantes repostas, acompanhadas derepetidas emanifestas

235 hostilidades; quevizivelmente sedirigem anos lan= çarforadaquelles importissimos Dominios da Coroa dePortugal.

19 Estas saõ emfimas Ordens que EIREY NossoSenhor heServido queVossaSenhoria exe= 240 cute semduvida, replica, ouContestaçaõ qualquer queellaseja; esemamenor perdadetempo; avizandoVossaSenhoria aoMarquezdoLavradio ViceREY doBrazil, detudo o queobrar; para elle combinar as dis= posiçoens feitas nessaCapitania comoServiço, eOperaçoens Militares, quedeve mandarpraticar em Viamaõ, eRioGrandedeSaoPedro.

20 Utimamente devo preveniraVossaSenhoria 
||15v\|

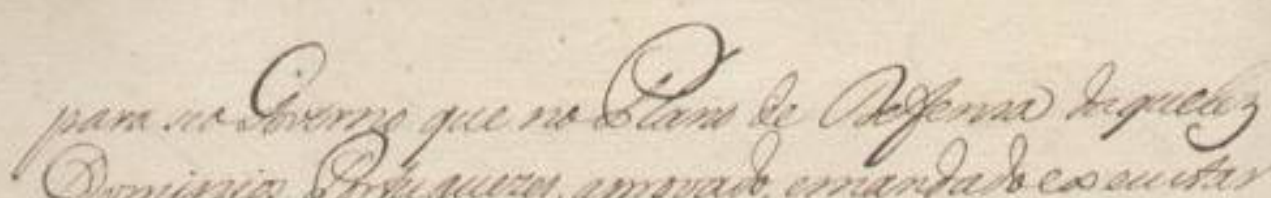

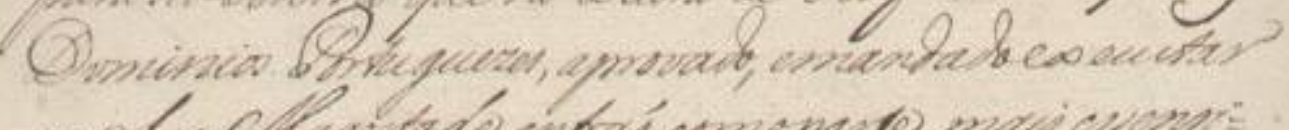

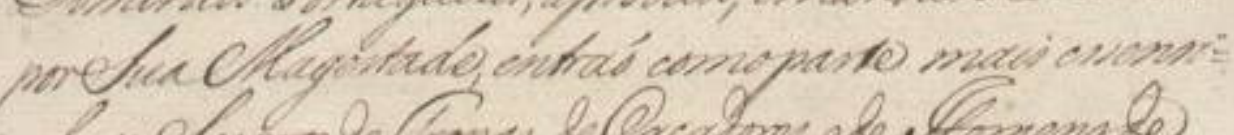

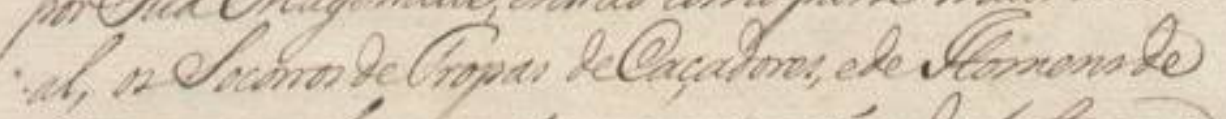

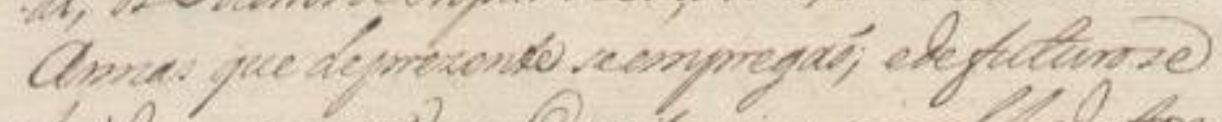

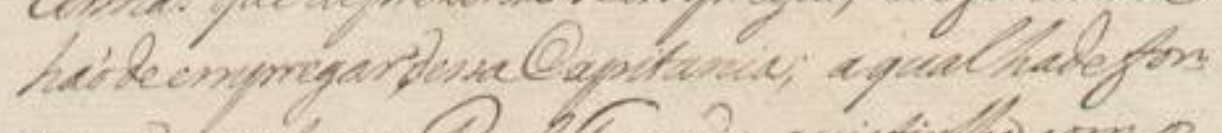

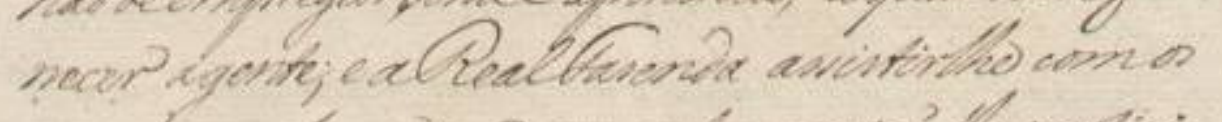

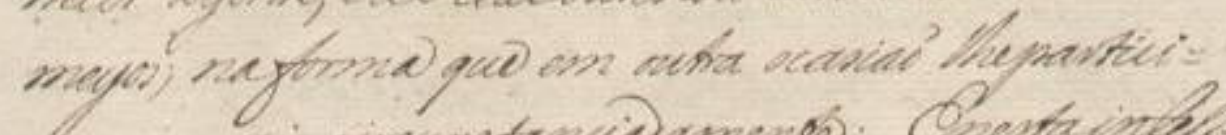

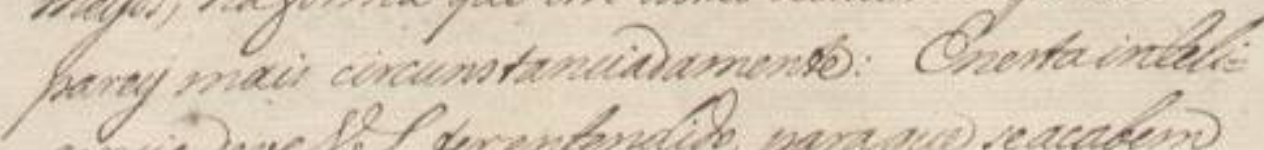

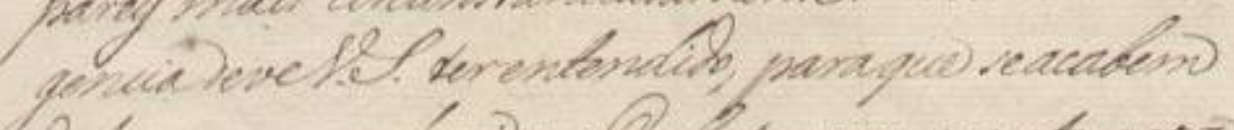

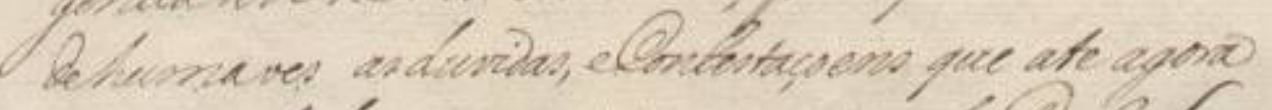

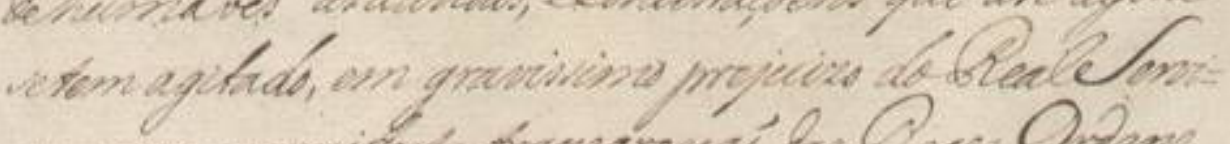

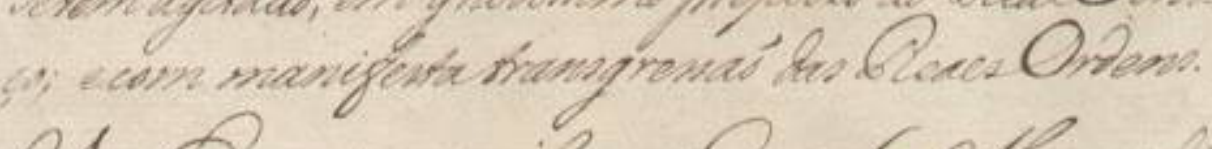

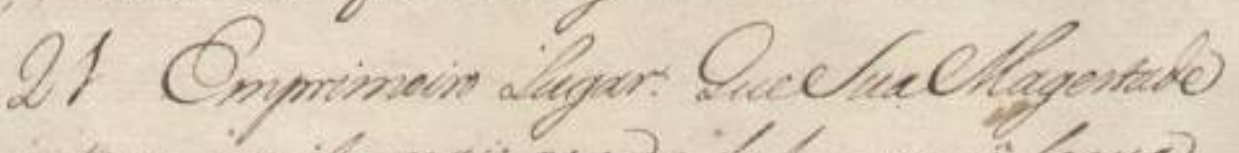
intina meits mais aperda dé buma of lesero

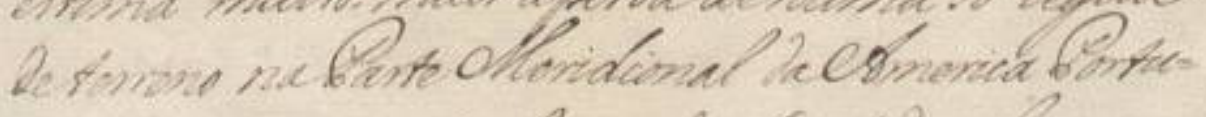

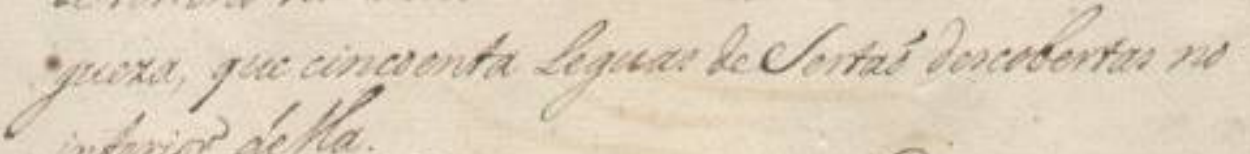
no

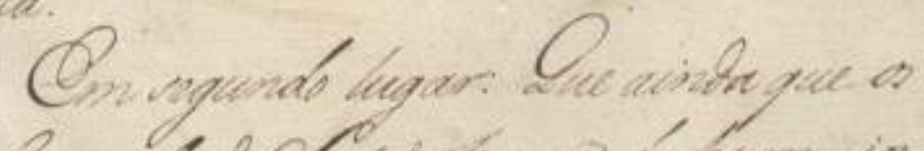

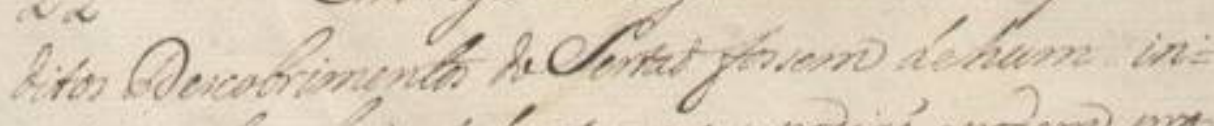

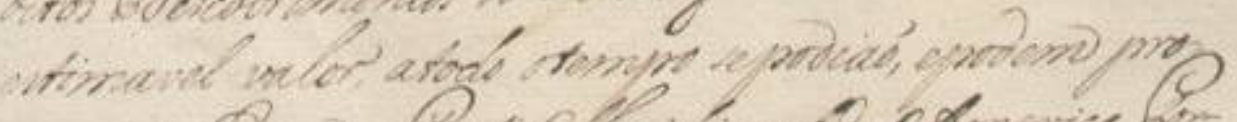

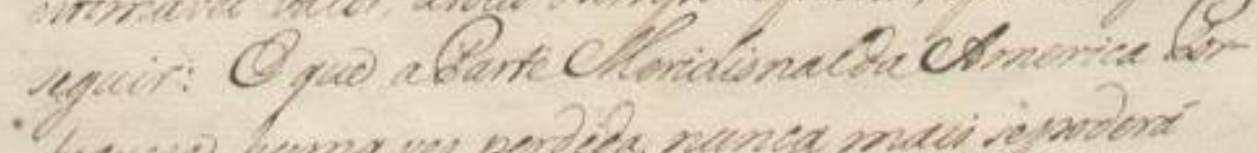

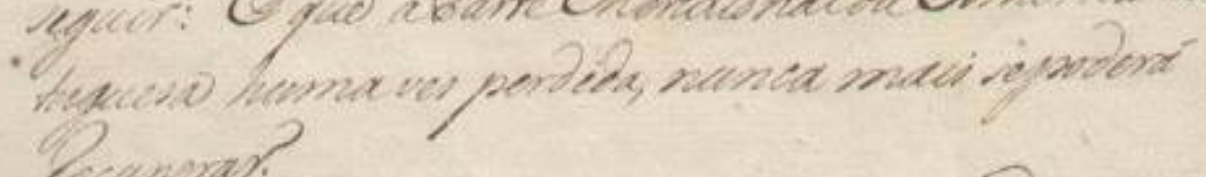
- cecmprat?

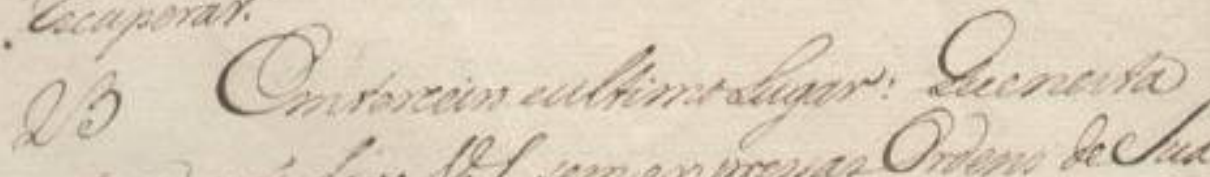

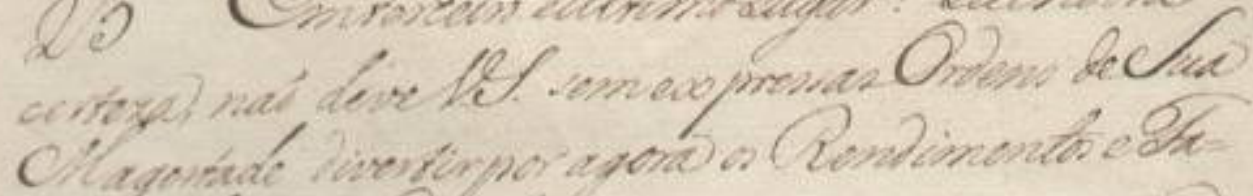

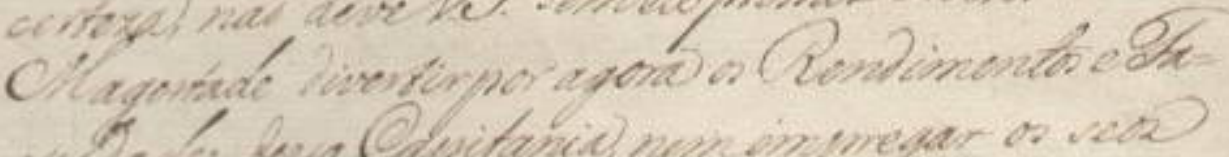

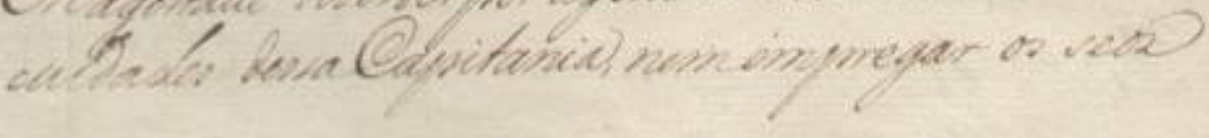

133 
\|15v\| [[para]] seoGoverno que noPlano de Defensa daquelez

250 Dominios Portuguezes, aprovado, emandadoexecutar porSuaMagestade, entraõ comoparte mais essensi= al, osSocorros deTropas deCaçadores, edeHomensde Armas que deprezente seempregaõ; edefuturose haõdeempregar dessaCapitania; aqualhadefornecer agente; e aRealFasenda assistirlhe com os meyos; naforma que em outra ocasiaõ Ihepartici= parey mais circunstanciadamente: Enestainteli= gencia deveVossaSenhoria ter entendido, paraque seacabem dehumaves as duvidas, eContestaçoens que ate agora setem agitado, em gravissimo prejuizo doRealServi= ço; ecom manifestatransgressaõ das ReaesOrdens.

21 Emprimeiro Lugar: QueSuaMagestade estima muito mais aperda dehuma sô legua deterreno naParte Meridional daAmerica Portu= gueza, que cincoenta Leguas deSertaõ descobertas no interior della.

22 Em segundo lugar: Que ainda que os ditos Descobrimentos doSertaõfossem dehum in= estimavel valor, atodo otempo sepodiaõ, epodem pro= seguir: E que aParteMeridionaldaAmerica Portuguesa huma ves perdida, nunca mais sepoderá recuperar.

23 Emterceiro eultimoLugar: Quenesta certeza, naõ deveVossaSenhoria sem expressasOrdens deSua Magestade divertir por agora os Rendimentos eFa= culdades dessaCapitania, nemempregar os | seos 


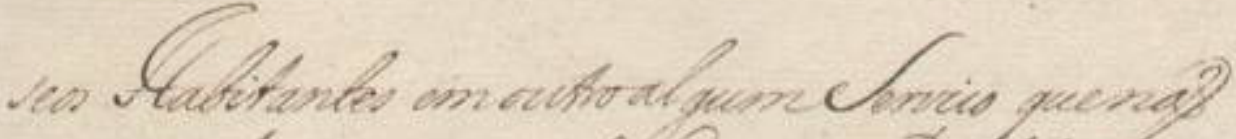

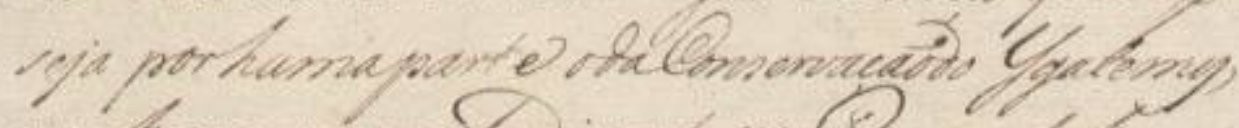

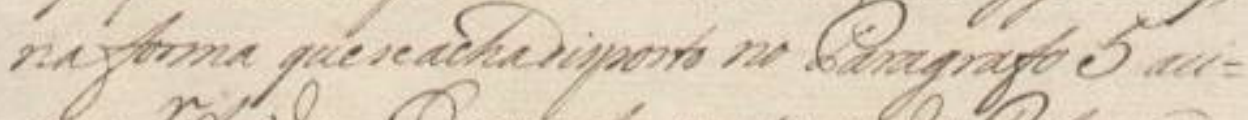

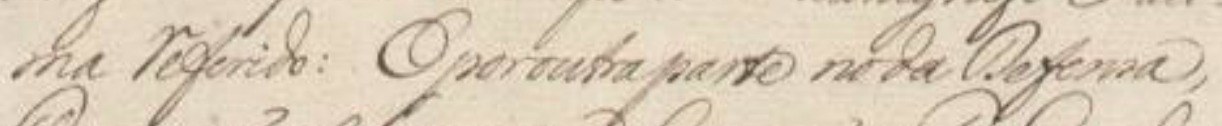

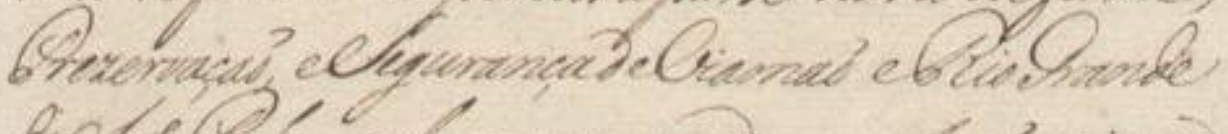

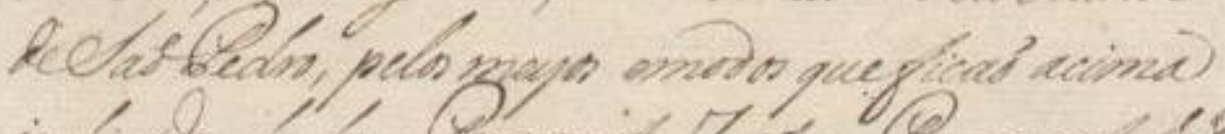

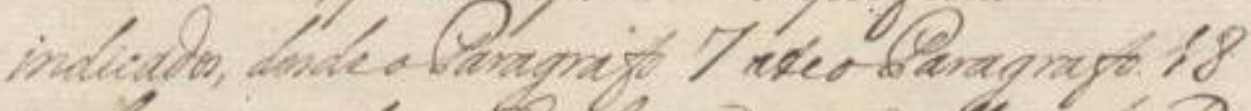

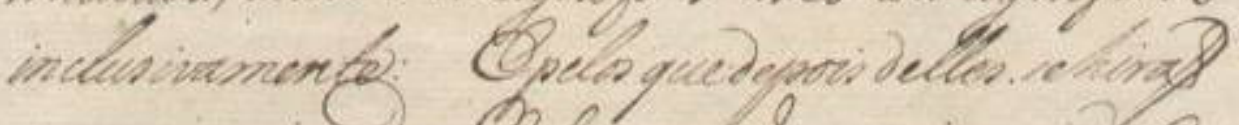

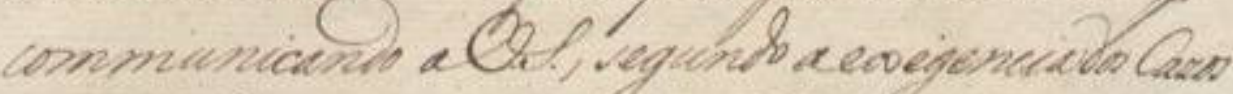

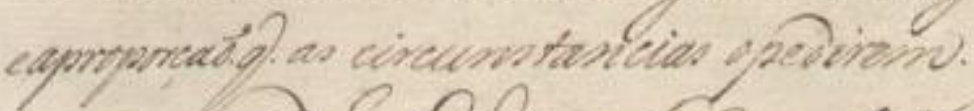

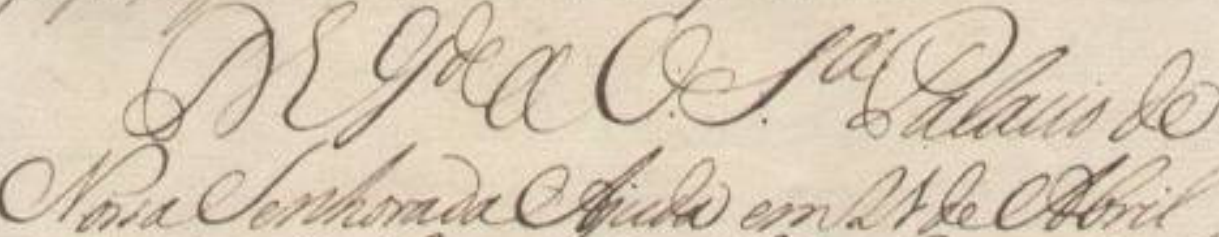

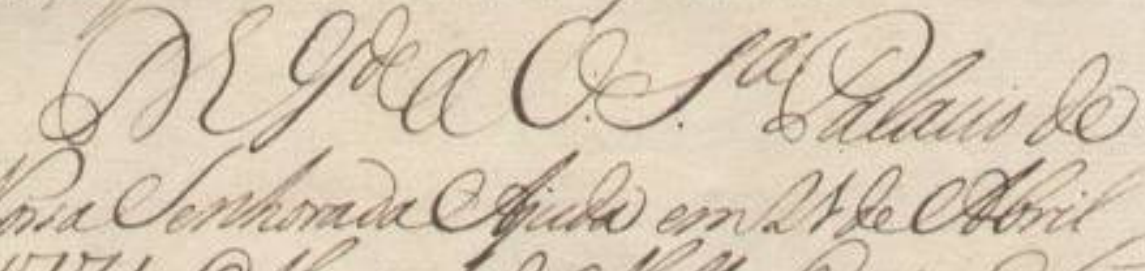

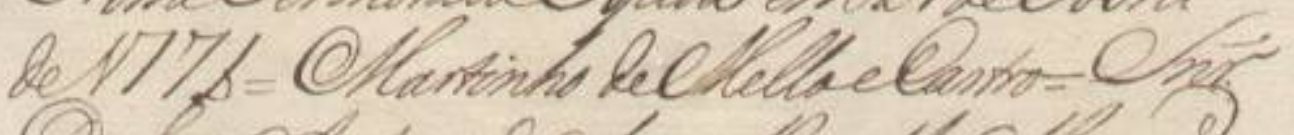

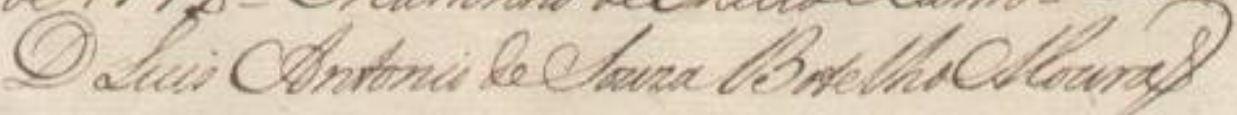

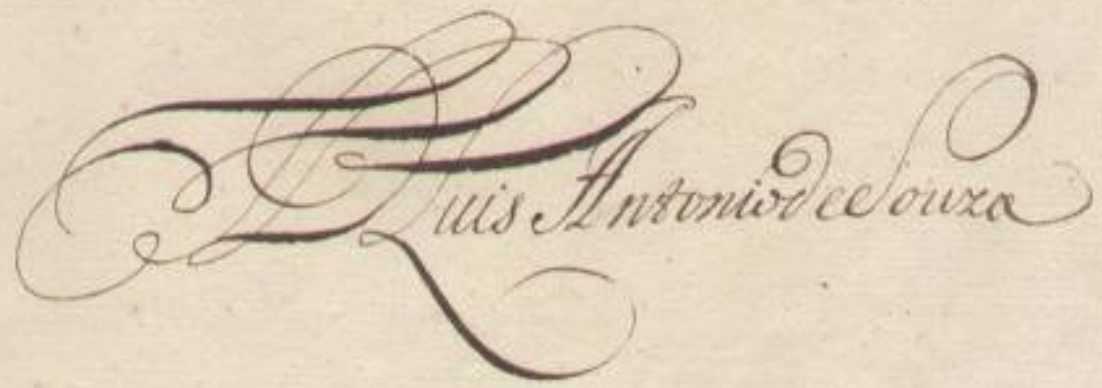


||16r|| [[seos]] Habitantes em outroalgumServiço quenaõ

seja porhumaparte odaConservaçaõdo Ygatemy,

280 naforma queseachadisposto no Paragrafo $5 \mathrm{aci}=$

ma referido: E poroutraparte noda Defensa,

Prezervaçaõ, eSegurançadeViamaõ eRio Grande

deSaõPedro, pelos meyos emodos queficaõ acima

indicados, desdeoParagrafo 7 ateoParagrafo 18

285 inclusivamente: Epelos quedepois delles sehiraõ

communicando aVossaSenhoria, segundo aexegencia dos Cazos

eaproporçaõ que as circunstancias opedirem.

DeosGuardea VossaSenhoria Palacio de

NossaSenhoradaAjuda em21 deAbril

290 de1774 $=$ Martinho deMelloeCastro $=$ Senhor

Dom Luis Antonio deSouzaBotelhoMouraõ

DomLuis AntoniodeSouza 
$[7]$
$\|17 r\|$

Com 2

Antonis de lourat Gomens nador, e Capitaó General dalaritunia de elaó Sauto, truigo.

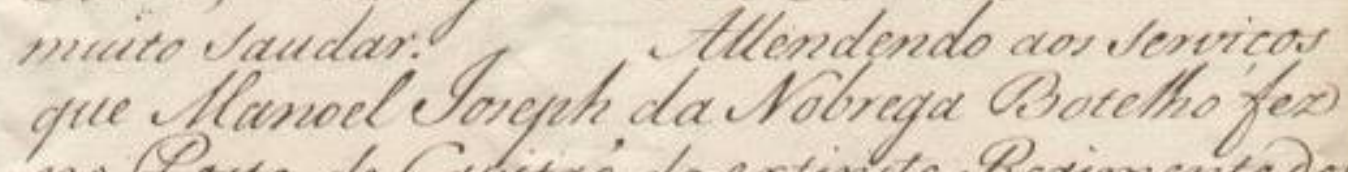

oll collegen nom into no. Gorta de Capitai do extinuto Reqimento dor lolunirior Geaies:

Eley porbem nomeallo varqene tlor de I nfantaria da Seqiao de QS Du=

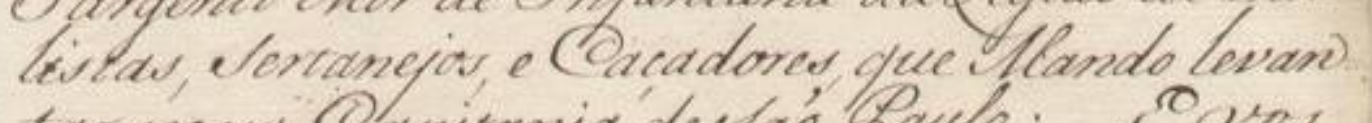
tar nand Ohyitania dectá Saulo: Conos os deno, oue the mandeiv eventar praca, darpos se coagar us oldas comerponderies no referido

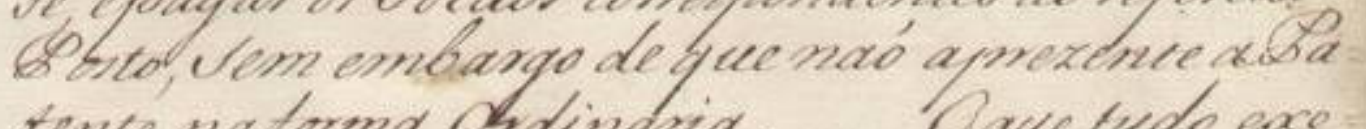
tene nef orma osdinalia. Oque tude exe suareis nó vortantes quear quen (eys, Creqi: mentos, on Deispuricué, que tejam em contravis. Eucrijue no Pulucio de esora centerada) utiuda en dex de feremoro, de miluteseconios Hellenta equatro. 2

Cley:

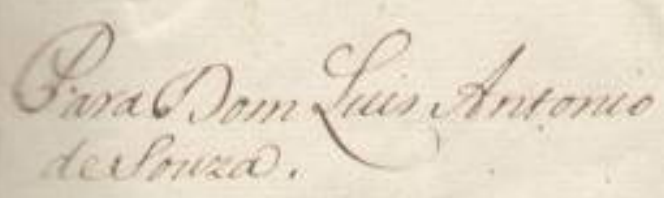

137 
||17r|| Dom Luis Antonio de Souza Gover= nador eCapitaõ General daCapitania deSaõ Paulo, [espaço] Amigo. [espaço] EU ELREY vos invio muito saudar. [espaço] Attendendo aos Serviços

5 que Manoel Joseph da Nobrega Botelho fez no Posto de Capitaõ do extincto Regimento dos Voluntarios Reáes: [espaço] Hey porbem nomeallo Sargento Mor de Infantaria da Legiaõ de Pau= listas, Sertanejos, e Caçadores, que Mando levan-

10 tar nessa Capitania de Saõ Paulo: [espaço] E vos Ordeno, que the mandeis sentar praça, dar posse, epagar os Soldos correspondentes ao referido Posto, Sem embargo de que naõ aprezente $\mathrm{aPa}=$ tente naforma Ordinaria. [espaço] $O$ que tudo exe=

15 cutareis naõ obstantes quaes quer Leys, Regi= mentos, ou Dispoziçoẽs, que sejam em contrario. Escripta no Palacio de Nossa Senhora da Ajuda em dez deSetembro, demil setecentos settenta equatro.

Para Dom Luis Antonio deSouza. 
[8]

||18r||

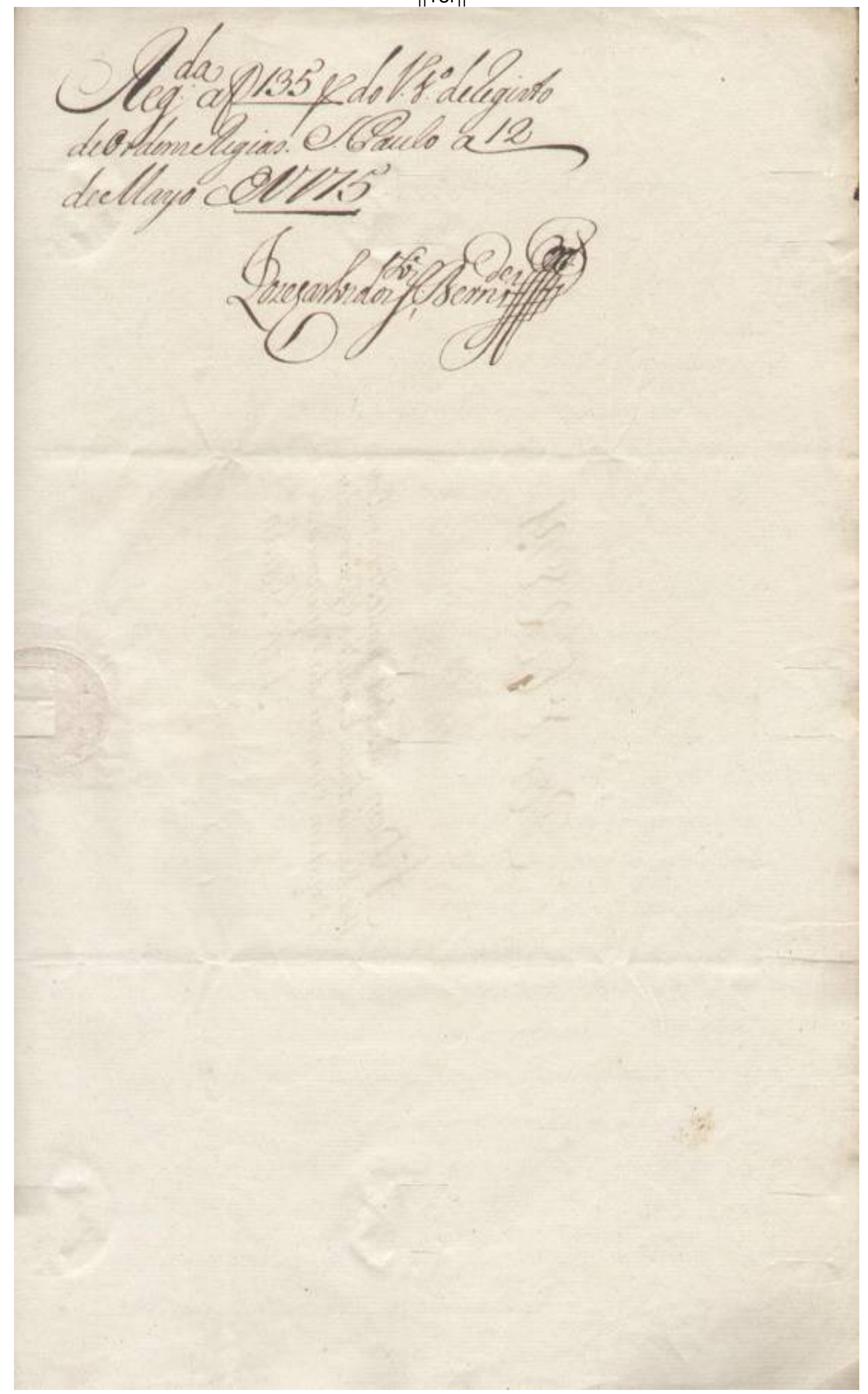


||18r|| Registada a folhas $\underline{135}$ do livro primeiro deregisto deOrdensRegias. SaõPaulo a12 deMayo de $\underline{1775}$

$\underline{\text { lozeCarlosdosSantosBernardes }}$ 


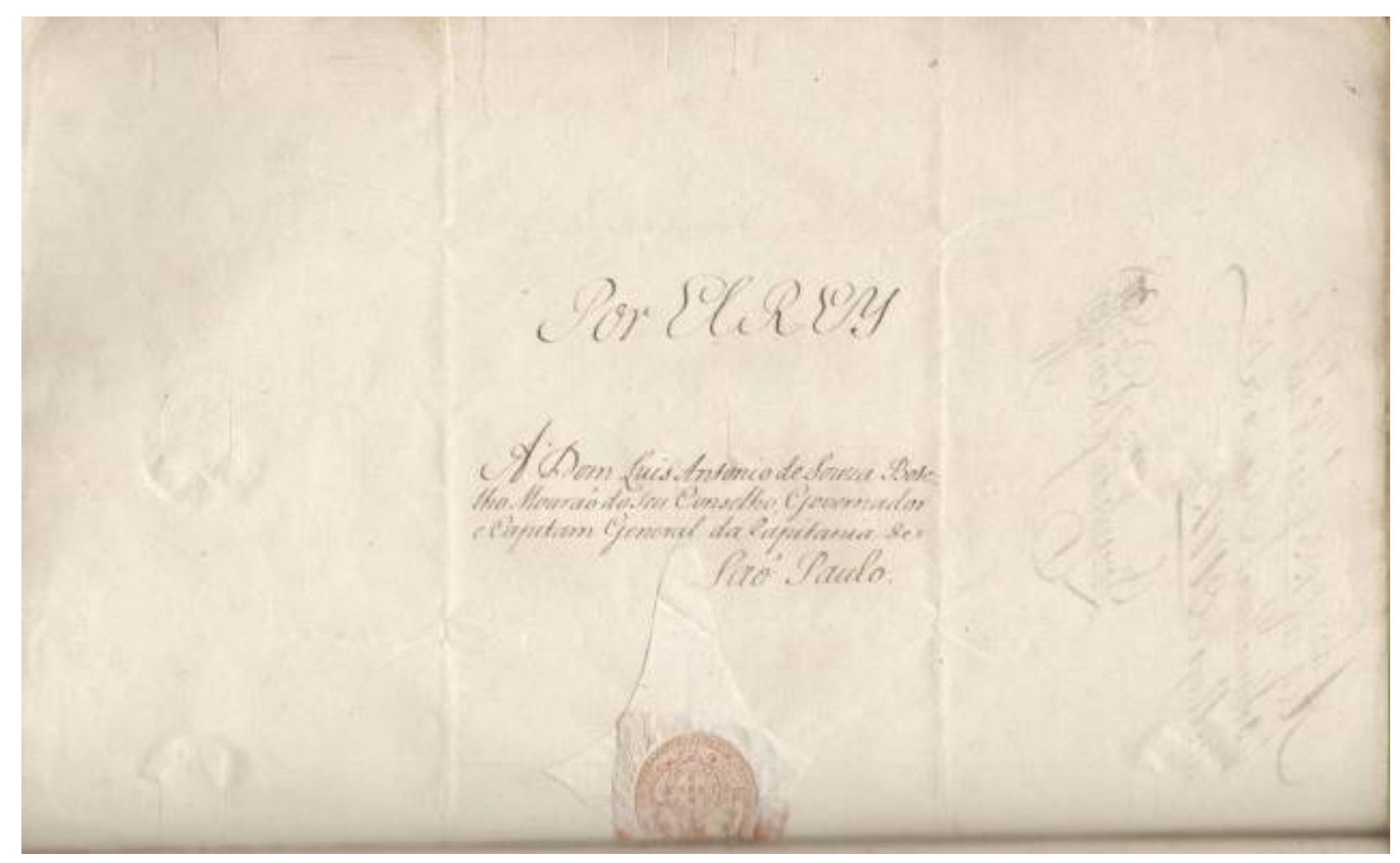




\author{
$\|18 \mathrm{v}\|$ Por ELREY \\ A Dom Luis Antonio deSouza Bote= \\ Iho Mouraõ do seu Conselho, Governador \\ eCapitam General daCapitania de \\ Saõ Paulo.
}




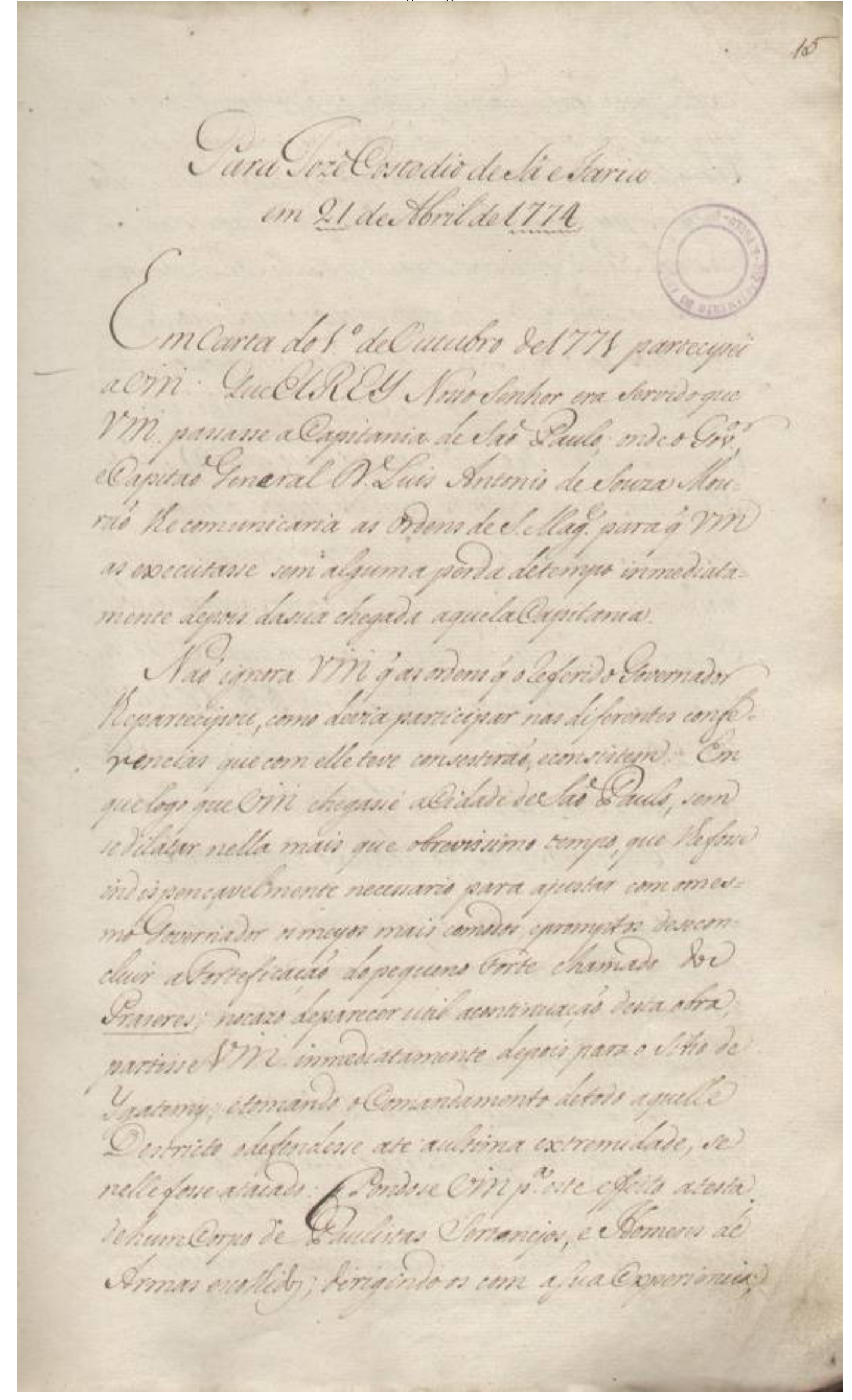


||19r|| Para lozêCostodio deSâ eFaria em $\underline{21}$ deAbril de 1774 *

Em carta do primeiro deOutubro de1771 partecipei aVossaMerce: QueEIREY NossoSenhor eraservidoque VossaMerce passasse aCapitania deSaõPaulo; ondeoGovernador eCapitaõGeneralDomLuis Antonio deSouza Mouraõ lhe comunicaria as ordens deSua Magestade paraque VossaMerce as executasse sem algumaperda detempo inmediata= mente depois dasua chegada aquelaCapitania. Ihepartecipou, como devia participar nas diferentes conferencias que com elle teve consestiraõ, econsistem: Em quelogo queVossaMerce chegasse aCidade deSaõPaulo, sem sedilatar nella mais que obrevissimo tempo, que lhefosse indispençavelmente necessario para ajustar com omesmoGovernador os meyos mais comodos, epromptos deseconcluir aForteficaçaõ do pequeno Forte chamado dos Praseres; nocazo deparecer util acontinuaçaõ desta obra; partisseVossaMerce inmediatamente depois para o Sitio de

20 Ygatemy; etomando oComandamento detodo aquelle Destricto odefendesse ate aultima extremidade, se nellefosse atacado: PondoseVossaMercepara esteeffeito atesta dehumCorpo dePaulistas Sertanejos, e Homens de Armas escolhidos; dirigindoos com asuaExperiencia;

\footnotetext{
* Abaixo e à direita destas duas linhas centralizadas há o número um carimbo circular do AESP.
} 


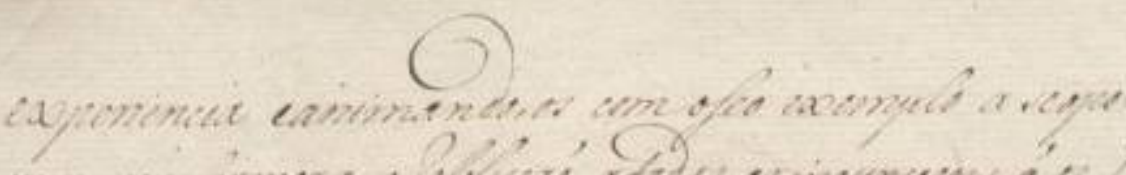

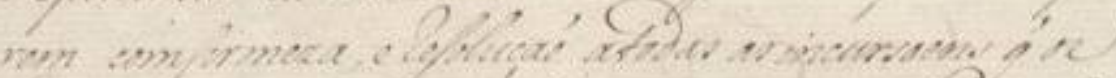

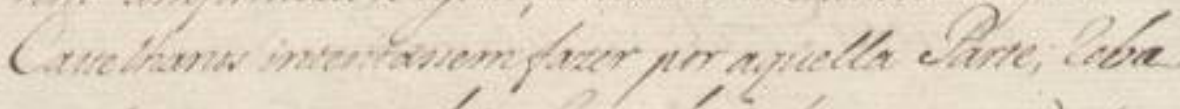

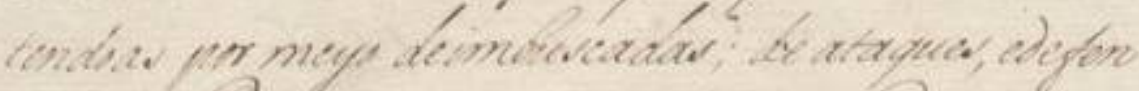

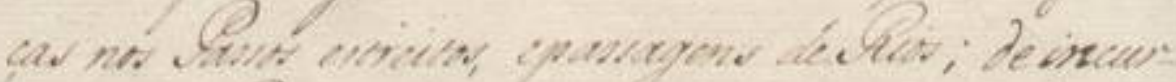

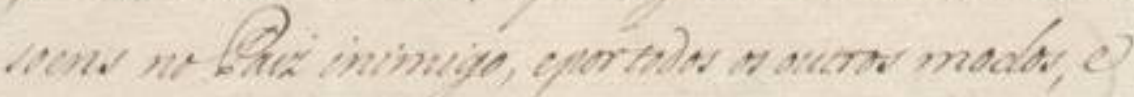

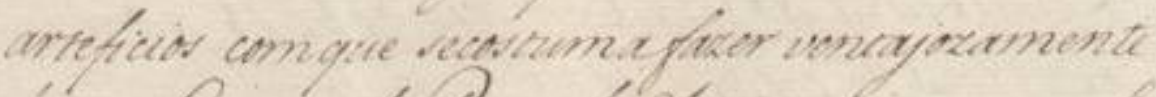

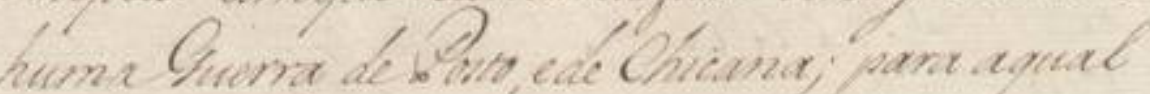

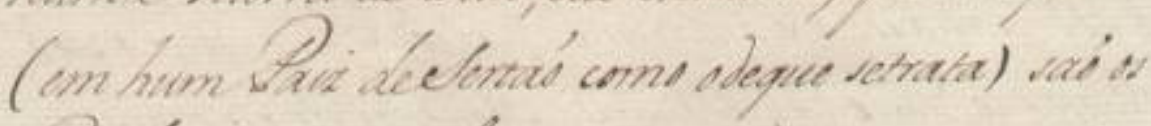

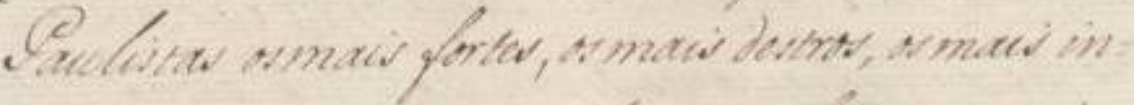

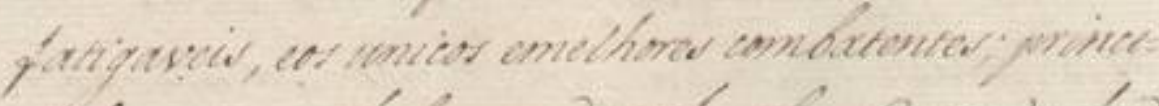

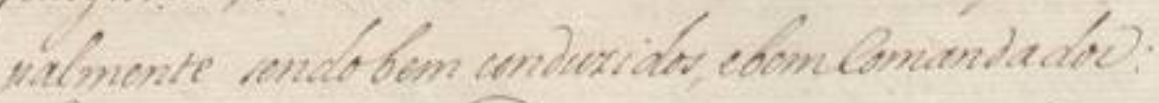

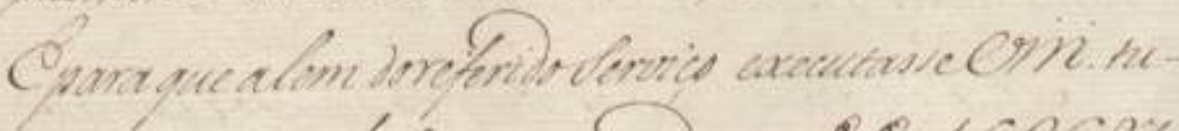

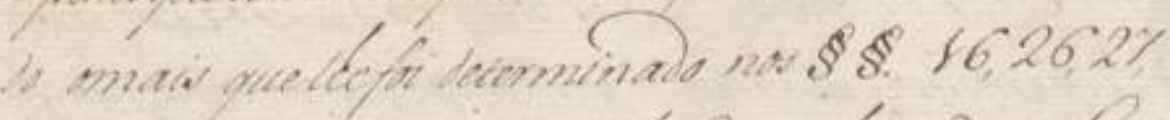

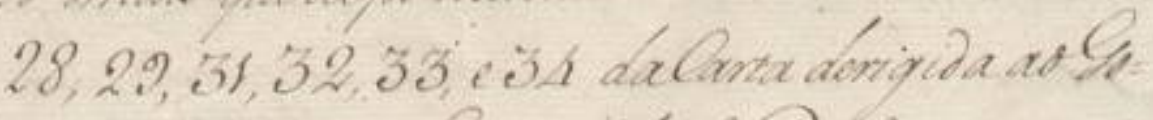

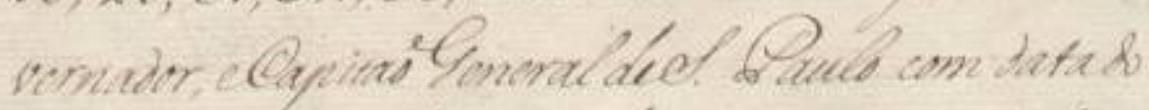

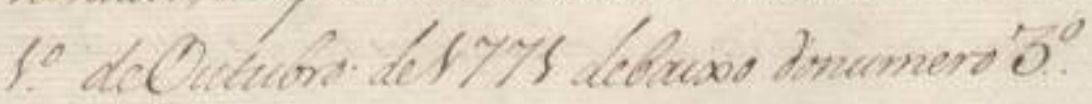

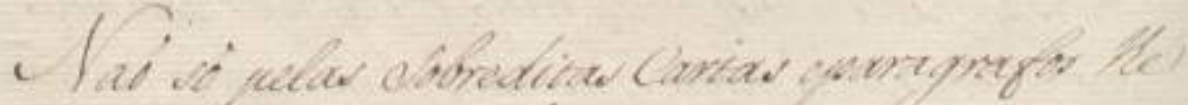

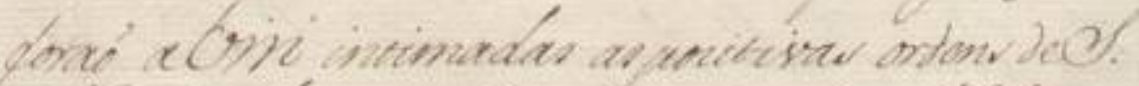

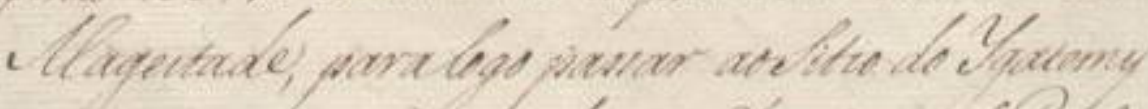

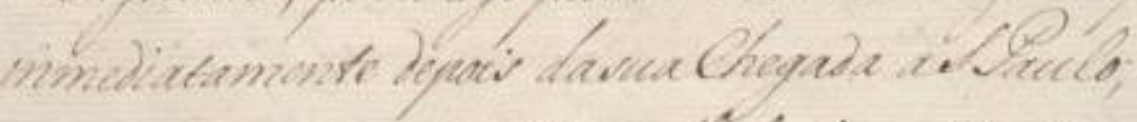

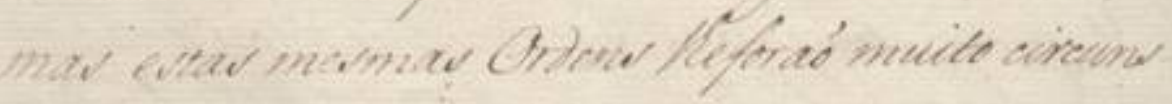

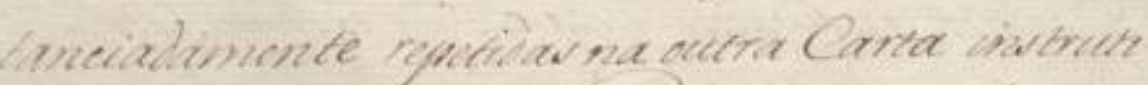

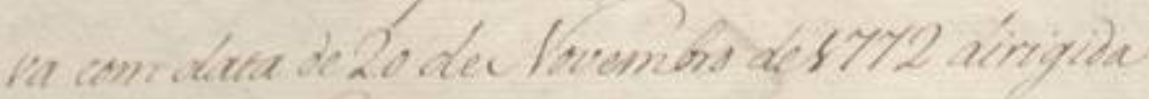

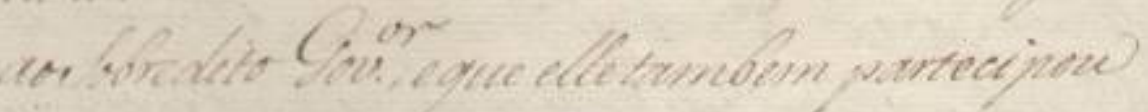


||19v\| [[experiência]] eanimando-os com oseo exemplo a seopo= rem comfirmeza, e resoluçaõ atodas as incursoens que os Castelhanos intentassemfazer por aquella Parte; reba tendo as por meyo deimbuscadas; de ataques, edefen ças nos Passos estreitos, epassagens deRios; de incursoens noPaiz inimigo, eportodos os outros modos, e arteficios com que secostumafazer ventajozamente humaGuerra dePosto, ede Chicana; para aqual (em humPaiz deSertaõ como o deque setrata) saõ os Paulistas os mais fortes, os mais destros, os mais in= fatigaveis, eos unicos emelhores combatentes; princi= palmente sendobem conduzidos, ebemComandados: E para que alem doreferidoServiço executasseVossaMerce tudo omais quelhefoi determinado nos paragrafos, 16, 26, 27, $28,29,31,32,33$, e 34 daCarta derigida aoGo= vernador, eCapitaõGeneral deSaõ Paulo com data do primeiro deOutubro de1771 debaixo donúmero terceiro. Naõ só pelas Sobreditas Cartas e paragrafos the foraõ aVossaMerce intimadas as positivas ordens deSua Magestade, paralogo passar aoSitio do Ygatemy inmediatamente depois dasuaChegada aSaõPaulo; mas estas mesmas Ordens Iheforaõ muito circunstanciadamente repetidas na outra Carta instrutiva com data de 20 deNovembro de1772 dirigida aoSobredito Governador, e que elle tambem partecipou 


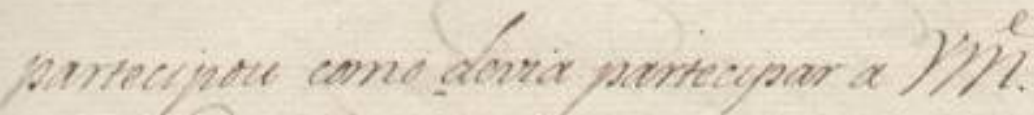

2

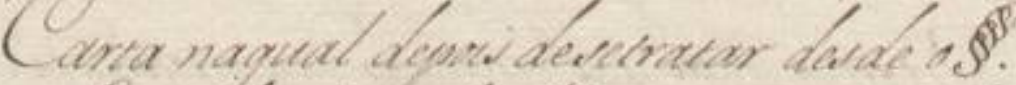

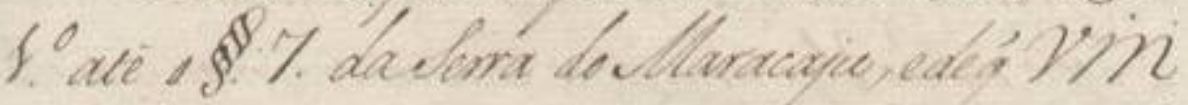

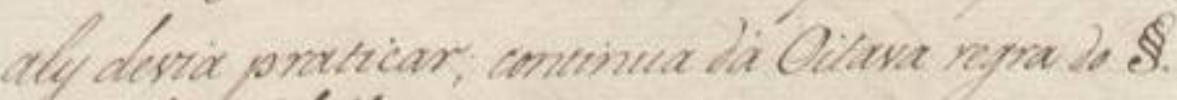

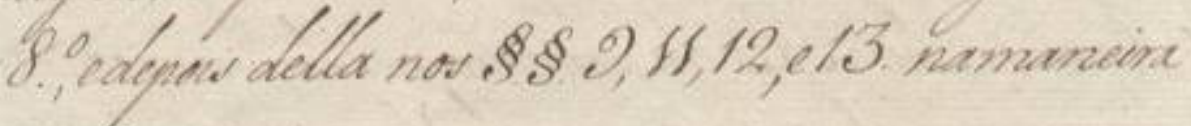
reglinte.

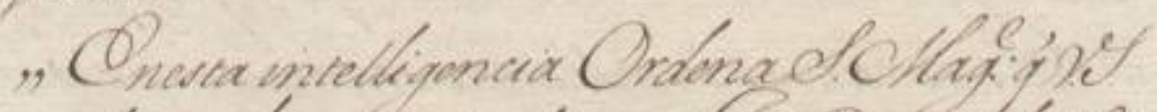

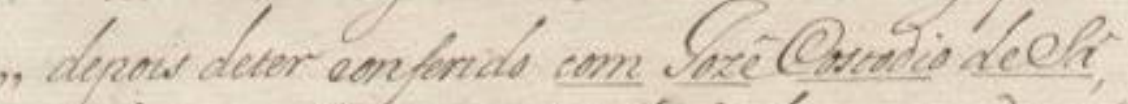
"Efmia, natoma queji hegor derominadiga

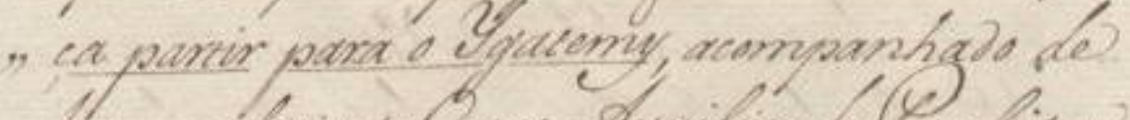

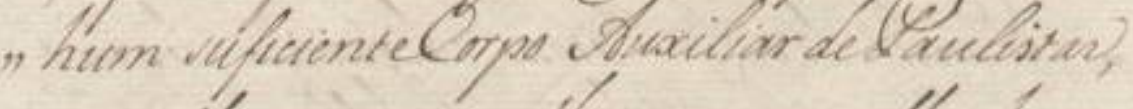
"que elle meins evester eque an ally chemen.

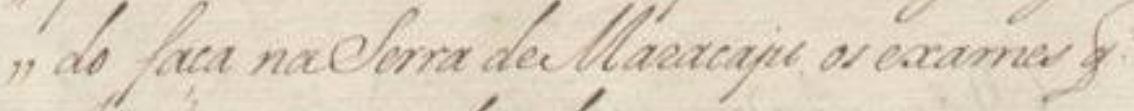
"Yíse acima indicados.

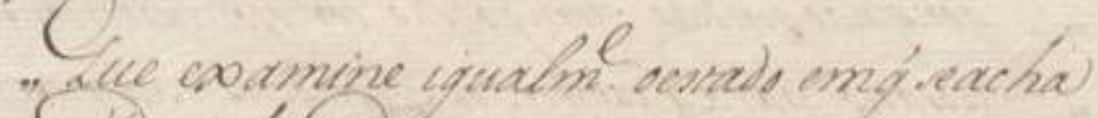

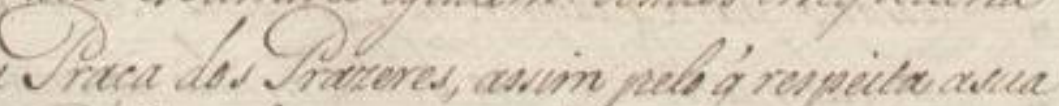

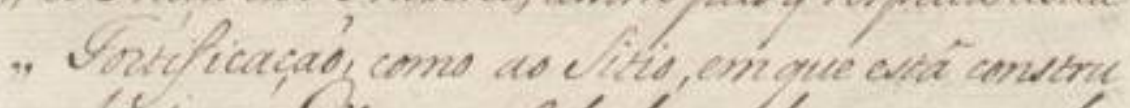

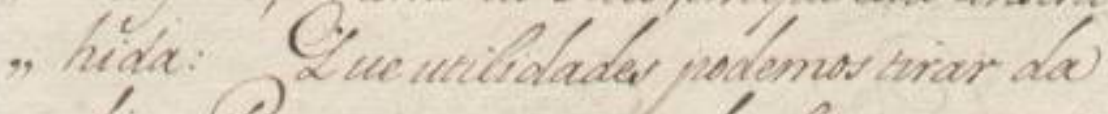
" dita maca nomencionado fitio cevena

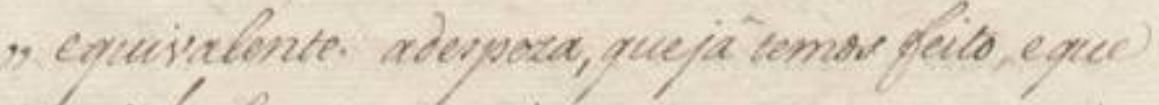

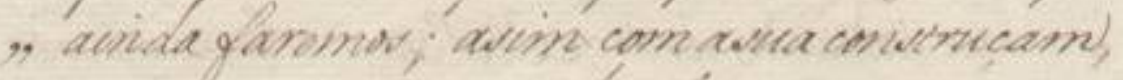

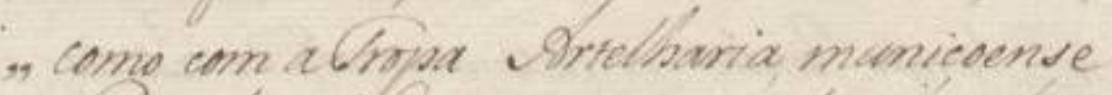

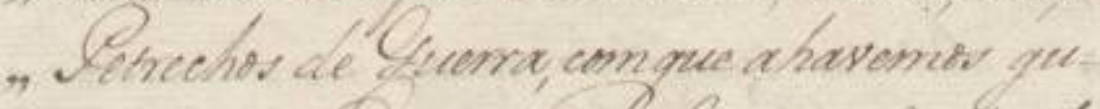

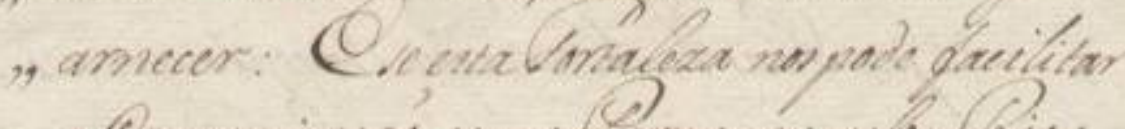

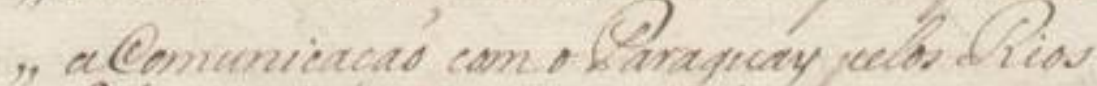

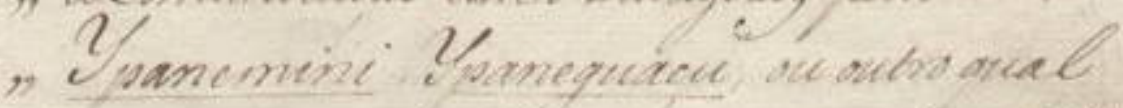

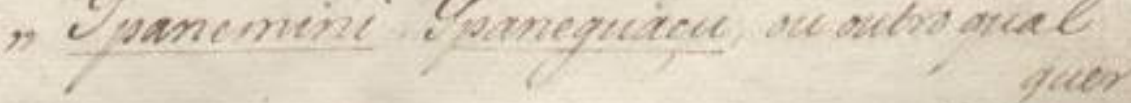


Carta naqual depois desetratar desde o paragrafo.

primeiro até o paragrafo 7. daSerra do Maracaju, edeque VossaMerce aly devia praticar; continua da Oitava regra do paragrafo.

oitavo, edepois della nos paragrafos $9,11,12$, e 13. na maneira seguinte.

„, E nesta intelligencia OrdenaSua Magestade que VossaSenhoria

,, depois deter conferido com lozêCostodio deSâ,

,, efaria, naforma quejâ lhefoi determinado, ofa-

,, ça partir para oYgatemy, acompanhado de

60 ,, hum suficienteCorpo Auxiliar dePaulistas,

,, que elle mesmo escolher; eque em ally chegan-

,, do faça naSerra deMaracaju os exames que

, , ficaõ acima indicados.

„, Que examine igualmente o estado emque seacha

65 ,, a Praça dos Prazeres, assim pelo que respeita asua

,, Fortificaçaõ, como ao Sitio, em que estâ constru-

,, hida: Que utilidades podemos tirar da

,, ditaPraça nomencionadoSitio; eseserâ

,, equivalente adespeza, quejâ temos feito, eque

70 ,, aindafaremos; asim com asua construçam,

,, como com aTropa Artelharia, muniçoens, e

,, Petrechos de Guerra, comque ahavemos gu=

,, arnecer: Ese estaFortaleza nos pode facilitar

,, aComunicaçaõ com oParaguay pelos Rios

75 ,, Ypanemini Ypaneguaçu, ou qual quer 


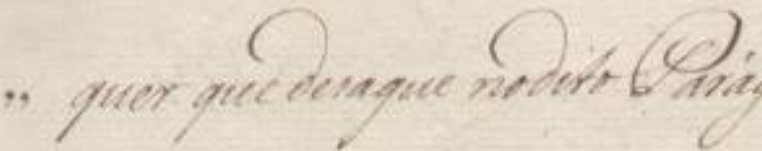

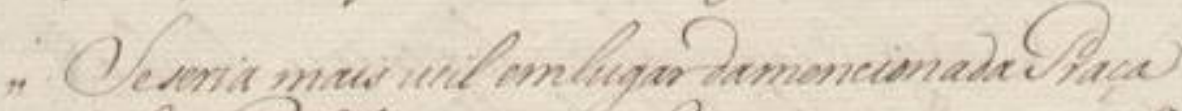

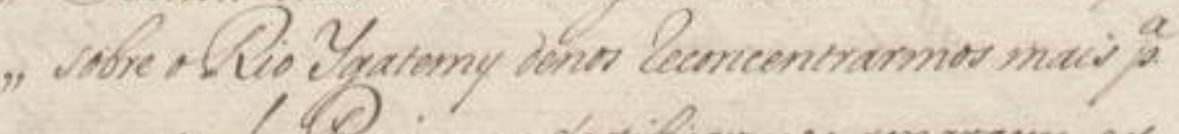

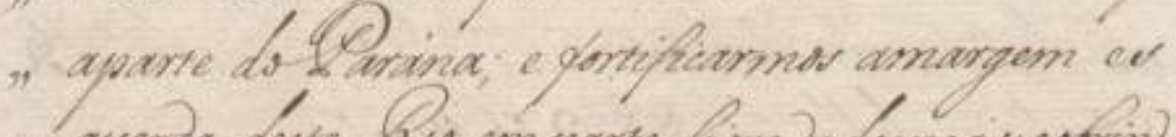

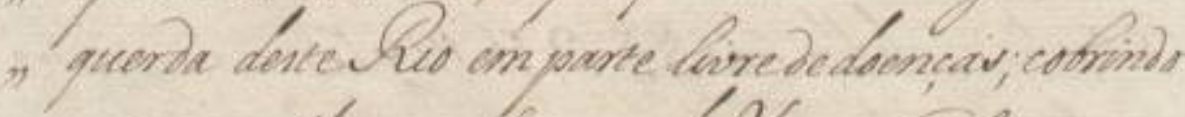

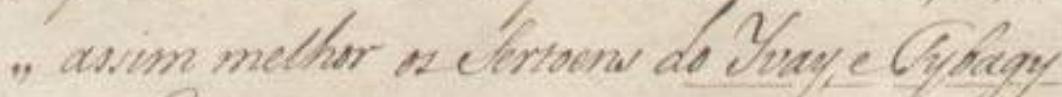
(b)

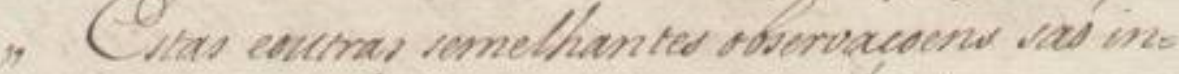

" dimencavelmente necessaria inter ó entremvz

" ho impeno de dortefiear dum livis destande

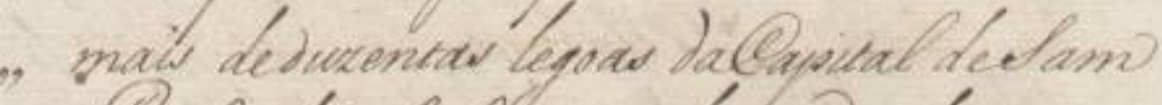

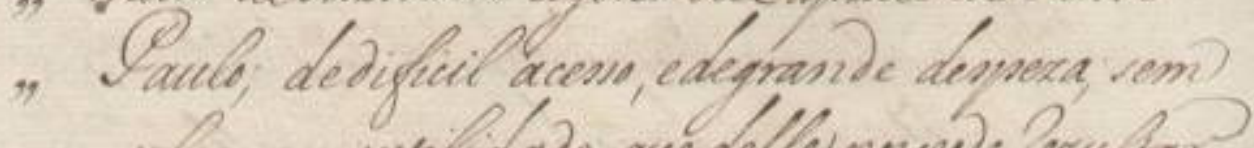

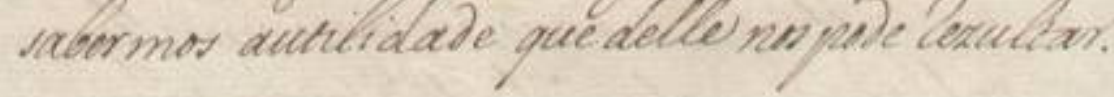

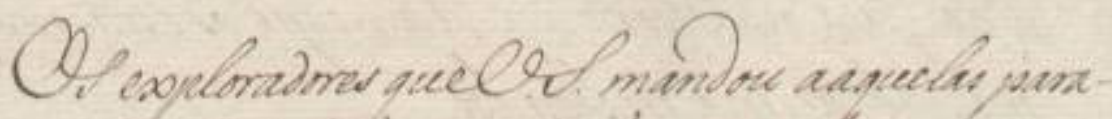

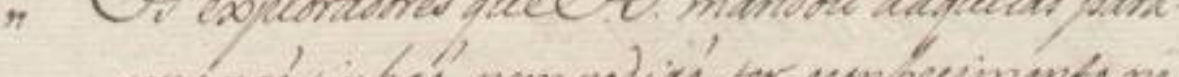

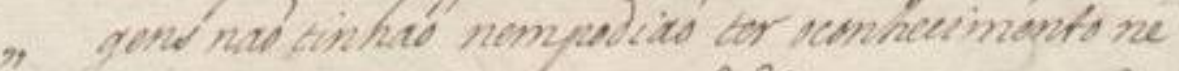
curanis varz patorem oz eforedits cormew \&

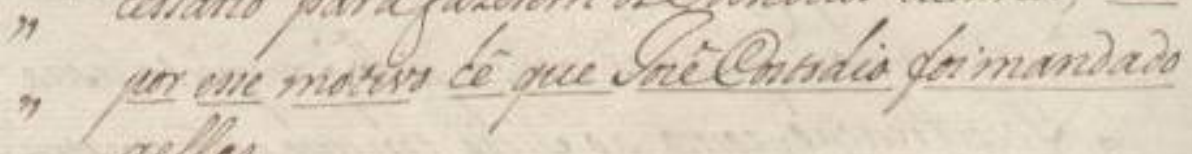
aclas.

10

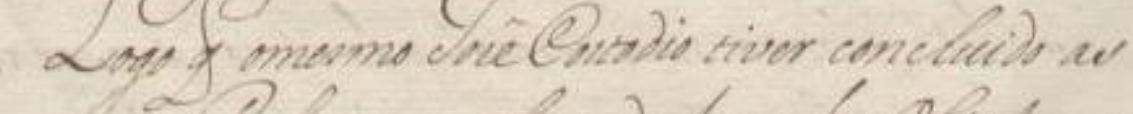

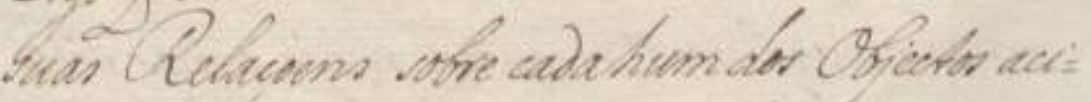

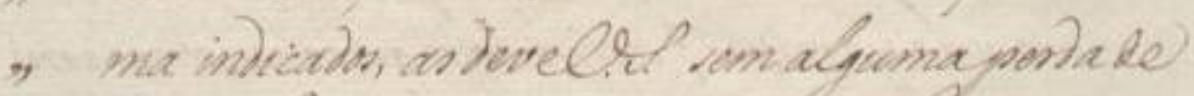

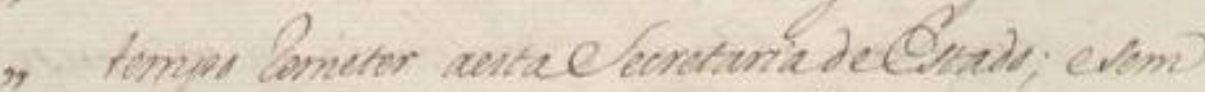

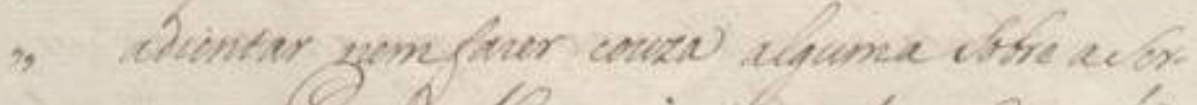

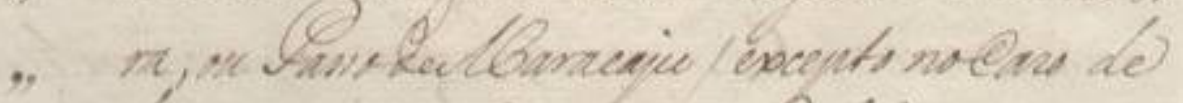

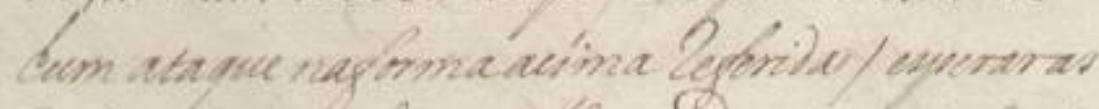

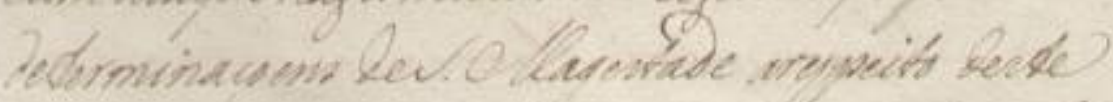


||20v\| ,, quer quedesague noditoParáguay.

„, Seseria mais util emlugar damencionada Praça

,, sobre oRio Ygatemy denos reconcentrarmos mais para

,, aparte doParana; e fortificarmos amargem es

80 ,, querda desteRio em parte livrede doenças; cobrindo

,, assim melhor osSertoens do Yvay, eTybagy

". Estas eoutras semelhantes observaçoens saõ in=

,, dispençavelmente necessarias antes que entremos

„, no empenho deforteficar hum Sitio distante

„, mais deduzentas legoas daCapital deSam

„, Paulo; dedificil acesso, edegrande despeza, sem

,, sabermos autilidade que delle nos pode rezultar.

„, Os exploradores queVossaSenhoria mandou aaquelas para-

,, gens naõ tinhaõ nempodiaõ ter oconhecimento ne

90 ,, cessario parafazerem osSobreditos exames; $\underline{E}$

,, por esse motivo hê que lozêCostodio foi mandado

, aellas.

,, Logo que omesmo lozêCostodio tiver concluido as

,, suas Relaçoens sobre cadahum dos Objectos aci=

95 „, ma indicados, as deveVossaSenhoria sem algumaperda de

,, tempo remeter aestaSecretariadeEstado; esem

,, adientar nemfaser couza algumasobre aSer-

„, ra, ou PassodeMaracaju / excepto noCaso de

,, hum ataque naformaacima referida / esperaras

100 ,, determinaçoens deSua Magestade arespeito deste

importante 
"importante Oedicade Alrige.

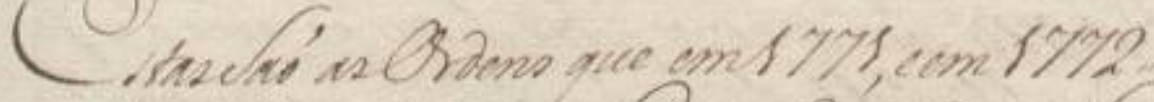

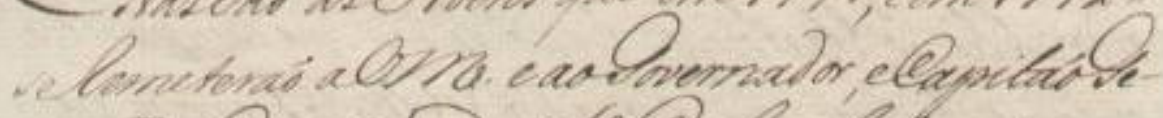

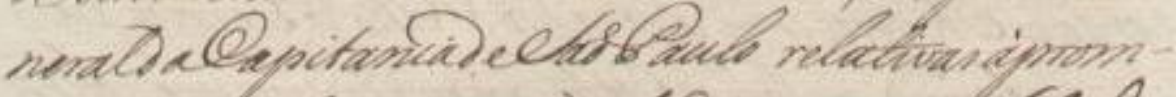

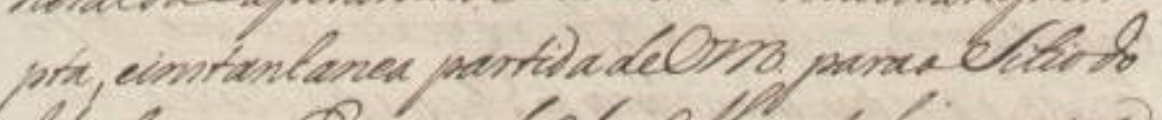

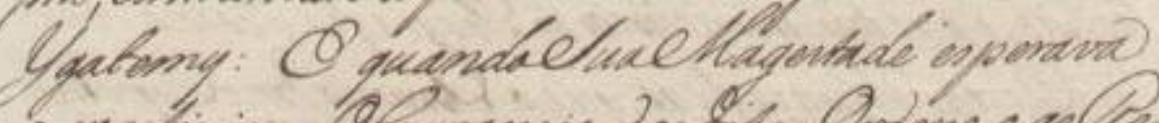
a exactivioma orienancia las firas Omers, cad Relacsem doqueleps. sivess exsecutide no veforide Oitus en virtude dellas, aparaconá nesté ense vucesivos Chrirs denselexitamix, dos quan consta. quel In nat is nat tom executado ate oprorente crusa alguma orquethe fri inumbris; mas pue

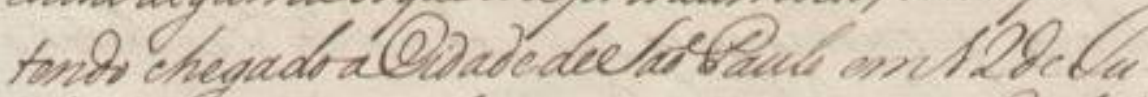

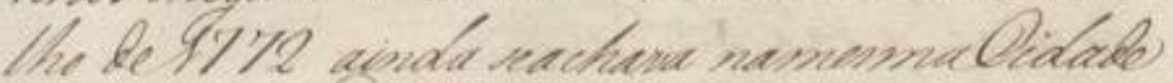

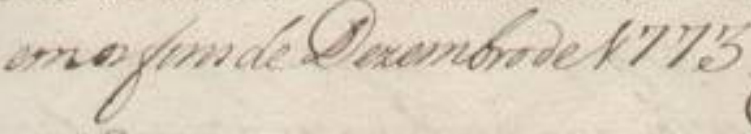

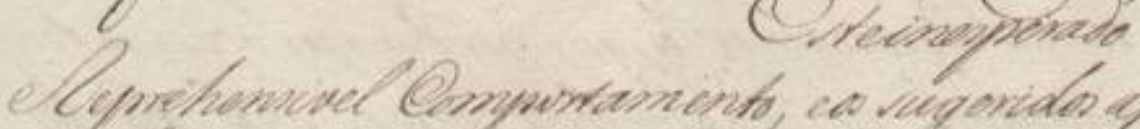

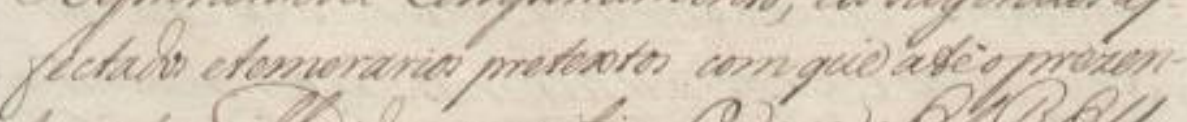

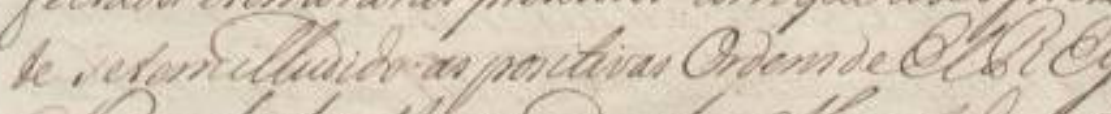

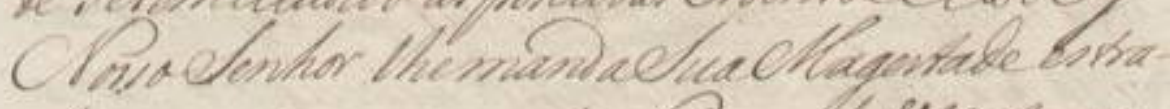

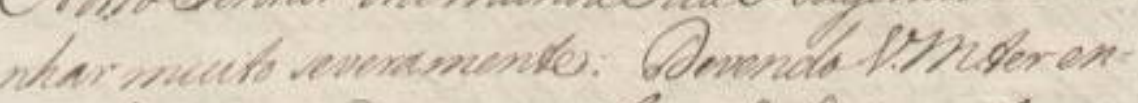
twrdiso que ainda yuc entlugar hs hitos meleoros unitrueme CVro as malis voluses lazsens; nenta-

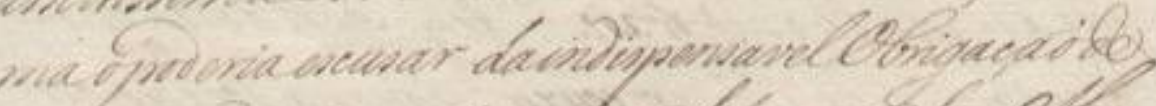

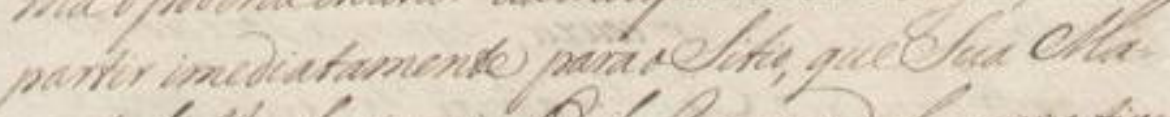

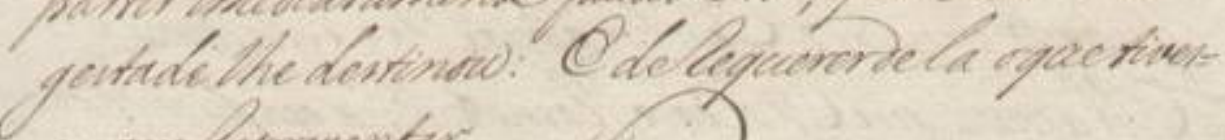
re que lomerenter:

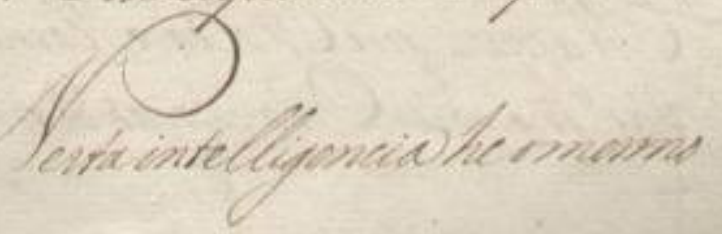


||21r | ,, [[importante]] edelicado Artigo.

EstasSaõ asOrdens que em1771, e em 1772 ,, seremeteraõ aVossaMerce eaoGovernador, eCapitaõGe-

neraldaCapitaniadeSaõPaulo relativas àprom-

pta, einstantanea partida deVossaMerce. paraoSitiodo

Ygatemy: E quandoSuaMagestade esperava

a exactissimaObservancia das ditasOrdens, e as Relaçoens doqueVossaMerce tivesse executado no referido

110 Sitio em virtude dellas; apareceraõ nesteCorte sucessivos Avizos dessaCapitania, dos quaes consta; queVossaMerce naõ so naõ tem executâdo ateoprezente couza algumadoquelhefoi incumbido; mas que tendo chegadoaCidade deSaõPaulo em12de luIho de1772 ainda seachava namesmaCidade emosfins deDezembro de1773.

Esteinsperado ereprehensivel Comportamento, eos sugeridos affectados etemerarios pretextos com que atéoprezente setemilludido as positivas Ordens deEIREY NossoSenhor IhemandaSuaMagestadeestranhar muito severamente: DevendoVossaMerceter entendido que ainda que emlugar dos ditos pretextos assistissem aVossaMerce as mais solidas razoens; nenhuma opoderiaescusar daindispensavelObrigaçaõde partir imediatamente para oSitio, queSua $\mathrm{Ma}=$ gestade The destinou: $\mathrm{E}$ derequererdela oquetives= se quereprezentar. 


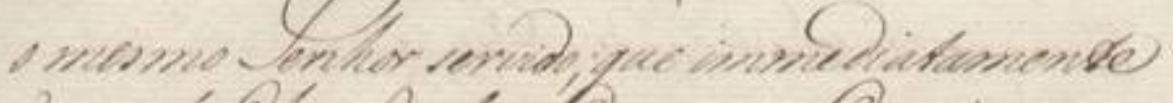

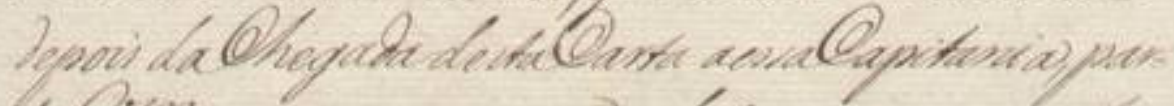

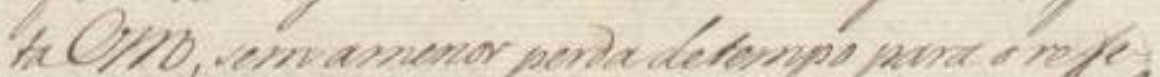

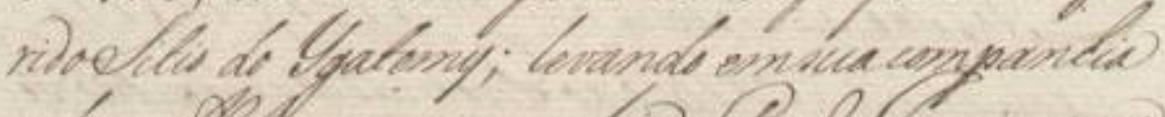

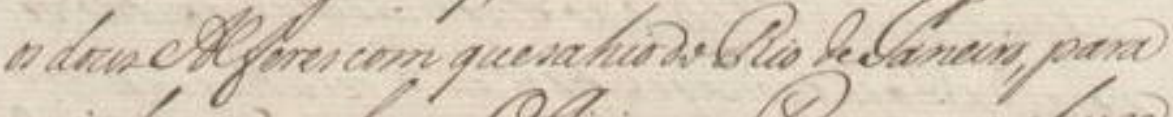

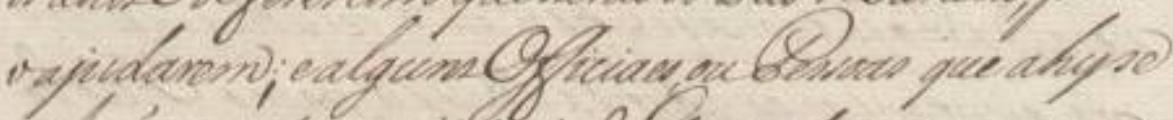

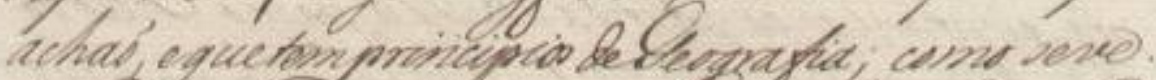

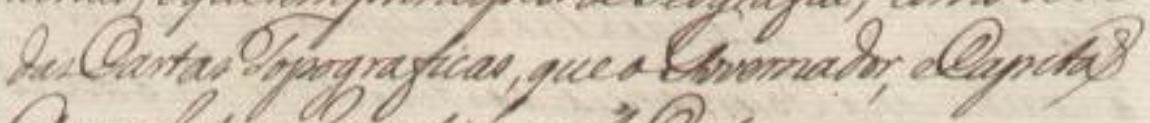

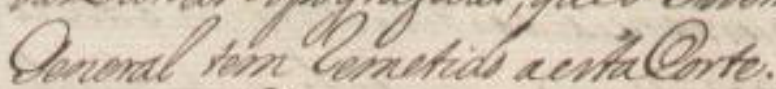

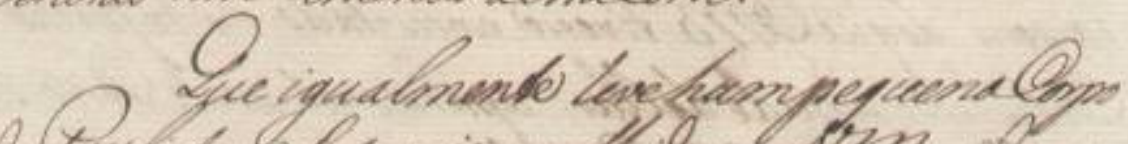

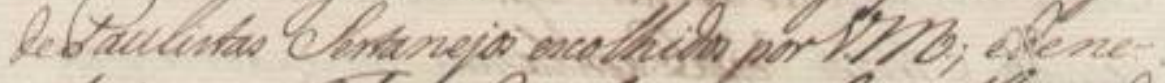

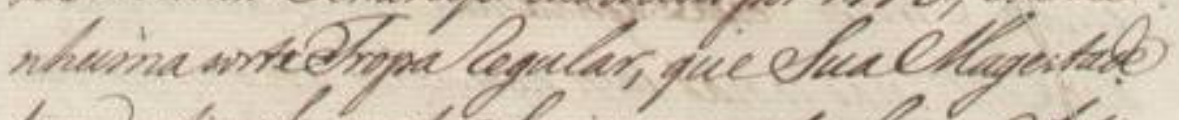

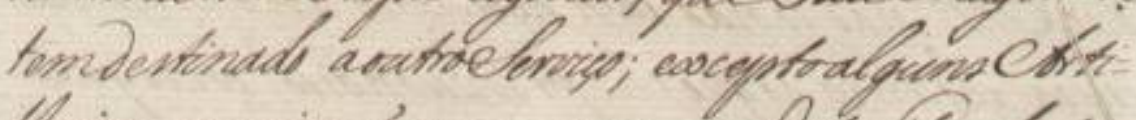

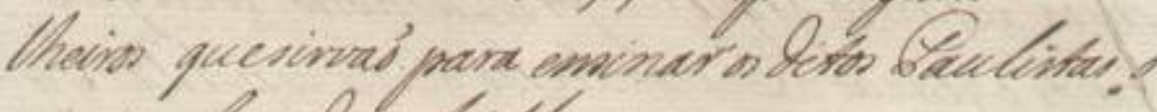

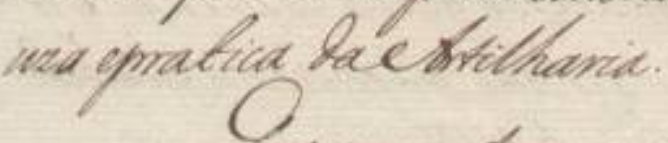

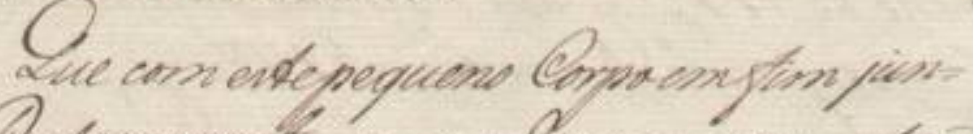

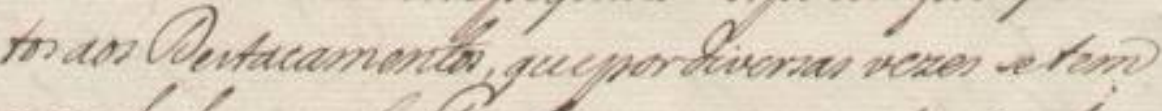

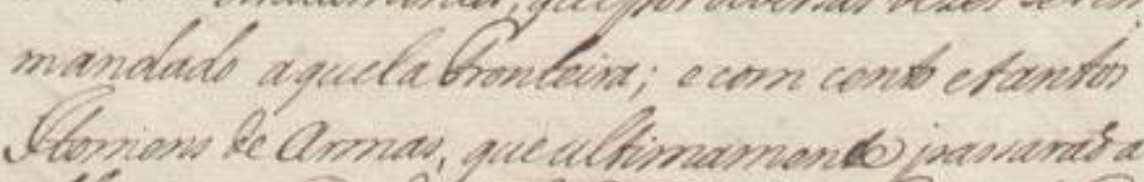

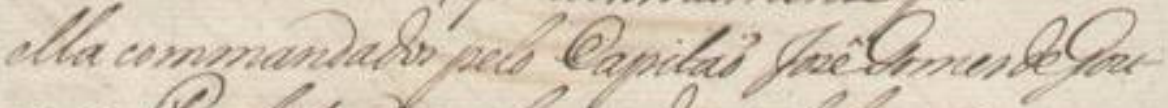

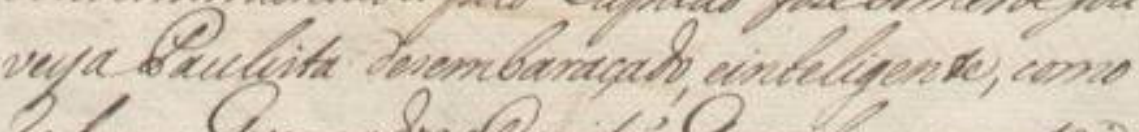

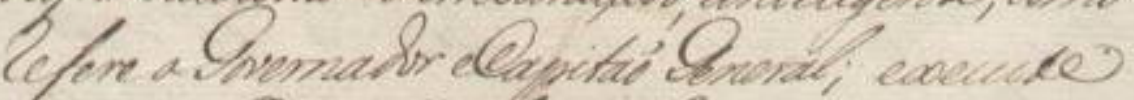

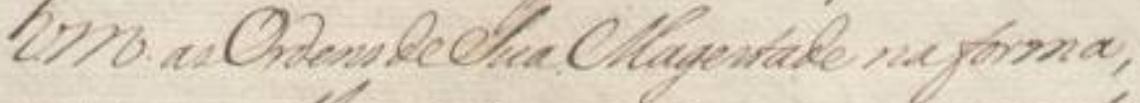

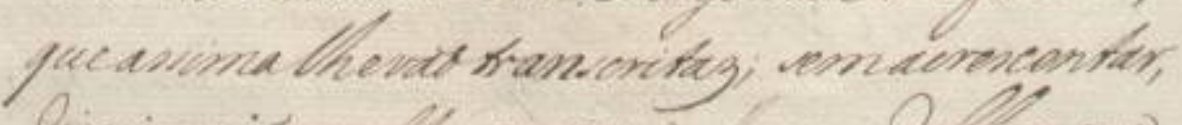

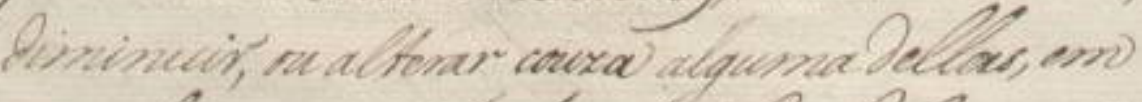

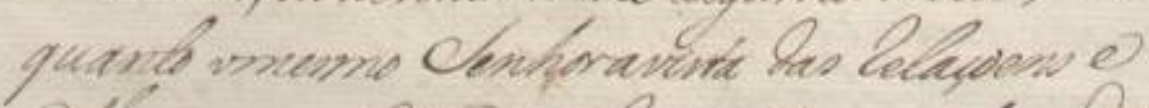

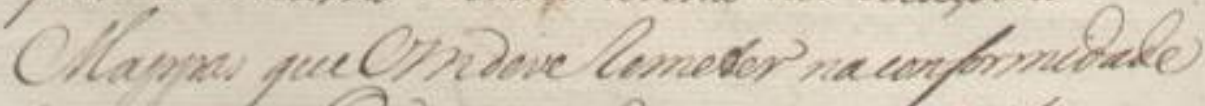

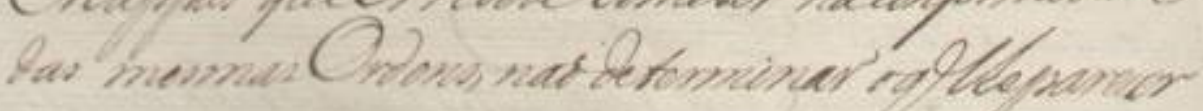


\|21v $\|$ [[o mesmo]] Senhor servido; que immediatamente depois daChegada destaCarta aessaCapitania, par= taVossaMerce, sem amenor perda detempo para orefe= ridoSitio do Yagatemy; levando emsuacompanhia os dousAlferes com quesahio doRio delaneiro, para oajudarem; ealgunsOfficiaes, ouPessoas que ahyse achaõ, equetemprincipios deGeografia; como seve dasCartas Topograficas, queoGovernador, eCapitaõ General tem remetido aestaCorte.

Que igualmente levehumpequenoCorpo dePaulistas Sertanejos escolhidos porVossaMerce; edenenhumasorteTroparegular, queSuaMagestade temdestinado aoutroServiço; exceptoalguns Arti= Iheiros quesirvaõ para ensinar os ditos Paulistas o uzo epratica daArtilharia. Que com estepequeno Corpoemfim jun= tos aos Destacamentos, quepordiversas vezes setem mandado aquelaFronteira; e com cento etantos Homens deArmas, queultimamente passaraõ a ella commandados pelo Capitaõ lozêGomes deGouveyaPaulista desembarCado, einteligente, como refere oGovernador eCapitaõ General; execute VossaMerce asOrdens deSua Magestade na forma, queassimalhevaõ transcritaz; semacrescentar, diminuir, ou alterar couza alguma dellas, em quanto omesmo Senhoravista das relaçoens e Mappas queVossaMercedeveremeter naconformidade das mesmasOrdens, naõdeterminar oquelheparecer 


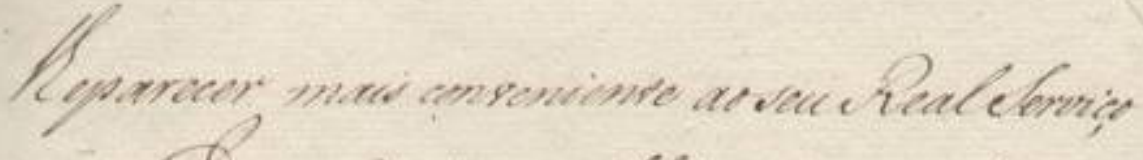

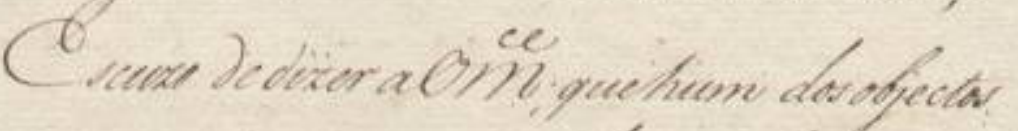

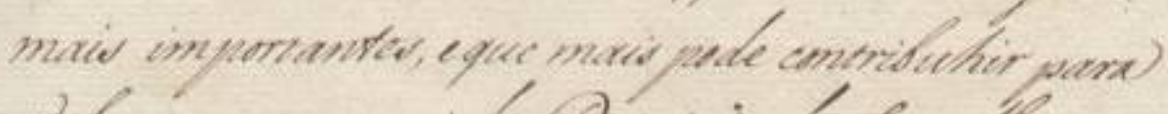

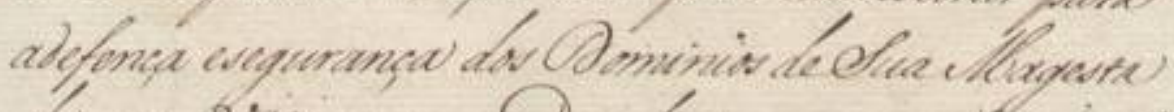

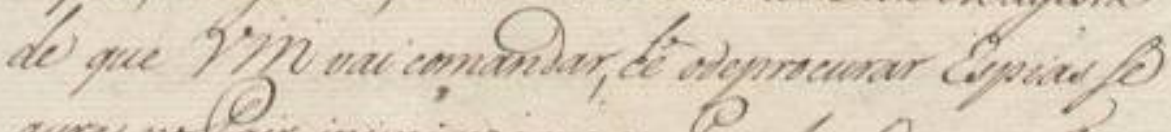

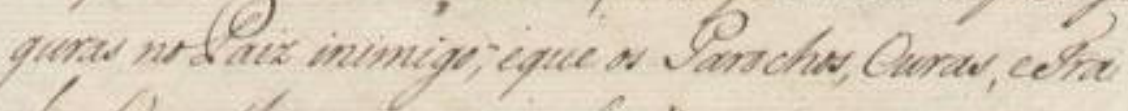

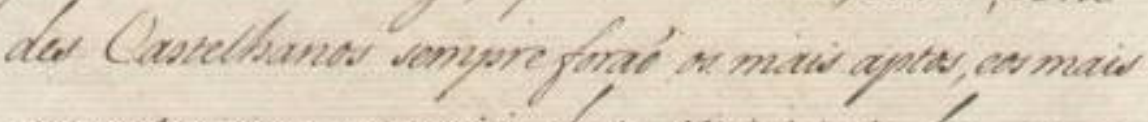

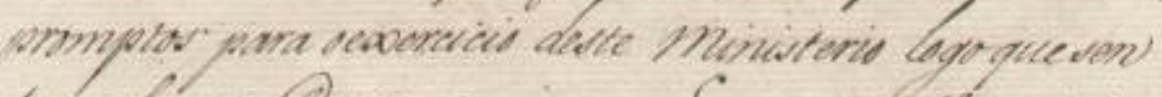
tomalquma@onsmiencia: Crumbinielagoncid derel

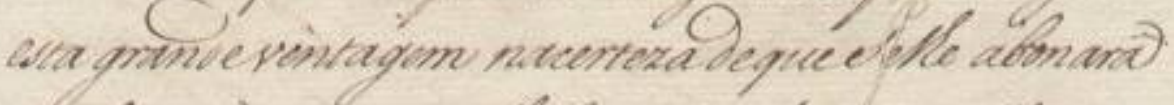

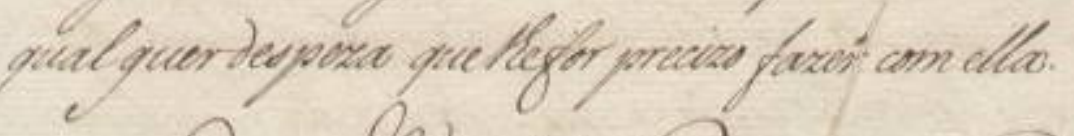

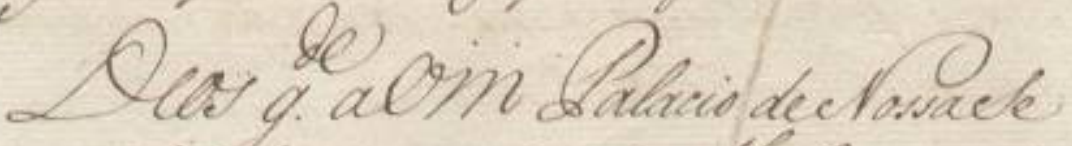

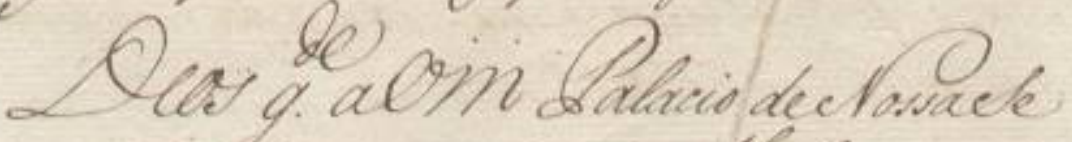

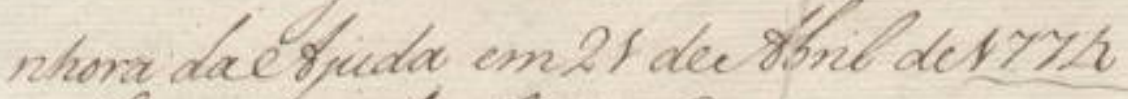

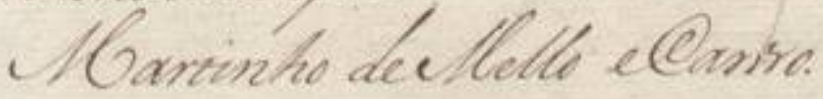

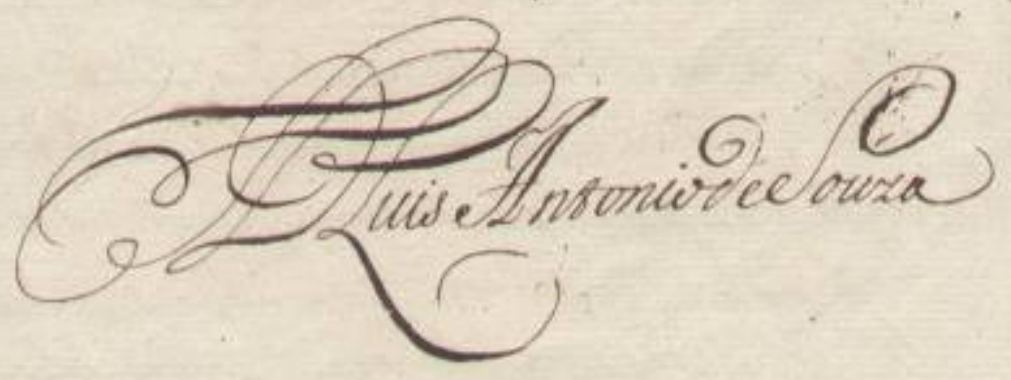


||22r|| [[lheparecer]] mais conveniente aoseu RealServiço

Escuzo de dizer aVossaMerce; quehum dos objectos

mais importantes, eque mais pode contribuhir para

adefença esegurança dos Dominios deSua Magesta

de que VossaMerce vai comandar, hê odeprocurar Espias se

guras noPaiz inimigo; eque os Parochos, Curas, eFra

des Castelhanos sempreforaõ os mais aptos, eos mais

promptos para o exercicio deste Ministerio logoquesen

tem algumaConveniencia: Enesta intelligencia

deveVossaMerce fazer as possiveis deligencias por conseguir

esta grandeventagem nacerteza deque selhe abonarâ

qualquerdespeza quelhefor precizo fazer com ella.

nhora daAjuda em21 deAbril de $\underline{1774}$

Martinho deMello eCastro.

DomLuis AntoniodeSouza 
(2)

opiat

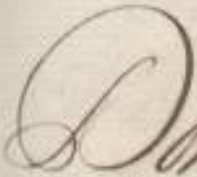

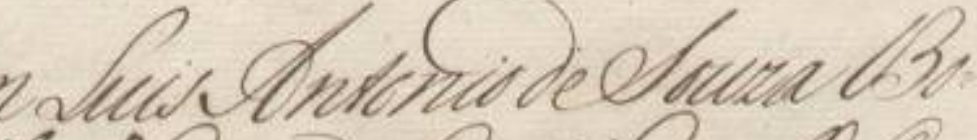

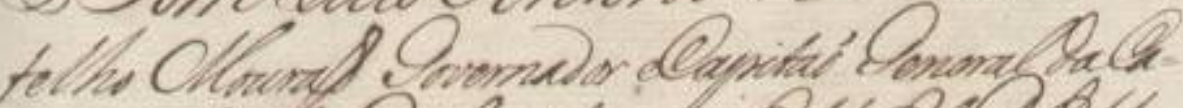

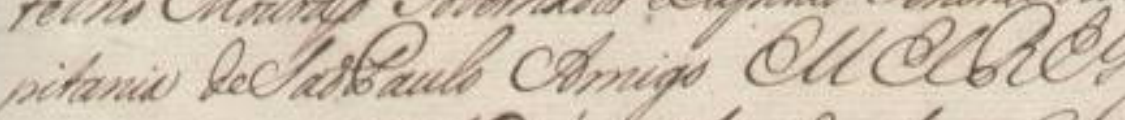

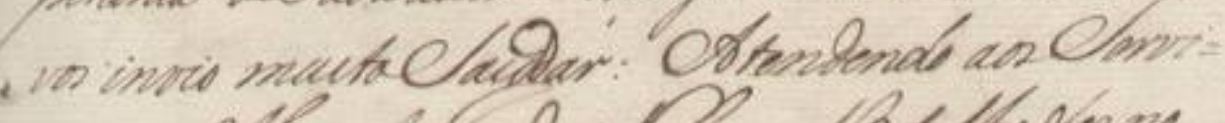

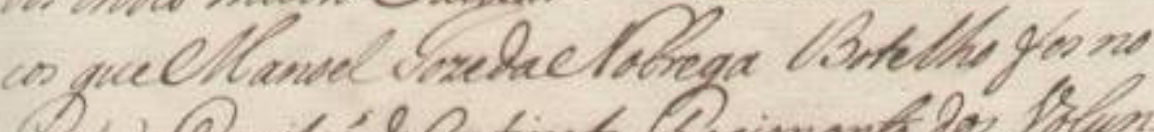

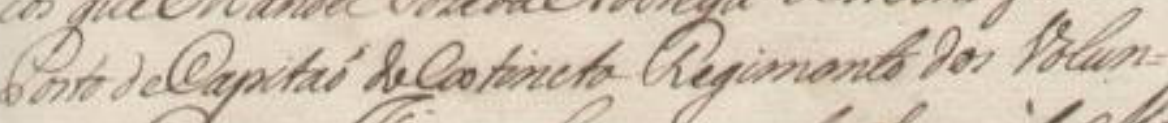

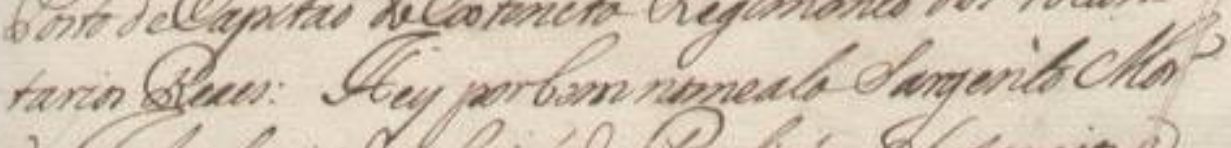

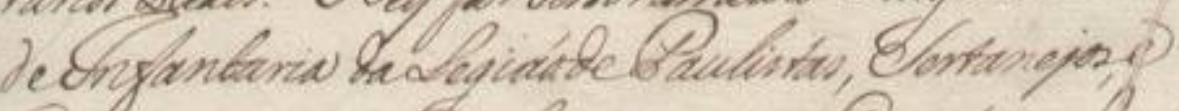

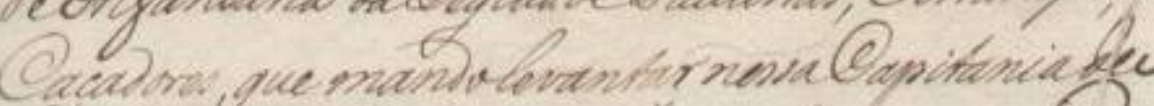

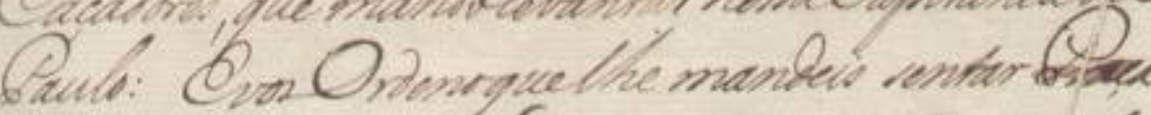

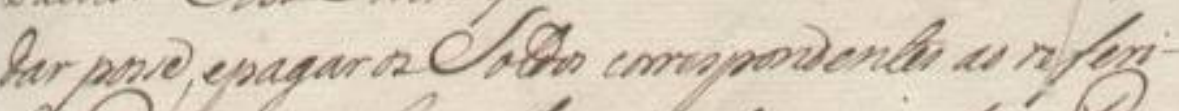

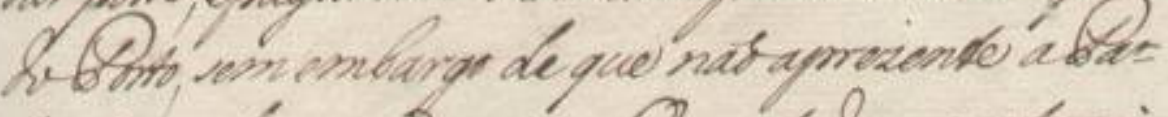
ronde neforme minarix. Oquetub escecutarnis

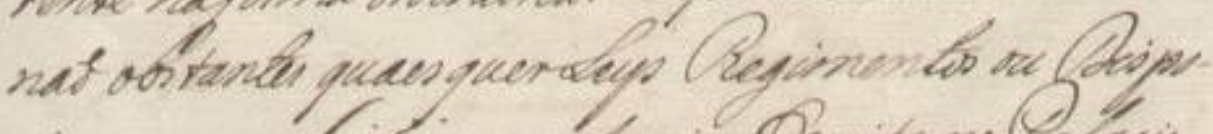

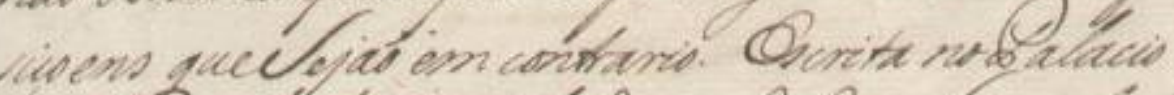

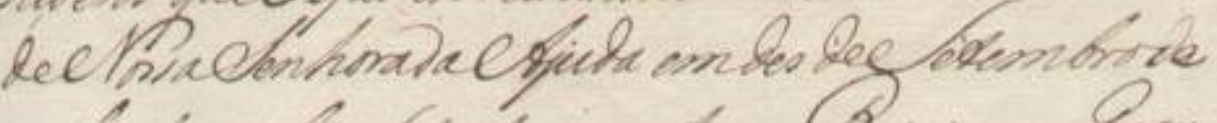

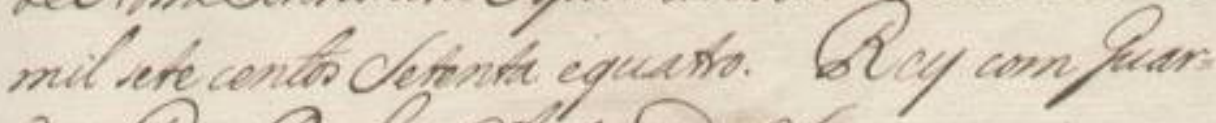

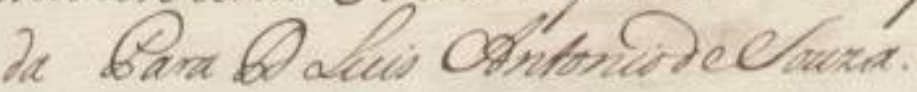

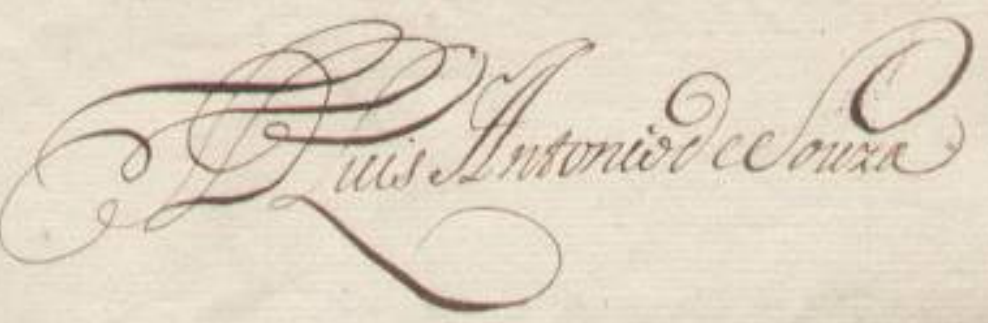


||23r|| Copia

Dom Luis Antonio deSouza $\mathrm{Bo}=$

telho Mouraõ Governador eCapitaõ General daCa=

5 pitania deSaõPaulo Amigo EU ELREY

vos invio muitoSaudar: Atendendo aos Servi=

cos queManoel JozedaNobrega Botelho fes no

Posto deCapitaõ deExtincto Regimento dos Volun=

tarios Reaes: Hey porbem nomealoSargento Mor

10 deInfantaria daLegiaõdePaulistas, Sertanejos,e

Caçadores, que mandolevantar nessaCapitaniade Saõ

Paulo: EvosOrdenoquelhe mandeis sentar Praça

dar posse, epagar osSoldos correspondentes ao referi-

doPosto, sem embargo de que naõaprezente $\mathrm{aPa}=$

15 tente naforma ordinaria. O quetudo executareis

naõ obstantes quaes querLeys Regimentos ou Dispo-

siçoens queSejaõ em contrario. Escrita no Palacio

deNossaSenhoradaAjuda emdes deSetembrode

mil sete centos Setenta equatro. Rey com Guar=

da Para Dom Luis AntoniodeSouza.

Dom Luis AntoniodeSouza 
$[12]$
$\|24 r\|$

Copica

Serre cuta be enderta a Cantal Re

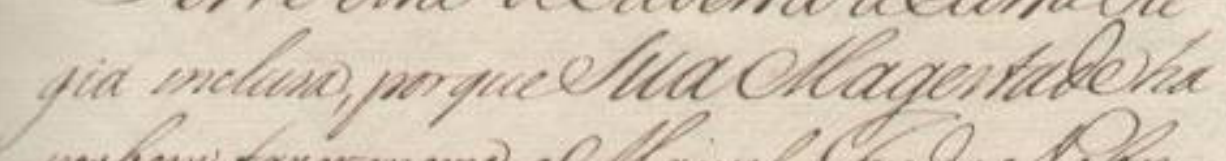

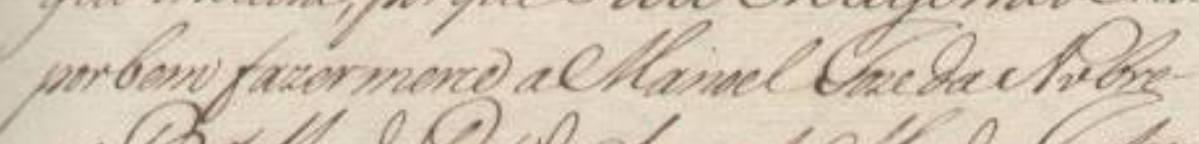

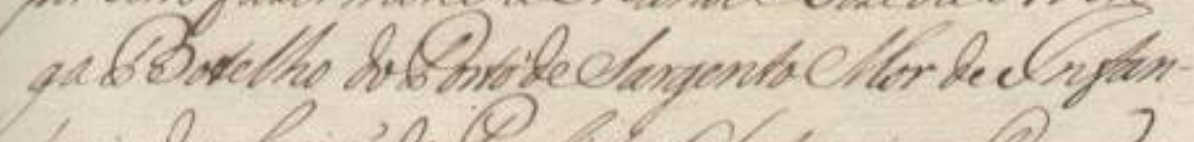

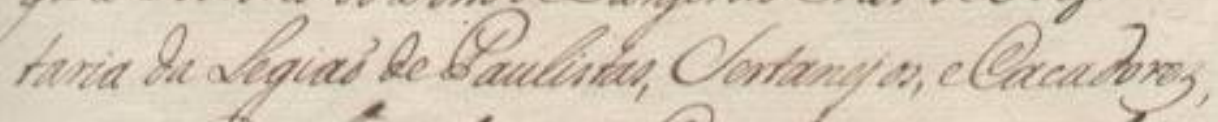

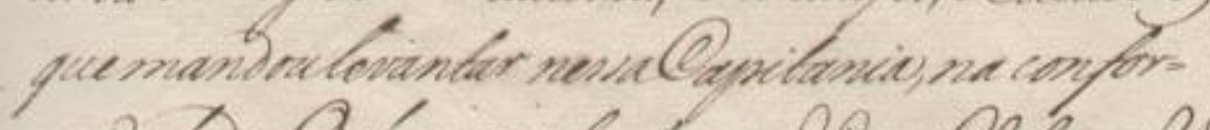

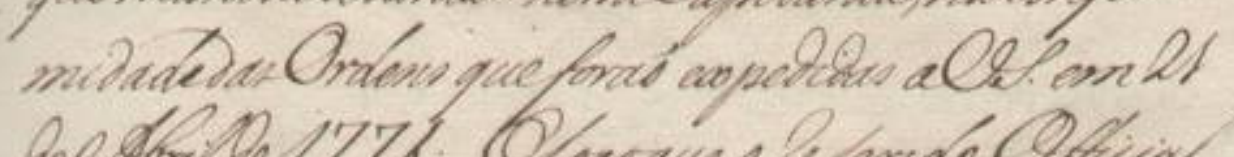

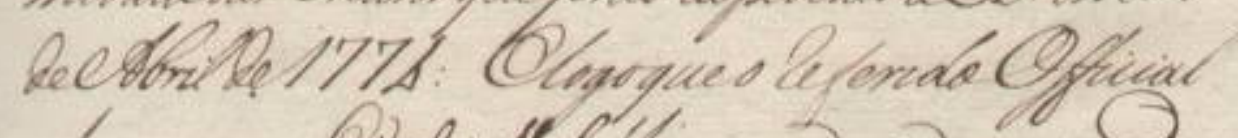

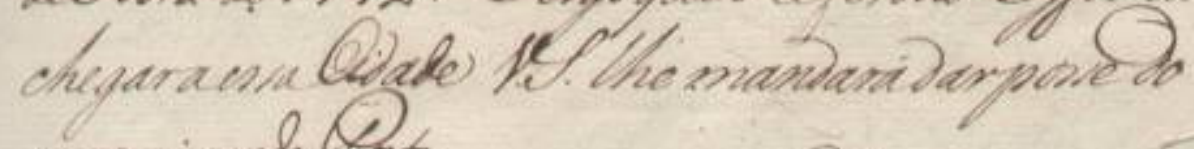
moncionad blits.

Acer forelat.

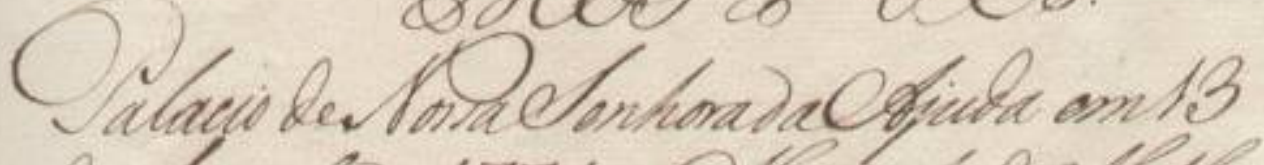

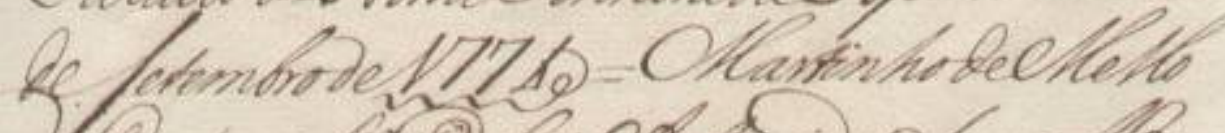

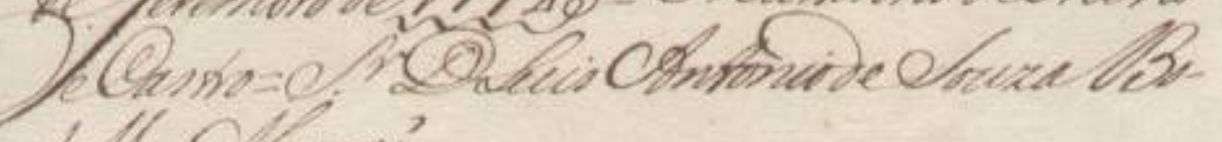
dello Claumas'

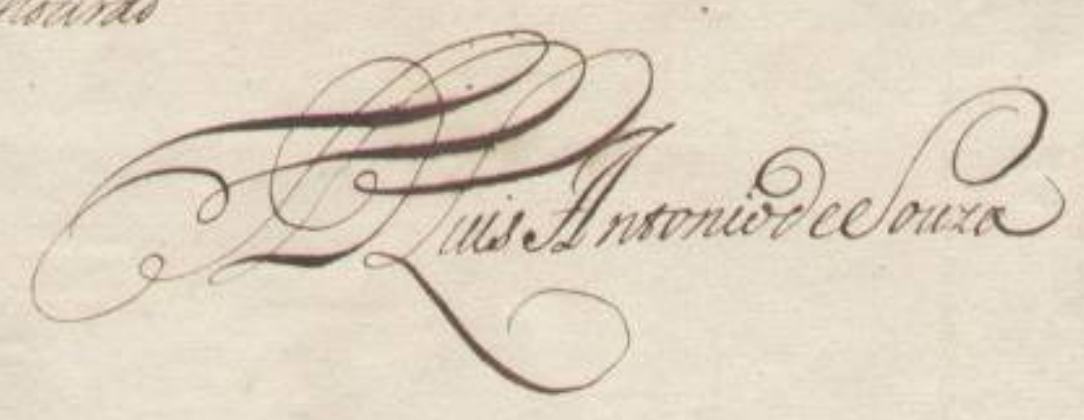

159 
||24r|| Copia

Serve esta deCuberta aCartaRe-

gia inclusa, porqueSuaMagestadeha

porbem fazer merce aManoellozedaNobre-

5 gaBotelho doPosto deSargentoMor delnfan-

taria da Legiaõ dePaulistas, Sertanejos, eCacadorez,

quemandoulevantar nessaCapitania, na confor=

midadedasOrdens queforaõ expedidas aVossaSenhoria em 21

deAbril de1774: Elogoqueo referidoOfficial

10 chegaraessaCidade VossaSenhoria lhe mandarádarposse do mencionadoPosto.

DEOS Guarde aVossaSenhoria

Palacio deNossaSenhoradaAjuda em13

deSetembrode 1774=MartinhodeMello

15 eCastro=SenhorDom Luis AntoniodeSouzaBo-

telho Moraõ

Dom Luis AntoniodeSouza 
$[13]$
$\|25 r\|$

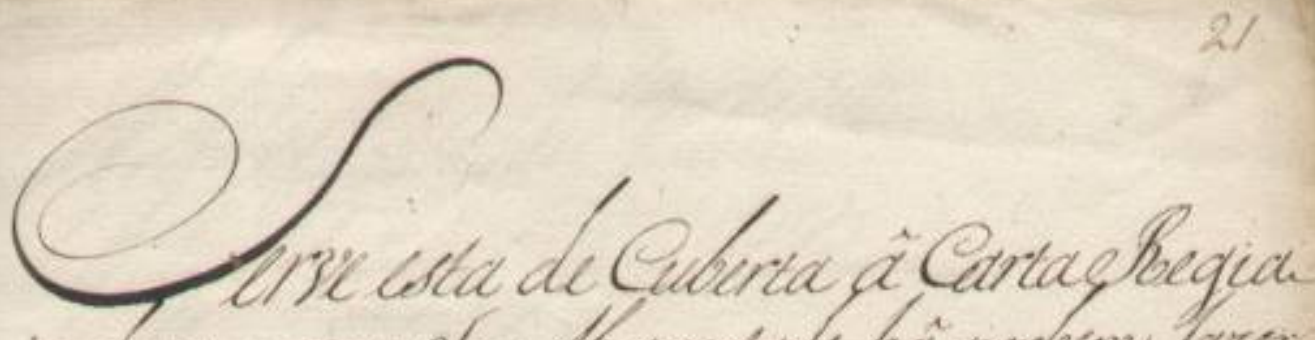

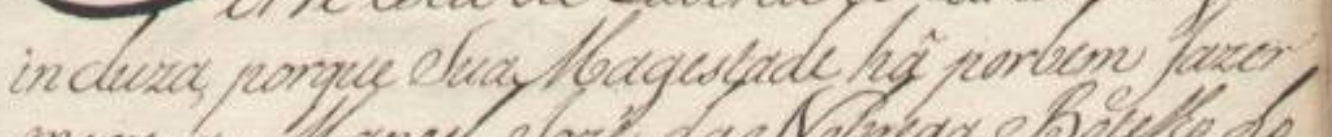

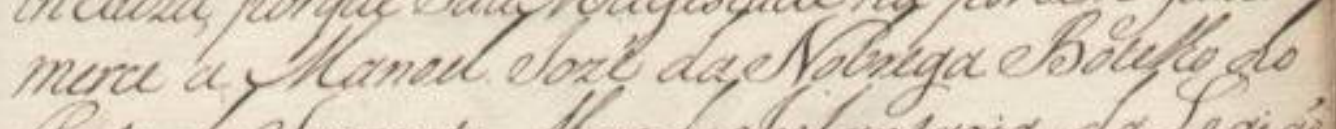
arsfo de largento Wor de enfanlaria da Legias deparulistas Dentanios \& Cassadoras que manLoy Lyantay nessa. Coppitania, na Conformida de play ondens que farcis axpesidaer alpes im 25

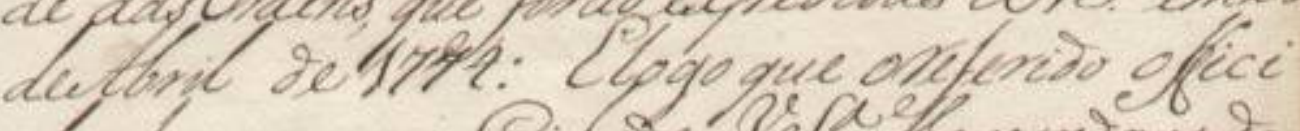

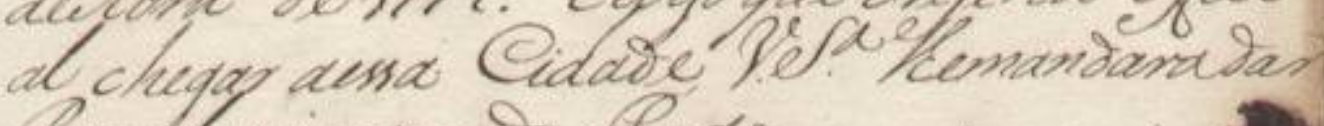
bose blominciunado Dosto.

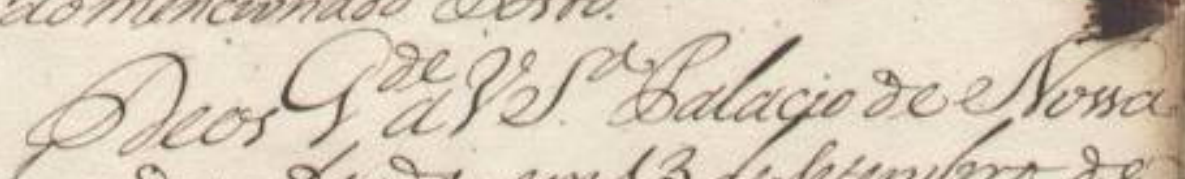

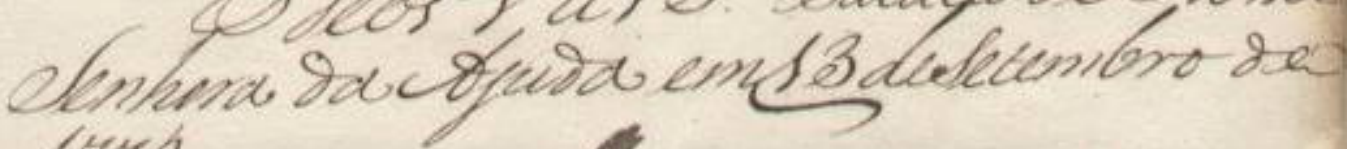
lyit

ellarerestets efarmp

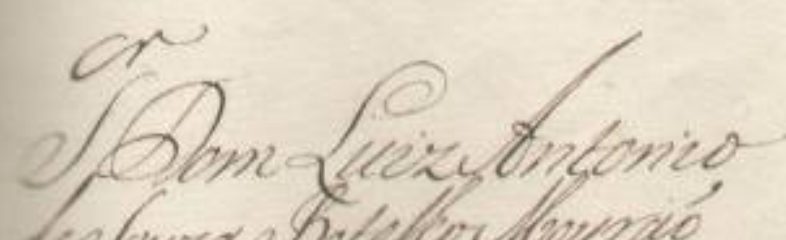

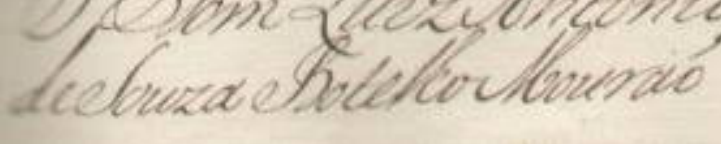

161 
||25r|| Serve esta de Cuberta â Carta Regia

incluza, porque Sua Magestade hâ porbem fazer

merce a Manoel lozé da Nobrega Botelho do

Posto de Sargento Mor delnfantaria da Legiaõ

5 de Paulistas Sertanejos e Cassadores, que man=

dou Levantar nessa Capitania, na Conformida-

de das Ordens, que foraõ expedidas a Vossa Senhoria em 21

deAbril de 1774: E logo que oreferido offici=

al chegar aessa Cidade Vossa Senhoria Ihemandaradar

10 Posse do mencionado Posto.

Deos Guarde a Vossa Senhoria Palacio de Nossa

Senhora da Ajuda em $\underline{13}$ deSetembro de

1774

Martinho deMello eCastro

15 Senhor Dom Luiz Antonio

deSouza BotelhoMouraõ 

||26r|| Registada afolhas $\underline{136}$ do livro primeiro deregisto

deOrdensRegias. SaõPaulo a12

deMayo de $\underline{1775}$

lozeCarlosdosSantosBernardes 


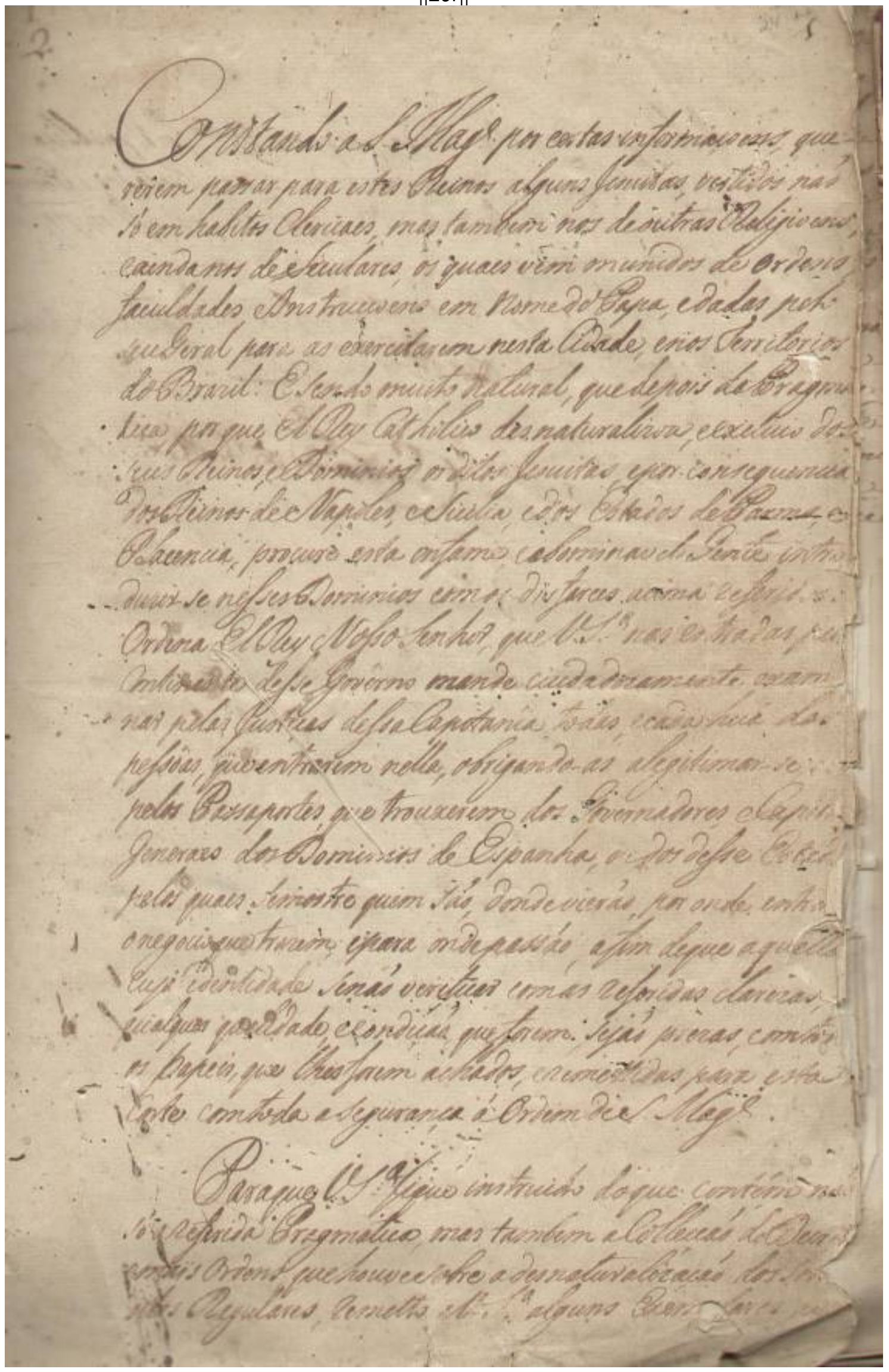


||29r|| Constando aSua Magestade por certas informaçoens, quererem passar para estes Reinos alguns lesuitas, vestidos naõ só em habitos Clericaes, mas tambem nos deoutras Religioens, eaindanos deSeculares, os quaes vem munidos de Ordens,

5 faculdades elnstrucçoens em NomedoPapa, edadas pelo seuGeral para as exercitarem nesta Cidade, enos Territorios doBrasil: E sendo muito natural, quedepois daPragmatica, por que El Rey Catholico des naturalizou, eexcluio dos seus Reinos, eDominios os ditos lesuitas, epor consequencia

10 dosReinos deNapoles, eSicilia, edos Estados deParma, e Placencia, procure esta infame, eabominavel Gente introduzir se nessesDominios comos disfarces acima referidos: Ordena EIRey NossoSenhor, queVossaSenhoria nas entradas pe[los] Continentes desseGovêrno mande cuidadozamente examinar pelas Justiças dessaCapitanîa todas, ecada huá das pessôas, que entrarem nella, obrigando-as alegitimar-se: pelos Passaportes, que trouxerem dos Governadores eCapi[taens] Generaes dosDominios deEspanha, oudos desse Estado pelos quaes semostre quem saõ, dondevieraõ, por onde entra[raõ] o negocio que trazem, epara ondepassaõ, afim deque aquelle cuja identidade senaõ verificar comas referidas clarezas, qualquer qualidade, econdiçaõ, queforem, sejaõ prezas, comto[dos] os Papeis, que Ihes forem achados, eremettidas para esta Corte comtoda asegurança áOrdem deSua Magestade. Paraque VossaSenhoriafique instruido doque contém naõ só areferida Pragmatica, mas tambem aCollecçaõ doDecr[eto] emais Ordens quehouvesobre adesnaturalizaçaõ dos seos ditos Regulares, remetto aVossaSenhoria alguns Exemplares 
||29v\|

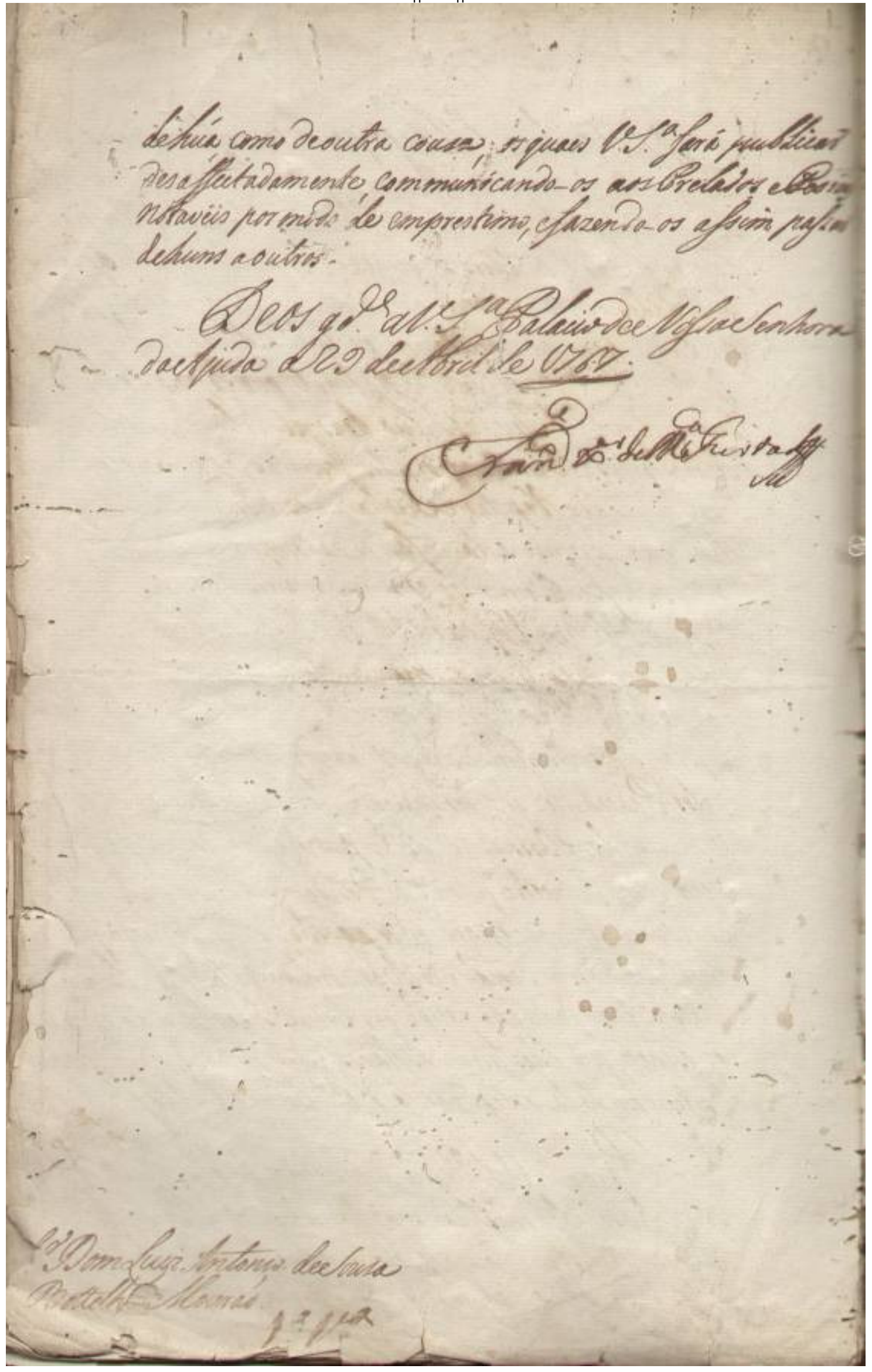


||29v|| dehuá, como deoutra cousa; os quaes VossaSenhoria fará publicar

desaffectadamente, communicando-os aosPrelados ePessoas

notaveis por modo de emprestimo, efazendo-os assim passar

dehuns aoutros.

Deos guarde a VossaSenhoria PalaciodeNossaSenhora

daAjuda a29 deAbril de 1767.

Senhor Dom Luis Antonio deSousa*

Botelho eMouraõ

Primeira Via

\footnotetext{
* Escrito ao final da página.
} 
[16]
|| $30 \mathrm{r} \mid$

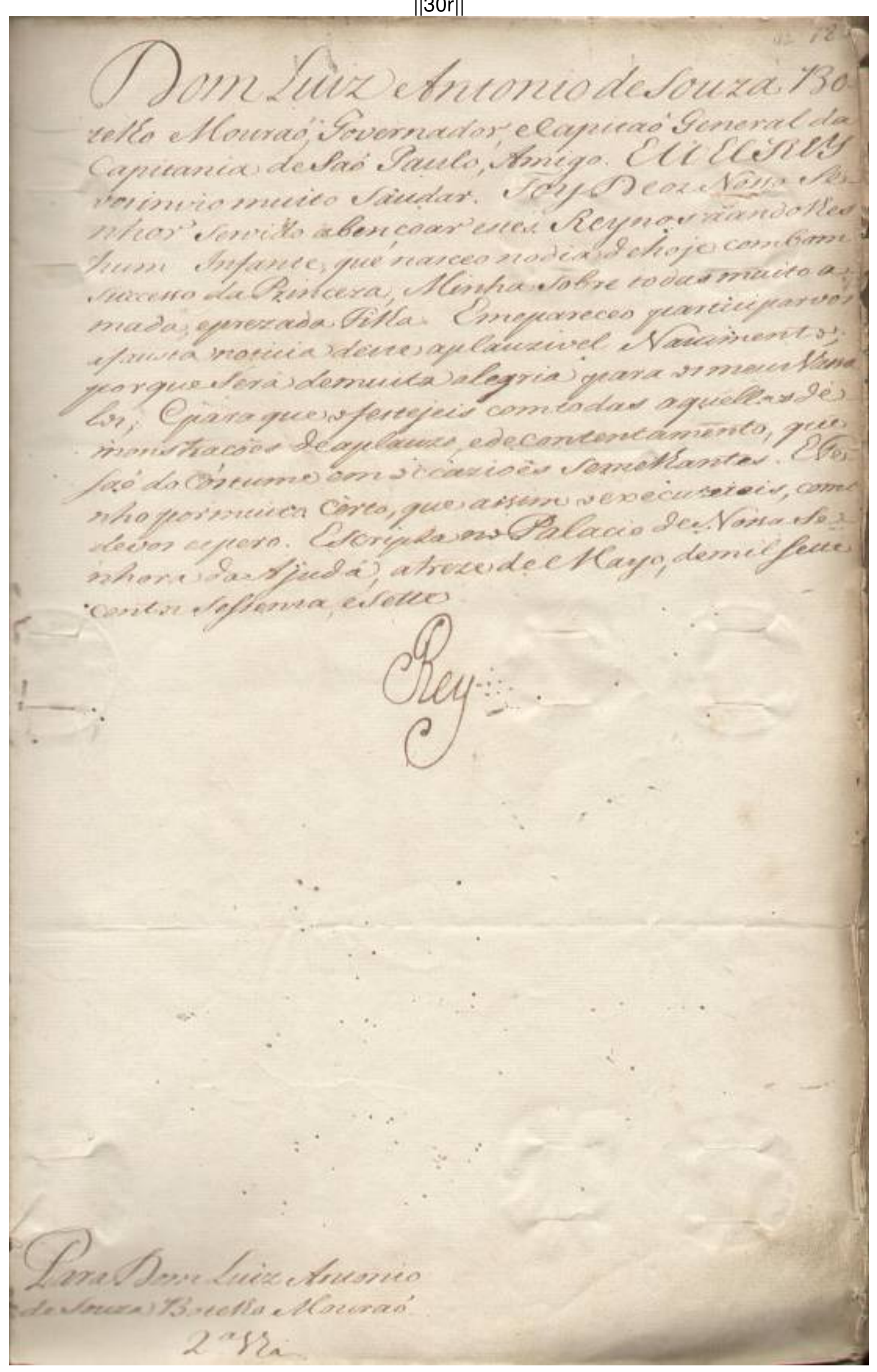

169 
||30r|| Dom Luiz Antonio deSouza Bo-

telho Mouraõ, Governador, eCapitaõ General da Capitania deSaõ Paulo, Amigo. EU EIREY vos invio muito Saudar. FoyDeos Nosso Se-

5 nhor servido abençoar estes Reynos dandolhes hum Infante, que nasceo nodia dehoje com bom successo daPrinceza, Minha sobre todas muito amada, eprezada Filha. Emepareceo participarvos afausta noticia desse aplauzivel Nascimento;

10 porqueSerá demuita alegria para os meusVassa los; Epara que ofestejeis comtodas aquellas demonstraçoẽs deaplauzo, edecontentamento, que saõ do costume em occazioẽs Semelhantes. ETe= nho pormuito certo, que assim o executareis, como

15 devos espero. Escripta noPalacio deNossa Senhora daAjuda, atreze deMayo, demilsette centos Sessenta, eSette.

\section{$\underline{\text { Rey }}$}

ParaDom Luiz Antonio

20 deSouza Botelho Mouraõ

Segunda Via 
[17]

||31v||

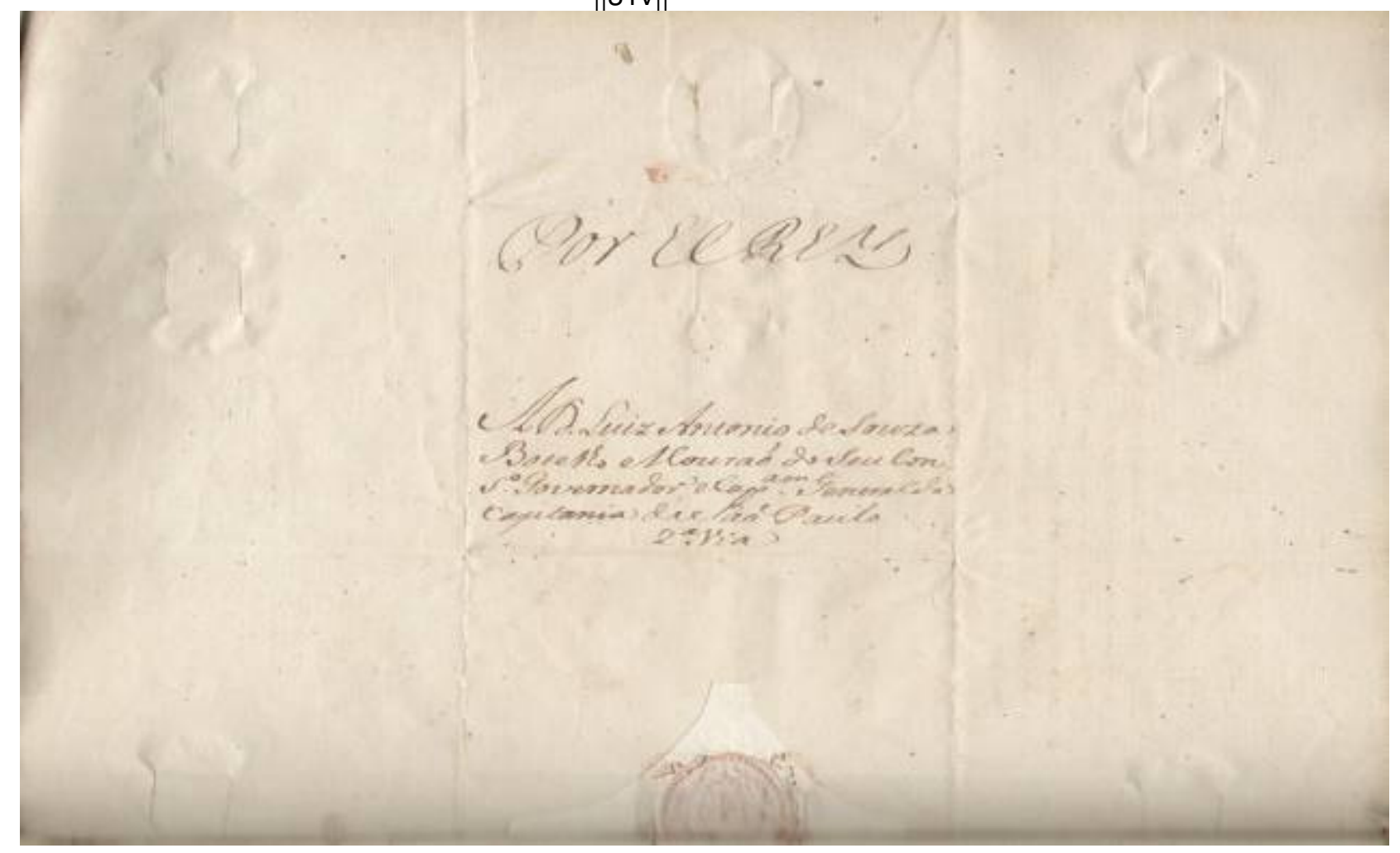


||31v|| Por EIREY

ADom Luiz Antonio deSouza

Botelho Mouraõ doSeu Con-

Selho Governador, eCapitamGeneralda

Capitania deSaõ Paulo

Segunda Via*

* Selo na margem inferior. 
[18]

||32r||

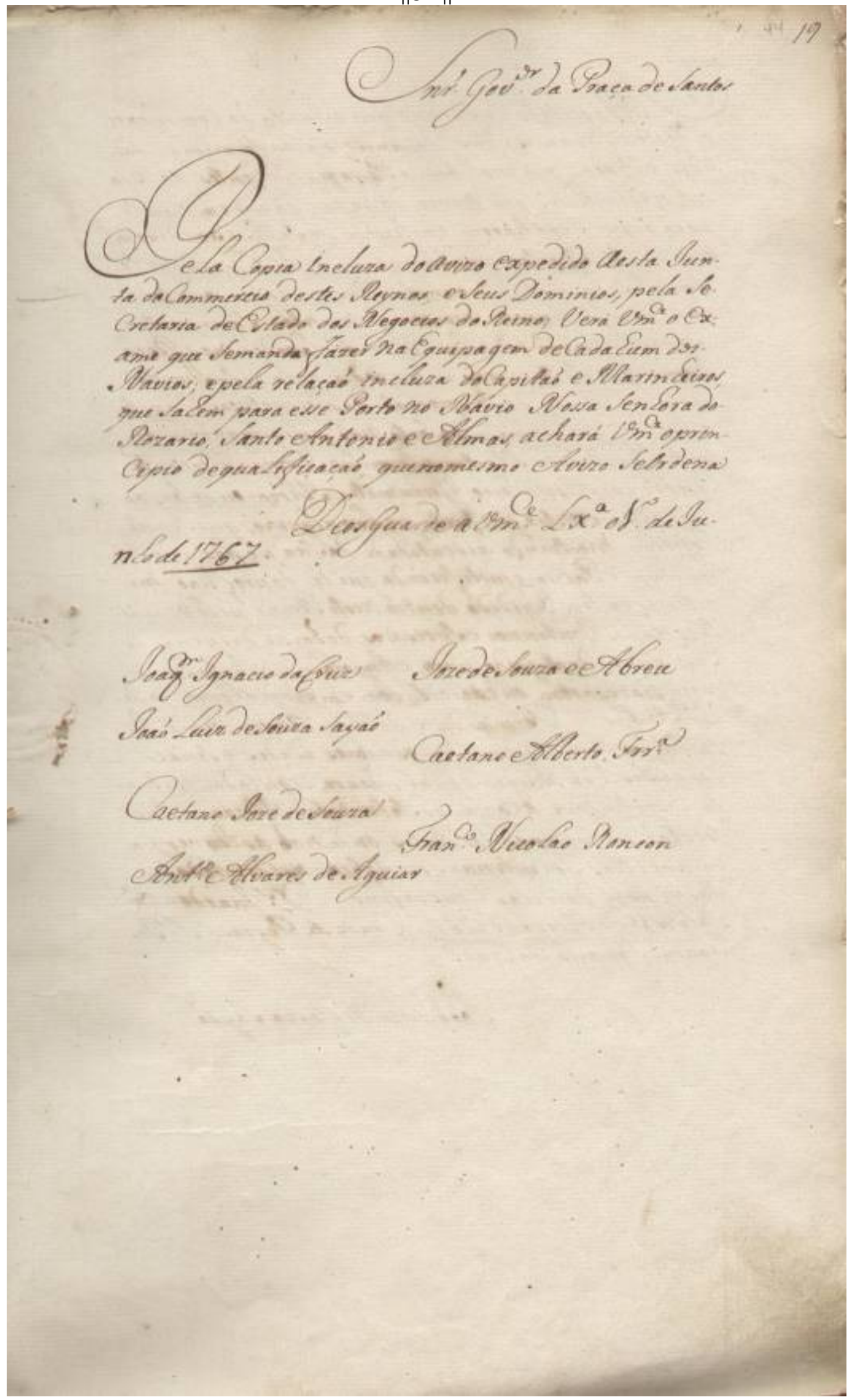


\|32r I Senhor Governador da Praça de Santos

Pela Copia incluza do avizo expedido aesta lun-

ta do Commercio destes Reynos, e Seus Dominios, pela Se-

Cretaria deEstado dos Negocios do Reino; Verá Vossamerce o Ex-

5 ame que Semanda fazer na Equipagem de Cada hum dos

Navios; e pela relaçaõ incluza do Capitaõ e Marinheiros,

que sahem para esse Porto no Navio Nossa Senhora do-

Rozario, Santo Antonio e Almas, achará Vossamerce o prin-

Cipio de qualificaçaõ, que no mesmo Avizo SeOrdena

nho de1767

loaquim Ignacio daCruz

$\underline{\text { loze Souza eAbreu }}$

loaõ Luiz deSouza Sayaõ

Caetano Alberto Ferreira

15 Caetano loze deSouza

Francisco Nicolao Roncon

AntonioAlvares de Aguiar 


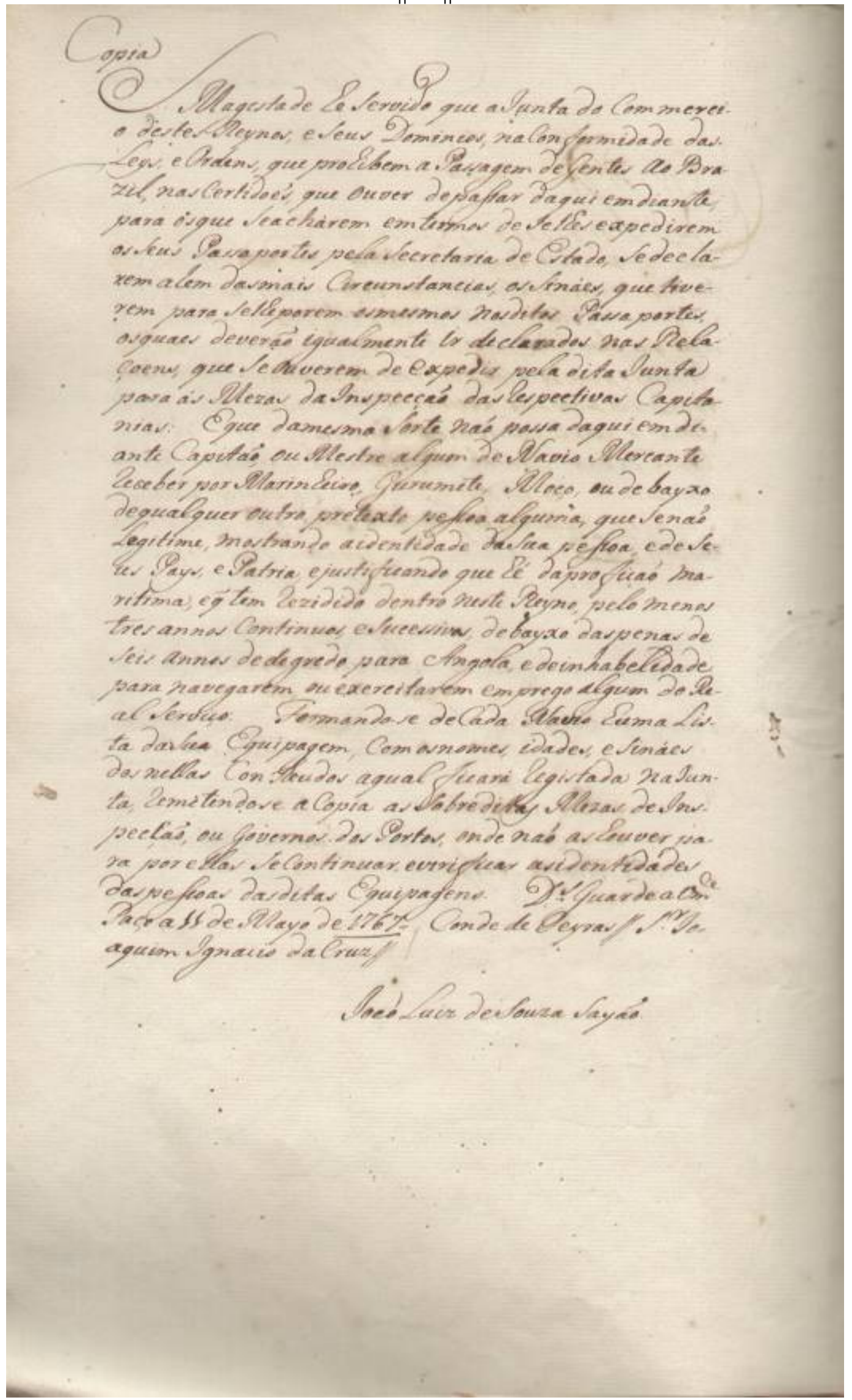


||32v || Copia

Sua Magestade he servido que a lunta do Commerci-

o destes Reynos, e Seus Dominios, na Conformidade das

Leys, e Ordens, que prohibem a Passagem de Gentes ao Bra-

5 zil, nas Certidoẽs, que ouver depassar daqui em diante,

para os que Seacharem em termos de selhes expedirem

os Seus Passaportes pela Secretaria de Estado, Se decla-

rem alem das mais Circunstancias, os Sináes, que tive-

rem para Selheporem osmesmos nosditos Passaportes,

10 osquaes deveraõ igualmente ir declarados nas Rela-

çoens, que Se ouverem de expedir pela dita lunta

para ás Mezas dalnspecçaõ das respectivas Capita-

nias: Eque damesma Sorte naõ possa daqui em di-

ante Capitaõ, ou Mestre algum de Navio Mercante

receber por Marinheiro, Gurumete, Moço, ou de bayxo de qualquer outro pretexto pessoa alguma, que senaõ Legitime, mostrando a identidade daSua pessoa, ede Seus Pays, e Patria, e justificando que hé daprofiçaõ maritima, eque tem rezidido dentro neste Reyno, pelo menos tres annos Continuos, eSucessivos, de bayxo daspenas de seis annos de degredo para Angola, e deinhabelidade para navegarem, ou exercitarem emprego algum do Real Serviço: Formando-se de Cada Navio huma Lista daSua Equipagem, Com os nomes, idades, e Sináes dos nellas Contheudos a qual ficará registada na lunta, remetendo-se a Copia as Sobreditas Mezas de Inspecçaõ, ou Governos dos Portos, onde naõ as houver para por ellas Se Continuar, e verificar as identidades das pessoas dasditas Equipagens. Deos Guarde a Vossamerce Paço a 11 de Mayo de 1767, , Conde de Oeyras// Senhor loaquim Ignacio da Cruz// 


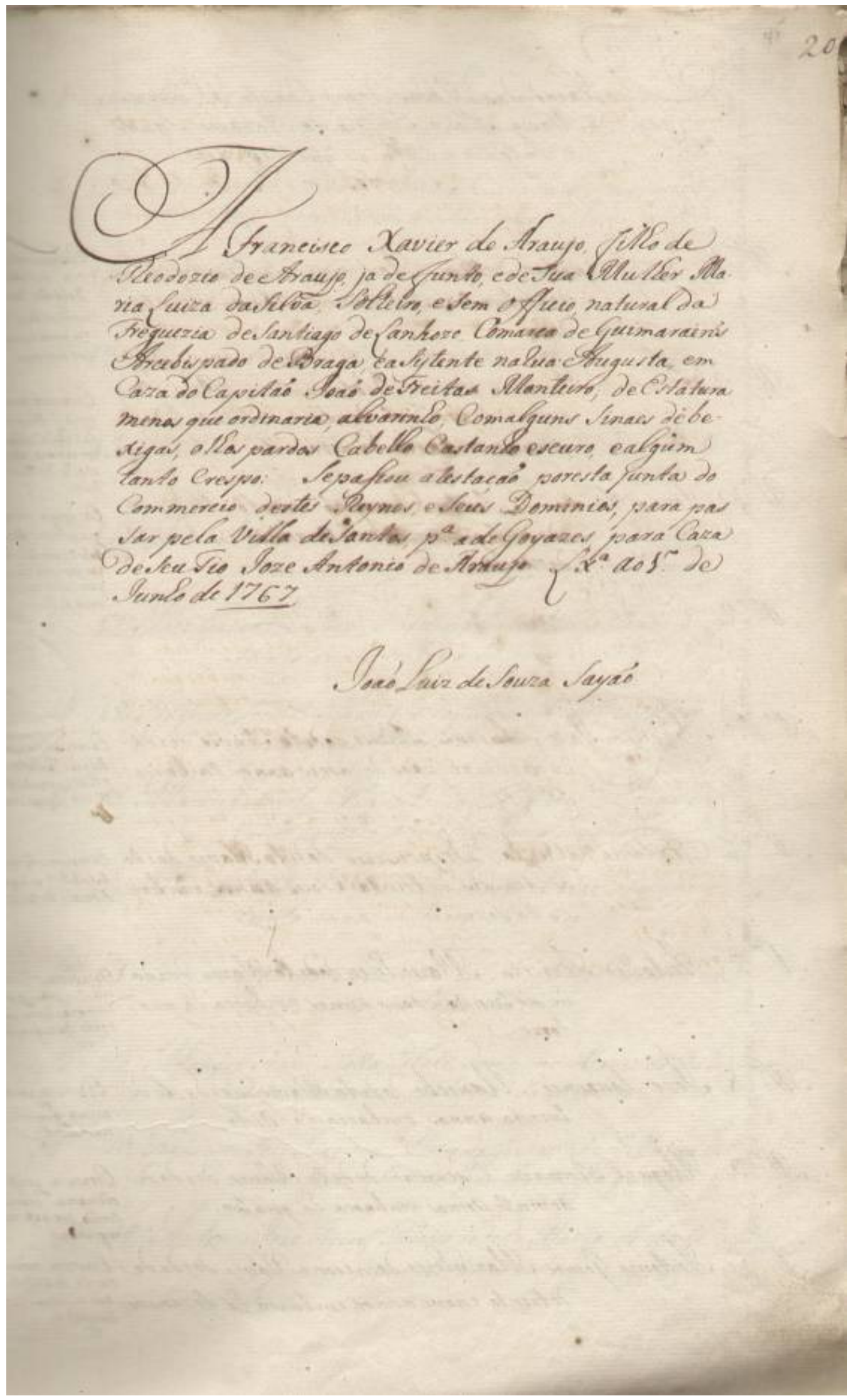


||33r|| A Francisco Xavier de Araujo, filho de

Theodozio de Araujo, ja defundo, e de sua Mulher Ma-

ria Luiza daSilva, Solteiro, e sem Officio, natural da

Freguezia de Santiago de Lanhozo Comarca deGuimaraẽns

5 Arcebispado deBraga, eaSistente na rua Augusta, em

Caza do Capitaõ loaõ de Freitas Monteiro; de Estatura

menos que ordinaria, alvarinho, Com alguns Sinaes de be-

xigas, olhos pardos Cabello Castanho escuro, ealgum

tanto crespo: Sepassou atestaçaõ poresta junta do

10 Commercio destes Reynos, e Seus Dominios, para pas

Sar pela Villa de Santos, para a de Goyazes, para Caza

deSeuTio loze Antonio de Araujo Lixboa ao primeiro de

lunho de $\underline{1767}$

loaõ Luiz de Souza Sayaõ 
[21]

||33v $\mid$

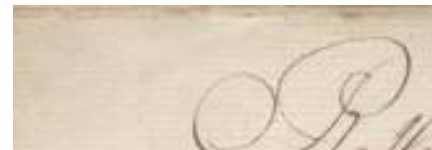

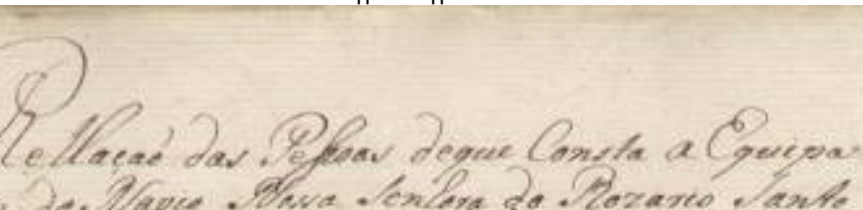

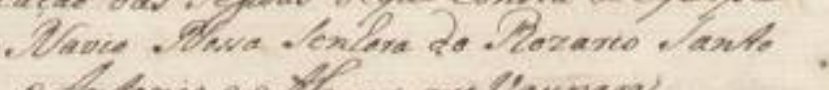
ethilowe e rthar que Vaypana

- arto.

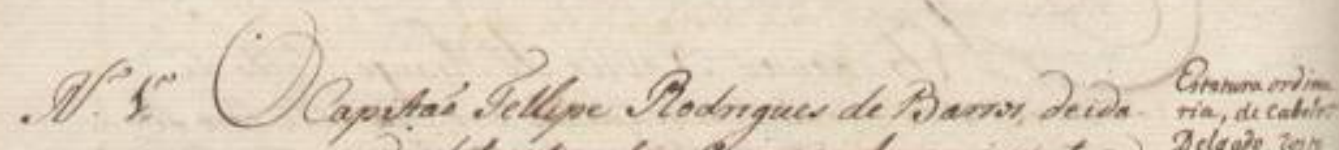

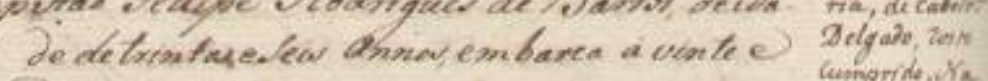
Joos nopmereagude

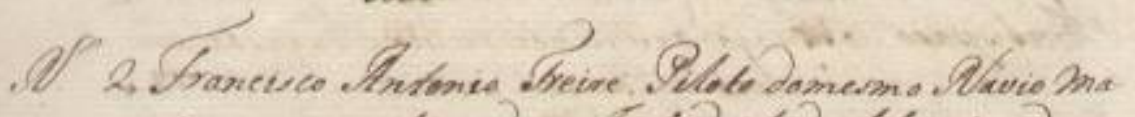

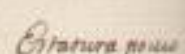

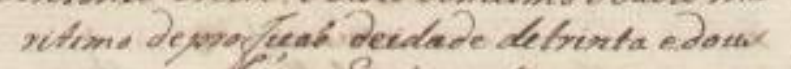

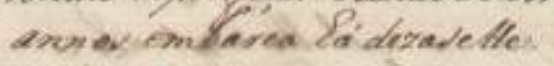

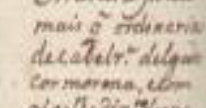
ofelinirion

Of.

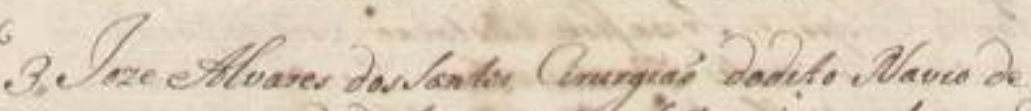
6

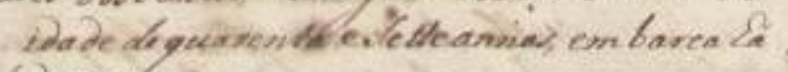
'Desterciere:

Tr 2 pe viectivertive Gebtion them cormerema ka

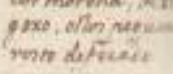

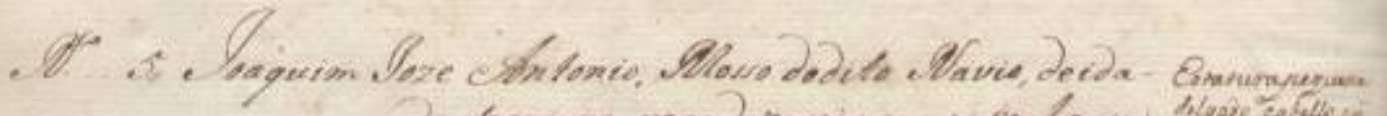

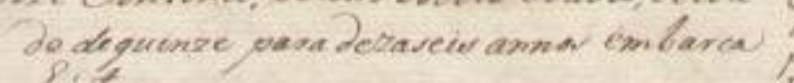
wigaze calidica is tres.

reon olgemiaren

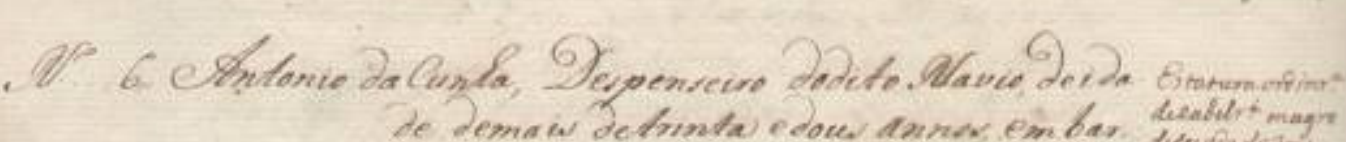
calodere.

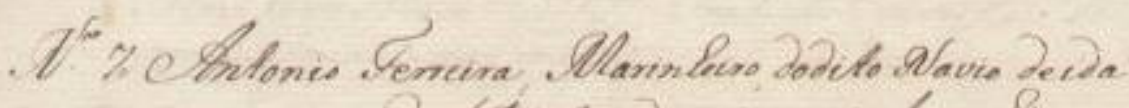
De de trinta edow anrev enbarce begue torae.

Buperara कीima. ma corminges furoma Benirias

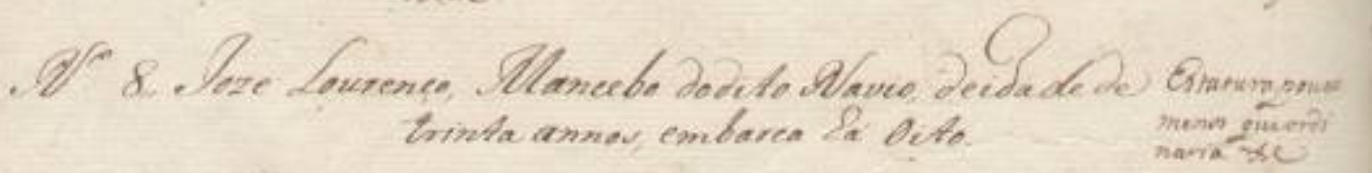

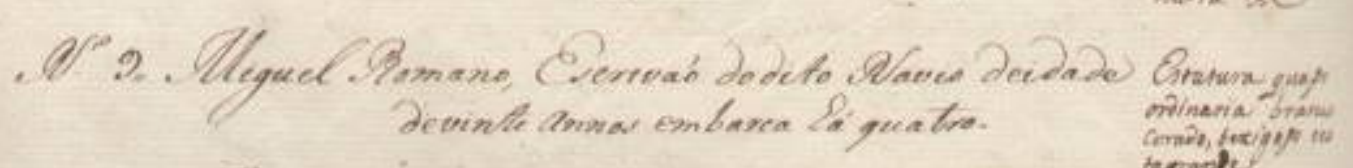

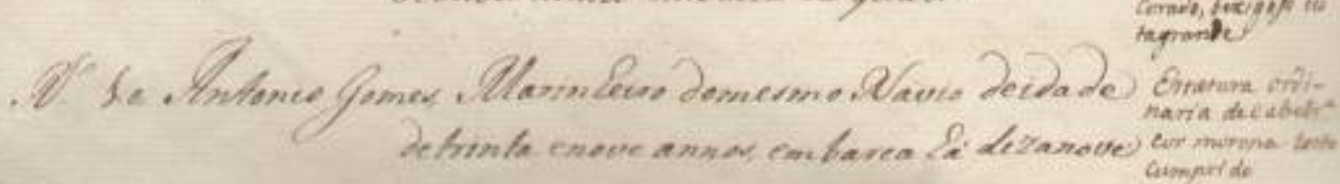

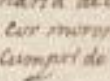

179 
||33v|| Rellaçaõ das Pessoas deque Consta a Equipa-

gem do Navio Nossa Senhora do Rozario Santo

Antonio e Almas que Vay para

Santos.

5 Número primeiro,, O Capitaõ Fellipe Rodrigues de Barros, deidade de trinta e seis annos, embarca á vinte e

dous.

Número 2,, Francisco Antonio Freire Piloto domesmo Navio Maritimo de profiçaõ deidade de trinta edous annos, embarca há dezasette.

Número 3,, loze Alvares dosSantos, Cirurgiaõ dodito Navio de idade de quarenta e Sette annos, embarca há 'dezasette.

Estatura ordina ria, de cabeleira Delgado, rosto Cumprido, $\mathrm{Na}$ ris ponte agudo cor morena.

Estatura pouco mais que ordinaria decabeleira delgado cor morena, ecom ojoelho direito desno cado.

Estatura menos queordinaria deca beleira cara redonda cor morena, bexigoxo, olhos pequenos rosto defecado

Número 4,, OPadre

Número 5, loaquim loze Antonio, Mosso do dito Navio, de idade de quinze para dezaseis annos embarca

Estaturapequena delgado cabello cũ prido castanho cla ro com algum crespo há tres.

Número 6,, Antonio da Cunha, Despenseiro do dito Navio, de idaEstaturaordinaria decabeleira magro de demais detrinta e dous annos, embarca há doze.

Número 7,, Antonio Ferreira, Marinheiro dodito Navio deida

Estaturaordina ria cor mais que morena rosto cum de de trinta e dous annos, embarca há quaprido bocagrande torze.

Número 8,, loze Lourenço, Mancebo do dito Navio, de idade de trinta annos, embarca há Oito.

Número 9, Miguel Romano, Escrivaõ do dito Navio deidade devinte annos embarca há quatro.

Estatura quasi ordinaria branco corado, bexigoso tes tagrande

Número 10,, Antonio Gomes, Marinheiro domesmo Navio deidade Estatura ordinaria deCabeleira cor morena rosto detrinta enove annos, embarca há dezanove. cumprido 


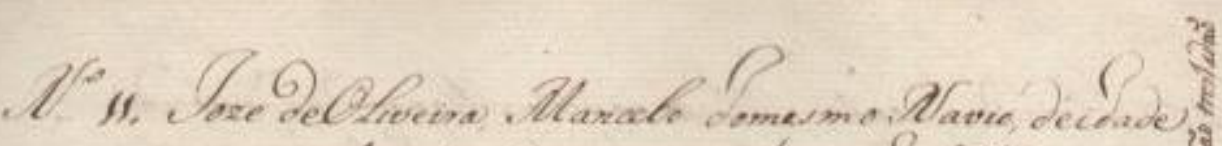
deumfe theirana, embarea Ri.letie?

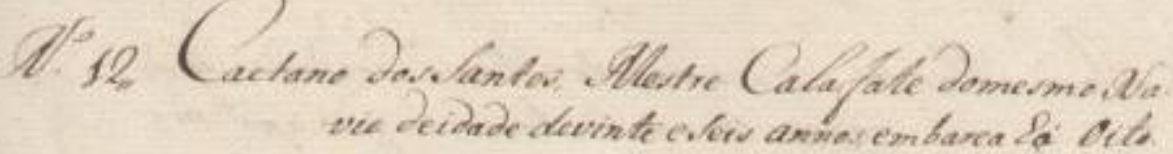

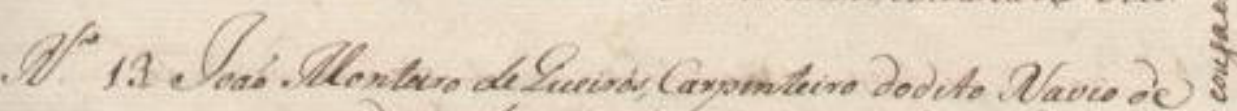

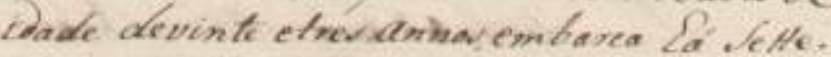

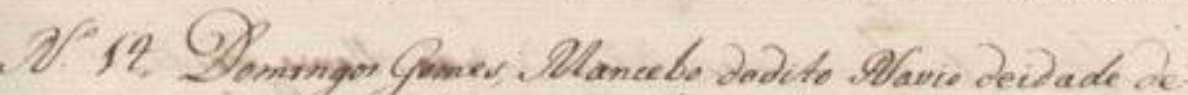
seinte annas embarca lá terve.

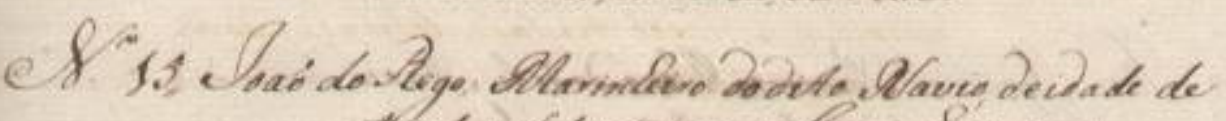

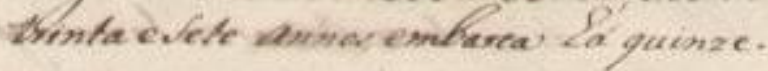

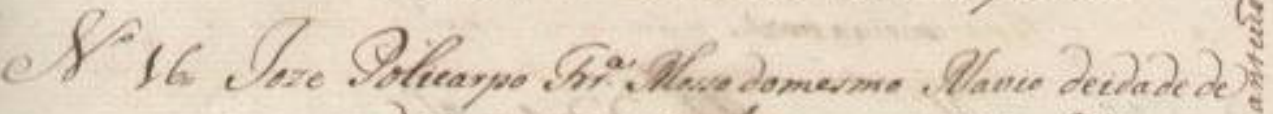

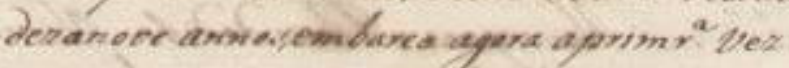

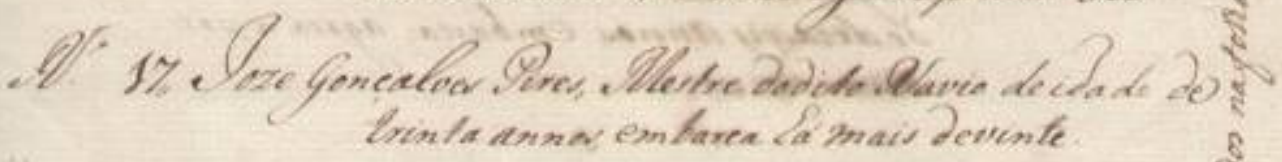

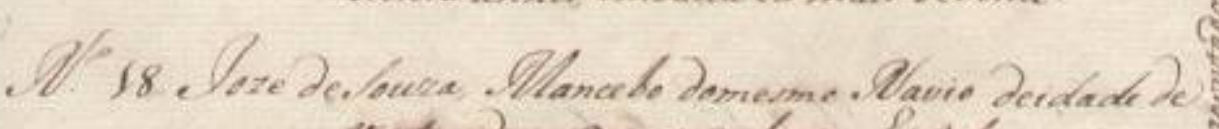

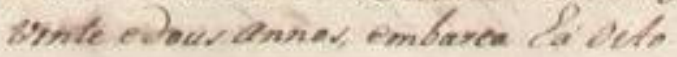

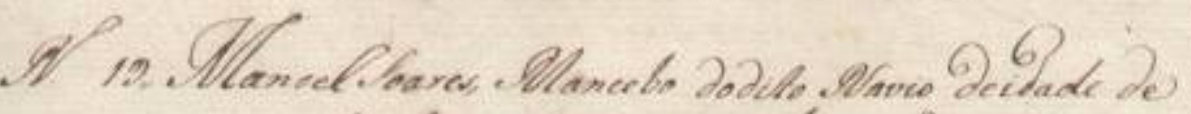
vinte equatro anna endarce la quedre.

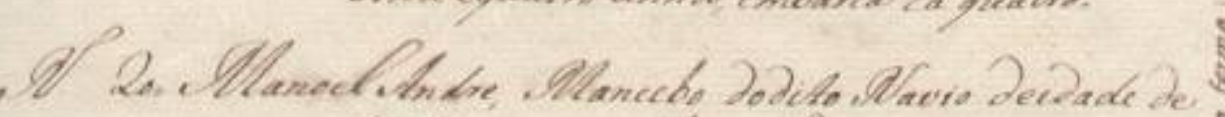
ininla anna embarea Sa cince

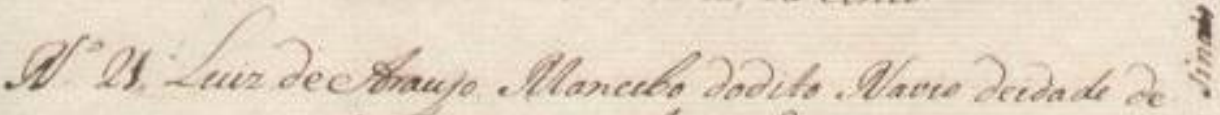
trinta annes embarce li emin.

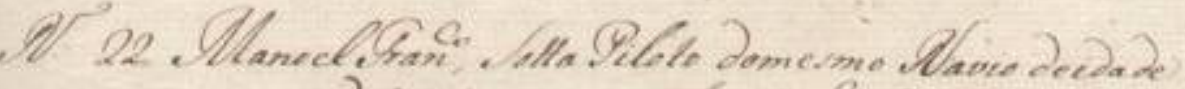
Detrinla anower embasea La derorte.

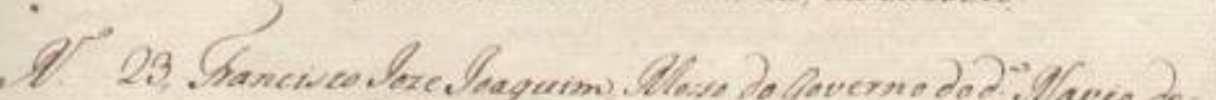
Dade Dederoite annse embarea la quatro. है

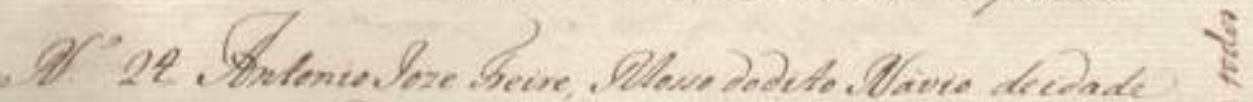
Dequenze para deraveu comer embarcas of in tre. 
$30 \quad\|34 r\| \quad<t m$ todos estes se apontao seus sınais na torma que vao apontados natolna antecedente, quepornaõ ser cousaessencial se naõ tresladaõ ${ }^{*}$

Número 11,, loze deOliveira, Mancebo domesmo Navio, de idade

devinte etres annos, embarca há Sette.

Número 12,, Caetano dos Santos, Mestre Calafate domesmo Navio deidade devinte e Seis annos, embarca há Oito.

Número 13,, loaõ Monteiro deQueirós, Carpinteiro do dito Navio de idade de vinte e tres annos, embarca há Sette.

Número 14,, Domingos Gomes, Mancebo do dito Navio deidade de vinte annos, embarca há Sette.

Número 15,, loaõ do Rego, Marinheiro do dito Navio, de idade de trinta e Sete annos, embarca há quinze.

Número 16,, loze Policarpo Ferreira Mosso do mesmo Navio deidade de dezanove annos, embarca agora aprimeira vez.

Número 17,, loze Gonçalves Pires, Mestre do dito Navio de idade de trinta annos, embarca há mais devinte.

Número 18,, loze de Souza, Mancebo domesmo Navio deidade de vinte e dous annos, embarca há Oito.

Número 19,, Manoel Soares, Mancebo do dito Navio de idade de vinte equatro annos, embarca há quatro.

Número 20,, Manoel Andre, Mancebo do dito Navio deidade de trinta annos, embarca, há cinco.

Número 21,, Luiz de Araujo, Mancebo do dito Navio deidade de trinta annos, embarca, há cinco.

Número 22,, Manoel Francisco, Sotta Piloto domesmo Navio deidade detrinta annos, embarca, há dezoito.

Número 23,, Francisco loze loaquim, Mosso do Governo do dito Navio deidade dedezoito annos, embarca, há quatro.

Número 24,, Antonio loze Freire, Mosso do dito Navio deidade dequinze para dezasseis annos, embarca há tres.

\footnotetext{
* Esta observação encontra-se à margem direita, escrita por outra mão na vertical de baixo para cima.
} 


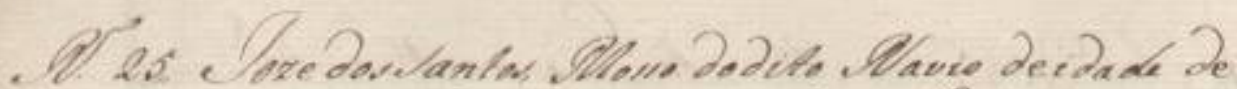
Dezocto enrear en berace, la tree.

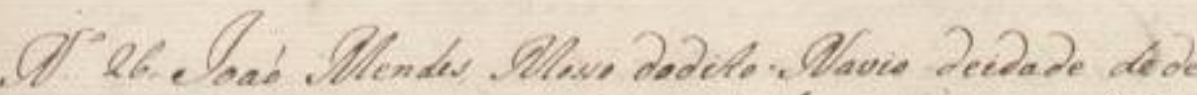

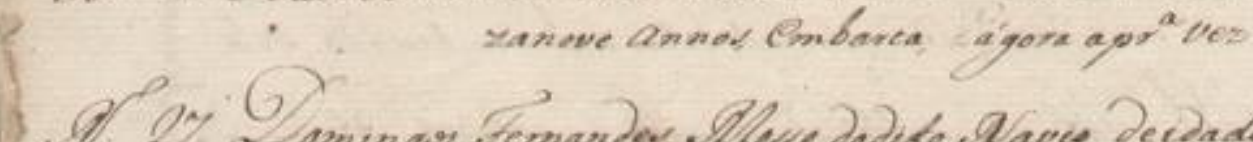

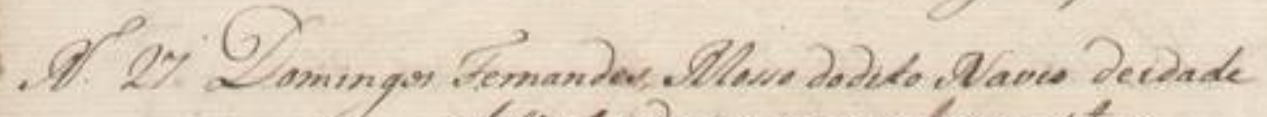

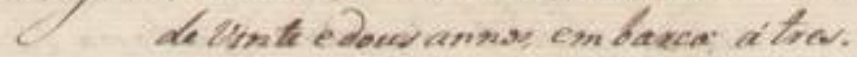

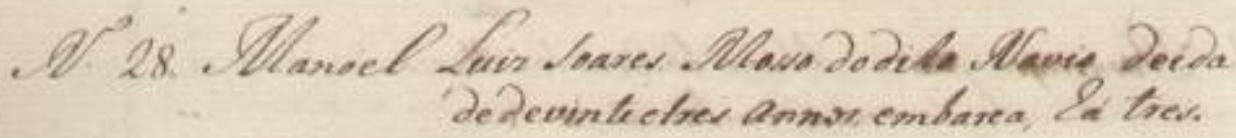

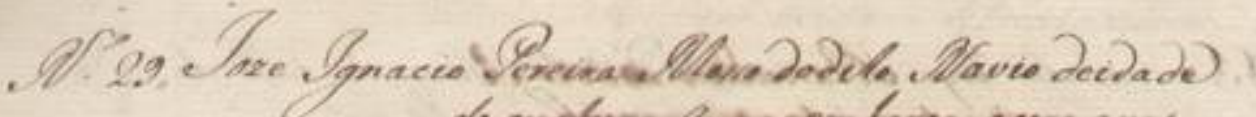

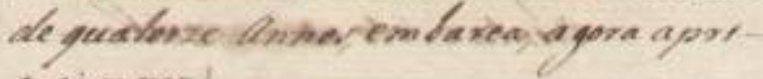
nieiravez?

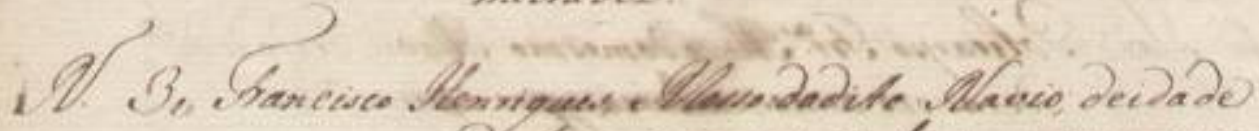

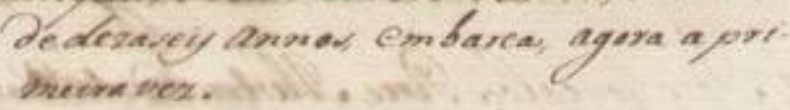

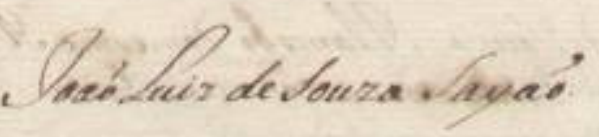

siture otimes

Sh. Antoment

i +ove 
||34v|| Número 25,, loze dos Santos, Mosso do dito Navio deidade de dezoito annos, embarca, há tres.

Número 26, loaõ Mendes, Mosso do dito Navio deidade de de zanove annos, embarca, ágora aprimeira vez. de vinte e dous annos, embarca, á tres.

Número 28,, Manoel Luiz Soares Mosso do dito Navio deida de devinte etres annos, embarca, há tres.

Número 29,, loze Ignacio Pereira Mosso dodito Navio deidade de quatorze annos, embarca, agora aprimeira vez.

Número 30,, Francisco Henriques, Mosso dodito Navio, deidade dedezaseis annos, embarca, agora a primeira vez. 


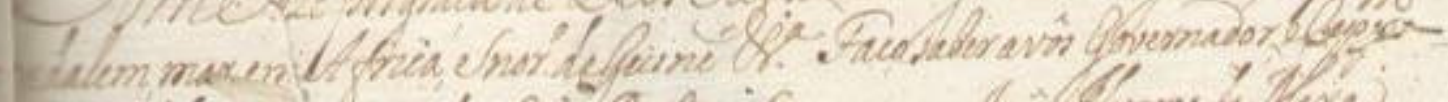

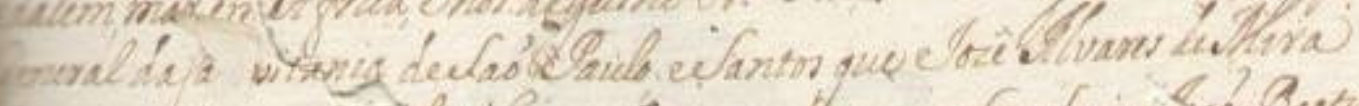

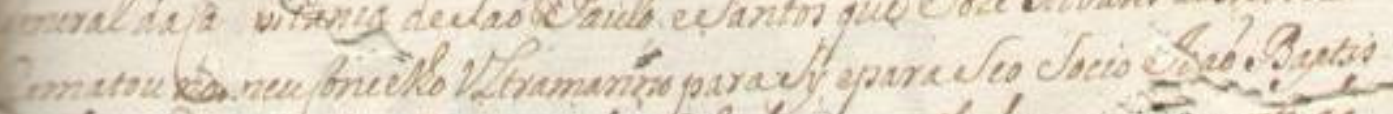

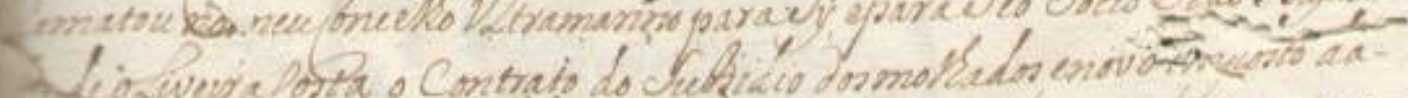

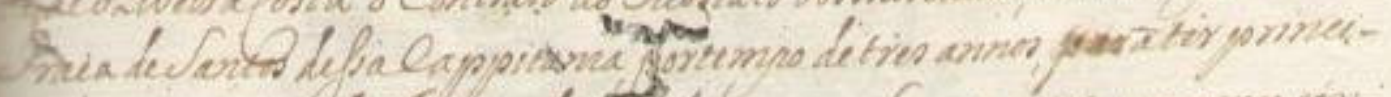

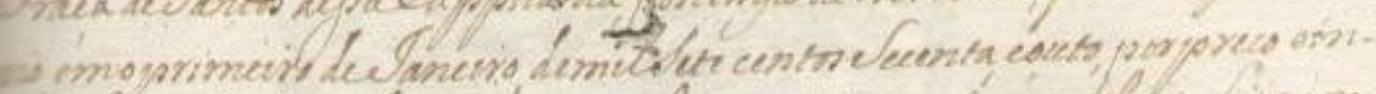

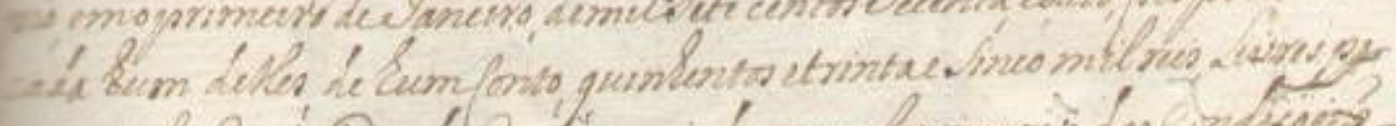

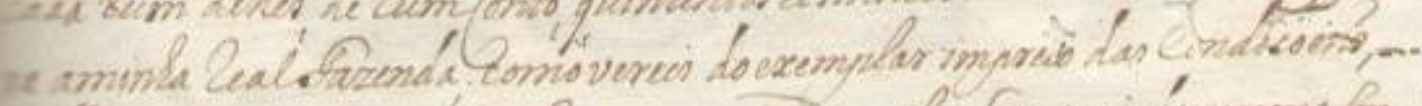

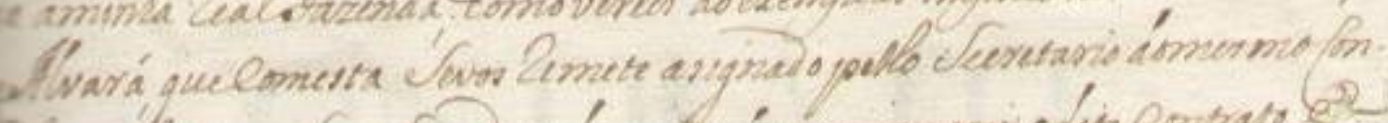

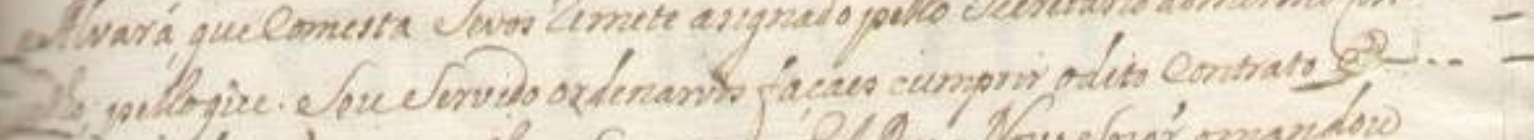

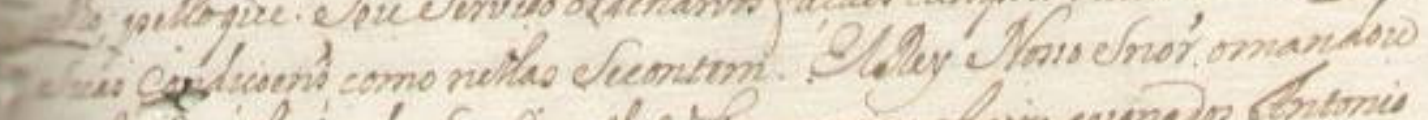

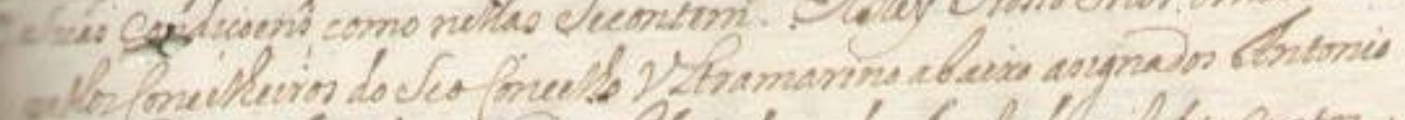

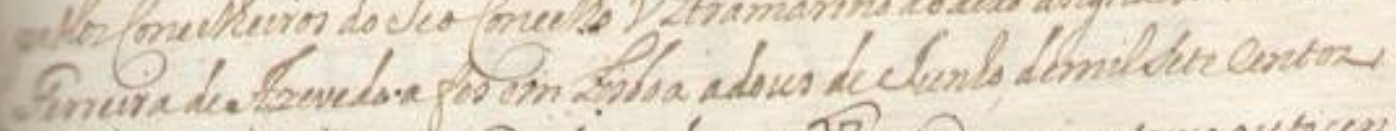

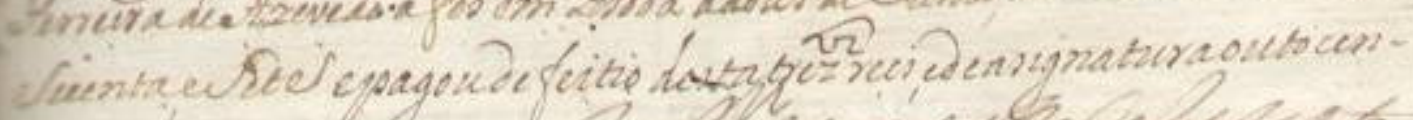
comir. Aejelosid.

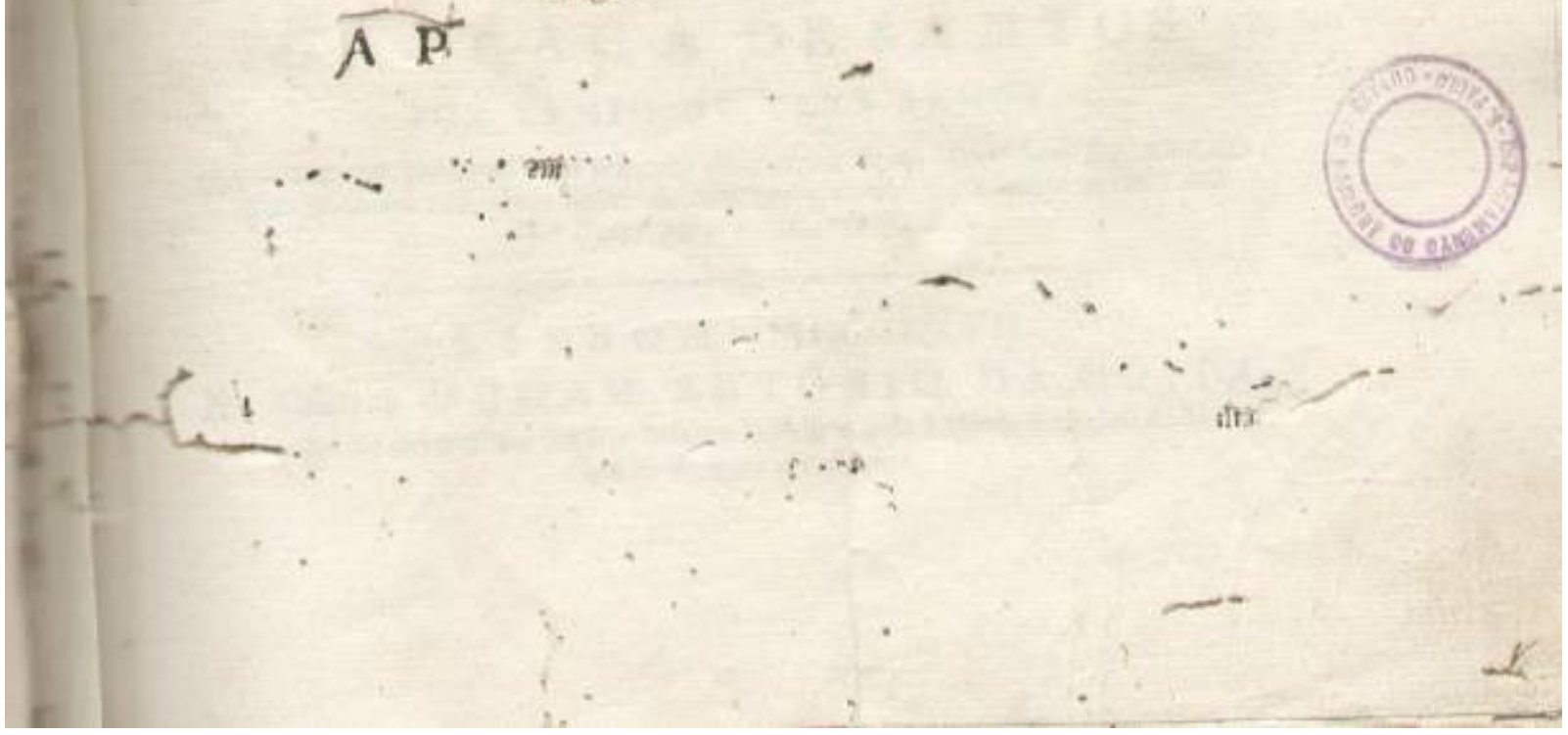


||36r|| Domlozé porgraça de Deos Rey dePortugal edos Algarves daquem edalem mar em Africa, Senhor deGuiné etcoetera Faço saber avôs Governador, eCappitam General daCapitania deSaõ Paulo, eSantos que lozê Alvares deMira rematou no meu Concelho VLtramarino paraSy, eparaSeo Socio loaõ Baptis-

5 [ta] deoLiveiraCosta o Contrato do Subsidio dos molhados, enovo imposto daPraça deSantos dessaCappitania, portempo de tres annos, parater principio, emo primeiro delaneiro, demilSete centos Secenta, eouto, por preço emcada hum delles, de humConto, quinhentos etrintae Sinco mil reis, Livres para aminha realFazenda; como vereis do exemplar impreco* dasCondiçoẽns,

10 eAlvará, quecomesta Sevos remete asignado pello Secretario domesmo Conselho; pelloque SouServido ordenarvos façaes cumprir odito Contrato e suas Condiçoẽns como nellas Secontem. EIRey Nosso Senhor omandou pellosConcelheiros do SeoConcelho VLtramarino abaixo asignados Antonio FerreiradeAzevedo afes em Lisboa adous delunho, demilSeteCentos

15 Secenta,eSete epagoude feitio destatrezentos reis, edeasignaturaouto centos reis. Secretario loaquim [onnofre de farea] [ilegível] DiogoRangeldeAlmeida[Cardozo] FranciscoMarcellinodeGouveia*

\footnotetext{
" "impreco" por "impreço".

* Carimbo da AESP na margem direita.
} 


\section{Qin}

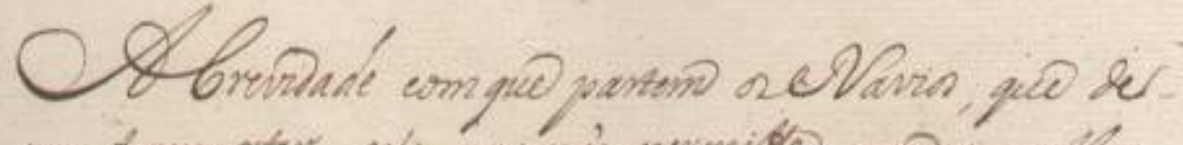

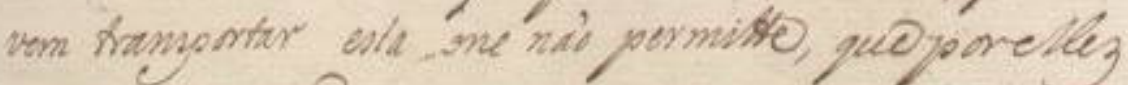

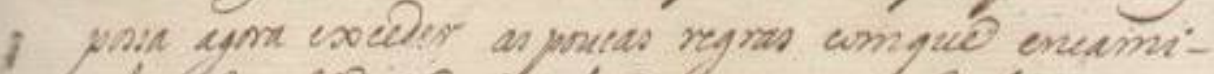

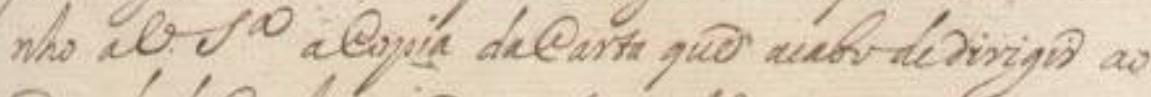
Andedelunh, equomdi contix a meis exaut

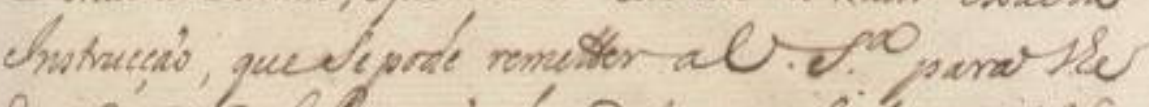

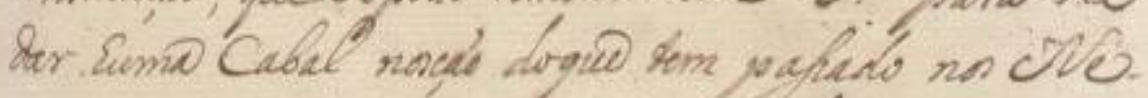

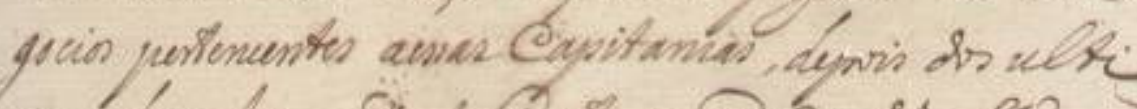

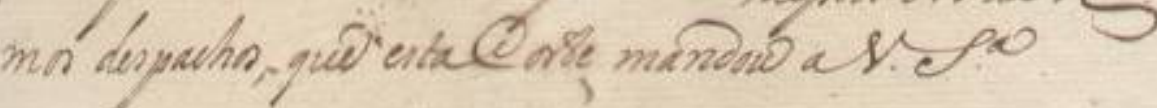

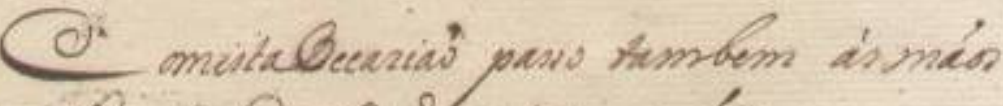
del.20 vutra@opia Is uteis, yiuduion repans

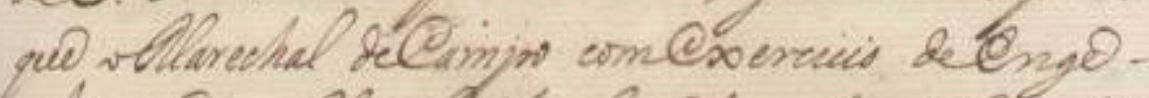

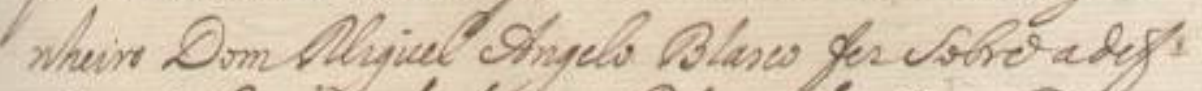

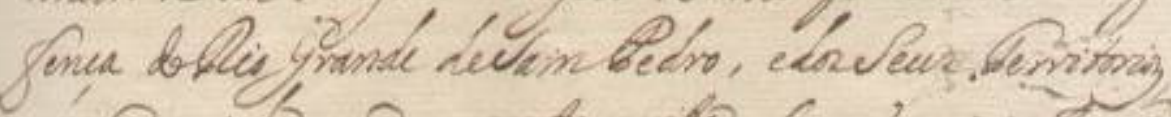

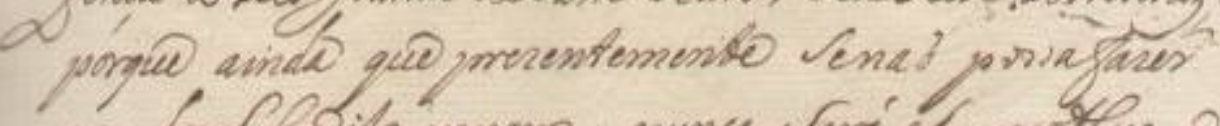

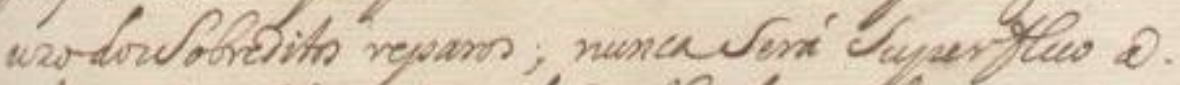

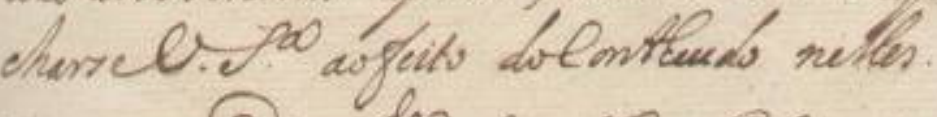

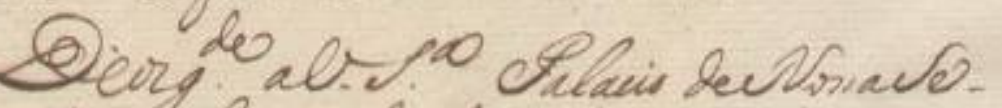

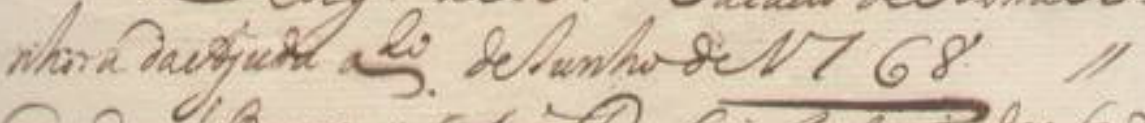

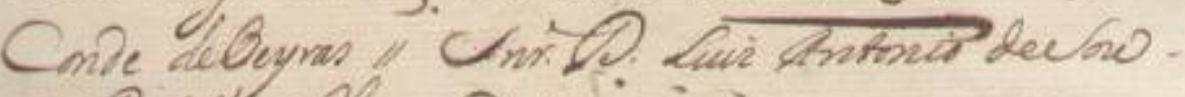
ze Brtitho chourano

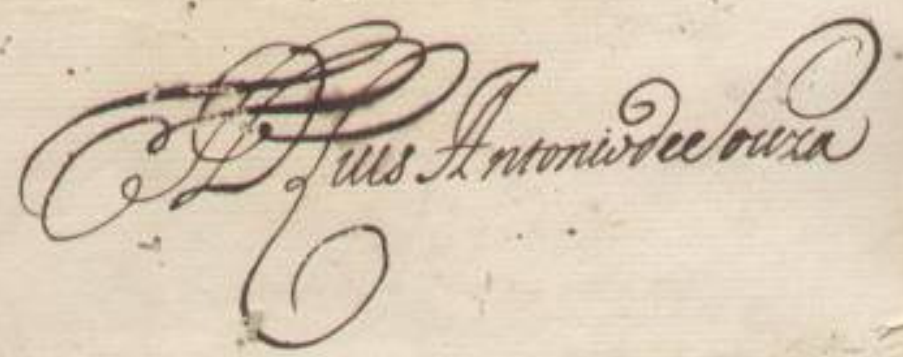


||37r|| Copia

Abrevidade com que partem osNavios, que devem transportar esta [one] naõ pormitte, que porellez possa agora exceder as poucas regras comque encami-

5 nho aVossaSenhoria aCopia daCarta que acabodedirigir ao Conde deCunha, eque emSi contêm a mais exacta Instrucçaõ, queSe pode remetter aVossaSenhoria paralhe dar huma Cabal nosçaõ doque tem passado nos $\mathrm{Ne}$ gocios pertencentes aessasCapitanias, depois dos ulti-

10 mos despachos, que estaCorte mandou aVossaSenhoria

ComestaOccaziaõ passo tambem ás maõs deVossaSenhoria outraCopia dos uteis, ejudiciozos reparos que oMarechal deCampo comExercicio deEngenheiro DomMiguel Angelo Blasco fesSobre adeffença doRio Grande deSamPedro, edosSeus Territorioz, porque ainda que prezentemente Senaõ possafazer uzodosSobreditos reparos; nuncaSerá Superfluo acharseVossaSenhoria aofeito doContheudo nelles. Deosguarde aVossaSenhoria Palacio deNossaSe-

20 nhora daAjuda a20 delunhode $\underline{1768 . / /}$

Conde deOeyras // SenhorDom Luis Antonio deSouzaBotelho Mouram // 


\section{Copia}

$$
\text { USe eno. now }
$$

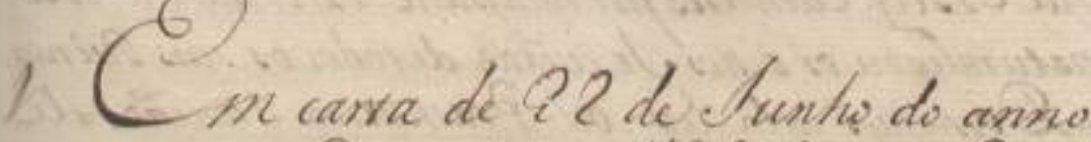

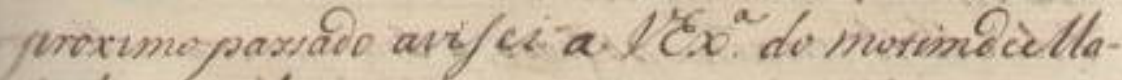

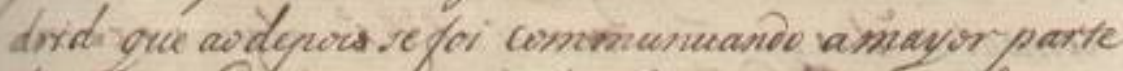

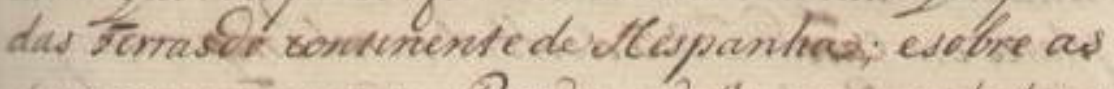

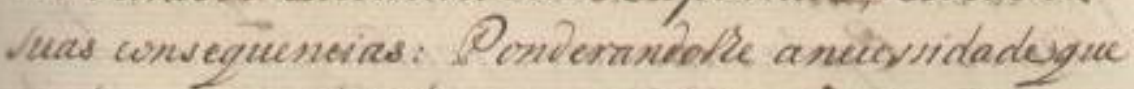
tinhamiv; naté so donispreaverpara inzurtumes as

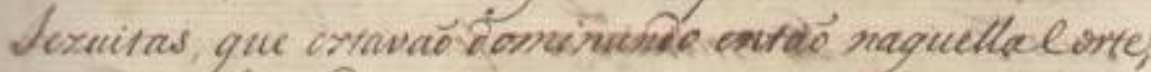

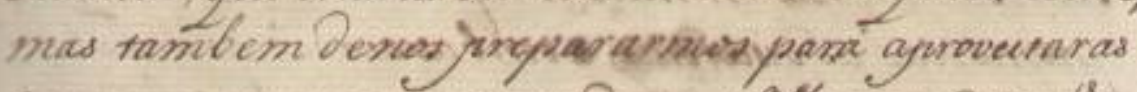

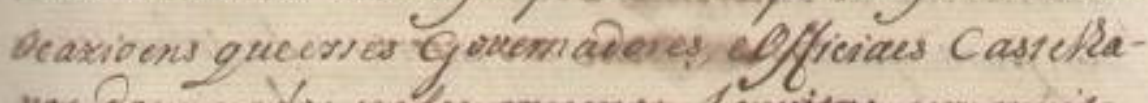
nos, Donunados petos maner lexuitad en maito

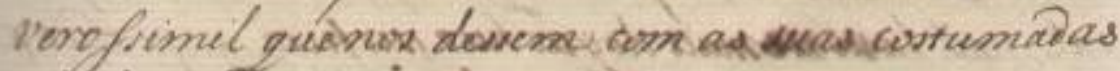

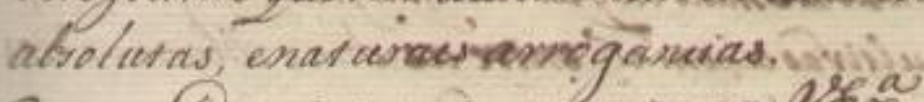

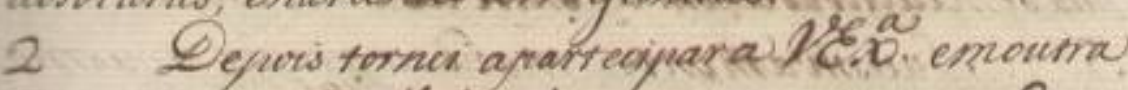
carta de 22 de Slanio dexteprexente anno as Rexo. tuwens quec luailingossade for sorrido tomar/na-

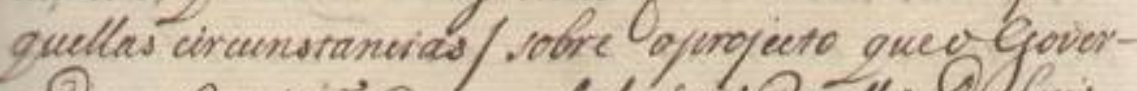

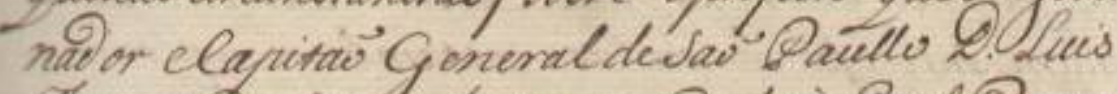

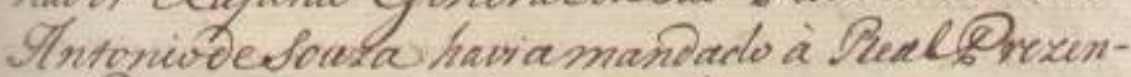
ca Donianis fentrox, esobreos meys, cos mo. dos para deailatarem pelos Cerroens daguella la-

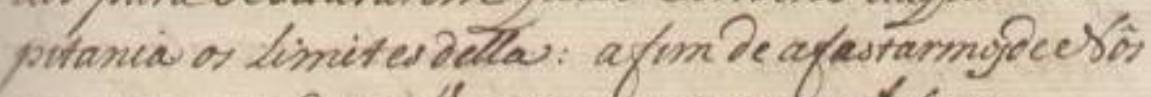
onmesmos Castetlasios quanto popord fore.

3 Com o a fumpre das ryoridas duas carras e doquesolne las ondens senthudas nellas havia Tlimamente awento a isea omesmo Gever-

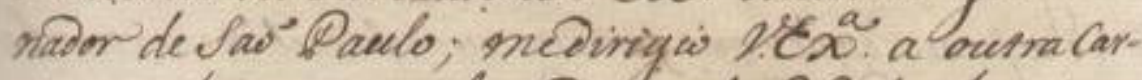
ta que hapow reubi noara de 29 de lanciro Qenteprexenteefrino: Peondo $180^{a}$ nella novas Reriwens decluae lagertadedore os temose or mod para seexhutarem aguellas duces antriedontes Instruevens dentro dos lequlabos Limites da beal intences domesmo fentor 
1. Em carta de 22 de lunho do anno proximo passado avisei a VossaExcelência do motimdeMadrid que ao depois se foi communicando amayor parte das Terras do continente de Hespanha; esobre as suas consequencias: [espaço] Ponderandolhe anecessidade que tinhamos; naõ só denos precaverpara rezistirmos aos lezuitas, que estavaõ dominando entaõ naquellaCorte, mas tambem denos prepararmos para aproveitar as ocazioens queesses Governadores, eOfficiaes Castelhanos, dominados pelos mesmos lezuitas era muito verossimil quenos dessem com as suas costumadas absolutas, enaturaes arrogancias.

2 Depois tornei apartecipara VossaExcelência emoutra

15 Carta de 22 de Março desteprezente anno as Rezoluçoens, queSuaMagestade foi servido tomar / naquellas circunstancias / sobre oprojecto queoGovernador eCapitaõ General deSaõ Paullo Dom Luis AntoniodeSouza haviamandado à RealPrezen-

20 ça domesmoSenhor; esobreos meyos, eos modos parasedilatarem pelos Certoens daquellaCapitania os limites della:[espaço] afim de afastarmosdeNôs os mesmos Castelhanos quantopossivel fosse.

3. Com o assumpto das referidas duas Cartas, e doquesobre as ordens contheudas nellas havia ultimamente avizado aVossaExcelência omesmoGovernador deSaõ Paulo; medirigio VossaExcelência a outra Carta quehapouco recebi nadata de 29 de laneiro desteprezenteAnno: Pedindo VossaExcelência nellanovas

30 Rezoluçoens deSuaMagestadesobre os termos e os modos paraseexecutarem aquellas duas antecedentes Instruçoens dentro dos regulados Limites daReal intençaõ domesmoSenhor. 
t Quanes erta Cortere aulava won a dec Pland

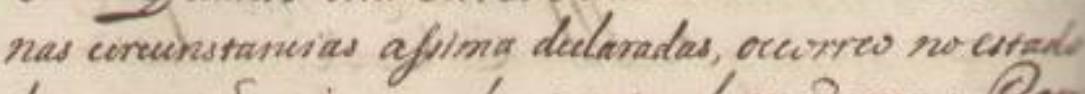
das couxas sux inopunada, eneravel mudanua: Oor que EMR oy Castrotres nor huaparte; exterminow, Desnatumberou or Dittos. Jexutus de toder os seus Reines, e Dominis pela ly, on enamarica Sanizas de

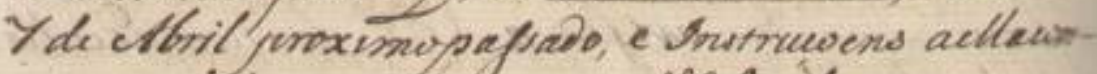
umentes; das ques ja remeri al $\mathscr{C}^{a}$ alyens exemplares en cartide 25 dutbril, tambeingmoimuprcedente: Evelavomarite manowe commumicar?

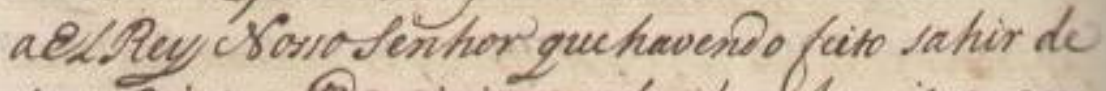

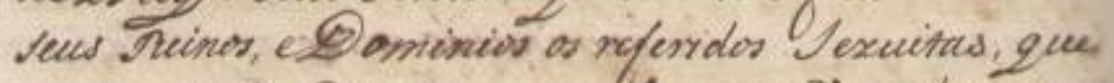
promovia as Discoritis, embanuevas as duas con tes, para ambas vervirom as intonsses da bobreotrass. ciedad Jexwivica; esponva que overis da dittaexpol-

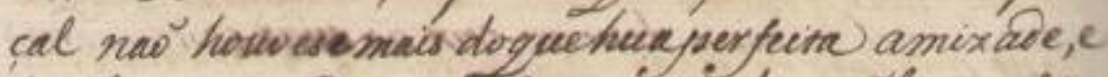
hua bemultivas avenias entres as duas Thonare ivas 5. Sucisivamiente mandoupropior omesmo

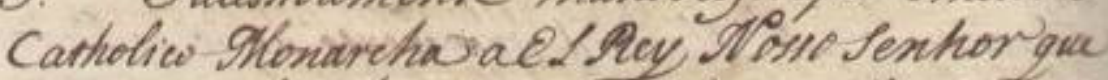
nos tormos desetworer consolidado aquella amixa de, eunia entress dues Corres: erer ella do conum interefie de ambas, entambem conforme amedma amixide, emusues intoresres que as questo ens quede allao peniontes sobre or limetes of 3 mazil 1 ajustassemparticularmente entreas deres Gabi-

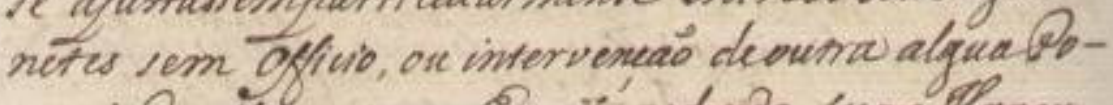
tenvia da Heuropa: Enais vonterto. uac Plager-

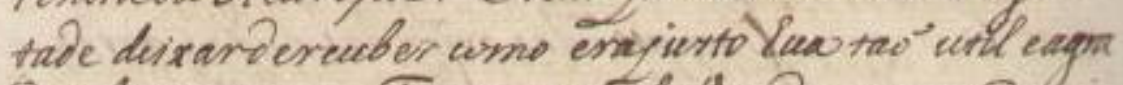

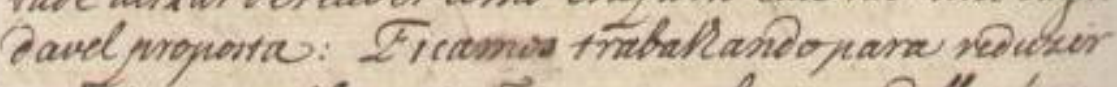
acf fuito expersequciaces; se na dertura Della houve a finurionde gue faxom vengfimil aspunturbawens eng re actav os Msues prixintwos, a firm den-

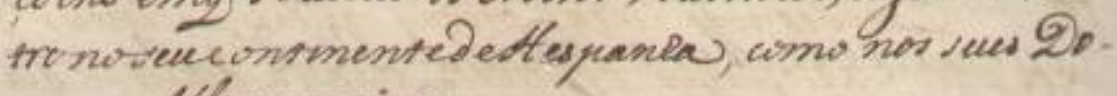
menus Whramarinos.

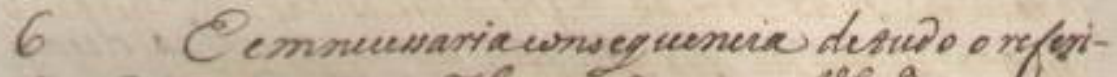

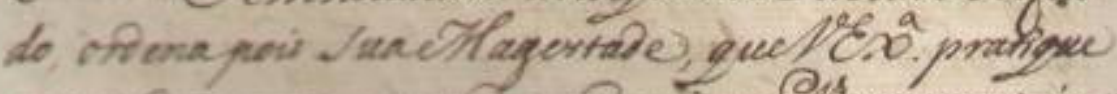

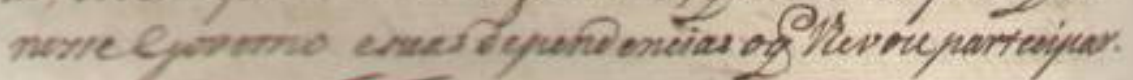
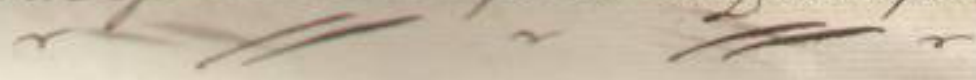
||39v\| 4. Quando esta Cortese achava com a deMadrid nas circunstancias assima declaradas, occorreo no estado das couzas hua inopinada, e notavel mudança: [espaço]Por queEIRey Catholico porhuaparte; exterminou, edesnaturalizou os dittos lezuitas detodos os seus Reinos, eDominios pelaLey, ou PramaticaSanção de

407 de Abril proximopassado, e Instruçoens aellaconcernentes; das quaes ja remeti aVossaExcelência alguns exemplares emCartade 25 deAbril, tambemproximoprecedente: [espaco] Epelaoutraparte mandou communicar aELRey NosssoSenhor quehavendo feito sahir de

45 seus Reinos, eDominios os referidos lezuitas, que promoviaõ as discordias, e embaracavaõ as duas cortes, para ambas servirem aos interesses dasobreditasociedade lezuitica; esperava quedepois da dittaexpulçal naõ houvesemais doquehuaperfeita amizade, e

50 huabemcultivadauniaõ entre as duas Monarchias. 5. Sucessivamente mandoupropôr omesmo CatholicoMonarcha aEL Rey NossoSenhor que nos termos desehaver consolidado aquella amiza de, euniaõ entreas duas Cortes: eser ella docomum interesse de ambas; eratambem conforme amesma amizade, emutuos interesses que as questoens quese achaõ pendentes sobre os limites doBrazil se ajustassemparticularmente entreos dous Gabinetes sem officio, ou intervençaõ deoutra alguaPo-

60 tenciada Heuropa: [espaço] E naõ podendo SuaMagestade deixardereceber como erajusto hua taõ util eagra davel proposta: [espaço] Ficamos trabalhandopara reduzir aeffeito estaNegociaçaõ; se na aberturadella houve asinceridade que fazem verossimil as perturba-

65 çoens emque se achaõ os Nossos vizinhos, assim dentronoseucontinentedeHespanha, como nos seus Dominios Ultramarinos.

6. E emnecessariaconsequencia detudo o referido, ordenapois SuaMagestade, que VossaExcelência pratique nesseGoverno esuas dependencias oque Ihevoupartecipar. 
||40r||

(3)

\%. Primiraminte opena omesmo fenthor que oque avixu a erex nnoura Carra guelledinigion 22 We Charro doprexonte anno, votre oprofuro do Governasor, elapiras G enenal de das paulo; ou que nellavereir despe os. I: ateofiom do s. 6., faw aimpreterrivel reprade 1 \&. a. ed a dito goverraior, comohepracizo g face nas curcunstanias qued-

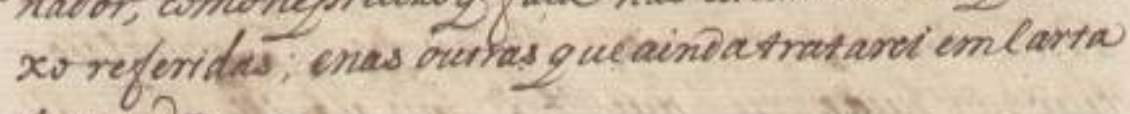
separias.

8.

Qquescieve praticar en ralforma, quefaxendefeverfompre aus Cartellanos, eivernosetres, que

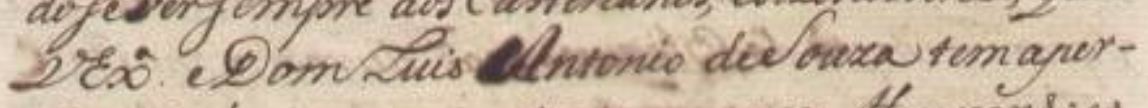
tadas Ondens para praticaremo amos thespanioves veus Confin antes amayon amixas depors daex-

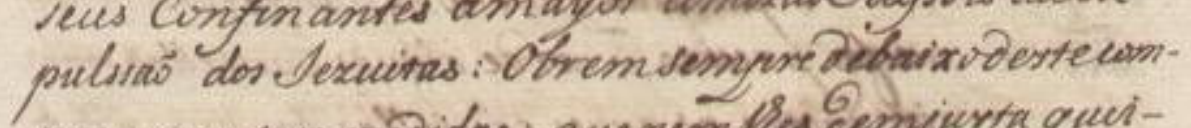
passo cuntaus mididns, quenem kes benyurta qui$x$ adientanio, nor home sobre thes a b ominio, nem Thes pumento queclles ve aivientem pellas Fomas, C Dostos degucentivemos atte agorase enosio 9 Enveaxs de Clles queriem abuxar destanyf

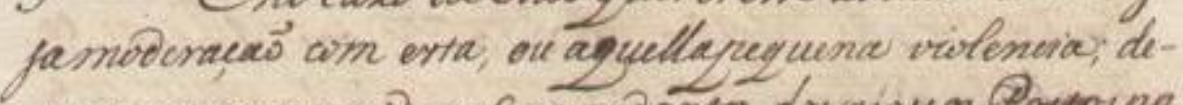
van estrayprevenios os Comano antes dos niossos Prosospa

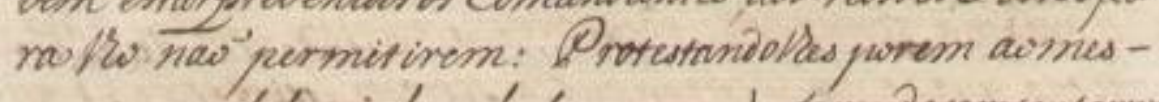
mo tempo (teywis dese desforcarem) efaxendop rotestantor Excrito maniande as Cimmandante mues vexintio do

- Caxo quesucider. Que or sues Jubalternorficeños esta or aquelladexinem, contra aintima amixade que se labe que reina entre as duas Cortes. Equedella ficanoio no

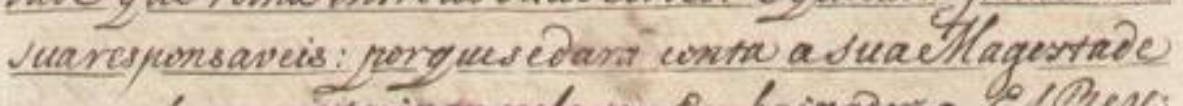
para ofaxer partecipar pelo sue embaixador a Es puy Cartolico yeubom mov, el untrio. or.

10. Emseguria lugar ordenaumesmo Sention g reos ditos Castrnlanes obrigaros; ourela dexercaso gue faxem as suas Inoras; overela nuessidade de hirem acuoir a conguirst das Thirroens do Vruguay, on à deleza de Duenes Iyres, forem abanoonanov algüs Postos nas partes de Rive grande. orio Riv bando.

193 
||40r|| $7 . \quad$ Primeiramente: ordenaomesmo Senhor que oque avizei aVossaExcelência nadita carta quelhedirigi em 22 deMarço doprezente anno, sobre oprojecto do Governador, eCapitaõ General deSaõ Paulo; ou o

75 que nellaescrevi desde o parágrafo primeiro atheofim do paragrafo 6. , faça aimpreterivel regrade VossaExcelência, edoditoGovernador, comoheprecizoque faça nas circunstancias quedeixo referidas; enas outras que aindatratarei emCarta separada.

$808 . \quad$ O quesedeve praticar em tal forma, que fazendoseversempre aos Castelhanos, edizendoselhes, que VossaExcelência eDom Luis Antonio deSouza tem apertadas Ordens parapraticarem com os Hespanhoes seus Confinantes amayor amizade depois daexpulssaõ dos lezuitas: Obremsempre debaixodestecompasso comtaes medidas; quenemlhes demjunsta queixa adientando por hora sobre elles o Dominio; nem lhes permitaõ queelles se adientem pellas Terras, $\mathrm{e}$ Postos dequeestivemos athe agoradeposse

90 9. Enocazo de Elles quererem abuzar destanos samoderaçaõ com esta, ou aquellapequena violencia; devem estarprevenidos os Comandantes dos nossos Postos pa ra Iho naõ permitirem: Protestandolhes porem aomesmo tempo (depois dese desforçarem) efazendoprotestarpor

95 Escrito mandando ao Commandantemais vezinho do cazo quesuceder: Que os seus Subalternos fizeraõ esta ou aquelladezordem, contra aintima amizade quese sabe que reina entre as duas Cortes: E quedella ficaraõ na suaresponsaveis: porquesedará contra aSuaMagestade para ofazerpartecipar pelo seuEmbaixador aEIRey

Catholico seubom Irmaõ, eCunhado. etcetera 10. Emsegundo Lugar ordenaomesmoSenhor, que seos ditos Castelhanos obrigados; oupela dezerçaõ que fazem as suas Tropas; oupelanecessidade de hirem acudir aconquista das Missoens do Vruguay, ou à defeza de Buenos Ayres, forem abandonando algũs Postos nas partes deRioGrande, oudoRioPardo. 
Woremos entaw oupar os mesmes Postos onde el les sahina, debaixio dopretexto de os deferdermes contra as invafoens, ecomunicawens dis texuetas. \&s.

11. En terciro Lugar ordena omesmo fentor que 'Ex." Jaca a lama a boasontude, queos caste-

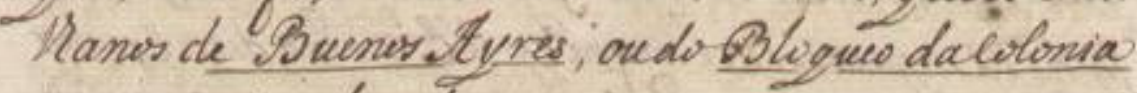
parueguetem de nelaxaren o aperto, enquecrava adria Pnac da lolvinia: Braventaie aqualpa-

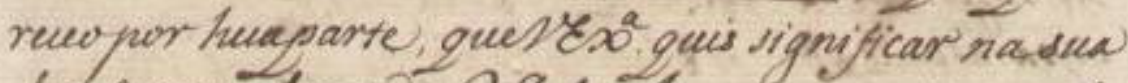
dutal arta utrmate 2 Ide canciro proximoprefTad, emquanto nulla aivere: Que entenaia que eqrande averto do 3 lequendivis dunaria maito : parew pula ourmpante questambem significav âs as quantidadus depataras quevesas partes tem vinoo; duorte que for previxe uxar be alyues cautelles para as enwotris entre as quas cautellas for hua ade ge comprarom as 8 itis patanes dentro na laxa dartoe 2a paras athemesta en oiro unhado.

12. Omodopois que E.Rey. Dero centur aclore quepwoder mais natum noprexentestaidos

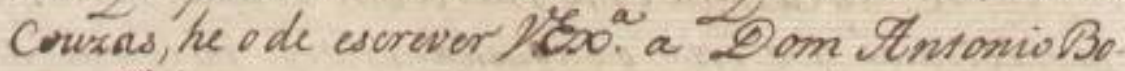
cardli hua lanta Familiar, convebidanes termes que fas naturas amuonue do estado das duas Cortes afimarefrida; dixenoo vexa nelta: Quedalo Linia relse aviza, que aquella Prua enta en hum litio formal, winmohibicaö fehadaparatodas as $\omega^{\circ}$ municawens, carhepara cimprar or cumestivcis mais croinarios nas Ferras, elugares dijauntes amesma Prua Guetum Bloquio que emproetodrawmmunicaias etodo aguelle rugueno fratico ven Qll bem

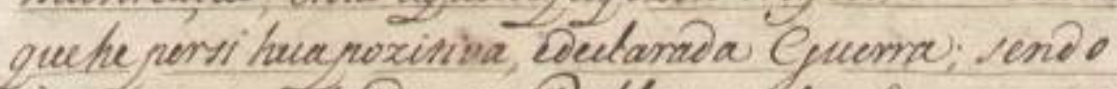

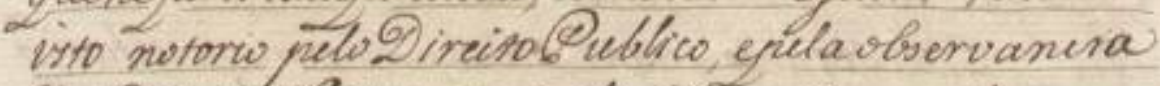
detodas as eraswens civilixadas: Que athe agena posto que assim o conhuiams, sabiamos aomesmo temp, querwido oreferido provintia de nequeviawens,

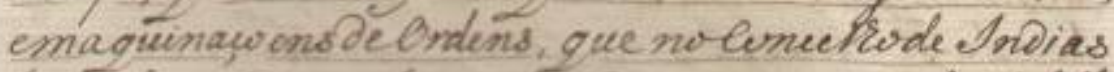

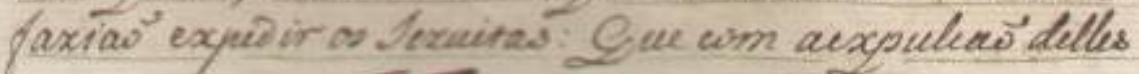


||40v\| poderemos entaõ ocupar os mesmos Postos, donde elles sahiraõ; debaixo dopretexto de os defendermos con-

110 tra as invasoens, ecomunicaçoens dos lezuitas. etcetera

11. Em terceiro Lugar: ordena omesmoSenhor

que VossaExcelência faça acama a boavontade, queos Caste-

Ihanos de Buenos Ayres, oudoBloqueo daColonia

parecequetem de relaxarem o aperto, emqueestava

115 a dita Praca daColonia: Boavontade, aqualpa-

receopor huaparte, queVossaExcelência quis significar nasua

ditacarta ultimade 29 de laneiro proximopas-

sado, em quanto nella avizou: Que entendia, que

o grande aperto doBloqueio naõ durariamuito: $\mathrm{E}$

120 pareceo pela outraparte, quetambemsignificavaõ

as quantidades depatacas quedessas partes temvindo;

desorte quefoi precizo uzarde alguas cautellas para

as encobrir; entre as quaes cautellas foi hua adese

comprarem as ditas patacas dentro nacaza daMoe

125 da parasahiremdella em Ouro cunhado.

12. O modopois que EIRey Nosso Senhor a-

chou quepodeser mais natural no prezenteestadodas

Couzas, he o de escrever VossaExcelência a Dom Antonio Bo-

catelli huaCartaFamiliar, concebidanos termos

130 que fas naturaes amudança do Estado das duas Cor-

tes assimareferidas; dizendo VossaExcelência nella: QuedaCo-

Lonia selhe aviza, que aquella Praça está emhum

Sitio formal, comprohibicaõ fechadaparatodas as cõ-

municacoens, eathepara comprar os comestiveis mais

135 ordinarios nas Terras, elugares adjacentes amesma

Praç: Quehum Bloqueio que empedetoda acom-

municaçaõ, etodo aquelle pequeno trafico, verá Elle bem

quehe persi huapozitiva, edeclarada Guerra; sendo

isto notorio pelo Direito Publico, epelaobservancia

140 detodas as Nascoens civilizadas: Que athe agora

posto que assim o conheciamos, sabiamos ao mesmo

tempo, quetudo oreferido provinha de negociacoens,

emaquinaçoensdeOrdens, que noConcelhode Indias

faziaõ expedir os lezuitas: Que com aexpulcaõ delles 


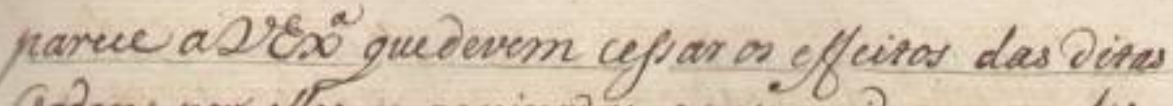
ordens for elles maquinades, exiorguidas, pam difiaboriarem, embaracarem, eaticnarem as duas corres; fazendo amà inteligeneici entre cllas humponto efienund tos interyfres dasua Sociednde: Siu as corexas tem muado intunamente desemblante; nong ave:ose avizue deste a dara de 25 deetloril inoxime nassado, quelogo, que or Texuitas fono expulses der Dominos de terpantha revelrisas as rortus, naö $10^{\circ}$ abowinteligenisa, mas tamberv a mais sincena, cintima Amixaie, gue ficarañ foxenb arrgra das duas respue fivas Hagertindes, é das vuas Reuw Familias: Cree

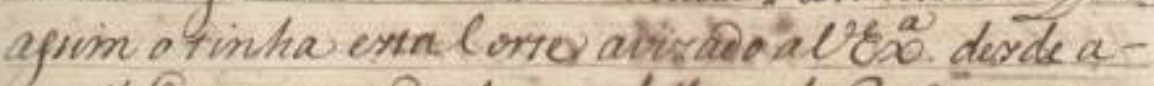
quellas ata, cainda denors della pela Batia, para que emrodas as Caniranias berres Gominios d'EL ruy boso fentwor, se ultivasiem com os liafiaLos dec uae Alagertade Catholica) amais nerfuira Armonia, eamais amigarel conresponoenera. Que asim otem vicso. ordenado arodos os Commandantes das depindeneias desia laputanio, Que omesmo tem firo of everriadordec av Paullo: Equ OED espera que Cll Dometrionis Docardli faca cusar truas hostelidades rao inumpativeis com o actual irstema de amizade, cunias inmmadas duad cortes; mandando abrir com a Colonia aumunicaias / p ara aqual bastaria a Pas entre as duas sascuens emnido oquenao for contnabando; efaxendo ingiar, e cartigar on wnmabanoistas seis horver, com as nenas das discontraelles ertablevidas; porquenäo hyiusto quepelo recevo des culpas eventuass, desimitrantes oriminofos sefuthem atodos os innocentes as fortas rara aquella mutua communicaias, ervinnow thate que a hum anidade requerfursi muma entre as Alucoens que rearlai empas; ainoaquando nä criurrem nellis as outras mais atendiveis mafo ens deertruto parentesce, eintima amixade que 
$145 \quad|| 41 r \|$ parece av ossatxcelencla quedevem cessar os etteltos das ditas

Ordens por elles maquinadas, e extorquidas, para dissa-

boriarem, embaracarem, e alienarem as duas Cortes; fa-

zendo amà inteligencia entre ellas humponto essen-

cial dos interesses dasua Sociedade: Que as couzas, tem

150 mudado inteiramente desemblante; porque aVossaExcelência se

avizou desde a data de 25 deAbril proxime passado,

quelogo, que os lezuitas foraõ expulsos dos Domini-

os de Hespanha, se abriraõ as portas, naõ só aboa in-

teligencia, mas tambem a mais sincera, eintima

amizade, que ficaraõ fazendo a regra das duas respec-

tivas Magestades, e das suas Reaes Familias: Que

assim o tinha estaCorte avizado a VossaExcelência desde a-

quelladata, e ainda depois della pelaBahia, para

que emtodas as Capitanias desses Dominios d'EL-

160 Rey NossoSenhor, se cultivassem com os Vassa-

los deSuaMagestade Catholica amais perfeita

Armonia, e amais amigavel conrespondencia:

Que assim o temVossaExcelência ordenado atodos os Com-

mandantes das dependencias dessaCapitania; Que

165 omesmo tem feito oGovernadordeSaõ Paullo:

E que VossaExcelência espera, que Elle DomAntonio Bo-

carelli faca cessar huas hostelidades taõ incom-

pativeis com o actual sistema de amizade, euni-

aõ intimadas duas cortes; mandando abrir com

170 a Colonia acomunicaçaõ / para aqual bastaria

aPaz entre as duas Nascoens/ emtudo, o quenaõ

for contrabando; e fazendo vigiar, e castigar os con-

trabandistas, seos houver, com as penas das Leis con-

traelles establecidas; porquenaõ hejusto quepelo re-

175 ceyo das culpas eventuaes, desimilhantes crimino-

sos, se fechem atodos os innocentes as portas para

aquellamutua communicaçaõ, ereciproco trato

que ahumanidade requerpersi mesma entre as

Nasçoens que se achaõ empas; ainda quando naõ

concorrem nellas as outras mais atendiveis raso

ens destreitoparentesco, eintima amizade que 
$\|4 \mathrm{TV}\|$

two cuidas ox amente re exta cultivanto ontre os dous rasuectivas Honarchas cor Pafialos dos seus Rimos, nertaparicoo Mundo; a ondesepermute efomenta ruiprocamente todu o trifico, que fermirido elicito: esecastiga $\overrightarrow{0}$ tambem reispro camente os contrabandos punindose or que nelles se aciao comprehendides. S.

1.2. Oroutries Gronsdectaroch agenta de quidevo avizaral $18 x$. naprexintewnjantura Re voupartecipar loge en carra separada.

Qees Cuane alcs. Dalaivdier of

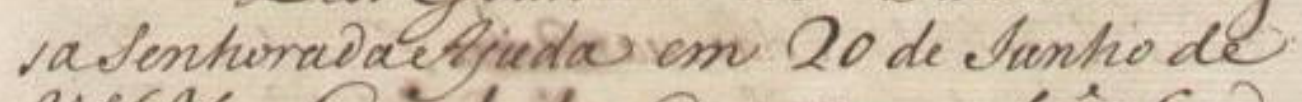
$\frac{9 Y 6 \%}{\partial a c u n i a}=$ Conde des Qeyras $=$ Inir Conoc Citacunforme win o original dalopiague luebi.

199 
$\|41 v\|$ taõ cuidadozamente se estaõ cultivando entre os

dous respectivos Monarchas, eos Vassalos dos seus

$\underline{\text { Reinos, nestaparte do Mundo; aondesepermite }}$

185 e fomenta reciprocamente todo o trafico, quehe

permitido elicito: ese castigaõ tambem recipro-

camente os contrabandos punindo-se os que nelles

se achaõ comprehendidos. etcetera.

13. As outras Ordens deSuaMagesta-

190 de quedevo avizaraVossaExcelência naprezenteconjuntura Ihe vouparteciparlogo em cartaseparada.

Deos Goarde aVossaExcelência PalaciodeNos

saSenhoradaAjuda em 20 de lunho de

1767. $=$ Conde de Oeyras $=$ Senhor Conde

195 daCunha $=$

Estaconforme com o original daCopiaquerecebi.

DomLuis AntoniodeSouza 
[25]

||43r||

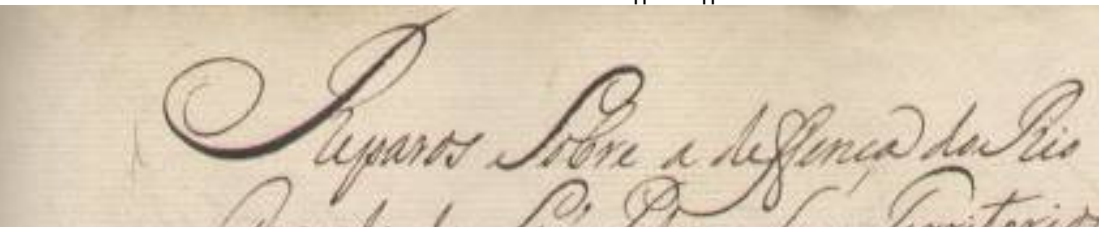

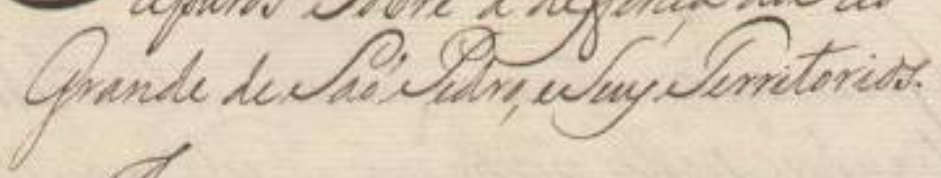

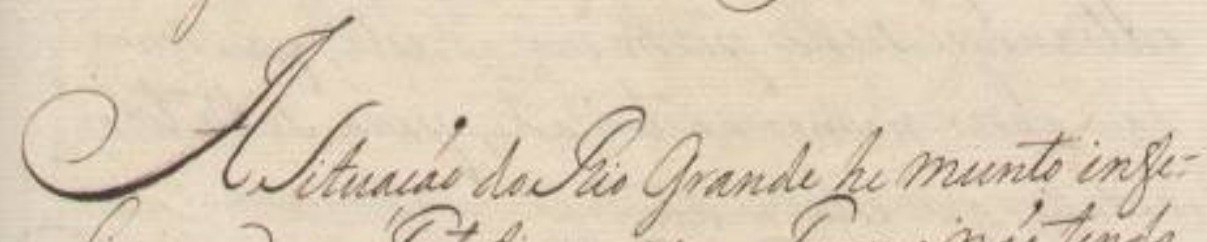
dis pard ve Sortificar, wex Sorrens ina' tende solides nenhuma sende piura ariystré mivida

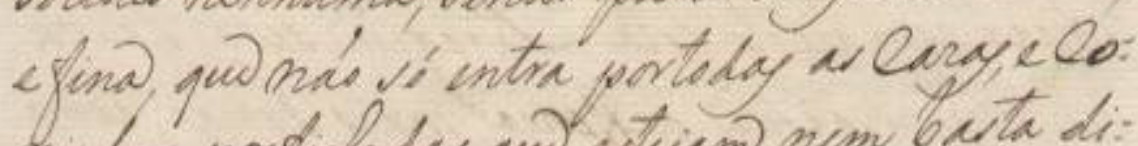
zinhry porfuladas juo istiem, nem besta di: agunia relguma para impeder pub nas ve in:

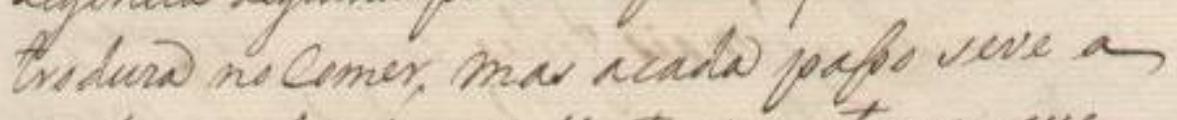
metemorghove /um or Vientey impecturey ques neita sisegem dominam decchar ristlenty

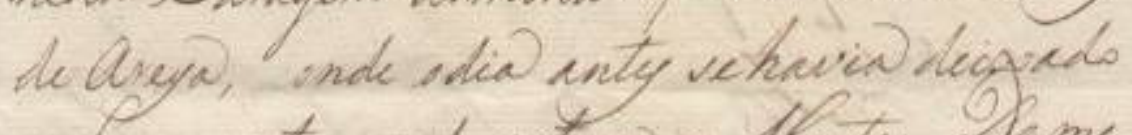
upiano, eerte ande vitar whonte: $2 \mathrm{cms}$.

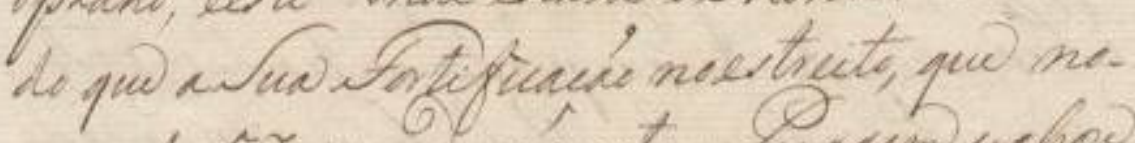
ami de 5.5 puanes poncita sangen perposo

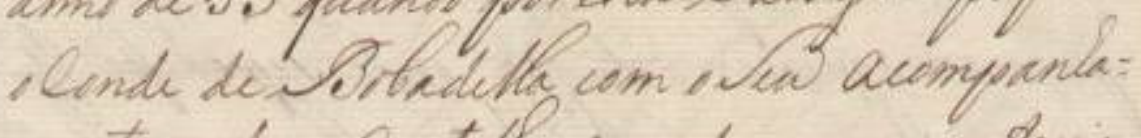
mente, indo a Custihly grandy prara fonferir

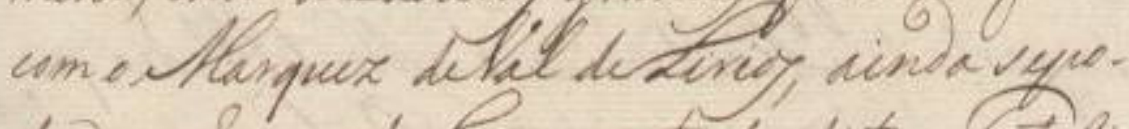
dia conlever desiniamento da dite Sortefi:

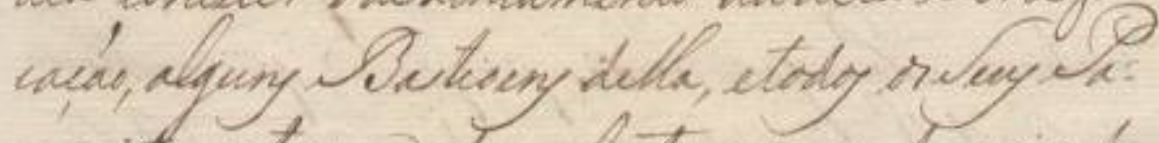
mpeity estuvam tescubentey, mas duposy des

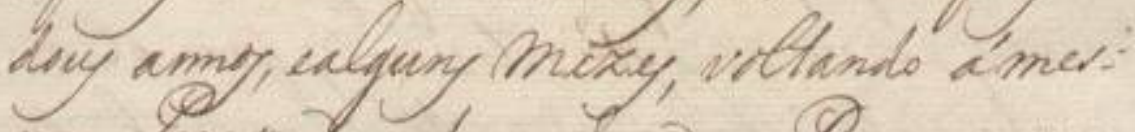

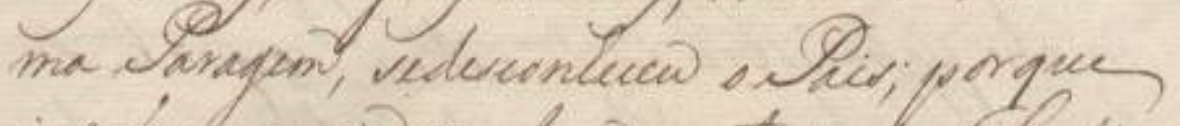

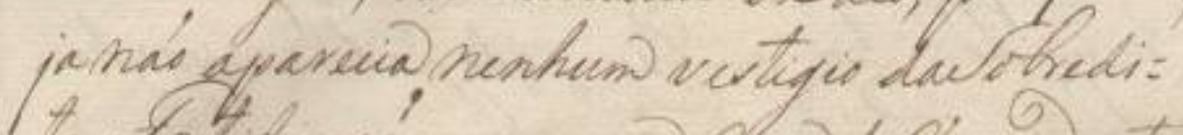
ta Inliguneś, e comerma Casd do Cemiendante, us

201 
Grande de Saõ Pedro, eSeus Territorios.

A Situaçaõ do Rio Grande he munto infe-

Lis para se Fortificar; oseu Terreno naõ tendo

5 solides nenhuma, sendo pura areya taõ miuda,

e fina, que naõ só entra por todas as Cazas, e Co=

zinhas por fichadas que estejam, nem basta di= Ligencia alguma para impedir, que naõ se in= troduza no Comer, mas acada passo seve a

metamorphose / com os Ventos impetuozos que nesta Paragem dominam / deachar os Montes de Areya, onde o dia antes se havia deixado o pLano, eeste onde estava o Monte: Demodo que a Sua Fortificaçaõ no estreito, que noanno de 53 quando por esta Paragem passou o Conde de Bobadella com o Seu acompanha= mento, indo a Castilhos Grandes para conferir com o Marquez deVal deLirios, ainda sepodia conhecer 0 deLiniamento da dita Fortefi=

20 caçaõ, alguns Bastioens della, etodos os Seus $\mathrm{Pa}=$ rapeitos estavam descubertos; mas despois de dous annos, ealguns Mezes, voltando ámes= ma Paragem, sedesconheceu o Pais; porque ja naõ aparecia nenhum vestigio daSobredi= 25 ta Fortificaçaõ, e amesma Caza do Comandante, 


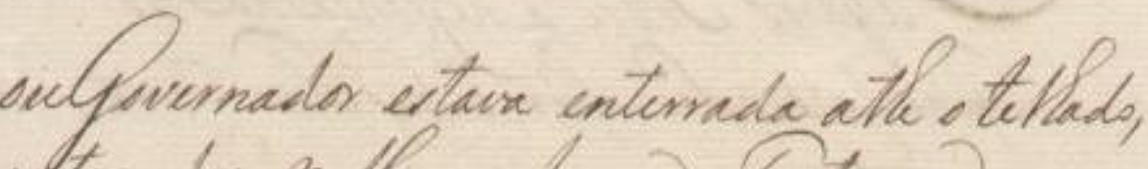

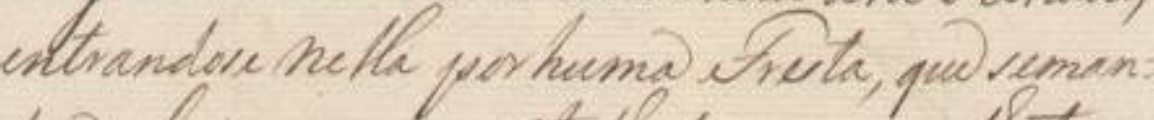
dow chrir nomermo te lado, pora selle tiras ovth, que citur dentro.

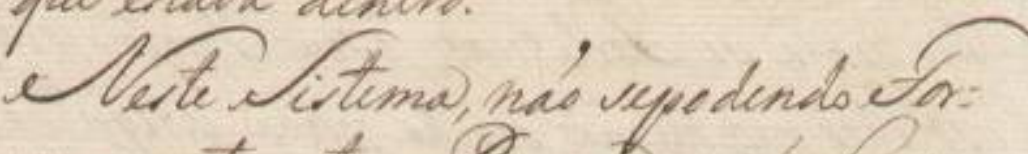

tifiear com acerto erta Oenqum, vera nowe:

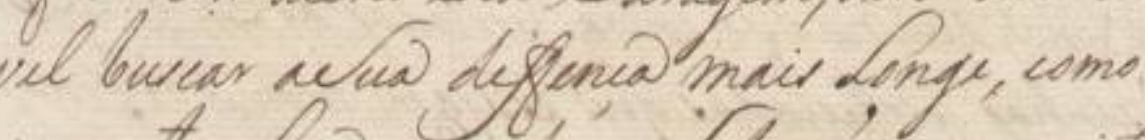

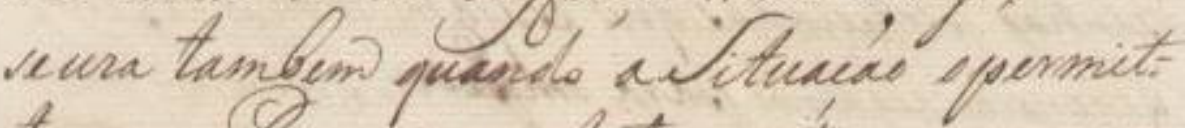

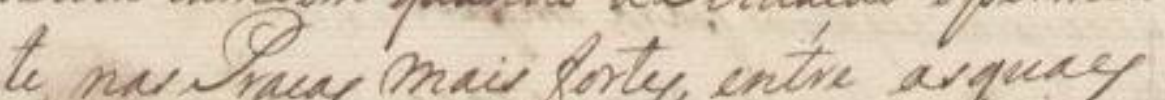
wo mais ertimaves, e lepectada de mayor prertione uqua podem entreter is nimifes mair afartarly.

(7) Sriquare Wreph devilex caer, luquito dexaquado intendimento

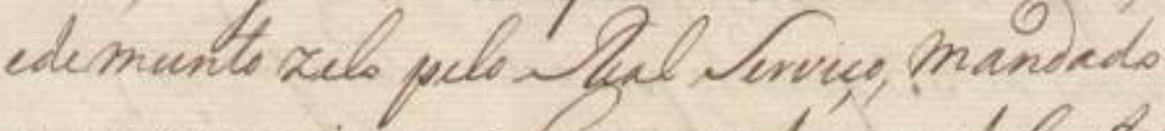
pana examinar daquer unde nestefe ga: zer mitor opporicas cham animig, ques daport de

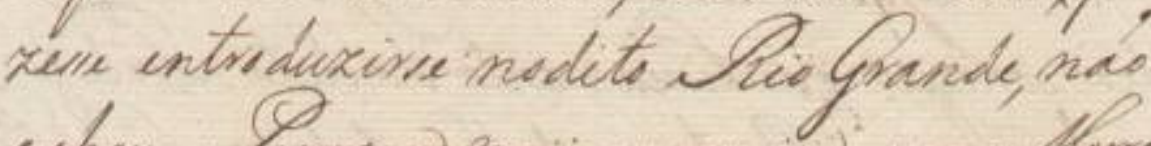

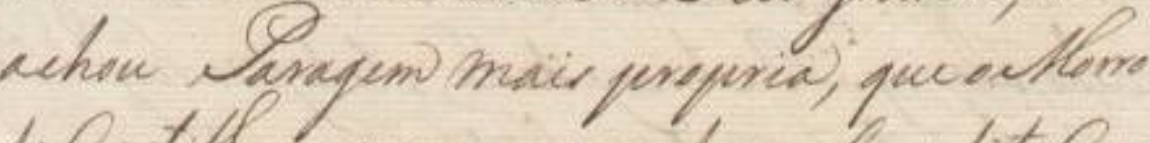
de Qutth pequene, por ende popa sdito $\mathrm{Ca}_{\text {. }}$ minhe, eveve amgyon ertreitoza poir o Oa:

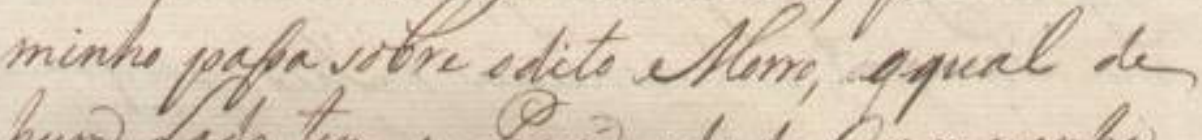
ham Lado tem a Sraji, ede da Crmpanha

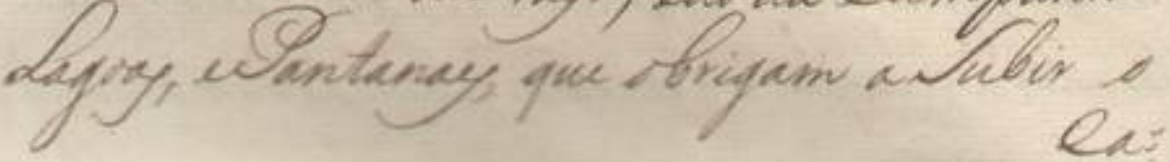


$\|43 v\|[[o u]] G o v e r n a d o r ~ e s t a v a$ enterrada athe o telhado,

entrandose nella por huma Fresta, que seman-

dou abrir no mesmo telhado, para se lhe tirar

30 o Fatto, que estava dentro.

Neste Sistema, naõ sepodendo For= tificar com acerto esta Paragem, será Louva= vel buscar aSua deffença mais Longe, como se uza tambem quando aSituaçaõ o permit=

35 te, nas Praças mais fortes, entre as quaes saõ mais estimaveis, e reputadas de Mayor prestimo as que podem entreter os Inimigos mais afastados.

O Brigadeiro loseph daSilva

40 Paez, Sugeito de adequado intendimento, edemunto zelo pelo Real Serviço, mandado para examinar oLugar onde sepodesse $\mathrm{fa}=$ zer milhor oppoziçaõ ahum Inimigo, que daparti de Maldonado, e Monte Vidio qui=

45 zesse introduzirse no dito Rio Grande, naõ achou Paragem mais propria, que o Morro de Castilho pequeno, por onde passa o dito $\mathrm{Ca}=$ minho, eseve amayor estreiteza; pois o $\mathrm{Ca}=$ minho passa sobre o dito Morro, o qual de

50 hum Lado tem aPraya, edo da Campanha Lagoas, ePantanaes, que obrigam aSubir 
||44r||

- Caminhs pocla galda dodeto Clomo.

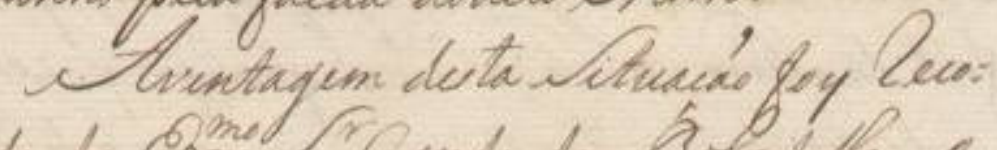
neseuda de Eomad. Fende de Sibadella, qual acsominaw na eccaxiás sobrodita, pus papiép pola dita Sarrem, indo conferir cam Sharquax Valde tinil, como ccima Que dito; eme ordenow de esurar en fue flappa ditex minando garer eli hama Aoteficuas; mey.

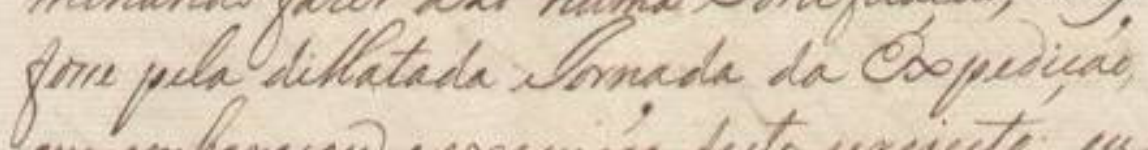

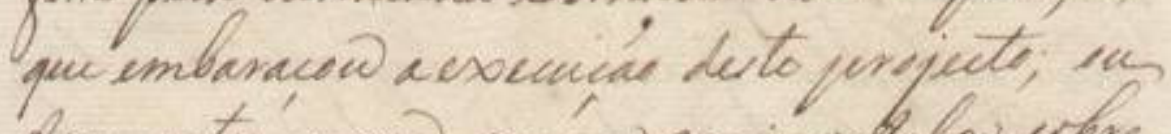
frice sutrá caura; nunea mais sefolno vore este partiular.

Cinlepufe millor incupidade dector tefuares norte Lugar, quando cultiriamente is

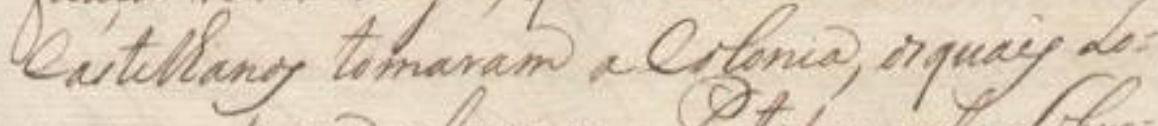
yo mandaram elgumy sartidy pete bore dito Caminhs dow tir Grande, crpallando ha: ma vir que as lequin oforte da hur siver, pura ethuar edita billa de lis Grande.

cupnta ancupidadedcitertefuncá nestu sugar, pode ver, secpermanente, nuper sapina. Stpermanente, quevefer lepedre

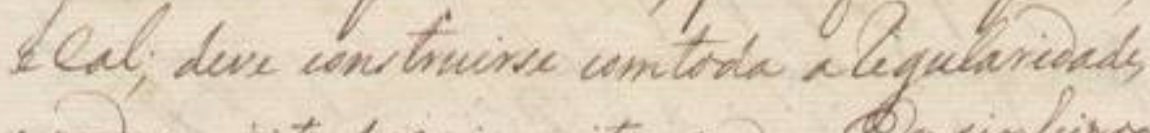

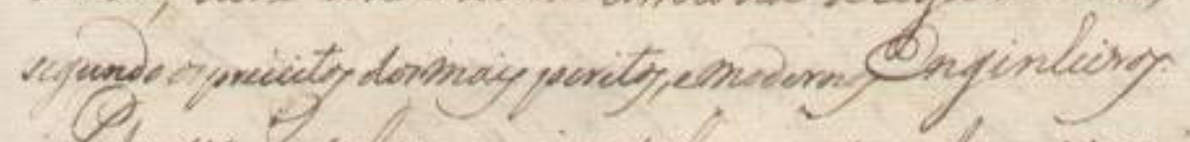
Sile ver teqular, su incqualar, sequenda yoen mitir serrene, edeptandere tibry Regres, ques

205 
||44r\| [[o Ca]]minho pela falda do dito Morro.

Aventagem desta Situaçaõ foy reco=

conhecida do Excelentíssimo Senhor Conde deBobadella, o

55 qual aexaminou na occaziaõ sobredita, que passou pela dita Paragem, indo conferir com

o Marquez ValdeLirios, como acima fica dito;

eme ordenou de eLevar o Seu Mappa; deter-

minando fazer aLi huma Fortificaçaõ; mas

60 fosse pela dillatada lornada da Expediçaõ,

que embaraçou a execuçaõ deste projecto; ou

fosse outra cauza; nunca mais sefalou sobre

este particular.

Conheseuse milhor anecessidade deForti-

65 ficaçaõ nesteLugar, quando ultimamente os

Castelhanos tomaram a Colonia, os quaes $\mathrm{LO}=$

go mandaram algumas Partidas pelo Sobre=

dito Caminho do Rio Grande, espalhando hu=

ma vez, que as Seguia o forte daSua Tropa,

70 para attacar adita Villa do Rio Grande.

Suposta anecessidade deFortificaçaõ

nesteLugar, pode ser, ou permanente, ou pas-

sageira. A permanente, que sefaz depedra,

e Cal; deve construirse com toda a regularidade,

75 segundo os priceitos dos mais peritos, emodernos Enginheiros.

Pode ser regular ou irregular, segundo oper-

mitir o Terreno, adoptandoa ás boas Regras, 


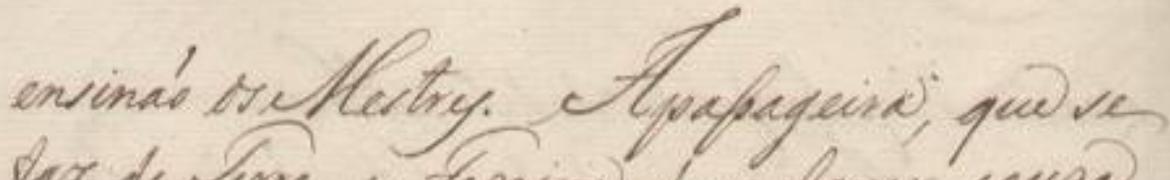
fax de ome, es tesoine dequalquer cousa

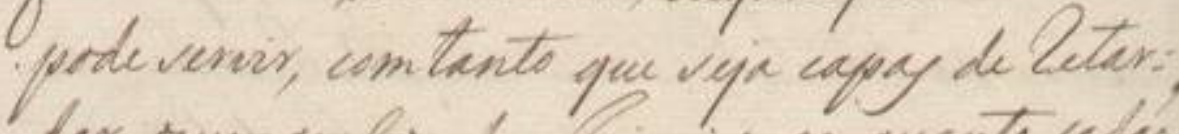

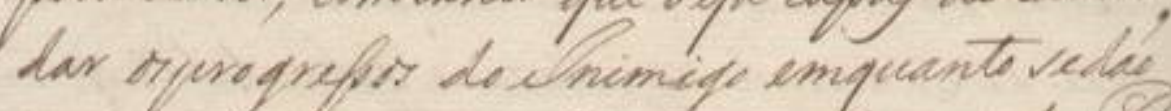

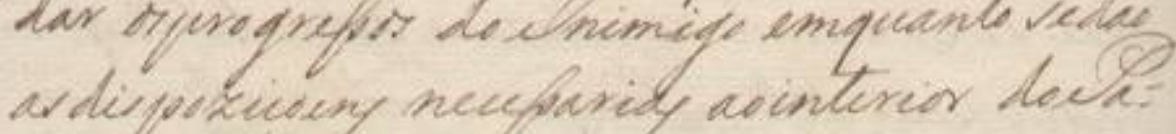
ix.

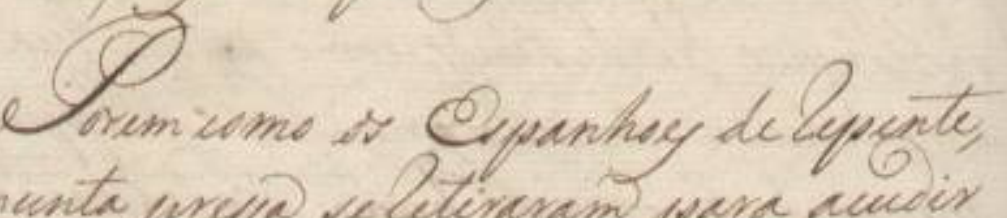

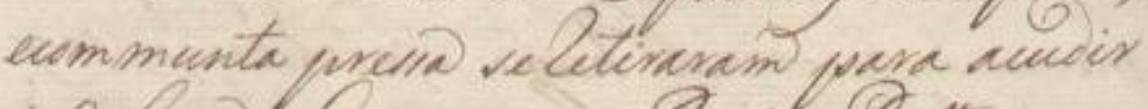

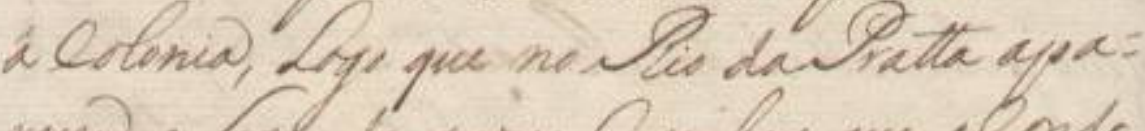

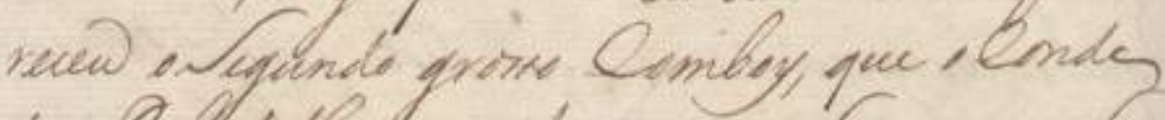
de Brodella inandou para locorrer wele-

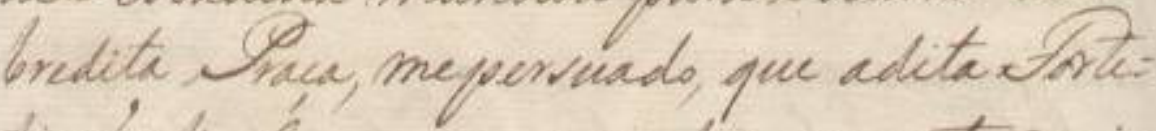

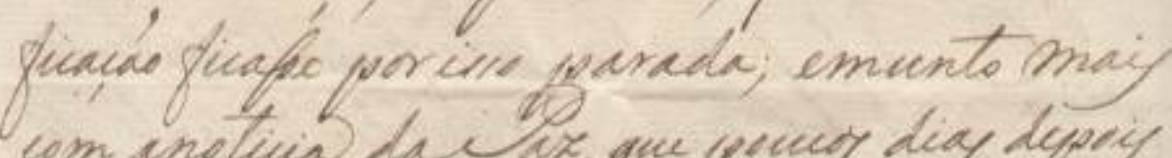

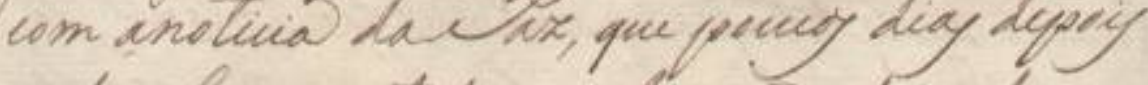
sedivelgea portorle a America; demodo ques

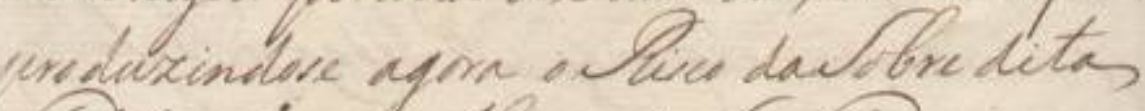

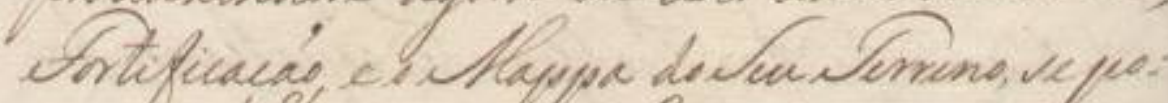

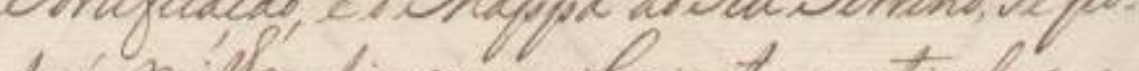
Lire millor dicorrer retre erte pertiular, s

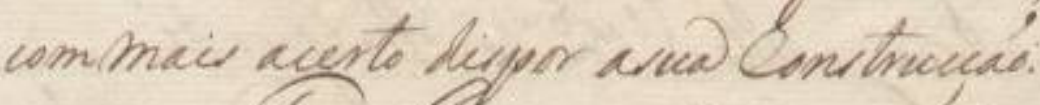

Oun ovimiqo ovitry mai Exmi-

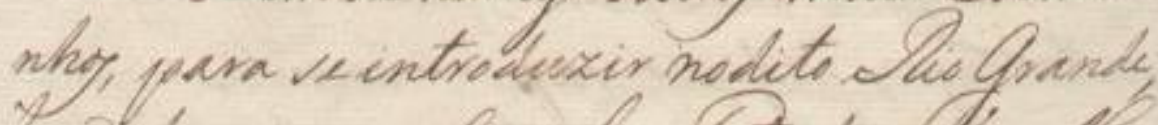

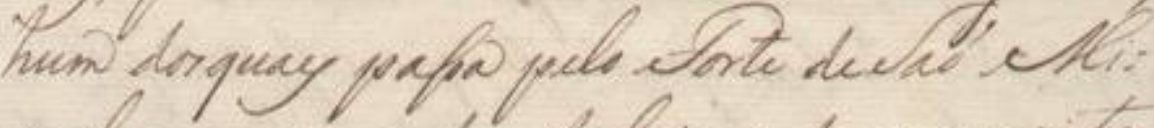
quel, que vinandou fabrieer deperopezita

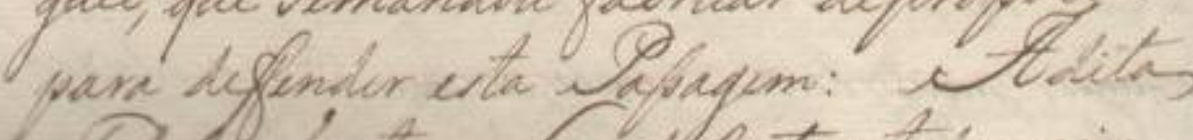

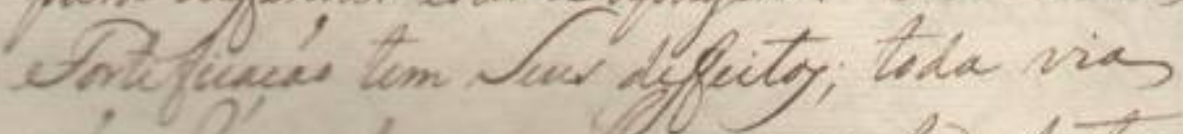

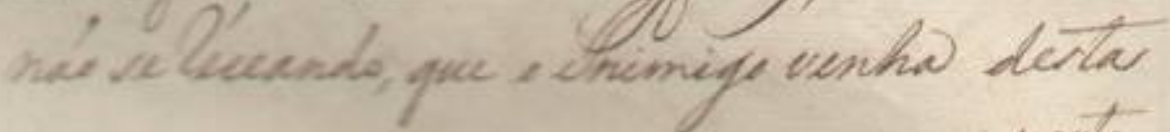
parte 
faz de Terra, e Faxina, dequalquer couza

pode servir, com tanto que seja capas de retar= dar os progressos do Inimigo emquanto sedaõ as dispoziçoens necessarias ao interior do $\mathrm{Pa}=$ iz.

Porem como os Espanhoes de repente, ecom munta pressa se retiraram para acudir á Colonia, Logo que no Rio daPratta apa= receu o Segundo grosso Comboy, que o Conde de Bobadella mandou para Soccorrer aSo= bredita Praça, mepersuado, que adita Forte= ficaçaõ ficasse por isso parada; emunto mais com anoticia da Paz, que poucos dias depois se divulgou por toda a America; demodo que produzindose agora o Risco daSobre dita Fortificaçaõ, e o Mappa do Seu Terreno, se po= derá milhor discorrer sobre este particular, e com mais acerto dispor asua Construcçaõ.

Tem o Inimigo outros mais Caminhos, para se introduzir no dito Rio Grande; hum dos quaes passa pelo Forte deSaõ $\mathrm{Mi}=$ guel, que semandou fabricar depropozito para deffender esta Passagem: A dita Fortificaçaõ tem Seus deffeitos; toda via naõ se receando, que o Inimigo venha desta 


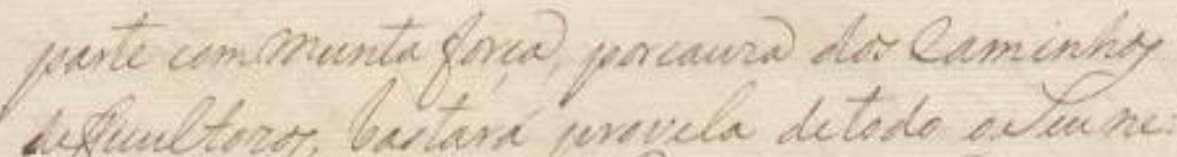

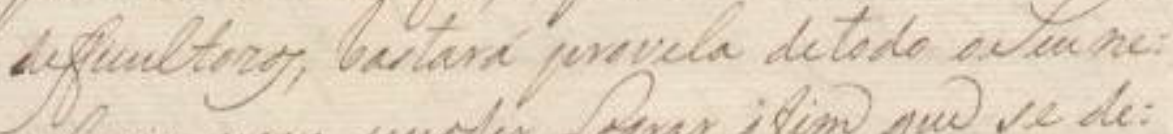

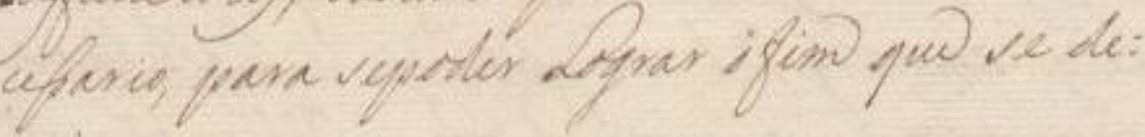

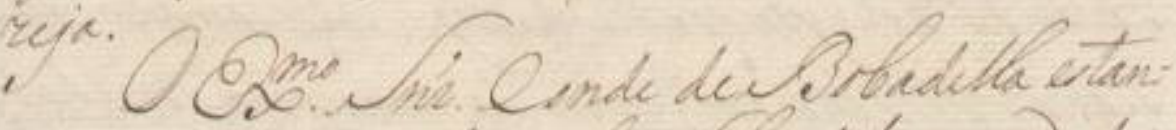

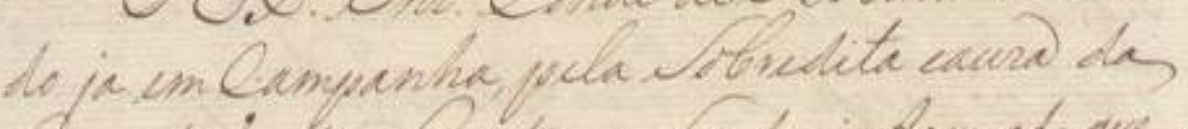

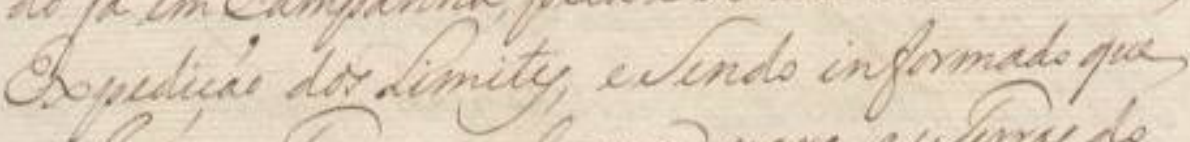

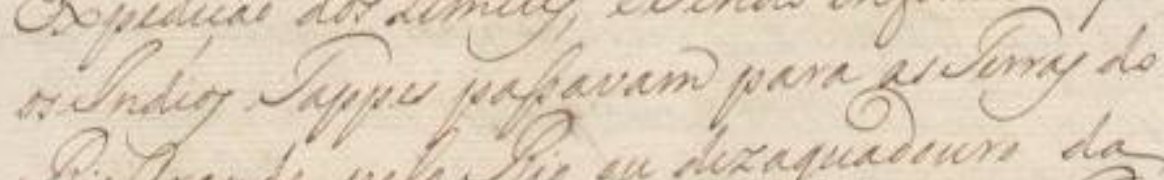

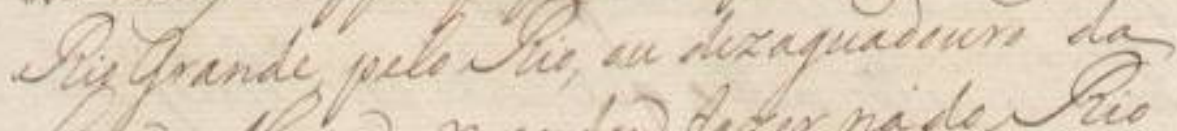

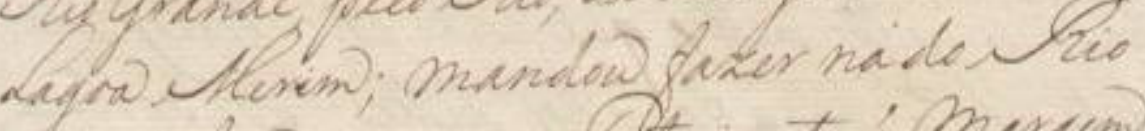

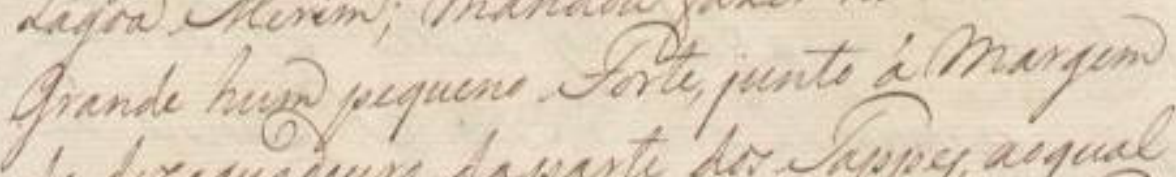

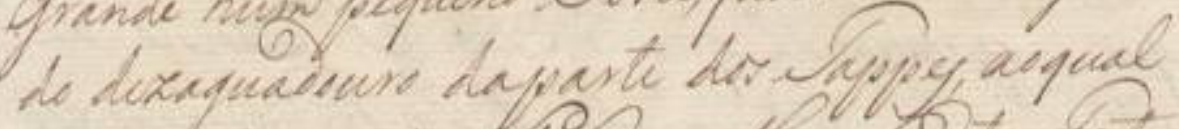

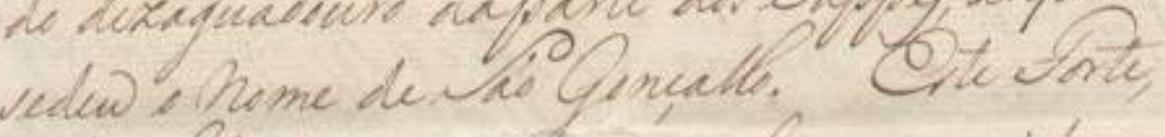

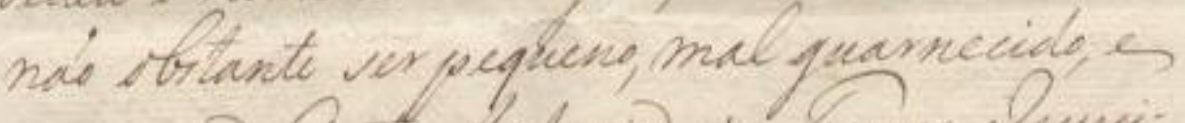

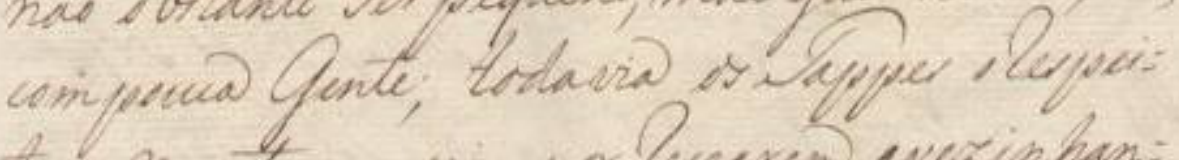
tam munto, weve por Lecearem wexinhan:

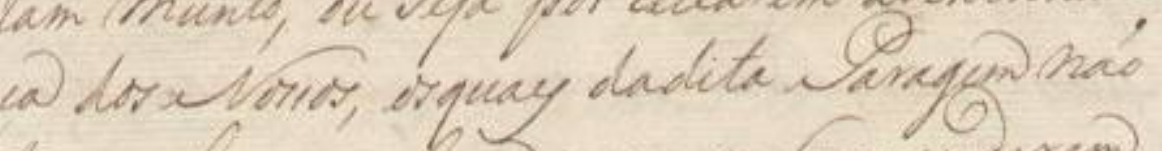

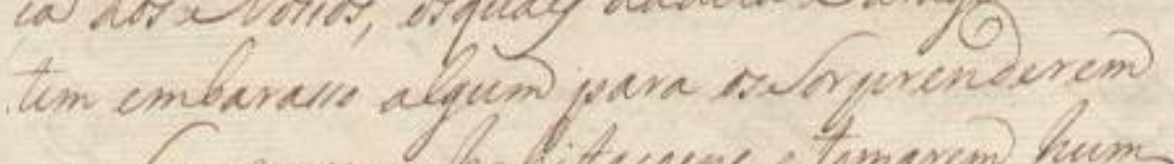
narsuy meing habitwoevy, itomarem hums

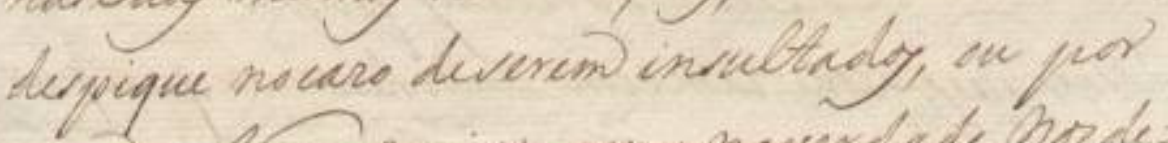

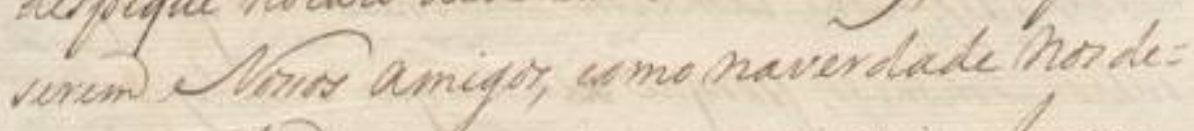

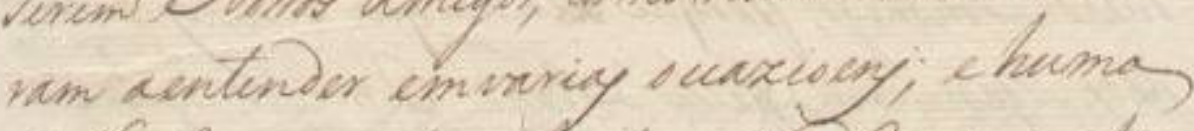

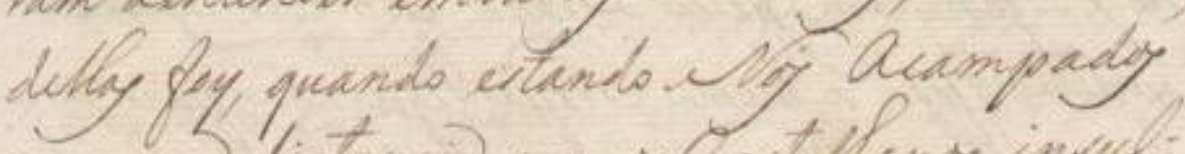

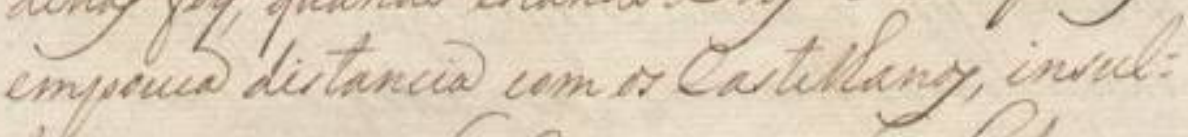

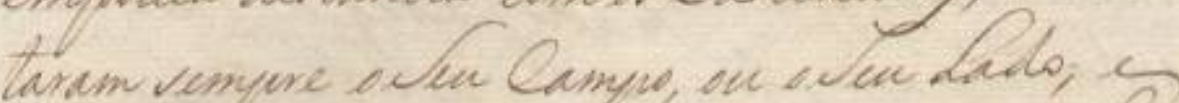

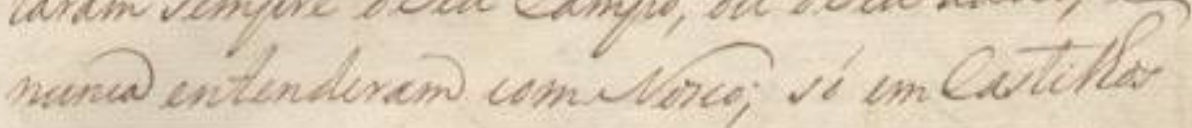


||45r|| [[parte]] communta força; por cauza dos Caminhos

defficultozos, bastará provela de todo oSeu ne= cessario, para sepoder Lograr o fim que se de= zeja.

O Excelentíssimo Senhor Conde deBobadella estan= do ja em Campanha, pela Sobredita cauza da Expediçaõ dos Limites, e Sendo informado que os Indios Tappes passavam para as Terras do Rio Grande, pelo Rio, ou dezaguadouro da

115 Lagoa Merim; mandou fazer na do Rio Grande hum pequeno Forte, junto á Margem do dezaguadouro daparte dos Tappes, ao qual sedeu o Nome de Saõ Gonçallo. Este Forte, naõ obstante ser pequeno, mal guarnecido, e com pouca Gente; todavia os Tappes o respei= tam munto, ou seja por recearem avezinhan= ça dos Nossos, os quaes dadita Paragem naõ tem embarasso algum para os Sorprenderem nas Suas mesmas habitaçoens, e tomarem hum despique no cazo deserem insultados, ou por serem Nossos amigos, como naverdade nos $\mathrm{de}=$ ram aentender em varias occazioens; e huma dellas foy, quando estando Nós Acampados empouca distancia com os Castelhanos, insul= 130 taram sempre o Seu Campo, ou o Seu Lado; e nunca entrenderam comNosco; só em Castilhos 
Arandy morfuntaram dunoute quanticade do

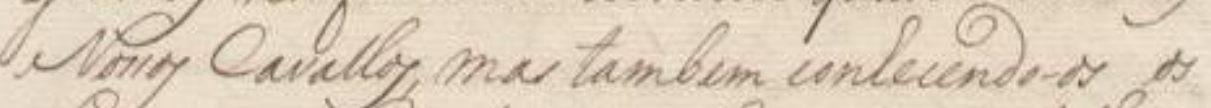

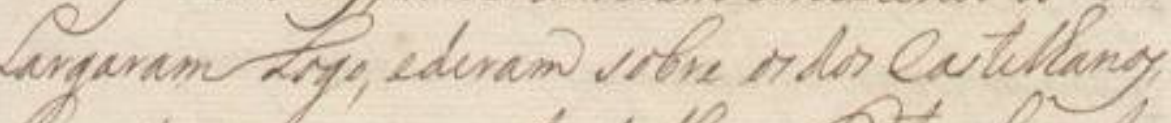

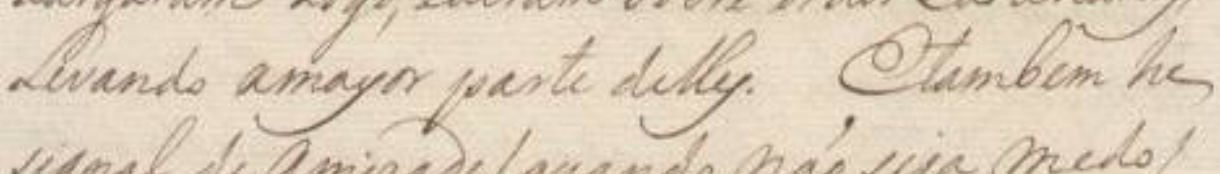

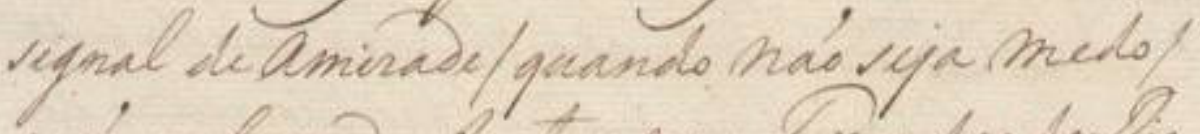

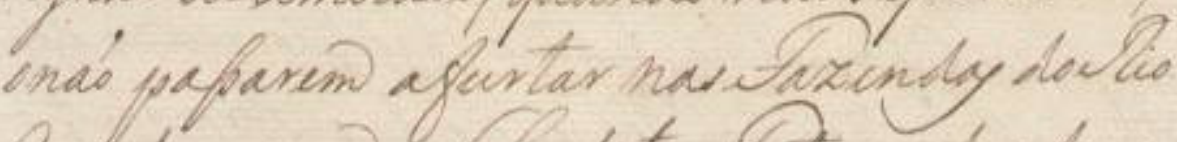
Prande porpw sobedito sorte, podende a

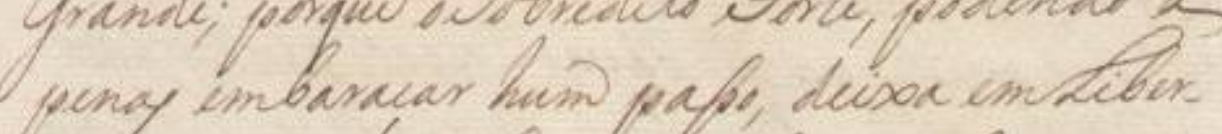
have munto's delle due sita' uncuberto

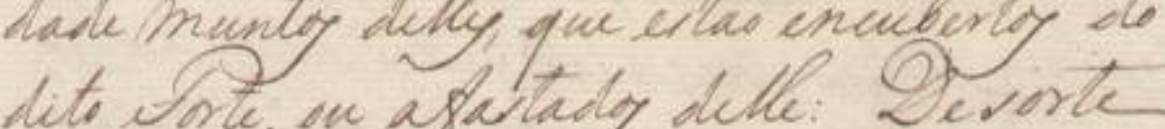
dite sorte, w afertady delle: berorte

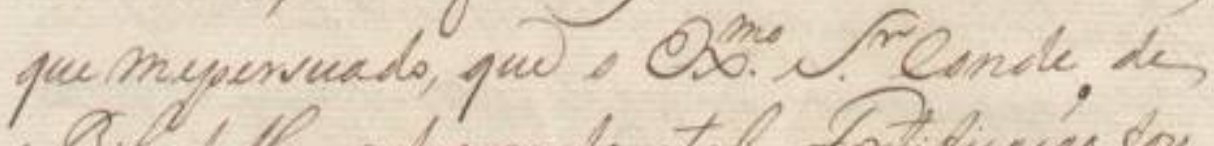

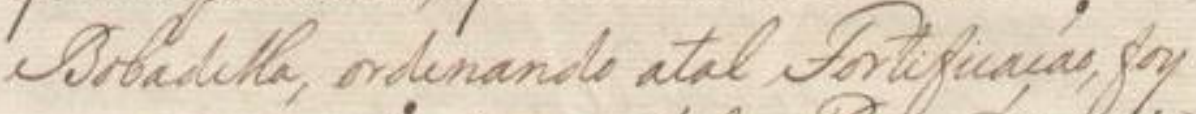
com eprevencé depue ctal sarequm veria

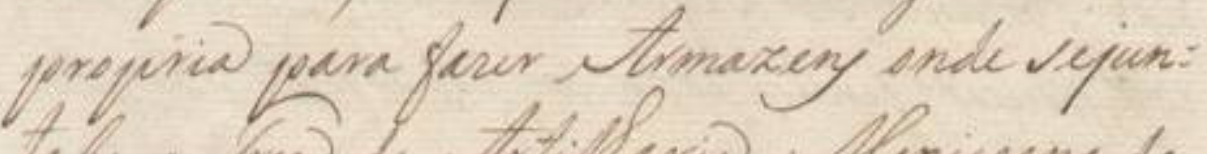

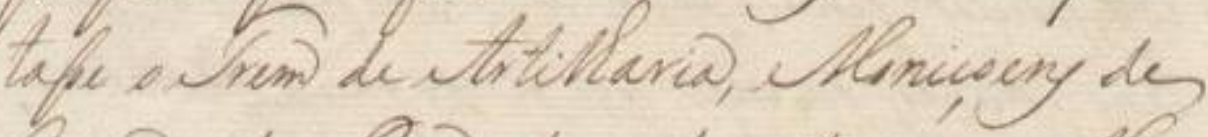
Vurra, edeclea, devendo entror navelle:

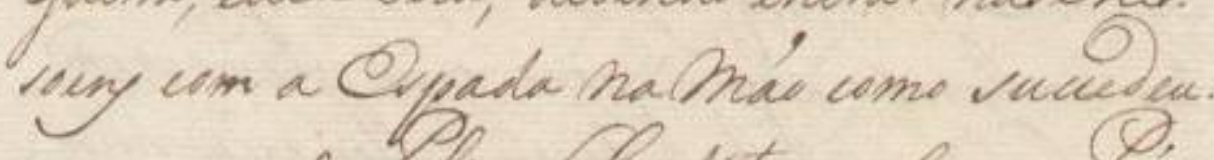

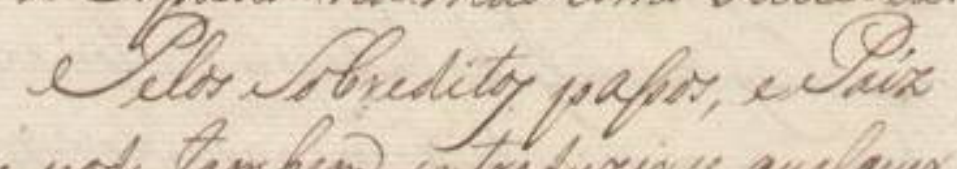

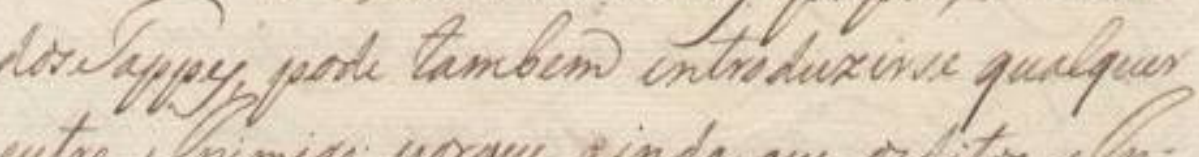
sutro nimigi porque inda que or vitoy en:

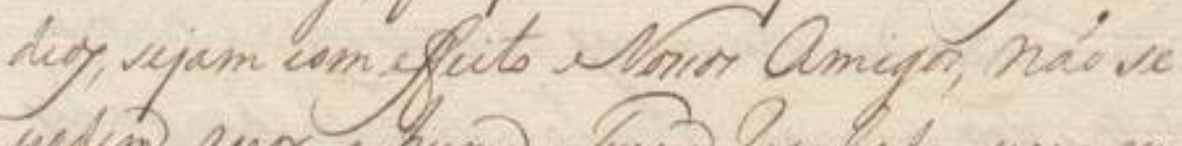

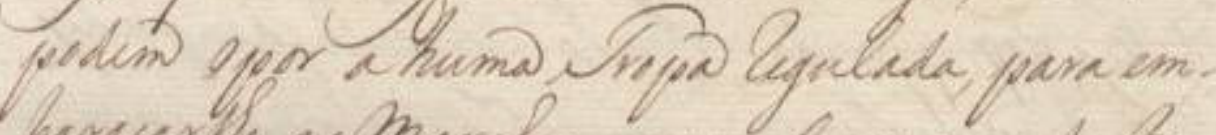

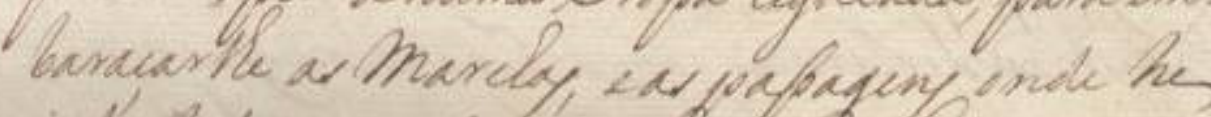

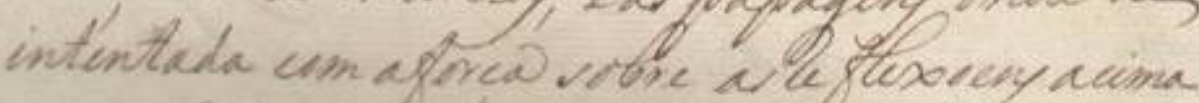

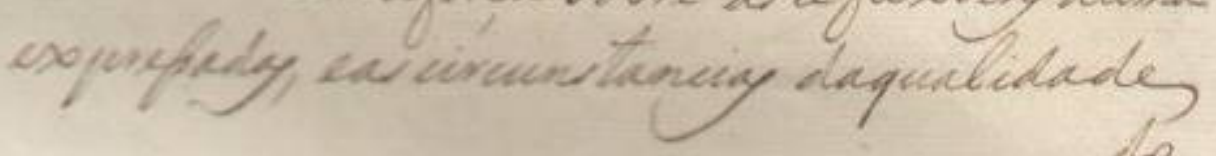


||45v\| [[gran]]des nos furtaram denoute quantidade dos

Nossos Cavallos, mas tambem conhecendo-os os

135 Largaram Logo, ederam sobre os dos Castelhanos,

Levando amayor parte delles. Etambem he

signal de Amizade / quando naõ seja medo/

o naõ passarem afurtar nas Fazendas do Rio

Grande; porque o Sobredito Forte, podendo a

140 penas embaraçar hum passo, deixa emLiber-

dade muntos delles, que estaõ encubertos do

dito Forte, ou afastados delle: De sorte

que mepersuado, que o Excelentíssimo Senhor Conde de

Bobadella, ordenando atal Fortificaçaõ, foy

com aprevençaõ deque atal Paragem seria

propria para fazer Armazens onde sejun=

tasse o Trem de Artilharia, Moniçoens de

Guerra, ede Boca; devendo entrar nas Mis=

soens com a Espada naMaõ como succedeu.

Pelos Sobreditos passos, e Paíz

dos Tappes, pode tambem introduzirse qualquer

outro Inimigo; porque ainda que os ditos $\ln =$

dios, sejam com effeito Nossos Amigos, naõ se

podem opor a huma Tropa regulada, para em-

baraçarlhe as Marchas, e as passagens onde he

intentada com aforça sobre as reflexoens acima

expressadas, eas circunstancias daqualidade 


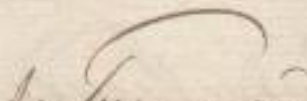

docurone, quo he homa pelanice deveuberta, sem

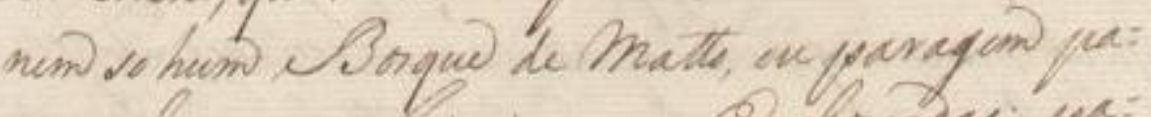

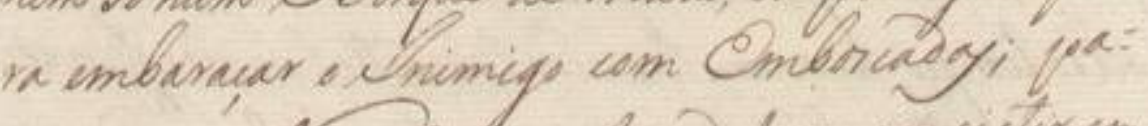

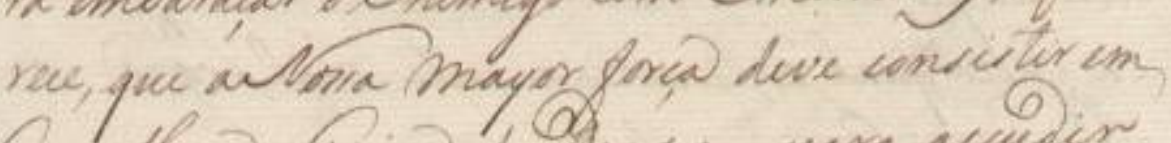

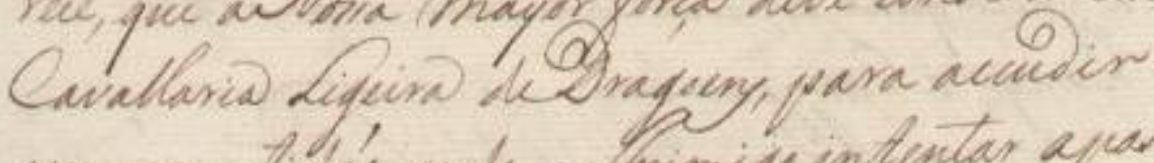
compormptidí onde on mimige interitar apar:

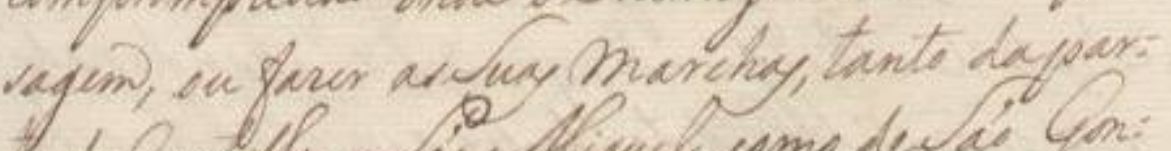

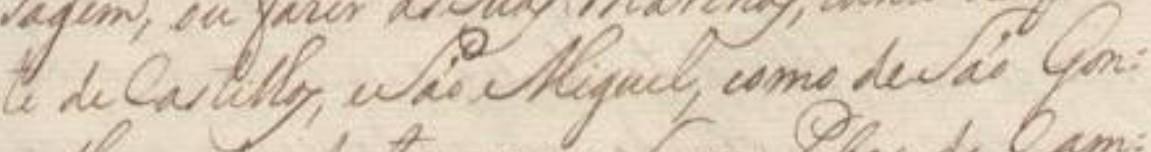
allo potendo truer wour Seper de Cam: ponha, sy de amivor.

Oemais todaclavalaria do lica

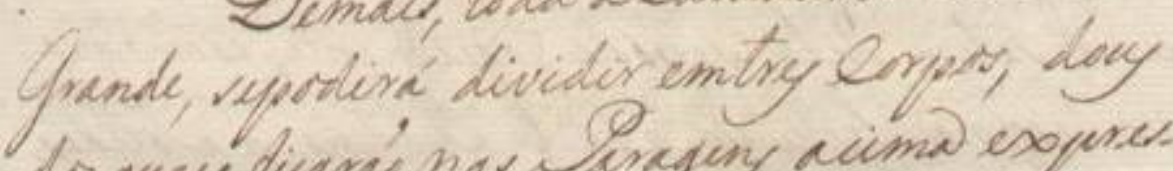

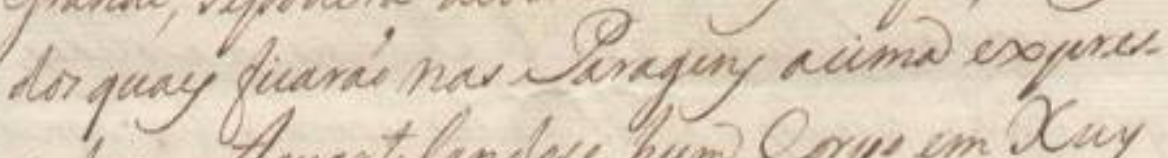

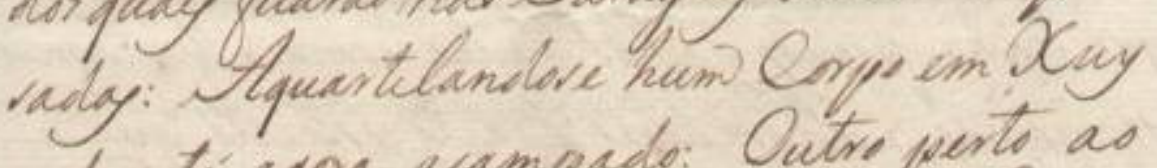
ande erti agon acampado: Outre perts as

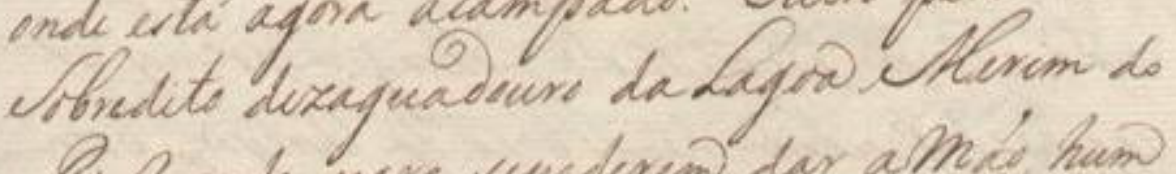

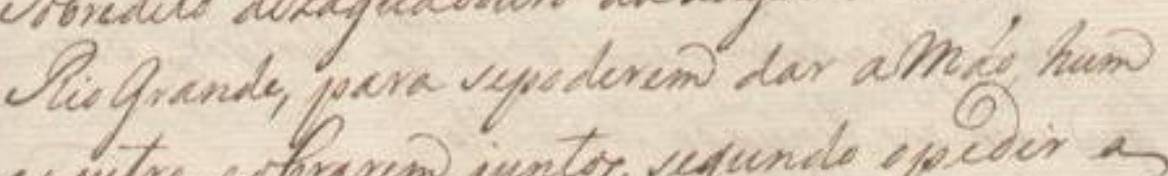
covitr, evoraren juntoy, sefunde opedir as suaxiá: Otruiro Orpo poderá vereir pe.

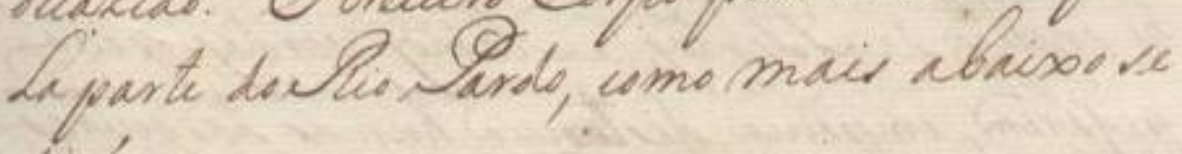
dere.

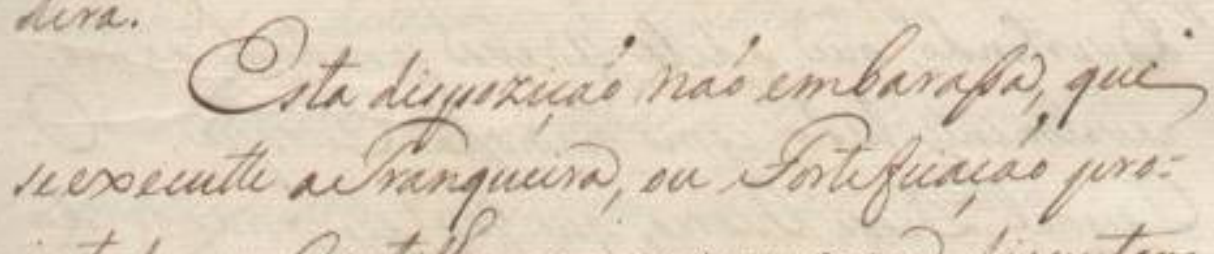
jatada em Qutilo pequengiporquo virpectax-

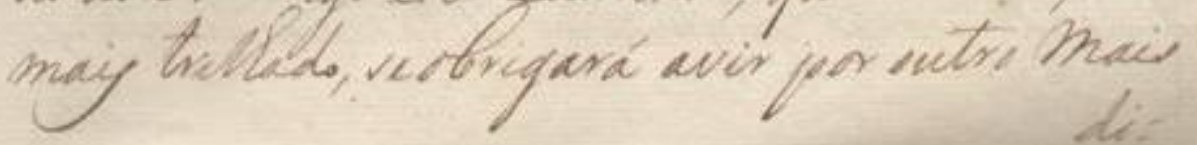


||46r|| do Terreno, que he huma planice descuberta, sem

nem so hum Bosque de Matto, ou paragem pa=

ra embaraçar o Inimigo com Emboscadas; pa= rece, que aNossa Mayor força deve consistir em Cavallaria Ligeira deDragoens, para accudir com promptidaõ onde o Inimigo intentar apas= sagem, ou fazer as Suas Marchas, tanto dapar= te de Castilhos, eSaõ Miguel, como deSaõ Gon= çallo; podendo trazer as Suas Pessas deCam= panha, ou de amiudar.

Demais, toda a Cavallaria do Rio

170 Grande, sepodirá dividir emtres Corpos, dous dos quaes ficaraõ nas Paragens acima expressadas: Aquartelandose hum Corpo em Xuy onde está agora acampado: Outro perto ao Sobredito dezaguadouro da Lagoa Merim do Rio Grande, para sepoderem dar aMaõ, hum ao outro, eobrarem juntos, segundo o pedir a occaziaõ: O terceiro Corpo poderá servir peLa parte do Rio Pardo, como mais abaixo se dirá.

Esta dispoziçaõ naõ embarassa, que se executte aTranqueira, ou Forteficaçaõ pro= jectada em Castilhos pequenos; porque disputan= do ao Inimigo este Caminho, que he real, eomais trilhado, se obrigará avir por outro mais

$$
d i=
$$


||46v $\|$

dilatade, cincomorlo, poor onde, taluy vellipordes flarer mair vigorra yporicás, exom isr vega: nle tompe, circunstancia tas wtel nadefenci: ix ocla qual ordinariamente mald rypa crimige a Oampanho.

Alespite pois da Ortefiencás no estreite do Slic frande, que setem cbandonads pen cauza Sorredita bever a una Situacás arya micuda, efteicia, que cada vento atrens. porta de huma pante cocitri, cenobre Caxy,

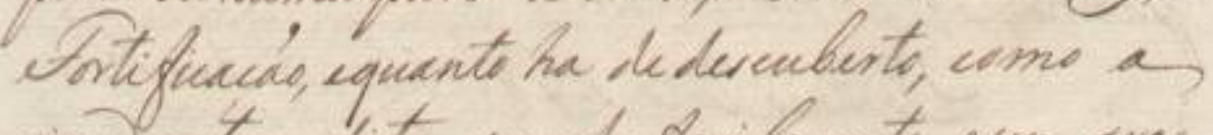
cima vetem dito, sepode gacilmente, erem gra:

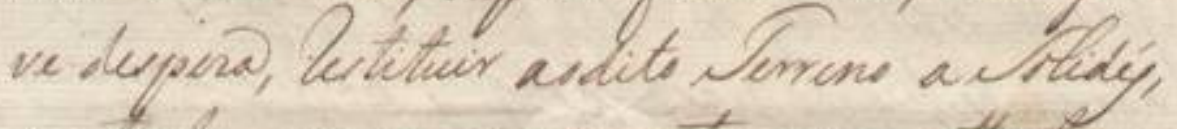
que tinha poung annos ante, como atturams nimumos Sloradorer dodito ertreito, que as inda vivem, etem nerta Aregim arvusy $C_{\text {: }}$ zey, eardifindem de rovedita Arejo, bem quit com untimuad traballe.

Omedo de ertablear idito curme,

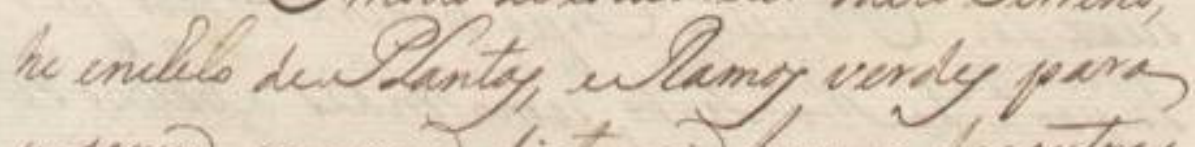

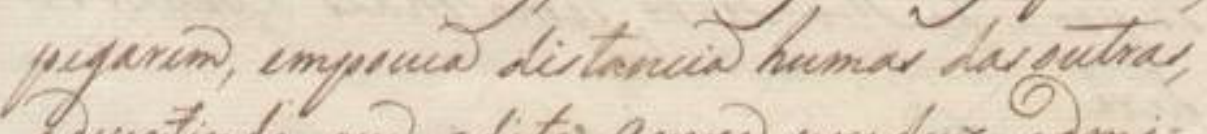
soventindo, quo edito arye furodwe edmi: revelmente tudo, come nanofia Curop: O

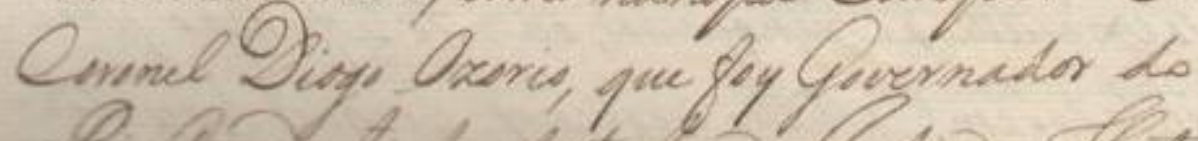

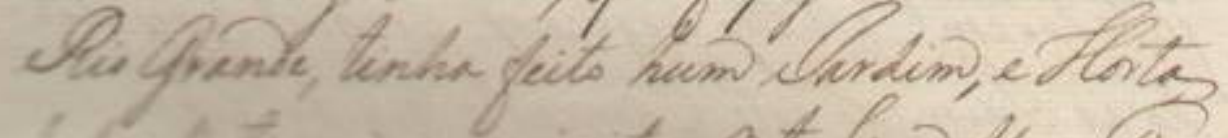

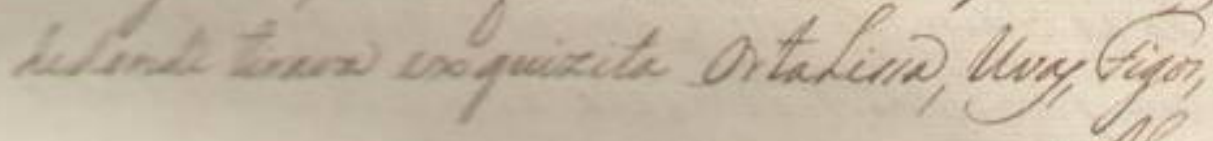

He:

215 
\|46v || dilatado, eincomodo, por onde talves se lhe pode

fazer mais vigoroza opoziçaõ, e com isso se gan=

nha tempo, circunstancia taõ uttil nadeffenci=

va, pela qual ordinariamente mal Logra o

190 Inimigo a Campanha.

A respeito pois daForteficaçaõ no

estreito do Rio Grande, que setem abandonado

pela cauza Sobredita deser aSua Situaçaõ

areya miuda, e fLuida, que cada vento atrans=

195 porta de huma parte aoutra, eencobre Cazas,

Fortificaçaõ, equanto ha de descuberto, como a

cima setem dito, sepode facilmente, esem gra=

ve despeza, restituir ao dito Terreno a Solidés,

que tinha poucos annos antes, como attestam

200 os mesmos Moradores do dito estreito, que a

inda vivem, etem nesta Paragem as Suas $\mathrm{Ca}=$

zas, eas deffendem daSobredita Areya, bem

que com continuado trabalho.

O modo de establecer o dito Terreno,

205 he enchelo dePLantas, eRamos verdes para

pegarem, empouca distancia humas das outras,

advertindo, que adita areya produz admi=

ravelmente tudo, como nanossa Europa: O-

Coronel Diogo Ozorio, que foy Governador do

210 Rio Grande, tinha feito hum lardim, e Horta

dedonde tirava exquizita OrtaLissa, Uvas, Figos,

$\mathrm{Ma}=$ 


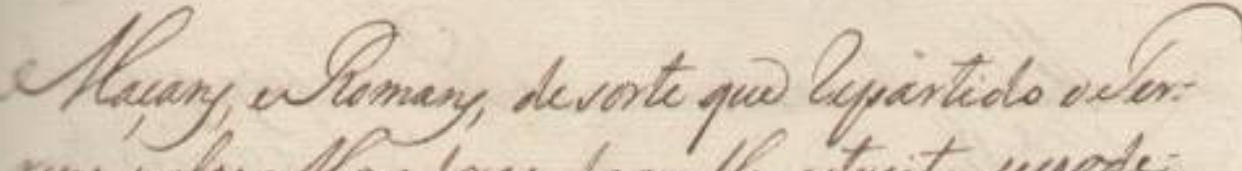

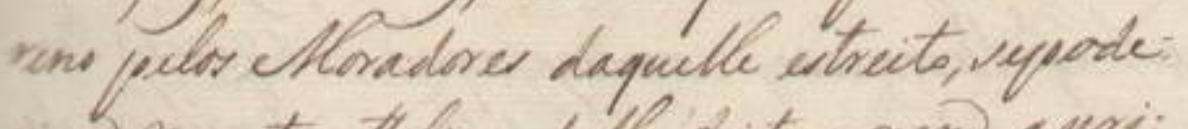
rien munte utilizar dolle; gita porem operi:

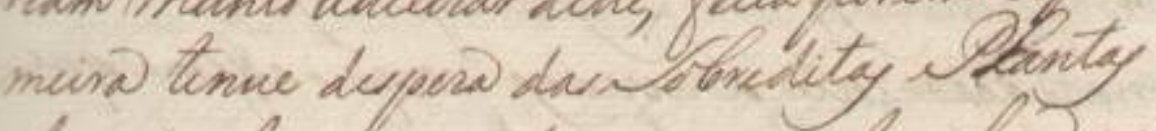

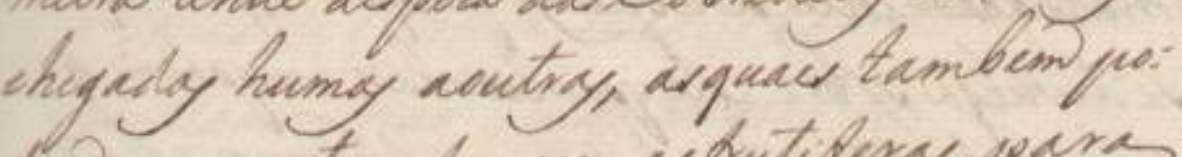

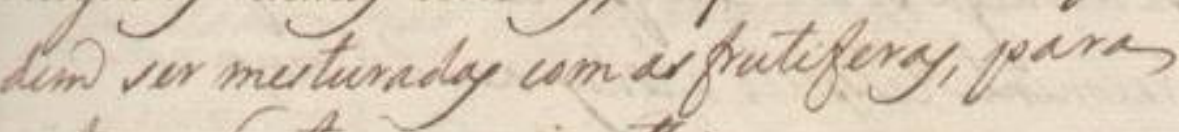

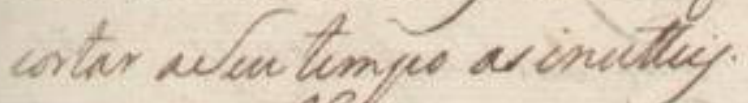

e lle sperincipies duta Lertauruas de. ve comecar determinundo primuirs him Qa: minhe onde lwem popar of Corros, elevelli: ros oqual Qaminho veje de huma parte, exitra

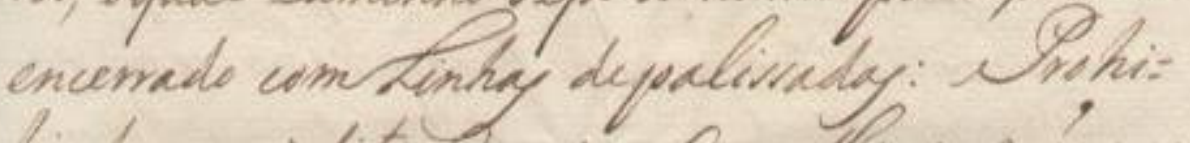

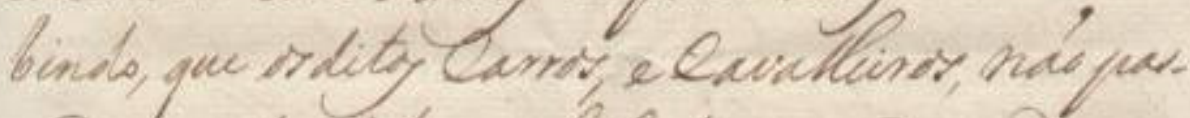

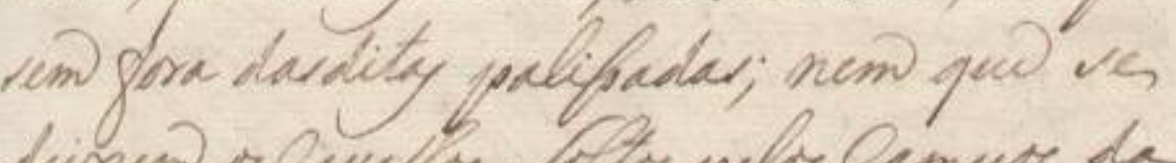

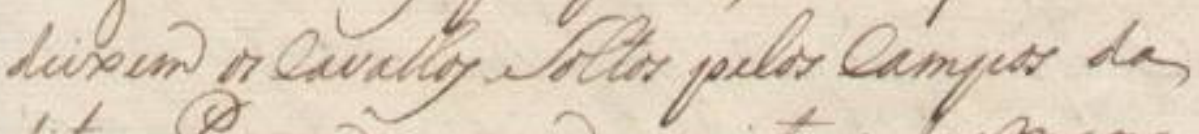

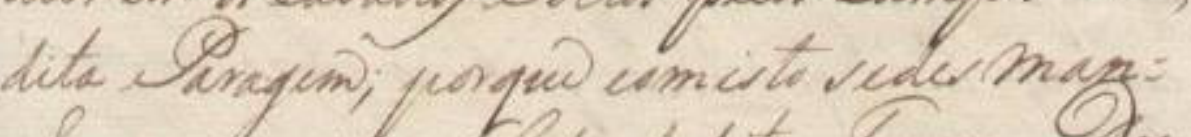

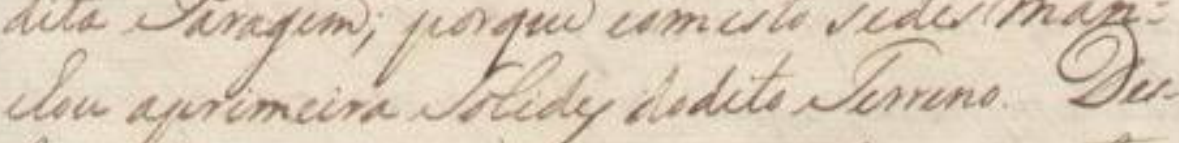

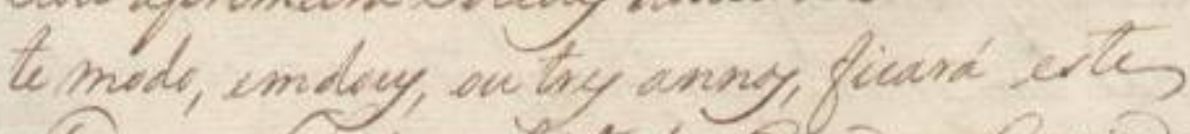

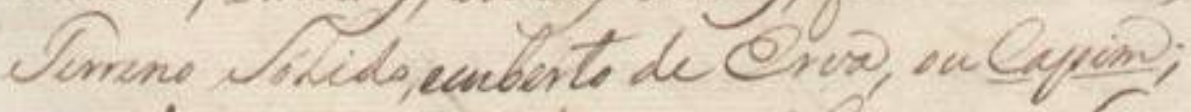
enciás sepoderi entrar na fora la leas

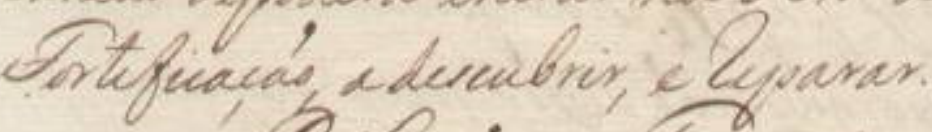

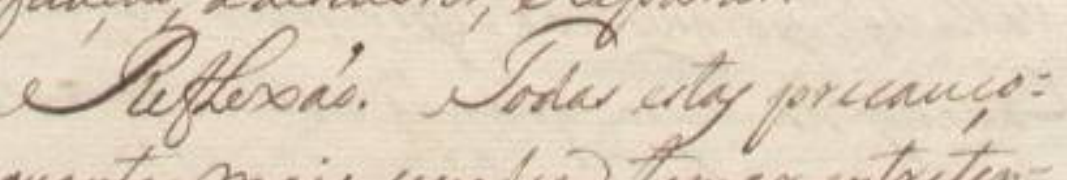

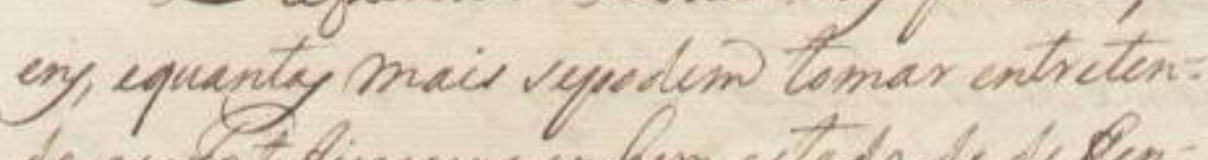

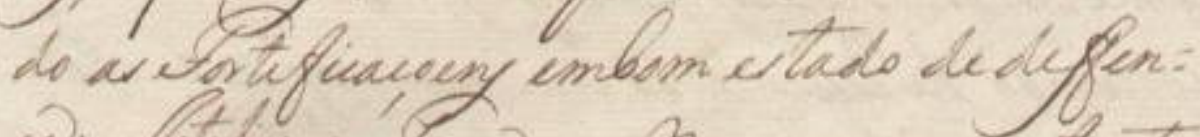

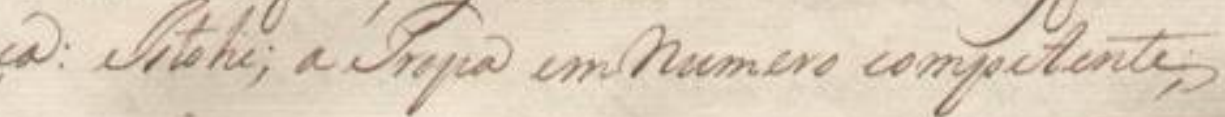


||47r|| [[Ma]]çans, eRomans, desorte que repartido oTer-

reno pelos Moradores daquelle estreito, sepode= riam munto uttilizar delle; feita porem apri=

meira tenue despeza das Sobreditas PLantas

chegadas humas aoutras, as quaes tambem po= dem ser mesturadas com as frutiferas, para cortar aSeu tempo as inutteis.

Mas o principio desta restauraçaõ de-

220 ve começar determinando primeiro hum $\mathrm{Ca}=$ minho onde devem passar os Carros, eCavallei= ros, o qual Caminho seja de huma parte, eoutra encerrado comLinhas depalissadas: Prohi= bindo, que os ditos Carros, e Cavalleiros, naõ passem fora das ditas palissadas; nem que se deixem os Cavallos Soltos pelos Campos da dita Paragem; porque com isto sedesman= chou aprimeira Solides dodito Terreno. Deste modo, em dous, ou tres annos, ficará este

230 Terreno Sólido, ecuberto deErva, ou Capim; eantão sepoderá entrar na Obra da Sua Forteficaçaõ, adescubrir, e reparar.

Reflexaõ. Todas estas precauço= ens, equantas mais sepodem tomar entreten= do as Fortificaçoens embom estado de deffen= ça: Isto he; a Tropa emNumero competente; 
||47v

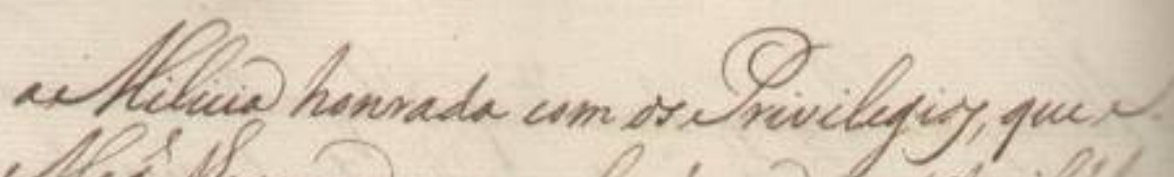

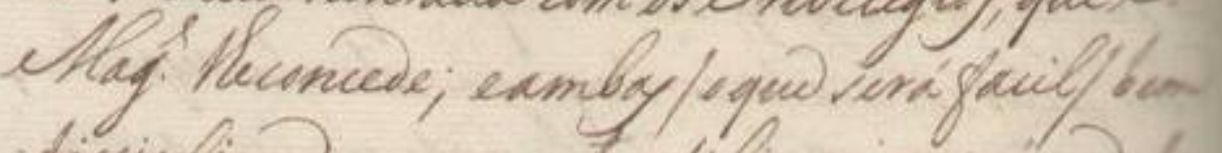
dicuplinadoy; com estay diligenciag ninca de

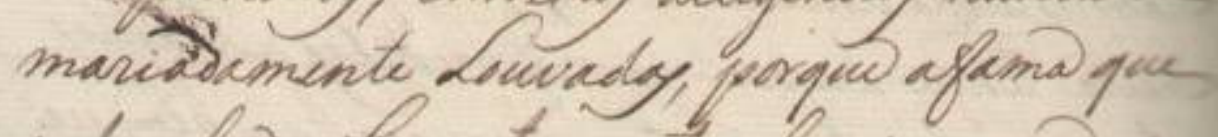

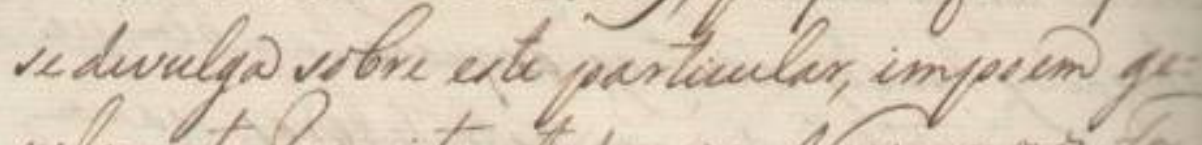

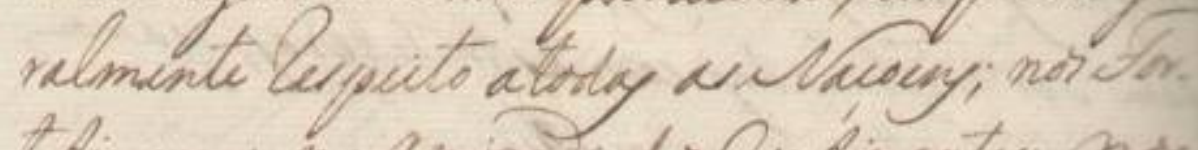
tifianmig na Amirave do enfinanty, nos

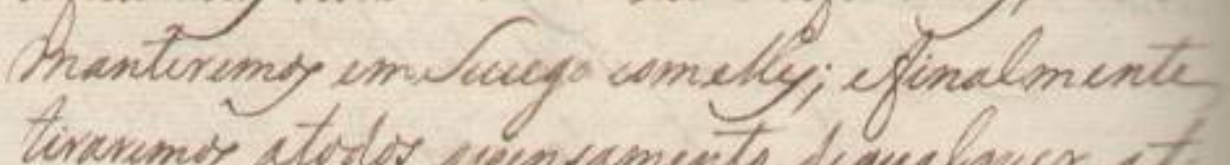
tirarimiy atodos piensamento dequalquer ats

- Vas parrece porum tás facil, que

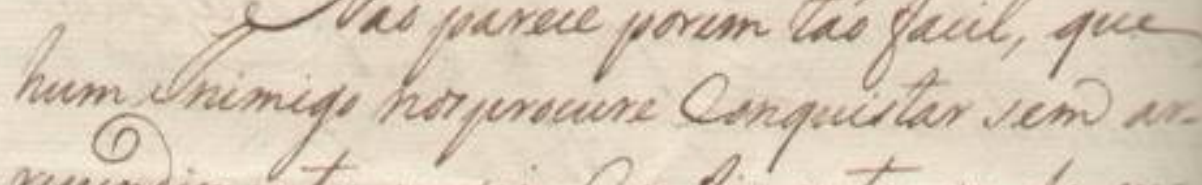
rypendiminte; w wyja Confinante; ou de we: Ir affartade. Clima; joorqui ves Animifo he Curgpes, nais porde, ipmorimeiro tuyar, trover comsige tudo juo the he preciers para huma tal imprereas; equande gerre piravids detudo, nás tem omodo de otranoportar portás dela=

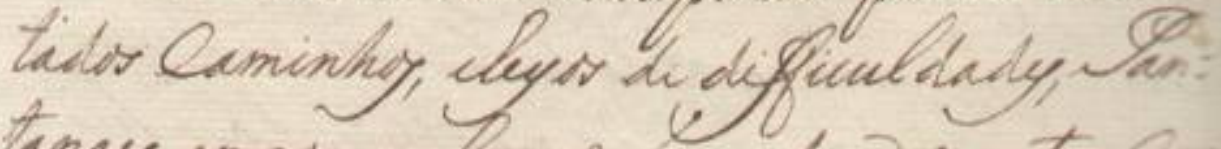
tanay, emady papsy: nao posdem montar Ca: vallaria, porguw nas sepidem servir com do Owatly da Sira, quando aclem quem tho de,

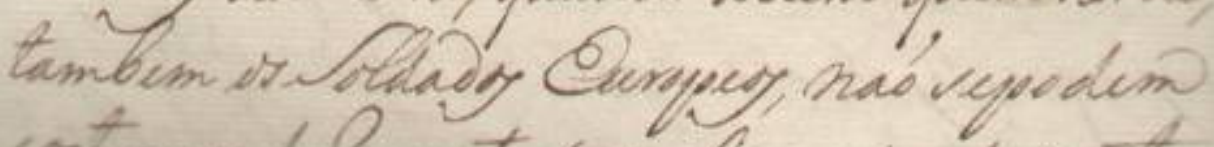
cortumer de Revente is inclemencisy do ar thre.

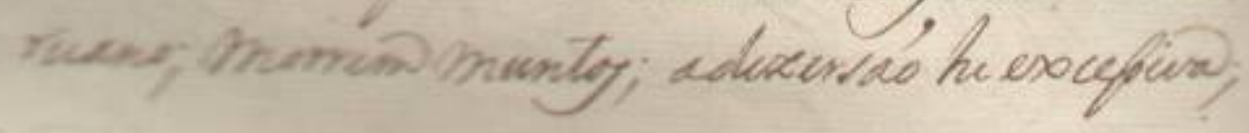

219 
||47v || [[a]]Milicia honrada com os Privilegios que Sua

Magestade Iheconcede; eambas / o que será facil / bem

disciplinadas; com estas diligencias nunca de maziadamente Louvadas, porque afama que se divulga sobre este particular, impoem ge= ralmente respeito atodas as Naçoens; nos For= tificaremos na amizade dos Confinantes; nos manteremos em Sucego com elles; efinalmente tiraremos atodos o pensamento dequalquer at= tentado contra Nós.

Naõ parece porem taõ facil, que hum Inimigo nos procure Conquistar sem ar= rependimento; ou seja Confinante; ou de ou= tro afastado Clima; porque se o Inimigo he Europeo, naõ pode, emprimeiroLugar, trazer comsigo tudo que the he precizo para huma tal impreza; equando fosse provido detudo, naõ tem omodo de 0 transportar portaõ dila= tados Caminhos, cheyos de difficuldades, Pan= tanaes, emaos passos; naõ podem montar $\mathrm{Ca}=$ vallaria; porque naõ sepodem servir com os Cavallos daTerra, quando achem quem Ihos de; tambem os Soldados Europeos, naõ sepodem costumar de repente ás inclemencias do ar Ame= ricano; morrem muntos; adezersaõ he excessiva; 
\|48r

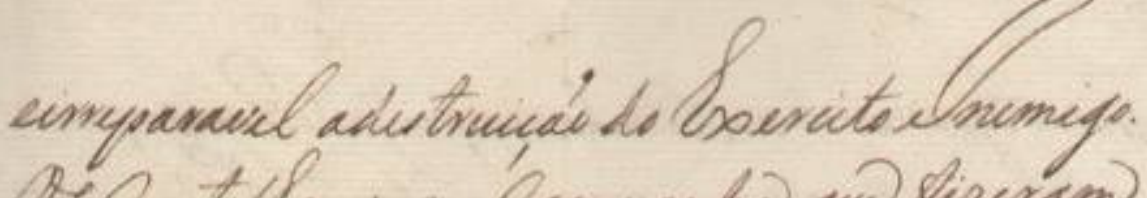

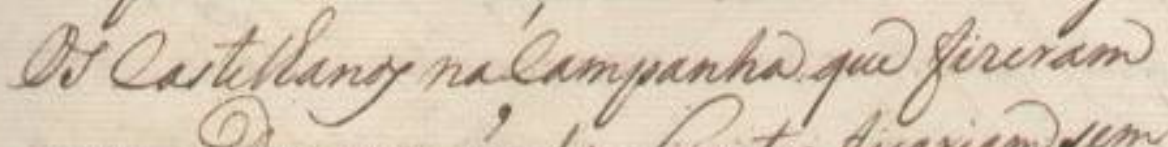

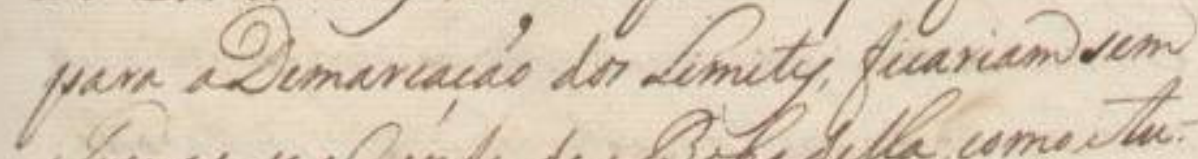

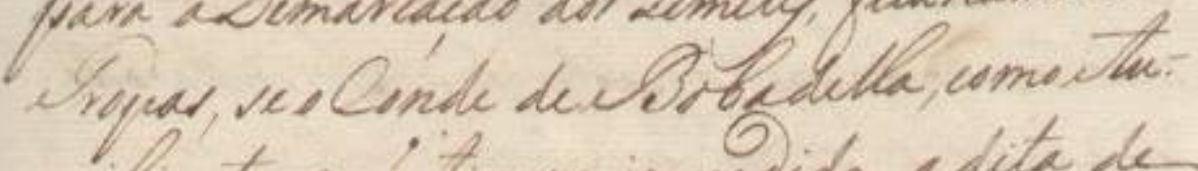
sciliante, nas twene impeidido adita des zercas.

Omair, sunde linta edifiuuldaid,

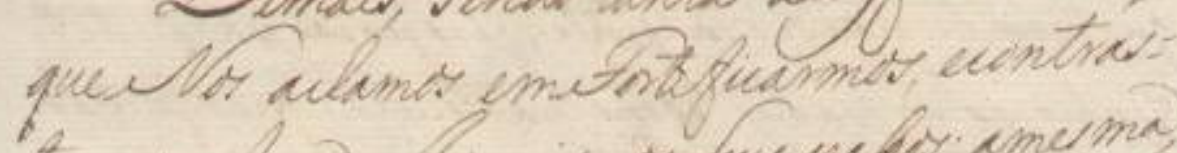

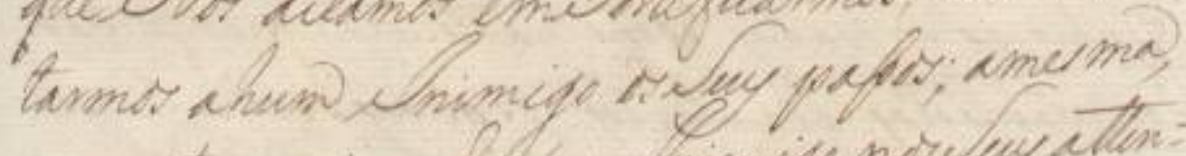
emuente mair vala simige noveluy ettur: tado emeitallecerse: Oupor waxo conve-

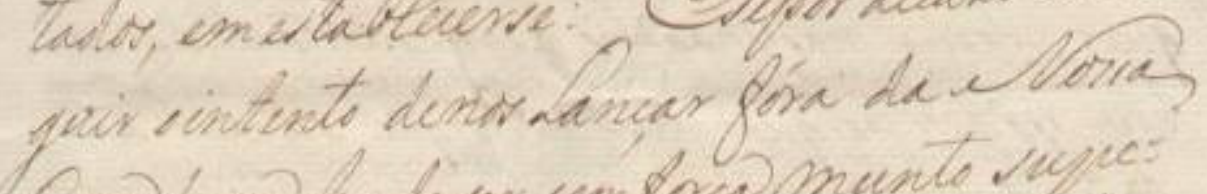

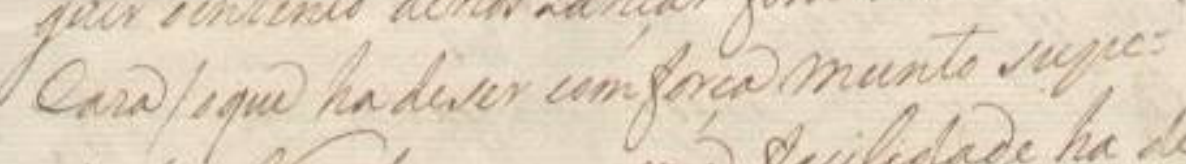

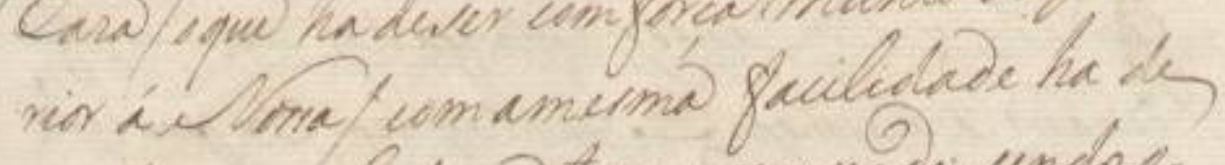
verder a yesfe dequid tiver waurpace, sundo a. - brigade urorsy meumo usebandonas; posque

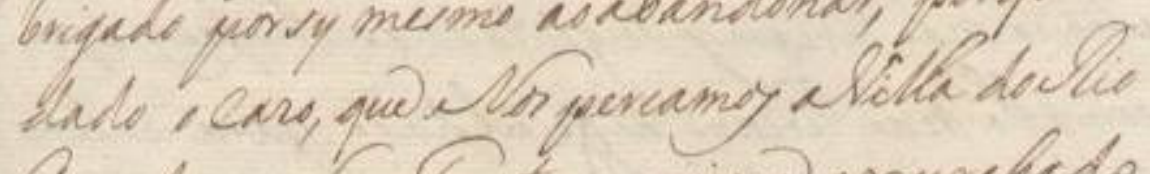

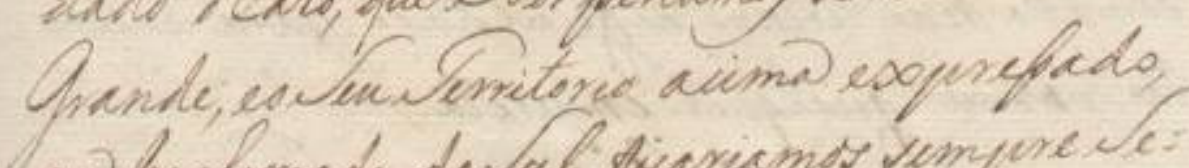
qui hechanade de at ficarianos sempore des

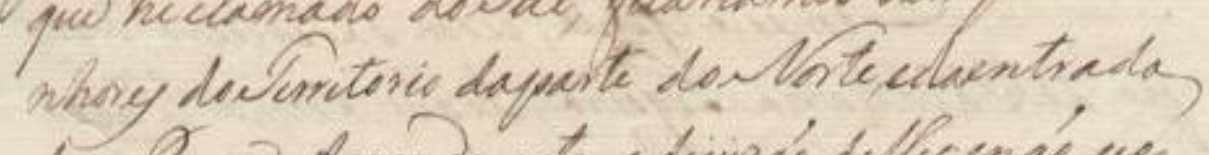

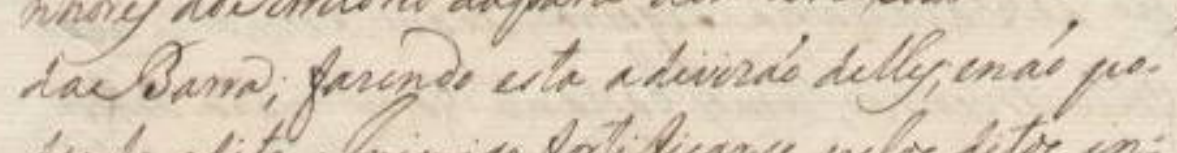
undo dito Inimige fortifienre pally litey in:

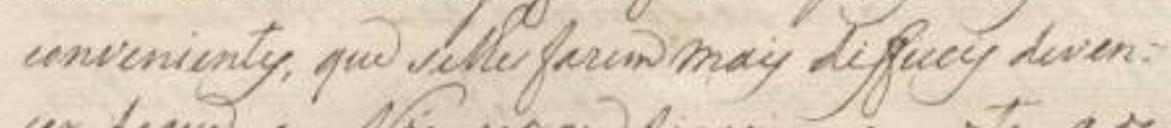

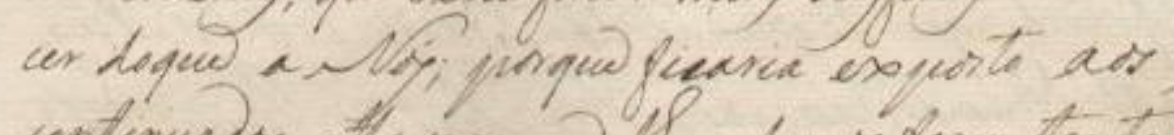
continualing allaquy, quid the pedemer farer, tanto por

221 
||48r|| [[e]]irreparavel adestruiçaõ do Exercito Inimigo.

185 Os Castelhanos naCampanha que fizeram para aDemarcaçaõ dos Limites, ficariam sem Tropas, se o Conde de Bobadella, como Au= xiliante, naõ tivesse impedido a dita de= zerçaõ.

Demais, sendo tanta adifficuldade, que Nos achamos emFortificarmos, econtras= tarmos a hum Inimigo os Seus passos; amesma, emunta mais achará o Inimigo nos Seus atten= tados, em establecerse: Esepor accazo conse=

195 guir o intento denos Lançar fóra da Nossa Caza $/$ o que ha deser com força munto supe $=$ rior á Nossa/ com amesma facilidade ha de perder a posse do que tiver uzurpado; sendo $0=$ brigado por sy mesmo as abandonar; porque 200 dado o cazo, que Nos percamos aVilla do Rio Grande, eo Seu Territorio acima expressado, que he chamado do Sul; ficariamos sempre $\mathrm{Se}=$ nhores do Territorio daparte do Norte, edaentrada daBarra; fazendo esta a divizão delles; enaõ po205 dendo 0 dito Inimigo fortificarse pelos ditos in= convenientes, que selhes fazem mais difficeis deven= cer do que a Nós; porque ficaria exposto aos continuados attaques, que lhe podemos fazer, tanto 


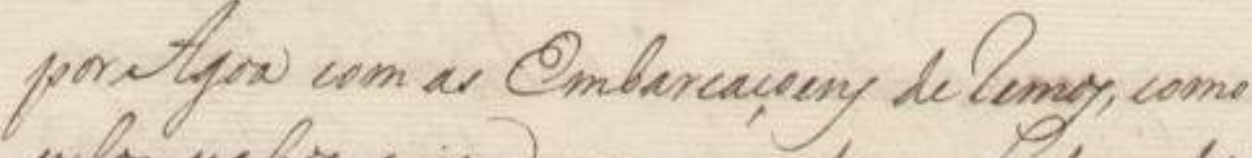

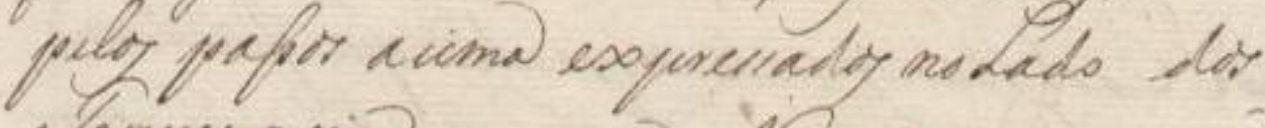

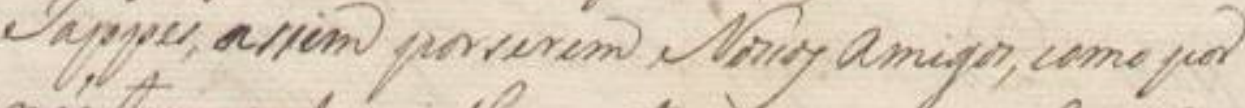

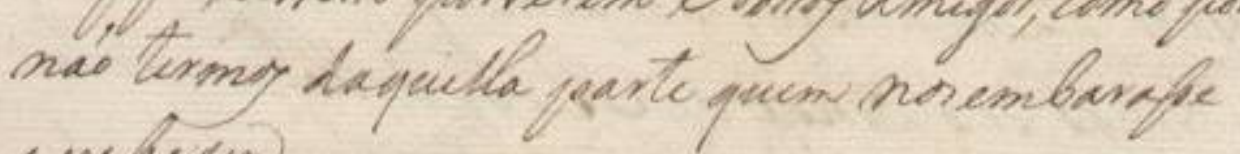
epeperfer.

2 har countaren perincipal quelos

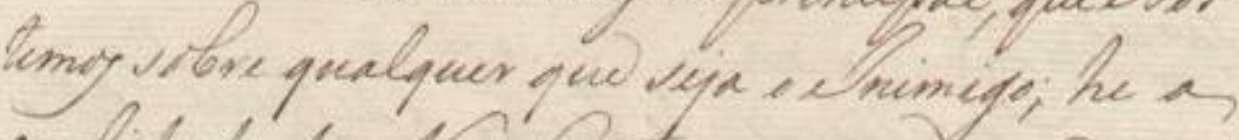

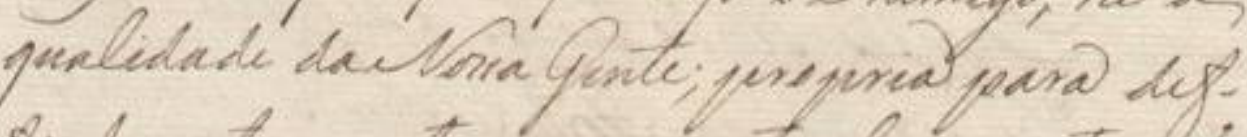
Qunder erta parter come partivelarmente teo

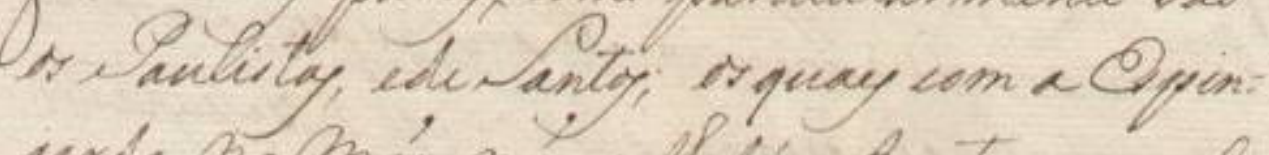

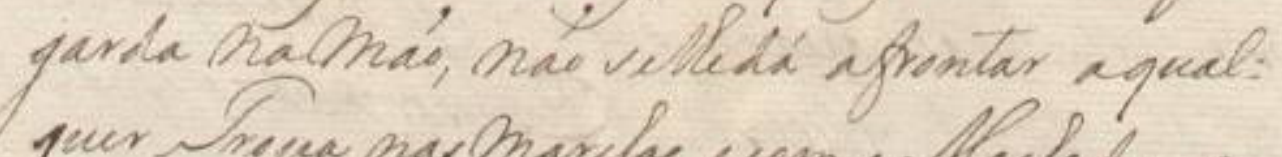

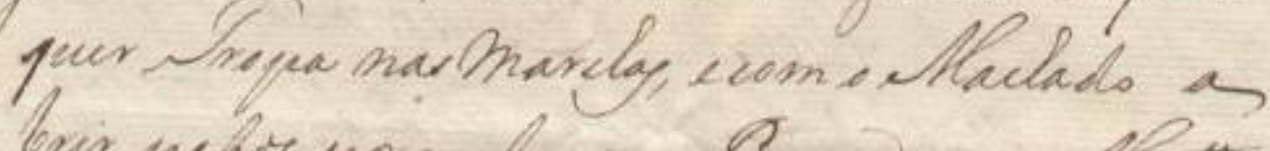

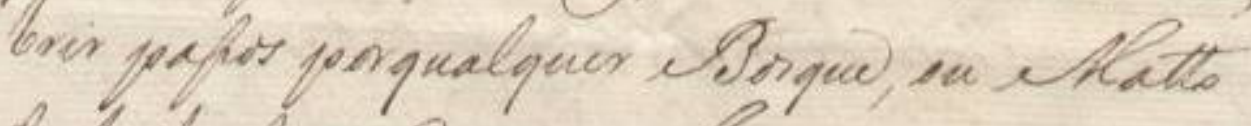

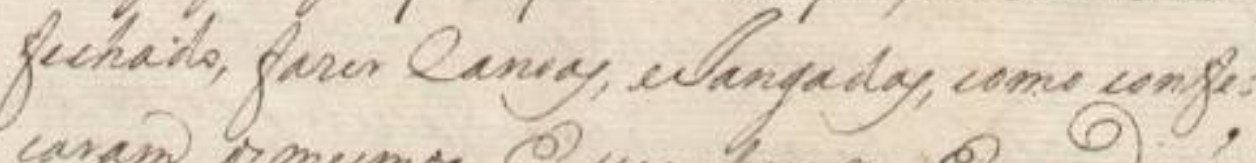

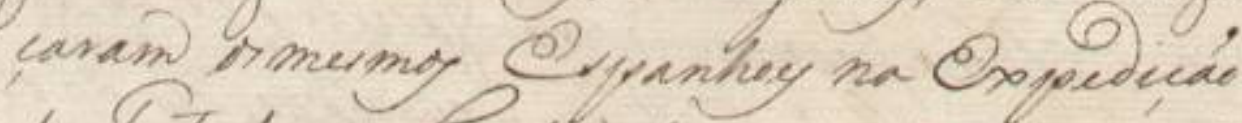
dos retado denimity dizendo, jud vem erta

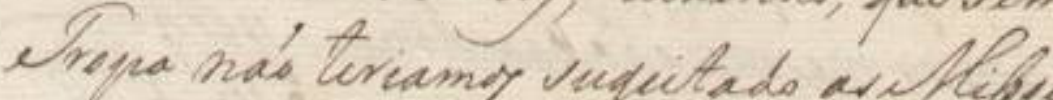
If, a comstha né teriam digiveldade pare inter. Ar, severer qualquer imperesa.

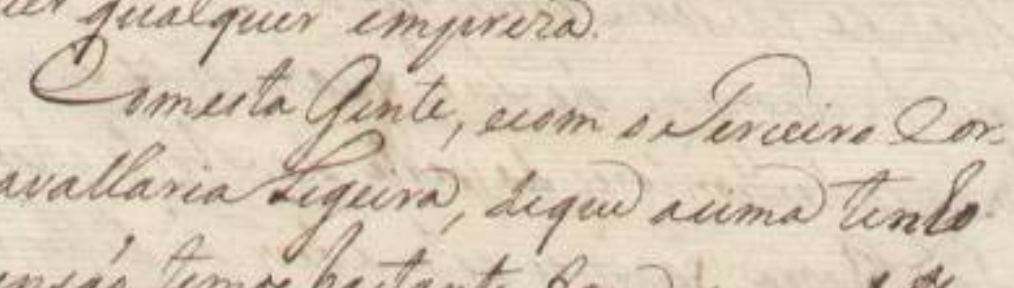

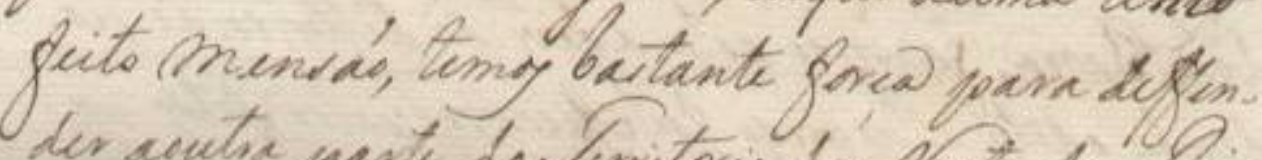

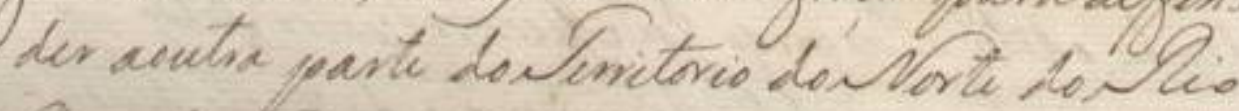

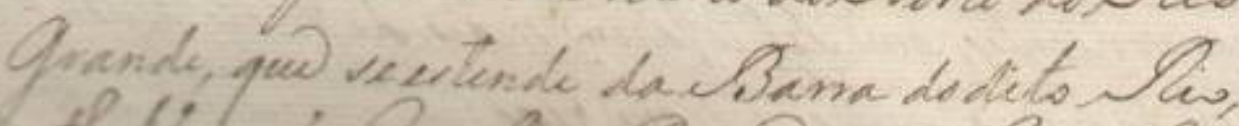

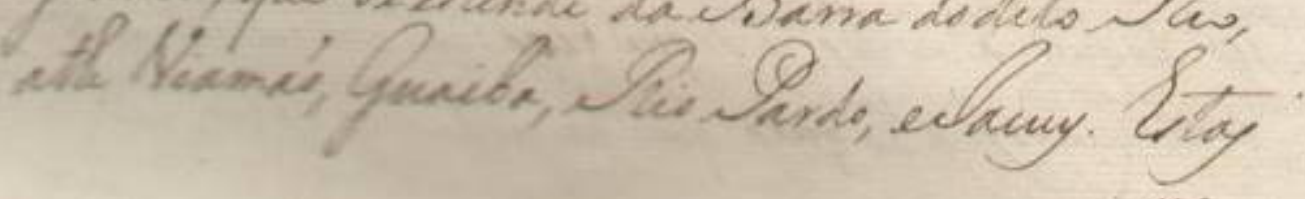


$210\|48 \mathrm{v}\|[[$ por]] Agoa com as Embarcaçoens de remos, como

pelos passos acima expressados no Lado dos

Tappes, assim por serem Nossos amigos, como por

naõ termos daquella parte quem nos embarasse

a passagem.

Mas aventagem principal, que Nós

temos sobre qualquer que seja o Inimigo; he a

qualidade da Nossa Gente; propria para def-

fender estas partes, como particularmente saõ

os Paulistas, ede Santos; os quaes com a Espin=

220 garda NaMaõ, Naõ selhedá afrontar aqual=

quer Tropa nas Marchas, e com o Machado a

abrir passos porqualquer Bosque, ou Matto

fechado, fazer Canoas, elangadas, como confe $=$

çaram os mesmos Espanhoes na Expediçaõ

225 do Tratado deLimites; dizendo, que sem esta

Tropa naõ teriamos sugeitado as Missoens, eque

com ella naõ teriam difficuldade para inten=

tar, evencer qualquer empreza.

Comesta Gente, ecom o Terceiro Cor-

230 po de CavallariaLigeira, deque acima tenho

feito mensaõ, temos bastante força para deffen-

der aoutra parte do Territorio do Norte do Rio

Grande, que se estende da Barra do dito Rio,

athe Viamaõ, Guaiba, Rio Pardo, elacuy. Estas 
||49r\|

paragery tedeflenden in muntic mair facilia:

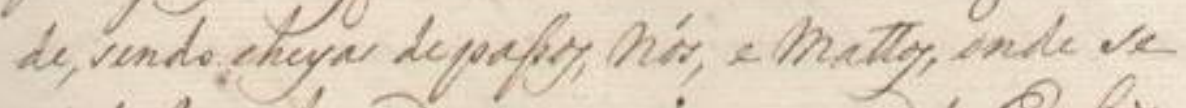

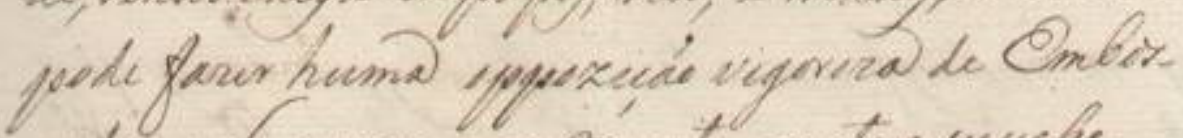

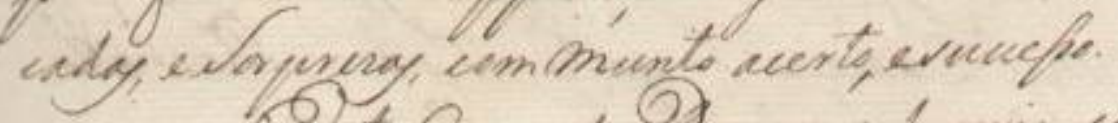

(6) Emper de Orequery teveria com. pletarve, porqua inyparece etar munto demi: nutto: Verdade he, que veconta munte vothe

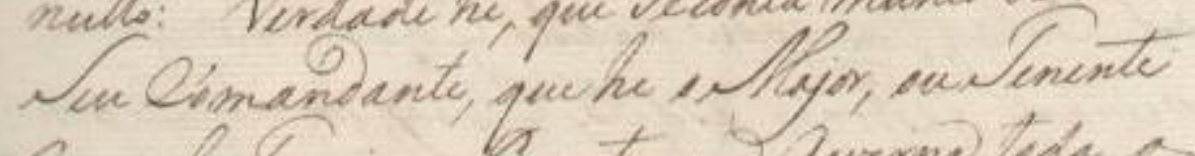

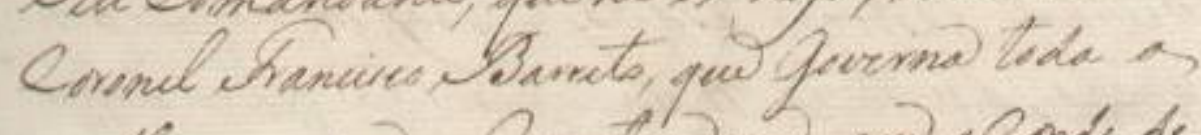

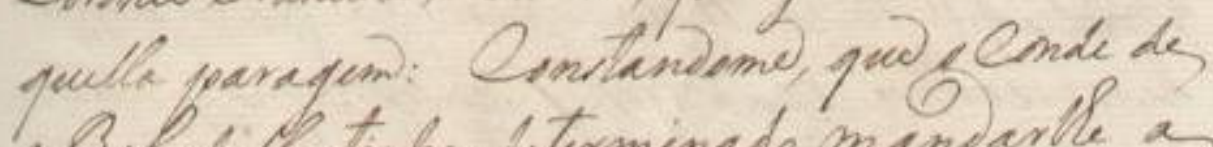
c. Sibadita tinha determinado mandarle as

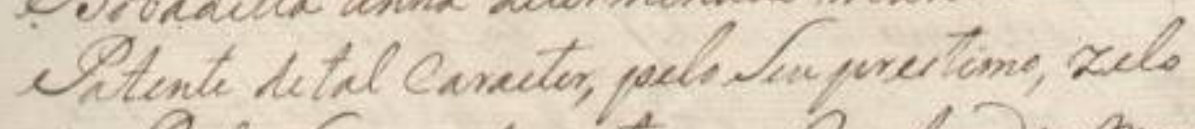

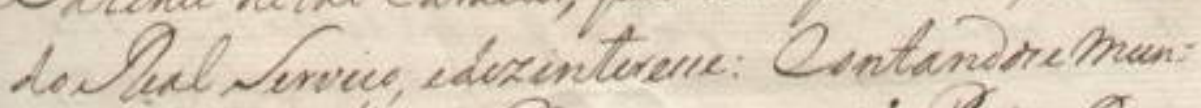

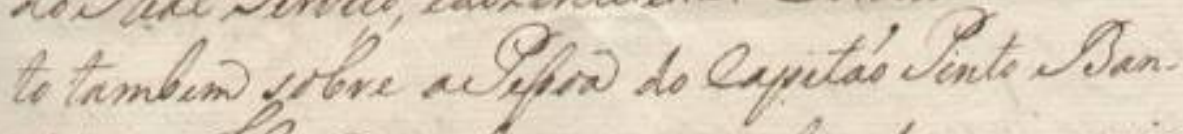
sura, formem valerese, arquel dedue emper:

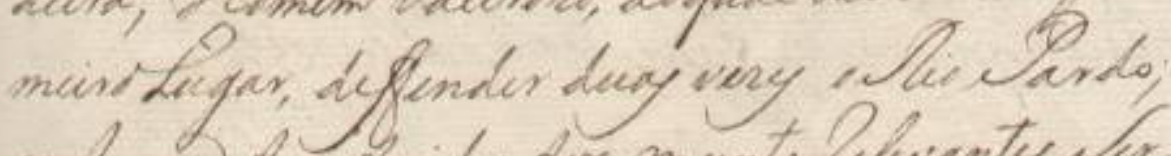

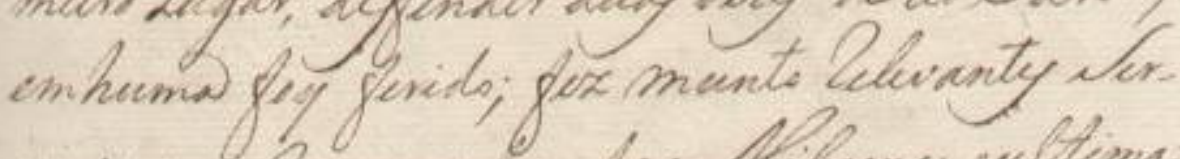

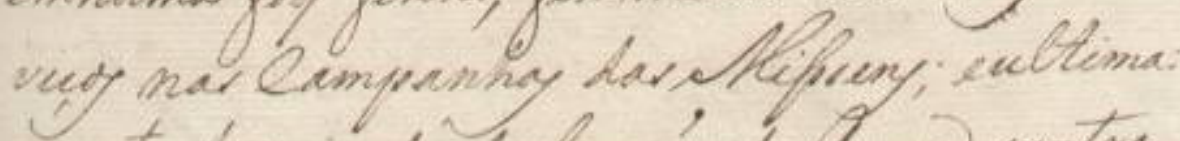

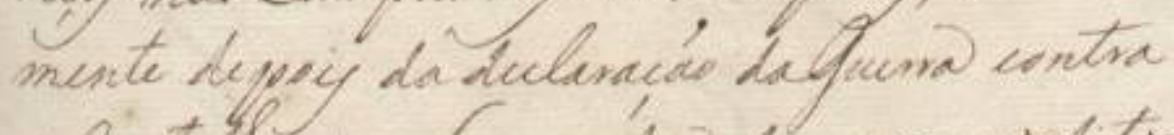

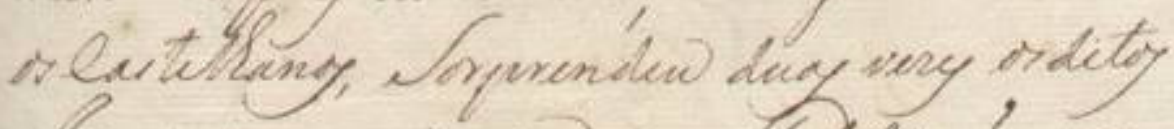

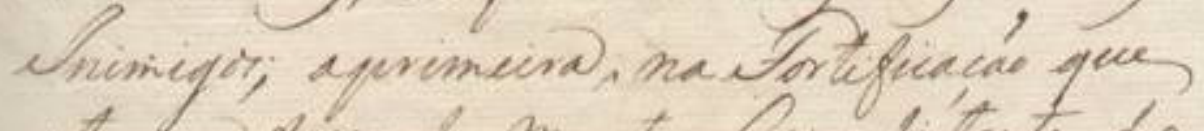

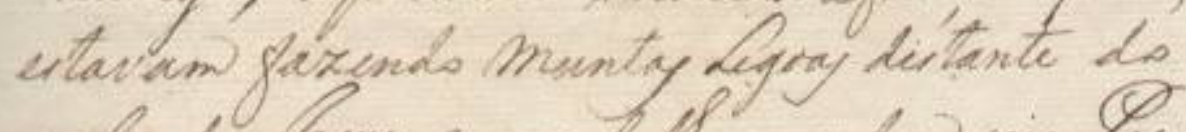

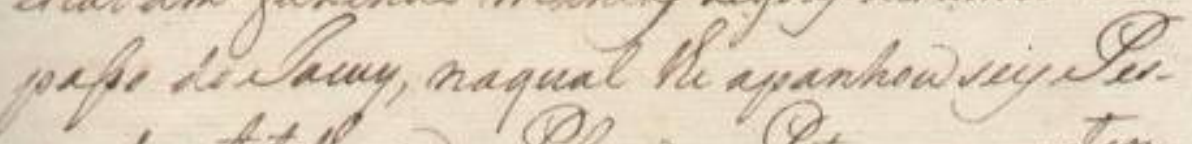

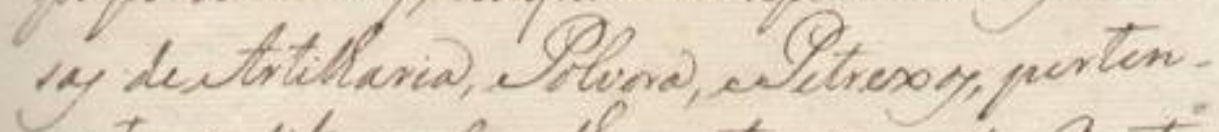
unty aedito poepe, ollemator meenta Gionte, gugindolle somente - eqpitio Exetan comelfour (3)

225 
||49r|| [[pa]]ragens sedeffendem com munta mais facilida= de, sendo cheyas de passos, Nós, e Mattos, onde se pode fazer huma oppoziçaõ vigoroza de Emboscadas, e Sorprezas, com munto acerto, esuccesso. Este Corpo deDragoens deveria completar-se, porque meparece estar munto dimi= nutto: Verdade he, que seconta munto sobre o Seu Cõmandante, que he o Major, ou Tenente Coronel Francisco Barreto, que Governa toda a 245 quella paragem: Constandome, que o Conde de Bobadella tinha determinado mandarlhe a Patente de tal Caracter, pelo Seu prestimo, zelo do Real Serviço, edezinteresse: Contandose mun= to tambem sobre aPessoa do Capitaõ Pinto Ban250 deira, Homem valerozo, ao qual sedeve em pri= meiroLugar, deffender duas vezes o Rio Pardo; em huma foy ferido; fez munto relevantes Serviços nas Campanhas das Missoens; eultima= mente depois da declaraçaõ daGuerra contra 255 os Castelhanos, Sorprendeu duas vezes os ditos Inimigos; aprimeira, na Fortificaçaõ que estavam fazendo muntas Legoas distante do passo do lacuy, naqual the apanhou seis Pessas de Artilharia, Polvora, ePetrexos, pertencentes ao dito passo, e Ihematou munta Gente, fugindolhe somente o Capitaõ Caetano comalguns 
(2)

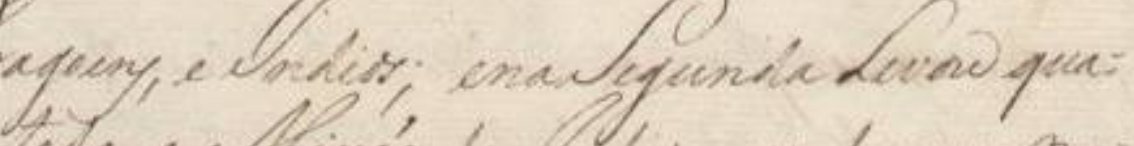

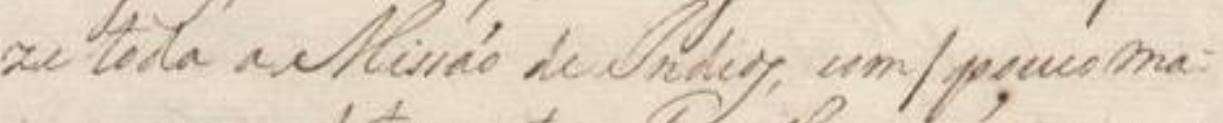

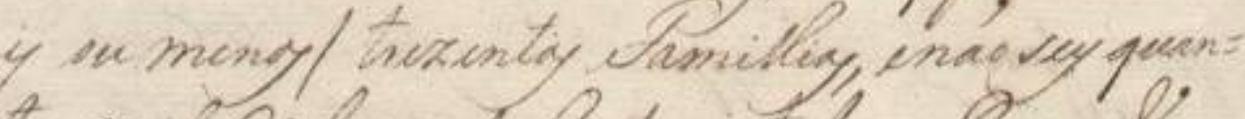

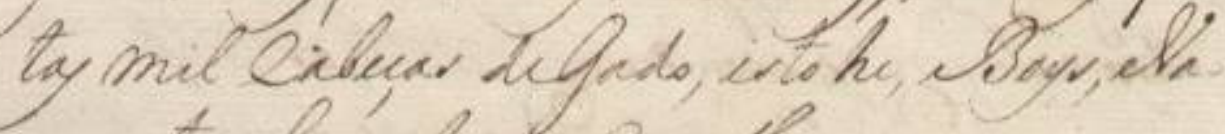
col, chanbem alpoñ Lavelle.

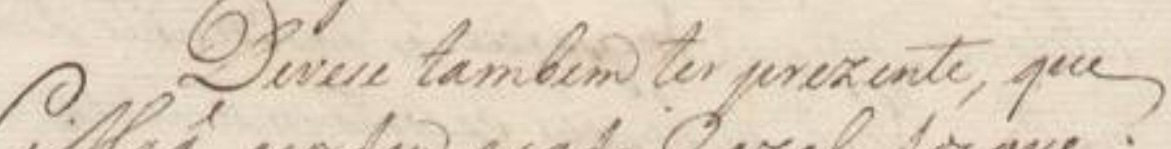

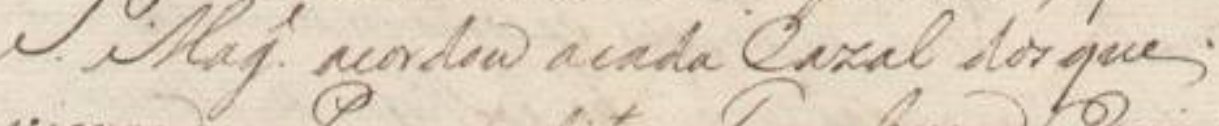

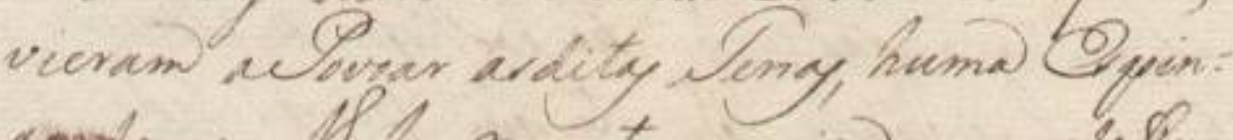

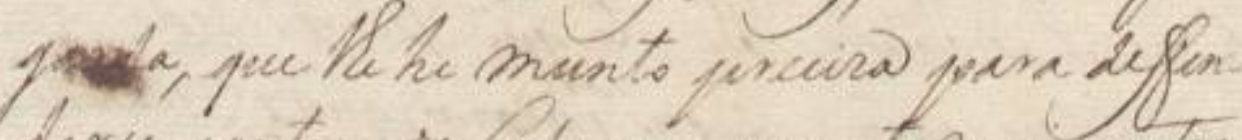

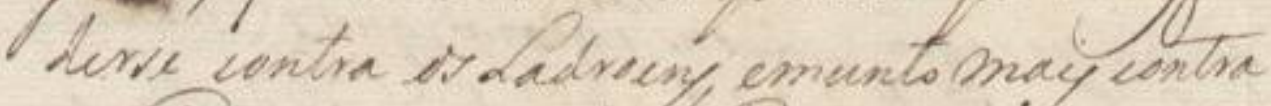

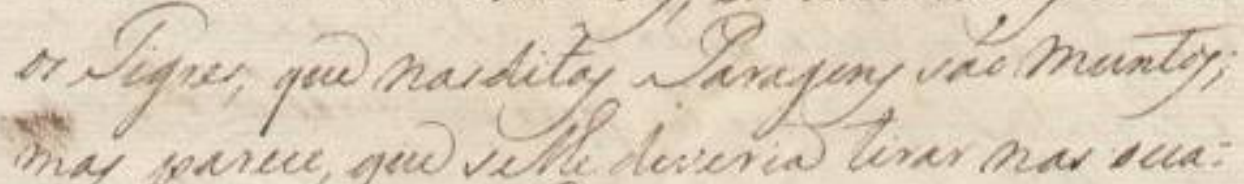

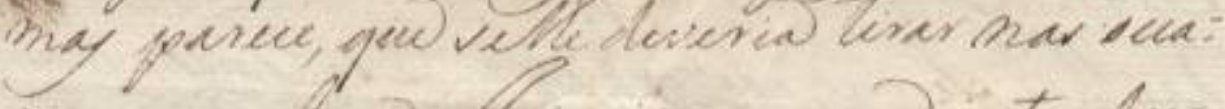

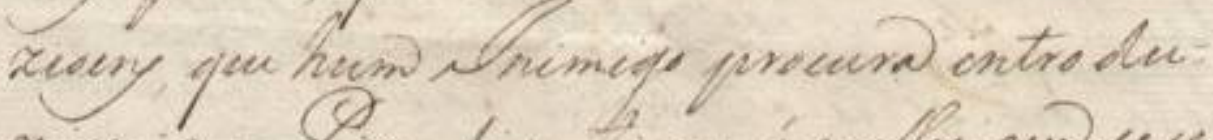

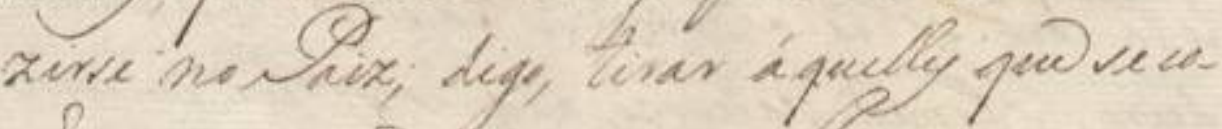

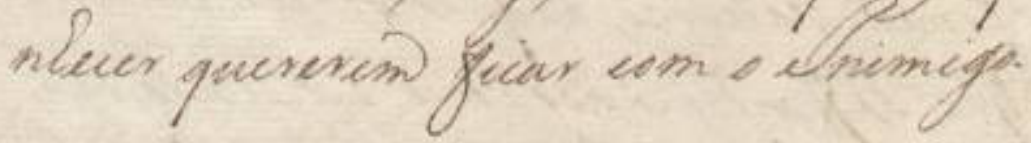


||49v|| [[Dra]]goens, e Indios; enaSegunda Levou qua= ze toda aMissaõ de Indios, com / pouco ma=

265 is ou menos/trezentas Famillias, enaõ sey quan= tas mil Cabeças deGado, isto he, Boys, eVacas, e tambem alguns Cavallos.

Devese tambem ter prezente, que Sua Magestade acordou a cada Cazal dos que vieram aPovoar as ditas Terras, huma Espin= garda, que the he munto preciza para deffen= derse contra os Ladroens, emunto mais contra os Tigres, que nas ditas Paragens são muntos; mas parece, que selhe deveria tirar nas occa= zioens, que hum Inimigo procura intro du= zirse no Paiz; digo, tirar áquelles que se conhecer quererem ficar com o Inimigo. 


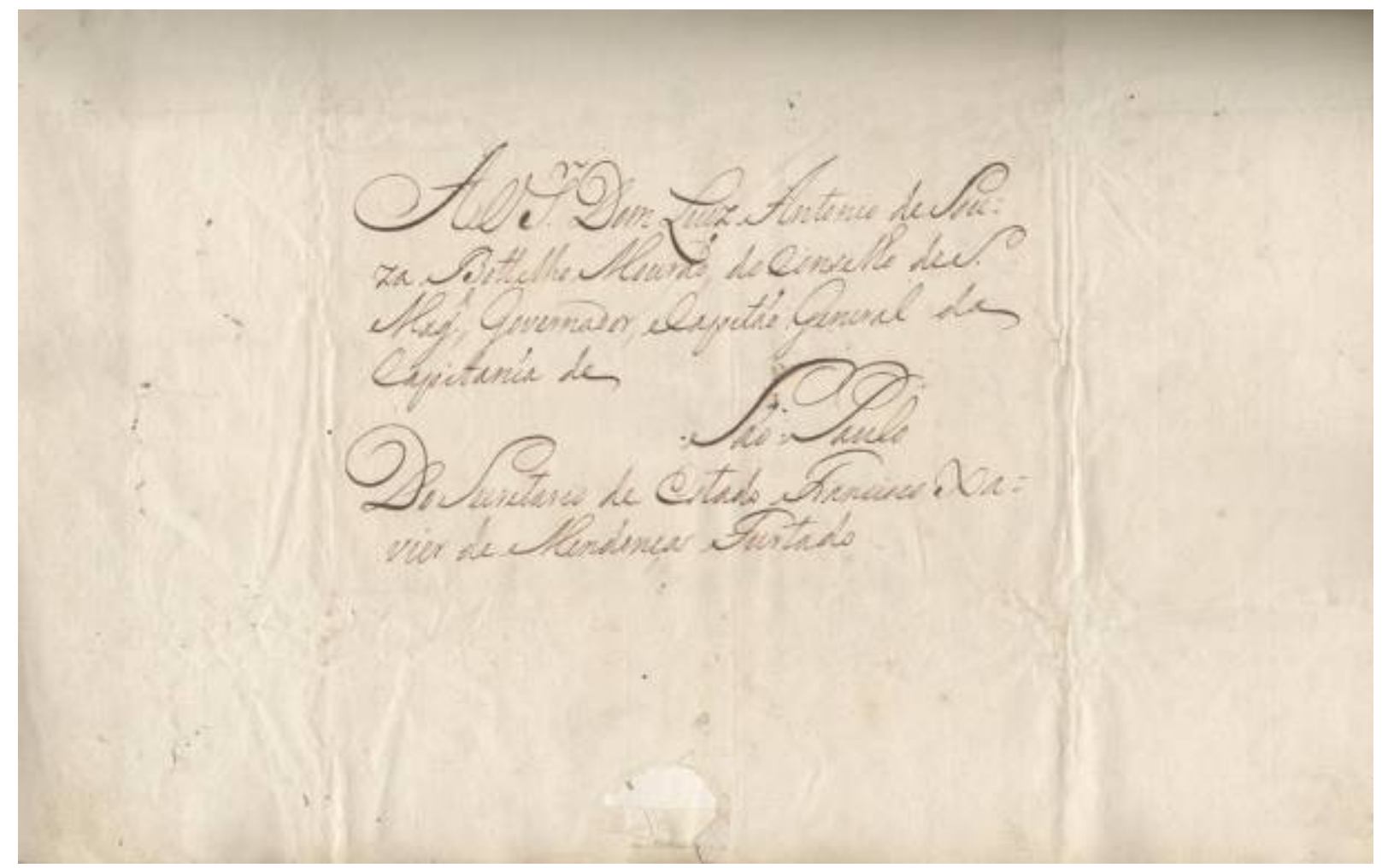


\|50r $\|$ AoSenhor Dom Luiz Antonio de Sou= za Botelho Mouraõ, do Conselho deSua Magestade, Governador, eCapitaõ General da Capitania de

Saõ Paulo

Do Secretario de Estado Francisco $\mathrm{Xa}=$ vier de Mendonça Furtado 
[27]

\|51r

(opia)

(-).

$-i$.

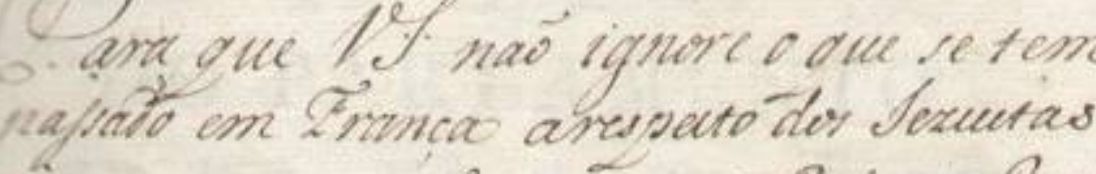
güese censervavas no mesmo Roino. Reme- to alt alguens exemplares do Rcto do Pavlamusto de Pariz, que foi publicado em nove de Mayo do prexenst anno; eulomamente trauxido 2 a lingoa Franeza no nofro tho ma Porruguex

(6) eos ac al: 8 allavio de

7)

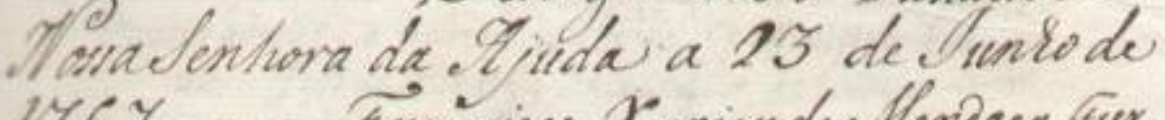
$196 \%$ Francisw. Tavierdectlenooca fur

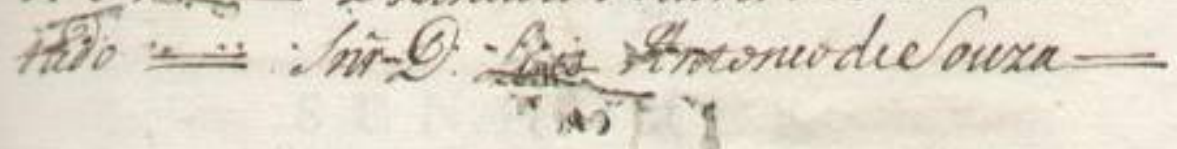

Extri conforme
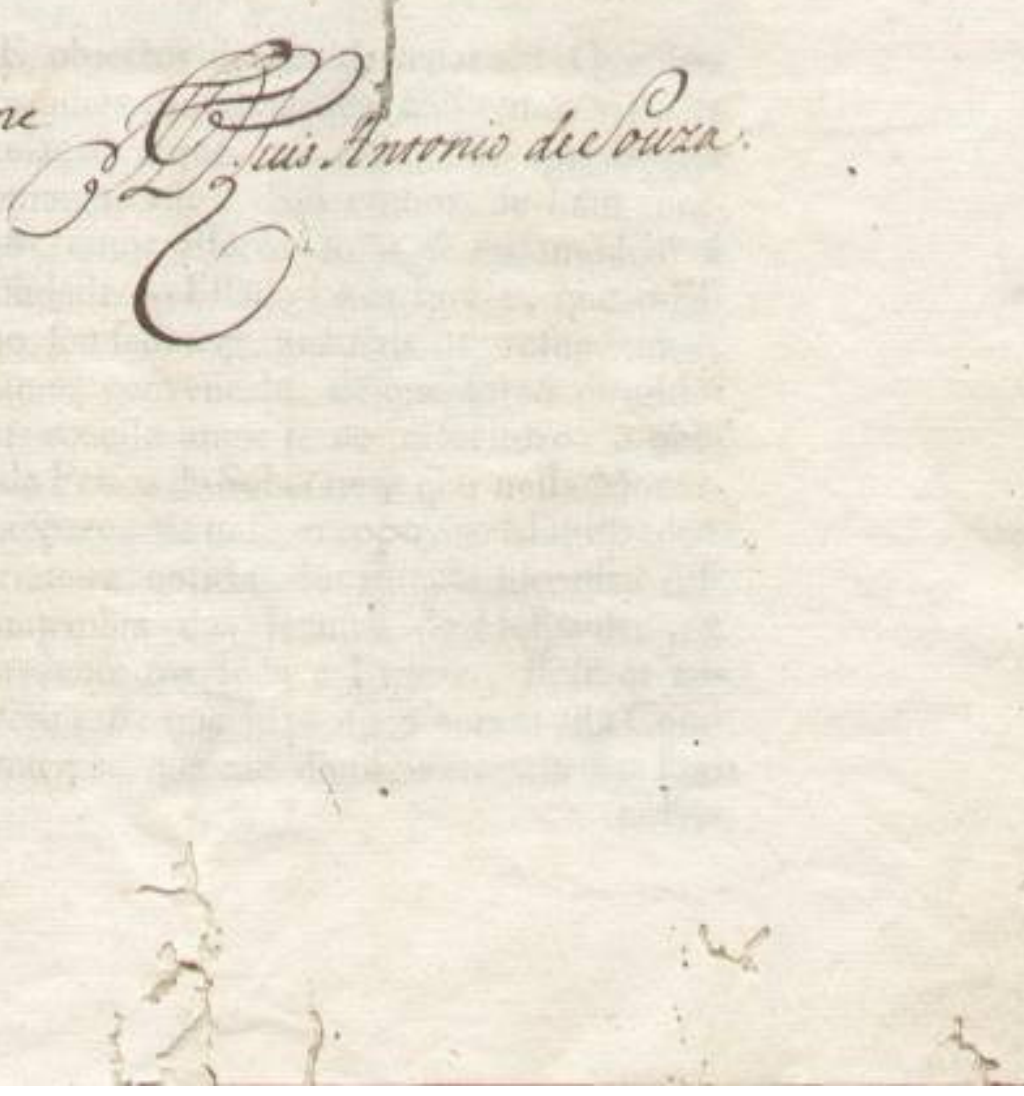

231 
||51r|| Copia

Para que VossaSenhoria naõ ignore o que se tem passado em França arespeito dos lezuitas quese conservavaõ no mesmo Reino: Reme-

5 to a VossaSenhoria alguns exemplares do Acto do Parlamento de Pariz, que foi publicado em nove de Mayo do prezente anno; eultimamente traduzido dalingoa Franceza no nosso Idio maPortuguez. Deos guarde aVossaSenhoria Pallacio de NossaSenhora da Ajuda a 23 de lunho de $1767=$ Francisco XavierdeMendocaFurtado $=$ Senhor Dom Luis AntoniodeSouza $=$ está conforme DomLuis Antonio deSouza. 

de no dravQ I dee Havo, epor cauxa de huounevoa que nessa madrugada howe errou o lugar ove dervia faxer o dexembaraue, emetenio pur erte

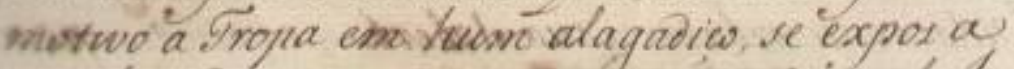

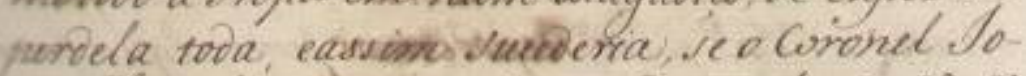
ze Harcelino dewem comandante da Aucao nas roncase o partido destediman porem semprea ar thlivia da Onua, he matoun tres Soldades, eter ferro. Leis axdelte.

$$
\text { Mo dia I do Iunho foi omes }
$$
mo Governador dar hem afralwo em a Torrefica-

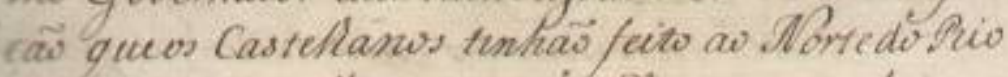
Grande, mas elles näs quizerä espemr, edexam -

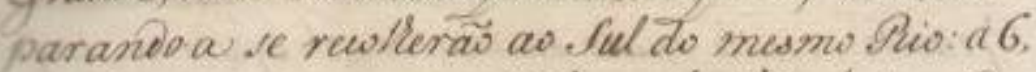
se alworou ne prineipal Forre da Trincheira es pantwla, a nuja \$Bandeina, csedew ac tome de

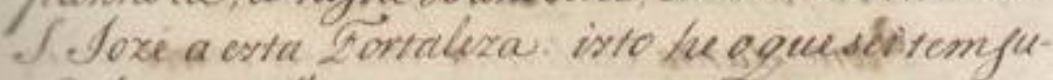
coido naquelle continente, eparciemse que stomis fora delle esta pessima STasias he implert antesigu-

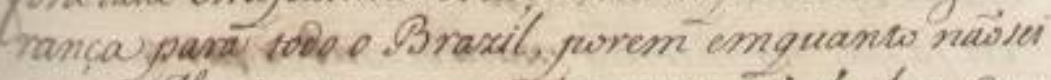
wuae Mlag iaprova exra dereminaias de Soxe Cus-

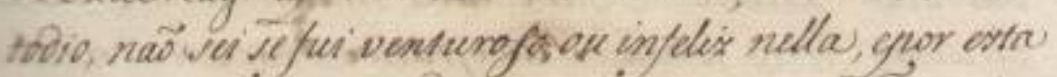

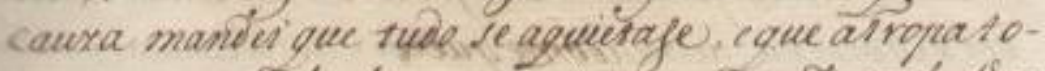
mase quarret le. Inverno aform petanas trabaliar

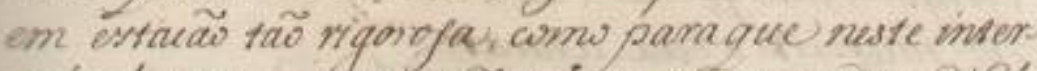

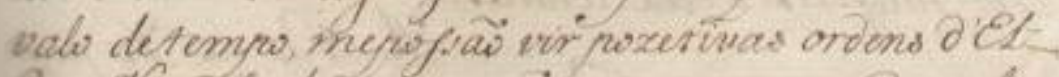

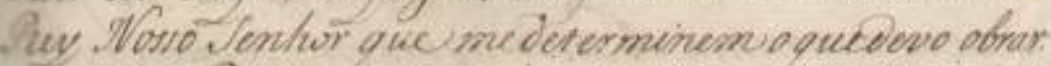
Waw obstante o sobreoto rempure orvencia Soxi Custodio que no cars de que on castellanes nos venthas inguition os anersimes, evames restauran- 
||52r|| Copia Illustríssimo e Excelentíssimo Senhor

O Governador do Rio Grande loze Cus-

todio de Sá e Faria, mal intendidamente quis

surprender os Castelhanos na Villa deRio Gran-

de no dia 29 deMayo, epor cauza de hua ne-

voa que nessa madrugada houve errou o Lugar

onde devia fazer o dezembarque, emetendo por este

motivo a Tropa em hum alagadiço, se expos a

perdela toda, eassim sucederia, se o Coronel lo-

10 ze Marcelino que era Comandante da Acçaõ naõ tomase o partido deseretirar; porem sempre a Artelharia da Praça, Ihe matou tres Soldados, elhe ferio Seis ouSette.

No dia 5 de lunho foi omes

15 mo Governador dar hum assalto em a Forteficaçaõ queos Castelhanos tinhaõ feito ao Norte doRio Grande, mas elles naõ quizeraõ esperar, edezamparando a se recolheraõ ao Sul do mesmo Rio: a 6, se alvorou noprincipal Forte da Trincheira Espanhola, a nossa Bandeira, ese deo oNome de Saõ lozé a esta Fortaleza: isto he o quesei temsucedido naquelle continente, epareceme que o termos fora delle esta pessima Nasçaõ, he importantesigurança para todo o Brazil, porem emquanto naõ sei se SuaMagestade aprova esta determinaçaõ de loze Custodio, naõ sei se fui venturoso, ou infeliz nella, epor esta cauza mandei que tudo se aquietase, e que aTropatomase quartel de Inverno, assim pelanaõ trabalhar em estacaõ taõ rigorosa, como paraque neste inter-

30 valo detempo, mepossaõ vir pozetivas ordens d'ElRey Nosso Senhor que me determinem o quedevo obrar.

Naõ obstante o sobredito sempre ordeneia lozé Custodio que no cazo de que os Castelhanos nos venhaõ inquietar, os apertemos, evamos restauran- 
do os territorios que elles nos tem tomado; mas $\omega$ mo näे vei ve al uurra se rompe agona pula colo nia, ousepulos guis, Grande des lodro, ou Pando, ouse estes Castellanos quer onas tambem ofrpri meiro entus noticias asua) (orre, enabightrem)

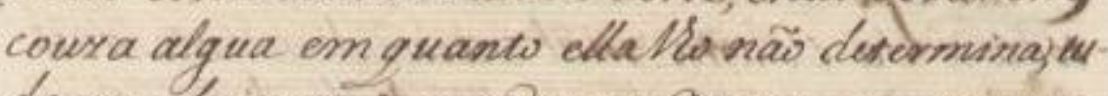
do me obriga a duspender as armas newsenvaria Iropow en descanco em quanto elles qusterem es

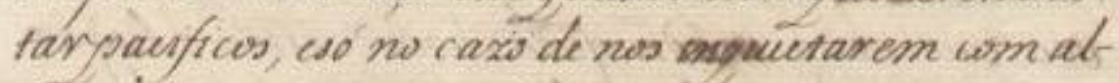
qum dos seus costumados insultos, nos vent permi-

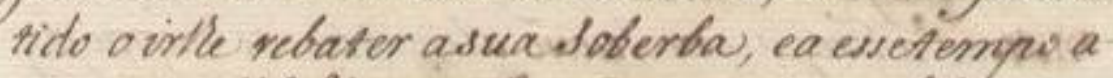

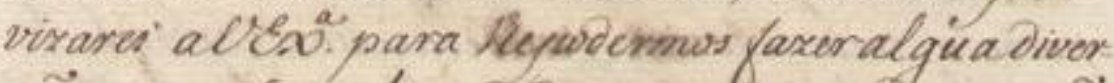
sâ wo a forca dessa cantama por onde mais $\tilde{\omega}$

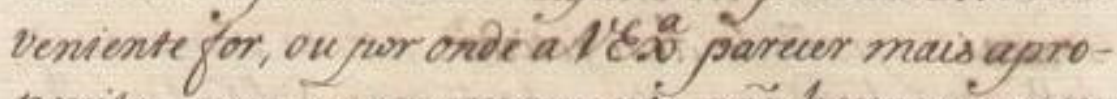
poxito: epwr agora em quanio naw hower mayor novidade hepruixo que nos tranquilizemos, nois. \&

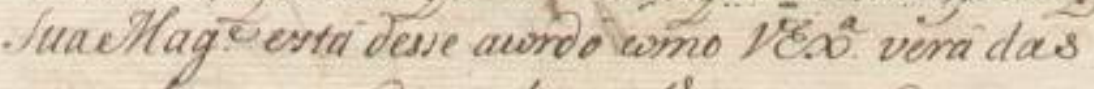
tuas utrimas ondens de que tie remets Cornia.

6 Wes morimentes onverdades mefixesso contuer que enäs neussarios mais Soldades ne? hio Yrande; enelle maw muricoens de guerra, eaf im tamben dinheino para nagamento da inopa Q que tudo ja partw a 10. doprexente.

Dara fanta tarterina mander tambemoinheiro, eamantram the remeto viveres, enunvi-

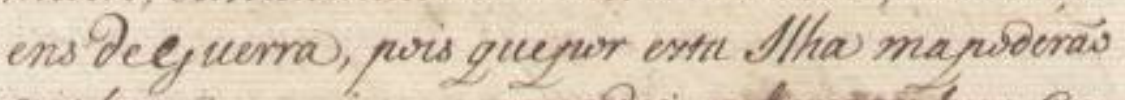
vir faxer, namesma mandes embargar huca embarcaias Castellana quelevova mantmentos de Buenos Iires para. Rio grande, ese ali os näohou verderexerva pursuadome que os Castcllanes reveñi ofrigados alangarnos tambem apartedo ful sem ver nuefiamio sila atacer.

- H Naw de Yo puess queertafusima Nascas aquitem, requeria faxer

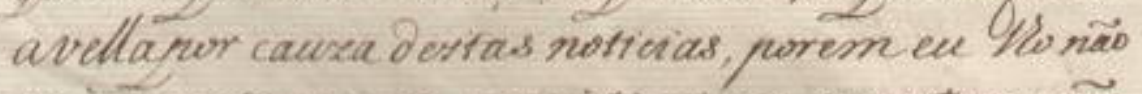
quis pormitir, nem permitires em quanto meños constar se metomi ou nat delarato a guerra na 
||52v || do os territorios que elles nos tem tomado; mas co-

mos naõ sei se aGuerra se rompe agora pela Colonia, ousepelos Rios, Grande deSaõ Pedro, ou Pardo, ouse estes Castelhanos quereraõ tambem dar primeiro estas noticias asua Corte, enaõ obrarem

40 couza algua em quanto ellalho naõ determina, tudo me obriga asuspender as Armas, econservar a Tropa em descanço em quanto elles quizerem estarpacificos, esó no cazo de nos inquietarem com algum dos seus costumados insultos, nos será permitido o irlhe rebater asuaSoberba, ea essetempo avizarei aVossaExcelência para Ihepodermos fazer alguadiversaõ com a forca dessa Capitania por onde mais cõveniente for, ou por onde aVossaExcelência parecer mais apropozito: epor agora em quanto naõ houver mayor novidade heprecizo que nos tranquilizemos, pois que SuaMagestade está desse acordo como VossaExcelência verá das suas ultimas Ordens de que lhe remeto Copia.

Estes movimentos enovidades me fizeraõ conhecer que eraõ necessarios mais Soldados noRio

55 Grande, enelle mais muniçoens deGuerra, eassim tambem dinheiro parapagamento da Tropa o que tudo japartio a $\underline{10}$ doprezente.

ParaSantaCatherina mandei tambemdinheiro, eamanham lhe remeto viveres, e muniço-

60 ens deGuerra, pois quepor esta Ilha mapoderaõ vir fazer; namesma mandei embargar hua embarcaçaõ Castelhana quelevava mantimentos de Buenos Aires para Rio Grande, ese ali os naõ hou verderezerva persuadome que os Castelhanos severaõ

65 obrigados alargarnos tambem apartedo Sul sem ser necessario o hila atacar.

A Nao de 70 peças queestapessima Nasçaõ aquitem, se queria fazer avellapor cauza destas noticias, porem eu lho naõ quis permitir, nem permitirei em quanto menaõ constar se metem ou naõ declarado aGuerra na 
Colonia, ou no la aviow no Riv Grande. Tambern partuip aveso que duas Fra gatas de Guerratranceras que aquir vem estade, ea sue bordo traxem hum mosso que se intitullas Prinupe de Orange ceraxaw thotem firo alguas inf Lenvias, que me obrigaras a serpridente de nuef- vidade, fer me näs parcer auirtado romper agona com esta. Nascais, que corn amesma. Hespantw La esta ainda ligada; porem extes dous A Aurios extä ja no Oo, experando tempu parasahirem deste Porto.

CHas $1 \overrightarrow{0}$ as cauxas porque aquive rom demurado mais alguns dias a craü MS Sens.

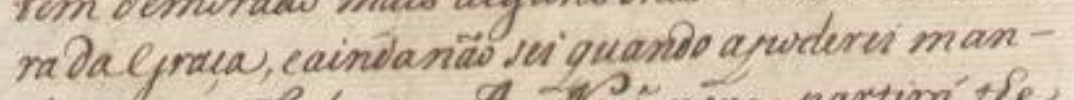
dar para firboa. A. Mai-nivas partimi te

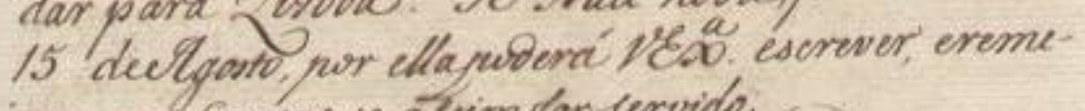
torme as cartas se afrim for servids.

Deos Coar

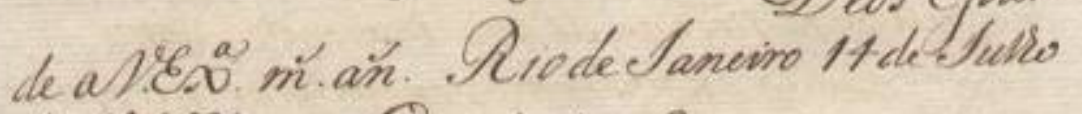
de 1967 Conde liubley

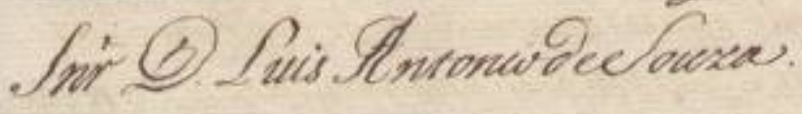

(6) Ita conforme comopropio original fficana

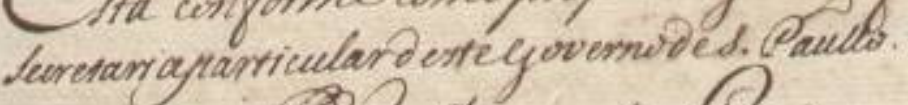

G.juis Intonis declowa. 
||53r|| Colonia, ou no la avivaõ no RioGrande.

Tambem partecipo aVossaExcelência que duas Fra-

gatas de Guerra Francezas que aqui tem estado, ea

seu bordo trazem hum mosso quese intitulla Prin-

cepe de Orange eNazau metem feito alguas inso

Lencias, que me obrigaraõ aser prudente de neces-

sidade, por me naõ parecer acertado romper agora

com esta Nasçaõ, que com amesma Hespanho-

80 La estâ ainda ligada; porem estes dous Navios estaõ já no Poço, esperando tempo parasahirem deste Porto.

Estas saõ as cauzas porque aqui se tem demorado mais alguns dias a Naû Nossa Senho-

85 ra daGraça, e aindanaõ sei quando apoderei mandar para Lisboa. [espaço] A Naû-nova, partirá the 15 deAgosto, por ellapoderá VossaExcelência escrever, eremeterme as Cartas se assim forservido.

Deos Goar-

90 de aVossaExcelência muitos anos. Rio de laneiro 14 de lulho de1767. [espaço] Conde ViceRey

Senhor Dom Luis AntoniodeSouza.

Esta conforme comopropio original que ficana secretariaparticulardesteGovernosdeSaõ Paullo. 
[29]

||54r

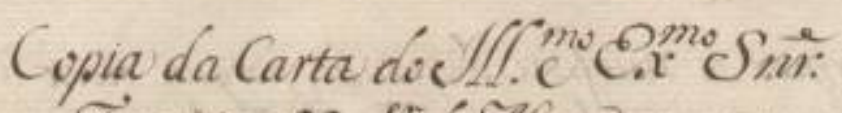

49 Irantisar Tavide MAlenocra panu. Conde da Cunha escripta a 22 dootlargode146\%. undiprezunte $a$ Sua \$llagswa

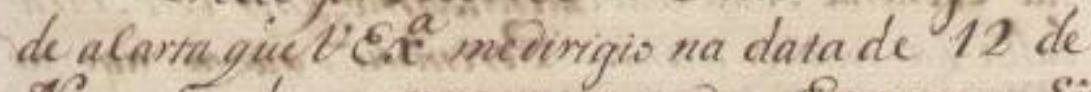

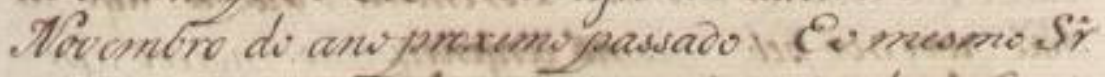

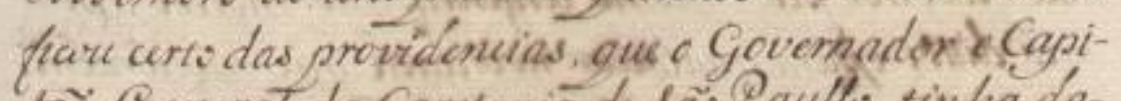

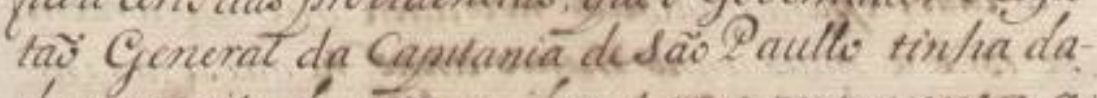

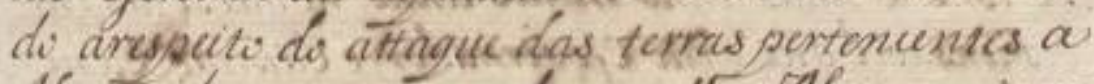

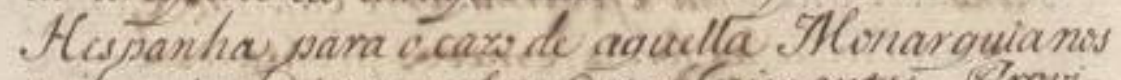

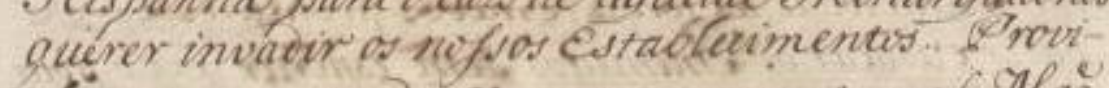
- Cénuias que agradaras sum mamente ac. Hlaj

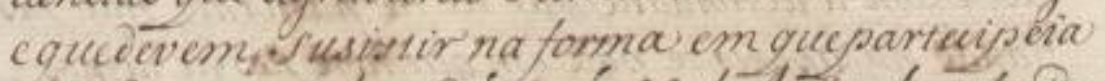

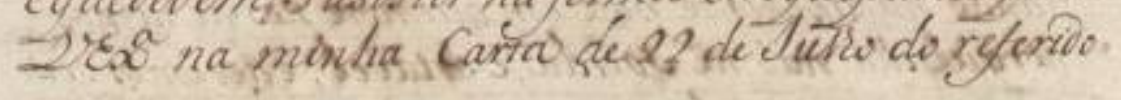
anne.

CPoxen convor morina que horwe assimem

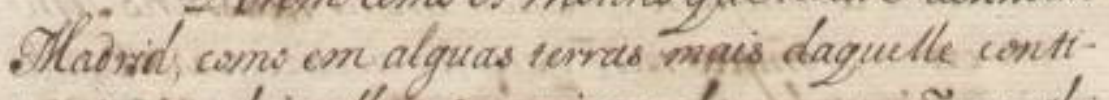

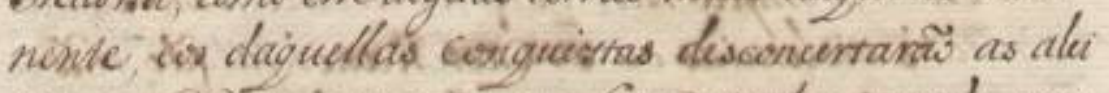

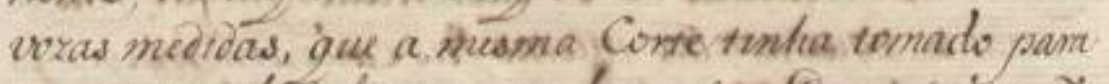

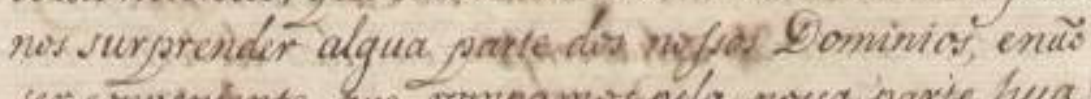
ser onvendente bue rompamess ocla nessa paric hua. querra quswe sinicuriami on toda a parte: Porestwe fundamentos ondena Suachllagestrade que renser

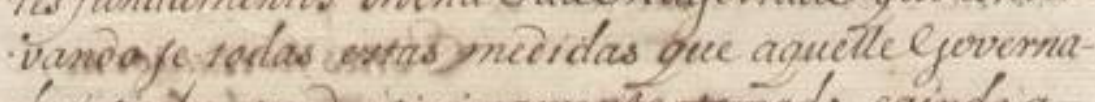

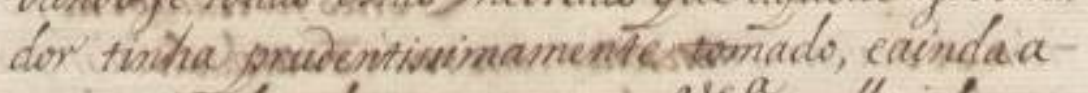

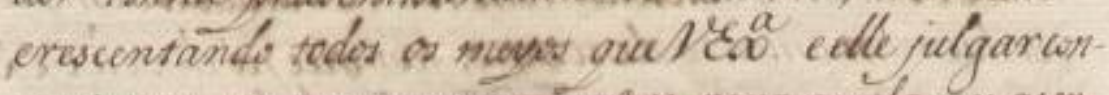

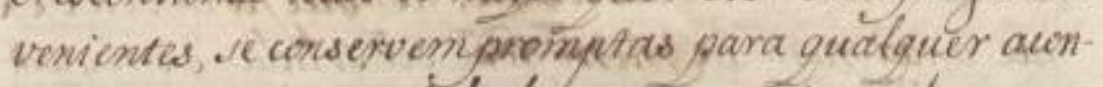

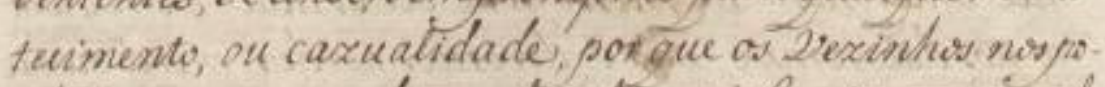

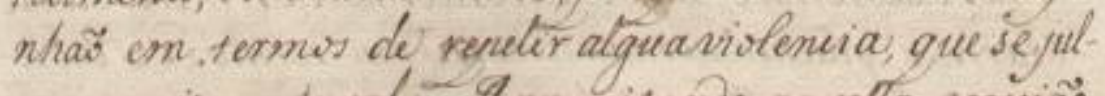

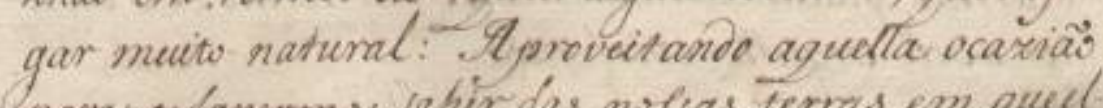

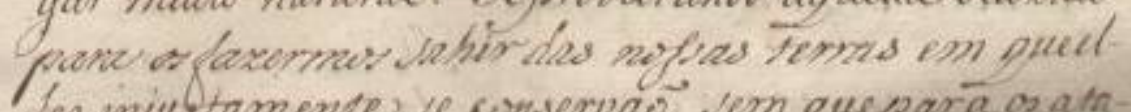
Leo injustamente ve corservac, vem quepara os ara-

239 
||54r|| Copia da Carta do Illustríssimo e Excelentíssimo Senhor

Francisco Xavier de Mendonça pa-

ra o Conde da Cunha escripta

a 22 deMarço de 1767.

5 Sendo prezente a Sua Magesta-

de aCarta queVossaExcelência medirigio na data de 12 de

Novembro do anoproximo passado: Eo mesmo Senhor

ficou certo das providencias, que o Governador e Capi-

taõ General da Capitania deSaõ Paullo tinha da-

10 do arespeito do attaque das terras pertencentes a

Hespanha, para o cazo de aquella Monarquianos

querer invadir os nossos Establecimentos. Provi-

dencias que agradaraõ summamente aSua Magestade

e quedevem Susistir na forma em quepartecipeia

15 VossaExcelência na minha Carta de 22 de lulho do referido anno.

Porem como os motins quehouve assim em

Madrid, como em alguas terras mais daquelle conti-

nente, eos daquellas conquistas disconcertaraõ as alei

20 vozas medidas, que a mesma Corte tinha tomado para

nos surprender algua parte dos nossos Dominios, enaõ

ser conveniente que rompamos pela nossa parte hua

guerra que se incendiará em toda a parte: Por es-

tes fundamentos ordena SuaMagestade que conser-

25 vandose todas estas medidas que aquelleGoverna-

dor tinha prudentissimamente tomado, eainda a-

crescentando todos os meyos queVossaExcelência e elle julgar con-

venientes, se conservempromptas, para qualquer acon-

tecimento, ou cazualidade, por que os Vezinhos nos po-

30 nhaõ em termos de repelir alguaviolencia, que se jul-

gar muito natural: Aproveitando aquella ocaziaõ

para os fazermos sahir das nossas terras em queel-

les injustamente se conservaõ, sem quepara os ata- 


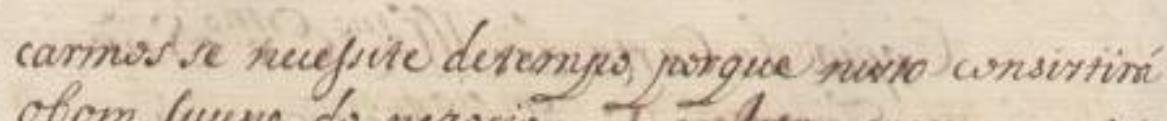
obom fuusso do negovio. T, oldowirem se entende no casio dos diros vexinhos wintererem algum aten-.

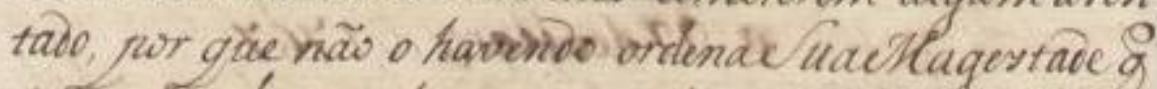
se Juspenda por hon naquella imvaxas peeb mitivo afrima fonderaito: He certo, esem-duvido que

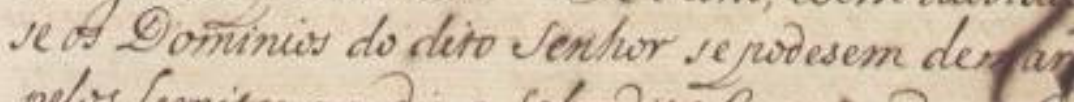
pelos Lemites que des ovelredito Cuveswad or (Capit

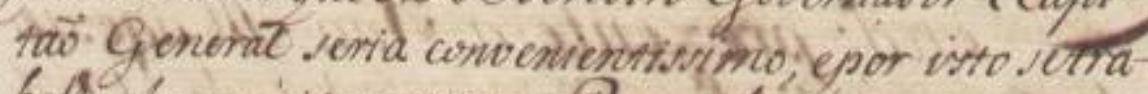
balla ha mivitos annos: Porem the opweporagono haw roves is pelo mesmo unglowisiono motivo afi-

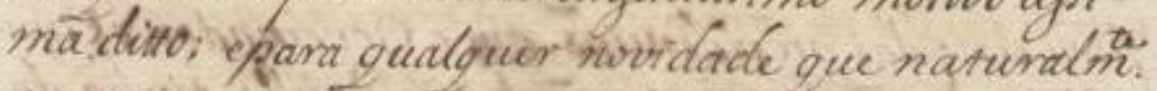

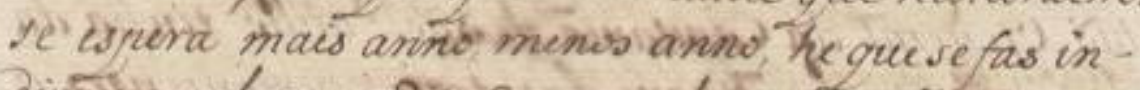
dispensavel que odifo Governador, e capitiougenemal venhatodas as forcts, emevis promptos paratebater e atacar os stimigos señ espuntar que secor. ras, e com a actividade que the he natural; nä nos fiands na aparente paz en quetige ros achamos;

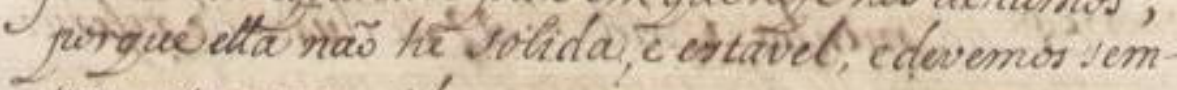
pre estarprevenidos coms se a querra estivese mui proximá arompurse: Quvo riso he niess turio sem-

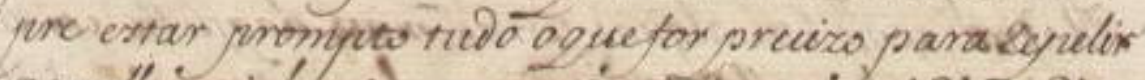

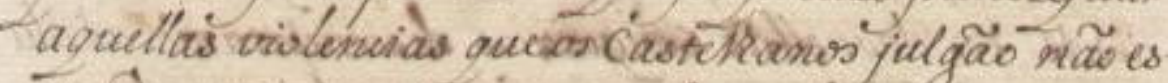

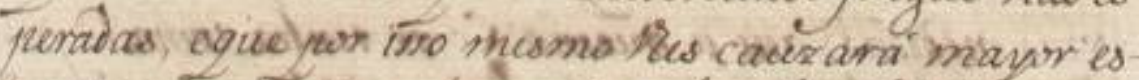
pants, econfica acharemferebatides dé impmovi-

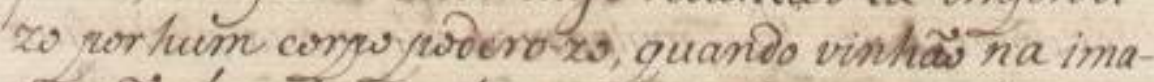
ginaiä de actharem hats tertas doxemas, chuns pu-

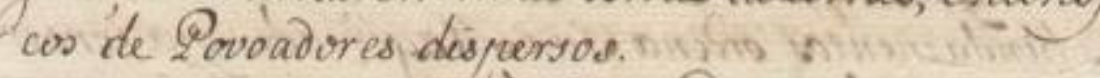

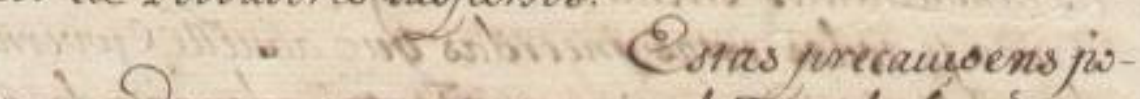
rem ve devem Subtentaricom inalo oxcuidado vém pur.

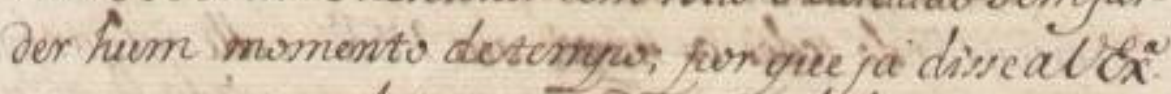
que apar nem he, rum vode ser sotida; e em quanto nos dä timpo, nä'o devemos perder para nosaclarmes quando nes atacarem en teinos de Zebafor o sue Onguth eviolonia.

Mas extrs priden -

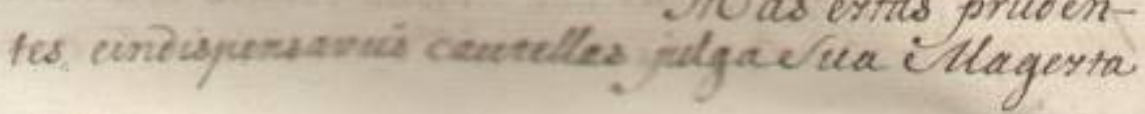


||54v||carmos se necessite detempo, porque nisto consistirá

obom sucesso do negocio. Isto porem se enten-

de no cazo dos ditos vezinhos cometerem algum atentado, por que naõ o havendo ordenaSuaMagestade que se suspenda por hora naquella invazaõ pelomotivo assima ponderado: He certo, esem duvida que se os Dominios do dito Senhor se podesem demarcar pelos Lemites que dis o SobreditoGovernador e Capitaõ General seria convenientissimo, epor isto setrabalha ha muitos annos: Porem he o quepor agora naõ podeser pelo mesmo urgentissimo motivo assima ditto; epara qualquer novidade que naturalmente se espera mais anno, menos anno, he que se fas indispensavel que o dito Governador, e Capitaõ General tenhatodas as forças, emeyos promptos pararebater e atacar os Inimigos sem esperar que o socorraõ, e com a actividade que the he natural; naõ nos fiando na aparente paz em quehoje nos achamos; porque ella naõ he solida, e estavel, edevemos sempre estarprevenidos como se a guerra estivese mui proxima aromperse: Epor isso he necessario sem-

55 pre estar prompto tudo o quefor precizo para repelir aquellas violencias que os Castelhanos julgaõ naõ esperadas, e que por isso mesmo lhes cauzará mayor espanto, e confuzaõ acharemse rebatidos de improvizo por hum corpo podero-zo, quando vinhaõ na ima-

60 ginaçaõ de acharem huas terras dezertas; ehuns poucos de Povoadores dispersos.

\section{Estas precauçoens po-}

rem se devem sustentar com todo o cuidado semperder hum momento detempo, por que ja disse aVossaExcelência

65 que apaz nem hé, nem pode ser solida; e em quanto nos daõ tempo, naõ o devemos perder, para nos acharmos quando nos atacarem em termos de rebater o seu Orgulho, eviolencia.

$$
\text { Mas estas pruden- }
$$

70 tes, eindispensaveis cautellas julgaSua Magesta 
de que naö devem ser empregadas en Rum nompimento pela nofpa parte com a consequencia deyor to. da a TCuropa em armas, quando nos fressemos agref cores intempertivamente, porem se fas nuessario que stejas sempre vivas, e consolidiatas con tal aetunidade quesurtenternis as forcas pof sivecs naquellas partes, lem com 1 ubo as mover, ve nas no caxo em queos las-

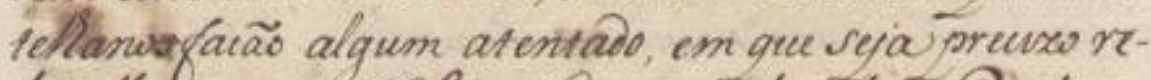

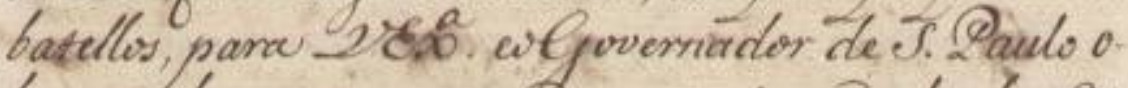
brareno dewm num aunde na conformionde das or

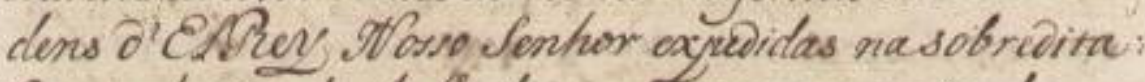
Cartu de 22 de tutho do amonoproximo pafsado.

Quanto av establecimentodos chefes Levan-

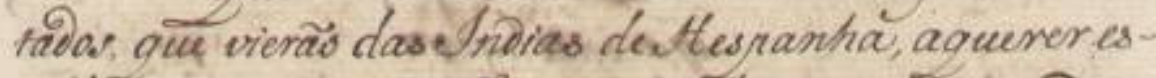
tableurse ras nogras Fronteins: The negocip quepreter. da areflex $\widetilde{w}$, por que ao mesmo tempo quipodem ser muito weis se acaxo selle unirem os sus. It miges, eparentes para formarem nos Dominies dec uachagestade hua nova Qovacias, tambem povem ser summ

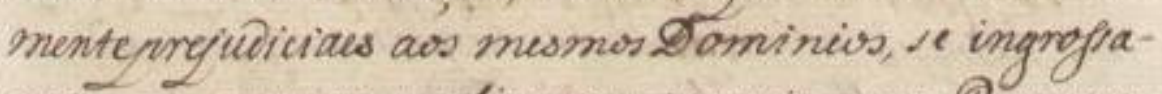
rem em numen, esefixerem sureriores aes Portuguexes que com elles si devern ajuntar, wroue com amesma favilidade am que fatrarä a obcorenvia do sew

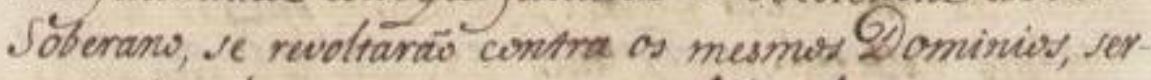
vinooles de movo para o secerrendä, ode entregarema nova conquistio nas mas dosvies Parentes: Of or cuja m-

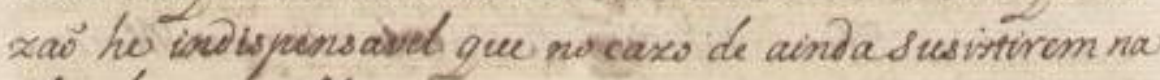
idea de se estrableverim nas nofras wnquistas; riasempre en tal forma, quever Oorraquexes os excidä muito in numero, cen quatida de de gente, eque em nenhuadestas Povoacoons novas doix s de haver hua tal, ouqual Fortalexa, naqual assistra scom qranie cuidado os?or. tuguexes, pañ poverem rebater ovalyuex insulhs des

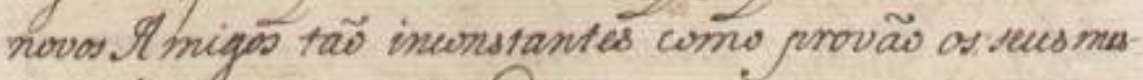
mes facto agonapraticados:

Con exta ocarias dévo partuigar alcso. para o sugegrverno duas coreras; a 
||55r|| de que naõ devem ser empregadas em hum rompimento pela nossa parte com a consequencia depor toda a Heuropa em Armas, quando nos fizessemos agres sores intempestivamente, porem se fas necessario que es-

75 tejaõ sempre vivas, e consolidadas com tal actividade quesustentemos as forças possiveis naquellas partes, sem com tudo as mover, se naõ no cazo em queos Castelhanos facaõ algum atentado, em que seja precizo rebatellos, para VossaExcelência eoGovernador de Saõ Paulo obrarem decommum acordo naconformidade das Ordens d'EIRey Nosso Senhor expedidas nasobredita: Carta de 22 de lulho do annoproximo passado.

Quanto ao establecimento dos chefes Levantados, que vieraõ das Indias de Hespanha, aquerer establecer-se nas nossas Fronteiras: he negocio quepedetoda areflexaõ, por que aomesmo tempo quepodem ser muito uteis se acazo selhe unirem os seus Amigos, eParentes para formarem nos Dominios deSuaMagestade hua nova Povoaçaõ, tambem podem ser summa

90 menteprejudiciaes aos mesmos Dominios, se ingrossarem em numero, esefizerem superiores aos Portuguezes que com elles se devem ajuntar, porque com amesma facilidade com que faltaraõ a obediencia do seu Soberano, se revoltaraõ contra os mesmos Dominios, ser-

95 vindolhes de meyo para o seuperdaõ, o de entregarem a nova conquista nas maos dos seus Parentes: Por cuja razaõ he indispensavel que no cazo de aindasusistirem na idea de se establecerem nas nossas conquistas; sejasempre em tal forma, que os Portuguezes os excedaõ muito em numero, e em qualidade de Gente, eque em nenhuadestas Povoaçoens novas deixe de haver hua tal, ou qual Fortaleza, na qual assistaõ, ecom grande cuidado osPortuguezes, para poderem rebater qualquer insulto dos novos Amigos taõ inconstantes como provaõ os seus mesmos factos agorapraticados:

Com esta ocaziaõ devo partecipar aVossaExcelência para o seugoverno duas couzas; a 


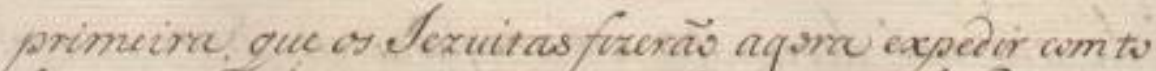
do o degrato hum novo. Brovepela Curra depoma,

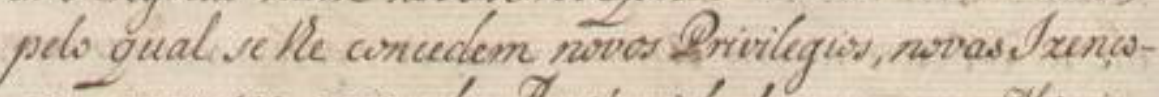
ens, emustas eqrandus. Tusturvidadas as seud Mlission-

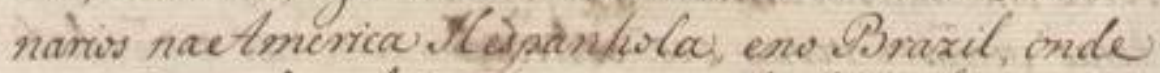
acxpedicas do tal Berve, cordegredo delle thes serias

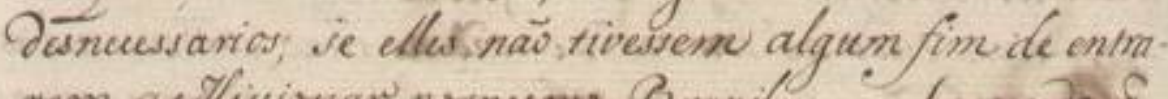
rem activionar womesme Bmxil: Cegundas

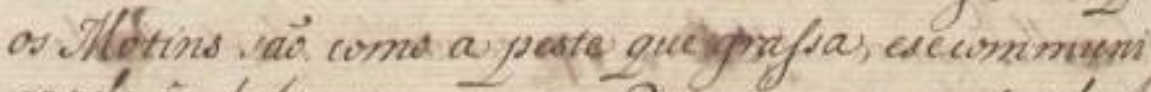

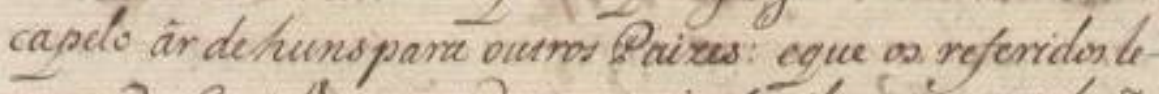

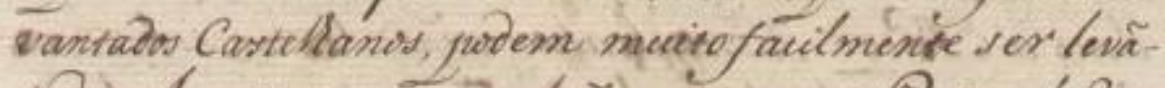

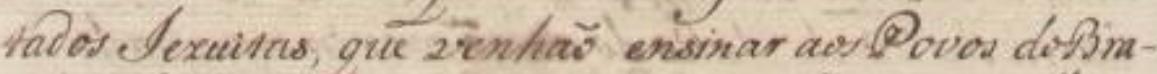
zit os lavantamentos gue ank aquen foxio por clleo

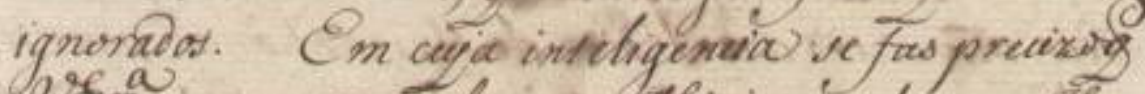

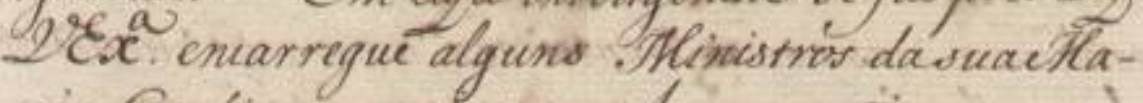
vor Confiania en rorrm hum centinud, eexdcro cuidado sobro os te ruetas pac satirä dalumpantua, ese achwo por ahi dispersos por essos Capi-

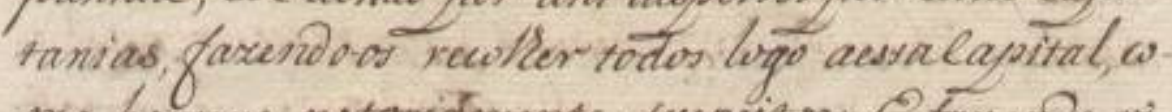
no homens notariamente sispeitso: Cfaxendo vigiar sobre dles, csobre os veus Warentes, ce tmigos, Hdlurentes, em tal forma, que logo que gicos quil

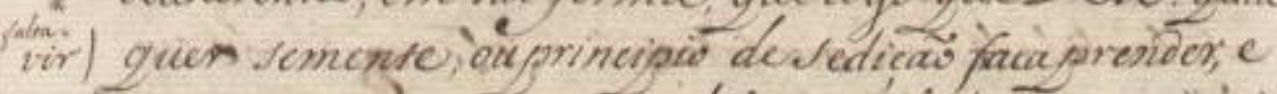
Castigar cons tal promperitas, edcuendade os primei-

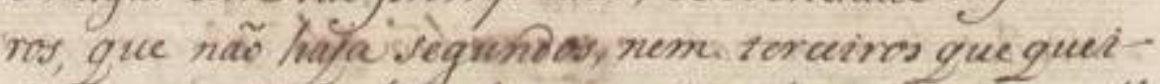
mi imitalles: Ito for oque fes ulvimamenteodlar

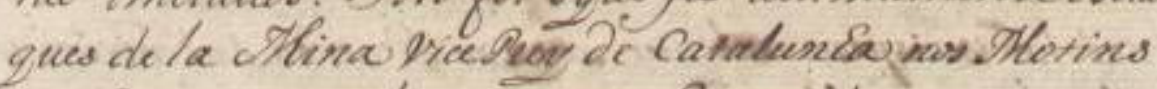
que Suve em todes os ourran Paises to continente

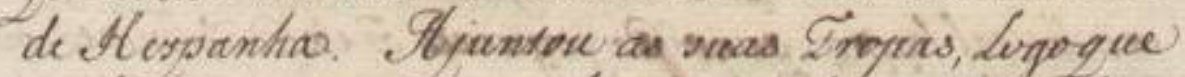
soube que os Casataens derongunava spuir os llcspanioes, eatustic dellas com as Sorralexas muniviadas declarow ass tabitantes de Barcelona, que clle exrana ali firompito pior estres pane censervar obublico Soceqo: Edue tiveson entondido que aprimeina bie

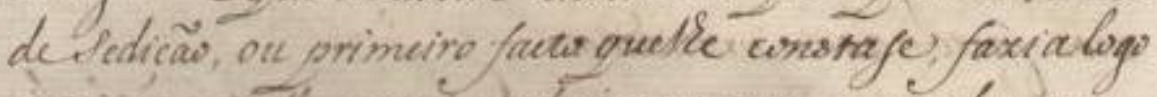
fasticar aquetles que as on ferisom sem mais demona,

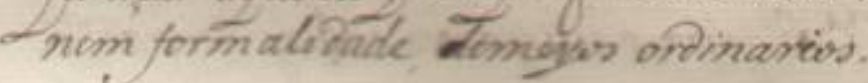


||55v|| primeira que os lezuitas fizeraõ agora expedir com to do o Segredo hum novo Breve pela Curia deRoma,

110 pelo qual se lhe concedem novos Privilegios, novas Izençoens, emuitas, e grandes Authoridades aos seus Missionarios naAmerica Hespanhola, eno Brazil, onde aexpediçaõ do tal Breve, eoSegredo delle Ihes seriaõ desnecessarios, se elles naõ tivessem algum fim de entrarem a Missionar nomesmo Brazil: [espaço] Segunda que os Motins saõ como a peste que grassa, esecommuni capelo âr dehuns para outros Paizes: eque os referidos levantados Castelhanos, podem muito facilmente ser levãtados lezuitas, que venhaõ ensinar aos Povos doBrazil os levantamentos, que athe agora foraõ por elles ignorados. [espaço] Em cuja inteligencia se fas precizoque VossaExcelência encarregue alguns Ministros dasuaMayor Confiança em terem hum continu-o, eexacto cuidado sobre os lezuitas que sahiraõ daCom-

125 panhia, ese achaõ por ahi dispersos por essas Capitanias, fazendo-os recolher todos logo aessaCapital, como homens notoriamente suspeitos: $E$ fazendo vigiar sobre elles, esobre os seus Parentes, eAmigos, e Adherentes, em tal forma, quelogo que VossaExcelência* qual $<\left({ }^{*}\right.$ falta $=$ vir $)>$ quer semente, ou principio de sediçaõ facaprender, e castigar com tal promptidaõ, eseveridade os primeiros, que naõ haja segundos, nem terceiros que queiraõ imitallos: Isso foi o que fes ultimamente o Marques de la Mina ViceRey de Catalunha nos Motins que houve em todos os outros Reinos do Continente de Hespanha. Ajuntou as suas Tropas, Logoque soube que os Catalaens determinavaõ seguir os Hespanhoes, eatesta dellas com as Fortalezas municiadas, declarou aos Habitantes de Barcelona, que elle estava 140 ali prompto por EIRey para conservar o Publico Socego: E que tivessem entendido que aprimeira Vôz desediçaõ, ou primeiro facto quelhe constase, fazialogo justiçar aquelles que aproferissem sem mais demora, nem formalidade demeyos ordinarios. 
||56r||

Para extes Caxos sao exculentes as rumutas das . 5l Mas, as quass naw tendo nusas Temas, Darentus, nimu

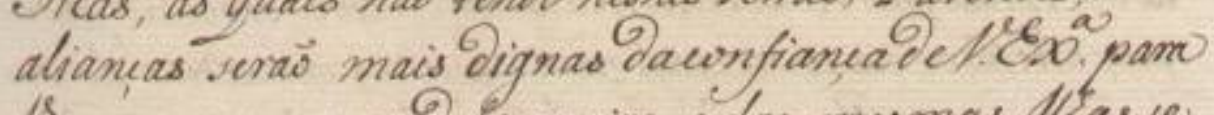
Hes encarregar as Qeligeneias, edas mesmas ditas ve hirat transfortando or lothades yoficieces como ja tento arixado alcas.

Delo que respuita as faes Porrugue zes quevevem in pam aguella Frontein unifecomes rejo desses chamados Eniminojos quando onas forem de crimes exurandes, porg estud deñad a poderäo servinpana obom-ruesso to Eregovio eque os dittos chamaides Criminofos, cos vngabunidis dispersos se unäo pur modo de quem vae fuginds as castigo, evä̀ viver naguelLas Irontionis cirn os taes Conogatis indo aguelles queparcurem mais capaxes instruhides particulamisimamente na formaping devem ofrar a fim de extablecerem naquella Inoritum dorts ientqlexa publicarbo ainda aes mesmer Congatis quevãoli a frocianse parajworem alcansindee lua Thag. co os ceus generaus openiab, oupare ficarem ali, oupara de riolkerem aduas caxas: oque certamente maisdepressiciconseguiras, se virem que elles Coregatis sefa sem nawinas, evafialos dec uachag firquedsta Sorte Lograño nav so or Privilegios gut iono taes lecompetem, mas enyrosiaris muito em cabedacs com owmercis queporem faxer de di wom os veus. Rmigis, e Darentes, ivris dos grandes tributos que pagai naquellas Iroias csiguros dos insultos aque cortamente eytab expostos vivendo entre a ambicas Iexuitica cas Iusticas d'elPuy Calholico; Interesses que nuncaseforem combinar, eque preciramente as conseque cias dequalquer das partes que elles rejai, hes fav deser tai funestas como elles fom experimentado. Thestas centes deve o Covemador, e Capitav General de Sav doulo faxex instrutir on forma, que renä pur coba nuneague elles tem consentiments rec; anses

247 
||56r|| Para estes Cazos saõ excelentes as recrutas das Ilhas, as quaes naõ tendo nessas Terras, Parentes, nem alianças seraõ mais dignas daconfiança deVossaExcelência para Ihes encarregar as deligencias, e das mesmas Ilhas se hiraõ transportando os Soldados possiveis como já tenho avizado aVossaExcelência.

Pelo que respeita aos taes Portugue zes quedevem ir para aquella Fronteira unirse com os novos hospedes, achou SuaMagestade tambem justo, que sejaõ desses chamados Criminosos, quando onaõ forem de crimes execrandos, porque estes denada poderaõ servir para o bom-sucesso do Negocio; eque os dittos chamados Criminosos, eos Vagabundos dispersos, se unaõ por modo de quem vae fugindo ao castigo, e vaõ viver naquellas Fronteiras com os taes Corogatîs indo aquelles queparecerem mais capazes instruhidos particularissimamente na formaporque devem obrar a fim de establecerem naquella Fronteira aditta Fortaleza publicando ainda aos mesmos Corogatîs quevaõ ali associarse parapoderem alcançar deSua Magestade edos seus Generaes o perdaõ, oupara ficarem ali, oupara se recolherem asuas Cazas: o que certamente mais depressa conseguiraõ, se virem que elles Corogatis sefa zem nacionaes, evassalos deSuaMagestade porquedesta Sorte Lograraõ naõ só os Privilegios que como taes lhecom170 petem, mas engrossaraõ muito em cabedaes com o comercio quepodem fazer de ali com os seus Amigos, e Parentes, Livres dos grandes tributos que pagaõ naquellas Indias, esiguros dos insultos aque certamente estaõ expostos, vivendo entre a ambiçaõ lezuitica eas lustiças d'El Rey Catholico; Interesses que nunca sepodem combinar, eque precizamente as consequẽcias de qualquer das partes que elles sejaõ, Ihes haõ deser taõ funestas como elles tem experimentado. A estas Gentes deve o Governador, eCapitaõ General de 180 Saõ Paulo fazer instruhir em forma, que senaõ perceba nunca que elles tem consentimento seu; antes 
$\|56 \mathrm{v}\|$

pelo contranio publicar que fas toda adeligonianelos prom der: mas particularissimamente deve oronar avde que ellefixer mavor confianca, que va avizanoo do que howier dnquellas partes, eda negovincä com corrogatis fingindose algum Dexertor daquelle wryo que jussa servir de correyo.

Mesta in formidade, ena das Reaes Omlens contheudas nariferida de 22 de Trth do anmo proximopassado; onterioc ua Mag: que

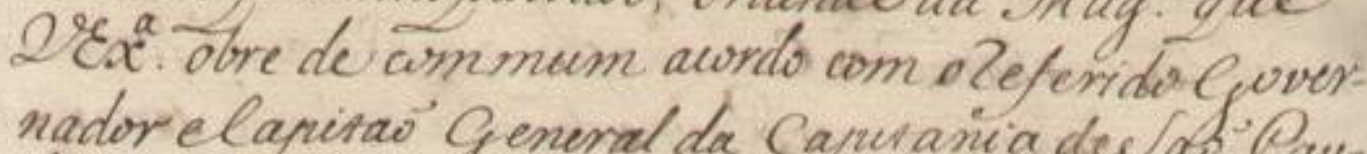
nador e lapira. General da Camañia dec ab baulo; Isto he nas dellarano numea luerna, mas repelindo com amavon eficacia, que corber nifw pliar os Dominis de Iua Mage wmo resem ordenado naleferida cartov.

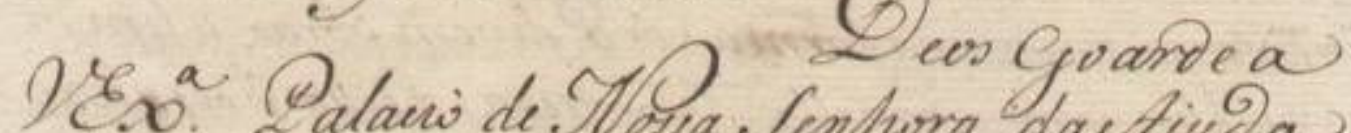
co. Lalaw de sisa Ientwora dactiuga a 22 de Marco de $176 \%$ Fr conde da Cunha 'Pranuse $X$ er de Henduca Fumbo.

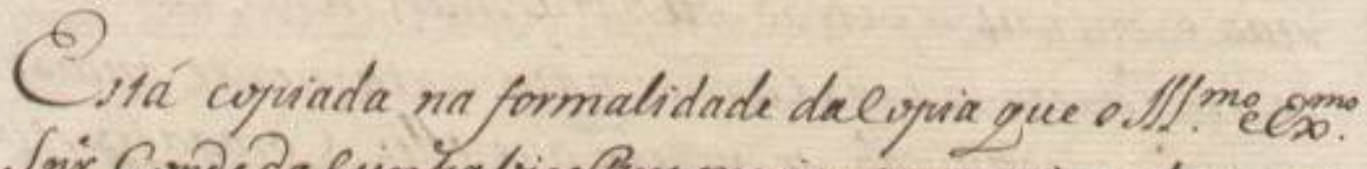

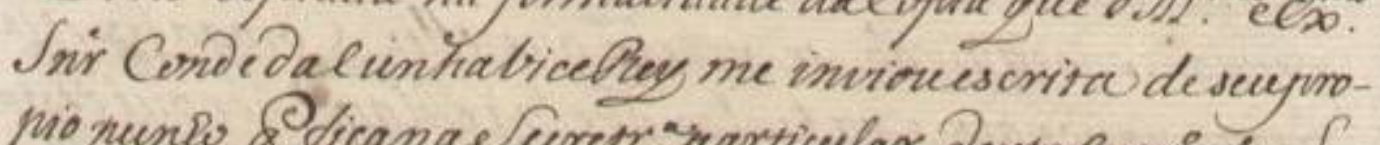
pio punio \& ficanac aretryarticular Destegovi dee. baullo emjidogue me afiino

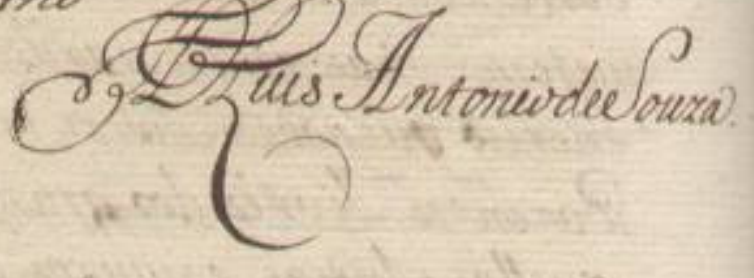

249 
||56v $\|$ pelo contrario publicar que fas toda a deligenciapelos pren

der; mas particularissimamente deve ordenar aode que elle fizer mayor confiança, que vá avizando do que houver daquellas partes, e da negociaçaõ com os $\underline{\text { Coro- }}$ gatís fingindose algum Dezertor daquelle corpo que possa servir de Correyo.

Nesta conformidade, ena das

Reaes Ordens contheudas nareferida de 22 de lulho do annoproximopassado; ordenaSua Magestade que VossaExcelência obre de commum acordo com o referidoGovernador eCapitaõ General da Capitania deSaõ PauIo; Isto he naõ declarando nuncaGuerra, mas repelindo com amayor eficacia, que couber nopossivel, eaproveitando se dessas ocazioens, para ampliar os Dominios de Sua Magestade como setem ordenado nareferida Carta.

\section{Deos Goarde a}

VossaExcelência Palacio de Nossa Senhora daAjuda

200 a 22 de Março de 1767. = Senhor Conde da

Cunha $=$ Francisco Xavier deMendonça Furtado.

Está copiada na formalidade daCopia que o Illustríssimo eExcelentíssimo

Senhor Conde daCunhaViceRey me inviouescrita deseupro-

pio punho que ficanaSecretaria particular desteGoverno deSaõ

Paullo em fé do queme assino

DomLuis AntoniodeSouza. 
[30]

$\|58 r\|$

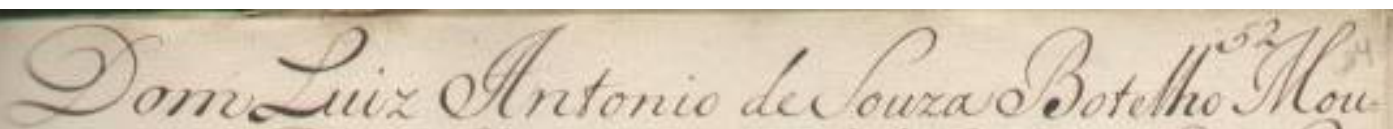
nag Governador Capitao Qeneral da Capitania dec am

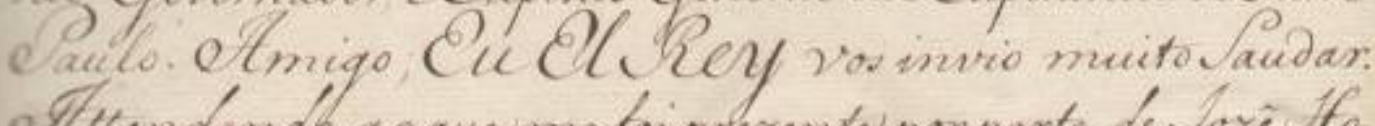

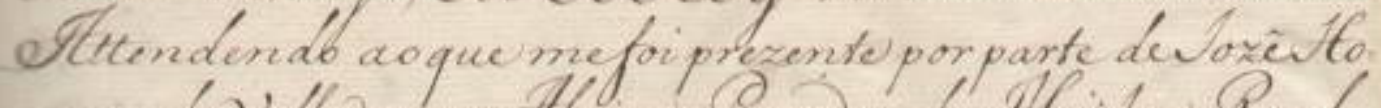
norio de Valladares a tbom, orovedor de Jlinha oreal Fazenda nava Oapitania due acharpencebendo com Dito Oficio unicamente o Ordenado que, the Competo em Correqu= Encea das. Ginhas Ordenes eprivado da ajuda décuto, e Q Coozentadoria que Logram os hinistros della aomesmo tempo que fora obrigado nao'so' a alugar Cazas para Sue labi: facao e existencia dac Provedoria, mas tambem asua Custa mandar faxer todos ospreparos de mexa, bancos estantes epano: Hey porbern Ordenarvos que pela mama rovedo na mandeil dar por huma vez sómento ac Ceferido Tox Q Conorio de valladares e Aboirn duzentos mil reis dequeke faco mence de cyuda de Custo para uprir a despexa quepos com veu trans porte; eiqualmente the mandew Satiof aseor sacóso'todas as desporas que tom fito com as ditas merabanen, estantas spano mas tambor tudo omais que for precixo pa: ra oxpediento da. obre dita rovedoria; arbitrando the oque

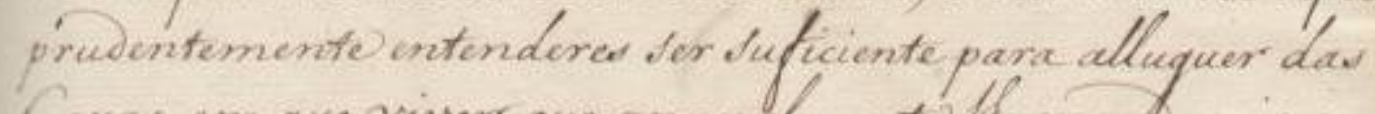
Cazas, em queviver que annualmente the mandoreis en. rreqar. Eoripta no Palacio de Nos lencora da Luda

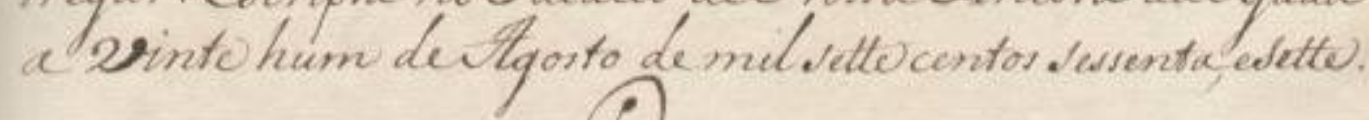

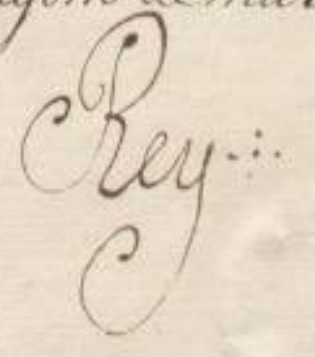

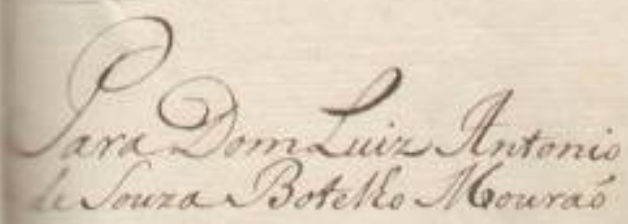
2ayia

251 
||b8r|| Uom LuIz Antonı desouza BoteIno IMou=

raõ Governador, eCapitaõ General daCapitania deSam

Paulo. Amigo; Eu El Rey vos invio muito Saudar.

Attendendo ao que mefoi prezente por parte delozêHo=

norio de Valladares, e Aboim, Provedor deMinha Real

Fazenda nessaCapitania dese achar percebendo com odito

Officio unicamente o Ordenado, que Ihe Compete em Consequ= encia das Minhas Ordens, eprivado daajuda deCusto, e Apozentadoria, queLogram os Ministros della, ao mesmo

10 tempo, quefora obrigado naõ sõ aalugar Cazas para sua habi= taçaõ, eexistencia daProvedoria, mas tambem asua Custa mandar fazer todos os preparos de Meza, bancos, estantes, epano: Hey por bem Ordenar-vos quepela mesma Provedo= ria mandeis dar por huma vez sómente ao referido lozê

15 Honorio de Valladares, eAboim duzentos mil reis, dequelhe faço Mercê deAjuda deCusto paraSuprir adespeza quefes com oseu transporte; eigualmente Ihe mandeis Satisfazer naõ só todas as despezas que tem feito com as ditas Meza,bancos, eestantes, epano, mas tambem tudo omais quefor precizo pa= ra o expediente dasobre dita Provedoria; arbitrando-Ihe o que prudentemente entenderes ser suficiente para alluguer das Cazas, em queviver, queannualmente Ihemandareis en= tregar. Escripta no Palacio deNossa Senhora daAjuda a Vinte hum deAgosto demil sette centos sessenta,esette.

ParaDomLuiz Antonio deSouzaBotelho Mouraõ SegundaVia

\footnotetext{
* Abaixo há o carimbo circular do AESP.
} 
[31]

||59v|

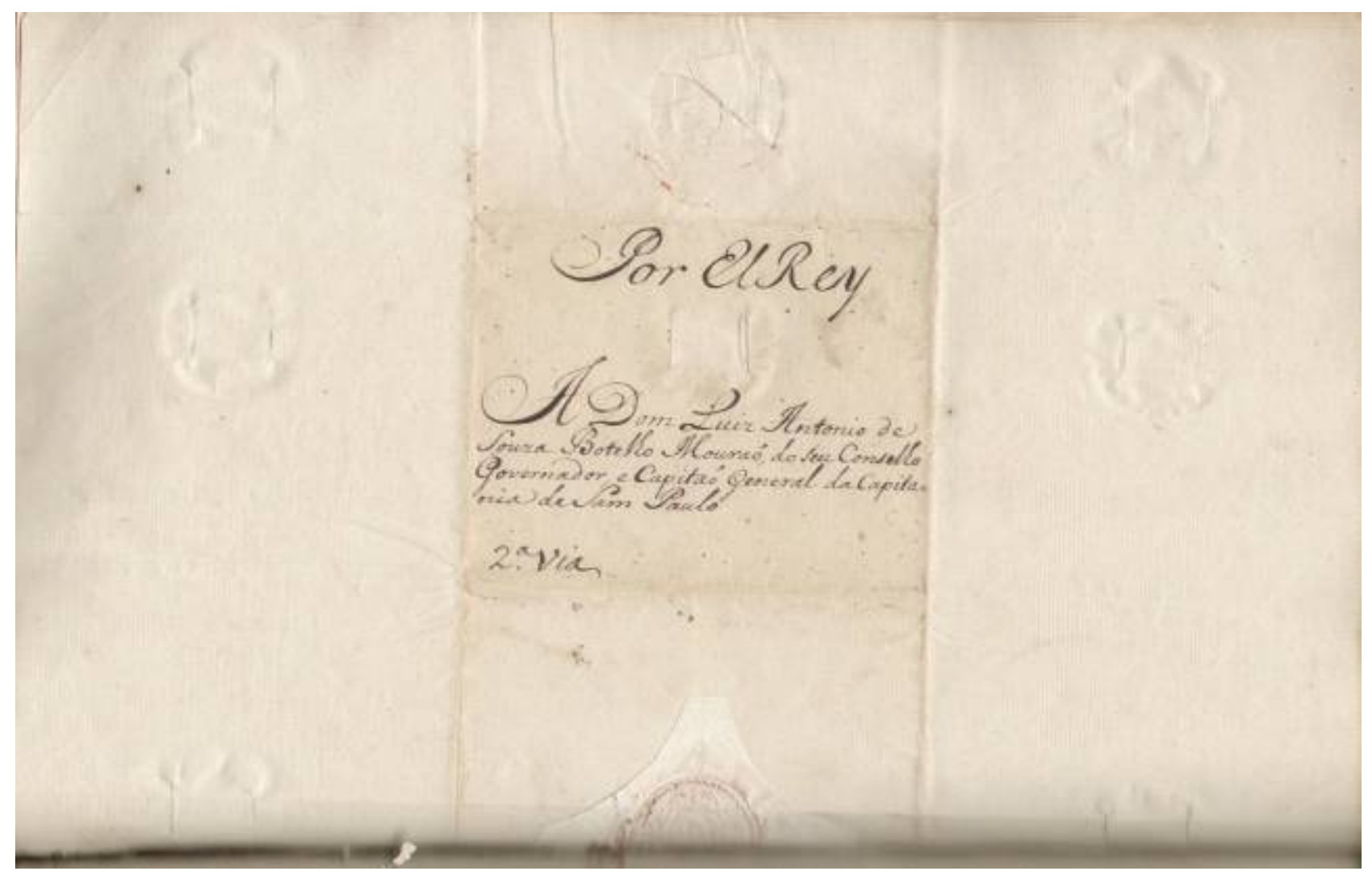


||59v|| Por EIRey*

A Dom Luiz Antonio de

Souza Botelho Mouraõ, do Seu Conselho

Governador, eCapitaõ General daCapita=

nia deSam Paulo.

SegundaVia

* Abaixo há um selo de cera, com papel sobreposto. 
[32]

||60r

Cquid

2.3

Sipois deser Peudids asio

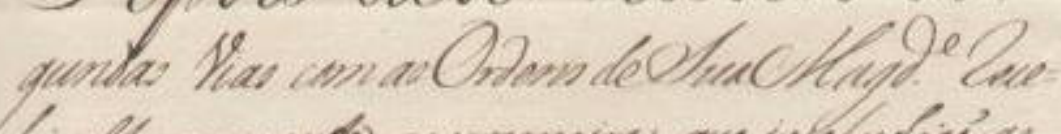

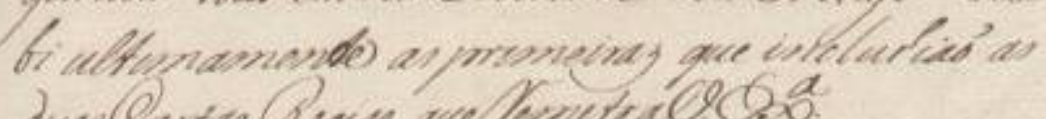

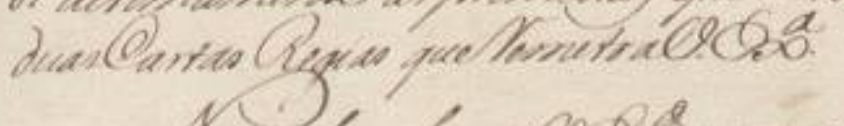

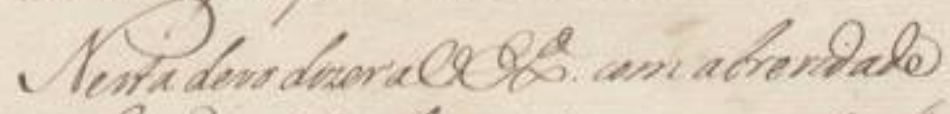

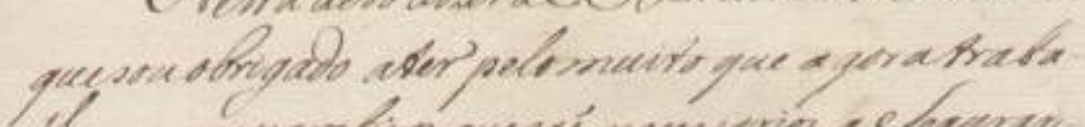

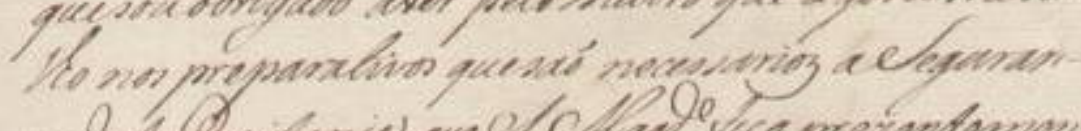

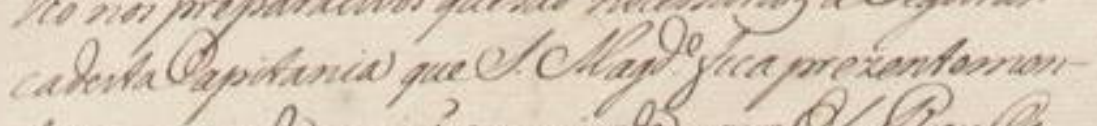

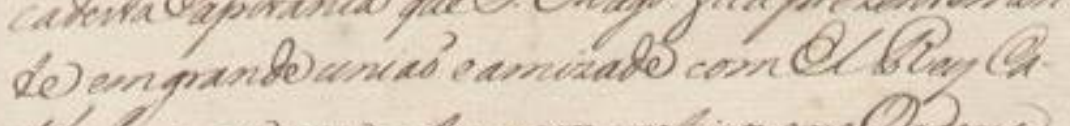
Shave, equil con estes mon motion me Orderix

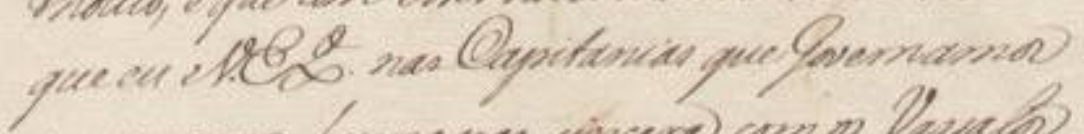

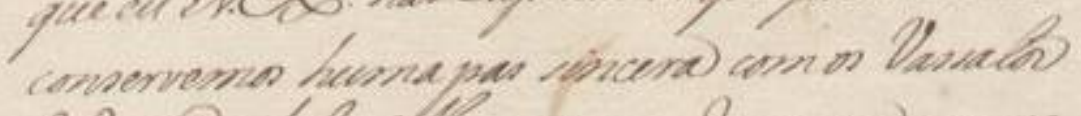

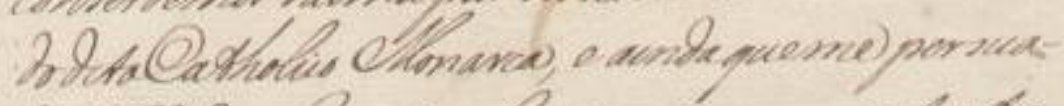

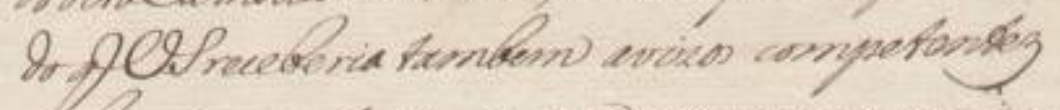

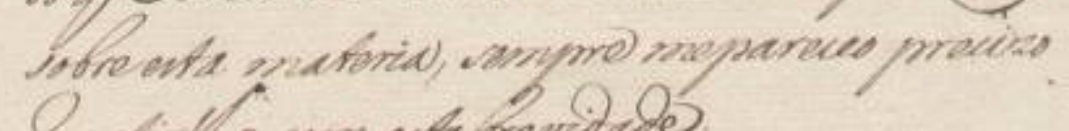

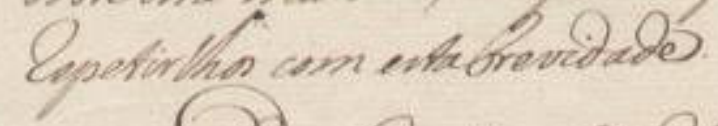

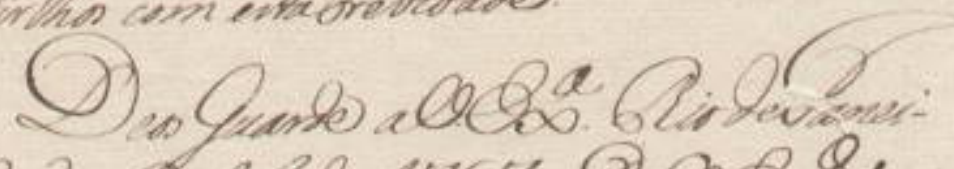

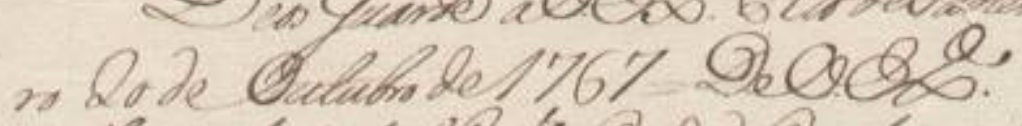

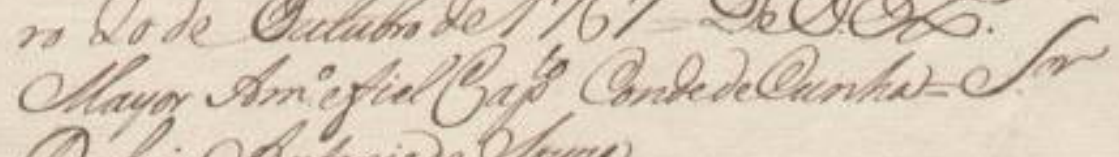

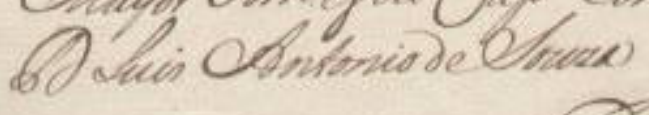

255 
||60r|| Copia

Depois deter recebido as se

gundas Vias com asOrdens deSuaMagestade rece=

bi ultimamente as primeiraz que incluhiaõ as

5 duasCartas Regias queremeto aVossaExcelência.

Nesta devo dizer aVossaExcelência com abrevidade

quesouobrigado ater pelomuito que agoratraba-

Iho nos preparativos quesaõ necessarioz aSeguran-

cadestaCapitania queSua Magestade fica prezentemen-

10 te emgrande uniaõ eamizade comEIRey Ca-

tholico, e que com estes novos motivos meOrdena

queeu eVossaExcelência nasCapitanias que Governamos

conservemos huma pas sincera com os Vassalos

doditoCatholico Monarca, e aindaqueme persua-

15 doqueVossaSenhoria receberia tambem avizos competentez

sobre esta materia, sempre mepareceo precizo

repetir Ihos com estabrevidade.

Deos Guarde aVossaExcelência Rio delanei-

ro 20 deOutubro de1767 = DeVossaExcelência.

20 Mayor Amigo efiel Capitivo CondedeCunha $=$ Senhor

Dom Luis Antonio deSouza

DomLuis AntoniodeSouza 
[33]

||62r

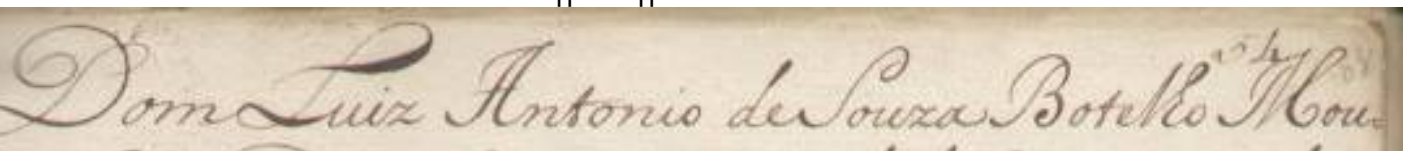
rao, Qovernadore Capitaó Qenenal da Capitania do sao. aulo. Atmigo eu QLRey vos invio muito sau. dar como aquelle que amo. Oroy Ques. Nosiro inhor servido abencoar estes Reinbs, dando thes huma $\Omega_{n}$. fanta, que Maveeo no dia de hoje com bom Successo $2 x$ Q rincexa do Braxil Minha obre to das muito ama: da, ev rexada Fitha: Ome pareces participar vor afous ta noticia deste plauxivel or ascimento; porque sera de muita alegrio para os 1 Geus Vwastlos epara que of festes jeis com to daw aquellas demonstracóes de ap lauro, e decone tentamento, que daó do costume en occaxisés Semelkan tes: Fendo por muito corto, que assim o excecutareis como devios expero. Evoripta no Aalacio de Mosia enhoro dí tiuda a quinze de Pexemboro de mil, seltecentos ves

$\because \cdots$ ezral e oito.

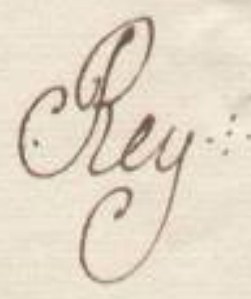

Arra Dom Luir Antorio

Soura Botello Ml boureó

2.ria.

257 
||62r|| DomLuiz Antonio deSouza Botelho Mou= raõ Governador, e Capitaõ General daCapitania de Saõ Paulo. Amigo EuELRey vos invio muito sau= dar como aquelle que amo. Foy Deus Nosso Senhor

5 servido abençoar estes Reinos, dando-Ihes huma In= fanta, que Nasceo no dia dehoje com bom Successo da Princeza do Brazil, Minha sobre todas muito ama= da, ePrezada Filha: Eme pareceo participar-vos afaus= ta noticia deste plauzivel Nascimento; porque serà de

10 muita alegria para os Meus Vassallos; epara que ofeste= jeis com todas aquellas demonstraçoẽs de aplauzo, e de con= tentamento, queSaõ do costume em occazioẽs semelhan tes: Tendo por muito certo, que assim o executareis, como de vòs espero. Escripta no Palacio deNossaSenhora

15 daAjuda a quinze de Dezembro demil, settecentos, ses senta e oito.

$\underline{\text { Rey }}$

Para Dom Luiz Antonio

deSouzaBotelho Mouraõ

20 SegundaVia 
[34]

||63v |

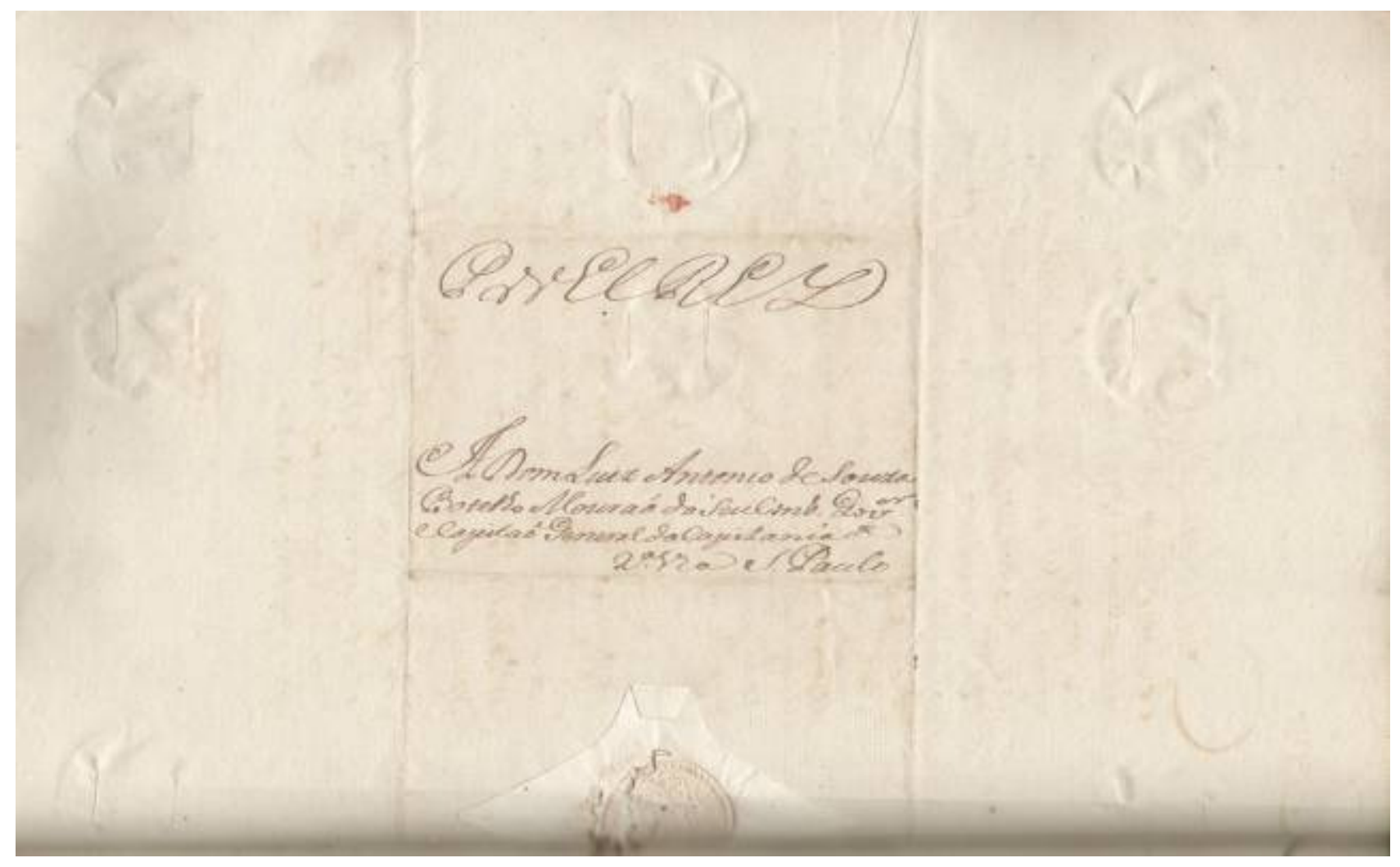


\|63v $\|$ Por El REY*

A DomLuiz Antonio deSouza

Botelho Mouraõ, do SeuConselho Governador

eCapitaõ General daCapitania de

SegundaVia Saõ Paulo 
opu

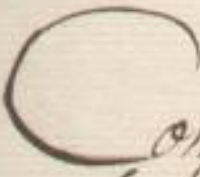

em a chequat 9 o (c)

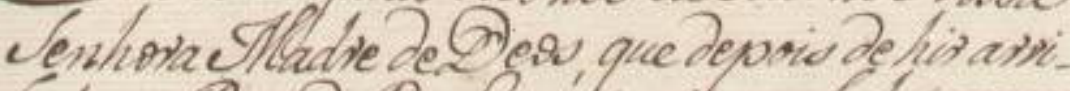

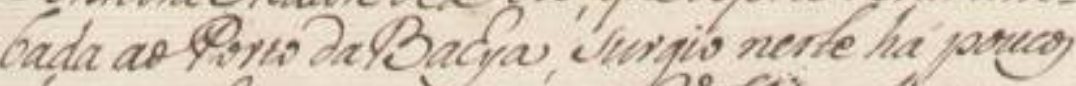

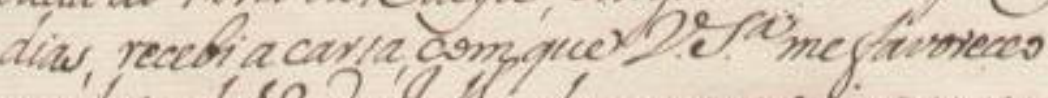

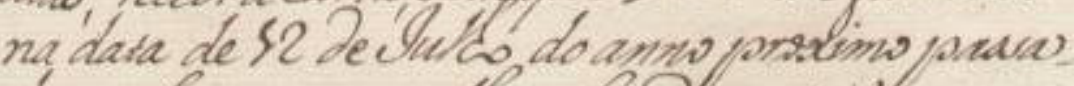

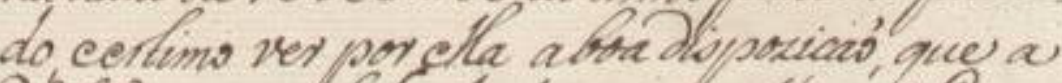

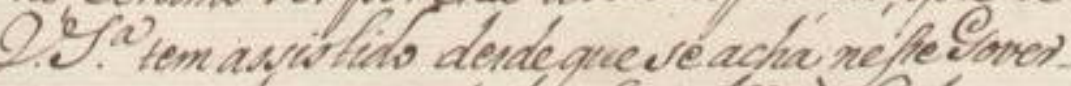

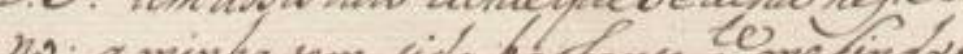

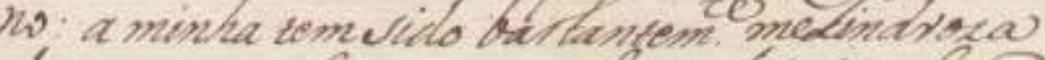

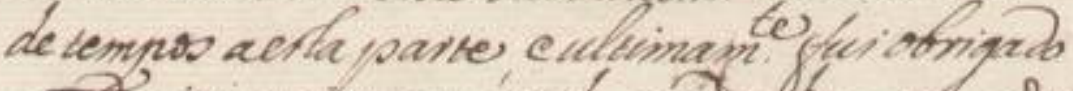

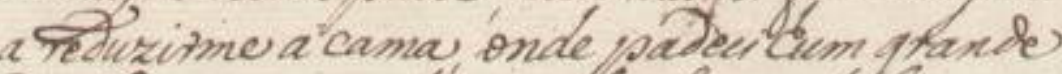
degtux cominuato com motarter feores, eaix

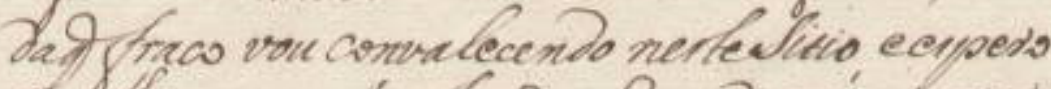

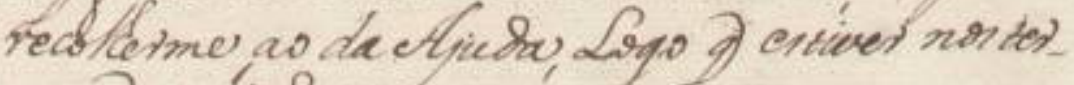
mo, devain becara.

6 Coresionotion es

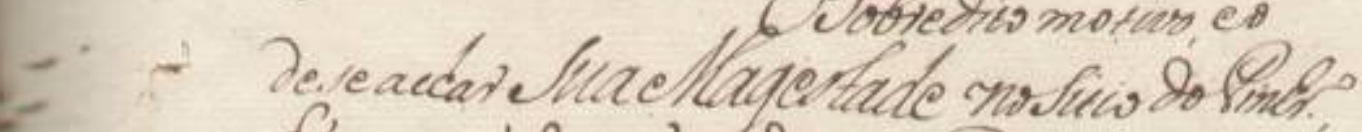
C'ocaria's de nav pob' rernonder ao mai, que

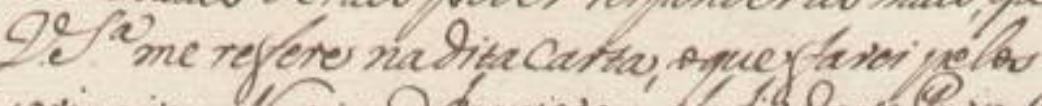

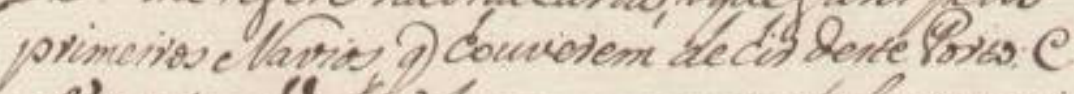

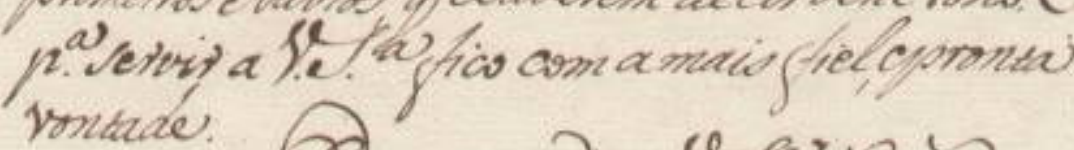

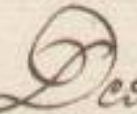

Lesquatera la mian.

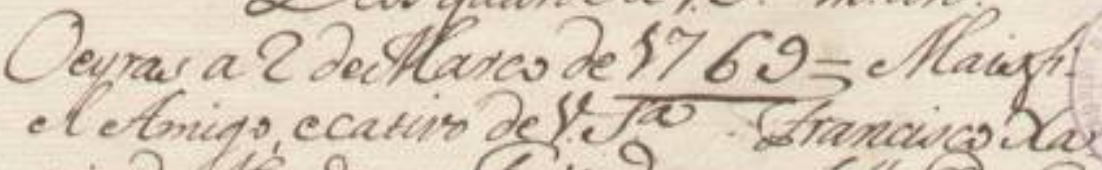

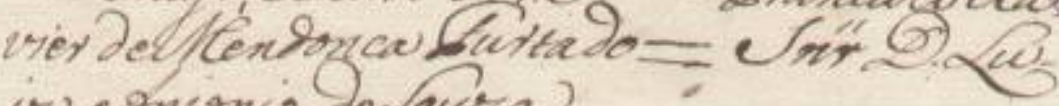
is entomis declovia

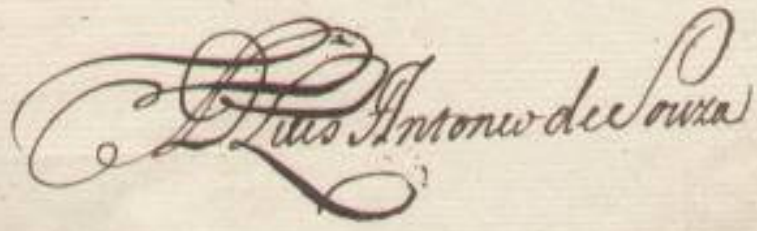


||64r|| Lopıa

Com a chegada daNao deGuerra Nossa

Senhora Madre de Deos, que depois de hir arri-

bada aoPorto da Bahya, surgio neste há poucos

5 dias, recebi a carta, com que VossaSenhoria mefavoreceo

na data de 12 de lulho do anno proximo passa-

do eestimo ver por ella aboa dispoziçaõ, que a

VossaSenhoria tem assistido desde que se acha nesse Gover-

no: a minha tem sido bastantemente meLindroza

10 de tempos aesta parte, e ultimamente fui obrigado

a reduzirme a cama, onde padeci hum grande

defluxo continuado com bastantes febres, eain-

daquefraco vou convalecendo nesteSitio, eespero

recolherme ao da Ajuda, Logo que estiver nos ter-

15 mos desahir de caza.

OSobredito motivo, eo

dese achar Sua Magestade noSitio doPinheiro

hé ocaziaõ de naõ poder responder ao mais, que

VossaSenhoria me refere nadita Carta, oque farei pelos

20 primeiros Navios, que houverem de hir deste Porto: $\mathrm{E}$

para servir a VossaSenhoria fico com a mais fiel, epronta

vontade.

Deos guarde a VossaSenhoria muitos annos

Oeyras a 2 deMarço de $\underline{1769}=$ Maisfi-*

25 el Amigo, ecativo de VossaSenhoria. Francisco Xa

vier deMendonça Furtado $=$ Senhor Dom Lu-

iz Antonio deSouza

Dom Luis AntoniodeSouza

* Abaixo há o carimbo do AESP. 


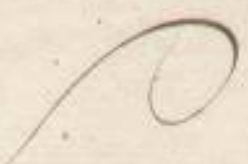

?

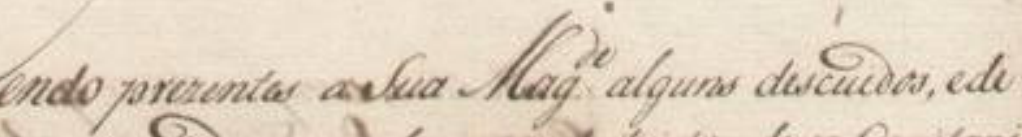

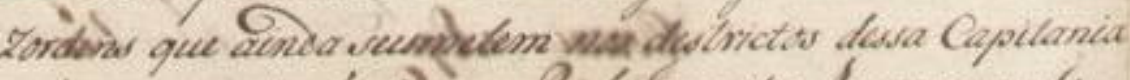

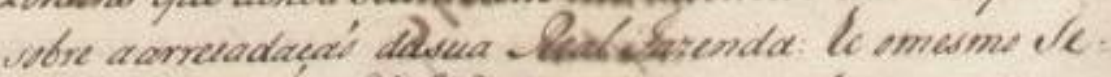

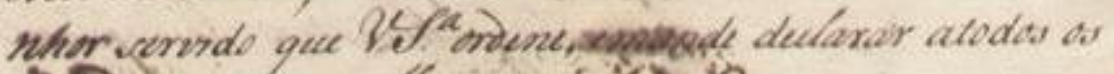

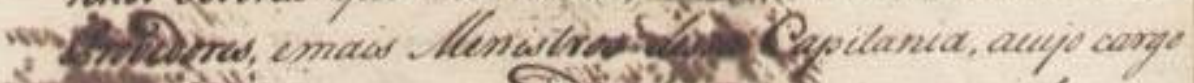

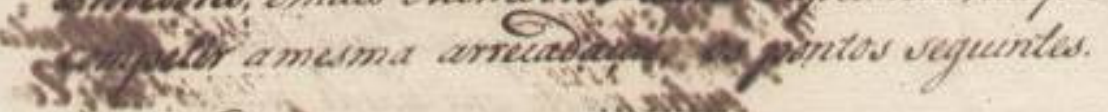

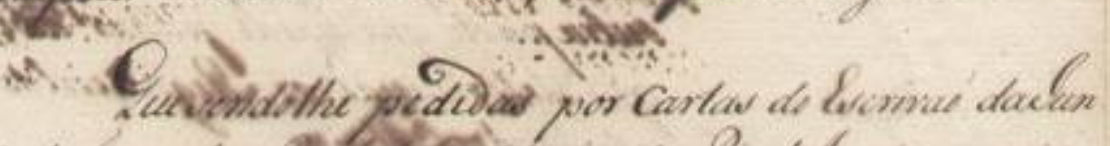

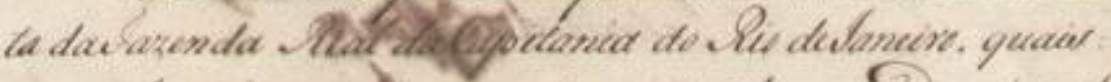

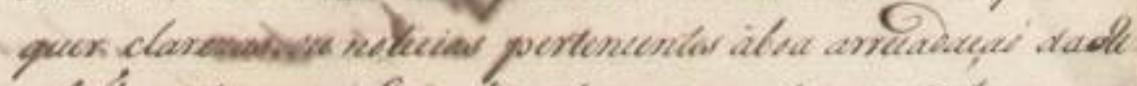

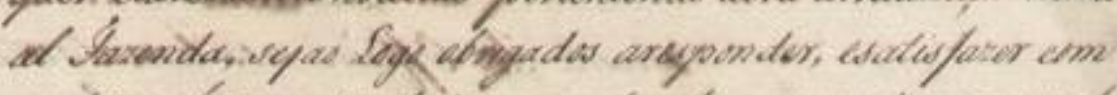

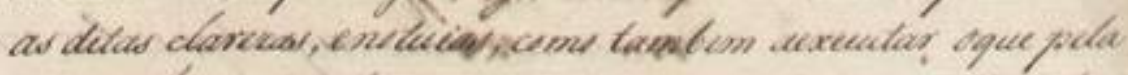

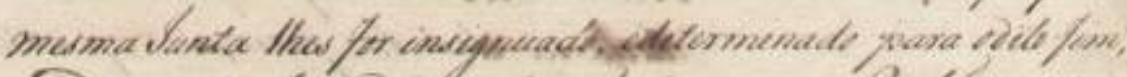

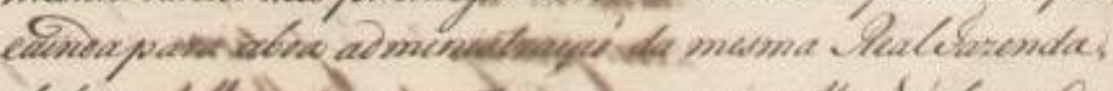

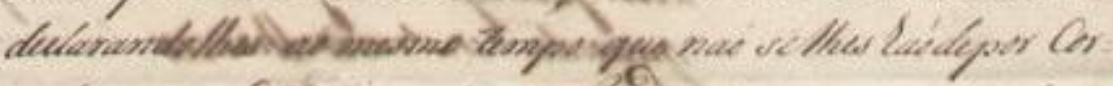

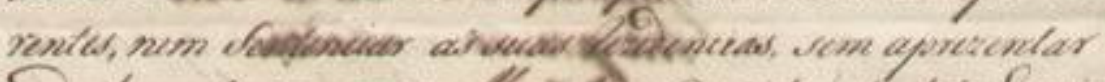

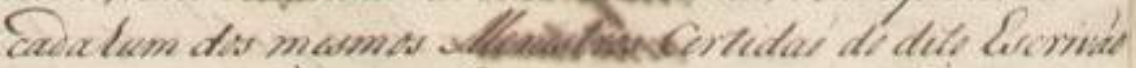

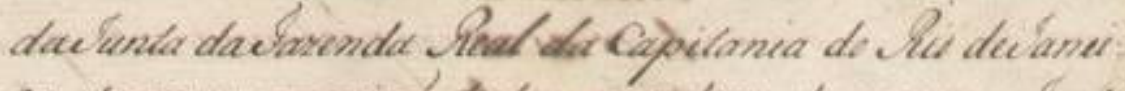

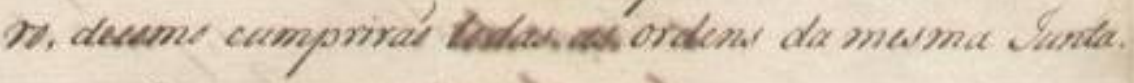

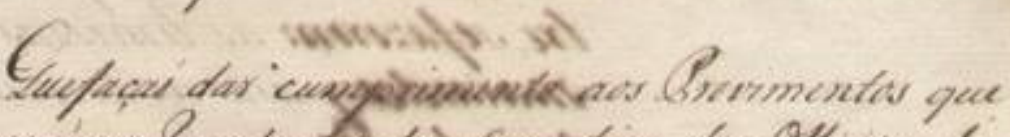

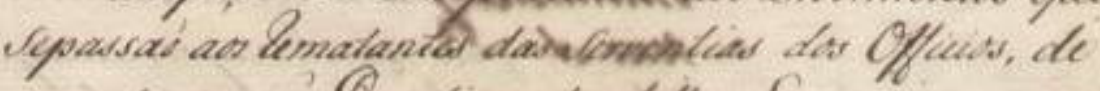

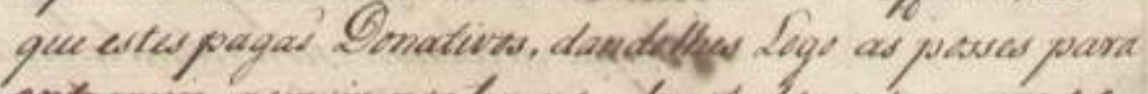

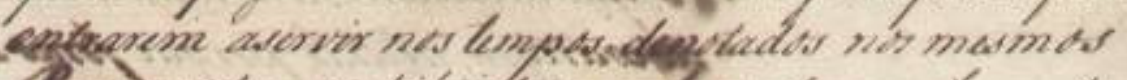

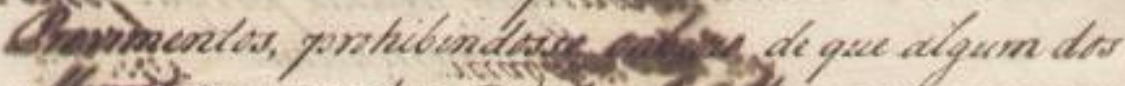

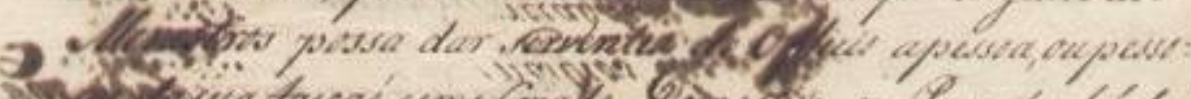

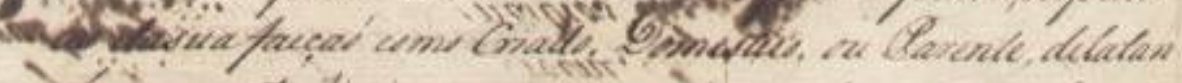

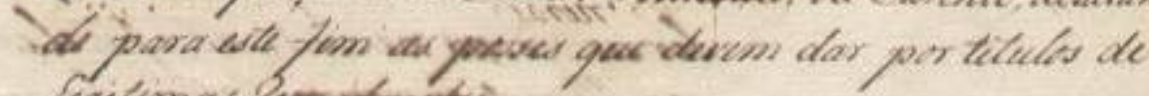

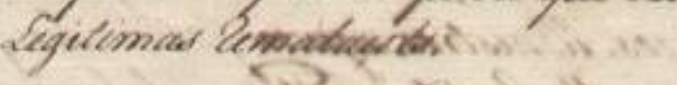

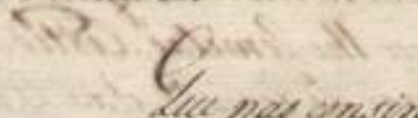

Yue nas amintá yus a lomatinteer

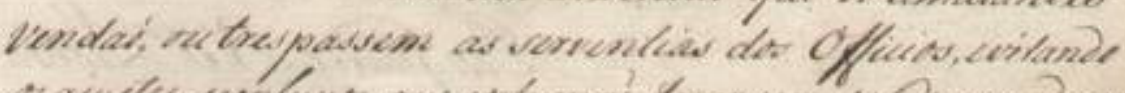

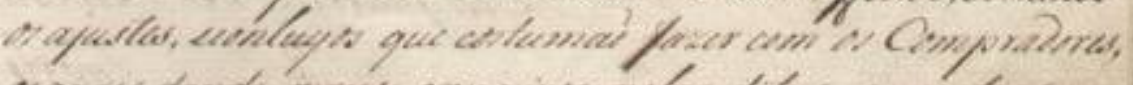

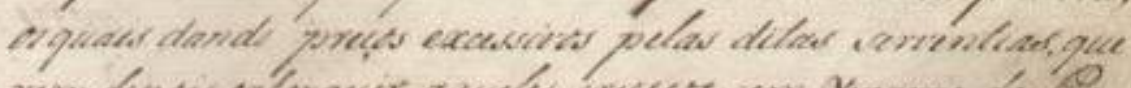

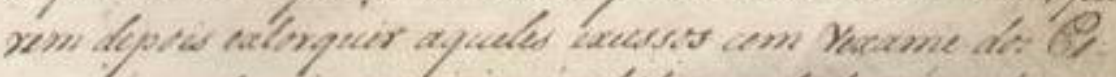

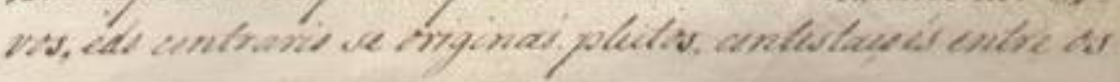


||67r|| Sendo prezentes a Sua Magestade alguns descuidos, ede= zordens que ainda secometem nos destrictos dessa Capitania sobre a arrecadaçaõ dasua Real Fazenda: he o mesmo $\mathrm{Se}=$ nhor servido que VossaSenhoria ordene, emande declarar atodos os Provedores, emais Menistros dessa Capitania, acujo cargo competir a mesma arrecadaçaõ, os pontos seguintes.

Que sendo the pedidas por Cartas do Escrivaõ dalun ta daFazenda Real daCapitania do Rio delaneiro, quais= quer clarezas, ou noticias pertencentes àboa arrecadaçaõ daRe=

10 al Fazenda, sejaõ Logo obrigados aresponder, esatisfazer com as ditas clarezas, enoticias, como tambem aexecutar oque pela mesma lunta Ihes for insignuado, edeterminado para odito fim, eainda para aboa administraçaõ da mesma RealFazenda, declarando Ihes ao mesmo tempo que naõ selhes haõ depor Cor= rentes, nem Sentenciar as suas rezidencias, sem aprezentar cadahum dos mesmos Menistros Certidaõ do dito Escrivaõ dalunta daFazenda Real da Capitania do Rio delanei= ro, decomo cumpriraõ todas as ordens da mesma lunta.

Quefaçaõ dar cumprimento aos Provimentos que

20 Sepassaõ aos rematantes das Serventias dos Officios, de que estes pagaõ Donativos, dando lhes Logo as posses para entrarem aservir nos tempos denotados nos mesmos Provimentos, prohibindosse oabuzo de que algum dos Menistros possa dar serventia de Officio apessoa, ou pesso= as dasuafacçaõ como Criado, Domestico, ou Parente, dilatan do para este fim as posses que devem dar por titulos de Legitimas remataçoẽs.

Que naõ consintaõ que os rematantes vendaõ, ou trespassem as serventias dos Officios, evitando os ajustes, econluyos que costumaõ fazer com os Compradores, os quais dando preços excessivos pelas ditas serventias, que rem depois extorquir aqueles excessos com Vexame dos $\mathrm{Po}=$ vos, edo contrario se originaõ pleitos, contestaçoẽs entre os 


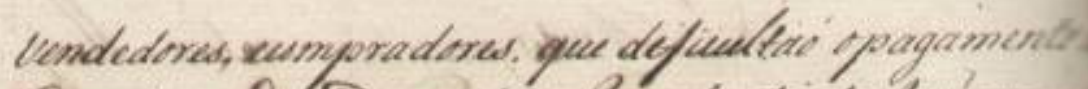

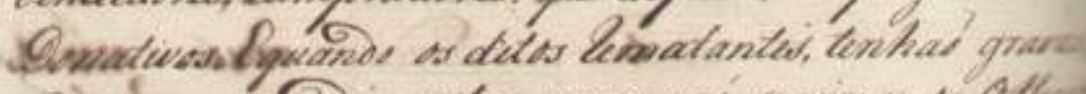

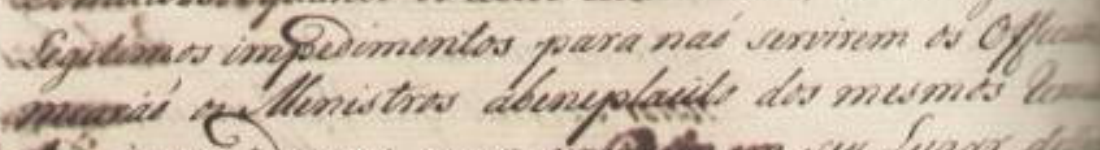

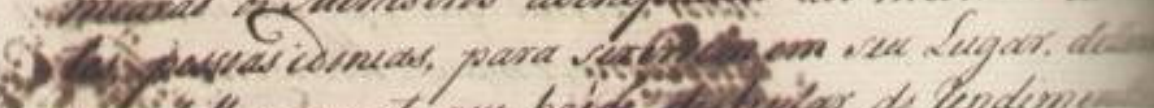

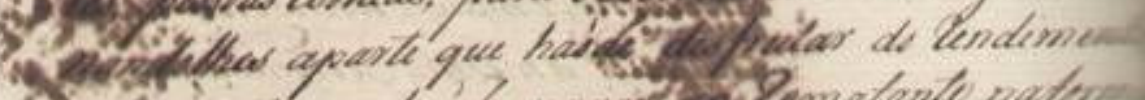

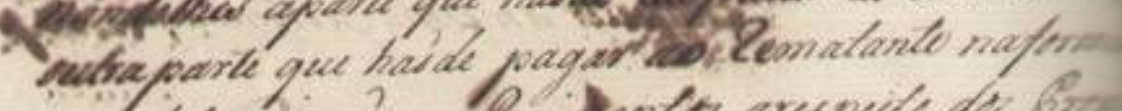

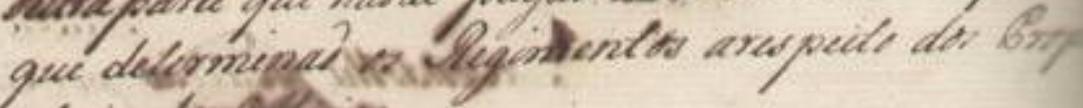
elaritodoctaigs. ...

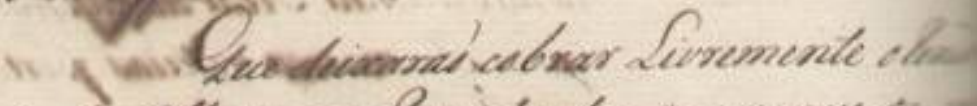

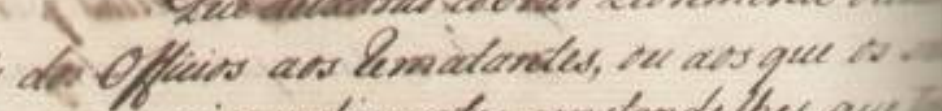

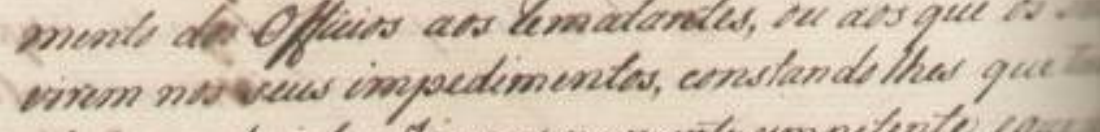

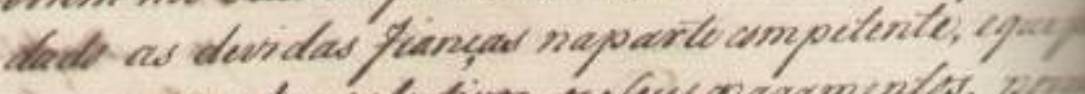

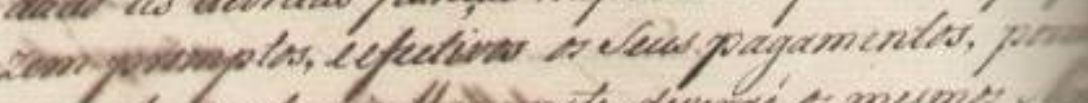

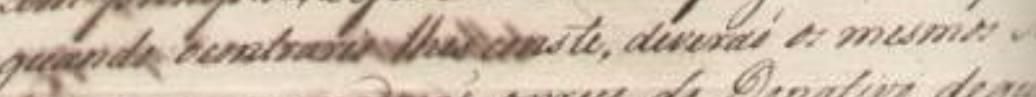

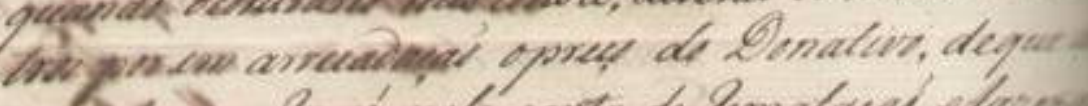

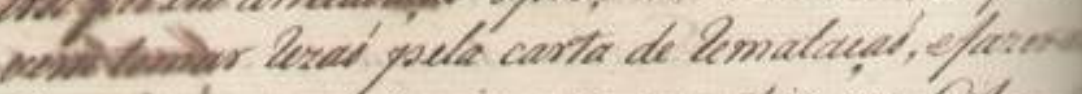

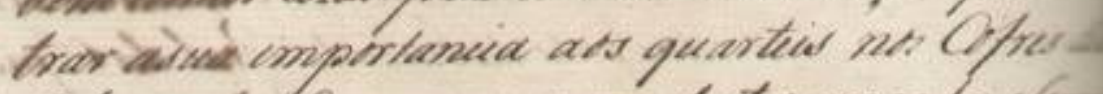

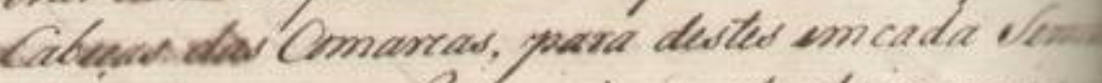

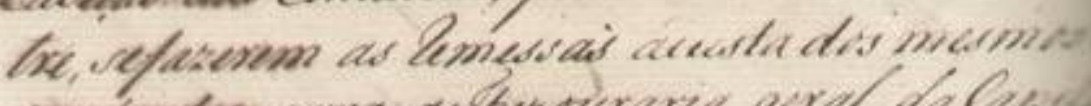

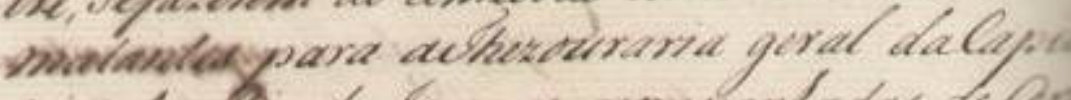

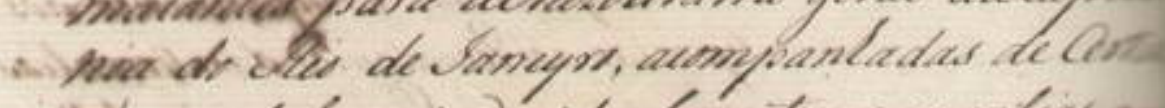
tof pue dedarem indierdualmente as quantias.

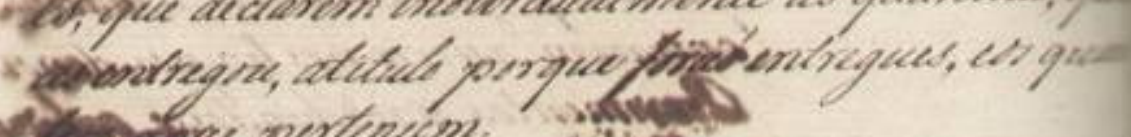

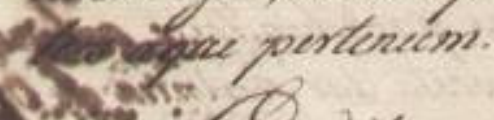

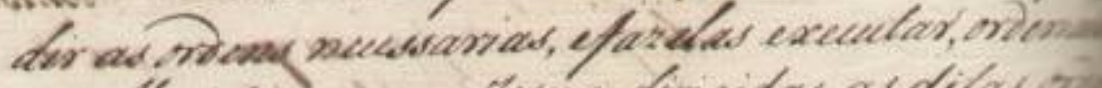

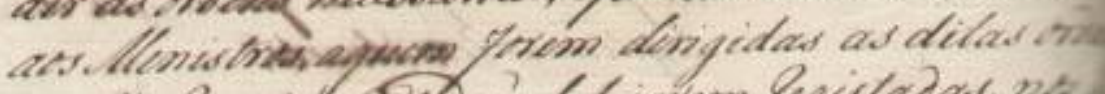

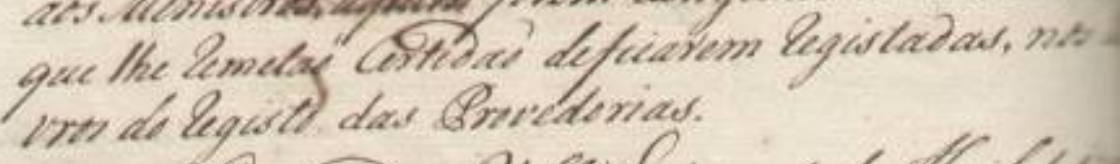

$$
\begin{aligned}
& \text { Qungunde a li pulven ale de. Pbridel } \\
& \text { ondedeleyray }
\end{aligned}
$$


||67v || vendedores, ecompradores, que deficultaõ opagamento [de]

35 Donativos, Equando os ditos rematantes, tenhaõ gran[des e]

Legitimos impedimentos para naõ servirem os Offici[ais no]

mearaõ os Menistros abeneplacito dos mesmos [rematan-]

tes, pessoas idoneas, para servirem em seu Lugar, de[termi-]

nandolhes aparte que haõ de disfrutar do rendimento [em]

40

outra parte que haõ de pagar ao rematante naforma [em]

que determinaõ os Regimentos arespeito dos Pro[pri-]

etarios dos Officios.

Que deixaraõ cobrar Livremente o rendi-

mento dos Officios aos rematantes, ou aos que os ser-

45 virem nos seus impedimentos, constando Ihes que tem

dado as devidas fianças naparte competente, equefa-

zem promptos, e efectivos os seus pagamentos, po[rem]

quando o contrario lhes conste, deveraõ os mesmos Menis-

tros por em arrecadaçaõ opreço do Donativo, deque de-

vem tomar rezaõ pela carta de remataçaõ, efazer [encon-]

trar asua importancia aos quarteis nos Cofres [das]

Cabeças das Comarcas, para destes em cada Semes-

tre, sefazerem as remessas acusta dos mesmos [re-]

matantes para aThezouraria geral daCapita-

55 nia do Rio de laneyro, acompanhadas de Certido-

ẽs, que declarem individualmente as quantias, que

as entregou, atitulo porque foraõ entregues, eos quar-

teis aque pertencem.

Enadita conformidade, mandará VossaSenhoria expe-

60 dir as ordens necessarias, efazelas executar, ordena[ndo] aos Menistros, aquem forem dirigidas as ditas ordens que lhe remetaõ Certidaõ deficarem registadas, nos [ $\mathrm{Li}-]$ vros do registo das Provedorias.

Deos guarde a VossaSenhoria Lisboa a 4 de Abril de 176[9]

Senhor Dom Luis Antonio deSouza 
[37]

||69v|

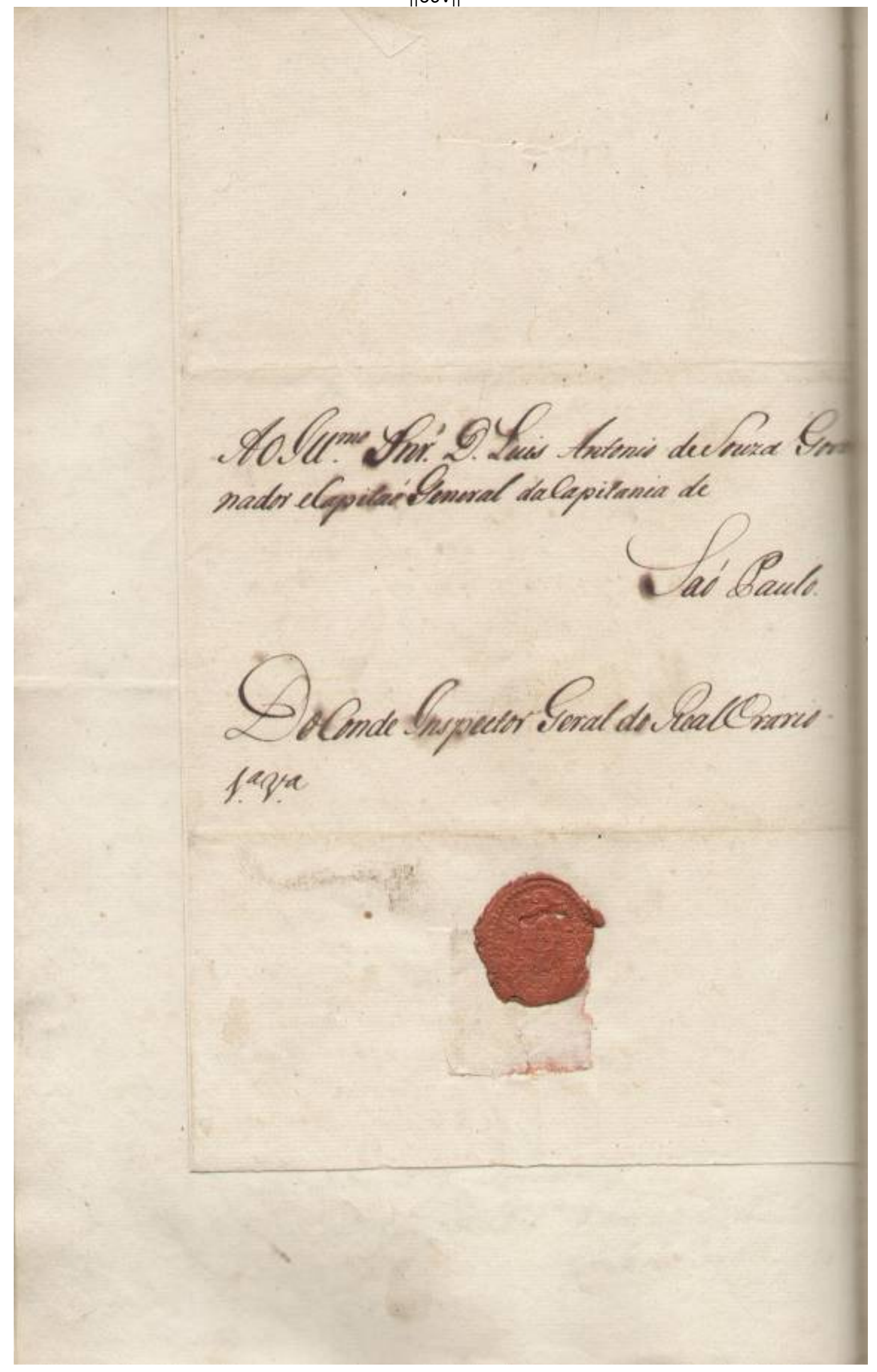


\|69v || Ao Illustríssimo Senhor Dom Luis Antonio deSouza Governador eCapitaõ General daCapitania de Saõ Paulo.

DoConde InspectorGeral do RealOrario 


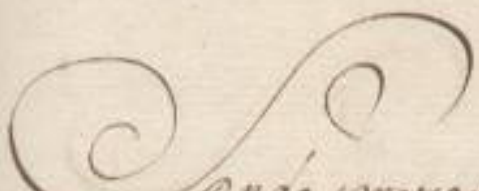

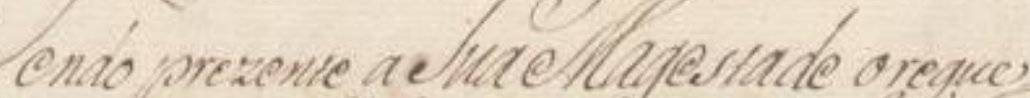

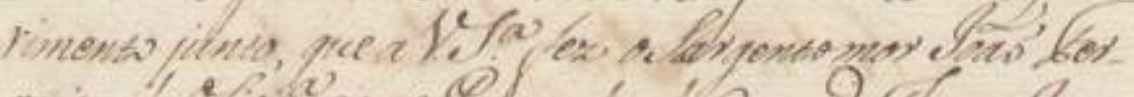

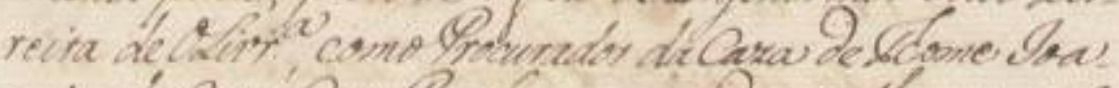

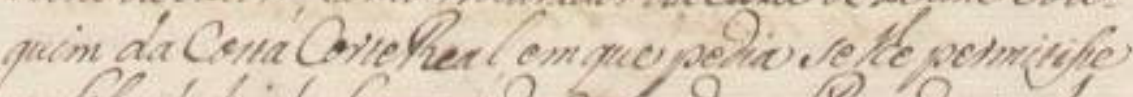

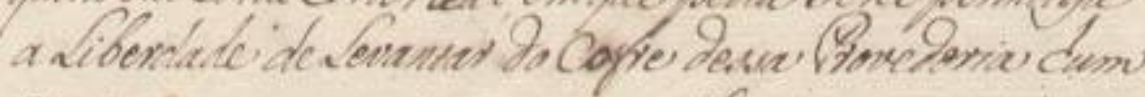

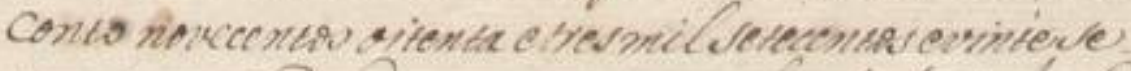

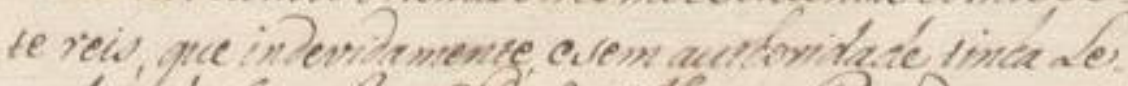

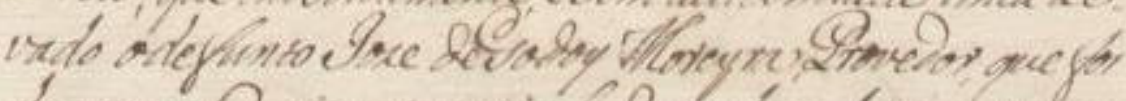

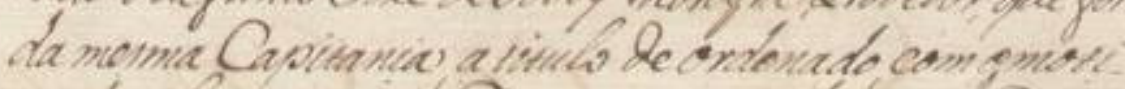

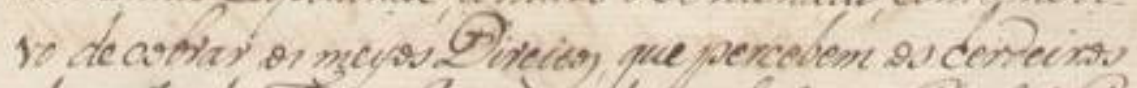

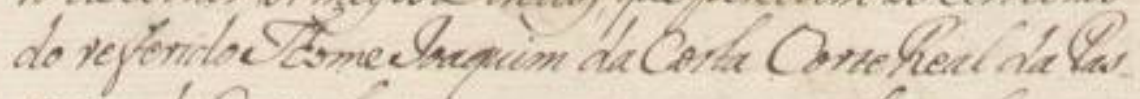

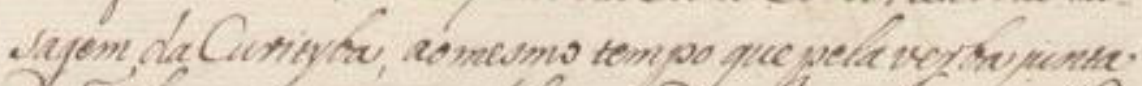

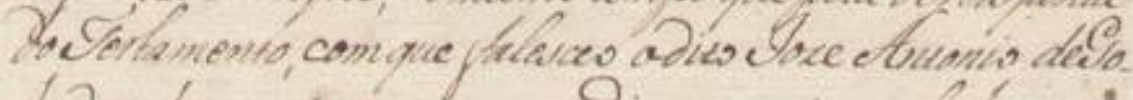

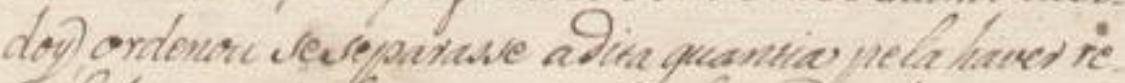

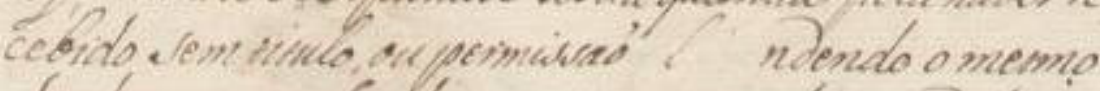

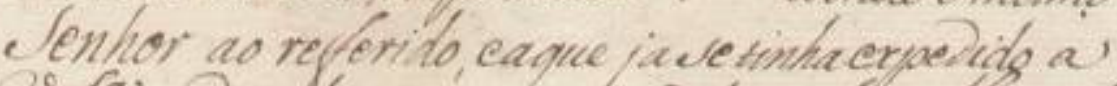

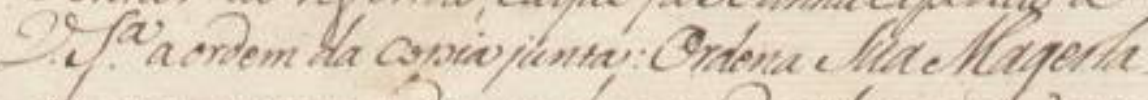
de que a mima orien tence ama devila exendan, eve

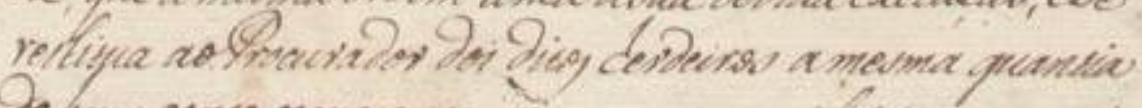

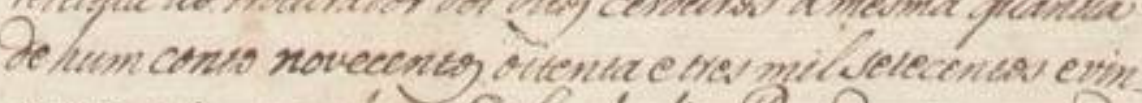

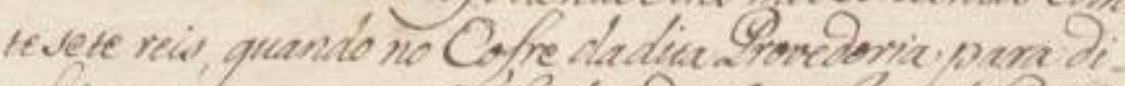

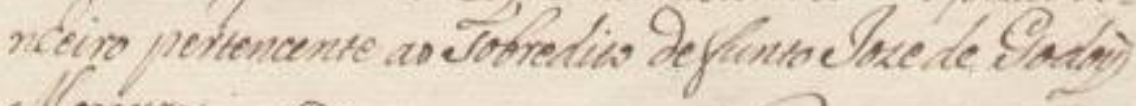
enevin:

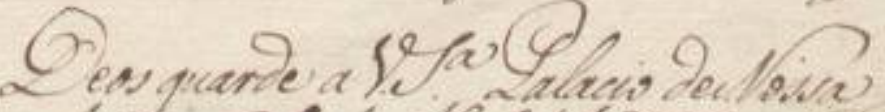

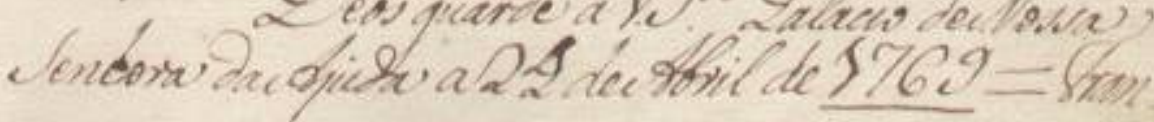


||70r|| Sendo prezente a Sua Magestade oreque-

rimento junto, que a VossaSenhoria fez oSargentomor loaõ Fer-

reira de Oliveira, como Procurador da Caza de Thome loa-

quim da Costa CorteReal, em que pedia se Ihe permitisse

5 a Liberdade de Levantar do Cofre dessa Provedoria hum conto novecentos oitenta etres mil setecentos evinte sete reis, que indevidamente, e sem authoridade tinha Levado odefunto loze deGodoy Moreyra, Provedor, que foi da mesma Capitania, a titulo deordenado, com omoti-

10 vo de cobrar os meyor Direitos, que percebem os herdeiros do referido Thome loaquim da Costa Corte Real da Passagem da Curityba, ao mesmo tempo que pela verba junta do Testamento, com que falesceo odito loze Antonio deGodoy, ordenou seseparasse adita quantia pela haver re-

15 cebido sem titulo, ou permissaõ [ilegível]ndendo o mesmo Senhor ao referido, eaque jase tinha expedido a VossaSenhoria a ordem da copia junta: Ordena Sua Magestade, que a mesma ordem tenha asua devida execuçaõ, ese restitua aoProcurador dos ditos herdeiros amesma quantia

20 de hum conto novecentos oitenta etres mil setecentos evintesete reis, quando no Cofre dadita Provedoria para dinheiro pertencente ao Sobredito defunto loze de Godoy Moreyra.

Deos guarde a VossaSenhoria Palacio deNossa

25 Senhora daAjuda a24 deAbril de $\underline{1769}=$ Fran- 


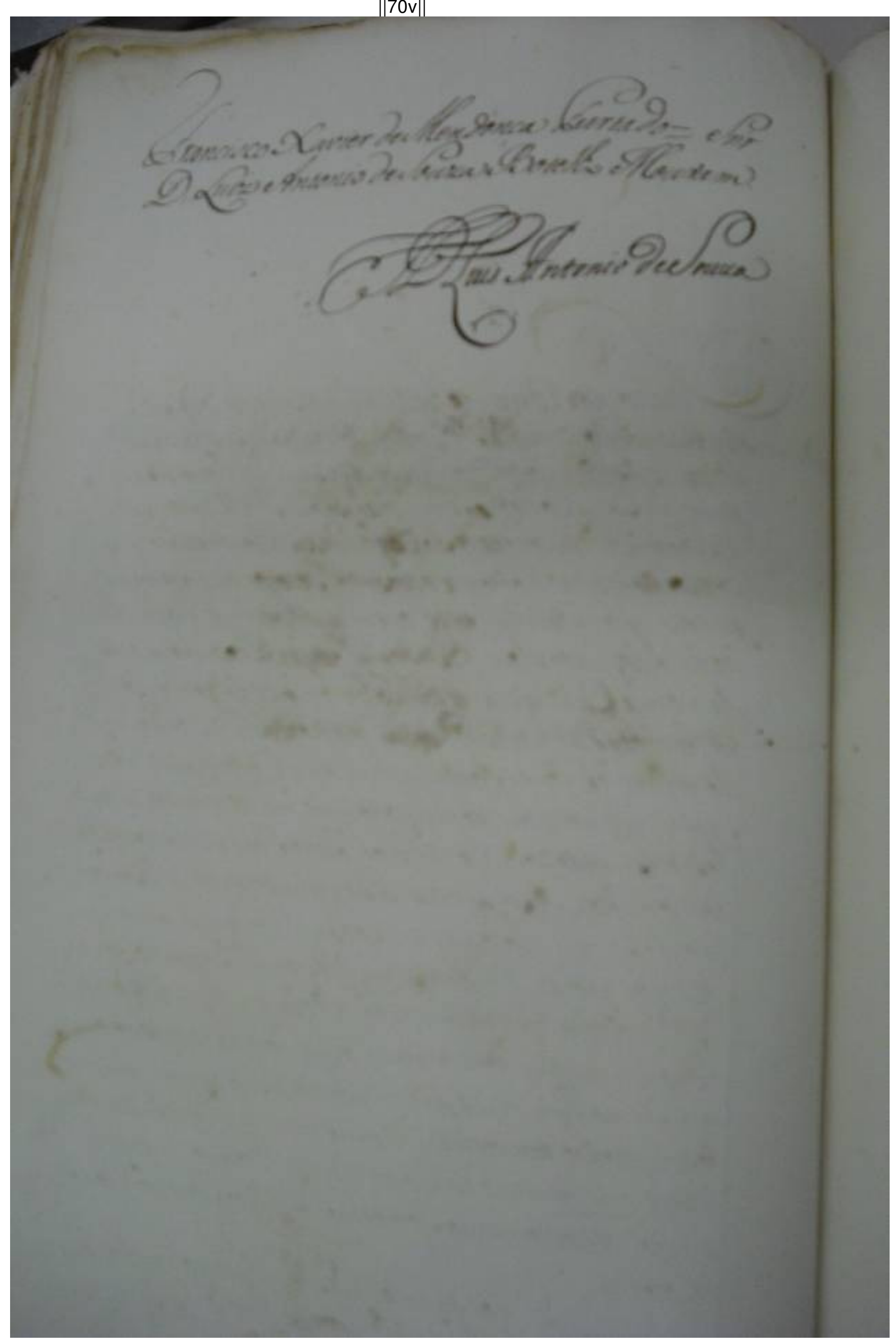


||70v|| [[Fran]]cisco Xavier deMendonça Furtado= Senhor

Dom Luiz Antonio deSouza Botelho Mouram.

DomLuiz Antonio deSouza 


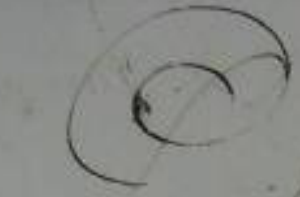

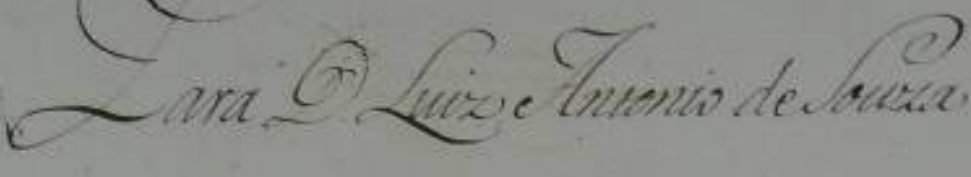

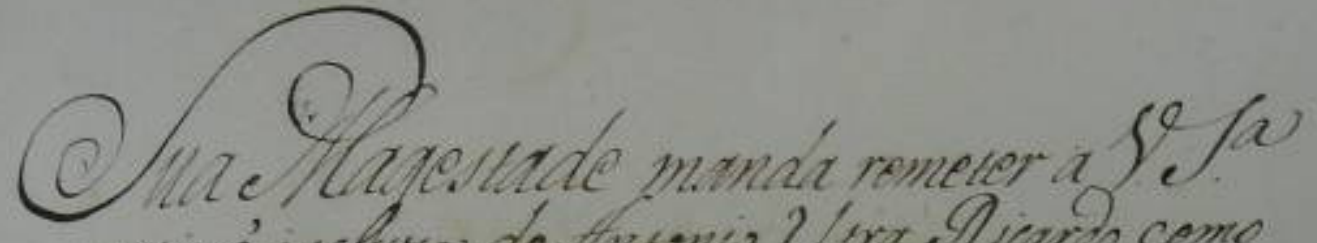

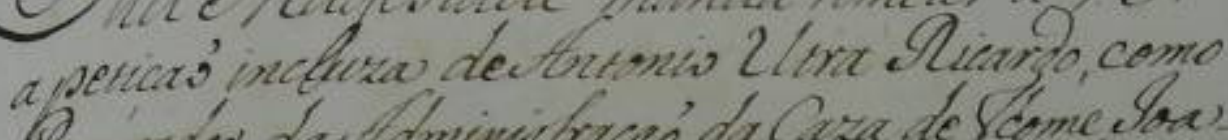

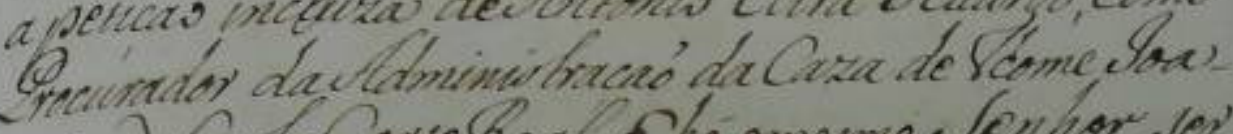

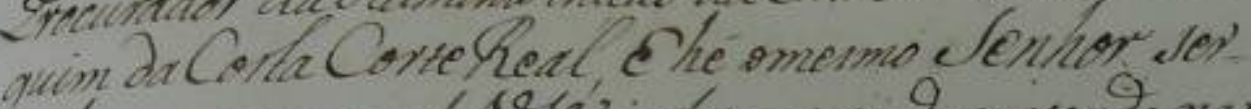

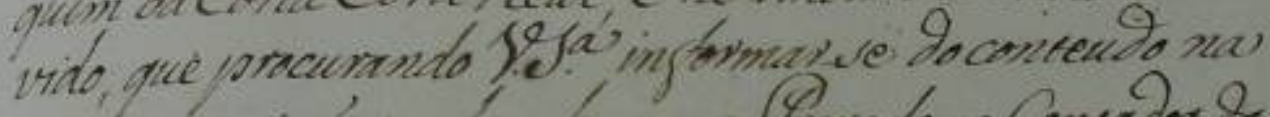

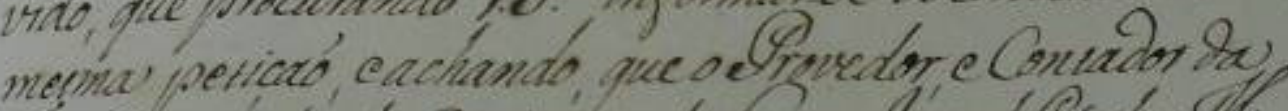

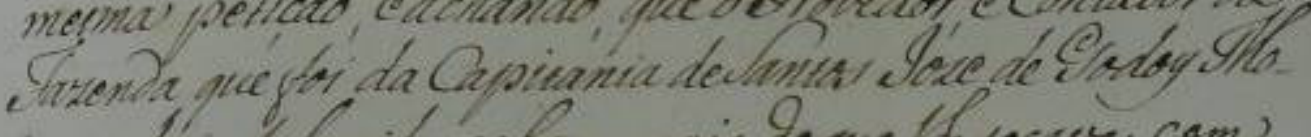

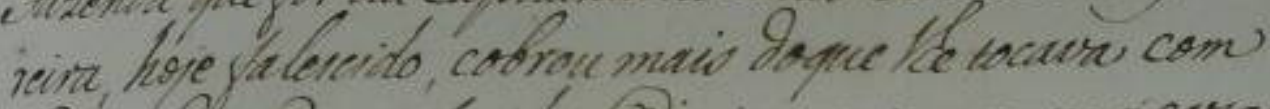

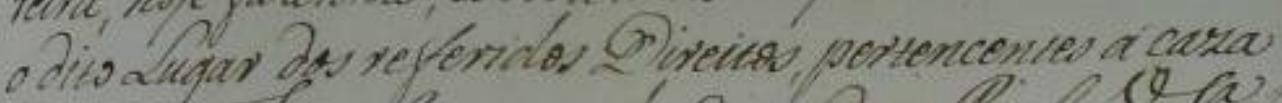

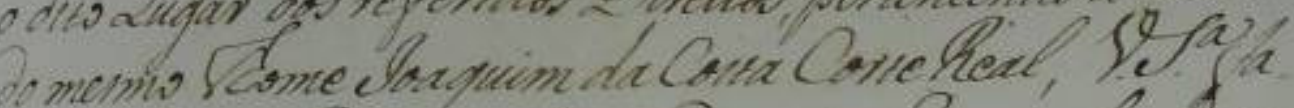

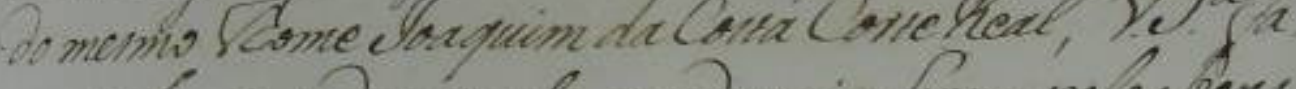

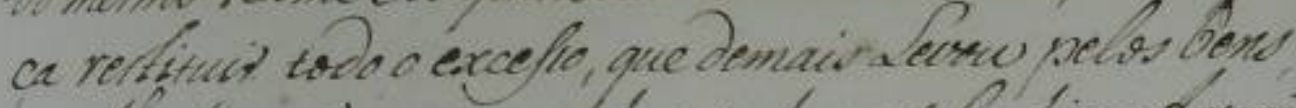

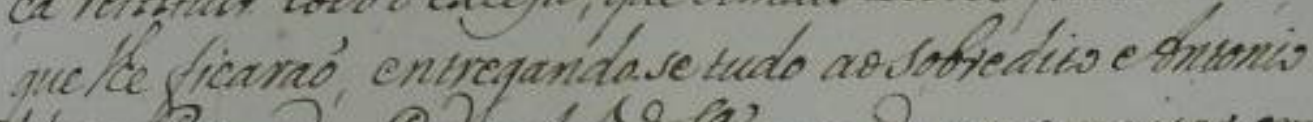

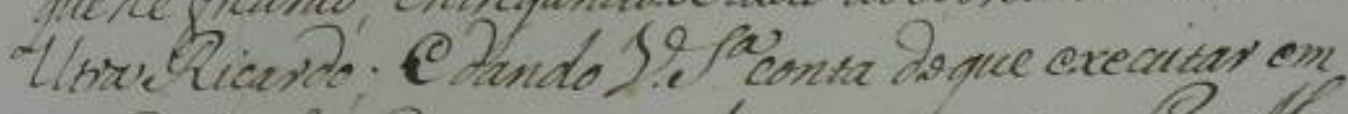

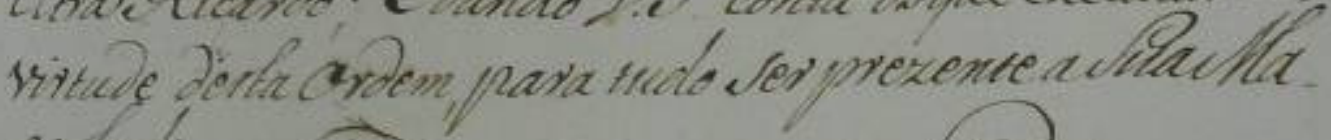

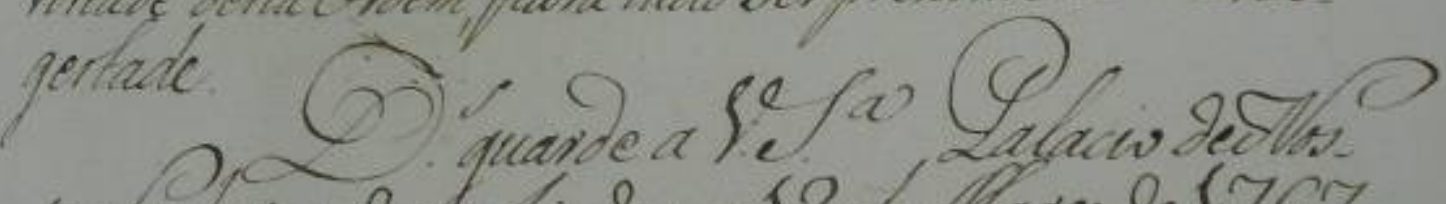

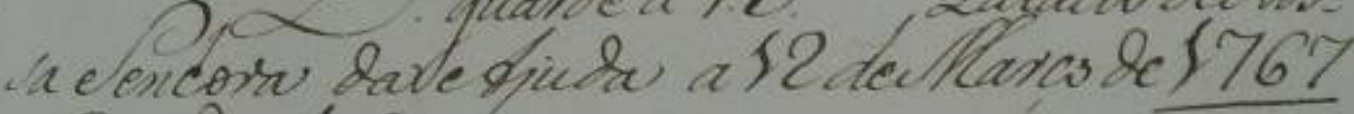
"Conde délornte.

Qu rev tev

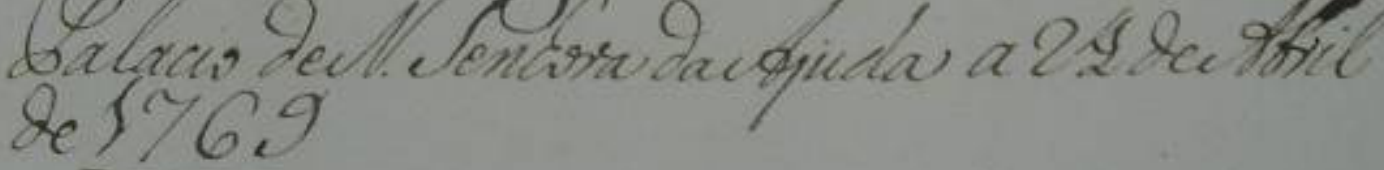

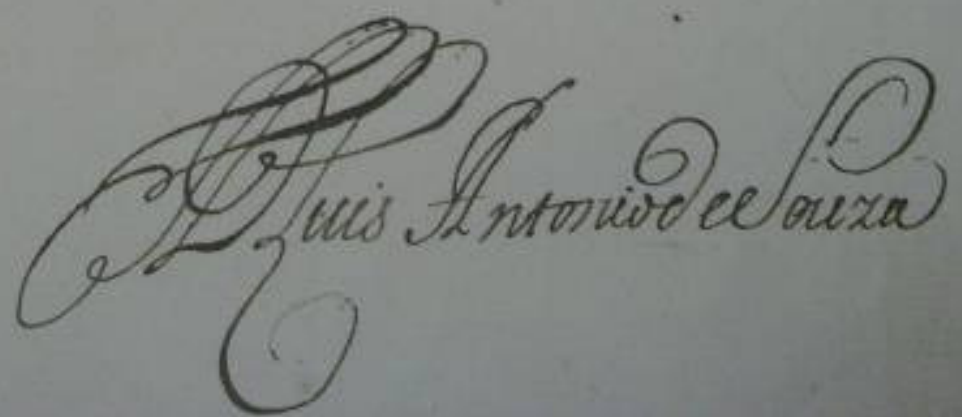


\|71r\| Para Dom Luiz Antonio deSouza

Sua Magestade manda remeter a VossaSenhoria

a petiçaõ incluza deAntonio Utra Ricardo, como

Procurador da Administraçaõ da Caza de Thome loa-

5 quim da Costa Corte Real, E hé omesmo Senhor ser-

vido, que procurando VossaSenhoria informar-se do conteudo na

mesma petiçaõ, eachando, queo Provedor, eContador da

Fazenda que foi da Capitania deSantos loze de Godoy Mo-

reira, hoje falescido, cobrou mais doque the tocava com

10 o dito Lugar dos referidos Direitos, pertencentes á caza

do mesmo Thomé loaquim daCosta Corte Real, VossaSenhoria fa-

ça restituir todo o excesso, que demais Levou pelos bens,

que Ihe ficaraõ, entregandose tudo aosobredito Antonio

Utra Ricardo; E dando VossaSenhoria conta doque executar em

15 virtude desta Ordem, para tudo ser prezente a Sua Ma-

Gestade.

Deos guarde aVossaSenhoria Palacio deNos-

sa Senhora da Ajuda a 12 deMarço de $\underline{1767}$

// Conde de Oeyras.

20 Palacio deNossa Senhora daAjuda a 24 deAbril

de $\underline{1769}$

DomLuis AntoniodeSouza 
(1)

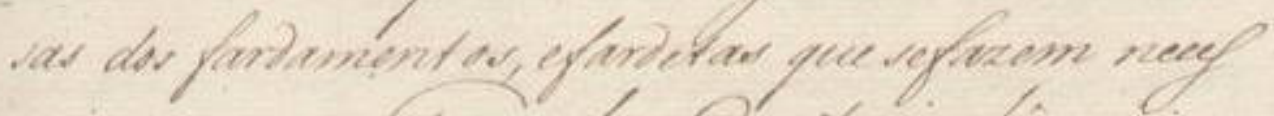

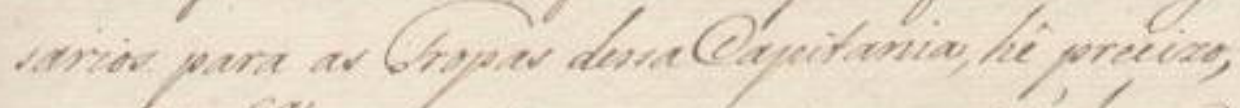

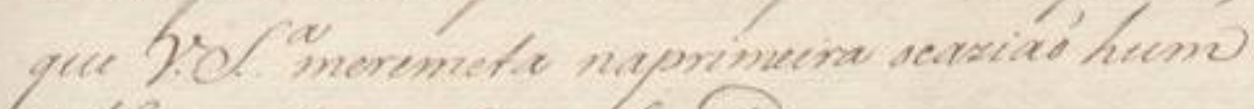

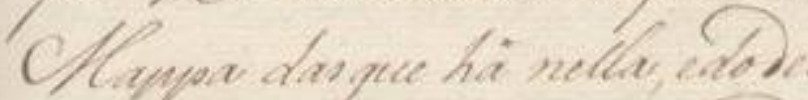

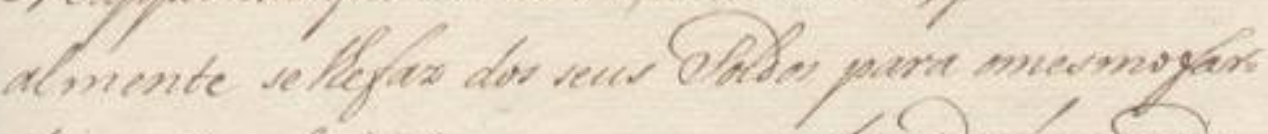

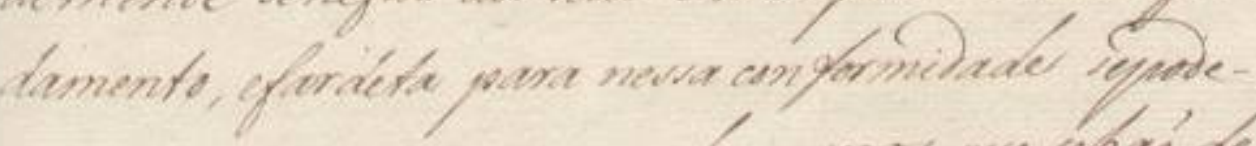

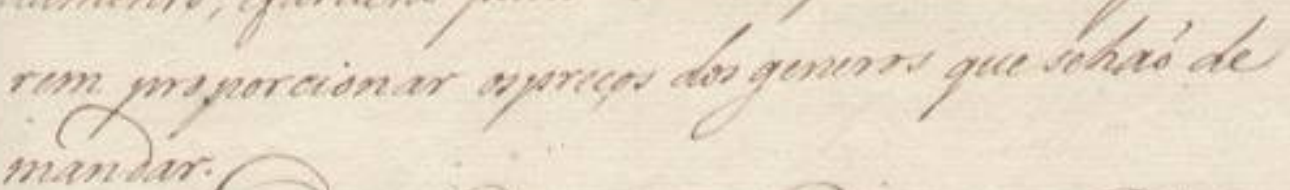

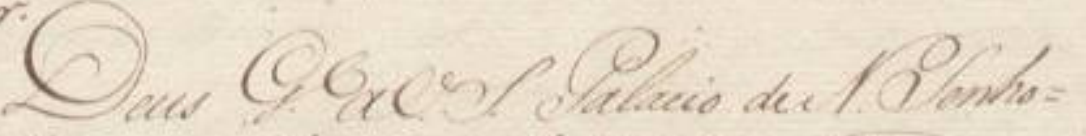

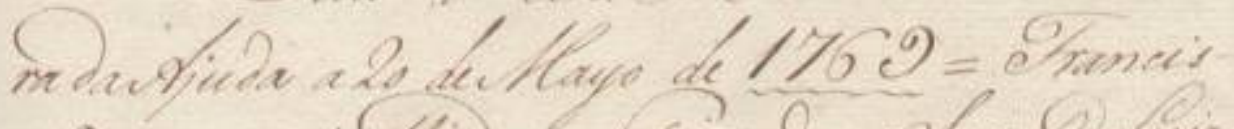

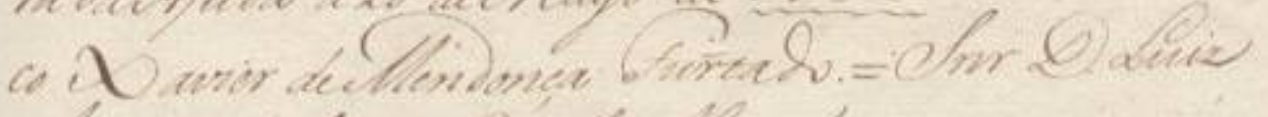

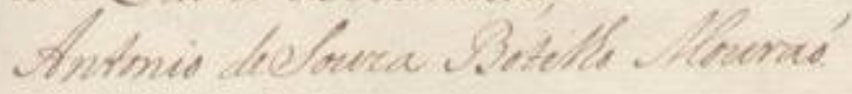

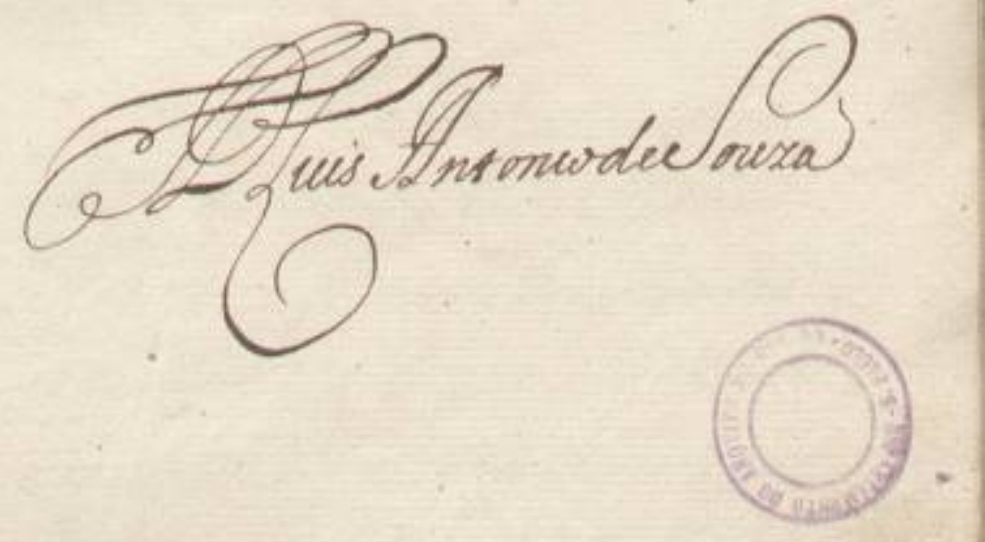


||74r|| Para sepoderem regular as remes-

sas dos fardamentos, efardetas que sefazem neces

sarios para as Tropas dessaCapitania, hê precizo,

que VossaSenhoria meremeta naprimeira ocaziaõ hum

Mappa das que hâ nella, edodesconto, que annu-

almente se Ihefaz dos seus Soldos para omesmofar=

damento, efardeta para nessa conformidade sepode-

rem proporcionar os preços dos generos que sehaõ de mandar.

Deus Guarde aVossaSenhoria Palacio deNossa Senho= ra daAjuda a 20 deMayo de $\underline{1769}=$ Francis -

co Xavier deMendonça Furtado. = Senhor Dom Luiz

Antonio deSouza Botelho Mouraõ.

\section{Dom Luis AntoniodeSouza}

\footnotetext{
* Abaixo da assinatura, há o carimbo circular do AESP.
} 


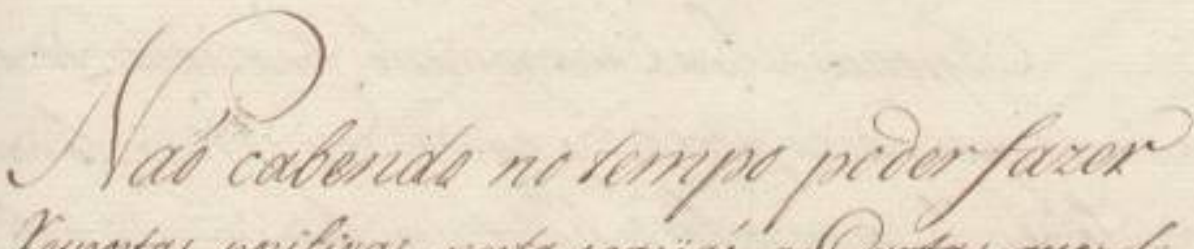

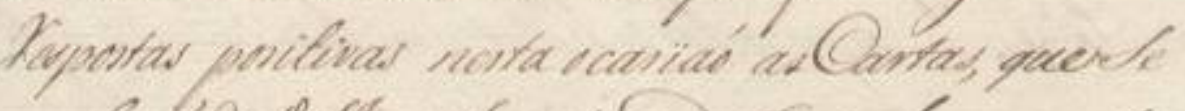

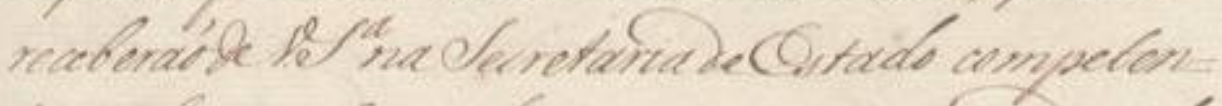

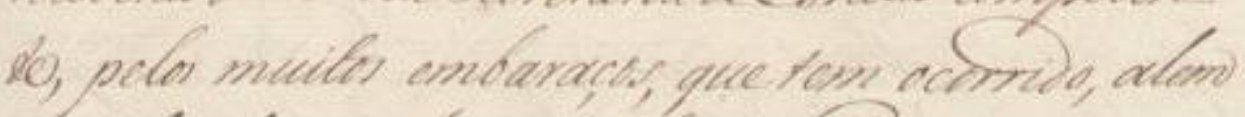

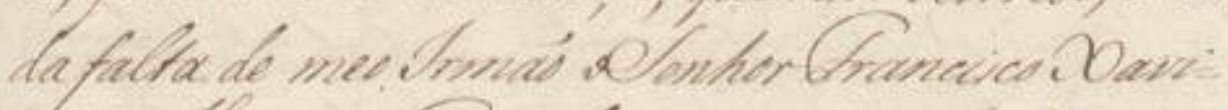

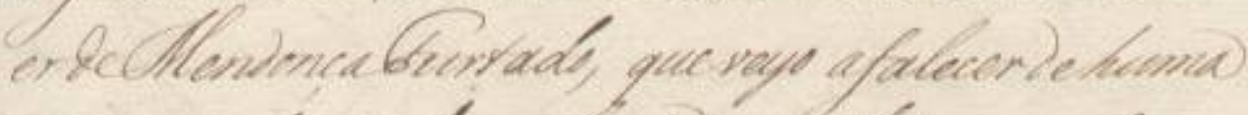

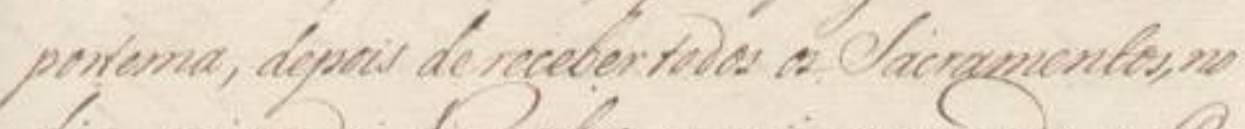

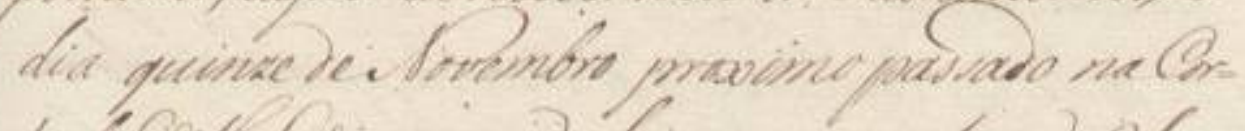

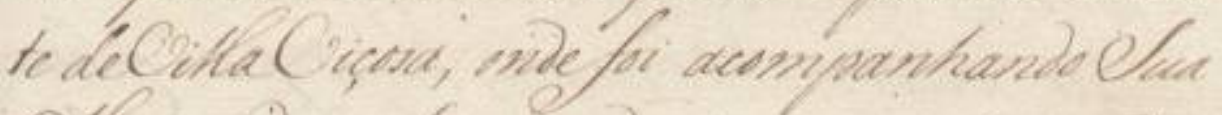

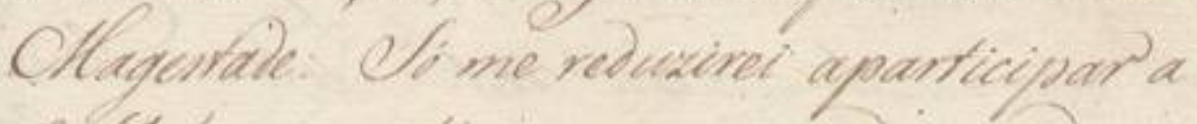

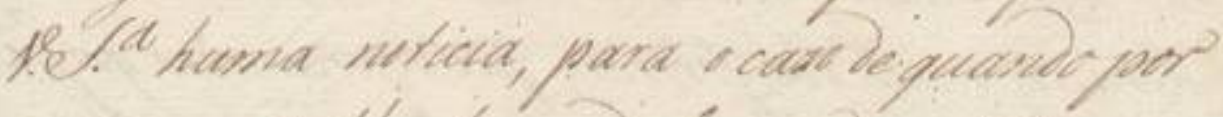

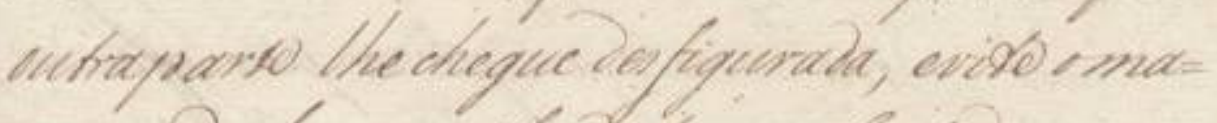

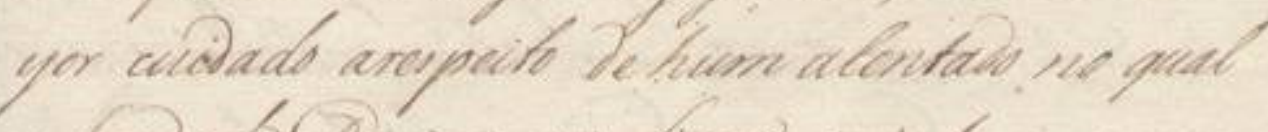

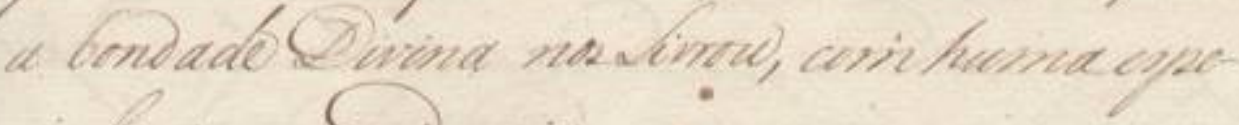
cialivinna fimidencia.<smiles>C1CCCCC1</smiles>

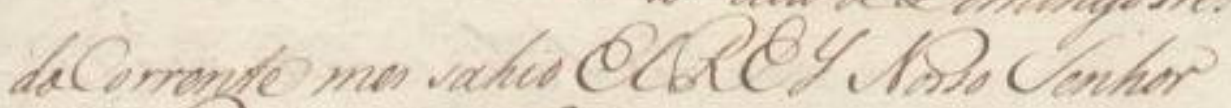

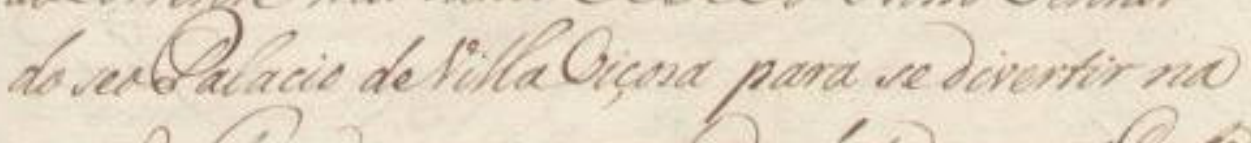

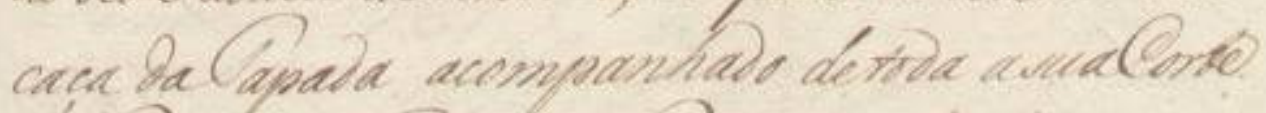

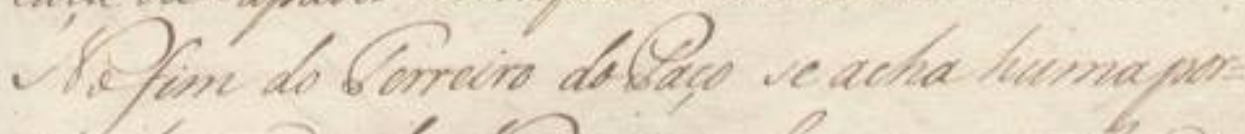

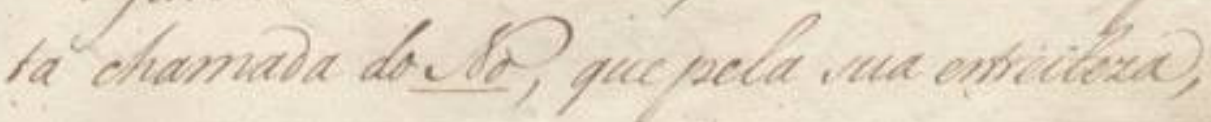


||75r|| Naõ cabendo no tempo poder fazer

respostas positivas nesta ocasiaõ as Cartas, queSe

receberaõ deVossaSenhoria na Secretaria deEstado competen=

te, pelos muitos embaraços, que tem ocorrido, alem

5 dafalta de meo Irmaõ oSenhorFrancisco Xavi=

er deMendonçaFurtado, que veyo afalecer dehuma

postema, depois de receber todos os Sacramentos, no

dia quinze deNovembro proximo passado na Cor=

te deVillaViçosa, ondefoi acompanhando Sua

10 Magestade: Só me reduzirei aparticipar a

VossaSenhoria huma noticia, para o caso de quando por

outraparte lhe chegue desfigurada, evite oma=

yor cuidado arespeito de hum atentado no qual

a bondade Divina nos Livrou, com huma espe-

15 cialissima providencia.

No dia deDomingotres

doCorrente mes sahio EIREY Nosso Senhor

do seoPalacio deVillaViçosa para se divertir na

caça daTapada acompanhado de toda asuaCorte.

20 Nofim do Terreiro doPaço se acha humapor=

ta chamada do $\underline{\text { No}}$, que pela sua estreiteza, 


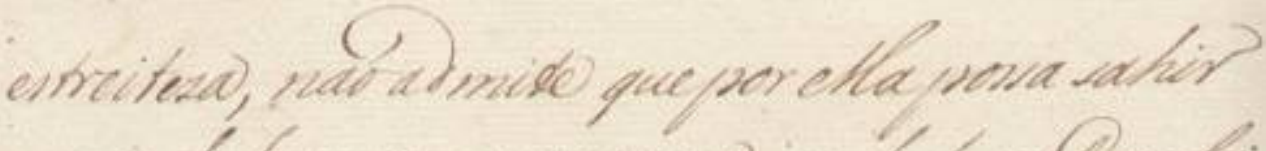

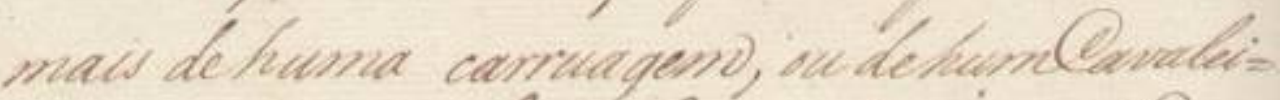

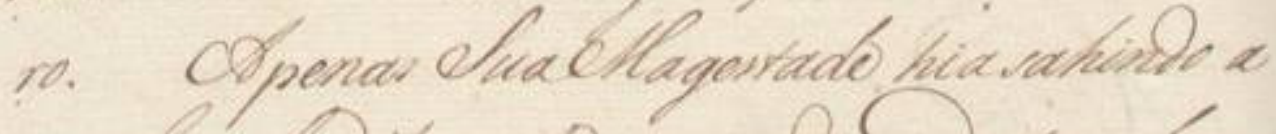
cavale pela dire pome, quarbo tio de tran de mu$n$ dearats esquarato detha hum tromen na fo: gum de mendigs, que con hum qrande vava: pau, sucheirt anmow, epmaina descarregar

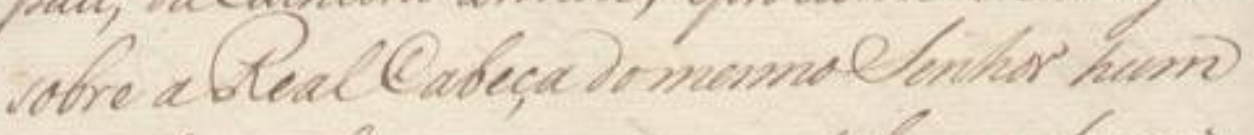
acrilege qoupe, queseria motiel, se actupenis:

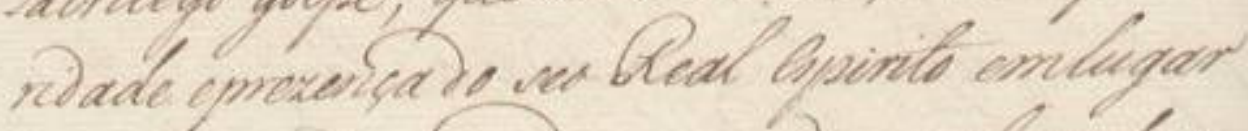

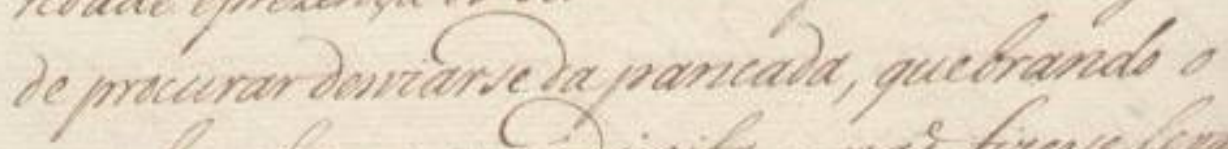

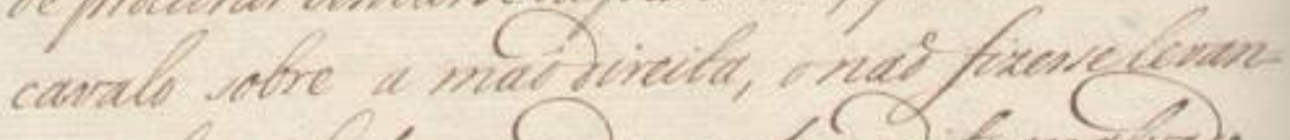

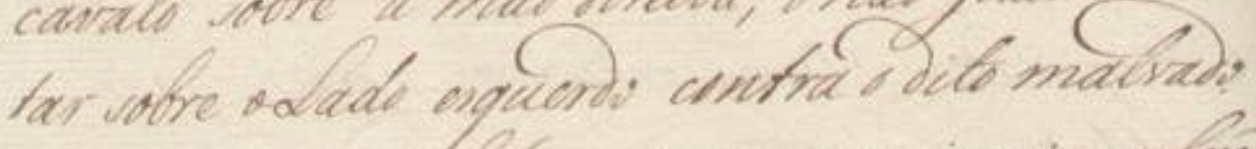

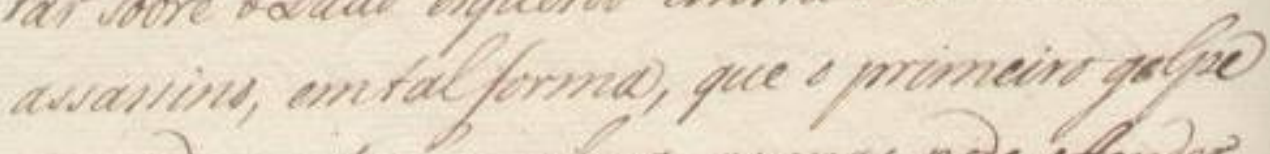
armade contra a caveca apevas pode iffender

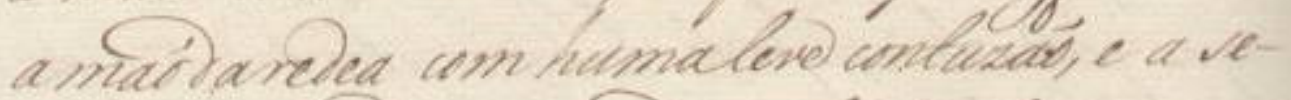
qunda wancala, que Einda interiou descarreprt

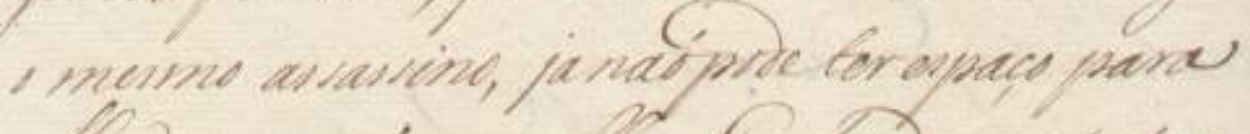
offuer renas scavales. (ahinto neste tem=

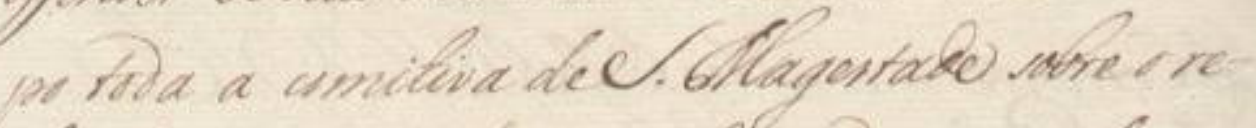

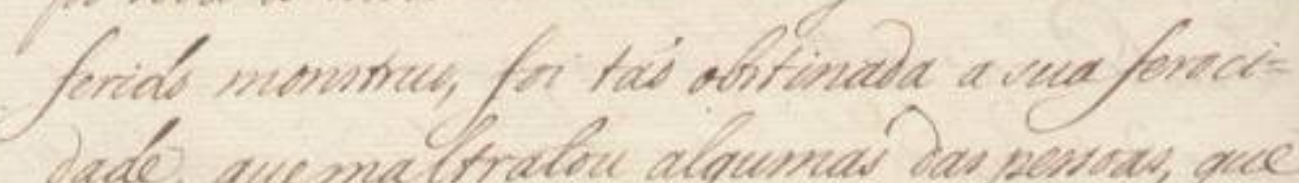
dade, que ma trabou alqumai das pervas, que chavai mais perts on quants nat for press, min= cipalmente ponpec blagernate com outra 
\|75v\| [[estreiteza]], naõ admite que porella possa sahir mais dehuma carruagem, ou dehumCavalei= ro. [espaço] Apenas SuaMagestade hia sahindo a cavalo peladita porta, quandovio detras do muro doLado esquerdo della humhomem nafi= gura de mendigo, que comhum grandevara= pau, ouCacheira armou, eprocurou descarregar sobre aRealCabeça domesmoSenhor hum sacrilego golpe, queseria mortal, se a Superio= ridade eprezença do seo Real Espirito emlugar de procurar desviarse dapancada, quebrando o cavalo sobre a maõdireita, onaõ fizesse levan= tar sobre oLado esquerdo contra o dito malvado assassino, emtalforma, que o primeiro golpe armado contra a cabeça apenas pode offender a maõ daredea com humaleve contuzaõ, e a segundapancada, que ainda intentou descarregar o mesmo assassino, ja naõpodeter espaço para

40 offender se naõ o cavallo. Cahindo nestetem= po toda a comitiva deSua Magestade sobre o referido monstruo, foi taõ obstinada a sua feroci= dade, quemaltratou algumas das pessoas, que estavaõ mais perto em quanto naõ foi prezo; prin= cipalmente porqueSua Magestade comoutra 


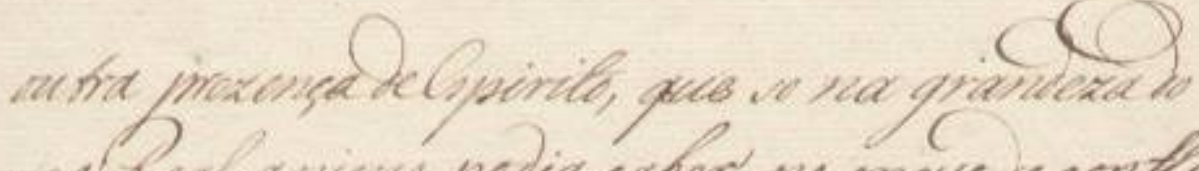

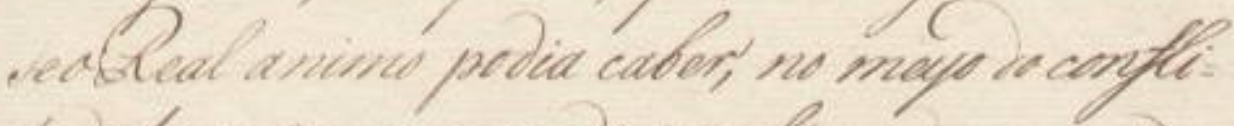

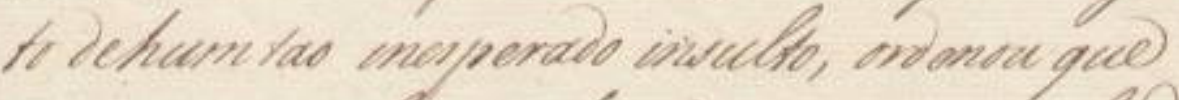
ninguem. mabare, ne feriso omenno malved

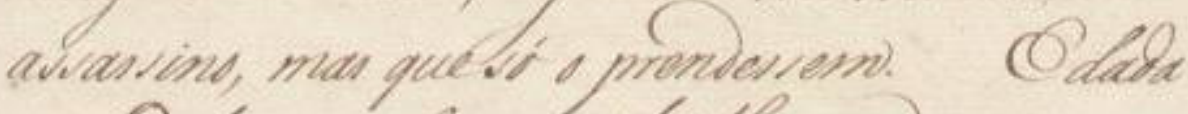

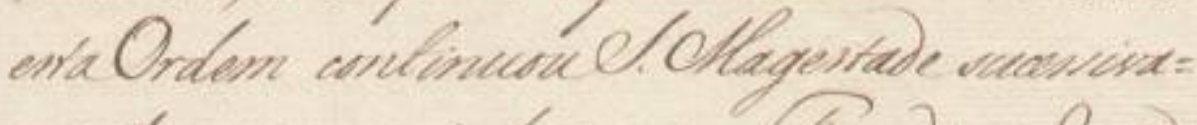
monte, wer camintus pard a (apada, nide ere Qivertis ate arvite naforme do coverne dor ned

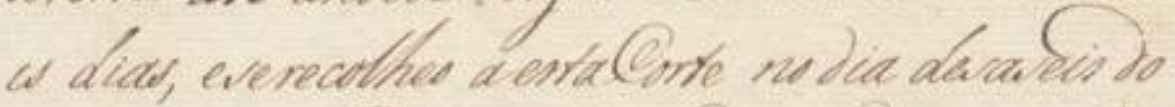

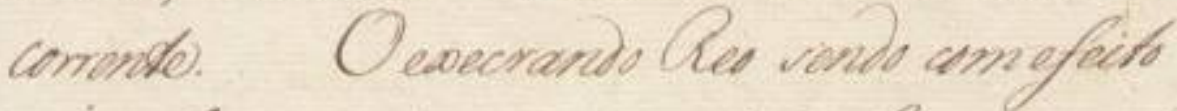
tomads as nabis, press earads for cordurids

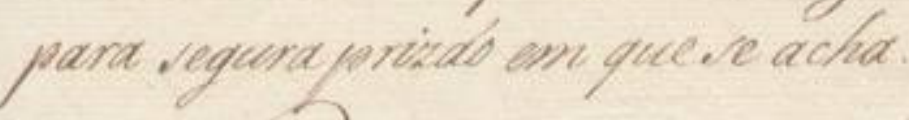<smiles></smiles>

L clas primeinas endareadow, que laques

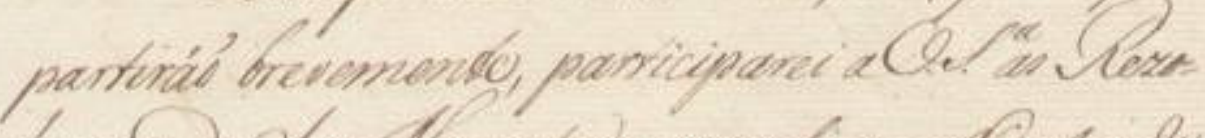

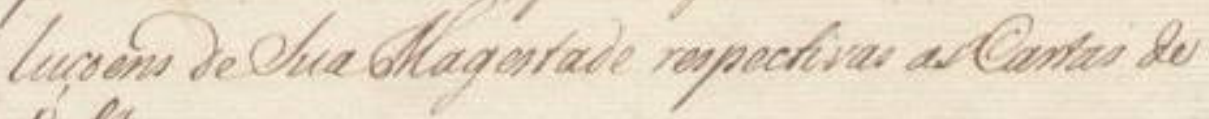
1. pa

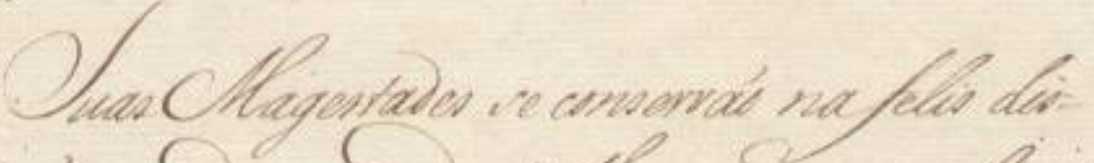

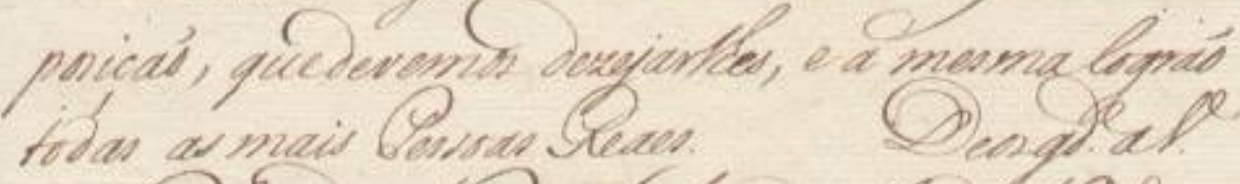

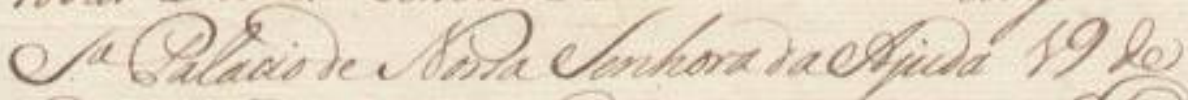

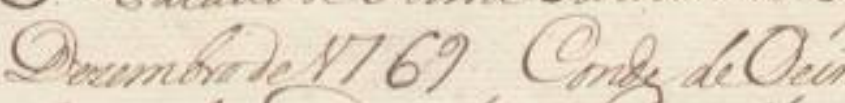

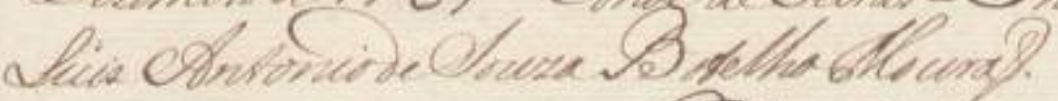

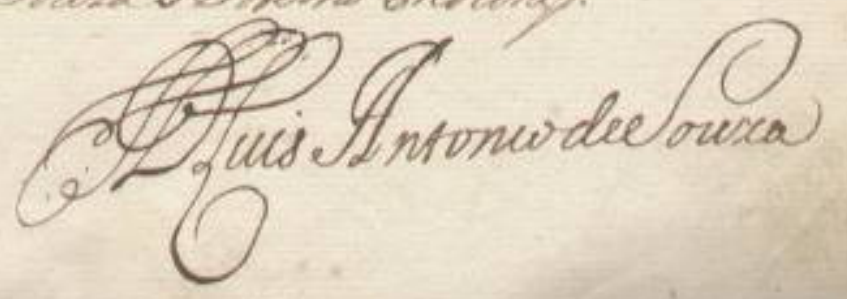


||76r|| [[outra]] prezença deEspirito, que so na grandeza do seoReal animo podia caber, no meyo do confli= to dehum tao inesperado insulto, ordenou que ninguem matasse, ouferisse o mesmo malvado

50 asssassino, mas quesó o prendessem. [espaço] E dada estaOrdem continuouSua Magestade sucessiva= mente o seo caminho para aTapada, ondese divertio ate anoite naforma do costume dos ma= is dias, eserecolheo aestaCorte no dia desaseis do

55 corrente. [espaço] O execrando Reo sendo com efeito tomado as maõns, prezo, e atado foi conduzido para segura prizaõ em quese acha.

Pelas primeiras embarcaçoens, que daqui partiraõ brevemente, participarei aVossaSenhoria Rezo= 60 luçoens deSuaMagestade respectivas asCartas de VossaSenhoria.

SuasMagestades se conservaõ nafelis dis= posiçaõ, quedevemos dezejarlhes, e a mesmalograõ todas as mais Pessoas Reaes. [espaço] Deosguarde aVossa 65 SenhoriaPalacio deNossaSenhora daAjuda 19 de Dezembro de1769 Conde deOeiras $=$ Senhor Dom Luis AntoniodeSouza Botelho Mouraõ.

DomLuis AntoniodeSouza 
$[42]$
$\|78 \mathrm{r}\|$

$63^{5}$

- Cope pitas cineco horas churmo

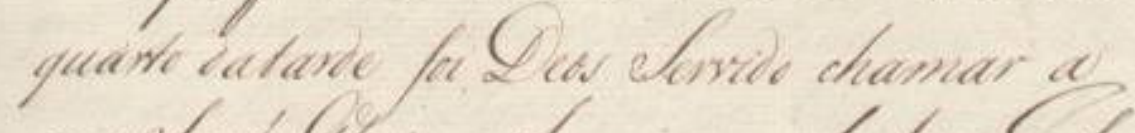

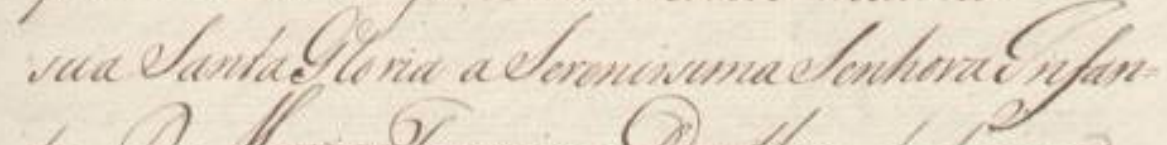

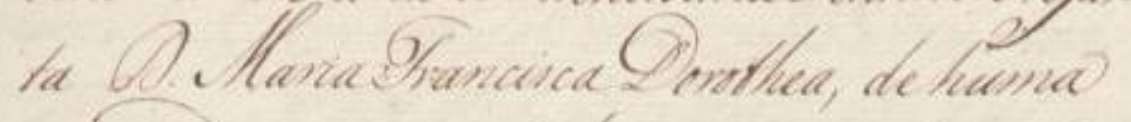

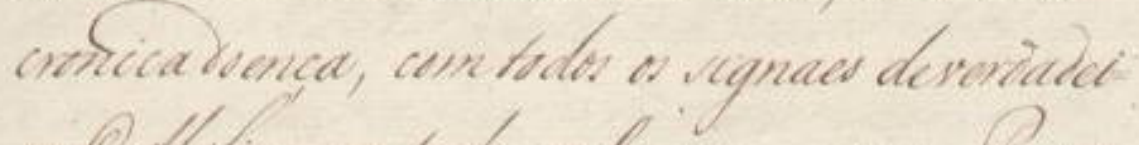

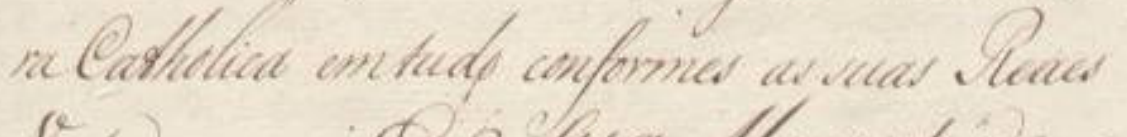
fimuade.

- eleallagestice 6

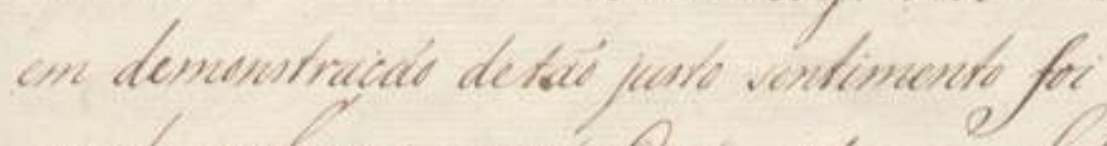

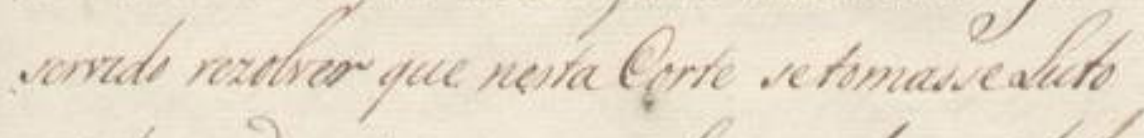

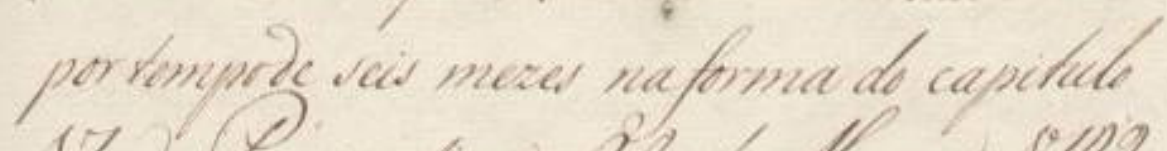

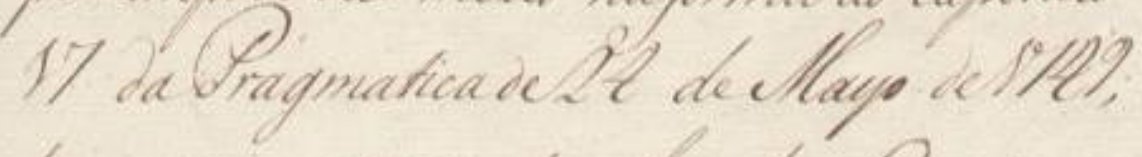

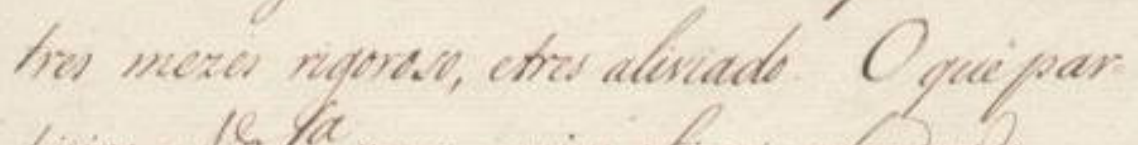

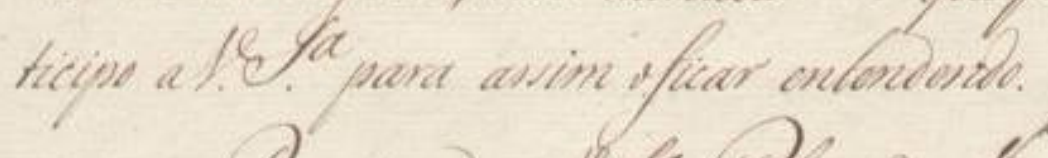

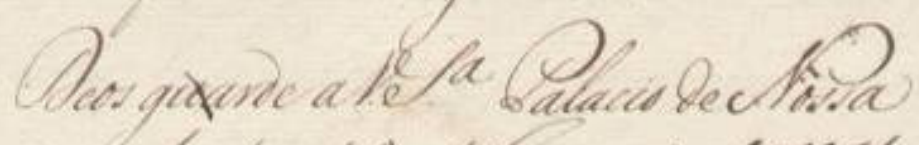

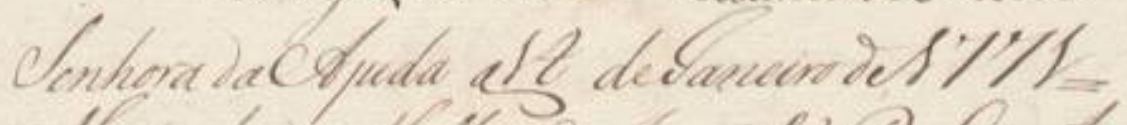

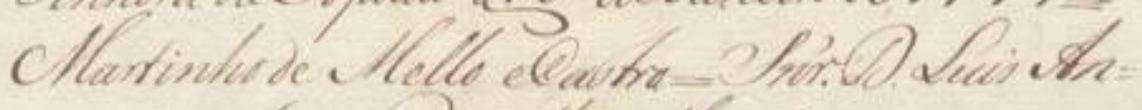

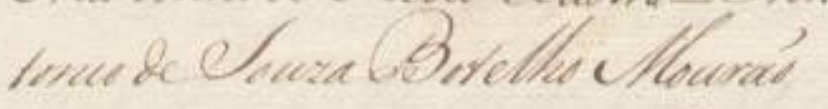

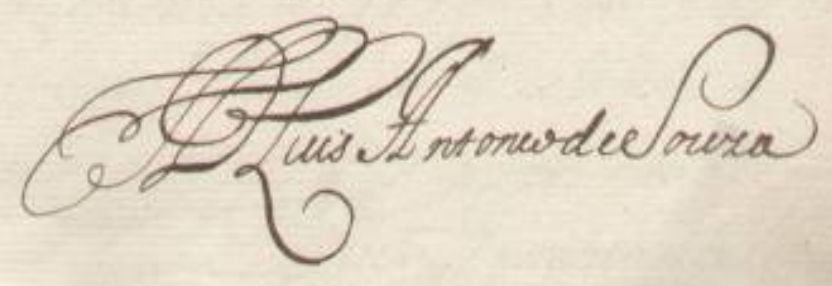

283 
||78r|| Hoje pelas cinco horas ehum

quarto datarde foi Deos Servido chamar a

suaSantaGloria aSerenissima Senhora Infan=

ta Dona Maria Francisca Dorothea, dehuma

5 cronica doença, com todos os signaes deverdadei=

raCatholica emtudo conformes as suas Reaes

Virtudes. [espaço] E SuaMagestade

em demonstraçaõ detaõ justo sentimento foi

servido rezolver que nesta Corte setomasseLuto

10 por tempo de seis mezes naforma do capitulo

17 daPragmaticade24 de Mayo de1749;

tres mezes rigoroso, etres aliviado. O quepar=

ticipo aVossaSenhoria para assim oficar entendendo.

Deos guarde aVossaSenhoria Palacio deNossa

15 Senhora daAjuda a14 delaneiro de1771 =

Martinho de Mello eCastro $=$ Senhor Dom Luis An=

tonio de Souza Botelho Mouraõ

Dom Luis AntoniodeSouza 
$[43]$
$\|79 r\|$

64.

2

- mito prexonte a dua llargestade

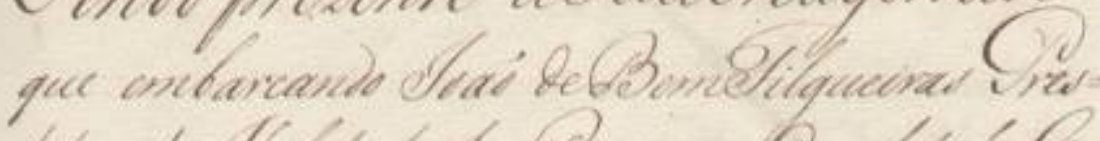

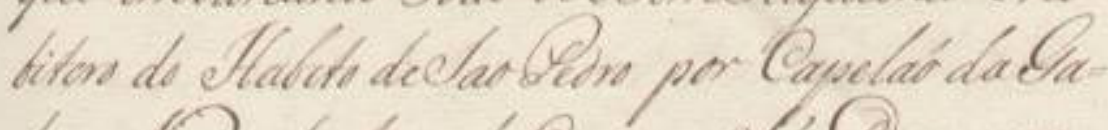

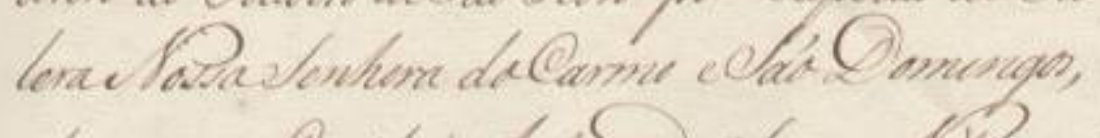
de que on lapitai Ansosur de elawa ctess, que

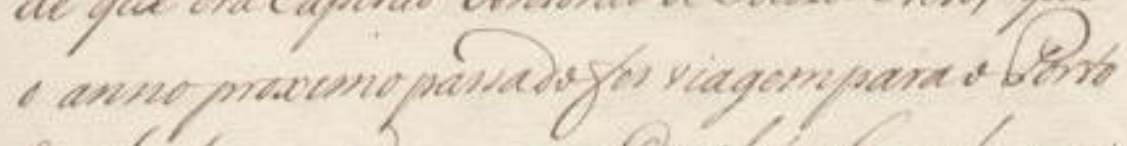

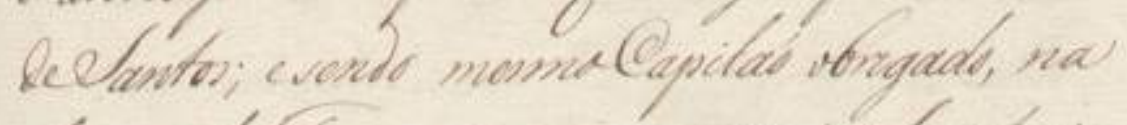

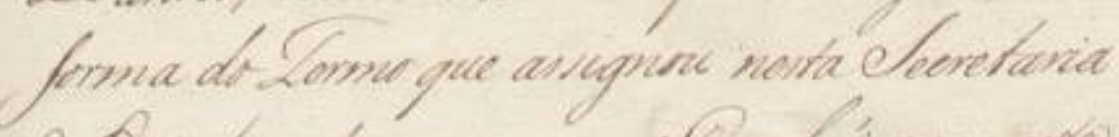

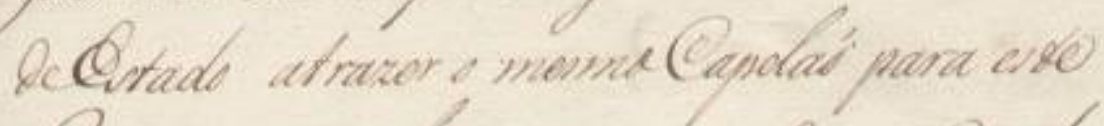

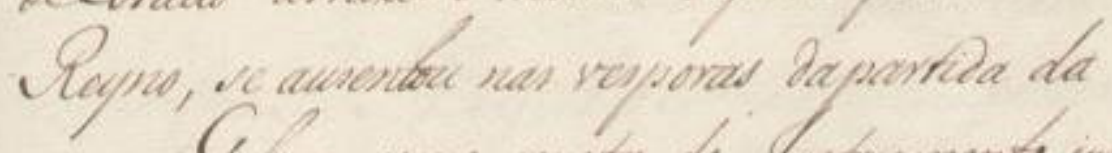

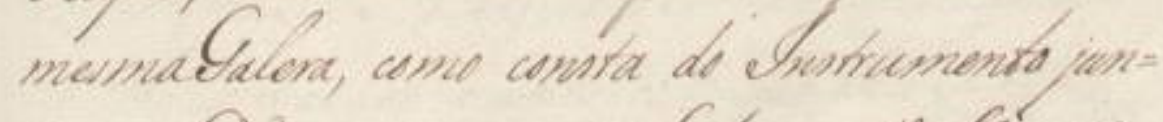

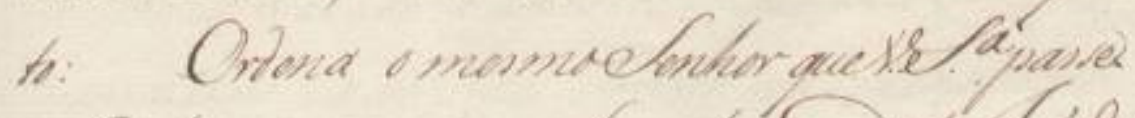

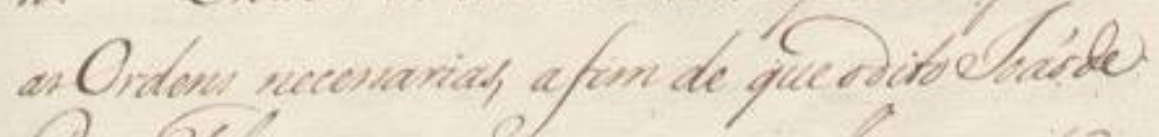

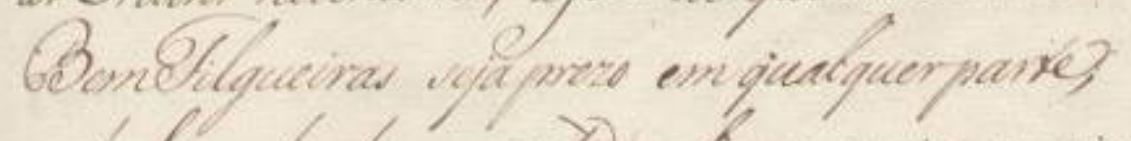

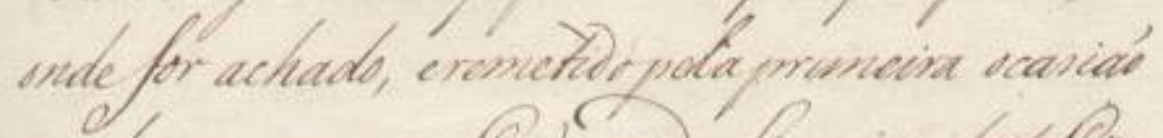

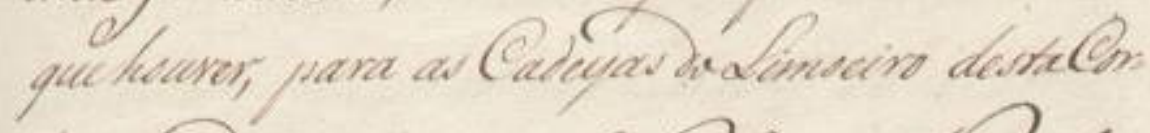

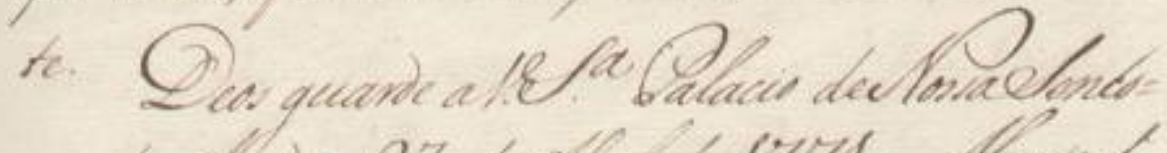

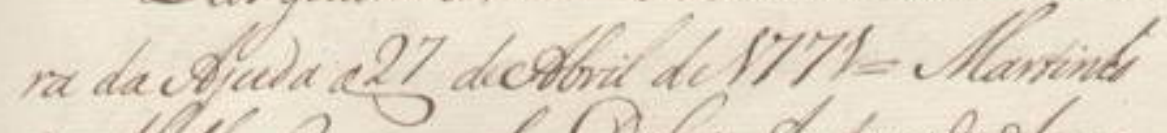

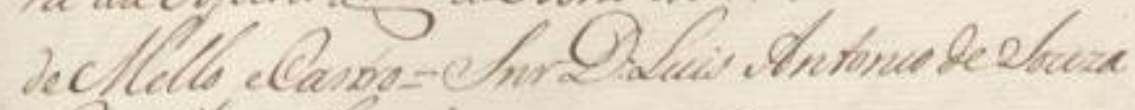

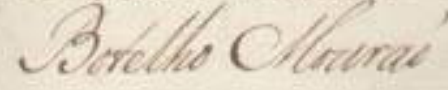

285 
||79r|| Sendo prezente aSuaMagestade

que embarcando loaõ deBemFilgueiras Pres= bitero do Habito deSaoPedro por Capelaõ da $\mathrm{Ga}=$ leraNossaSenhora doCarmo eSaõDomingos,

5 de que eraCapitaõ Antonio deSouza Neto, que o anno proximo passadofes viagempara oPorto deSantos; e sendo mesmoCapitaõ obrigado, na forma do Termo que assignou nestaSecretaria deEstado atrazer o mesmoCapelaõ para este

10 Reyno, se ausentou nas vesporas dapartida da mesmaGalera, como consta do Instrumento jun= to: [espaço] Ordena o mesmoSenhor queVossaSenhoria passe asOrdens necessarias, afim de queodito loaõ de BemFilgueiras seja prezo em qualquer parte,

15 ondefor achado, eremetido pelaprimeira ocasiaõ quehouver, para as Cadeyas doLimoeiro destaCor= te.

Deos guarde aVossaSenhoria Palacio deNossaSenho= ra daAjuda a르 deAbril de1771 = Martinho

20 deMello eCastro=Senhor Dom Luis Antonio deSouza

Botelho Moraõ

Dom Luis AntoniodeSouza 
Cartas se

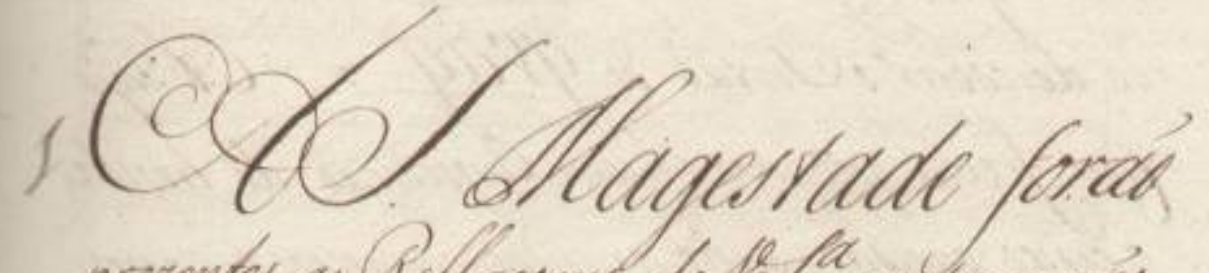

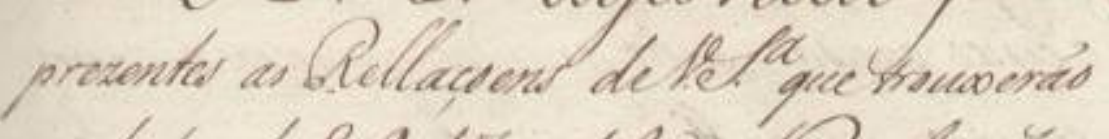

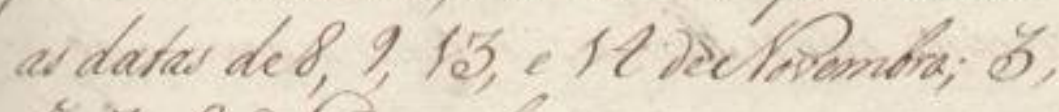

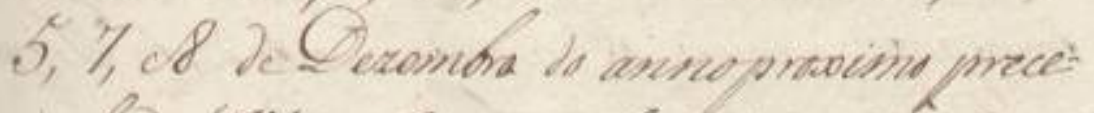

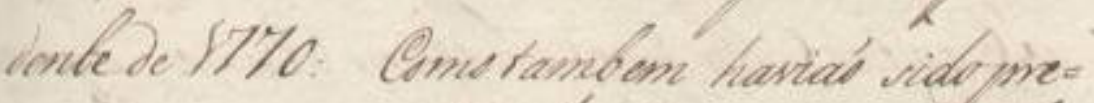

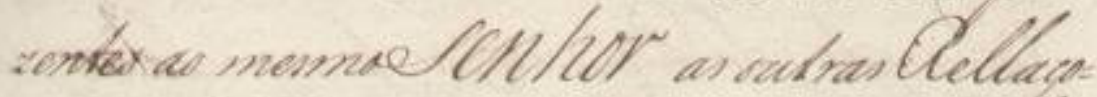

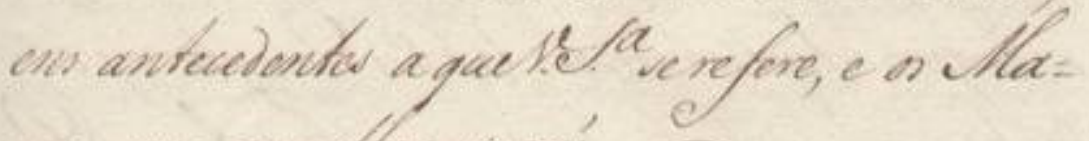
ף pas que come dlat nomat

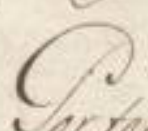

cooser fica. Sagerstade na intelegoncia 2izdo activisade i acorto com que bel vetom

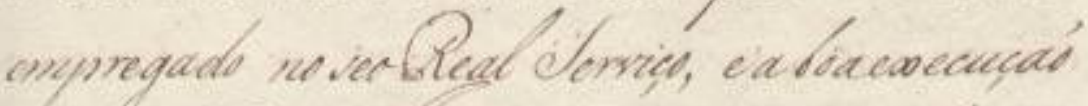

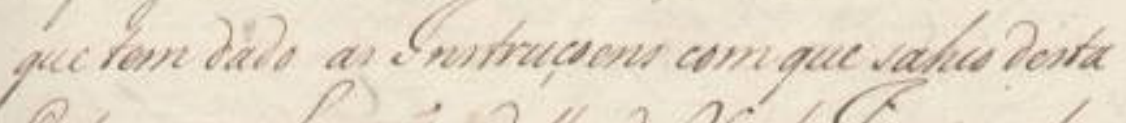
Corre, eque a varas alatha 2026 de Savein de 17685 , come rambon air que the forai sucas - ivamente dingidar kas dattas de 20 dev forms molosobedito anne de 1765.22 de Sultho 201766: 22 dichance 20 decuonturbe 1767

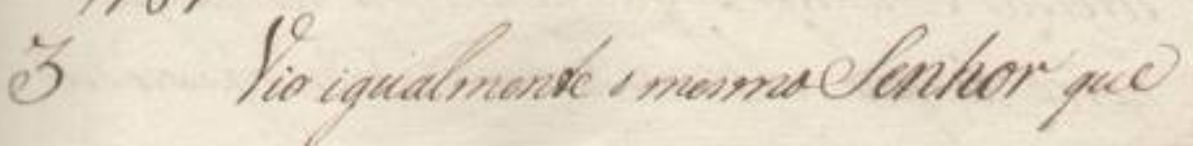


||80r||Cartaprimeira

\section{A Sua Magestade foraõ}

prezentes as Rellaçoens deVossaSenhoria quetrouxeraõ

as datas de8, 9, 13, e 14 deNovembro; 3,

5 5, 7, e8 deDezembro do annoproximo prece=

dente de 1770: Como tambem haviaõ sidopre=

zentes ao mesmoSenhor as outras Rellaço=

ens antecedentes aqueVossaSenhoria serefere, e os $\mathrm{Ma}=$

pas que com ellas vieraõ

102 Por todas estas Rella=

çoens fica Sua Magestade na inteligencia

do zelo actividade e acerto com queVossaSenhoria setem

empregado no seoReal Serviço, e a boaexecuçaõ

que tem dado as Instruçoens com que sahio desta

15 Corte, e que Levaraõ a datta de26 delaneiro de

1765, como tambem as que Iheforaõ succes-

sivamente dirigidas nas dattas de20 deNovem=

bro do sobredito anno de1765: 22 delulho

de1766: 22 de Março e20 de lunho de

$20 \quad 1767$

3 Vio igualmente o mesmoSenhor que 


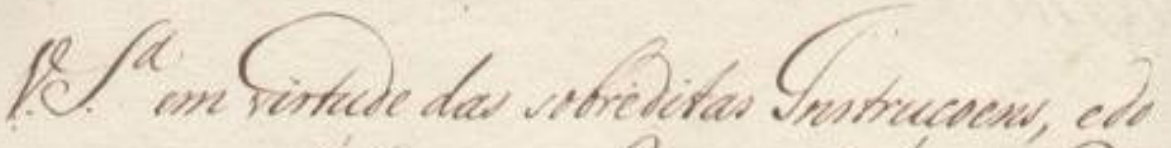

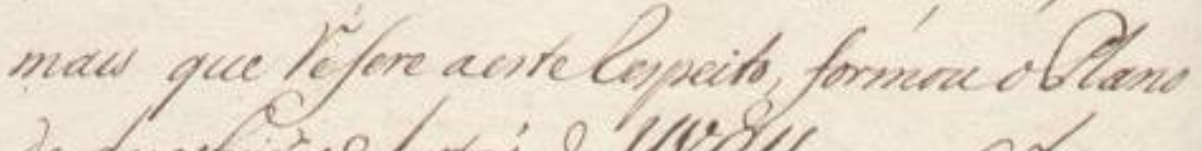

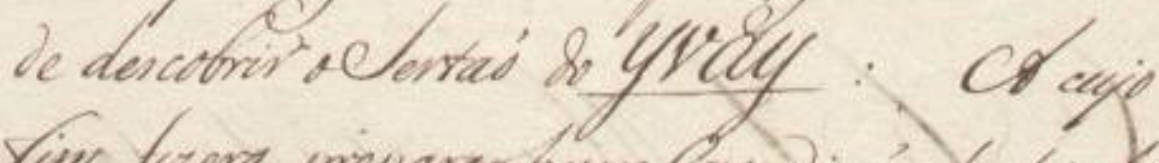
five frem prepanar hum lavpedicas de trinta

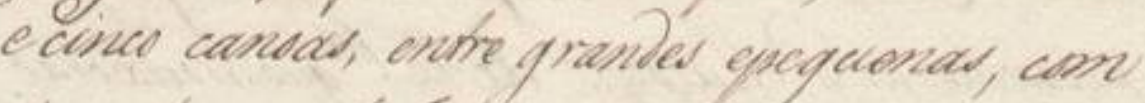
trontos eninte firmons de conusagem, ede

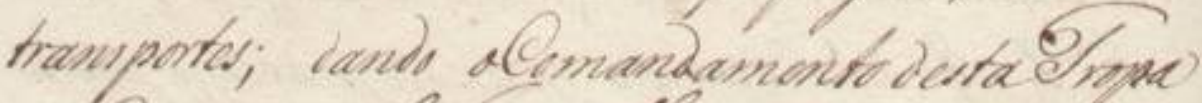

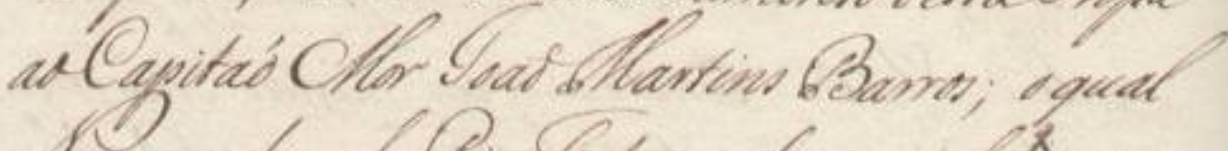

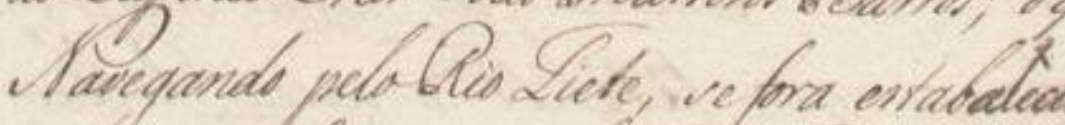

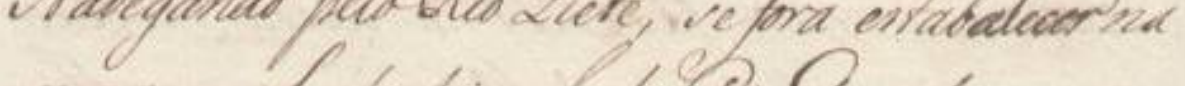

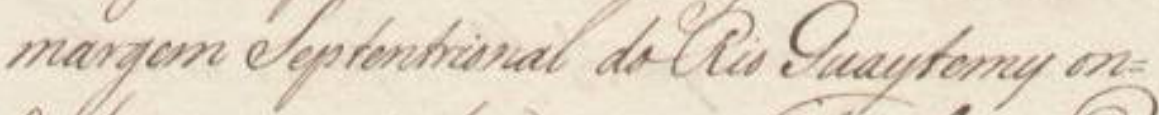
be ficaur commutiondo huna s/ortalora, ebove acai, parr coonir ai@ampanmin ra facania;

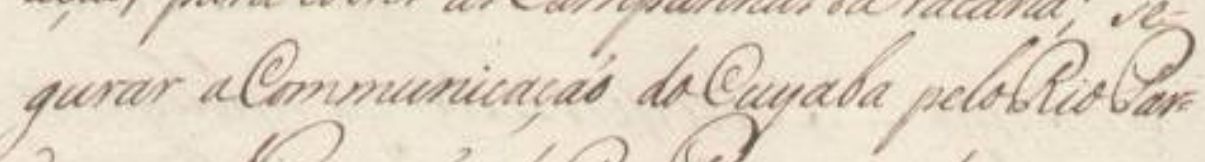
bi ca Maveqacas do Piv barama; de queds Castehans epodorias amparar, e nat tivese= 2 mos ocuirato de os movoir.

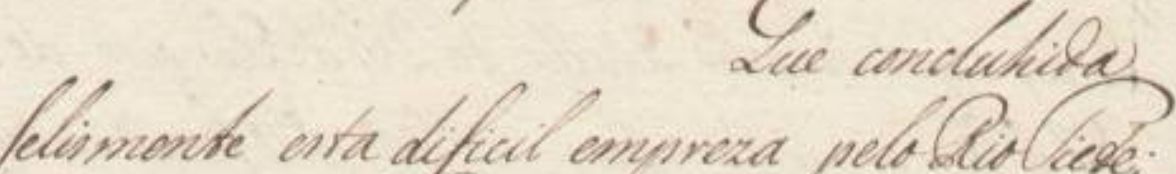

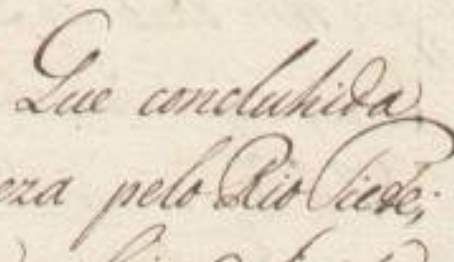

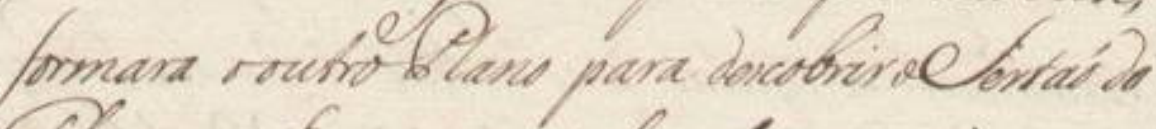
Gibagy: Cqui a ortefim, fixena nai so par:

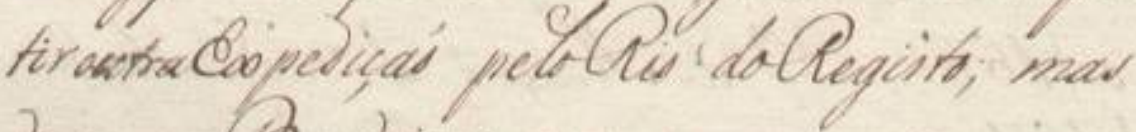
Divorsa, be anteinas que as mome romps pes

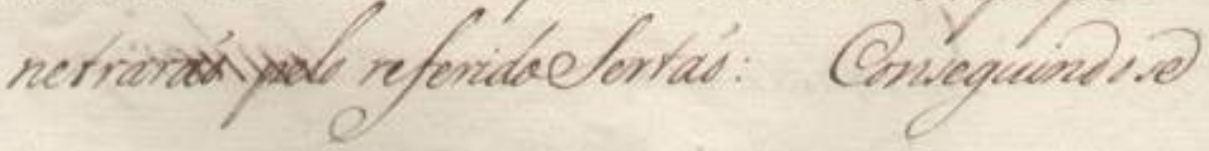


||80v|| VossaSenhoria em virtude das sobreditas Instruçoens, edo mais que refere aesterespeito, formouoPlano de descobrir oSertaõ do Yvay: [espaço] A cujo

25 fim fizera preparar humExpediçaõ de trinta e cinco canoas, entre grandes epequenas, com trezentos evinte Homens de Equipagem, ede transportes; dando oComandamento destaTropa aoCapitaõ Mor loaõMartins Barros; o qual

30 Navegando peloRio Tiete, se fora estabelecer na margem Septentrional doRio Guaytemy on= de ficava construhindo humaFortaleza, ePovo= açaõ, para cobrir as Campanhas daVacaria; se= gurar aCommunicaçaõ doCuyaba peloRioPar=

35 do; e a Navegaçaõ doRioParana; de que os Castelhanos sepoderiaõ amparar, se naõ tivessemos o cuidado de os prevenir. 4 Que concluhida felismente esta dificil empreza peloRioTiete;

40 formara ooutroPlano para descobrir oSertaõ do Tibagy: $E$ que a estefim, fizera naõ so par= tir outraExpediçaõ peloRio doRegisto; mas diversas Bandeiras que ao mesmo tempo pe= netraraõ pelo referidoSertaõ: [espaço] Conseguindo se 


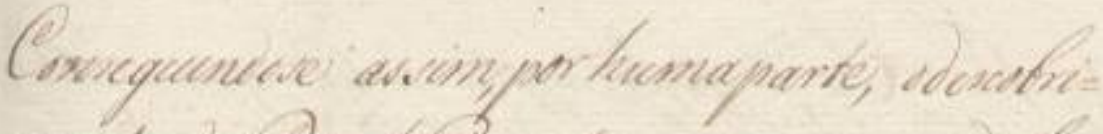

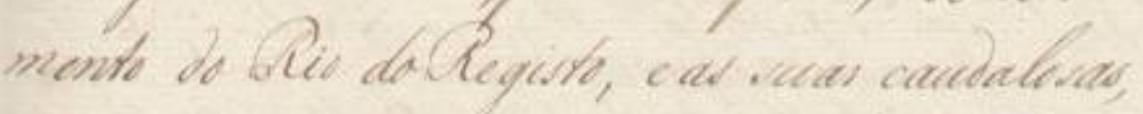
emacipitalar Comentas, ate onde ella entra ne.

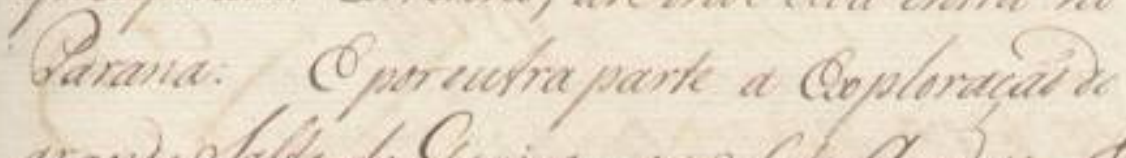

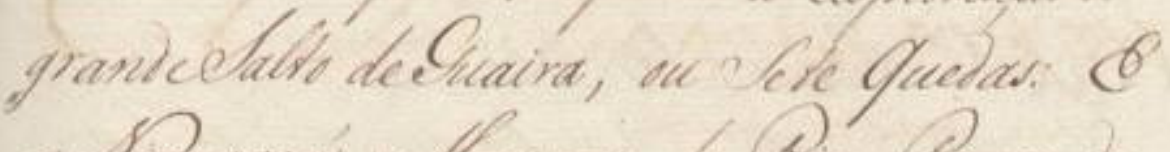

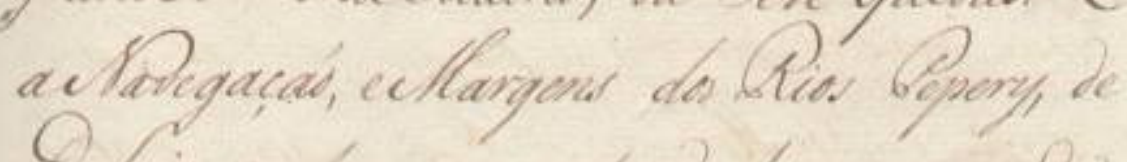
Q alcil, casmas, que cortands heersa qrande

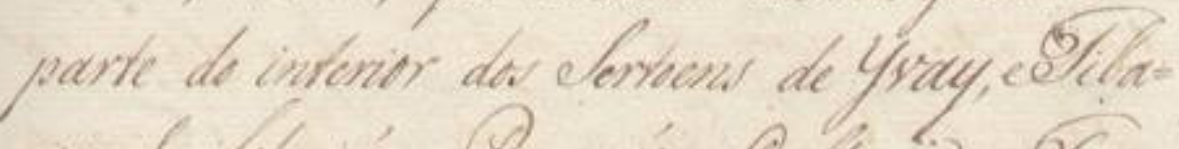

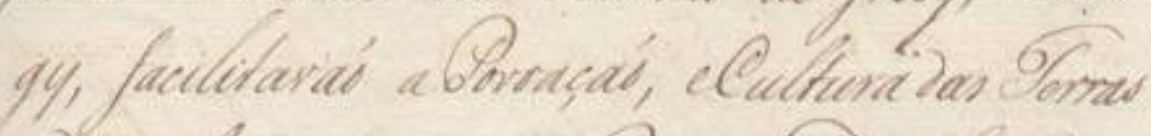
adjacentes as menno Ries: Descobrintare

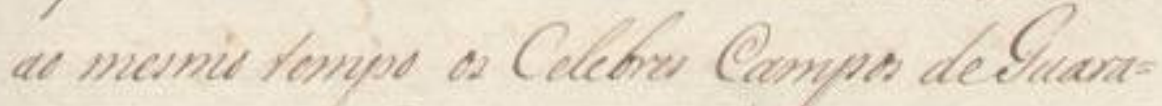
puan, onde a Commandante Candido Davior dectlmeda freava darde princisse a huma itorialcas.

e)<smiles>C1CC2CCCC(C1)C2</smiles>
tes Eescatrimenter on 2 de Adqarto de 1761,

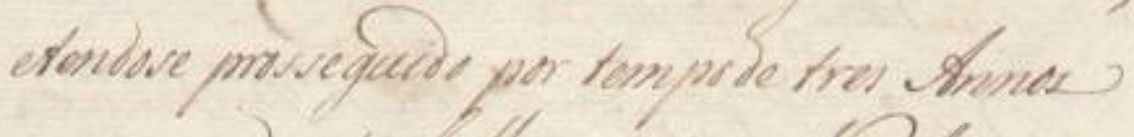
con qrandos srabalus, periqos, Wanfragies, e destreas padecedas, cocportadas coin inenisel contancia, e timhar adiantads on mimes Das. cobrinontos ate purte quereforom a Cartas 2i. Exploradores, elufor das bardainas, de que tis romcteo as eqpias. 
45 ||81r|| [[Conseguindose]] assim, porhuma parte, o descobri= mento do Rio doRegisto, e as suas caudalosas, eprecipitadas Correntes, ate onde ella entra no Parana: [espaço] E por outra parte a Exploraçaõ de grandeSalto deGuaira, ou Sete Quedas: E

50 aNavegaçaõ, eMargens dos Rios Pepery, de Dom Luis, eoutros, que cortando huma grande parte do interior dos Sertoens de Yvay, eTiba= gy, facilitavaõ a Povoaçaõ, eCultura das Terras adjacentes aos mesmos Rios: [espaço] Descobrindo se

55 ao mesmo tempo os Celebres Campos deGuara= puava, onde oCommandante Candido Xavier deAlmeida ficava dando principio ahuma Fortaleza.

5 Que havendose em fim comessado es=

60 tes Descobrimentos em 2 de Agosto de1767, etendose prosseguido por tempo de tres Annos com grandes trabalhos, perigos, Naufragios, e desgraças padecidas, e soportadas com incrivel constancia, se tinhaõ adiantado os mesmos Des=

65 cobrimentos ate o ponto que referem asCartas dos Exploradores, eCheffes das Bandeiras, de queVossaSenhoria remeteo as Copias. 
||81v $\|$

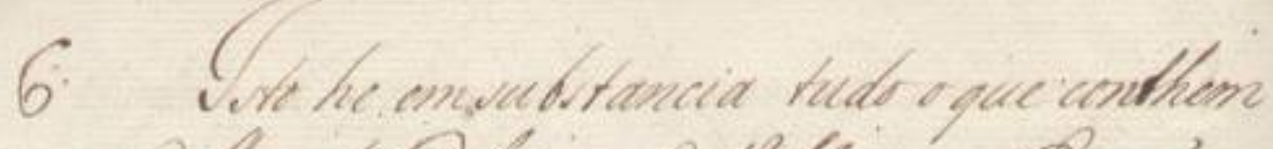
as ifforeston Relacionn be tela Q nal

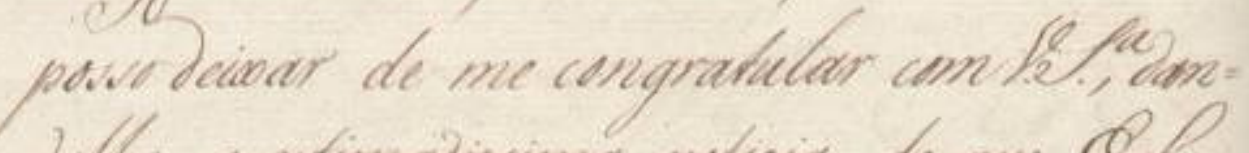
dolle a estimadisima noticie, de que $\mathrm{Ca}$

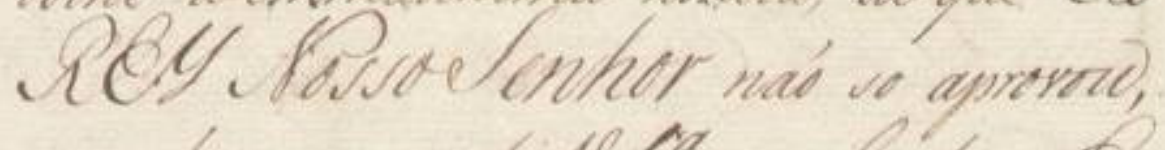
mas lewsu quante te fatem obrads:

(C) que cutre as importanter. Fequivicaons. feitas

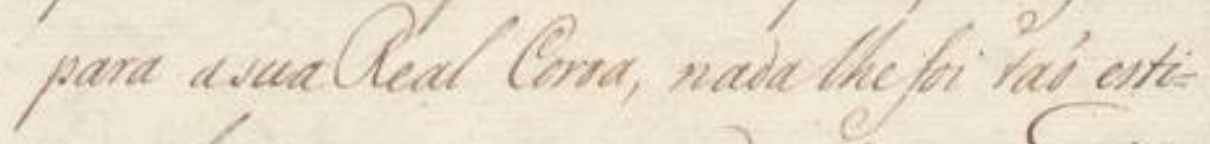
maxd, coms a prova quederai, eque fraidan=

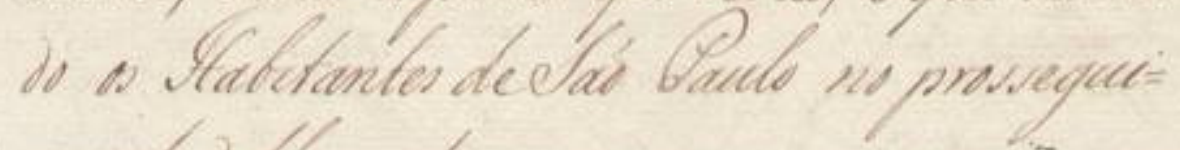
monte dellat; de cossermarem a nesina coms:

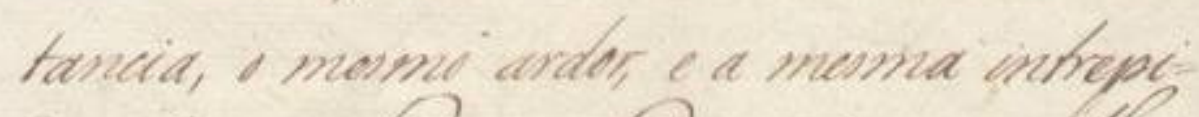

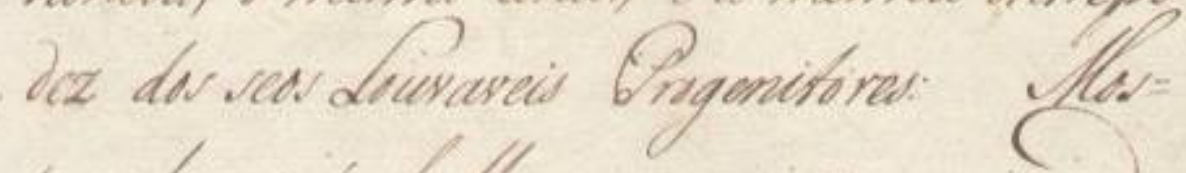
trando no traballes nes porigos, onas ardeas, edificultosas mprovas, que ainda sais as mesmes que Clles forad.

I

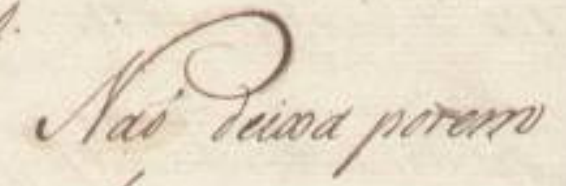
- Hagestade de conhecer, com as suas clarisionas sures, que na qrande decadencia, sunquercacha eva Colonid, the va's preci: 21. Ousiliss, wn a quad, nom repostena pro. requir, vien adiantar, nem conderir o que $a=$ te aqom re achafais, come tie fa refere:

293 
$\|81 \mathrm{v}\|[[6]]$ Isto he em substancia tudo o que conthem

as differentes Relaçoens deVossaSenhoria; [espaço] E naõ posso deixar de me congratular comVossaSenhoria, dan= dolhe a estimadissima noticia, de que EL REY NossoSenhor naõ so aprovou, mas louvou quanto VossaSenhoria tem obrado: [espaço] E que entre as importantes Acquisiçoens feitas para asuaReal Coroa, nadalhefoi taõ esti= mavel, como a prova que deraõ, e que vaõ dan= do os Habitantes deSaõ Paulo no prossegui= mento dellas; de conservarem a mesma cons=

80 tancia, o mesmo ardor, e a mesma intrepi= dez dos seos Louvaveis Progenitores: [espaço] Mos= trando nos trabalhos nos perigos, e nas ardu= as, e difficultosas emprezas, que ainda saõ os mesmos que Elles foraõ.

Sua Magestade de conhecer, com as suas clarissimas Luzes, que na grande decadencia, em que se acha essaColonia, Ihe saõ preci= zos Auxilios, sem os quaes, nem sepoderia pro=

90 seguir, nem adiantar, nem concluir o que $a=$ te agora se achafeito, como VossaSenhoria refere: 
12

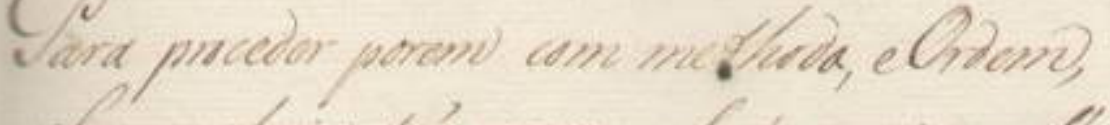

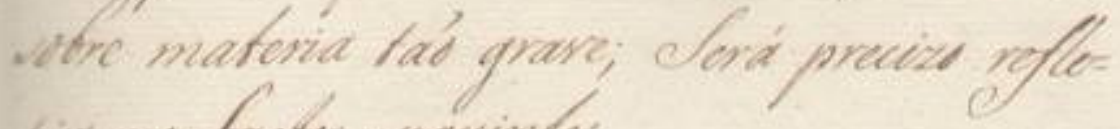
tir we facto sequintes.

5 Grincinamente icterem pentoner:

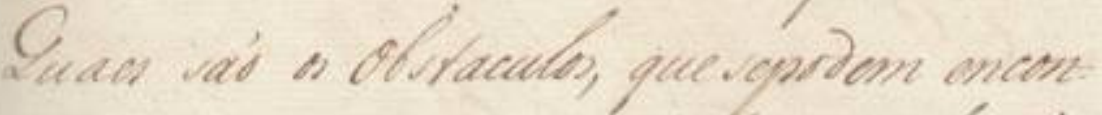

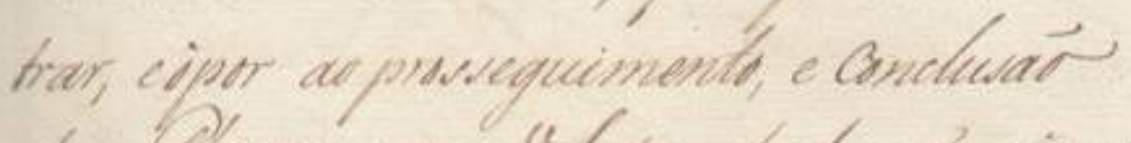

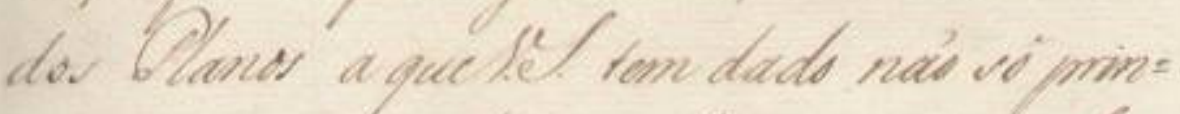
rivis, was abamad, na forma acins nefe

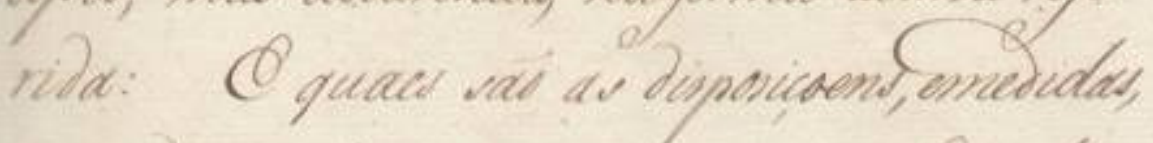
quevederon tomat para provenis: forendo precias nowior a dires Oefracules.

(in requnde lugar Suar as s mu-

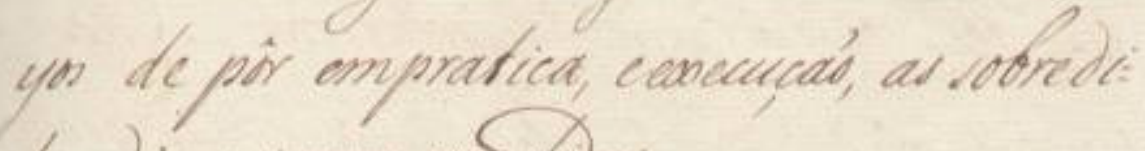
tar disporicoent, enedidas.

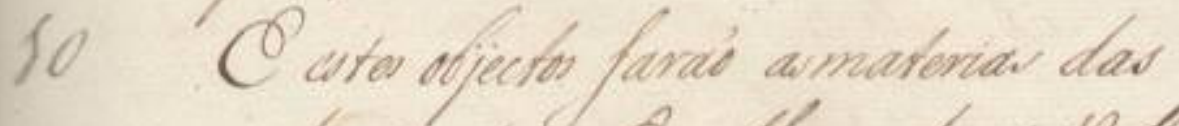

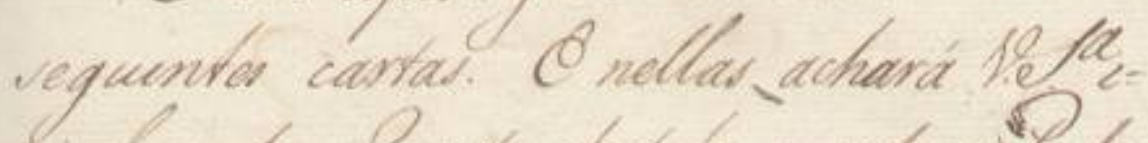

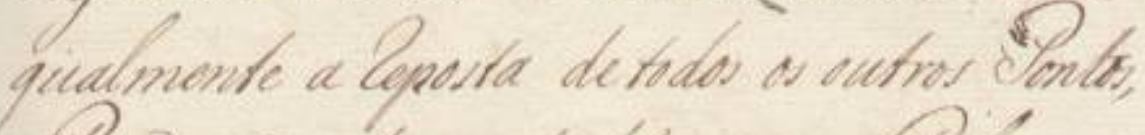

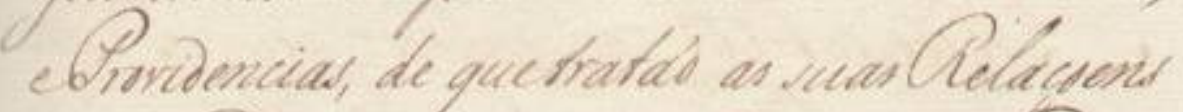

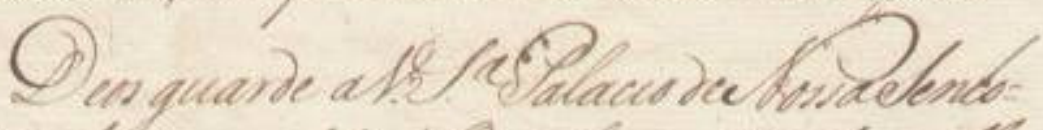

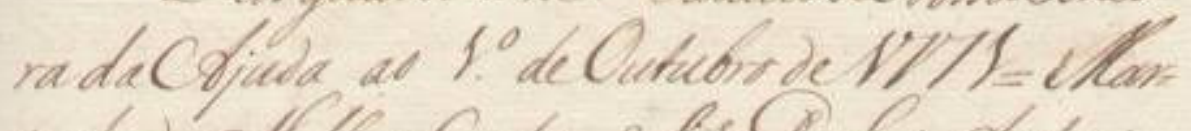

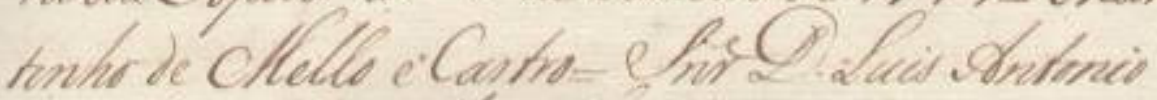

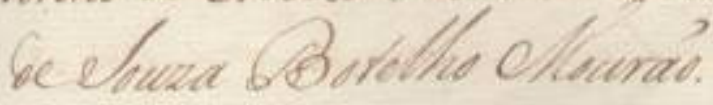

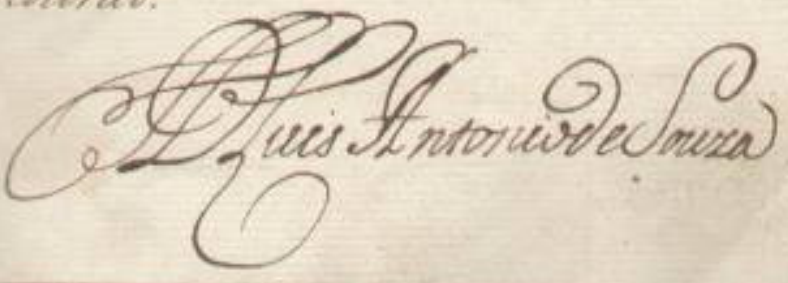


||82r|| Para proceder porem com methodo, eOrdem, sobre materia taõ grave; Será precizo refle= tir nos factos seguintes.

958 Primeiramente sedevem ponderar:

Quaes saõ os Obstaculos, que sepodem encon= trar, eôpor ao prosseguimento, e Conclusaõ dos Planos a queVossaSenhoria tem dado naõ sô prin= cipio, mas adiantado, naforma acima refe=

100 rida: [espaço] E quaes saõ as disposiçoens, emedidas, que sedevem tomar para prevenir; / esendo precizo / rebater os ditos Obstaculos:

9 Em segundo lugar: [espaço]Quaes saõ os me= yos de pôr empratica, eexecuçaõ, as sobredi= 105 tas disposiçoens, emedidas.

10 E estes objectos faraõ as materias das seguintes cartas. E nellas achará VossaSenhoria i= gualmente a reposta de todos os outros Pontos, eProvidencias, de quetrataõ as suas Relaçoens. ra daAjuda ao primeiro deOutubro de1771 = Mar= tinho de Mello eCastro= SenhorDom Luis Antonio deSouza Botelho Mouraõ.

\section{DomLuis AntoniodeSouza}


[45]

||86r||

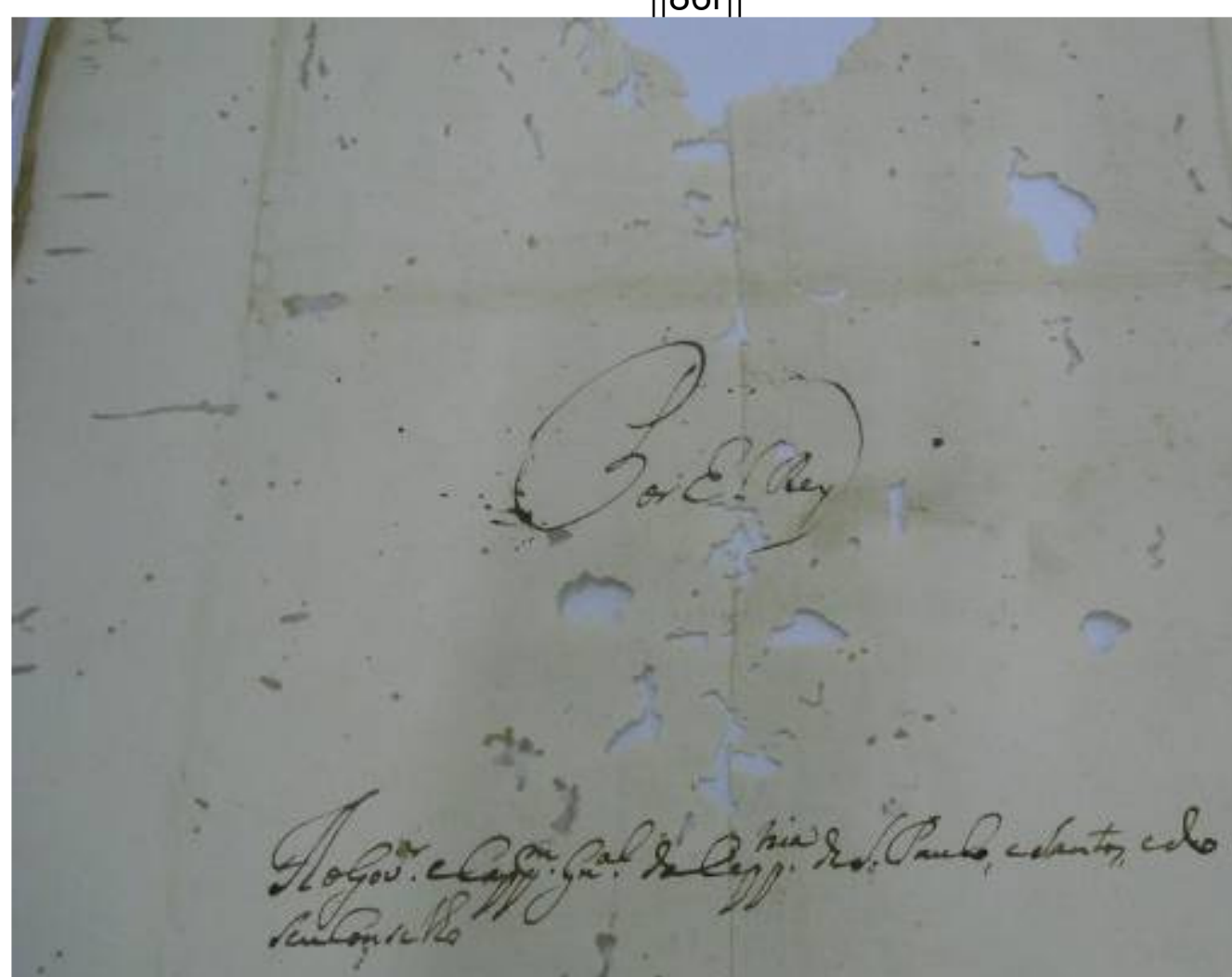

297 
||86r $\|$

Por El Rey

AoGovernador eCappitam General daCappitania deSaõ Paulo, eSantos, edo SeuConselho 


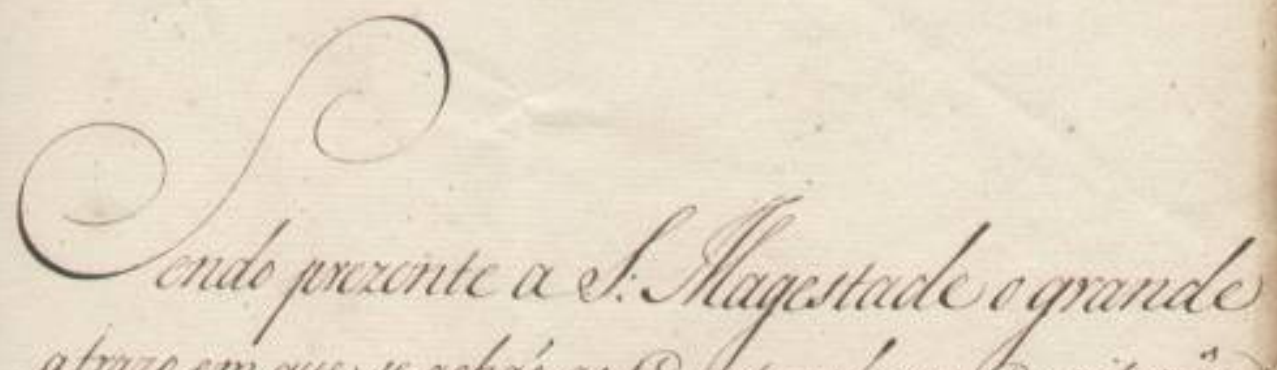

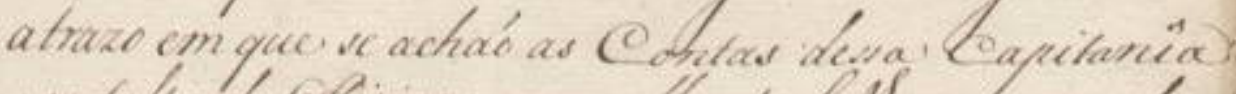

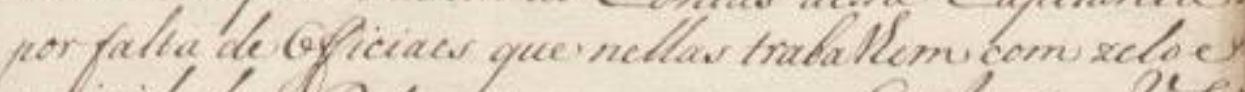

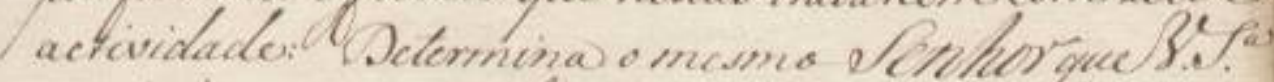
nonhainesto particular a mais concta vigilancia) as

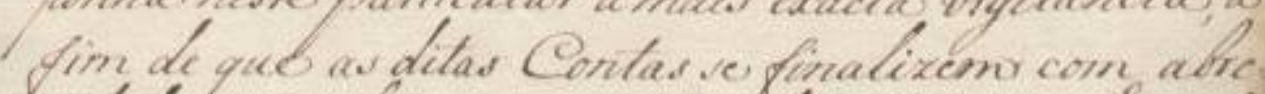

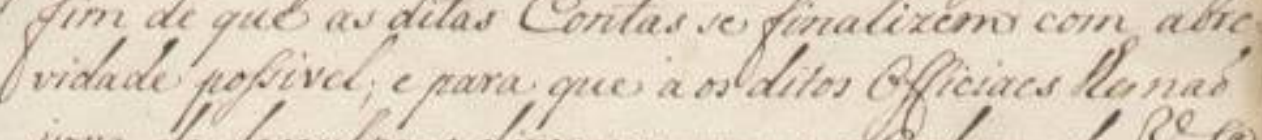
irva de desculpa o dizerem que por Gratern de P. fa

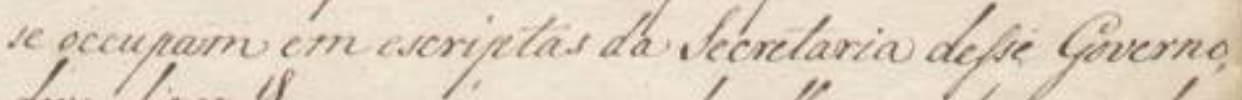

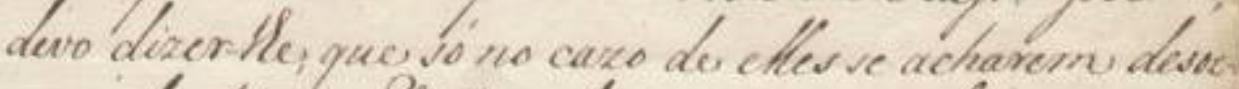
- cupados hé aue Pe pos pode occupar on alquenas deli qencias breves e cazuar que ter nas ornsarastem os obriqacogns dop. ues impregos. buscedendo haver ne cefidade de pepoas pues encreva's na ilcorclaria, neme

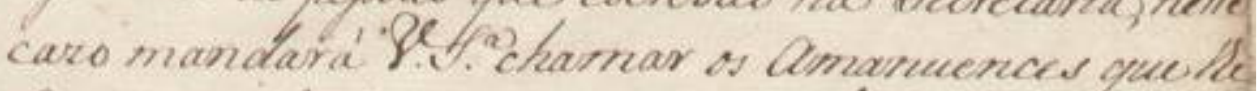

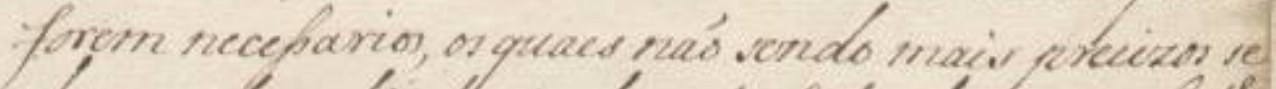
C devom despedis depoin de vatispeitor do Meu traballo.

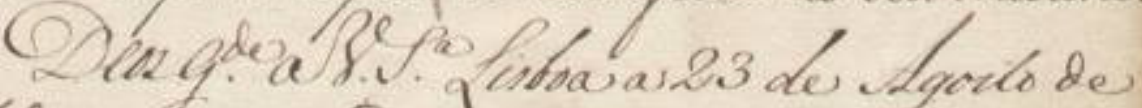

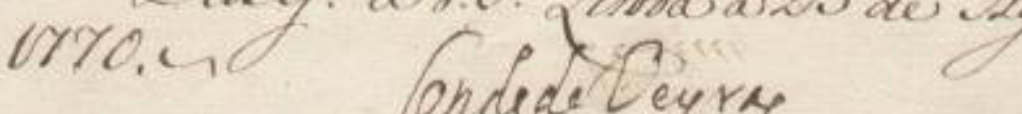

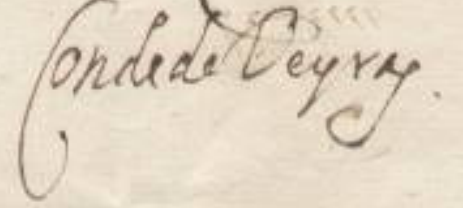

Don quive stutorio 
||87r|| Sendo prezente aSua Magestade o grande

atrazo em que se achaõ as Contas dessa Capitanîa

por falta de Officiaes que nellas trabalhem com zelo e

actividade: Determina o mesmo Senhor queVossaSenhoria

5 ponha neste particular a mais exacta vigilancia, a

fim de que as ditas Contas se finalizem com abre=

vidade possivel; e para que a os ditos Officiaes Ihes naõ

sirva de desculpa o dizerem que por Ordem deVossaSenhoria

se occupam em escriptas da Secretaria desse Governo,

10 devo dizer-lhe, que só no cazo de elles se acharem desoc=

cupados hé que VossaSenhoria os pode occupar em algumas deli-

gencias breves, e cazuaes que lhes naõ embarassem as o-

brigaçoens dos Seus Empregos: E succedendo haver ne=

cessidade de pessoas que escrevaõ na Secretaria, nesse

15 cazo mandará VossaSenhoria chamar os Amanuences que lhe forem necessarios, os quaes naõ sendo mais precizos se devem despedir depois de satisfeitos do seu trabalho.

DeosGuarde aVossaSenhoria Lisboa a 23 de Agosto de 1770.

Senhor Dom Luiz Antonio*

deSouza.

[SegundaVia]

\footnotetext{
* Acima há o carimbo circular do AESP.
} 
[47]

||89v $\|$

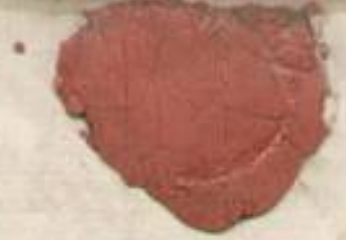

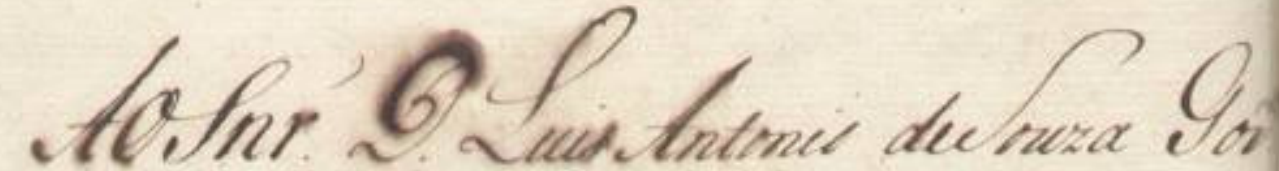
elap. Gen dalapidania do
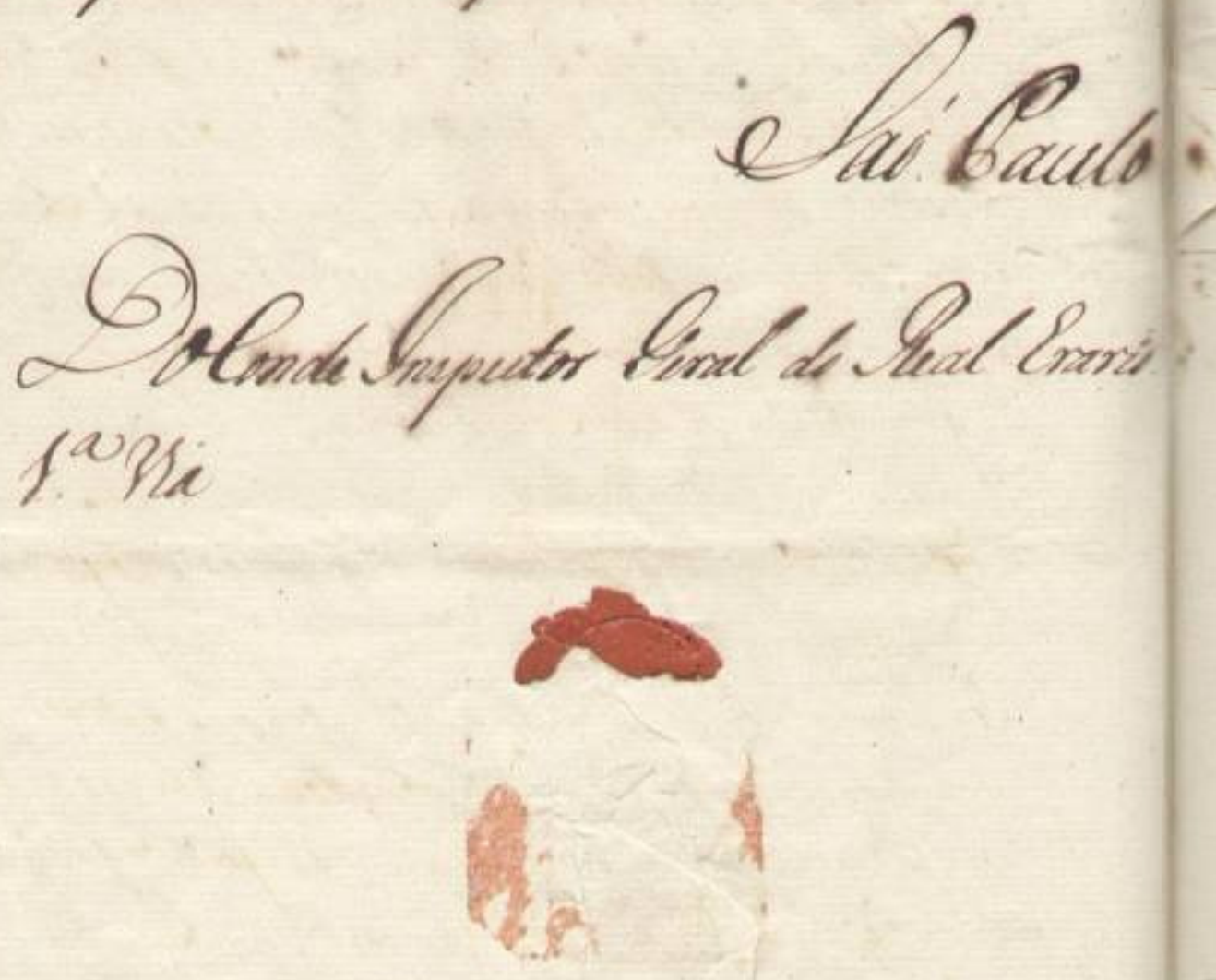
\|89v $\|$ Ao Senhor Dom Luis Antonio deSouza Governador eCapitam General daCapitania de

Saõ Paulo.

Primeira Via* 
[48]

||90r|

6.8

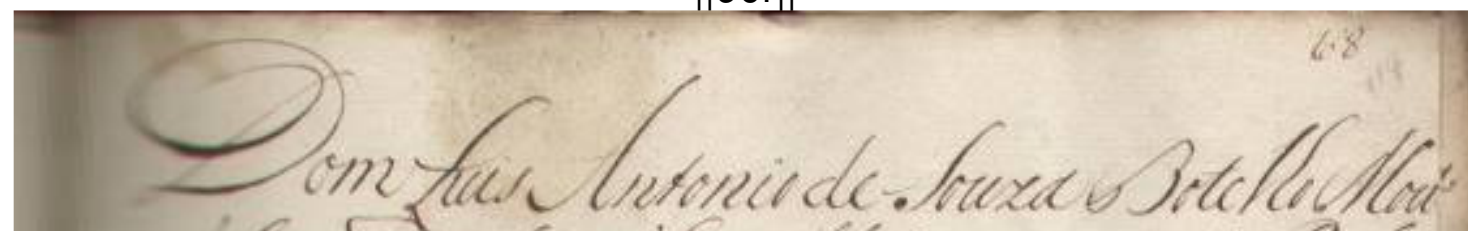

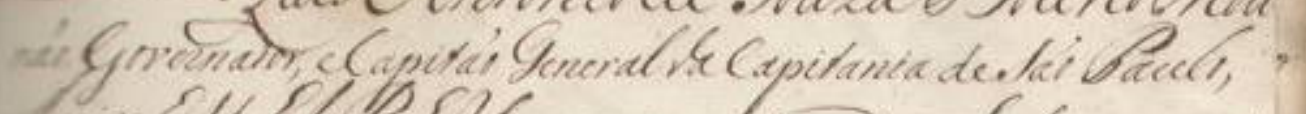

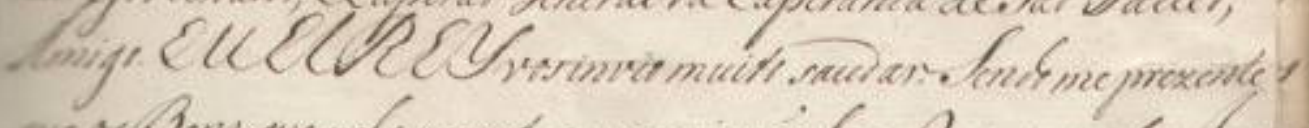

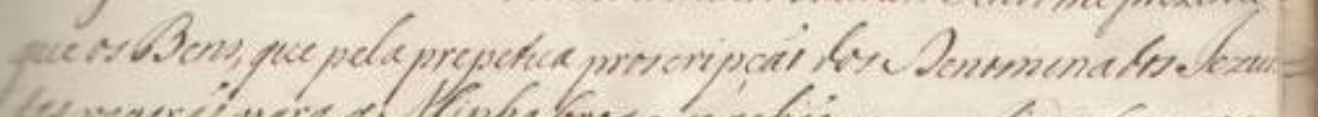

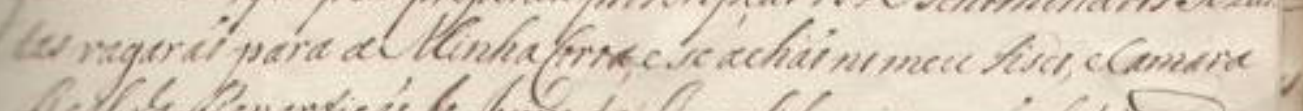

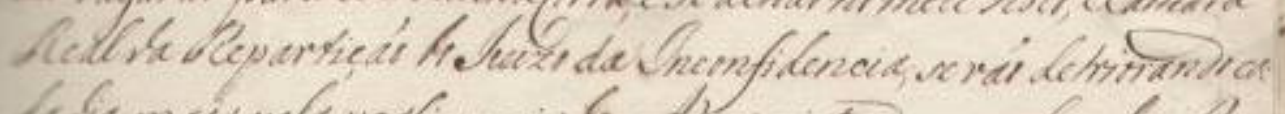

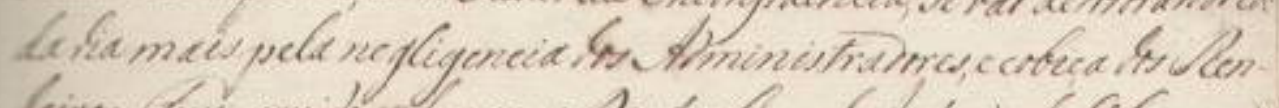

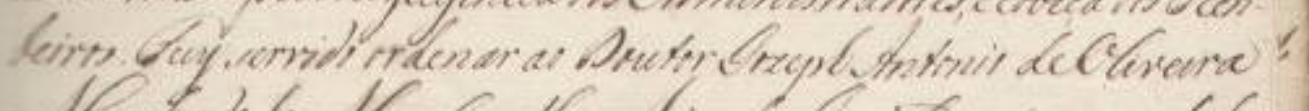

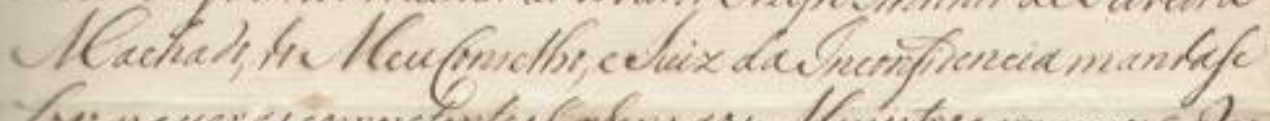

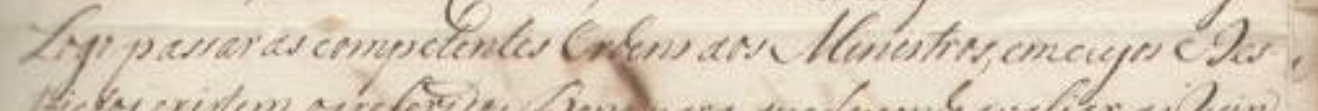

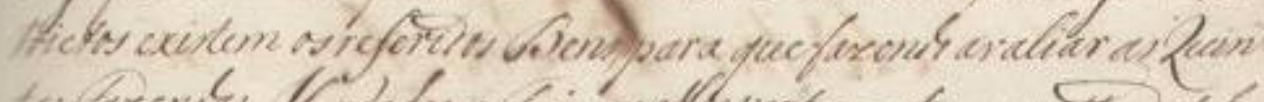

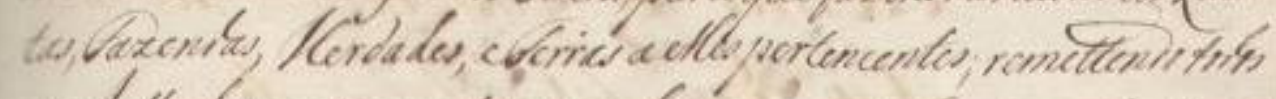

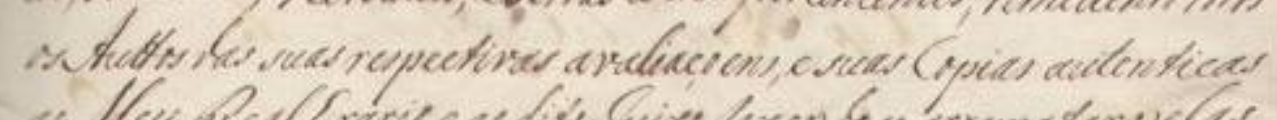

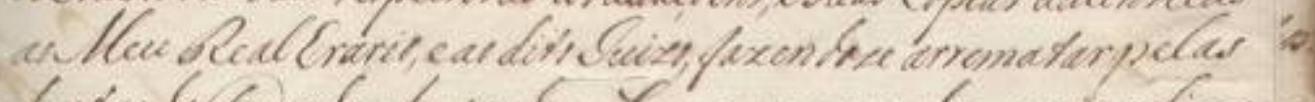

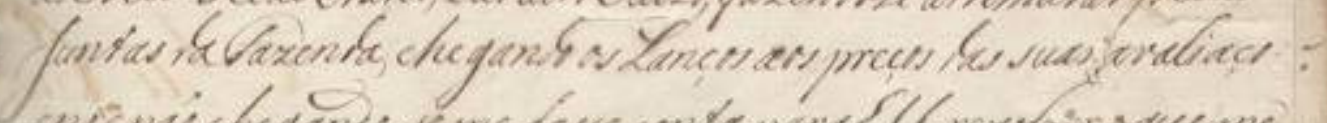

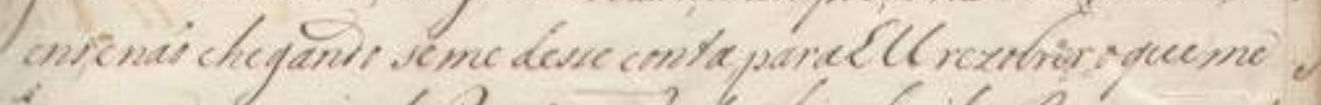

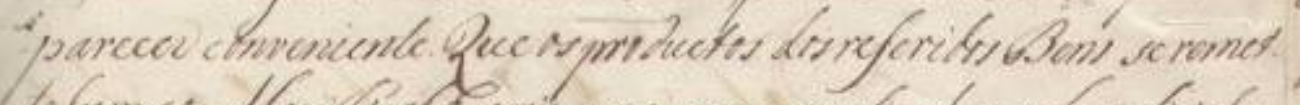

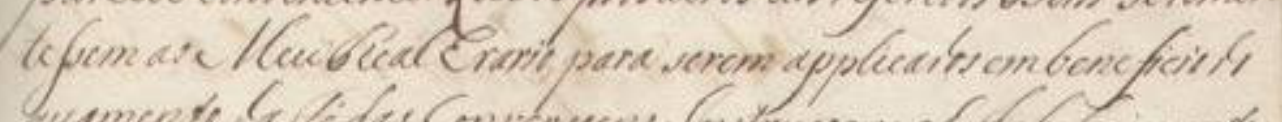
If

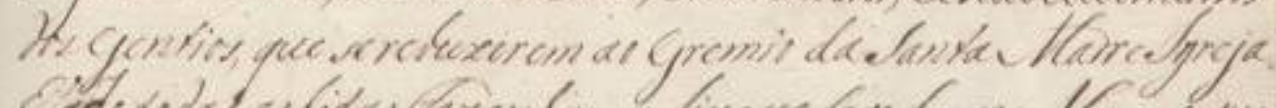

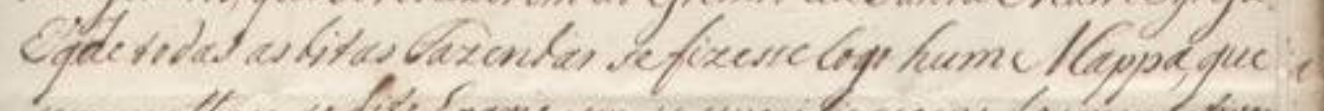

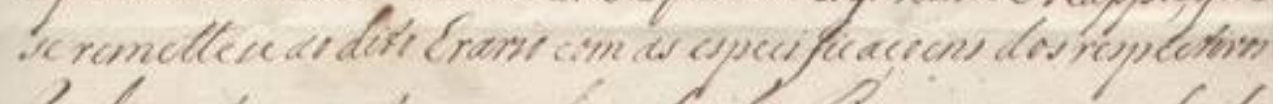

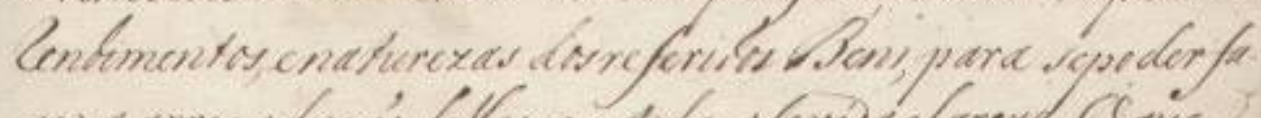

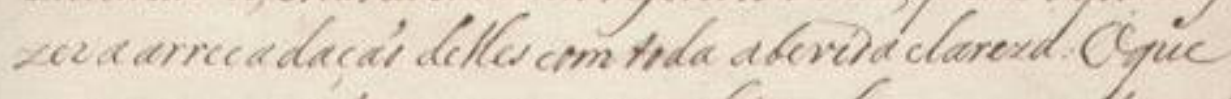

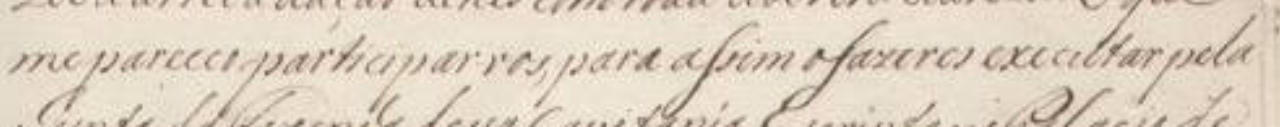

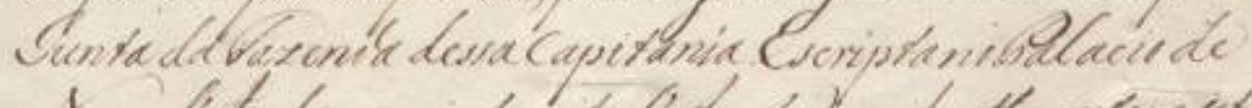

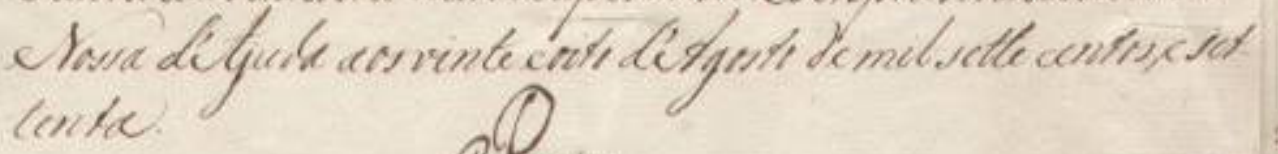

Quy :

inavinzacicongmis

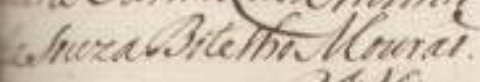

2xise

303 
||90r|| Dom Luis Antonio de Souza Botelho Mou-

raõ Governador, eCapitaõ General daCapitania deSaõ Paulo,

Amigo. EuEIREY vos invio muito saudar. Sendo me prezente

que os Bens, que pela prepetua proscripçaõ dos Denominados lezui=

5 tas vagaraõ para aMinhaCorte,e se achaõ no meu Fisco, eCamara

Real da Repartiçaõ do luizo da Inconfidencia, se vaõ detriorando ca-

da dia mais pela negligencia dos Administradores, e cobiça dos Ren-

deiros. Fuy servido ordenar ao Doutor lozeph Antonio deOliveira

Machado, do MeuConselho, e luiz dalnconfidencia mandase

Logo passar as competentes Ordens aos Ministros, emcujos Destrictos existem os referidos Bens, para quefazendo avaliar as Quintas, Fazendas, Herdades, eTerras a elles pertencentes; remettendo todos os Auttos das suas respectivas avaliaçoens, e suas Copias autenticas ao Meu Real Erario, eo dito luizo, fazendose arrematar pelas Juntas daFazenda, chegando os Lanços aos preços das suas avaliaçoens, enaõ chegando se me desse conta para EU rezolver o que me parecer conveniente. Que os productos dos referidos Bens se remettessem ao Meu Real Erario para serem applicados em beneficio do augmento da Fé, das Conversoens, Instrucoens, eEstabelecimentos

20 dos Gentios, que se reduzirem ao Gremio daSanta Madre Igreja. Equede todas as ditas Fazendas sefizesselogo hum Mappa, que se remettese ao dito Erario com as especificaçoens dos respectivos rendimentos, enaturezas dos referidos Bens, para sepoder fazer a arrecadaçaõ delles com toda adevida clareza. Oque

25 me pareceo participar-vos, para assim ofazeres executar pela lunta da Fazenda dessa Capitania. Escripta no Palacio de Nossa d'Ajuda aos vinte eoito d'Agosto de mil sette centos, e settenta. 


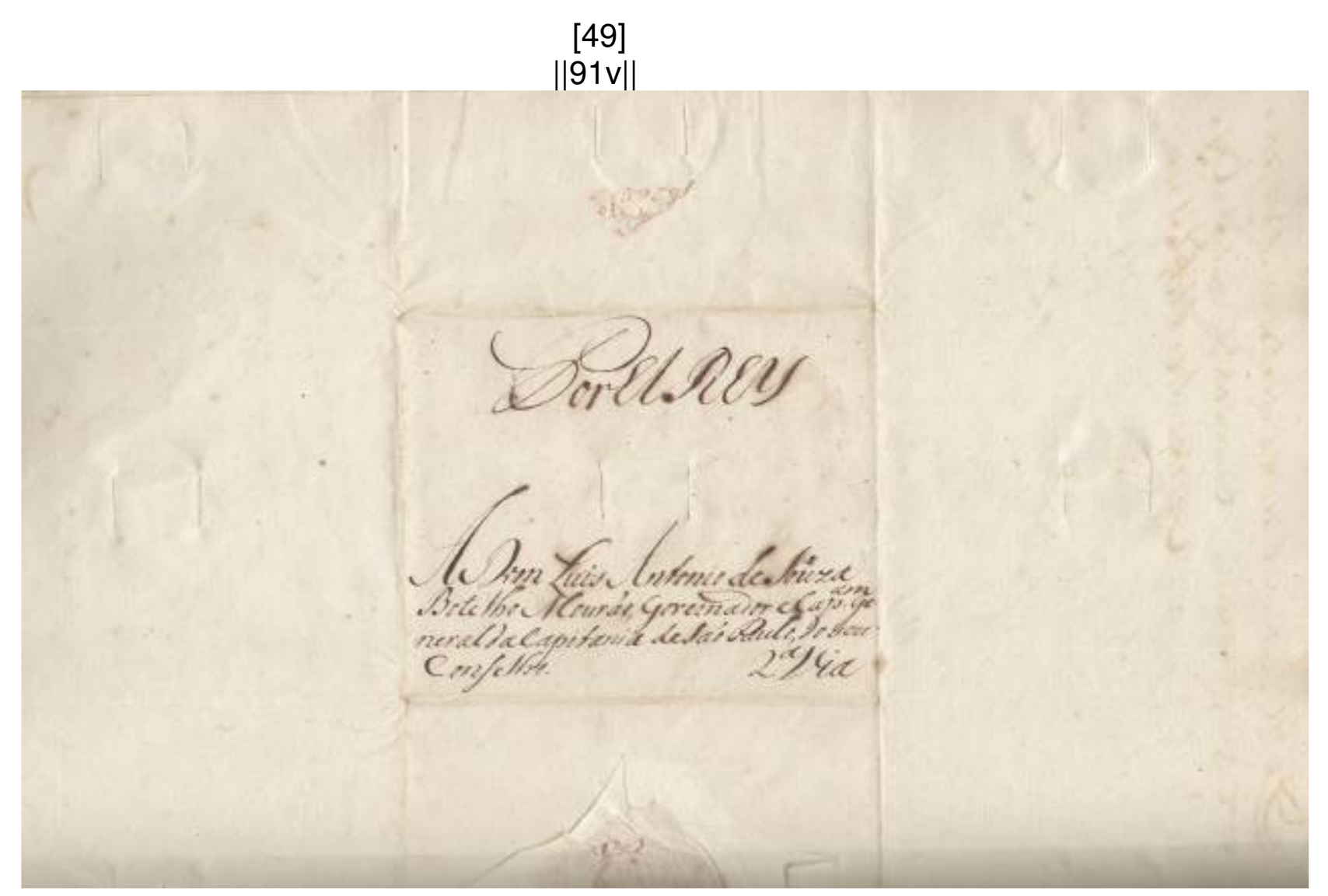

305 
$\|91 v\|$

Por EIREY*

A Dom Luis Antonio deSouza

Botelho Mouraõ, Governador eCapitam Ge-

neral daCapitania deSaõ Paulo, do seu

5 Conselho.

SegundaVia

* Abaixo há parte de um selo em forma de estrela com carimbo circular. 
[50]

||92r||

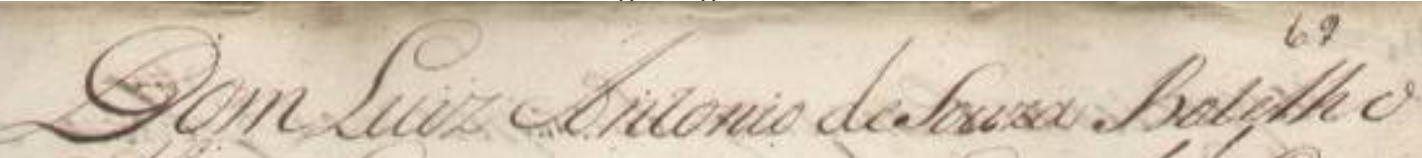

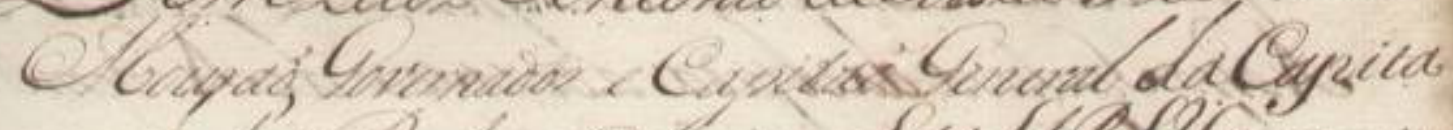

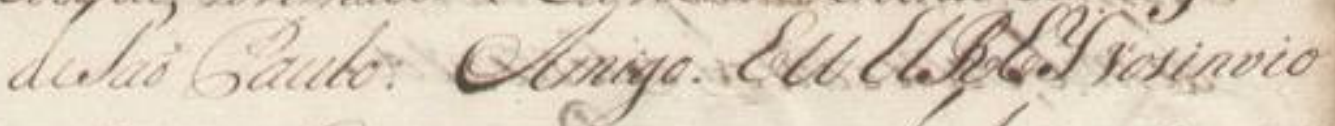

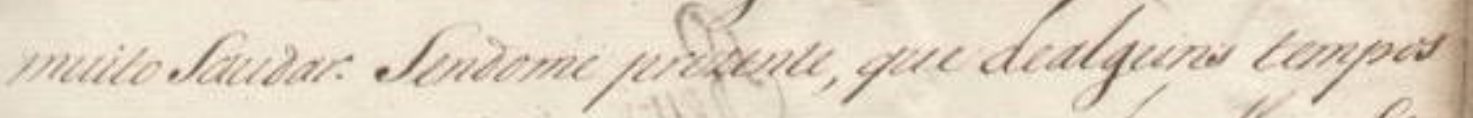

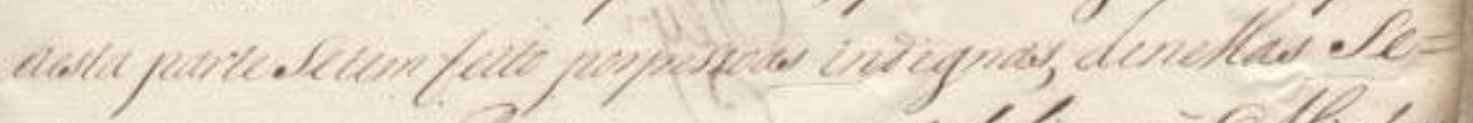

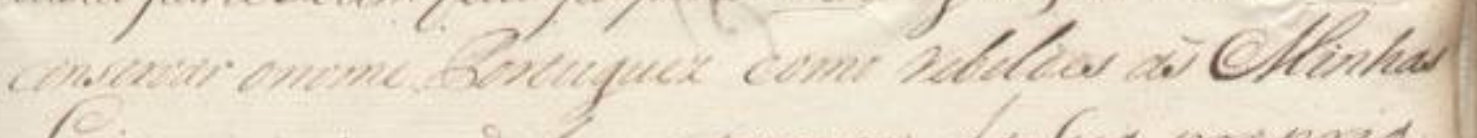

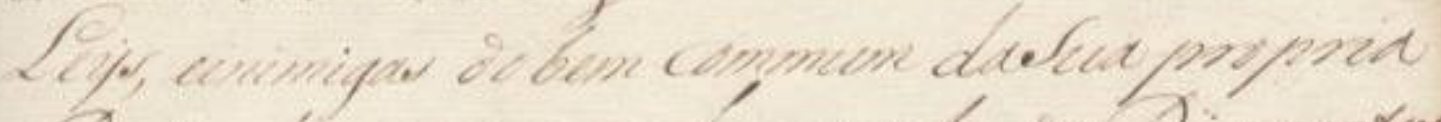

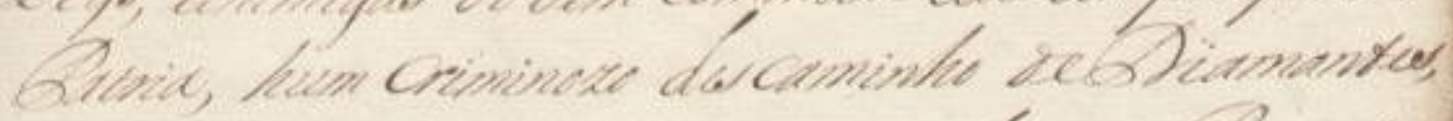

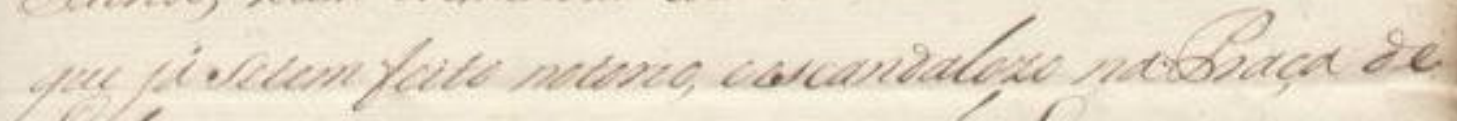

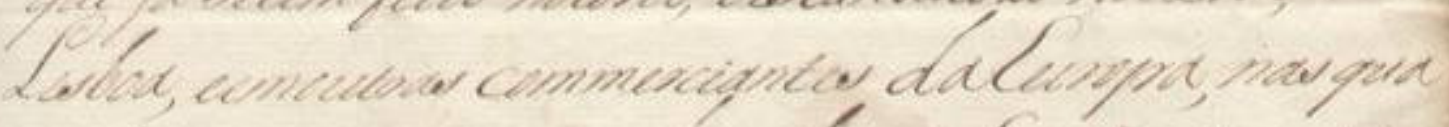

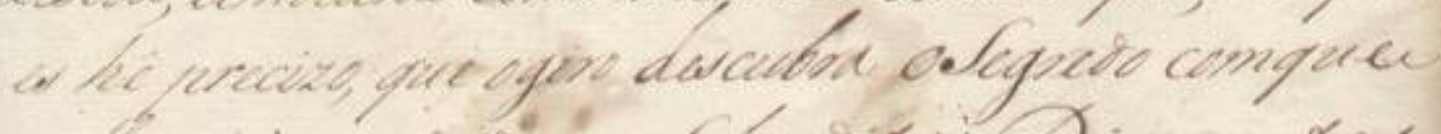

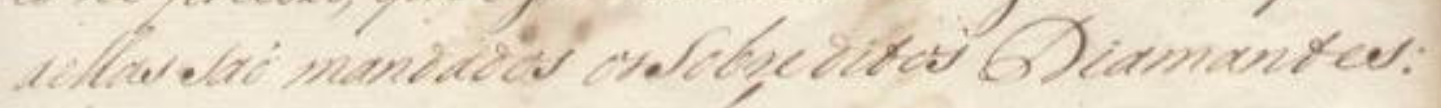

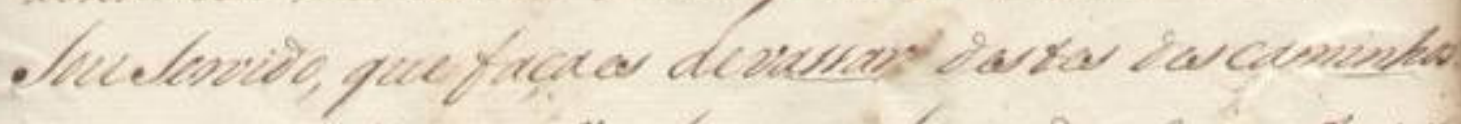

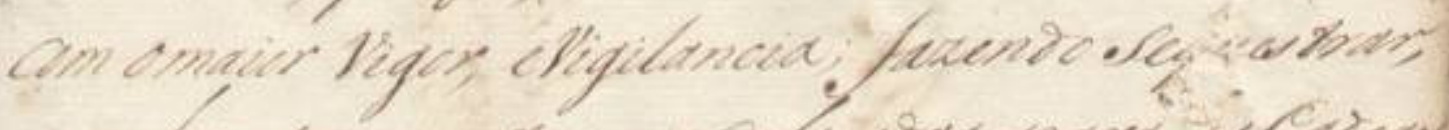

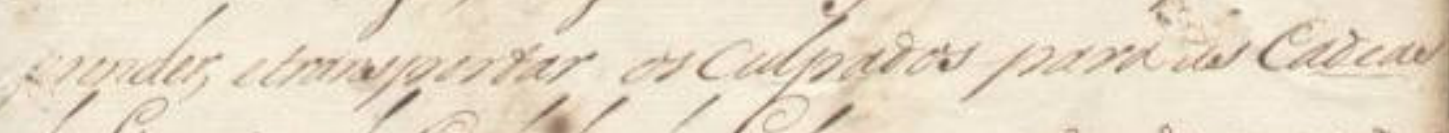

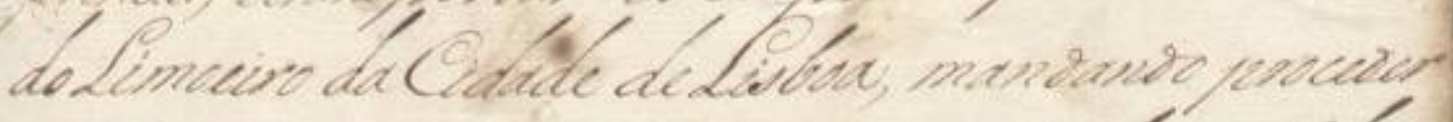

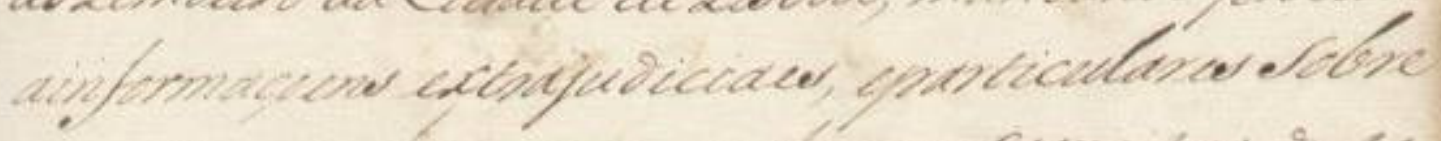

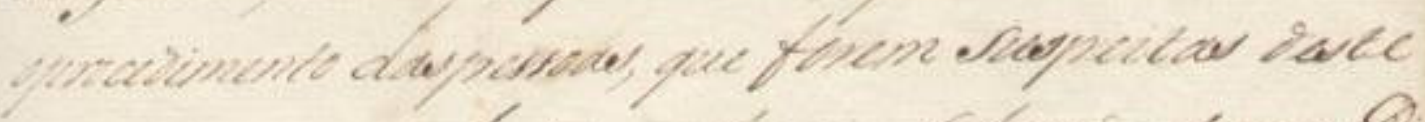

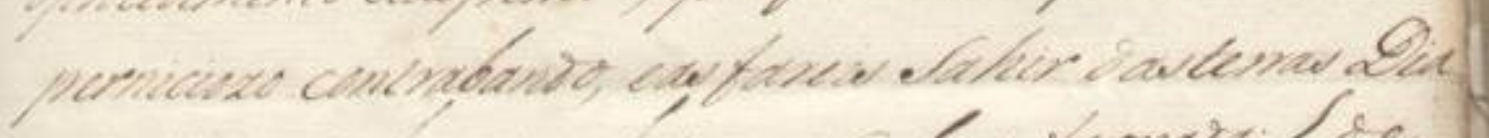

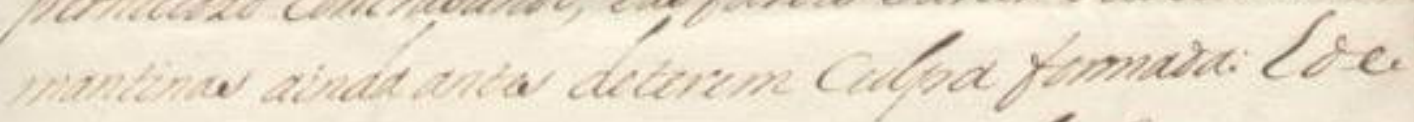

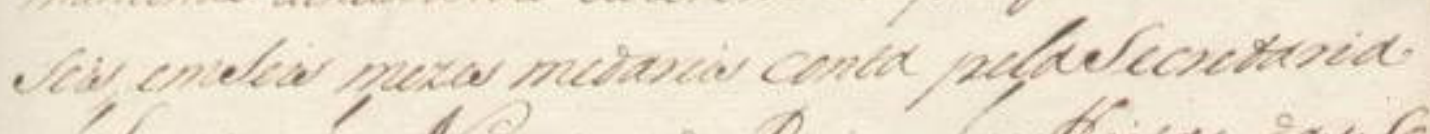

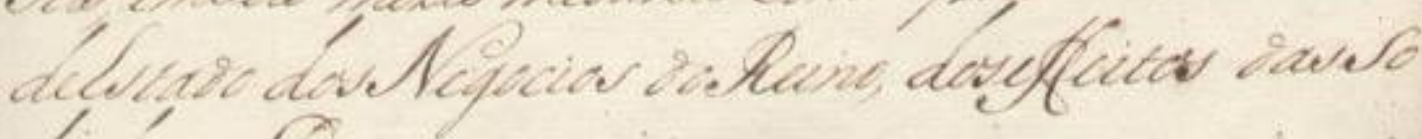

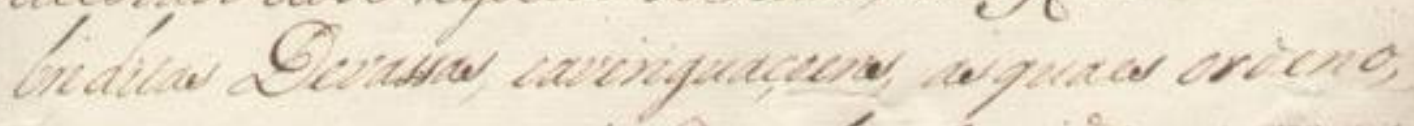

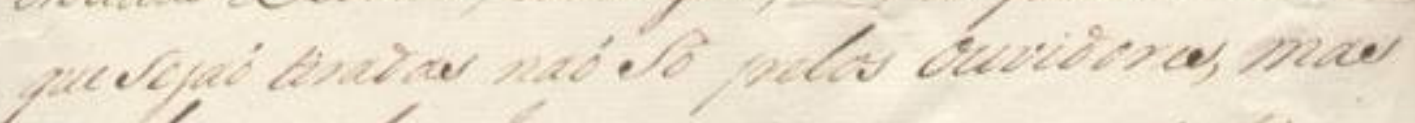

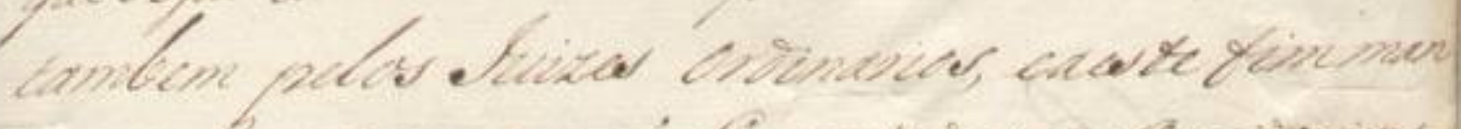

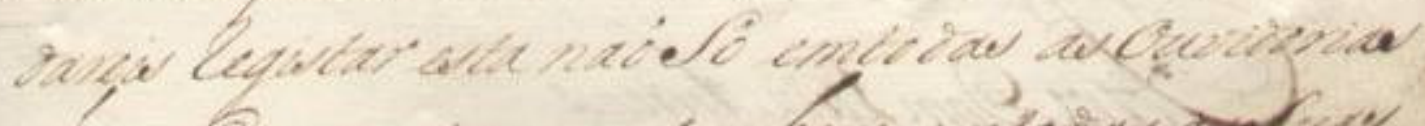

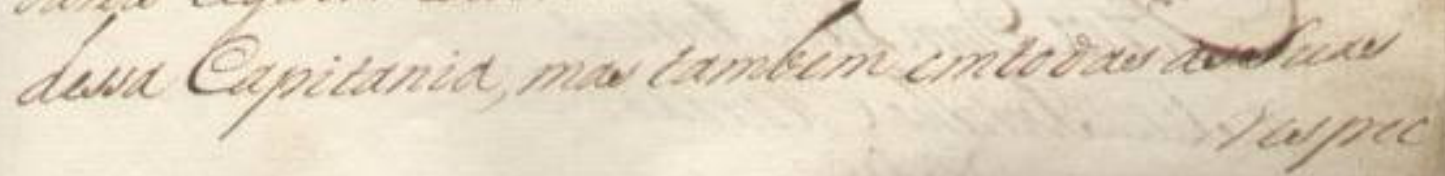

307 
||92r|| Dom Luis Antonio deSouza Botelho

Mouraõ, Governador e Capitaõ General daCapita

nia deSaõ Paulo: Amigo. EU EIREY vos invio

muito Saudar. Sendome prezente, que dealguns tempos

5 aesta parte setem feito porpessoas indignas, denellas $\mathrm{Se}=$ conservar onome Portuguez como rebeldes ás Minhas Leys, einimigos do bem commum daSua propria Patria, hum criminozo descaminho deDiamantes, que já setem feito notorio, eescandalozo naPraça de

10 Lisboa, eemoutras commerciantes daEuropa, nas qua es hê precizo, que ogiro descubra o Segredo comque a ellas saõ mandados osSobreditos Diamantes: SouServido, que façaes devassar destes descaminhos com o maior Vigor, e Vigilancia; fazendo sequestrar,

15 prender, etransportar os Culpados para as Cadeas do Limoeiro da Cidade de Lisboa, mandando proceder ainformaçoens extrajudiciaes, eparticulares sobre oprocedimento das pessoas, que forem suspeitas deste perniciozo contrabando, eas fareis Sahir das terras Dia

20 mantinas ainda antes deterem Culpa formada: E de Seis, emSeis mezes medareis conta pelaSecretaria deEstado dosNegocios do Reino, dos effeitos das So breditas Devassas, eaveriguaçoens, as quaes ordeno, que sejaõ tiradas naõ Só pelos ouvidores, mas

25 tambem pelos luizes ordinarios, eaeste fim man dareis registar esta naõ Só emtodas as Ouvidorias dessa Capitania, mas tambem em todas as Suas respec 
||92v $\|$

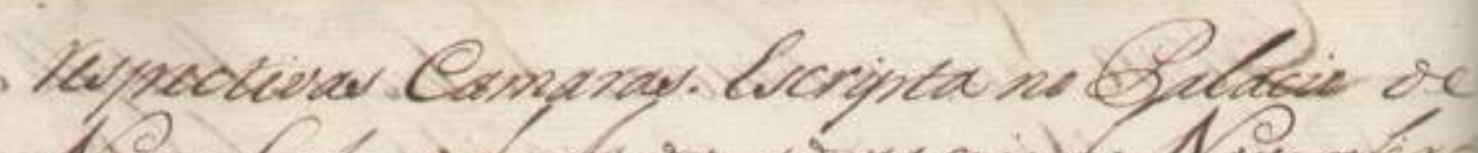

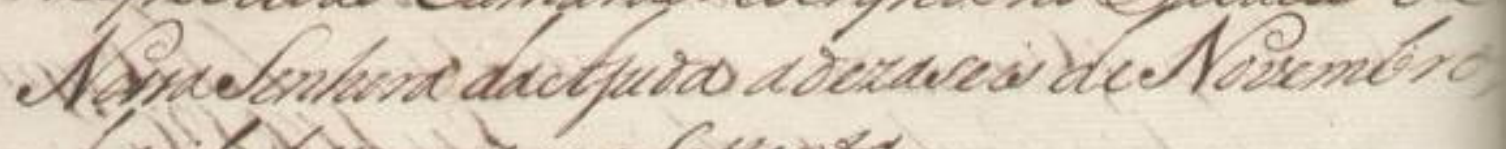

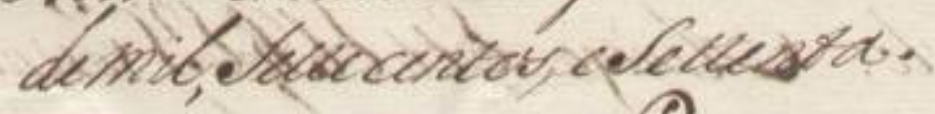

Chey:
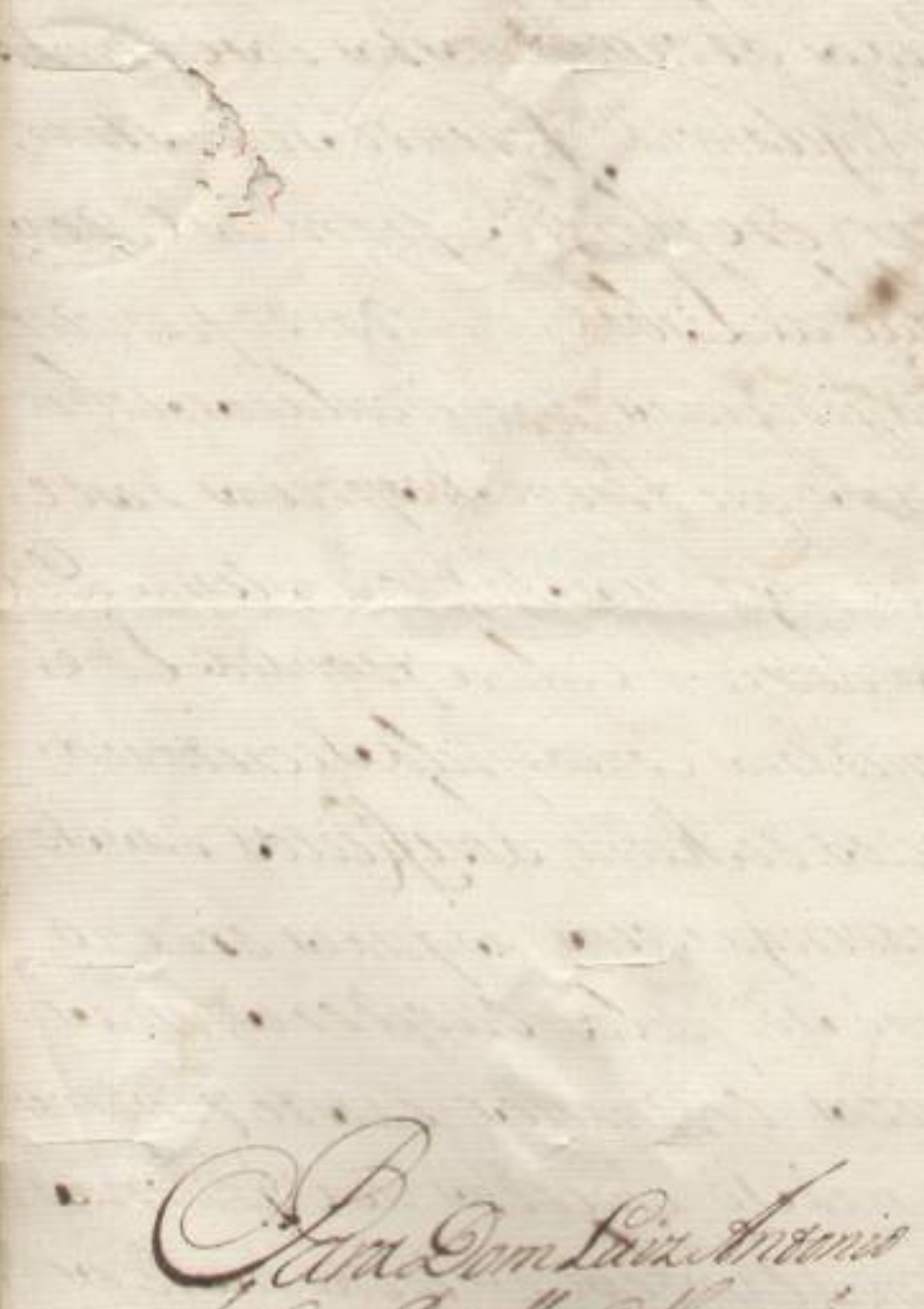

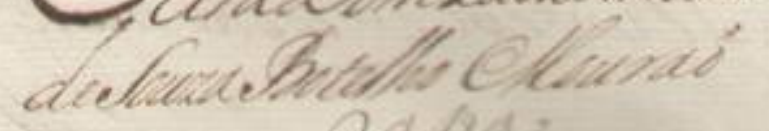

zapa

309 
\|92v || [[respec]]tivas Camaras. Escripta no Palacio de

NossaSenhora daAjuda a dezaseis de Novembro,

30 de mil, Settecentos, eSettenta.

\section{$\underline{\text { Rey }}$}

Para Dom Luiz Antonio

deSouza Botelho Mouraõ. 
[51]

||93v |

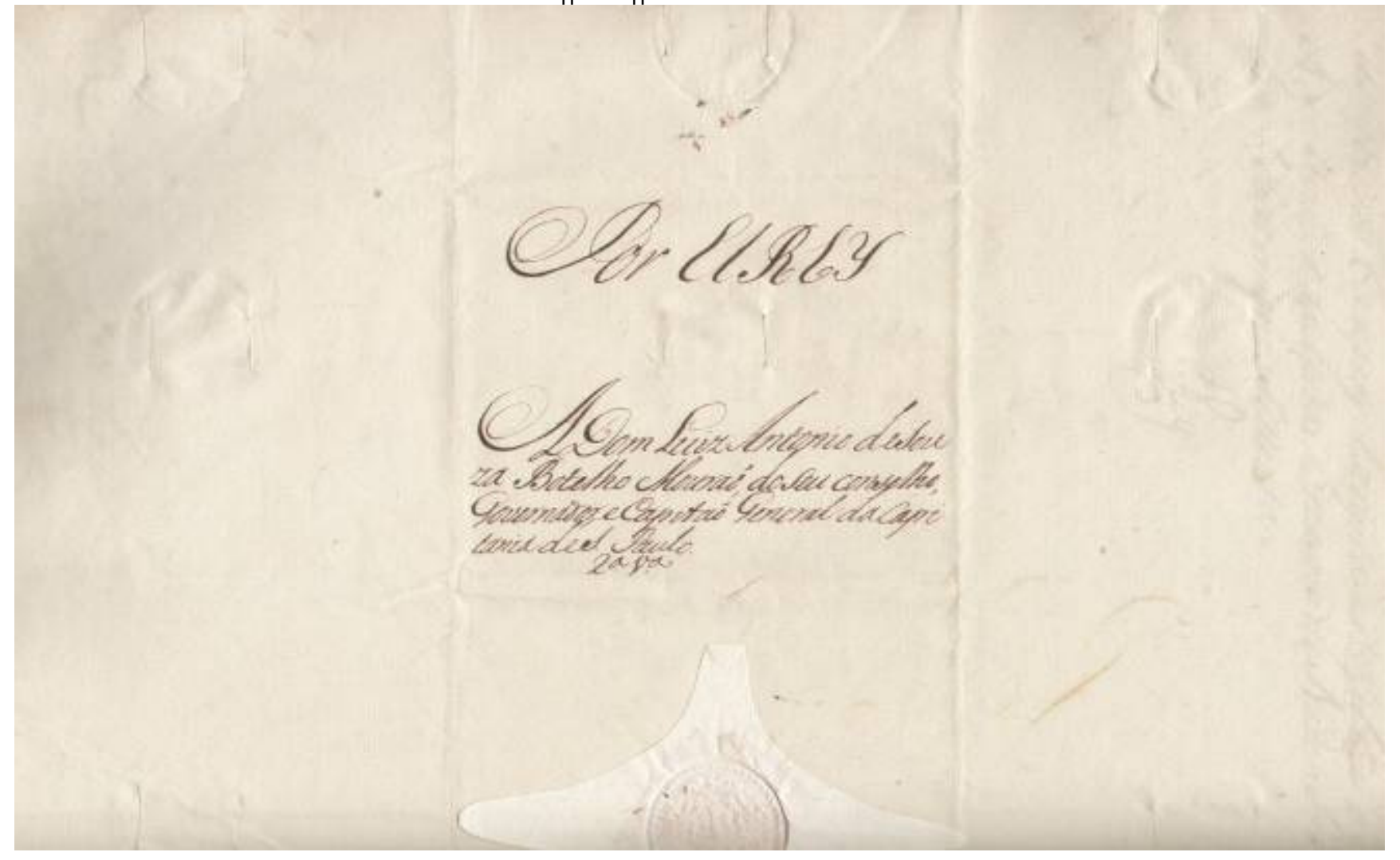


||93v || Por EIREY*

ADom LuizAntonio deSou

za Botelho Mouraõ, do Seu Conselho,

Governador, eCapitaõ General daCapi

5 tania deSaõ Paulo.

SegundaVia

*Abaixo há parte de um selo em forma de estrela com carimbo circular. 


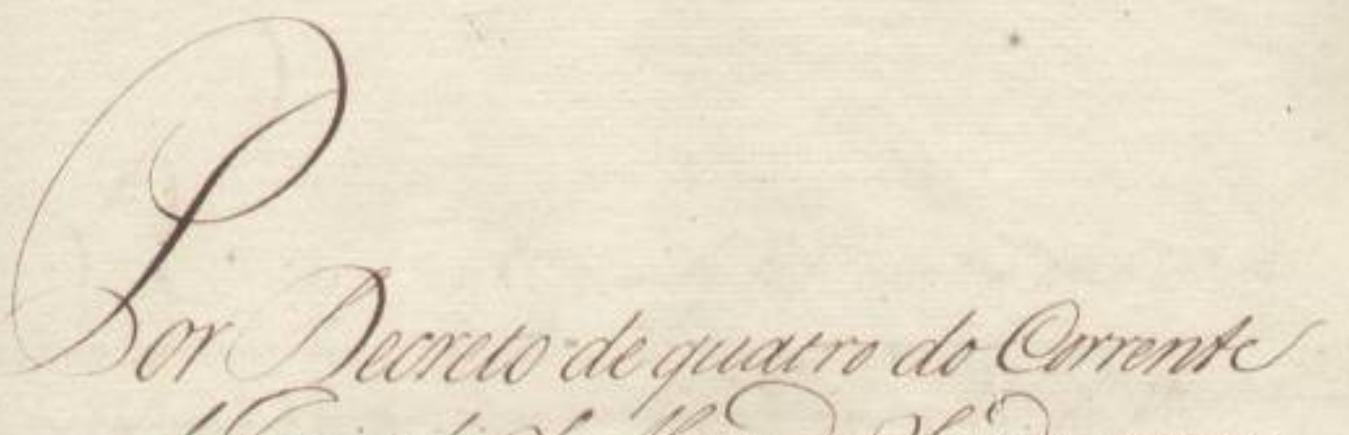

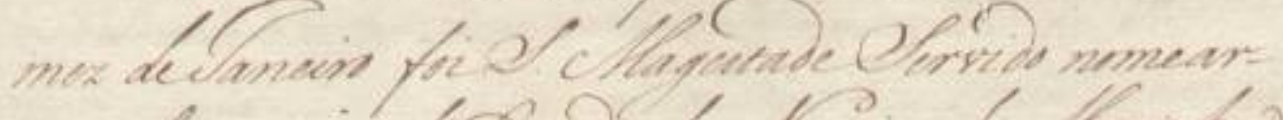

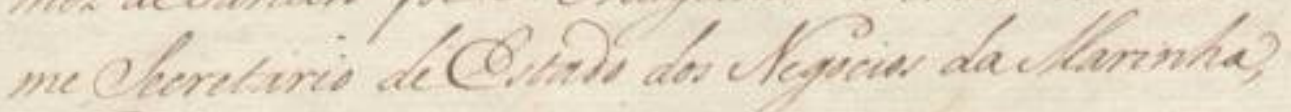

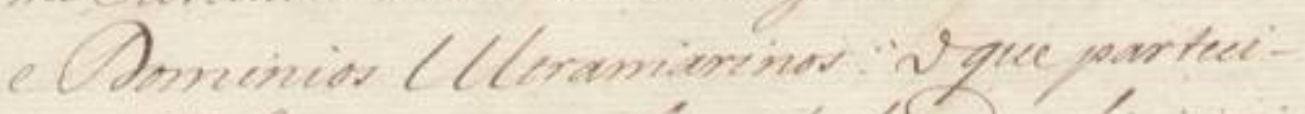

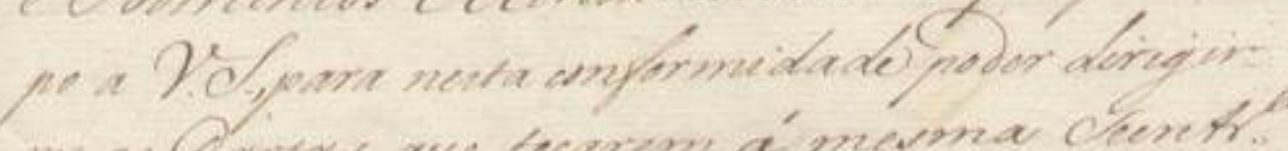

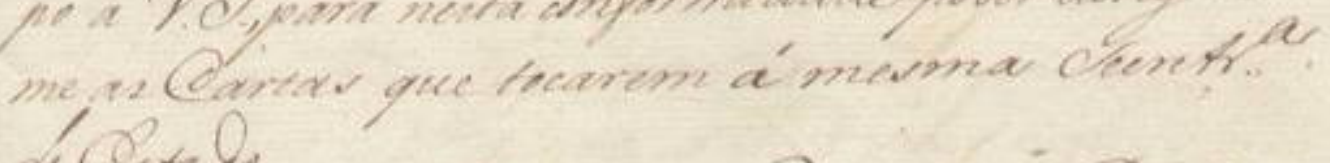
acento

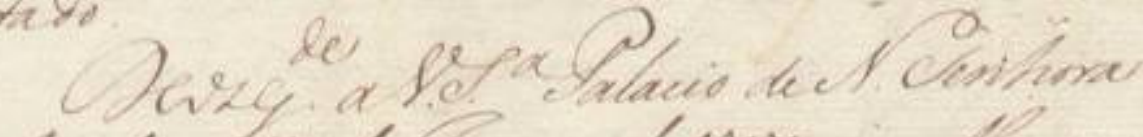

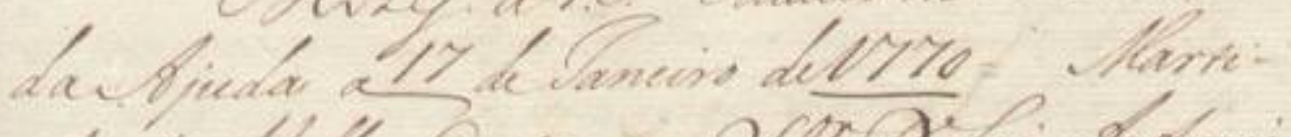

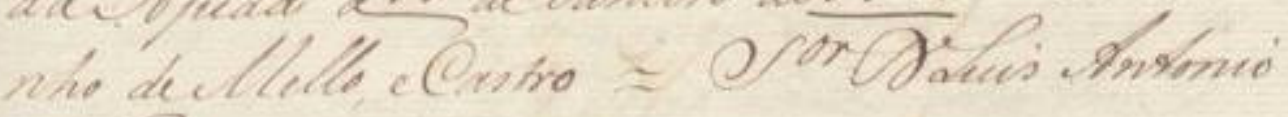
$\operatorname{lec} 0$
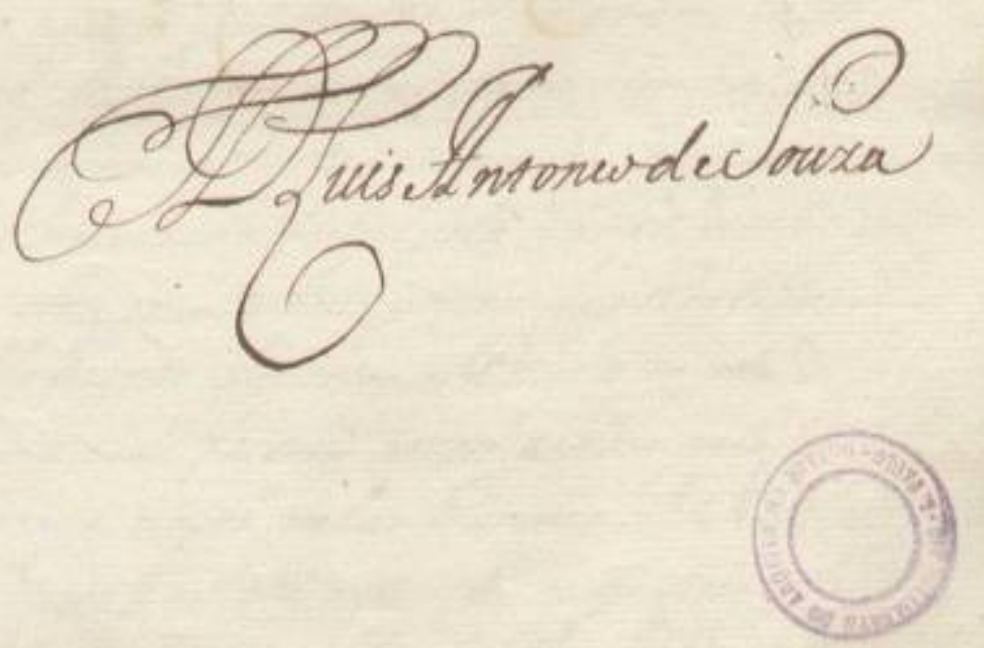
||94r|| Por Decreto de quatro doCorrente

mez delaneiro foiSua MagestadeServido nomear-

me Secretario deEstado dos Negocios daMarinha,

e Dominios Ultramarinos: Oque parteci-

5 po a VossaSenhoria, para nesta conformidade poder dirigir=

me as Cartas que tocarem á mesma Secretaria

deEstado.

Deosguarde aVossaSenhoriaPalacio deNossa Senhora daAjuda a17 delaneiro de $\underline{1770}=$ Marti -

10 nho deMello, eCastro $=$ SenhorDomLuis Antonio

deSouza

DomLuis AntoniodeSouza*

* Ao final do documento, na margem direita, há o carimbo circular do AESP. 


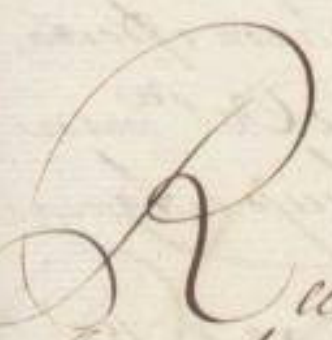

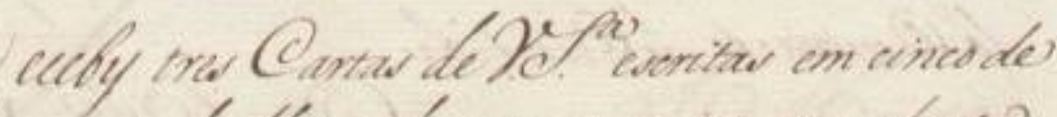

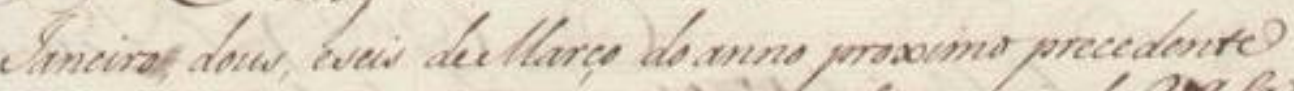

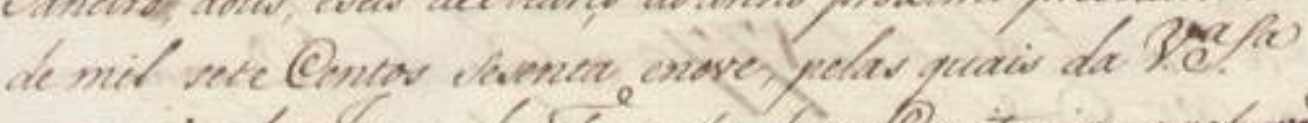

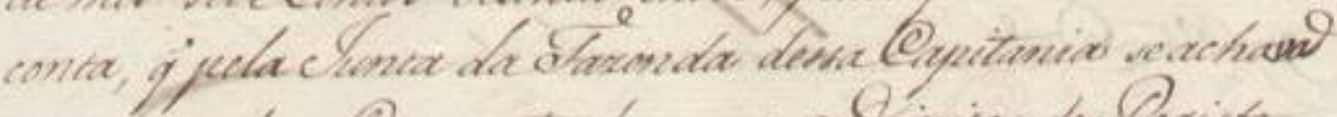

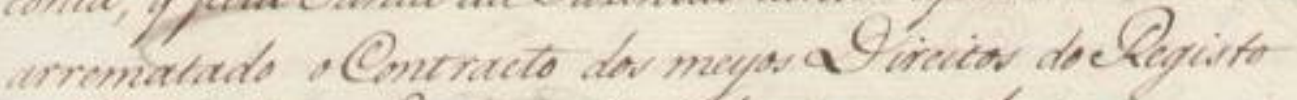

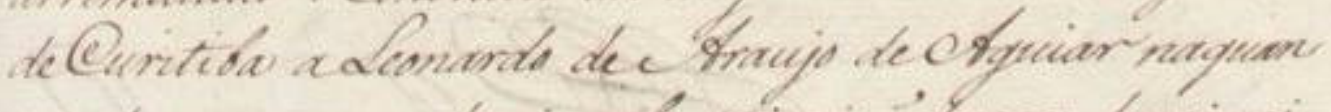

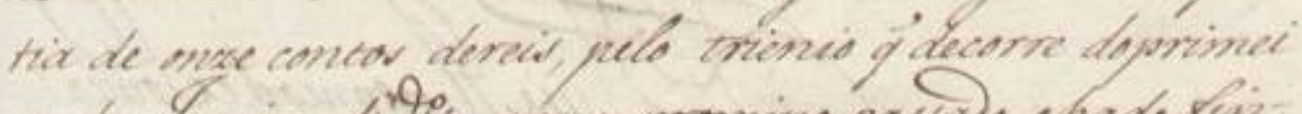

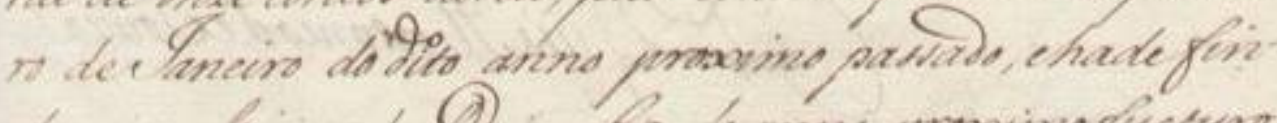

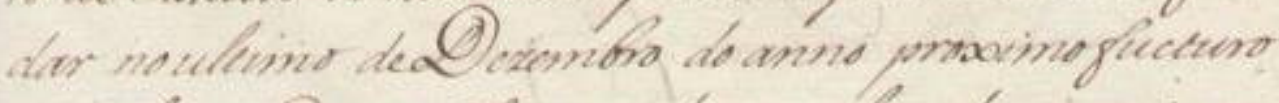

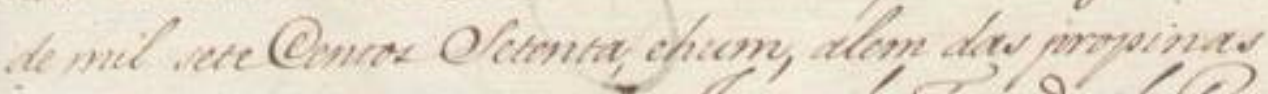

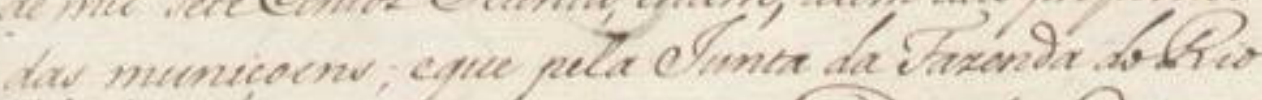

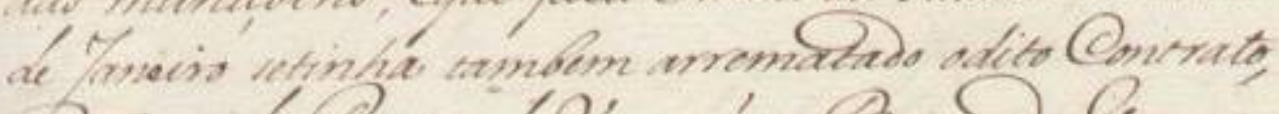

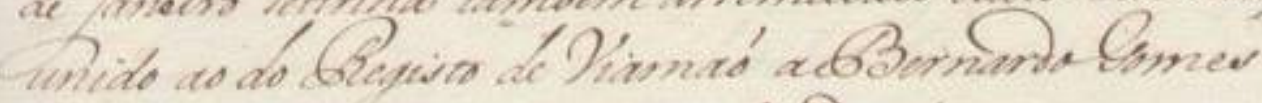

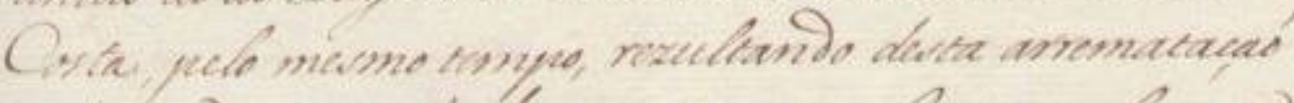

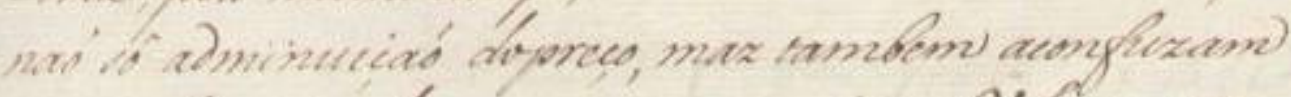

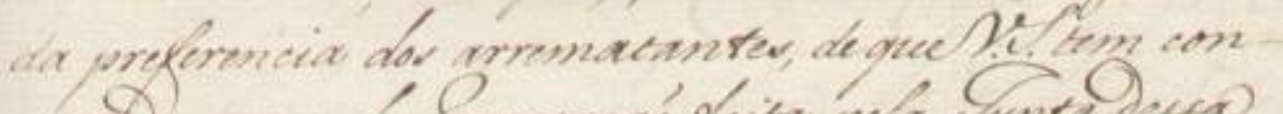

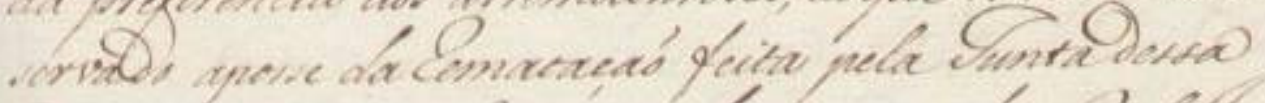

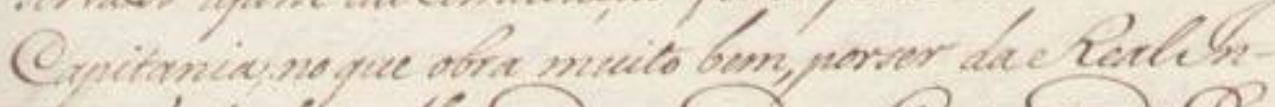

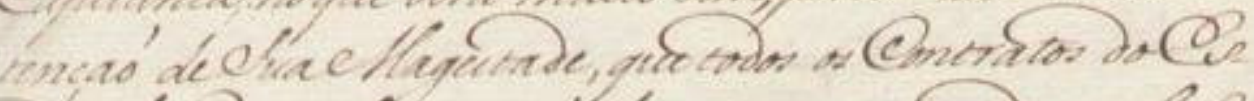

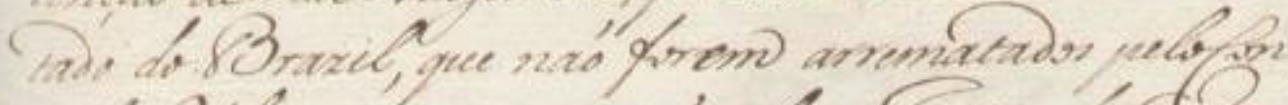

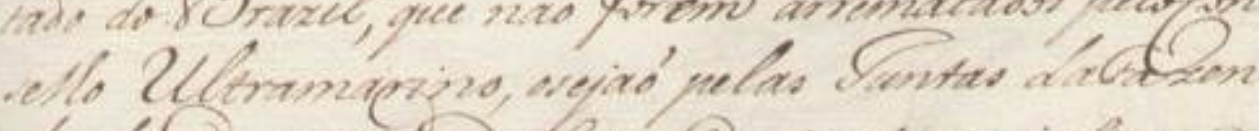

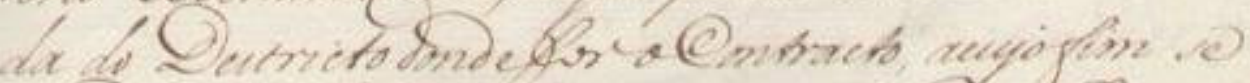

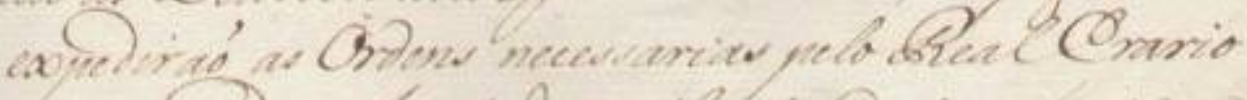

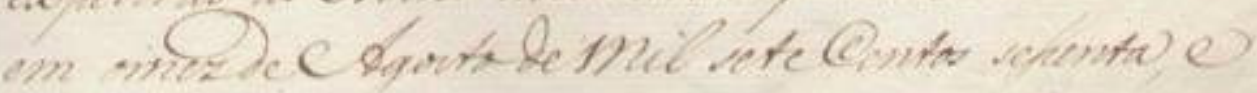


||95r|| Receby tres Cartas de VossaSenhoria escritas em cinco de laneiro, dous, eseis deMarço do anno proximo precedente de mil seteCentos Sesenta enove, pelas quais da VossaSenhoria conta, que pela lunta daFazenda dessaCapitania seachava

5 arrematado oContracto dos meyos Direitos do Registo deCuritiba aLeonardo deAraujo deAguiar naquan tia de onze contos dereis, pelo trienio que decorre doprimei ro delaneiro do dito anno proximo passado, ehadefindar no ultimo deDezembro do anno próximo fucturo

10 de mil seteCentos Setenta, ehum, alem das propinas das muniçoens; eque pela lunta da Fazenda doRio de Janeiro setinha tambem arrematado odito Contrato, unido ao do Registo de Viamaõ aBernardoGomes Costa, pelo mesmo tempo, rezultando desta arremataçaõ

15 naõ sô adiminuiçaõ dopreço, maz tambem aconfuzam da preferencia dos arrematantes, de que VossaSenhoria tem conservado aposse da remataçaõ feita pela lunta dessa Capitania, no que obra muito bem, porser daReallntençaõ deSuaMagestade, que todos os Contratos doEs-

20 tado do Brazil, que naõ forem arrematados peloConselho Ultramarino, osejaõ pelas luntas daFazenda do Destricto dondefor oContracto, acujo fim se expediraõ as Ordens necessarias pelo RealErario em omezdeAgosto deMil seteCentos sessenta, e 
$\|95 \mathrm{v}\|$

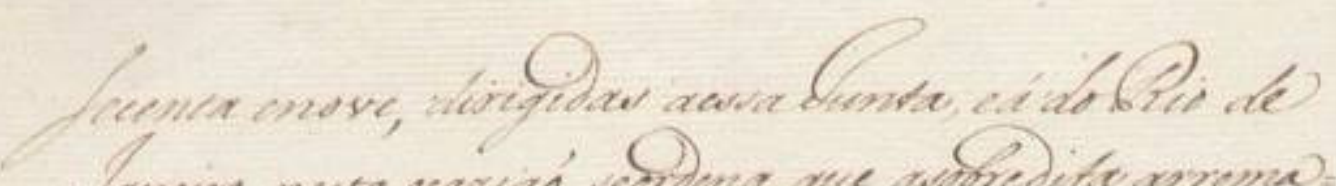

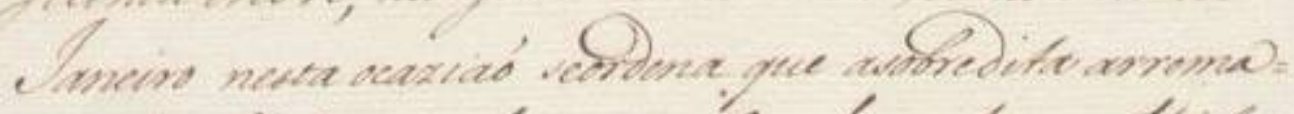

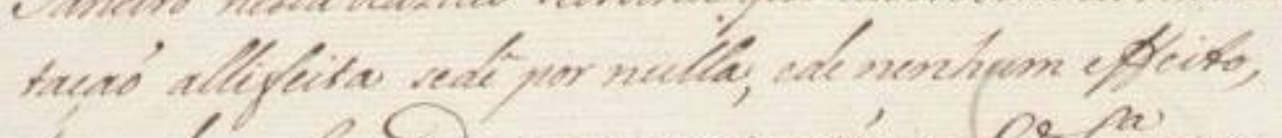

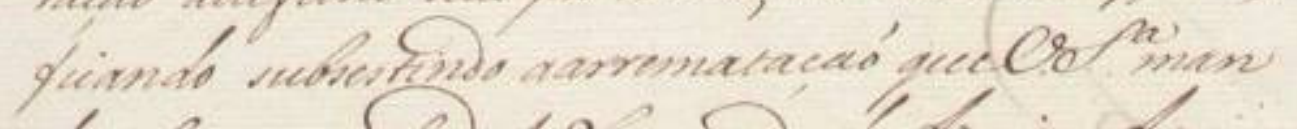

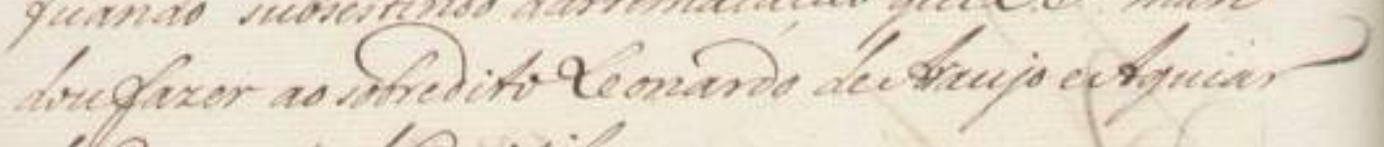
do@moneto de (imition.

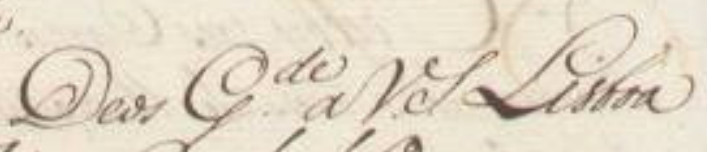

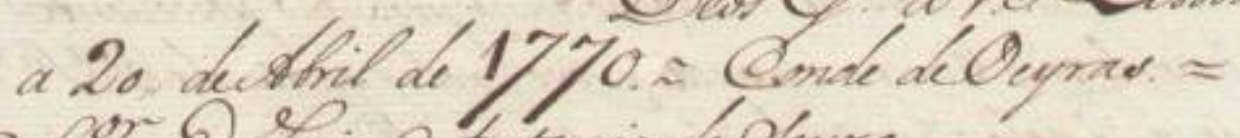

9 or Earue ctritonis de Cloure

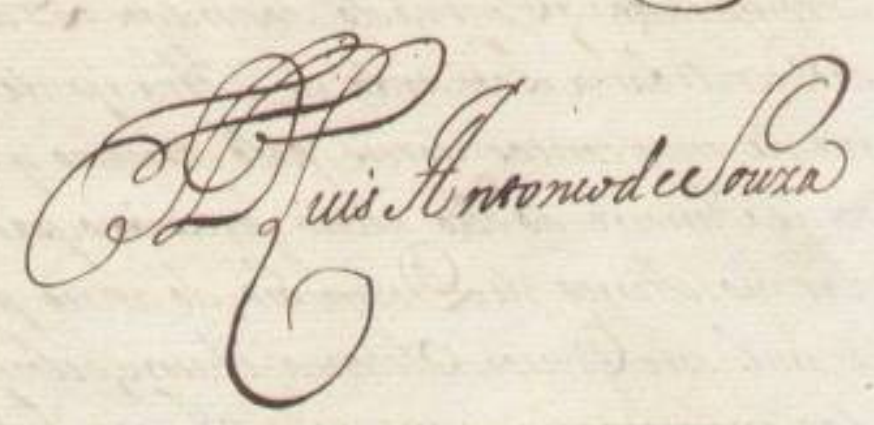

317 
\|95v || [[secenta e]]nove, dirigidas aessa lunta, eá doRio de laneiro nesta ocaziaõ seordena que asobredita arrema= taçaõ allifeita sedê por nulla, ede nenhum effeito, ficando subsestindo aarremataçaõ queVossaSenhoria man doufazer ao sobreditoLeonardo deAraujo eAguiar

30 doContracto deCuritiba.

Deos Guarde aVossaSenhoria Lisboa a 20 deAbril de 1770. = Conde deOeyras. = Senhor DomLuis Antonio deSouza

DomLuis AntoniodeSouza 


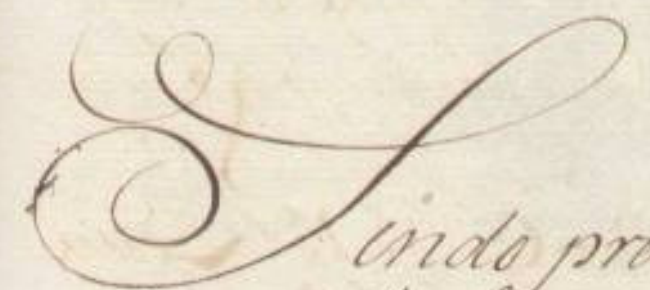

- pravente a COAdeo

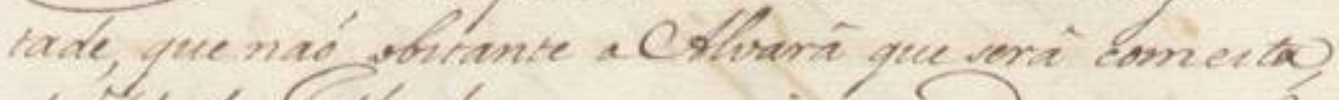

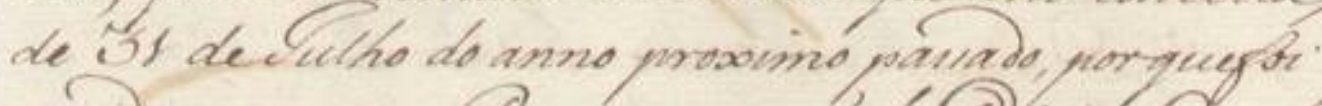

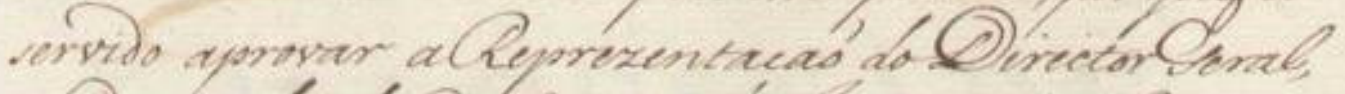

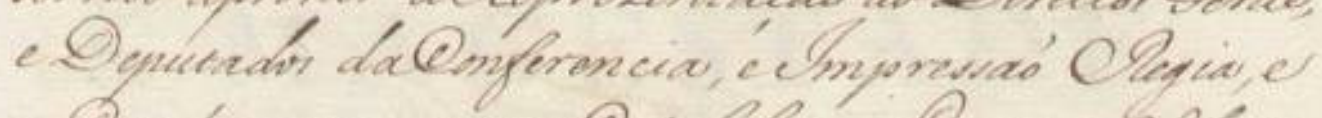

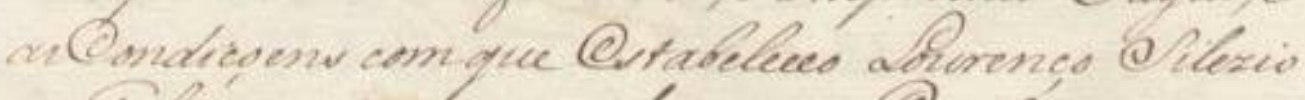

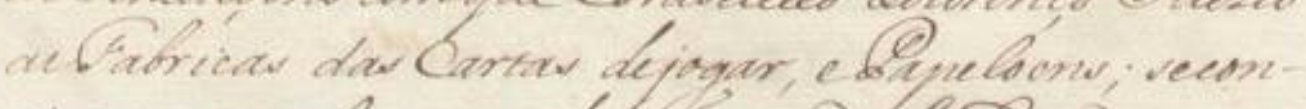

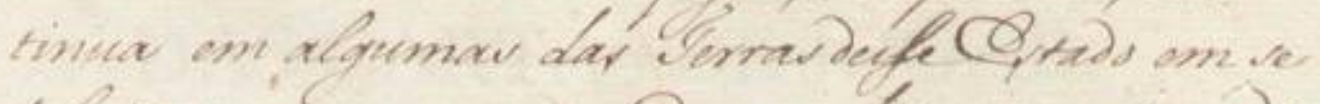

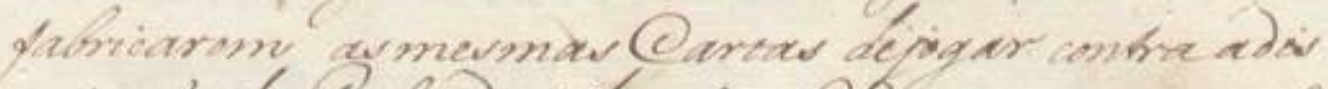

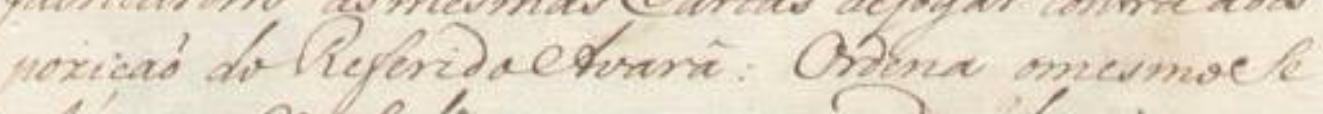

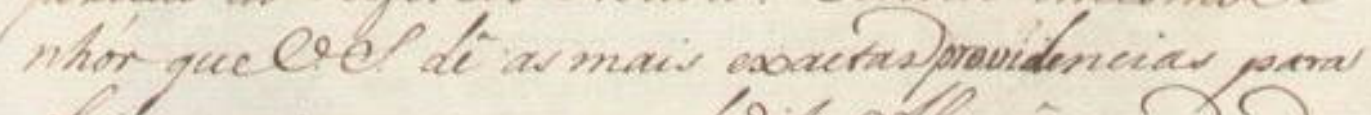

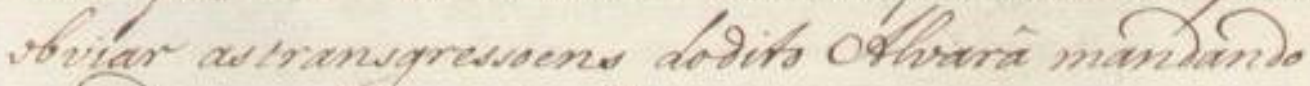

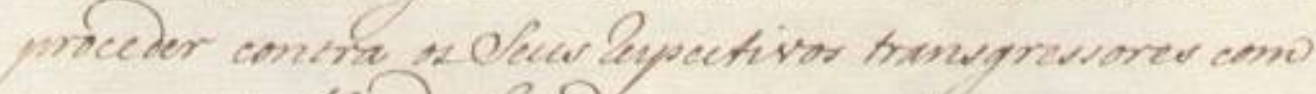

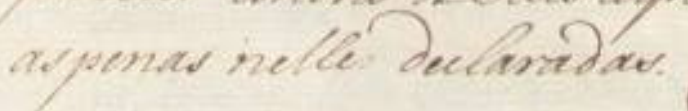

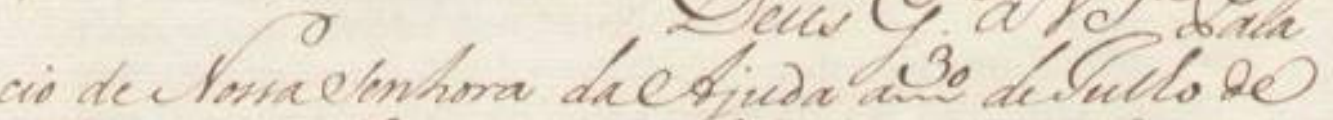

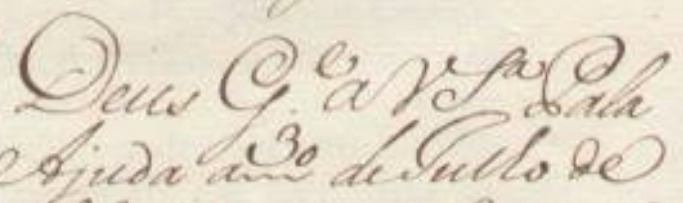

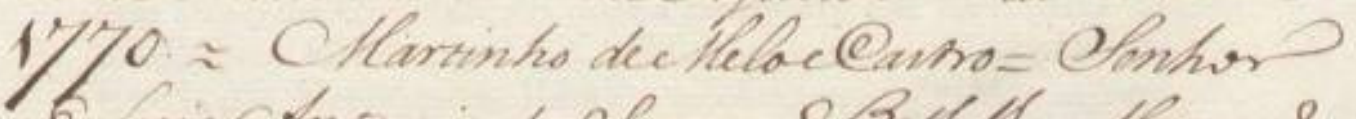

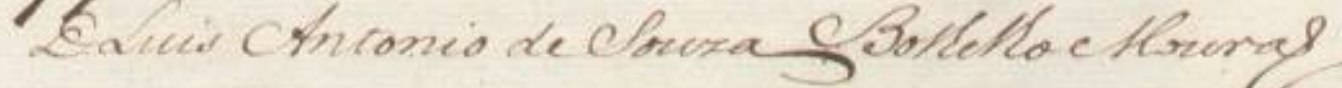

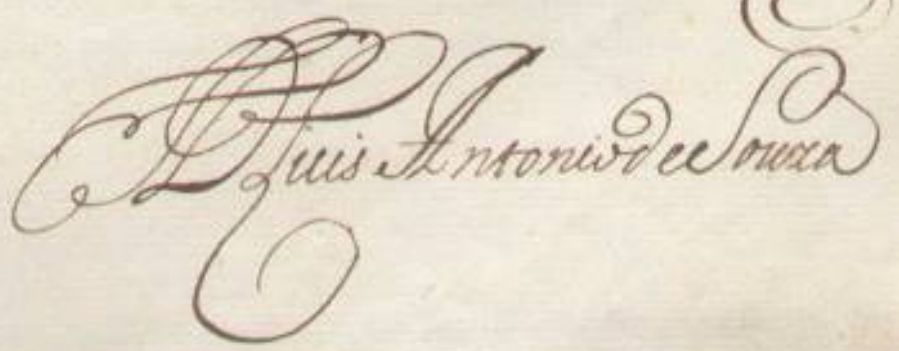


||96r|| Sendo prezente aSua Mages-

tade, que naõ obstante aAlvarâ que serâ comesta

de 31 delulho do anno proximo passado, porquefoi

servido aprovar aReprezentaçaõ doDirectorGeral,

5 e Deputados daConferencia, elmpressaõ Regia, e asCondiçoens comque Estabeleceo Lourenço Silezio asFabricas das Cartas dejogar, ePapeloens; secontinua em algumas das Terras desseEstado em se fabricarem as mesmas Cartas dejogar contra adis

10 poziçaõ doReferidoAlvarâ: Ordena omesmoSe nhor queVossaSenhoria dê as mais exactas providencias para obviar as transgressoens dodito Alvarâ mandando proceder contra osSeus respectivos transgressores com as penas nelle declaradas. Deus Guarde aVossaSenhoria Pala cio deNossaSenhora daAjuda a 30 delulho de 1770. $=$ Martinho deMelloeCastro $=$ Senhor DomLuis Antonio deSouza Botelho Mouraõ Dom Luis AntoniodeSouza 
[55]

|100r\|

(

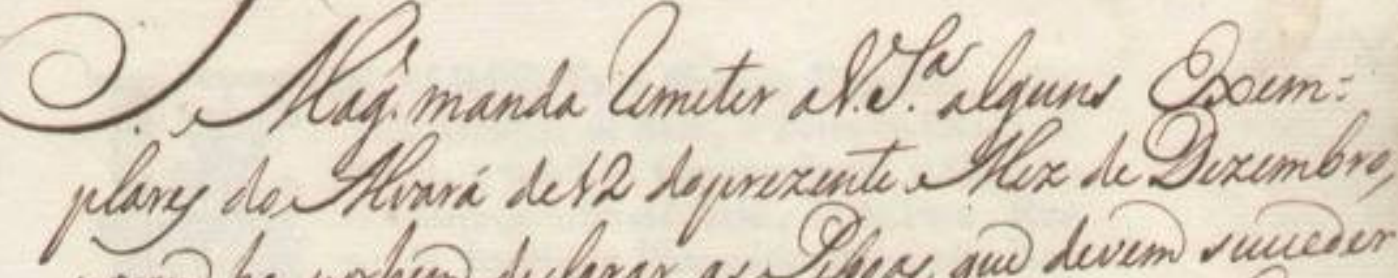

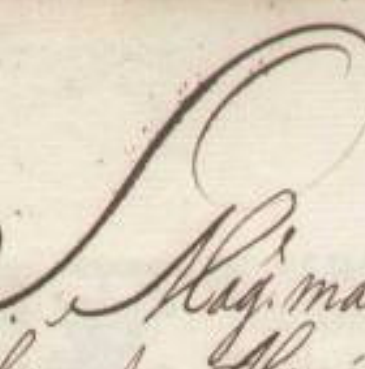

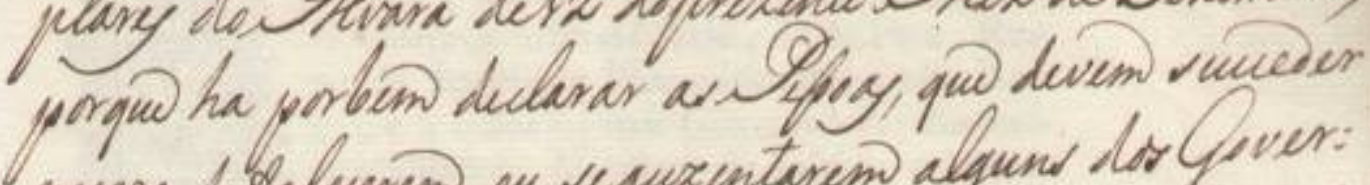
nocars defaluerem, on se cuxenturgm alguns dos Gover:

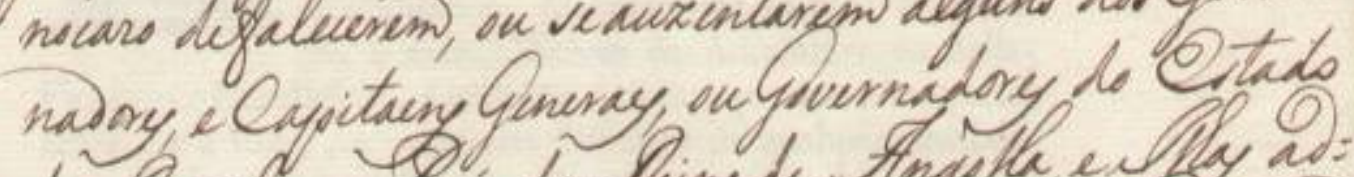

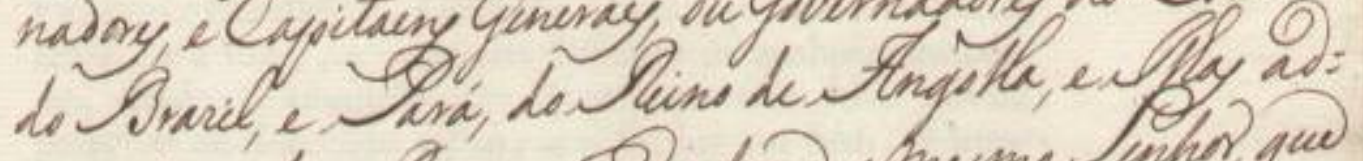

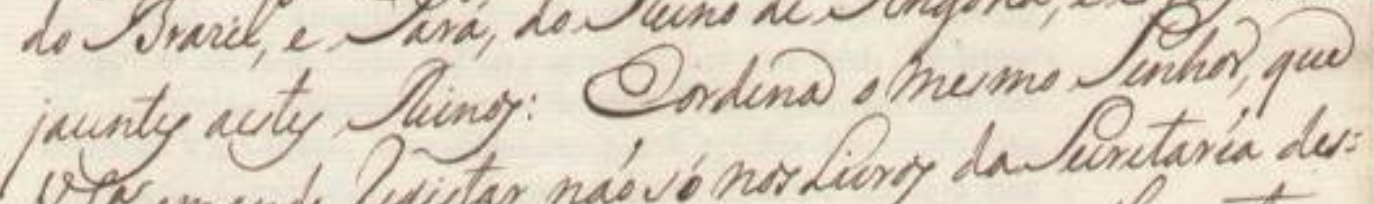

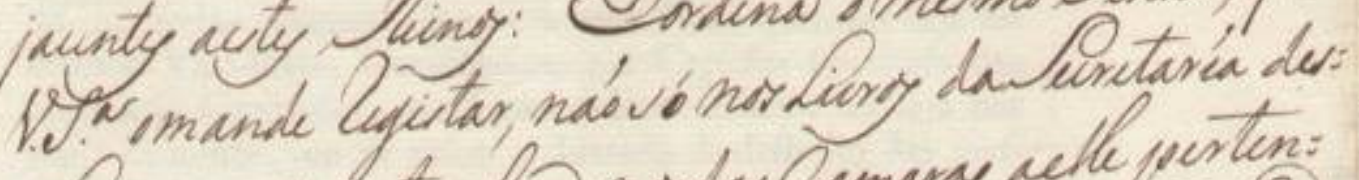
ve Governa; ma tambim norda Camary ache pierten: unty, para qui nor carry Sobredity tunha in ua devida excucias.

Ood

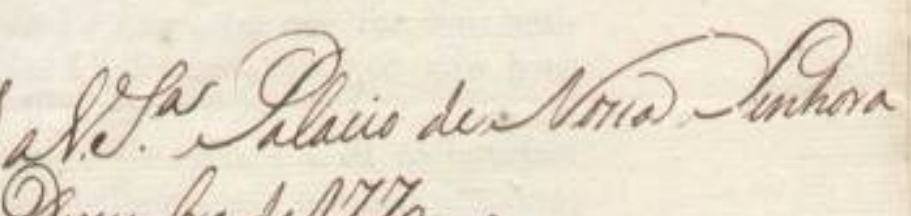

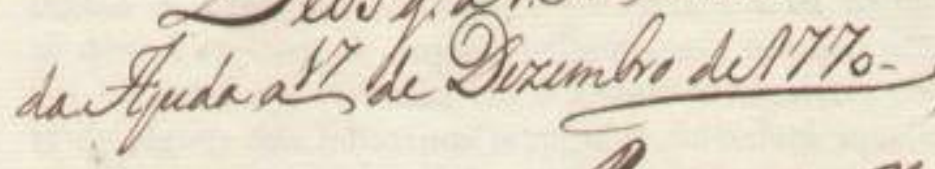

etweresplatectity

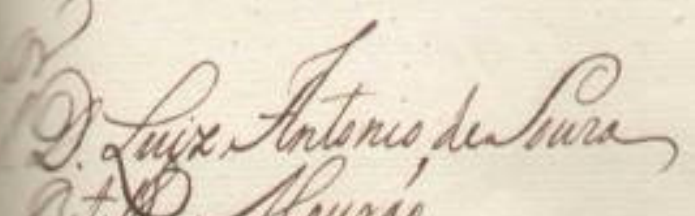

iitos staunío fuft:

321 
||100r|| Sua Magestade manda remeter aVossaSenhoria alguns Exem= plares do Alvará de12 doprezente Mez de Dezembro, porque ha porbem declarar as Pessoas, que devem succeder no cazo defalecerem, ou se auzentarem alguns dos Gover= 5 nadores, e Capitaens Generaes, ou Governadores do Estado do Brazil, e Pará, do Reino de Angolla, e llhas ad= jacentes aestes Reinos: Eordena o mesmo Senhor, que VossaSenhoria o mande registar, naõ só nos Livros daSecretaria des= se Governo; mas tambem nos das Camaras aelle perten=

10 centes, para que nos casos Sobreditos tenha aSua devida execuçaõ.

Deos guarde aVossaSenhoria Palacio de Nossa Senhora daAjuda a17 de Dezembro de1770.

Martinho deMello eCastro

15 Senhor Dom Luiz Antonio deSouza

Botelho Mouraõ

PrimeiraVia 


\section{Cantala}

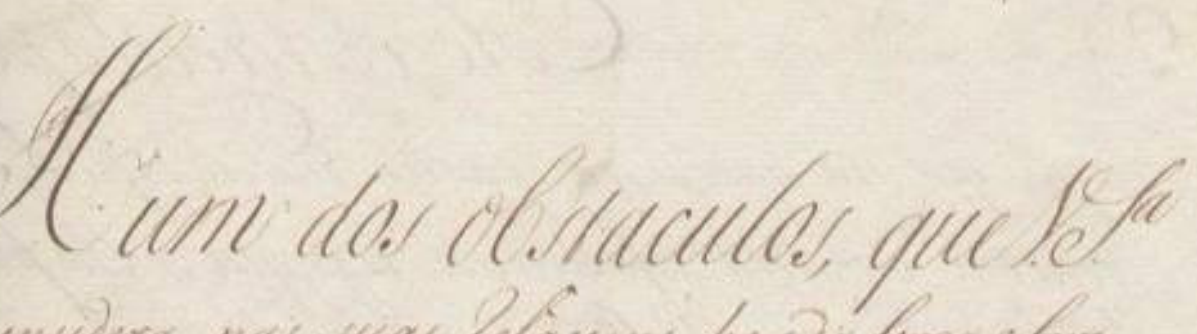

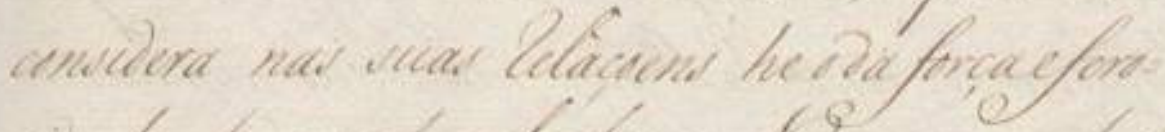

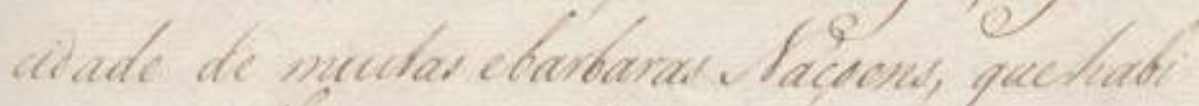

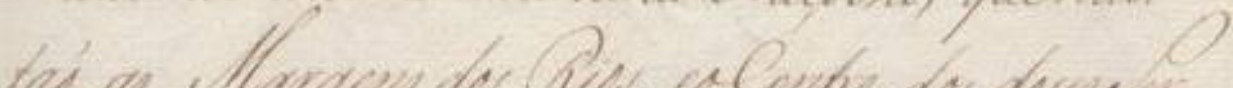

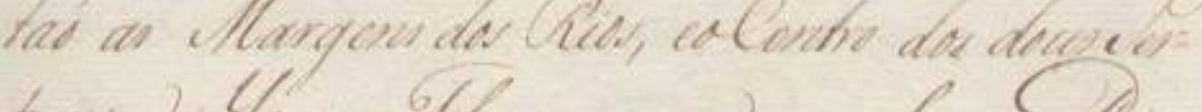

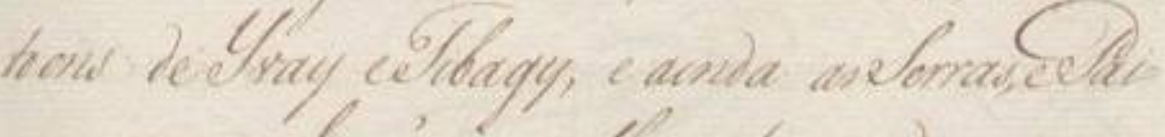

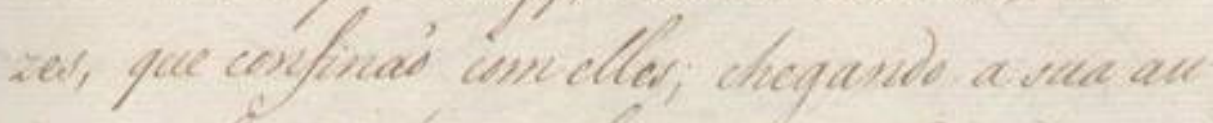

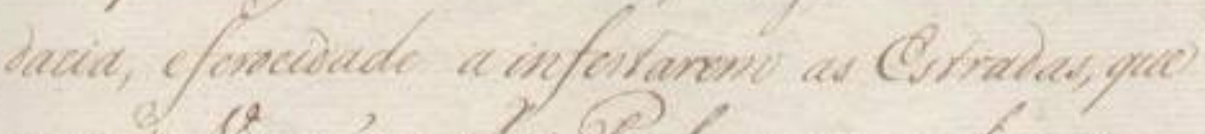

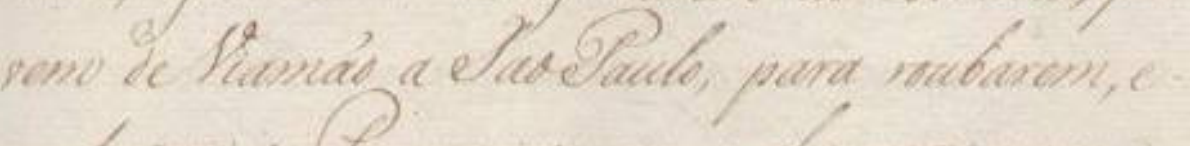

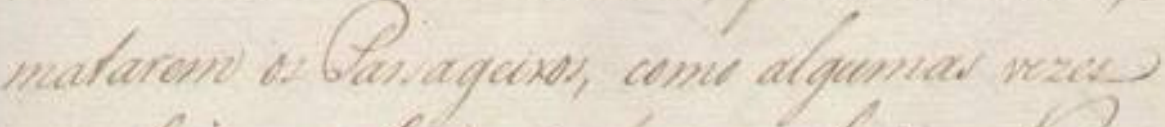

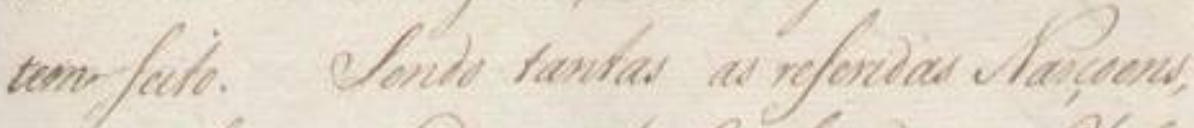

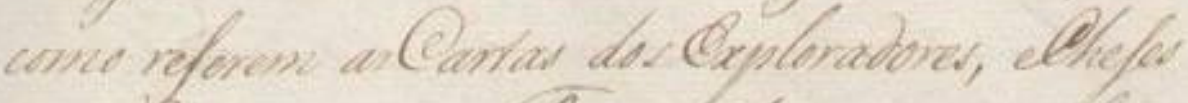

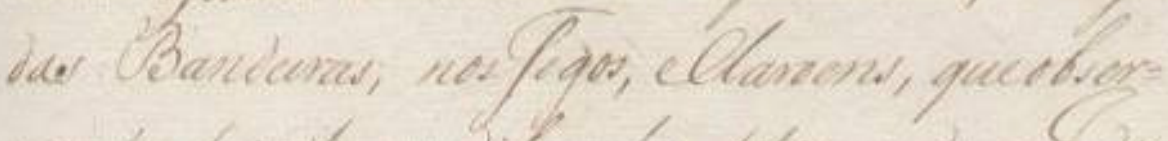

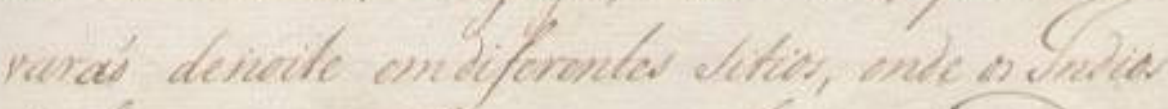

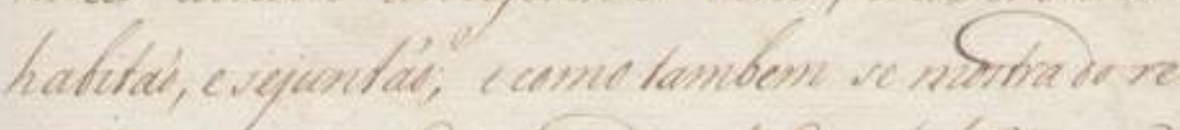

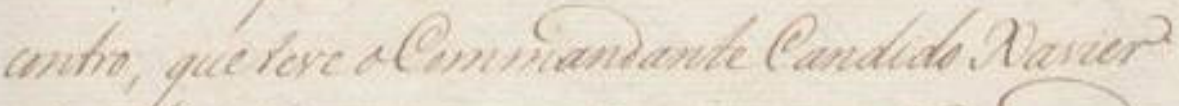

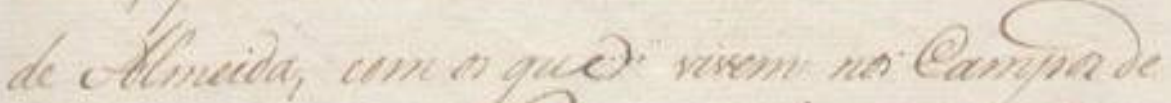

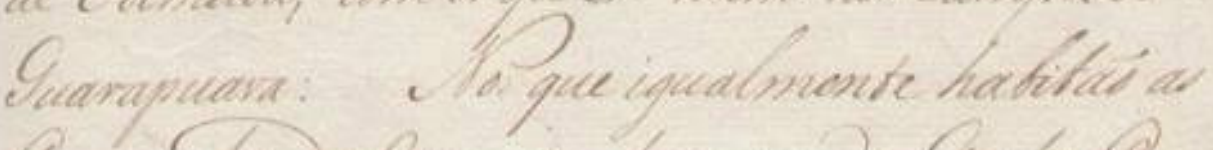

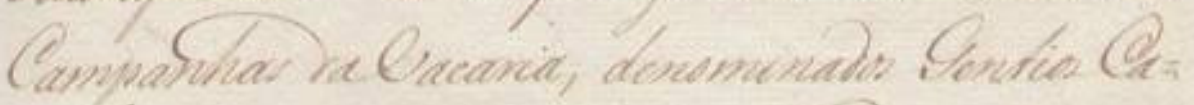

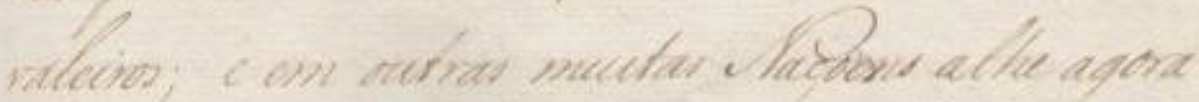

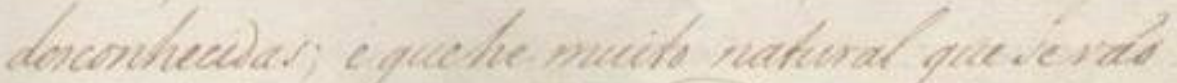

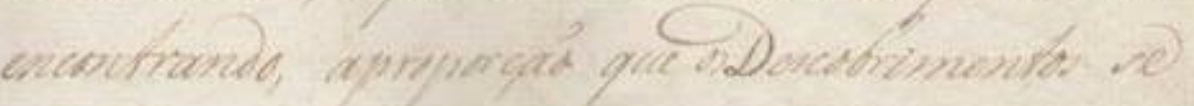


||102r|| Carta segunda

Hum dos obstaculos, queVossaSenhoria

considera nas suas relaçoens he o da forçaefero= cidade de muitas ebarbaras Naçoens, quehabi

5 taõ as Margens dos Rios, eoCentro dos dous Ser= toens de Yvay eTibagy, e ainda as Serras, ePai= zes, que confinaõ com elles; chegando a sua audacia, eferocidade a infestarem as Estradas, que vem deViamaõ a SaõPaulo, para roubarem, e-

10 matarem os Passageiros, como algumas vezes tem feito. [espaço] Sendo tantas as referidas Nasçoens; como referem as Cartas dos Exploradores, eChefes das Bandeiras; nos Fogos, eClaroens, queobser= varaõ denoite em diferentes sitios, onde os Indios

15 habitaõ, e sejuntaõ; e como tambem se mostra do re contro, que teve oCommandanteCandido Xavier de Almeida, com os que vivem nos Campos de Guarapuava: [espaço] Nos que igualmente habitaõ as Campanhas daVacaria, denominados GentiosCa= 20 valeiros; e em outras muitas Naçoens athe agora desconhecidas; e quehe muito natural que se vaõ encontrando, aproporçaõ que osDescobrimentos se 
(2) form prengende. Conte ablacilopie

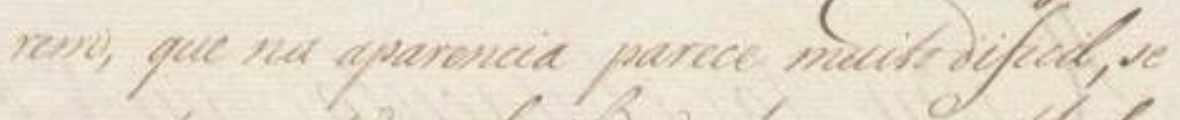

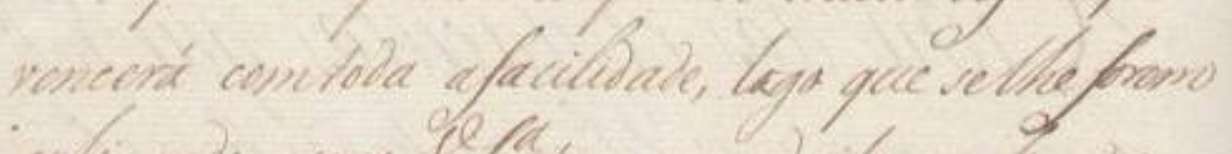

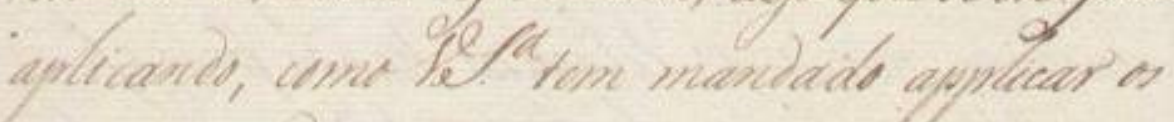

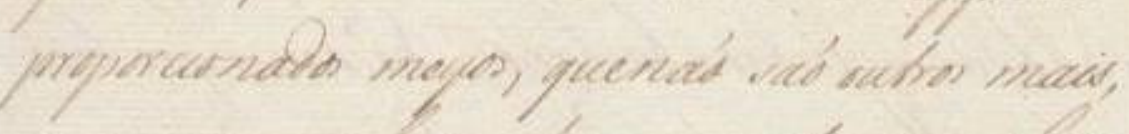

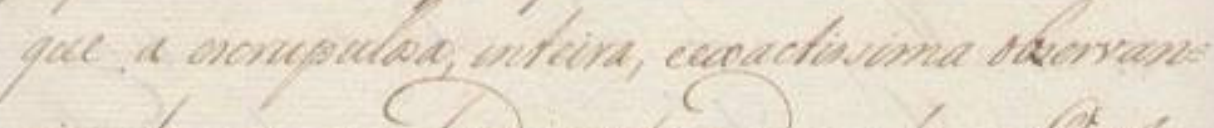

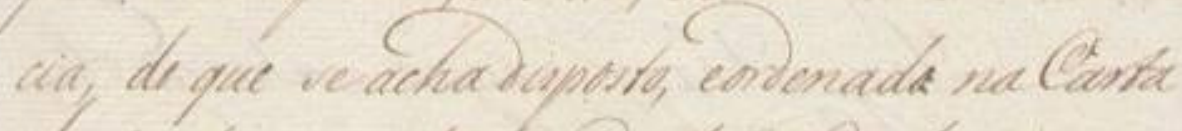

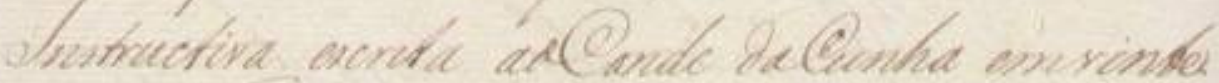

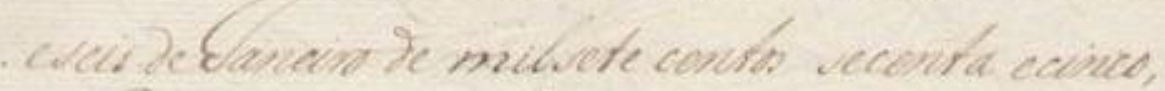

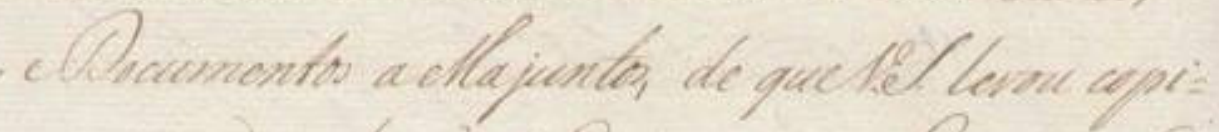

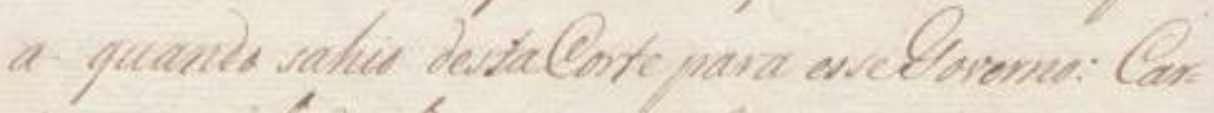

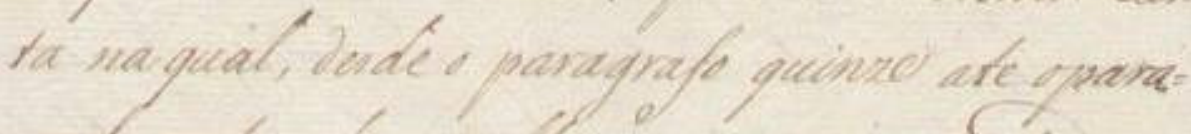

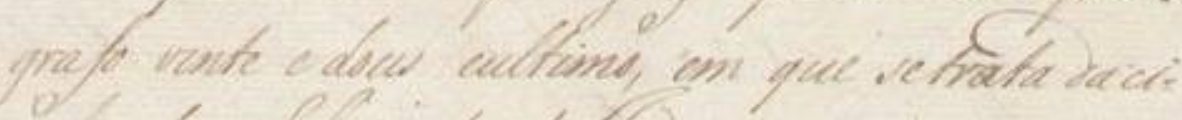

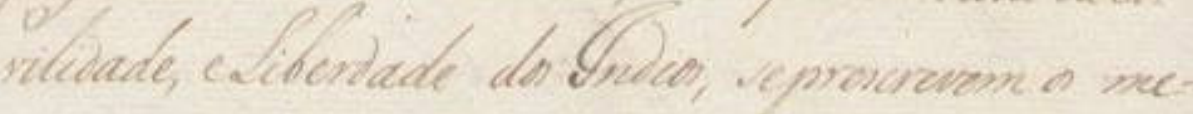

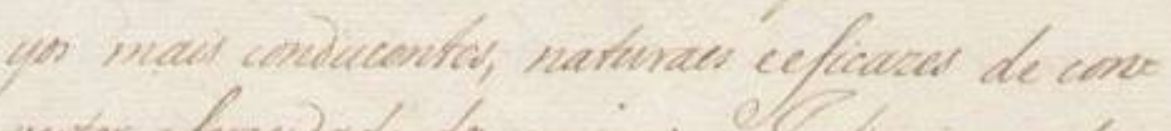

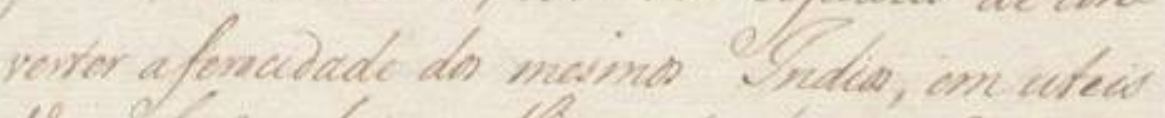

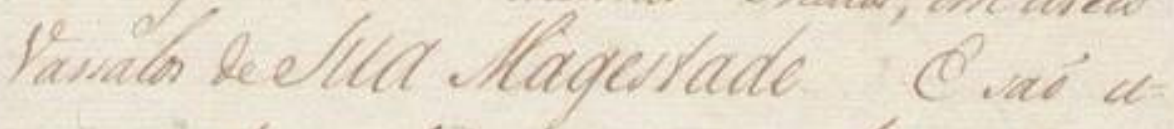

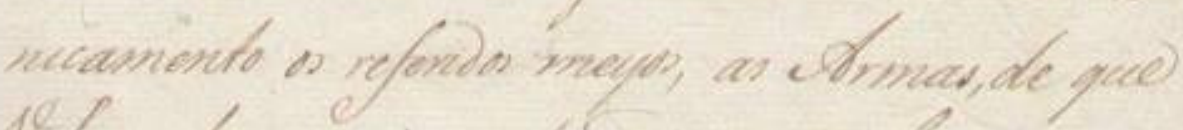

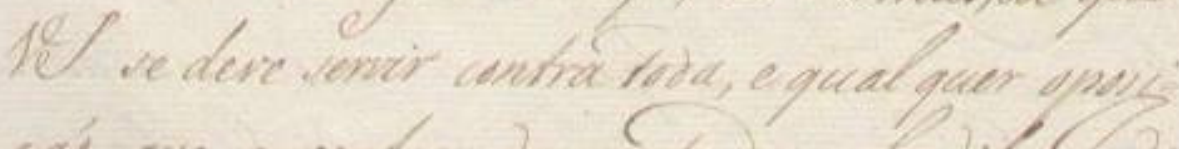

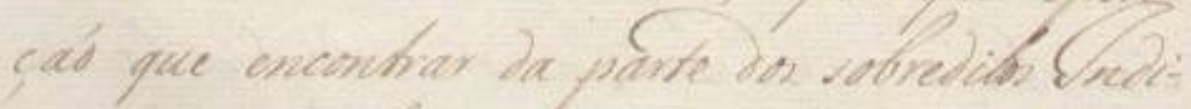

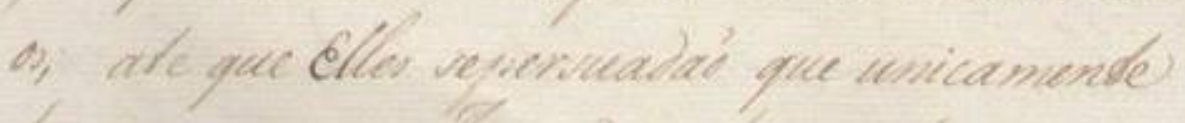

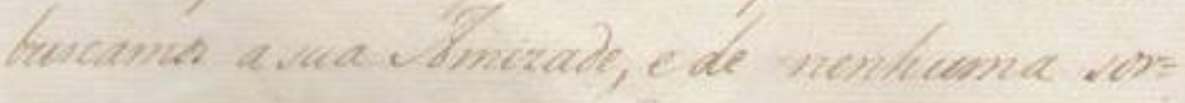

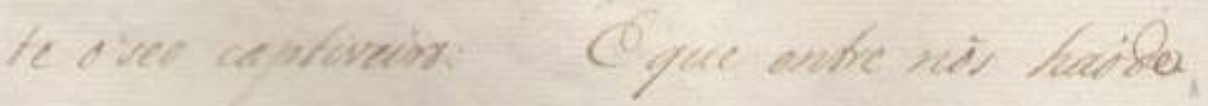


||102v || [[se]] forem proseguindo.

2

Este obstaculo po=

rem, que na aparencia parece muito dificil, se vencerá comtoda afacilidade, logo que selhe forem aplicando, como VossaSenhoria tem mandado applicar os proporcionados meyos, quenaõ saõ outros mais, que a escrupulosa, inteira, eexactissima observan=

30 cia, do que se acha disposto, eordenado naCarta Instructiva escrita aoConde daCunha emvinte eseis delaneiro de milsete centos secenta ecinco, eDocumentos a ellajuntos, de queVossaSenhoria levou copi= a quando sahio destaCorte para esseGoverno: $\mathrm{Car}=$ ta na qual, desde o paragrafo quinze ate opara $=$ grafo vinte e dous eultimo, em que setrata da ci= vilidade, eLiberdade dos Indios, seprescrevem os me= yos mais conducentes, naturaes eeficazes de con= verter aferocidade dos mesmos Indios, em uteis

40 Vassalos deSua Magestade. [espaço] E saõ u= nicamente os referidos meyos, as Armas, de que VossaSenhoria se deve servir contra toda, e qualquer oposi= çaõ que encontrar da parte dos sobreditos Indios; athe que Elles sepersuadaõ que unicamente 45 buscamos a sua Amizade, e de nenhuma sor= te o seo captiveiro: [espaço] E que entre nôs haõde 
||103r |

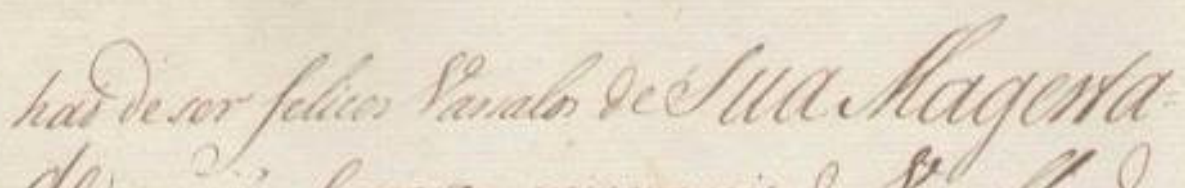
do, cinas Gicravo miscraveis los Sarrallos \&o neeno elentuar.

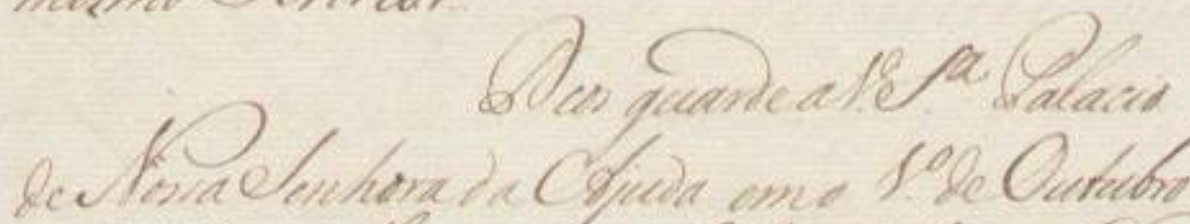

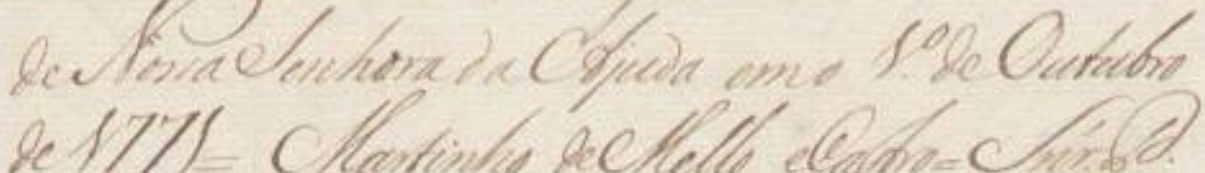

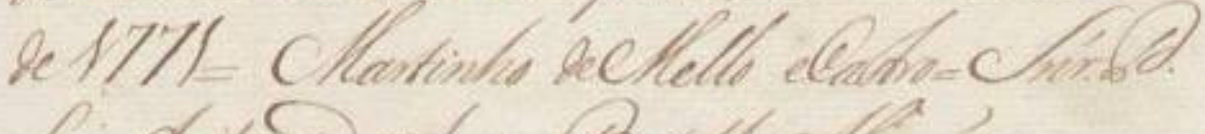

$6 \%$,

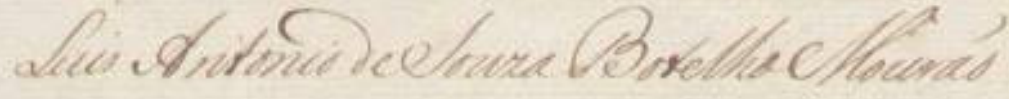

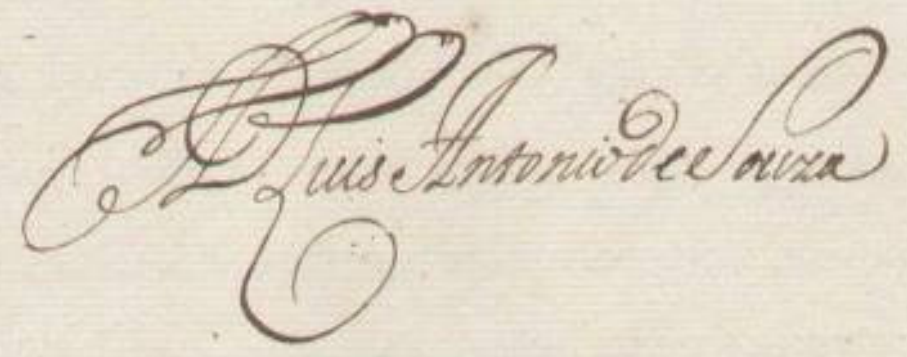

327 
||103r|| [[haõ de]] ser felices Vassalos deSuaMagesta= de, enaõ escravos mizeraveis dosVassallos do mesmoSenhor.

deNossaSenhora daAjuda em o primeiro deOutubro

de1771 = Martinho deMello eCastro $=$ SenhorDom

Luis Antonio deSouzaBotelhoMouraõ

DomLuis AntoniodeSouza 
Corta ba

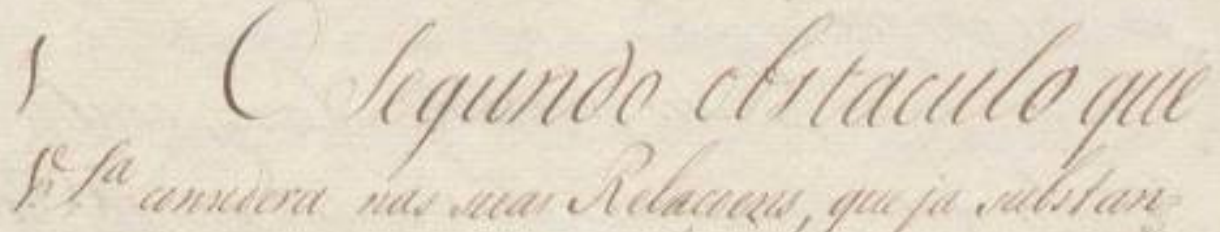

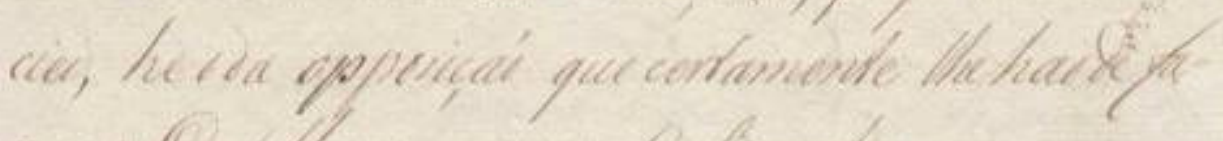

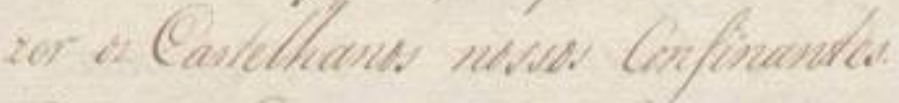

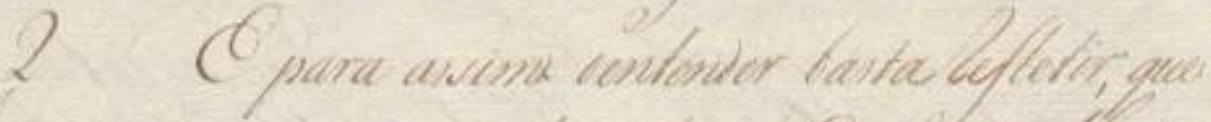

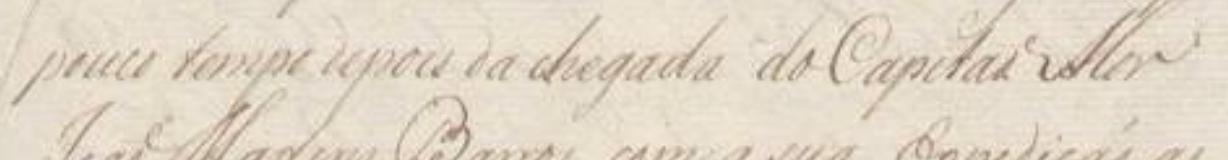

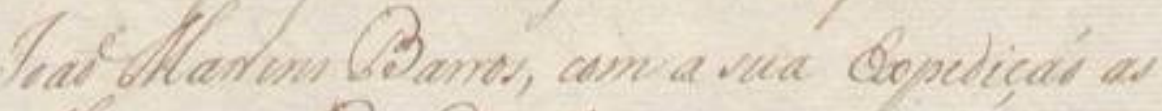

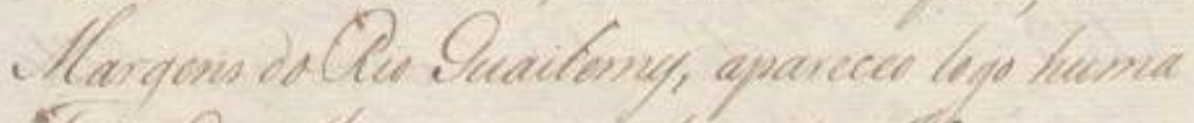

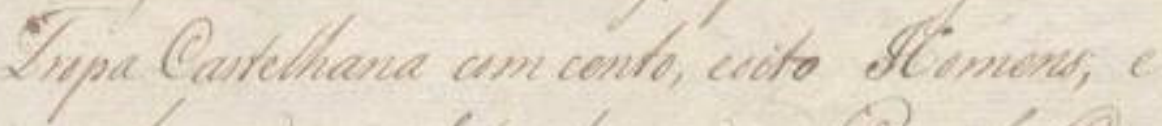

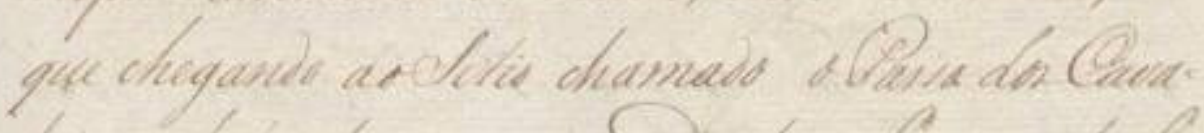

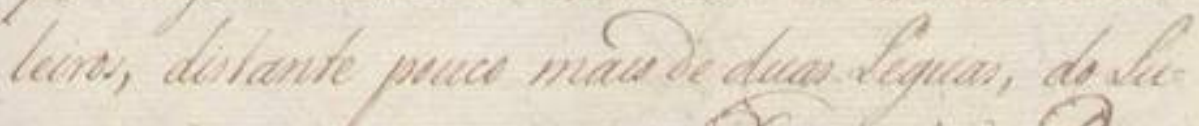

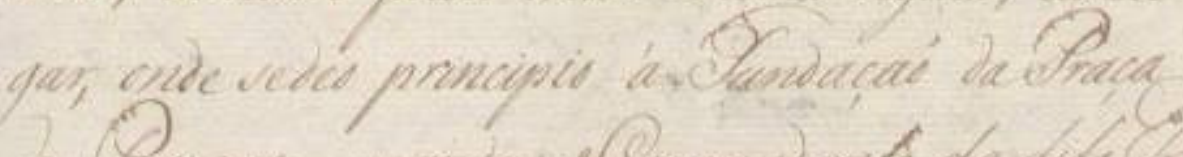

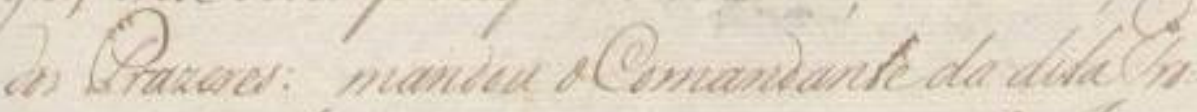

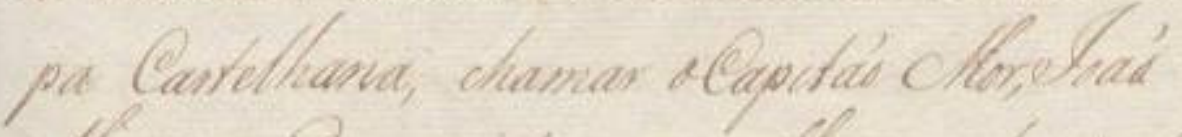

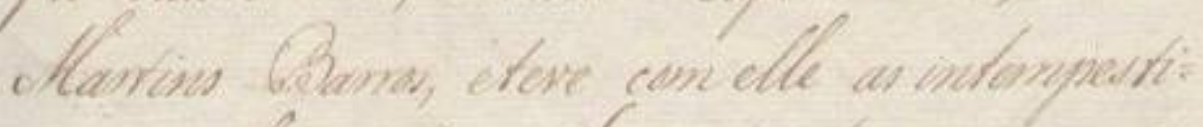

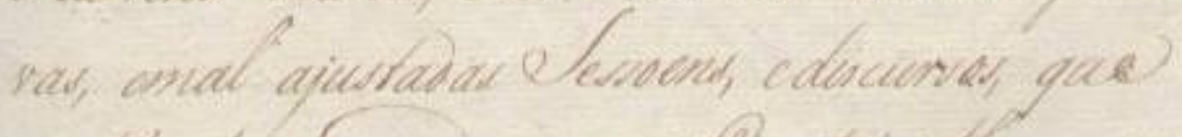

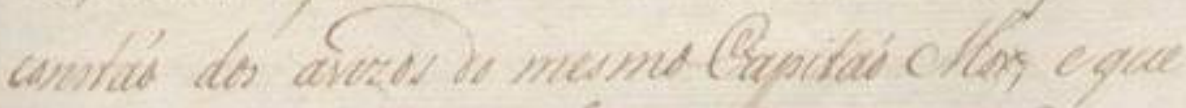

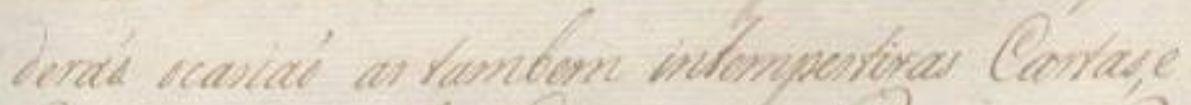

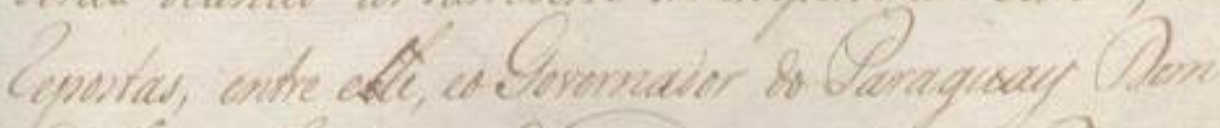

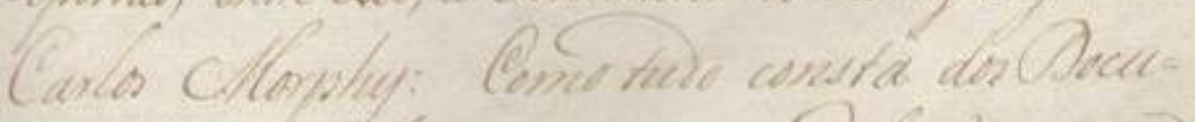

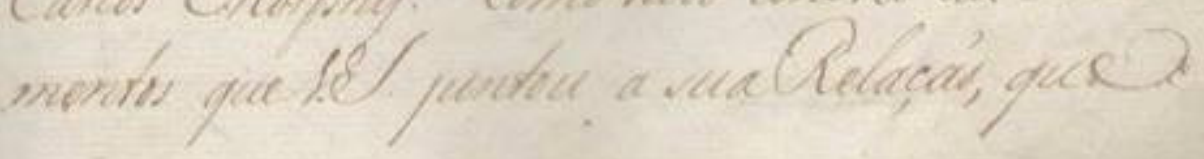


||104r|| Carta Terceira

1 O Segundo obstaculo que

VossaSenhoria considera nas suas Relaçoens, que ja substan= ciei, he o da opposiçaõ que certamente lhehaõ de fa=

5 zer os Castelhanos nossos Confinantes.

2 E para assim oentender bastarefletir, que pouco tempo depois da chegada doCapitaõ Mor loaõ Martins Barros, com a sua Expediçaõ as Margens doRio Guaitemy, apareceo logo huma

10 Tropa Castelhana com cento, eoito Homens; e que chegando aoSitio chamado oPasso dosCavaleiros, distante pouco mais de duas Leguas, do Lu= gar, onde sedeo principio à Fundaçaõ daPraça dos Prazeres: mandou oComandante da ditaTro=

15 pa Castelhana, chamar oCapitaõ Mor, loaõ Martins Barros, eteve com elle as intempesti= vas, emal ajustadas Sessoens, ediscursos, que constaõ dos avizos do mesmoCapitaõ Mor, e que deraõ ocasiaõ as tambem intempestivas Cartas, e

20 repostas, entre elle, eo Governador do Paraguay Dom Carlos Morphy: Como tudo consta dos Docu= mentos queVossaSenhoria juntou a sua Relaçaõ, que 
noune a datla de 203 dectulus de $\$ 768$, que $a=$

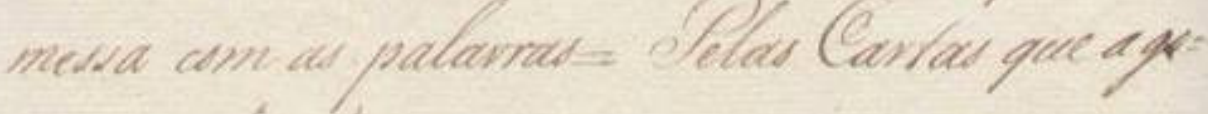
ne me cheqai-

c)

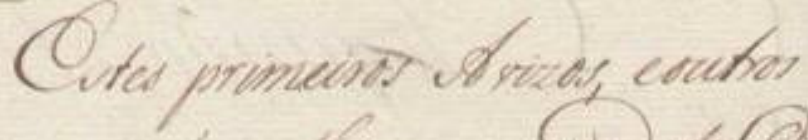

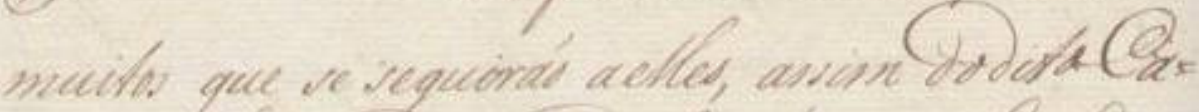

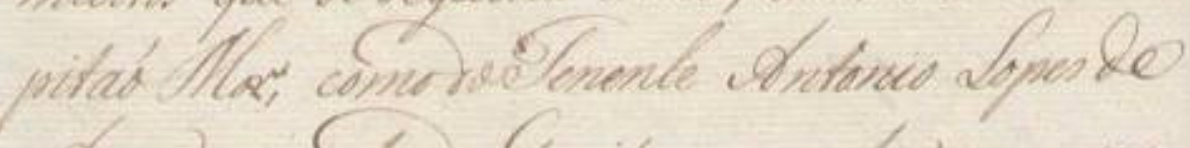

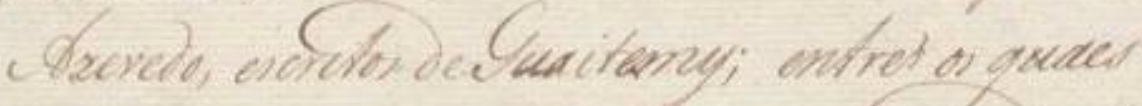
vad os mais emportantos, orque ron as datas

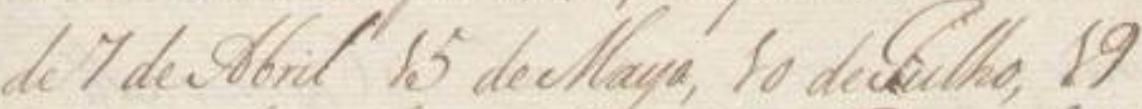

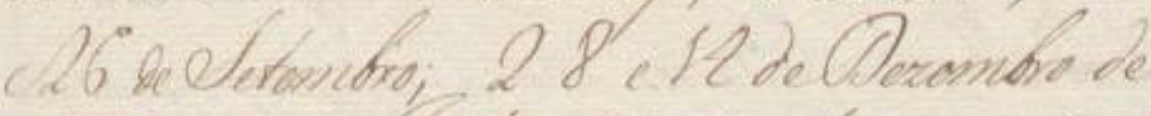

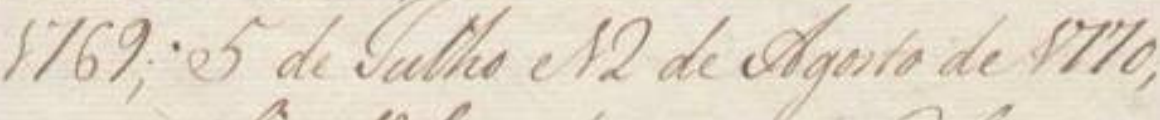
quetambern te funsou, as suar Recrasens

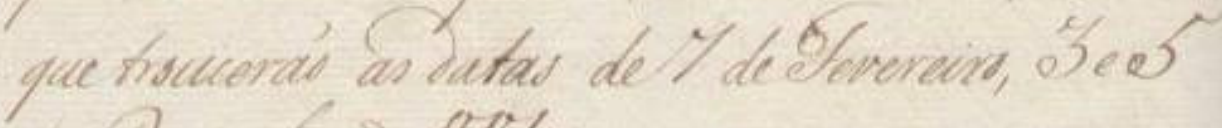
ae Derembro De IIIO 2

Qfodes a diter Griesa

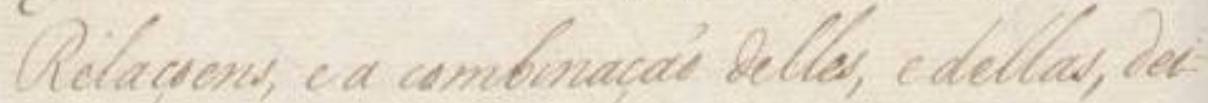

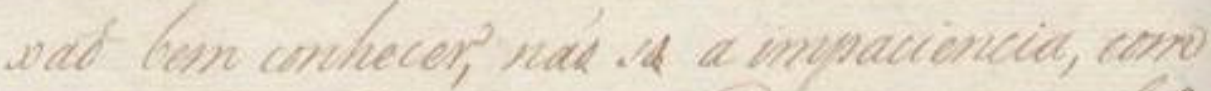

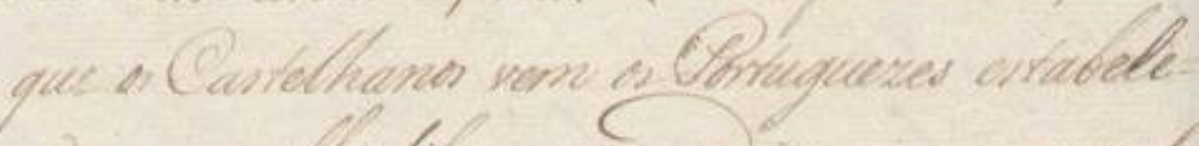

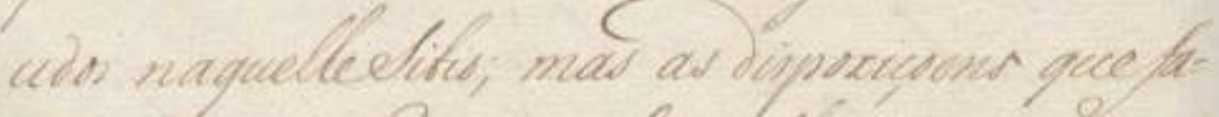
zom pard os ancaron fora delle; de que vars prosed hat cquincad.
(e)
(5)
minciramente aparte quedec o

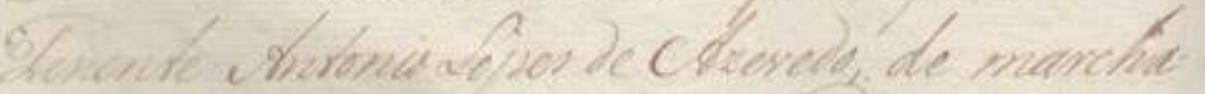

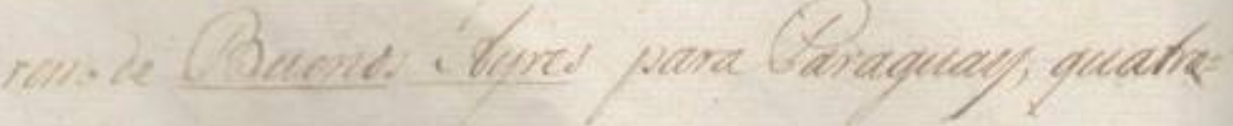


||104v || trouxe a datta de23 delulho de1768, que co= messa com as palavras $=$ Pelas Cartas que a go $=$ ra me chegaõ $=$

3 Estes primeiros Avizos, eoutros muitos que se seguiraõ aelles, assim doditoCa= pitaõ Mor, como doTenente Antonio Lopes de Azevedo, escritos deGuaitemy; entre os quaes saõ os mais emportantes, os quetem as datas de7 deAbril 15 deMayo, 10 delulho, 19 e26 deSetembro; 28 e 14 deDezembro de 1769; 5 de lulho e12 deAgosto de1770, quetambem VossaSenhoria juntou, as suas Relaçoens quetrouceraõ as datas de7 deFevereiro, 3 e 5 deDezembro de1770 4 Todos os ditos Avizos e Relaçoens, e a combinaçaõ delles, edellas, dei= xaõ bem conhecer, naõ so a impaciencia, com 40 que os Castelhanos vem osPortuguezes estabele= cidos naquelleSitio; mas as dispoziçoens quefa= zem para os Lançarem fora delle; de que saõ provas naõ equivocas.

$5 \quad$ Primeiramente aparte quedeo o

45 Tenente Antonio Lopes de Azevedo, de marcha= rem de Buenos Ayres paraParaguay, quatro= 


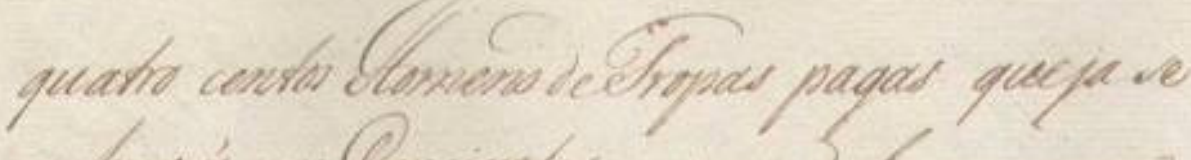

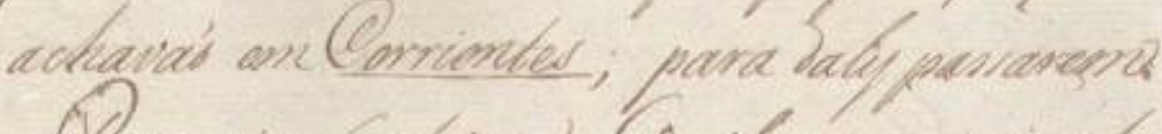

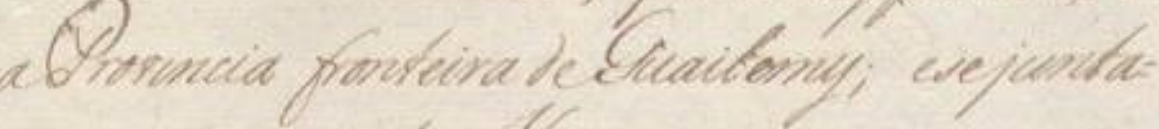

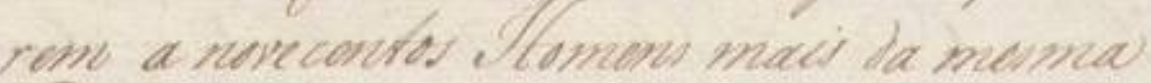
(2)

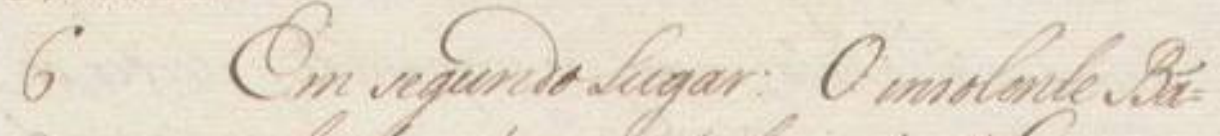

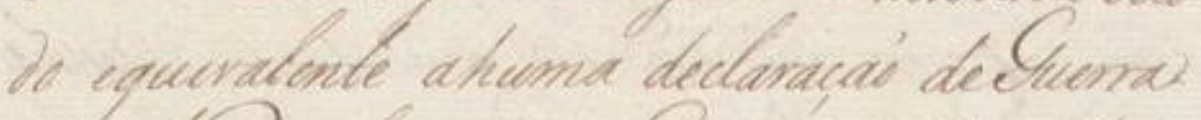

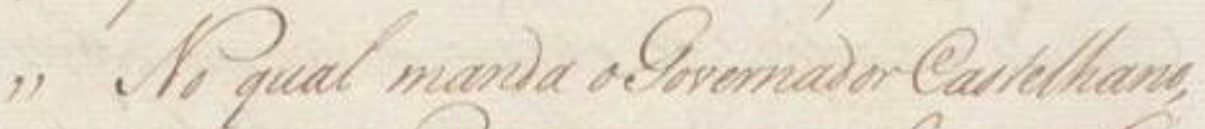

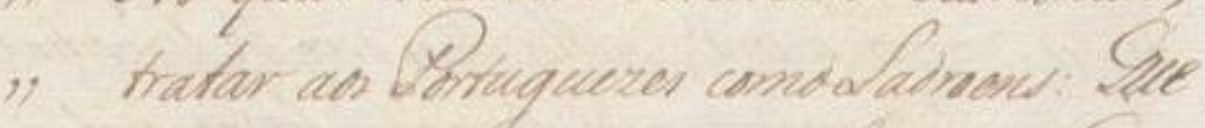

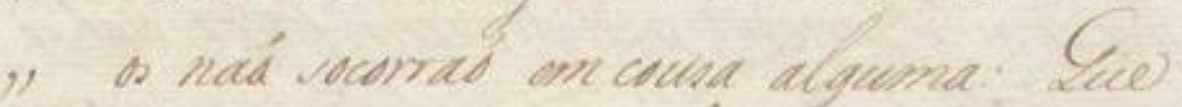

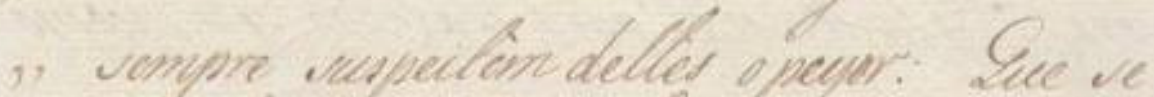

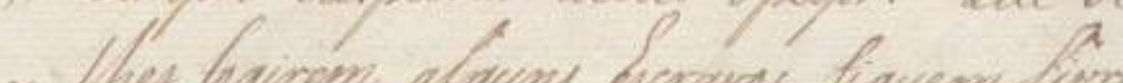

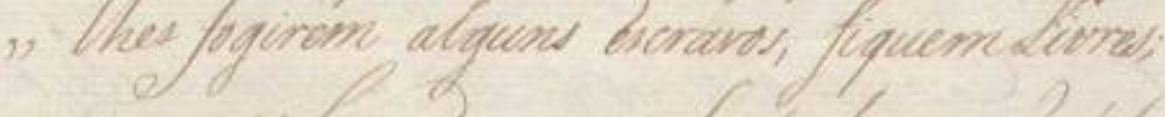

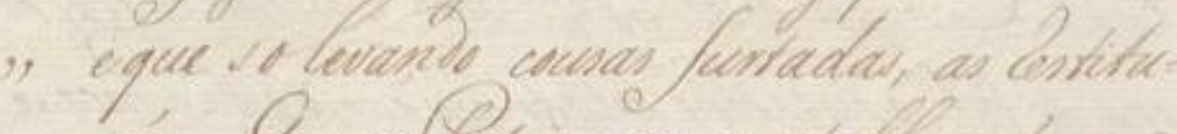

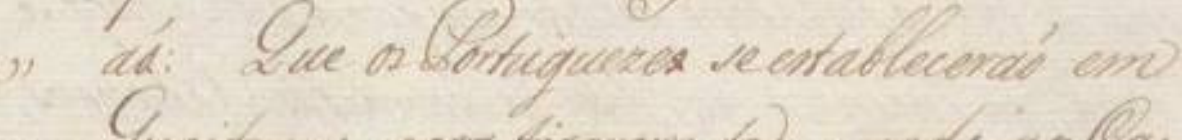

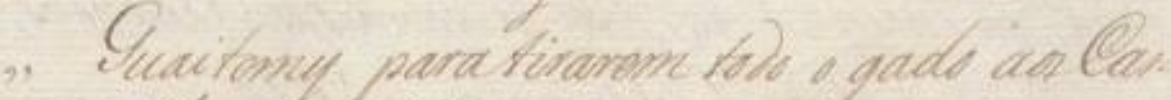

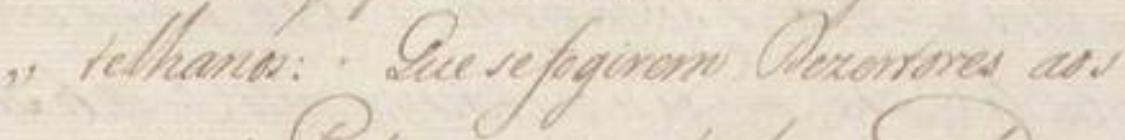

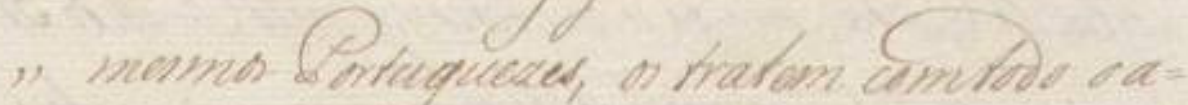

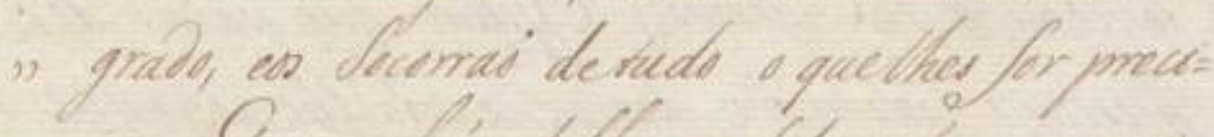

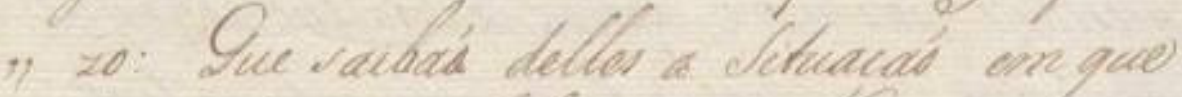

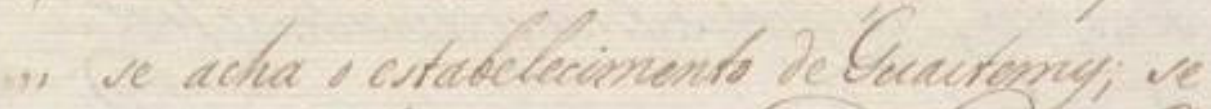

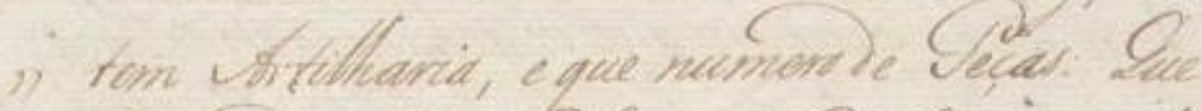

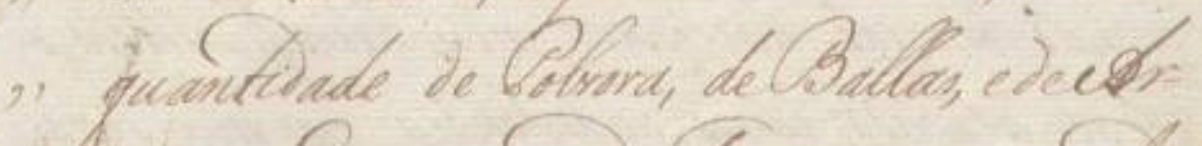

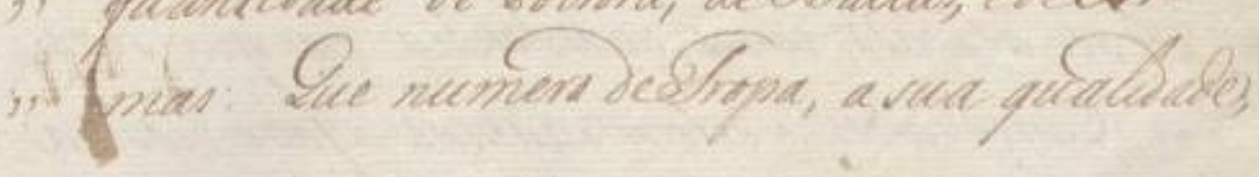


||105r|| [[quatro]] centos Homens deTropas pagas queja se achavaõ em Corrientes; para daly passarem aProvincia fronteira deGuaitemy; esejunta= rem a nove centos Homens mais da mesma Provincia.

6 Em segundo Lugar: $\mathrm{O}$ insolente $\mathrm{Bã}=$ do equivalente ahuma declaraçaõ deGuerra ", No qual manda oGovernadorCastelhano, , $\quad$ tratar aos Portuguezes comoLadroens: Que

", os naõ socorraõ em cousa alguma: Que

," sempre suspeitem delles o peyor: Que se

, Ihes fogirem alguns Escravos, fiquemLivres;

". e que solevando cousas furtadas, as restitu=

$60 \quad, \quad$ aõ: Que osPortuguezes seestableceraõ em

, Guaitemy paratirarem todo 0 gado aosCas=

", telhanos: Que sefogirem Dezertores aos

„, mesmos Portuguezes, os tratem comtodo o $\mathrm{a}=$

,, grado, eos Socorraõ detudo o quelhes for preci=

, $\quad$ zo: Que saibaõ delles a Situaçaõ em que

", se acha o estabelecimento de Guaitemy; se

", tem Artilharia, e que numero de Peças: Que

,, quantidade de Polvora, deBallas, edeAr-

," mas: Que numero deTropa, a sua qualidade, 


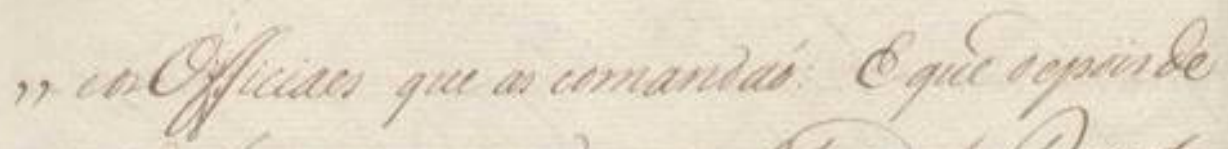

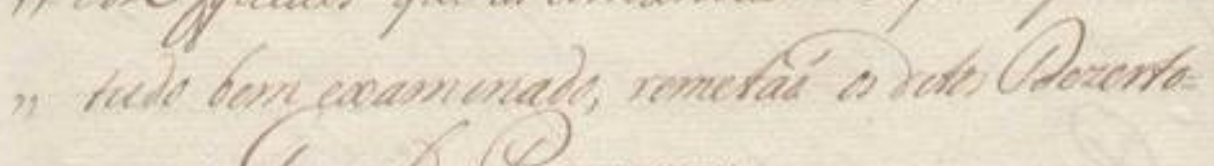

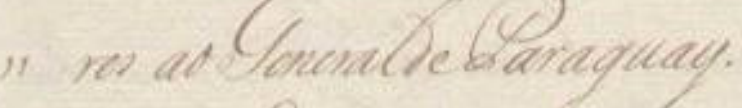

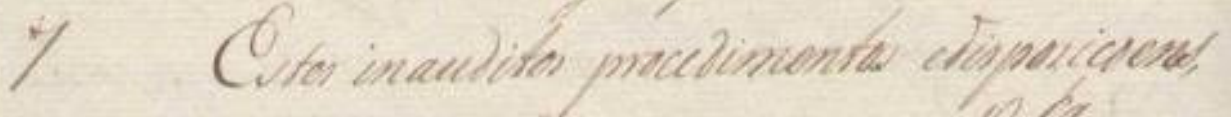

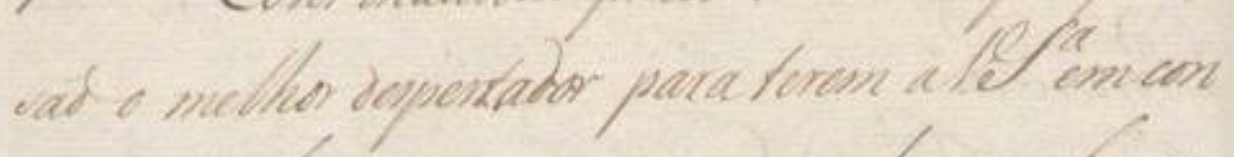

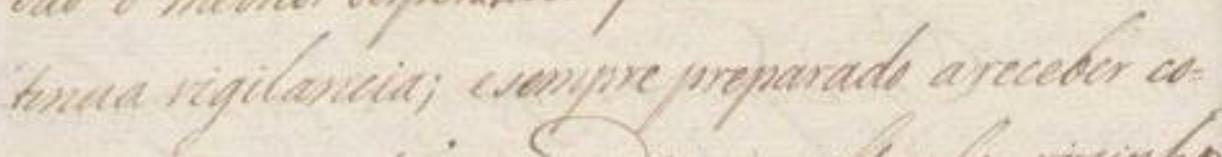

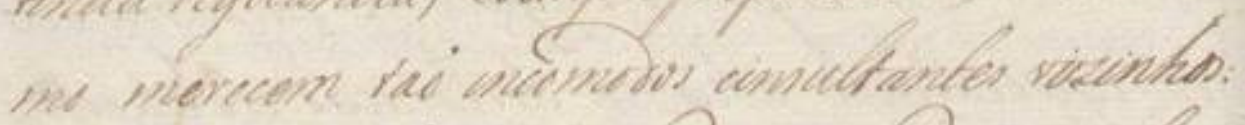

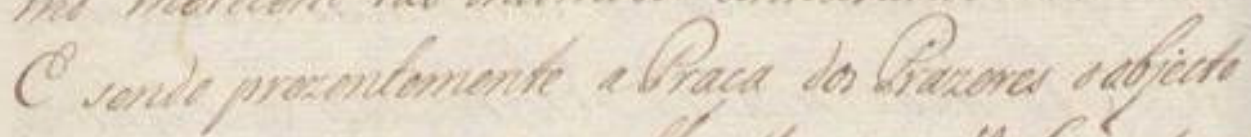

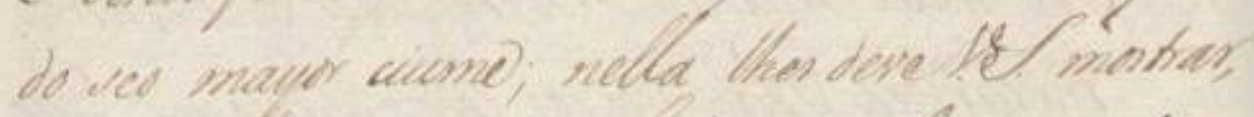

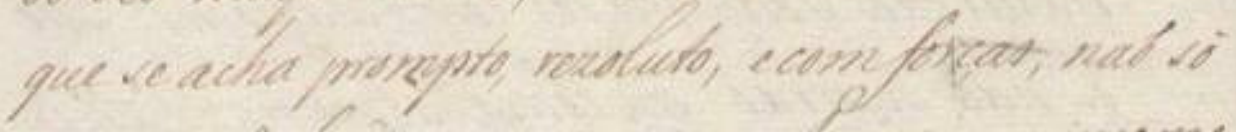
pard velefurdor mas pand o aracar ie o ineme:
Jamin.

o Conminands nomen nas momm Vulacs:

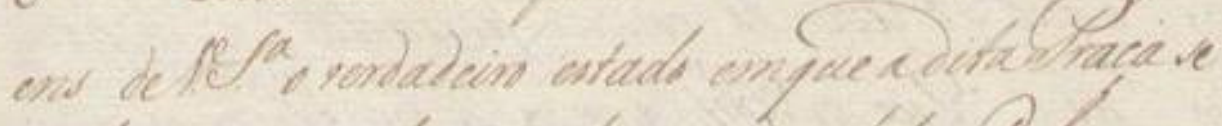

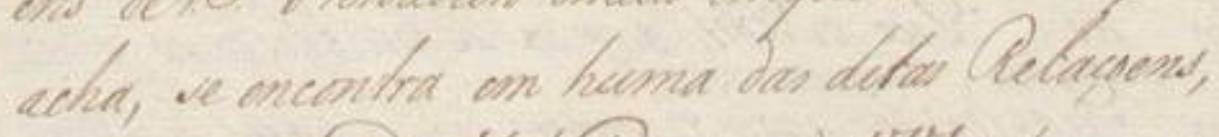

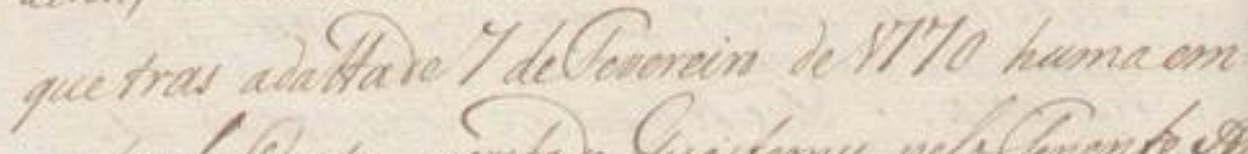

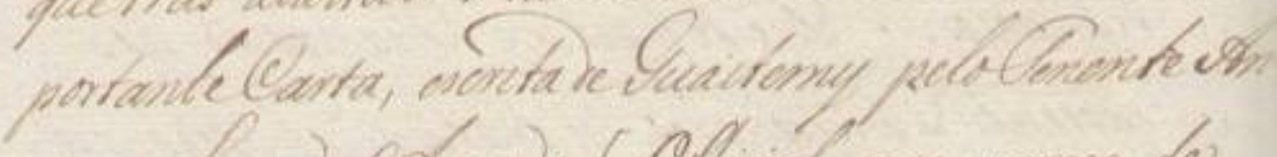

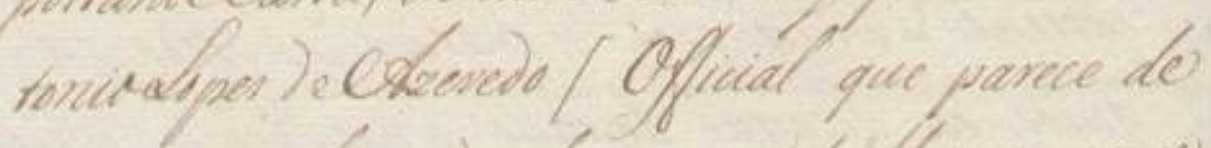
prestione pels medes dareat, ederable con ques

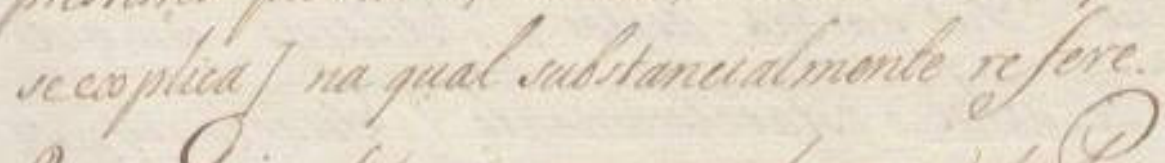

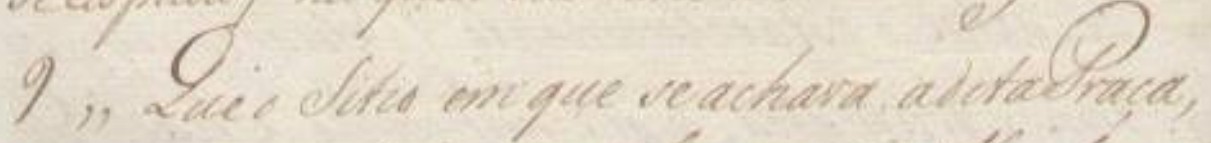

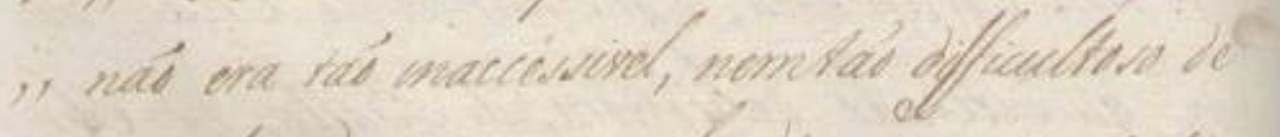

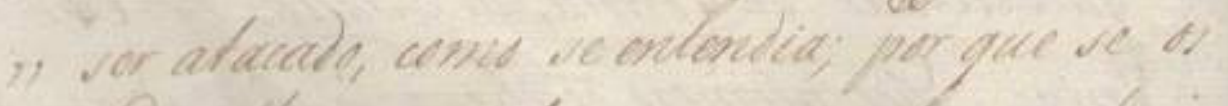

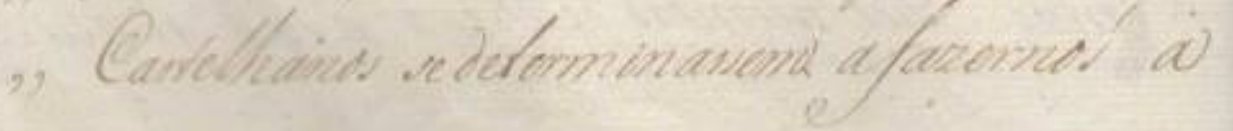


$70\|105 v\|$,, eosOfficiaes que as comandaõ: E que depois de

,, tudo bem examinado, remetaõ os ditos Dezerto=

, res ao GeneraldeParaguay.

7 Estes inauditos procedimentos edisposiçoens,

saõ o melhor despertador para terem aVossaSenhoria em con

75 tinua vigilancia; e sempre preparado areceber $\mathrm{co}=$

mo merecem taõ incomodos einsultantes vizinhos:

E sendo prezentemente aPraça dos Prazeres o objecto

do seo mayor ciume; nella lhes deveVossaSenhoria mostrar,

que se acha prompto, rezoluto, e comforças, naõ só

80 para sedefender, mas para os atacar se o incomo $=$ darem.

8 Examinando porem nas mesmas Relaço= ens deVossaSenhoria o verdadeiro estado emque aditaPraça se acha, se encontra em huma das ditas Relaçoens,

85 que tras adatta de7 deFevereiro de1770 humaem= portante Carta, escrita deGuaitemy peloTenente $\mathrm{An}=$ tonioLopes deAzevedo / Official que parece de prestimo pelo modo, clareza, e detailhe com que seexplica / na qual substancialmente refere.

909 , Que o Sitio em que se achava aditaPraça,

, $\quad$ naõ era tão inaccessivel, nemtaõ difficultoso de

, $\quad$ ser atacado, como se entendia; por que se os

, Castelhanos sedeterminassem afazernos a 


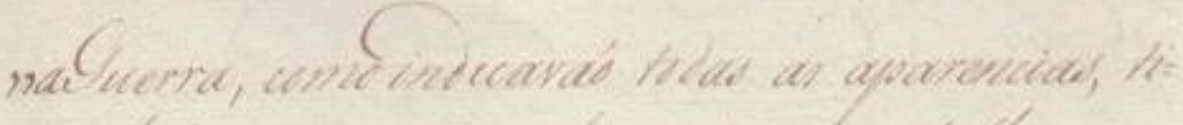

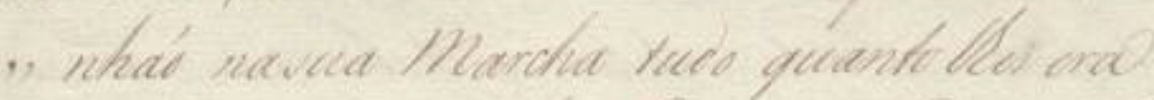

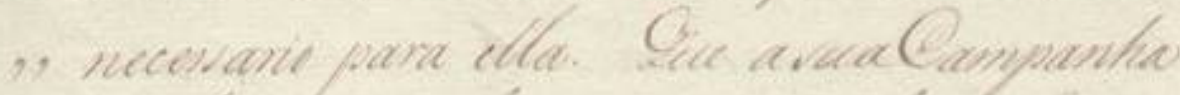

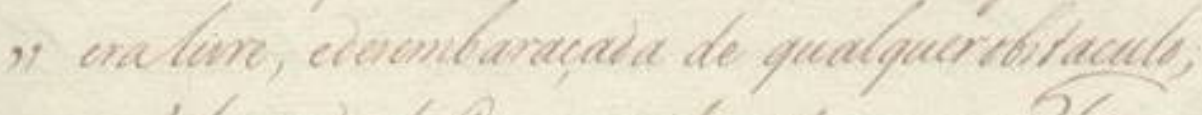

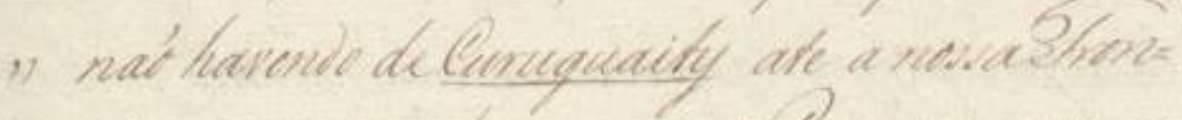

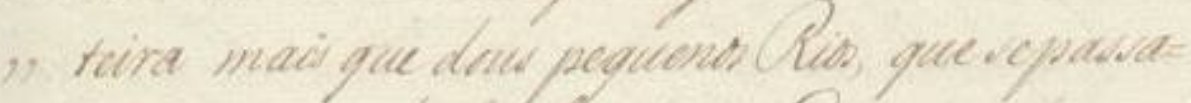

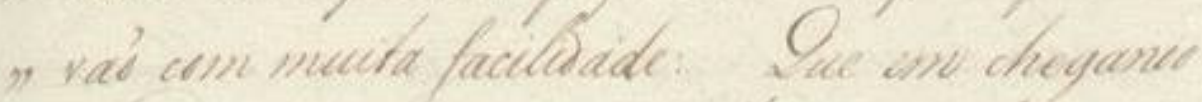

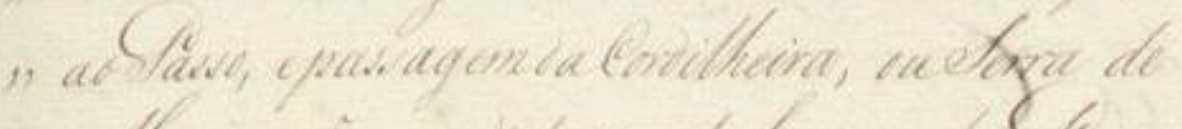

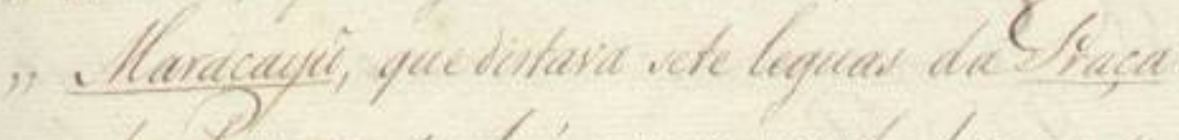

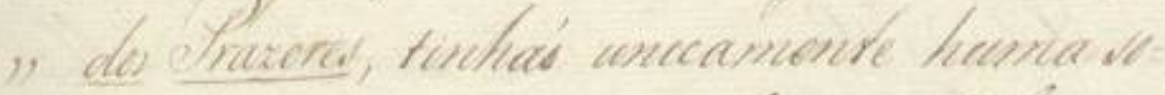

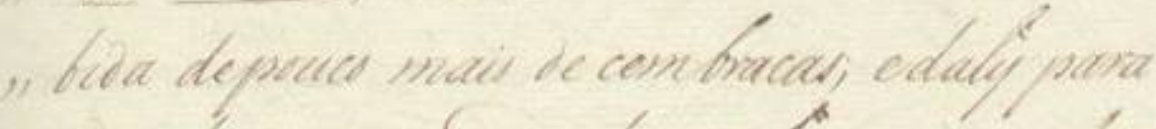

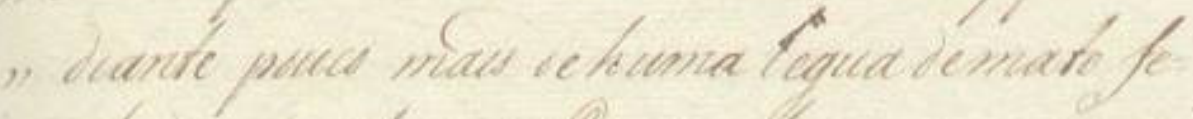

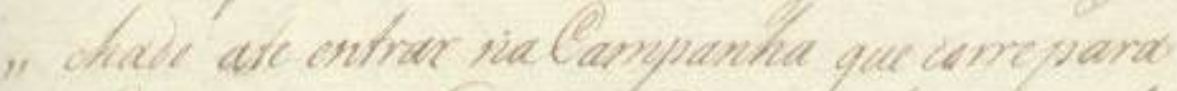

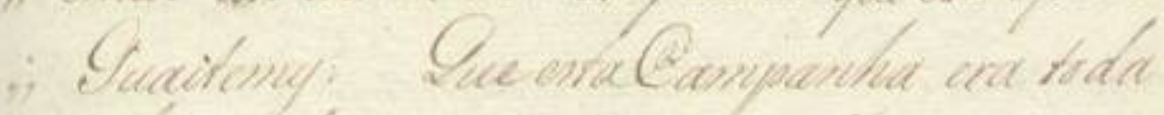

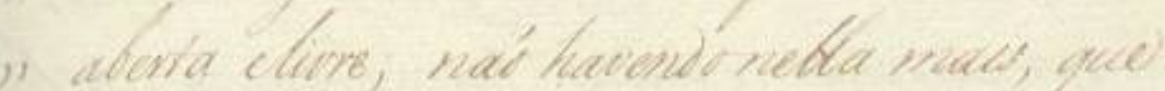

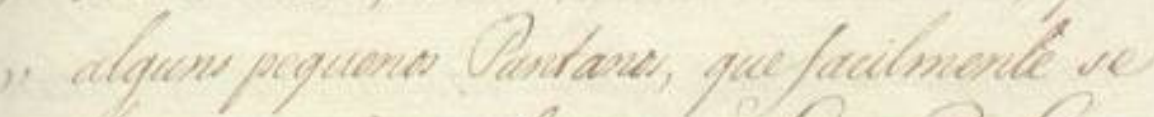

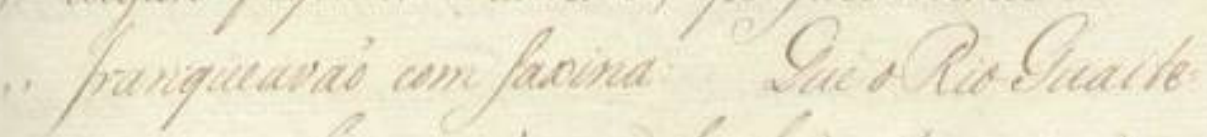

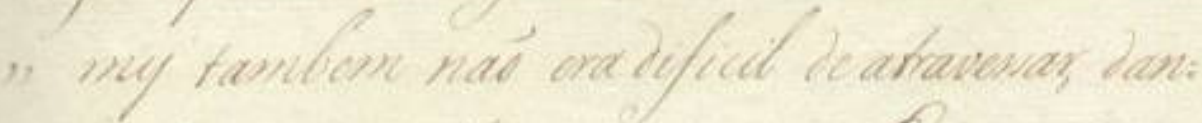

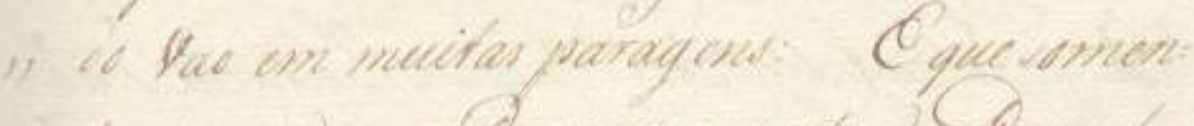

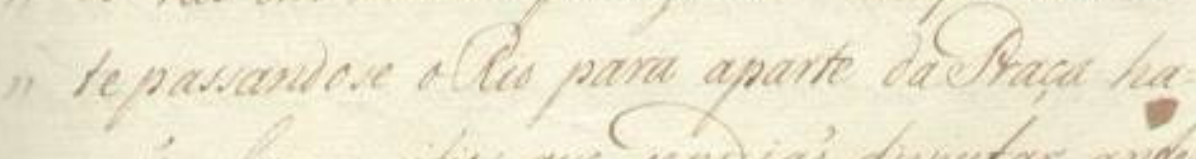

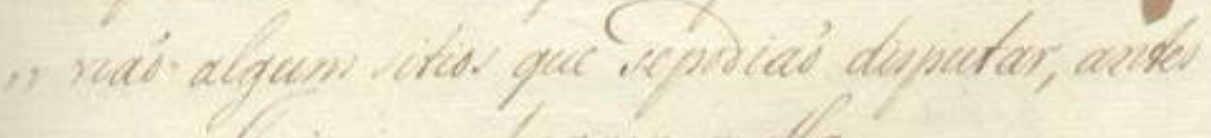

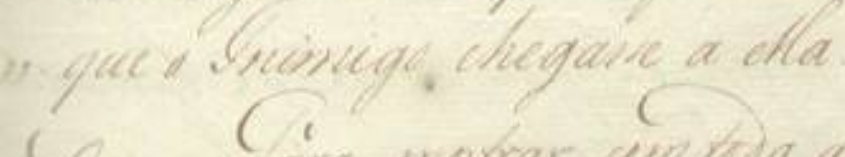

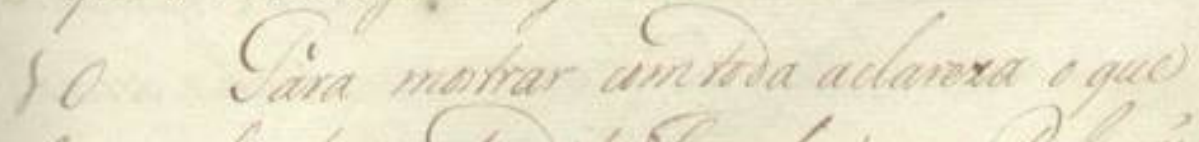

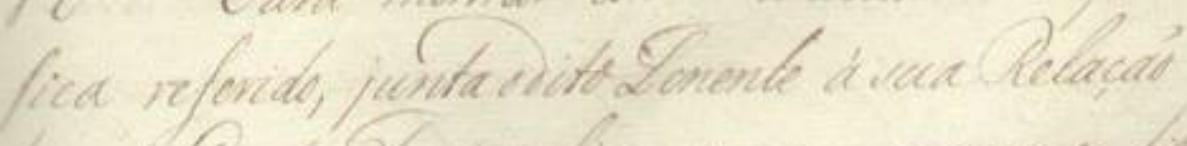

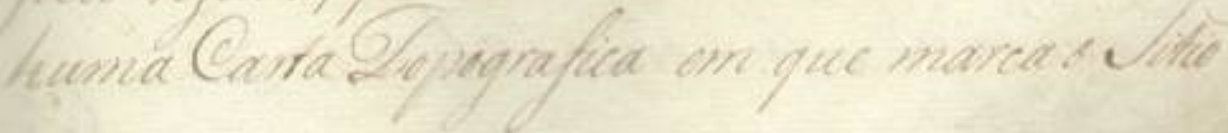


||106r|| naGuerra, como indicavaõ todas as aparencias, ti=

95 ,, nhaõ nasua Marcha tudo quanto lhes era

, necessario para ella. [espaço] Que a suaCampanha

, $\quad$ eralivre, edesembaraçada de qualquerobstaculo;

,, naõ havendo decuruguaity ate a nossaFron=

,, teira mais que dous pequenos Rios, que sepassa=

100 „, vaõ com muita facilidade: [espaço] Que em chegando

,, aoPasso, epassagemdaCordilheira, ouSerra de

, $\quad$ Maracaijûu, que distava seteleguas daPraça

", dos Prazeres, tinhaõ unicamente huma so=

, $\quad$ bida depouco mais de cembracas; edaly para

105 ," diante pouco mais dehuma legua demato $\mathrm{fe}=$

,, chado ate entrar naCampanha que correpara

,, Guaitemy: [espaço] Que estaCampanha era toda

,, aberta elivre; naõ havendo nella mais, que

,, alguns pequenos Pantanos, quefacilmente se

110 ,, franqueavaõ com faxina: Que oRio Guaite=

,, my tambem naõ era dificil de atravessar, dan=

, do Vao em muitas paragens: [espaço] E que somen=

,, te passandose oRio para aparte daPraça ha=

, $\quad$ viaõ alguns sitios que sepodiaõ disputar, antes

115 ,, que o Inimigo chegasse a ella.

10 Para mostrar comtoda aclareza o que

fica referido, junta o dito Tenente à sua Relaçaõ

huma Carta Topografica em que marca o Sitio 
Circa do:

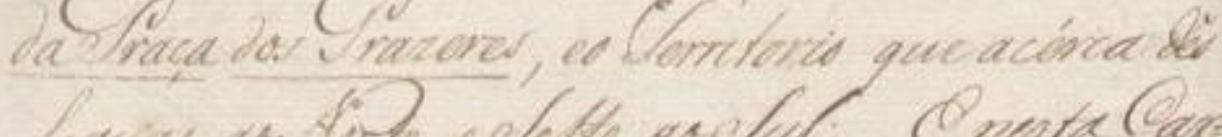

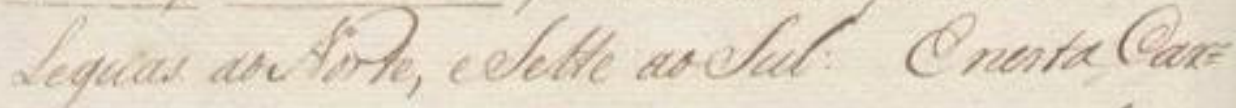

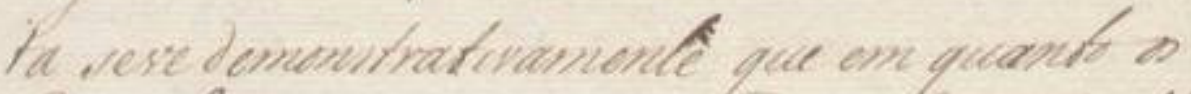

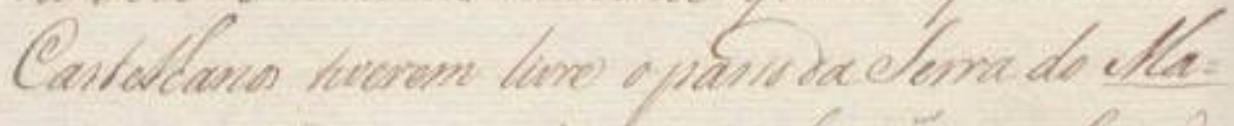
racaya, prieninir atacarnes, elancarmos fora de

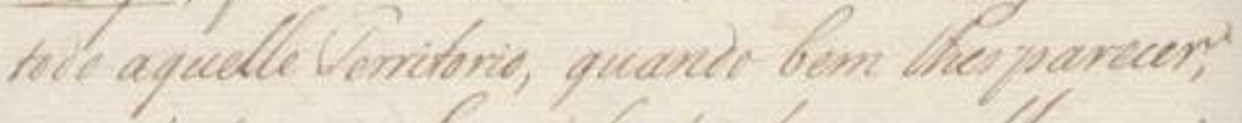
we naverne finas bastanter para the rezix fir: $(x)$

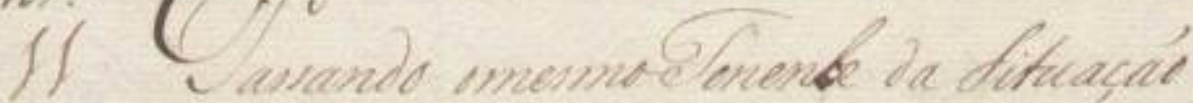
da Ceforda Errea ae ertads de deferwa della

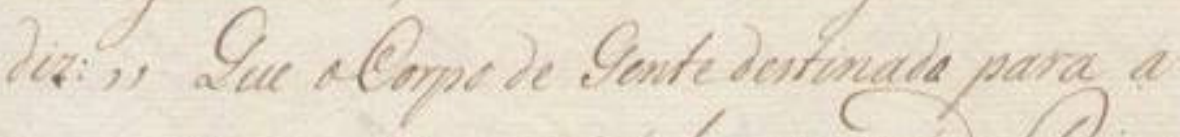

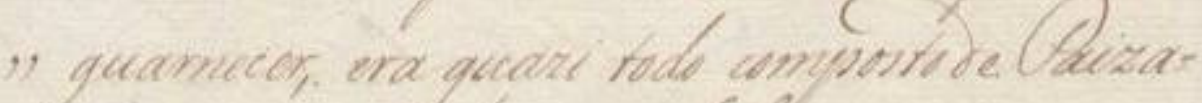

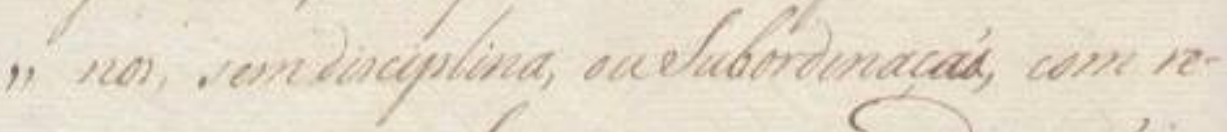

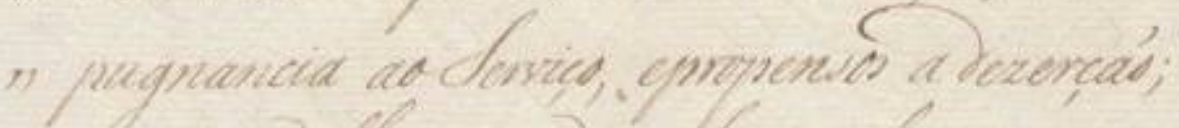
"1" ion quededer vepudove farer alquind conf: "area, para humb ofiecto tai qravide cdetan: " tr imponfarcia, come ond oda deforia de her. " ne Etruteira

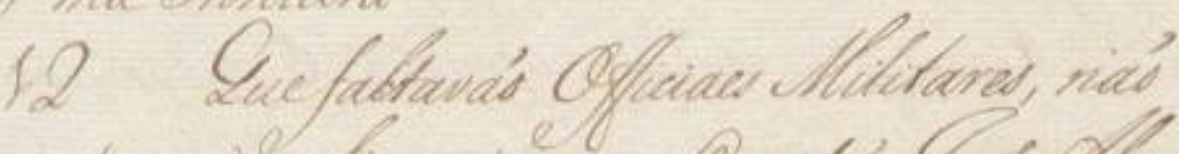

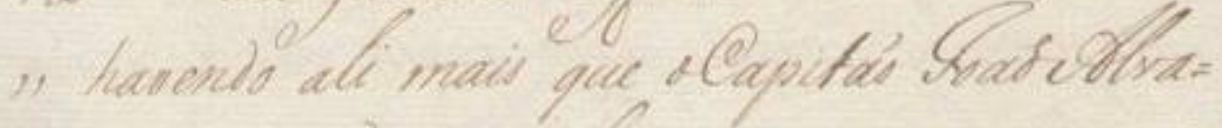
"res, que patrcia molorial, eque ve momesse "nde hwia quem a suprive. "Geotover eloxe Zumante Eacturande

"quecanas, eque avila que re achara cenn nige?"

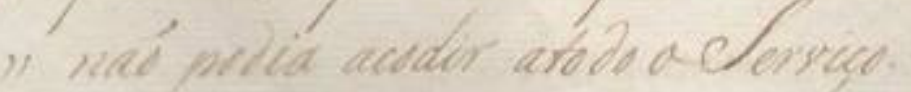


\|106v $\|$ daPraça dos Prazeres, eo Territorio que acérca dês

Leguas aoNorte, eSette aoSul: [espaço] Enesta Car=

ta seve demonstrativamente que em quanto os

Castelhanos tiverem livre o passo daSerra do $\underline{\mathrm{Ma}=}$

racayu, podemvir atacarnos, elancarnos forade

todo aquelle Territorio, quando bem Ihes parecer;

se naõ tivermos forças bastantes para lhes rezis=

tir.

11 Passando o mesmoTenente da Situaçaõ

da referidaPraça ao estado de defensa della

diz: ,, Que oCorpo de Gente destinada para a

130 ,, guarnecer, era quazi todo composto de Paiza=

, nos, sem disciplina, ouSubordinaçaõ, com re-

,, $\quad$ pugnancia aoServiço, epropensos a dezerçaõ;

,, sem que delles sepudesse fazer alguma confi=

,, ança, para humobjecto taõ grande ede tan=

135 ,, ta importancia, como era o da defensa dehu=

,, ma Fronteira

12 Quefaltavaõ Officiaes Militares, naõ

, $\quad$ havendo ali mais que oCapitaõ loaõAlva=

, res, que padecia molestias, e que se morresse

$140 \quad, \quad$ naõ havia quem o suprisse: [espaço] E oAjudante

, Theotonio loze Zuzarte [espaço] tinha suas

, queixas, e que ainda que se achava comvigor,

,, nã̃ podia acodir atodo oServiço. 


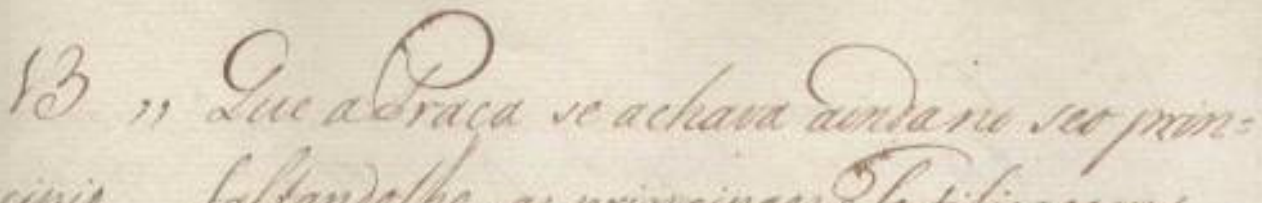
uivis fablandothe as princisacs Etortificecerses, 1) wen as quew nat vendoa defortor com nepes:

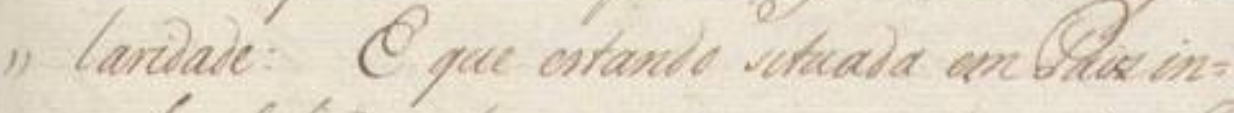
1" utho, falto de tode o necoviand, cadurevitas de " quar Pistante Re Caprial, ond muito mecour so. " comba cont tola a anticivacá, pana Sepred? 1. corventar.

It Cmoutm Carráa quambervem innts

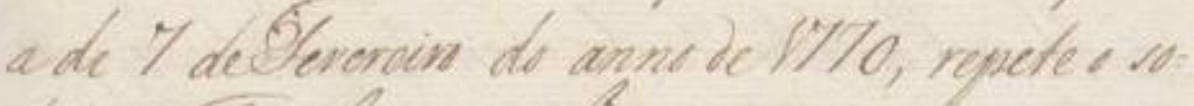

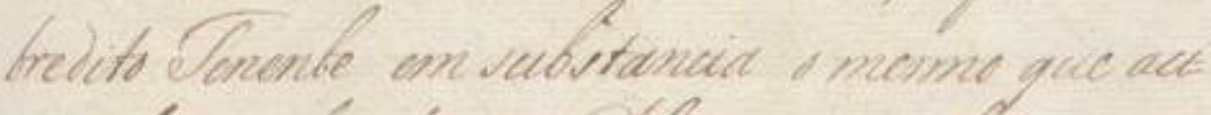

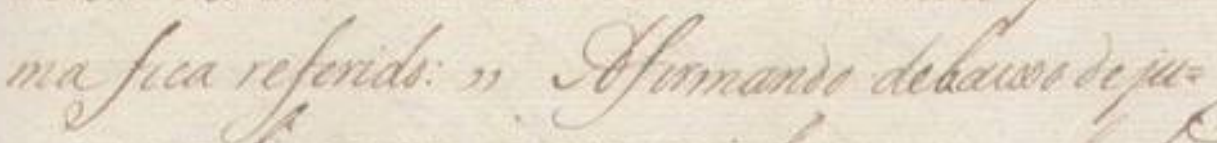
"raments, ccoms qupon seintersoman pelacter

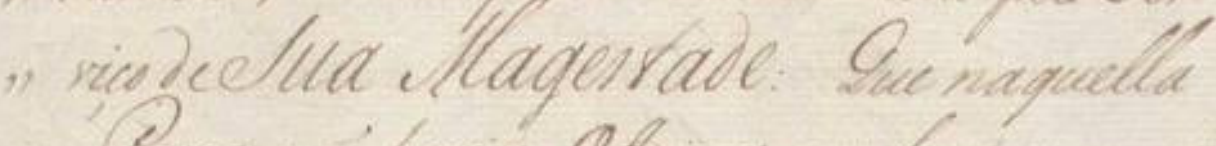

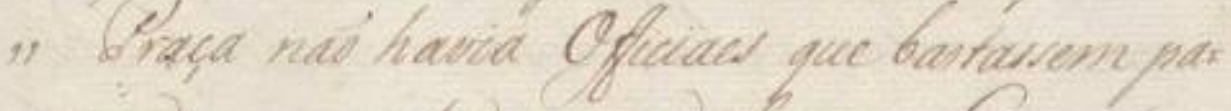
" ratareme contala nua deforva Lue onava

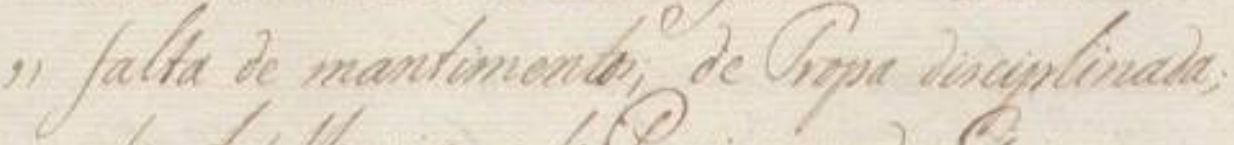

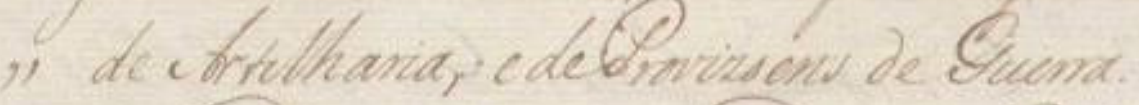

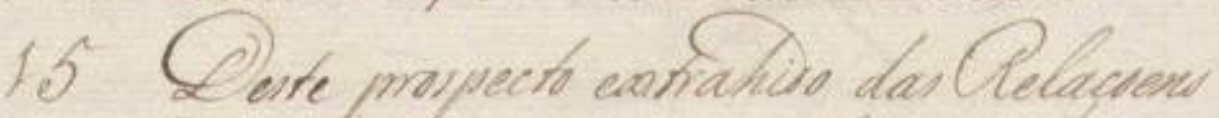

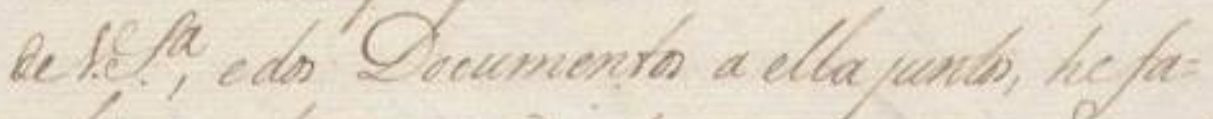
"le confecer o wadente perigs en que se ada - ertablecimento de Suatany, car comequen.

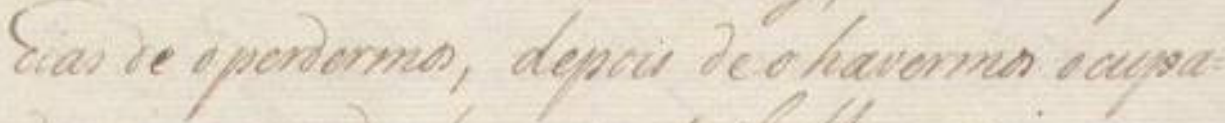
2d com qrane despera, etrabatho, ecomi ina as inconteriavel Oimeite 
145 \|107r\| [[13]],, Que aPraça se achava aindano seo prin=

cipio [espaço] faltandolhe as principaes Fortificaçoens,

,, $\quad$ sem as quaes naõ sepodia defender com regu=

, laridade: [espaço] E que estando situada em Paiz in=

, $\quad$ culto, falto detodo o necessario; e a duzentas Le=

150 ,, guas distante daCapital, era muito precizo so=

,, correla com toda a anticipaçaõ, para sepoder

„, conservar.

14 Em outra Carta que tambem vem junta

a de 7 deFevereiro do anno de1770, repete o so=

bredito Tenente em substancia o mesmo que aci=

ma fica referido: ,, Afirmando debaixo deju=

, ramento, ecomo quem seinteressava peloSer=

,, viço deSua Magestade: [espaço] Que naquella

,, Praça naõ havia Officiaes que bastassem pa=

,, ra darem contada sua defensa: [espaço] Que estava

,, falta de mantimentos; de Tropa disciplinada;

,, de Artilharia, e deProvizoens deGuerra.

15 Deste prospecto extrahido das Relaçoens

deVossaSenhoria, edos Documentos a ella juntos, hefa=

cil de conhecer o evidente perigo em que se acha

o estabelecimento deGuatemy, e as consequen=

cias de o perdermos, depois deo havermos ocupa=

do com grande despeza, etrabalho, e com o ma-

is incontestavel Direito 


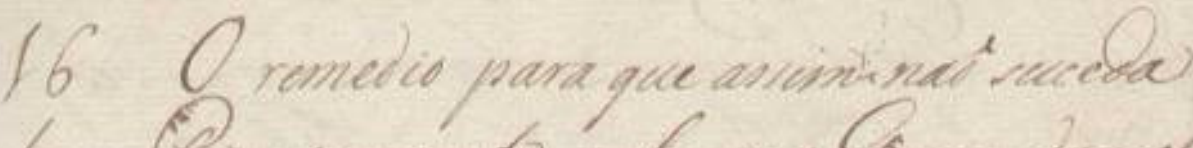

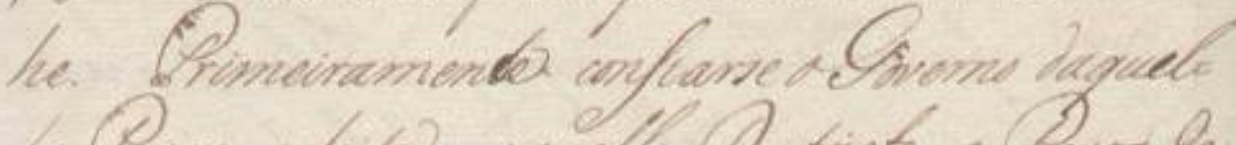

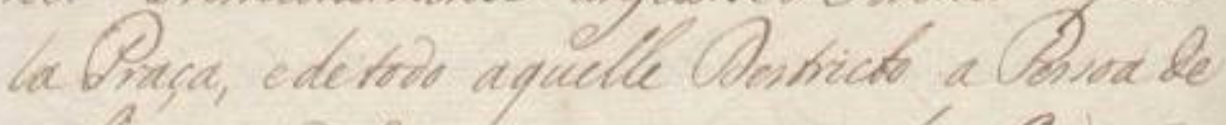
valor, capacialde cexpenioncia, que leve Orems ve abiantar ceondur as Obras la meima brace com a maynotiligencie, que the for soviond: है que ne care de ver atacalo, of seja antes bac des pois de acabada areforida Graca, se defonea $a=$

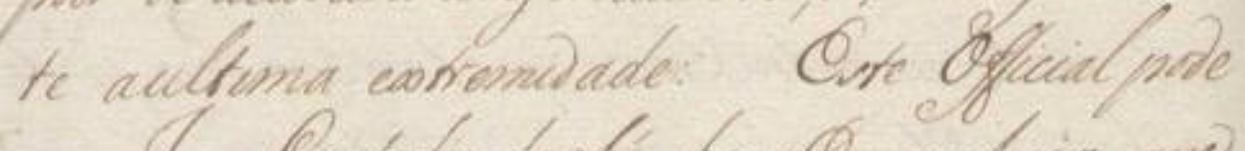

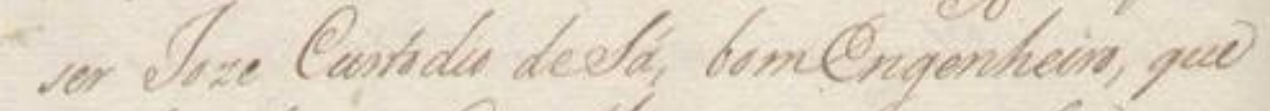
conture bom os Carthand, que ia conterter or Lerosanonte curn clles: Co que porto que fordo

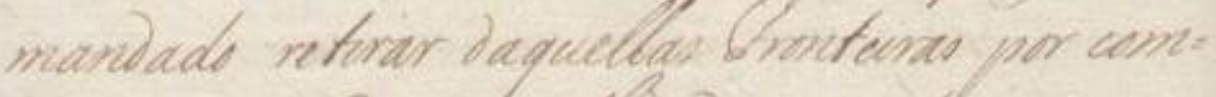
paremina a Ente de Chabii), ve acha agora nos

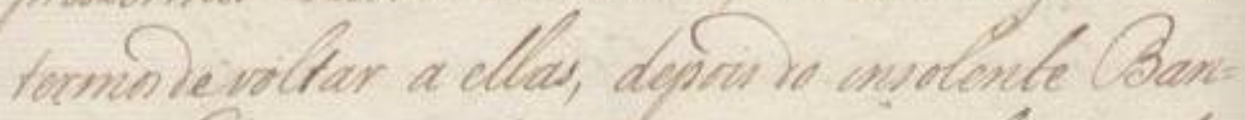
do do Gormador Carteluans, ne quad re cintorn huma formal dectaraceás de Cuema

17 Onvegundo lugar: Due dira Oficiat ex:

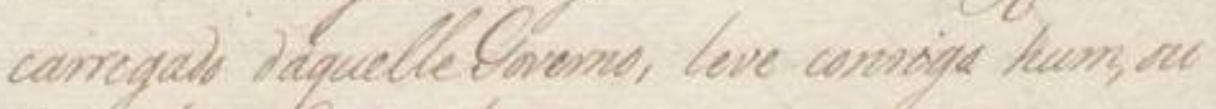
Dous bors Ongenheins, para 1 ajuidarm ne onportante elovies de quevary inceempirs.

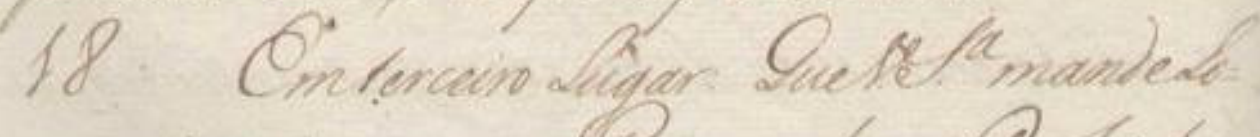

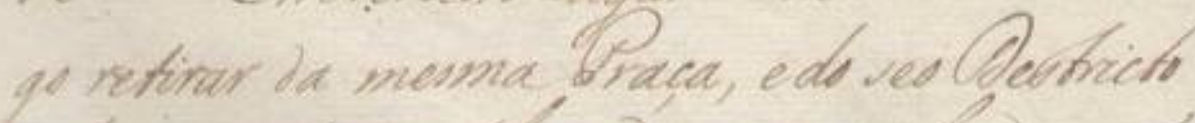
toda a qovse incent evalion, som webordinacá que aly sechids mecrito ortenado de baias 
||107v\|| [[16]] O remedio para que assim naõ suceda

he. [espaço] Primeiramente confiarse oGoverno daquel= laPraça, edetodo aquelle Destricto aPessoa de valor, capacidade eexperiencia, que leve Ordem

175 de adiantar e concluir asObras da mesma Praça com a mayor diligencia, quelhefor possivel: [espaço] E que no cazo de ser atacado, ou seja antes, ou de= pois de acabada areferidaPraça, se defenda $\mathrm{a}=$ te aultima extremidade: [espaço] Este Official pode 180 ser loze Custodio deSá, bomEngenheiro, que conhece bem osCastelhanos, que ja contendeo va= lerosamente com elles: [espaço] E que posto quefosse mandado retirar daquellas Fronteiras por com= prazermos aCorte deMadrid; se acha agora nos

185 termos devoltar a ellas, depois do insolente Ban= do doGovernador Castelhano, no qual se contem huma formal declaraçaõ deGuerra.

17 Em segundo lugar: Que o ditoOfficial en= carregado daquelleGoverno, leve consigo hum, ou 190 dous bons Engenheiros, para o ajudarem no em= portanteServiço de quevay incumbido.

18 Em terceiro Lugar: [espaço] QueVossaSenhoria mandeLo= go retirar da mesma Praça, e do seo Destricto toda a gente inutil evadios, sem subordinaçaõ que aly se achaõ vencendo ordenados debaixo 
||108r

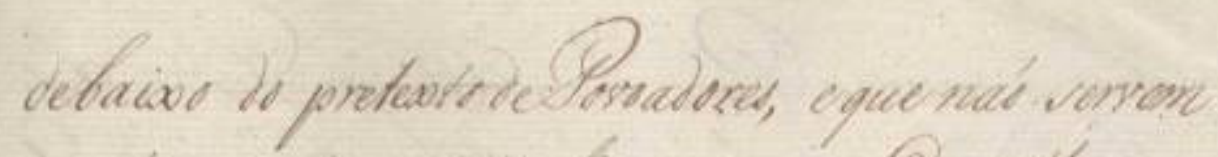

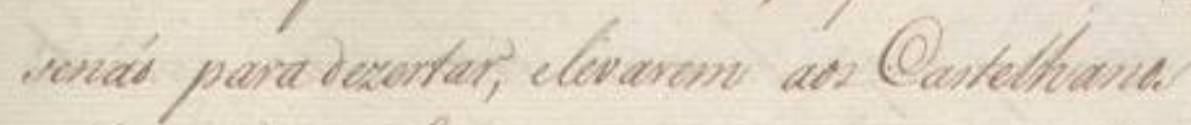
noticias, is qucforome, come aexporioncia tome moirrado.

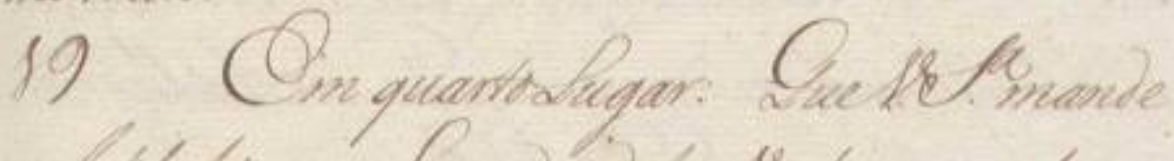

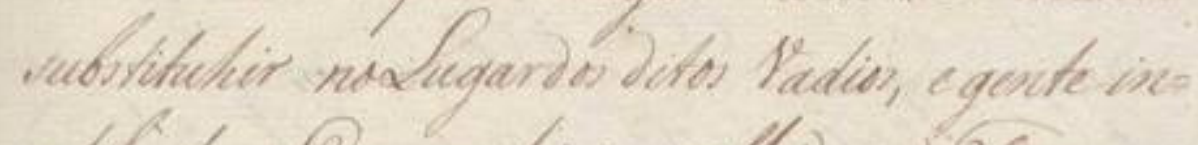
util,duas@ompartiar escolthinar deefropa va-

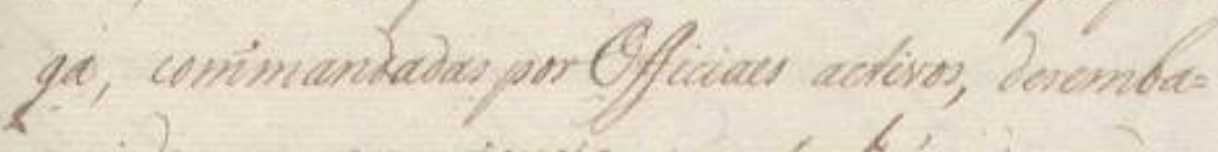

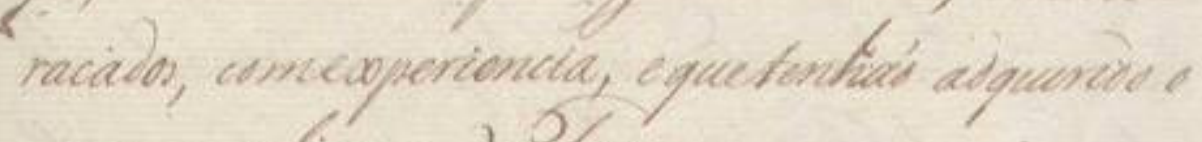
anos econfiance das/roua.

20

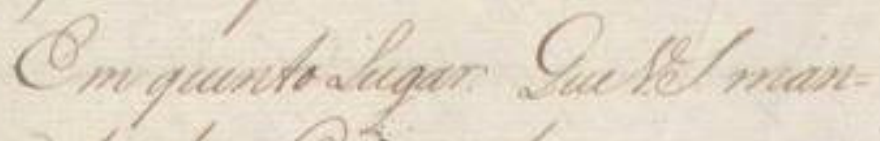

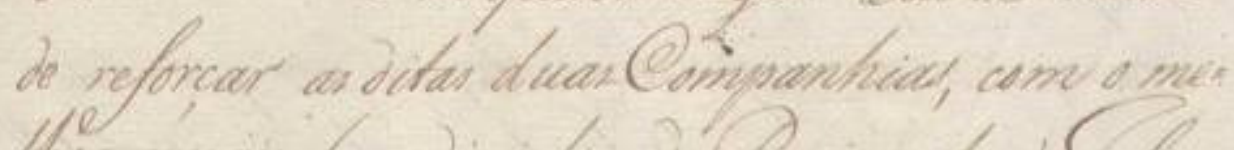

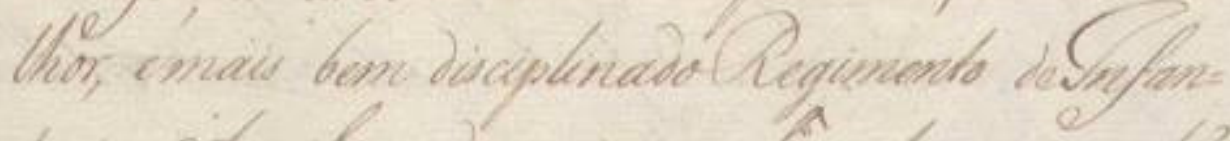
ravia cofunitian, dos veir que levantou, eve achase

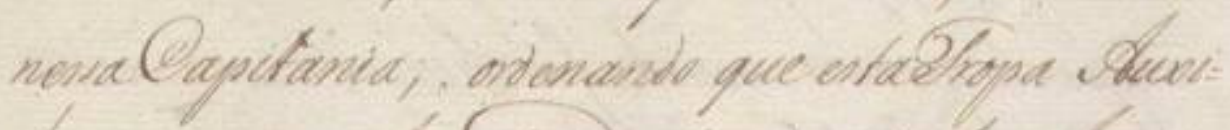

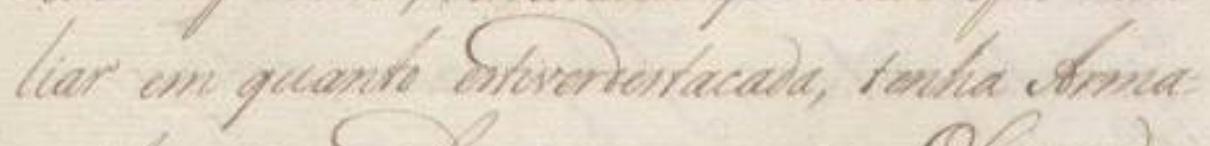

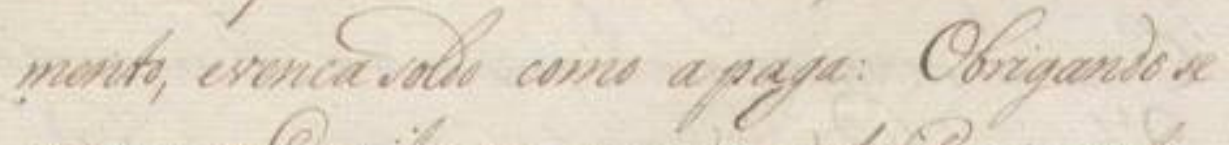

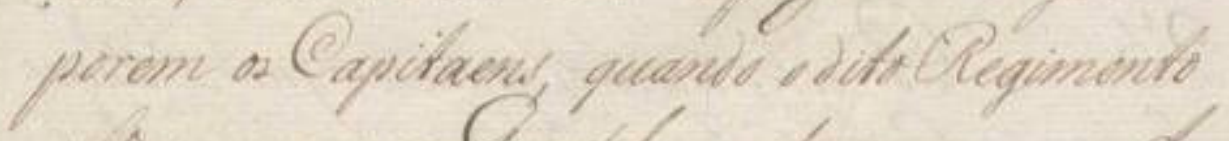

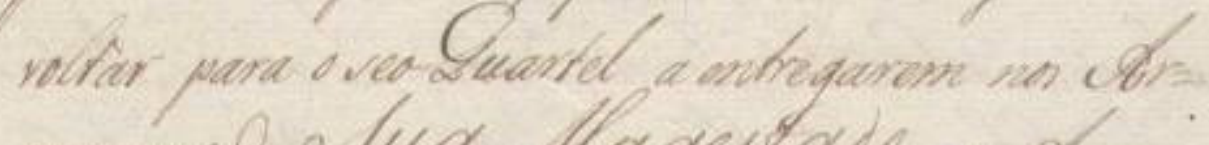

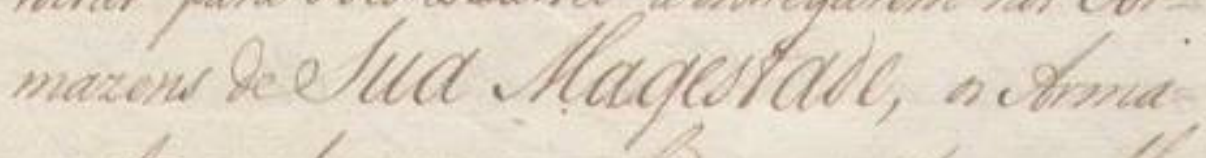
monss que howerem nechuds; covcess aqualles,

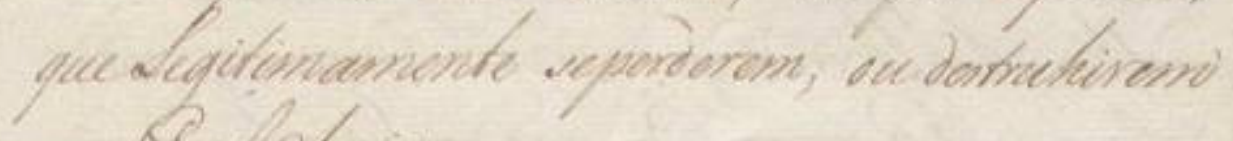
ne Gleal elovias.

2)

Cm mortr angurn: Que les mande

345 
||108r|| debaixo do pretexto dePovoadores, e que naõ servem senaõ para dezertar, elevarem aosCastelhanos noticias, do quefazemos, como aexperienciatem mostrado.

20019 Em quartoLugar: [espaço] QueVossaSenhoria mande substituhir noLugardos ditos Vadios, e gente in= util, duasCompanhias escolhidas deTropa pa= ga, commandadas porOfficiaes activos, desemba= racados, comexperiencia, e quetenhaõ adquirido o 205 amor, econfiança daTropa.

20 Em quinto Lugar: QueVossaSenhoria man= de reforçar as ditas duasCompanhias, com o me= Ihor, e mais bem disciplinadoRegimento delnfan= taria Auxiliar, dos seis que levantou, e se achaõ

210 nessaCapitania; ordenando que estaTropa Auxi= liar em quanto estiverdestacada, tenha Arma= mento, evenca soldo como a paga: [espaço] Obrigando se porem os Capitaens, quando o ditoRegimento voltar para o seoQuartel a entregarem nos $\mathrm{Ar}=$ 215 mazens deSua Magestade, os Arma= mentos que houverem recebido; excepto aquelles, queLegitimamente seperderem, ou destruhirem no RealServiço.

21 Em sextoLugar: QueVossaSenhoria mande 


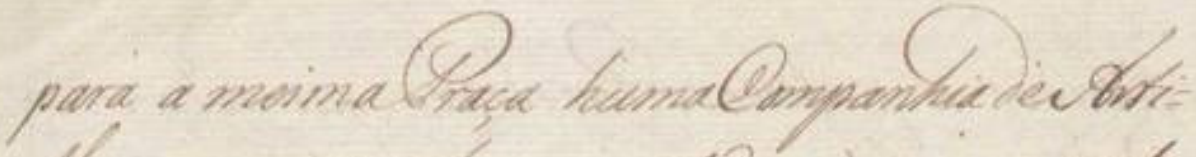

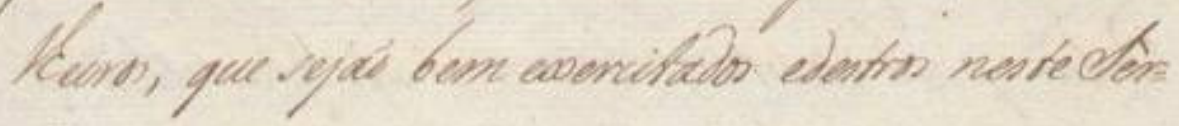
Hed

290 humetuficiente numoro de paras rec omblharia

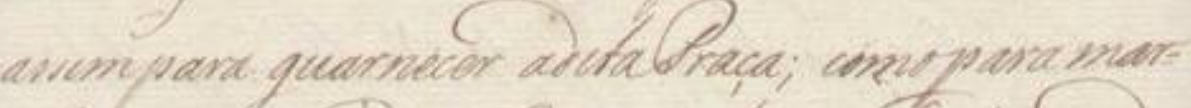

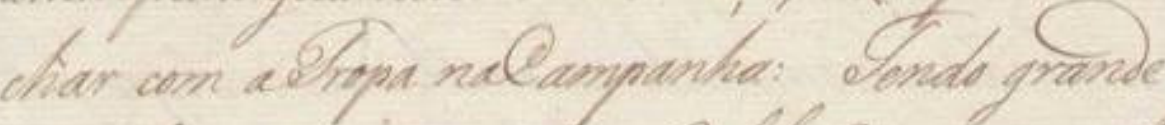

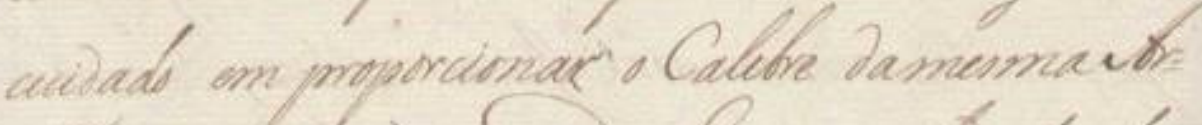

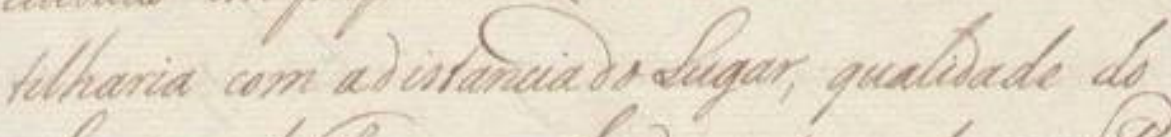

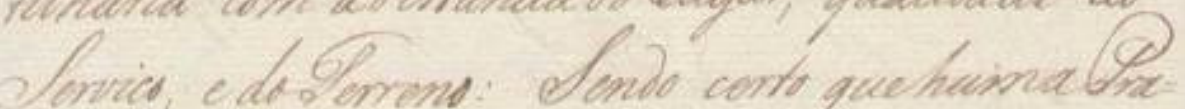

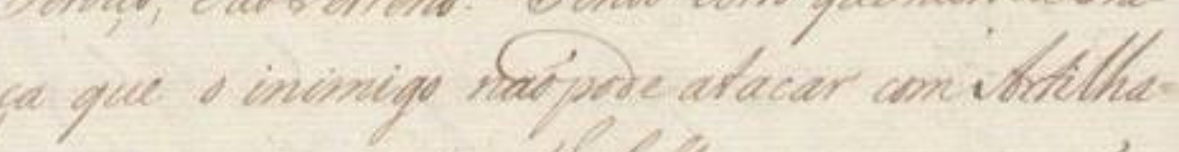
wre qrowa, suporgue de fare, we por que nats

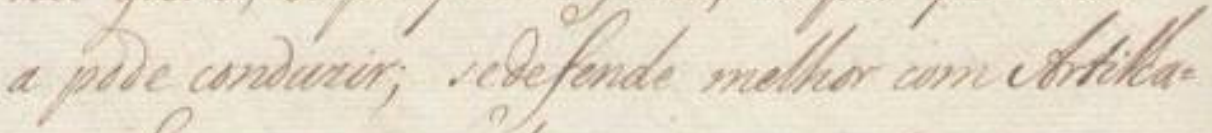
wa aliqeina, por que he mais monsta; mosere, e aprotase com mucta/acilitale, ecome maid aiviada pontaria, efariga mones a a mue. (A) wha mermas roviagow tom ne Campanca.

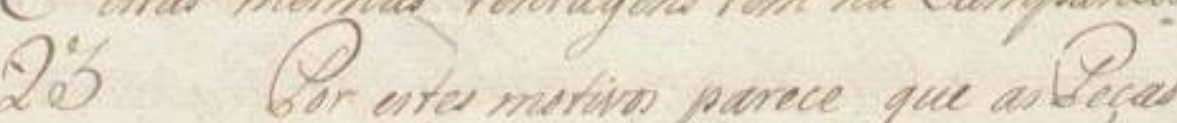

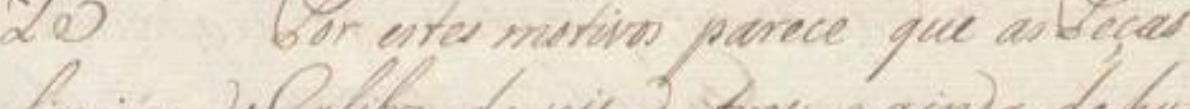

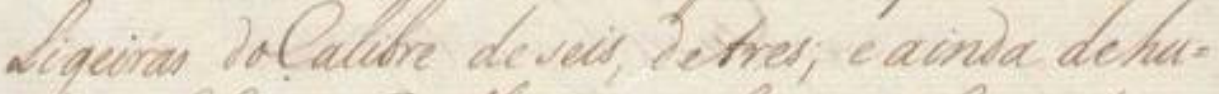
ma sibne de Bable; som alquess Obumes do Ca: libre de veit, que tambem wás liquma; verás a

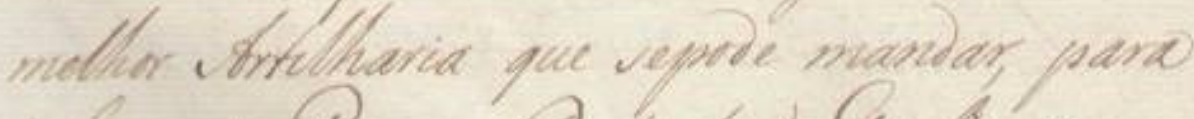

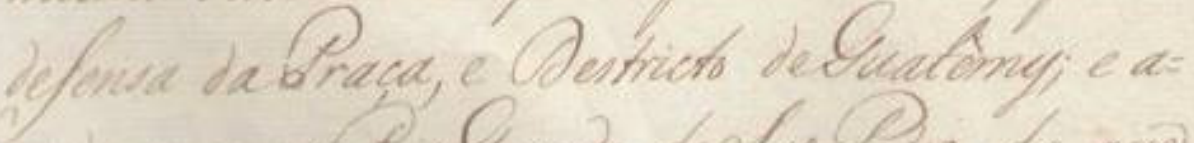

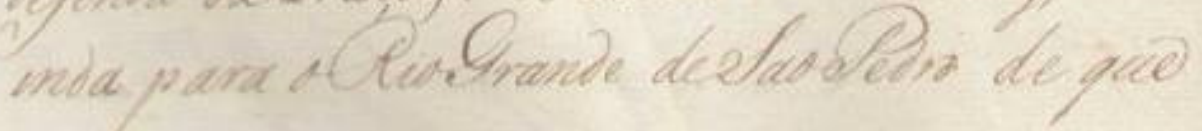


||108v|| para a mesmaPraça humaCompanhia deArti=

220 Iheiros, que sejaõ bem exercitados edestros neste Ser=

viço

22 Em setimo Lugar: [espaço] QueVossaSenhoria mande

humsuficiente numero de pessas deArtilharia

assim para guarnecer aditaPraça; comopara mar=

char com aTropa naCampanha: [espaço] Tendo grande

cuidado em proporcionar o Calibre damesmaAr=

tilharia com adistancia doLugar, qualidade do

Serviço, e doTerreno: Sendo certo quehumaPra=

ça que o inimigo naõpode atacar comArtilha=

230 ria grossa, ou porque Ihefalta, ou por que naõ

a pode conduzir; se defende melhor com Artilha= ria grossa, ouporquelhefalta, ou por que não

a pode conduzir; sedefende melhor comArtilha= riaLigeira, por quehe mais prompta; movese,

e aponta se com muitafacilidade, e com mais

ajustada pontaria, efatiga menos aTropa.

E estas mesmas ventagens tem na Campanha.

23 Por estes motivos parece que as Peças

Ligeiras doCalibre de seis, detres; e ainda dehu=

240 maLibra de Balla; com alguns Obuzes do $\mathrm{Ca}=$ libre de seis, quetambem saõ ligeiras; seraõ a

melhor Artilharia que sepode mandar, para

defensa daPraça, e Destricto deGuatemy; e a=

245 inda para oRioGrande deSaoPedro de que 
que abaial matriney.

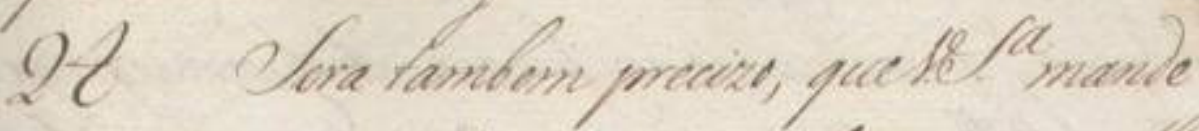

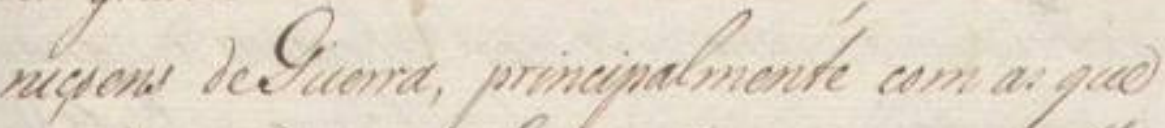

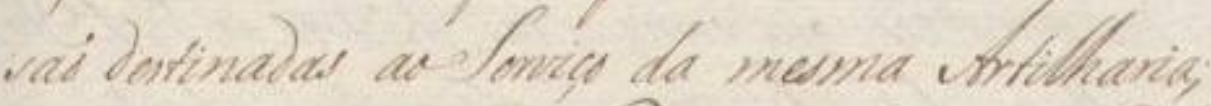

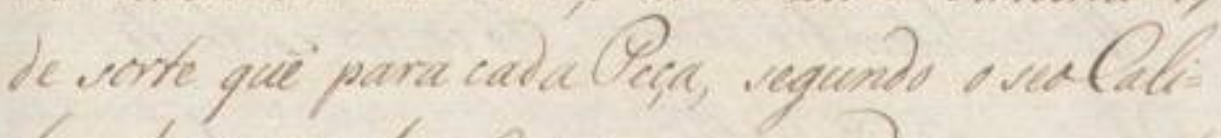
one, haia tanta Cainas wumoralas, que wite.

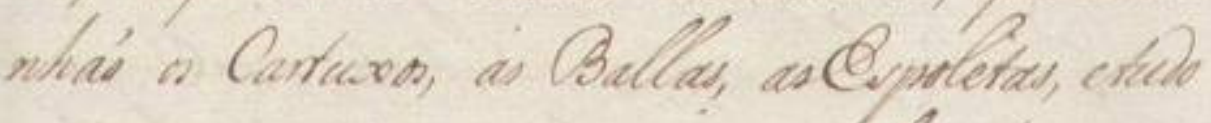
- mais apestad, on nemong qualdade, quan tidale, peze, emovorcal as Calion, enecesarid

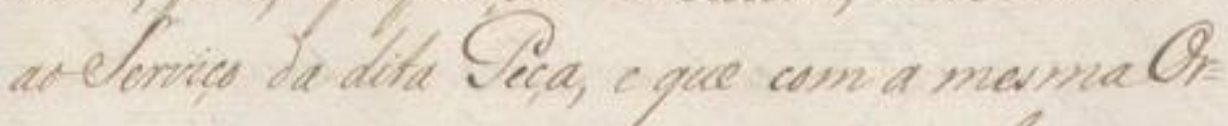

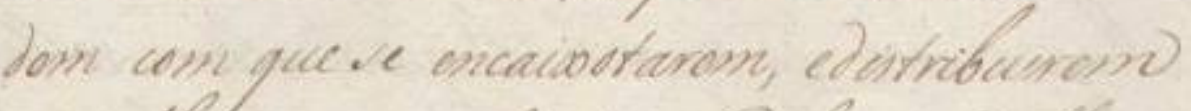

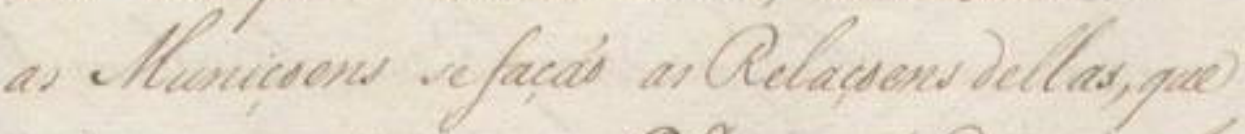

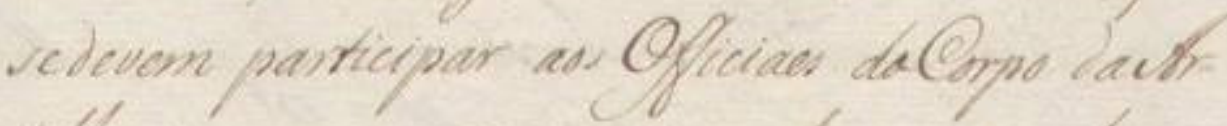

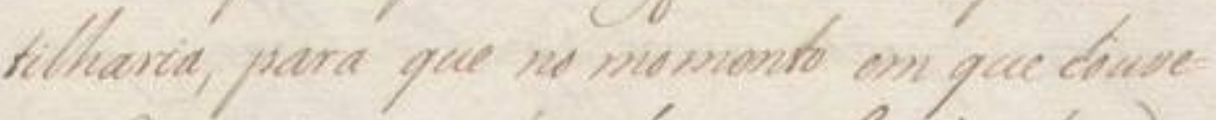

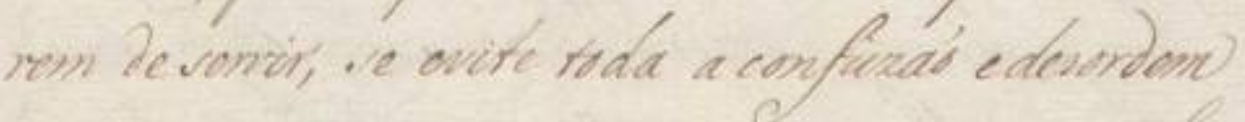
que tom as pornicives comsequencias, que ens bon

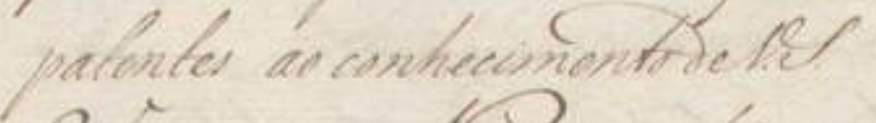

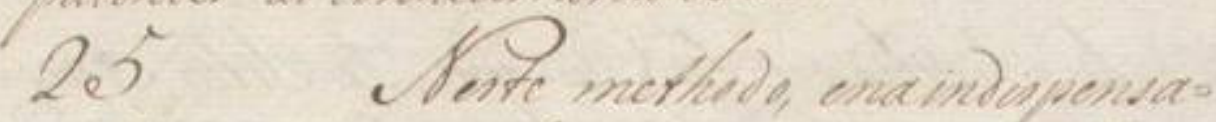

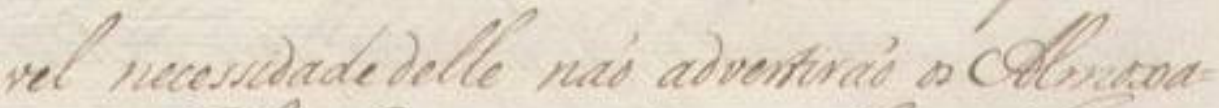

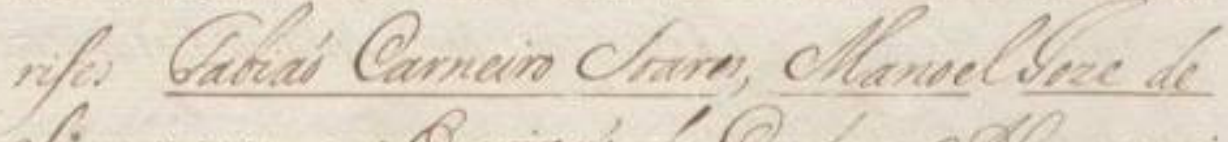

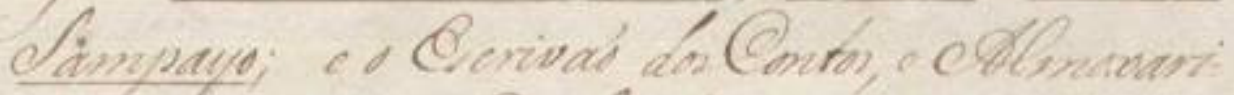

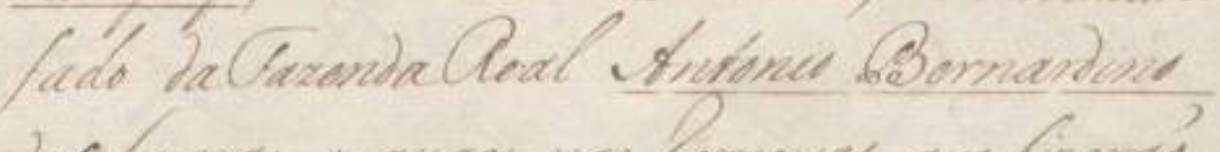

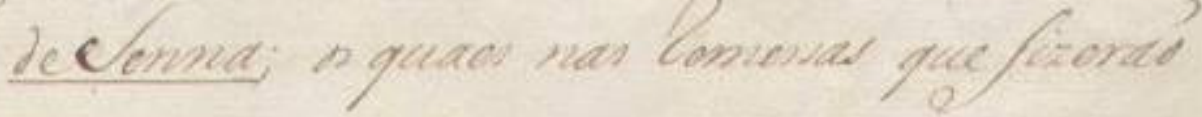


||109r|| [[que]] abaixo tratarey.

24 Sera tambem precizo, queVossaSenhoria mande ter grande cuidado com a destribuiçaõ das $\mathrm{Mu}=$ niçoens deGuerra, principalmente com as que 250 saõ destinadas aoServiço da mesma Artilharia; de sorte que para cada Peça, segundo o seoCali= bre, haja tantas Caixas numeradas, que conte= nhaõ os Cartuxos, as Ballas, asEspoletas, etudo o mais ajustado, em numero, qualidade, quan=

255 tidade, pezo, eproporçaõ ao Calibre, e necessario aoServiço da dita Peça, e que com a mesmaOr= dem com que se encaixotarem, edistribuirem as Muniçoens se façaõ as Relaçoens dellas, que se devem participar aos Officiaes doCorpo da $\mathrm{Ar}=$

260 tilharia, para que no momento em quehouve= rem de servir, se evite toda a confuzaõ edesordem que tem as perniciosas consequencias, que saõ bem patentes ao conhecimento deVossaSenhoria. 25 Neste methodo, ena indispensa= 265 vel necessidade delle naõ advertiraõ os Almoxa= rifes Fabiaõ Carneiro Soares, Manoel loze de Sampayo; e o Escrivaõ dosContos, e Almoxarifado daFazendaReal Antonio Bernardino deSenna; os quaes nas remessas que fizeraõ 


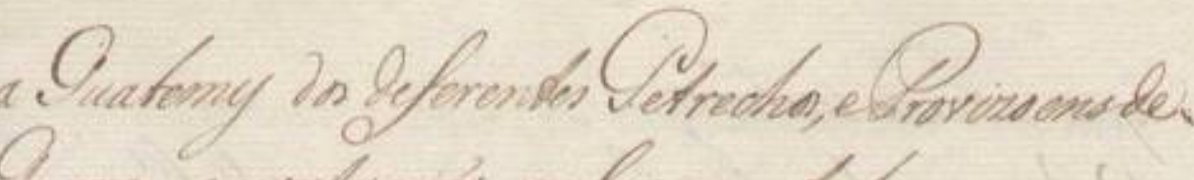

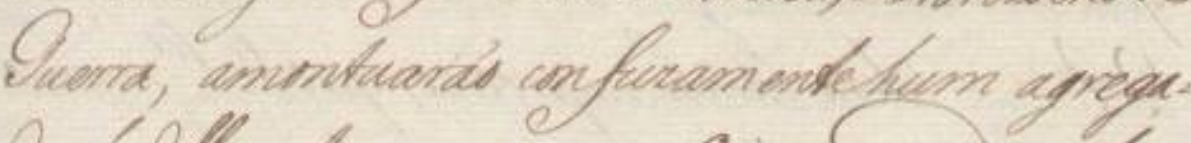

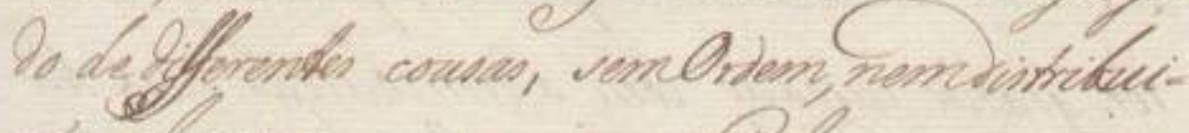

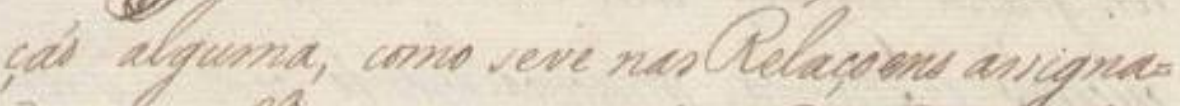

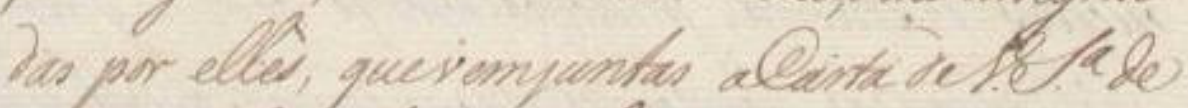

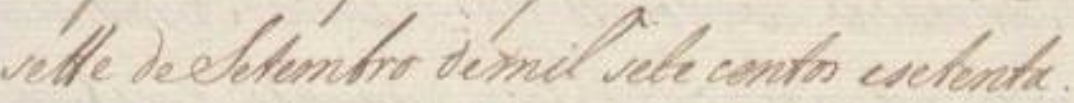

26

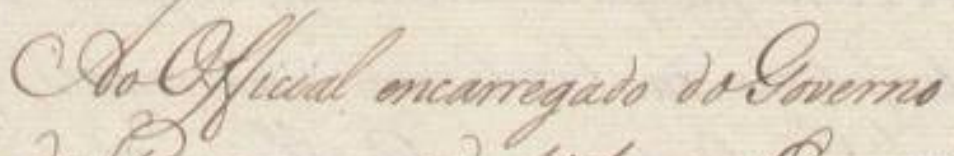

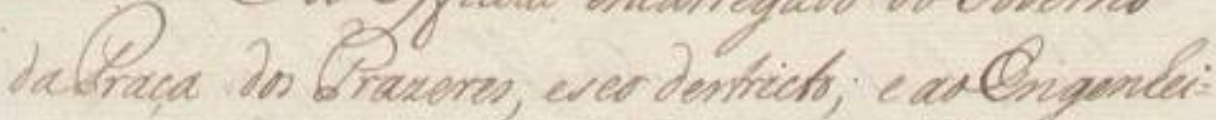
nisa@ngowhins que from comelle, re deve

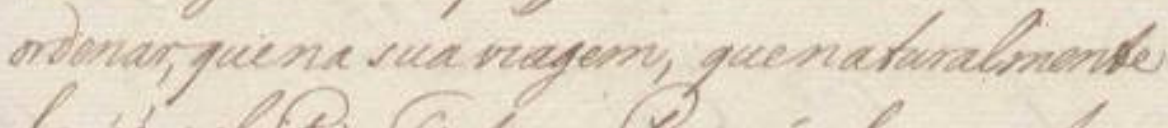

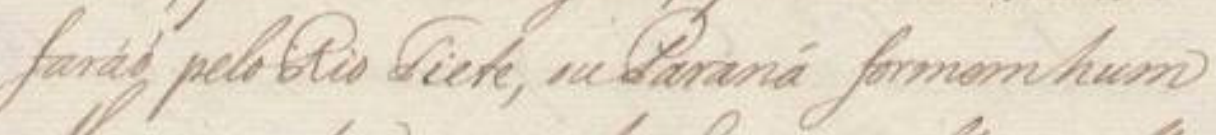

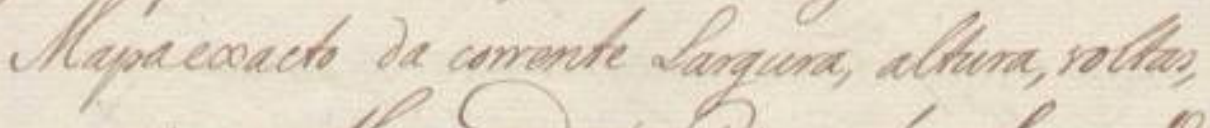

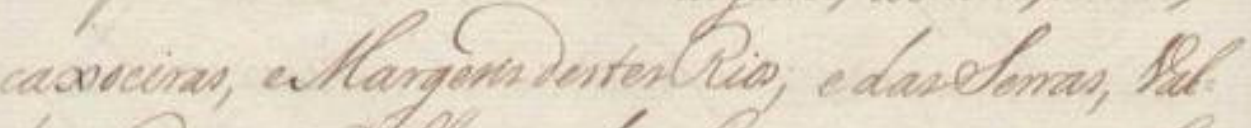
Los, elis que detlos ve doscominom, supara eth

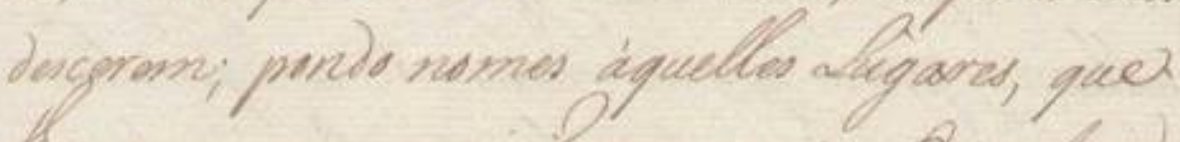

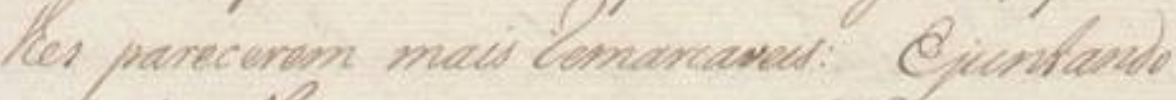

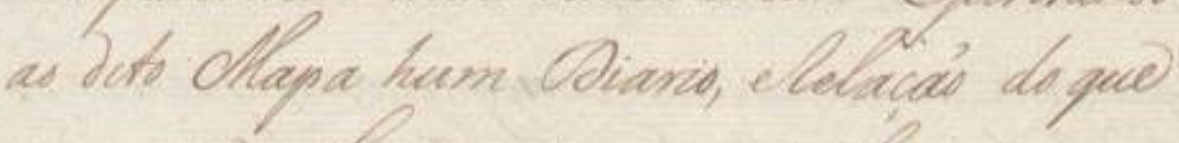

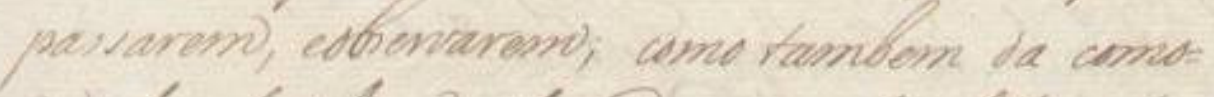

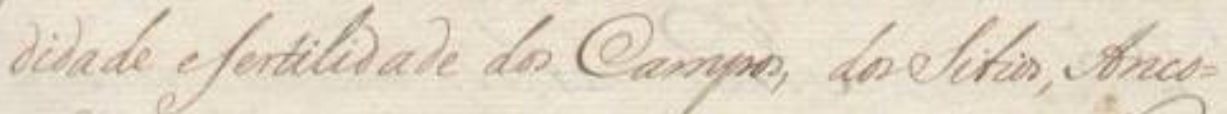
novourd, spara qeas mai mgmial pare a Wade-

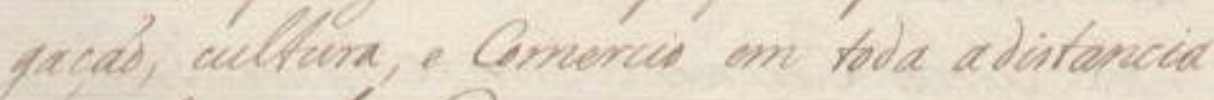
dos refendes deru (vios.

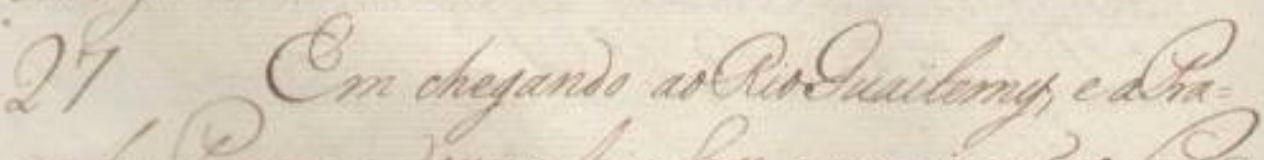

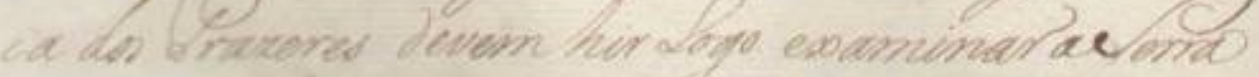


$270 \quad\|109 v\|$ a Guatemy dos deferentes Petrechos, eProvizoensde

Guerra, amontuaraõ confuzamentehum agrega= do de differentes cousas, semOrdem, nemdistribui= çaõ alguma, como seve nas Relaçoens assigna= das por elles, quevemjuntas aCarta deVossaSenhoria de 275 sette deSetembro demil sete centos esetenta.

26 AoOfficial encarregado doGoverno daPraça dos Prazeres, eseo destricto; e aoEngenhei= ro; ouEngenheiros queforem com elle, se deve ordenar, quena sua viagem, quenaturalmente

280 faráõ peloRio Tiete, ouParaná formemhum Mapaexacto da corrente Largura, altura, voltas, caxoeiras, eMargens destesRios; edasSerras, Val= les, eRios que delles se descobrirem, ou para elles descerem; pondo nomes àquelles Lugares, que

285 Ihes parecerem mais remarcaveis: Ejuntando ao dito Mapa hum Diario, erelaçaõ do que passarem, eobservarem; como tambem da como= didade efertilidade dos Campos, dosSitios, Anco= radouros, eparagens mais proprias para a Nave-

290 gaçaõ, cultura, e Comercio em toda a distancia dos referidos dous Rios.

27 Em chegando aoRioGuaitemy, e aPra= ca dos Prazeres devem hir Logo examinar aSerra 


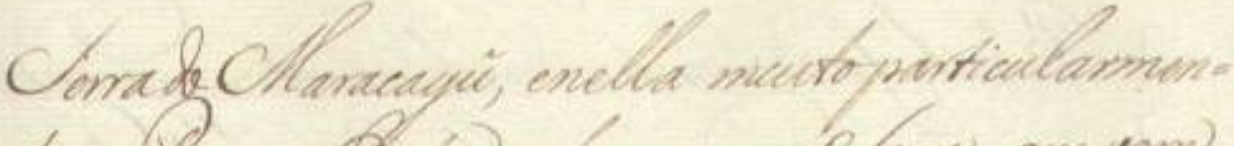

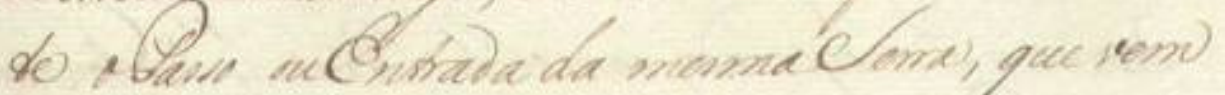

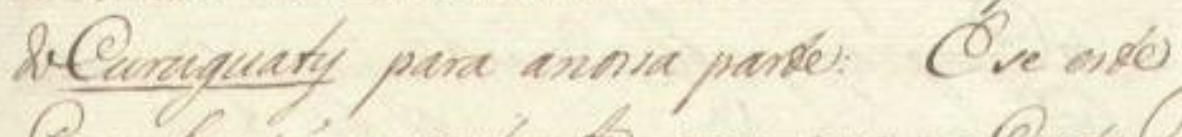

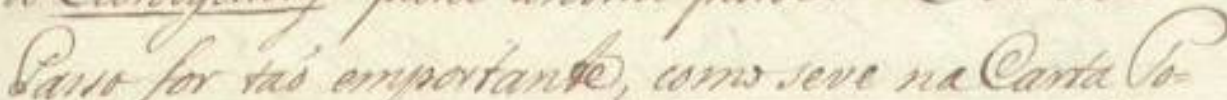

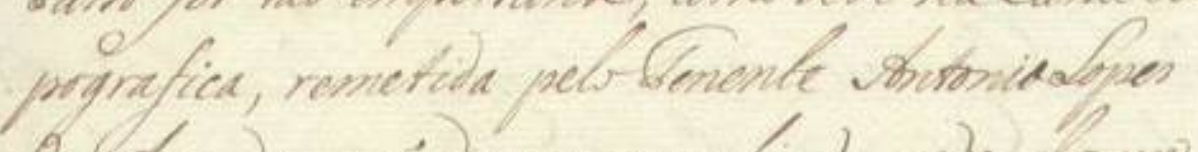

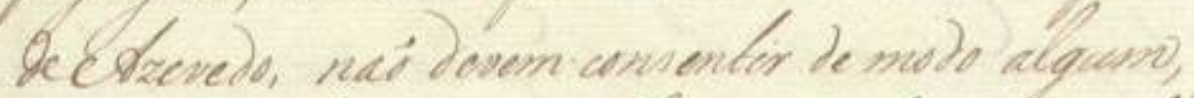

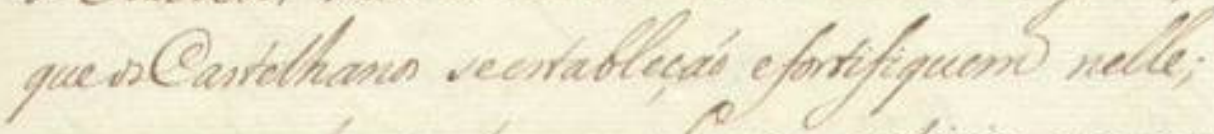
mas as constrais longue dover notidias nequas,

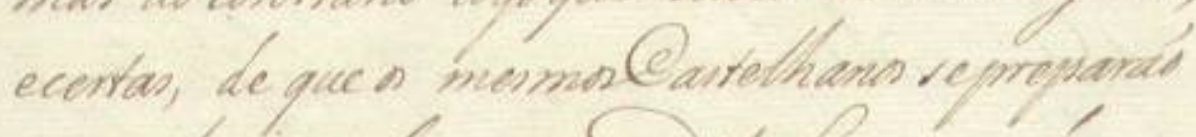

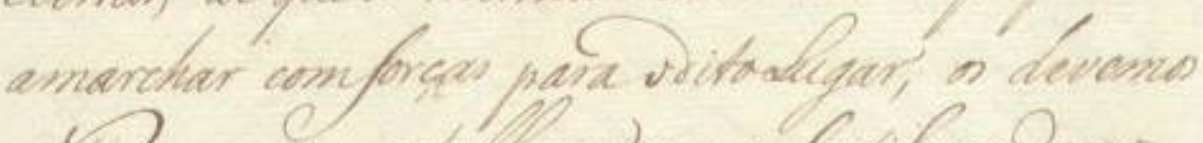

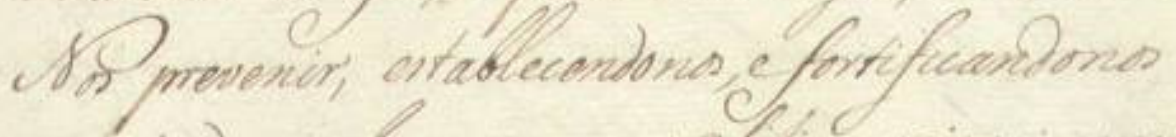

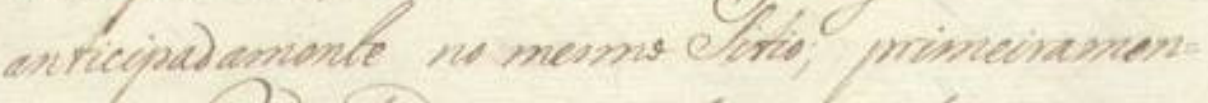

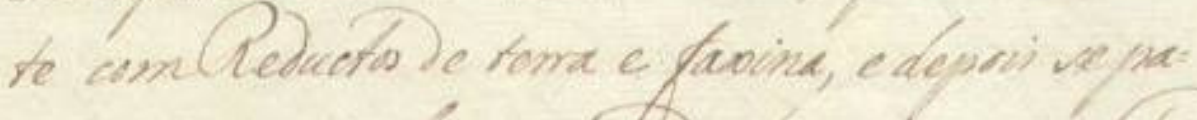

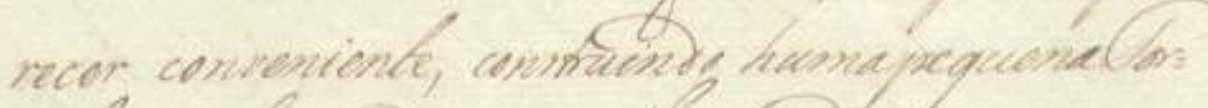

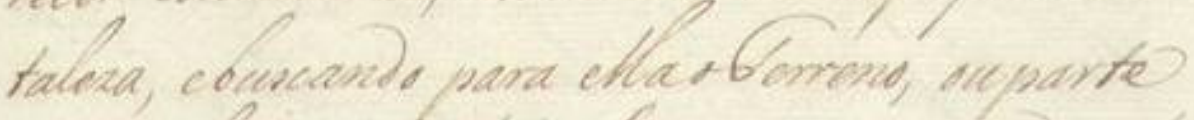
mais clevala di dixelena, que commandands - caminho, cdonumando para stadas as ware, nés Seia bominate de alpioma.

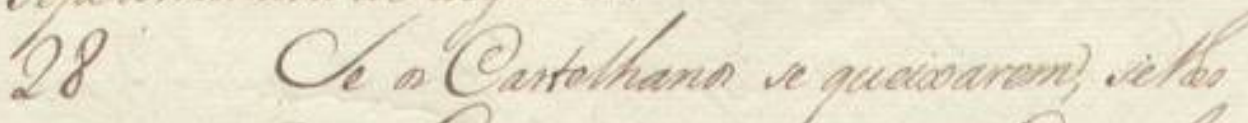

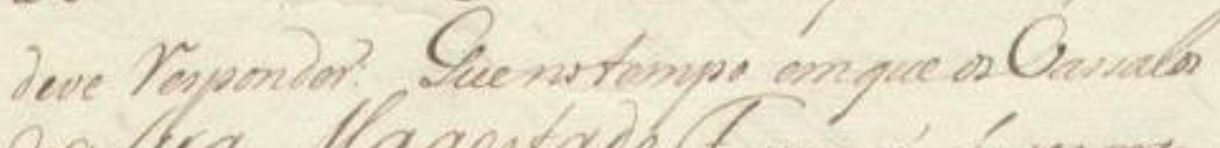

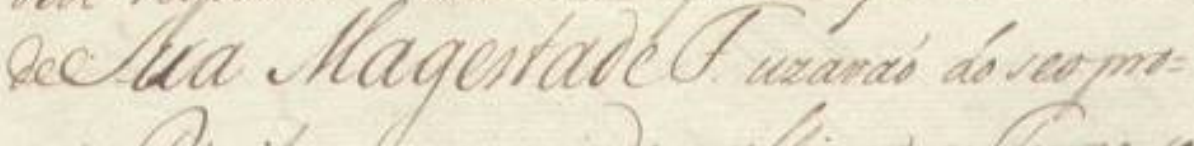

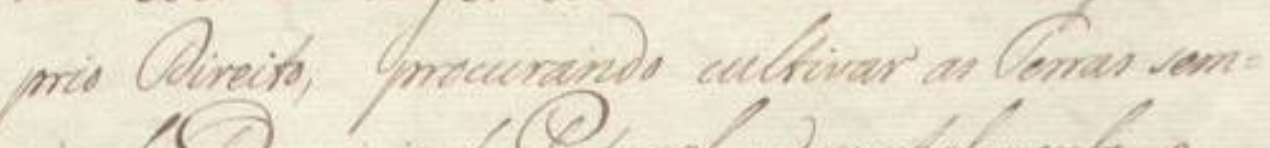

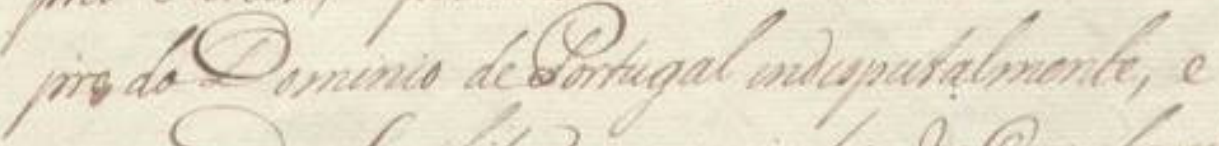

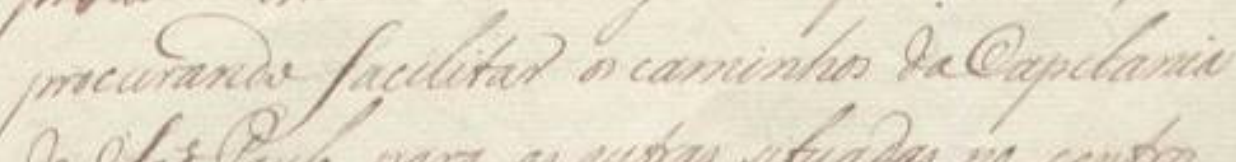

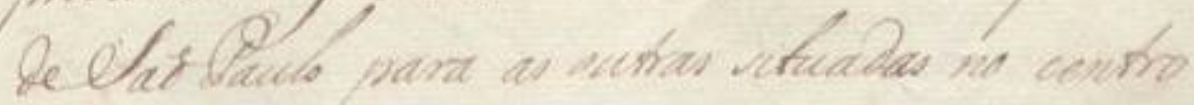


||110r|| [[Serra]]doMaracayû, enella muito particularmen=

295 te oPasso ouEntrada da mesmaSerra, que vem

doCuruguaty para a nossa parte: [espaço] E se este

Passo for taõ emportante, comoseve naCarta $\mathrm{To}=$

pografica, remetida peloTenente AntonioLopes

deAzevedo, naõ devem consentir de modo algum,

queosCastelhanos seestableçaõ efortifiquem nelle;

mas ao contrario logoquehouver noticias seguras,

ecertas, de que os mesmosCastelhanos sepreparaõ

amarchar comforças para o ditoLugar, os devemos

Nos prevenir, establecendo nos, e fortificandonos

anticipadamente no mesmo Sitio; primeiramen-

te comReductos de terra e faxina, e depois se pa= recer conveniente, construindo humapequenaFor= taleza, ebuscando para ella oTerreno, ou parte mais elevada da ditaSerra, que commandando

310 o caminho, edominandoparatodas as partes, naõ seja dominada de alguma.

28 Se os Castelhanos se queixarem, selhes deve responder: Quenotempo em que osVassalos deSua MagestadeFidelíssima uzavaõ do seopro= prio Direito, procurando cultivar as Terras sem= pre doDominio dePortugal indisputalmente, e procurando facilitar os caminhos daCapitania deSaõ Paulo para as outras situadas no centro 


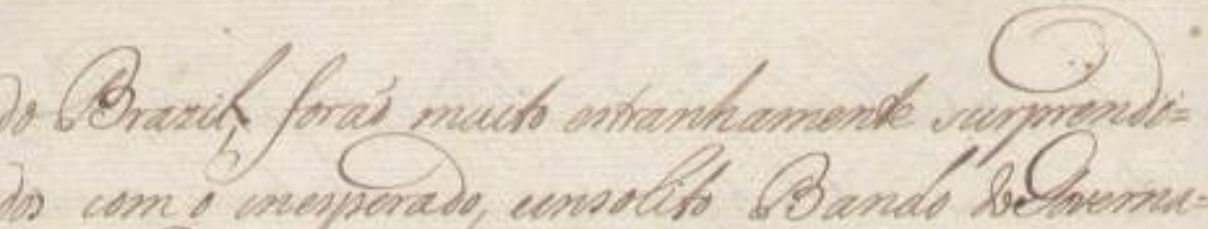

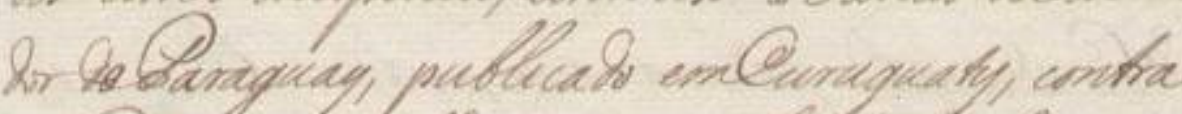

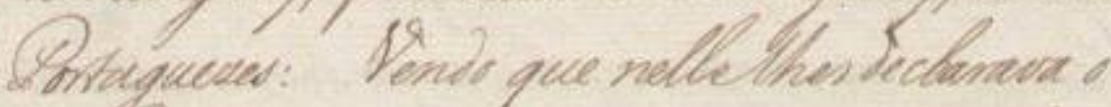

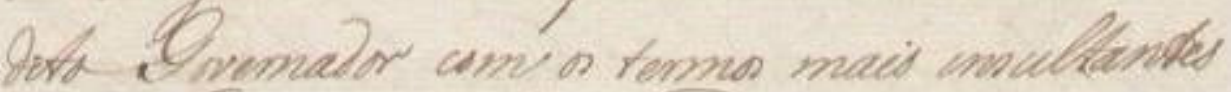

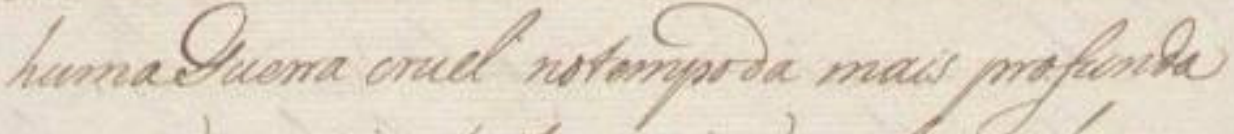
par, cta mais entreita amiate entre as dues

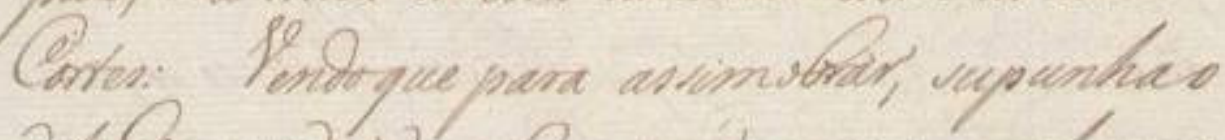

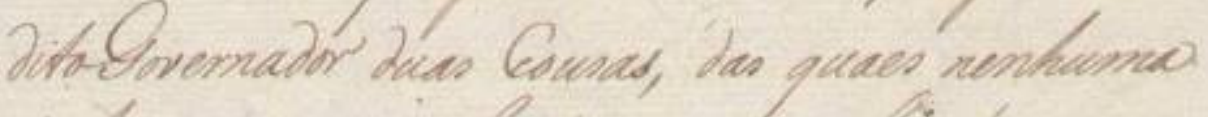

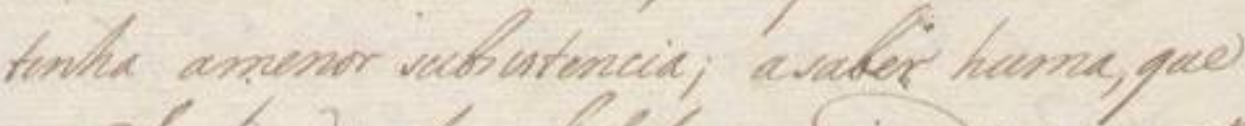

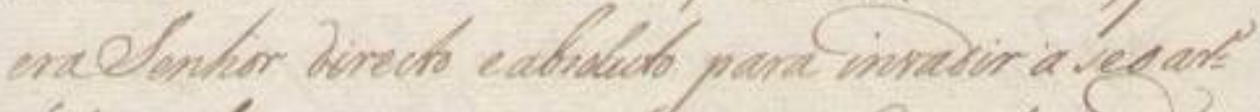

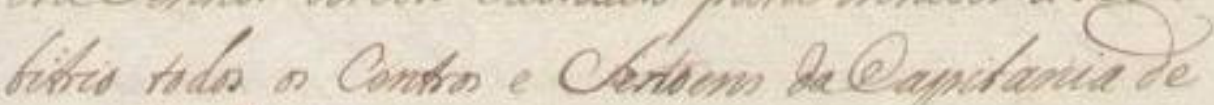

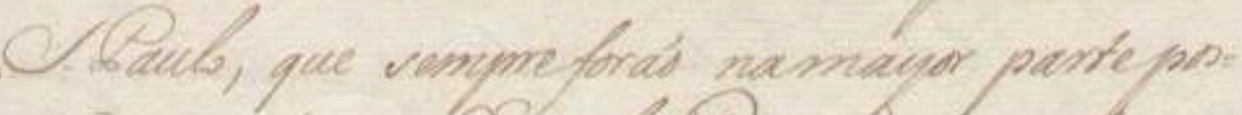
wido, eate porretos pelos bontuqueses; suba, que

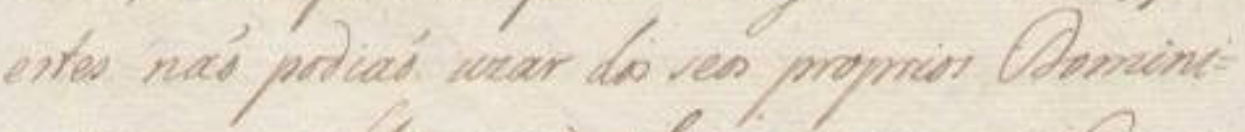
os para os cultivaram), efranpuearem os Came who de hurs para sumos e firios minger dono

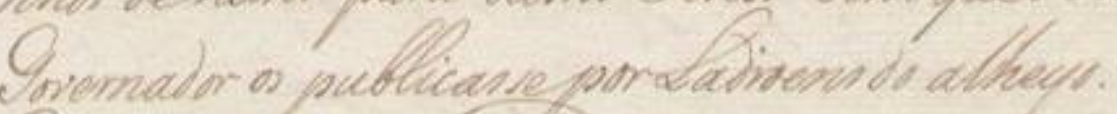

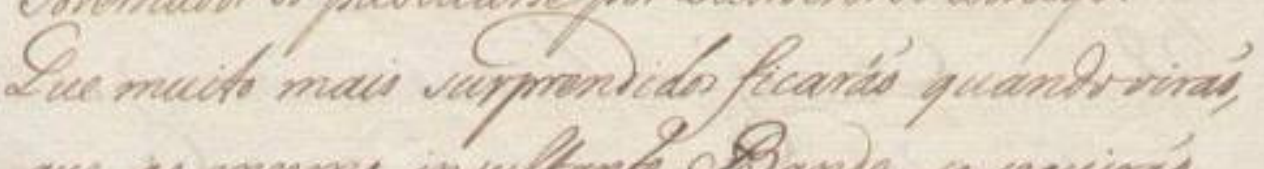
que is mant insultante asmo reveguind

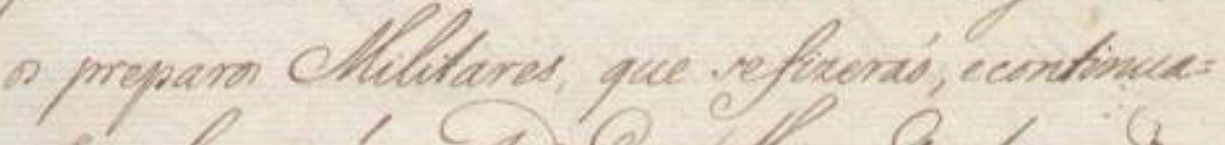

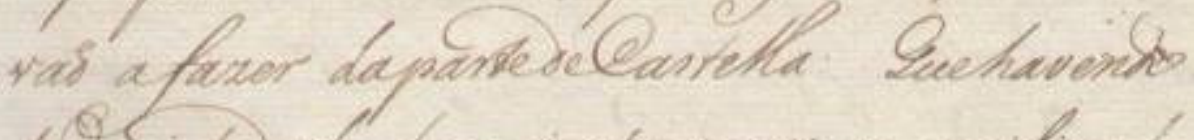

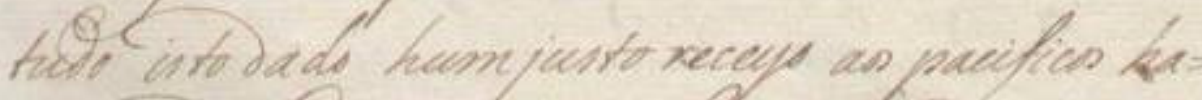

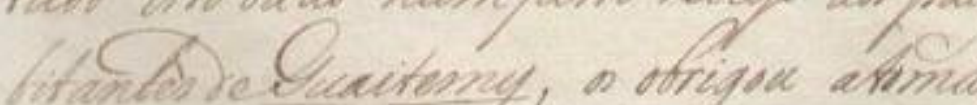

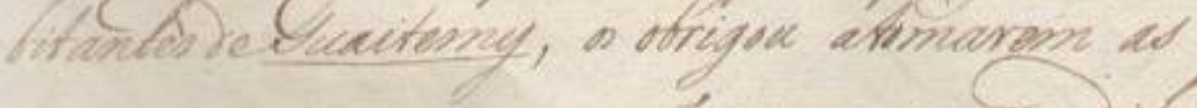

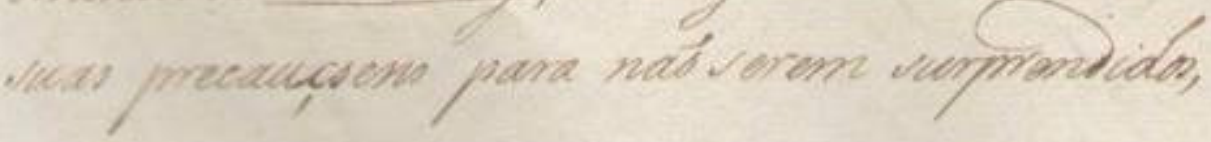


||110v || doBrazil, foraõ muito estranhamente surprendi= dos com o inesperado, einsolito Bando doGoverna= dor doParaguay, publicado emCuruguaty, contra os Portuguezes: [espaço]Vendo que nellelhes declarava o ditoGovernador com os termos mais insultantes humaGuerra cruel notempoda mais profunda paz, eda mais estreita amizade entre as duas Cortes: [espaço] Vendoque para assim obrar, supunhao ditoGovernador duas Cousas, das quaes nenhuma tinha amenor subsistencia; asaber huma, que eraSenhor directo e absoluto para invadir a seo ar=

330 bitrio todos os Centros e Sertoens daCapitania de Saõ Paulo, que sempreforaõ namayor partepos= suidos, e ate povoados pelos Portuguezes; outra, que estes naõ podiaõ uzar dos seos proprios Domini= os para os cultivarem, efranquearem os Cami= nhos dehuns para outrosSitios sem queo dito Governador os publicasseporLadroens do alheyo: Que muito mais surprendidos ficaráõ quandoviraõ, que ao mesmo insultante Bando se seguiraõ os preparos Militares, que sefizeraõ, e continua= 340 vaõ afazer dapartedeCastella: Quehavendo tudo isto dado hum justo receyo aos pacificos ha= bitantes deGuaitemy, os obrigou atomarem as suas precauçoens para naõ serem surprendidos, 
$\|111 r\|$

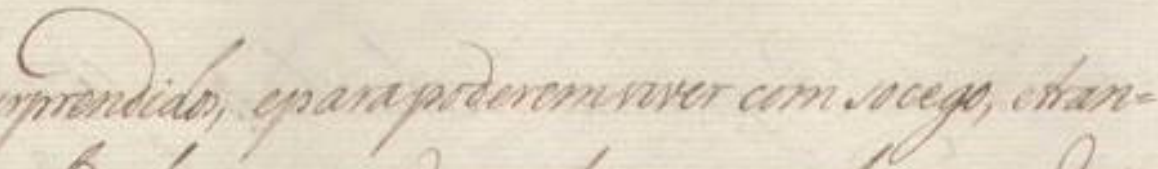
juiliade, ne wer on que heves, que heorque beze=

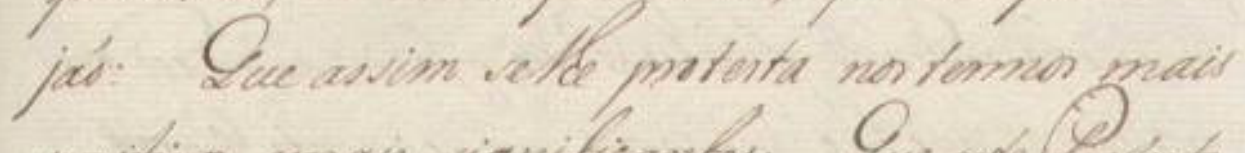
ponition, emais rignificantes. Que cone buresto.

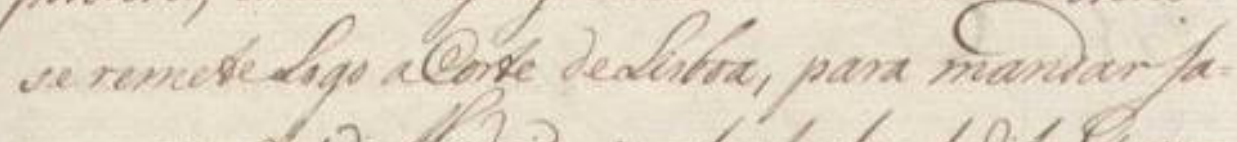

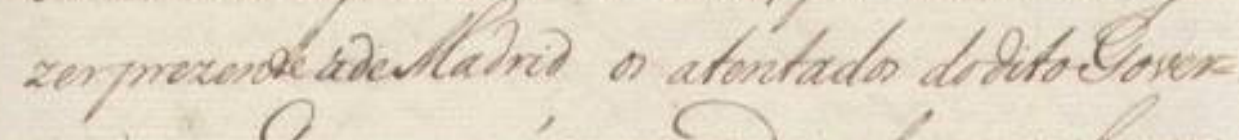

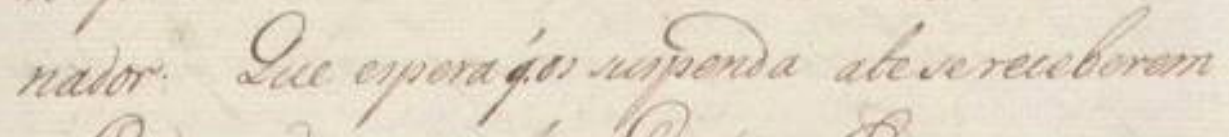

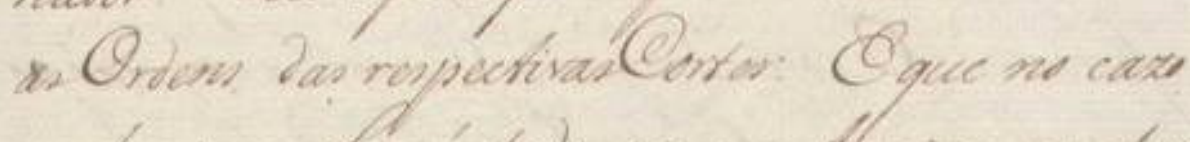
conmarid se obrará tude, que aushoriza ancitural iefora

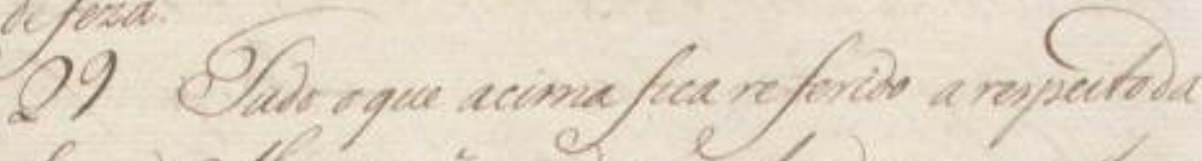
comalectlanacayie, redeve entower somorde m cars dever acrorradalella achave conn que o. Qs relhans sccopandor no fecturn por tuena vas

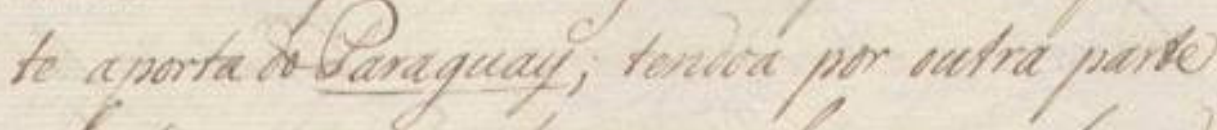
acorta para un atacarom elancarom fora do Guaitemy; yor que ve adita entrada for der. ta empontancia, nad Jevenues por agone alians tarnos a muais, que a fornificar edeforder abyse caculition brameres.

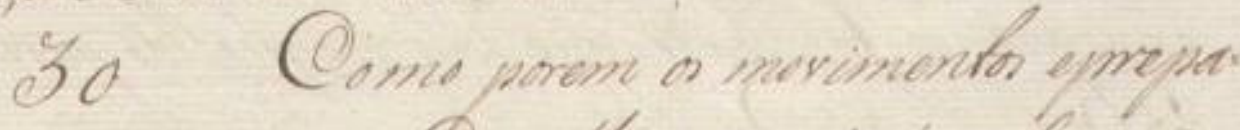
ndonmono@aitulhano, nas.ó.refaremo souti Da parte \&e barana; mas fameom $2 a$

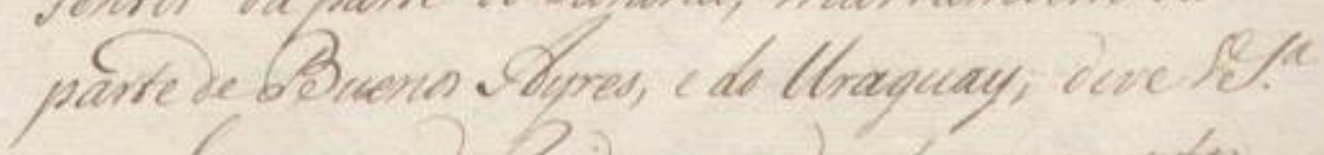

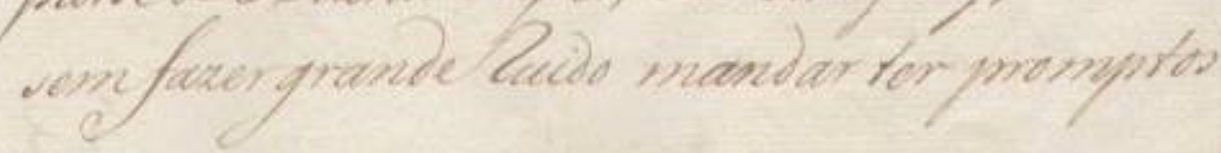

357 
||111r|| [[surprendidos,]] epara poderemviver com socego, etran=

345 quilidade, no uzo doquehe seo, quehe o que deze= jaõ: [espaço] Que assim selhe protesta nos termos mais positivos, emais significantes: [espaço] Que esteProtesto se remeteLogo aCorte deLisboa, para mandarfa= zerprezente ádeMadrid os atentados doditoGover= nador: [espaço] Que espera que os suspenda atesereceberem asOrdens das respectivasCortes: E que no cazo contrario se obrará tudo, o que authoriza anatural defeza.

29 Tudo o que acima fica referido a respeito da

355 Serra deMaracayû, sedeve entender somente no cazo deser aentrada della achave com que osCas= telhanos ocupando-a nos fechempor huma par= te aporta doParaguay; tendoa por outra parte aberta para nos atacarem elançarem fora do

360 Guaitemy; por que se adita entrada for des= ta emportancia, não devemos por agora adian= tar nos a mais, que a fortificar edefender aPra= ça e Sitio dos Prazeres.

30 Como porem os movimentos eprepa= ros dos mesmos Castelhanos, naõ só sefazem sentir da parte doParana; mas tambem da parte deBuenos Ayres, e do Uraguay; deveVossaSenhoria semfazer granderuido mandar ter promptos 


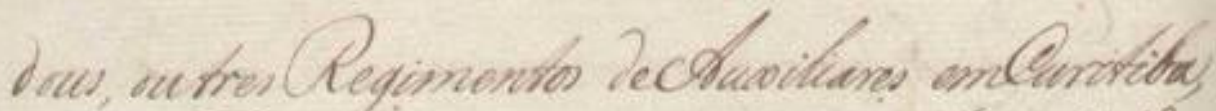

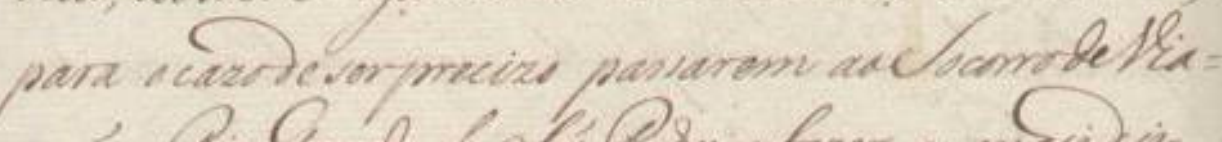

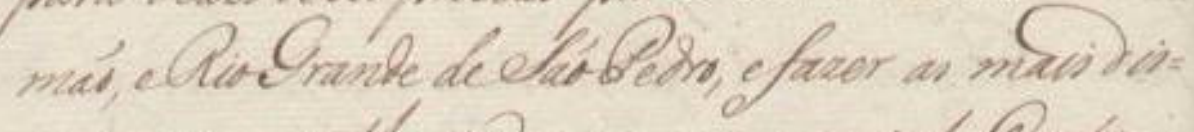
posicens, quethe miciany na veguinte Canta.

o) Devere te, quepor caurelle veja mecizo. dezar comacto: vidade, evigilancise Detodas an requerancas que Deion reforidas: Ocents he que s@astelthanos, neips

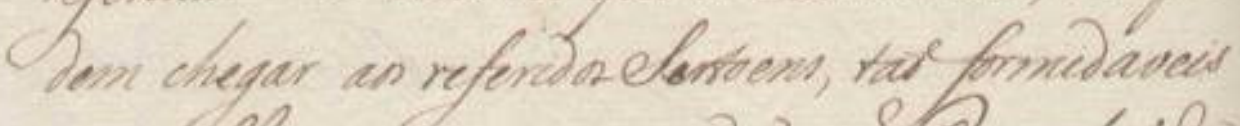
amo clan ve queran porsuadid? OP guehaide marchar por Oexerros, elomas epor Bos ques fal so do necosseris para subivirio avida humana:

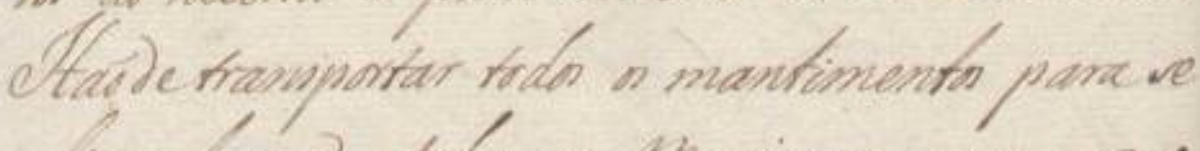
alimertarend, ersdas as Mumicoems prana nos forderem: etrasdepassar muirson Genctoric fal

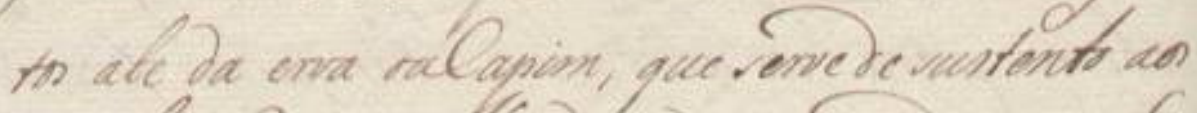

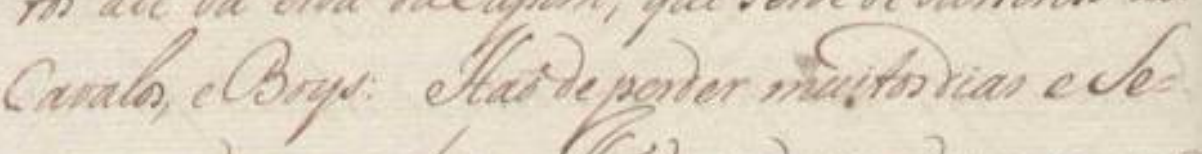
manas de marcha: Stasidepadecer Deserceemse

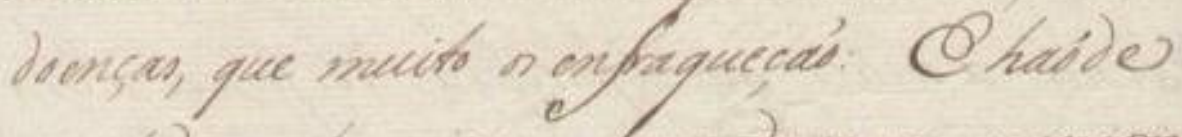

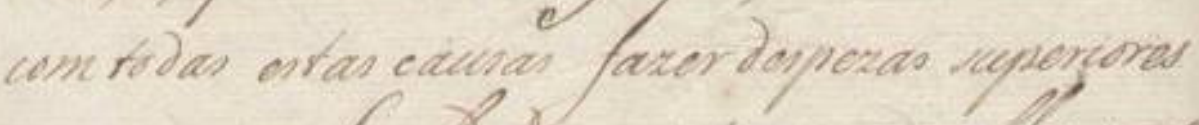
as pequenas facubs abo que tom naquellas parses 3. Unta corra comidoracaís a maí ruose turna untagem enaturat Befou que til podo

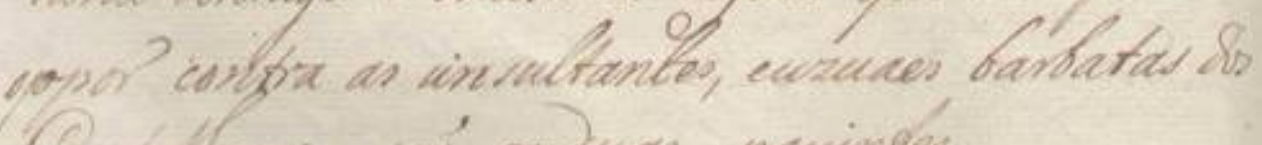

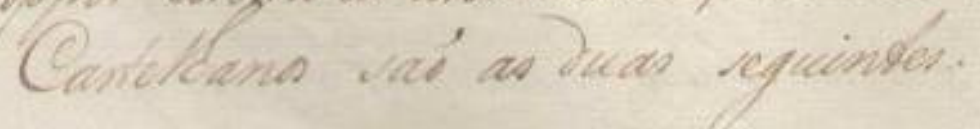


\|111v\| dous, outres Regimentos deAuxiliares emCuritiba, para o cazode serprecizo passarem aoSocorrodeVia= maõ, eRioGrande deSaõPedro, efazer as mais dis= posiçoens, quelhe indicarey na seguinte Carta. 31 Devese porem reflectir, que naõ obstan= te, quepor cautella seja precizo uzar com acti= 375 vidade, evigilancia detodas as seguranças que deixo referidas: [espaço] $O$ certo he que os Castelhanos, naõpo= dem chegar aos referidosSertoens, taõformidaveis como elles se querem persuadir: Porquehaõ de marchar por Dezertos, eSerras, eporBosques fal=

380 tos do necessario para subsistir avida humana: Haõ detransportar todos os mantimentos para se alimentarem, etodas as Muniçoens para nos $0=$ fenderem: [espaço] Haõ de passar muitos Territorios fal= tos ate da erva ouCapim, que serve de sustento aos

385 Cavalos, e Boys: [espaço] Haõ de perder muitos dias eSe= manas de marcha: [espaço] Haõ depadecer deserçoens, e doenças, que muito os enfraqueçaõ: [espaço] E haõ de com todas estas causas fazer despezas superiores as pequenas faculdades que tem naquellas partes

39032 Nesta certa consideraçaõ amais opor= tuna ventagem enatural defeza queVossaSenhoria pode oppor contra as insultantes, euzuaes barbatas dos Castelhanos saõ as duas seguintes. 
23

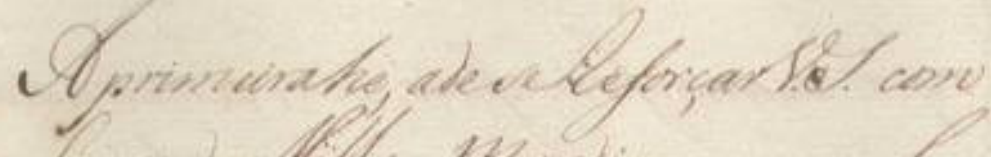

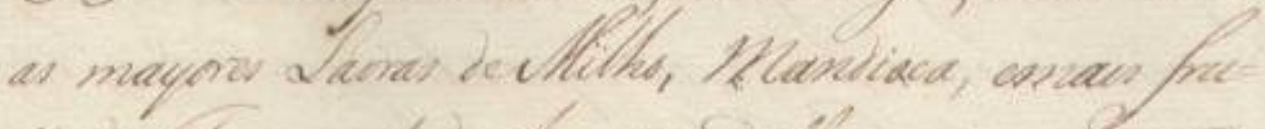

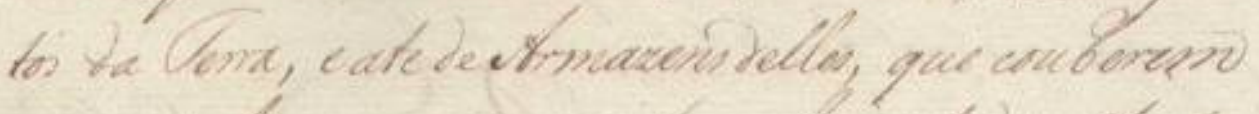

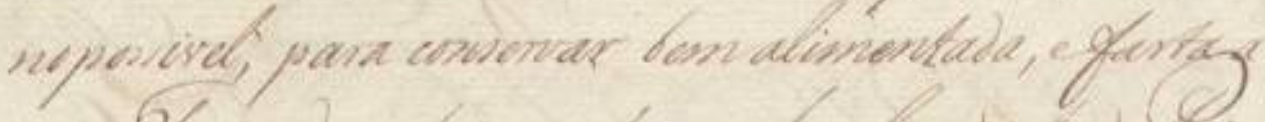

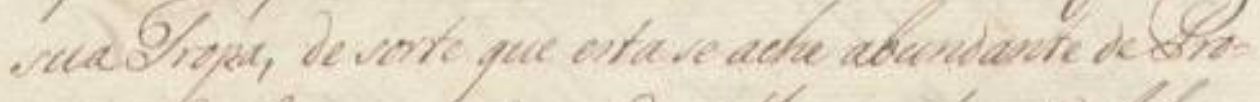

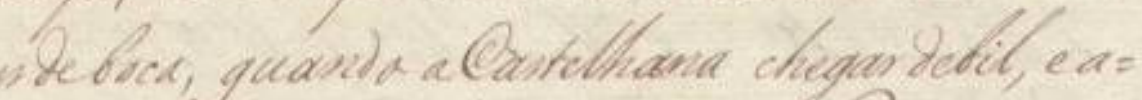

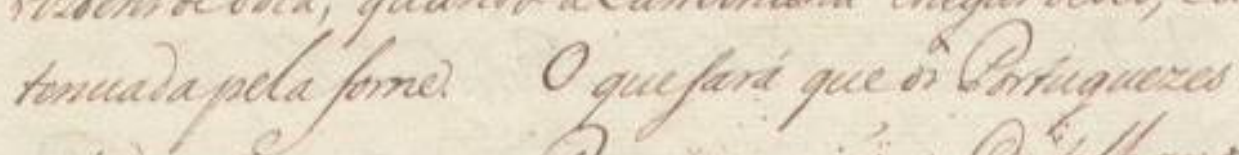

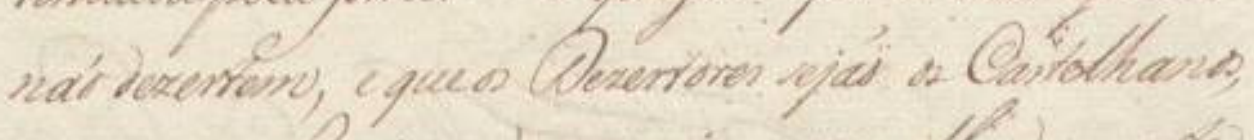

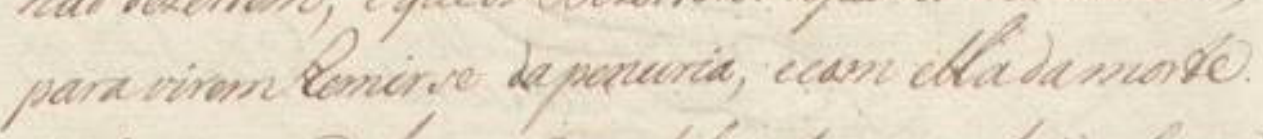

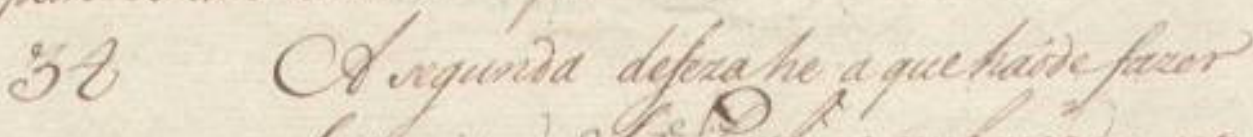

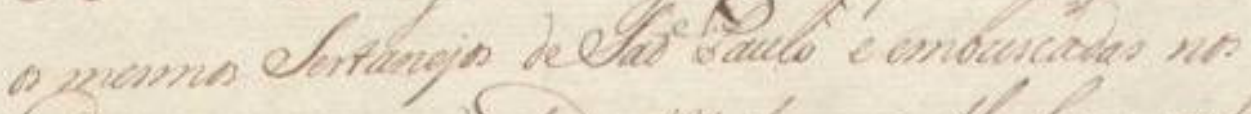

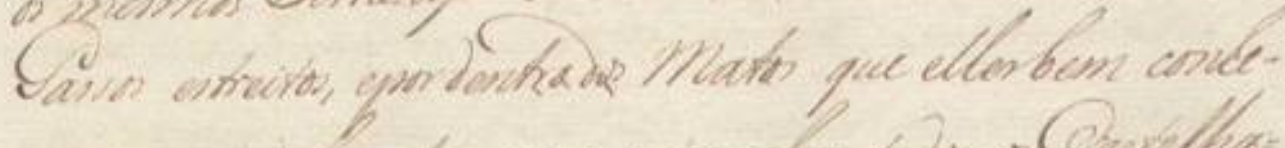

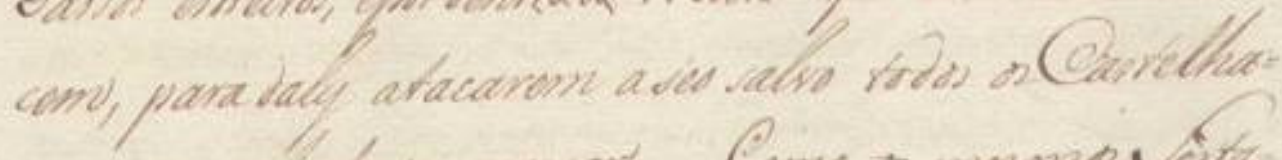

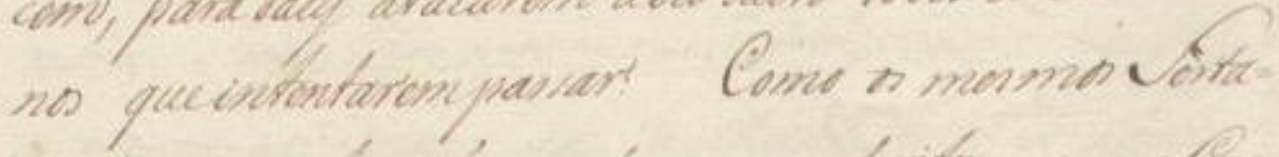
nitas a paricarad no tempos pmeterits; cons a (Dn. requoniave fareremevacuar pelos reforsin (Conte-

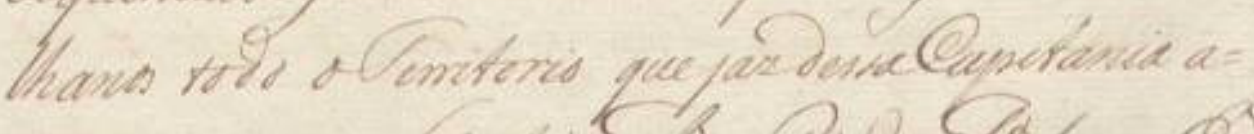

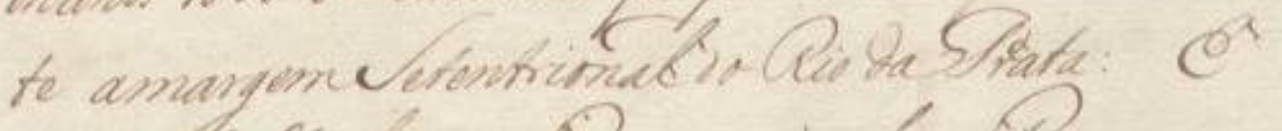

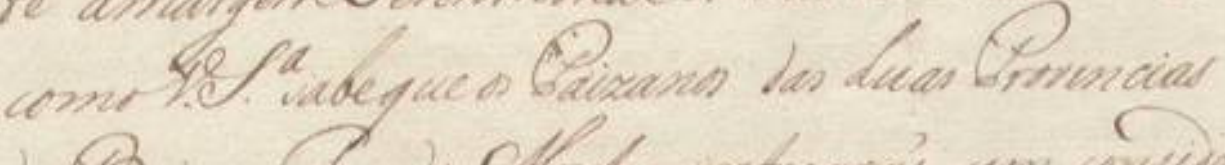

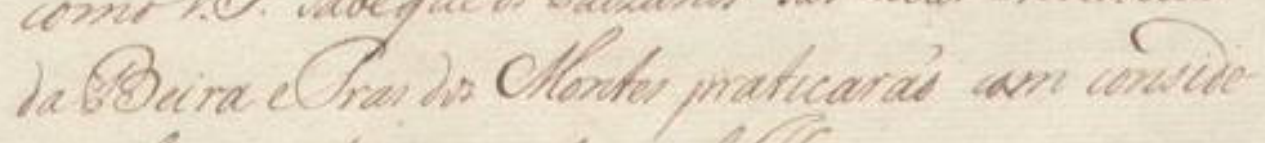
ravel parte ds vesenta mil Stoment, em que cons as Orovinicias

๖ீ

(c) Harllapertate unfia ne

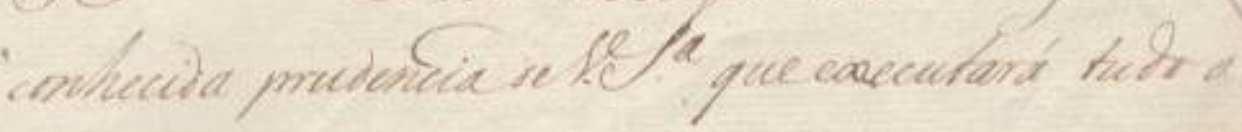

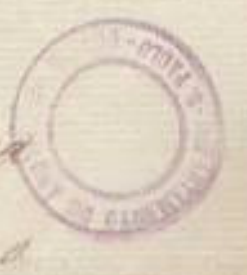


as mayores Lavras deMilho, Mandioca, emais fru= tos da Terra, e ate deArmazens delles, que couberem nopossivel, para conservar bem alimentada, efarta a sua Tropa, de sorte que esta se ache abundante dePro= vizoens deboca, quando aCastelhana chegar debil, e a= tenuada pela fome. [espaço] O quefará que os Portuguezes naõ dezertem, e queos Dezertores sejaõ osCastelhanos, paraviremremir se dapenuria, ecom ella damorte.

34 A segunda defezahe quehaõ defazer

405 os mesmos Sertanejos deSaõ Paulo e embuscadas nos Passos estreitos, epor dentro dos Matos que ellesbem conhecem, para daly atacarem aseo salvo todos osCastelha= nos queintentarem passar: [espaço] Como os mesmos Serta= nistas japraticaraõ nos tempos preteritos; com a Con-

410 sequencia defazeremevacuar pelos referidosCasteIhanos todo oTerritorio quejaz dessaCapitania $\mathrm{a}=$ te amargemSetentrional doRio daPrata: [espaço] E comoVossaSenhoria sabeque os Paizanos das duas Provincias daBeira eTras dos Montes praticaraõ com conside= 415 ravel parte dos sessenta mil Homens, emque con= sistia o Exercito Espanhol, que invadio as ditas $d u=$ as Provincias

35 Sua Magestade confia na* conhecida prudencia deVossaSenhoria queexecutará tudo o

\footnotetext{
* Há, ao lado, o carimbo circular do AESP.
} 


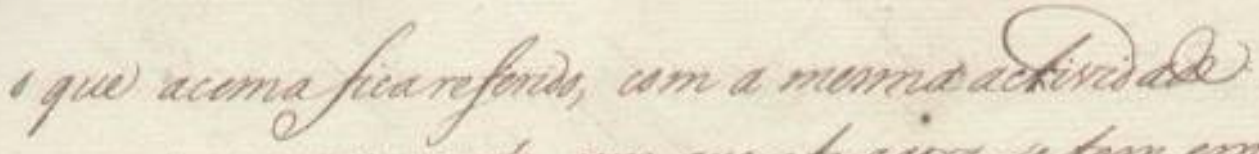

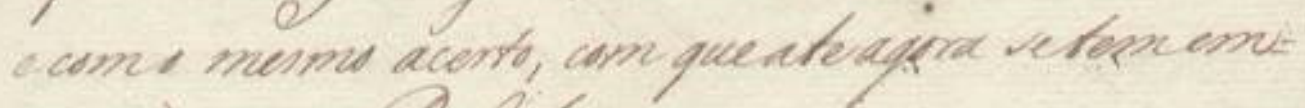

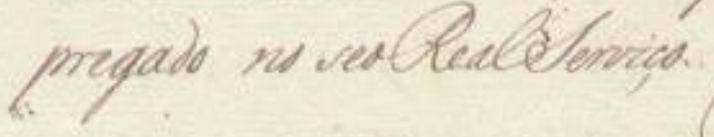

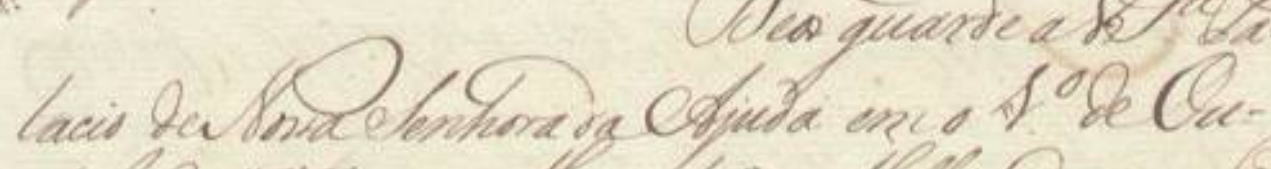

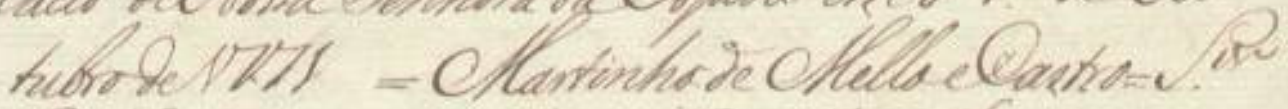

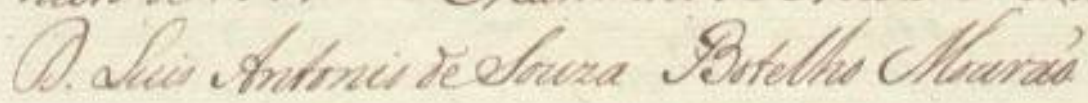

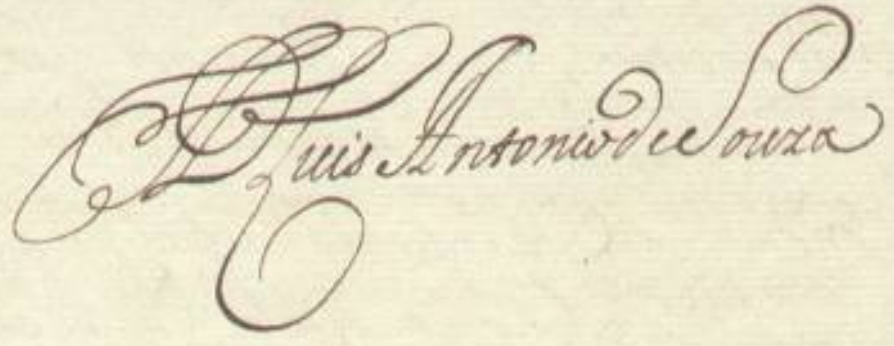


$420 \quad\|112 v\|[[0]]$ que acimaficareferido, com a mesma actividade ecomo mesmo acerto, com que ate agora setemem= pregado no seoRealServiço.

Deos guarde aVossaSenhoria $\mathrm{Pa}=$ lacio deNossaSenhora daAjuda em o primeiro deOu=

425 tubrode1771 $=$ Martinho de MelloeCastro $=$ Senhor

Dom Luis Antonio deSouza Botelho Mouraõ.

DomLuis AntoniodeSouza 


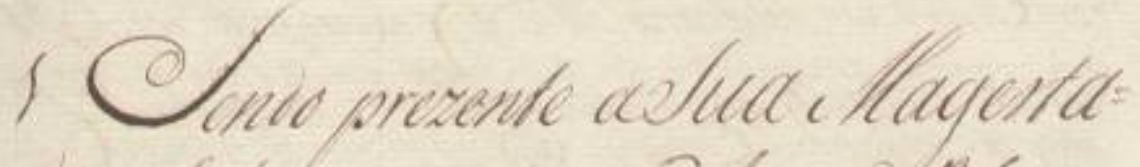

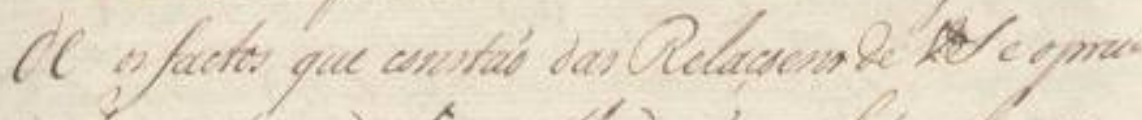

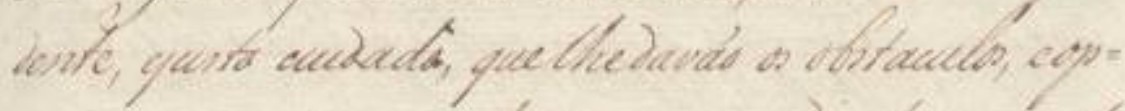

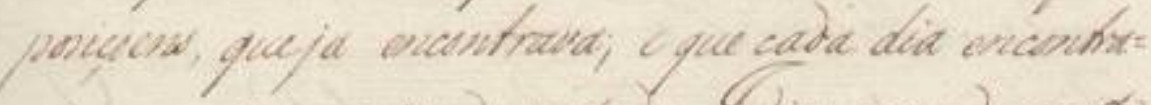

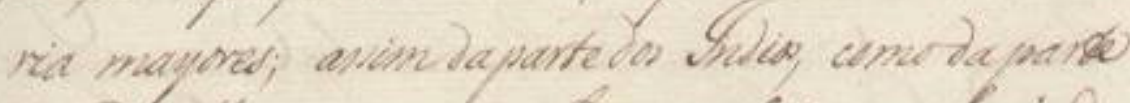
Qn (E)

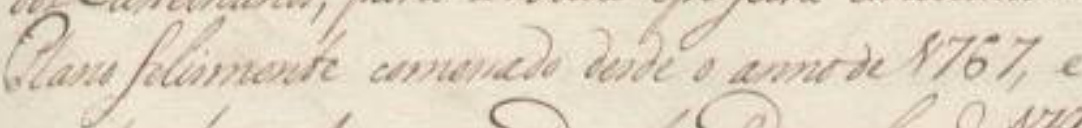

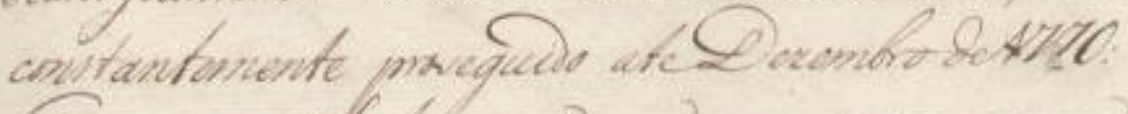

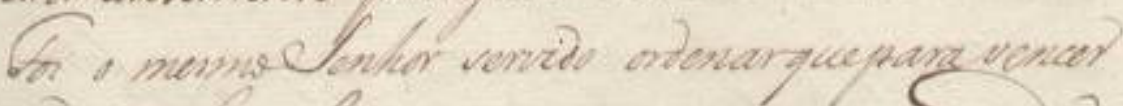

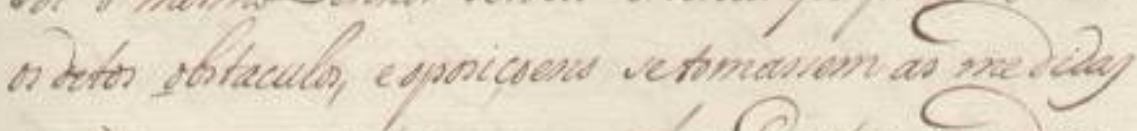

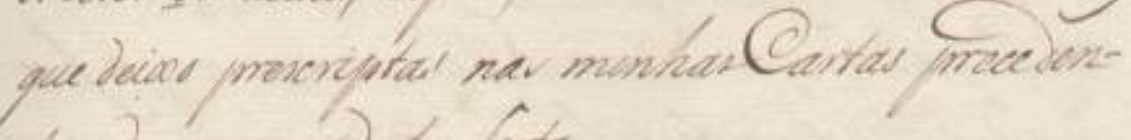

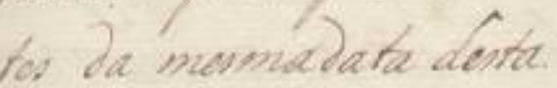

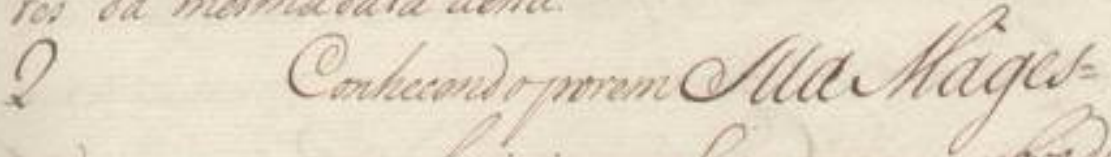

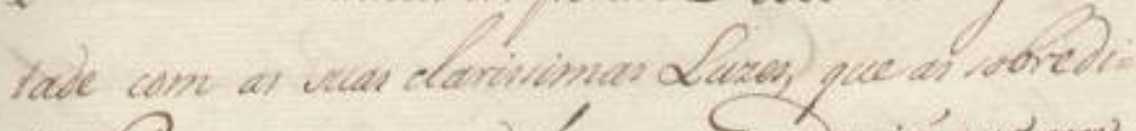

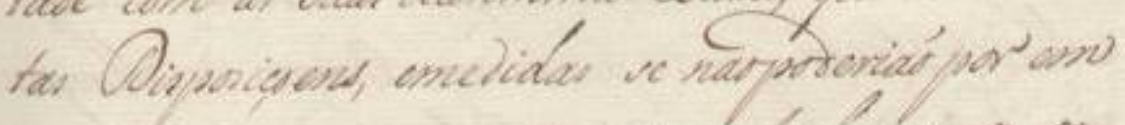

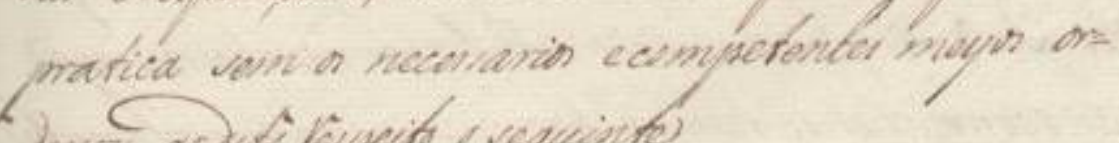

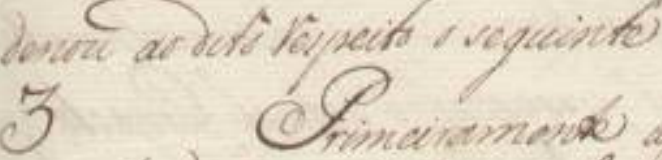

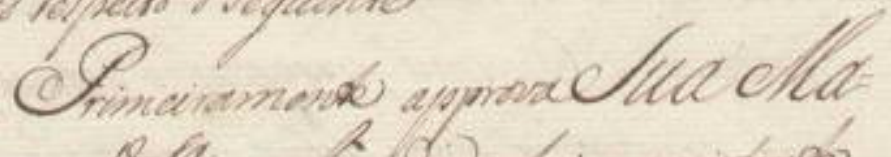

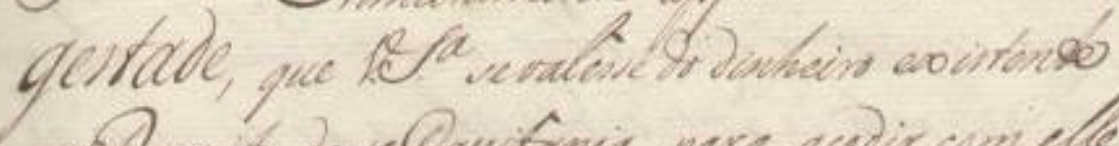

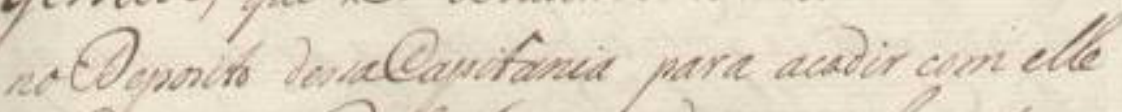

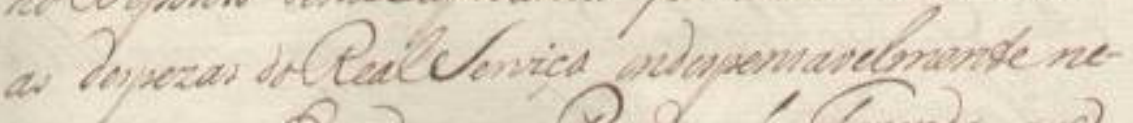

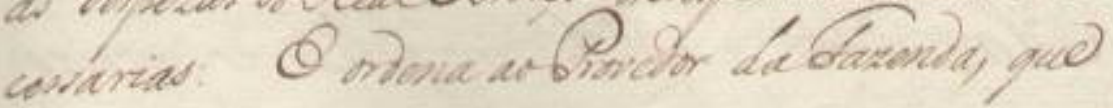


||113r|| Carta quarta

1 Sendo prezente aSua Magesta=

de os factos que constaõ das Relaçoens deVossaSenhoria e opru= dente, ejusto cuidado, quelhedavaõ os obstaculos, eop=

5 posiçoens, queja encontrava; e que cada dia encontra= ria mayores; assim daparte dos Indios, comodaparte dosCastelhanos, para a solida eperfeita conclusaõ do Plano felismente comessado desde o annode1767, e constantemente proseguido ateDezembrode1770:

10 Foi o mesmoSenhor servido ordenarqueparavencer os ditos obstaculos, e oposiçoens setomassem as medidas que deixo prescriptas nas minhasCartas preceden= tes da mesma data desta.

\section{ConhecendoporemSuaMages=}

15 tade com as suas clarissimas Luzes, que as sobredi= tas Disposiçoens, emedidas se naõpoderiaõ por em pratica sem os necessarios ecompetentes meyos or= denou ao dito respeito o seguinte 3 Primeiramente approvaSua $\mathrm{Ma}=$

20 gestade, que VossaSenhoria sevalesse do dinheiro existente noDeposito dessaCapitania para acodir com elle as despezas doRealServiço indispensavelmentenecessarias: [espaço] E ordena aoProvedor daFazenda, que 


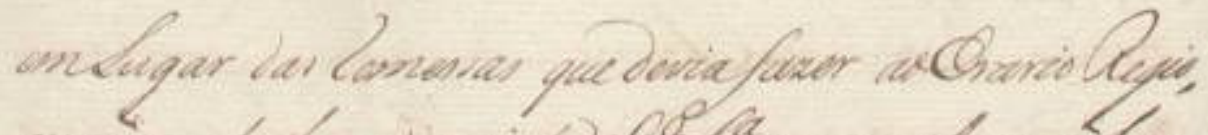

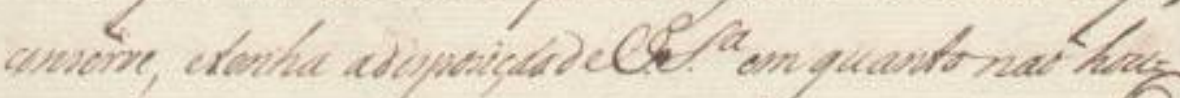

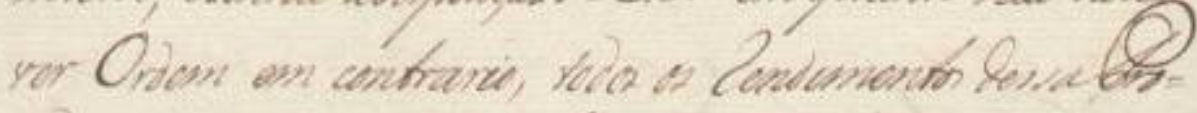

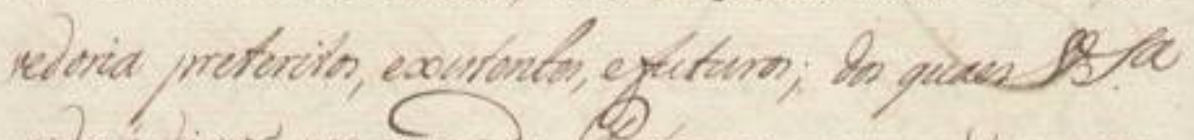

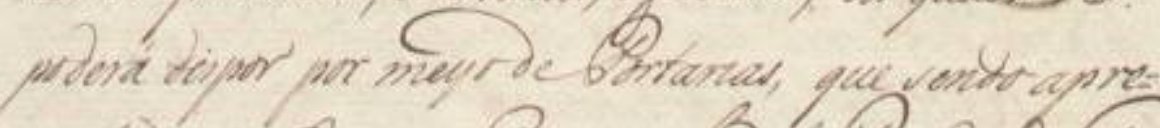

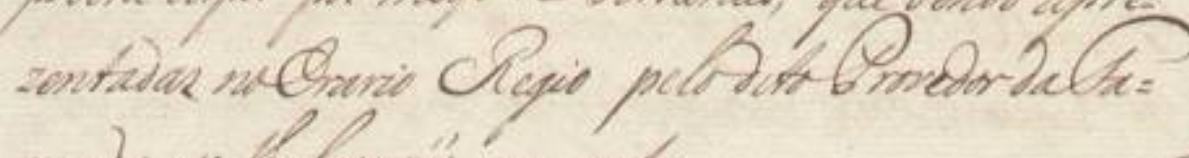
zenda veluelevirí con conta.

2

(O)<smiles>C1=CC2C=CC2=C1</smiles>
Ointela vera at bedrominula pana mandar lop varifurer newo

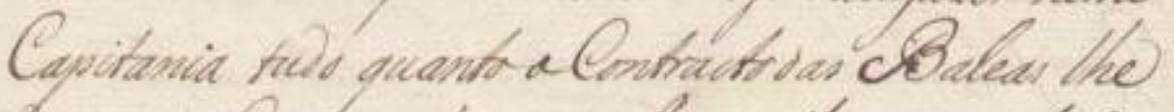

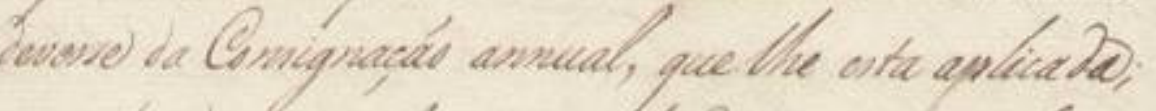
aceptuais vomente veis conts berais que nue formo

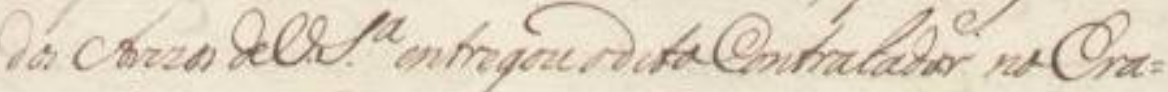

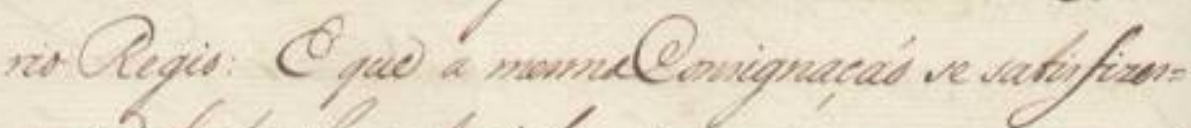

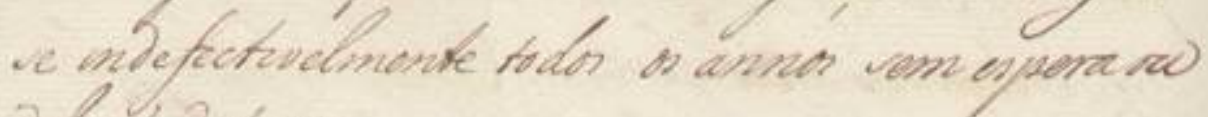
delaces deromse.

25

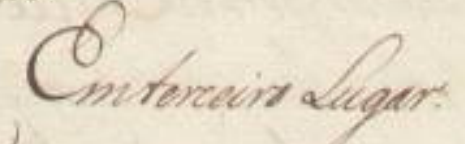

chaper

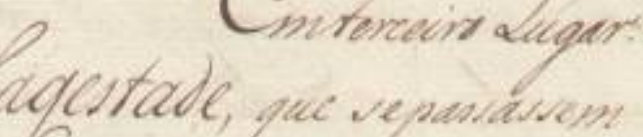
C. Onders al Clamper

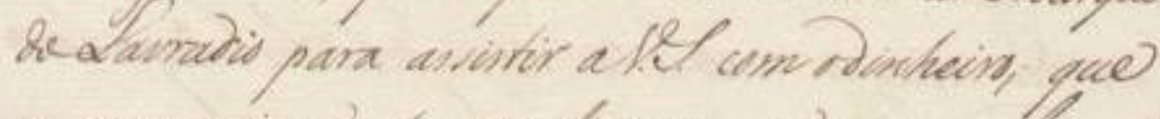

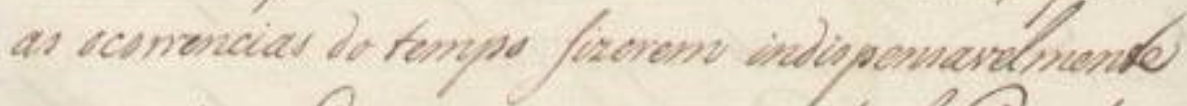

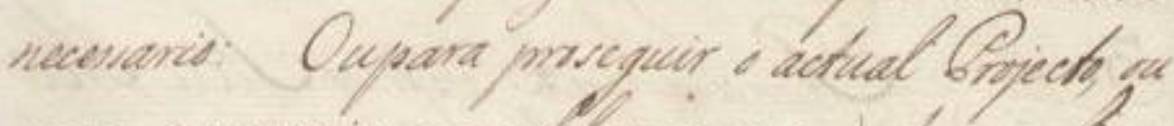

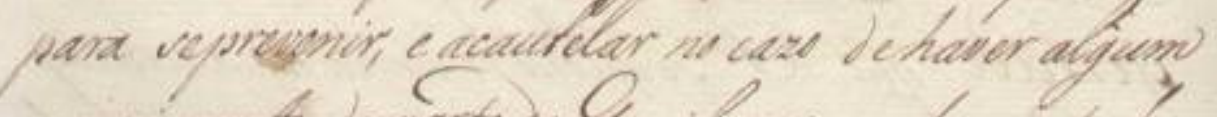

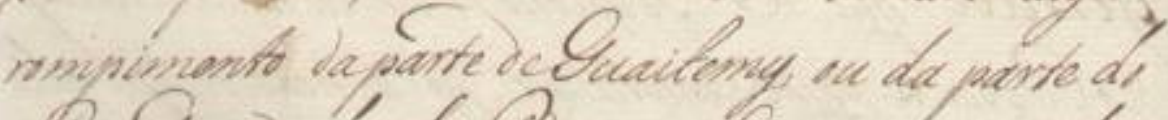

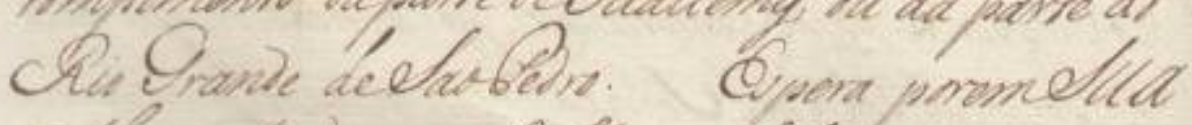

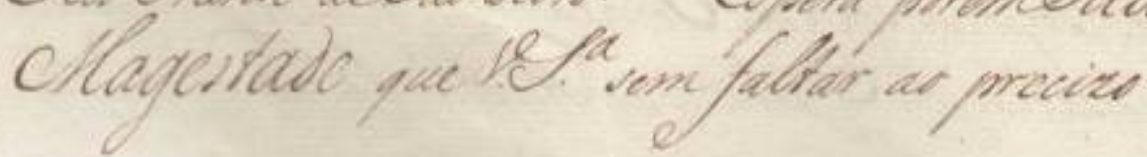


||113v|| emLugar das remessas quedeviafazer aoErario Regio, conserve, etenha adisposiçaõ deVossaSenhoria em quanto nao hou= ver Ordem em contrario, todos os rendimentos dessaPro= vedoria preteritos, existentes, efuturos; dos quaes VossaSenhoria poderá dispor por meyo dePortarias, que sendo apre= zentadas noErario Regio peloditoProvedor daFa= 30 zenda se lhelevaráo em conta.

4 Em segundoLugar se deoOrdem algna= cioPedroQuintela para mandar logo satisfazer nessa Capitania tudo quanto oContracto das Baleas Ihe devesse da Consignaçaõ annual, quelhe esta aplicada;

35 exceptuados somente seis contos dereis, quenaforma dos Avizos deVossaSenhoria entregou oditoContratador noEra= rio Regio: [espaço] E que a mesmaConsignaçaõ se satisfizes= se indefectivelmente todos os annos sem espera ou dilaçaõ detempo.

405 Emterceiro Lugar: [espaço] DeterminouSua Magestade, que sepassassem Ordens ao Marquez doLavradio para assistir aVossaSenhoria com odinheiro, que as ocorrencias do tempo fizerem indispensavelmente necessario: [espaço] Oupara proseguir o actual Projecto, ou

45 para seprevenir, e acautelar no cazo dehaver algum rompimento daparte deGuaitemy, ou da parte do Rio Grande deSaoPedro. [espaço] Espera poremSua Magestade queVossaSenhoria sem faltar ao precizo 


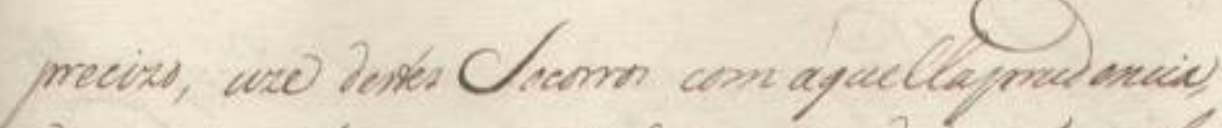
Dirconimente, eccomonicy leque tom late hat andecitas mors.

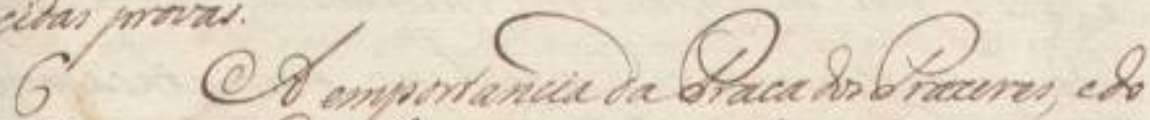

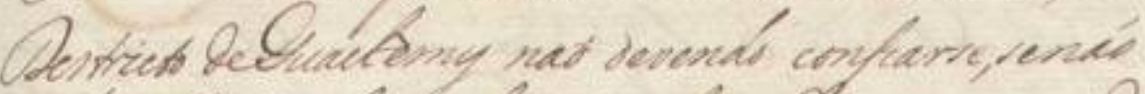

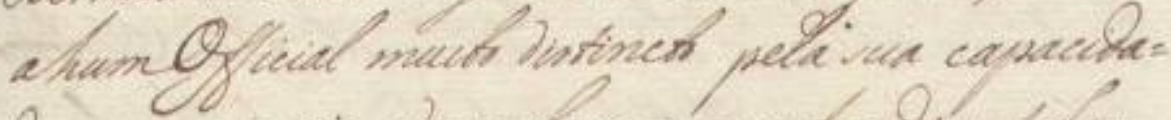

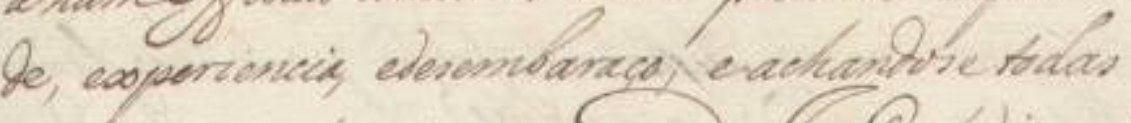

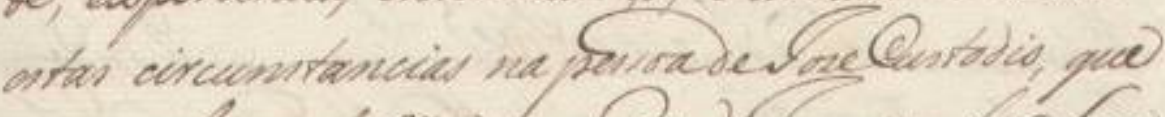

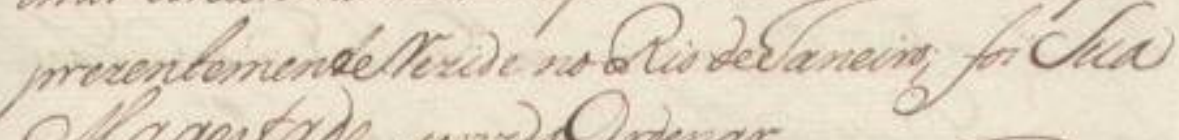
Onaportade remidonteriar

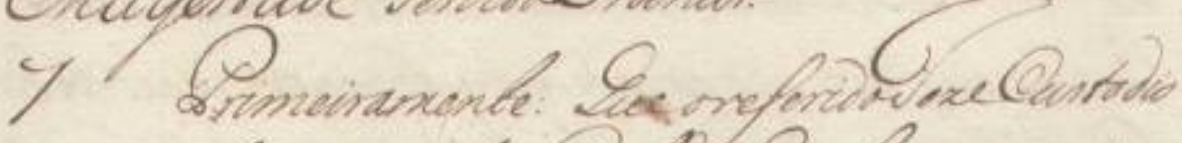

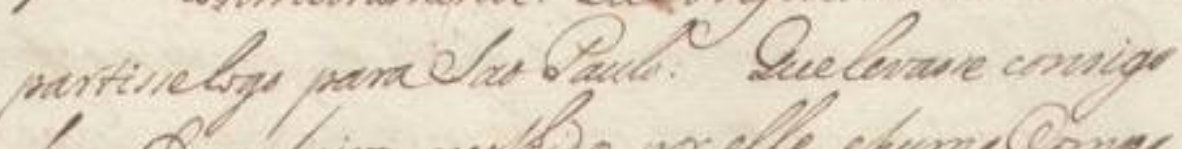

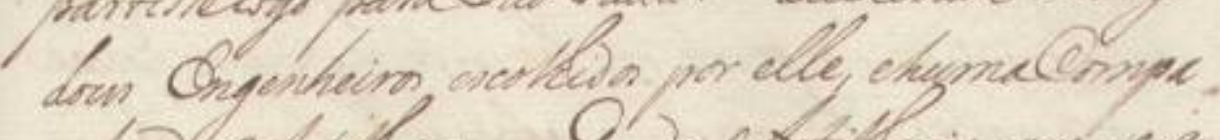

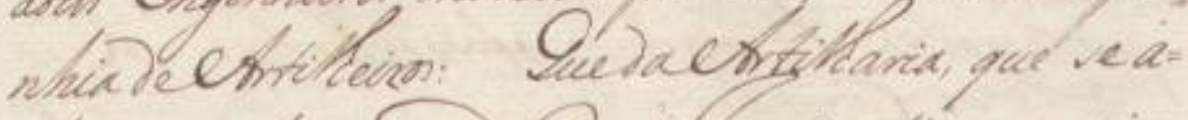

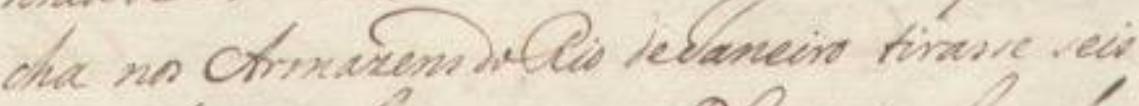

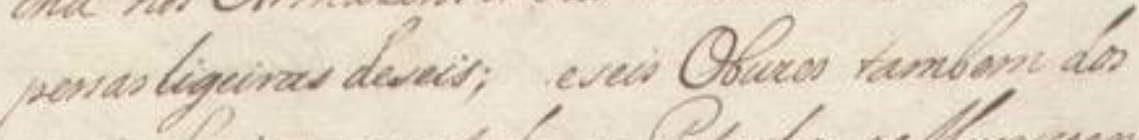

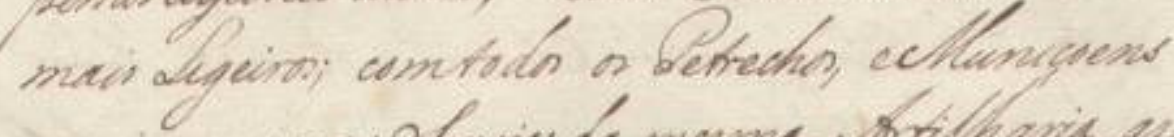

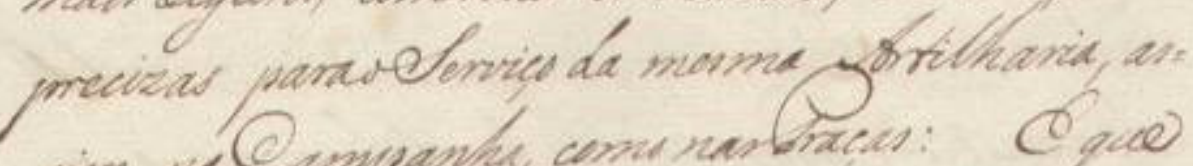

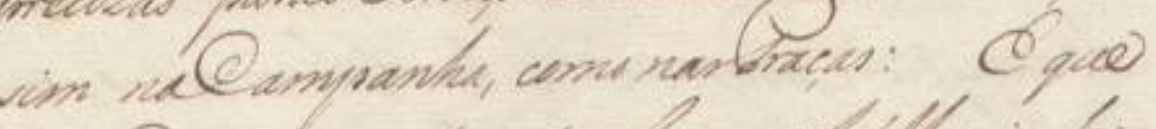

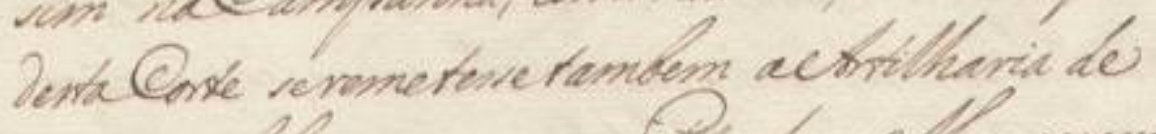

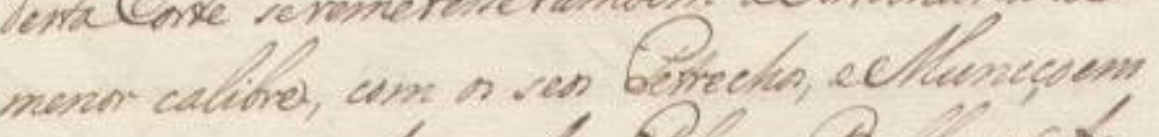

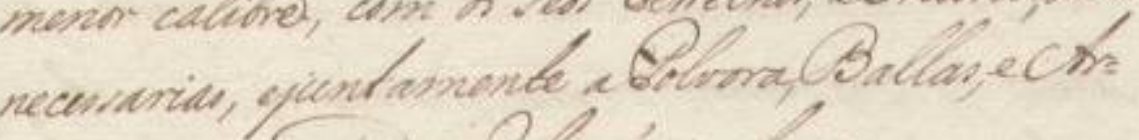
mas que contatire Celacé incluse.

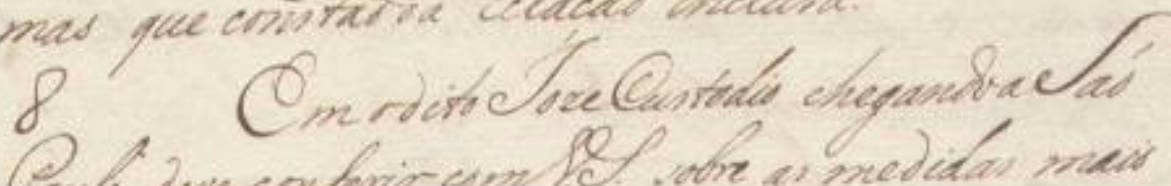

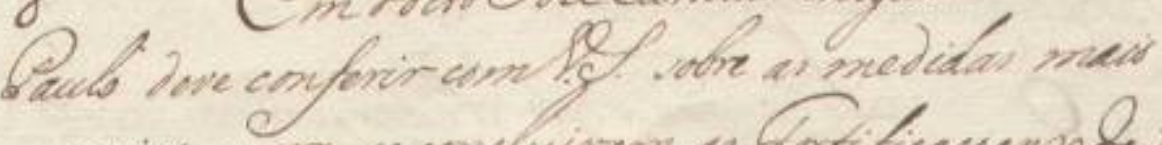

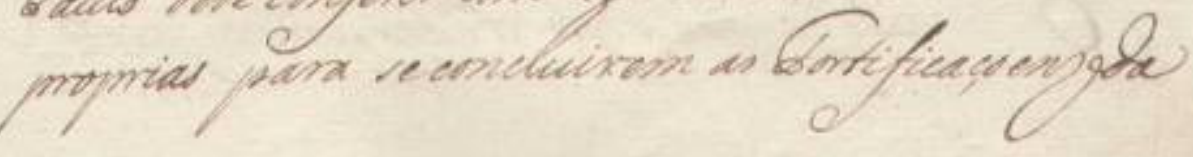


||114r|| [[precizo]], uze destes Socorros com aquellaprudencia,

50 discernimento, e economia, dequetem dado taõ conhecidas provas.

6 A emportancia daPraça dos Prazeres, edo

Destricto deGuaitemy naõ devendo confiarse, senaõ ahumOfficial muito distincto pela sua capacida=

55 de, experiencia, edesembaraço; e achandose todas estas circunstancias na pessoadelozeCustodio, que prezentementerezide noRio delaneiro; foi Sua Magestade servidoOrdenar.

7 Primeiramente: Que oreferidolozeCustodio

60 partisselogo paraSaoPaulo: [espaço] Quelevasse consigo dous Engenheiros escolhidos por elle, ehumaCompa nhia deArtilheiros: [espaço] QuedaArtilharia, que se $a=$ cha nos Armazens doRio delaneiro tirasse seis pessas ligeiras deseis; [espaço] e seis Obuzes tambem dos

65 mais Ligeiros; comtodos os Petrechos, eMuniçoens precizas paraoServiço da mesma Artilharia, as= sim naCampanha, como nasPraças: [espaço] E que destaCorte seremetessetambem aArtilharia de menor calibre, com os seos Petrechos, eMuniçoens

70 necessarias, ejuntamente aPolvora, Ballas, eAr= mas que constãoda relaçaõ inclusa.

$8 \quad$ Em odito lozeCustodio chegandoaSaõ

Paulo deve conferir comVossaSenhoria sobre as medidas mais proprias para seconcluirem as Fortificaçoensda 
010

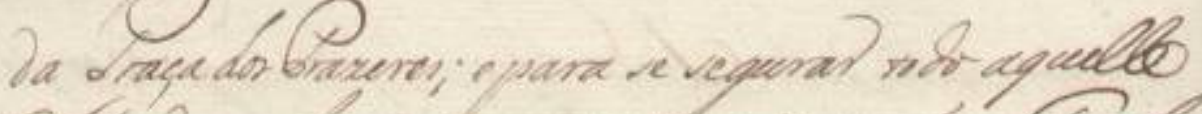

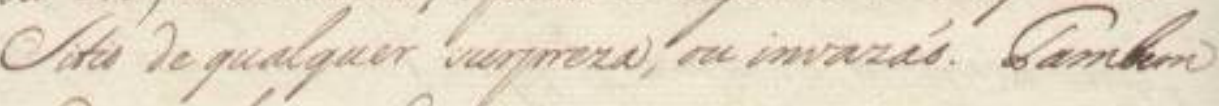

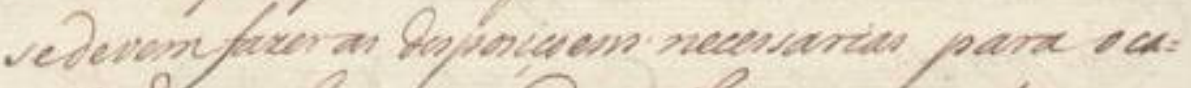

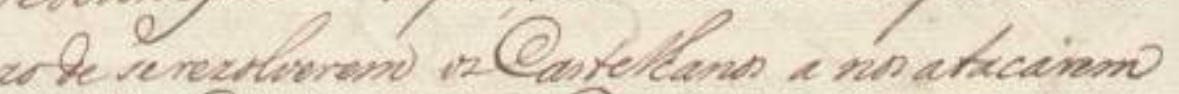

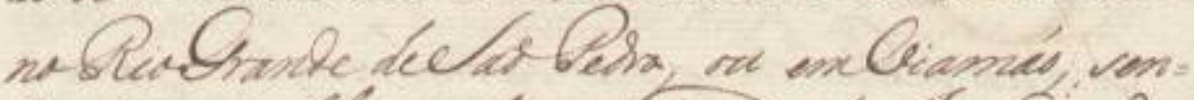

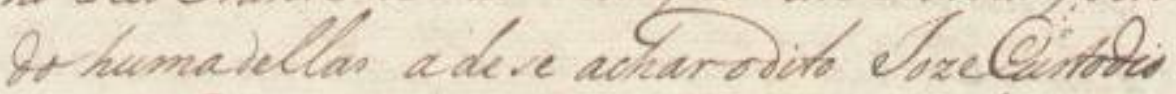
meparte, econveficiontas forcas para thes fares?

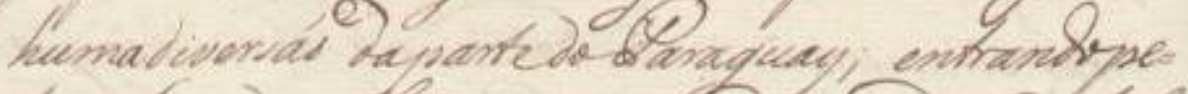

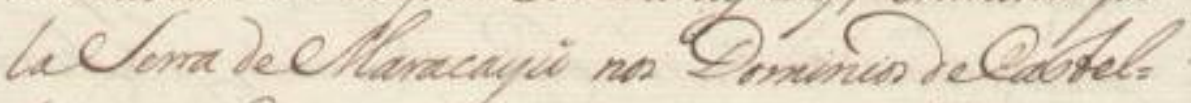

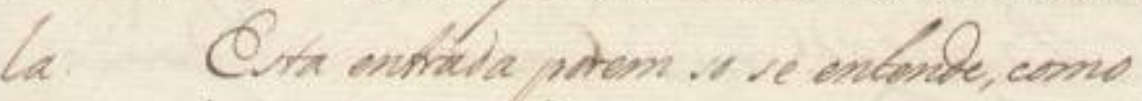
acimefece in na courdennosimens davarte hs

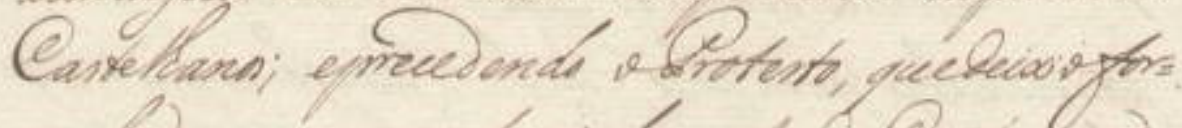
mulats managray vinte enin be Cant que mincipia $=$ Oequats ofreculs = 9) Detual ique ve quastar nas une.

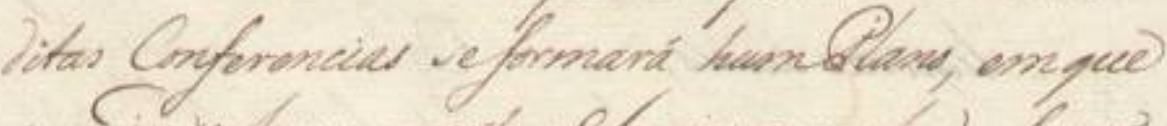

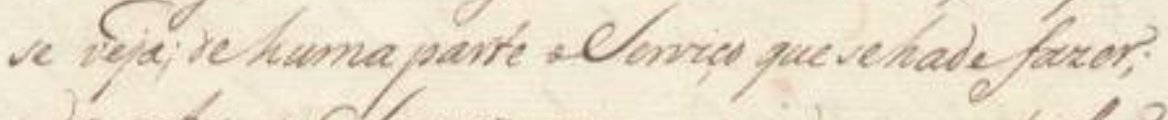
eda ruma on d/ganos um quevereve sustortar? emarequir: Grevenintove on trad scase cper: is derompe, que rempm for a mayor inimige

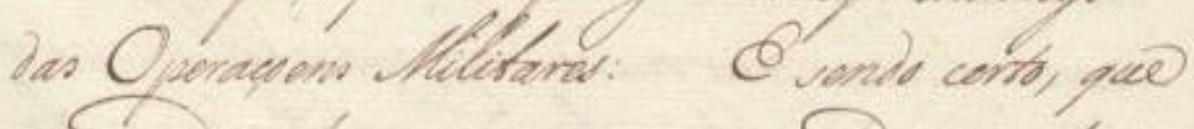

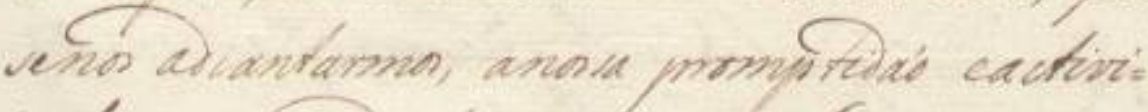

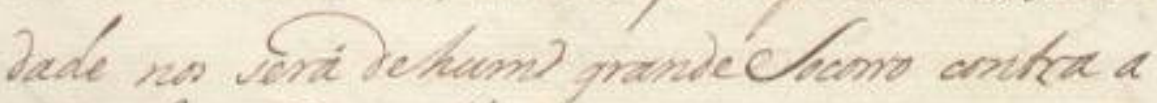
intorencenrelhave.

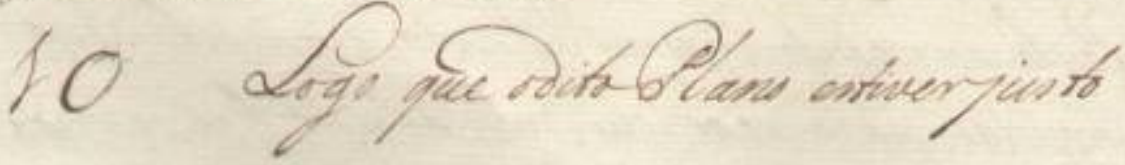


75 ||114v|| [[da]] Praça dos Prazeres; e para se segurar todo aquelle

Sitio de qualquer surpreza, ou invazaõ. Tambem sedevemfazer as desposiçoens necessarias para o ca= zode serezolverem osCastelhanos a nos atacarem noRioGrande deSaõ Pedro, ou emViamaõ, sen=

80 do huma dellas a de se acharodito lozeCustodio preparado, ecom suficientes forças paralhes fazer huma diversaõ dapartedoParaguay; entrandope= laSerra deMaracayû nos Dominios deCastel= la. [espaço] Esta entrada porem so se entende, como

85 acimafica dito no cazoderompimento daparte dos Castelhanos; eprecedendo oProtesto, quedeixofor= mulado noparagrafo vinte eoito daCarta que principia $=\underline{\mathrm{O} \text { segundo obstaculo }}=$ 9 Detudo o que se ajustar nas sobre=

90 ditas Conferencias seformará humPlano, em que se veja; dehuma parte oServiço que sehadefazer; eda outra os Socorros com que sedeve sustentar, eproseguir: [espaço] Prevenindo se em todo o cazo aper= da detempo, que sempre foi o mayor inimigo das Operaçoens Militares: [espaço] E sendo certo, que senos adiantarmos, anossa promptidaõ eactivi= dade nos será dehum grandeSocorro contra a indolenciaCastelhana.

10 Logo que oditoPlano estiverjusto 
||115r $\|$

86

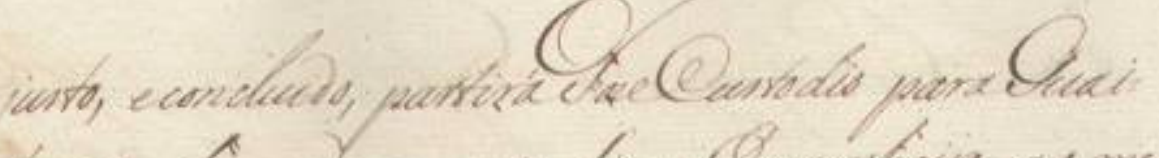

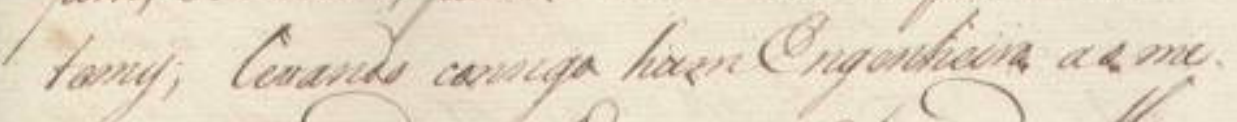

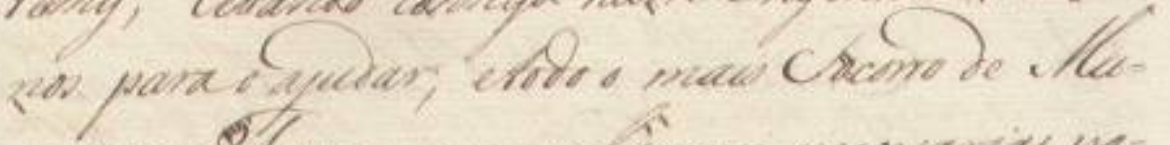

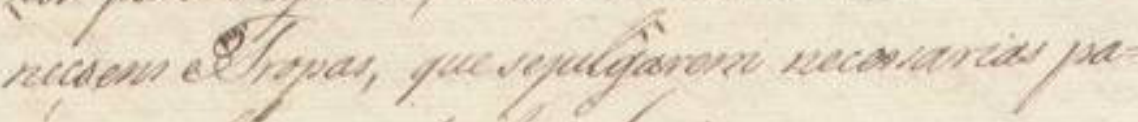
12 apuele omporiavide Eloxica.

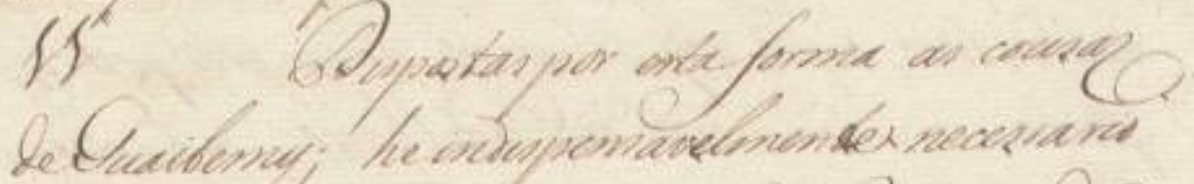

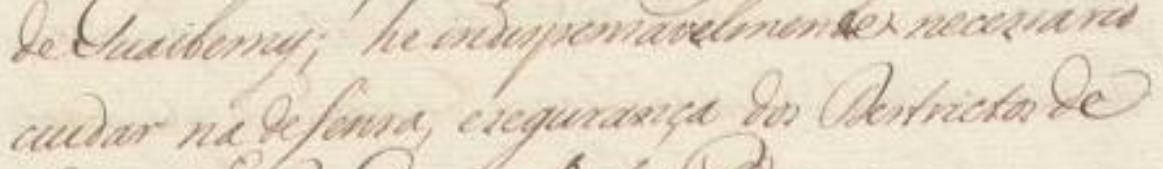

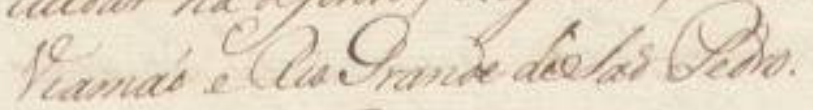

(c)

Qun ente fine ja naCemp prea-

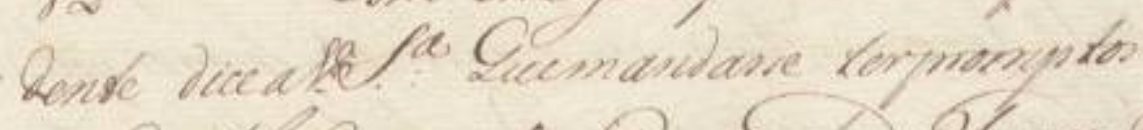

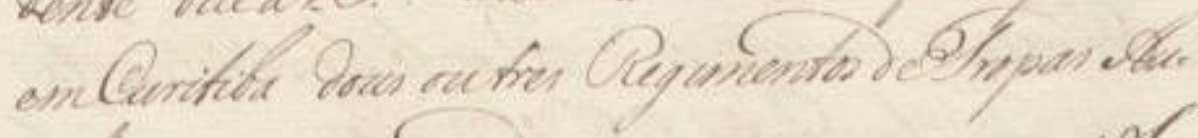

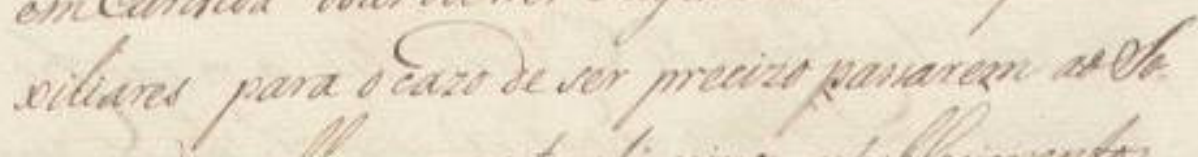

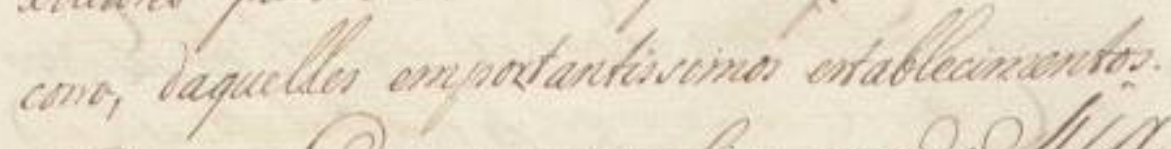

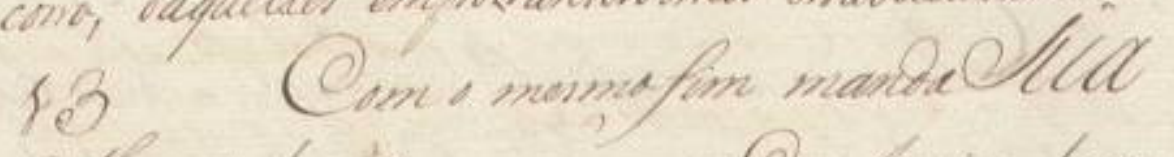

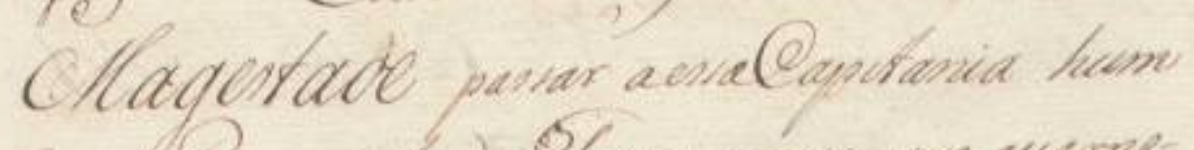

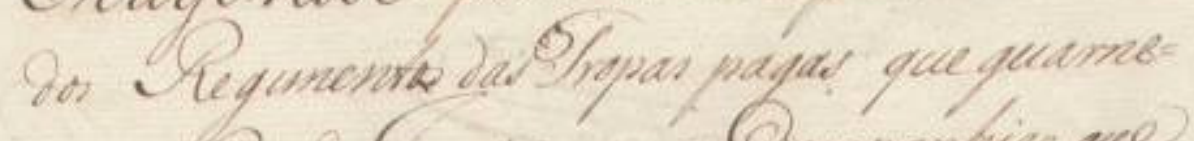

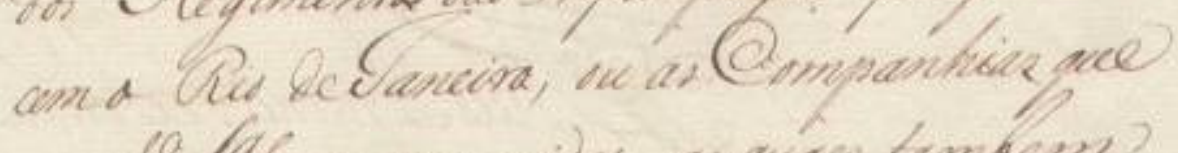

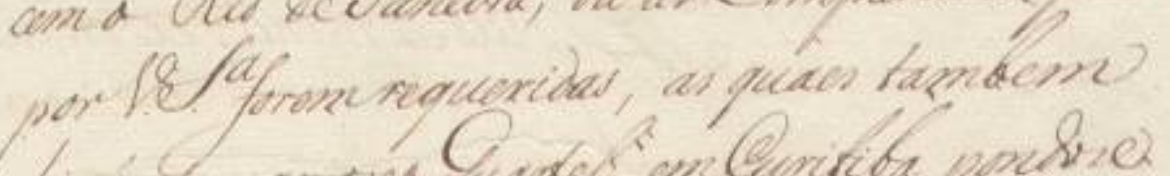

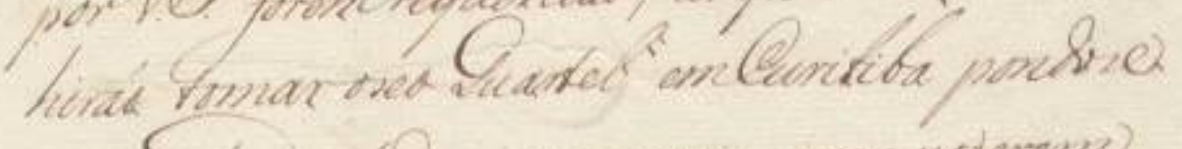

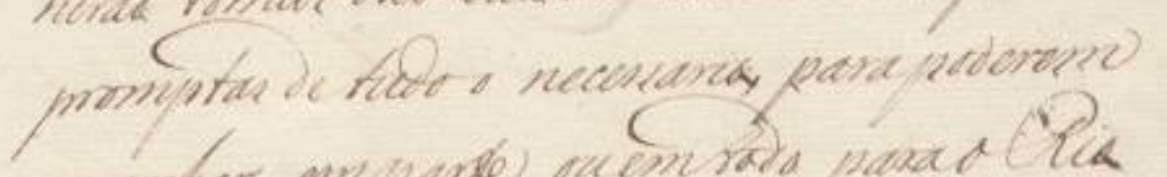

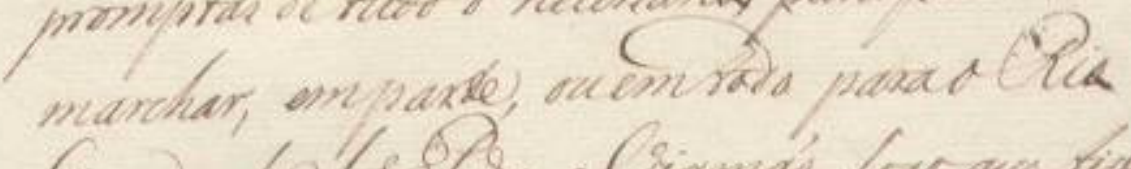

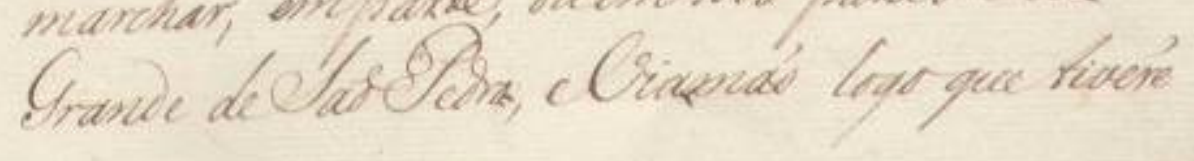

373 
100 ||115r|| [[justo]], econcluido, partirá lozeCustodio paraGuai= tamy; levando consigo humEngenheiro ao me nos parao ajudar; etodo o mais Socorro de $\mathrm{Mu}=$ niçoens eTropas, quesejulgarem necessarias $\mathrm{pa}=$ ra aquelle emportanteServiço.

10511 Dispostas por estaforma as cousas deGuaitemy; he indispensavelmente necessario cuidar na defensa, esegurança dos Destrictos de Viamaõ eRio Grande deSaõ Pedro. 12 Com estefim ja naCarta prece-

110 dente diceaVossaSenhoria: Quemandasse terpromptos emCuritiba dous outres Regimentos deTropas $\mathrm{Au}=$ xiliares para o cazo de ser precizo passarem aoSo $=$ corro, daquelles emportantissimos establecimentos. 13 Com o mesmo fim mandaSua

115 Magestade passar aessaCapitania hum dos Regimentos das Tropas pagas que guarne= cem o Rio delaneiro, ou as Companhias que porVossaSenhoria foremrequeridas, as quaes tambem hiraõ tomar oseo Quartel emCuritiba pondose 120 promptas detudo o necessario, para poderem marchar, emparte, ouemtodo paraoRio Grande deSaõPedro, eViamaõ logo que tiverẽ 


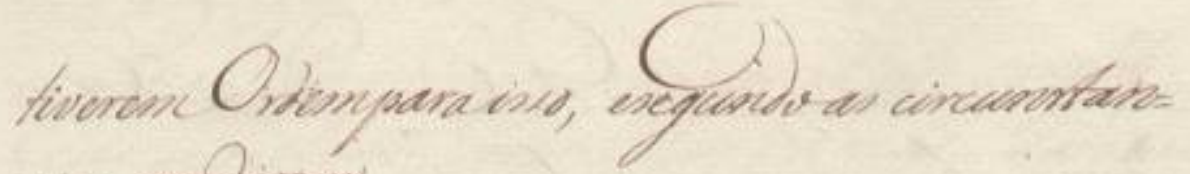
cis spctirion

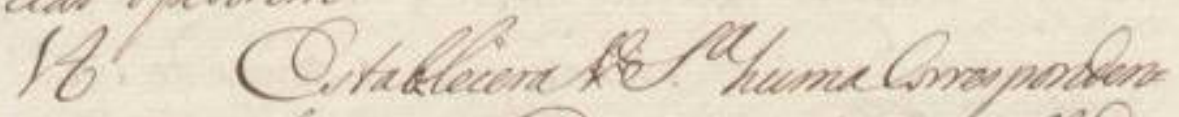
cieleyular.umos@mandandes_oujuelew des

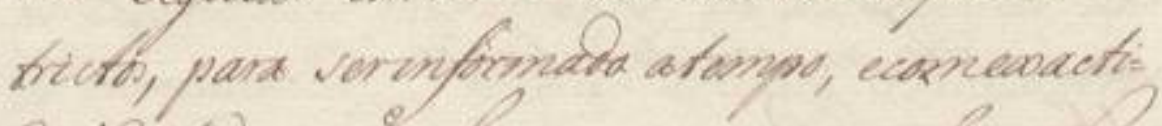

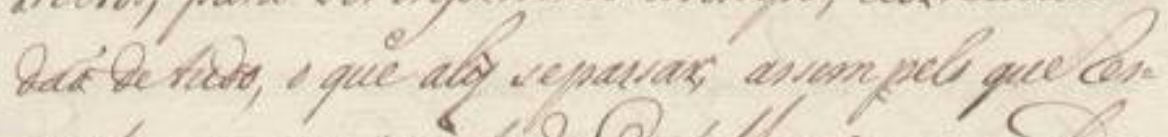

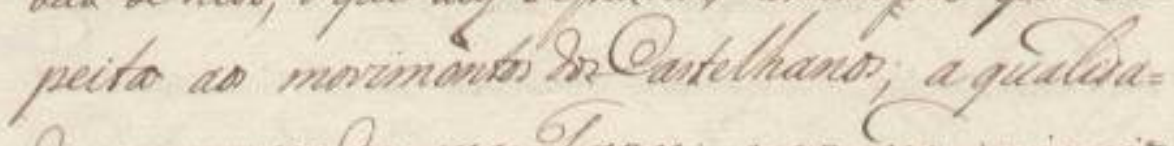
Se encument des suas Stropas; ecos seos sesignies, comopelífue race as forcas, conque aly nes acture

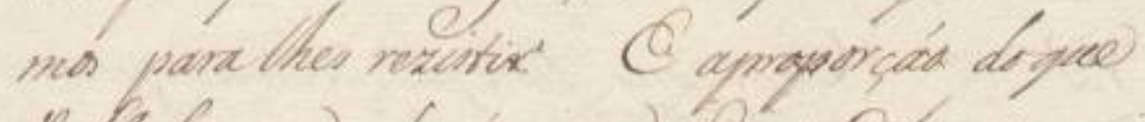

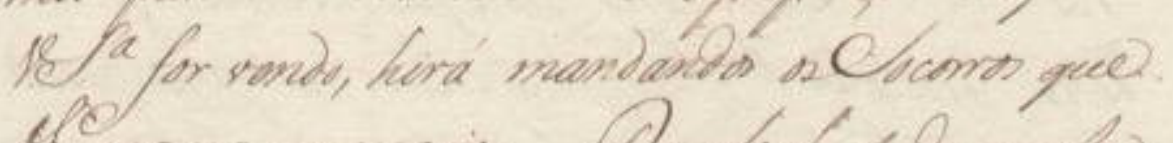

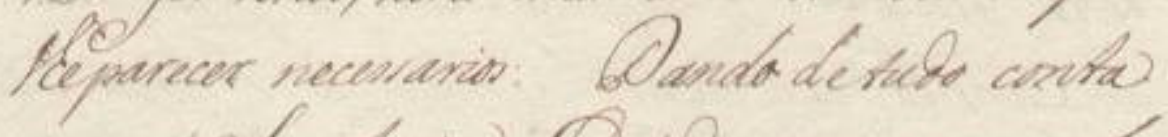

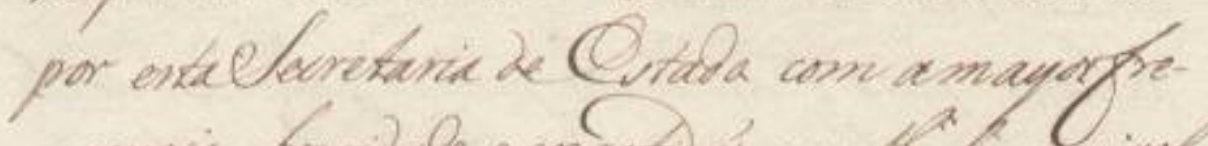

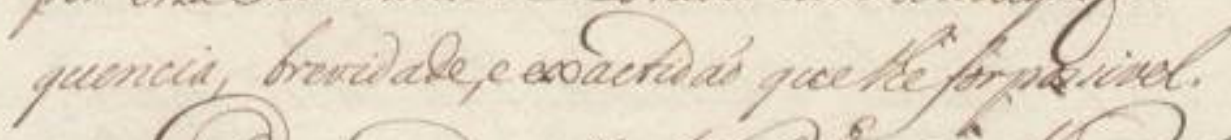

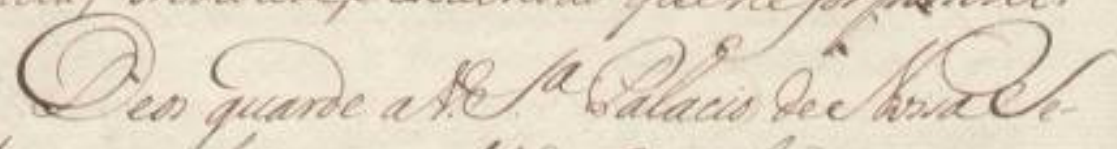

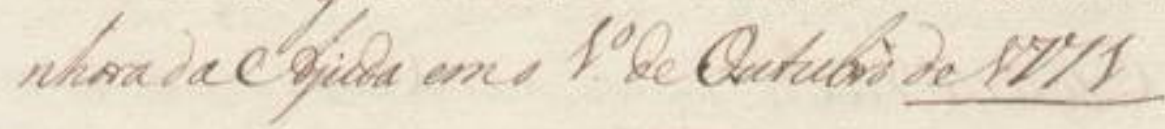

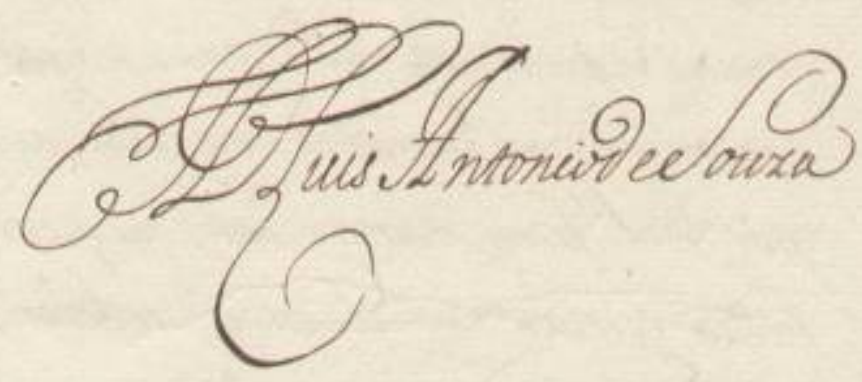


||115v || tiverem Ordemparaisso, esegundoas circunstan= cias opedirem

12514 EstableceraVossaSenhoria humaCorresponden= cia regular comosComandantes daquelles des trictos, para serinformado atempo, ecomexacti= daõ detudo, o que aly sepassar, assim pelo queres= peita aos movimentos dosCastelhanos; a qualida= de, enumero das suas Tropas; e aos seos designios, comopeloquetoca asforças, com que aly nos acha= mos para lhes rezistir. [espaço] E aproporçaõ doque VossaSenhoria for vendo, hirá mandando osSocorros que Iheparecer necessarios: [espaço] Dando detudo conta por estaSecretaria deEstado com amayorfrequencia, brevidade, e exactidaõ quelhe forpossivel. Deos guarde aVossaSenhoria Palacio deNossaSenhora daAjuda emo primeiro de Outubro de1771 
Carta. id

\section{Dypous des qualto Cartas}

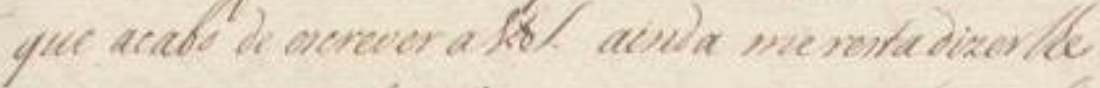
que wh paragrafo $26^{\circ}$ da quee comera polas pala.

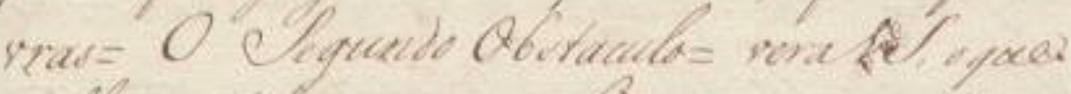

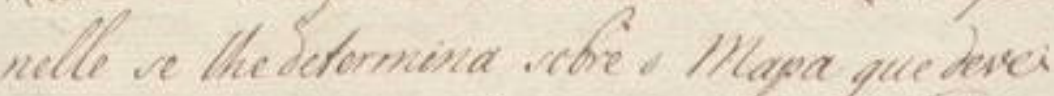

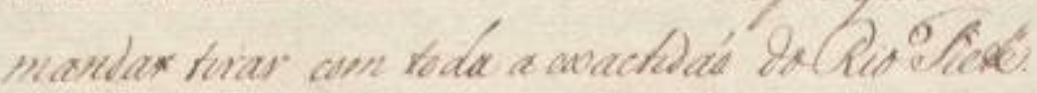

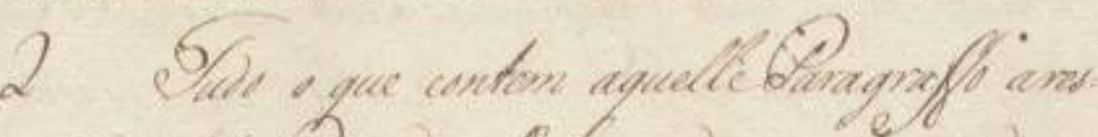

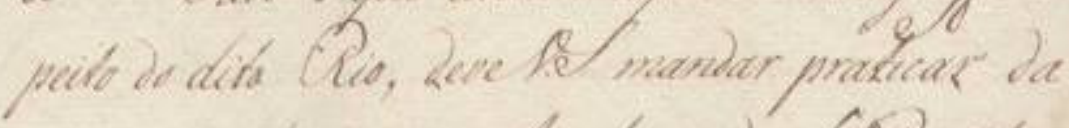

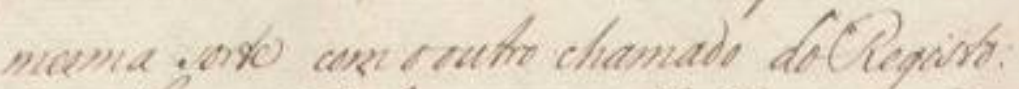

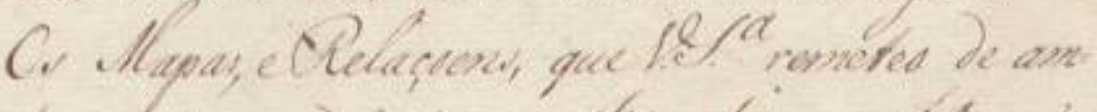

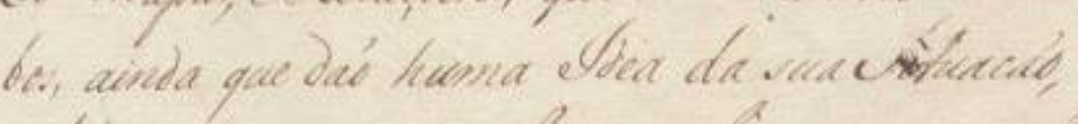

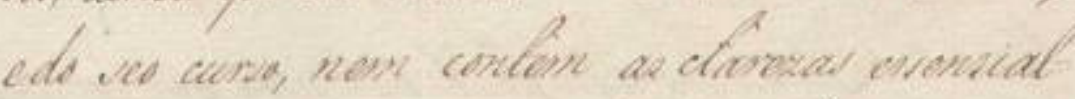

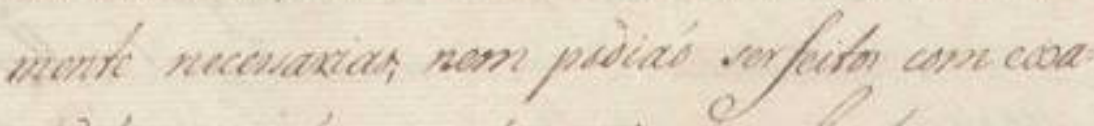

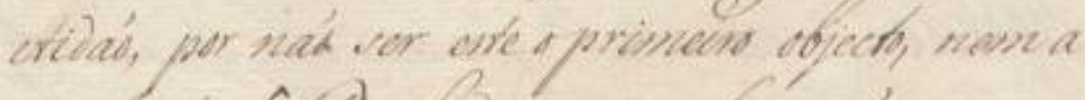

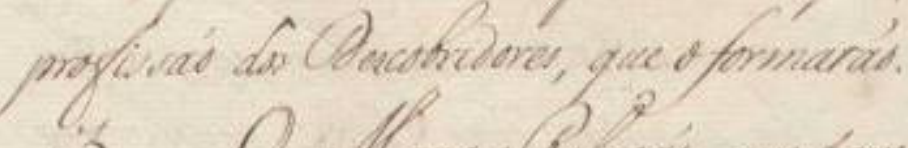

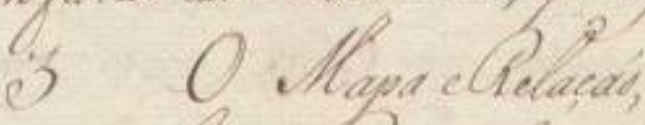

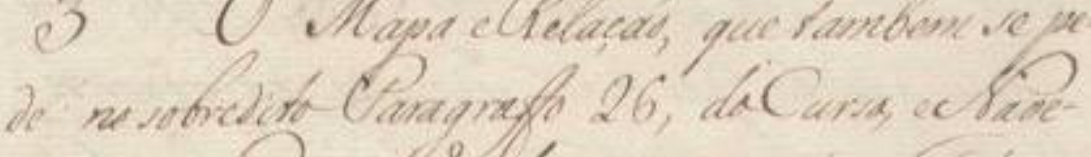

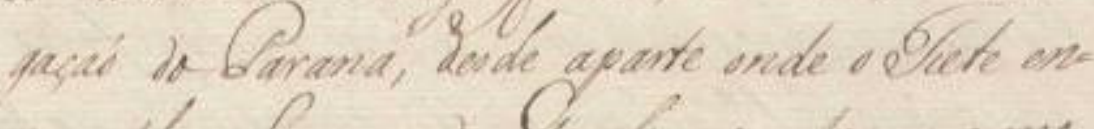

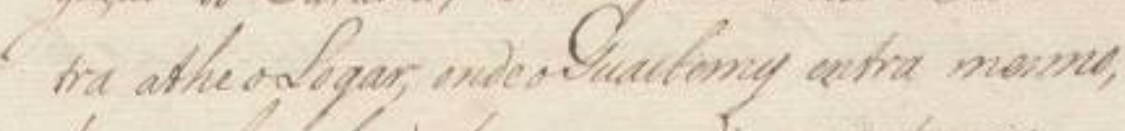

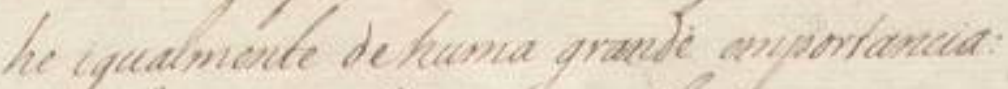

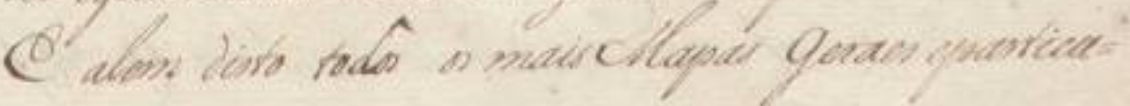


||118r|| Carta quinta

1 Depois das quatro Cartas

que acabo de escrever aVossaSenhoria ainda merestadizerlhe que no paragrafo 26 da que começa pelas pala=

5 vras $=$ O Segundo Obstaculo $=$ veraVossaSenhoria o que

nelle se the determina sobre o Mapa que deve

mandar tirar com toda a exactidaõ doRioTiete.

2 Tudo o que me contem aquelle Paragraffo ares= peito do dito Rio, deveVossaSenhoria mandar praticar da

10 mesma sorte com ooutro chamado doRegisto:

Os Mapas, eRelaçoens, que VossaSenhoria remeteo de am= bos, ainda que daõ huma Idea da sua Situacaõ, edo seo curso, nem contem as clarezas essensial= mente necessarias, nem podiaõ ser feitos com exa=

15 ctidaõ, por naõ ser este oprimeiro objecto, nem a profissaõ dos Descobridores, que oformaraõ.

3 O Mapa eRelaçaõ, que tambem se pe= de no sobreditoParagraffo 26 , doCurso, eNavegaçaõ doParana, desde aparte onde o Tiete en=

20 tra athe oLogar, onde oGuaitemy entra mesmo, he igualmente dehuma grande emportancia:

E alem disto todos os mais Mapas Geraes eparticu= 


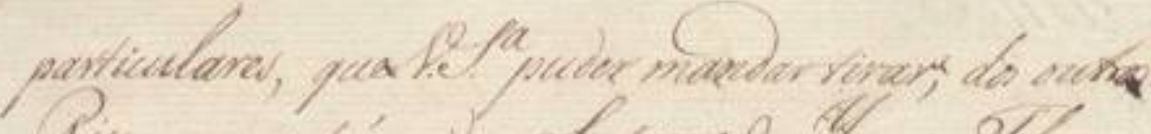

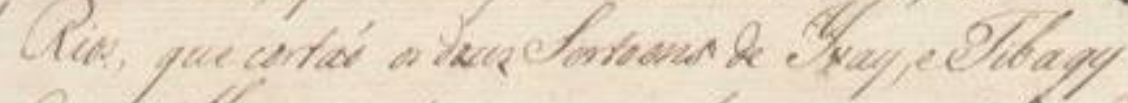

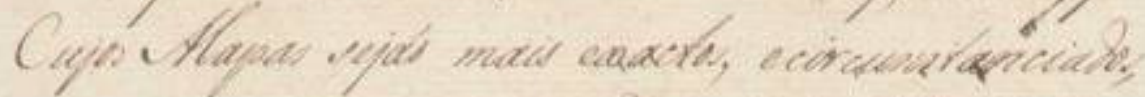

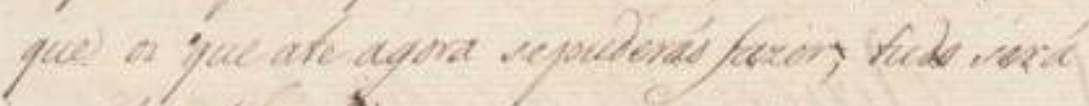

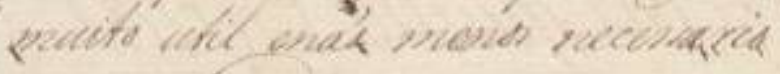

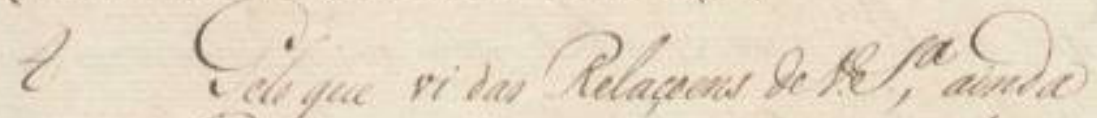

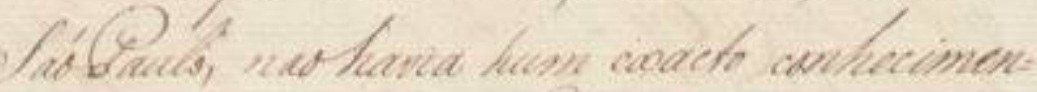

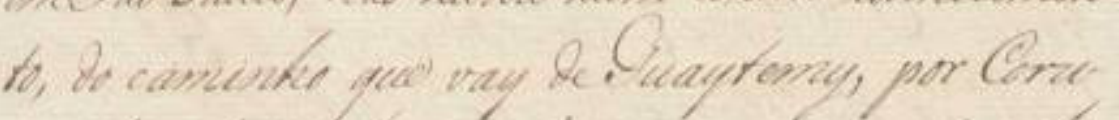

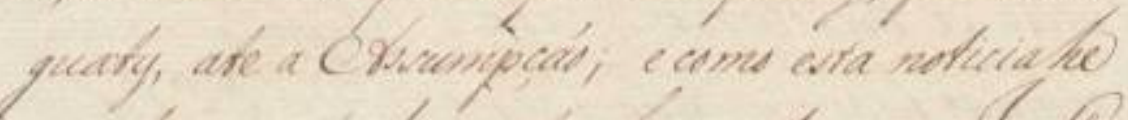

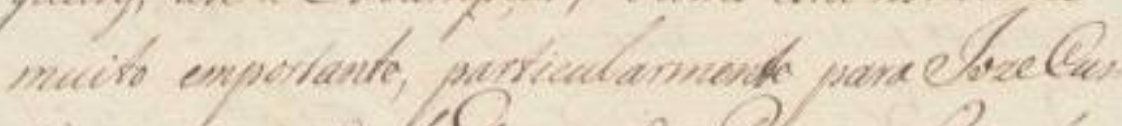

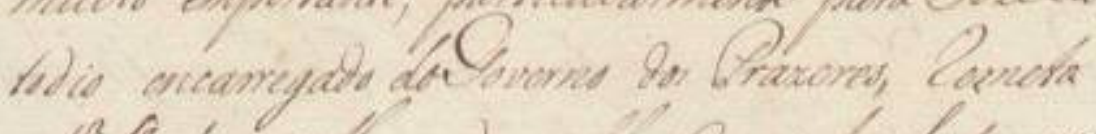

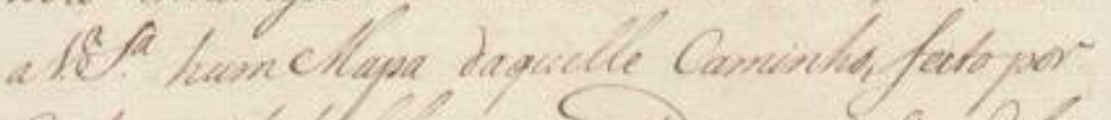

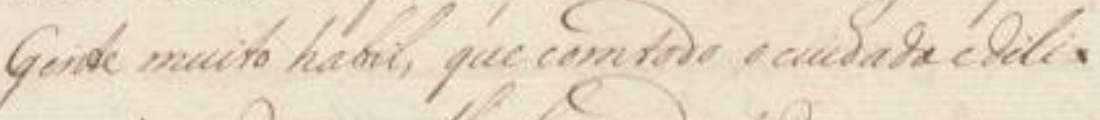

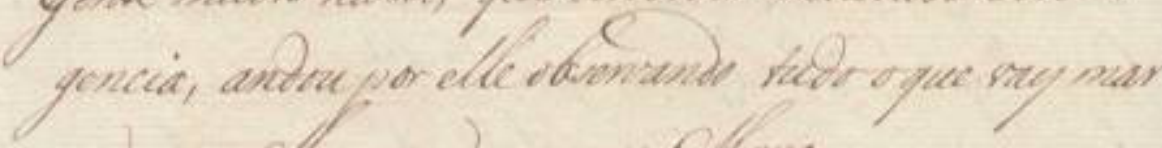
cate na Chrogent de merome Clapene.

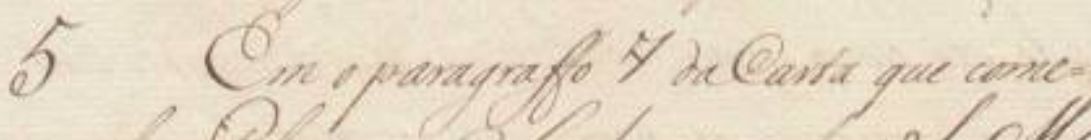

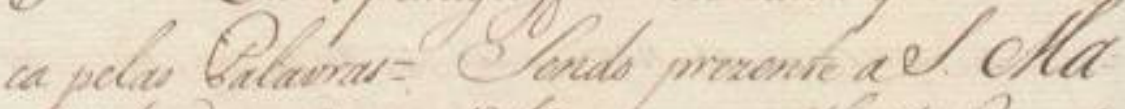

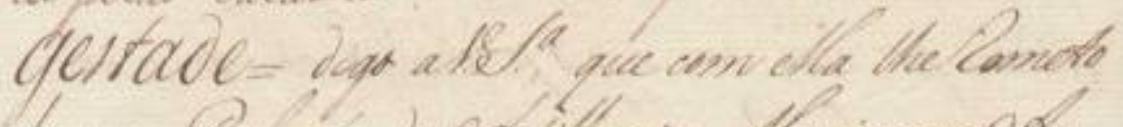

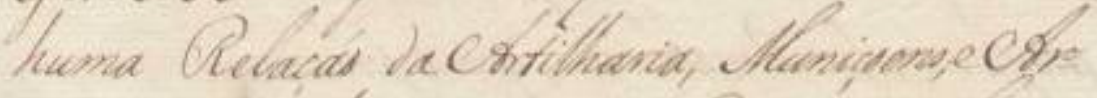

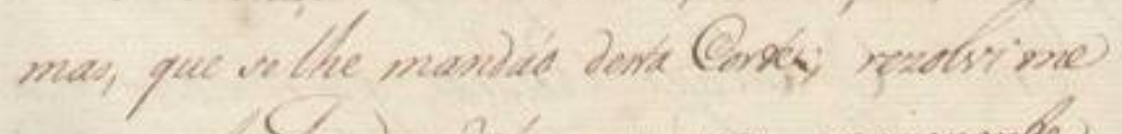

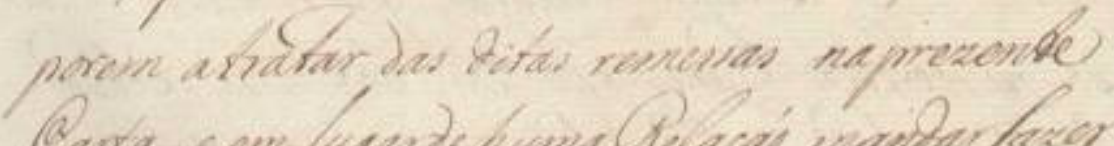

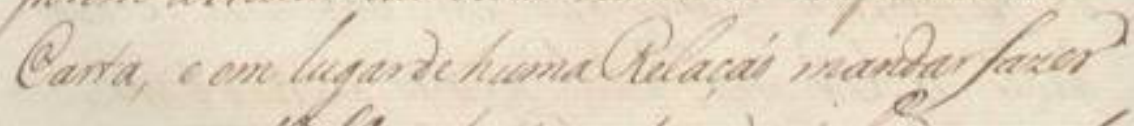

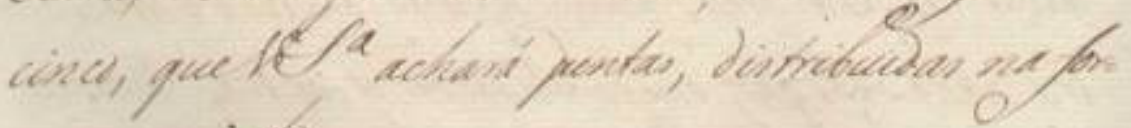
nerequisito

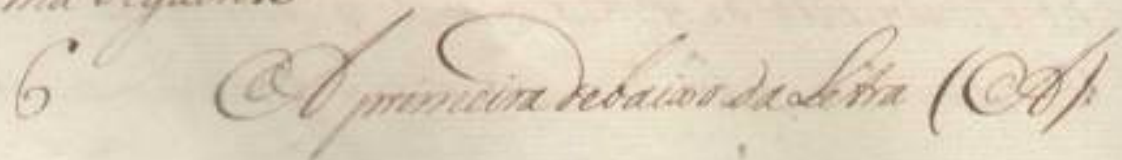


||118v|| [[particu]]lares, queVossaSenhoria puder mandar tirar, dos outros

Rios, que cortaõ os dous Sertoens de Yvay, eTibagy

Cujos Mapas sejaõ mais exactos, ecircunstanciados,

que os que ate agora sepuderaõ fazer, tudo será

muito util enaõ menos necessario

4 Pelo que vi das Relaçoens deVossaSenhoria, ainda

emSaõPaulo, naõhavia hum exacto conhecimen=

to, do caminho que vay deGuaytemy, por Coru-

30 guaty, ate a Assumpçaõ; e como esta noticiahe

muito emportante, particularmente para lozeCus=

todio encarregado doGoverno dos Prazeres, remeto

aVossaSenhoria hum Mapa daquelle Caminho, feito por

Gente muito habil, que comtodo o cuidado edili=

gencia, andou por elle observando tudo o que vay mar

cado na Margem do mesmo Mapa.

5 Em o paragraffo 7 daCarta que come $=$

ca pelas Palavras $=$ Sendo prezente aSua $\mathrm{Ma}=$

gestade $=$ digo aVossaSenhoria, que com ella Iheremeto

40 huma Relaçaõ daArtilharia, Muniçoens, eAr=

mas, que selhe mandaõ desta Corte; rezolvi me

porem atratar das ditas remessas na prezente

Carta, e em lugar de humaRelaçaõ mandar fazer

cinco, queVossaSenhoria achará juntas, distribuidas na for=

ma seguinte

6 A primeira debaixo daLetra $(A)$ 


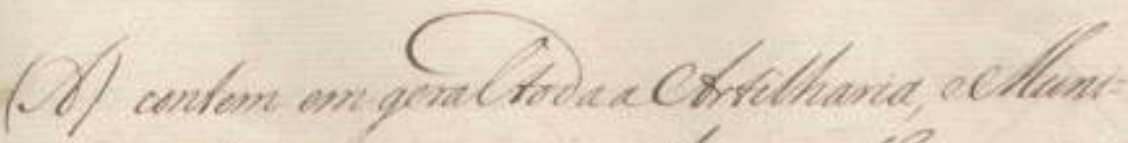

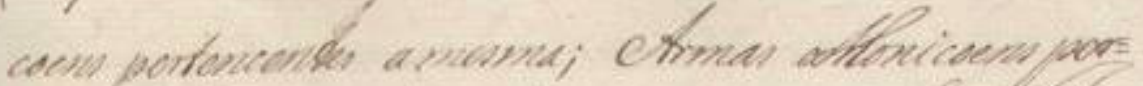

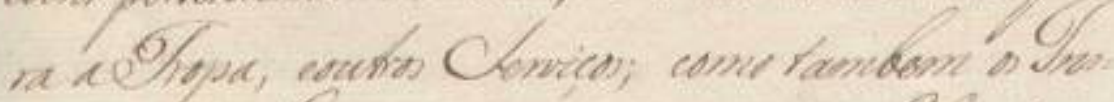

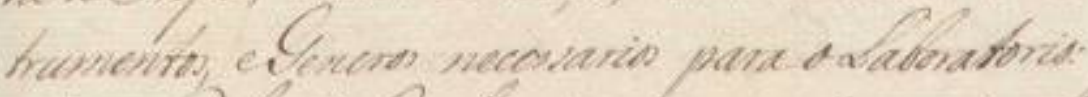

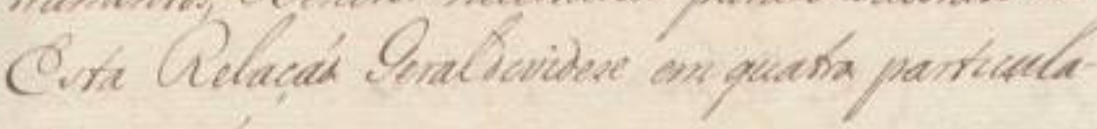
ive quevad

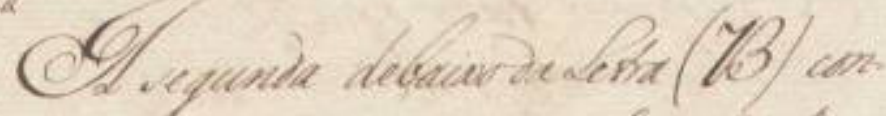

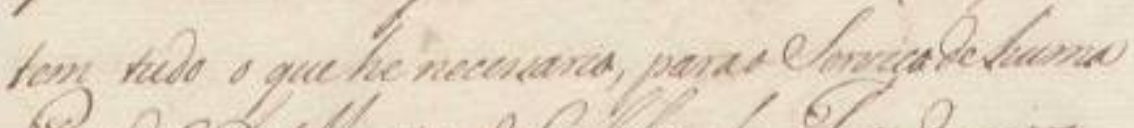

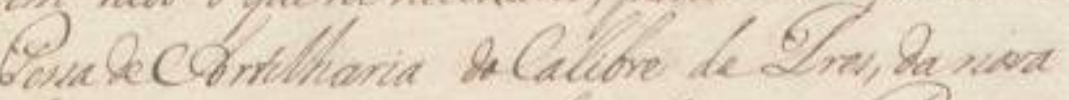

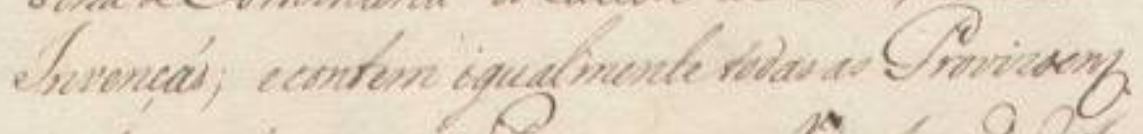

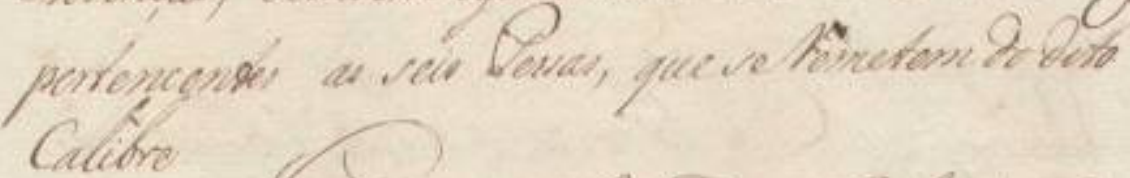

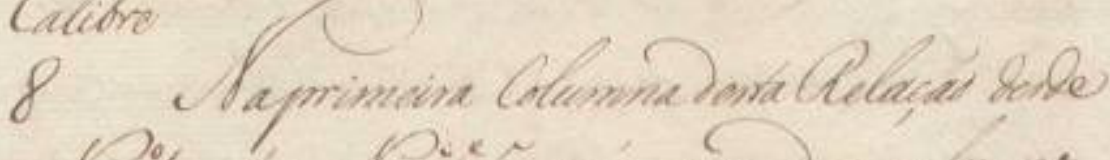

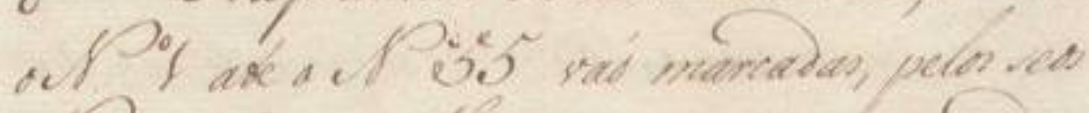

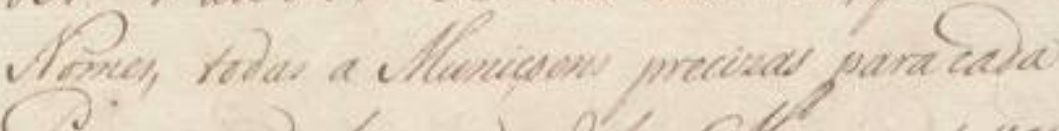

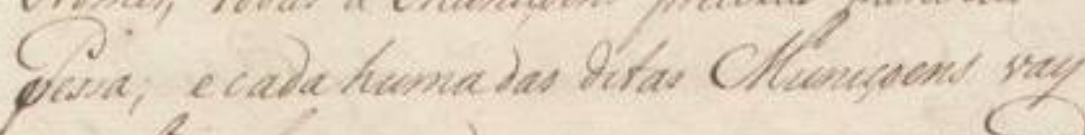

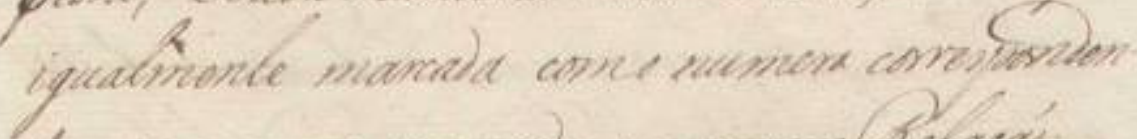

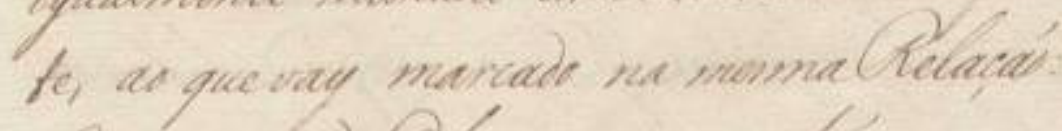

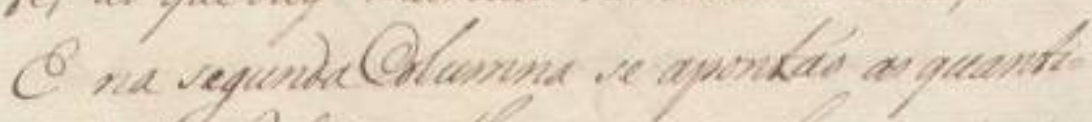

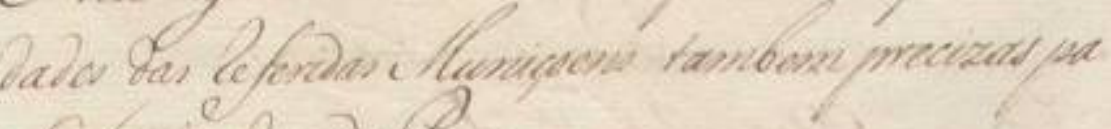
Comier Reada beria.

1) borata fonme anvervomate a

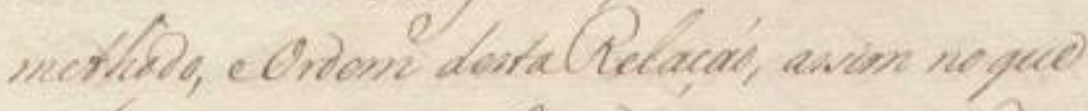

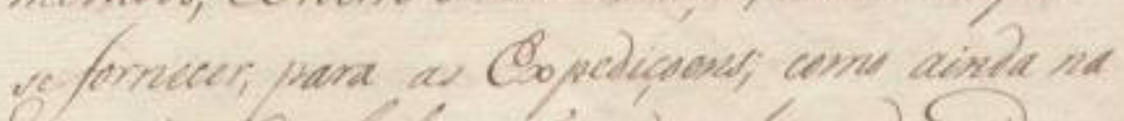

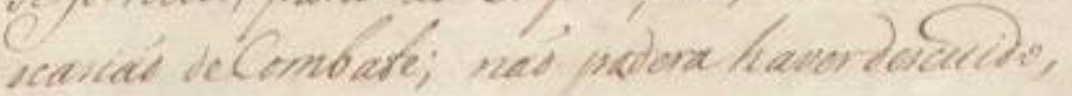


||119r|| [[(A)]] contem em geral toda aArtilharia, eMuni= coens pertencentes a mesma; Armas eMonicoens pa= ra aTropa, eoutros Serviços; como tambem os Ins=

50 trumentos, eGeneros necessarios para oLaboratorio:

Esta Relaçaõ Geral devidese em quatro particulares que saõ

6 A segunda debaixo da Letra $(B)$ con $=$ tem tudo o que he necessario, para o Serviço de huma

55 Pessa deArtilharia doCalibre deTres, da nova Invençaõ; e contem igualmente todas as Provizoens pertencentes as seis Pessas, queseremetem dodito Calibre

8 Naprimeira Columna desta Relaçaõ desde

60 o Numero 1 ate o Numero 55 vaõ marcadas, pelos seos Nomes, todas a Muniçoens precizas para cada Pessa; e cada huma das ditas Muniçoens vay igualmente marcada como numero correspondente, ao que vay marcado na mesma Relaçaõ:

65 E na segundaColumna se apontaõ as quanti= dades das referidas Muniçoens tambem precizas $\mathrm{pa}={ }^{*}$ oServiço de cada Pessa.

9 Por esta forma, em se observando o methodo, eOrdem destaRelaçaõ, assim no que

70 se fornecer, para as Expediçoens; como ainda na ocasiaõ deCombate; naõ podera haver descuido,

* "Pa=" por "para". 


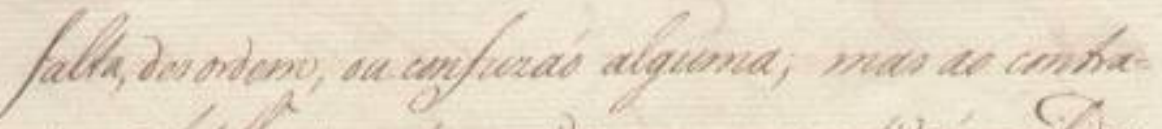

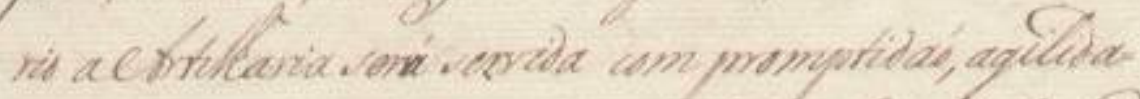
be; cacerta, que hes que provontemente dueide bas ba talhas, das fiestrias, edas Consucinas.

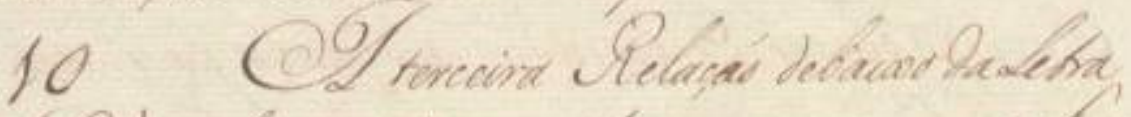

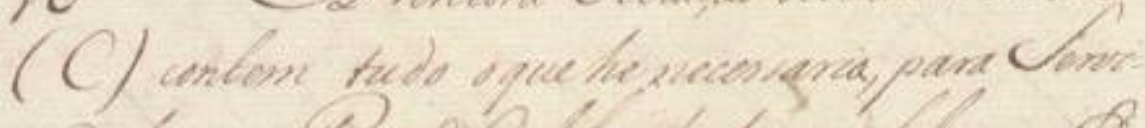

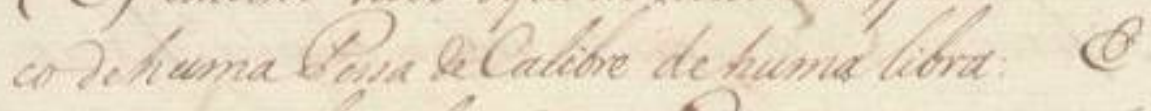

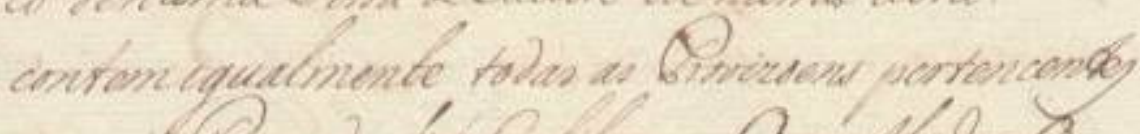

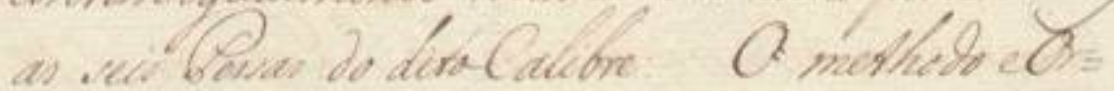

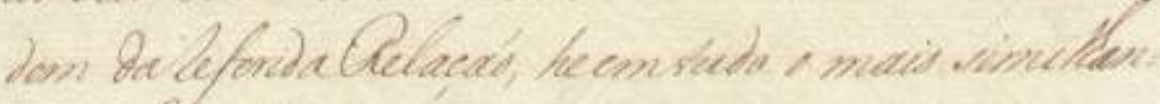
te aveyundi

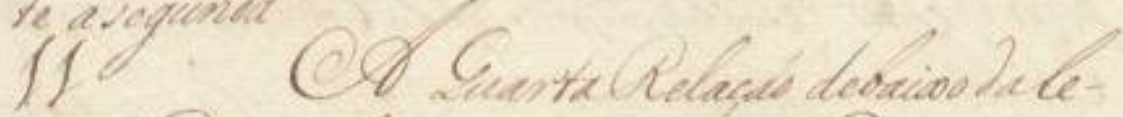

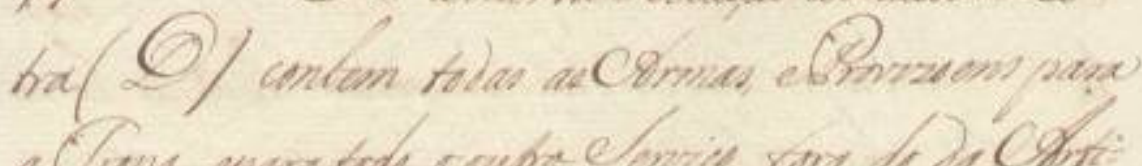

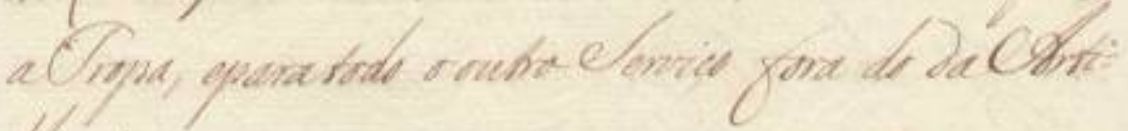
tharid

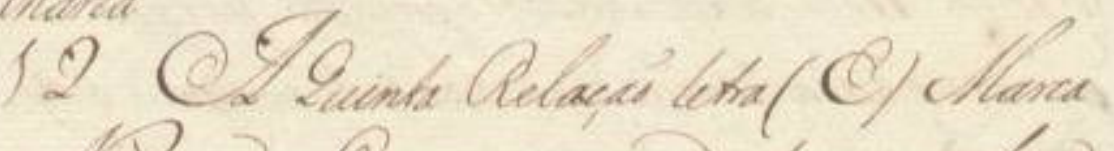

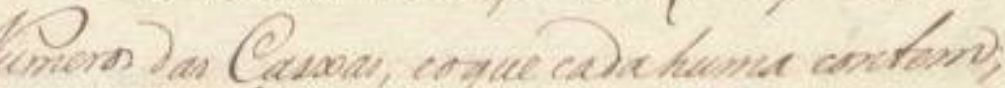

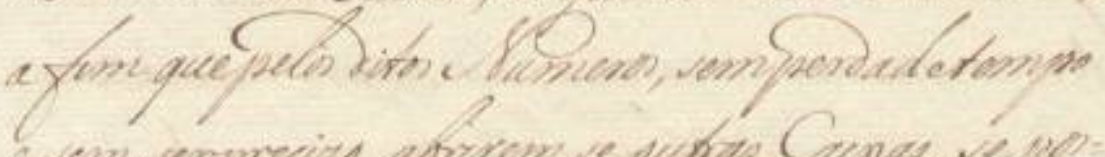

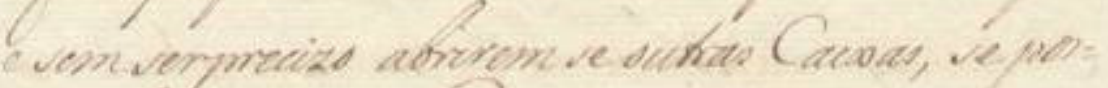

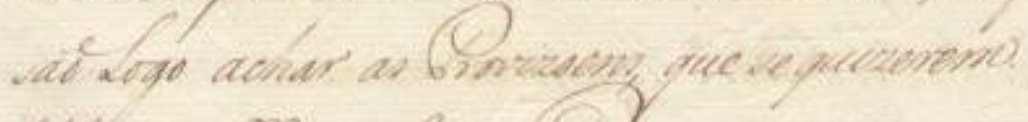

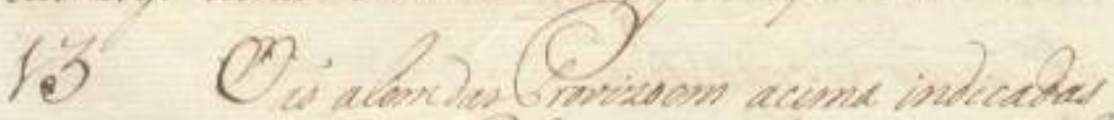

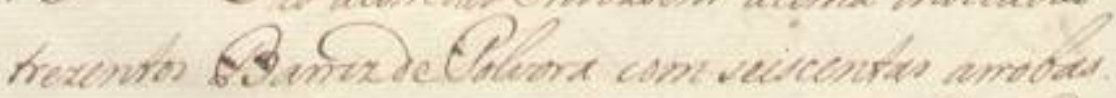

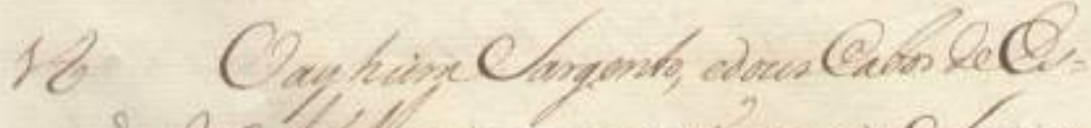

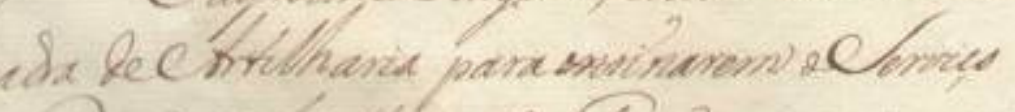

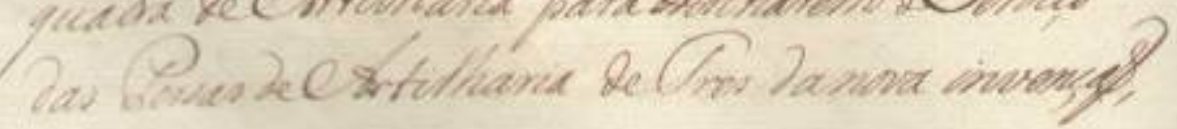


||119v\| falta, desordem, ou confuzaõ alguma; mas ao contra= rio aArtilharia será servida com promptidaõ, agilida= de, e acerto, que he o que prezentemente decide das $\mathrm{Ba}$ talhas, das Victorias, edas Conquistas.

10 A terceira Relaçaõ debaixo daLetra

(C) contem tudo o que he necessario, para Servi= co dehuma Pessa deCalibre dehumalibra: [espaço] E contemigualmente todas as Provizoens pertencentes as seis Pessas do ditoCalibre: [espaço] O methodo eOr= dem dareferida Relaçaõ, heemtudo o mais similhan= te a segunda 11 A Quarta Relaçaõ debaixo daletra (D) contem todas as Armas, eProvizoens para 85 aTropa, epara todo o outroServiço fora do daArti= Iharia

12 A Quinta Relaçaõ letra (E) Marca os Numeros das Caixas, eoque cadahuma contem; a fim quepelos ditos Numeros, sem perda detempo e sem serprecizo abrirem seoutras Caixas, sepos= saõLogo achar as Provizoens, que sequizerem. 13 Vaõ alem dasProvizoens acima indicadas trezentos BarrizdePolvora com seiscentas arrobas. 14 Vay humSargento, edousCabos deEs= quadra deArtilharia para ensinarem oServiço das Pessas deArtilharia deTres danova invençaõ, 
||120r||

84.16

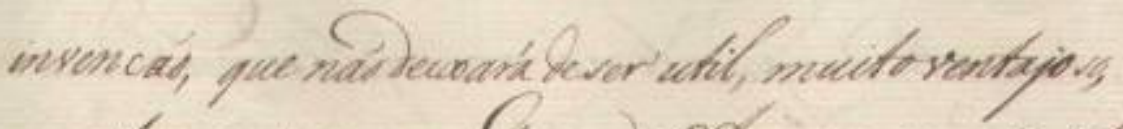

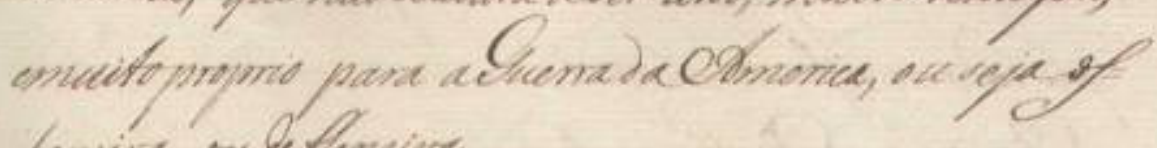
fension rebefersing 13

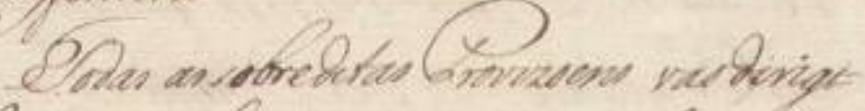

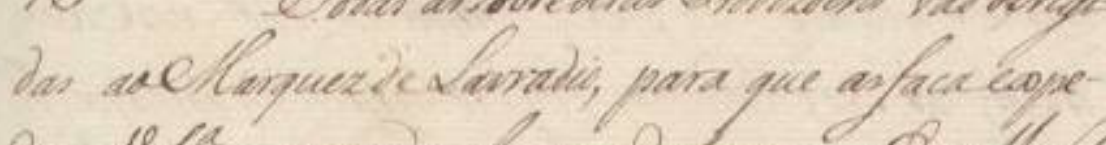

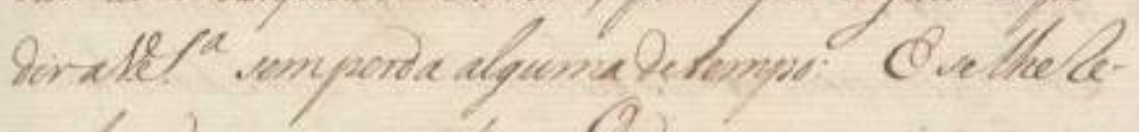

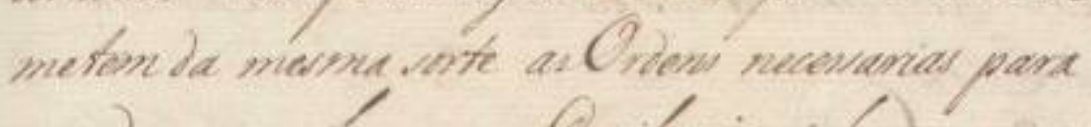

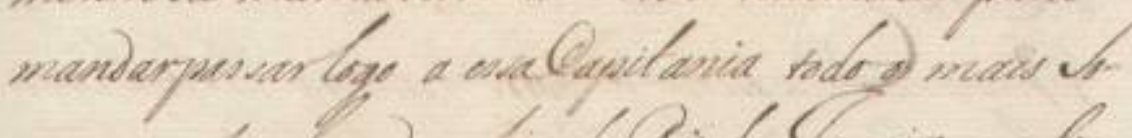

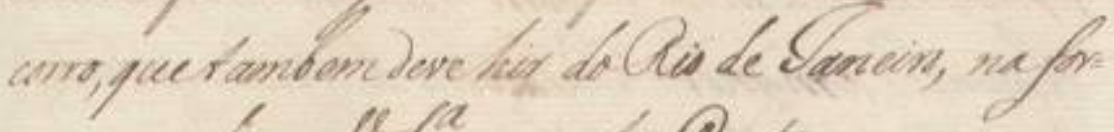
ma que digu alc pa mumalarta.

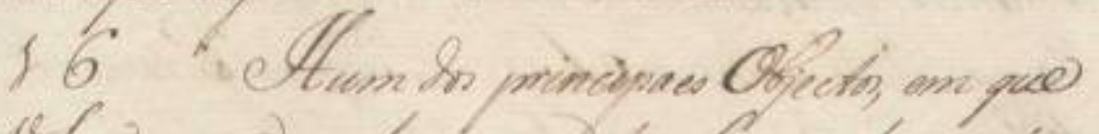

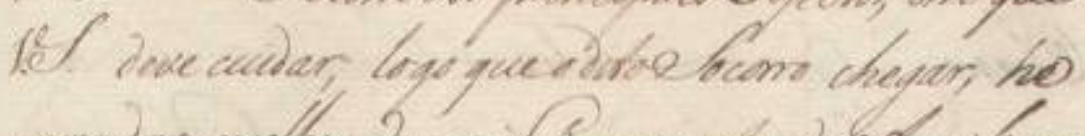

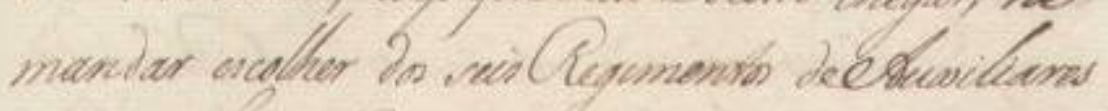

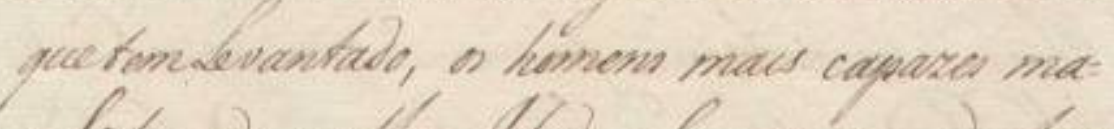

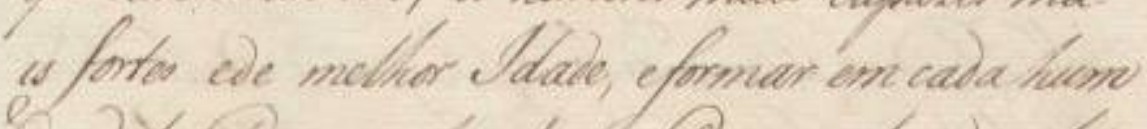

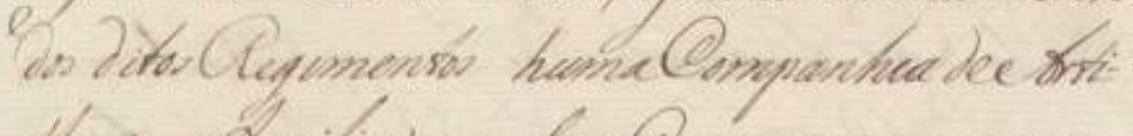

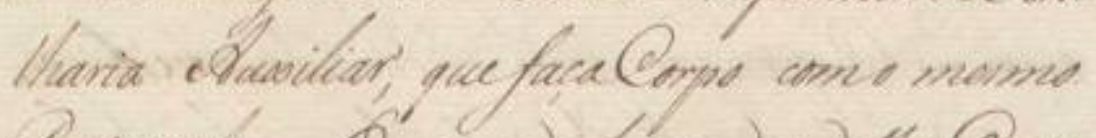

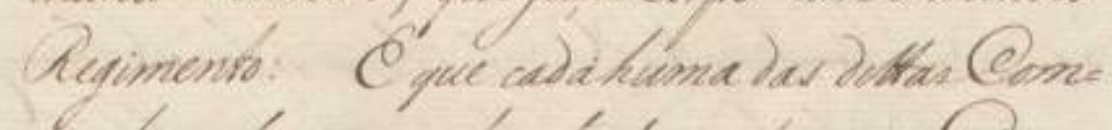
pantias de campontua de too homens: Qe vor.

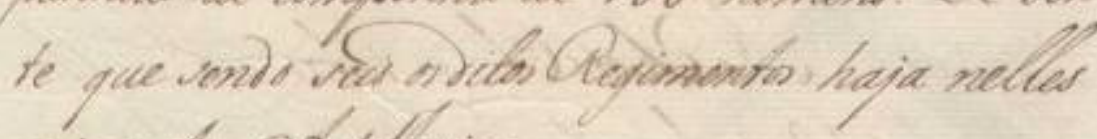
evicutos Cortulueis.

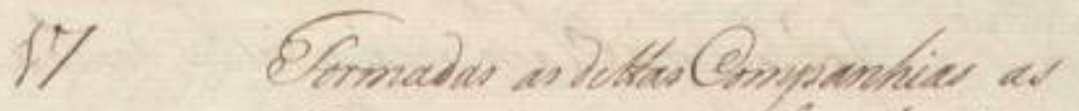

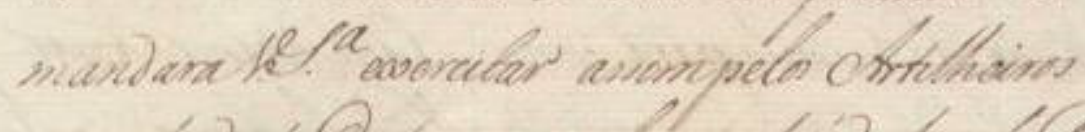

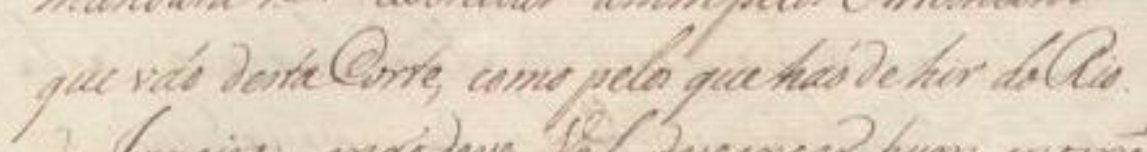

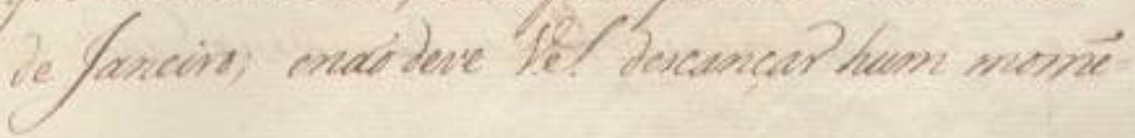

385 
||120r|| [[invenção]], que naõ deixará deser util, muito ventajoso,

emuitoproprio para aGuerra daAmerica, ou seja of $=$ fensiva, ou deffensiva

15 Todas as sobreditas Provizoens vao dirigi= das aoMarquezdeLavradio, para que asfacaexpe-

dir aVossaSenhoria semperda alguma detempo: [espaço] E selheremetem da mesma sorte asOrdens necessarias para mandarpassarlogo a essaCapitania todoo mais Socorro, quetambem deve hir doRio de laneiro, nafor= ma que digo aVossaSenhoria emoutraCarta 16 Hum dos principaes Objectos, em que VossaSenhoria deve cuidar, logo queo ditoSocorro chegar, he mandar escolher dos seis Regimentos deAuxiliares

110 quetemLevantado, os homens mais capazes ma= is fortes ede melhor Idade, eformar em cada hum dos ditos Regimentos humaCompanhia deArti= Iharia Auxiliar, quefaçaCorpo com o mesmo Regimento: [espaço] E que cadahuma das dittasCom= panhias de componha de 100 homens: De sor= te que sendo seis os ditos Regimentos haja nelles seis centos Artilheiros.

17 Formadas as dittas Companhias as mandaraVossaSenhoria exercitar assimpelos Artilheiros quevaõ destaCorte, como pelos quehaõ de hir doRio de Janeiro; enaõ deve VossaSenhoria descançar hum momẽ= 
|| $120 v \mid$

- momornt, en quanto nas mor complestamende dices: Mlinade a mforida $5 /$ iove. 18 Qetha, edetride amas, que quarnece

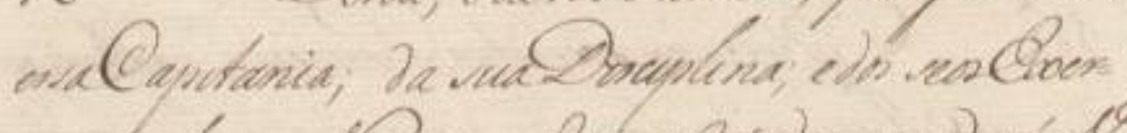

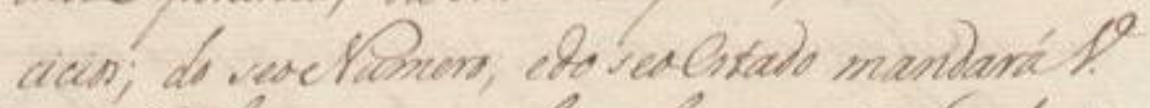

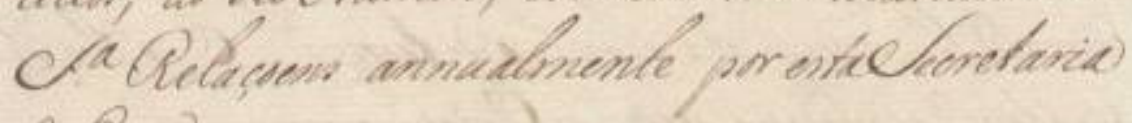
Qentala.

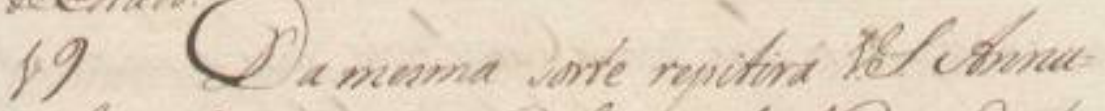

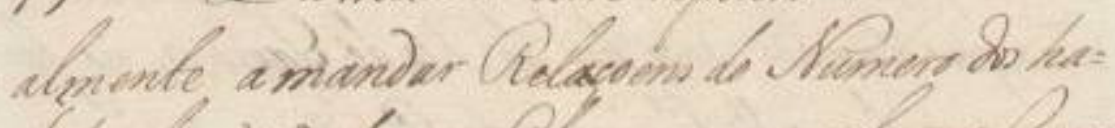

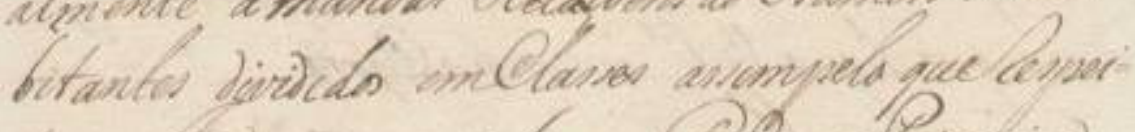

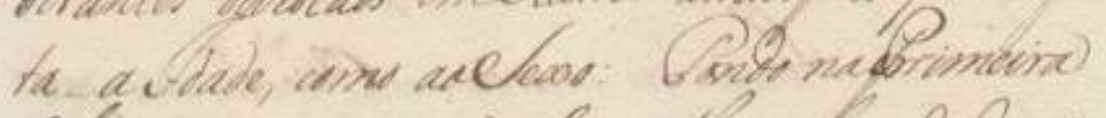

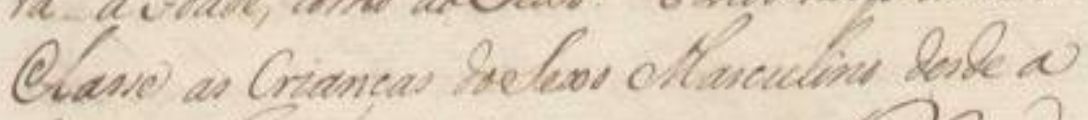

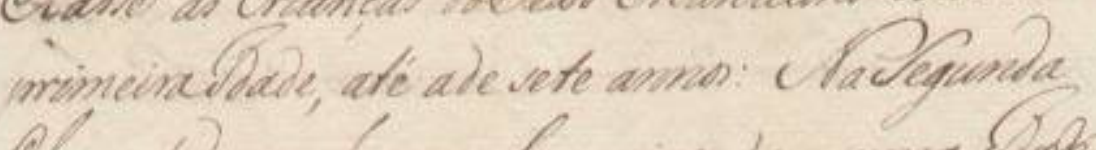

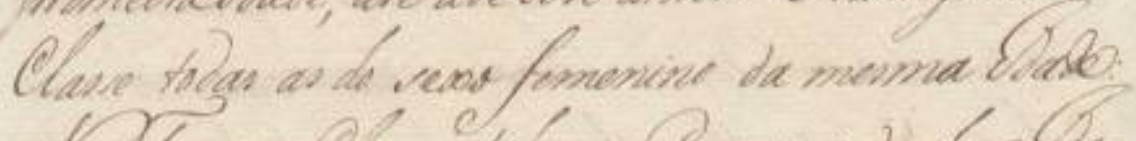

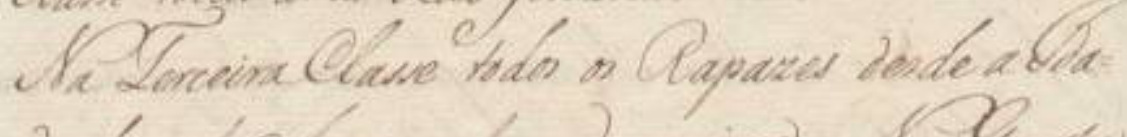

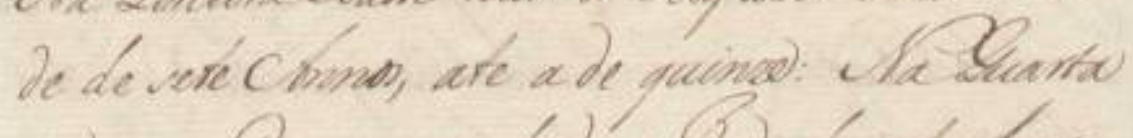

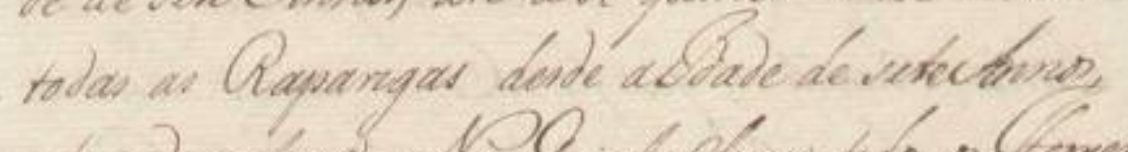

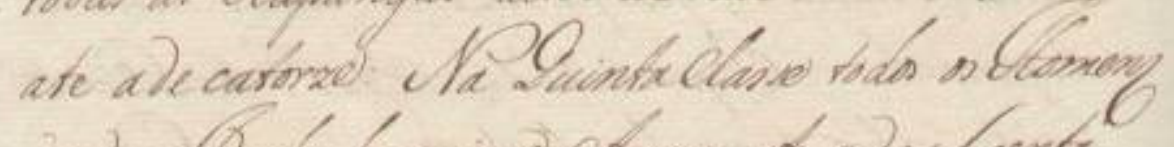

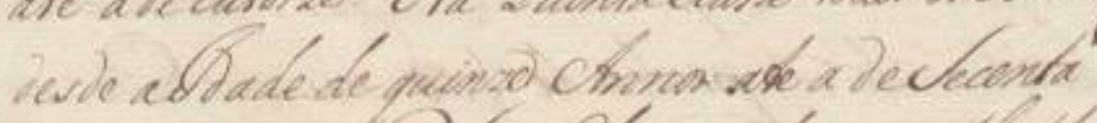

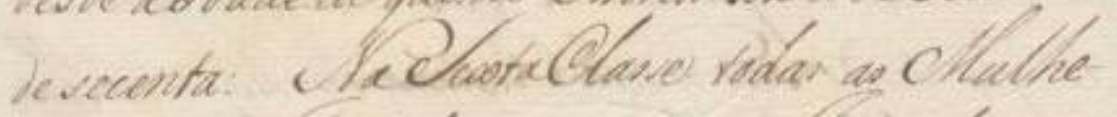
mi loule a blade de catorad a ré a bode de cines

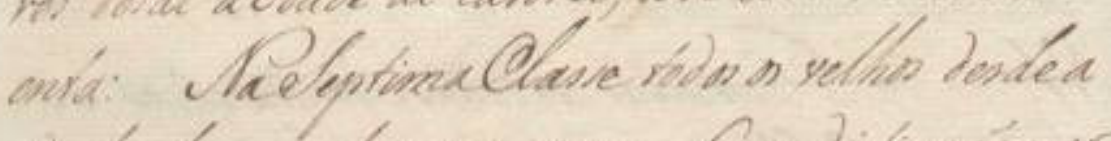
iade fevecontapara cina: Ome listmcatspat

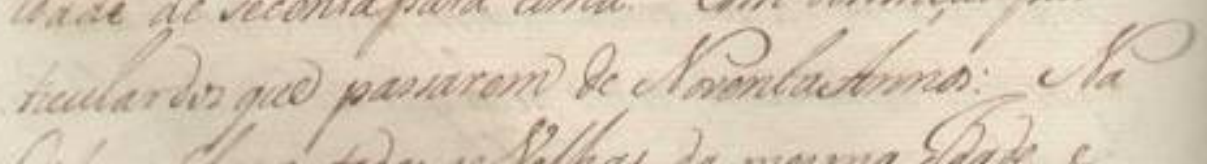

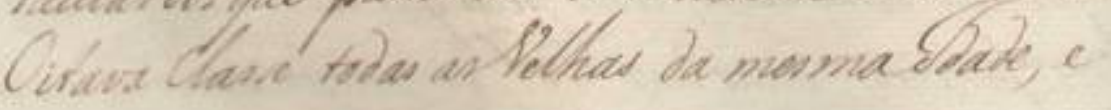

387 
||120v\| [[momen]]to, em quanto naõ vir completamentedisci= plinada a referidaTropa.

18 Della, e detoda amais, que guarnece essaCapitania; da sua Disciplina; e dos seosExer= cicios; do seoNumero, e do seoestado mandaráVossa Senhoria Relaçoens annualmente por estaSecretaria deEstado.

19 Da mesma sorte repitirá VossaSenhoria Annu= almente a mandar Relaçoens do Numero dos ha= bitantes divididos emClasses assimpelo querespei= ta a Idade, como aoSexo: [espaço] Pondo naPrimeira Classe as Crianças doSexo Masculino desde a primeiraldade, até a de sete annos: $\mathrm{Na}$ Segunda

135 Classe todas as do sexofeminino da mesma Idade: $\mathrm{Na}$ Terceira Classe todos os Rapazes desde a lda= de de sete Annos, ate a de quinze: Na Quarta todas as Raparigas desde aldade de seteAnnos, ate a de catorze: Na Quinta Classe todos os Homens 140 desde aldade de quinze Annos ate a deSecenta [[de secenta]]: [espaço] Na SextaClasse todas as Mulheres desde aldade de catorze, ate a Idade de cinco= enta: [espaço] NaSeptimaClasse todos os velhos desdea idade de secentapara cima: [espaço] Com distinçaõ par= 145 ticulardos que passarem de NoventaAnnos: [espaço] $\mathrm{Na}$ Oitava Classe todas asVelhas da mesmaldade, e 


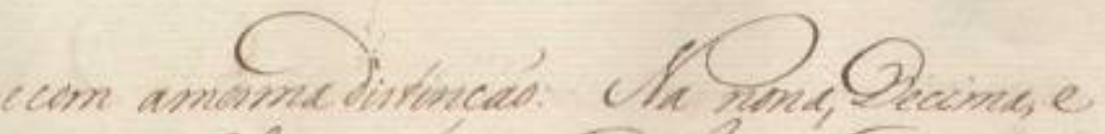

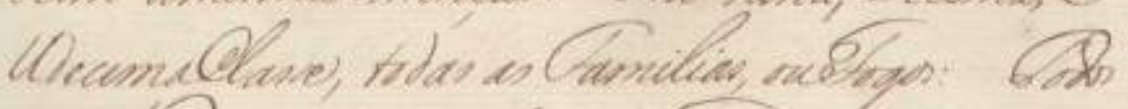

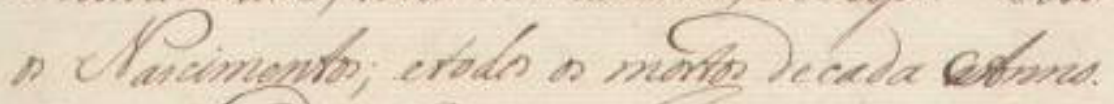

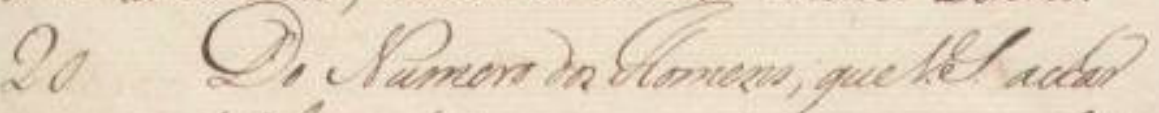

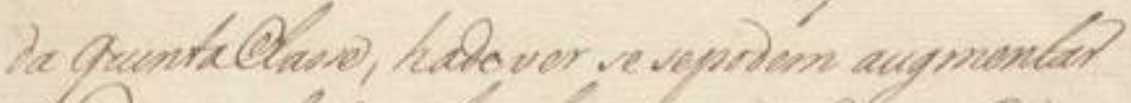

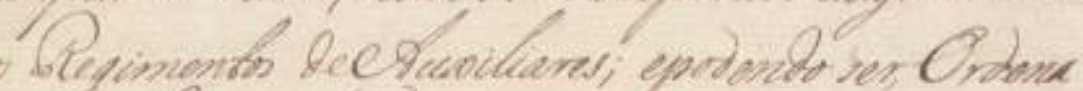

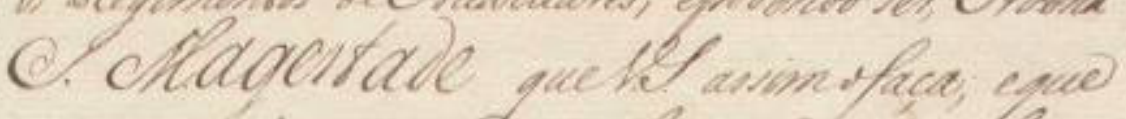

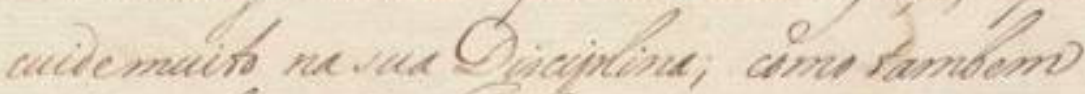

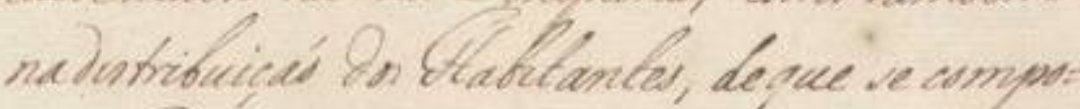

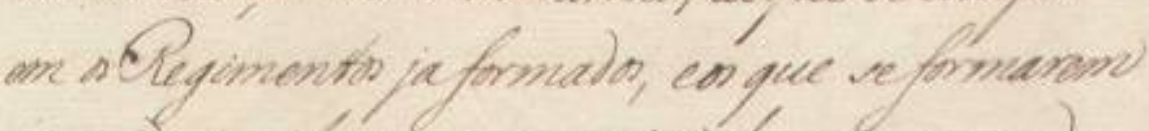

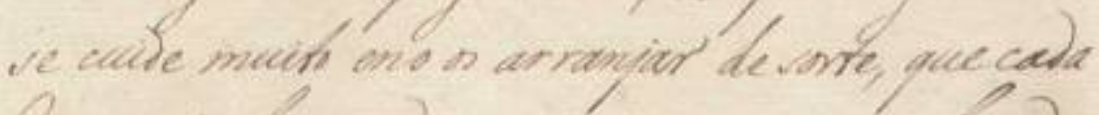

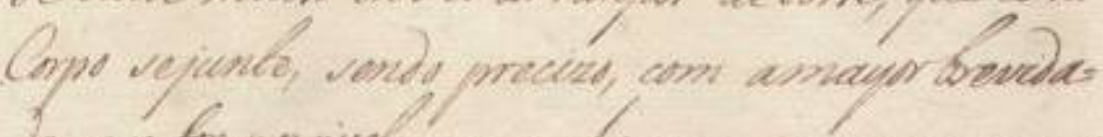
Ic pue for nowive; 8 mantue con a mesme, para

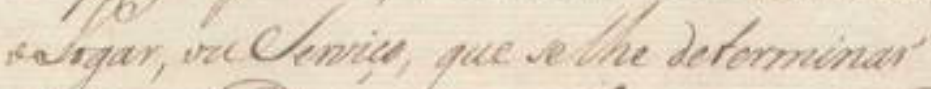
2)
.
bito toios
Quprado

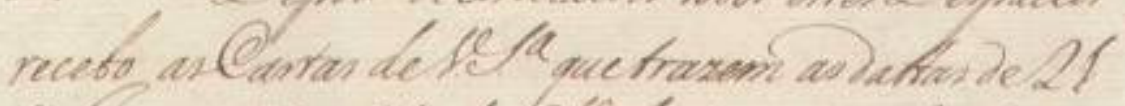

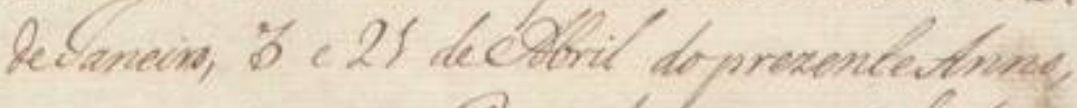

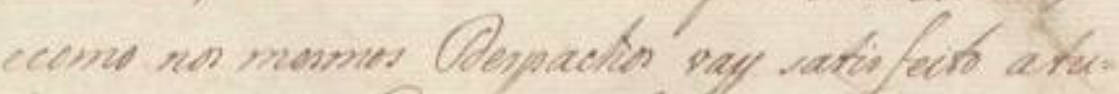

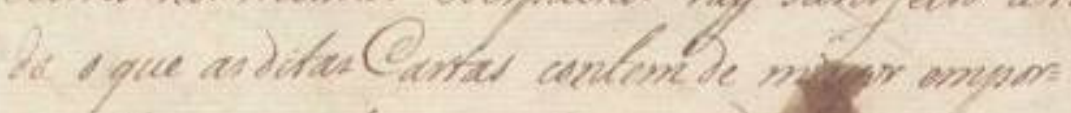

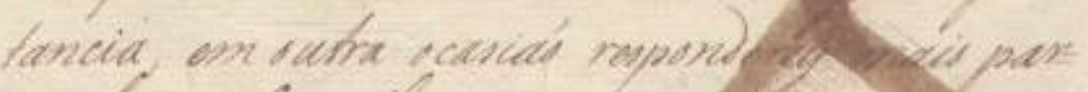

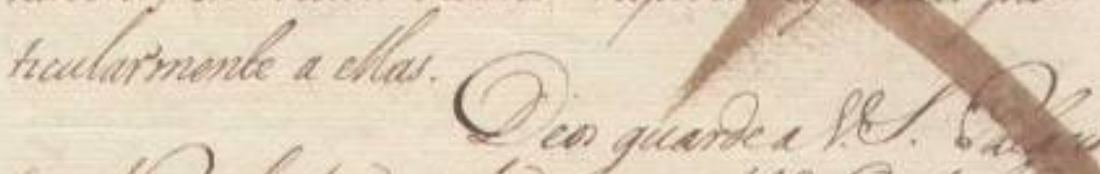

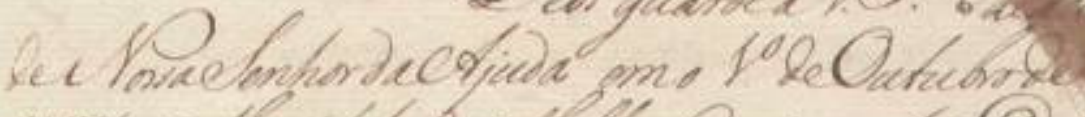

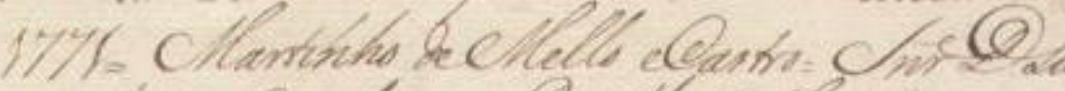

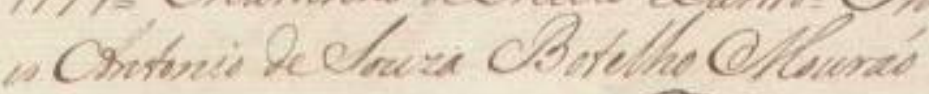

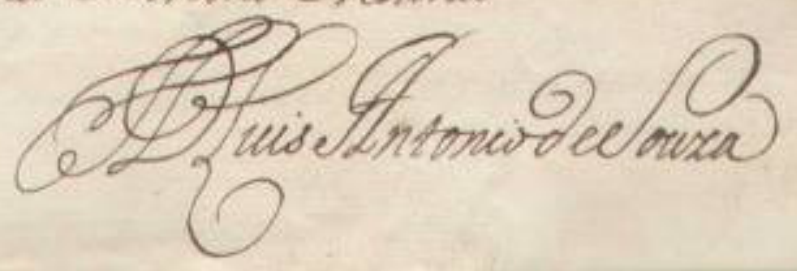


||121r|| [[e]]com amesma distinçaõ: [espaço] Na nona, Decima, e UdecimaClasse, todas as Familias, ouFogos: [espaço] Todos os Nascimentos; etodos os mortos de cada Anno.

20 Do Numero dos Homens, queVossaSenhoria achar da quintaClasse, hade ver se sepodem augmentar os Regimentos deAuxiliares; epodendo ser, Ordena Sua Magestade queVossaSenhoria assim ofaça, eque cuidemuito na sua Disciplina; como tambem na distribuiçaõ dos Habitantes, de que se compo= em os Regimentos jaformados, eos que seformarem se cuide muito eno os arranjar de sorte, que cada Corpo sejunte, sendo precizo, com amayor brevida= de quefor possivel; e marche com a mesma, para oLogar, ouServiço, que selhe determinar 21 Depois de concluidos todos estes Despachos recebo asCartas deVossaSenhoria quetrazem as dattas de21 delaneiro, 3 e 21 deAbril doprezente Anno, e como nos mesmos Despachos vay satisfeito atu= do o que as ditas Cartas contem de mayor empor= tancia, em outra ocasiaõ responderey mais par= ticularmente a ellas.

Deos guarde aVossaSenhoria Palacio deNossaSenhor daAjuda em o primeiro deOutubrode

$1701771=$ Martinho deMello eCastro $=$ SenhorDomLu= is Antonio deSouza Botelho Mouraõ 
(C) Pacaio ditana arti.

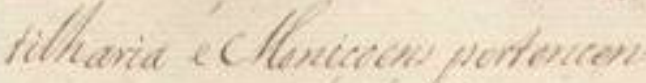

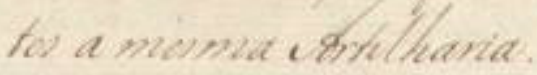

$(1$

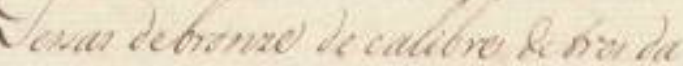

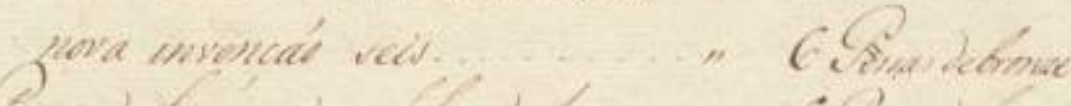

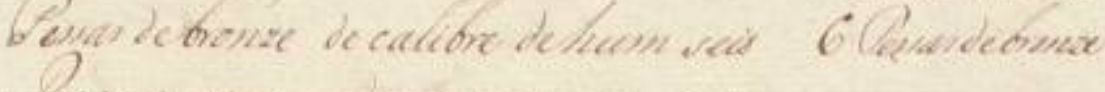

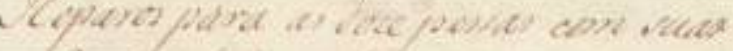

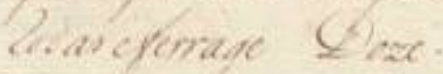

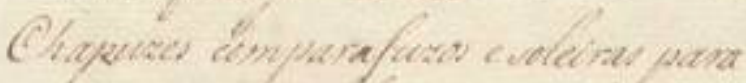

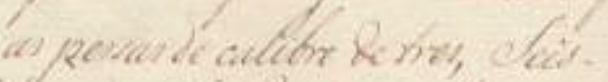

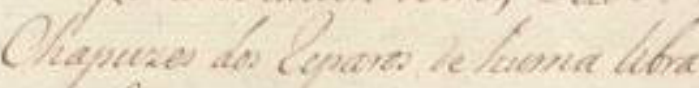
cles

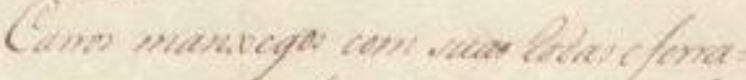

12 Renore

Geingurer

6 Chepresos

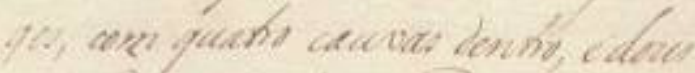
arkaco cala hum Sies.

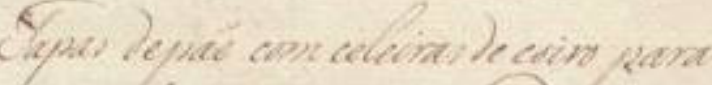

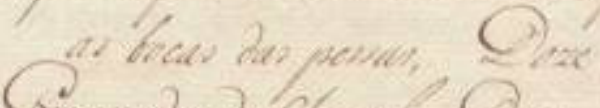
Srimuada ze Chombe Q.ee

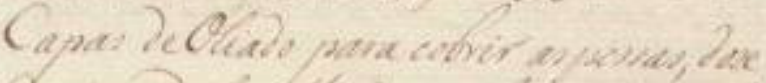

19 Com mas areso

20lementerwas

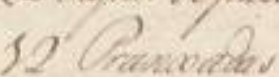

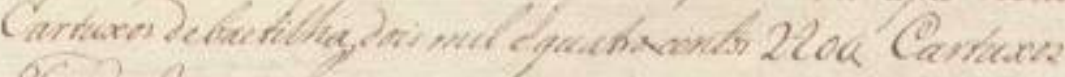

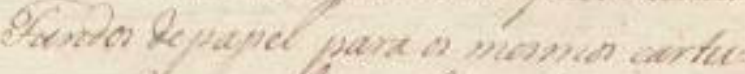

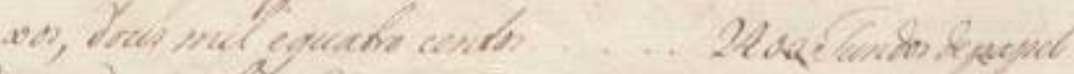

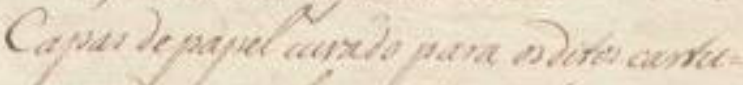

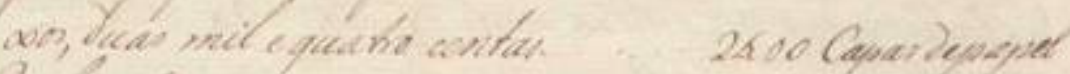

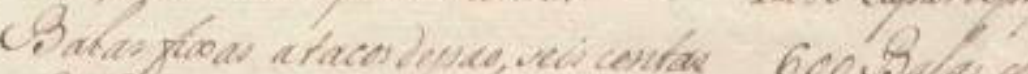

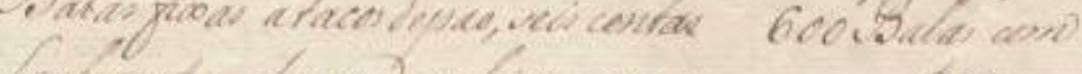

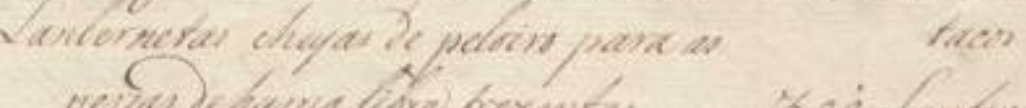

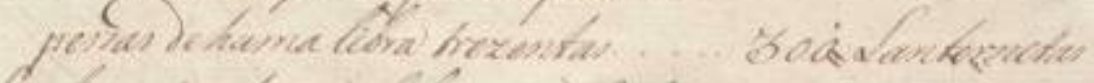

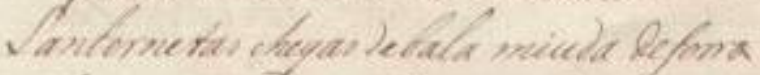

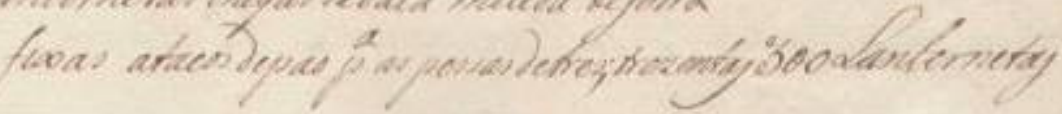


Relaçaõ detoda a $\mathrm{Ar}=$ tilharia e Moniçoens pertencen= tes a mesma Artilharia.

Pessas debronze de calibre detres da

nova invençaõ seis

6 Pessas debronze

Pessas debronze de calibre dehum seis 6 Pessas debronze

Reparos para as doze pessas com suas

rodas eferrage Doze

12 Reparos

Chapuzes comparafuzos e soleiras para

as pessas de calibre de tres, Seis.

6 Chapuzes

Chapuzes de reparos dehuma libra

Seis

6 Chapuzes

15 Carros manxegos com suas rodas eferra=

ges, com quatro cauxas dentro, e dous

cadeados cadahum Doze.

12 Carros man-

Tapas depaô com coleiras de coiro para xegos.

as bocas das pessas, Doze

12 Tapas de pau

20 Pranxadas de Chumbo, Doze.

12 Pranxadas

Capas deOliado para cobrir as pessas, doze 12 Capas deOliado

Cartuxos debaetilha, dois mil e quatrocentos 2400 Cartuxos

Fundos de papel para os mesmos cartu=

xos, dous mil equatro centos 2400 Fundos de papel

25 Capas de papel curvado para os ditos cartu= xos, duas mil e quatro centas.

2400 Capas depapel

Balas fixas atacos depao, seis centas

600 Balas com

Lanternetas cheyas de peloiro para as

tacos

pessas dehumalibra trezentas. 300 Lanternetas

30 Lanternetas cheyas debala miuda deferro

fixas atacos depao para as pessas detres; trezentas 300 Lanternetas 
Clfawe conla de vida pare atares

Camicoor, sere

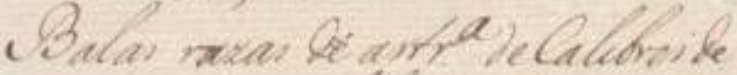

32. Haresece: de tevine

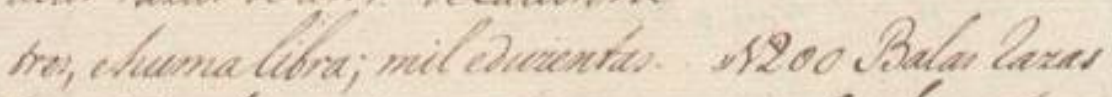

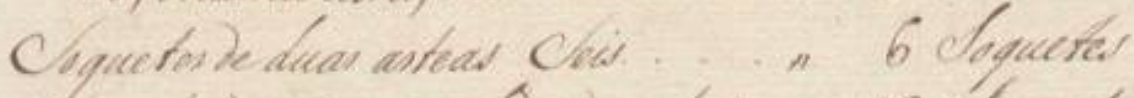

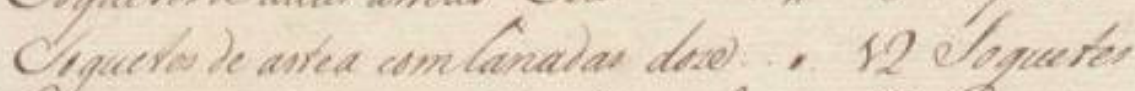

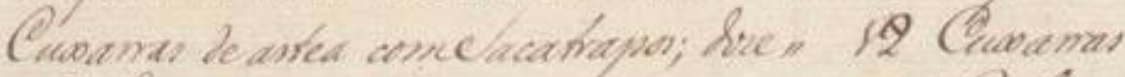

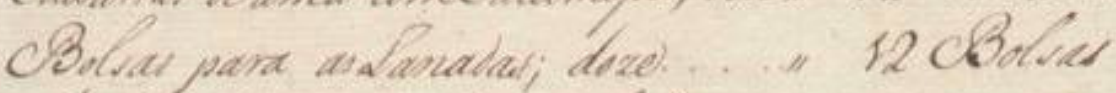

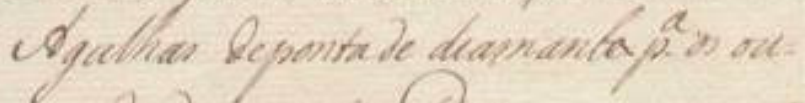
not dai powain, Lec. .......

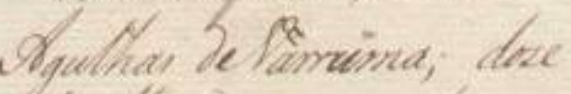
Aquellas de quive, dece.

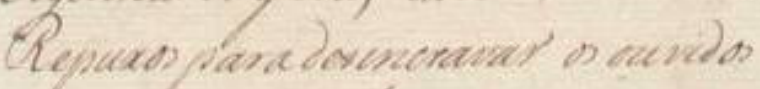
Daspora; dow......... 12 Repuno

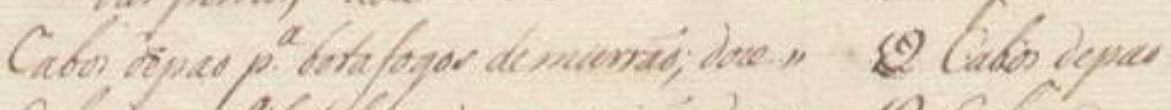

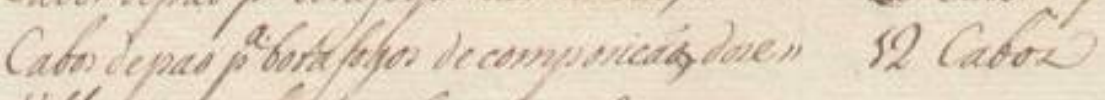

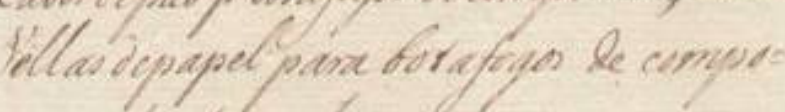

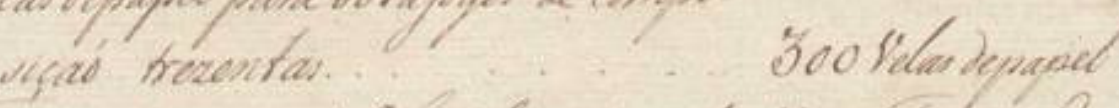

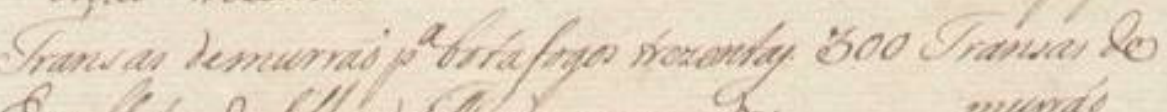

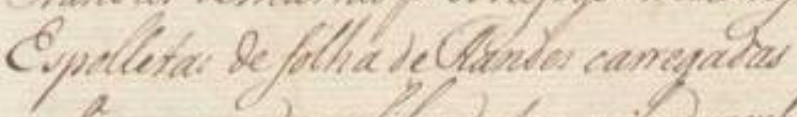
12. Aquiliae 12. Ofulliar 12. spullias 12 Repund
\& Cinos de
'2 Cabos

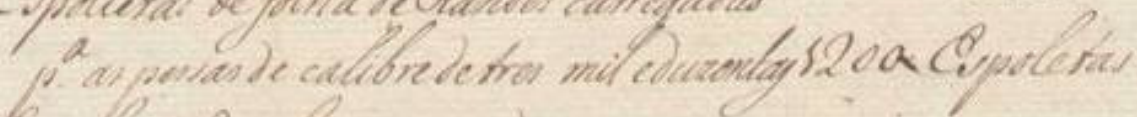
E. pretera le cono, camegalas pard no wo

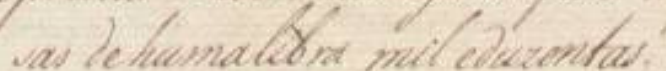

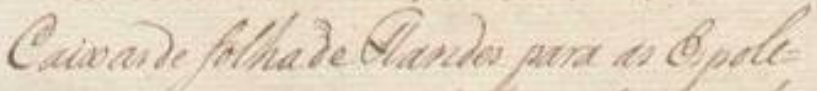

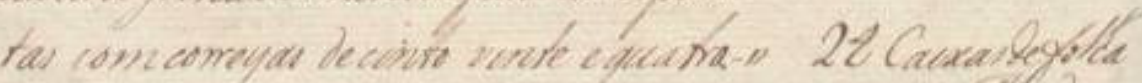

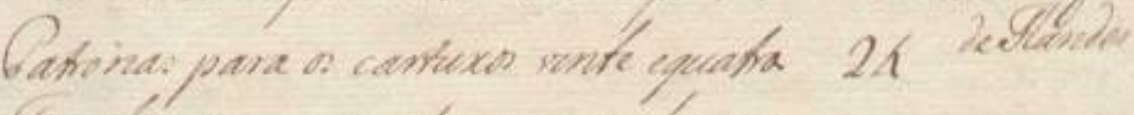

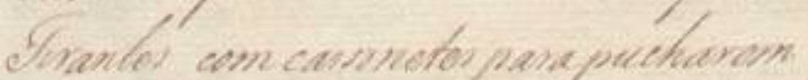
liencerse rowe cquath

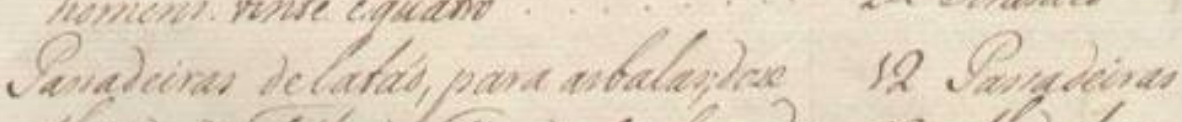

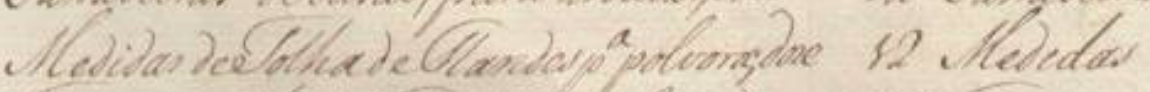

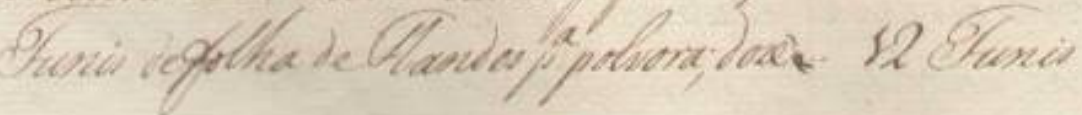


||12'2v || Massos de corda deviola para ataros

Cartuxos, doze.

Balas razas de artilharia deCalibres de

tres, ehumalibra; mil eduzentas.

Patronas para os cartuxos vinte equatro 24

Tirantes com cassonetes para pucharem homens. vinte equatro 24 Tirantes

Passadeiras delataõ, para asbalas; doze 12 Passadeiras

60 Medidas deFolha deFlandes para polvora, doze 12 Medidas Funis defolha deFlandes para polvora; doze 12 Funis
12 Maços decor da deviola 1200 Balas razas 6 Soquetes 12 Soquetes 12 Cuxarras 12 Bolsas 12 Agulhas 12 Agulhas 12 Agulhas 12 Repuxos
Cabos depao para botafogos de composicaõ, doze,, 12 Cabos

Vellas depapel para botafogos decompo= siçaõ trezentas 300 Velas depapel

Transas demurraõ parabotafogos trezentas. 300 Transas de para as pessas de calibre detres mil eduzentas 1200 Espoletas

Espoletas de cobre carregadas para as pes $=$ sas de humalibra mil eduzentas......., 1200 Espoletas

Caixas de folha deFlandes para as Espole= tas com correyas decinto vinte equatro,, 24 Caixas defolha [deFlandes] 
\|123r

Qeelentar Q.

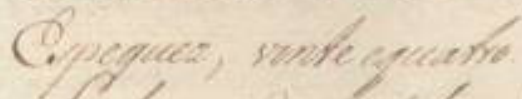

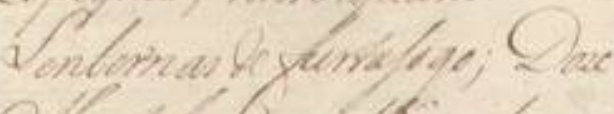

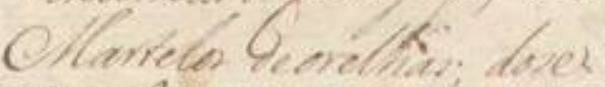

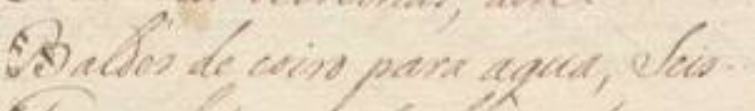

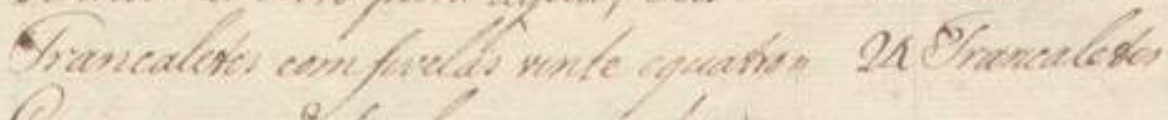

Compar un fuclas pana a lá

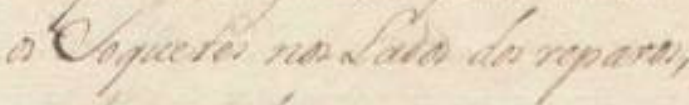
wate cyuarm

Cmadas, Oa.

Gigaratas Qme

(R) ${ }^{2}$ fom Q Q

cliagho. Q ae

Qfleodintas Qies

Ecitum Q eac.

21 Emanas

12 Qriarlas

12 Exeratis

" 12 valcóno

120 inarsos

re chlapadinctes

12 fencers

87

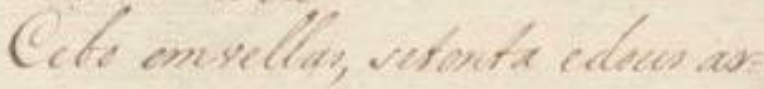
ration

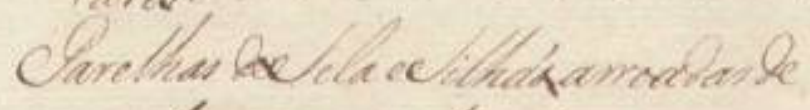

redrofurecias desorta

yo. giveneceds

npe prolía

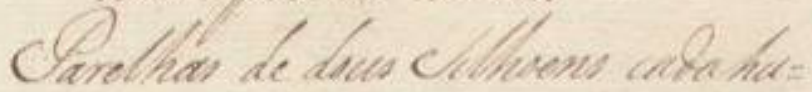

ma curcadas detole smmeise

para os reparss das veswas te bres

da novia invoncati; scis.

Arren que vaé nos Deres amese,

quarentic ucito

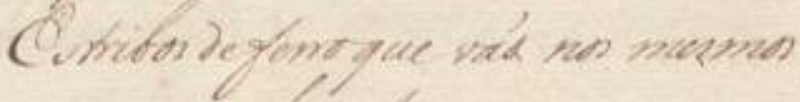

S)

18 erdecuritoo

18 efrues

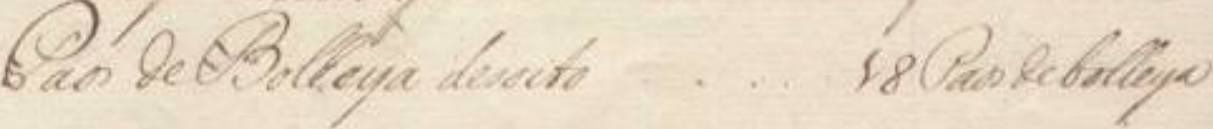

395 
||123r|| Pes deCabra: Doze 12 Pes deCabra

Espequez, vinte equatro 24 Espequez

Lenternas de furtafogo; Doze. 12 Lenternas

Martelos deorelhas; doze. 12 Martelos

Baldes de coiro para agua, Seis ,6 Baldes

Francaletes com fivelas vinte equatro 24 Trancaletes

Correyas com fivelas para atar os Soquetes nos Lados dos reparos, vinte e quatro

24 Correyas

Enxadas, Doze. 12 Enxadas

Picaretas, Doze 12 Picaretas

Pas de ferro, Doze 12 Pas de ferro

Maxados; Doze 12 Maxados

Maxadinhas Doze. 12 Maxadinhas

Podoens Doze. 12 Podoens

Cebo emvellas, setenta edous ar= rates

72 Arrates decebo

Parelhas deSela eSilhaõ arreadas de todo o precizo desoito 18 Parelhas

Parelhas de dous Silhoens cadahu= ma arreadas detodo oprecizo para os reparos das pessas de tres da nova invençaõ; Seis 6 Parelhas

85 Freyos quevaõ nos ditos arreyos,

quarenta eoito 48 Freyos

Estribos deferro que vaõ nos mesmos arreyos dezoito pares 18 pares deestribos Paos deBolleya desoito 18 Paos debolleya 
||123v $\|$

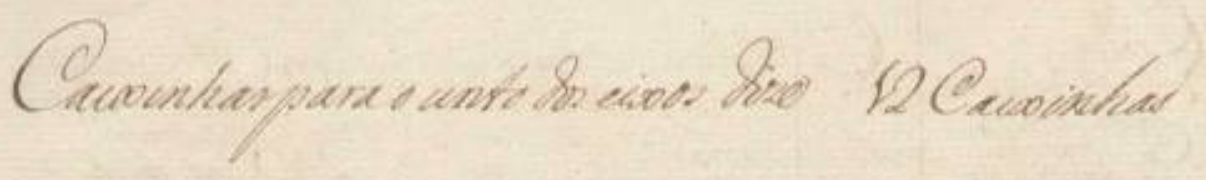

Cloniconsis desolrece

levié para as ditas dose?

posas

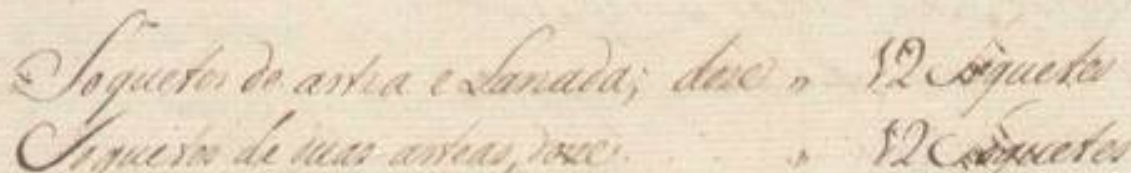

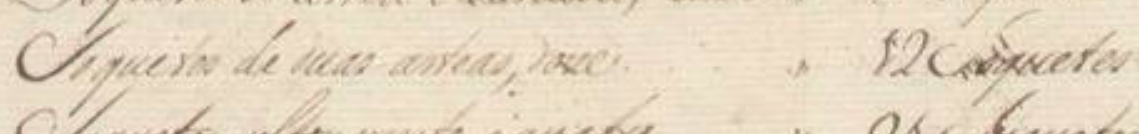

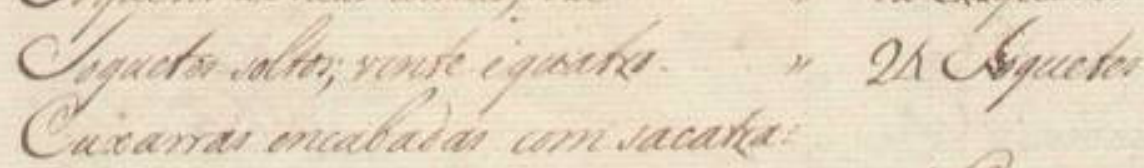
vin, yuaŕm Cofoulua depontade diamanle

- LCumams

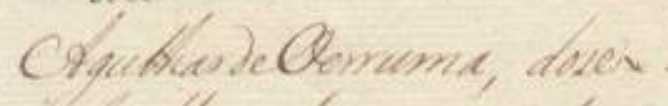

- 12 cotgibiar

Compulliai de grisa, oito

- 12 colqutur

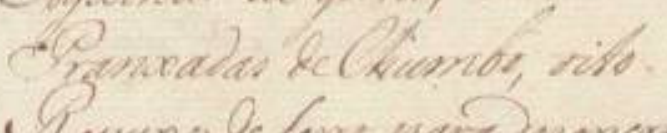

8 eguthas

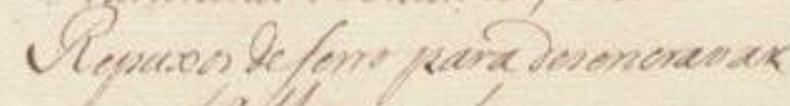

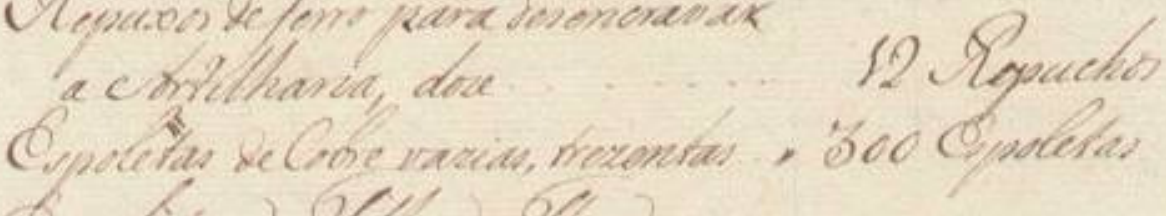

8 inarelas

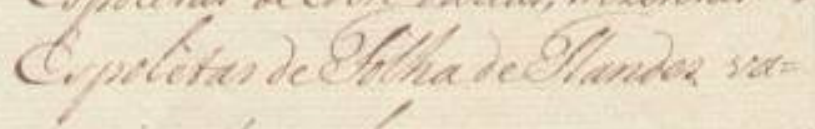
zias; noerctas

ctrantos com cassureres para pa:

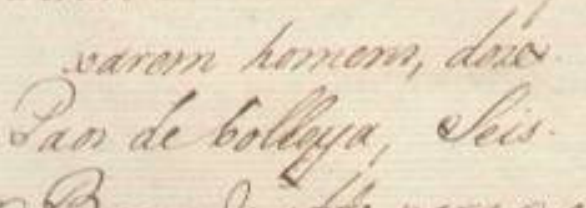

- Joorepritias

- 12 Strmantés

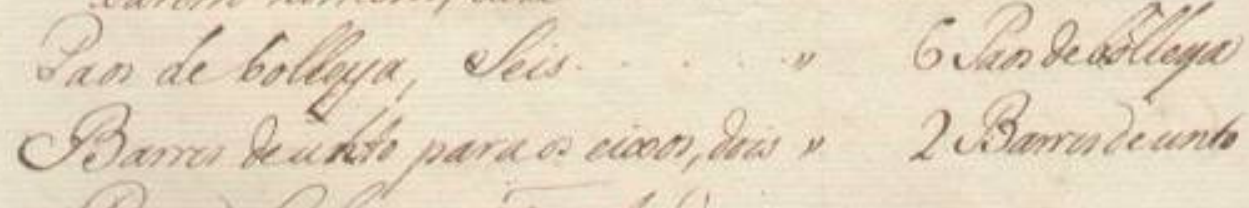
Oever be hors para biranto tas buras, daes.

-26enar beca: ba 6

397 
90 ||123v\| Caixinhas para o unto dos eixos doze 12 Caixinhas

Moniçoens de sobrece

lente para as ditas doze

Pessas

Soquetes de astia e Lanada; doze.............,., 12 Soquetes

95 Soquetes de duas asteas, doze 12 Soquetes

Soquetes soltos; vinte equatro 24 Soquetes

Cuxarras encabadas com sacatra

pos, quatro 4 Cuxarras

Agulhas deponta de diamante doze 12 Agulhas

Agulhas deVerruma, doze 12 Agulhas

Agulhas de goiva, oito 8 Agulhas

Pranxadas deChumbo, oito 8 Pranxadas

Repuxos deferro para desencravar

a Artilharia, doze 12 Repuchos

Espoletas deCobre vazias, trezentas....,, 300 Espoletas

Espoletas deFolha deFlandes va= zias; trezentas 300 Espoletas

Tirantes com cassonetes para $\mathrm{pu}=$ xarem homens, doze

12 Tirantes

Paos debolleya, Seis

6 Paos debolleya

Barris deunto paraos eixos, dois...., 2 Barris deunto

Pessas deCabo paraTirantes das bestas, duas 2 Pessas de ca= 
(2)

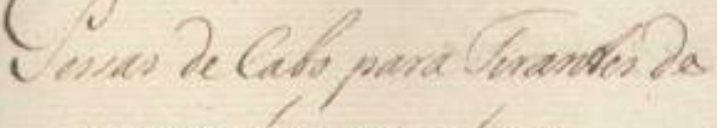
puadi homeras deas.

2 vour belale

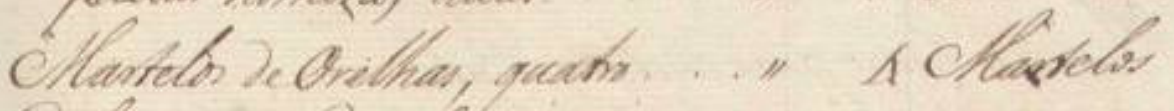
Q abos para.c. Darafore de memes, quethe.

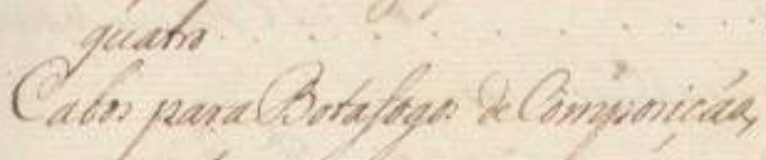
Qunts

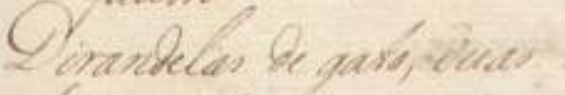

Comoser befermo: Cxis

Pus ale rille, wro amates.

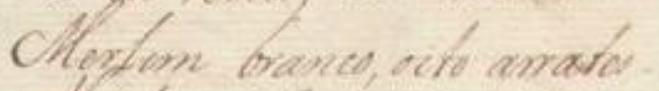

¿ Cava

chertom accerrades verénates

cominula pare alumedes, hos ....

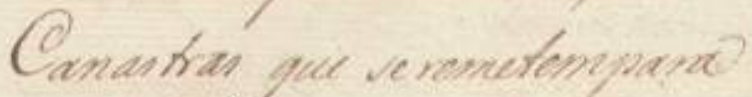
movelle, ar quese roming pard condersio as thoscoence precizas para ladoramen as ponas le mes

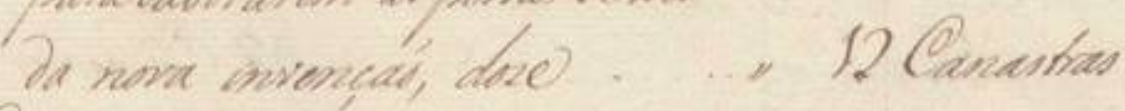
Corias coni wes gare je jom para inquerit ceida dual ceriander yure equatro.

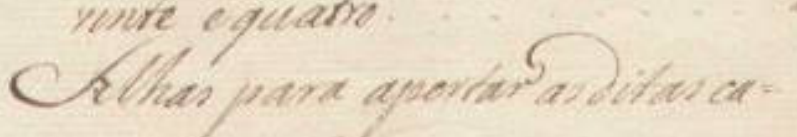
namar ocá

C Caves

Q Dirsuleter

GCleas

8 coréreris

8con: he hen:

8 conterentive 5 Gemitrelles

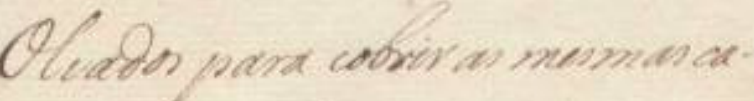
neinas, veis.

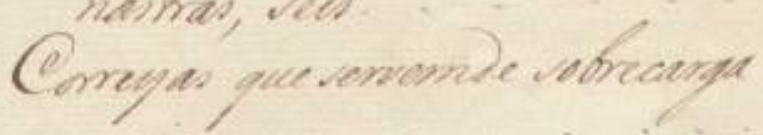
cers.

- 24 Marieripur Gover 6 Clias GConeras 
||124r|| Pessas deCabo para Tirantes de

puxar homens, duas

2 Pessas deCabo

Martelos deOrelhas, quatro

Cabos para Botafogos de murraõ,

120 quatro

Cabos paraBotafogo deComposiçaõ,

quatro.

4 Cabos

Dirandelas de gato, duas

Sotrossos de ferro; Seis. 6 Seis

Fio de vella, oito arrates.

Merlim branco, oito arrates

Merlim alcatroado, oito arrates

Feminelas paraLanadas, tres

Canastras que se remetempara
8 Arrates defio

8 Arrates de Merlim

8 Arrates deMerlim

3 Feminellas
12 Canastras

Cordas com seos gatos deferro para

inquerir cada duas canastras

vinte equatro

24 Cordas deinque $=$

Silhas para apertar as ditas ca= rir nastras Seis 6 Silhas

Oliados para cobrir as mesmas canastras, seis. 6 Oliados

Correyas que servemde sobrecarga seis. 


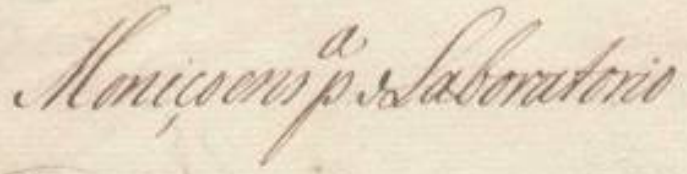

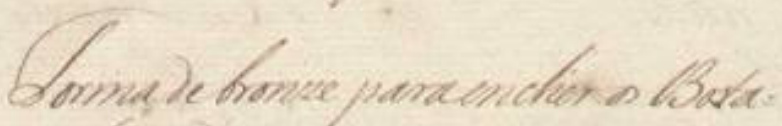

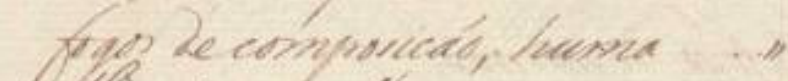
e) Laces lepari, dores.

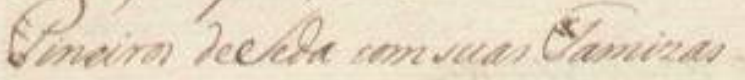

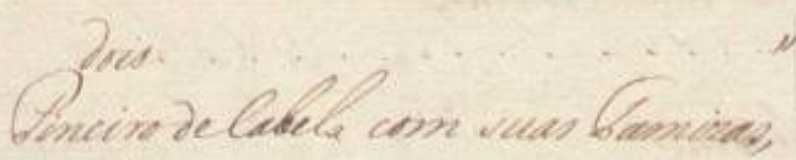

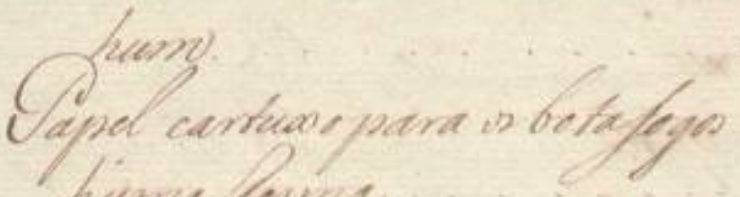

Cudamintias becubre pure oncher? - Burafoga yecas

(avorisile Ginhé eng queval as pare

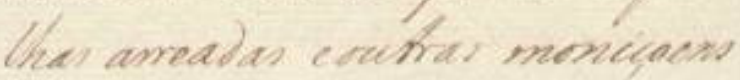
quenas vis no canto manoges, quarentewra.

1 \%orne fenme

- 2chaner lesen

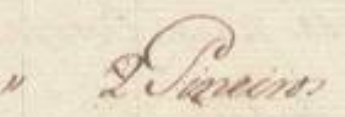

$\rightarrow$

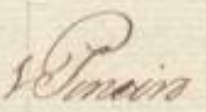

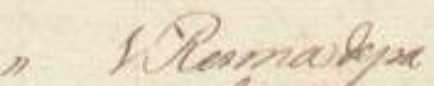
5. Ponatias lovelforrotacesin the 2 Cuasonintes

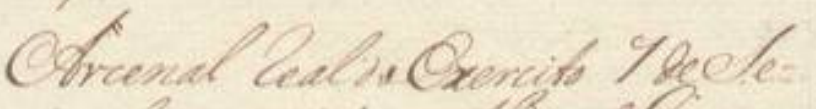

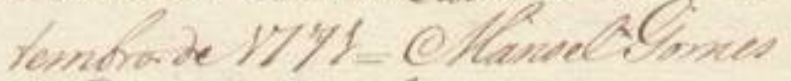

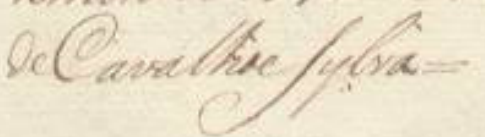


||124v|| Moniçoens para oLaboratorio

Forma debronze paraencher os Bota= fogos decomposiçaõ, huma............, 1 Forma debronze

Pineiros deSeda com suas Tamizas

dois.

2 Pineiros

Pineiro deCabelo com suas Tamizas, hum 1 Pineiro

150 Papel cartuxo para os botafogos humaresma.

1 Resma depa | pel Cartuxo

Salitre refinado tres arrobas.

3 Arrobas desali- | tre

Enxofrehuma arroba

1 Arroba deEnxo | fre

Cuxarrinhas decobre para encher os Botafogos duas.

2 Cuxarrinhas

Caixoens dePinho em quevaõ as pareIhas arreadas e outras moniçoens que naõ vaõ nos carros manxegos, quatentaedois 42 Caixoens

160 Arcenal real doExercito $7 \mathrm{deSe}=$ tembro de1771 = ManoelGomes deCarvalhoe Sylva == 


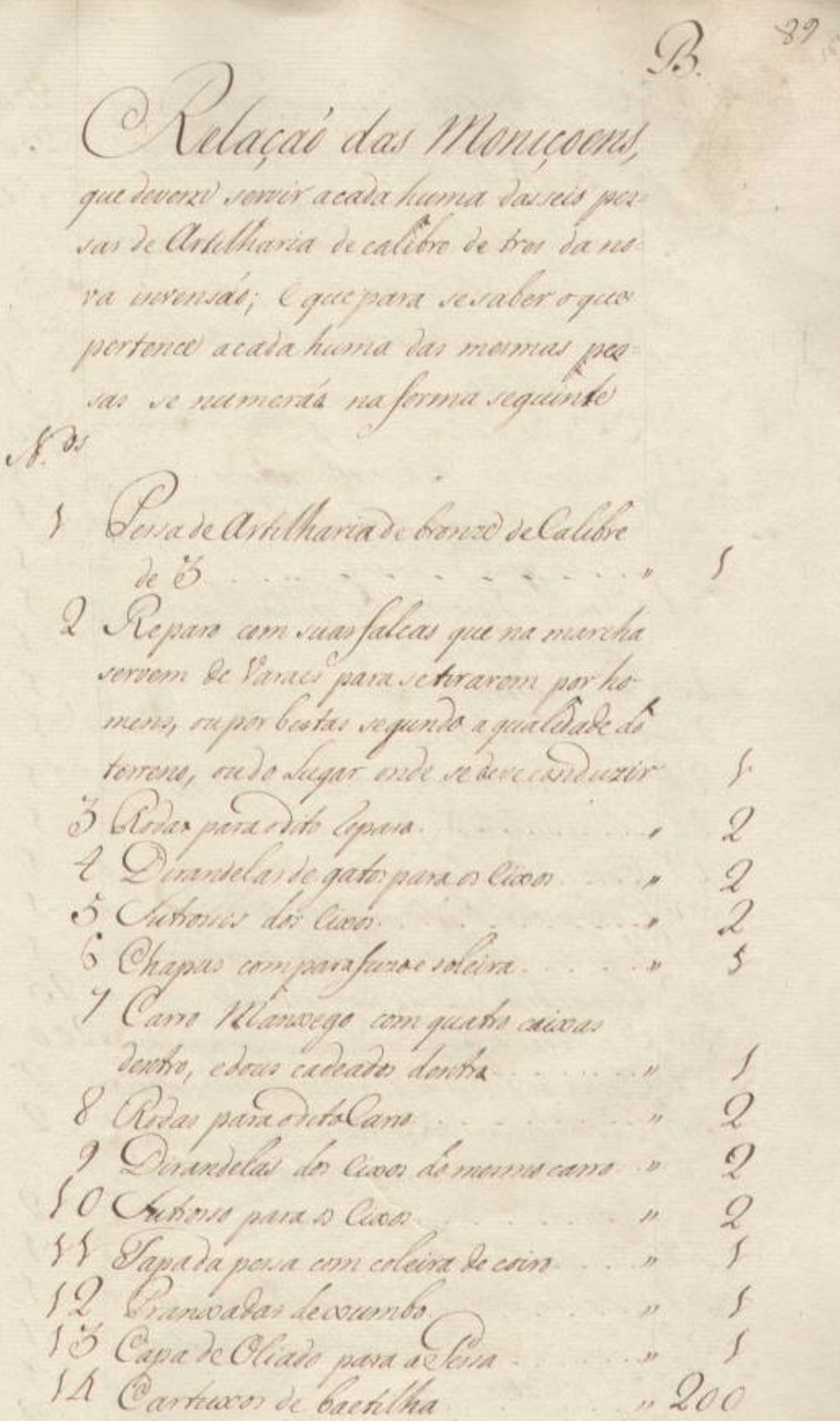


Relaçaõ das Moniçoens, que devem servir a cada huma das seis pes= sas de Artilharia de calibre de tres da no= va invensaõ; e que para se saber oque pertence a cada huma das mesmas pes $=$ sas se numeraõ naforma seguinte

Numeros

1 Pessa deArtilharia debronze deCalibre de 3

2 Reparo com suasfalcas que na marcha servem de Varaes para setirarem por ho= mens, ou por bestas segundo a qualidade do terreno, ou do Lugar onde se deve conduzir

153 Rodas para odito reparo...............................................,

$4 \quad$ Dirandelas de gatos para os eixos.............................., $\quad 2$

$5 \quad$ Sutrossos dos eixos.............................................., $\quad 2$

$6 \quad$ Chapas comparafuzoe soleira..................................., $\quad 5$

$7 \quad$ Carro Manxego com quatro caixas dentro, edous cadeados dentro.

$8 \quad$ Rodas para o ditoCarro........................................, $\quad 2$

$9 \quad$ Dirandelas dos eixos do mesmo carro..........................., $\quad 2$

10 Sutrosso para os eixos............................................., $\quad 2$

11 Tapadapessa com coleira de coiro...........................,., 1

$25 \quad 12$ Pranxadas dexumbo.................................................., 1

13 Capa deOliado para aPessa..................................., 1

14 Cartuxos de baetilha............................................, 200 


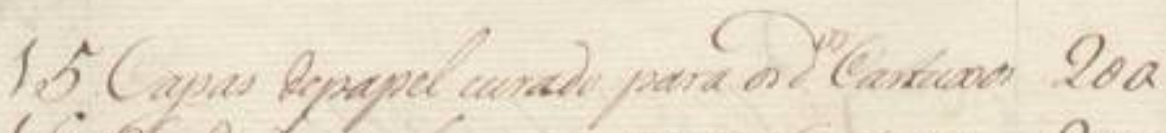

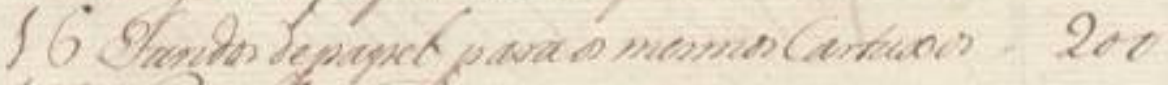

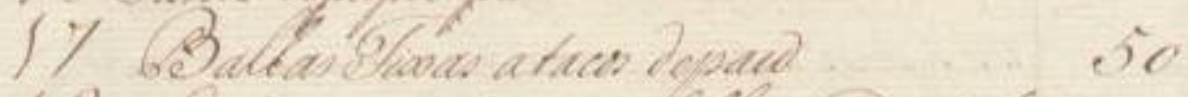
I8 devometar cherpos bialla nienda befor

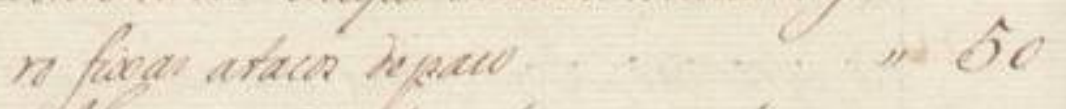

(9) Cllaw becorda Leviola pase atar

20 Calias lames

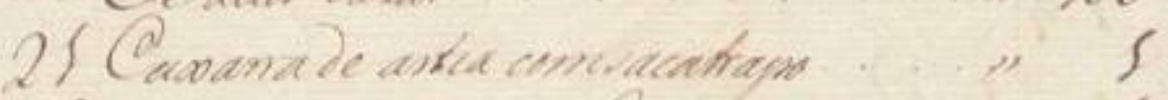

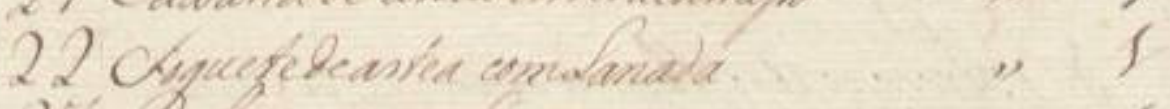

25 bolca para ad avada ......... of

22 copulia depenta de Q amante paras :" 5

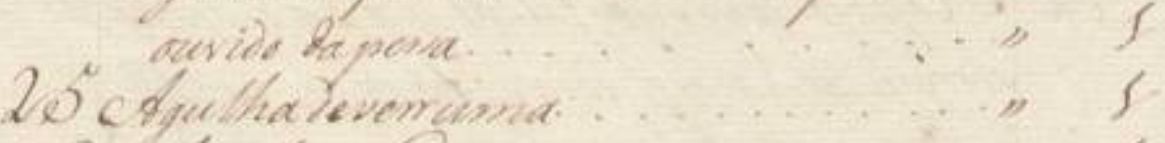
26 ctgatha deolowa............ \&

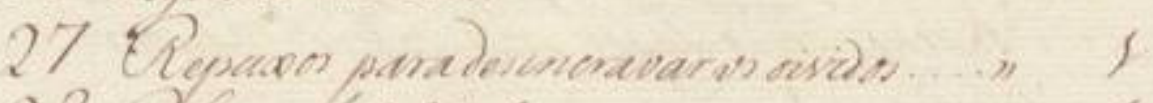

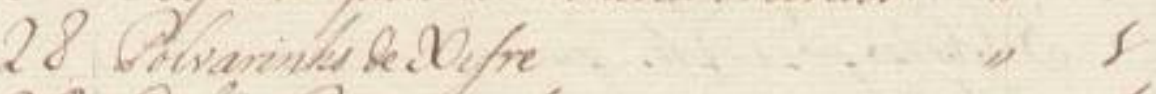
29 Catidelorafoga de montie......... I

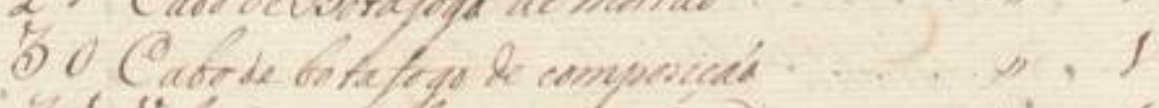

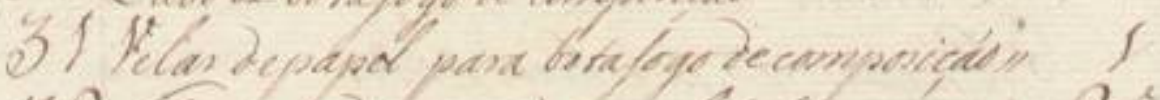

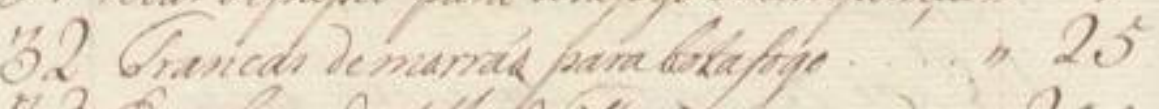

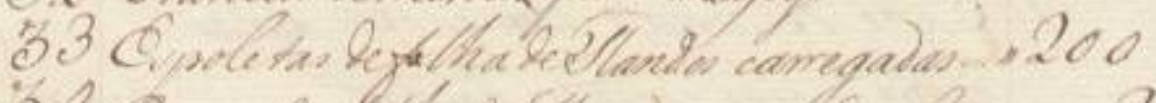

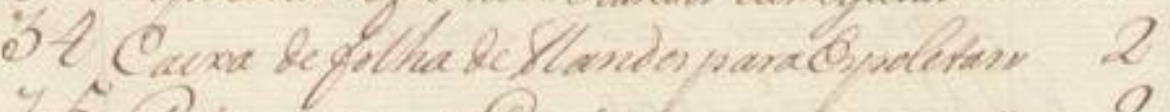

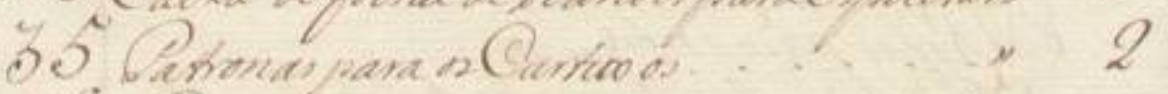

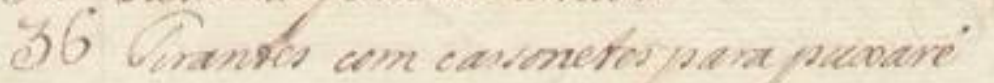

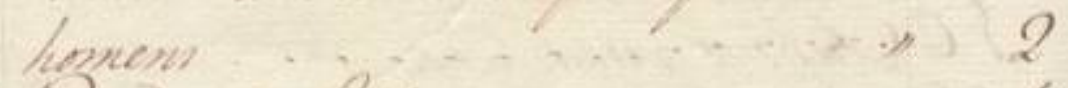

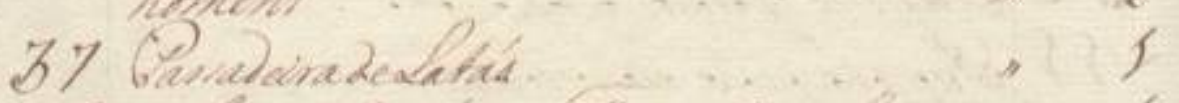

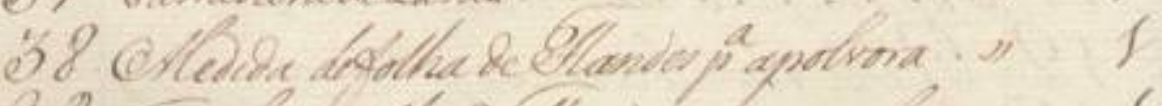

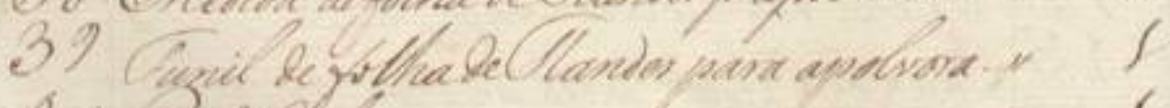
40 . हe bora ............ I

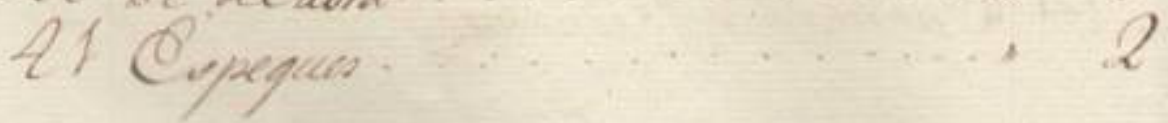


||126v|| 15Capas depapel curado para os ditos Cartuxos 200

16 Fundos depapel para os mesmos Cartuxos,, 200

$30 \quad 17 \quad$ Ballas Fixas a tacos depau..................................... 50

18 Lenternetas cheyas de balla muida defer= ro fixas atacos depau.

19 Masso de corda deviola para atar

os cartuxos.......................................................,

$35 \quad 20 \quad$ Balas razas.......................................................,

21 Cuxarra de astia com sacatrapo.........................., $\quad 1$

22 Soquetedeastea comLanada.................................,, 1

23 Bolça para aLanada........................................., , 1

24 Agulha deponta de Diamante para o...................., 1

25 Agulha deverruma...........................................,

26 Agulha deGoiva..........................................,

27 Repuxos para desincravar os oividos.................,

28 Polvarinho de Xifre.........................................,

4529 Cabo deBotafogo de morraõ..............................,

30 Cabo de botafogo de composiçaõ.......................,

31 Velas depapel para botafogo decomposiçaõ..........,, 1

$32 \quad$ Trancas de marraõ para botafogo.......................,, $\quad 25$

33 Espoletas defolha deFlandes carregadas.............., , 200

5034 Caixa defolha deFlandes paraEspoletas............., , 2

35 Patronas para os Cartuxos.............................., 2

36 Tirantes com cassonetes para puxarẽ homens....................................................,, 2

37 Passadeira deLataõ........................................,, 1

$5538 \quad$ Medida defolha deFlandes para apolvora...........,, 1

39 Funil de folhadeFlandes para apolvora............,,

$40 \quad$ Pe deCabra...............................................,

$41 \quad$ Espeques................................................, 
23 Chanelvecirthes

23 Cilarielestegarraloge

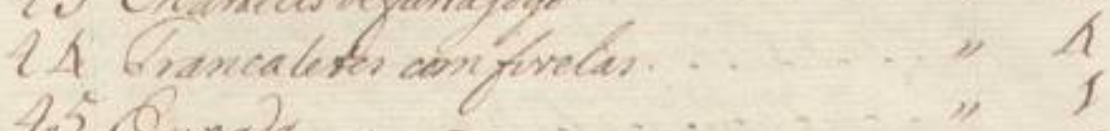

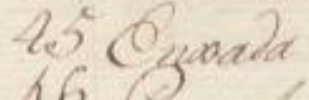

46 gearera

1\% ba kgen

48 chenatio.

49 Chaotinine

co gondos

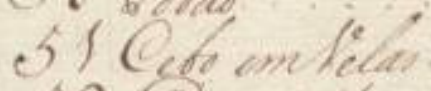

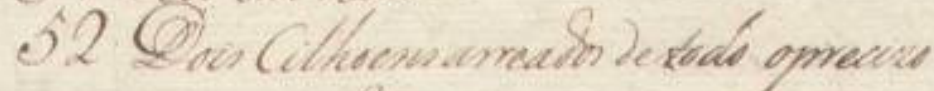

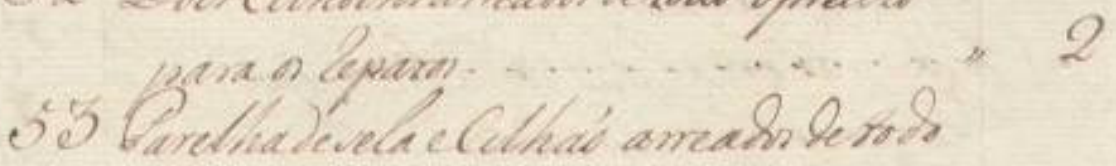

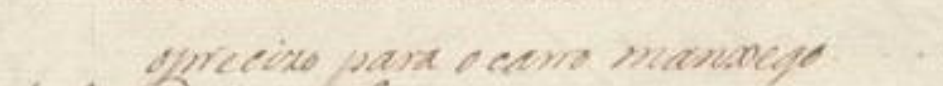

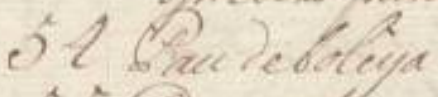

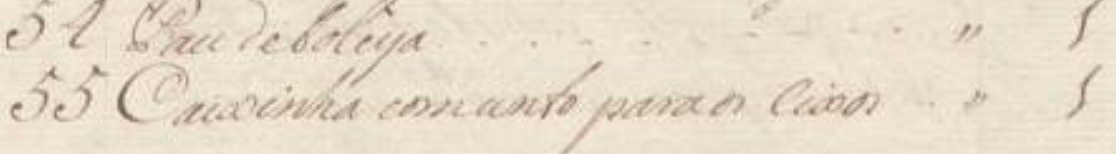

(O) orecelente para heled

(vias de Calibe de iv

Qipuetor deapher calsuela

Ospeces not

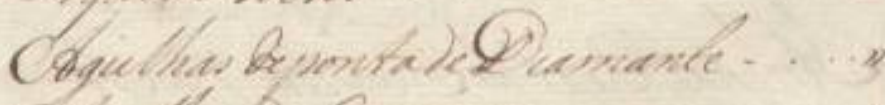

Coguthat de Cemment

Copulles bepeive pecens

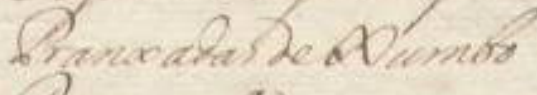

(Renavos ${ }^{2}$ )

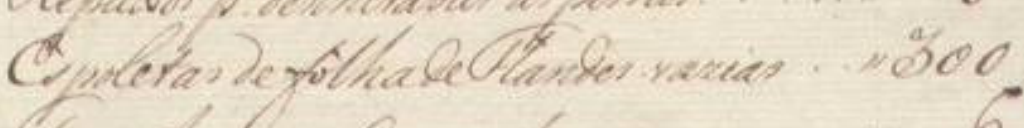

Cunesios conclaveneres. 
||127r|| 43 Martello deOrelhas.................................,

$6043 \quad$ Martello defurtafogo................................., 1

$44 \quad$ Francaletes com fivelas.................................,

$45 \quad$ Enxada..........................................................,,$\quad 1$

$46 \quad$ Picareta........................................................,, 1

$47 \quad$ Pá de ferro.................................................,

$6548 \quad$ Maxado.......................................................,

49 Maxadinha................................................,,$\quad 1$

$50 \quad$ Podaõ.......................................................,,

$51 \quad$ Cebo emVelas................................................, $\quad 6$ arrates

52 Dois Cilhoens arreados detodo oprecizo

53 Parelha de sela eCilhaõ arreados detodo oprecizo para o carro manxego.........................,, 1

$54 \quad$ Pau deboleya................................................,

55 Caixinha comunto paraos eixos........................,

Pessas deCalibre de3

Soquetes deastea eLanada..............................,, 12

Soquetes soltos.........................................., $\quad 12$

Agulhas depontadeDiamante........................,, 6

Agulhas degoiva quatro...........................,

Pranxadas deXumbo..................................,

Repuxos para desincravar as pessas...............,, $\quad 6$

Espoletas defolha deFlandes vazias...............,, 300 


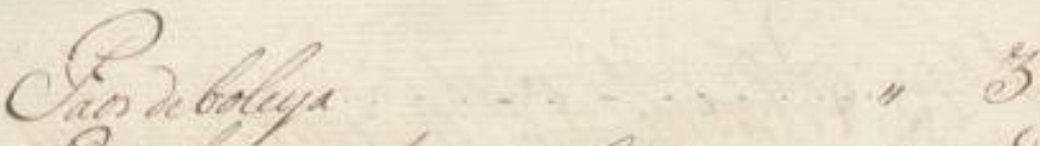
Cognat cumanthuare os canos.......... S

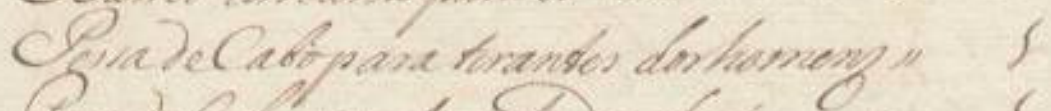

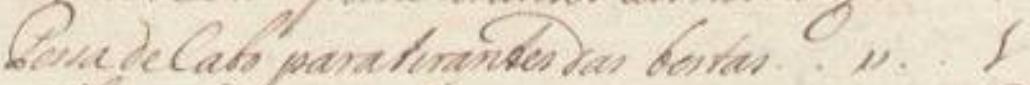
charrelosbeoneluar.............. 2 Qimandegat..........., ? Caon pane botafopeenemad...... ?

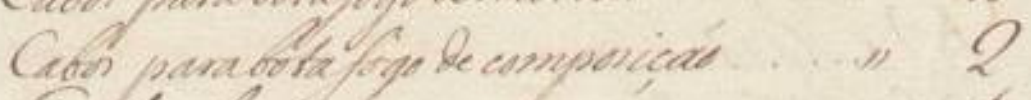

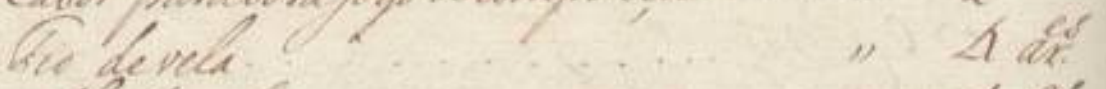
cterfen onanes............. "hal Clortion alcanbads........... $A$ is

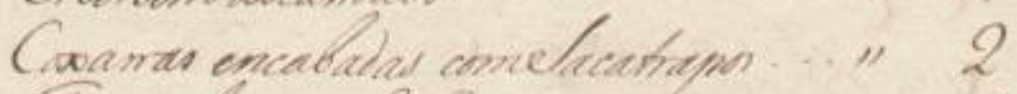
Gemincer 2carnuar......... 4 Cumondegene............. है

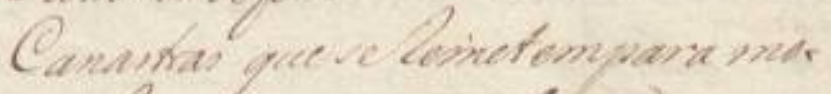

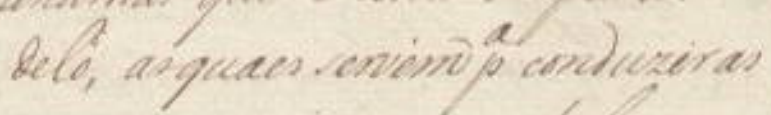

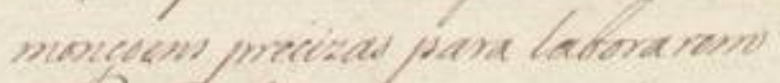

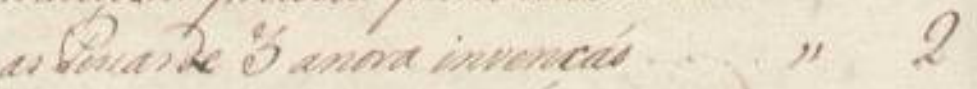
Cotas con en parto le ferr pan in: quener as into canashá........ A

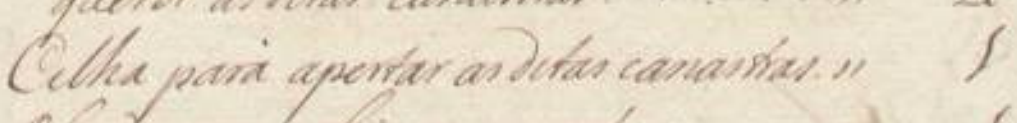

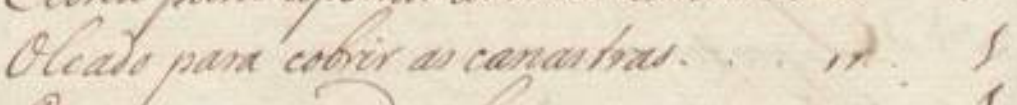

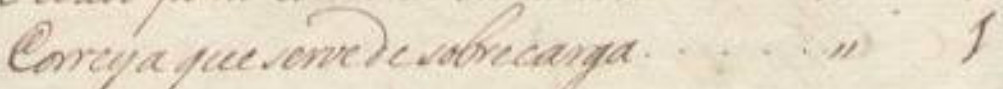

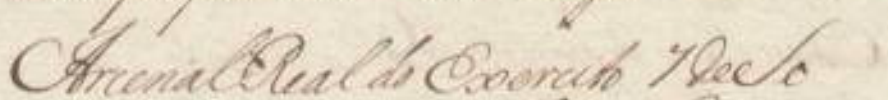

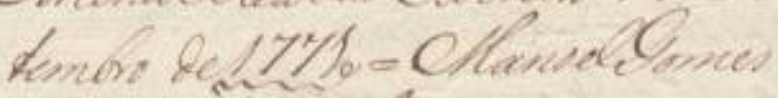
eccanalioc fore 
||127v\| Paos deboleya.....................................,

Barril comunto para os eixos......................,

Pessa deCabo para tirantes doshomens.......,, 1

Pessa deCabo para tirantes das bestas........,,

90

Martellos deOrelhas............................., , 2

Dirandelas de gato..............................,

Cabos parabotafogo demorraõ.................,

Cabos parabotafogo de composição.........., , 2

Fio devela.........................................., $\quad 4$ arrates

Merlimbranco......................................,

Merlim alcatroado.................................., $\quad 4$ arrates

Coxarras encabadas comSacatrapos........,, 2

Feminelas deLanadas..........................,, $\quad 4$

Sutrossos deferro..............................,

$100 \quad$ Canastras que seremetempara mo-

delo, asquaes servem para conduzir as

monçoens precizas para laborarem

as Pessas de 3 anova invençaõ.

Cordas com seos gatos deferro para in=

Cilha para apertar as ditas canastras......,

Oleado para cobrir as canastras............,,$\quad 1$

Correya que serve de sobrecarga..........,

ArcenalReal do Exercito 7 deSe

tembro de $\underline{1771}=$ ManoelGomes

deCarvalhoeSylva = 


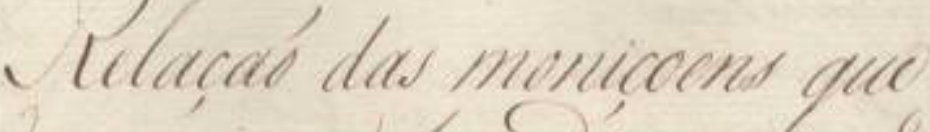

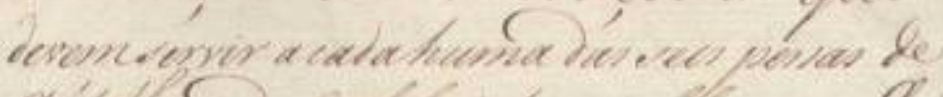

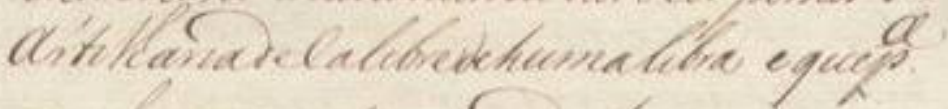

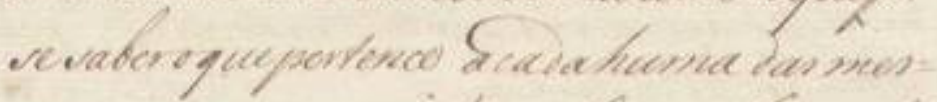

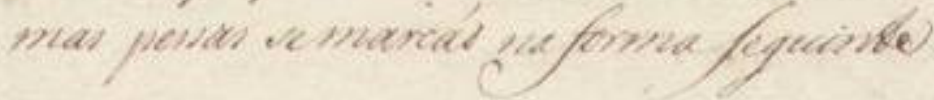

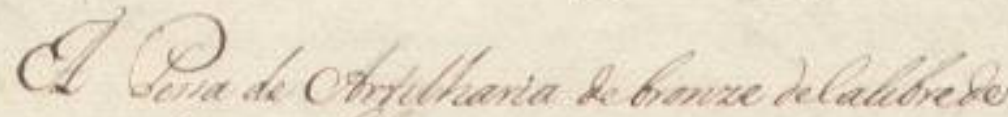

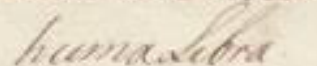

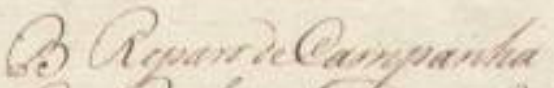

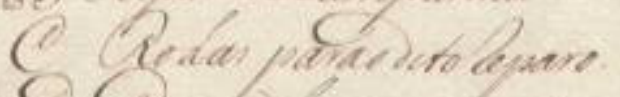

(1) Convelas pare bo lives

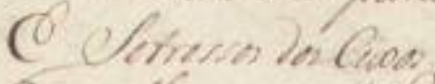

Q) L Livangar de Guam

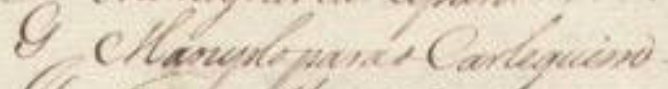

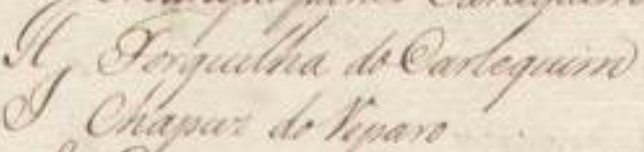

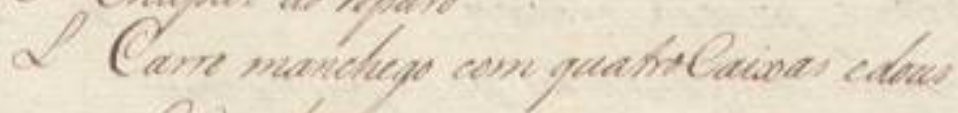

$$
\text { Calinde }
$$

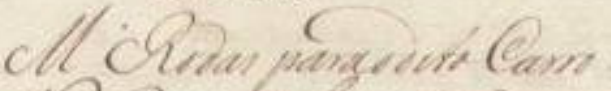

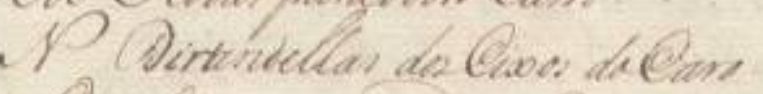

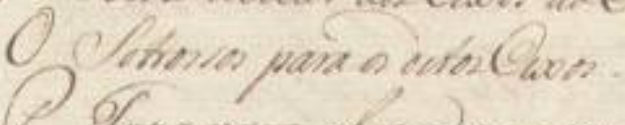

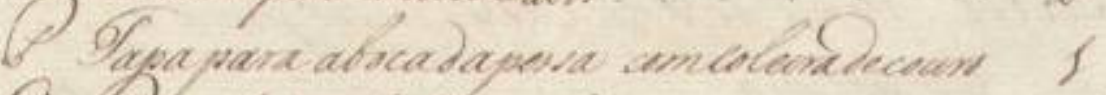

Q Shachada de eluments

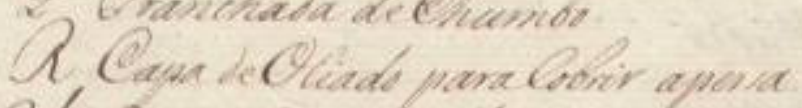

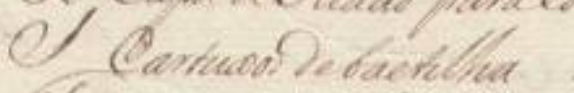

of 9 " "200

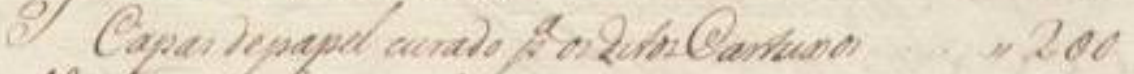

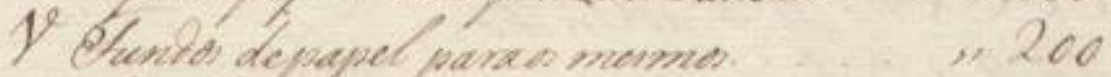

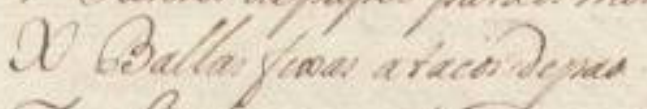

10.50

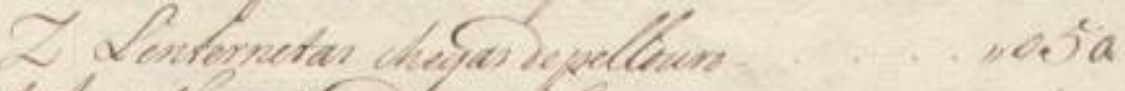

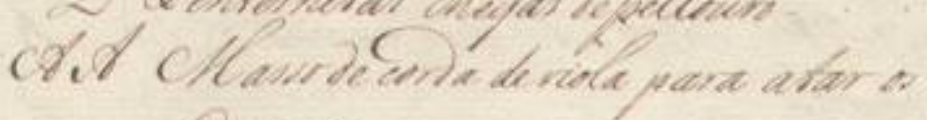

Cerrivas 

devem servir a cada huma das seis pessas de Artilharia deCalibredehumalibra e quepara se saber 0 que pertence a cada huma das mes= mas pessas semarcaõ na forma seguinte

A Pessa deArtilharia debronze deCalibrede humaLibra

10 B Reparo deCampanha

C Rodas parao ditoreparo.

D Dirandelas para os eixos

E Sotrossos dos eixos

F Missagras do reparo

15 G Maniplo para oCarlequim

H Forquilha doCarlequim

I Chapuz doreparo.

L Carro manchego com quatroCaixas edous

Cadeados

20 M Rodas parao ditoCarro

N Dirandellas dosEixos doCaro.................................., , 2

O Sotrossos para os ditosEixos......................................, $\quad 2$

P Tapa para abocadapessa comcoleiradecouro..............,., 1

Q Pranchada deChumbo......................................., , 1

$25 \mathrm{R} \quad$ Capa deOliado paraCobrir apessa..........................., , 1

S Cartuxos debaetilha..............................................., , 200

T Capas depapel curado paraos ditosCartuxos.............., $\quad 200$

V Fundos depapel paraos mesmos..........................., $\quad 200$

X Ballas fixas atacos depao....................................., $\quad 050$

$30 \quad$ Z Lanternetas cheyas depellouro............................., $\quad 050$

AA Masso decorda de viola para atar os

Cartuxos. 
S3.5 Ginlas laxas

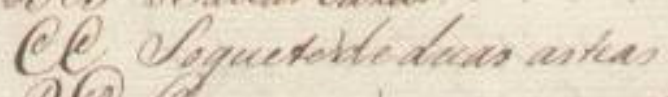

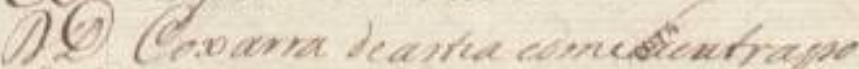

¿c elopueti de aurie om alasiála

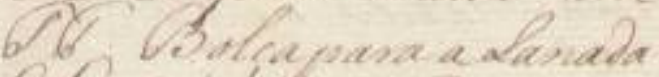

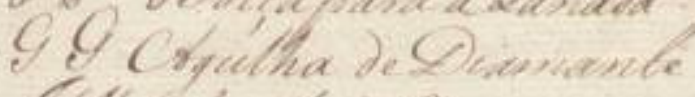

Clet Enoulia de liomerna

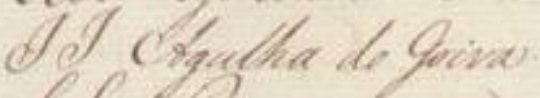

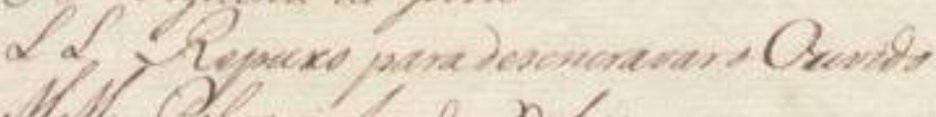

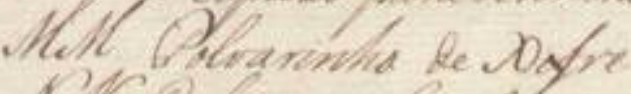

III Cabopara bola folgo semomas.

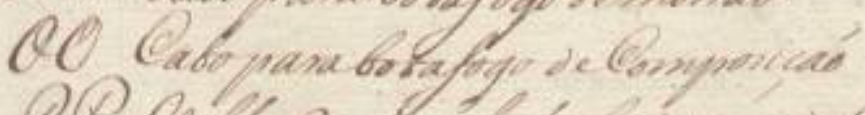

Too

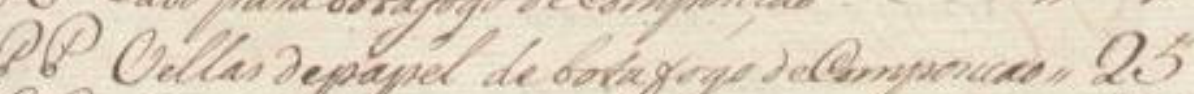

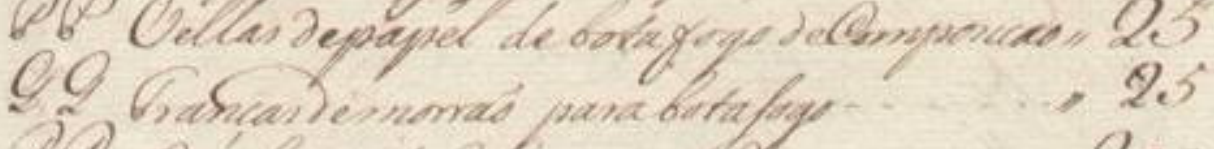

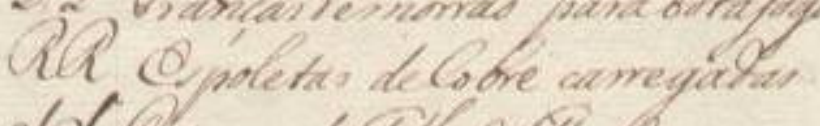

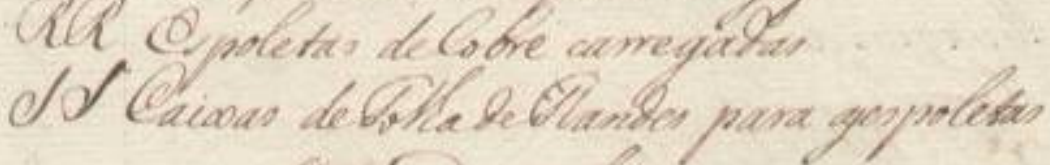

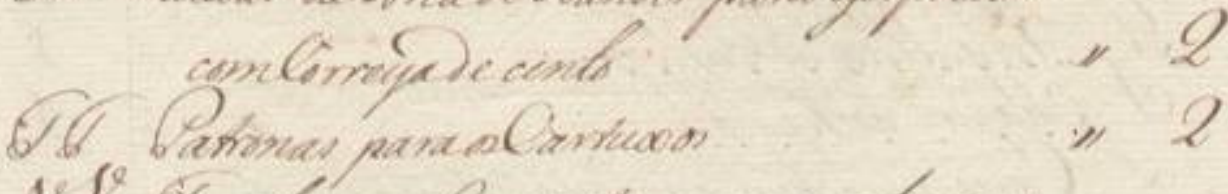

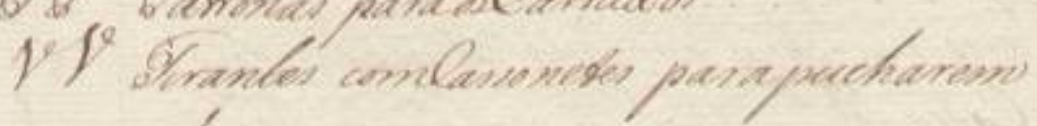

lipmons

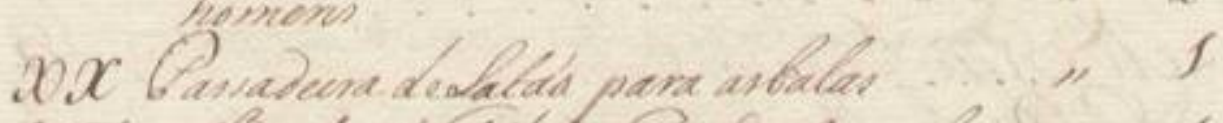

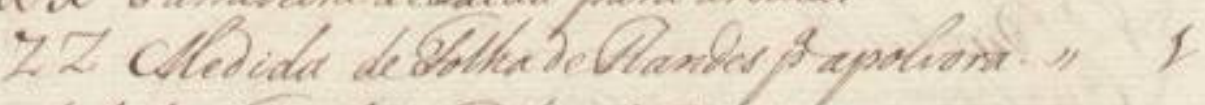

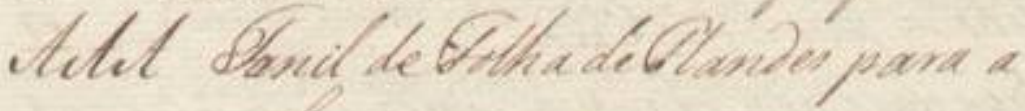

938 be delana

ce@ciserues

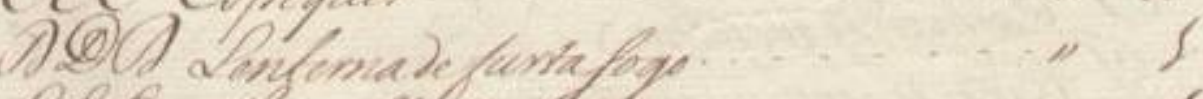

QQC Charrello dedintha, ..........1

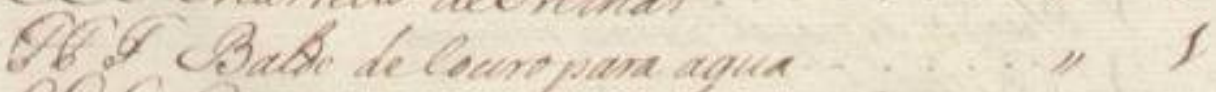

QQ. Comresas confivelas pare char os

chithe Enodar

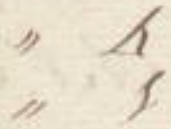


||128v\| BBBallasrazas. ....

CC Soquete de duas asteas...................................., 1

DD Coxarra deastia comSacatrapo..........................,, 1

35 EE Soquete de astia comLanada..............................,., 1

FF Bolça para aLanada..........................................,., 1

GG Agulha deDiamante......................................,

$\mathrm{HH} \quad$ Agulha deVerruma.....................................,,$\quad 1$

II $\quad$ Agulha de Goiva..........................................,,$\quad 1$

40 LL Repuxo paradesencravar oOuvido..................., , 1

MM Polvarinho de Xifre........................................,

NN Cabo para botafogo demorraõ.........................,, 1

OO Cabo parabotafogo deComposicao....................,., 1

PP Vellas depapel debotafogo deComposiçaõ..........., $\quad 25$

45 QQ Tranças demorrã̃ parabotafogo......................., , 25

RR Espoletas deCobre carregadas...........................,, 200

SS Caixas deFolha deFlandes para asespoletas comCorreya decinto.

TT Patronas paraosCartuxos..............................,,

50 VV Tirantes comCassonetes parapucharem homens.................................................,

XX Passadeira deLataõ para asbalas......................,., 1

ZZ Medida deFolha deFlandes para apolvora.........., 1

AAA Funil deFolha de Flandes para a polvora.

BBB Pe deCabra...............................................,

CCC Espeques.................................................,

DDD Lanterna defurtafogo................................, $\quad 1$

EEE Martello deOrelhas.......................................,,

60 FFF Balde deCouro para agua............................,

GGG Correyas comfivelas para atar os

Soquetes nos Lados das pessas........................, 4

$\mathrm{HHH}$ Enxada. 


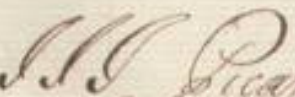

120

eferno

Huthell elfretuado

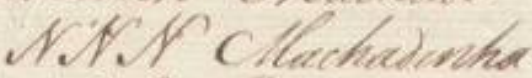

QQP GPAR

Qbe Con andere

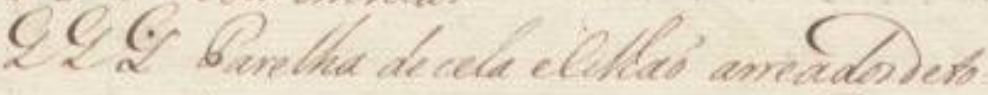

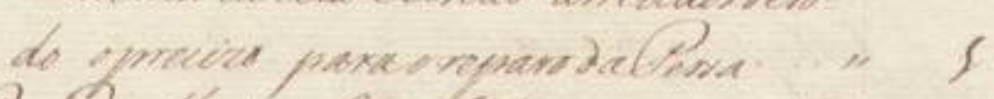

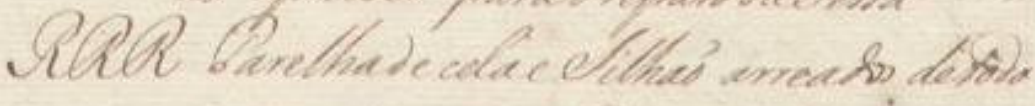

11
11

11

2.) 1

1) $f$

- Gal?

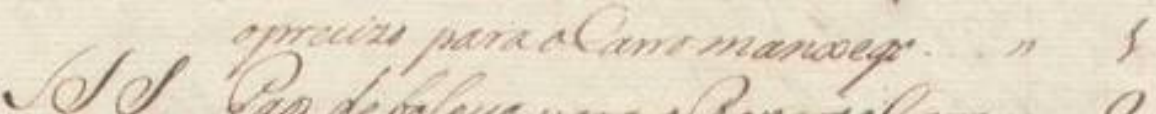

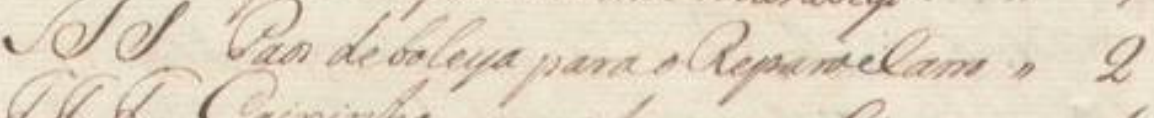

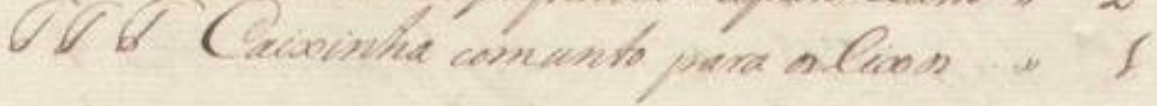

obrecellente parid as
dine bevies

C

cy drouetes whs

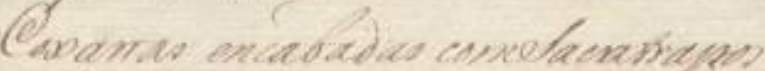

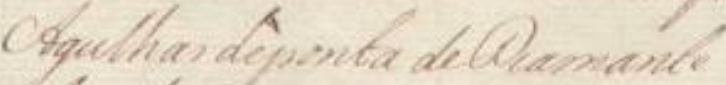

Opulhes telemema................. h

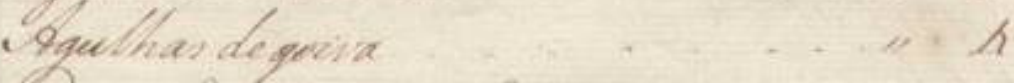

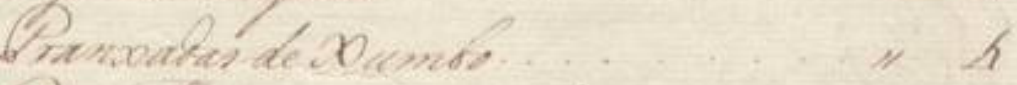

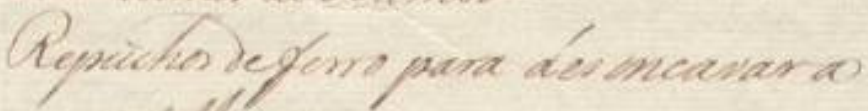
antellarie

Qundias decem vems.

(1) 6

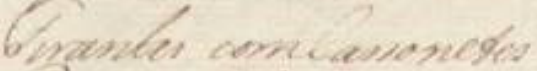

(Q) de bovera

110300

yod de bovelfa 
||129r|| III Picareta..............................................., $\quad 1$

65 LLL Pa deferro........................................,

MMM Machado...............................................,

NNN Machadinha............................................,, 1

O०O Podaõ ........................................................,

PPP Cebo emvelas............................................., $\quad 6$ arrates

70 QQQ Parelhade celaeCilhaõ arreados deto= do oprecizo para o reparo daPessa................,

RRR Parelhade celaeSilhaõ arreados detodo oprecizo paraoCarro manxego.....................,

SSS Paos deboleya para oReparoeCarro................, , 2

Sobrecellente para as

ditas Pessas

Soquetes de duas astias.

Soquetes soltos

Agulhas deponta deDiamante.

Agulhas deVerruma.................................,,

Agulhas de goiva...................................., , 4

Pranxadas deXumbo.................................,

Repuchos deferro para des encavar a

artilharia.

Espoletas deCobre vazias.

Tirantes comCassonetes.

Paos deboleya. 


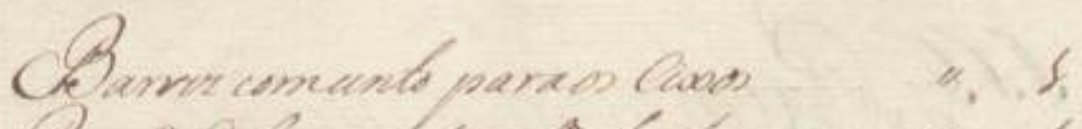

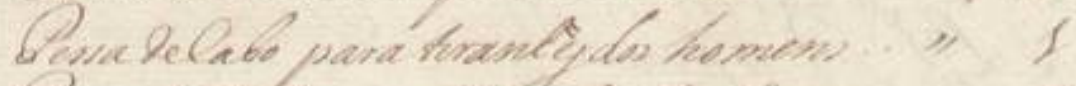

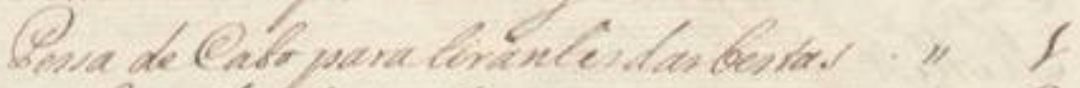

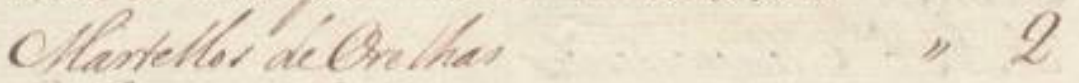

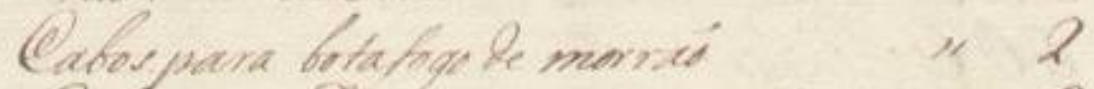
Cabor parabotaforge elomponices ..... 8 bedsacta $O \quad \cdots h \&$

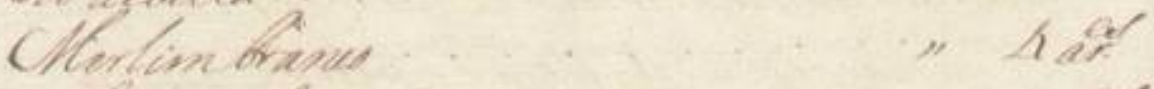

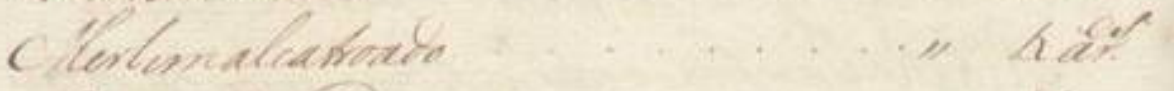

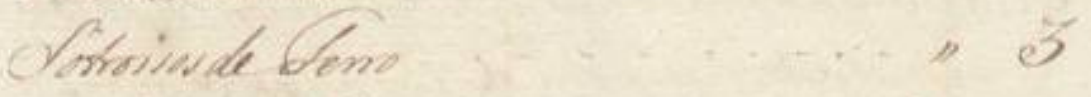

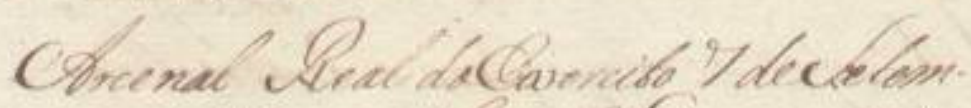

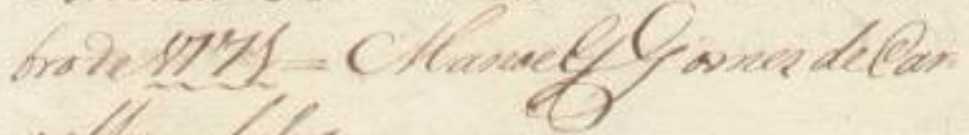
rathe a fitwa 
Pessa deCabo para tirantes doshomens.......,.,

Pessa deCabo para tirantes das bestas........,,

Martellos deOrelhas.

Cabos para botafogo de morraõ...

Fio devella

Merlimbranco.

Merlimalcatroado.

4 arrates

Sotrossos deFerro.

Arcenal Real doExercito 7 deSetem-

bro de $\underline{1771}=$ ManoelGomes deCar-

valho eSylva 


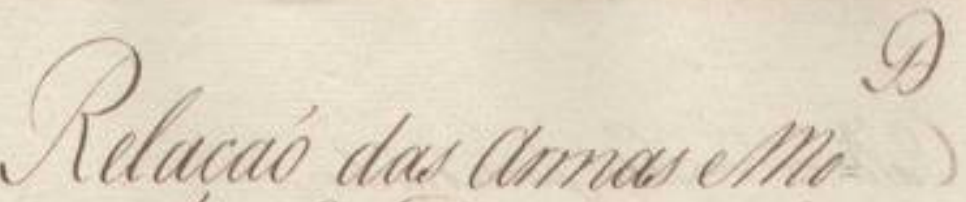

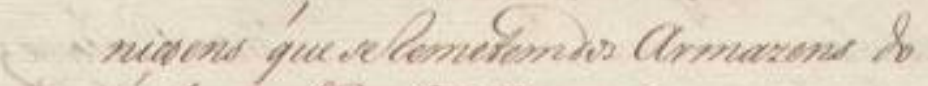

Inceralled dechoencito

$(0$

epengarlas cencayenester exa:

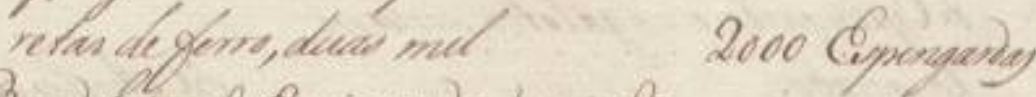
Bandeline be epingarda decoindo atanad, venas meil

Q Solvin de atamate

2000 venturisas

2000. Bolies

basminas le elola ven cumeyas de

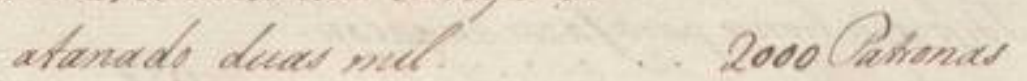

Guarda feians de deremo

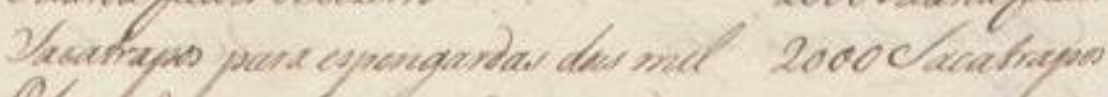

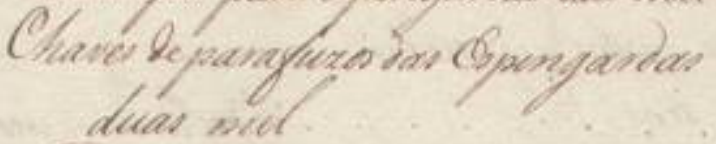

Cfromas Depri ane farer cortun:

2000 dherew be

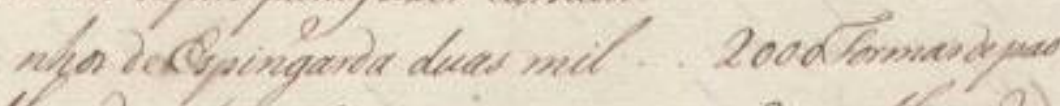

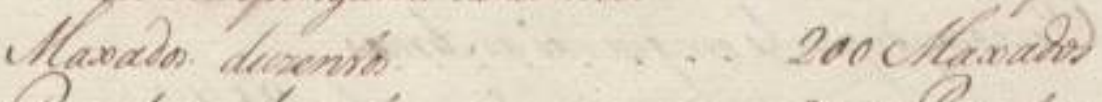

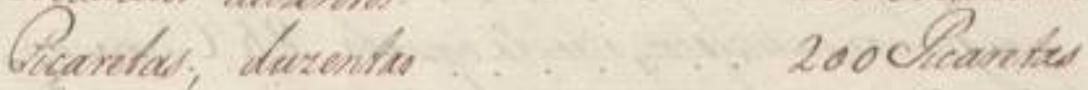

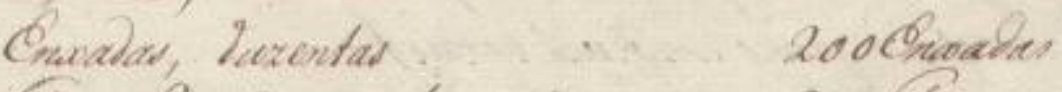

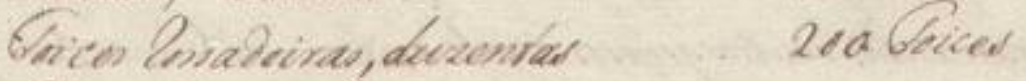

Qheonte unpeline para Cungar

Pe, cem emovad.

bes de fores, deavinas

Pes de catre, com

100 trodar expon-

20 boupetion

200 vid de dim.

100 les icentio.

Pereveina para espongalas rindes

20000 Cenneizas 
Relaçaõ das Armas eMo=

niçoens que seremetemdos Armazens do

ArcenalReal doExercito

5 Espingardas combayonetas eva $=$

retas deferro, duas mil.................................................., $\quad 2000$ Espingardas

Bandoleiras deEspingarda decoiro de

atanado, duas mil.

2000 Bandoleiras

Boldries de atanado

2000 Boldries

10 Patronas deSola com correyas de

atanado duas mil

Guarda feixos debezerro

Sacatrapos para espingardas dois mil.

Chaves deparafuzos das Espingardas

duas mil

Formas depao para fazer cartuxi=

nhos deEspingarda duas mil

Maxados duzentos

Picaretas, duzentas

20 Enxadas, duzentas

Foices rossadeiras, duzentas

Chumbo empeloiro paraEspingar=

da, cem arrobas de xum-

Pas deferro, duzentas

Pes de cabra, cem

Pedreneiras para Espingarda vinte mil. 20000 Pedreneiras

2000 Patronas 2000 Guarda feixos 2000 Sacatrapos 2000 Chaves de parafuzos 2000 Formas depao 200 Maxados 200 Picaretas 200 Enxadas 200 Foices .,,100 Arrobas bo empeloiro ,200 Pas de ferro ,, 100 Pes de cabra 
$\|130 v\|$

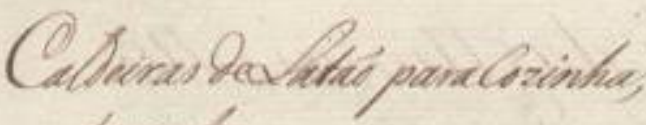
trexerstas.

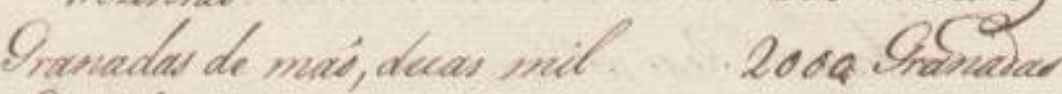

Espollitar zopas carregalas para as Ditas Gignaias Juas mél.

Chumbo mbarro para feres balas ? be Copengarla e aragelores, conuenta arrobas

Chumito en xagalotes, dere amodas Serma tebrence para farer belas dele. pinganda.

Sormaste bromse para fareo zagaloses duad.

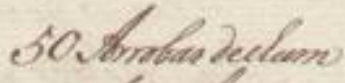
10 bemigano 12 Trodas fere

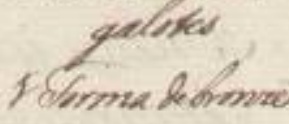

Conctén de masi, das

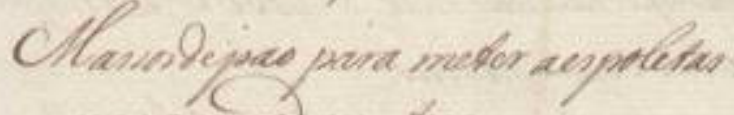

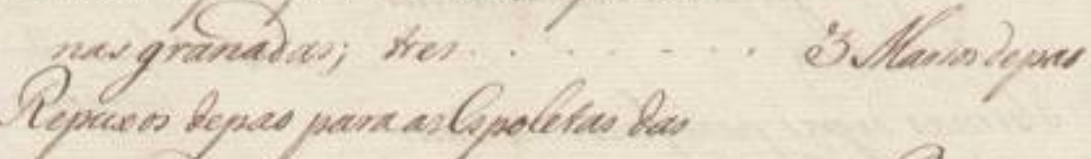
2 formad 2 comatis

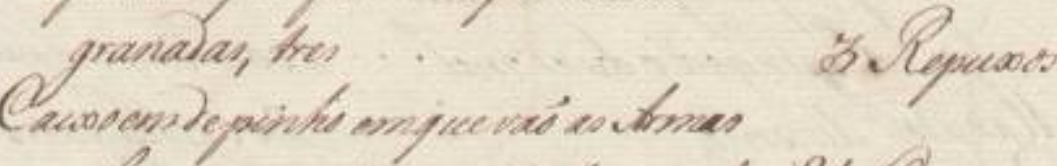

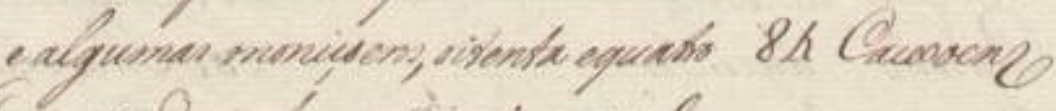

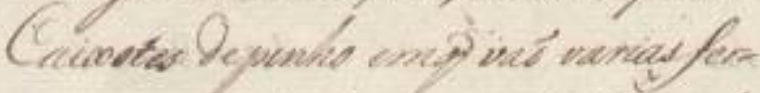

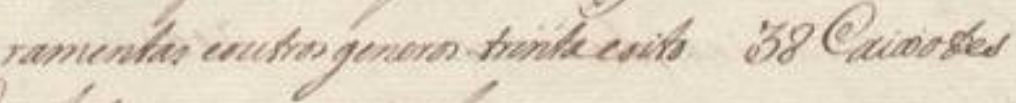
Centicés on quevere ypelouns cras

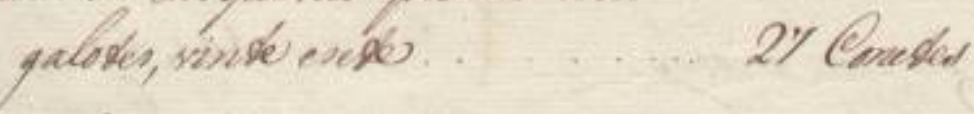

Qmenal Veal de Qxonis Yde

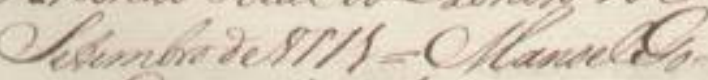

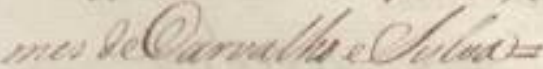


||130v|| Caldeiras deLataõ paraCozinha,

trezentas.

300 Caldeiraz

Granadas de maõ, duas mil. 2000 Granadas

Espolletas depao carregadas para as ditas Granadas duas mil 2000 Espolletas

Chumbo embarra parafazer balas deEspingarda e zagalotes, cincoen-

ta arrobas ,50Arrobas dechum bo embarra

Chumbo em zagalotes, doze arrobas , 12 Arrobas deza galotes

40 Forma debronze parafazerbalas deEs-

pingarda 1Forma debronze

Formas de bronze parafazer zagalotes duas 2 Formas

Serrotes demaõ, dois 2 Serrotes

Massos depao para meter aespoletas nasgranadas;tres ,3 Massos depao

Repuxos depao paraasEspoletas das

Granadas, tres

3 Repuxos

Caixoens depinho emquevaõ as Armas

e algumas moniçoens, oitenta equatro

84 Caixoens

Caixotes depinho emque vaõ variasferramentas eoutros generos trintaeoito. 38 Caixotes

Cunhetes em quevai opelouro eza= galotes, vinte esete. 27 Conetes

Arcenal Real doExercito 7de

Setembro de1771 = ManoelGo-

mes deCarvalho eSylva $=$ 
[64]

||132r|

Pelaceá das ofrnas ce threica.

(6) 940

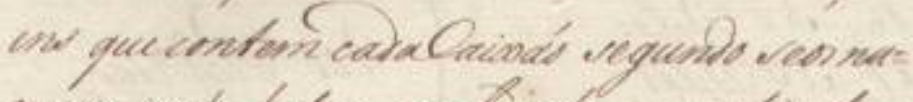

- morn porte defora qualeidele equantuader

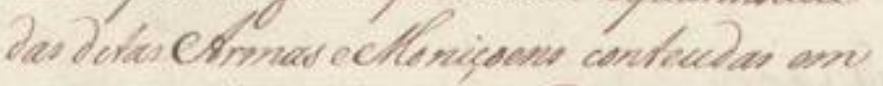

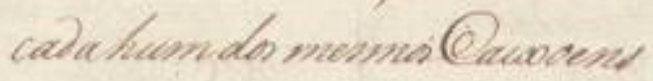

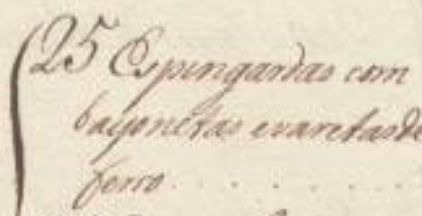

25 Bandolenas bea. tanailo para es bitar 25630 rio dectanate

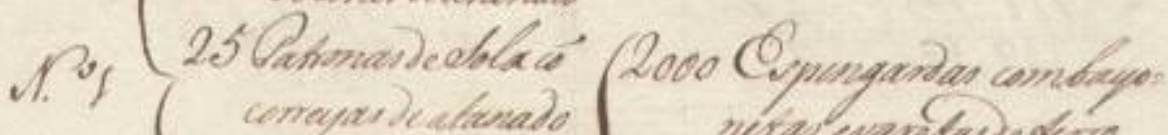

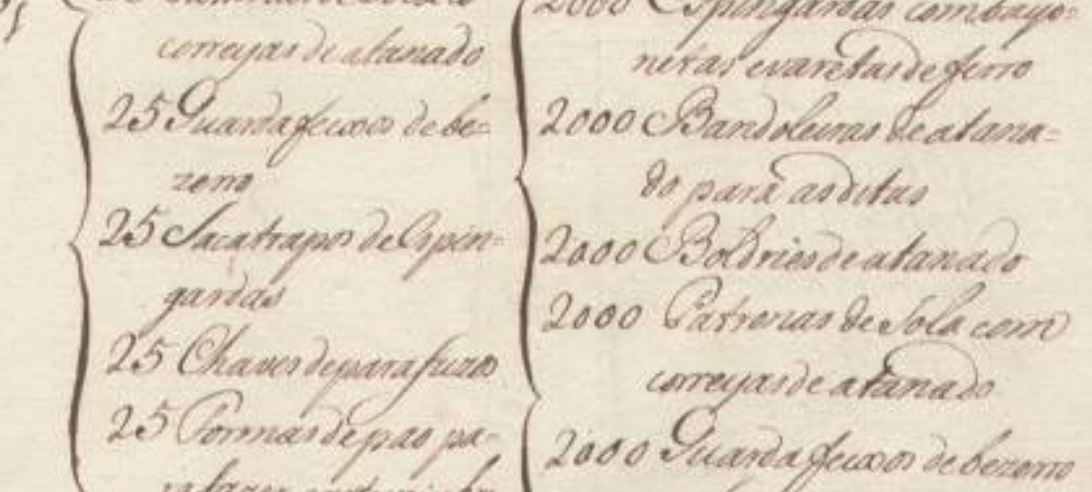

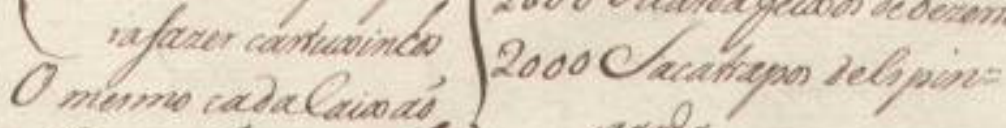
crobar a strmas ecth necsens eng poriste..... 2000 Chaves Deparafures

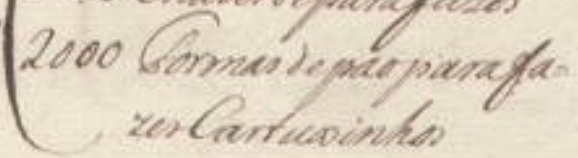

8) So thaorado

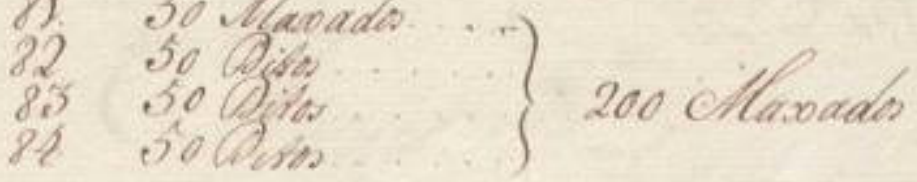

423 
Relaçaõ das Armas eMoniço= ens que contem cadaCaixaõ segundo seos nu= meros posto defora qualidade e quantidade das ditas Armas eMoniçoens conteudas em cada hum dos mesmosCaixoens

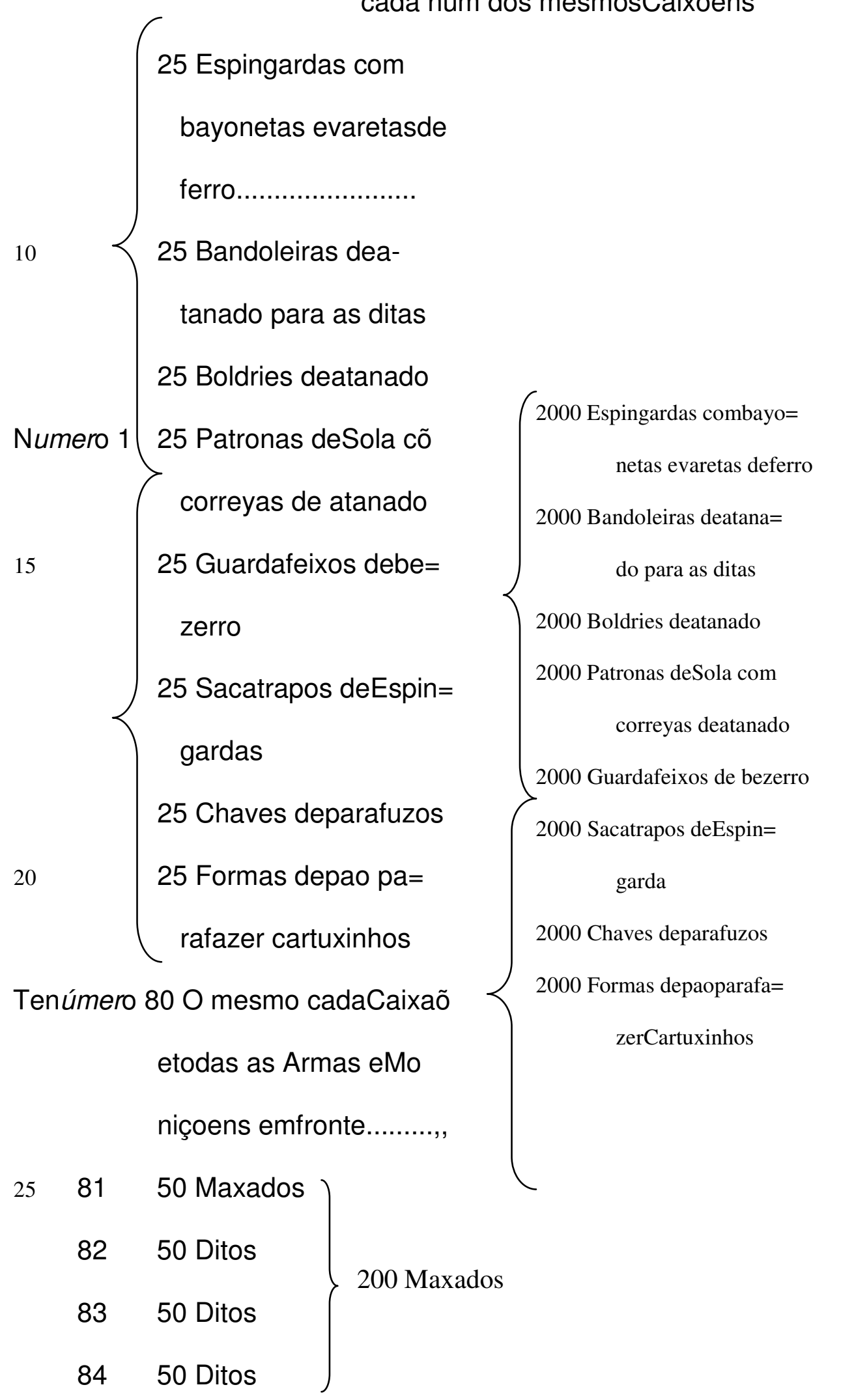


\|132v $\|$

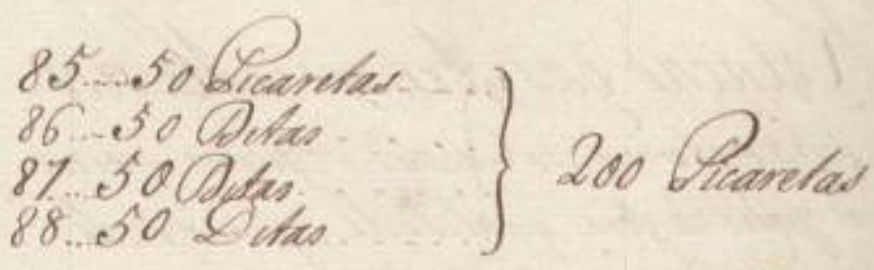

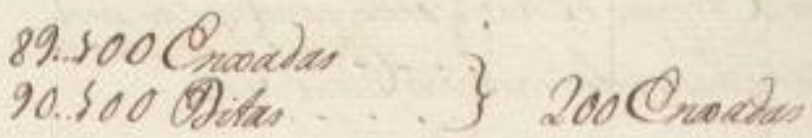

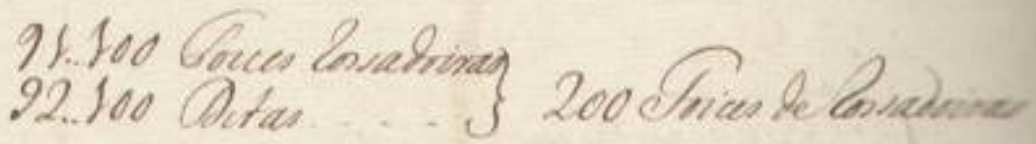

Mogste 11) Norte ccince Co. nheter Jeviturn pee mangorta coun quass iñ caln huent...

Foo, Arrobas delhumb oos pitivo p"epungente

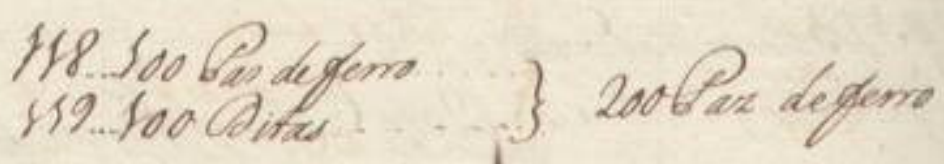

\} 100 brieleabra

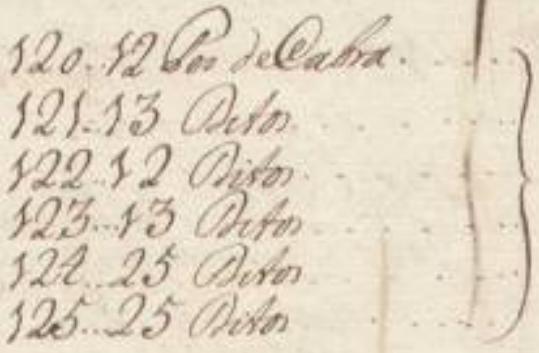

126.6200 Benenem 127.7200 Oitay 128.6.600 Sitas

$\{20000$ bemeneiras decenos

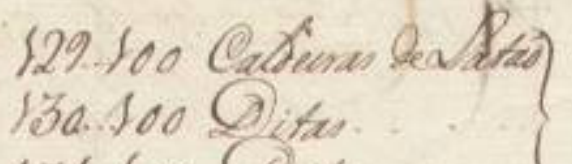
garia 101 100 Ditas. 300 Qdadira dealatios
Crinha.

425 


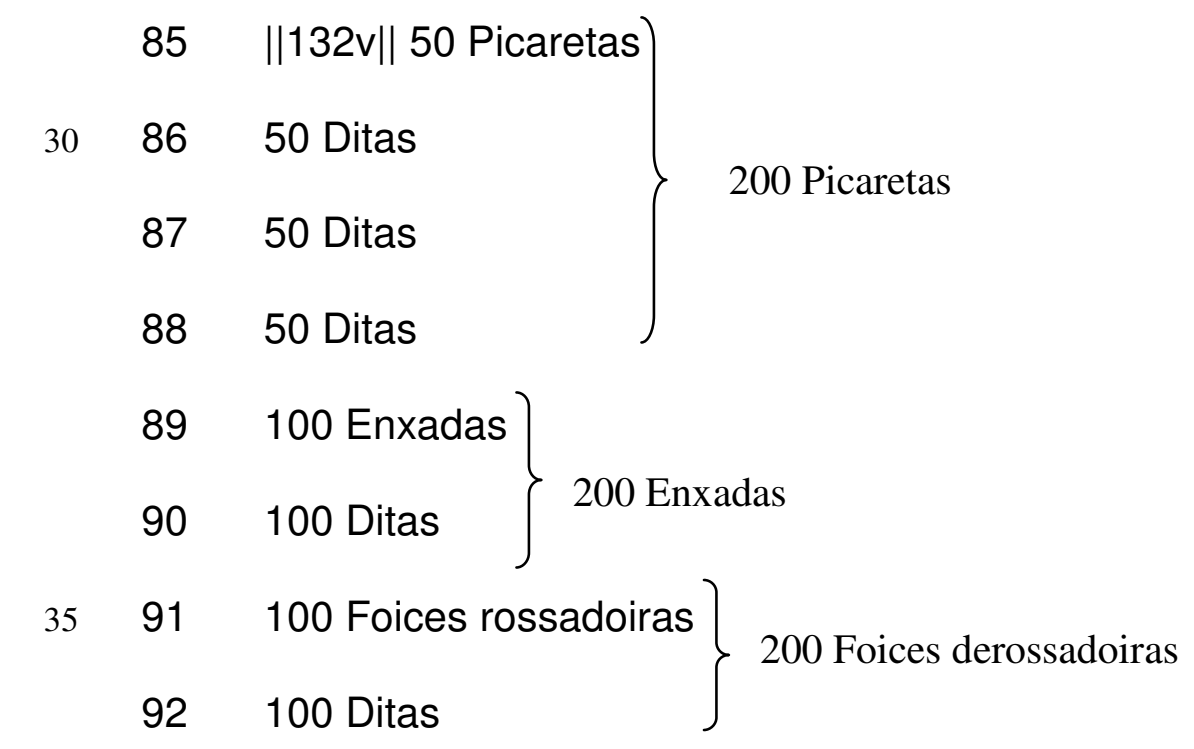

Número 93 de 117 Vinte e cinco Co= $\begin{array}{ll}\text { nhetes depiloiro paraEs- } & \begin{array}{l}100 \text { Arrobas deChumbo em } \\ \text { piloiro para Espingarda }\end{array}\end{array}$ pingarda com quatro arrobas cadahum..........,

118...100 Pas deferro 119...100 Ditas $\quad\} 200$ Paz deferro 120... 12 Pes deCabra 121... 13 Ditos

$45 \quad$ 122... 12 Ditos

123... 13 Ditos

124... 25 Ditos

125... 25 Ditos

100 Pes deCabra

126... 6:200 Pedreneiras

127... 7:200 Ditas

20000 Pedreneiras deEspingarda

128... 6:600 Ditas

$\int$

129... 100 Caldeiras deLataõ

130... 100 Ditas

131... 100 Ditas

300 Caldeiras deLataõ para Cozinha 
S. Dos

1322.225 Cheradas de nast 433.225 Qitas 134. 225 Detas. $135.225 @ 10$. 136.226 Qita. $15 \% .225$ Qiras 138.225 Ditas 139225 Qitas 120. 200 Diras

121.

2000 Quafleta beprac as

H22...20. Bames de Dianbo

2000 Crandas de mes 123... 20 Silas. 121. 20 Etas $145.2 a$ Eitas H26... IV Cutas reqadar pa cranadajo

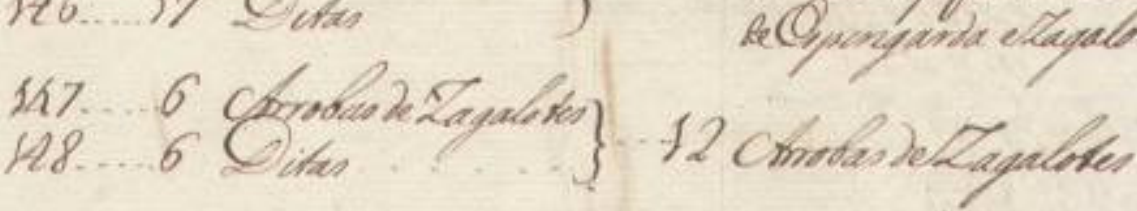

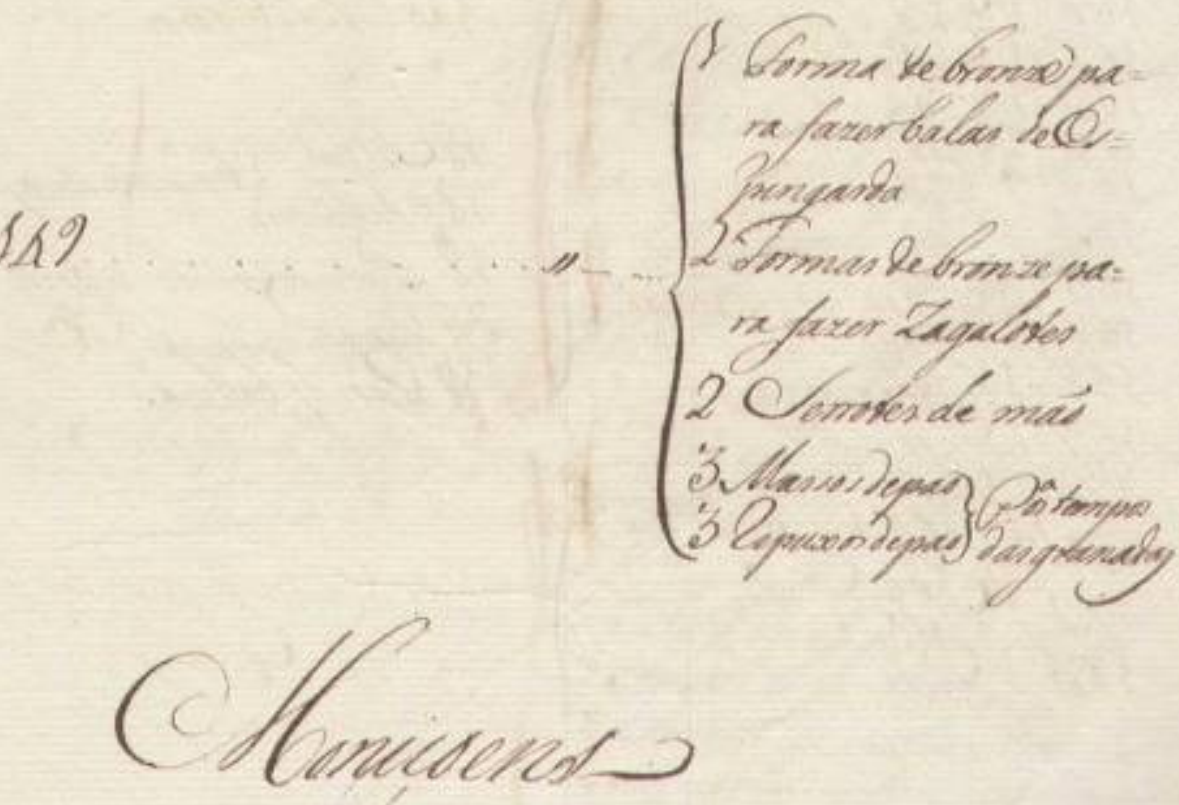


||133r|| Números

132... 225 Granadas demaõ

133... 225 Ditas

134... 225 Ditas

135... 225 Ditas

$60 \quad 136 \ldots 226$ Ditas

2000 Granadas de maõ

137... 225 Ditas

138... 225 Ditas

139... 225 Ditas

140... 200 Ditas

2000 Espolletas depao car=

regadas para Granadas

142... 20 Barras de Xumbo

143... 20 Ditas

144... 20 Ditas

$70 \quad 145 \ldots 20$ Ditas

146... 17 Ditas

50 Arrobas deXumbo em

97 barras parafazerbalas

deEspingarda eZagalotes

147... 6 Arrobas de Zagalotes

148... 6 Ditas

12 Arrobas deZagalotes

1 Forma debronze pa= ra fazerbalas deEs= pingarda

2 Formas debronze $\mathrm{pa}=$ ra fazer Zagalotes

2 Serrotes de maõ

3 Massos depao

3 repuxos depao $\}$ Para os tempos das granadas

Moniçoens 
||133v $\|$

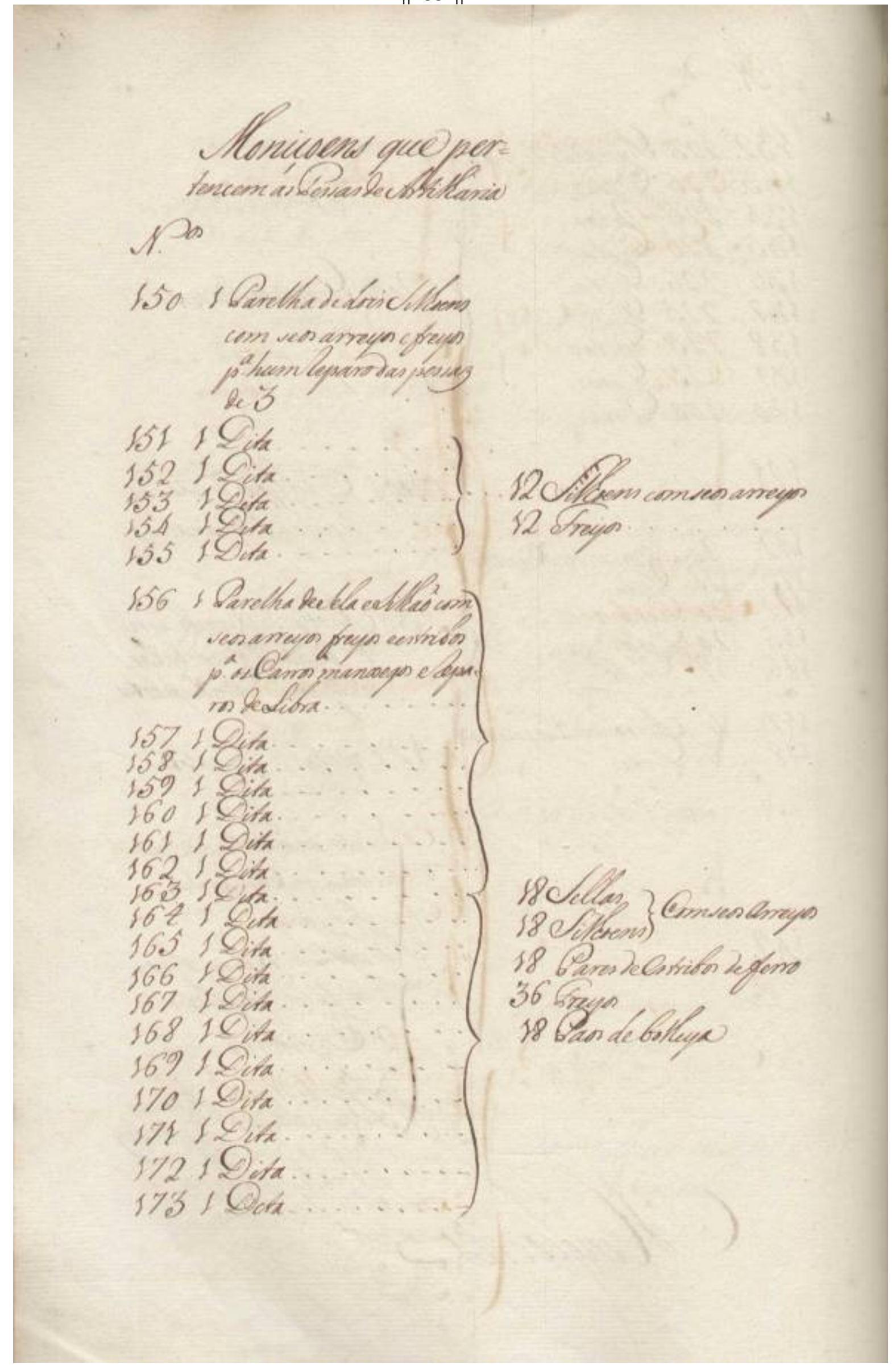


||133v || [[Moniçoens]] que per=

tencem as Pessas de Artilharia

Números

150... 1 Parelha de dois Silhoens

85

com seos arreyos efreyos

para hum reparo das pessaz

de3

$151 \ldots 1$ Dita

152... 1 Dita

$90 \quad$ 153... 1 Dita

154... 1 Dita

12 Silhoens comseos arreyos

12 Freyos

155... 1 Dita

156... 1 Parelha deSela eSilhaõ com seos arreyos freyos eestribos

95 para osCarros manxegos ereparos deLibra

157... 1 Dita

158... 1 Dita

159... 1 Dita

$100 \quad 160 \ldots 1$ Dita

161... 1 Dita

162... 1 Dita

163... 1 Dita

164... 1 Dita

$105 \quad 165 \ldots 1$ Dita

166... 1 Dita

167... 1 Dita

168... 1 Dita

169... 1 Dita

$110 \quad 170 \ldots 1$ Dita

171... 1 Dita

172... 1 Dita

173... 1 Dita

$\left.\begin{array}{l}18 \text { Sellas } \\ 18 \text { Silhoens }\end{array}\right\}$ Comseos arreyos

18 Pares deEstribos deferro

36 Freyos

18 Paos debolleya 
1. 20

17420

17 is 20 ditas. 3 .

176 Ditas .......

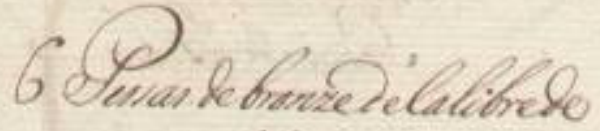

कs

(7) के Q

Chro desuredea?

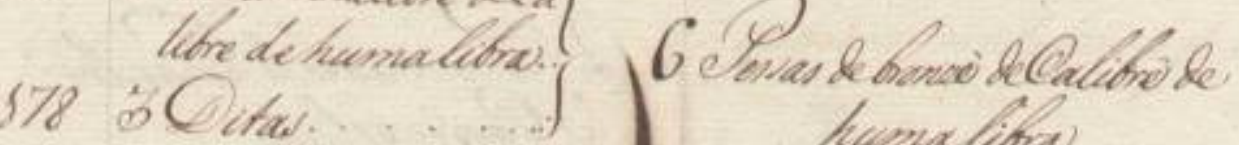

humaliona

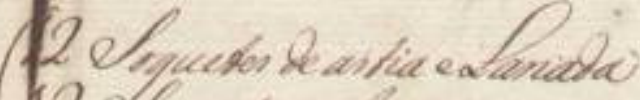

\section{2 elipueto valtos}

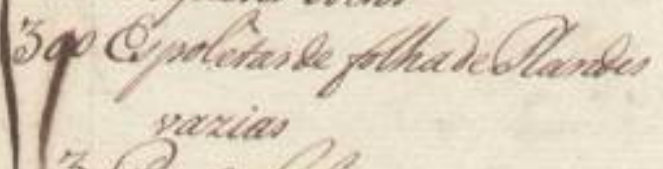

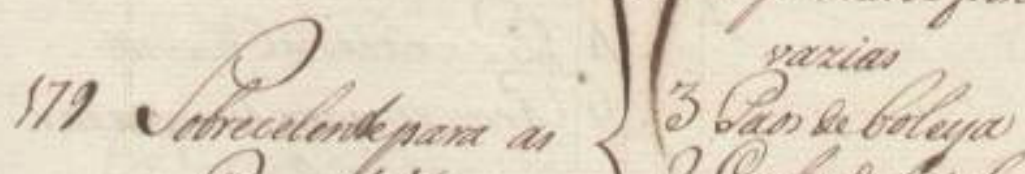
ben des

180 (itreceluch paria as)

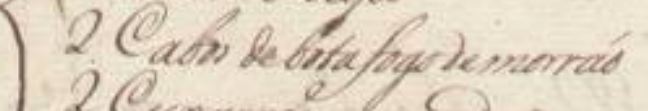
2 cuvarmi cheandal con 
||134r|| Números

$174 \ldots 2$ Pessas debronze deCali= bre de3

175... 2 Ditas

176... 2 Ditas

6 Pessas debronze deCalibre de 3

177... 3 Pessas deCalibre [[deCa libre]] dehumalibra

6 Pessas debronze deCalibre de humalibra

178... 3 Ditas

12 Soquetes de astia eLanada

12 Soquetes soltos

300 Espoletas de folha deFlandes vazias

Pessas de3

3 Paos deboleya

2 Cabos debotafogo demorraõ

2 Cuxarras encavadas com Sacatrapos

4 Feminelas deLanada

4 Agulhas deVarruma

4 Agulhas degoiva

4 Pranxadas deChumbo

6 Repuxos para desencravar aArtilharia

2 Pessas deCabo paraTirantes

Pessas de3

2 Martelos deorelhas

2 Dirandelas de gato

2 Cabos para botafogo deComposiçaõ

4 Arrates de fio devela

4 Arrates de merlim branco

4 Arrates demerlim alcatroado 
I. is

SPI verecelos sivas bestera...

S20 sureetes de dues anting (2@ator pitrabotaforgo denumas'

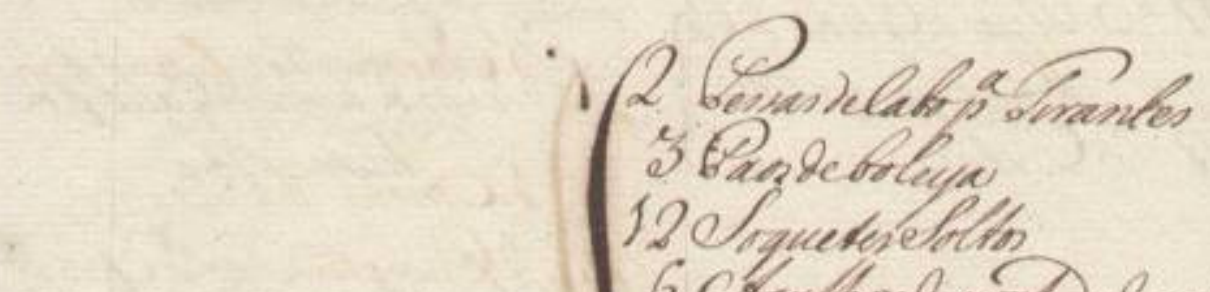

6 CAquthas le pontade rer niater

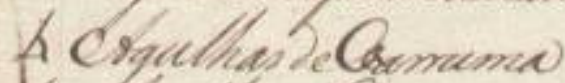
1 fecogulari be Sivina Ka.banodabletumo

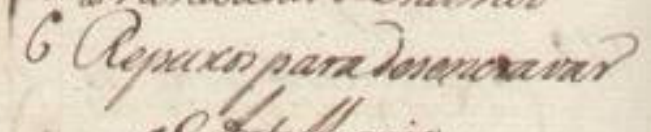

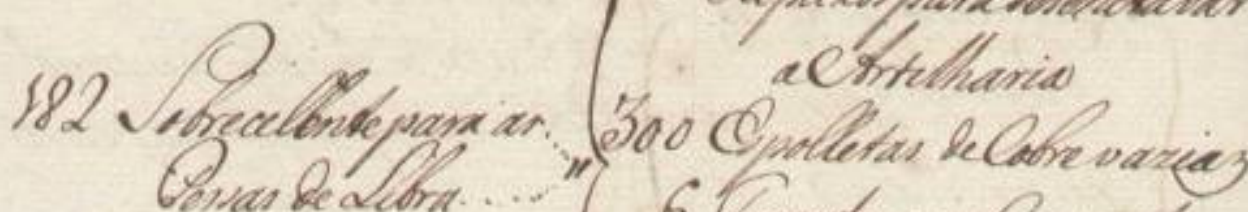

6 Vinanter con lasmedes 2 Clarples be Crethas 2 Caboprancotafipo delem piosicas

$\rightarrow$ hemates beftis de Culles

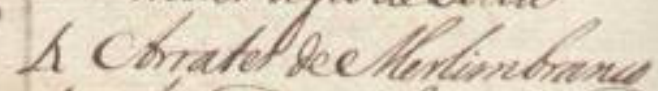
L. Convares declestim alcatian 585 a aboutorio....

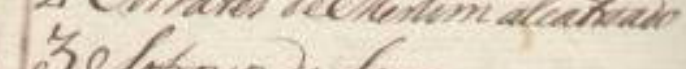




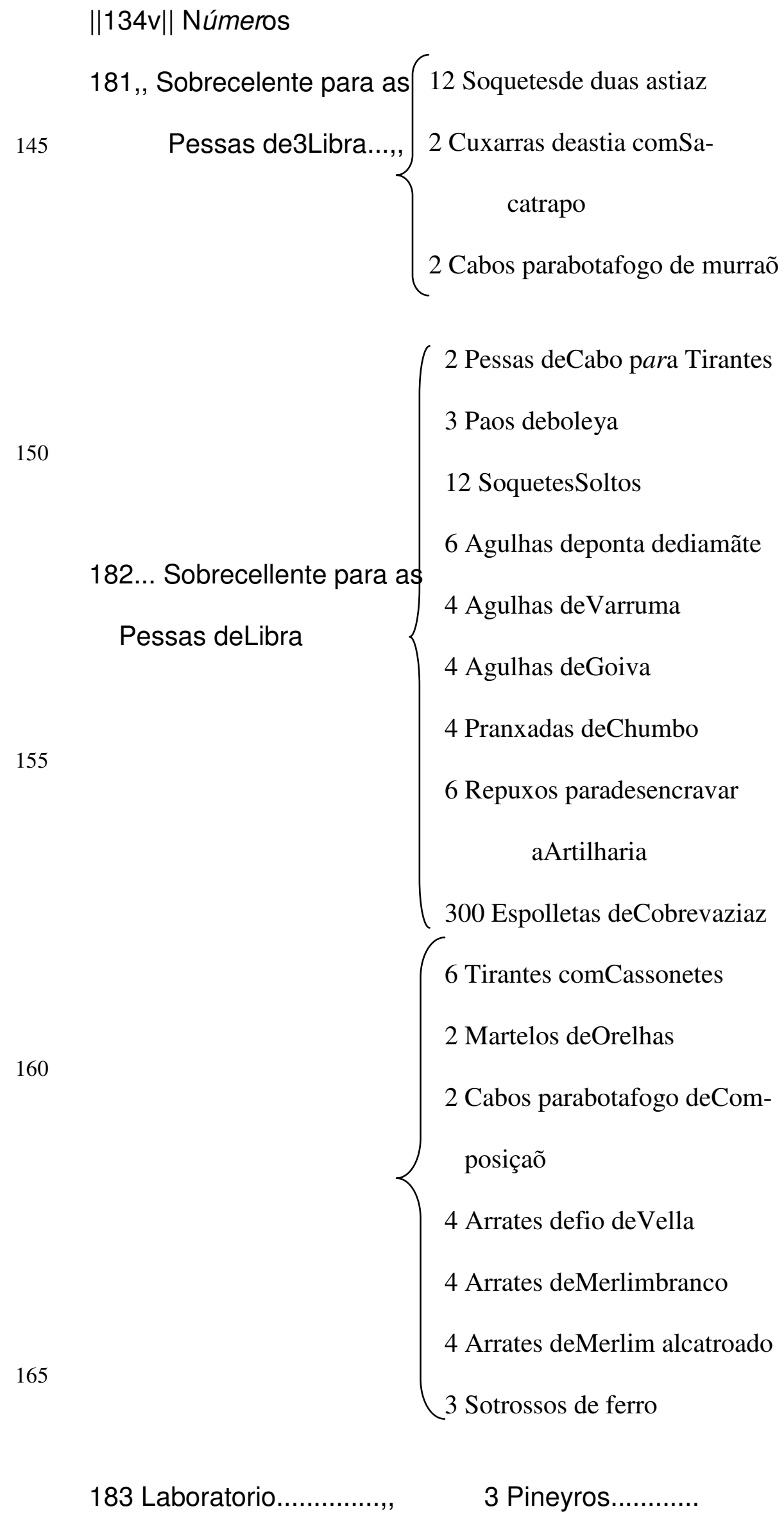


I. Po

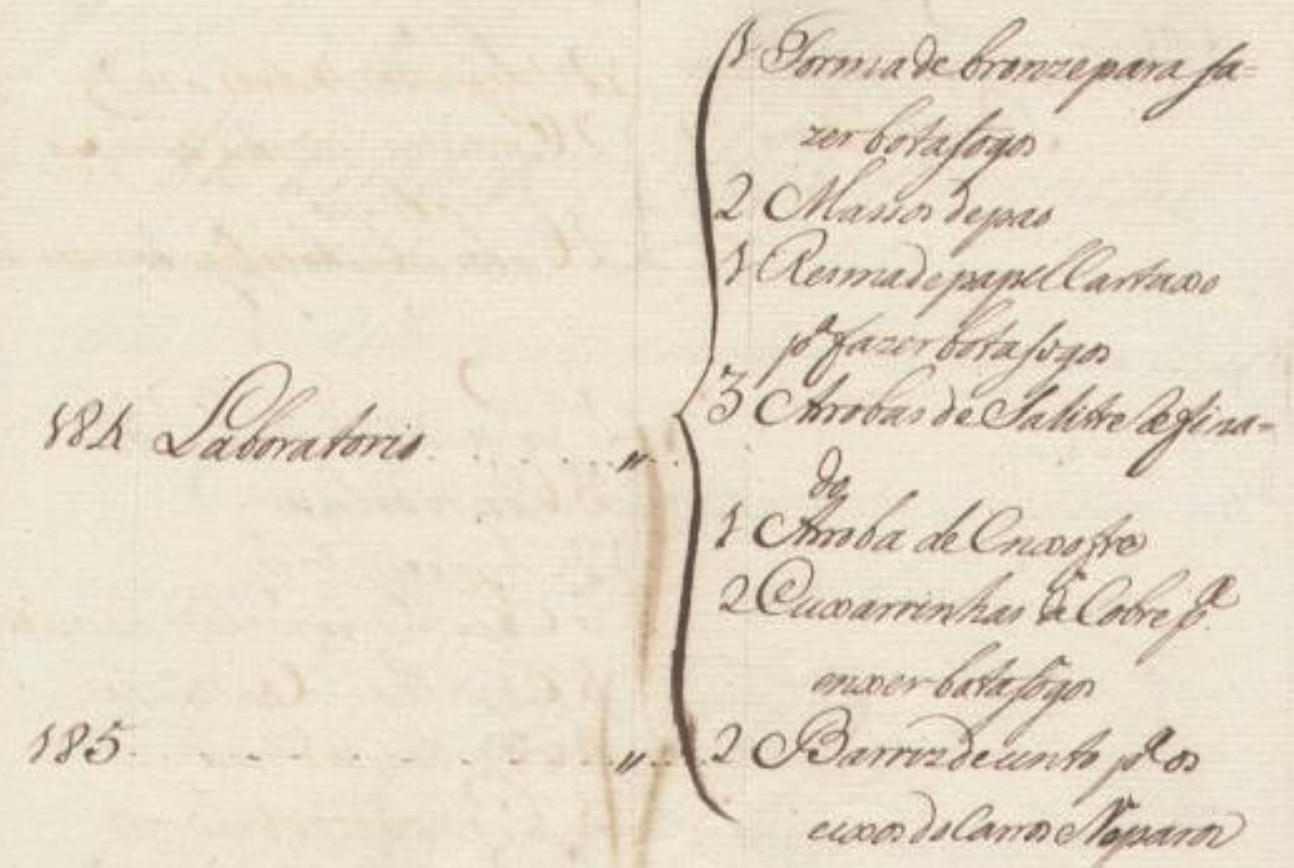

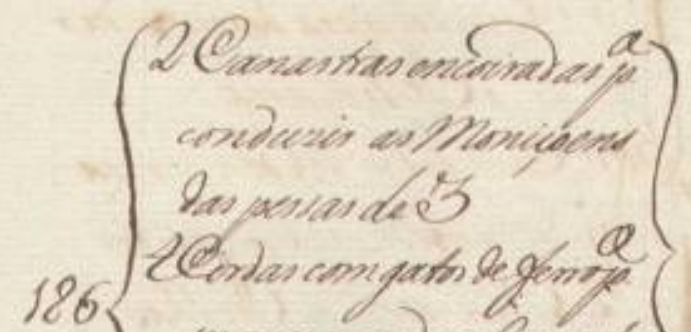

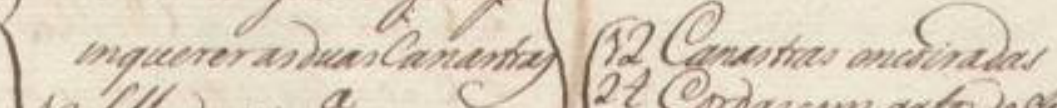

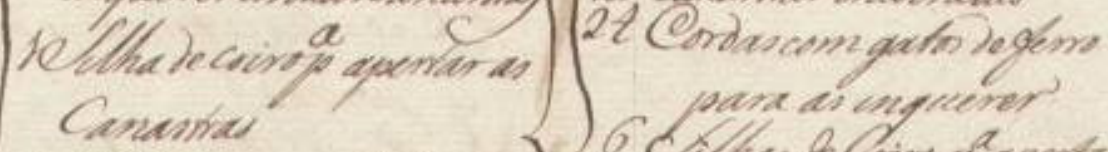

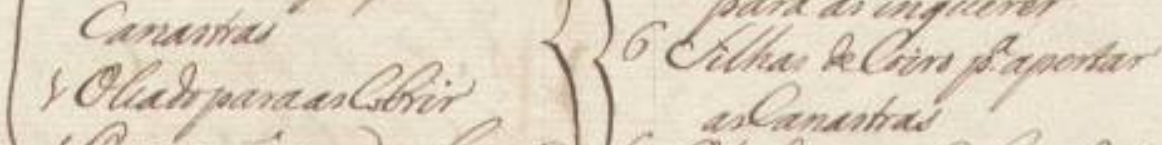

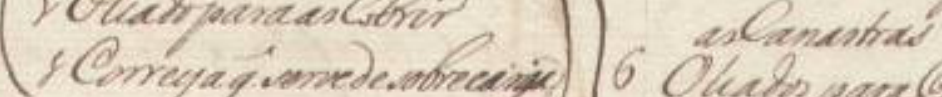

1870 menme.

1880 mesme.

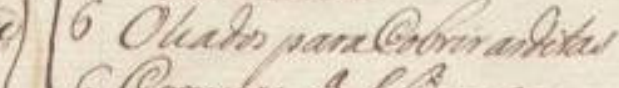

(9) 0 Oneme

s91 Onesme

6Cmejar of horicura

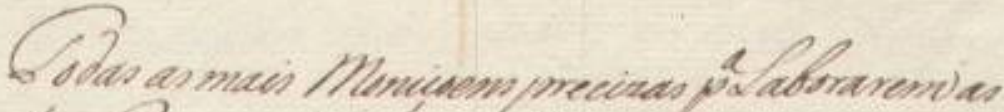

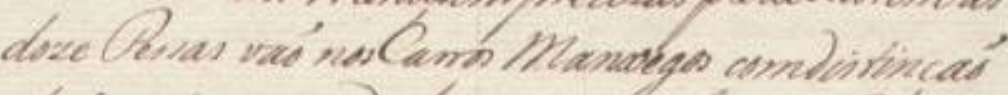

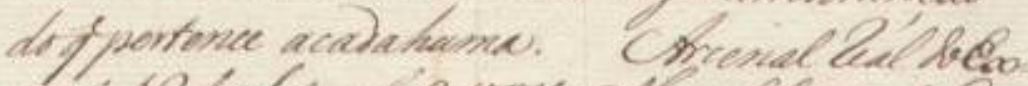

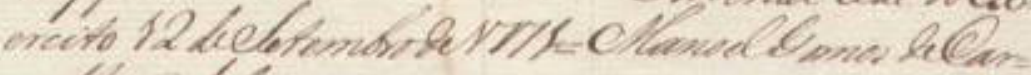
valuelare. 
1 Forma debronzeparafa= zerbotafogos

2 Massos depao

1 Resmade papelCartuxo para fazerbotafogos

3 Arrobas deSalitrerefina $=$

184 Laboratorio do

1 Arroba deEnxofre

2Curraxinhas deCobre para

enxerbotafogos

185

2 Barriz deunto para os

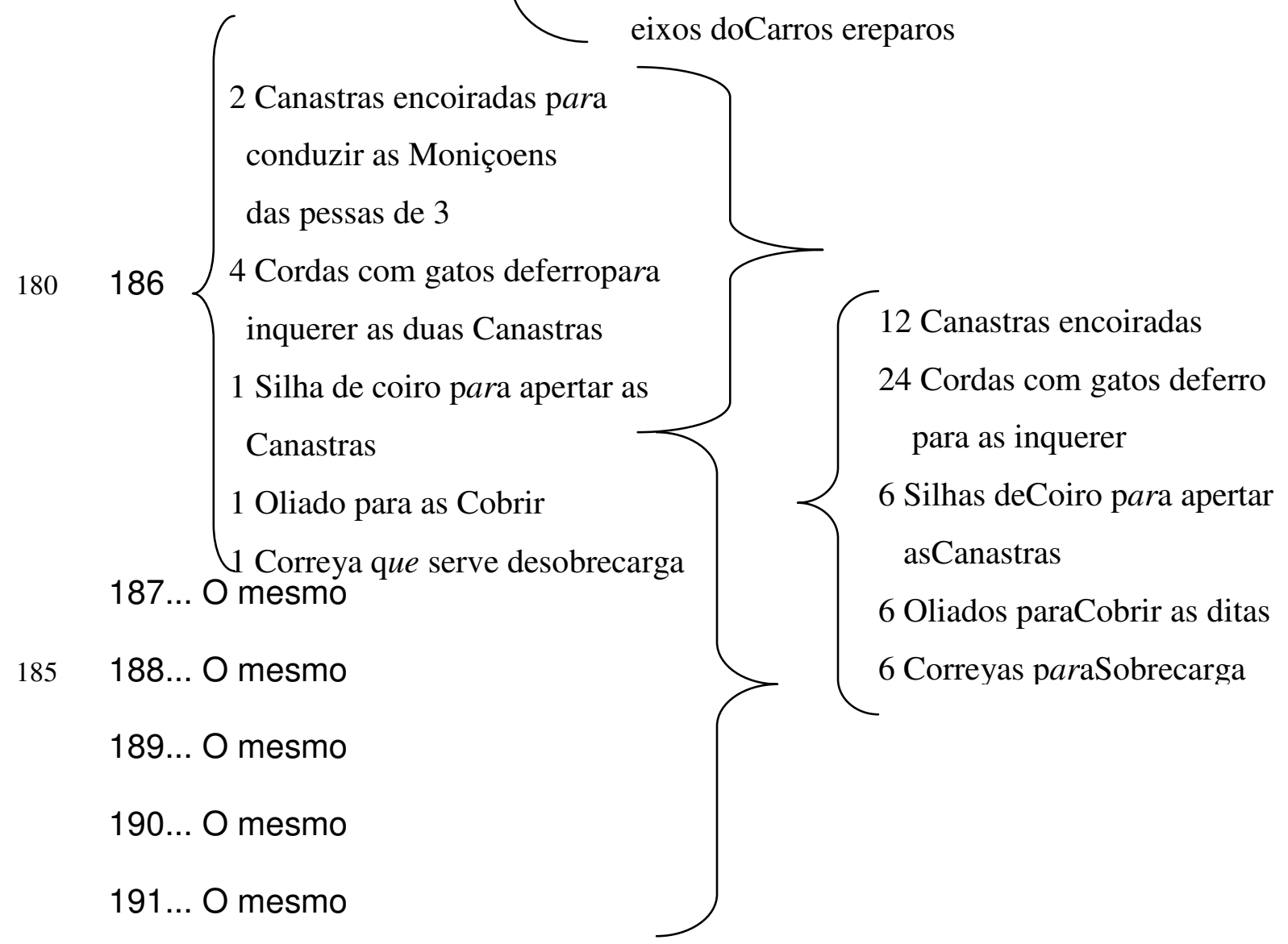

Todas as mais Moniçoens precizas paraLaborarem as doze Pessas vaõ nosCarros Manxegos com distinçaõ doquepertence acadahuma. [espaço] Arcenal real doEx= ercito 12 deSetembrode1771 = ManoelGomes deCar= valhoeSylva 
[65]

||136r||

99.

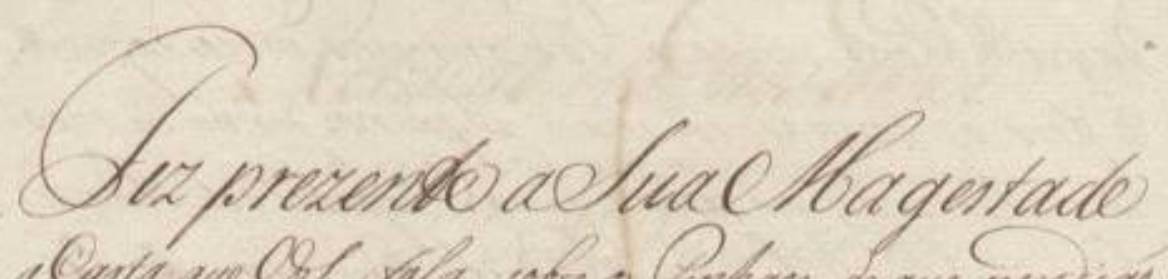

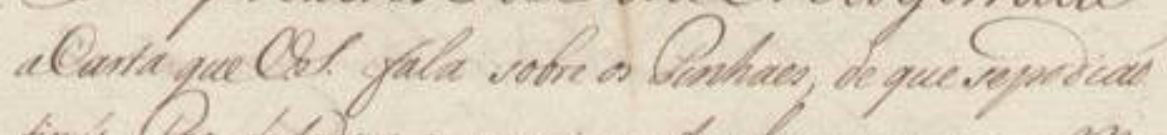

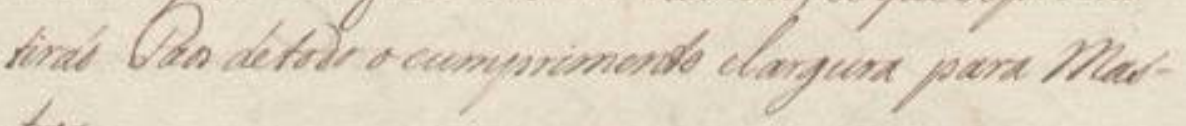
the.

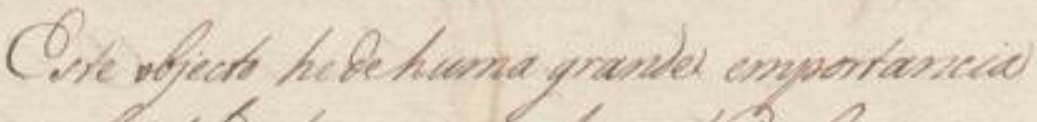

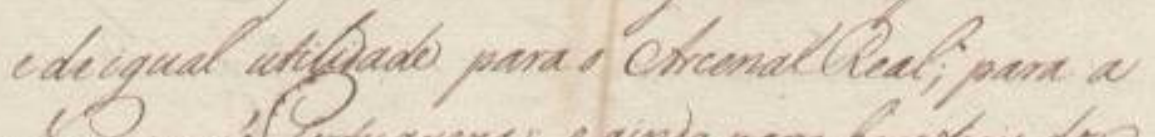

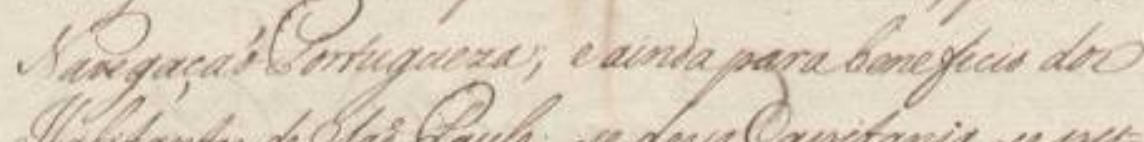

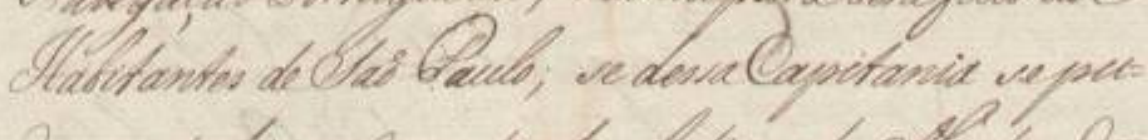

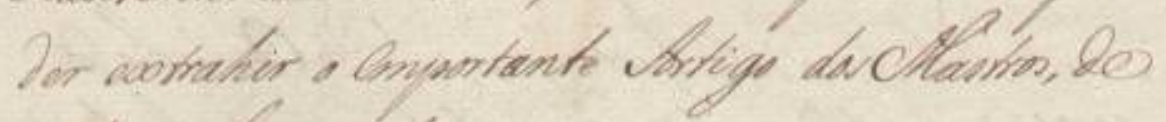

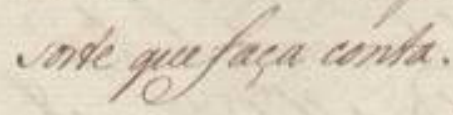

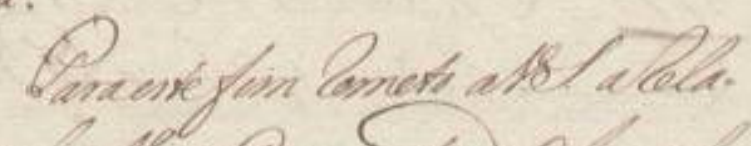

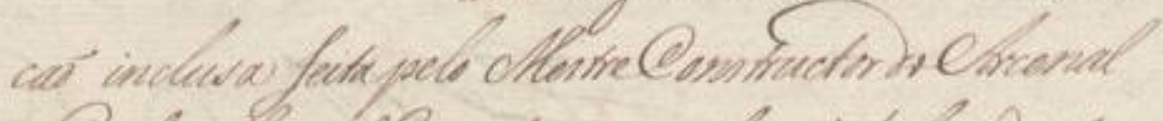

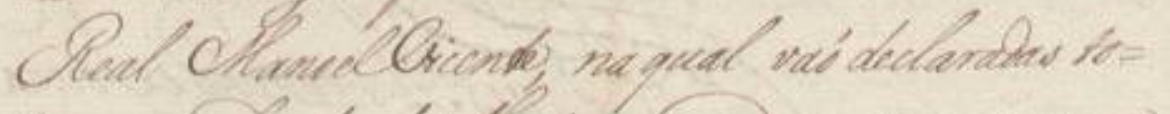

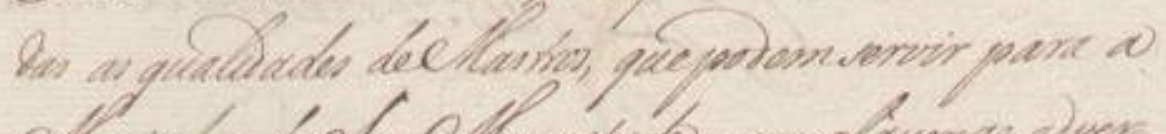

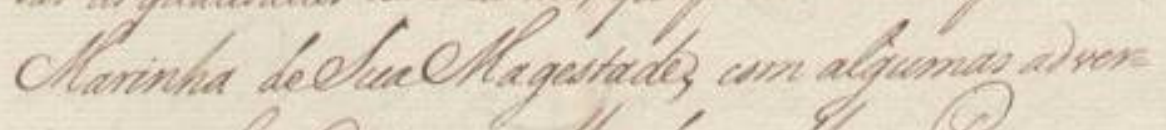

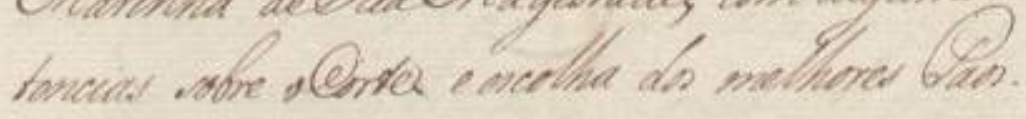

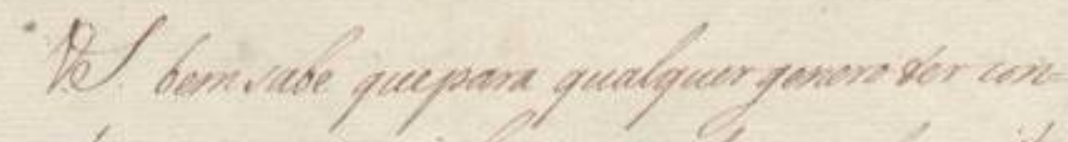

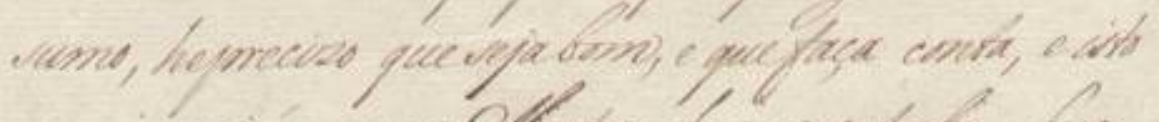

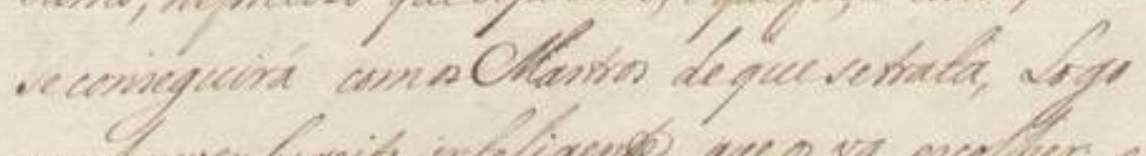

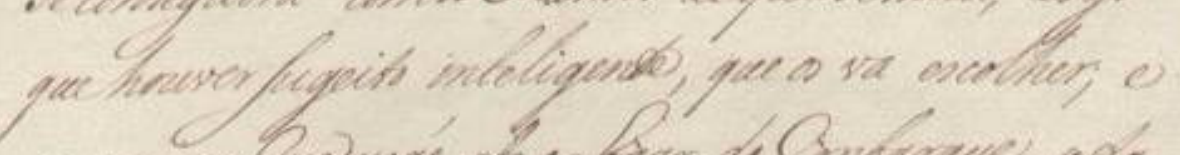

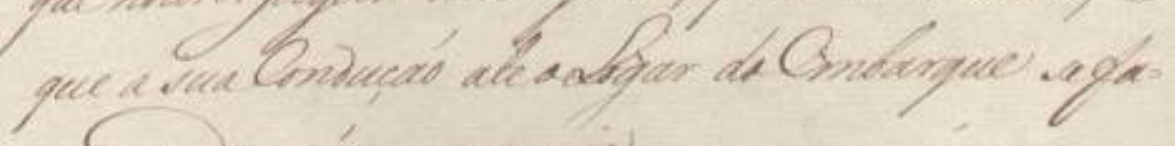

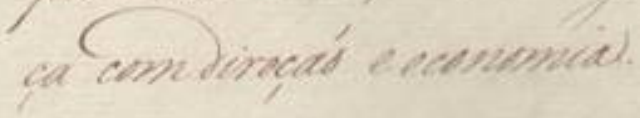

Otnumendé dale tos

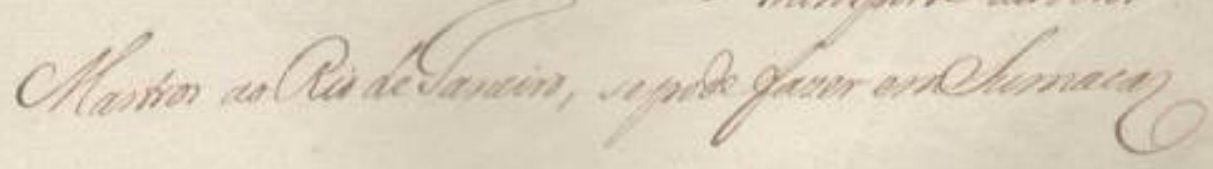

437 
||136r|| Fiz prezente aSuaMagestade

aCarta queVossaSenhoria fala sobre os Pinhaes, de que sepodiaõ tiraõ* Paos detodo ocumprimento elargura para Mastros.

Este objecto he dehuma grande emportancia

e de igual utilidade para o ArcenalReal; para a

Navegaçaõ Portugueza; e aindapara beneficio dos

Habitantes deSaõ Paulo; se dessa Capitania sepu= der extrahir o emportante Artigo dos Mastros, de sorte quefaça conta.

Paraeste fim remeto aVossaSenhoria arelacaõ inclusa feitapelo MestreConstructor doArcenal Real ManoelVicente, na qual vaõ declaradas to= das as qualidades deMastros, que podem servir para a

15 Marinha deSuaMagestade, com algumas adver= tencias sobre oCorte e escolha dos melhores Paos.

VossaSenhoria bem sabe quepara qualquer genero ter con= sumo, heprecizo que sejabom, e quefaça conta, e isto se conseguirá com osMastros deque setrata, Logo

20 quehouver Sugeito inteligente, que os va escolher; e que a suaConduçaõ ate oLogar doEmbarque sefa= ça com direçaõ e economia.

O transporte dos ditos Mastros aoRio de laneiro, se pode fazer emSumaca 
||136v $\|$

Jaquelle bonts, ninds of 6 an maynes mas ha para

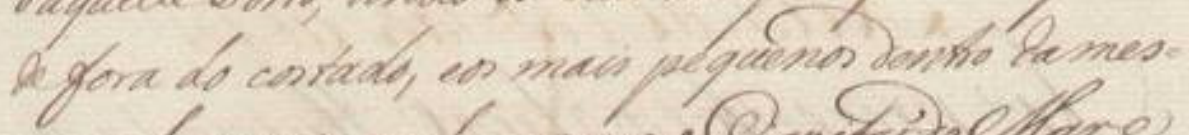

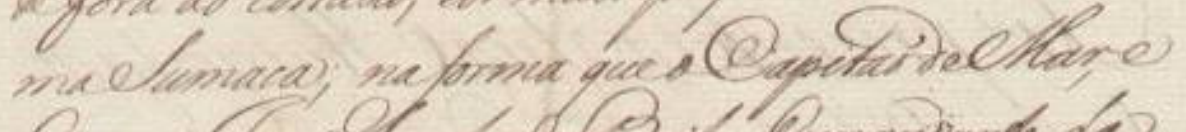

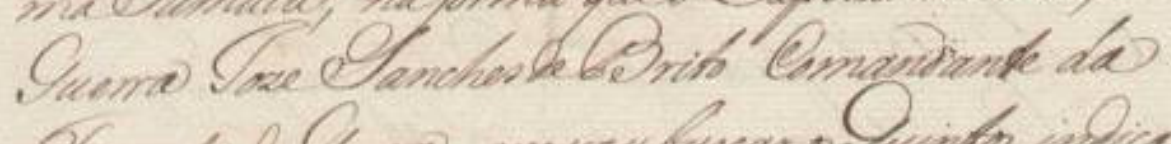

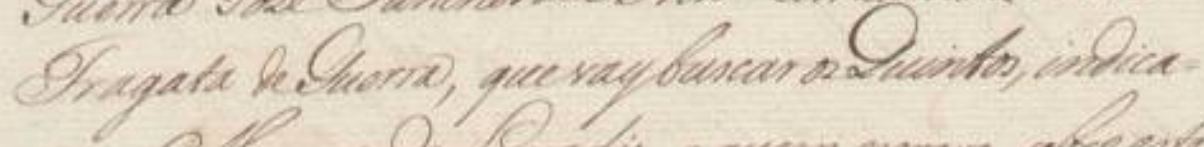

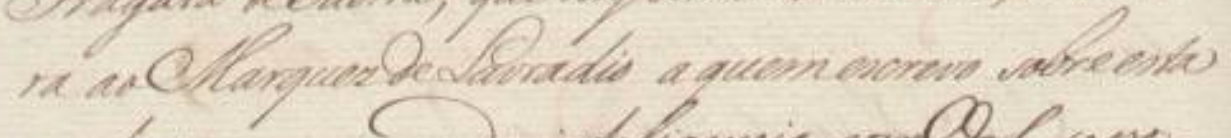

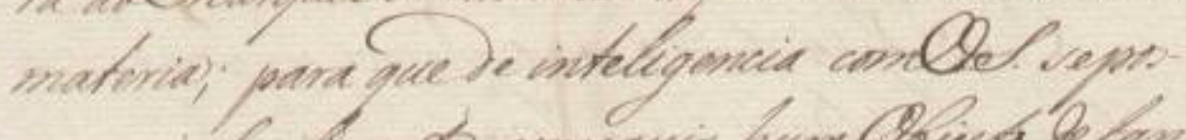

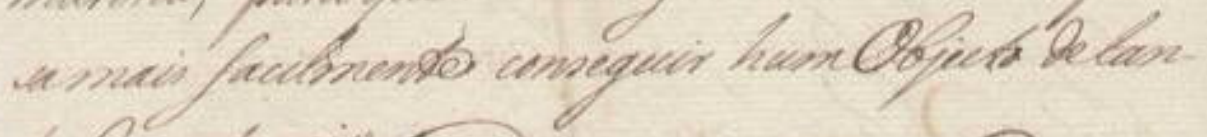
te Oinportancio

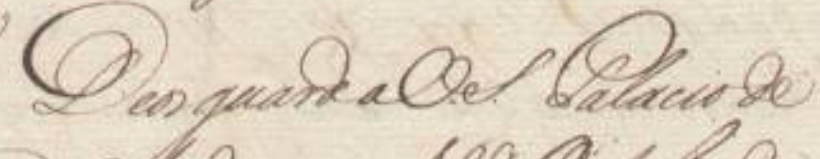

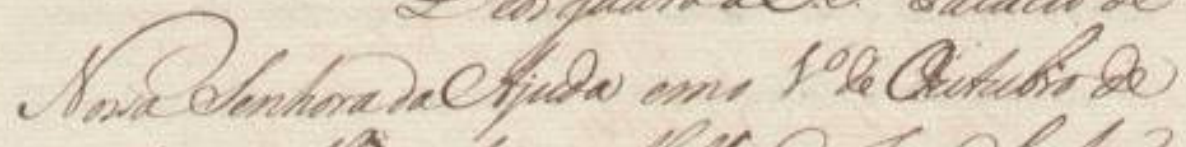

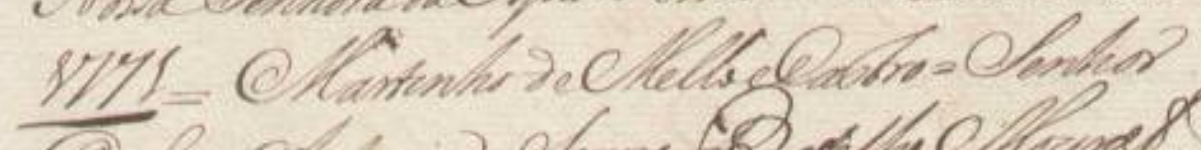
Q

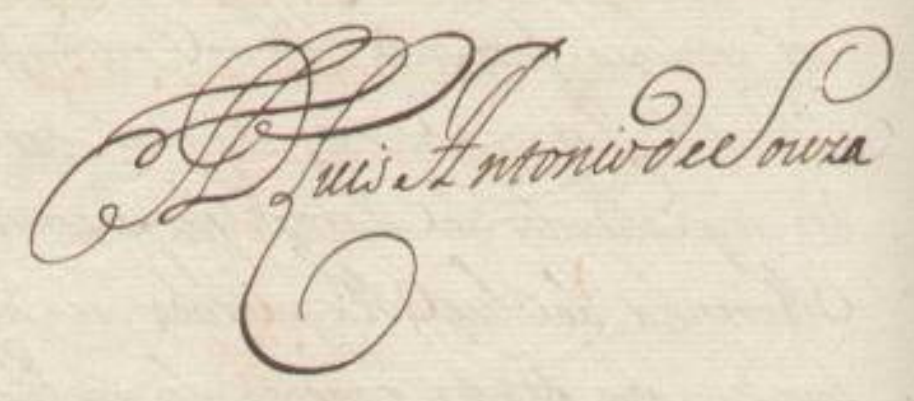

439 
$25 \quad\|136 v\|$ daquellePorto, vindo os Paos mayores prezos da parte defora do costado, eos mais pequenos dentro dames= ma Sumaca; naforma queoCapitaõ deMar, e Guerra lozeSanches deBrito Comandante da Fragata deGuerra, quevaybuscar osQuintos, indica=

30 ra aoMarquez deLavradio a quem escrevo sobreesta materia; para que de inteligencia comVossaSenhoria sepossamais facilmente conseguir humObjecto detantaEmportancia

Deosguarde aVossaSenhoria Palacio de

35 NossaSenhora daAjuda emo primeiro de Outubro de $\underline{1771}=$ Martinho deMello eCastro $=$ Senhor DomLuis Antonio deSouza BotelhoMouraõ

DomLuis AntoniodeSouza 


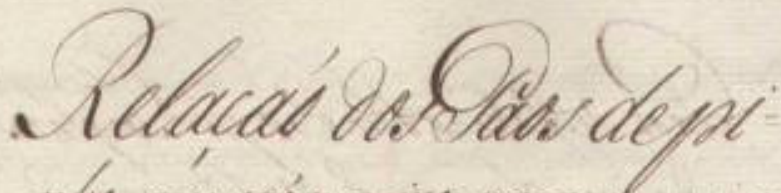 thil quelespreciso pare do mat

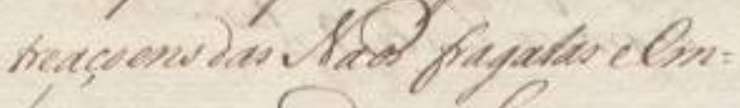

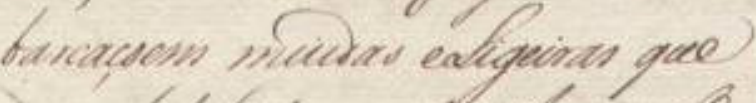

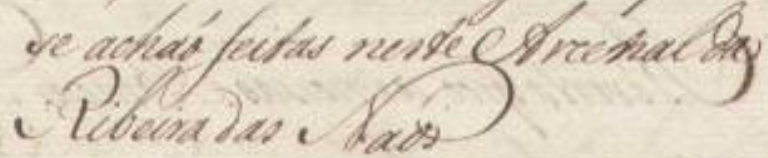

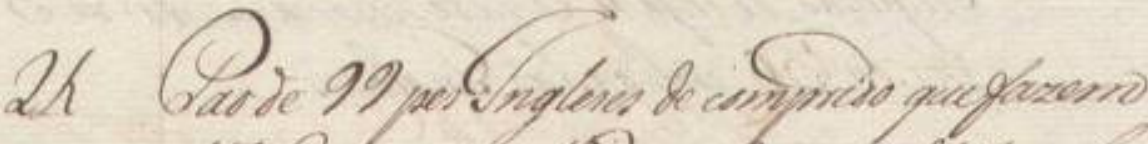

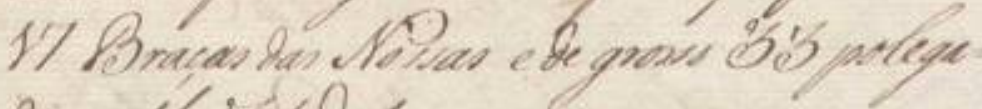
gis afle ent giro

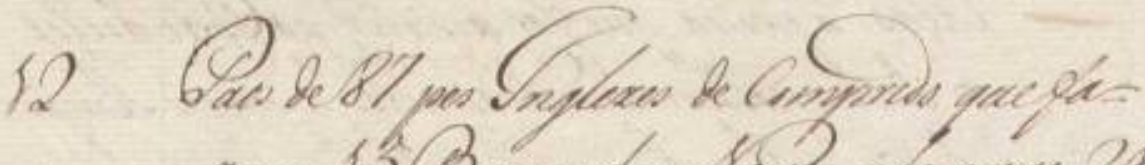

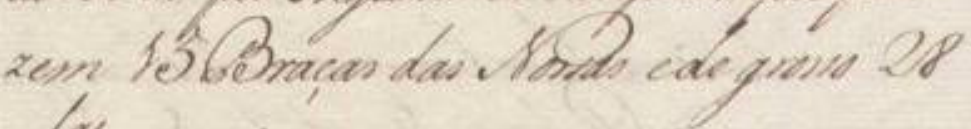
plas parn cinno

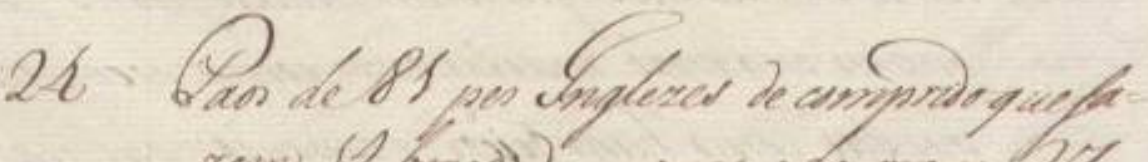

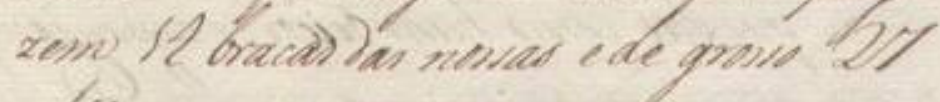
plespora ciend

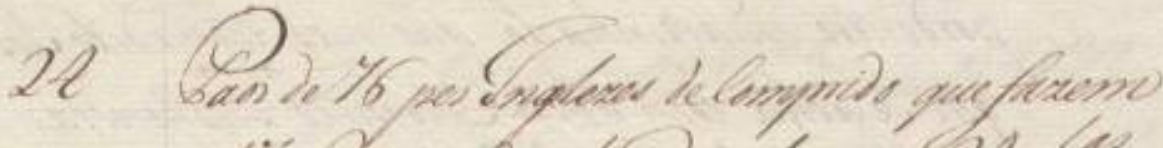

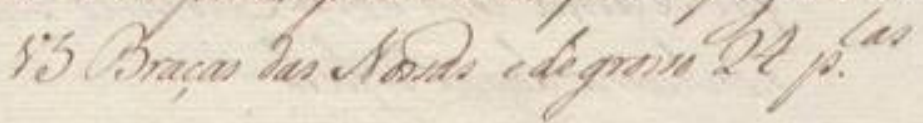

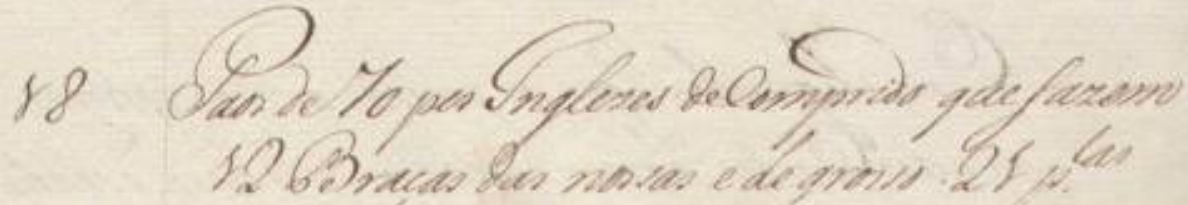


||137r|| Relaçaõ dos Paos depi= nho que saõ precizos para as mas= treaçoens das Naos fragatas eEm= barcaçoens miudas eLigeiras que se achaõ feitas neste Arcenal da

Ribeira das Naos

$24 \quad$ Pao de 99 pes Ingleses de comprido quefazem 17 Braças das Nossas e de grosso 33 polega= das athe 34 ditos

1012 Paos de87 pes Inglezes de Comprido quefa= zem 15 Braças das Nossas ede grosso 28 polegadas para cima

24 Paos de81 pes Inglezes de comprido quefa= zem 14 bracas das nossas e de grosso 27 polegadas para cima

$24 \quad$ Paos de76 pes Inglezes deComprido quefazem 13 Braças das Nossas e de grosso 24 polegadas 18 Paos de70 pes Inglezes deComprido quefazem 12 Braças das nossas e de grosso 21 polegadas 


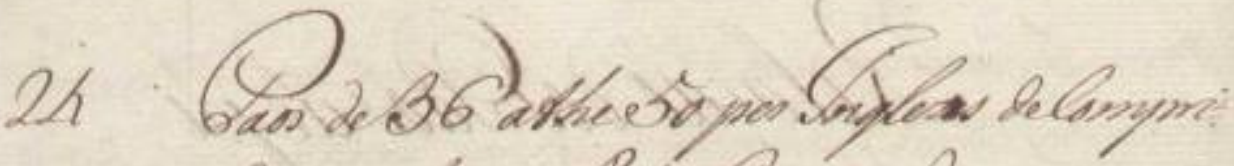

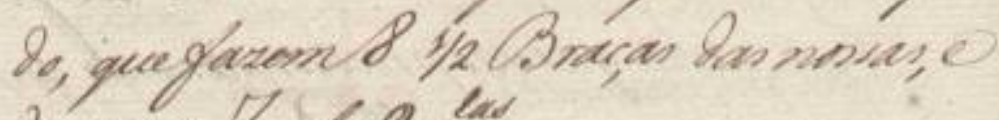
degrose 7 abe 9 per

(c)

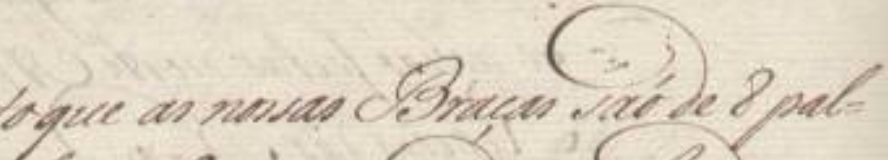

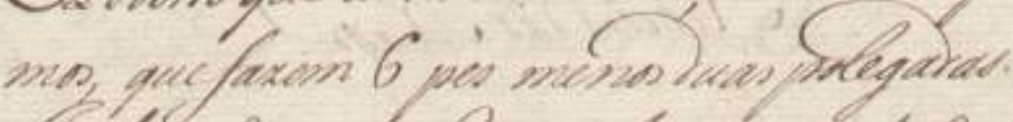

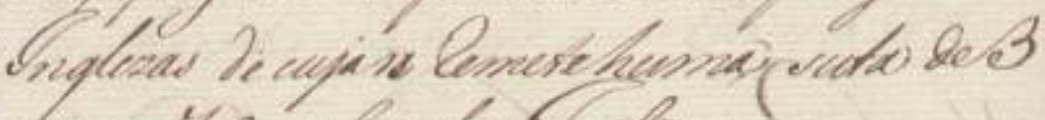
pes ne656 prequatas onglowe.

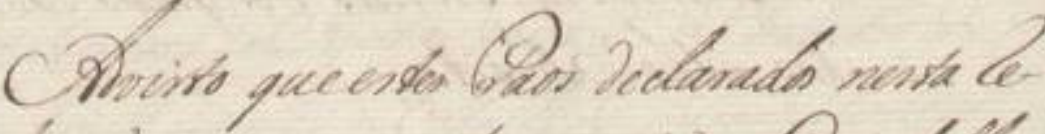

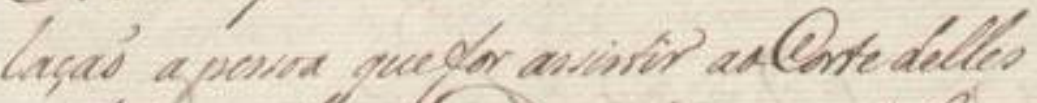

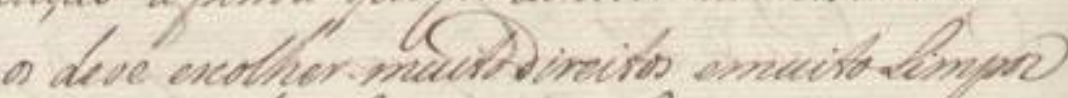
denos eofiar bompandeles porque ca nes

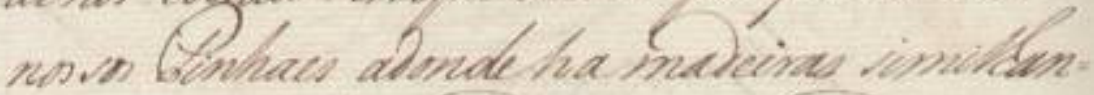

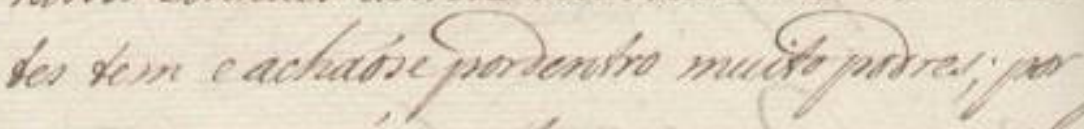
sue in enganas mueras pares cenes coconele quevero cone ham bich re coponie que nas cem imvaries partes pelos ofe acione pe-

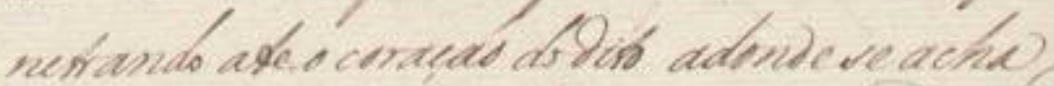

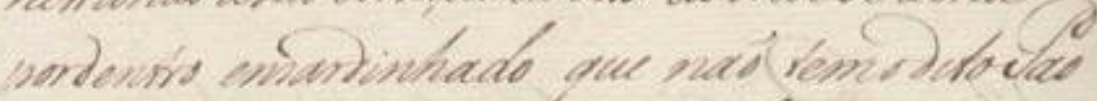

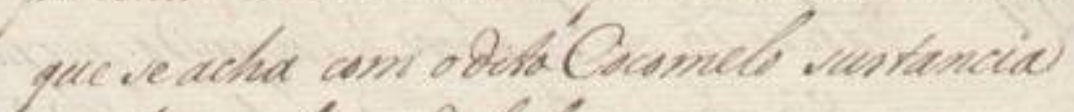
rentueuna dopme befecrs

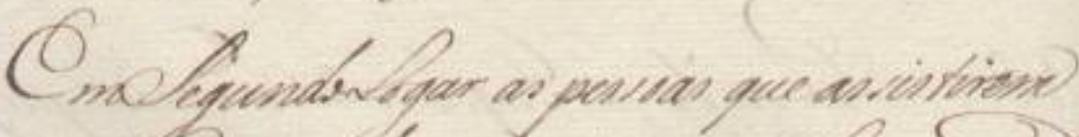

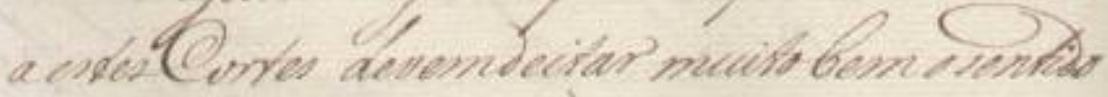


do, quefazem8 1/2 Braças das nossas, e degrosso 7 ate 9 polegadas

Advirto que as nossas Braças saõ de 8 pal= mos, quefazem 6 pes menos duas polegadas Inglezas de cujase remetehuma suta de3 pes ou36 polegadas Inglezas.

Advirto queestes Paos declarados nesta relaçaõ a pessoa quefor assistir aoCorte delles os deve escolher muitodireitos emuitoLimpos denõs eolhar bemparaelles por que ca nos nossos Pinhaes adondeha madeiras similhan= tes tem eachaõse pordentro muito podres; por que se enganaõ muitas vezes com o cocomelo que saõ como hunsbeiços deesponja que nas= cem emvarias partes pelos* Pao acima penetrando ate o coraçaõ dodito adonde se acha pordentro ensardinhado que naõ temo ditoPao que se acha com o ditoCocomelo sustancia nenhuma depois defeito EmSegundoLogar as pessoas queassitirem aestesCortes devemdeitar muitobem o sentido 


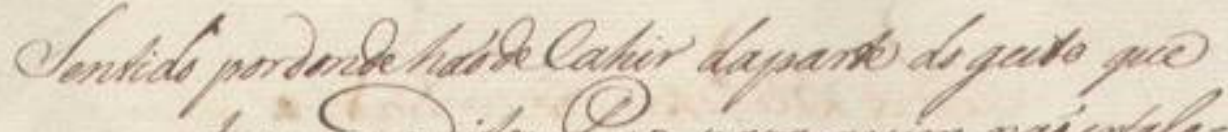

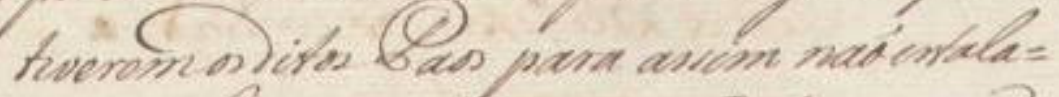
remporbaian enforme pueves Dequem on

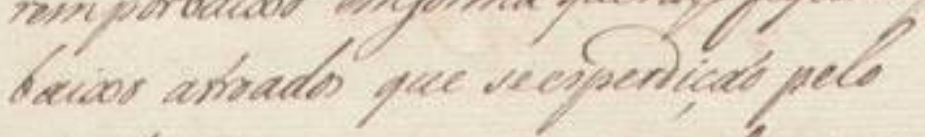

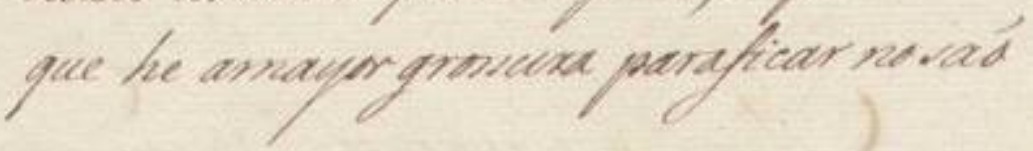

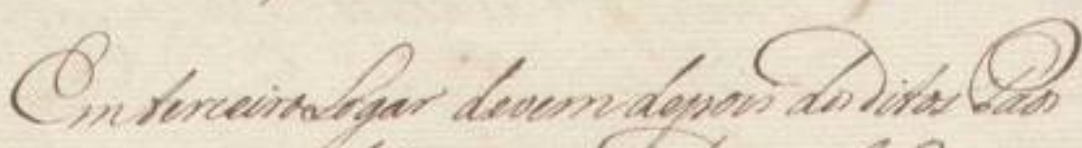

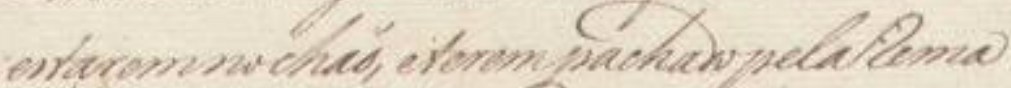

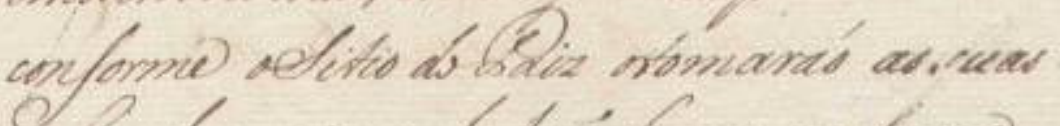
prepaded acima do hua orace conforme

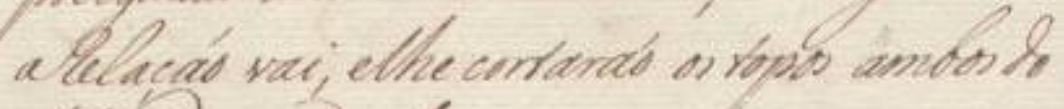
dinolus quetrats

0

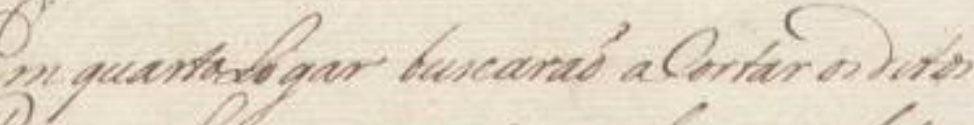

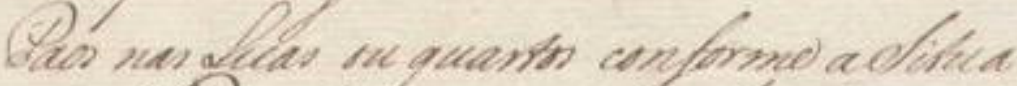

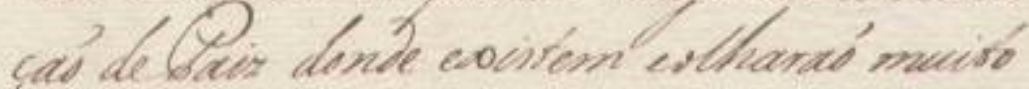
bon para elles pant combrem quelles reagh. menv devege muerof pine que he coma queds.

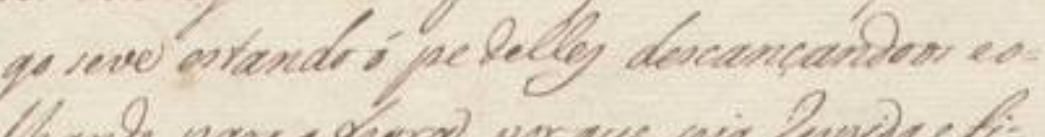

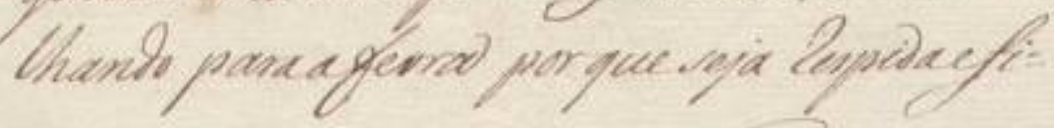

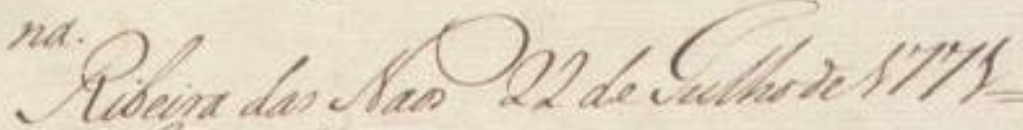

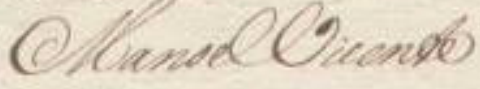


||138r|| [[Sentido]] pordonde haõ deCahir daparte do geito que tiverem os ditos Paos para assim naõestala $=$ rem porbaixo emforma quenaõ fiquempor baixo atroados que seesperdiçaõ pelo que he amayor grossura paraficar no saõ EmterceiroLogar devem depois dos ditos Paos estarem nochaõ, eterem pachado pelarema conforme oSitio doPaiz otomaraõ as suas polegadas acima do* huã braça conforme arelação vai, elhe cortaraõ os topos ambos do ditoPao quadrados Em quartoLogar buscaraõ aCortar os ditos Paos nas Luas ou quartos conforme aSitua çaõ dePaiz donde existem eolharaõ muito bem para elles para cortarem aquelles quefo= rem deveya muitofina quehe cousa queLogo seve estando ó pe delles descançandoos eo= Ihando para afevra porque seja respidaefi= na.

Ribeira das Naos 22 de lulho de1771= ManoelVicente 


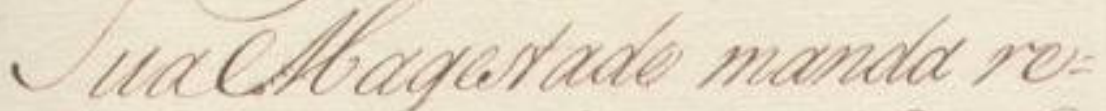

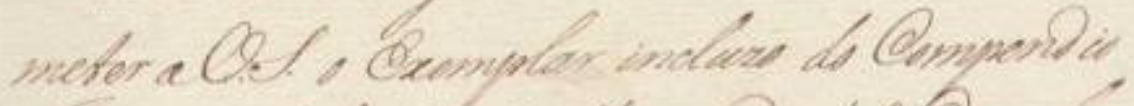

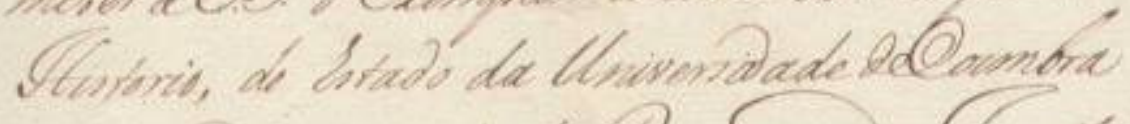

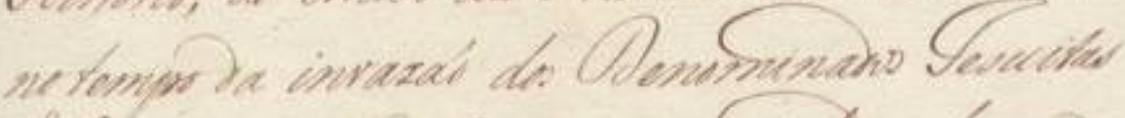

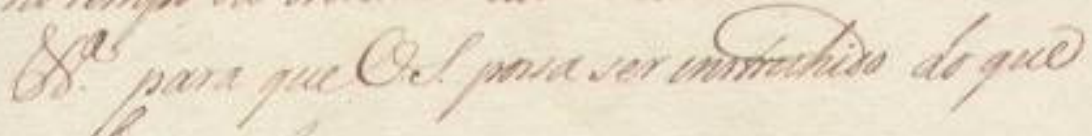
nethe recrinery.

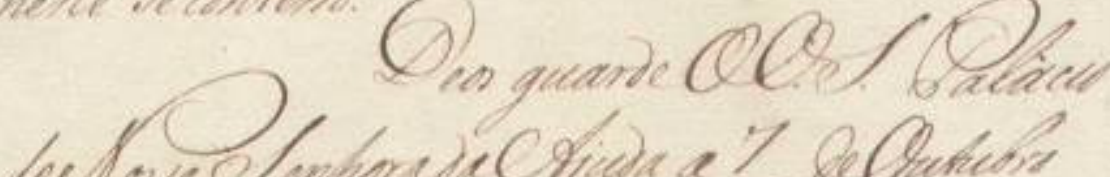<smiles>C1=CC(Cc2ccccc2)CCC1</smiles>

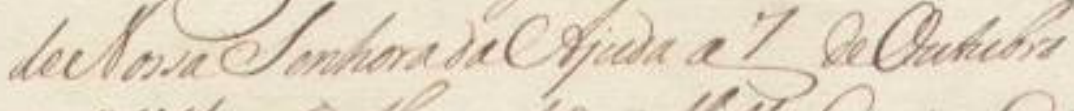

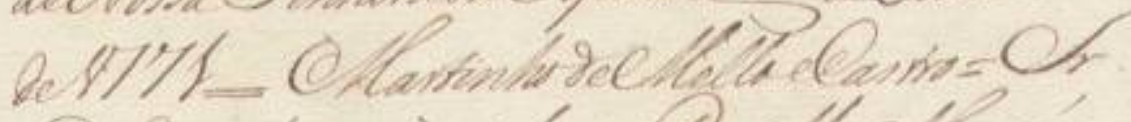

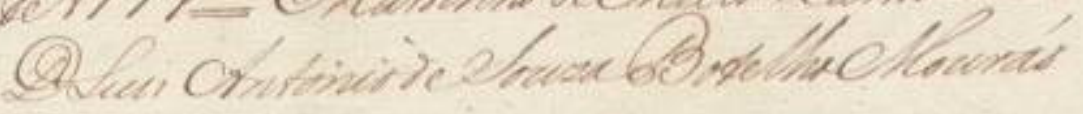

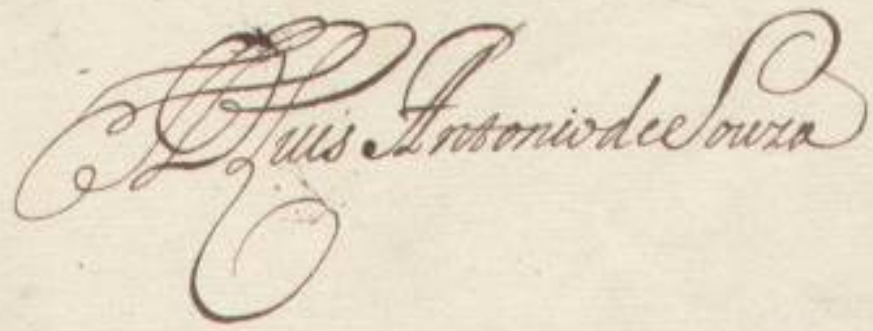


||140r|| SuaMagestade manda re=

meter aVossaSenhoria o Exemplar incluzo do Compendio

Historio*, do Estado da Universidade deCoimbra

notempo da invazaõ dos Denominados lezuitas

5 etcetera para queVossaSenhoria possa ser instruhido do que

nelle se contem.

Deos guardeAVossaSenhoria Palacio

deNossaSenhoradaAjuda azㅡ deOutubro

de1771 $=$ MartinhodeMelloeCastro $=$ Senhor

10 DomLuis Antonio deSouzaBotelhoMouraõ 


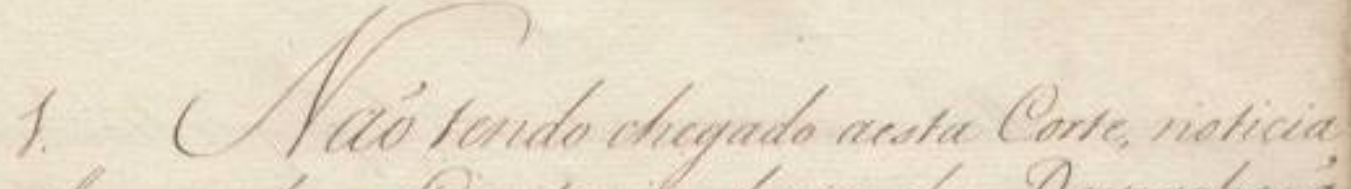

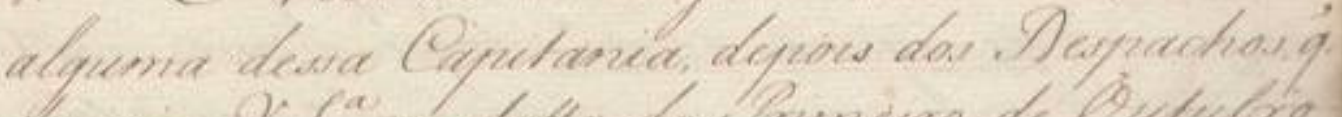

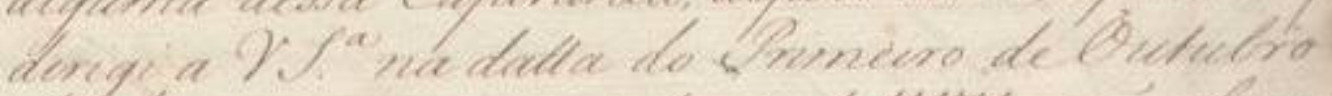

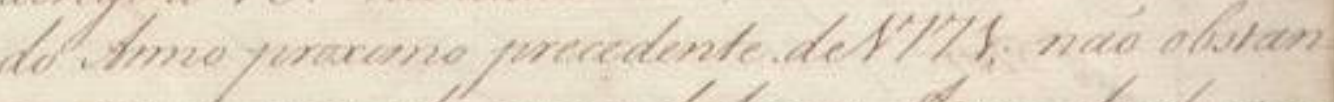

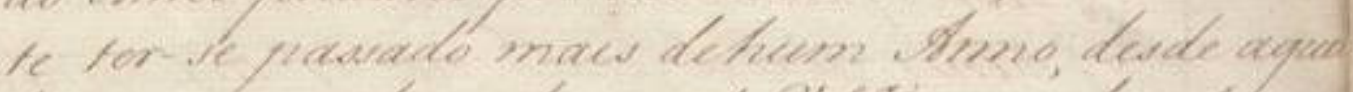

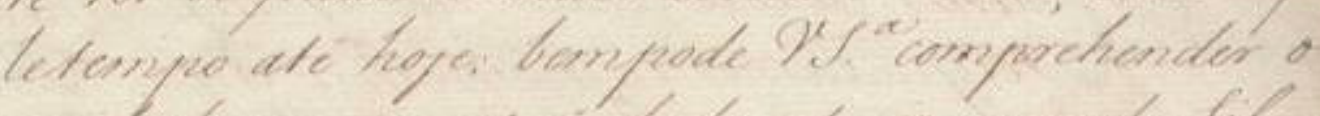

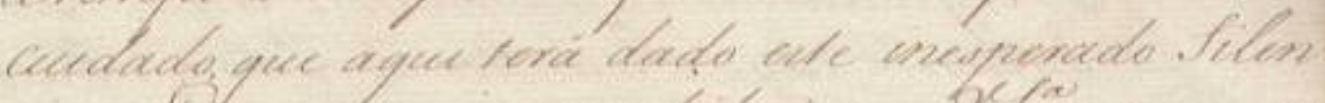

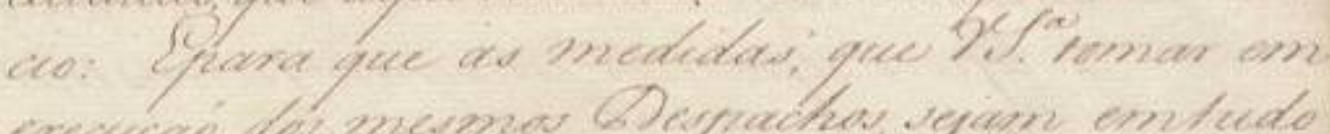

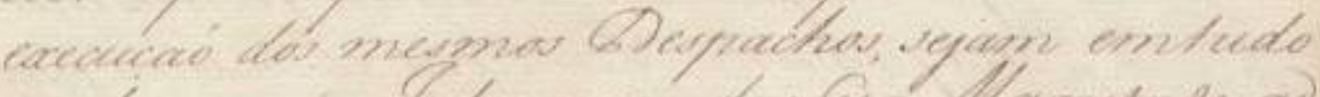

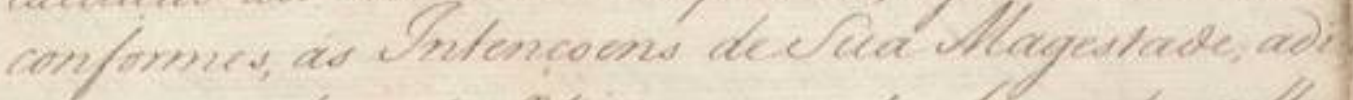

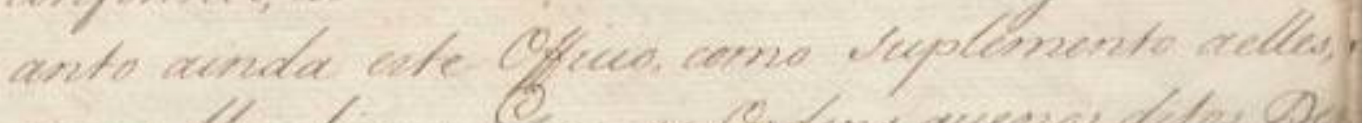

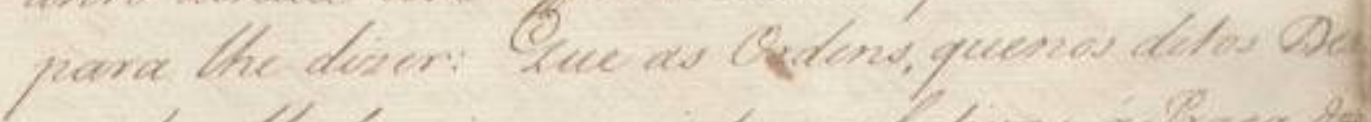

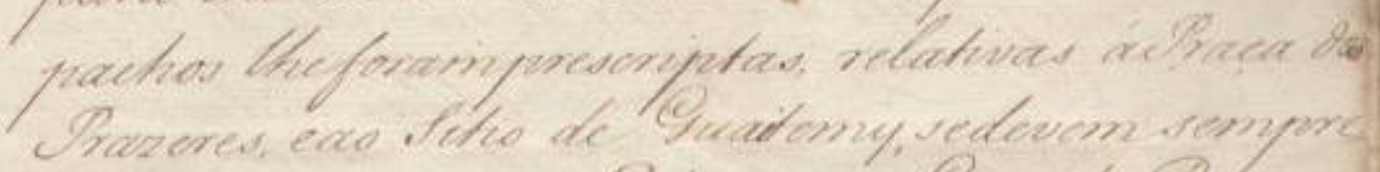

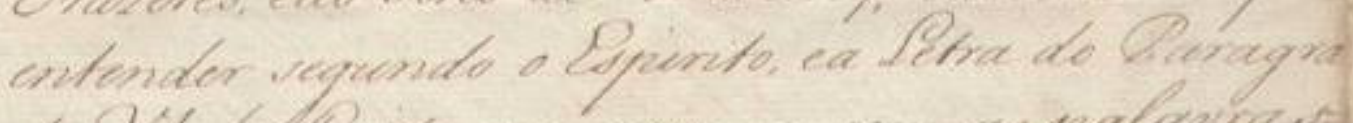

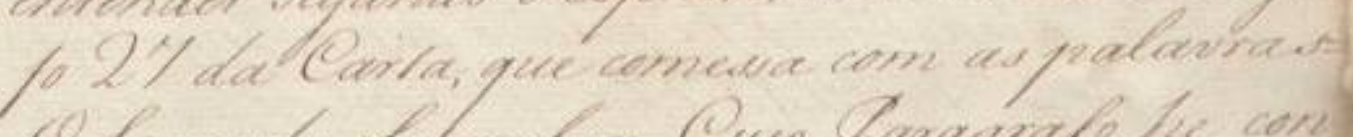

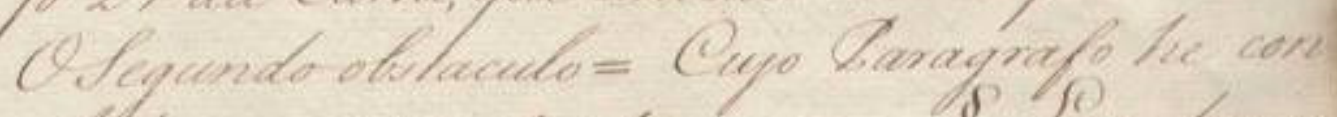

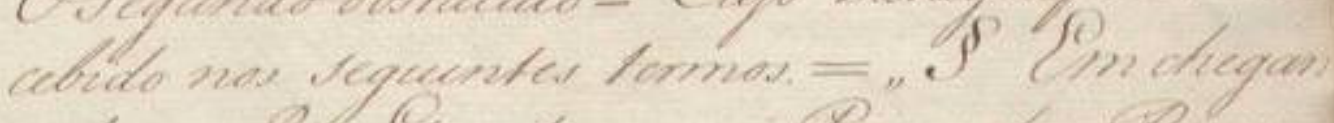

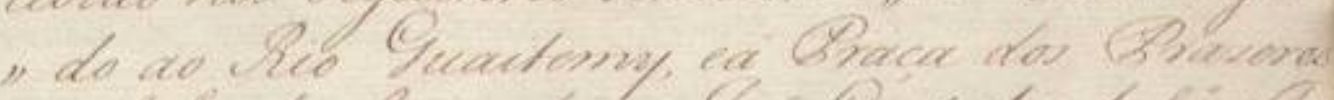

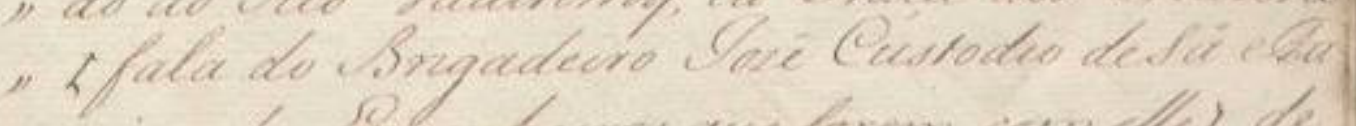

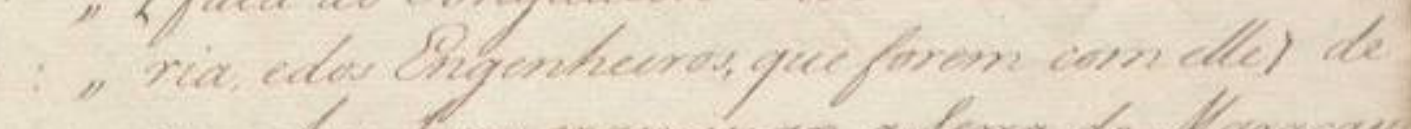

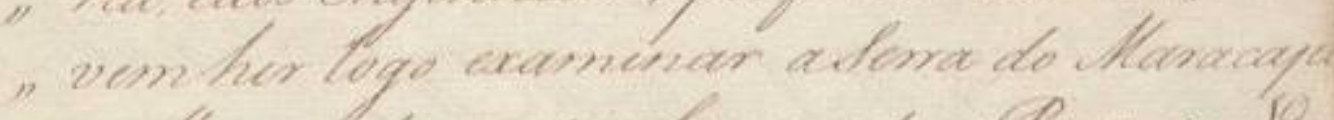

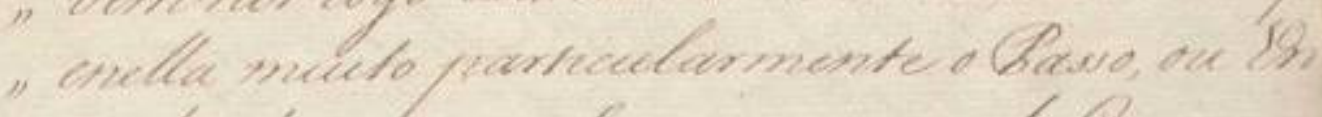

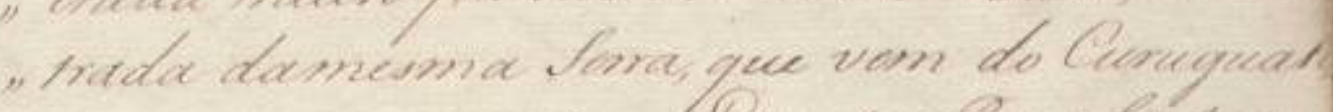

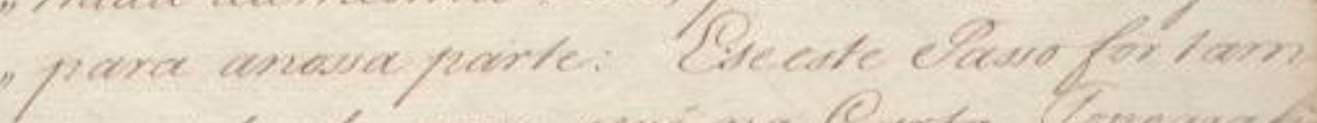

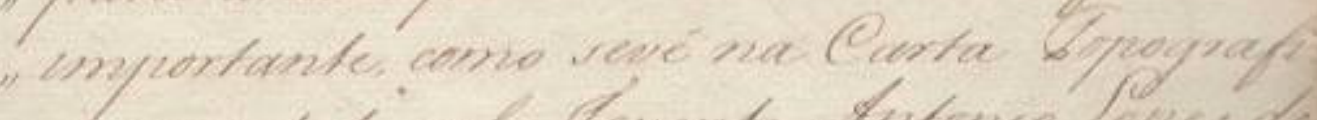

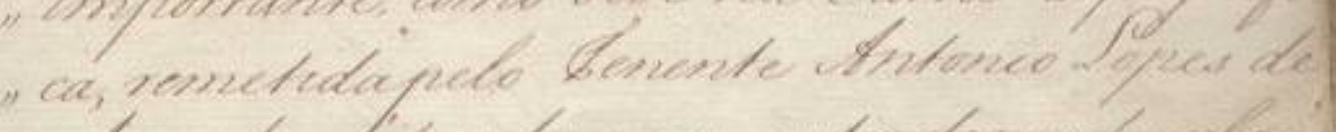

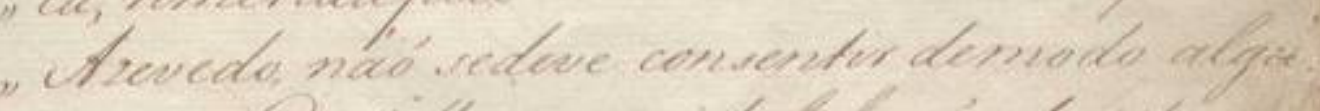

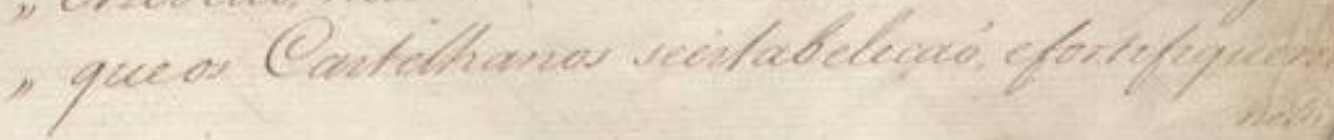


1. $\quad|142 r| \mid$ Naõ tendo chegado aesta Corte, noticia alguma dessa Capitania, depois dos Despachos que derigi a VossaSenhoria na datta do Primeiro deOutubro do Anno proximo precedente de1771, naõ obstan=

5 te ter-se passado mais dehum Anno, desde aquelletempo até hoje: bempode VossaSenhoria comprehender o cuidado, que aqui terá dado este inesperado Silen= cio: Epara que as medidas, que VossaSenhoria tomar em execuçaõ dos mesmos Despachos, sejam emtudo conformes, ás Intençoens deSua Magestade, adi= anto ainda este Officio, como suplemento aelles, para Ihe dizer: Que as Ordens, quenos ditos Despachos Iheforamprescriptas, relativas áPraça dos Prazeres, eao Sitio de Guaitemy, sedevem sempre

15 entender segundo o Espirito, ea Letra do Paragrafo 27 da Carta, que comessa com as palavras $=$ OSegundo obstaculo $=$ Cujo Paragrafo he con= cebido nos seguintes termos $=$,, parágrafo Em chegan„, do ao Rio Guaitemy, eá Praça dos Prazeres

20 ,, (fala do Brigadeiro lozê Custodio deSá eFa= „, ria, edos Engenheiros, que forem com elle) de „, vemhir logo examinar aSerra do Maracaju ,, enella muito particularmente o Passo, ou En ,, trada damesma Serra, que vem do Carugua[ti]

25 ,, para anossa parte: [espaço] Ese este Passo for tam ,, importante, como sevê na Curta* Topografi= „, ca, remetidapelo Tenente Antonio Lopes de „, Azevedo, naõ sedeve consentir demodo algũ ,, queos Castelhanos seestabeleçaõ, efortifiquem nell |[e]

\footnotetext{
* "Curta" por "casta".
} 


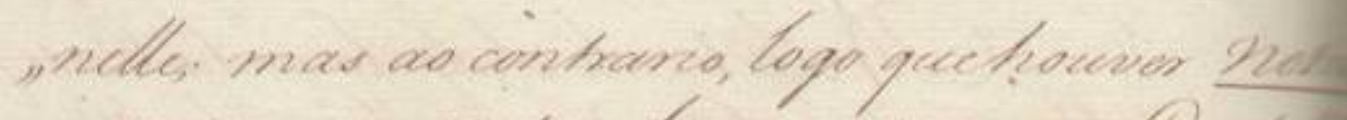

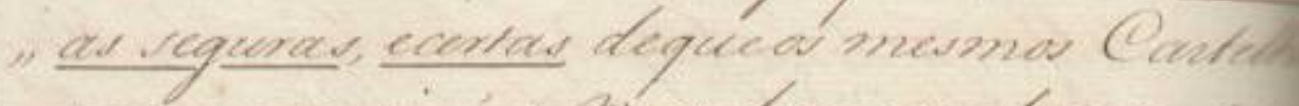

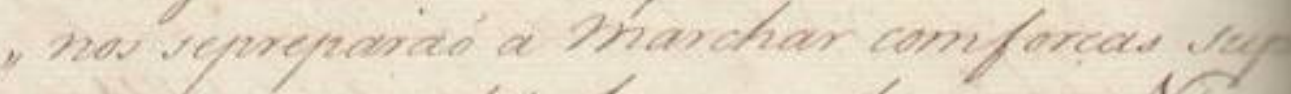

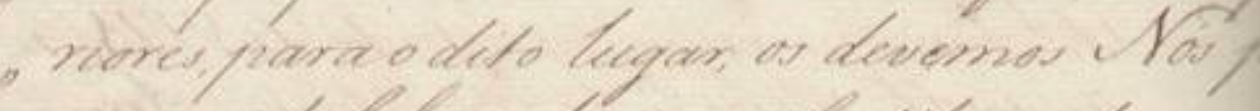
wener chabulerendo- nas eforlificando-nos

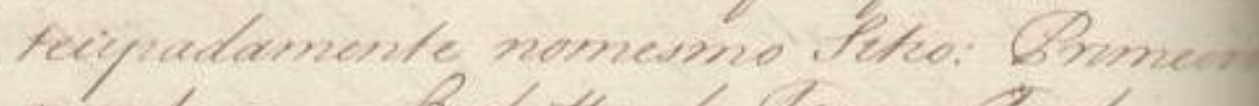

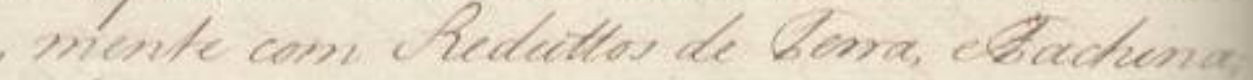

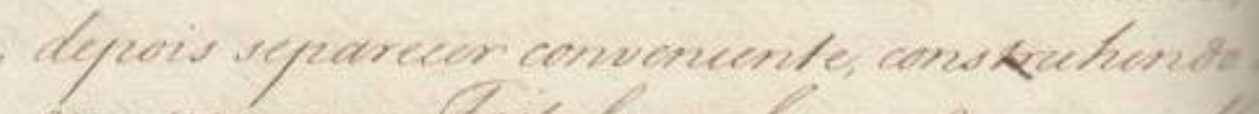

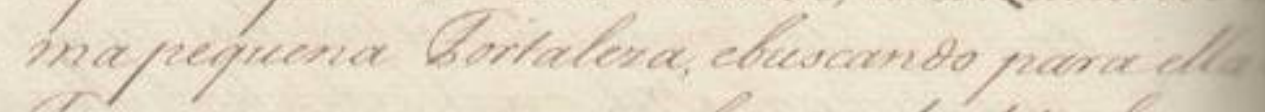

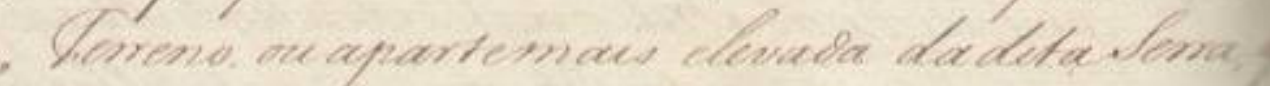

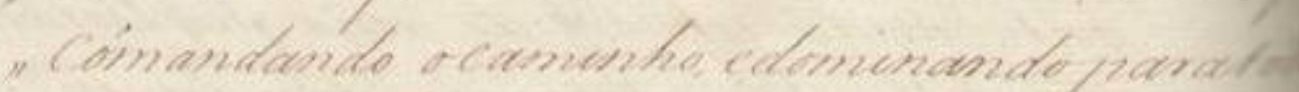

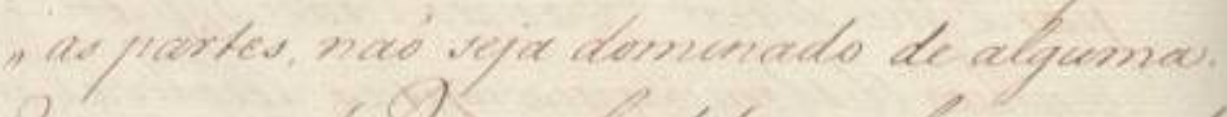
2. (1) woredete.

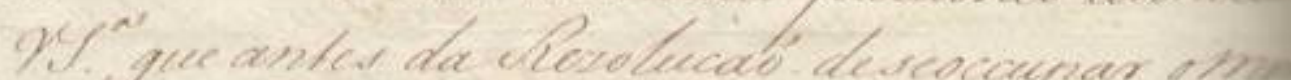
(D) unindo Gave, he preano que ocbrequatero va

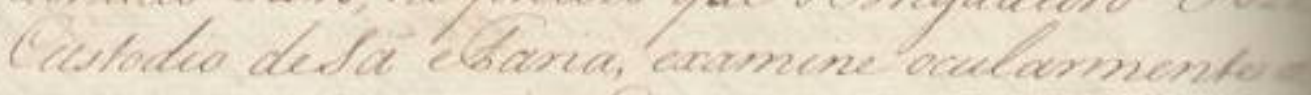

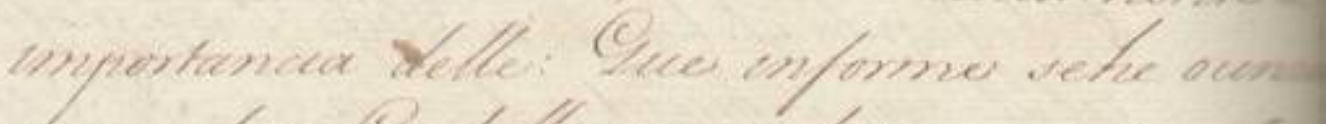

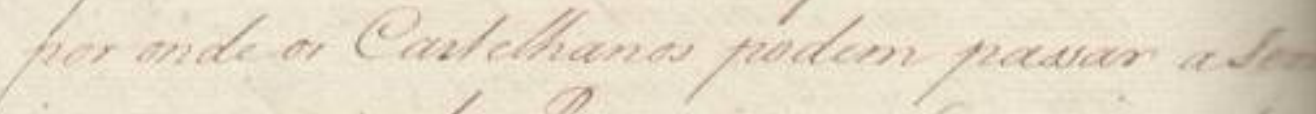

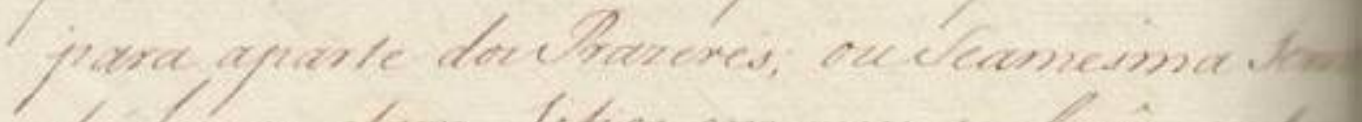

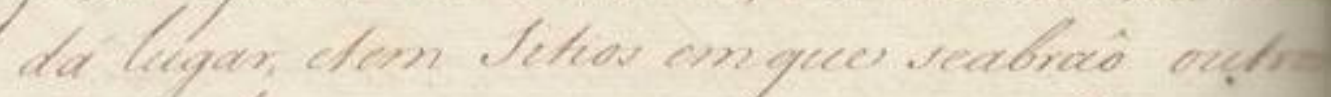

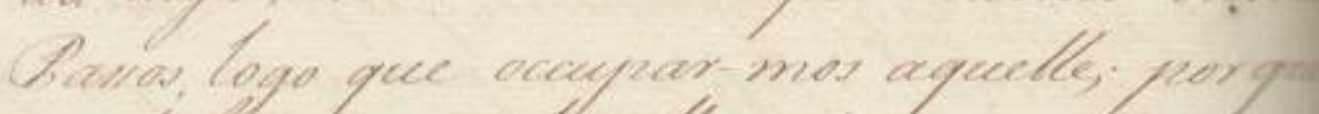

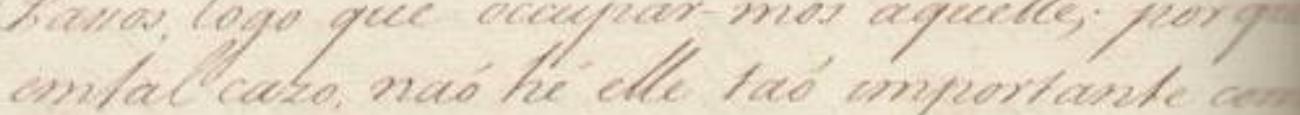

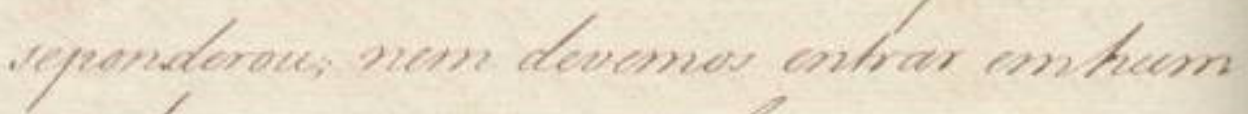

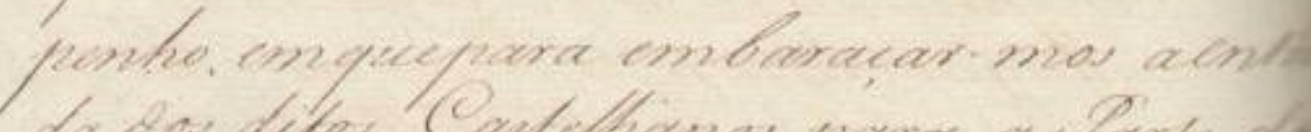

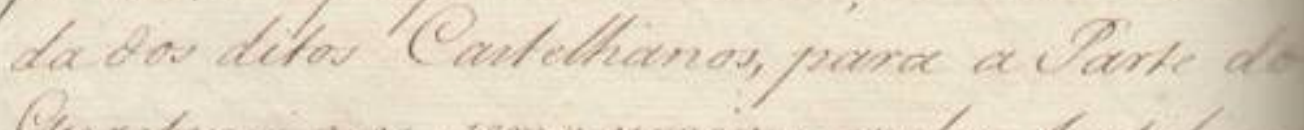

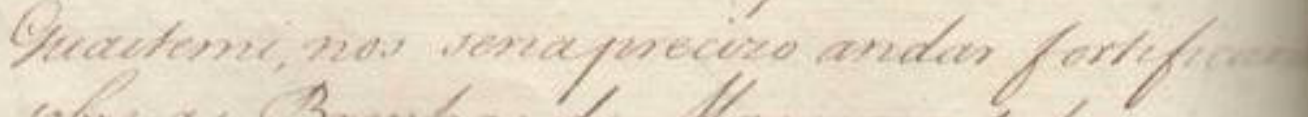

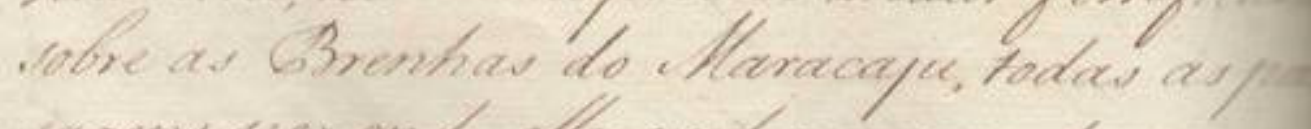

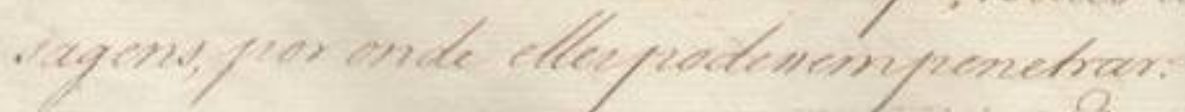


$30\|142 \mathrm{v}\|$, , [[nelle]]; mas ao contrario, logo quehouver notici=

, as seguras, ecertas dequeos mesmos Castelha=

,, nos sepreparaõ a Marchar comforças supe=

,, riores, para o dito lugar, os devemos Nos pre=

,, venir estabelecendo-nos, efortificando-nos an=

,, tecipamente nomesmo Sitio: Primeira=

,, mente com Reduttos de Terra, eFachina; [e]

,, depois separecer conveniente, construihindo hu=

,, mapequena Fortaleza, ebuscando para ella [o]

„, Terreno, ou apartemais elevada da ditaSerra, [que]

40 ,, Cõmandando ocaminho, edominando para[todas]

,, as partes, naõ seja dominado de alguma.

2. Das sobreditas palavras conhecem

VossaSenhoria, que antes daRezoluçaõ deseoccupar oMen= cionado Passo, he precizo que oBrigadeiro lozê

45 Custodio deSá eFaria, examine ocularmente a importancia delle: Que informe sehe ouni[co] por onde os Castelhanos podem passar a [Serra] para aparte dosPrazeres; ouSeamesma [Serra] dá lugar, etem Sitios emque seabraõ outros

50 Passos, logo que occupar-mos aquelle; porque emtal cazo, naõ hé elle taõ importante como seponderou; nem devemos entrar emhum em= penho, em quepara embaraçar-mos aentra= da dos ditos Castelhanos, para a Parte do

55 Gaitemi, nos seriaprecizo andar fortifica[dos] sobre as Brenhas do Maracaju, todas as pas= sagens, por onde ellespodessempenetrar: | 3. Ainda 


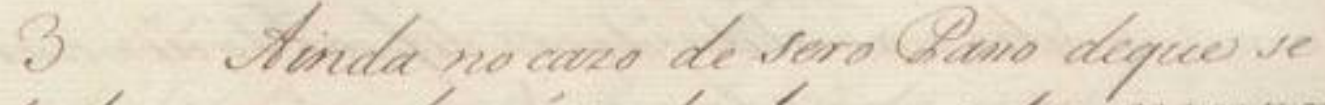
Irata ouneeo, edencé feoder hower outro, menpon wo odeve YS mandar occupean por Whe cular de

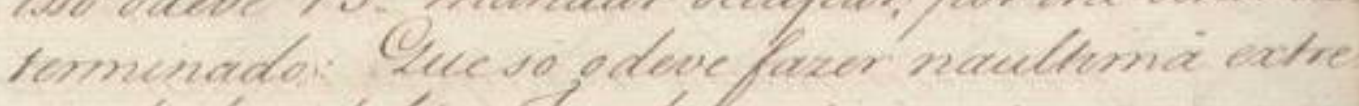
mudade utohie: Dendo monceas negunas econ

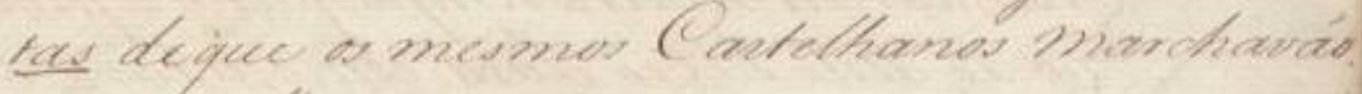
fand a atherm

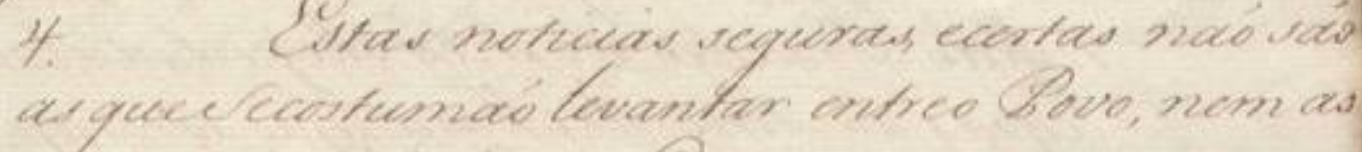

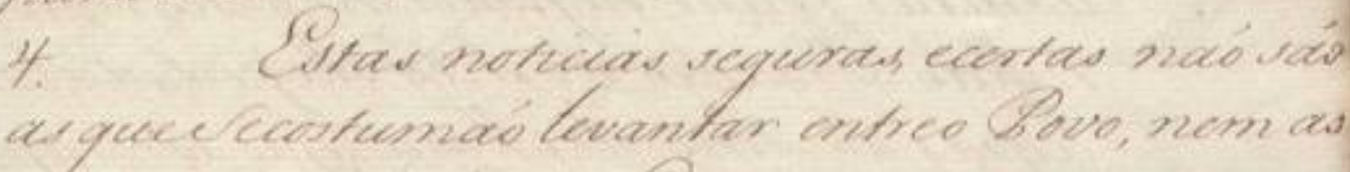

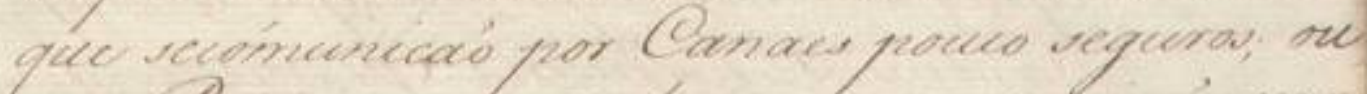

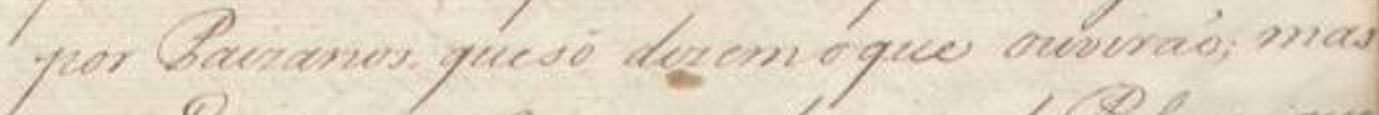

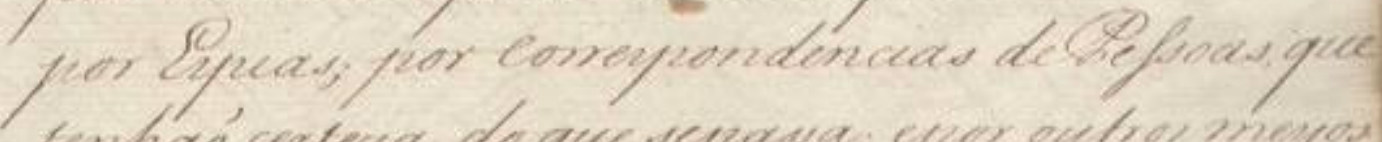

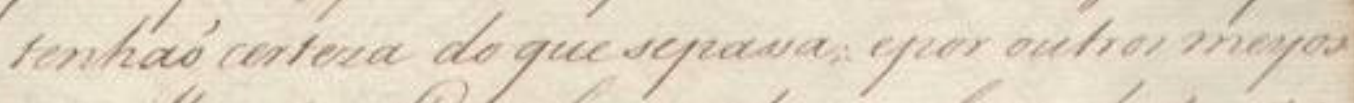

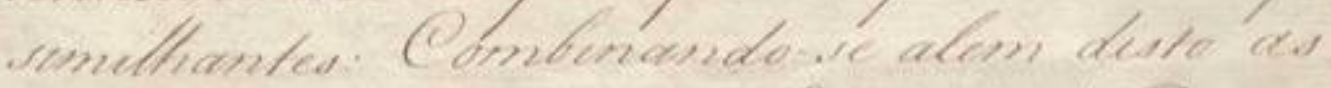

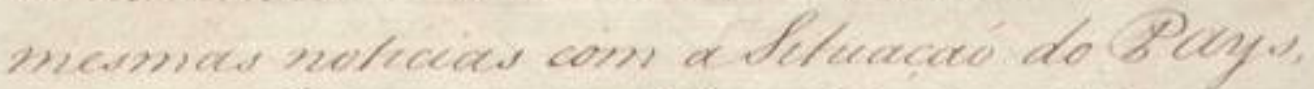
cann as desranceas, edeficudatades deles ceon

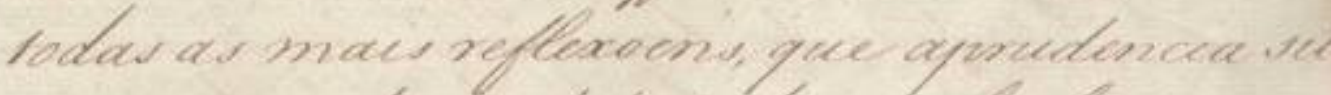
qere, pura depow Letubo bem calculabo sepo der mor modaro canhecenzento das counew ra

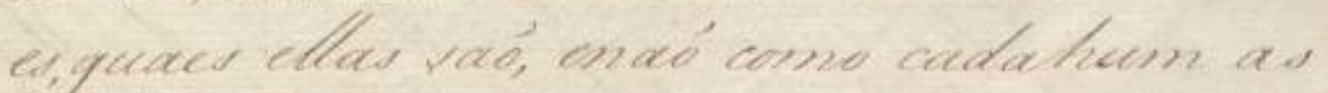
Eefieventa.

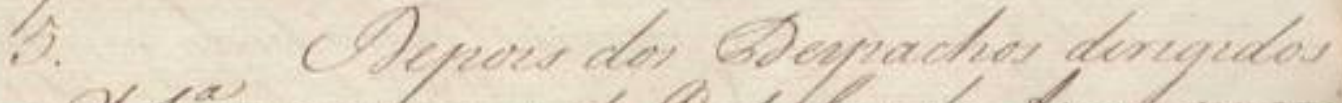

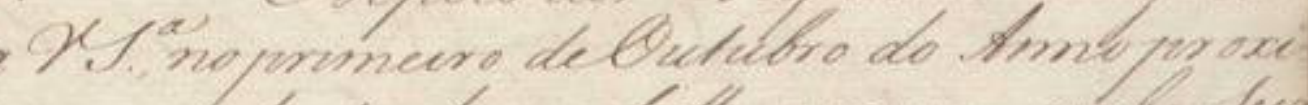
moprededentes deque fallo asoma soube. lear Magentade com poxitura cerlexd, que eraun

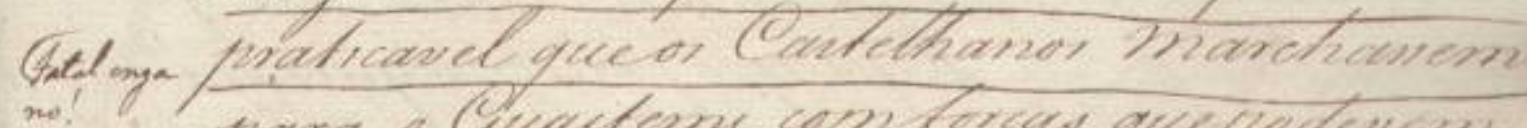

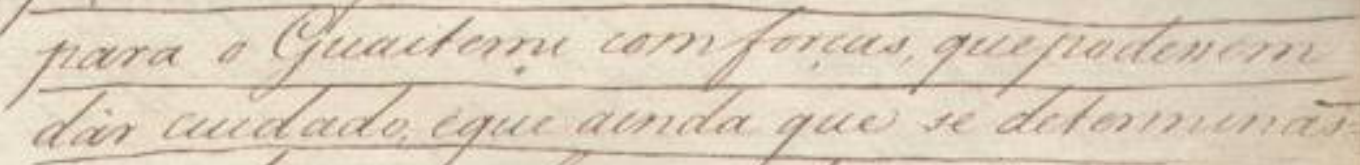

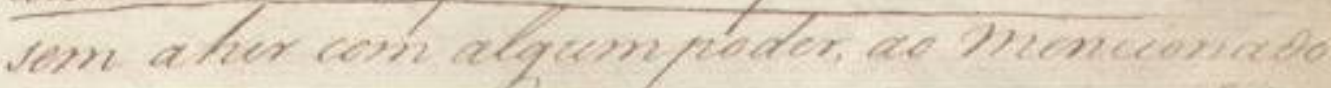
reke 
||143r|| [[3. Ainda]] no cazo de sero Passo deque se

60 trata ounico, edenaõ poder haver outro; nempor

isso o deve VossaSenhoria mandar occupar, por lhe estar de=

terminado: Queso o deve fazer naultima extre=

midade, isto hé: Tendo noticias seguras, ecer=

tas de que os mesmos Castelhanos marchavaõ

65 para o attacar.

3. Estas noticias seguras, ecertas naõ saõ

as que Secostumavaõ levantar entreo Povo, nem as

que secõmunicaõ por Canaes pouco seguros; ou

por Paizanos, quesó dizem o que ouviraõ; mas

70 por Espias; por correspondencias dePessoas, que

tenhaõ certeza do quesepassa; epor outros meyos

similhantes: Combinando-se alem disto as

mesmas noticias com aSituaçaõ do Pays,

com as distancias, edifficuldades delle; ecom

75 todas as mais reflexoens, que aprudencia su=

gere, para depois detudo bem calculado sepo=

der vir, no claro conhecimento das couzas ta=

es, quaes ellas saõ, enaõ como cadahum as

reprezenta.

$80 \quad 4$ - Depois dos Despachos dirigidos

a VossaSenhoria no primeiro deOutubro do Anno proxi=

moprecedente, dequefallo assima soube Sua

Magestade compozitiva certeza; que era im-

praticavel ${ }^{10}$ queos Castelhanos Marchassem

85 para o Guaitemi comforças, quepodessem

dar cuidado, eque ainda que se determinas $=$

sem ahir com algumpoder, ao mencionado | Sitio

${ }^{10}$ À margem esquerda há a nota: "Fatal engano", escrita em outra caligrafia. Tal trecho está sublinhado no manuscrito. 


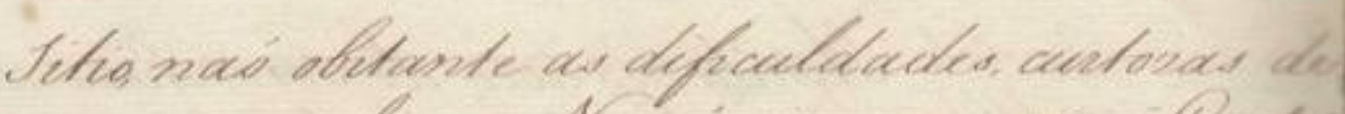

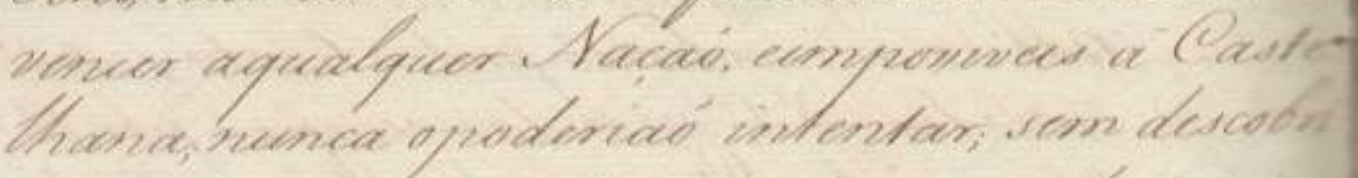

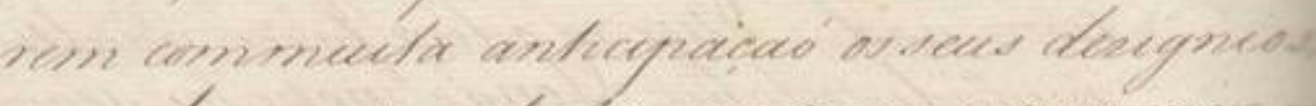
onas darem mueto lempro frara ofperenener

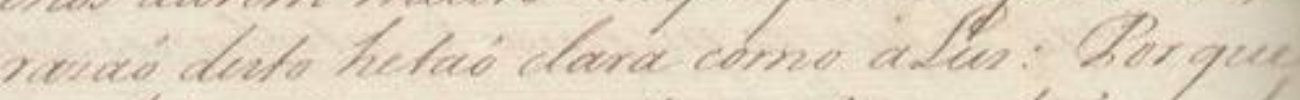
audetas forcas, ou poder naó seachaó nuchas made Srouedes de faró. Hequed, dutante des Legaas da Serra dev llaraciyus en caye Croses deo romente ha huma Guamecoro de quemost Gaunanos, cam dous bedracos ammates en asferquethas pand encholerem os Sudvosiv if sin Cennguati; destante coneo Legoas de feet

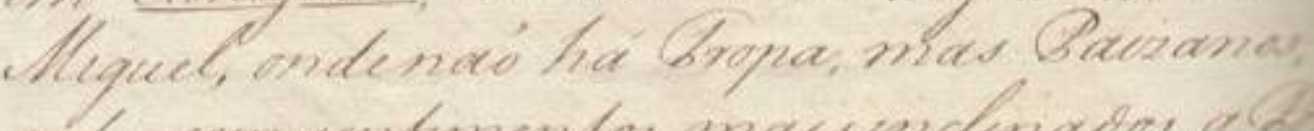

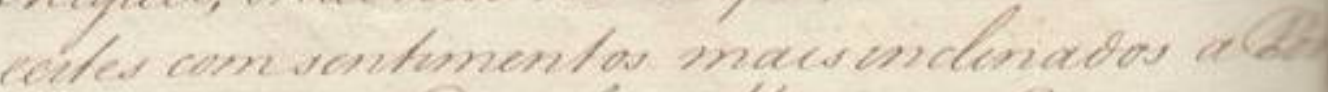
rugad.que a Contela: Nenos de Cenuquati at

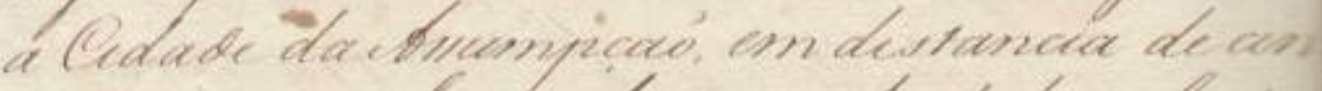
coerita, cumes legoas de cammentio, tode cerberto

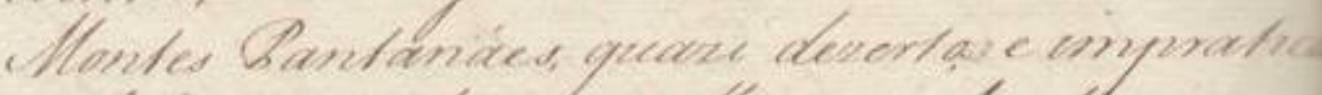

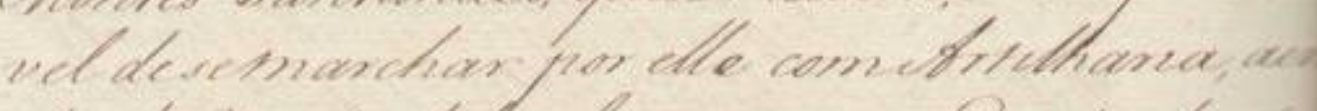

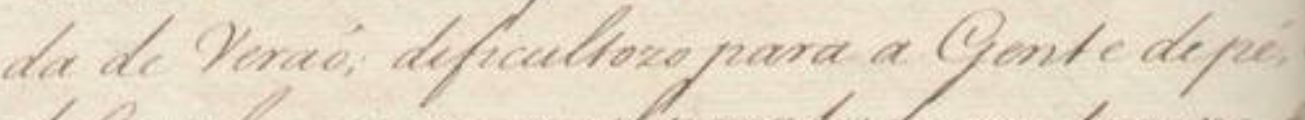
del asude: cen accensed para tudo on tompo of

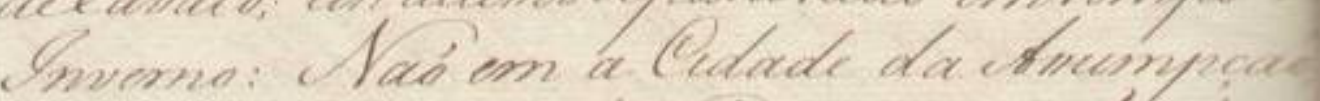
onde lamben naì hai Gropa, nem Sirelhan nem Qjeners algrom de Betrechor de Guema 6. Heprecero par consequencera que

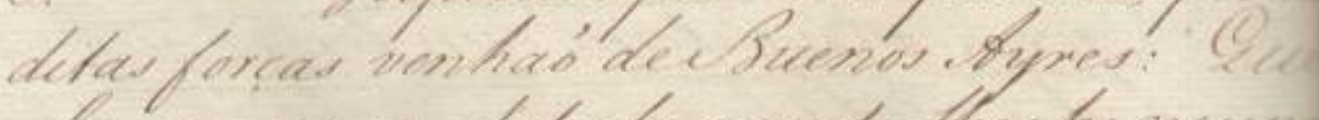

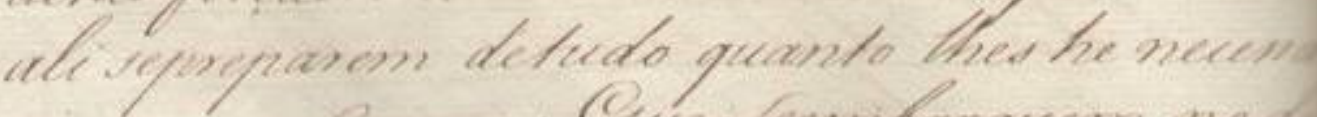
mo para a quema : Cuev combarquen nod 
||143V|| [lSıtıo]], nao obstante as dıtıculdades, custozas de

90 vencer aqualquer Naçaõ, eimpossiveis á Caste= Ihana, nunca opoderiaõ intentar; sem descobrirem commuita anticipaçaõ os seus designios, enos darem muito tempo para osprevenir; ea razaõ disto hetaõ clara como aLus: Por que 95 as ditas forças, ou poder naõ seachaõ no chamado Prezidio deSaõ Miguel, distante de legoas daSerra deMaracaju; em cujo Prezidio somente há huma Guarniçaõ de quinze Paizanos, com dous Pedreiros armados em [que] 100 as forquilhas para enchotarem os Indios: [Naõ]

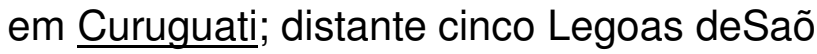
Miguel, ondenaõ há Tropa, mas Paizanos, eestes comsentimentos mais inclinados aPortugal, que a Castela: Menos de Curuguati a[té] 105 a Cidade da Assumpçaõ, em distancia de cin= coenta, ecinco legoas de caminho, todo cuberto [de] Montes Pantanáes, quazi dezertos e impraticavel desemarchar por elle comArtilharia, ain= da de Veraõ; dificultozo para a Gente depé, [ou]

110 deCavalo; ein accessivelparatudo emtempo de Inverno: Naõ em a Cidade daAssumpçaõ ondetambem naõ há Tropa, nem Artilharia nem Genero algum dePetrechos deGuerra.

5. Heprecizo por consequencia, que as

115 ditas forças venhaõ deBuenos Ayres: [espaço] Que ali sepreparem detudo quanto Ihes he necessario para aGuerra: QueSeembarquem no di [to] 


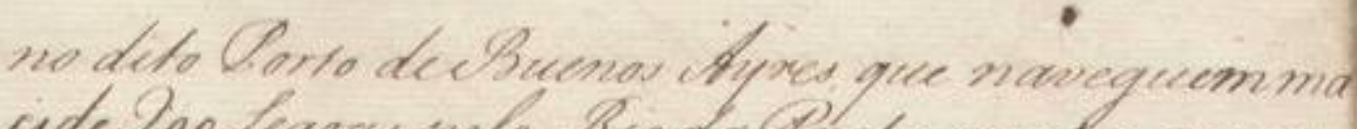

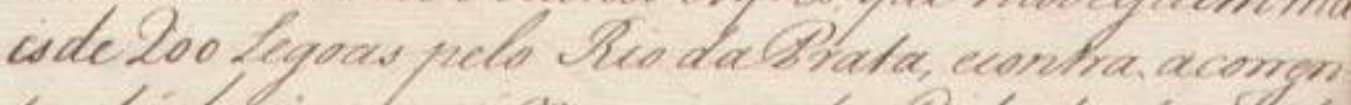

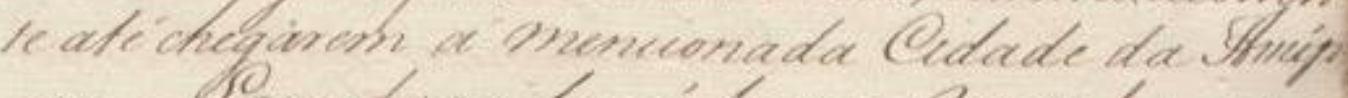

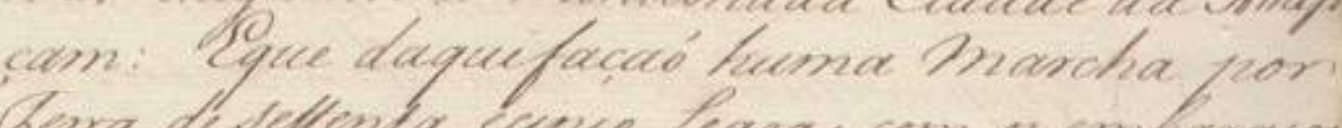

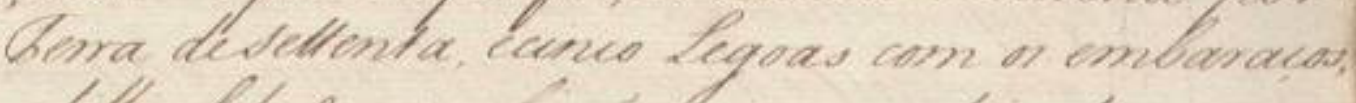

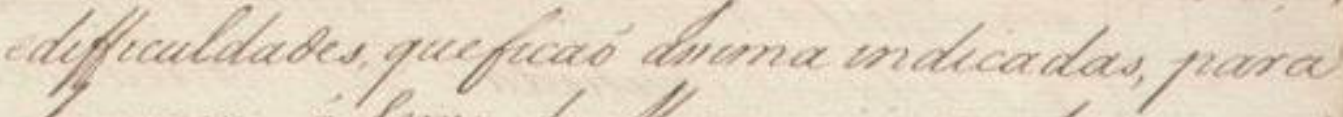

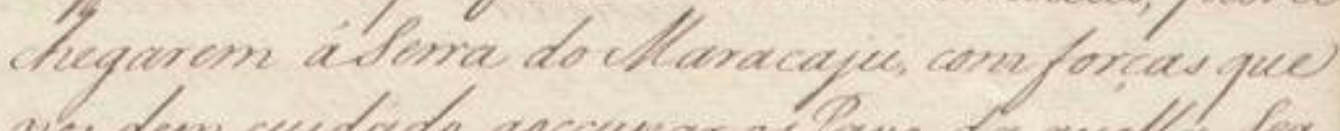

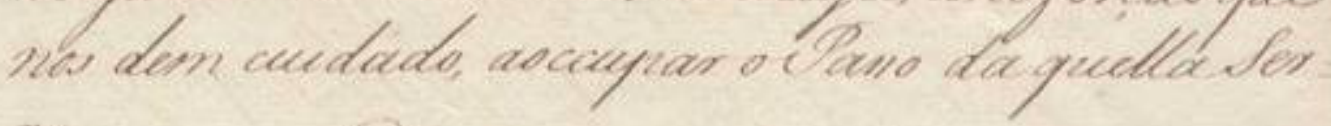

2x.

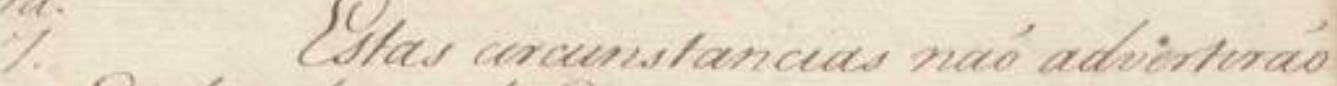

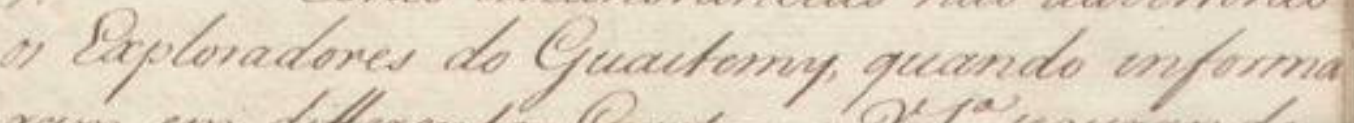

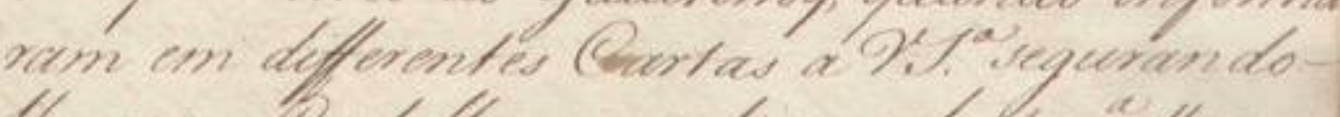

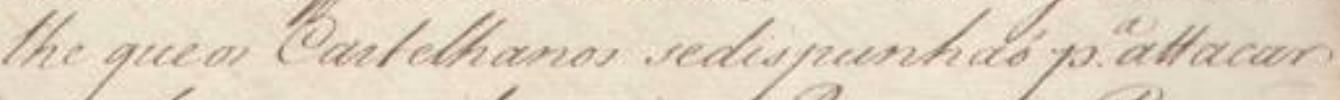

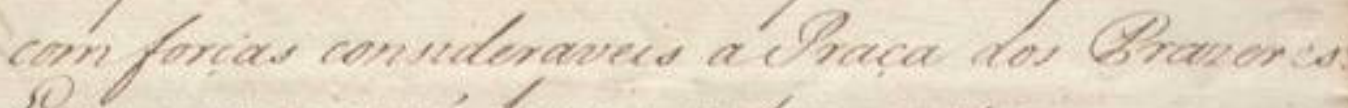

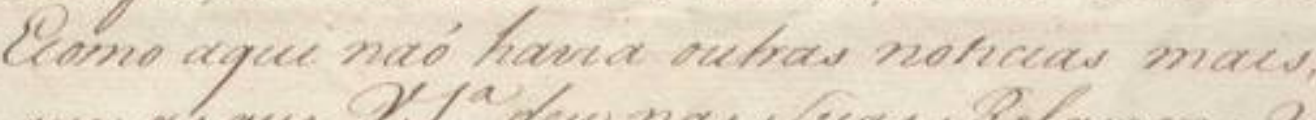

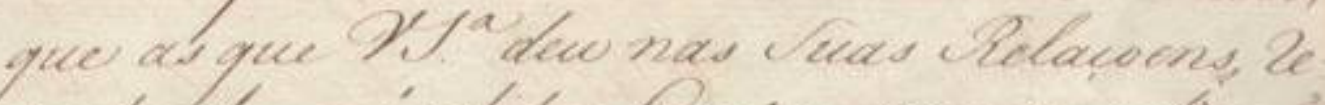

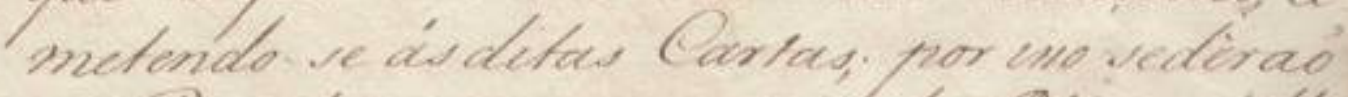

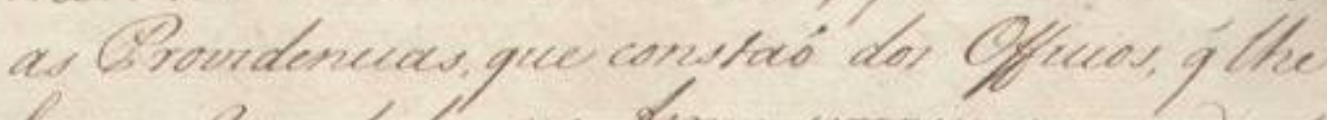

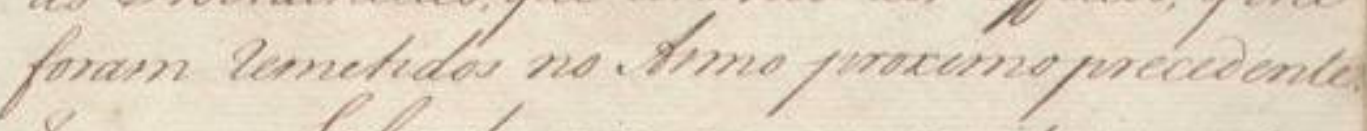

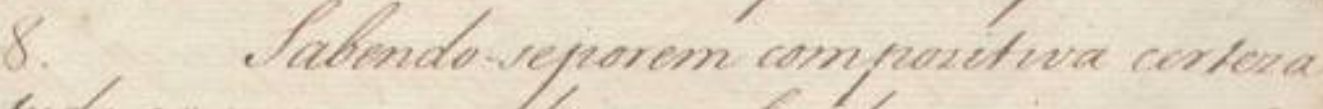

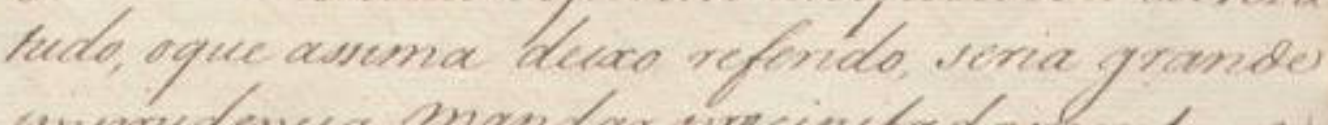

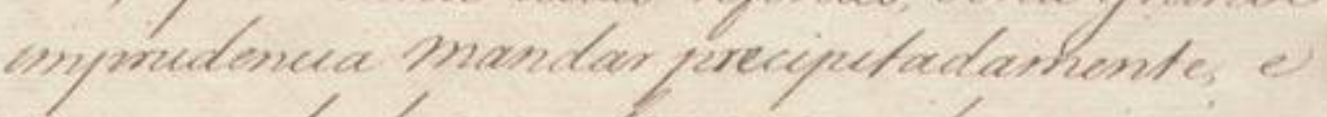
con qrande deypera forcas comenteramers, iqued

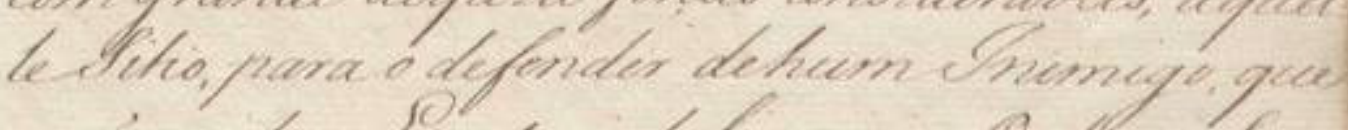

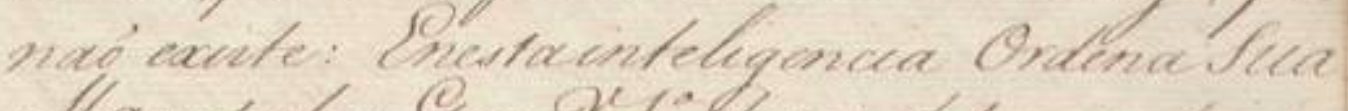

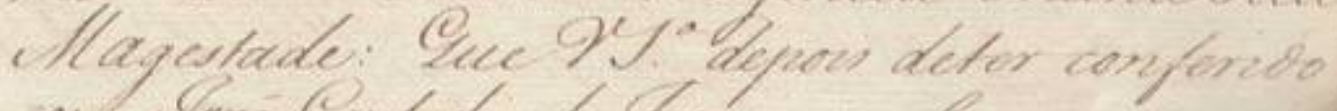

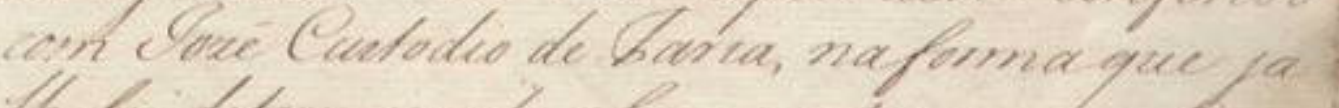

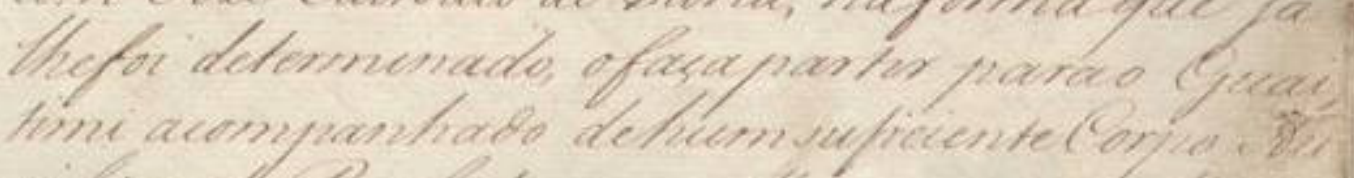

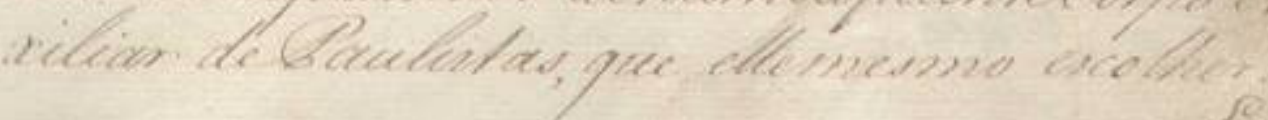


||144r|| [[no dito]] Porto deBuenos Ayres, que naveguem ma

is de 200 Legoas pelo Rio daPrata, econtra, acorren=

120 te até chegarem á mencionada Cidade da Assũp

çam: [espaço] Eque daquifaçaõ huma Marcha por

Terra desettenta, ecinco Legoas com os embaraços,

edifficuldades, queficaõ assima indicadas, para

chegarem áSerra do Maracajú, com forças que

125 nos dem cuidado, aoccupar o Passo daquellaSer=

ra.

6. Estas circunstancias naõ advertiraõ

os Exploradores do Guaitemy, quando informa

ram em differentes Cartas a VossaSenhoria segurando-

130 Ihe queos Castelhanos sedispunhaõ para attacar

comforças consideraveis aPraça dos Prazeres:

Ecomo aque naõ havia outras noticias mais,

que as que VossaSenhoria deu nas Suas Relaçoens, re-

metendo-se ás ditas Cartas; por isso sederaõ

135 as Providencias, que constaõ dos Officios, que the

foram remetidos no Anno proximo precedente.

7. Sabendo seporem compozitiva certeza

tudo, o que assima deixo referido, seria grande

imprudencia mandar precipitadamente, e

140 com grande despeza forças consideraveis, áquel=

leSitio, para o defender dehum Inimigo, que

naõ existe: Enesta inteligencia OrdenaSua

Magestade: QueVossaSenhoria depois deter conferido

com lozé Custodio de Faria, naformaque ja

145 Ihefoi determinado, ofaça partir parao Guai-

timi acompanhado dehum suficiente Corpo Au-

xiliar dePaulistas, que elle mesmo escolher: [[Eque]] 
ias

Eque un ali cheganse farra na Serra do tha

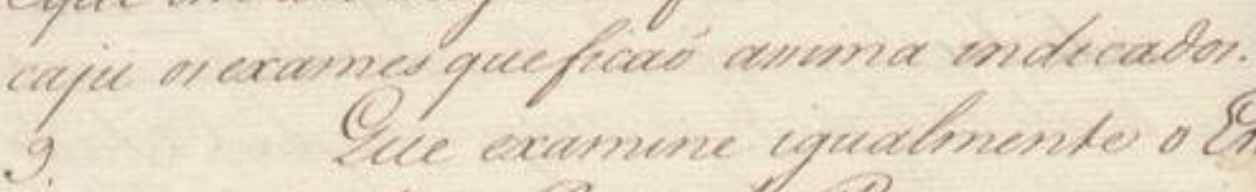

(c) iguedenente a 8

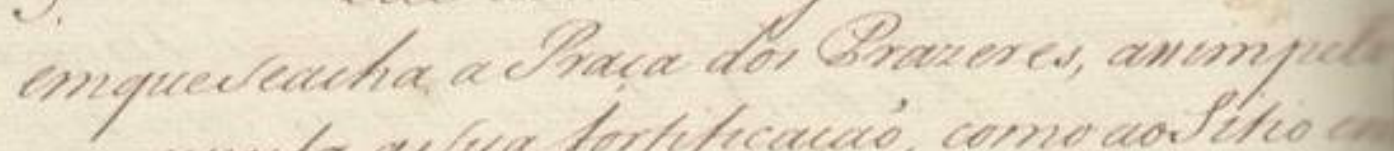

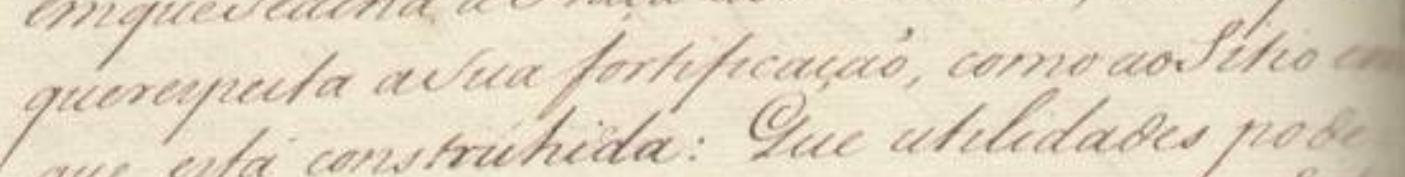
que eita contrutuda: Cue utilidaded pode

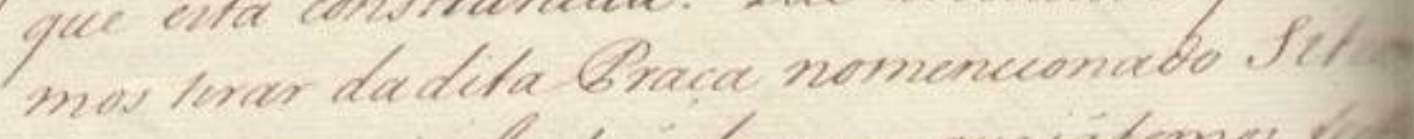
ere vena equevalented deysera quejutomor pas

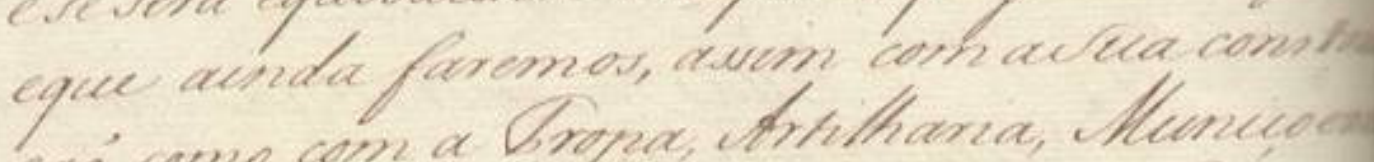

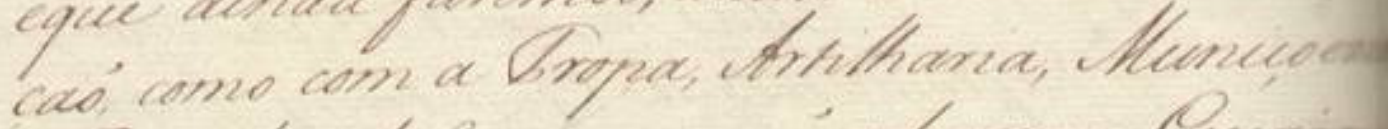

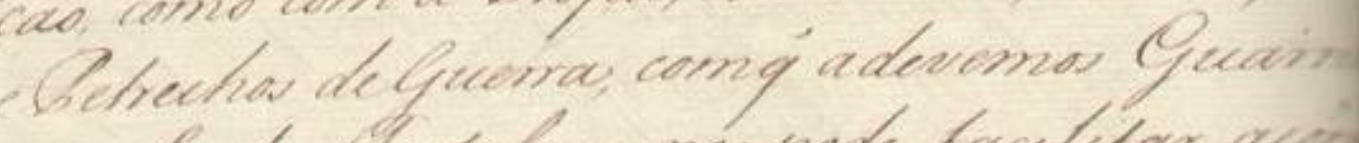

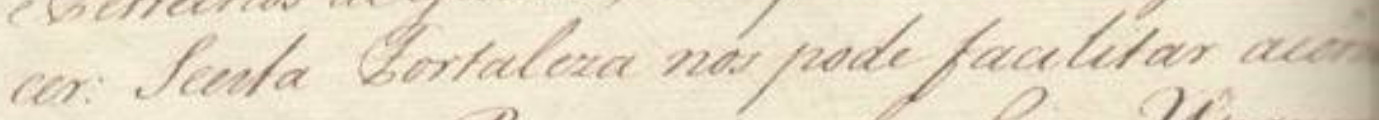

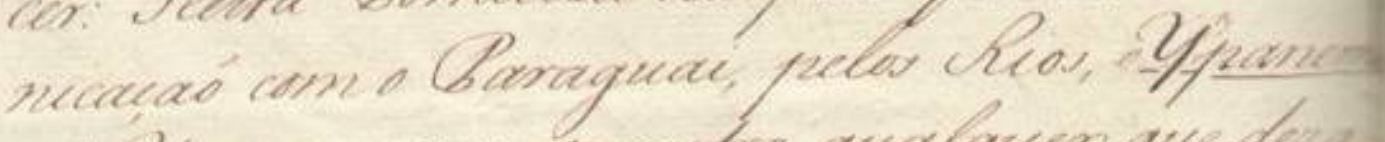

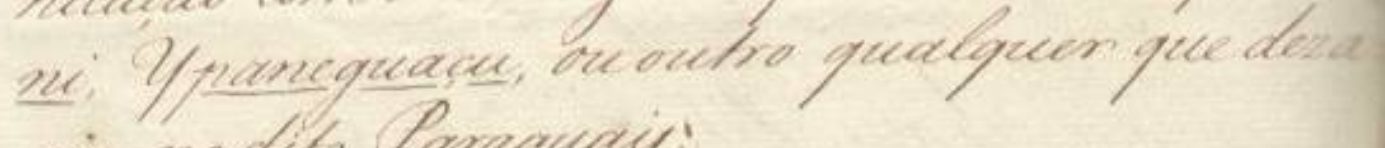
yiu no dito Samaraaij:

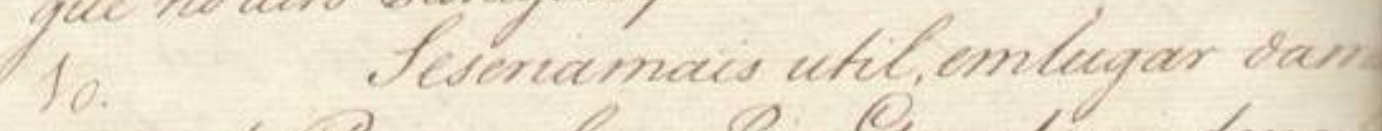

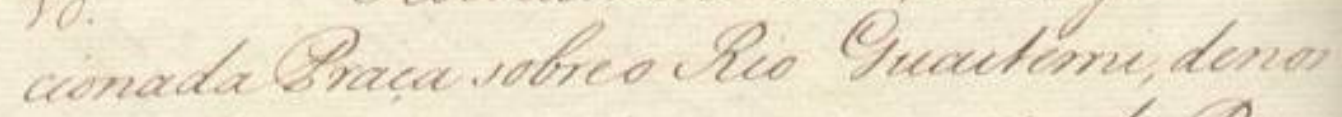
concentrar mos maen para aparte do bavar

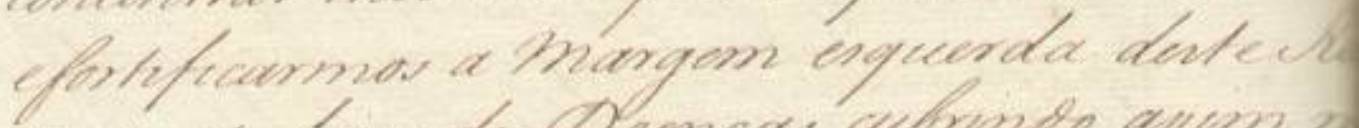

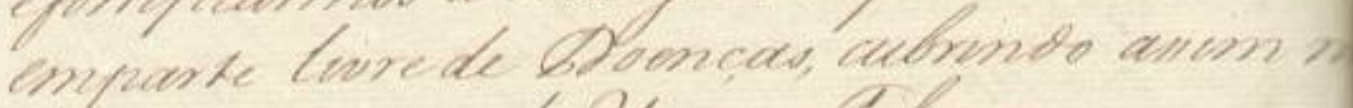

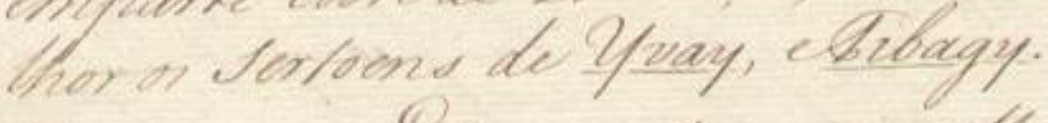

11.

Stas, eoutres temethantes odies veceend vas endisfremsavelinente necenareas antes yue ontremos no enzpenter, defortefer

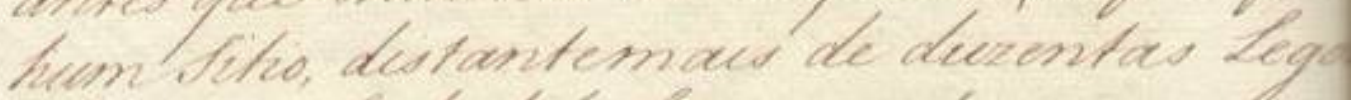
da enpital de dificil accerro, edegrande defper

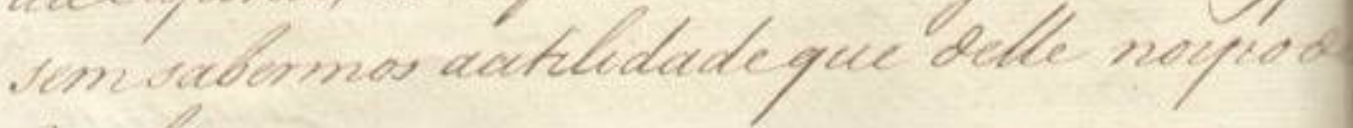
Zualtiar.

12. B.S Liplomi 
||144V\| l[tque]J em alı chegando tassa naserra do IVIara= caju os exames queficaõ assima indicados.

8. Que examine igualmente o Estado emqueseacha a Praça dos Prazeres, assimpelo querespeita aSuafortificaçaõ, como aoSitio em que está construhida: Que utilidades pode= mos tirar da dita Praça nomencionado Sitio ese será equivalente á despeza, quejátemos feito eque ainda faremos, assim com aSua constru= çaõ, como com a Tropa, Artilharia, Muniçoens ePetrechos deGuerra, comque a devemos Guarne= cer: Seesta Fortaleza nos pode facilitar acamunicaçaõ com o Paraguai, pelos Rios, Ypane ni, Ypaneguaçu, ou outro qualquer que deza= gue no dito Paraguay.

9. Seseriamais util, emlugar damen-

165 cionadaPraça sobreo Rio Guaitemi denos concentrar mos mais para aparte do Parana efortificarmos a Margem esquerda deste Rio emparte livre de Doenças, cubrindo assim me Ihor os Sertoens de Yvay, eTibagy.

170 10. Estas, eoutras similhantes observaçoens saõ indispensavelmente necessarias antes que entremos no empenho, defortificar humSitio, distantemais de duzentas Legoas daCapital; de dificil accesso, edegrande des[pesa] semsabermos autilidadeque delle nospode rezultar. 
12. U vopturadores que $y$ pinandou

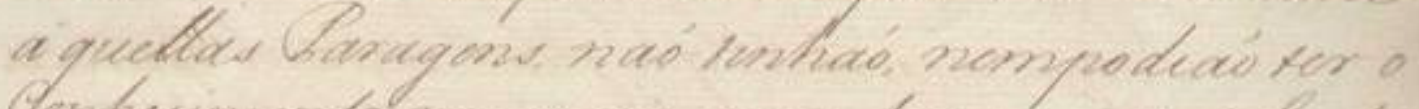
Conhecimento mecauare, from faroven os Sobredeto

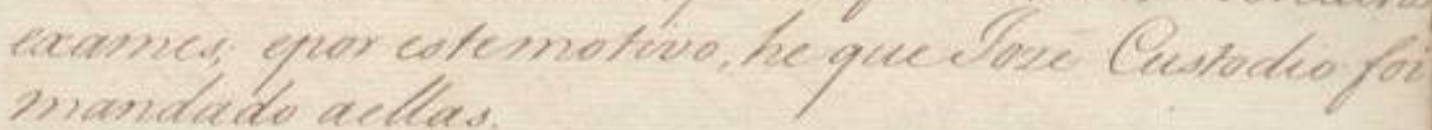

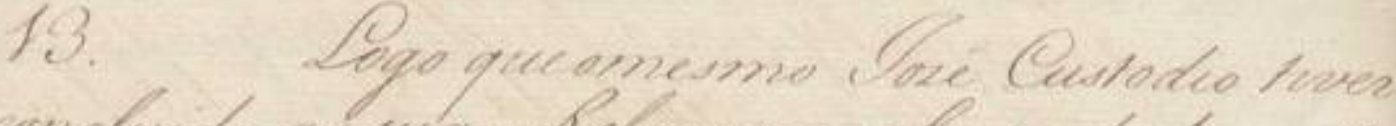
conclude as sues Relaceons, vobre cata hum Dos offectos asuma indecados, us deve Y.T, sem al yuma penda detonye remetor acita fearda na de Litado, wem adeantar, nem freser cound

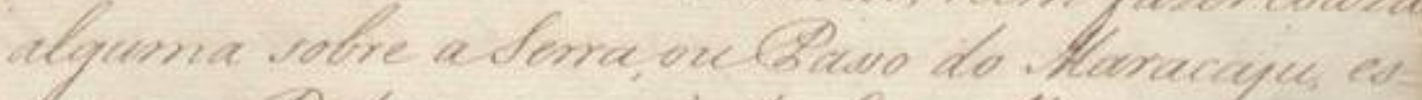
fenar a Betermenuscai de fuer. Hageslede, ares

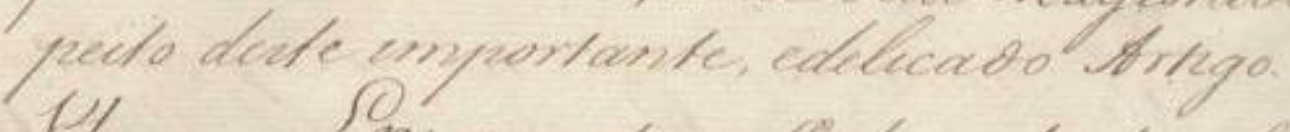

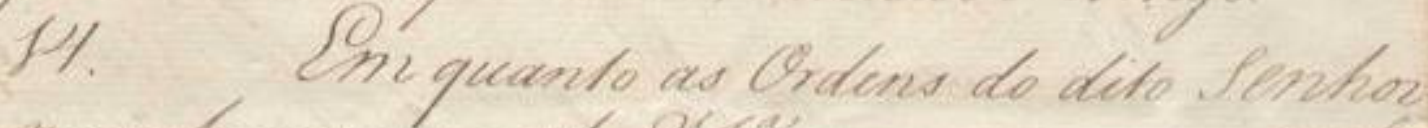

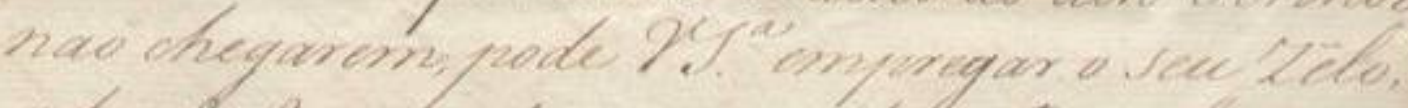

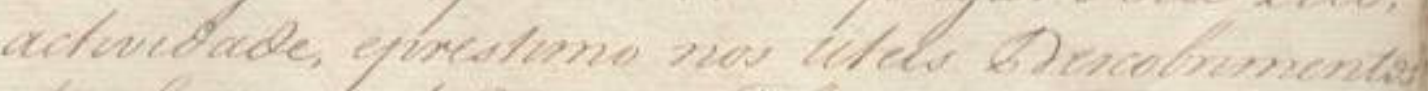

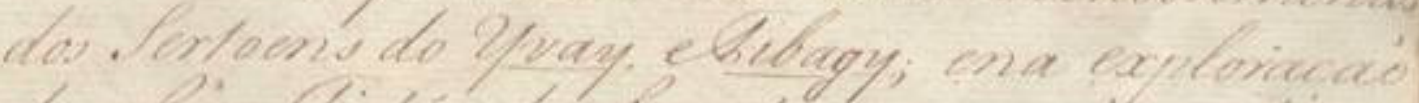

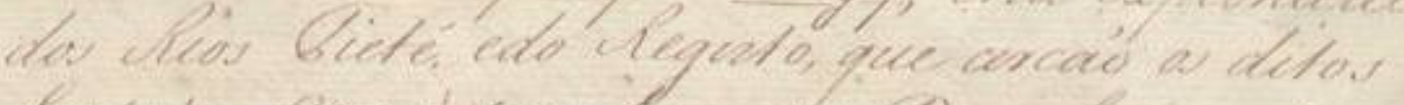

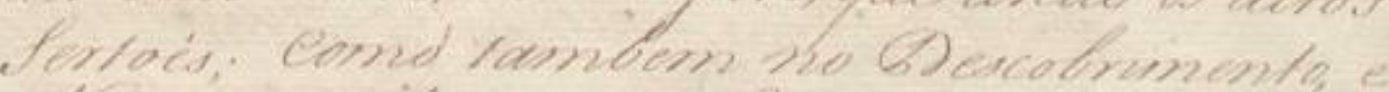

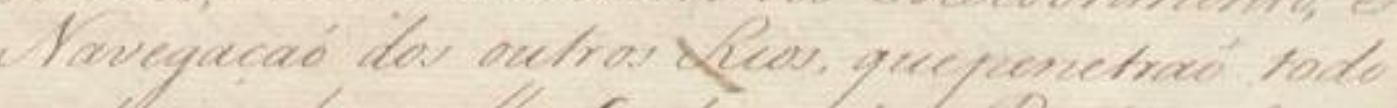

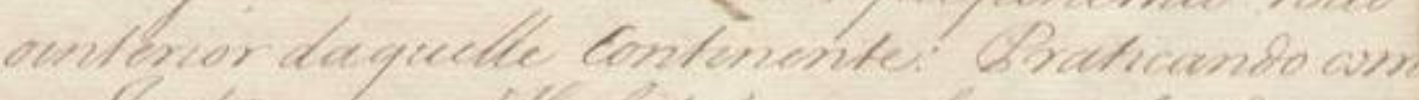

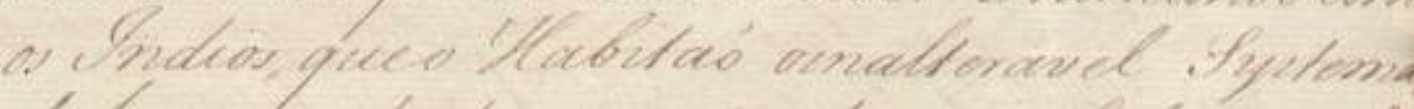

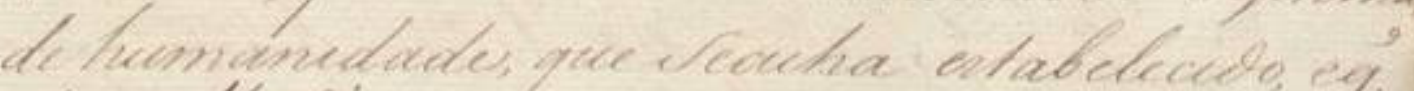

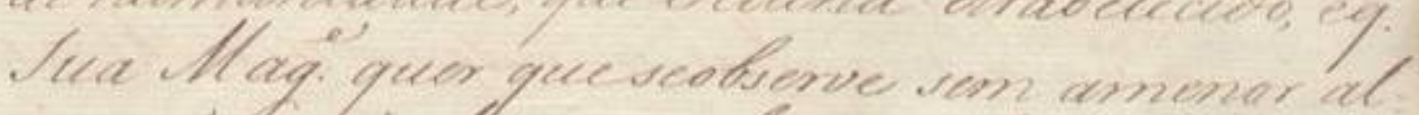
reracas, nhes alstante alquma berbandade of

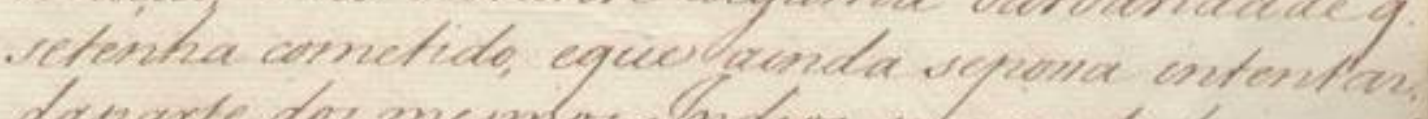
dapurte dos musmos madeos plur quetodas veeni

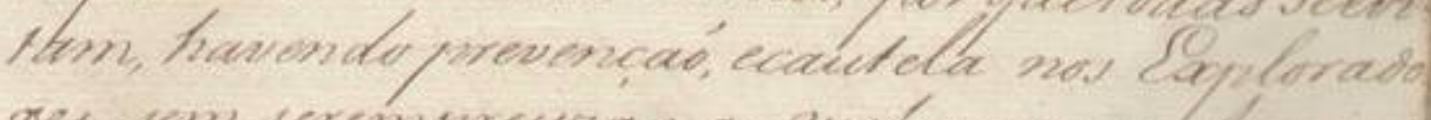

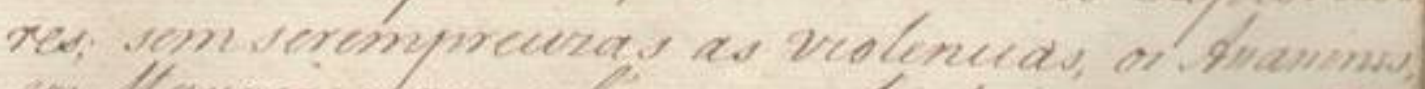

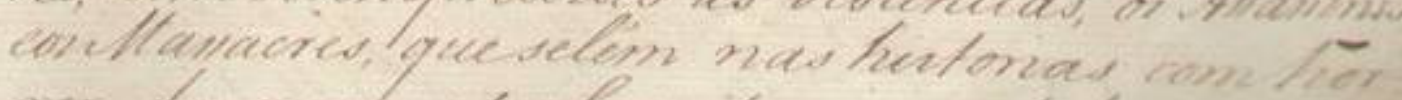
nox: dos qual efon Capetanea naś he 
11. $\|145 r\| \mid$ [[Os Exploradores]], que VossaSenhoria mandou

á quellas Paragens, naõ tinhaõ, nempodiaõ ter o

Conhecimento necessario, para fazerem os sobreditos

exames; epor estemotivo, he que lozé Custodio foi mandado aellas.

12. Logo queomesmo lozé Custodio tiver concluido as suas Relaçoens sobre cadahum dos

185 objectos assima indicadas, as deve VossaSenhoria, sem al= guma perda detempo, remeter aesta Secreta= ria de Estado; esem adiantar, nem fazer couza alguma sobre aSerra, ouPasso do Maracaju, es= perar aDeterminaçaõ deSua Magestade, ares=

190 peito deste importante, edelicado Artigo.

13. Em quanto as Ordens do dito Senhor nao chegarem, pode VossaSenhoria empregar o seu Zelo, actividade, eprestimo nos uteis Descobrimentos dos Sertoens do Yvay, eTibagy; ena exploraçaõ dos Rios Tieté, edo Registo, que cercaõ os ditos Sertoẽs; Como tambem no Descobrimento, e Navegaçaõ dos outros Rios, quepenetraõ todo ointerior daquelle Continente: Praticando com os Indios, queo Habitaõ oinalteravel Systema 200 de humanidade, que Seacha estabelecido, eque Sua Magestade quer queseobserve sem amenor $\mathrm{al}=$ teraçaõ naõ obstante alguma barbaridadeque setenha cometido, eque ainda seprossa intentar, daparte dos mesmos Indios; por quetodas seevi= 205 tam, havendo prevençaõ, ecautela nos Explorado= res; sem seremprecizas as violencias, os Assassinos, eosMassacres, queselém nas historias com hor= ror; dos quaes essaCapitania naõ hé amais 
ander momente.

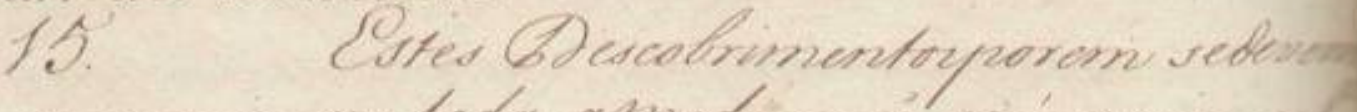
prouguer contoda anmoderacea, cecómomea, al culandare rempre ad faculataded desar Colones

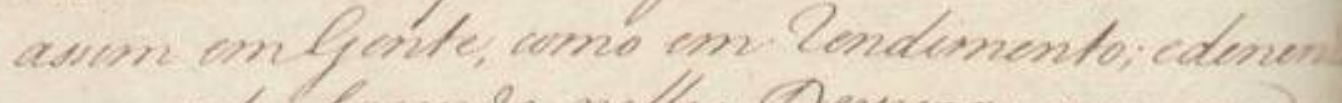

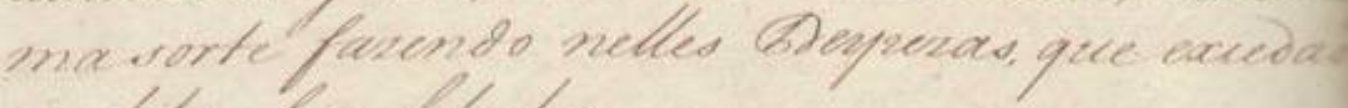
as detas frecelatudes.

16.

(Q) Chepourcoend. Heltares he sobre as socomos, que senpere devetorpromptos, para mandar deo ver Grande dedas beoro, quando Heyforem Requen des

1\%.

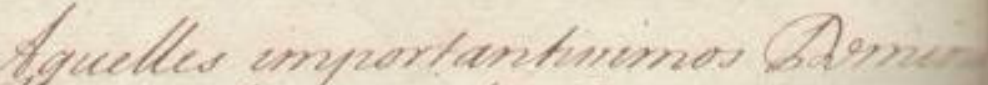

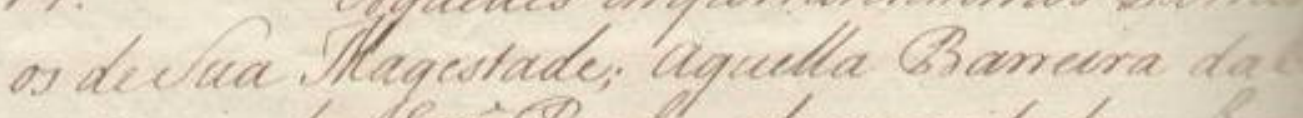
putanca de Swo Baulo, edequaritodo o sno

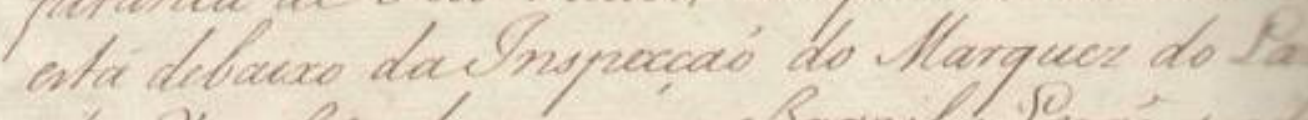

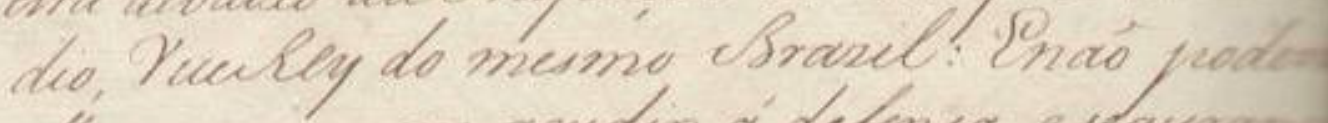
clle occomer, nem acuden d' defonsa, esequennas

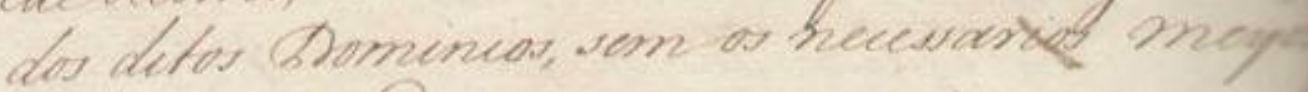

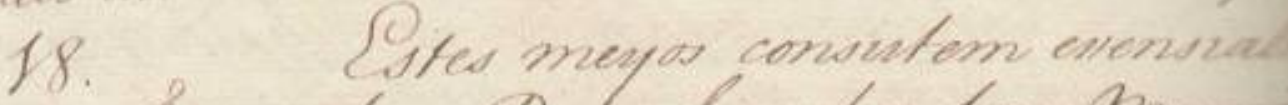

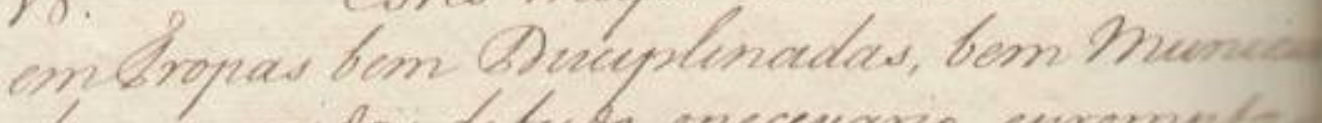
das, jumidas detubo necenaro, emomplas

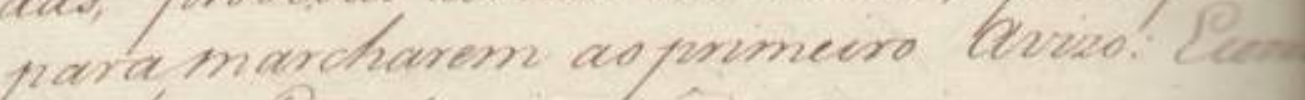
as dena Caputmea wo des maid propmas tever qualidade, eas mas innediatas fot

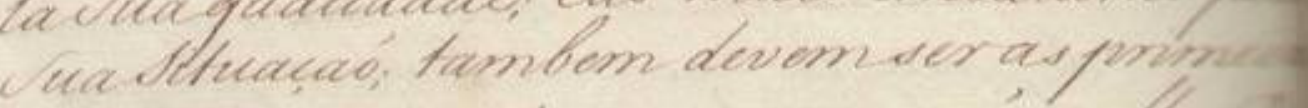
cas mace firomptas, apairarem áquelles bt inctor toglo que for necesuario.

19

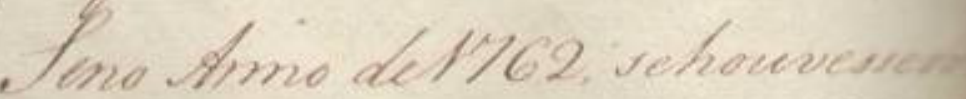

lomet 
||145v\|| [[amais]] innocente.

21015 Estes Descobrimentosporem sedevem

proceguir comtoda amoderaçaõ, eecónomia, cal-

culando-se sempre as faculdades dessa Colonia

assim emGente, como em rendimento; edenenhu=

masorte fazendo nelles Despezas, que excedaõ

215 as ditas faculdades.

16. Omayor, eomais importanteobjecto

emque VossaSenhoria deveempregar todo o seu Cuidado, e

Disposiçoens Militares he sobre os socorros, que

sempre deveter promptos, para mandar ao Rio

220 Grande deSaõ Pedro, quando Iheforem requeridos.

17. Aquelles importantissimos Domini-

os deSua Magestade; Aquella Barreira da [Ca-]

pitania deSaõ Paulo; edequazitodo o [Brazil]

está debaixo dalnspecçaõ do Marquez do Lavra

dio, ViceRey do mesmo Brazil: Enaõ podem [a]

elleoccorrer, nem acudir á defensa, esegurança

dos ditos Dominios, sem os necessarios meyos

18. Estes meyos consistem essensialmente

230 emTropas bem Disciplinadas, bem muni[cia]

das, providas detudo onecessario, epromptas

paramarcharem ao primeiro avizo: Ecomo

as dessaCapitania saõ as mais proprias, [pe]

laSuaqualidade; eas mais ĩmediatas [que]

235 Suasituaçaõ; tambem devemseras primeiras

eas mais promptas, apassarem áquelles des-

trictos logo quefor necessario.

19 Seno Anno de1762, sehouvessem | tomado 


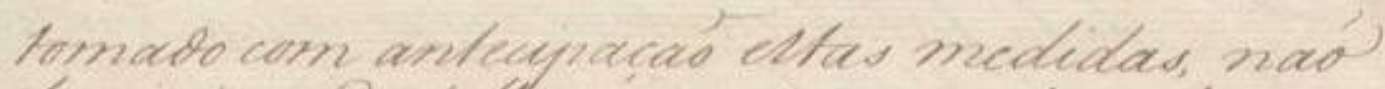

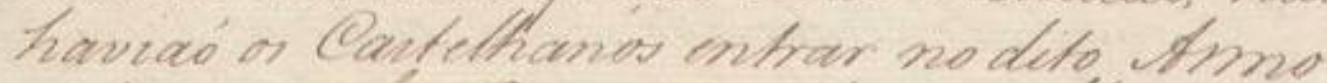
de1762, peos 60 menvos de fua Magestade,

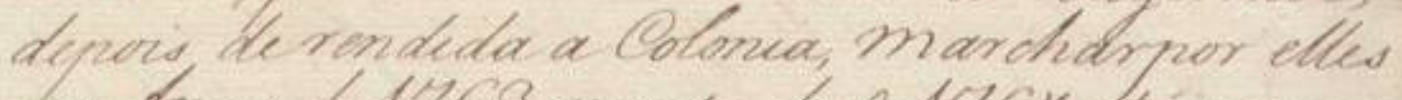

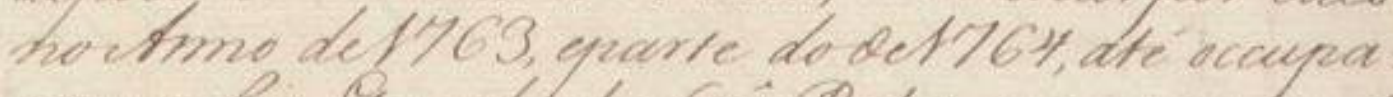

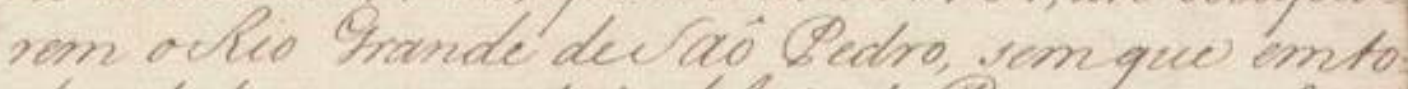

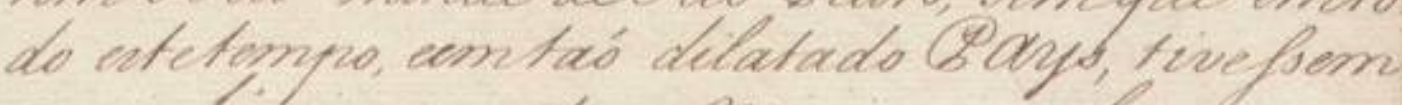
ondes liquero encontro, o Pneweino encharde, ex

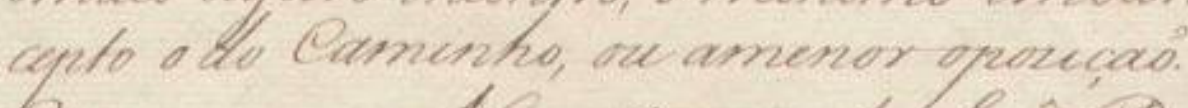

20.

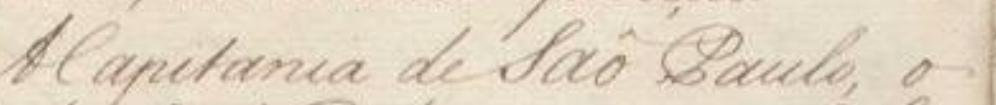

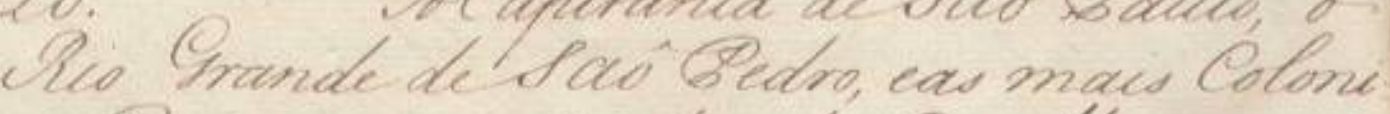

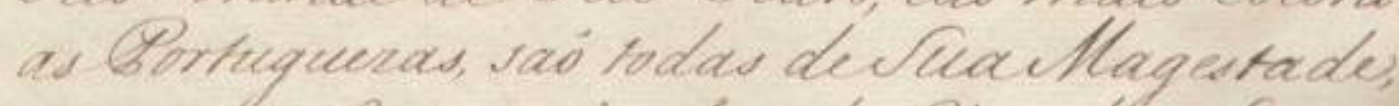

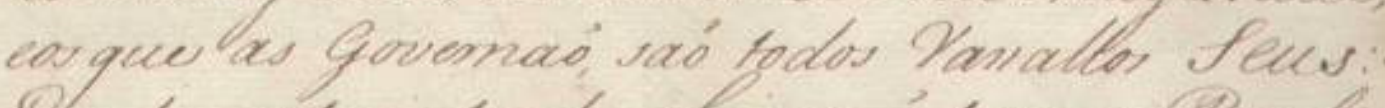

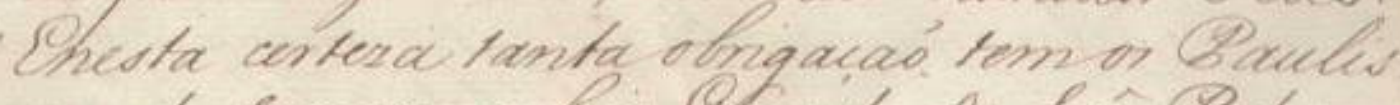
tas de focomer oveo grande de fâ bedre

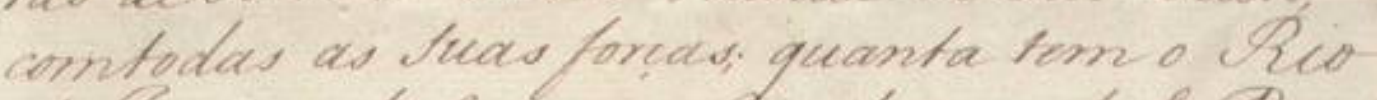

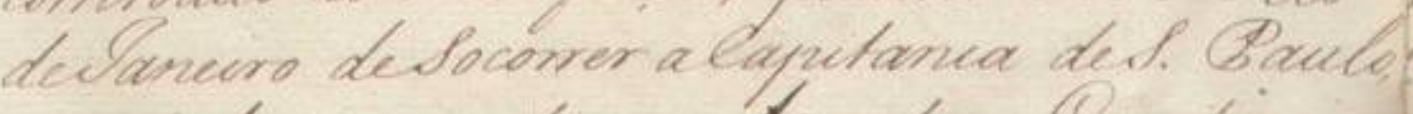
con todas as guetiver: Is outras Capetinuas

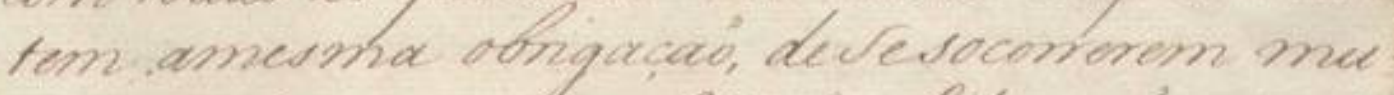

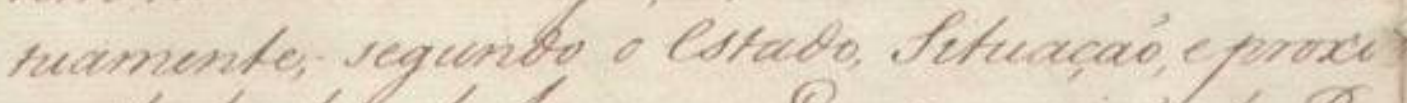
medade decadahuma. Souta unias de Pa: der heque converte cremsialmente toda. a forca

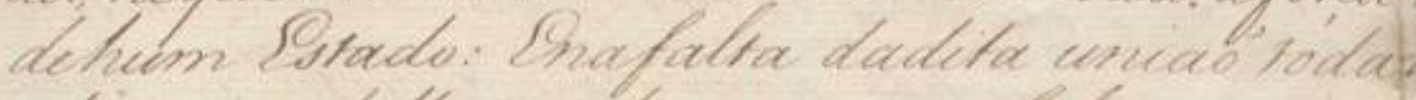

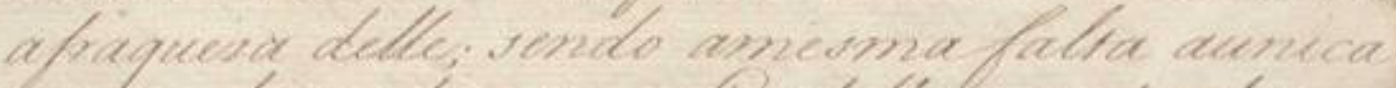

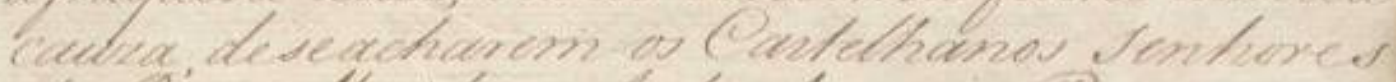

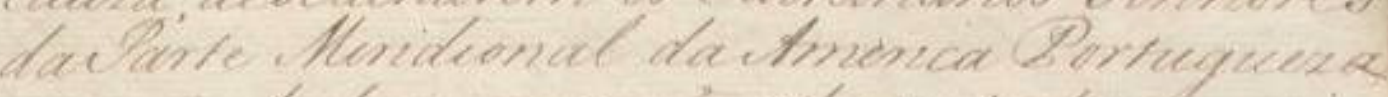

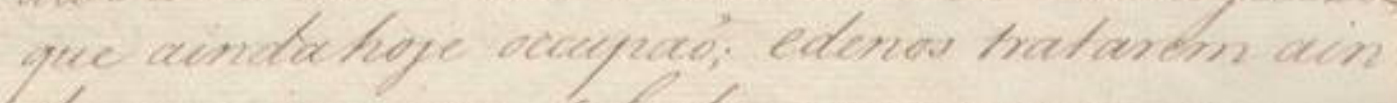

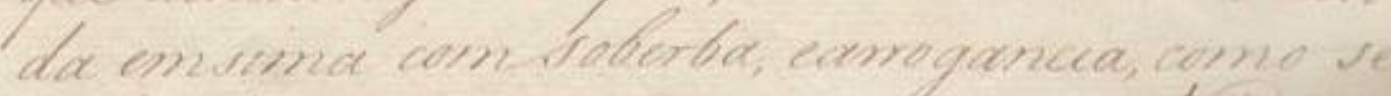

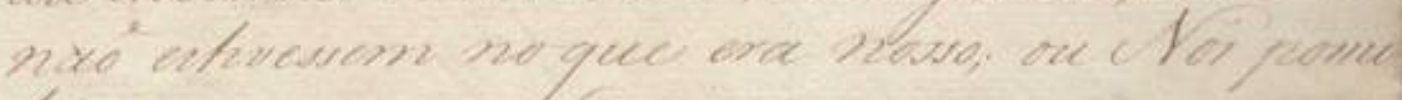
hevenos aque ena bee.

21.

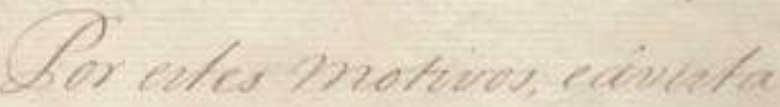


240 || 146r|| [ltomado]] com antecıpaçao estas medıdas, nao

haviaõ os Castelhanos entrar no dito Anno

de1762, pelos Dominios deSua Magestade, depois derendida a Colonia, Marcharpor elles no Anno de1763, eparte do de1764, até occupa= rem oRio Grande deSaõ Pedro, semque emto= do estetempo, eemtaõ dilatado Pays, tivessem omais ligeiro encontro, o Minimo embaraço, ex= cepto o do Caminho, ou amenor opoziçaõ.

20 ACapitania deSaõ Paulo, o

250 Rio Grande deSaõ Pedro, eas mais Coloni= asPortuguezas, saõ todas deSuaMagestade, eos que as Governaõ, saõ todos Vassallos Seus: Enesta certeza tanta obrigaçaõ tem os Paulis= tas deSocorrer o Rio Grande deSaõ Pedro,

255 comtodas as suas forças; quanta tem o Rio delaneiro desocorrer aCapitania deSaõ Paulo, com todas as quetiver: As outras Capitanias tem amesma obrigaçaõ, de Sesocorrerem mu= tuamente; segundo o estado, Situaçaõ, e proxi= midade decadahuma: Enesta uniaõ dePo= der heque consiste essensialmente toda aforça dehum Estado: Enafalta dadita uniaõ toda afraqueza delle; sendo amesma fatalta aunica cauza, deseacharem os Castelhanos Senhores daParte Meridional daAmerica Portugueza que ainda hoje occupaõ; edenos tratarem ain= da emsima comsoberba, earrogancia, como se naõ estivessem no que era nosso; ou Nós possu= hissemos, o que era Seu. 
$\|146 \mathrm{v}\|$

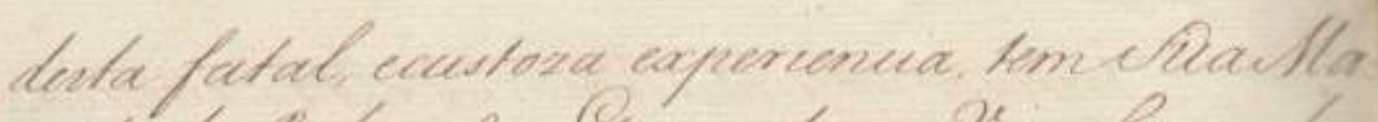

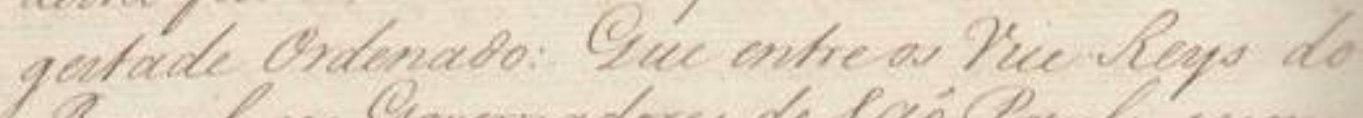
Brazel eos Oovemadores de facó Bceato secone nha, eavente nos soconos efecturos, que em hade? coutra parte has de atat sempre firomplos, para marcharem ao vico Chantec de f. Pes togo que for omprecisos.

C Stae Ordens tem sedo deniquas as:

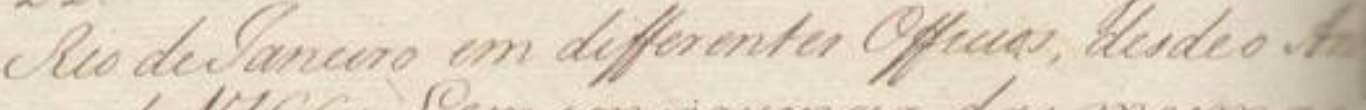
no de IIV6: Cem consequenaed das mesmas ortens, for fua tlagbutade servedo que eeves esorevenc a Difo oquecosusta do Qffuce of the derigi con dabta do f. de Cutubro do ctrme

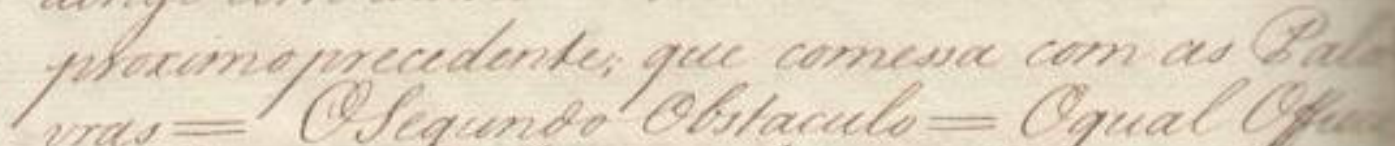

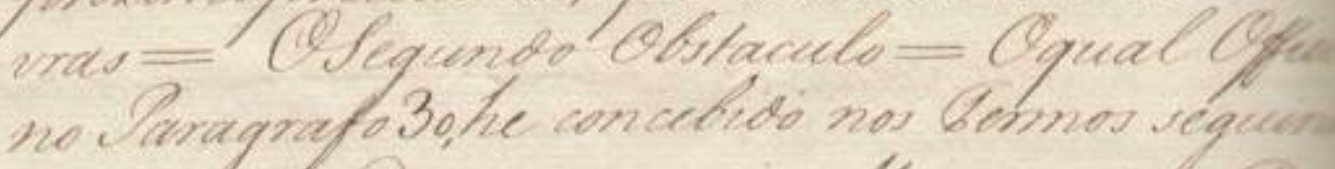
23." Oono prorem os thoumentos, eling "Tos der mesmos Castelhanos nas so sefarem

" Fir da Garte do Panmai, mas tambem das te des Puenos Sypres, edo thaquay. dove 99

"som fazer grande Quede mandar ter proms. iss dows butres Regumentos dectuxilines - Cunitiba, para ocaus deverpreciso panarem a a

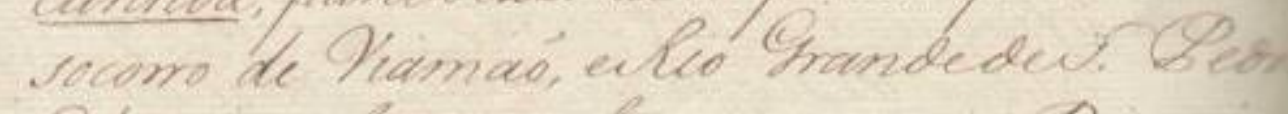
Edwerqualmente fazer as mases binposies - que thendicaree nac Sequente Oarla. 24.

A Carta deque fallaxo Banagrate precedente he ado. Atos. que comena fuelas 8

- Tarras= tendo preventes a Sua M llagertas

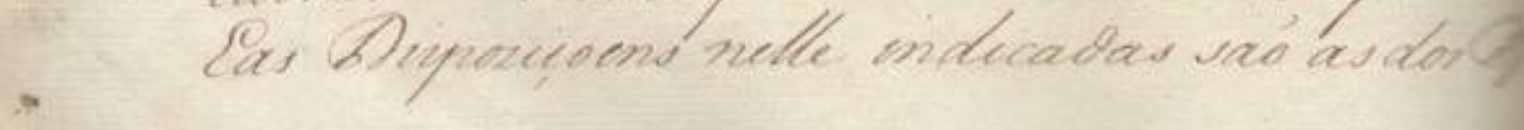

467 
||146v || [[desta]] fatal, ecustoza experiencia, temSuaMa=

gestade Ordenado: [espaço] Que entreos Vice Reys do

Brazil, eos Governadores deSaõ Paulo seconve=

nha, eassente nos socorros efectivos, que emhua

eoutra parte haõ de estar sempre promptos,

para marcharem ao Rio Grande deSaõ Pedro, logoqueforemprecizos.

22. Estas Ordens temsido dirigidas ao

Rio delaneiro em differentes Officios, desdeo $\mathrm{An}=$ no de1766: Eem consequencia das mesmas

Ordens, foi Sua Magestade servido, que eu escrevesse a VossaSenhoria, oqueconsta do Officio, que the dirigi com datta do primeiro deOutubro do Anno proximoprecedente; que comessa com as $\mathrm{Pala}=$ vras $=$ OSegundoObstaculo $=$ O qual Officio no Paragrafo 30, he concebido nos Termos seguintes 23. ,, Como porem os Movimentos, ePrepa= ,, ros dos mesmos Castelhanos, naõ so sefazem sen= ,, tir daParte do Paraná; mas tambem da[Par]

290 ,, te deBuenos Ayres, edo Uraguay; deve VossaSenhoria, „, semfazer grande ruido, mandar ter promp,, tos dous, outres Regimentos deAuxiliares em ,, Curitiba, parao cazo deserprecizo passarem ao „, socorro de Viamaõ, eRio GrandedeSaõ Pedro

295 ,, Edeveigualmente fazer as mais Dispoziçoens ,, que Iheincarei naSeguinte Carta.

24. A Carta deque falla o Paragrafo precedente, he ado Numero quarto que comessapelas $\mathrm{Pa}=$ lavras $=$ Sendo prezentes aSua Magestade 


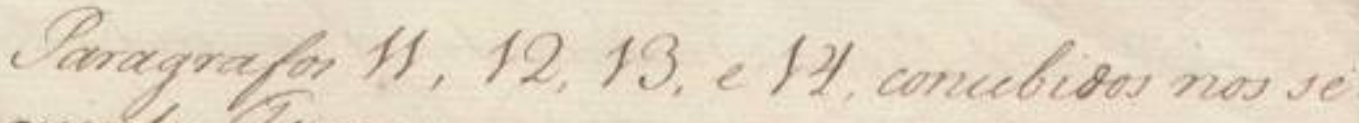
quenter bomos.

25.

CDisportar fior ata

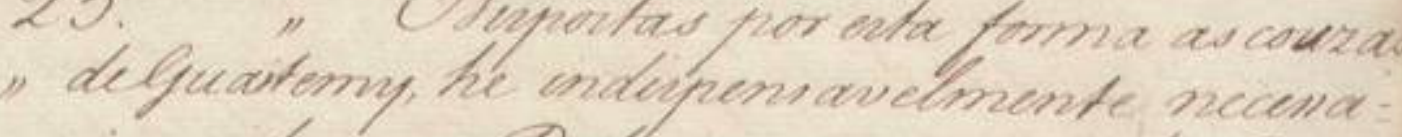

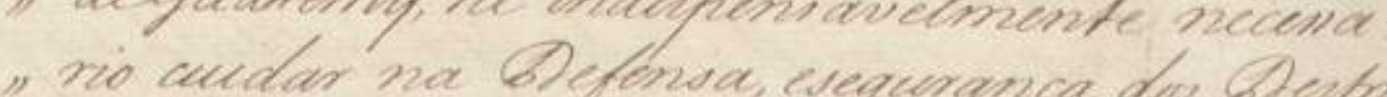

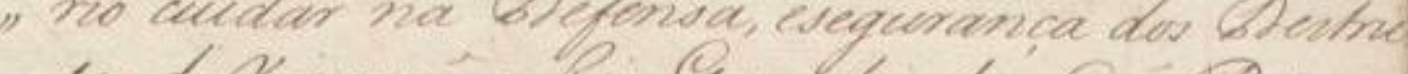

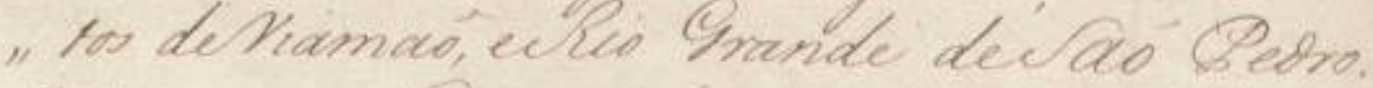
26.

(Conertefin

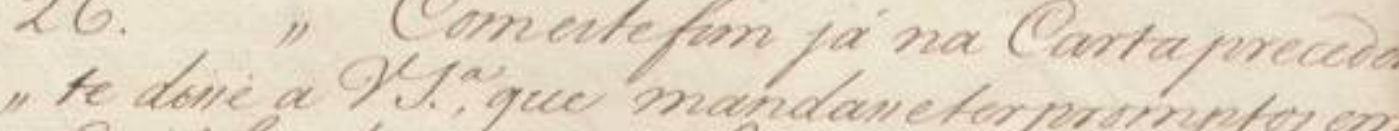

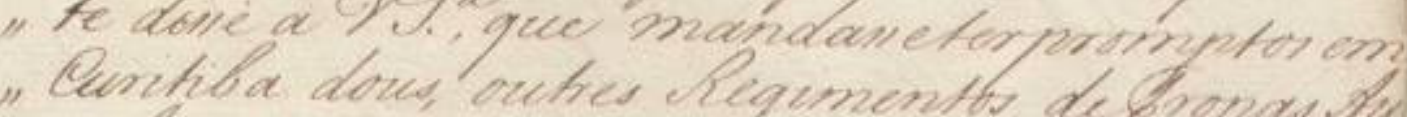
"xiluared, frand ocazo de derprecuso, parmanem do

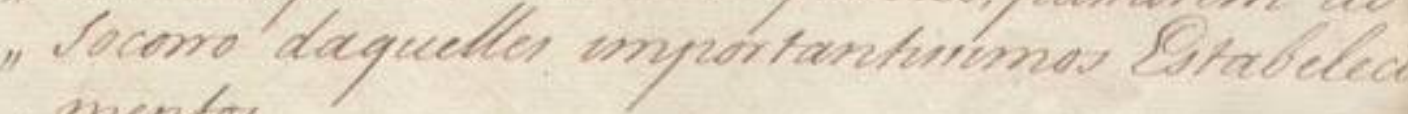
"nentos.

2\%.

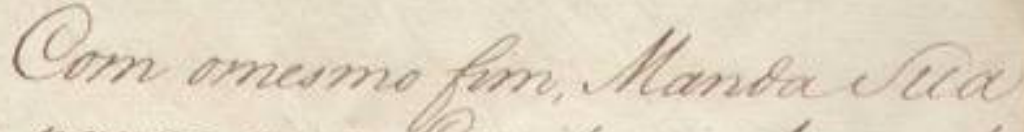
"Nagertade panar rena Capitama hum dos

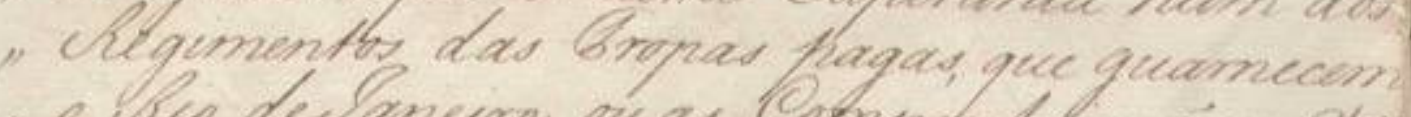

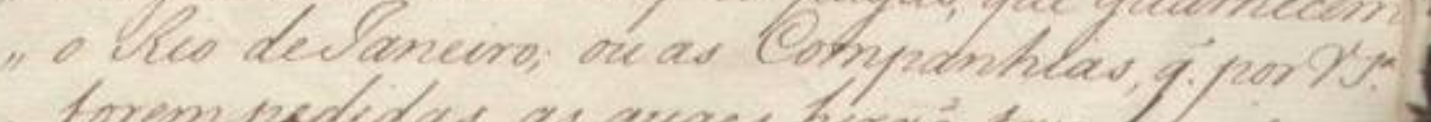

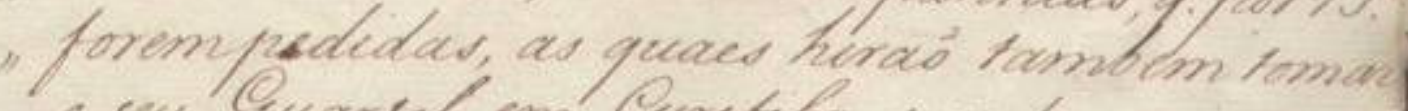

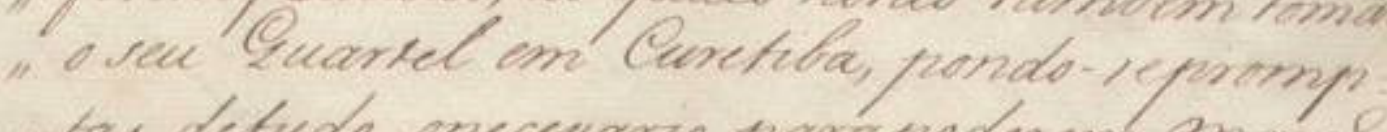

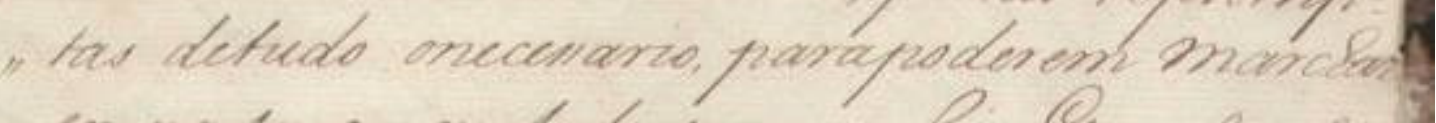
- empartes au entado jara a ver Gmande. de

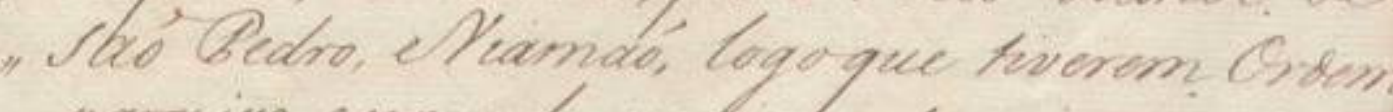

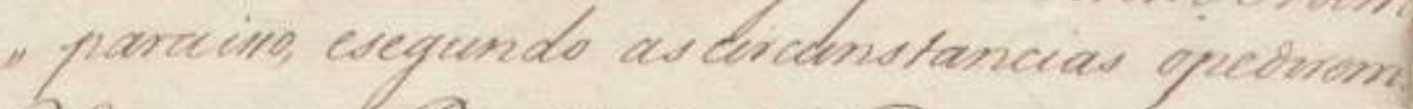
28 Cos Refondos lo 7)

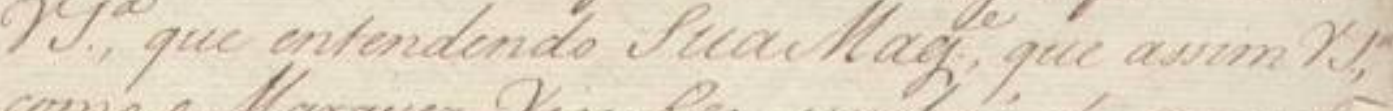

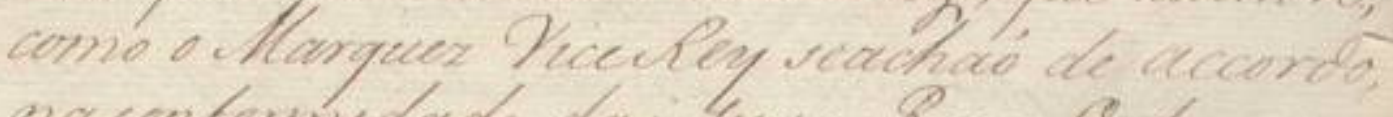

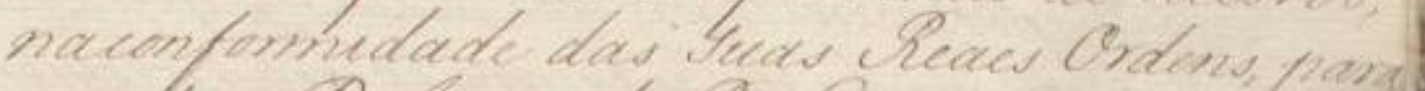

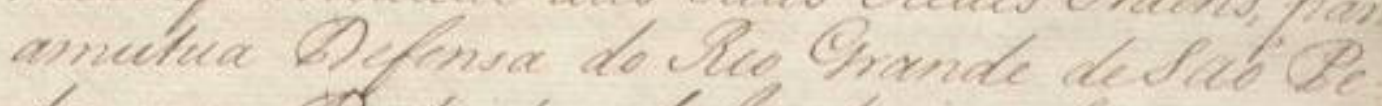

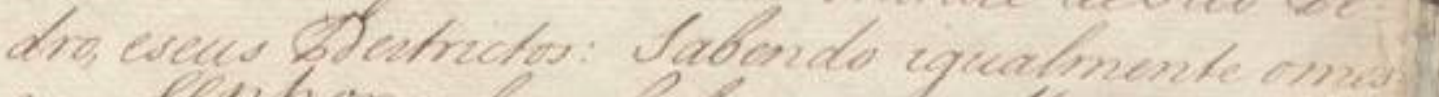

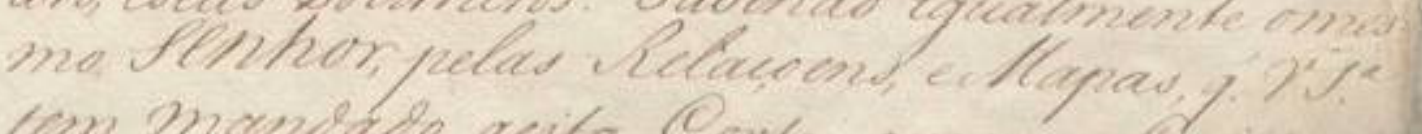

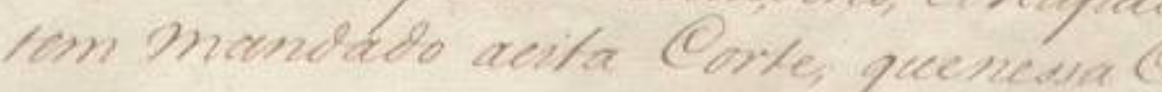


||147r|| [[Par]]agrafos 11, 12, 13, e 14, concebidos nos se=

guintes Termos.

25. ,, Dispostas por esta forma as couzas

,, deGuaitemy, he indispensavelmente necessa=

305

„, rio cuidar na Defensa, esegurança dos Destric-

,, tos deViamaõ, eRio Grande deSaõ Pedro.

26. „, Comestefim já na Carta preceden=

,, te disse a VossaSenhoria, que mandasseterpromptos em

,, Curitiba dous, outres Regulamentos deTropas $\mathrm{Au}$

310 ,, xiliares, parao cazo deser precizo, passarem ao

„, Socorro daquelles importantissimos Estabeleci

,, mentos.

27. ,, Com omesmo fim, MandaSua

„, Magestade passar aessa Capitania hum dos

315 ,, Regimentos das Tropas pagas, que guarnecem

„, o Rio delaneiro; ou as Companhias, que porVossaSenhoria

,, forem pedidas, as quaes hiraõ tambem tomar

,, o seu Quartel em Curitiba, pondo-sepromp=

,, tas detudo onecessario, parapoderem marchar

320 ,, emparte, ou emtodo, para o Rio Grande de

„, Saõ Pedro, eViamaõ, logoque tiverem Ordem

„, para isso, esegundo as circunstancias opedirem

28. Dos referidos Paragrafos verá

VossaSenhoria, que entendendo SuaMagestade, que assim VossaSenhoria,

como o Marquez ViceRey seachaõ de accordo,

naconformidade das suas Reaes Ordens, para

amutua Defensa do Rio Grande deSaõ Pe=

dro, eseus Destrictos: Sabendo igualmente omes=

mo Senhor, pelas Relaçoens, eMapas, que VossaSenhoria

tem mandado aesta Corte, quenessa Capitania | seachaõ 


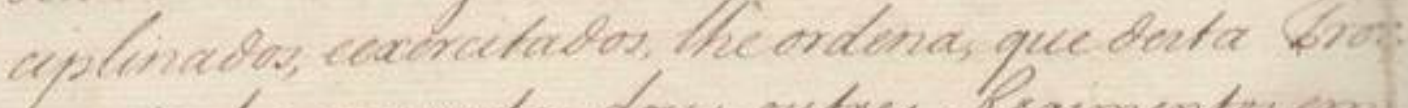

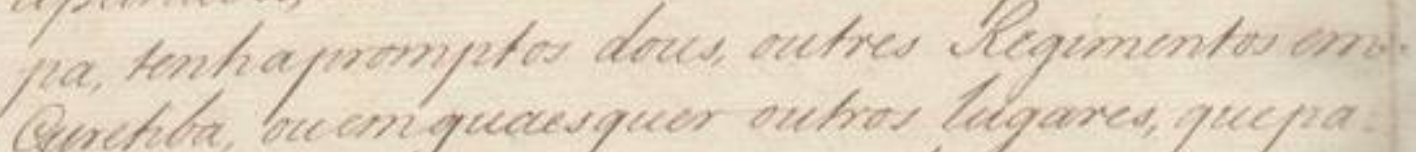

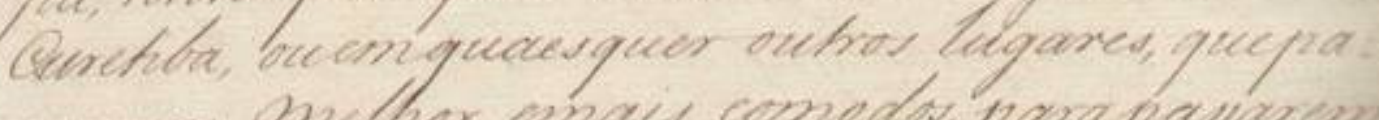

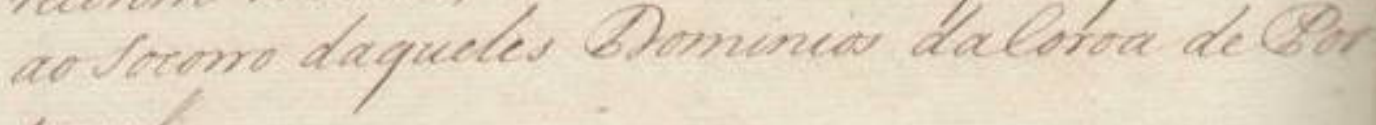
rigal.

29

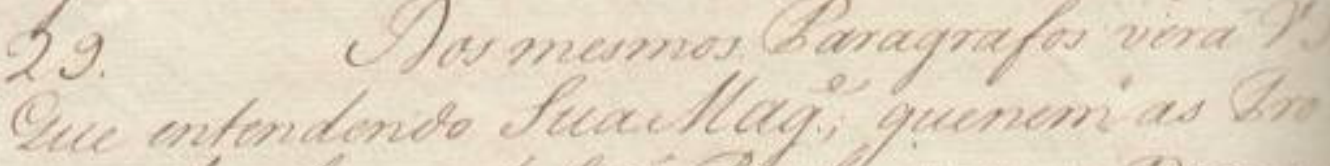

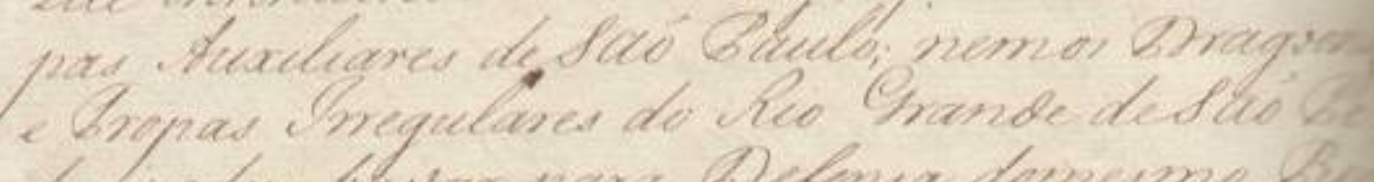

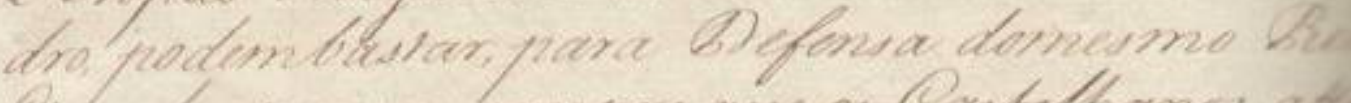

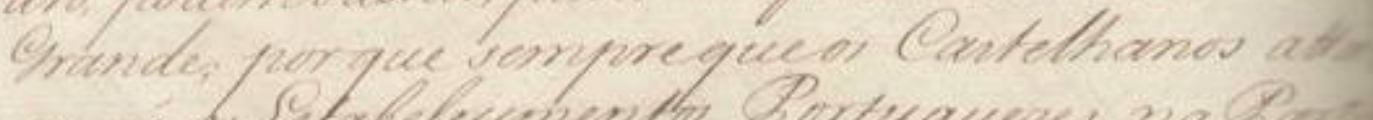

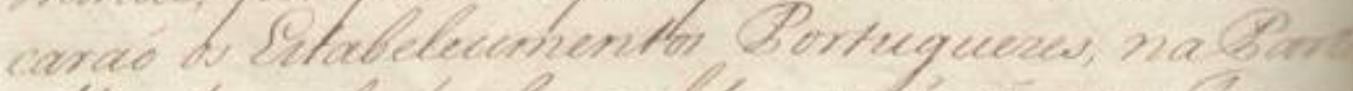

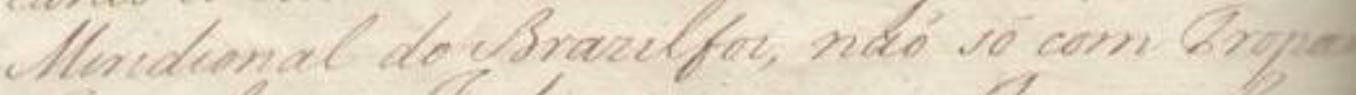

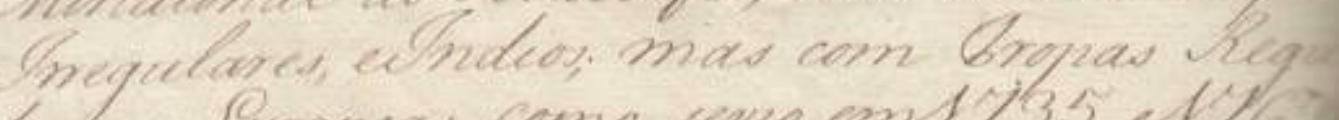

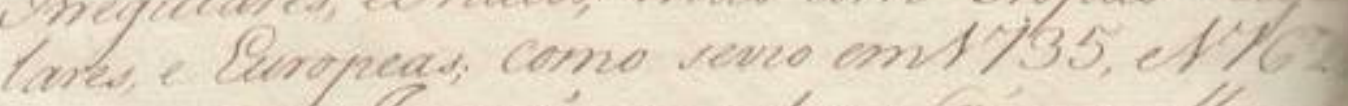

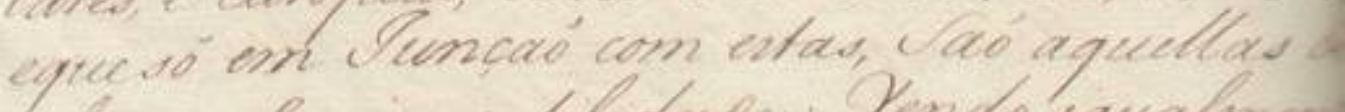

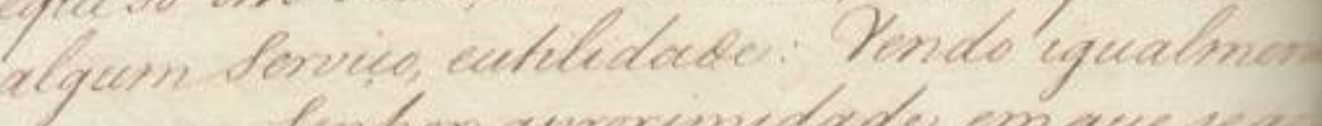

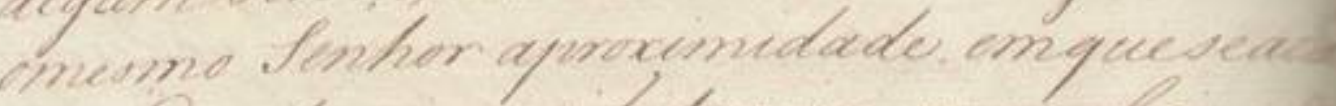

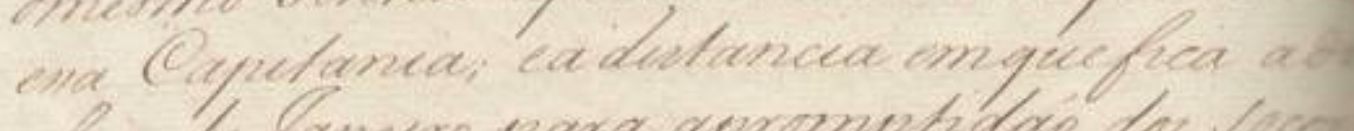

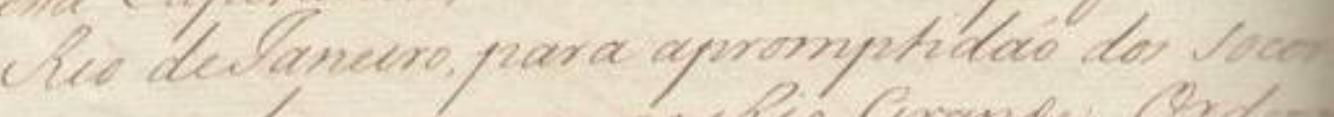

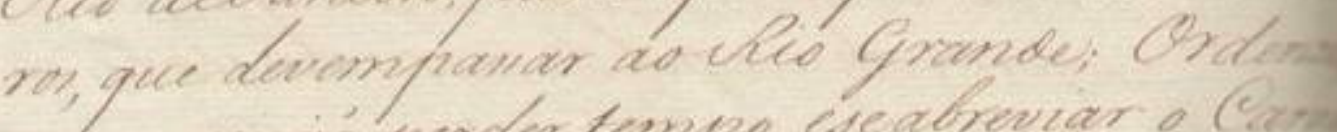

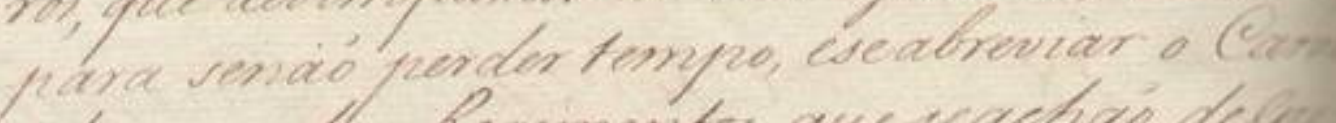

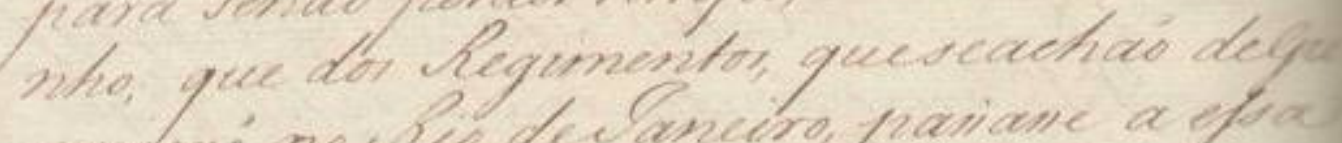

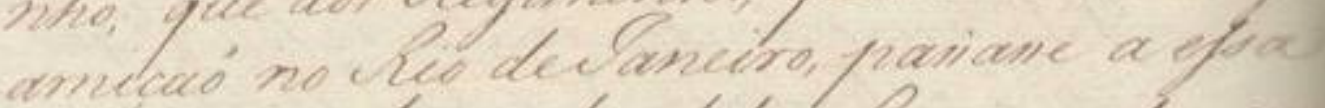

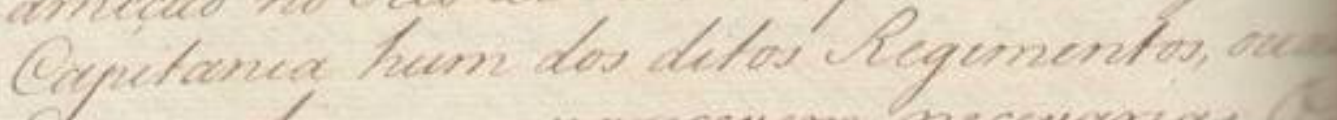

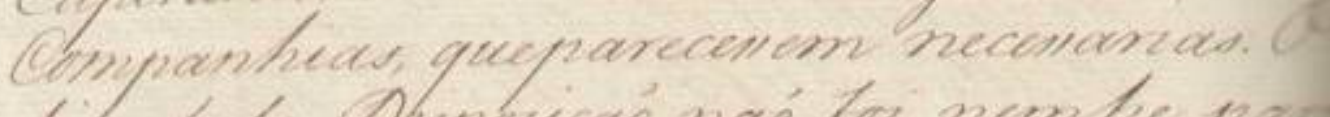
lin duta Arypuiraó naó for nembe par

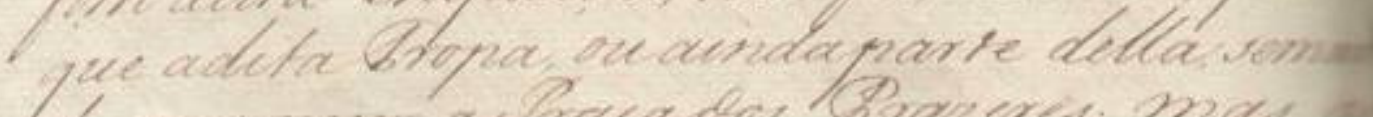

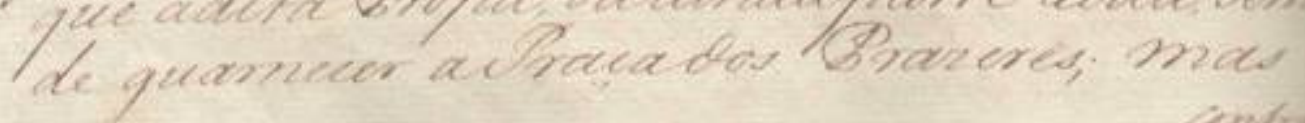
combres 
\|14/V || [Lseachao]] seıs Kegımentos Auxılıares, bem DıS=

ciplinados, eexercitados, Iheordena, quedesta Tro=

pa, tenhapromptos dous, outres Regimentos em

335 Curetiba, ou emquaesquer outros lugares, quepa= recerem Melhor, emais comodos, parapassarem aoSocorro daqueles Dominios daCoroa dePor= tugal.

29. Dos mesmos Paragrafos verá VossaSenhoria

340 Que entendendo SuaMagestade, quenem as Tro= pas Auxiliares deSaõ Paulo; nemos Dragoens e Tropas Irregulares do Rio Grande deSaõ Pe dro, podembastar, para Defensa domesmo Rio Grande; porque semprequeos Castelhanos atta= caraõ os Estabelecimentos Portuguezes, na Parte Meridional doBrazilfoi, naõ só com Tropas Irregulares, elndios; mas com Tropas Regu= lares, e Europeas; como sevio em1735, e1762, equesó em lunçaõ com estas, Saõ aquellas [de]

350 algum serviço, eutilidade: [espaço] Vendo igualmente omesmo Senhor aproximidade emquesecha essa Capitania; ea distancia emquefica ado Rio delaneiro, para apromptidaõ dos Socorros, que devempassar aoRio Grande; Ordena para senaõ perder tempo, eseabreviar o Caminho, que dos Regimentos, queseachaõ deGu= arniçaõ no Rio delaneiro, passasse a essa Capitania hum dos ditos Regimentos, ou[as] Companhias, queparecessem necessarias. 0 360 fim desta Dispoziçaõ, naõ foi, nemhe, para que adita Tropa, ou ainda parte della, semande guarnecer aPraçados Prazeres; mas ao | contrario 


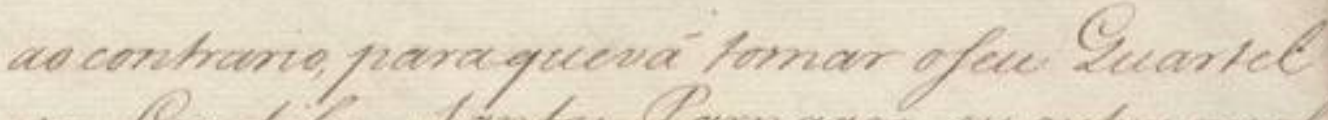

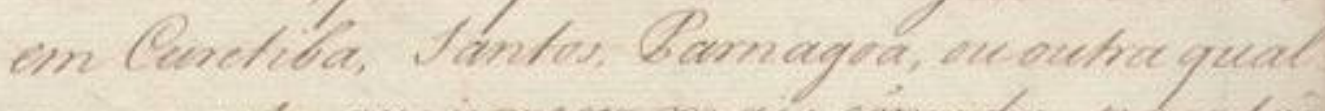

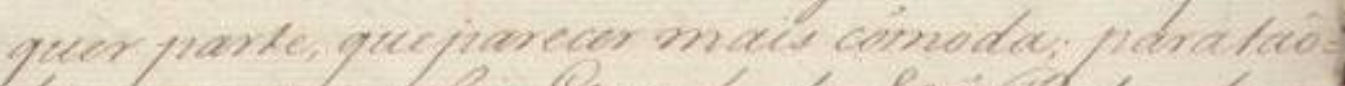

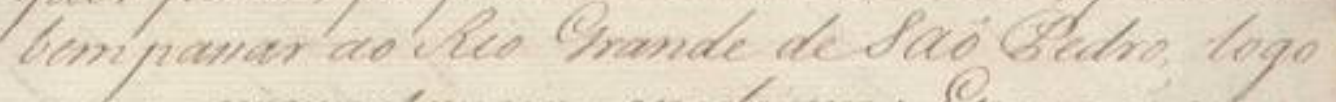

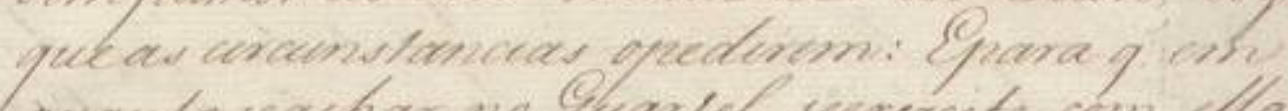

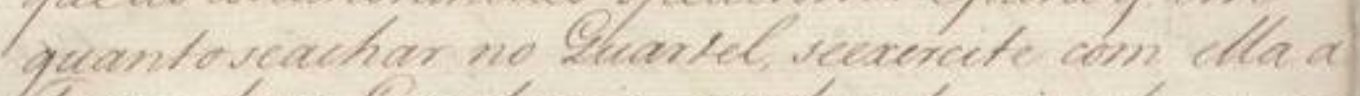

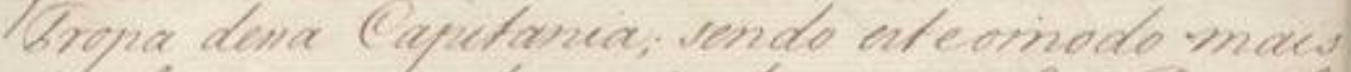

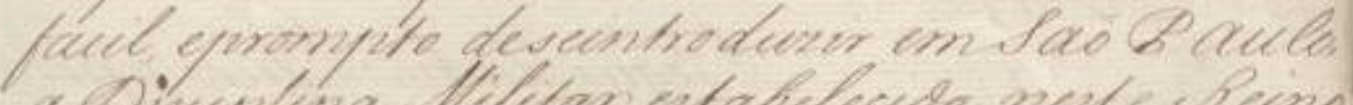

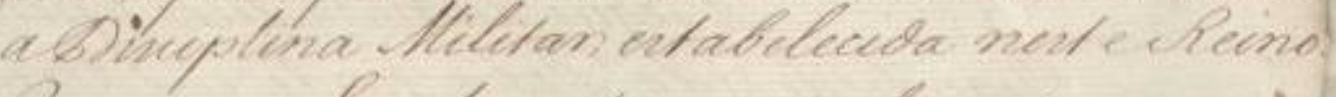

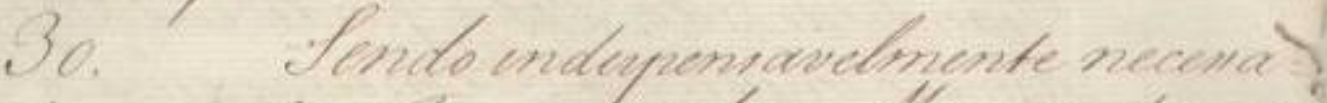

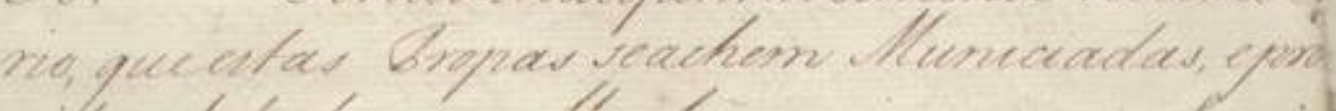

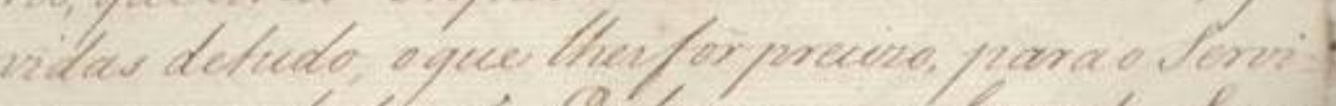

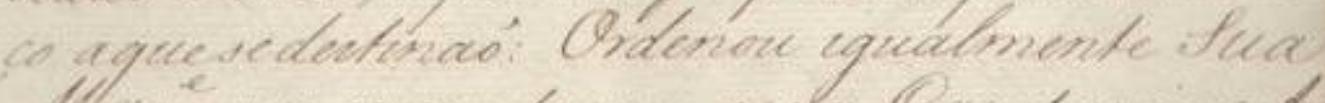

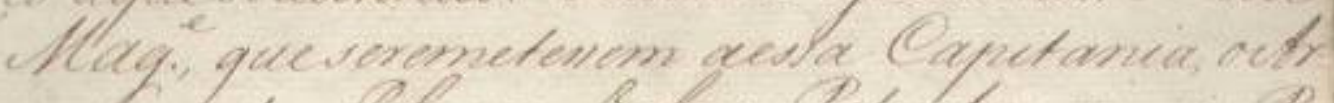

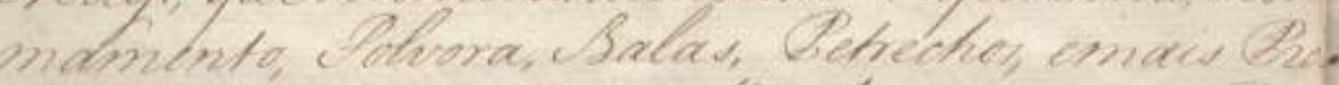

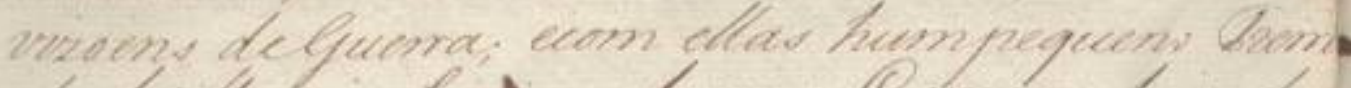

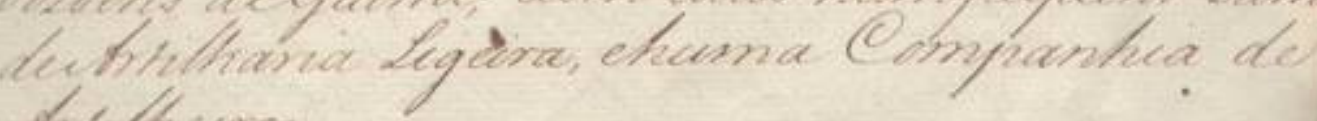
9) teleeros.

31

Betudo oqueficareferide, wera $X$ Ja:

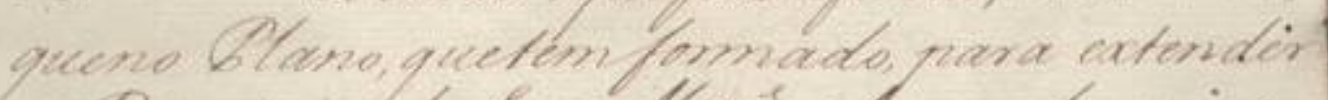

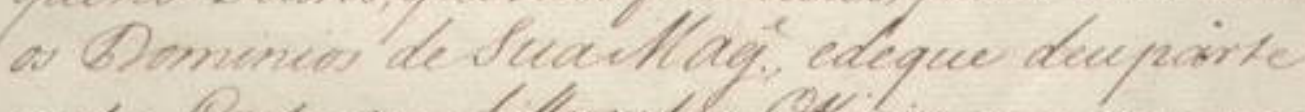

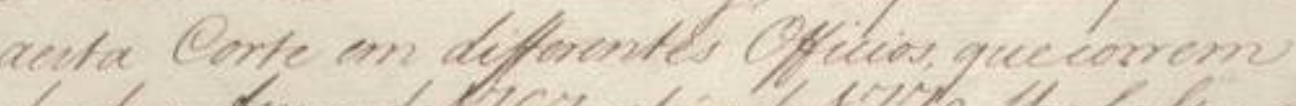

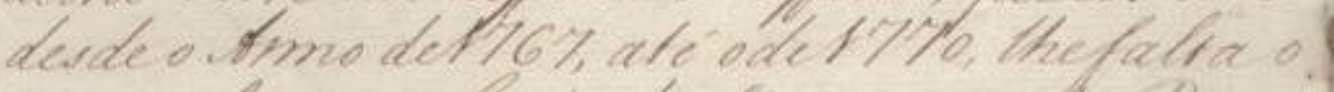

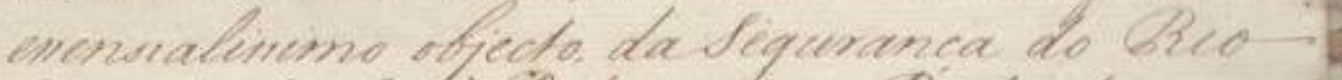

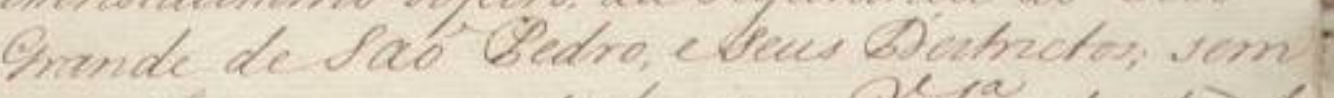

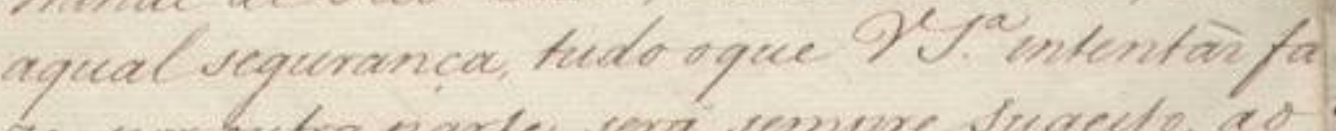

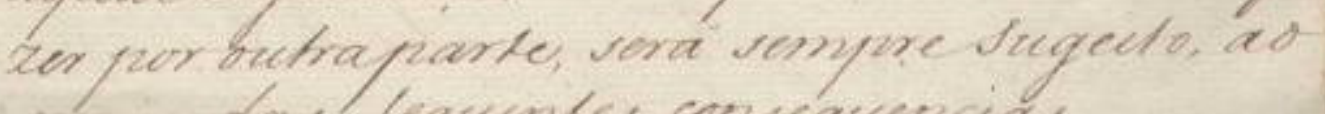

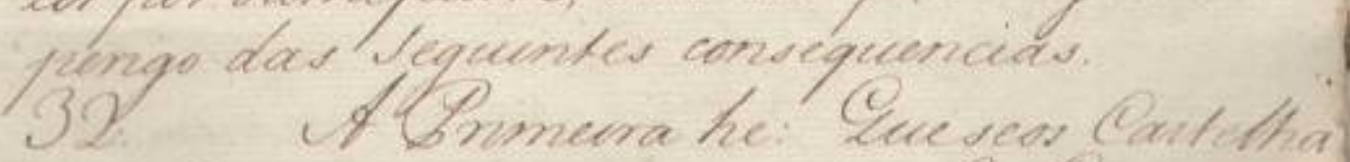

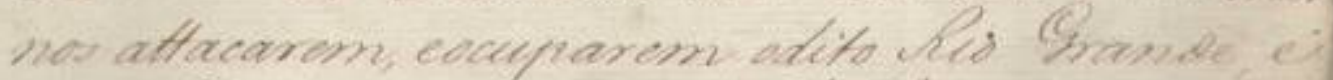

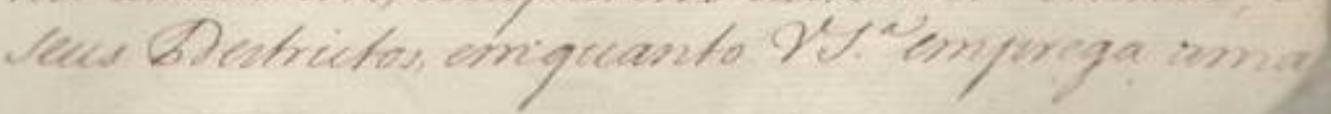


||148r|| [|ao contrarıo]], paraqueva tomar oseu Quartel

em Curetiba, Santos, Paranagoá, ououtra qual= quer parte, queparecer mais cõmoda; parataõ= bempassar ao Rio Grande deSaõ Pedro, logo queas circunstancias opedirem: Epara que em quanto seachar no Quartel, seexercite com ella a

370 Tropa dessa Capitania; sendo esteomodo mais facil, eprompto deseintroduzir emSaõ Paulo, aDisciplina Militar, estabelecida nesteReino.

30. Sendo indispensavelmente necessa $=$ rio, queestas Tropas seachem Municiadas, epro vidas detudo, o que Ihesfor precizo, para o servi= ço aquese destinaõ: Ordenou igualmente Sua Magestade, queseremetessem aessa Capitania, oAr= mamento, Polvora, Balas, Petrechos, emais Pro vizoens deGuerra; ecom ellas humpequeno Trem

380 deArtilharia Ligeira, ehuma Companhia de Artilheiros.

31. Detudo o queficareferido, verá VossaSenhoria queno Plano, quetemformado, para extender os Dominios deSuaMagestade, edeque deuparte 385 aesta Corte em differentes Officios, quecorrem desdeo Anno de1767, até o de1770, Ihefalta o essensialissimo objecto, daSegurança do Rio Grande deSaõ Pedro, eseus Desctrictos; sem aqualsegurança, tudooque VossaSenhoria intentar fa zer poroutraparte, será sempresugeito, ao perigo das seguintes consequencias.

32. A Primeira he: [espaco] Queseos Castelha nos attacarem, eocuparem odito Rio Grande, e seus Destrictos, emquanto VossaSenhoria emprega ama 
$\therefore$ :

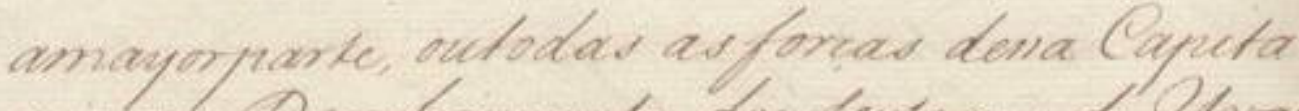
mea, no Bercolninento dos tertoend do ? eblbagy, ma Smana dor Smaneres tas luactla quilade huma fierda infiretanente maspon naquelled bomeness que todad as ofquirisoon

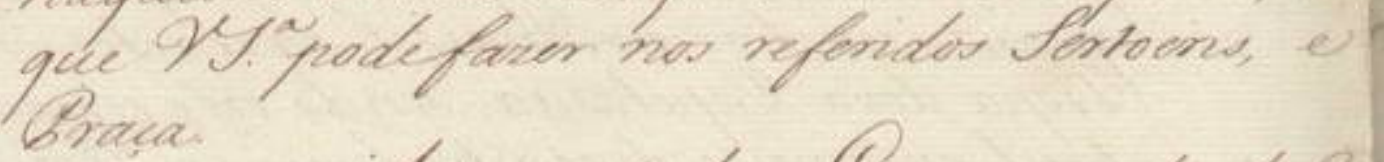

33.

Isequnda he:

(c)

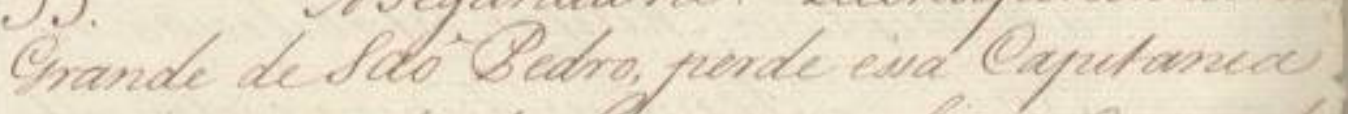

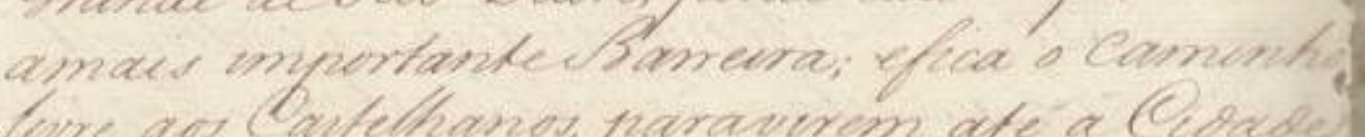

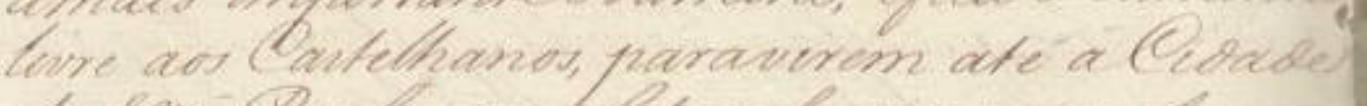

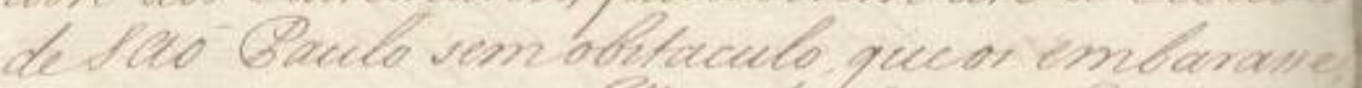

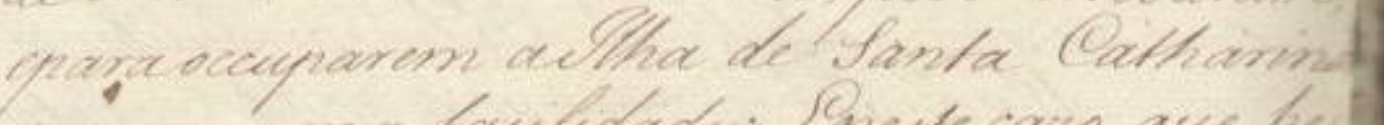

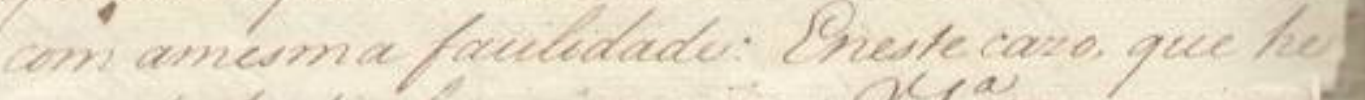

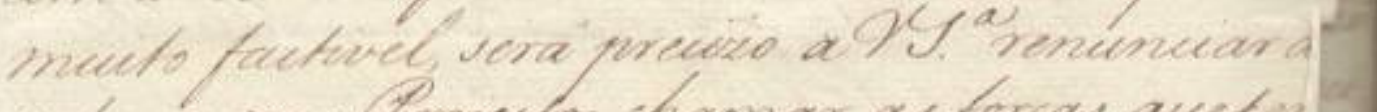

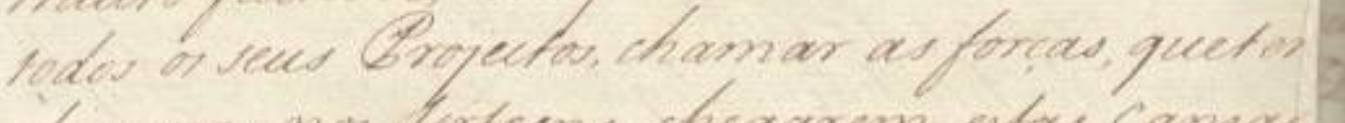

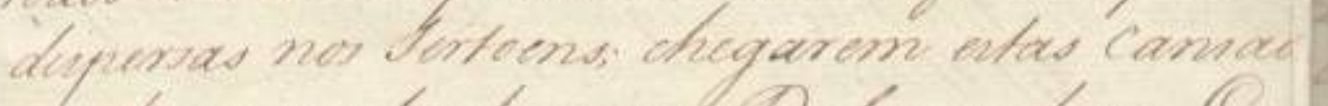

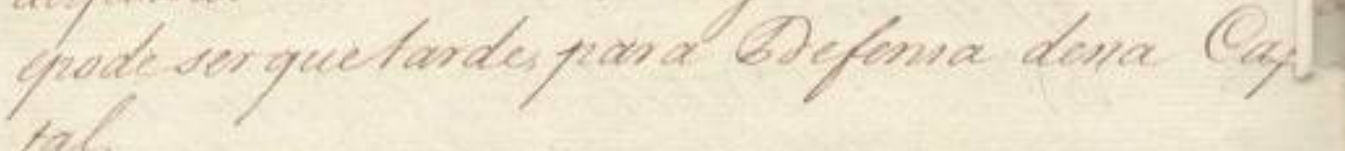

34

of Genceratue.

(1)

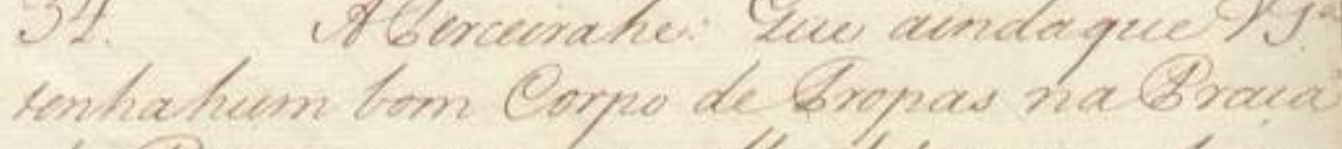

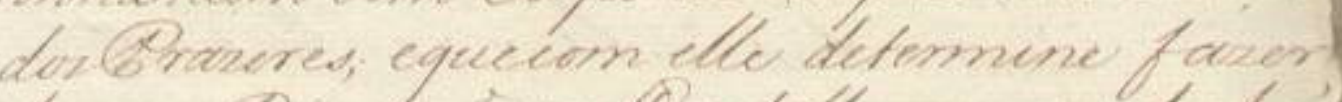

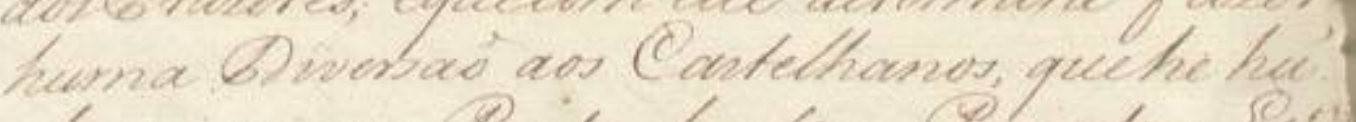

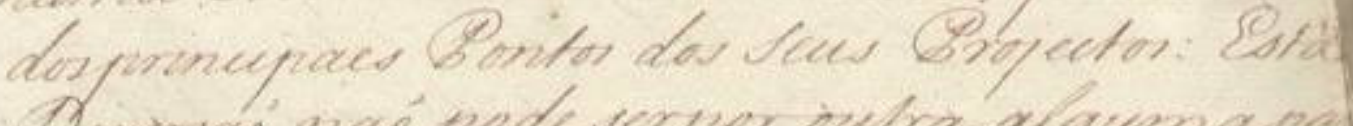

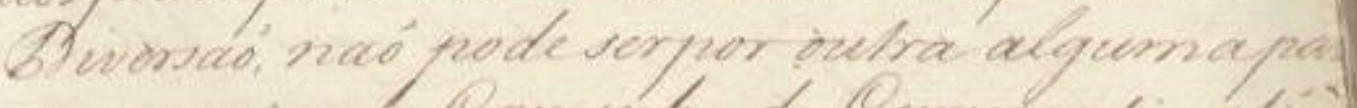

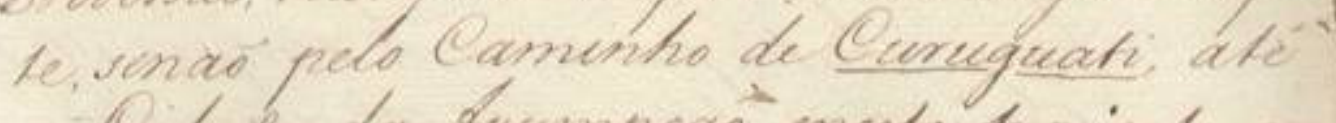
a Cidade da Alncenpicat enate trajecto on

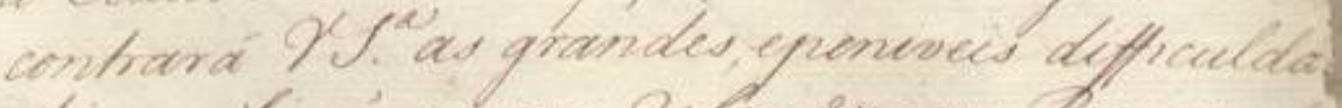

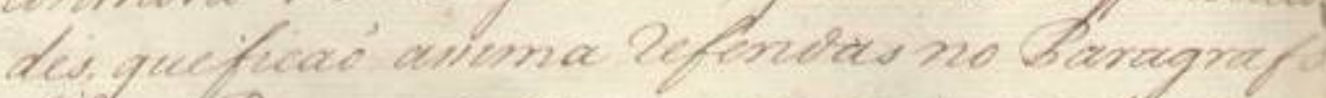

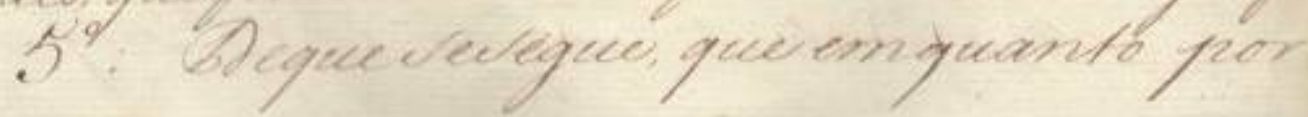


nia, no Descobrimento dos Sertoens do Yvay, eTibagy; enaPraça dos Prazeres; fás SuaMagestade huma perda infinitamente mayor naquelles Dominios, quetodas as Aquiziçoens que VossaSenhoria podefazer nos referidos Sertoens, e Praça.

33. Asegundahé: [espaço] Quenaperda doRio Grande deSaõ Pedro, perde essa Capitania amais importante Barreira; efica o Caminho

405 livre aos Castelhanos, paravirem até aCidade deSaõ Paulo semobstaculo, queos embarasse, epara occuparem allha de Santa Catharina com amesma facilidade: [espaço] Eneste cazo, que hé muito factivel, será precizo aVossaSenhoria renunciar a

410 todos os seus Projectos, chamar as forças, quetem dispersas nos Sertoens; chegarem estas cansadas epode serquetarde, para Defensa dessa Capi= tal.

34. ATerceirahe: Que ainda queVossaSenhoria

415 tenhahum bom Corpo deTropas naPraça dosPrazeres; equecom elle determine fazer huma Diversaõ aos Castelhanos, quehe hũ dosprincipaes Pontos dos seus Projectos: Esta Diversaõ, naõ podeserpor outra algumaparte, senaõ pelo Caminho de $\underline{\text { Curuguati, }}$ até á Cidade daAssumpçaõ; eneste trajecto en= contrará VossaSenhoria as grandes, epeniveis difficulda= des, queficaõ assima referidas no Paragrafo quinto: Dequesesegue, que emquanto por 
por humaparte, mencheo ad Gropas Bork-

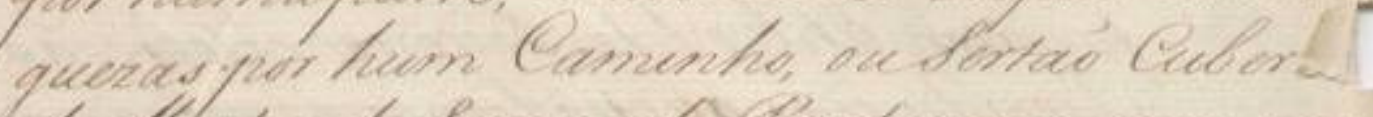

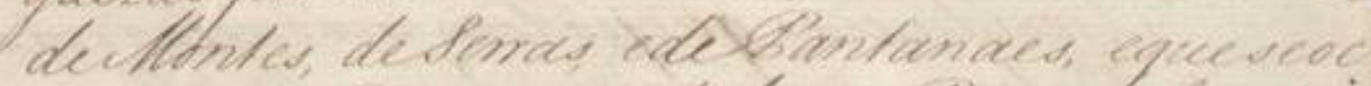

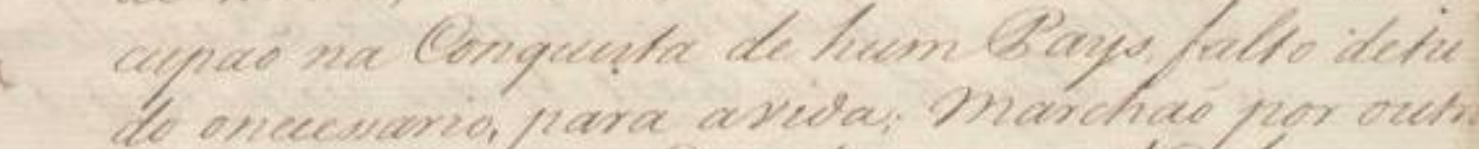

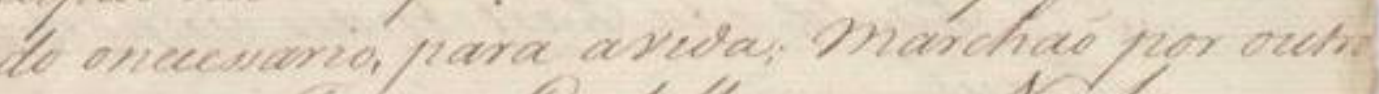

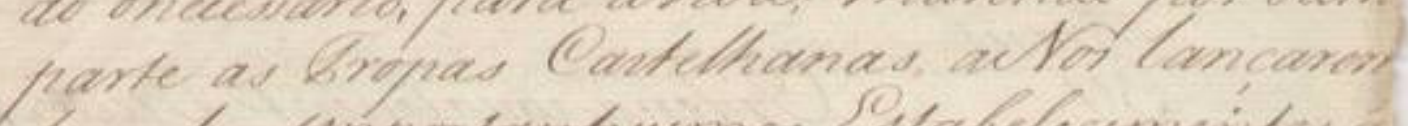

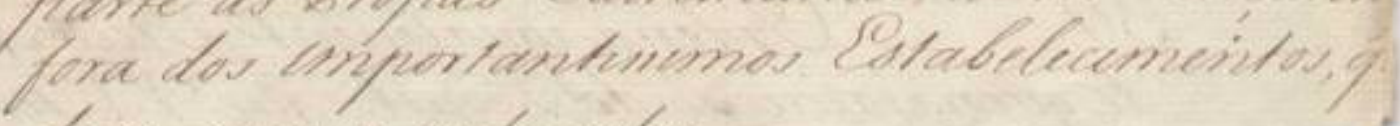
dexo anima miteciedos.

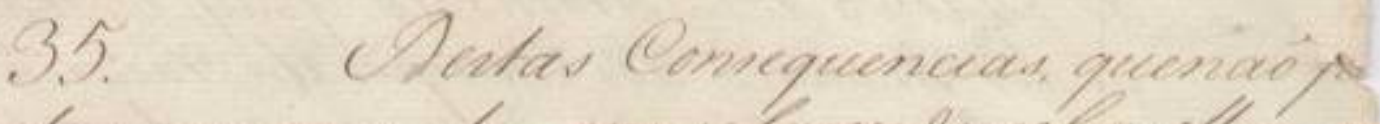

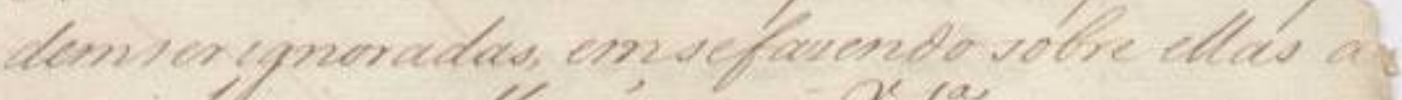

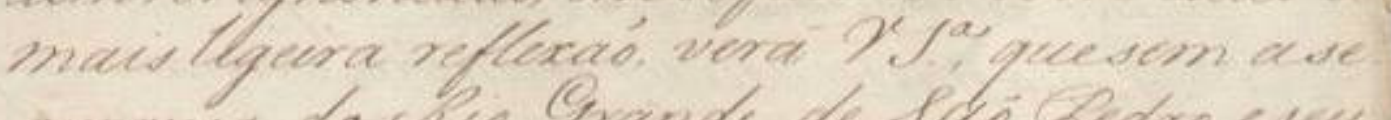

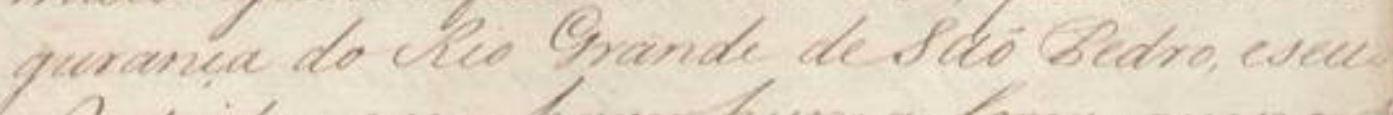

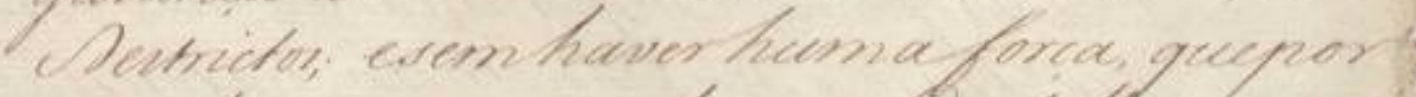

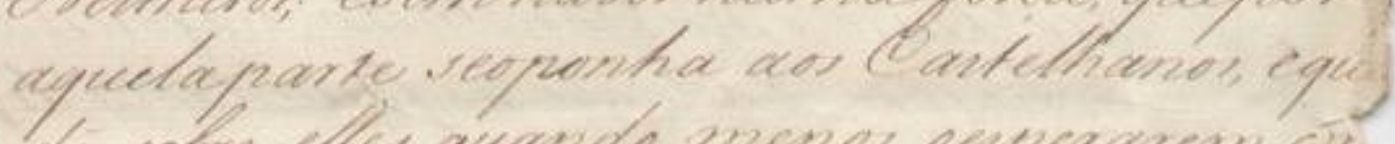

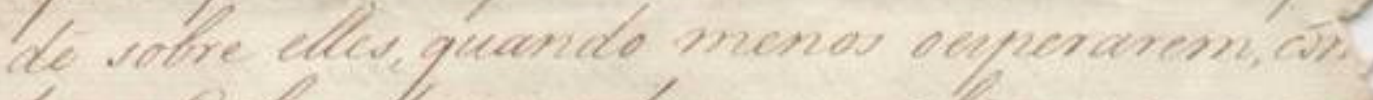

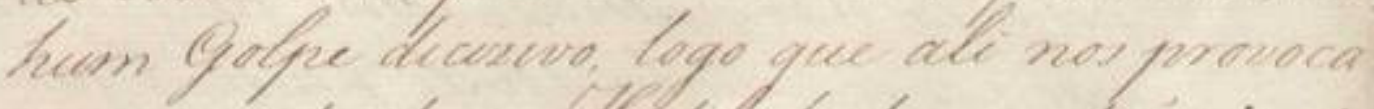

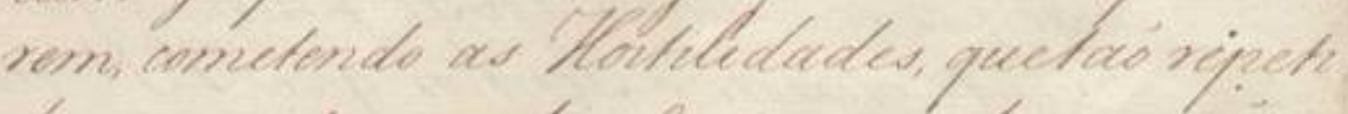

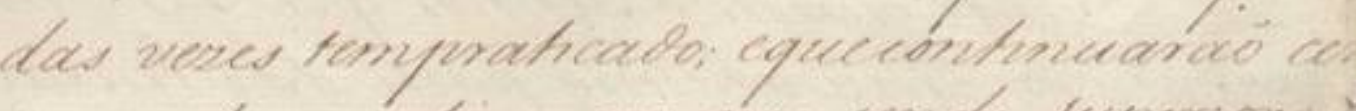

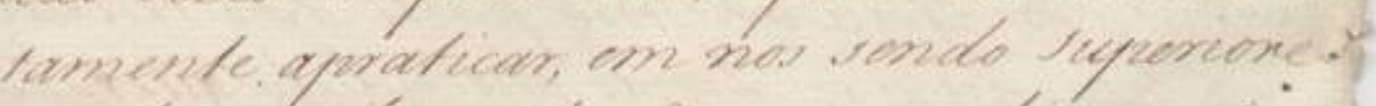

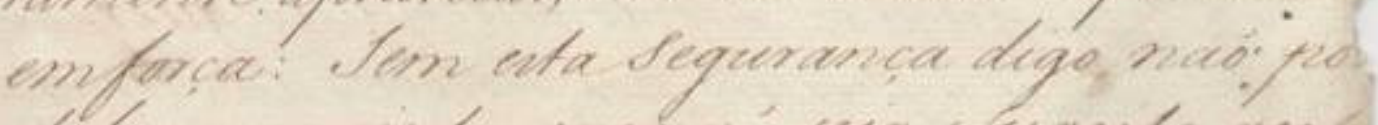

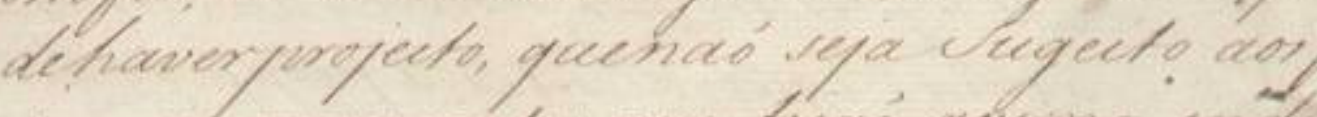

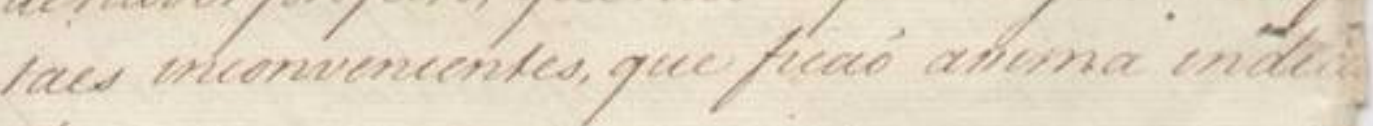
dos.

36 .

Soren

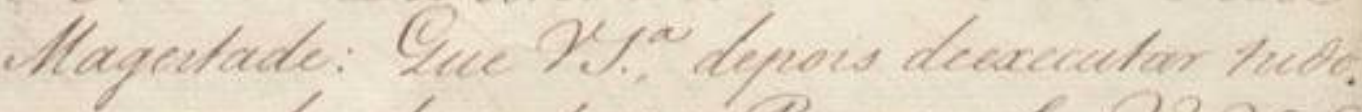

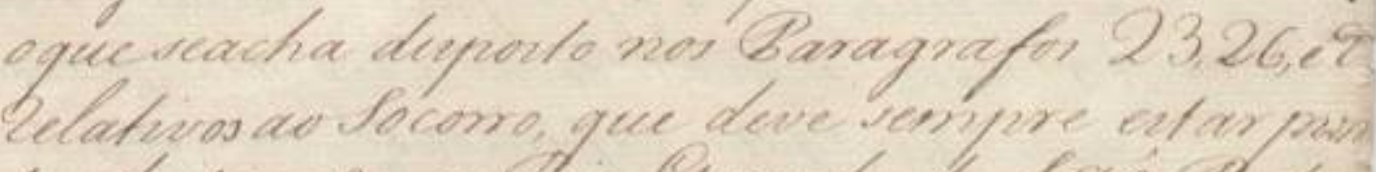

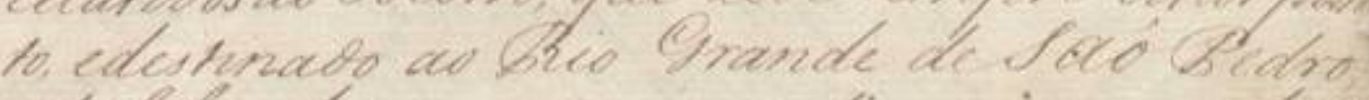

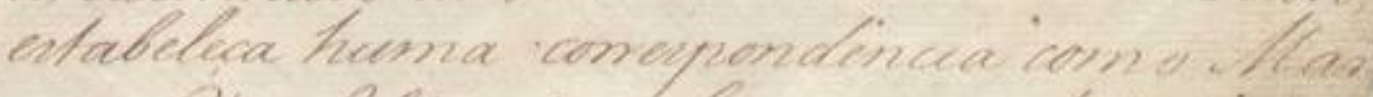

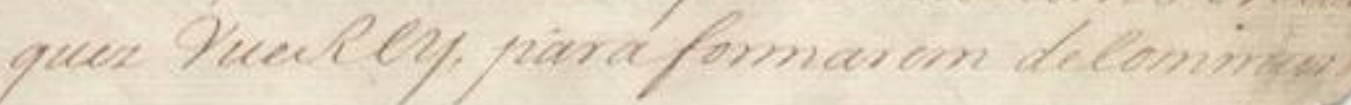


||149r|| [[por]] humaparte, marchaõ as Tropas Portu-

guezas por hum Caminho, ouSertaõ Cuber[to]

deMontes, deSerras, edePantanaes, equeseoc-

cupaõ na Conquista de humPays, falto detu=

do onecessario, para avida; Marchaõ por outra

parte as Tropas Castelhanas, aNos lançarem

fora dos importantissimos Estabelecimentos, que

deixo assima indicados.

35. Destas Consequencias, quenaõ po= demser ignoradas, emsefazendo sobre ellas a

mais ligeira reflexaõ, verá VossaSenhoria, quesem ase-

gurança do Rio Grande deSaõ Pedro, eseus

Destrictos; esemhaver humaforça, quepor

aquelaparte seoponha aos Castelhanos, eque

dê sobre elles, quando menos oesperarem, com

440 hum Golpe decizivo, logo que ali nos provoca

rem, cometendo as Hostilidades, quetaõ repeti

das vezes tempraticado; equecontinuaraõ cer-

tamente apraticar, em nos sendo superiores

emforça: [espaço] Sem estasegurança digo, naõ po

445 dehaverprojecto, quenaõ seja Sugeito aos fa-

taes inconvenientes, que ficaõ assima indica= dos.

36. Por estes motivos Ordena Sua

Magestade: [espaço] Que VossaSenhoria, depois deexecutar tudo

o queseacha disposto nos Paragrafos 23, 26 e 2[ilegível]

relativos aoSocorro, que deve sempre estar pron-

to, edestinado ao Rio Grande deSaõ Pedro,

estabeleça huma correspondencia com o Mar-

quez ViceRey, paraformarem deCommum ac[cordo] 


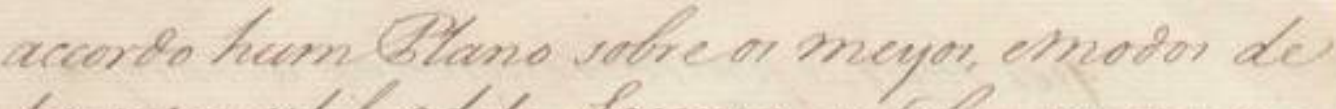
fauenem util odito Soccome; celobe as macd

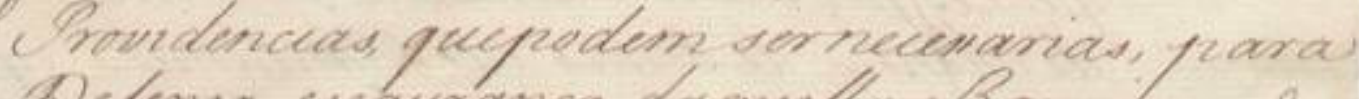

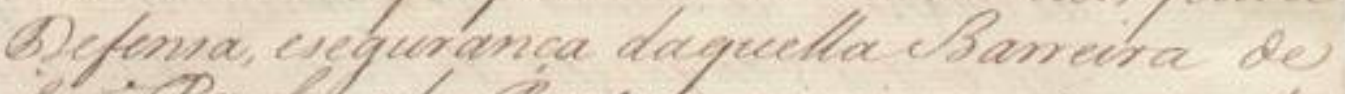

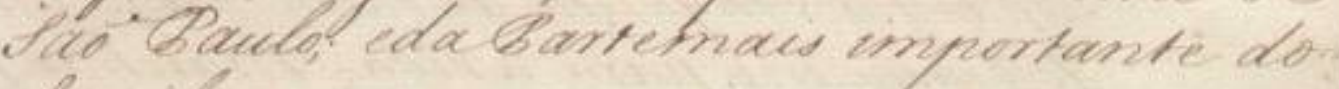
Bravil.

$3 \%$

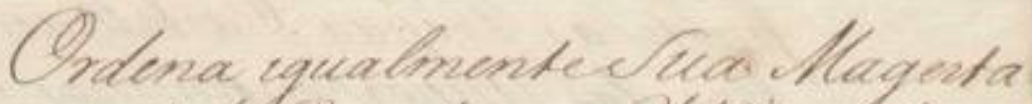

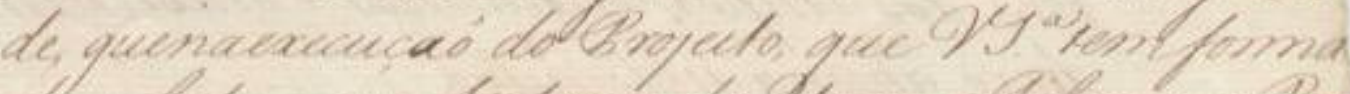

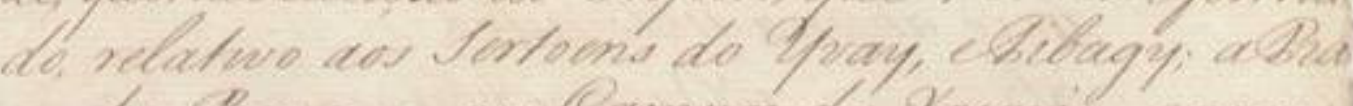

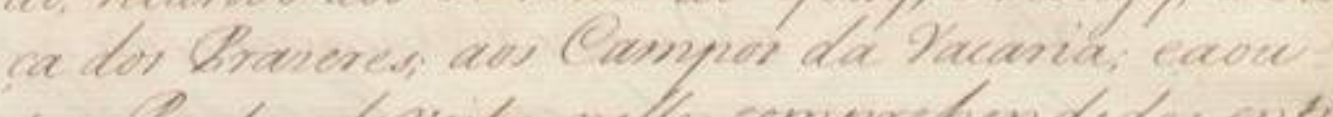

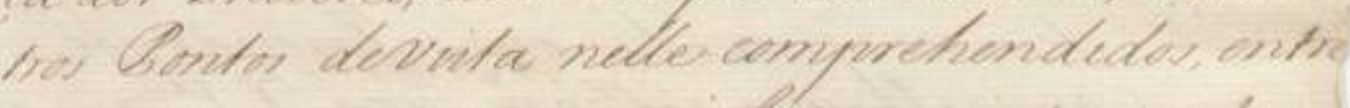

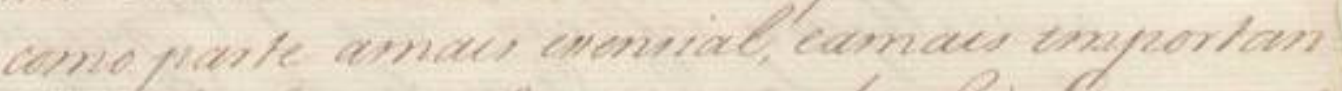

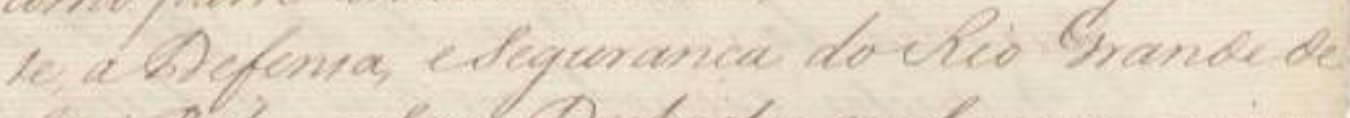

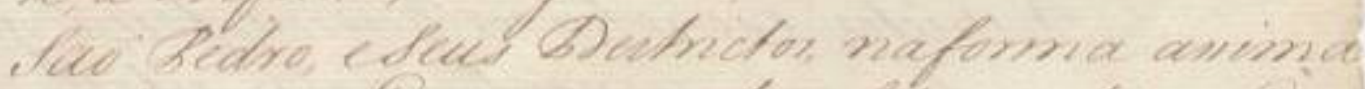

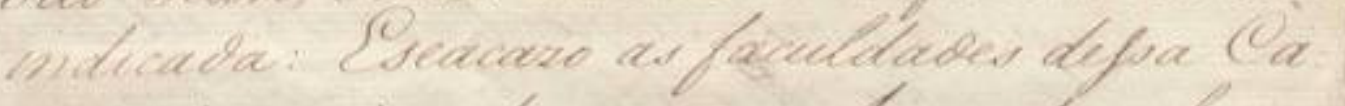

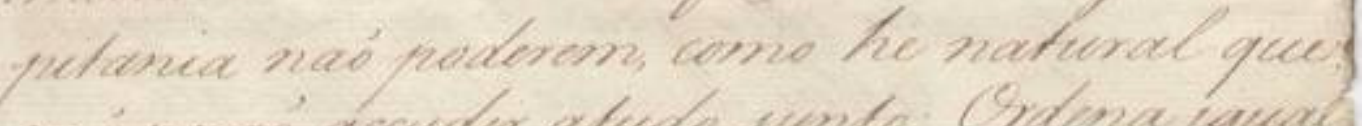

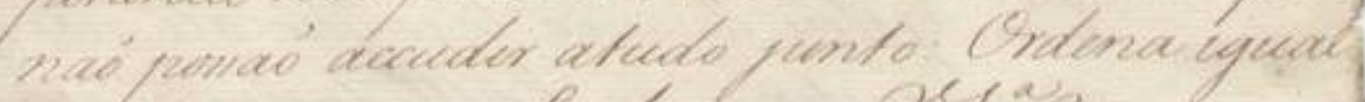

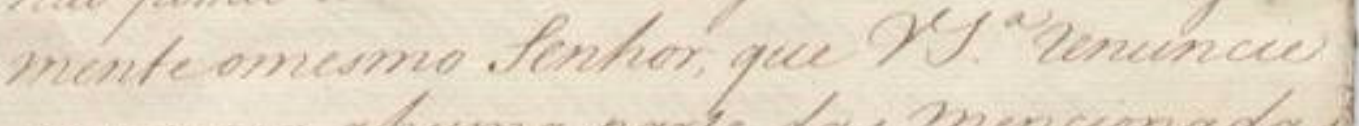
wer agora enuma parte das pronceonadas

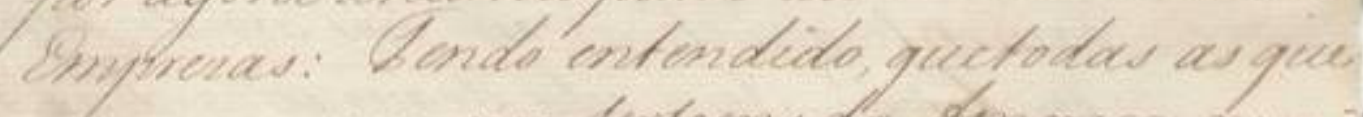

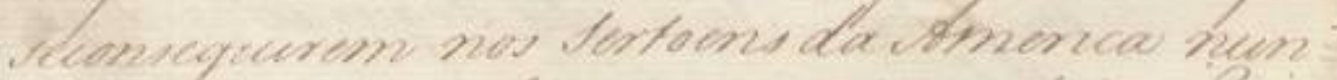

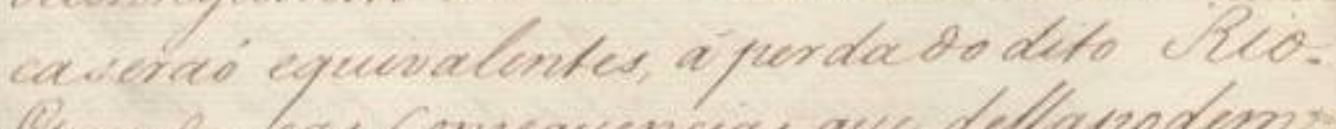

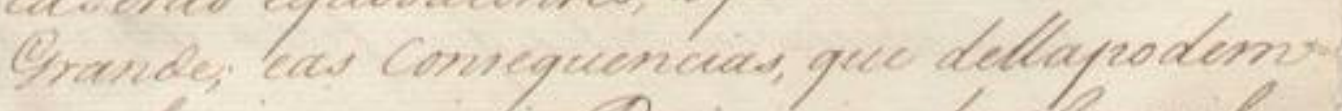

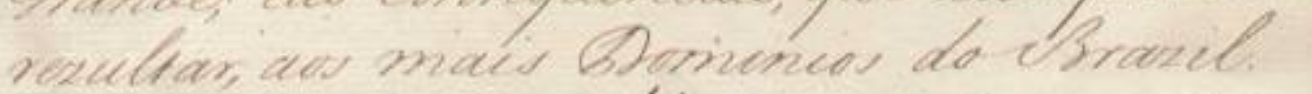
.38 Clue illagertade he rqualinen

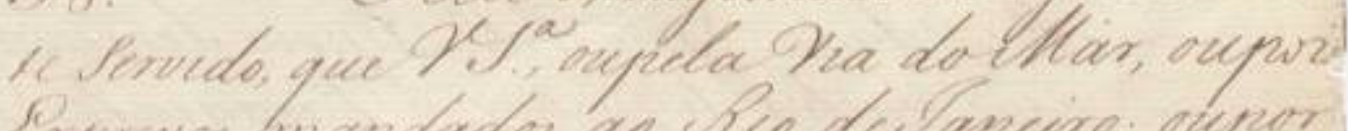

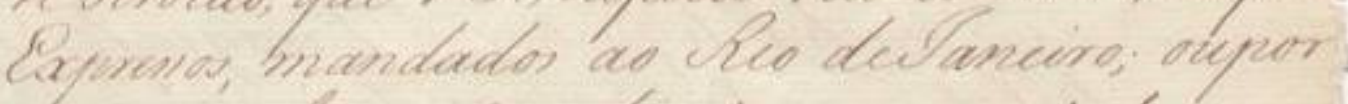

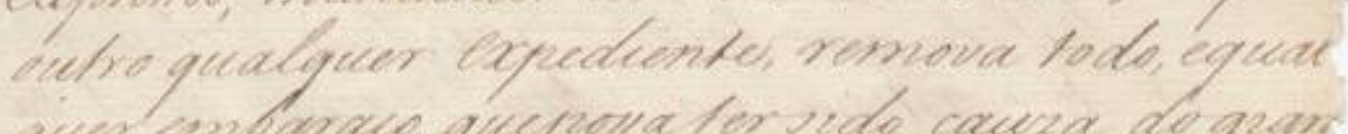

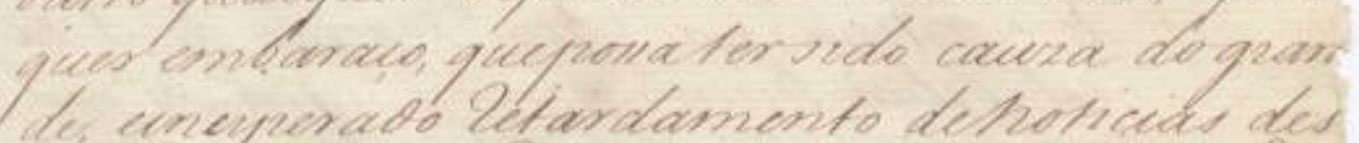

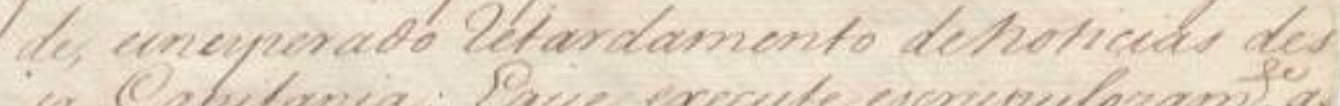

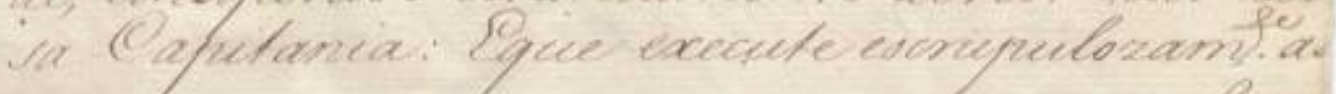


455 || 14Yv|| |laccordo]J humHlano sobreos meyos, emodos de

fazerem util o dito Soccorro; eSobre as mais

Providencias, quepodem sernecessarias, para

Defensa, esegurança daquellaBarreira de

Saõ Paulo; edaPartemais importante do

460 Brazil.

37. Ordena igualmenteSua Magesta=

de, quenaexecuçaõ do Projecto, que VossaSenhoria temforma

do, relativo aos Sertoens do Yvay, eTibagy; aPra

ça dos Prazeres; aos Campos da Vacaria; eaou=

tros Pontos devista nelle comprehendidos, entre

como parte amais essensial, eamais importan=

te, aDefensa, eSegurança doRio Grandede

Saõ Pedro, eSeus Destrictos, naforma assima

indicada: [espaco] Eseacazo as faculdades dessa $\mathrm{Ca}=$

470 pitania naõ poderem, como he natural que

naõ possaõ accudir atudo junto: [espaço] Ordena igual

mente omesmo Senhor, que VossaSenhoria renuncie

por agora ahuma parte das Mencionadas

Emprezas: [espaço] Tendo entendido, quetodas as que

seconseguirem nos Sertoens daAmerica nun=

caseraõ equivalentes, á perdado dito Rio

Grande; eas consequencias, que dellapodem

rezultar, aos mais Dominios doBrazil.

38. Sua Magestade he igualmen=

teservido, queVossaSenhoria, oupela Via doMar, oupor

Expressos, mandados ao Rio delaneiro; oupor

outro qualquer expediente, remova todo, equal=

quer embaraço, quepossater sido cauza do gran=

de, einesperado retardamento denoticias des 
||150r\|

III

Reaes Ordens do mesmio Senhor quethe for-

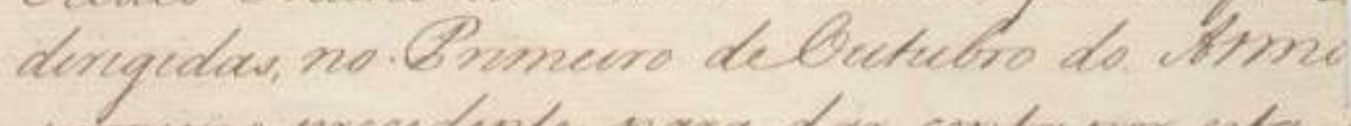
pramo precedentes para dar conta por enta: feoretaria de Btado detudo, oque bepanariena difa Orypetanio, com amayot brequencia, treve dade exactidaó, que the fore porivel.

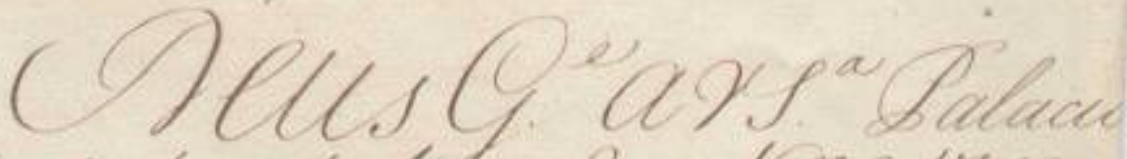

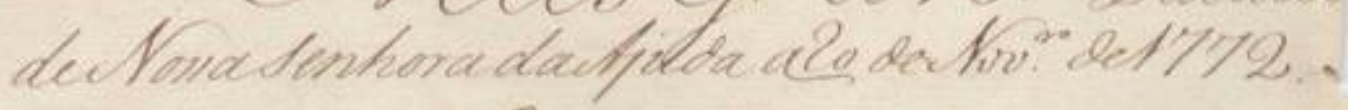
ellarkerdnetho efariz

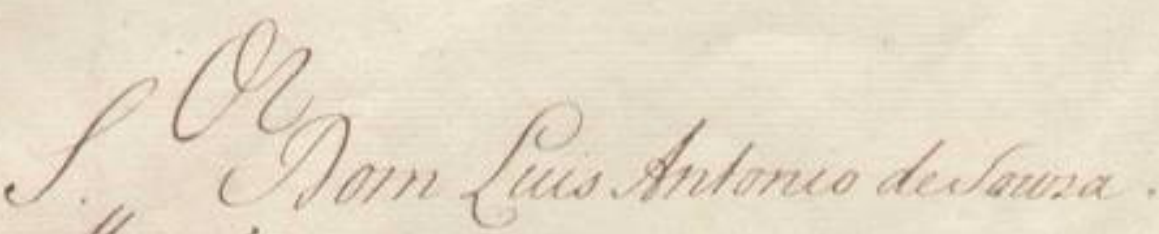
- Lourió.

481 
||150r|| Reaes Ordens do Mesmo Senhor, quelhefora[õ]

dirigidas, no Primeiro deOutubro do Anno

proximo precedente; para dar contapor esta

490 Secretaria de Estado detudo, oquesepassassena

dita Capitania, com amayor frequencia, $\underline{\text { brevi }}$

dade, eexactidaõ, que Ihefossepossivel.

Deus Guarde a VossaSenhoria Palacio

deNossaSenhora daAjuda a20 de Novembro de1772.

Martinho deMello eCastro

Senhor Dom Luis Antonio deSouza

Mouraõ. 


\section{CONSIDERAÇÕES FINAIS}

Este trabalho traz avanços em relação ao conhecimento filológico do livro manuscrito aqui estudado, uma vez que além de apresentar cópias facsimilares acompanhadas das respectivas transcrições semidiplomáticas de textos pouco conhecidos de nossa história, estuda aspectos paleográficos, codicológicos e diplomáticos até agora não explorados.

Quanto ao aspecto codicológico, verificou-se que o livro manuscrito estudado segue padrões regulares em suas características materiais. Essa regularidade vem indicar o cuidado com que foram compostos os manuscritos. Há diversos aspectos que evidenciam a composição de um livro a partir de documentos previamente soltos, embora não ainda não se possa afirmar em que momento essa composição tenha sido feita.

Em relação ao aspecto paleográfico, constatou-se que o suporte e o instrumento de escrita empregados nos documentos manuscritos estudados são conhecidos como usados em outras produções do século XVIII. Além disso, comprovou-se que existe uma multiplicidade de punhos, com características gráficas próprias, sem que nenhum dos documentos possa ser considerado autógrafo de D. Luís.

Quanto ao aspecto diplomático, constatou-se que, apesar de o livro manuscrito ser intitulado "Avisos e cartas régias", predomina espécie documental diversa, que é o ofício.

As transcrições apresentadas foram realizadas no intuito de constituir acervo de textos que possa servir de base sólida para estudo filológico, linguístico e histórico do período. Como cita Acioli (1994, p. 1), "O documento manuscrito é considerado a mola-mestra da História, [...] representando o melhor testemunho do passado, fonte direta de informação básica para o estudo da História.", o que permite concluir que a publicação desse livro manuscrito possa ser bastante profícua para futuros estudos referentes ao período. 


\section{BIBLIOGRAFIA}

ACIOLI, V. L. C. A Escrita no Brasil Colônia: um guia para leitura de documentos manuscritos. Recife: UFPE, Fundação Joaquim Nabuco, Massangana, 1994.

ALMEIDA, A. P. de. Deterioração da escrita e leitura paleográfica. v. 10. São Paulo: Boletim do departamento do arquivo, 1953.

ANDRADE, M. Revista do Arquivo Municipal de São Paulo. São Paulo: Casa Fuchs, 1935. 59-128 p.

ARRUDA, J. J. de A. (coord.). Documentos manuscritos avulsos da Capitania de São Paulo - Catálogo I (1644 - 1830). São Paulo: EDUSC, 1999.

AZEVEdo, J. L. de. O Marquês de Pombal e a sua época. São Paulo: Alameda Editorial, 2004.

BARBOSA, A. G. O contexto dos textos coloniais. In: ALKMIM, T. M. (org.) Para a história do português brasileiro. Novos estudos. São Paulo: Humanitas/FFLCH/USP, 2002. 421 - 431 p.

BARROS, J. de. Gramática da Língua Portuguesa Reprod. facsim., leit., introd. de BUESCU, M. L. C. Lisboa: Faculdade de Letras, 1971.

BARROS, L. G. A cidade e o planalto - processo de dinamização da cidade de São Paulo. Tomo I. São Paulo: Editora Melhoramentos, 1967. 164 - 200 p.

BECHARA, E. Moderna Gramática Portuguesa. 31 ed. São Paulo: Nacional, 1987.

BELLOTTO, H. L. Nem o tempo Nem a distância. Lisboa: Alêtheia Editores, 2007 (a). 
Autoridade e Conflito no Brasil Colonial: o Governo do Morgado de Mateus em São Paulo (1765-1775). $2^{\text {a }}$ ed. São Paulo: Alameda Casa Editorial, 2007 (b).

- Como fazer análise diplomática e análise tipológica de documento de Arquivo. São Paulo: Arquivo do Estado e Imprensa Oficial do Estado de São Paulo. 2002.

BROW, P. M.; LOVETT, P. The historical source books for scribes. Londres: British Library, 1999. Disponível em: <http://books.google.com.br/books> Acesso em: 05 mar 2009.

CAMARA JR, J. M. História e Estrutura da Língua Portuguesa. Rio de Janeiro: Padrão Livraria e Editora, 1975.

CambraiA, C. N.; CunHA, A. G. da.; Megale, H. A Carta de Pero Vaz de Caminha. São Paulo: Série Diachronica 1, Humanitas, 2001. Introdução à crítica textual. São Paulo: Martins Fontes, 2005.

CARVALHO, L. R. de. As Reformas Pombalinas da Instrução Pública. São Paulo: Saraiva: Editora Universidade de São Paulo, 1978.

COUTINHO, I. de L. Pontos de Gramática Histórica. $6^{\underline{a}}$ ed. Rio de Janeiro: Livraria Acadêmica, 1973.

COSTA, Pe. A. J. da. Álbum de Paleografia e Diplomática Portuguesa. Coimbra: Universidade de Coimbra, 1976.

CUNHA, C. Nova gramática do português contemporâneo. 2 ed. Rio de Janeiro: Nova Fronteira, 1984. 
FARACO, C. A. Lingüística Histórica (uma introdução ao estudo da história da língua). São Paulo: Editora Ática, 1991. 9 - 86 p.

FERREIRA, L. T. (org.), Anais do Museu paulistas. Tomo XIV. São Paulo: Imprensa Oficial do Estado, 1950. 385-393 p.

FIGUEIREDO, M. A., Nova Escola para aprender a ler, escrever, e contar... Lisboa: Officina de Bernardo da Costa de Carvalho, 1722. Disponível em: <http://purl.pt/107> Acesso em: 10 fev 2009

FLEXOR, M. H. Ochi. Abreviaturas: manuscritos dos séculos XVI ao XIX. 2 $2^{\underline{a}}$ ed. São Paulo: UNESP, Arquivo do Estado de São Paulo, 1991.

GUEDES, M.; Berlink, R. de A. (org.). E os preços eram cômmodos. São Paulo: Humanitas, 2000.

HAUY, A. B. História da Língua Portuguesa I. Séculos XII, XIII e XIV. São Paulo: Editora Ática, 1989.

HIGOUNET, C. História Concisa da Escrita. São Paulo: Parábola Editora, 2003. $165-169 \mathrm{p}$.

HOUAISS, A. et alii. Dicionário Houaiss da Língua Portuguesa. Rio de Janeiro: Editora Objetiva , 2001.

MAIA, C. A. História do Galego-Português: Estado lingüístico da Galiza e do Noroeste de Portugal desde o século XIII ao XVI. Coimbra: Instituto Nacional de Investigação Científica, 1986.

MALLON, J. Paléographie Romaine. Madri: Consejo Superior de Investigaciones Científicas, $1952 . \quad$ Disponível em: <http://bcs.fltr.ucl.ac.be/Transm.html> Acesso em: 10 abr 2009. 
MARQUES, M. E. A, Apontamentos históricos, biográficos, estatísticos e noticiosos da Província de São Paulo. Tomo I. São Paulo: Edusp, 1988. 201 p.

MARTINHEIRA, J. J. S. Tipologia documental nos arquivos. Um caso: Tipologias documentais da administração central no antigo regime. Lisboa, 1997. Não publicado.

MARTINS, W. A Palavra Escrita. 3ª ed. São Paulo: Editora Ática, 2000.

MARTINS, Z. Não mais que um capitão-general. Morgado de Mateus - 0 fidalgo. Vol. 1. Campos do Jordão: Editora Vertente, 1999.

Não mais que um capitão-general. Morgado de Mateus - 0 governante. Vol. 2. Sorocaba: Editora Vertente, 2000.

Não mais que um capitão-general. Morgado de Mateus - 0 desvalido. Vol. 3. Campos do Jordão: Editora Vertente, 2001.

MEGALE, H. "Pesquisa Filológica: os trabalhos da tradição e os novos trabalhos em língua portuguesa". In: Estudos Lingüísticos (Grupo de Estudos Lingüísticos do Estado de São Paulo). no 29. São Paulo: UNESP, 2000. 309$314 \mathrm{p}$.

e NETO, S. de A. T. (org.) Por minha letra e sinal (Documentos do Ouro do Século XVII). São Paulo: Ateliê Editorial - FAPESP, 2006. 172-177 p.

. "Documentos brasileiros do século XVIII para estudo lingüístico". In:

Estudos Lingüísticos (Grupo de Estudos Lingüísticos do Estado de São Paulo), nº 27, São José do Rio Preto: IBILCE, UNESP, 2000. 3-28 p. 
e CAMBRAIA, C. N. "Filologia Portuguesa no Brasil". In: DELTA Documentação de Estudos em Lingüística Teórica e Aplicada, v. 15. São Paulo: Educ. 1999. $1-22$ p.

(org) et alii. Filologia Bandeirante: Estudos 1, no 29. São Paulo: Humanitas, 2000. 309-314 p.

MENEZES, P. Guia do Acervo Permanente do Arquivo do Estado. São Paulo: IMESP, 1997.

MENEZES, R. Histórias da História de São Paulo. São Paulo: Editora Melhoramentos, 1954. 119-129 p.

MELO, A. F. A. O papel como elemento de identificação. Lisboa: Biblioteca Nacional, 1926. Disponível em: <http://purl.pt/182/1/P2.html>. Acesso em: 20 jul 2008.

MELO, G. C. de. Introdução à Filologia Portuguesa. $2^{\underline{a}}$ ed. Rio de Janeiro: Livraria Acadêmica. 1957. 33 - 39 p.

PAIVA, D. de F. História da Língua Portuguesa II. Século XV e meados do século XVI. São Paulo: Editora Ática, 1988.

PIRES, R. F. O Papel Selado em Portugal. Porto: Fundação Dr. António Cupertino de Miranda, 1997.

PINTO, R. M. História da Língua Portuguesa IV. Século XVIII. São Paulo: Editora Ática, 1988.

RODRIGUES, J. H. As fontes de História do Brasil na Europa. Rio de Janeiro: Imprensa Nacional, 1950. 
SAID ALI, M. Gramática Histórica da Língua Portuguesa. 5a ed. São Paulo: Edições Melhoramentos, 1964.

SALGADO, G. (coord.) Fiscais e Meirinhos. A Administração no Brasil Colonial. $2^{\underline{a}}$ ed. Rio de Janeiro: Arquivo Nacional. Editora Nova Fronteira, 1985.

SANTOS, M. J. A. Da Visigótica à Carolina. A escrita em Portugal de 882 a 1172 (aspectos técnicos e culturais). Lisboa: Editora Fundação Calouste Gulbenkian, 1994.

SILVA, R. V. M. e. Estruturas trecentistas; elementos para uma gramática do Português Arcaico. Lisboa: Imprensa Nacional - Casa da Moeda. 1989. $15-14 ; 148-151 ; 212-231 ; 838-859$ p.

SIMONSEN, C. R. História Econômica do Brasil: 1500 - 1820. São Paulo: Companhia Editora Nacional. 1937. 270-300 p.

SOROR, M. A. Cartas Portuguesas. São Paulo: Editora Publicações América, 1974.

SOUZA, J. S. (org.) Diário de Navegação. Teotônio José Juzarte. Campinas: Editora da Unicamp. 1999.

SPINA, S. Introdução a Edótica. São Paulo: Edusp, Ars Poética, 1994. História da Língua Portuguesa III. Segunda metade do século XVI e século XVII. São Paulo: Editora Ática, 1987.

TAUNAY, A. E. São Paulo nos primeiros anos. São Paulo: Paz e Terra, 2003. Assuntos de três séculos coloniais (1598-1790). In: Anais do Museu Paulista. Tomo duodécimo. São Paulo: USP, 1945. 139-146 p. 
História da Cidade de São Paulo. São Paulo: USP, 1953. 121-130 p.

Na Era das Bandeiras. São Paulo: Editora Melhoramentos, 1922. 138-143 p.

TRINDADE, J. B. Os tropeiros. São Paulo: Editora Comunicações, 1992. 


\section{ANEXO: textos impressos contidos no livro no $\mathbf{1 7 0}$ do AESP}

Como já mencionado, as páginas impressas encadernadas em meio aos documentos manuscritos encontram-se em um suporte menos resistente que 0 dos manuscritos e têm tamanho menor que eles. As 66 fólios (dos quais 61 estão impressos e 5 , em branco) medem $21 \mathrm{~cm}$ de largura por $31 \mathrm{~cm}$ de altura e estão encadernados de acordo com a ordem apresentada nos verbetes a seguir.

\subsection{Leitura dos documentos impressos}

Para uma leitura mais eficaz das cópias dos documentos impressos em anexo, vale lembrar que a ortografia empregada apresenta, bem como nos manuscritos, alterações em relação à atual. Há diversas letras duplicadas, como em "Collecção", "successivamente", "della"; bem como ortografias não mais empregadas, tais como "Catholica" e "prezidente".

Além dessas peculiaridades, o tipo de letra empregado apresenta alterações nos grafemas $<\mathrm{s}>$ minúsculos, grafados como: $\mathbb{f}^{11}$, conforme se verifica nas palavras a seguir: neceflarias fegundo "necessárias segundo", omiffo "omisso" e affiftencia "assistencia". Esse grafema pode ser facilmente confundido com $\mathrm{o}<\mathrm{f}$, conforme se verifica em Profifiá "Profissão". O <s> maiúsculos, em contrapartida, são iguais aos empregados atualmente, como em Sacêrdotes "Sacerdotes".

A imagem a seguir, publicada em 1722 por Figueiredo (1722, p. 38), prova que os documentos impressos encadernados junto ao corpus manuscrito seguem as mesmas tipologias e regras de impressão do século XVIII.

\footnotetext{
${ }^{11}$ Todas as palavras aqui exemplificadas foram retiradas da página 2 do anexo.
} 


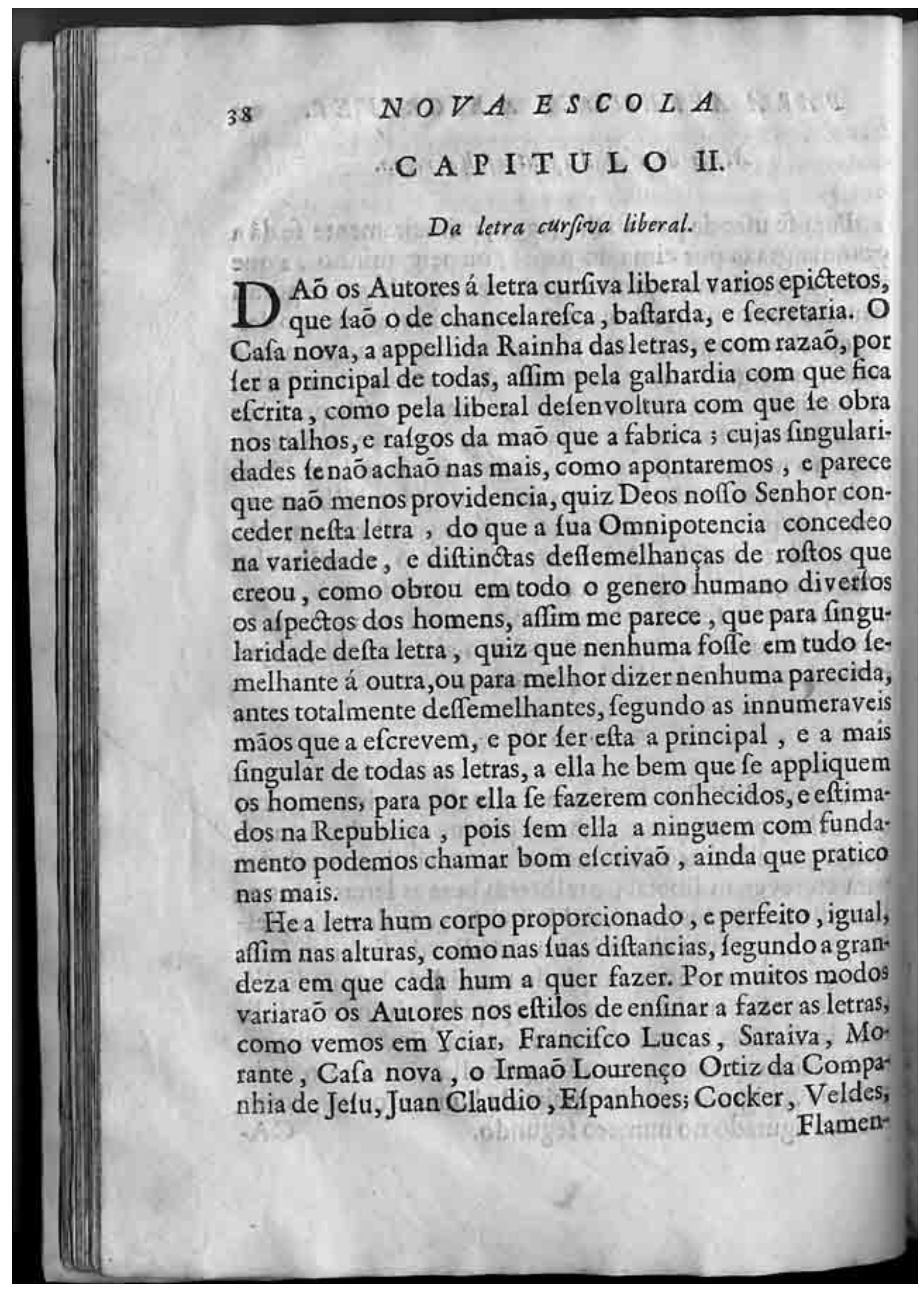

Figura 26: Página impressa de Figueiredo (1722, p. 39) sobre a escrita cursiva, com emprego do mesmo tipo de $<\mathrm{S}>$ encontrado nos documentos impressos do livro manuscrito. 


\subsection{Documentos impressos}

A seguir, inserem-se as cópias fac-similares de todos os documentos impressos encadernados no livro manuscrito estudado.

O Quadro 10 apresenta uma descrição de cada documento impresso, no intuito de facilitar a leitura desses textos encadernados de forma aleatória junto aos documentos manuscritos estudados neste trabalho.

Para tanto, a primeira coluna demonstra o título de cada documento, conforme encontrado na primeira página de cada um. Entre parênteses, foi colocada a paginação que tais documentos recebem neste trabalho.

A segunda coluna mostra a editora responsável pela publicação de cada documento na época.

Datas tópicas e cronológicas são explicitadas na terceira coluna.

A quarta coluna, por sua vez, apresenta o local em que cada documento impresso assume dentro do livro manuscrito estudado. Entre parênteses, há a quantidade de páginas impressas.

Por fim, a quinta ou última coluna demonstra o autor em todos os casos e o destinatário, após barra, quando explicitado pelo documento.

Quanto à espécie documental, seguindo as classificações de Bellotto (2002), vale mencionar que o primeiro documento é um "decreto", ou seja, um documento diplomático dispositivo normativo, descendente, usado na administração colonial como diploma de que o Rei se serve para acrescentar, modificar ou revogar uma lei.

O segundo documento impresso é um "contrato", classificado como "documento diplomático, dispositivo pactual horizontal. Registro pelo qual duas pessoas físicas ou jurídicas estabelecem entre si direitos ou obrigações." (BELLOTTO, 2002, p.60)

O terceiro, um "acto", "documento diplomático dispositivo de correspondência, descendente." (BELLOTTO, 2002, p.49) Consiste em ação interna dispositiva do Estado, para documentar funções como alteração de vencimento e vacância de cargos.

Os últimos dois são da espécie documental "alvará", "documento diplomático dispositivo, de correspondência, descendente." (BELLOTTO, 2002, 
p. 47). Empregado na administração colonial como modificação, declaração ou reiteração de normas previamente estabelecidas pelo Rei.

Quadro 10: Quadro sinóptico dos documentos impressos

\begin{tabular}{|c|c|c|c|c|}
\hline $\begin{array}{c}\text { Título } \\
\text { (página em que } \\
\text { se encontra no } \\
\text { anexo) }\end{array}$ & $\begin{array}{c}\text { Casa } \\
\text { impressora }\end{array}$ & $\begin{array}{c}\text { Data tópica } \\
\text { e } \\
\text { cronológica }\end{array}$ & $\begin{array}{l}\text { Localização no } \\
\text { livro } \\
\text { manuscrito } \\
\text { (Número de } \\
\text { páginas } \\
\text { impressas) }\end{array}$ & $\begin{array}{c}\text { Autor / } \\
\text { Destinatário }\end{array}$ \\
\hline $\begin{array}{l}\text { Collecçaõ do Real } \\
\text { Decreto de S. M. } \\
\text { Catholica } \\
\text { (pág. 1) } \\
\text { Seguida da } \\
\text { Pragmatica } \\
\text { Sançaõ } \\
\text { (pág. } 21 \text { ) }\end{array}$ & $\begin{array}{l}\text { Officina de } \\
\text { Antonio } \\
\text { Rodrigues } \\
\text { Galhardo. }\end{array}$ & $\begin{array}{c}\text { Lisboa, } 27 \\
\text { de fevereiro } \\
\text { de } 1767 .\end{array}$ & $\begin{array}{l}\text { Entre os fólios } \\
29 v \text { e } 30 r . \\
\text { (30 páginas } \\
\text { impressas) }\end{array}$ & $\begin{array}{c}\text { Sua } \\
\text { Magestade / } \\
\text { Senhor } \\
\text { Conde de } \\
\text { Aranda }\end{array}$ \\
\hline $\begin{array}{l}\text { Contrato, que se } \\
\text { fez no Conselho } \\
\text { Ultramarino, sobre } \\
\text { subsidio dos } \\
\text { molhados enovo } \\
\text { imposto da Praça } \\
\text { de Santos } \\
\text { (pág. 32) }\end{array}$ & $\begin{array}{l}\text { Officina de } \\
\text { Joam } \\
\text { Antonio da } \\
\text { Costa }\end{array}$ & $\begin{array}{c}\text { Lisboa, } \\
1777 . \\
\text { Com } \\
\text { princípio em } \\
1^{\circ} \text { de } \\
\text { Janeiro de } \\
1778 .\end{array}$ & $\begin{array}{l}\text { Entre os fólios } \\
\text { 36v e 37r. } \\
\text { (10 páginas } \\
\text { impressas) }\end{array}$ & $\begin{array}{c}\text { Joseph } \\
\text { Alvarez de } \\
\text { Mira e seu } \\
\text { sócio João } \\
\text { Baptista de } \\
\text { Oliveira } \\
\text { Costa }\end{array}$ \\
\hline
\end{tabular}




\begin{tabular}{|c|c|c|c|c|}
\hline $\begin{array}{c}\text { Acto do } \\
\text { Parlamento de } \\
\text { Pariz } \\
\text { (pág. 42) }\end{array}$ & $\begin{array}{l}\text { Officina de } \\
\text { Antonio } \\
\text { Rodrigues } \\
\text { Galhardo. }\end{array}$ & $\begin{array}{c}\text { Lisboa, } 9 \text { de } \\
\text { maio de } \\
1767 .\end{array}$ & $\begin{array}{l}\text { Entre os fólios } \\
51 v \text { e } 52 r . \\
\text { (12 páginas } \\
\text { impressas) }\end{array}$ & $\begin{array}{c}\text { Ministro } \\
\text { Homero Joli } \\
\text { de Fleury / } \\
\text { Parlamento } \\
\text { (Ministros, } \\
\text { Procuradore } \\
\text { s e Juizes da } \\
\text { Coroa) }\end{array}$ \\
\hline $\begin{array}{c}\text { Alvará de S. } \\
\text { Magestade } \\
\text { fidelíssima sobre a } \\
\text { fabrica da cartas } \\
\text { de jogar (pág. 54) }\end{array}$ & $\begin{array}{c}\text { Regia } \\
\text { Officina } \\
\text { Typografica. }\end{array}$ & $\begin{array}{c}\text { Lisboa, } \\
1769 .\end{array}$ & $\begin{array}{l}\text { Entre os fólios } \\
\text { 96v e 97r. } \\
\text { (4 páginas } \\
\text { impressas) }\end{array}$ & El Rey \\
\hline $\begin{array}{c}\text { Alvará de EL REY } \\
\text { ao Vice-Rei } \\
\text { (pág. 58) }\end{array}$ & $\begin{array}{c}\text { Regia } \\
\text { Officina } \\
\text { Typografica. }\end{array}$ & $\begin{array}{c}\text { Palacio de } \\
\text { Nossa } \\
\text { Senhora da } \\
\text { Ajuda, } 14 \text { de } \\
\text { dezembro de } \\
1770 .\end{array}$ & $\begin{array}{l}\text { Entre os fólios } \\
\text { 100v e 101r. } \\
\text { (3 páginas } \\
\text { impressas) }\end{array}$ & $\begin{array}{c}\text { Rey/ } \\
\text { Martinho de } \\
\text { Mello e } \\
\text { Castro. }\end{array}$ \\
\hline
\end{tabular}




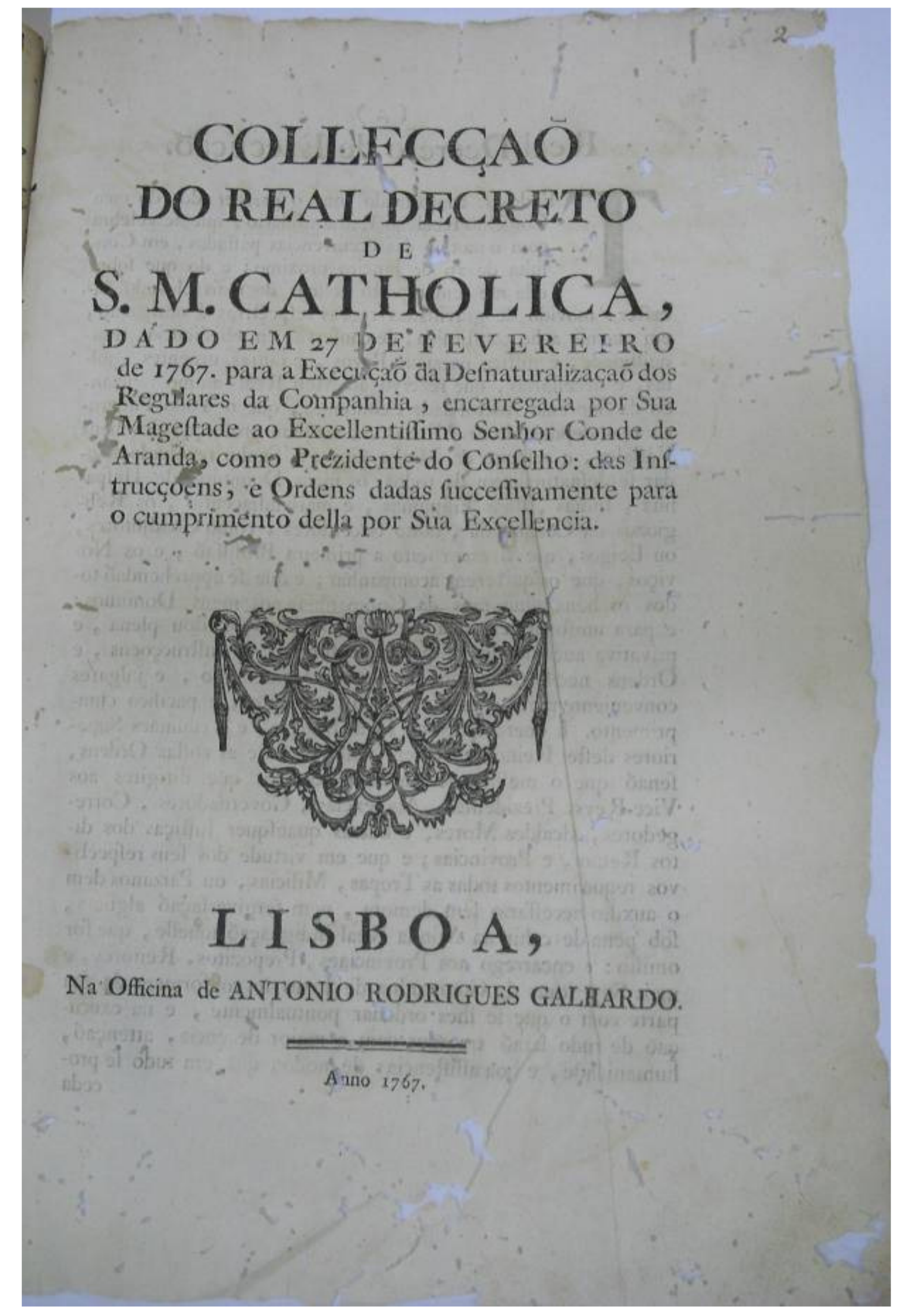




\section{Real Decreto de Execuçaõ.}

Enta-me confomado com o parecer dos do meu Eonfeltho Real no Extraordias paffadas, en Con com o motivo das occure proximo; e do que $\mathrm{Con}_{-}$ fulta de 29 de Janciro proas do mais elevabr ella me tem xpofto pelloas doctivas á obrigaça racter: movido de graviffmas cauzas refpectivar em obediencia em que me acho conftituico, de confervar e outras urgentes tranquillidade, e juftiça os neusvo ao Meu Real animo: quillidade, e juftiça que rezervo ao Meu Real animo : uzan-
tas, e neceflarias, que
do da Suprema Auctordade Economica, que o Todo Poderozo tem depozirido nas Minhas maons para protecçá dos meus Vaflalos, e refpeito da Minha Coroa ; Tenho rezolvido mindar fe defnaturalizem de todos os meus Dominios de Hefpanha, Indias, Ithas Filippinas, e mais adjacentes, os Religiozos da Compaphia, tanto Sacédotes, como Coadjutores, ou Leigos, que tiverem feito a priniejra Profiflá, e os Noviços, que os quizerem acompanhar; e que fe apprehendaó todos os bens iemporaes da Companhia nos meus. Domirios:e para uniforme execuçaó em todos elles vos dou plena, e privativa aucoridade, e para que formeis as Inftrucçoens, e Ordens neceffarias fegundo houveres entendido, e julgares conveniente para or mais effectivo, prompto, e pacifico cumprimento. E quero que naố fó as Juftiças, e Tribunaes Superiores deftes Reinos executem pontualmente as volfas Ordens, fenaó que o mefmo fe entendą com os que dirigires aos Vice-Reys, Prezidentes, Audiencias, Governadores, Corregedores, Alcaides-Mores, e outras quaefquer Juftiças dos ditos Reinos, e Provincias; e que em virtude dos feus refpectivos requetimentos todas as Tropas, Milicias, ou Paizanos dem o auxilio neceffario fenı demora, nem terǫiverfaçaó alguma, fob pena de cahir na Minha Real indignaçaó aquelle, que for mais Superiores parte com o que fe lhesanhia de Jezus fe conformenta fua çaó de tudo feraó tracalordcnar pontualmente, e na execuhumanidade, e boa affiftencia 'com a maior decencia, attençaó, c c:- ${ }^{-}$ ceda 
ceda conforme as Minhins Soberanas intençoens. Tello-heis entendido aflim para o feu exacto cumprimento, como fio, e efpero do vollo zelo, actividad:, e amor ao Meu Real ferviço: e para ifto dareis as Ordens, e Inftruccoenss neceflariàs, acompanhando a eftas os exemplares defte meu Real Decreto, aos quaes, eftando affinados por vós, fe thes dará a mefma fé, e credito, que ao original $=$ Rubricado da maó de Sua Mageftade $=$ No Pardo 27 de Fevereiro de $1767=$ Ao Conde de Aranda, Prezidents do Cenfelho.

He Copia do original, que Sa Magefade for fervido communicarme. Madrid, I. de Vifarço de $1767=$ Conde de Aranda.

Em confequencia d, fobredito fe expediraó as Ordens feguintes para Hefpanba.

Carta Circular com Reineffa de outra Carta de Prégo com rezerva atodos os Povos, em que bavia Cazas da Com-

$$
\text { pan'ia; e fe dirigio aos furizes }
$$
Reaes Ordinarios.

D. Emetto a V.... incluza a Carta de Prég, g que naó absi1 rá até ao dia a de Abril, e entaó, interado do que nella fe contém, dará cumprimento ás Ordens, que comprehende.

Devo advertir a V.... que a ninguem drve communicaî que tem recebido efta, nem a Carta de Prégo, rezervada para o dia determinado, que tenho dito bem utendido que, fe agora de prezente, ou depois de a ter abero no tempo devido, rezultafle trasluzir antes do dia affignalad, por defcuido, ou facilidade de V.... que exiftia no feu poder fimilhante Carta de Prégo com limitaçaó de termo para a urzo della, ferá V.... tratado como quem faita á obrigaçó do feu officio, e he pouco attento ao que Sua Mageftade he encarrega no feu Real Serviço; pois encarregando-fe a V.... com efta precizaó o fegredo, prudencia, e disfarce neceflaio, faltando a taó devida obrigaçaó, naó ferá tolenavel a infricçaó della. Pelo méfmo Correio nie refponderá $V$..... copiand recibo da Carta de Prégo, apontando a data da minha Carta, e promettendo-me obfervar o que fica expreflado; por aflim convir ao Real Serviço. Deos guarcie a V..... muitos annos. Madrid, zo de Março de $1767=$ o. Conde de Aranda $=$ S.. D. N. 


\section{(4)}

Carta de Prígo.

Q Egundo a ordem de Remelfa depa Carta de Prégo, que fe $\checkmark$ deve absir precisame dis, comprebender a $V$..... pelo traslado do Real Decreto, que remetio inpreffo, afjinado pela minba mas, e pela Intrucçaó igualmente y fei rezolvido por Sua Mageftade; nba, en cumprimento do qua fecugaó 'e pratique pontualmente nos quă impartante feja que axpetdida pa: a a Defnaturalizaçaó, deftes termos claros, que vai expe Companbia de fezus.

Reinos, dos Religiozarte de Prégo, no dia 2, que ba de fer Aberta pois a Cart. por dever efta verificar-fe naquella a vefpera da fubleer do dia 3 , advertina $\mathcal{K}$.... com igual fe-

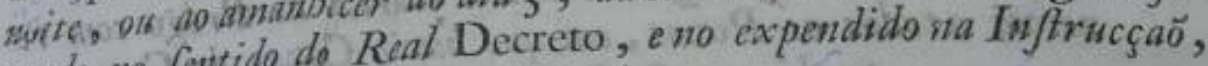
gredo no Pentido do Re fas difpoziçoens.

pa Efcrivaó, que $K$.... bowver de empregar nefas diligencias, naó ba ce communicar nada ate pouco antes de as comefar; e ainda ifto on acautella de o naü apartar do fen lado tanto que o wiver intorisialo acthes.

Nenbuma Caza de Jezuitas fe acba taó deftituida; qrue falte noquella bora alsum dinbeiro effectivo para a fua confervaçă, ou fructos exiftentis para fe converterem para ella :ie affim quando da primina effecie via acbar $V$... o fufficiente para o gafo do aviamenta até c Caixa deftinada, paffará a vender a quantidade de fructos corm/pondente ás difpezas da viagem: e quando o diuberro, efrusos naö baftarem para a. fupplemento da fabida, e condugyañ defta Regulares, fe valerá $V$.... dos fundos de Proprios, e Ailirios com a qualidade de os reintegrar; $e$ naō os alcanfando, pdirá $V . .$. dinbeiro a algum particular, afjegurando-lbe V.... por efcrito em nome de Sua Magefade a prompta reftituiçä, fem que je retarde o embolfo ao intereffado, nem. fe lhe fufciti a menor difputa para o feu pagamento, pois fe lbe ba de facilitar immediatomente das Caixas Reaes, e Sua Mage tade ba de aeitar fimilhante ferviço.

os rivelo primeiro Correio me parts ecsisdo a rifpeito defa feu cumprimento arid ammifjaó; devendo advertin a $V .2$ que $\theta$ - th 


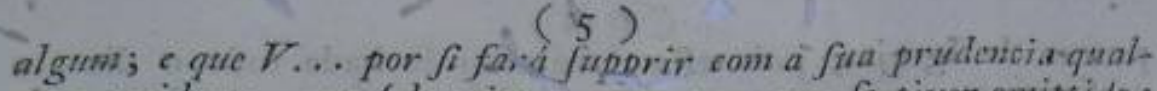
quer accidezte, que fobrevier, ou ponto, que fe tiver ominidos governando-fe pelo efpirito geral, que de li produzen o Real

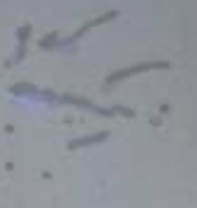
Decreto, a Infruç̧aó, e ofta Minba Ordem.

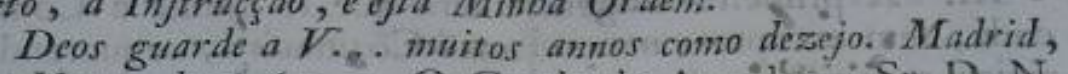
20 de Marģo de $1767 .=\mathrm{O}$ Conde de Arandá $=$ Sr. D. N. NOT A. A yuelles lugares, oride fe anticipou a execnçaó, fe advertio anticipadamente o feguinte. "Naó obftante que eftava difpofto naó pôr em effeito efta rezoluçaó até á noite de 2 para 3 de Abril, V... a ex cutará na de 31 defte para a madrugada do I de Abril, ep razaô de fe ter adiantado tambem o mefmo dia nefta Corte, e lugares proximos a ella. Madrid, -28 de Março de $1767 .=$ Aranda.,

- $O$ Real Decreto de Execuçaó be á letra o mefmo, que fica aflima, e de que fe remetteu hum tras ado igual a cada Commiffacio.

Inf fruçaó do que devem executar os Commifaros na Defnaturalizaçau, e appreben laś dos bens, e fazendas los Fezuitas neftes Reinos de Hefpanba, e Ilbas adjacentes cin conformids- de do que foi rezulurdo por Sua Magejade Catbolica.

1. A Berta efta Inftrucçaó, que eftará ceriada, e fecreta, A na vefpera do dia affinado para o feu cumprimento, o Executor fe inteirará bem della: fazendo reflexá nos feus Capitulos; e diffimuladamente lançará maó da Tropa prezente, ou immediata; ou na falta defta fe reforfará con outro auxilio á fua fatisfaçaó ; procedendo com prezença de animo, defafogo, e precauçaó, tomando antes de amanhecer as cntradas do Collegio, ou Collegios : para o que elle meimo no dia antecedente procurará em pelló certificar-fe da fia fituaçaó inteivor, e exterior; porque efte conhecimento pratico the facilitará o modo de impedir que ninguem entre, ou faia fem o feu conhecimento, e noticia.

- II. Naó revelará os leus fins a pefioa alguma, até que pela manhäa fedo, antes de abrirem as portas do Collegio na hora regular, fe anticipe com algum precexto, diftribuindo as ordens, para que a fua 'Tropa', ou Auxlio tome pela parte de dentro as entradas; porque naố dará lugar a que ie abraó as

C artas 
portss da Igreja; pois efta deve ritar fechada todo o dia, e Collegro. -III. A primena dilig o Irmaó Cozinheiro, requerendo pridade, fem exceptuar netror em nome de Sua Mageftade, fameito para iffo ao Superie da esmpainha interior particular, de que zendo-le ifto a toque da dacommunidade; e nefta fórma, effe fervem para os actos com eftimunhas feculares abonatando prezente o Efcro dc Defnat ralizaçaó, e apprehenfaó dos das, lera o Real Dexpreffando no Sermo os nomes, e claffes de todos os Jezuitas concurrentes.

IV. Ordenar-lhes-h que fe confervem na Caza Capitular: e fe fará Auto da aujes laó os moradores da Caza, ou páflageiros, e Colleģios, a que pertenceri: : tomando por efcritc. os nomes, e dettino dos feculares do ferviço, que habitaó dentro della, oufóménte concorrem de dia, para n hir huns, nem entrar outros no Collegio fem gravilfima cauza.

V. Se houver algum Jezuita fóra do Collegiv, enı outro $P_{2 v o}$, ou lugar, que naó fique diftante, requererá ao Superior que o mande chamar, para que fe recollra logo, fem dizer mais nada; dando a Carta aberta ao Executor, que a remetterá por pefloa fegura, que naó revele nada das diligencias fem perda de tempo.

VI. 'Feita à intimaçaố, procederá fucceflivamente na companhia dos Padres Superior, e Procurador da Caza á apprehenfaó judicial de Archivos, papéis de toda a efpecie, livraria commua, livros, e efcritorios de cubiculos; feparando os que per. ncem a cada Jezuita juntos em hum, ou mais lugares; entregandó-fe das chaves o Juiz da Commiffáó.

VII. Profeguirá confecutivamente o fequeftro com particular vigilancia : e tendo de antemaó pedido as chaves com cautela, apprehenderá todos os dinheiros, e os nuais effeitos de importancia, que ahi houver por qualquer titulo de renda, ou depozito, que for.

VIII. As alfaias da Sacriftia, e da Igreja baftará que fe fechem, para que fe inventariem a feu tempo com affiftencia do geral dos vutros I ümon: 


\section{$(7)$}

cleziaftico, ou o Paroco da Fréguezia, na falca de Juiz Eccleziaftico ; tratando-fe com- e refpeito, - decencia devida, efpecinlmente os Vazos fagrados i de modo, que naó haja isreverencia, nem o menor acto irrelig azo : affinando o Auto o Eccleziaftico, e o Procurador juntamente coin o Commiftario.

IX. $\mathrm{H}_{\mathrm{a}}$ de fe ter pąrticularifima attençaó pàra',que, naó obftante a preffa de tantas inftantaneas, e efficažes: diligencias judíciaes, naô falte por modo algum a mas commoda, e pontual affiftencia aos Religiozos, maior sinda do que a ordinaria, fe poffivel for: como tambem para qu: fe recolhao a defeanfar ás fuas horas regulares, ajunt: ndo as camas em luggares convenientes, para que naố eftejaó muito difperfos.

X. Nos Noviciados, ou Cazas, em que houver algum - Noviço por cazualidade, fe haó de feparar immediatamente os que naó tiverem feito os Votos Religiofos, para que defde aquelle momento naó communiquem com es mais, tranfportando-os a caza particular, donde com plen liberdade, e conhecimentor da profcripçaó perpetua, que ao: Individuos da fua - Ordem fe impoem, poffaó tomar o partido, a que a fua inclinaçau os induzir:- A eftes Noviços fe dev affíttir por conta da li eal Fazenda em quanto fe rezolverem, iegundo a decla-

raçaś de cacia humi, qü: ha de rezultar por auto aflinado com o feu nomé, e por fua mau, para o incorpcrar, fe quizer feguir a Companhia ; ou pôr em liberdade a zu tempo com os veftidos de fecular o que tomar efte ultimo jartido, fen que o Commiflario permitta fuggeftoens, para qui absace hum, ou outro extremo, para aflim ficar de todo uniamente ao livie arbitrio do intereffado: bem entendido que $k$ lhe naó affinará pençaó vitalicia por fe achar em tempo ce fe reftituir ao feculo, ou paffar a outra Ordem Religiofa, teido cor'lécimento de que fica defnaturalizado para fempre.

XI. Dentro de vinte e quatro horas, contidas defde a em que for intimada a Delnaturalızaçaó, ou o mas de preffa que poder fer, fe haб de, encaminhar os Jezuitas en direitura defde cada Collegıo aos Depozitos intermos, on Caixas, que haó de ir affinadas, bufcando-fe a carruajem newfaria na mefma povoaçaó, ou fuas vizinhanfas.

XII. Attendèndo a ifto, le deftinaó as Cairas geraes, ou Paragens feguintes para fe juntarem. 


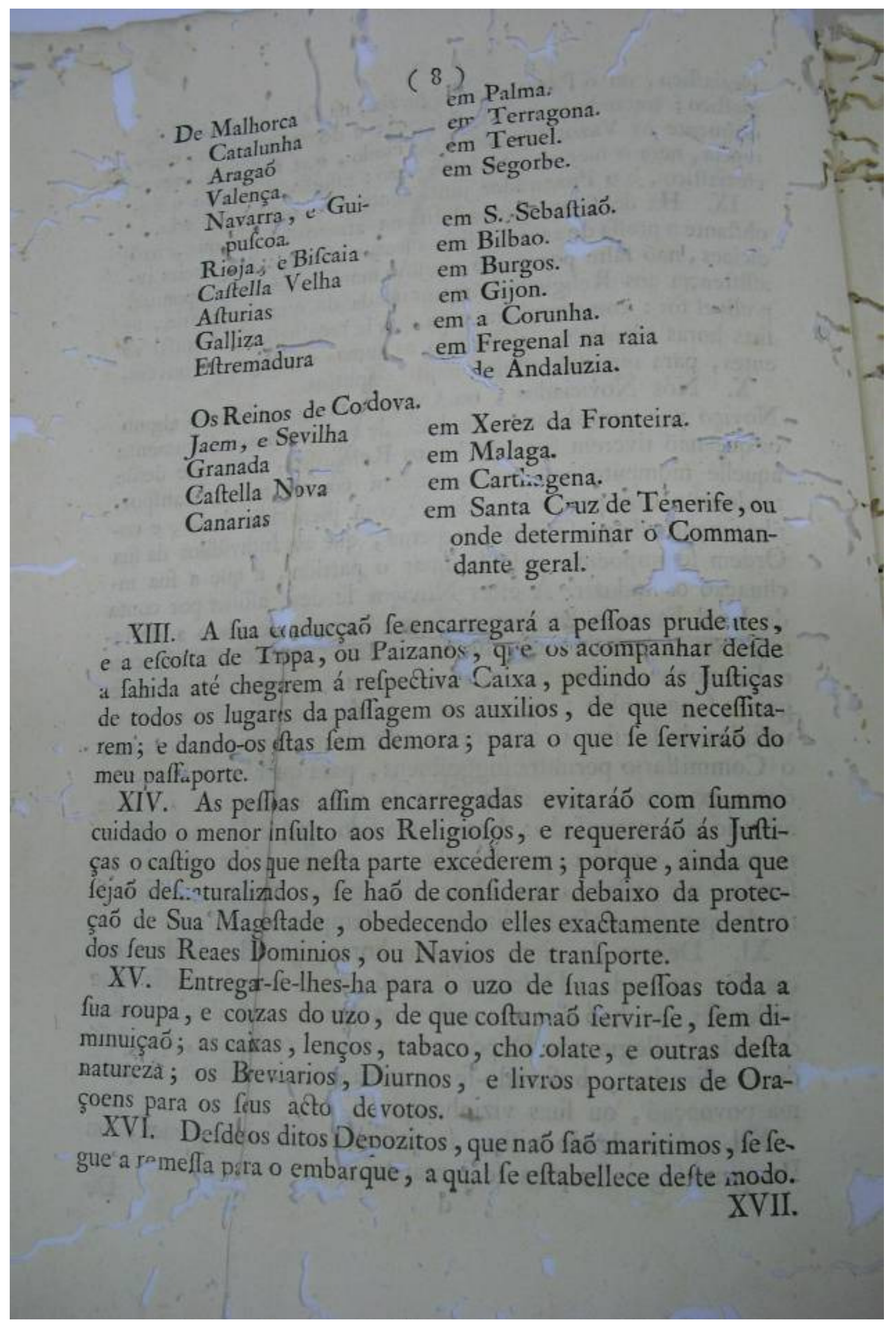




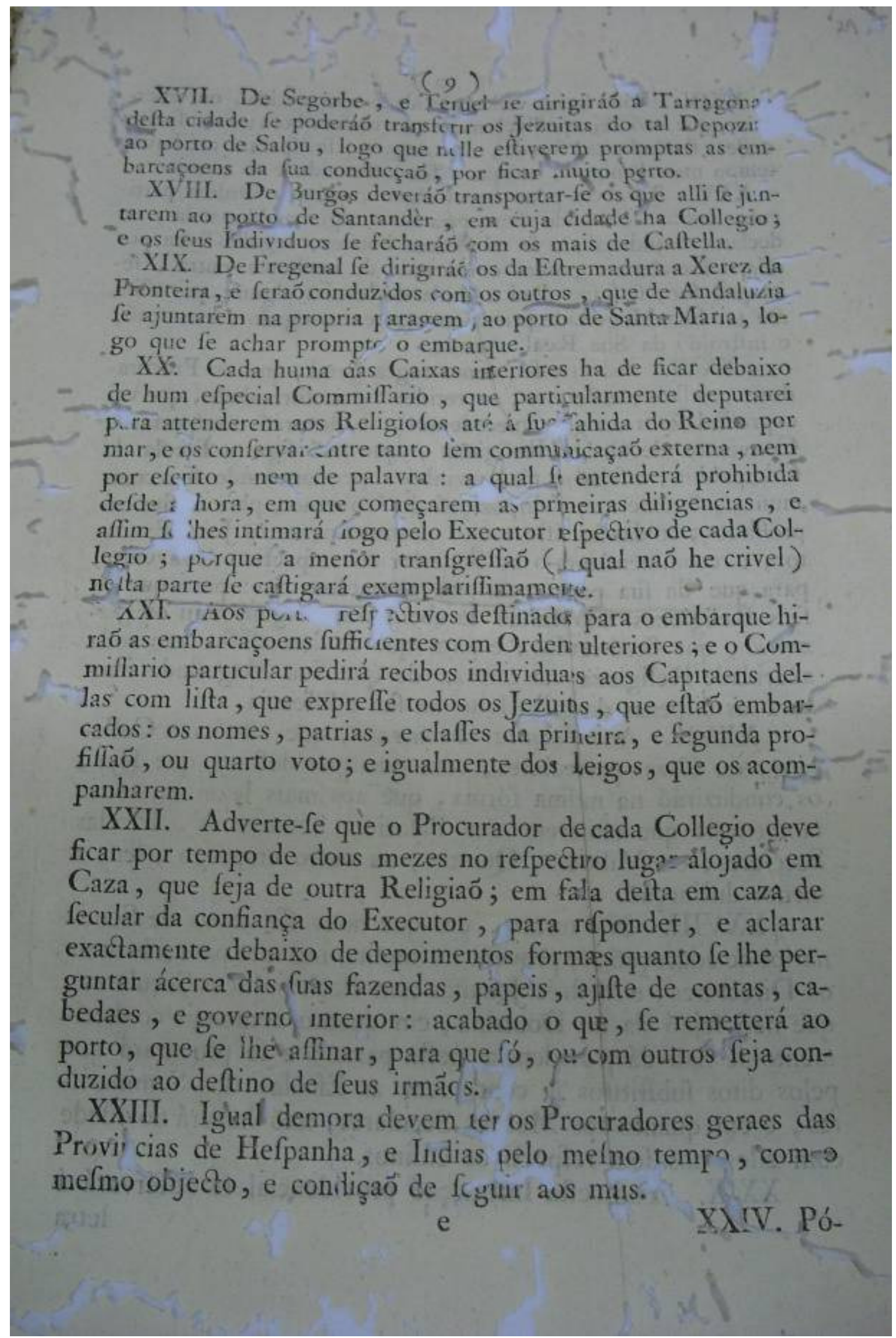




\section{(ro ) nui crecida, ou enfer-}

viv. Póde haver veílus de ro na mefma hora; e a refpeito

as, que ná feja polfivel nu na engano, le endade fe termine. telles, fem admitcirfia, ou que a lua en, que $p$ r Ordem parti-

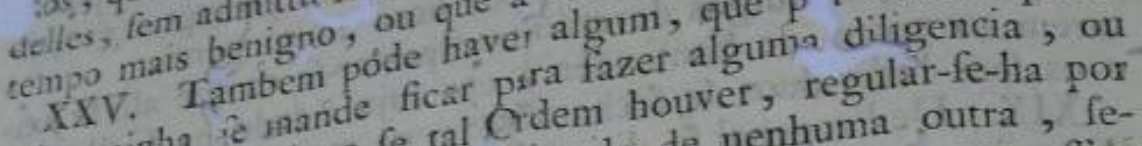
cular minha jadicial; e fe tal cratude de nenhuma outra, fedeclaracas jutor: porém em fidida de Jezuita algum, por affin ella o far, fe fúpenderá a flbremento encarregado a execuçaó, me ter Sus Mageltade preal voitade. $e$ initruido da Sua Rerre-fe, omo regra geral, qdverte

velhos, enfermos, uu retidos na conteráó traníportai a dores, velhos, artig ancecedentes, que naś figa a Eicola da expreflada nos Orden Religioza, que mermanecendo fem comCorventos de e ejá es mais vizinhos: Germerno, para ó fins exCompantiá externa, dripoziçaó do Governente o Juiz Execumulfiados; cuidando áfto muito promptar do refpectivo Cusvento, tor, e recommendando-o ao Superior mefmo fim: para que os

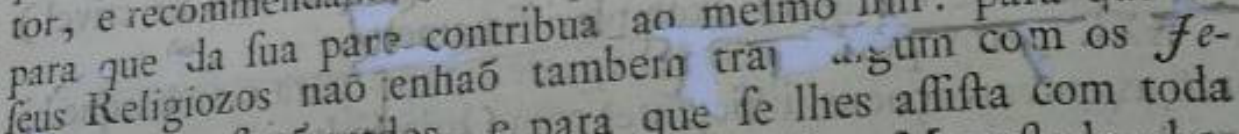
zuivas, que ficaó retdos, e para que fe lhes affifta com toda a caridade Religioza : na certeza de que Sua Mageftade abonará as difpezas dn zaßto feito na fua affiftencia.

XXVH. Aos Fezwitas Francezes, que eftaó em Collegios, ou Cazas partculares, com qualquer deftino que feja, os conduziráó na mifma fórma, que aos mais Jezuitas; como tambem os que eftiverem em Palacio, Seminarios, Efcolas Seculares, vi Militires, Quintas, ou outro emprego , fem a menor diftincçá.

XXVIII. Nas terras, em que houveffe cazas de Seminarios de educaçaó, fe proverá no mefmo inftante para fubftituir os Directores, e Meftres Jezuitas com Eccieriafticos Seculares, que naô fejaó da fta Doutrina, em quanto com mais conhecimento fe naó dá providencia nefta parte : e fe procurará que pelos ditos fubftituos fi ce ztit uem as Efcolas dos Seminariftas; e em quanto los Mel rec Seculares, naó haverá novidade cum eller nos fersis refpecti os enfinos.

XXIX. ioda efta Inttrucçaó providencial fe obfervará á letra 


\section{(ii)}

letra psios Juizes Executores, ou Courmifarios, a quem ficerá o a titrio livire para fupprirem fegur to a fua prudencia o que fe tivef omittido, e pedirem as circumf.dncias mutiores do dia; ma naó poderáó alterír neda do fubftancial, nem uzar da fua con defcendencia para .uftrarem no mais minimo porto o efpirito do que fe manisid. que fe reduz á prudente, e prompta expulfá dos -Jezuitas ; pôr em boa arrecadaçaó os feus effeitos; pacifica, decente, e fegura concúcçaó đas fuas pefloas, para $s$ Caixas, e lugares do Embarque, tratando-os com alivio, e caridade, e impedindo-lhes toda a communicaçaó externa por efcrito, ou de palavra, fem diftincçaó alguma de claffe, nem de peffoas ; affiftindo pontualmente ás diligencias para que da fua infrecrá̆ rezulte o acerto, e zelozo amor d Real fervico, com que fc tiverem pratiado ; avizando-me ficceffivamente legundo fe for adiantando. Que he o que devo advertir conforme as Orden ${ }^{2}$ de Sua Mageftade, com quz me acho, para que cada hum ru, feu diftricto, e no feu cazo fe regule pontualmente pelo "u teor. fem the contravir de modo algum. Madrid, I de Março de $1767=0$ Conde de Aranda.

Para que os Tribulaes Superiores las Provincias efrivelfem informados pontualmente da providencia geral, e podefem au-

$$
\begin{gathered}
\text { xilialla, fe efreveu aos feus Prezidentes na } \\
\text { fórma Jeguinte. }
\end{gathered}
$$

R Emetto a V.... incluza effa Carta de Prégo, que naó R ha de abrir até ao dia quinta feira 2 de Abril : e informado entaó do conteúdo nella, procederá ao cumprimep:j, que expreffa.

Convém ao Real ferviço que $V$.... naó manifefte toda a vez que efta receber, nem ainda ao feu Secretario, nem a outra peffoa da fua maior confiança, que fe acha com Carta de Prégo, que fó deve fer at erta em dia determinado; e aflim efpero que o execute $V . .$. , attentendo ao que the encarrego, ás fuas circumftancias peffoaes, e ao lers ço de Sua $\mathrm{Ma}$ geftade. Deos guarde a. $V_{1} \ldots$ muitos annos. Madrid, $2 u$ de Março de $1767=0$. Conde de Aranda. 


\section{$(12)$ \\ Carte de Prigo rezcruada.}

TT Areado rezolvido EIRey N. Ser hor a Defnaturalizară L te poda a Ordem Religioza da comprimento, como Reaes Do Real Decreto junto: e fendo efta execuçaó huma das qie requerem uniformidude de tempo para a fua pratica, e uniformidade de refrás para o feu acerto: tenho paflado $\mathrm{d}$ : rectamente as refpectivas Ordens a caditos Regulares, onde exiftir huma, ou mais Cazas dos ditos Regulares, a fim de que fe verifique geralmente no dia 3 de Abril: de cujas difpoziçoens Ce informará V.... pelo exemplar incluzo; que $\mathrm{fe}$ dirige a todas as paŕes.

Podera havei occorrido alguma equivocaçaó, ou neghgencia ná comy is indendo hum, ou outro Collegio pela fua pequenes, e retiro; nefte cazo governando-fe $V$... pela lifta, que vai juata, fe acazo tiver effeapado algur no deftricto đ̌effe Tribunal, immediatamente dará Y... providencia para que debaixo das maîus regras "ammas nelle o mefrm? que nos outros fe tem executado; 6 ifto 1 em perda de tempo; ailda que tenha precedido a execuçaó a refpeito dos conteúdos a hita.

O Real Decreto geral para que confte á Naçaó, e Tribunaes a natace de Sua Mageftade, fe publicará nefta Corte no dia prefixo da execuçaó ; e entaó fe communicará uni. verfalmente. Por hora governar-fe-ha V .... e o Tribunal, que eftá a feu cargo, pelo que vai incluzo, com a advertencia de que $V \ldots$ naố ha de manifeftar nada nelle melmo até a manhăa do dia 3 , em que já eftará intimado effectivamente, e fe terá dado principio á apprehenfaó dos bens.

A' vifta defca, e inftruido effe Tribunal de todos os papéis, que faó geiaes, attenderá a dar providencia por fi ao que fe tiver omittido, e zelar fob e os outros executores aquilto em que fe defcuidarem; mas fem lhes interromper as fuas funçoens, for tie cada hum ha de fer refponfavel da paite, que the toca. 1 eos guarde a V ... muitos annos. Madrid,

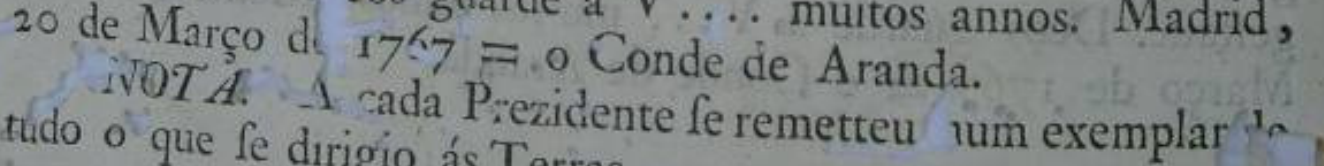
thido o que fe dirigio ás Terras. 
Lifta das Cazas, Collegios;, . Re idencias dos Regulares da Companbia de Fezus em Hespanba, e Ilbas adjacentes.

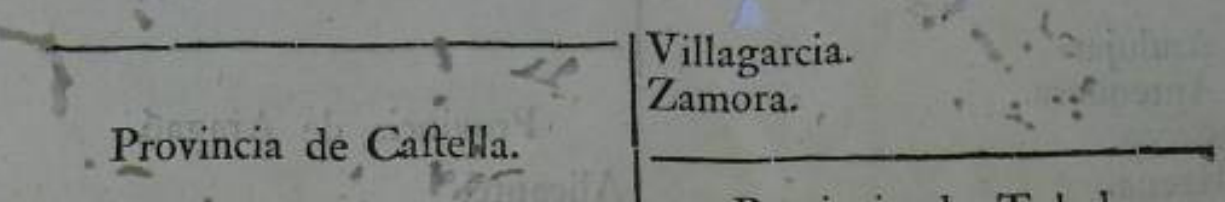

Areválo. Avila. Azcoitia. Bilbao. Burgos.

Coorunha. Leaó.

Lequeytio. Logronho.

Loyola. Medina del Campo. Monforte de Lemus. Monterry. Onhate. Ordunha.

Orenfe.

Oriedo.

Palencia.

Pamplona.

Ponte Vedra.

Salamanca.

Santander.

Santiago de Galiza.

S. Sebaftıoó.

Segovia.

Soria.

Tudela.

Vaihadolid.

Vergara.

Vitoria.

Villa Franca lel Bierzo.

Provincia de Toledo.

Albacete.

At.alú de Nares.

Alcaráz.

Almagro.

Almonacid.

Badajoz.

Belmonte.

Caceres.

Carabaca.

Carthagena.

S. Clemente.

Guenca.

Daymiel.

Fuente del Maeftre.

Guadalaxara.

Huete.

Jezus del Monte.

Lherena.

Lorca.

Madrid.

Murcia.

Navalcarnero.

Ocanha.

Oropeza.

Placencia.

Segura de la Sierra.

Talavera de la Keyna.

Toledo.

Villarejo de Fuentes.

Yẻbenes. 


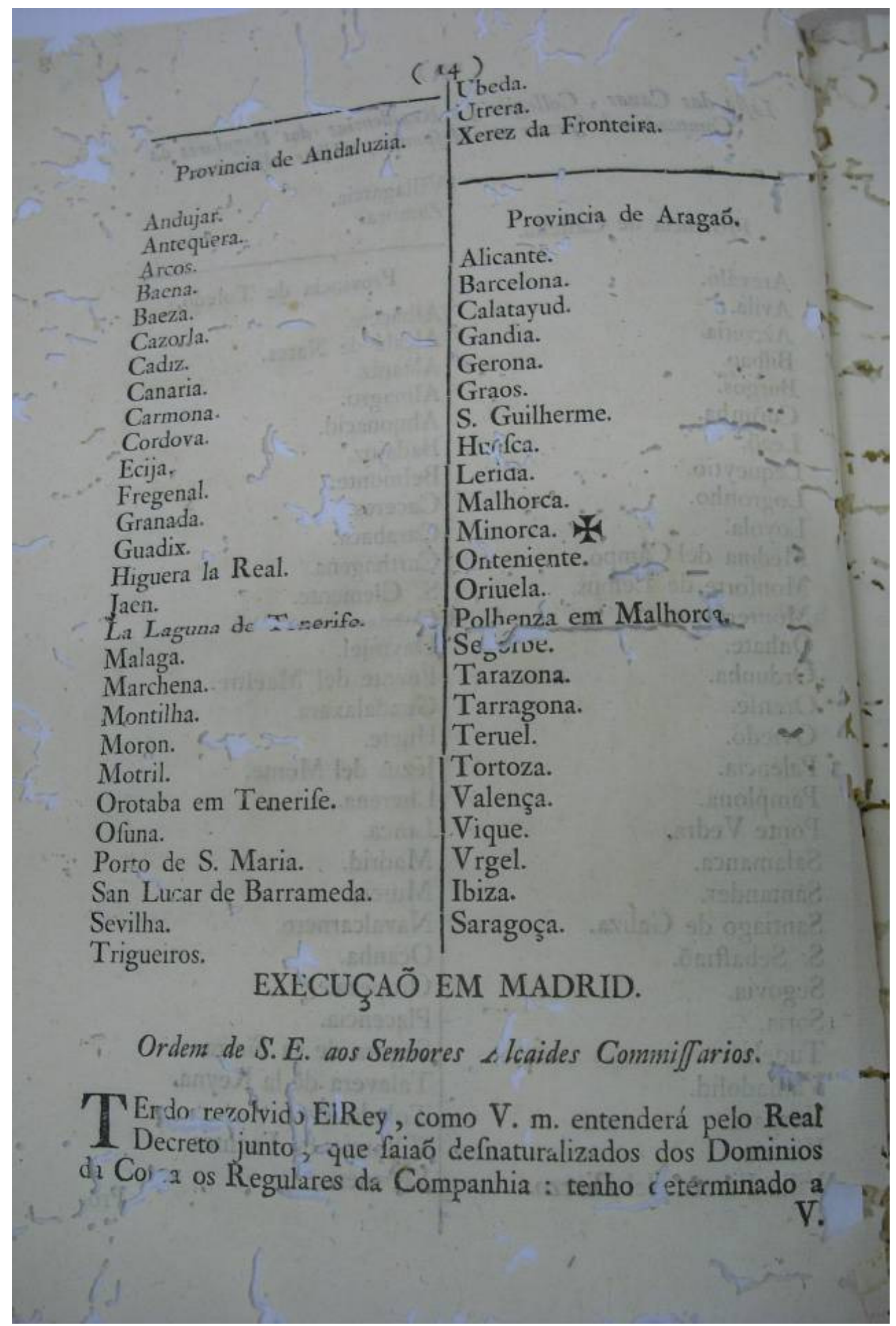




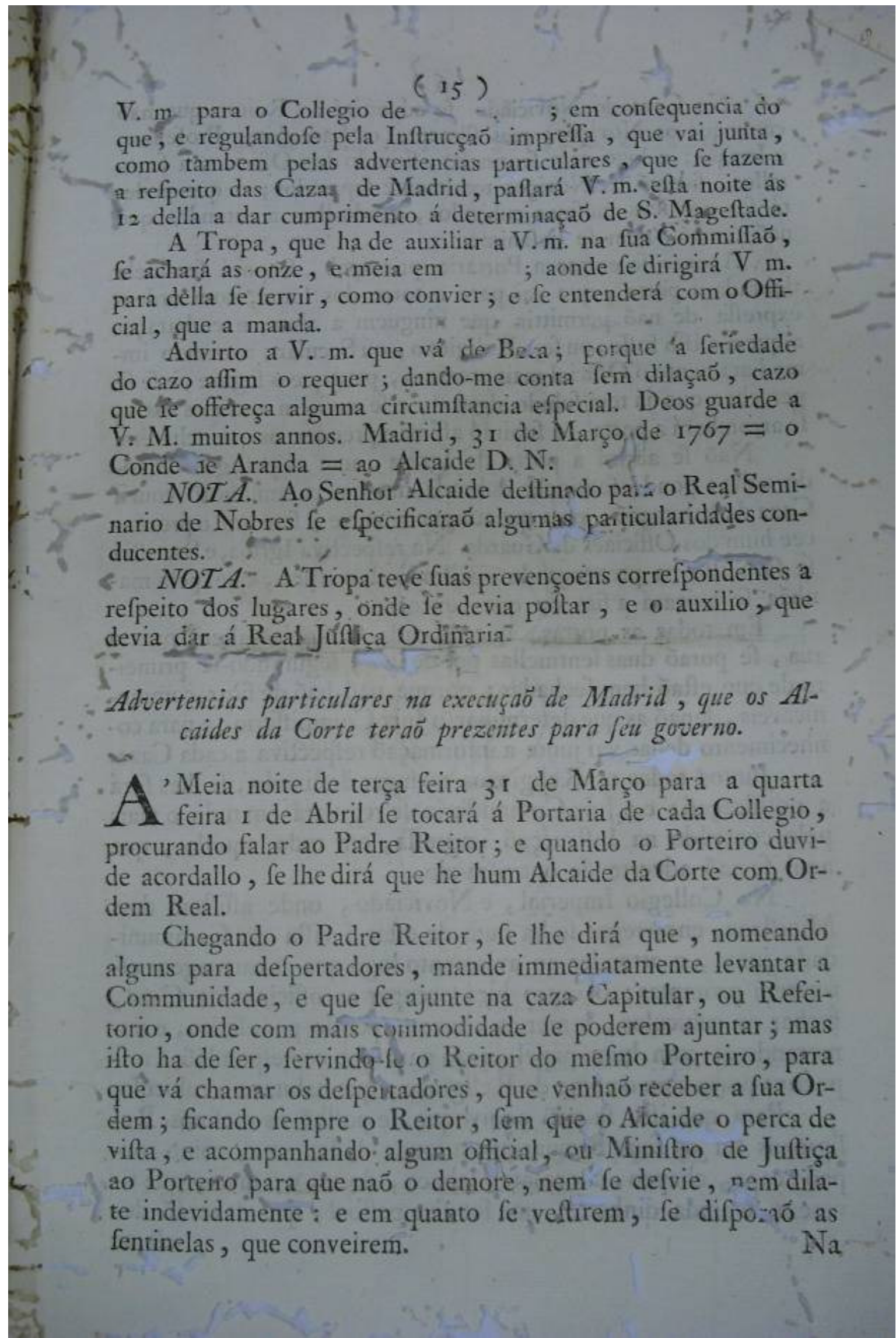


( 16$)$

$\mathrm{Na}$ Caza do Noviciado fe advertirá do Reitor que naó convoque os Noviços; mas fómente os Sacerdotes Profelios, e Irmaós; e hoo Noviços totalmente feparados; o que poderallos, ficarás os mefmos cubiculos, ciando-lhes a entender que rá fer pos feus be defanimem.

naó temaó, ncm le Cor a Portaria principal, ê porá fentinela

Apenas le entra vai para a torre dos finos, com ordem dobrada á porta, quétit que ninguem a abna, e embaraçar exprefla de nao per ou fej. Raligiozo, ou Secular; avizando ima quem a iffo folle, Official mais proximo, para que o fegure ; e fe fe mediatamente já tem fubido alguem, e fe ouvirem tocar os finos, le arrombará a porta , e fubiráó aftima a prender os que acharen.

Naó fe abri-á a porta da Igreja, nem os poftigos em tỏdo o dia; ponds fentinela dobrada nas que communicaó coma Caza da habitaçaô, para que ninguem entre, fem que o prezencee hum dos. Officiaes du Guarda. Na refpectiva Igreja, e Sacriftia fe fará ifto na prezença do auxilio siccleziaftico, que pela manháa fe avizará a fim de que concorra.

Em todas as portas, que de cada Collegio fahem para a rua, fe poraó duas fentinellas por de it.., legur indo-ic primeiro de que eftaó bem fechadas; porque naó haó de ficar communicaveis, fenaó as que determinar o Juiz Commiflario ; e para conhecimento dell ac vai junta a informaçaó refpectiva a cada Caza.

Juntos todos os Religiozos no lugar deftinado, fe lhes fará. a notificaçaó : e o Juiz Commiffario fe regulará em tudo o mais pelo conteúdo na Infrucçaó imprefla, em tudo aquillo, que aqui fe naó adverte de outro modo.

Nie Collegio Imperial, e Noviciado, onde affiftem dois Miniftros, encurregar-fe-ha hum de eftar á vifta da Communidade junta, e attender ao aviamento logo que as carruagens eftiverem promptas: o eutro hirá occupar as officinas da Caza, fechar os cubiculos, tomar as chaves, poudo por efcrito, e numerando-as com hum papel prezo para gae correfpondaó á refpectıva porta còm o nôme do Relígiozo, que habitava o cubiculo.

Para que ifto fe naó equivoque, e poffaó os mefmos Religiozos ter os feus Breviarios, a roupa de feu uzo, como roupaö, capa, chapeo, diocolate, tabaco, doce, e o mais, que tiverem, e ainda dinherró, que for feu peftoal, que deveráó declarar 


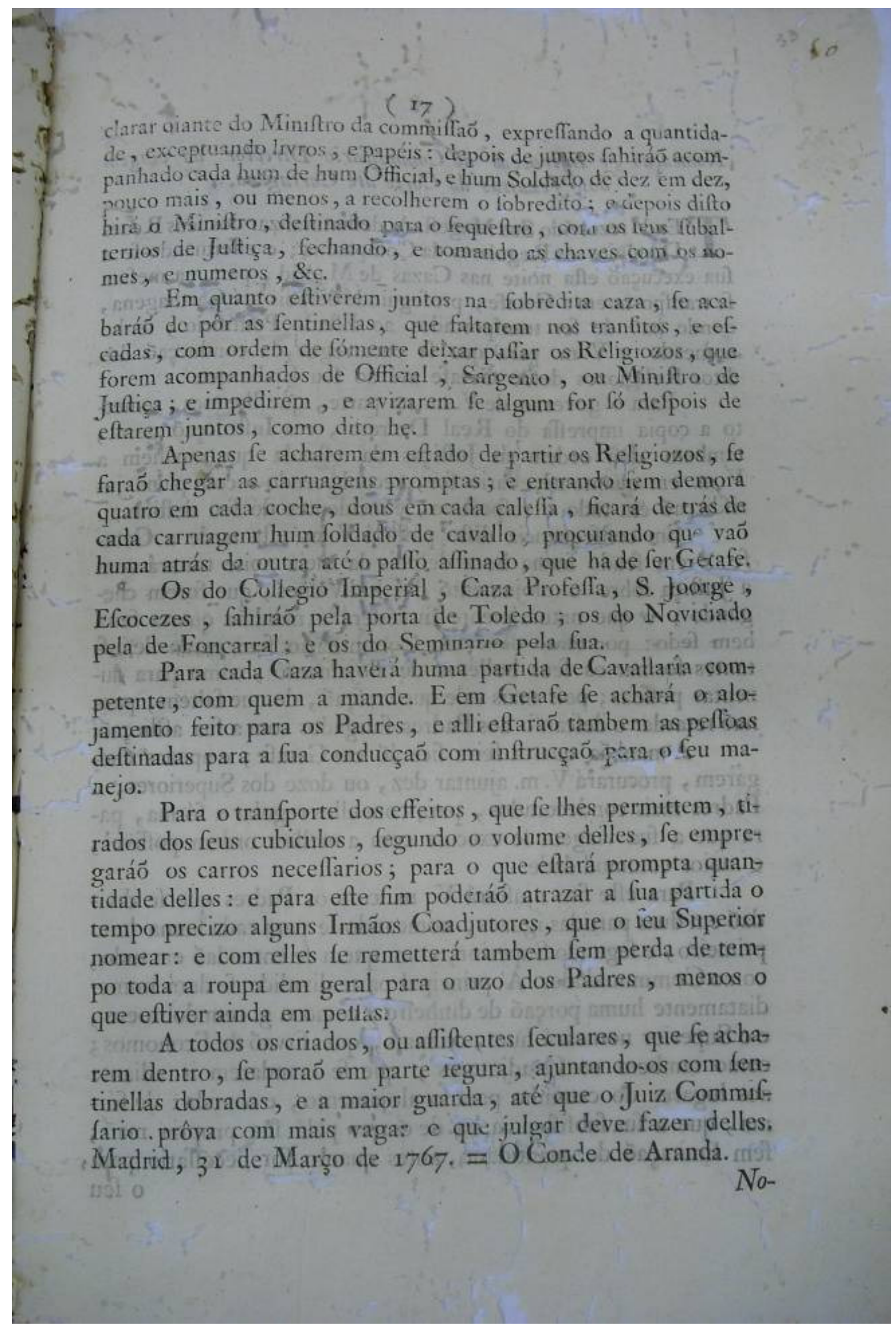




\section{(18)}

Nomeacaó, e Ingruçato do Commiffario Director da vingeng

Endó rezolvido Sua Mageftade defnaturalizar dos feus $\mathrm{R}$.

1. Duminios os Regulares da Companhia; e effeituando-fe a fua execuçaó efta noite fe tranfportarem a tranfportados ao Eftado Pontificio; tenh, donde haó de ler tara que fe encarregue da conducçaó do nomeado a . melde Getafe até ao feu Embarque.

Para o governo de V.m. na parte, que lhe toca, remetto a copia imprefla do Real Decreto, e a Inftrucçaô geral; tambem dou ordem ás Juftiças da eftrada que auxiliem a $V . m$. em quanto neceflario for, reconhecendo-o com plena jurifdicçá́ em udo o refpertivo, e incidertes do feu deftino.

5 Em confequencia difto paffará V.m. elta tarde a Getafe: e em fendo huma hora defpois da mieia noite tratará com a Juftiça fobre o alojamentó dis Irrdividuos, que forem chegando ; o que naturalmente fuccederá á manhảa quarta feira bem feith. por tanto devera o. Commilfario fem perda de inftantes formar os feus bolletos de alojamento, como para duzentas peffoas; pois mais vale que crefçaó, do que faltem, para naó retardar o defcanfo aos Padres fatigados com a fua afflicçaó. A'manłăa quarta feira ficaráó em Getafe ; e apenas chegarem, procurará V.m. ajuntar dez, ou doze dos Superiores, é Padres mais condecorados, para com elles regular a fórma, para que a fua viagem fe execute com a melhor ordem poffivel, e maior commodidade.

- Para efte fim ajuftará $\mathrm{V}$. m. com os Padres que fe dividaó em duas partidas iguaes, nomeando-fe para cada huma hum primeito, e fegundo Superior, com quem fe entendaó em tudo, como Communidades. A principal parte dividida fe dará immediatamente huma porçaó de dinheiro, como v. g. cem dobroens ; e o Superior nomeará hum, ou mais, que firvaó de Economos; como tamben os Coadjutores, que fe mandarem ir adiante aos lugares do caminho para o alojamento, e comida: de fórma, que a fua fubfiftencia ia de esrren pela fua propria maó, fem limitaçaó do quantidacto, antes quanto for necellario para o feu 


\section{$(18)$}

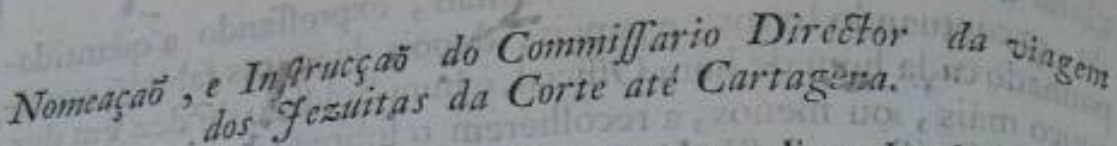
TEndó rezolvido Sua Mageftade defriaturalizar dos feus $\mathrm{R}_{\text {eaes }}$

1. D, minios os Regulares da Companhia ; e effeituando-fe a fua execuçaó efta noite Getafe, profeguindo defpois até Carthage fe tranfportarem a Geranfortados ao Eftado Pontificio; terh, donde haó de fer tara que fe encarregue da conducçaó ho nomeado a V.m. par

Para o governo de V.m. na parte, que lhe toca, remetto a copia imprefla do Real Decreto, e a Inftrucçaô geral; tambem dou ordem ás Juftiças da eftrada que auxiliem a V.m. em quanto nécetlario for, reconhecendo-o com plena jurifdicçá ém tudo o fefpestivo, e incidentes do feu deftino.

5 Em confequencia difto paffará V.m. efta tarde a Getafe: e en fendo huma hora defpois da nieia noite tratará com a Juftiça fobre o alojamentó diśs Individuos, que forem chegando ; o que naturalmente fuccederá á manhăa quarta feira berm fedn: por tanto dovera a Commiflafio fem perda de inftantes formar os feus bolletos de alojamento, como para duzentas peffoas; pois mais vale que crefçaó, do que faltem, para naố retardar o defcanfo aos Padres fatigados com a fua afflicçaố. - A'mankạa quarta feira ficaráó em Getafe; e apenas chegarem, procurará V.m. ajuntar dez, ou doze dos Superiores, c Padres mais condecorados, para com elles regular a fórma, para que a fua viagem fe execute com a melhor ordem poffivel, e maior commodidade.

- Para efte fim ajuftará V. m. com os Padres que fe dividaố em duas partidas iguaes, nomeando-fe para cada huma hum primeito, e fegundo Superior, com quem fe entendaó em tudo, como Communidades. A principal parte dividida fe dará immediatamente huma porçaó de dinheiro, como v. g. cem dobroens; e o Superior nomeará hum, ou mais, que firvaó de Economos; como tamben os Coadjutores, que fe mandarem ir adiante aos lugares do caminho para o alojamento, e comida : de fórmal, que a fua fubfiftencia áa de corren pela fua propria maó, fem limitaçaó dếquantidacio, antes quanto for necellario para o feu 
(20)

Nab́ davido que os Padres por fi mefmos evitaráó todo. motivo de perturbacas : por tanto atreva a aggravallos, procedendo feriainconlideradamente contra $\mathrm{a}$ de ique.

meate contra arthugena farí V. m. entrega a quem eftá encarrega: do da Rei off. ulrerioe dos ditos R. Ternando Coronel, e a de

A c...ruagem de fer paga, como as mais, pela corra Geral. D. Filippe Peres ha do caminho na hida, e volta aftino a $\mathrm{V} . \mathrm{m}$. A cada Official, Sargento, Cabo, e Soldado da Ffcalta fe the dará dnbrada paga diaria daquella, que recebem; e thes fará V.m. aflùir com paó, com palha, elevada, dando recibo do que mandar a cada bom.

Qualquer gafto e raordinario pagará a-V.m. D. Filippe Peres.

He corza difficultoza que poffa eu advertir a V. m. outros varros pontos, que haó de occorrer, prudencia de V.m. deverá expedir por fi: para iीto dou a V.m. plena faculdade; por-

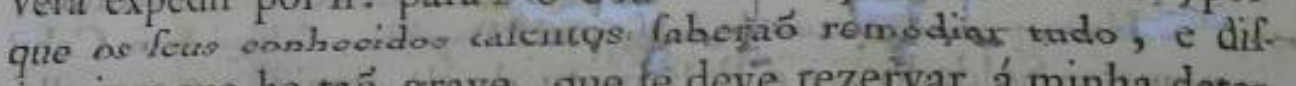
tinguir o que he taó grave, que fe deve rezervar á minha determınaçaó. Deos guarde a V.m. muitos annos. Madrid, $3 \mathrm{I}$ cte Março de $1767=0$ Conde de Aranda $=$ Senhor D. Joaó Acedo Rico.

NOT $A$. A Órdem dada para o uzo das Efcoltas, reduzida cada huma a hum Official Subalterno, hum Sargento, e dez Soldados montados, foi protegerem de qualquer infulto os Religiozos conduzidos; attenderem á pontualidade das carruagens, e obediencia dre shçes adiantarem-fe ó Cabo, e quatro homens com os Coadjutores de alojamento, e Paffaporte para exacto cumprimento das Juftiças, e auxiliar ao Director Commiffario no que elle julgar converiiente.

Por ultimo mandou S. Excellencía que dos Collegios da mefma Ordem fe levem colchoens, lençees, e cobertores com roupa de meza para os dives zos lugas es do embarque, para que todos os Religiozos tenhaó na viagem as pofliveis commodidades. 


\section{PRAGMATICA}

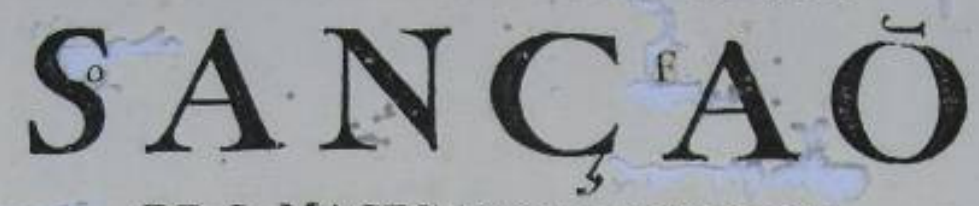

DE S. MAGESTADE CATHOLICA,

COM FORÇA DE LEY

Para a defnaturalizaçaó dos Regulares da Companhia, dos feus Reinos, apprehenfaó dos feus bens temporaes: e prohibiçás do feu reeftabelecimento em tempo algum; cóni as mais precaucoens, que - riella ie contem.

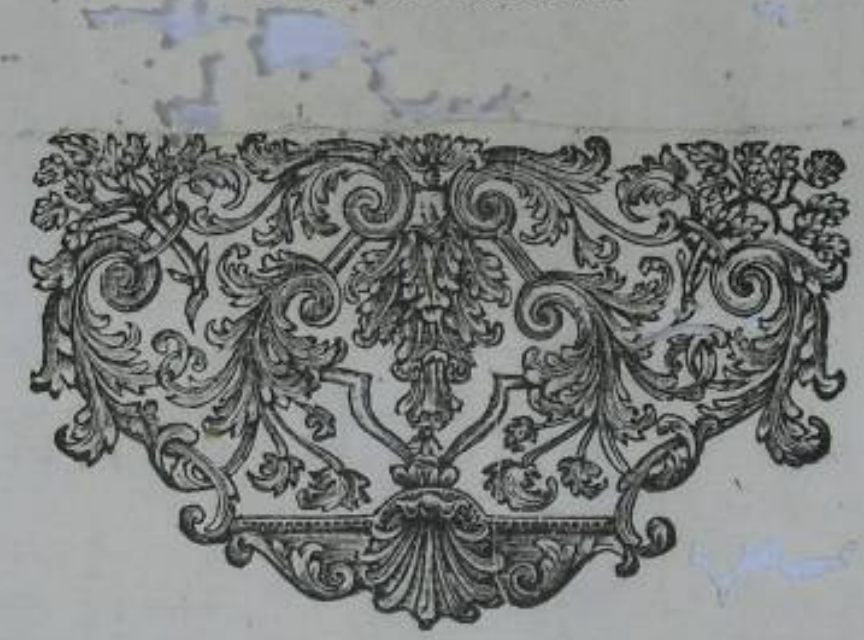

\section{I S B O A,}

$\mathrm{Na}$ Officina de ANTONIO RODRIGUES GALHARDO.

Anno 1707. 
( 3 )

OM GARLOS, por graça de Deos

Rey de Caftella, de Leá, de Aragaô, das duas Sicilias, de feruzalem, de Navarra, de Granada, de Toledo, de Valenfa, de Galiza, de Mialhorca, de Sevilha, de Serdanha, ac Cordova, de Corfega, de Murcia, de Jaem, dos Algarves, de Algecira, de Gibraltar, das Ilhas Canarias, das Indias Orientaes, e Occidentaes, Illkas . e Terra-Firme do Mar Oceano, Archiduqué de Auttria, Duque de Borgonha, de Brabante, e de Milaó, Conde de Abspurig, de Flandes, Tirol, e Barcelona; Senhor de Bifcaia, de Molina, \&c. Ao Sereniffimo Principe Dom Carlos meu muito amado, e prezado fitho ; aos Infantes ; Prelados, Duques, Marquezes, Condes, Ricos-Homens, Priores das Ordens, Commendadores, e Sul Comendadores, Alcaides dos Caftellos, Cazas fortes, e baixas : e aos do meu Confelho , Prefidente, "e Quvidores das minhas audiencias, Alcaidęs, Alguazis ua minhą Çaza, Corte, e Chancelarias; e a todos os Corregedores, e Intendentes, Affiftente, Governadores, Alcaides-Maiores, e Ordinarios, e outros quaesquer Juizes, e Juftiças deftes meus Reinos, tanto de Realengo, como de Senhorio, Abadengo, e Ordens de qualquer eftado, condiçaó, qualidade, e preeminencia, que fejaó, tanto aos que agora faó, como aos que forem daqui em diante, e a cada hum, e qualquer de vós: Sabei que, tendo-me conformado com o parecer dos do meu Confelho Rea' nn Extraordinario, que fe celebra com o motivo do que tem rezultado das occurrencias paffadas, em Confulta de 23 de Janeiro proximo; e do que fobre elle, concordando no mefmo voto, me expuzeraó peffoas do mais elevado caracter, e acreditada experiencia: movido de graviffimas cauzas refpectivas á obrigaçan,, em que me acho conftitudo, de confervar na obediencia, tranquillidade, 


\section{(4)}

e jutiça os meus Povos, e outras urgentes, juftas, e da Suprema auctoridade economica, que o Todo Poderozo tẹm depozitado nas refpeito da minha Coroa dos mevis Vaffalos nho determinado mandar defnaturalizar de todos os meus Dominios de Hefpanlia, e Indias, Ilhas Filippinac, e mass adjacentes os Regulares da Companhia, tanto Sacerdotes, como Coadjutores, ou Leigos, que tiverem feito a primeira profiflaó, e os Noviços, que os quiferem acompanhar: eque fe apprehendaó todos os bens temporaes da Companhia nos meus Dominios: e para á fua uniforme execuçaó em todos elles tenho dado plena, e privativa commiffaó, e auctoridade por outro meu Real Decreto de 27 de Fevereiro as Conde de Aranda, Pręzidente do meu Confelho com faculdade de proceder $\operatorname{logo}$ a tomar as providencias neceffarias.

I. E tenho rezolvido da méfma forte mandar que o Confelho faça notoria em todos eftes Reinos a dita Minha Real Determinaçaô, manifètando ás outras Ordens Religiozas a confiança , fatisfaçaó, e apreço, que me merecem pela fua fidelidade, e doutrina, obfervancia da vida monaftica, exemplar ferviço da Igreja, acreditada inftrucçaó dos feus eftudos, e fufficiente numerỏ de Inarviduos para ajudarem os $\mathrm{Bifpos,} \mathrm{e} \mathrm{Pa}$ rocos no pafto efpiritual das almas, e pela fua feparaçaó dos negocios do Governo, como alheios, e apartados da vida afcetica, e monaftica.

II. Igialmente fe monaftica.

Prelados Diecezente fe fará entender aos Reverendos afticos, e mais Ef, Congregaçoens, Cabidos Ecclezido Reino, que a corpos Politicos os juftos, e or Minha Real Peffoa ficaó rezervados raó o meu Real anotivos, que a meu pezar obrigavalendo-me unicanimo a efta necelfaria providencia: ceder por outros mice do poder économico, fem pro- 


\section{(5)}

fo da minha Real benignidade, como Pay, e Protector dos meus Povos.

III. Declaro que na apprehenfaó dos bens temporaes da Companhia fe comprehendem os bens, e effeitos, tanto moveis, como de raiz, ou rendàs Leccleziafticas, que legitsmamente poffuem no Reino, fem prejuizo dos feus encargos, intençaó dos Fundadores, e alimentos vitalicios dos individuos della, que haố de fer cem pezios, durante a fua vida, para os Sacerdotes; e noventa para os Leigos, pagos da Maffa total, que fe formar dos bens daj Companhia.

IV. Neftes alimentos vitalicios naổ feraó comprehendidos os Jezuitas eftrangeiros, que indevidamente exiftem nos meus Dohninios, dentro dos feus Collegios, ou fóra delles, ou em cazas particulares; veftindo roupeta, ou des Abates, e em qualquer deftino, em que fe acharem empregados; porque todos devem fahir dos meus Reinos fem diftincçaó alguma.

V. Da mefma forte niฉ feraó comprehendidos nos alimentos os Noviços, que quizerem voluntariamente feguir aos outros, vifto nao eftarem ainda obrigados com a profiflaó, e fe acharem com liberdade de le fepararem.

VI. Declaro que, fe algum Jeźuta fahì fóra do Eftado Eccleziafticu (para onde todos fe remettem) ou der jufto motivo de refentimento á Corte com fuas obras, ou efcritos, ceffará logo para com elle a penfaó, quefe acha afinada. E ainda que naó devo prefumir que o Corpo da Companhia, faltando as mais eftreitas, e fuperiores obrigaçoens, intente, ou permitta que algum dos feus individuos efcreva contra o refpeito, e fubmiffấ devida á minha Rezoluçaó, com tituculo, ou pretexto de Apologias, ou Defenfas dirigidas a perturbar a paz dós meus Reinos;, ou por meio de Emiffarios fecretos confpire para o melmo fim; em tal cazo, que fe naó efpera, ceffará a penfaó a rodos elles. 


\section{(6)}

VII. De fejs em feis, mezes fe entregará metade da penfá́ annual aos Jezuitas pelo Banco do Giru, intervindo o meu Miniftro, que fe achą em Roma; o qual terá partíalar cuidado de faber os que falecem, ou por fua culpa defmerecém a penfá́, para aflim abater o importe della.

VIII. Sobre a adminiftraçaó, e applicaçaó equivalente dos bens da Companhia em obras pias, como fao Dotaçaó de Paroquias pobres, Seminarios Conciliares, Cazas de Mizericordia, e outros fins pios ; fendo ouvidos os Ordinarios Eccleziafticos no que for necellario, e conveniente; rezervo tomar foparadamente as providencias, fem "que em, nada fe detraude a verdadeira piedade, nem prejudique a cauza pública, ou dirreito de tercerro."

IX. Prohibo por'ley, e regra geral que fe naỏ - polfa nunca tornar a admittir em todos os meus Reinos em particular nenhum Individuo da-Companhia, nem em Coppo de Communitade com nenhumi pretexto, ou motivo que feja; nem fobre ifto admuttirá o meu Confelho, nem outro Tribunal inftancia alguma; antes previniráó as Juftiças as mais feveras providencias contra os infraçtores, auxiliadores, e cooperadores de fimithante intents; caftigando-os como perturbadores do focego publico.

$X$. Nenhum dos actuaes Jezuitas profeffos, ainda que fáia da Ordem com licenfa formal do Papa, e fique Secular, ou Clerigo, ou paffe a outra Ordem, poderá tuinar a eftes Reinos fem alcançar efpecial li-
cenfa Minha.

XI. No cazo 'de a alcançar, que fe concederá tomadas as informaçoens convenientes, , teverá fazer juramento de fidelidade nas maons do Prezidente do meut Confelho; promettendo de boal ie, qué naó ha de tratar nem em publico nem em particular com os Individuos da Companhia, ou co $m$ o feu Geral; nênt ha de fazer 


\section{$(7)$}

diligencias, paffos, nem infinuaçoens directa, nem indirectamente a favor da Companhia; pena de fer tractado como reo de.Eftado, e valerem conträ .elle as provas privilegiadas.

XII. Da mefma forte naó poderá enfinar, pmégâi, nem confeffar, neftes Reinos, ainda que tenha fahido da Urdem, como fica dito, e largado a obediencia do Geral; poderá com tudo gozar rendas Ecclezíafticas, que naố requerem eftes e.icargos.

XIII. Nenhum Vaffalo meu, ainda que feja Eccieziaftico", Secular, ou Regular, poderá pedir Carta de Irmandade ao Geral da Companhia, nem a outrem eni feu nome; fobpena ue ter tractado como reo de Eftado, e contra elle valérem igualmente as provas privilegiadas.

XIV. Todos aquelles, que as tiverem ao prezente, deveráó entregallaš ao Prezidente do meu Confelho, ou aos. Corregedores ; e Juftiças do Reino ; para que as remettaó, e guìrdem, e fe naó uze dahi por diante dellas, fem que laes̄ firva de embaraço o tellas alcanfado de preterito; com tanto que pontualmente cumpraó com a dita entrega ; e as Juftiças confervaráó em fegredo os nomes das peffoas, que as entregarem, para que defte modo lhes naó firva de nota.

$\mathrm{XV}$. Toda a peffua, que intertiver correfpondencia com os Jezuitas, por fer efta prohibida geral, e abfolutamente, ferá caftıgado á proporçaó da fua culpa.

XVI. Prohibo expreflamente que ninguem poffa efcrever, declamar, ou commover com presexto veltas providencias nem pro, nem contra ellas; antes nefta materia imponho filencio a todos os meus Vaffalos, e Mindo que aquelles, que contravierem, fejaó caftigados como reos de leza Mageftade.

XVII. Para evitar altercaçoens, ou más intelligencias entre os particulares, a quem naó toca julgar, nem interpretar as Ordens de Suberano ; Mando expreffa-

mente 


\section{(8)}

mente que nifguem éfcreva, imprima, nem divulgue $\mathrm{pa-}$ péis, ou obras Dominios; naó.tends para iflo ef as para fóra dos meus Dono: e prohibo óutrofim ao Juipecial $\mathrm{l}_{\mathrm{i}}$. cenfr do Governo: e fubdelegados, e a tod Juiz das $I_{\mathrm{m}}$ pientas, aos feús fubdelederem taes permif as Juftiças dos meus Reinos, con deve correr debains, oúl. cenfas; porque tudo ifto deve correr debaixo das $\mathrm{O}_{\mathrm{r}}$ dens do Prezidente, e Miniftros do meu Confelho, ouvido o meu Fifcal.

XVIII. Encarrego muito eftreitamente aos Reverendos Prelados Diocezaíos, e aos Superiores das Ordens Regulares, que nau permittaó que os feus Súb. ditos efcievaó, imprimaó, nem declamem fobre efta materı; porque ficariaó refponfaveis da "naố efperada infracçaô da parte de qualquer delles:-a qual declaro comprehendida na ley do Senhror Dom Joaó o I, e Real "Cedula expedida circularmente pelo meu Confetho em, 18 de Setembro đo anno paflado, para a fua mais_pontual execiscañ : para a qual devem confpirar todos pelo que intereffa a Órdem publica, e a reputaçaó dos mefmos Individuos, para naố provocarem contra fi os effeitos do meu Real defagrado.

XIX. Ordeno ao meu Confelho que, conformando-fe com r que fica expreffado, faça expedir, e publicar a Real Pragmatica mais eitreita, e conveniente, para que chegue á noticia de todos os meus Vaftalos, e fe obferve inviolavelmente, publique, e executem pelas Juftiças, e Tribunaes refpectivos de cada Territorio as pẹas, que vaó declaradas contra os que quepto, e invariavè difpoziçoens para o feu pontual, promdas as Ordens cumprimento; e para efte fim dará toquer negocio, neceflarias com preferencia a outro qualna intelligeneia de que intereffa o meu Real Serviço: Indias, Ordens, éF que aos Confelhos da Inquiziçaó, pias do Meu Real Decida tenho mandado remeter co. para a fua refpectiva intel- 


\section{(g)}

ligencia, e cumprimento. E para a fua pontual, e invariavel abfervancia em todos: os meus. Dominios; tendo-fe publicado no Confelho pleno nefte diâ o Real Decreto de 27 de Março, que contém a anter̂ior rezoluçaó, que fe mandou guardar, e cumprir fegúpdo, e como nella fe contém, foi affentado expedir a prezente com forfa de Ley, e Pragmatica Sançaó, como fe foffe feita, e promulgada em Corte; pois quero que fe efteja, e paffe por ella fem the contravir de modo algum; $\mathrm{p} \% \mathrm{i}$ o que, fendo necelfario, derogo, e annullo todas as coizas, que forem, ou poderem fer contrarias a efta. Pelo que encarrego aos mui Reverendos Arcebifpos, Bifpoc, Superiores de todas as Ordens Regulares, Mendicantes, Monacaes; Vizitadores, Provi-

-zores, Vigarios, e mais Prelados, e Juizes Ecclezianticos deftes meus Reinos, obfervem a fobredita Ley, e Pragmatica, como nella fe contém, fem permitir que , com algum pretexto fe contravenha de modo algum a quanto nella fe ordena : e Mando aos do meu Confetho, Prezidente . e Ouvidores, Alcaides da Mimha Caza, e Corte, e das Minhas Audiencias, e Chancelarias, Affiftente, Governadores, Alcaides Maiores, e Ordinarios, e mais Juizes, e Juftiças de todos os meus Dominios, guardem, cumpraô, e executem a fobredita Ley, e Pragmatica Sançaó, e a façaó guardar, e obfervar em tudo, e por tudo, dando para iffo as providencias, que fe requerem, fem que feja neceffaria outra alguma declaraçaó mais, do que efta, que ha de ter a fua pontual execucaó delde o dia, que fe rublizar em Madrid, e nas Cidades, Villas, e Lugares deftes meus Reinos na fórma coltumada; por affim convir ao Meu Real ferviço, focego, bem, e utilidade da cauza pu* blica dos meus Vaffalos. Que affim he a Minha vontade, e que ao traslado impreffo defta minha Carta affinado por Dom Ignacio Eftevaó de Higareda meu Efcrivaó da Camera o mais antigo, e do Governo do Meu 


$$
\text { ( } 10 \text { ) }
$$

Men Confelho, fe the dê a mefma fé, e credito, que so feu Original. Dada no Pardo aos 2 de Abril de I767 annos. = Eu EIRey. Eu Dom Jozé Ignacio de Goyeneche, Secretario d'EIRey holfo Senhor, a fiz efcrever por feu mandado. $=O$ Conde de $A r a n d a=D$. Francifo Sepeda. $=$ D. Jacinto de Tudó $\Rightarrow$ Dom Francifco de Salazar, e Aguero = Dom Jozé Manoel Domingues $=$. Regiftrada. Dom Nicolau Berdugo, Tenente do Chanceler mor $\underset{\mathbf{T}}{ }$ Dom Nicolau Berdugo.

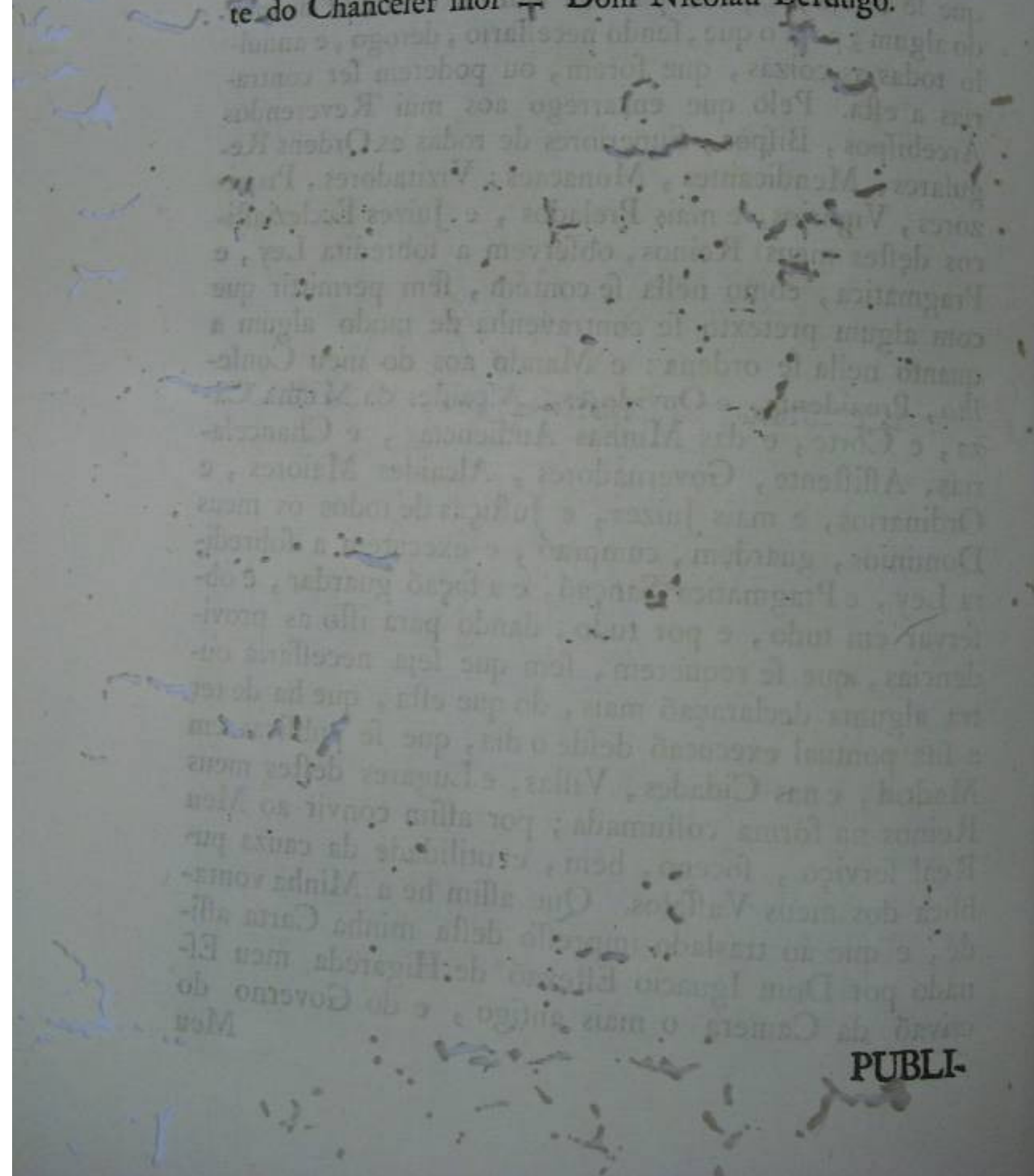




\section{(IL) \\ PUBLICAÇAÖ.}

T A Villa de Madrid aos 2 dias do mez de Abril de 1767 , diante das portas do Real Palacio, defronte da Janela principal d'elRey N. Senhor, e na porta de Gualdalajara, onde eftá o publico tracto, e commercio dos Mercadores, eOfficiaes ; eftando prezentes Dom Joaó Eftevaó de Sąlaverri, Dom Jeฉó Antonio de Penharedonda, Dom Bențo Antonio de Barreda, Dom Peáro Ximenes de Meza, Alcaides da Caza, e Corte de Sua Mageftade, fe publicou a Real Pragmatica San çaó antecedente com Trombetas, e Timbales, por voz do Porteiro publico, achando-fe prezentes differentes Alguazis da dita Real Caza, e Corte, e outras muitas Peffoas; de que certifico eu Dom Francifco Lopes Navamuel Efcrivaó da Camera d'elRey N. Senhor, dos que em feu Confelho rezidem. D. Francifco Lopes Navamuel.

He copia da Real Pragmatica Sançaó Original, e fua Publicaçaõ, de que certifico. 


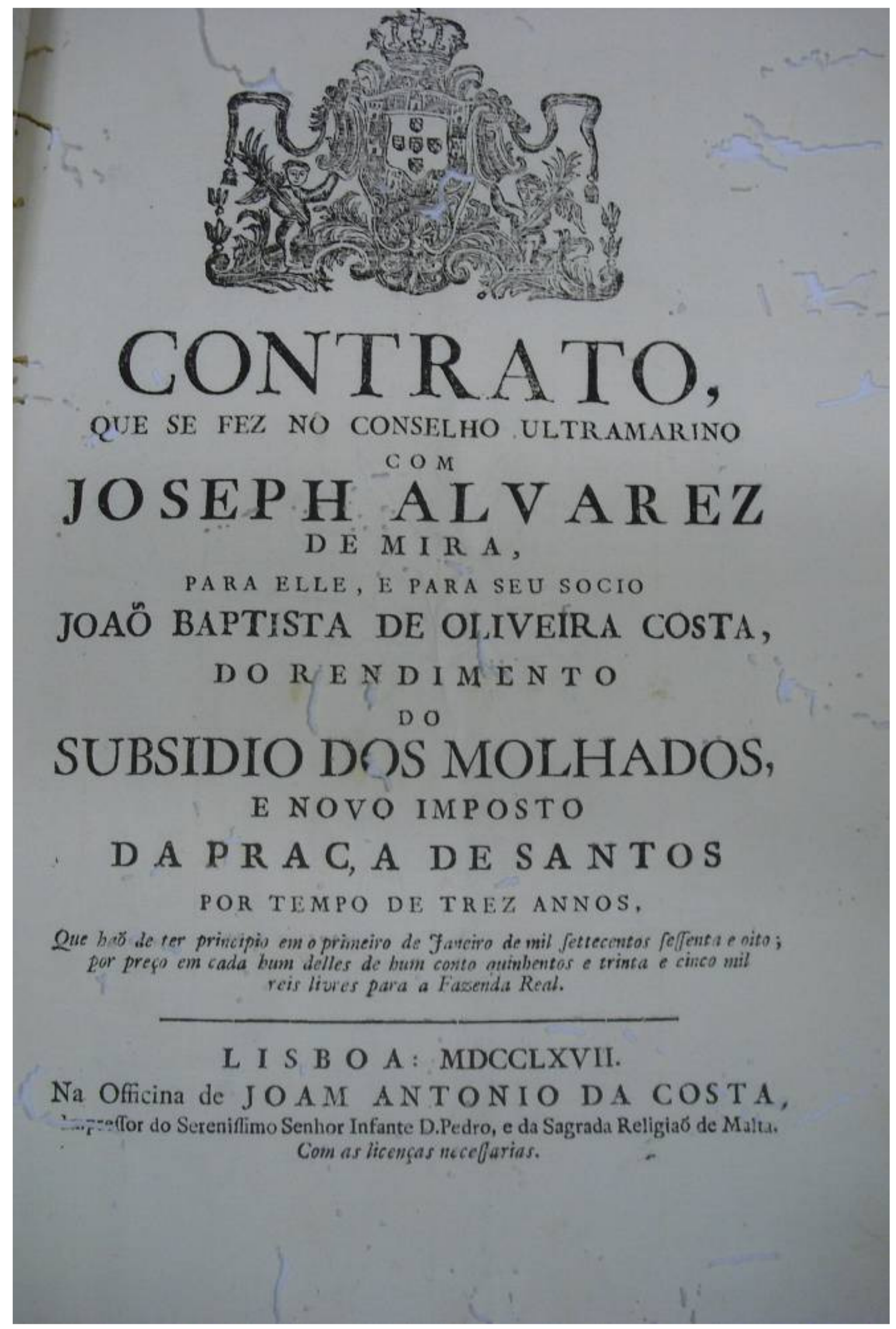




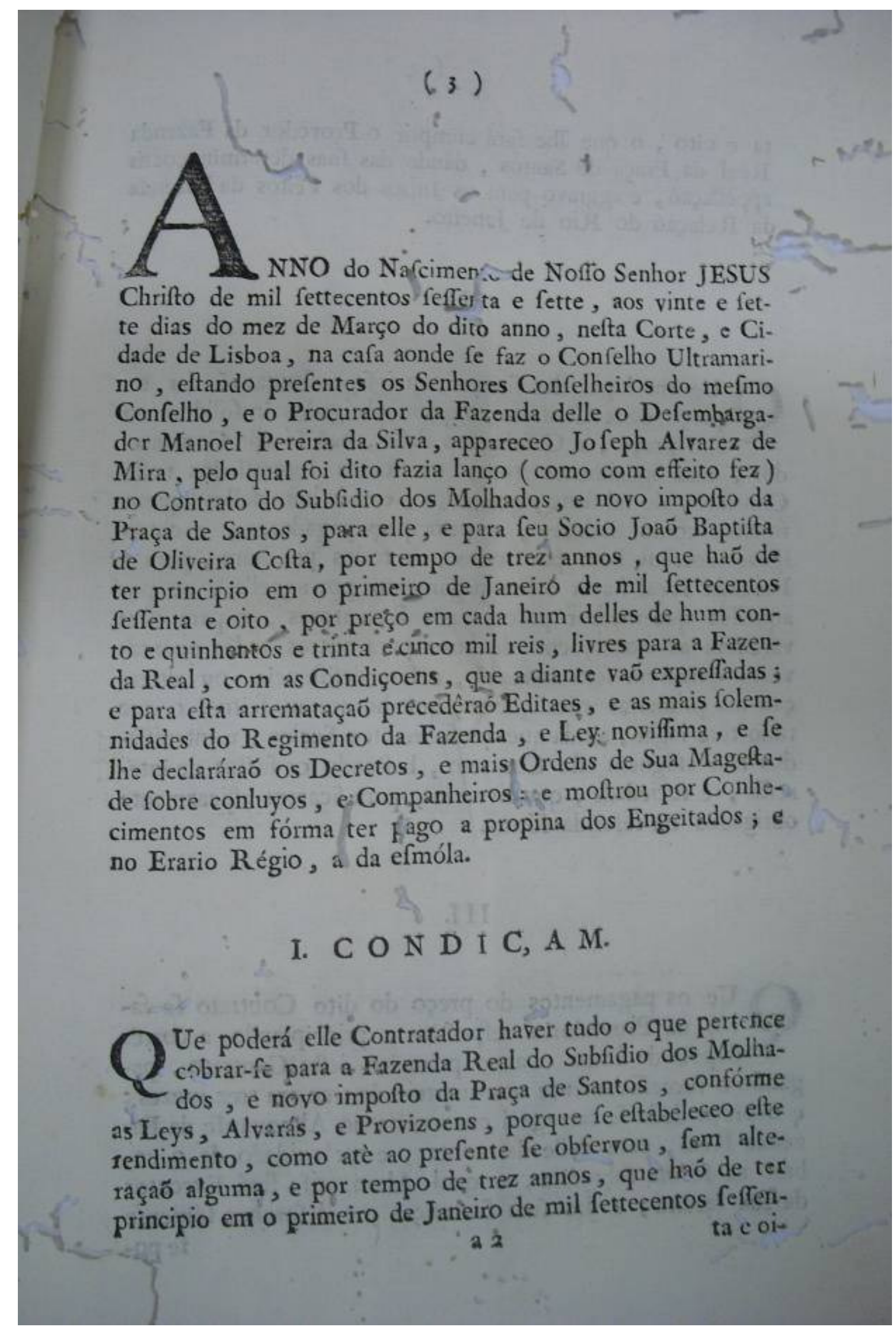




\section{(4)}

Citu ta e cito, o que The fará cumprir o Provedor d $t$ Fazenda Real da Praça de Santos, dando das fuas determinaçoens appellaçaó, e aggravo para os Juizes dos Feitos da Fazenda
da Relaçaó do Rio de Janeiro.
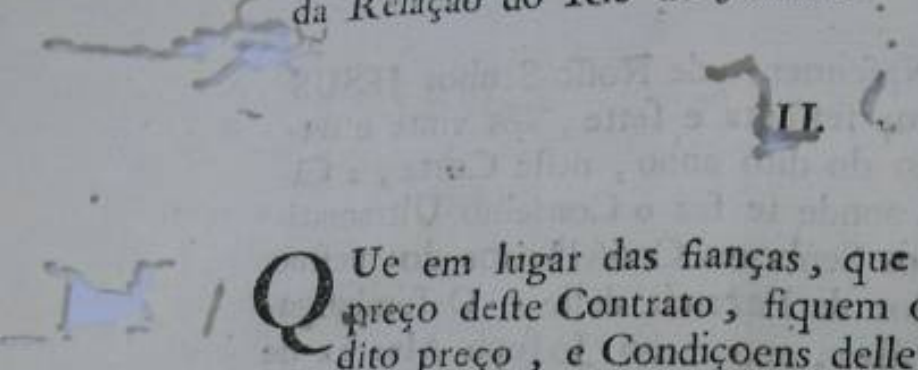

dor dito preço, e Condiçoens delle, naó fó elle ContrataContrato, igualmente todos os Socios intereffados nefte fujeitos como fiadores, e principaes padam delles fíquem iguaes corréos hum por todos, e comó Fazenda Real haver ò feu pagamento por hum, para a aquelles que melhor parecer aos Executores a variarem as execuçoens de huns pára vezes quizerem fem novaçaó., e fem defifros tedas quantas çaó das primeiras execuçoéns, qué houritencia, ou alteratudo terá lugar, ainda que os fobre houverem feito; o que dos naó affignem efte Cos fobreditos Socios, e intereffarefe, e fociedade, que tiverem, baftando os factos de inteobrigados na referida fórma.

\section{III.}

Q

Ue os pagamentos do preço do dito Contrato fe fadepois Provedoria refpectiva, principiando a correr gando-o fucceffivamente anno primeiro defte Contrato, pae o preço delle fe carregará quarteis de trez em trez mezes; zenda Real, para delle dax em receita ao Almoxarife da Fada fua forma fobredita, o qual , e ter cuidado de o corẹceita; o das fuas feúten Almoxarife ferá Executor

$$
\begin{array}{r}
. . \\
\therefore
\end{array}
$$


fe poderá appellar, e aggravar no effeito devolutivo, depois

de fegure o Juizo, para o Confelho Ultamarino.

\section{IV.}

Q

Ue feráó obrigados toùs os Meftres das Embarcaçoens, que entrarem naquelle Porto das Barras, e Fortalezas a dentro, e trouxerem qualquer genero de bebidas pertencentes a efte Contrato, ou venhaó em Pipas, Barriz, Frafqueiras, ou Botijas, a trazerem tudo no livro da fua carga com toda a clareza, e deftinçaó, o qual apron- taráó a elle Contratador, depois de o ter feito aos Officiaes da Fazenda Real, fobpena de pagarem anoveádo as bebidas, que diffimularem, e de fe tomarem por perdidas para o dito Contratador.

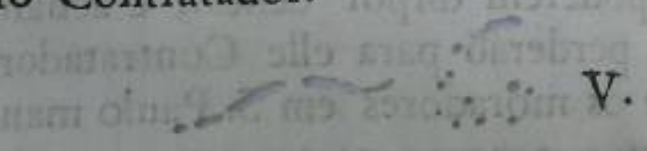

Ue naó poderáó os ditos Meftres tirarem generos alguns, que pertencerem aos direitos, fem primeiro dar parte a elle Contratador; e fazendo o contrario, the pagaráó todos os lireitps, que lhe tocarem.

\section{VI.}

Q Ue elle Contratador terá jurifdiçaó para ir, ou mandar, com Meirinho, e Efcrivaó da Fazenda Real, dar varejo em todas as cafas, e Embarcaçoens, de que tiver noticia, tem alguma Fazenda fobnegada, que lhe deva pagar direitos, fem para iffo the fer neceffario mandado algum; e achando-fe, fe tomará por perdida para elleContratador. 


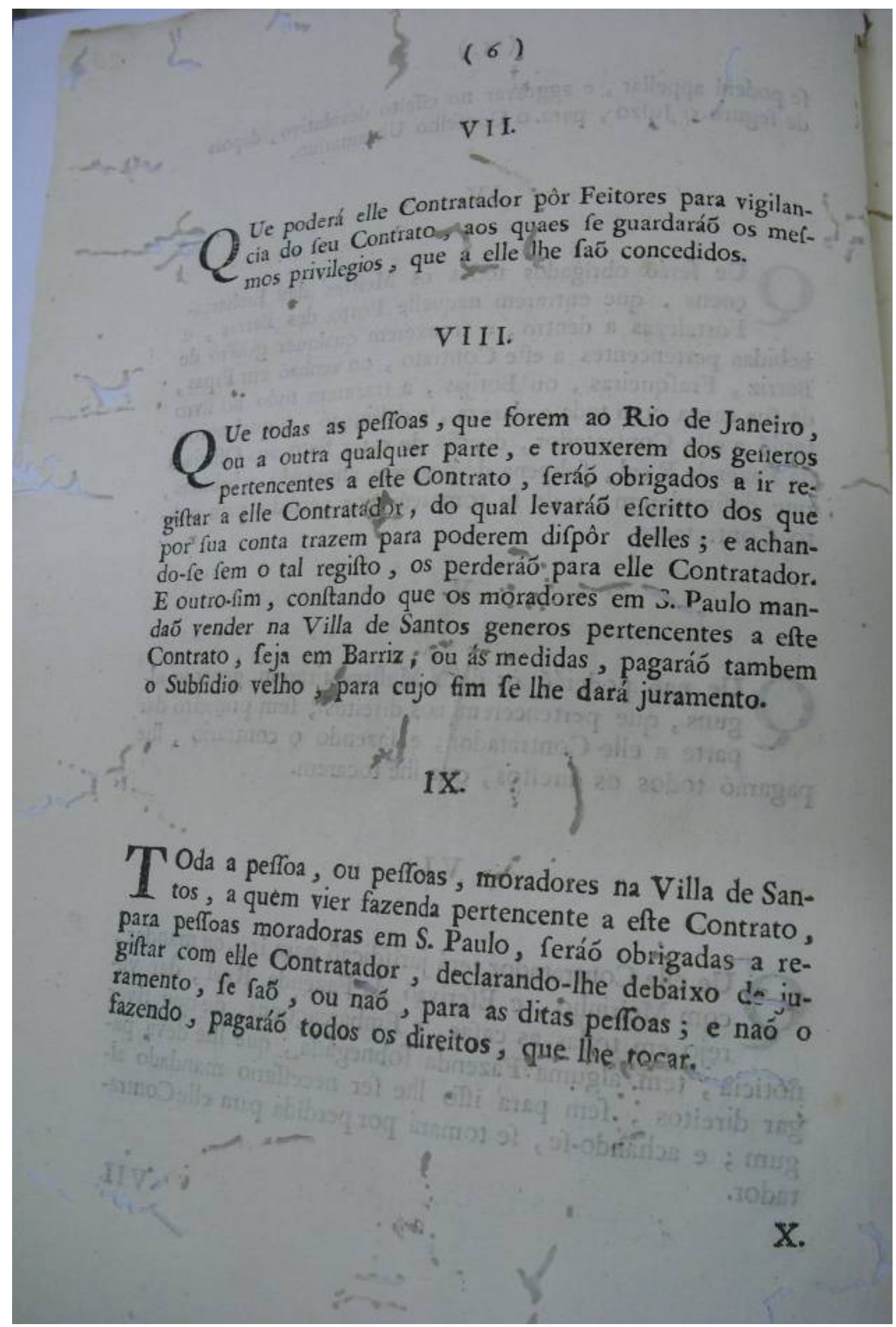




\section{( 7 )}

$\mathrm{x}$.

$\mathrm{Q}$

Ue elle Contratador naó poderá allegar perdas, nem uzar de incampaçoens algumas, ainda nos cafos, em que as admitte of Regimento da Fazenda, nem pedir quitas por cafos alguns furtuitos; porque todos renuncia, ordinarios, ou extraordinarios, folitos, ou infolitos, cogitados, ou ná́ cogitados ; e em todos, e cada hum delles ficará fempre obrigado, fem delles fe poder valer, nem os poder allegar em tempo algum para algum effeito, qualquer que elle feja.

\section{I.}

Ue elle Contratador gozará de todos os privilegios conce indos pelas, Ordenaçoens do Reyno aos Rendeiros das Rendas Reaes, nаб eftando derrogadas em parte, ou em todo ; e felhe dará pelos Governadores, e mais Miniftros de Juftiça, e Fazenda toda a ajuda, e favor licito, e jufto para a cobrança dos direitos, e dividas defte Contrato, durante o tempo dellia e o mais que the pclmitte a Ley, e Regimento da Fazenda.

\section{XII.}

Ue por conta delle Contratador feráó todas as defpezas feitas na arrecadaçaó delte Contrato, e fómente por conta da Fazenda Real os ordenados dos Officiaes nomeados por Sua Mageftade, que tiverem Cartas, Alvarás, ou Provizoens fuas. 
$\mathrm{X} I I I$.

Ue elle Contratador poderá uzar das Armas, que the furem neceffarias parafua defeza, fem prohibiçaó das Juftiças, para boa arrecadaçą do feu Contrato.

Fendo vifto pelos Senhores Confetheiros do ditó Con1 noel Pereira da Silya, Procurador-dabargador Mao contheûdo nefte Contrato o hoúvéraó por obrigáraó em Nome de Sua Mogeftade a por bem, e fe cumprimento, e os ditos Jofeph Alvarez the dar inteiro Baptifta de Olivel. Cofta,, que prefez de Mira, e Joaó raó, aceitavaó, e fe obrigavaó a cumprir eftavaó, diffedito Contrato, na fórma da fua a cumprir inteiramente o as condiçoens, e obrigaçoens nelle exprataçaó, com todas o cumprindo em parte, ou em todopreffadas; e que naó os feus bens, affim móreis, comó, pagariaó por todos por haver (os quaes para iffo obrigava raz, havidos, e e damno, que a Fazenda de Sua obrigavaó ) toda a perda, firmeza de tudo mandáraó elles Senhaftade receber. E por efte Contrato no livro delles, en da pelos Sentorta, de que fe the deú , e Joaó Baptifta drade Henriques Defembargadores Antona cupia anignaConfelheiros do e Fernando Jofeph da Silva, Official Confelho Ultramarino. Marqes Bacalháo, filva, Official mayor da Secretariarino. Jofeph Salgado ios.

a $\mathrm{fez}$ 


\section{(9)}

a fez em Lisboa a quatro de Abril de mil fettecentos feffenta e fette.

O Secretario Foaquim : Miguel Lopes de Lavre o fez efctever.

Antonio Freire de Andrade Fernando $\mathcal{F} 0$ feph Marques Henriques.

$$
\text { Bacalbáo. }
$$

Tirada do Liv. 3. de Contratos da Secretaria do Confelho Ultramarino, em que efte fe acha lançado a fol. 225. Lisboa; 8 . de Abril de 1767 .

Foaquim Miguel Lopes de Lavre. 


$$
\text { (10) }
$$

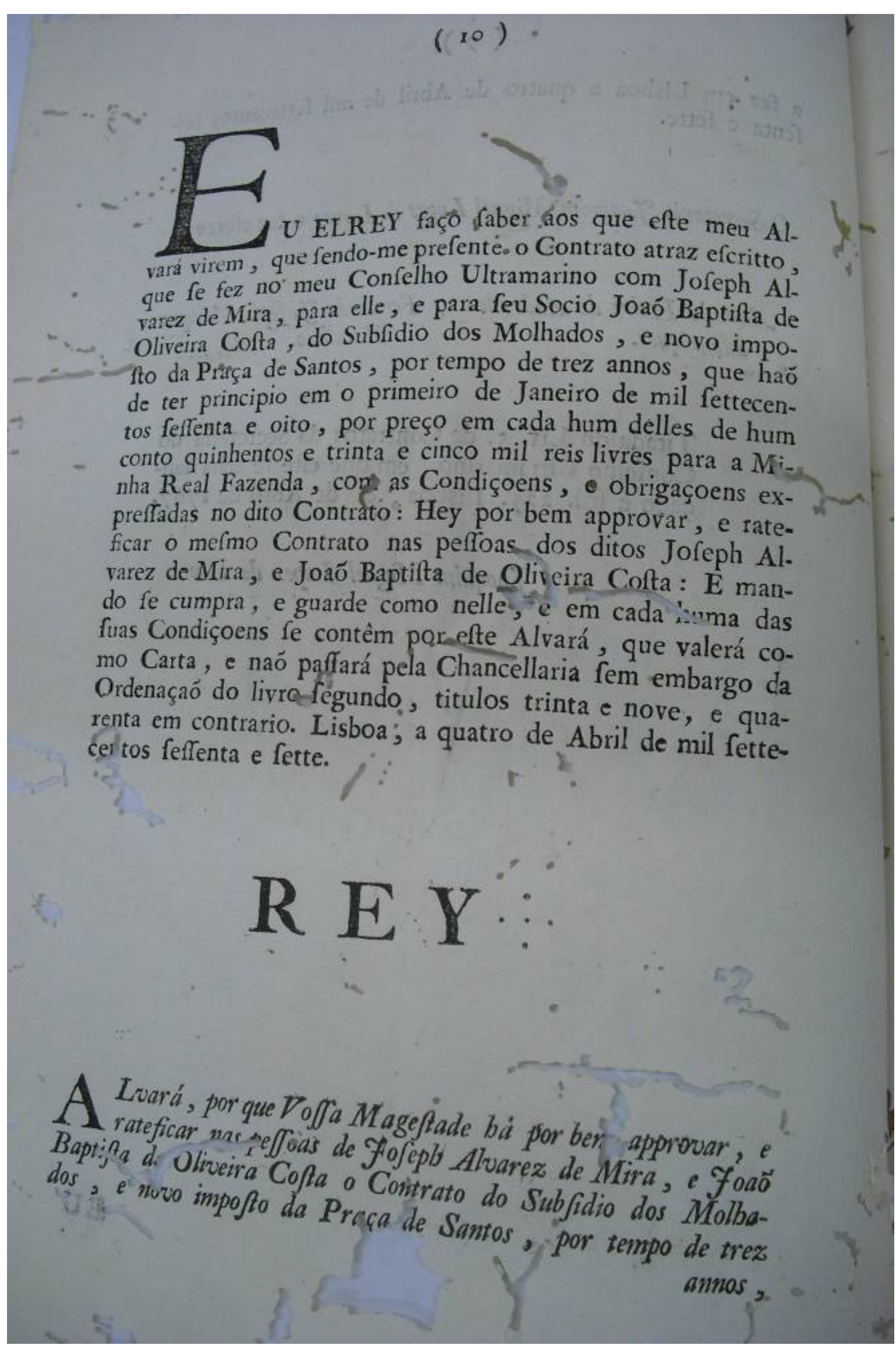




\section{(in )}

annos, e por preço em cada ban delles de bunn conto quisibentos e trinta e cinco mil reis livres para a Real Fazenda de Volfa Mageftade, como acima fe declara; o qual naó paffa pola Cboancellaria.

\section{Para Voffa Mageftade ver.}

Antonio Freire de Andrade Fernando $\mathcal{F}_{0}$ feph Marquez Henriques. Bacallíá.

O Secretario Foaquim Miguel Lopes de Lavre o fez efcrever.

Regiftado a fol. 229. do livro.3. de Contratos da Secretaria do Confelho Ultramarino. Lisboa, 8. de Abril de 1767 .

Foaquim Miguel Lopes de Lavre:

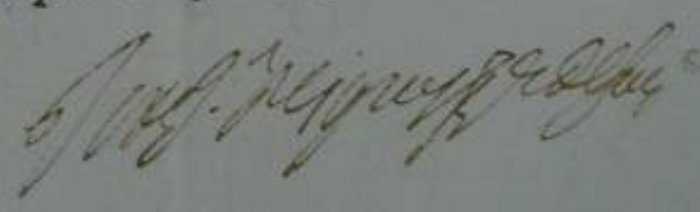

Fosepb Salgado da Silva o fez. 


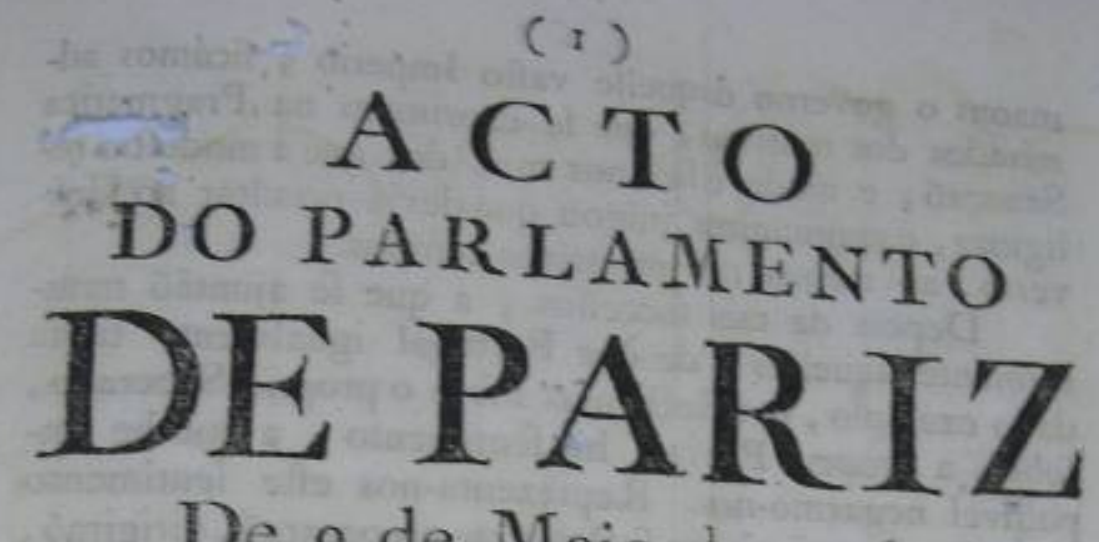

De 9 de Maio de 1767 .

Extrahido dos Regittros do Parlamento de fexta feire 8 de Maio.

Nefte dia, junto todo o Parlamento, entraraó os Miniftros,

Procuradores, e Fuizes da Coroa. O Miniftro Homero Foli de Fleury, Procurador da Coroa falou na forma Jéguinte.

\section{$S$ E N HORES.}

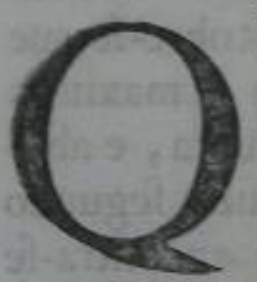

UE objectos dignos de reflexá́! Que importantes confideraçoens naó temos vifto na Relaçaó, que vós ordenaftes que fe nos communicafle ! Sá́ effitos de hum coraçaó, cujos affectos todos fe encaminhaó á paz , á tranquillidade do Eftado, e ca Igreja, que o Eftado recebeo no feu feio: quanto mis os profundamos, tanto mais ficamos convencidos de que foraó dirigidos unicamente por aquelle amor terno, refpeitozo, e obediente á Sagrada Pefloa do Soberano, que nefta Monarquia aníma as acçoens de todo o copo dos Magiftrados. Com a primeira noticia dos utimos fuccelfios refpectivos á Companhia dos Jezuitas de Hefpanha, e com que ao prezente foa toda a Erropa, ficámos admirados da profcripçaó, que fe proferio contra efta Companhia pelo Principe, que taó dignamente tem nas fuas

maons 


\section{$(=)$}

maons o governo daquelle vafto Imperio ; ficámos admirados dos motivos, que fe exp dos que a modeftica Sancçaó; $e$ ainda oficamos qulgou devia occultar ligioza, e magnanima julgou que tempos. verfo, ao menos ncs pucceffos, a que fe ajuntaó natuDepois de taes de que Portugal igualmente tinha ralmente aquelles, ectirmos fobre o proprio Soberano, dado exemplo, o retedt he fentimento, a que he imfobre a propria Patria Reprezenta-nos efte fentimento pollivel negarmo-nos. o quadro dos pr. França a extiç̧aó delta Companhia.

Por occaziaó do commercio o mais dilatado, que com o dezejo de amontoar riquezas immenfas, naó tinhaó os Membros defta Companhia deixado de continuar até 1760 , aos olhos do feu Geral, com vergonha da Religiaó, e com efcandab dos Infiéis, a pezar do que prefcrevem o Efpirito de Chriftianifmo, os Canones, os Decretos da Santa Sé, tinha a Companhia contrahido empenhos confiderareis. Para fe furtar á o. $\dot{o}_{1 i}$ gaçaó natıral, e jufta de tacisfacu, aprezenta ao Publico o feu Inftitut diante defte augufto Tribunal : abre a Juftiça aquelle ryfteriozo Codigo, examina-o : moftra com evidencia os icios de tal Inftituto: defcobre-fe que a Conftituiçaố detal Companhia he oppofta ás maximas da Igreja Gallicana: vê-fe a fua doutrina corrupta, e abominavel em muitc pontos, pofta em pratica fegundo as circumftancias, os lugares, e as pefloas: encontra-fe aquelle funefto Sytema auctorizado com tal doutrina para fe fuftentar portodos os meios os mais illicitos, e os mais deteftaveis : ıcha-fe efta Companhia defde o feu nafcimento em oppoziçaó, e em guerra com todas as Ordens do Reino, prturbando a boa ordem publica, enchendo a Igreja de divizoens, fuftentando no feu feio hum partido inimiro de toda a paz; cauzando em fim os feus principios ufto ao coraçaố dos Vaffalos a refpeito da fegurança do feu Rei.

vollo invioavel amor para com o Soberano, a vofla filial, e confante uniaó com a Igreja, e com a doutri- 


\section{$(3)$}

doutrina pertencente á Religiaó, e igualmente com 1 pureza da fua Moral, a volfa fidelidade aos verdadeiros interefles da Santa Sé, aos mais legitimos Direitos dos Bifpos, a vofla attençaô, continuada fempre pela tranquillidade pubhca, vos moverá́ a acabar em França com efta Companhia. Sem entrarmos no particular dos factos ulteriores, toda a França fabe que á bondade de Sua Mageftade, á qual vós julgaftes por obrigaçaó fujeitar-vos, he que os Membros, que compunhao efta Companhia, faó devedores da licença, que tiveraó de viverem como particulares, debaixo da auctoridade Efpiritual dos Ordinarios dos lugares, conformando-fe com as Leis do Reino, e bavendo-je em iudo como bons, e fiéis vaffallos.

Por maiores precatçoens, que a voffa fabedoria vos tenha lembrado entaó parı prevenires todos os inconvenientes, que a eftı graça fe podiaó feguir; com tudo he queftaó talve'z, que nos haveis de permittir depozitar no voffo peito, of fabermos: fe he poflivel tomar medidas, que fejaõ baftantemente feguras para os evitar todos? Efpalhados os Denominados Jezuitas por todas as Provincias do Reino; tolerartos diverfamente, conforme os uzos recebidos, ou a) modificaçoens admittidas em diverfos Territorios, defpidos do habito do feu Inftituto, fem terem querido dufpir-fe do feu efpirito, ficáraó confundidos de alguma forte com os $\mathrm{Sa}$ cerdotes Seculares de todas as Diocezes; preoccupaçoens difficultozas de vencer, ou enganos, de que algumas vezes naô he facil livrar, puderaó em muitas Diocezes fazer que elles tiveffem parte nas funçoens do fagrado Minifterio : que couza ha mais capaz de affuftar os $\mathrm{Ma}$ giftrados, os quaes guiados pelas fuas luzes, excitados pela fua fidelidade, penetráraó as occultas maquinas, que fazia mover a politica de hum Corpo, que em todos os tempos fe tem feito taó fornidavel ? A origem do $\mathrm{mal}$, que vós quizeftes deftruir, pôde por ventura diffipar-fe inteiramente, e por efta: occulta, feria menos perigoza? Naó vemos apparecerem já entre nós faifcas daquelle fogo, que a fabedoria do Soberano propoz, e propoem mais, do que nunca, extinguir de todo? 


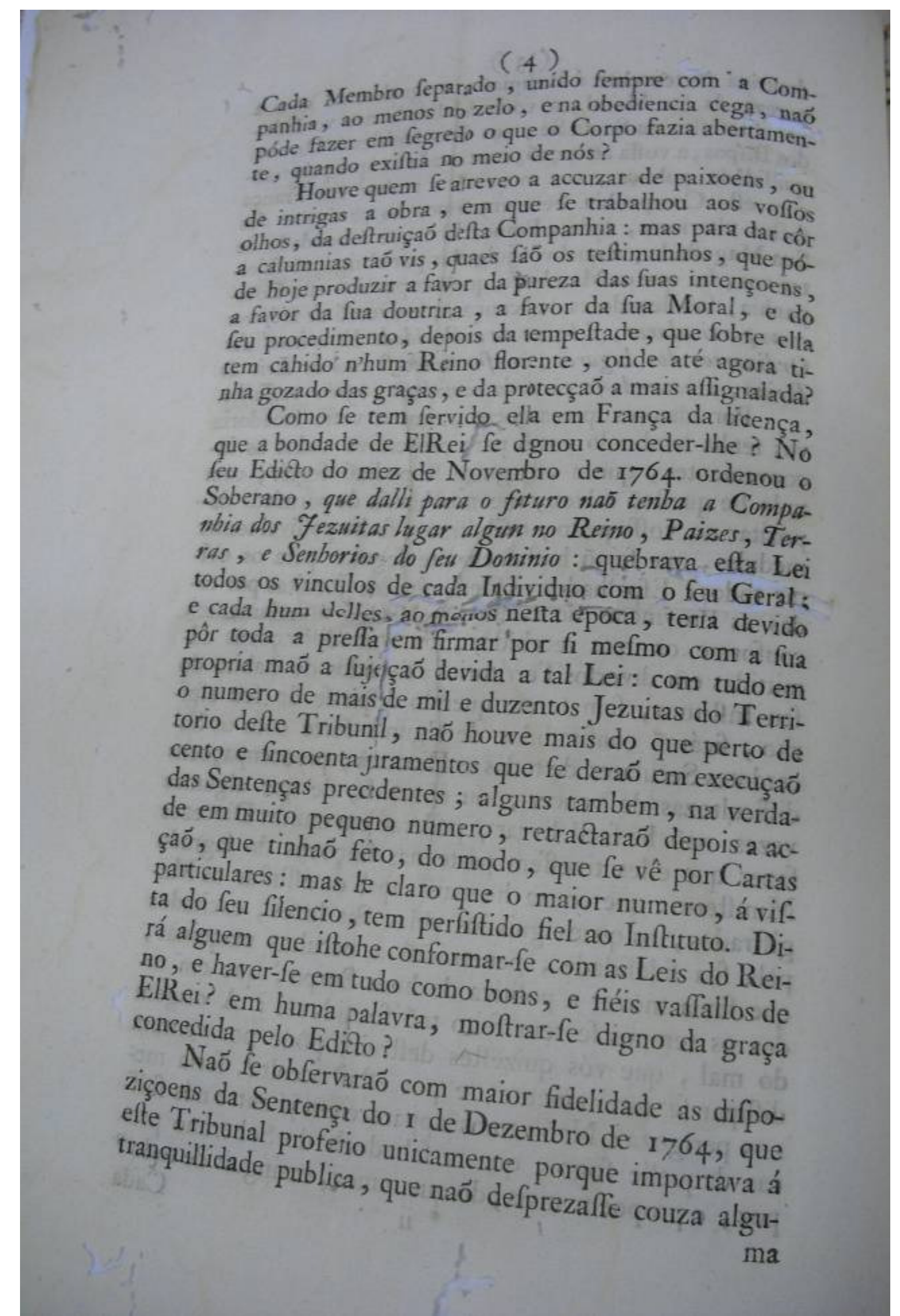




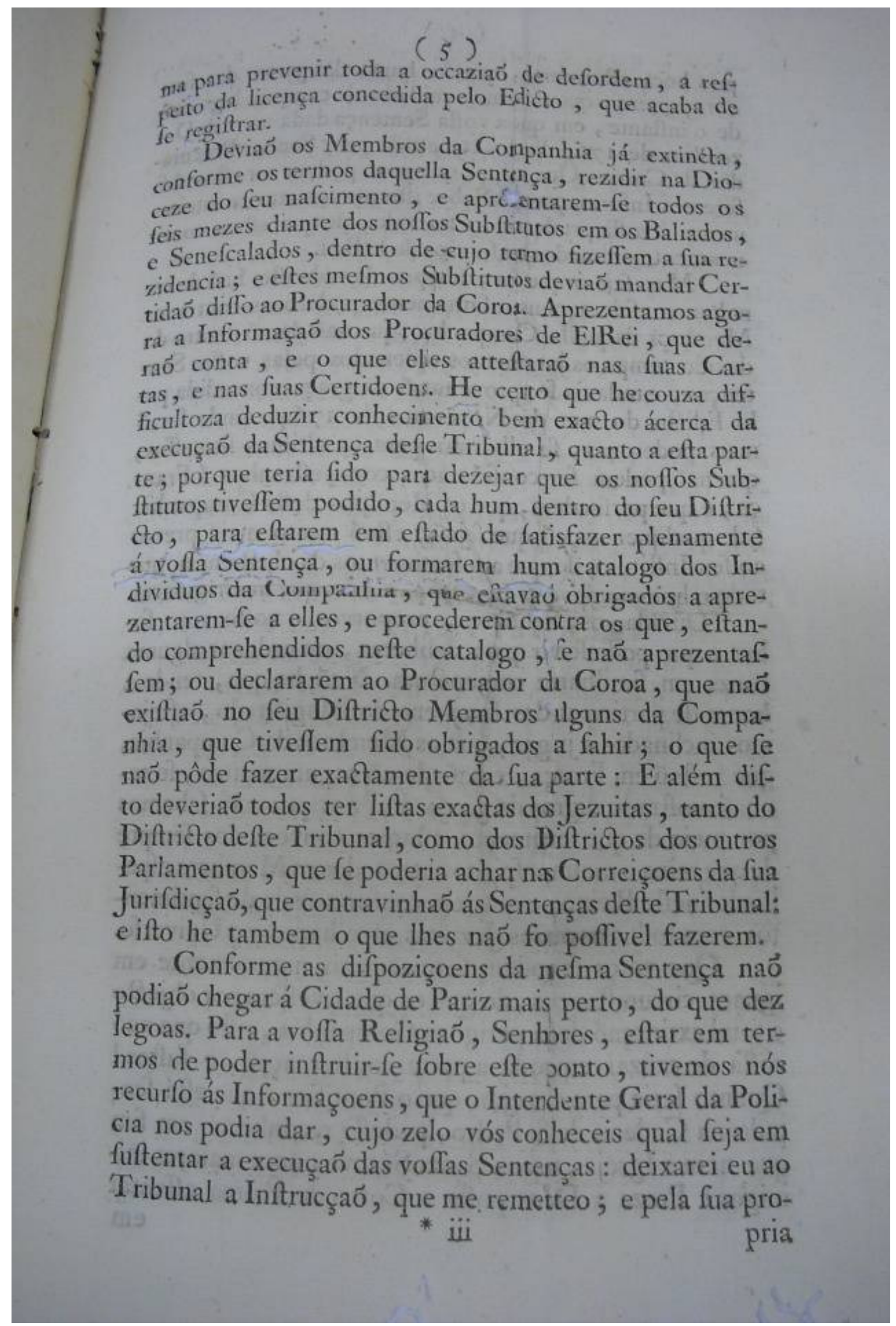




\section{(6)}

pria boca eftou certo, que he huma das partes das fuas obrigaçoens, que tevi mais cuidado de cumprir logo def de o inftante, em quc a vofla Sentença dada no 1 de Dezembro de 1764 thefoi remettida pelo Senhor Procurador da Coroa. Que valor, que pezo podem ter eftas differentes Informaçoen. Sobre ifto me remetto eu inteiramente á volla prudencia, e ao zelo, de que eftais continuamente animados no ferviço de ElRei.

Mas feja o que cor; fempre de tudo ifto haố de rezultar confideraçoens infinitamente poderozas contra os Membros daquella Companha, que naó deraó dentro do devido tempo os juramentos ordenados pelas voflas Sentenças, e todavia fe aproveitaraó da graça concedida pelo Édicto do mez de Novembro de 1764 : ainda feraö mais poderozas, fe olharmos para os ultimos fucceffos, que naó podem fer confideracos como eftranhos á Franç, e que perfuadem, que os Membros defta Companhia (de qualquer naçaó que fejaó) eftaó muito mais prezos ao feu Inftituto, do que aos fentimentos da obediencia, que todo o homem déve as Leis do paiź, èe que he originario.

Duvidamos, Sentiores, proporvos o noflo voto fobre a que pode fervir para deliberar, ou ordenar alguma couza em fimilharte conjunctura. Naô he que, tendo a honra de participar das funçoens do Magiftrado, eftejamos inclinados a jugar, que os Membros da Companhia, que reftaó em Frarça, e naó deraó os juramentos, fe tenhaố moftrado digmos da graça do Principe: naó fabemos por meio de que fertimento eftamos convencidos fempre de que reina o mefm efpirito entre todos os Membros efpatos com todeino : e que tem conformidade de fentimen-

Que yotos fe iguaes circumftanco formar mais naturalmente em a total extincçaô deta, do que os que tiveflem por objecto cella de cauzar em perigoza Companhia, vifto que naỏ Quanto feria para toda a parte confternaçaó, e fuftos ! tado na Cadeira dezejar que o Pontifice, que eftá fenque nem a Igreja de S. Pedro, pudefle reconhecer em fim migos! Praza nem a Santa Séteve nunca maiores inipoffa a Corte de Roma aflentar 


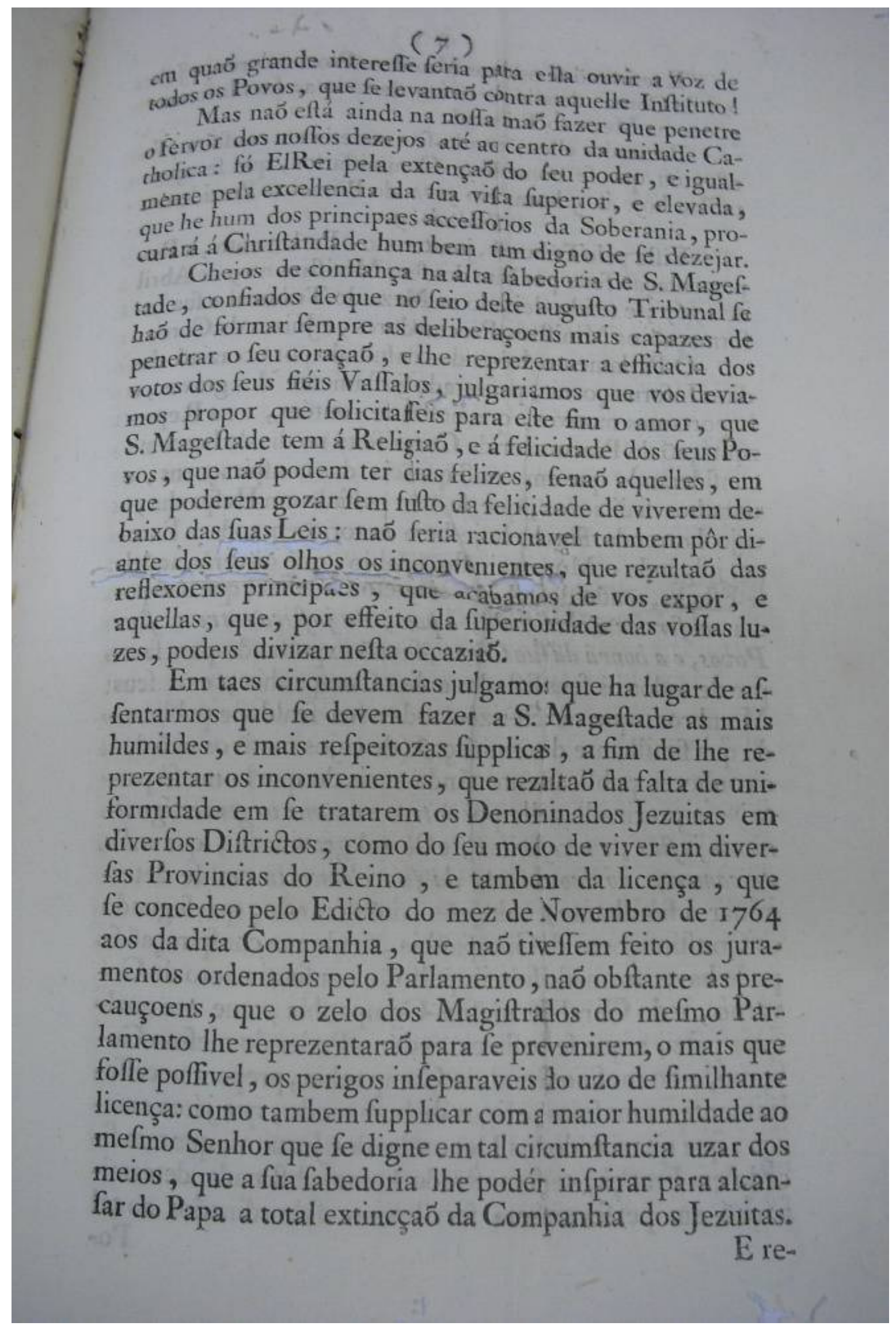




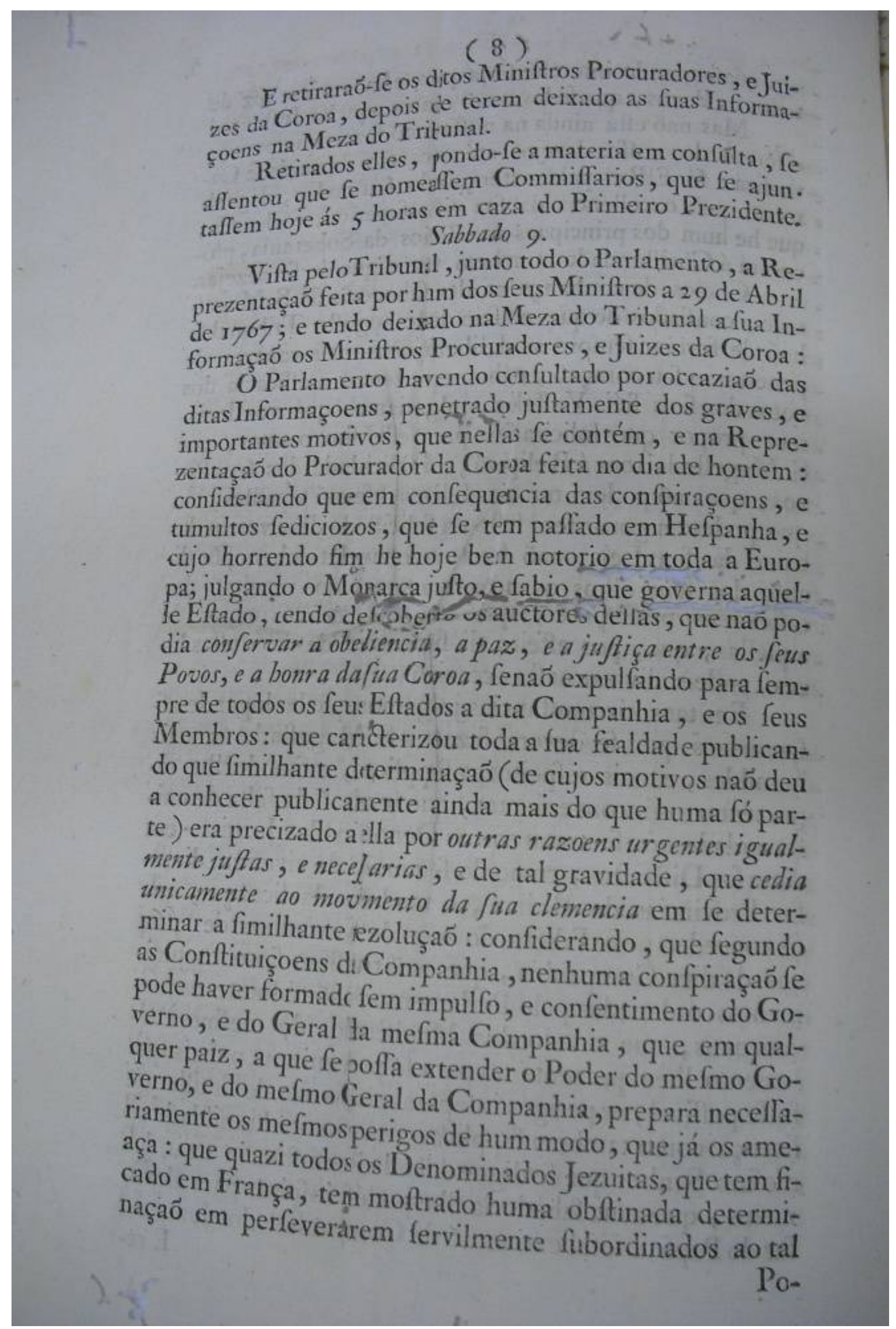


(9)

Poder: que a fua posfiada repulfa em darem hum juramento, que comprehendıa unicamente a expreffaó dos fontimentos, e daś de todas as que a tem todo o Vaffalo fiel, c a abjun moftrar que fomente paraflem contrarias, acabaó de mon do feu Geral abdi para fermanecerem na dependencia do fimilhante obedieaó ofeu Soberano, e a fua Patria: que fimilhante obediencia lem limites a hum Gogados de crimes de Eftado, faz em todo o paiz, qualquer que feja, incompativel a fua affiftencia com a fegurança publica; e difpoem todos os Membros da dita Companhia, para que a todo o inftante fejaó rebeldes a todo o Poder legitimo: que efte vicio, que he inherente ao feu Inftituto, e á fua Moral attentatoria da fegurança dos Soberanos, conftantemente fuftentada, e esfinada pela dita Companhia, fe maniféfta pelo molo o mais enorme defde certo numero de annos a efta parte nos attentados, que já cauzaraó a profcripçaó da melma Companhia em tres Reinos : confiderando em fim que, atiendida a unidade de Syftema, de Princioios, e do Procedimento, que hie da effencia da mefma Companha, sao pudem ier $n$, in fegurança as peffoas dos Reis, nem tranquillidade os Eltados, em quanto exiftirem alguns Membros da dita Companhia.

Tem declarado, e declara a dita Companhia, e todos os feus Membros publicos, e fecretos, pèr inimigos de todo - Poder, e de toda a Auctoridade legirina, da Pefloa dos Soberanos, da tranquillidade dos Eftados : em confequencia do que Ordena que todos os Denoninados Jezuitas fiquem privados do beneficio, que the for concedido pelo Edicto de Novembro de r764: Orden que todos, e cada hum daquelles, que eraó Membros dadita Companhia no dia 6 de Agolto de $176 \mathrm{I}$, fejaô obrigidos a fahir fóra do Reino dentro de 15 dias contados dapublicaçaó da prezente Sentença; a qual valerá por citaçaó feita a cada hum delles, fob pena de fe proceder contri elles extraordinariamente; exceptuando com tudo aquelles, que tiverem dado os juramentos ordenados pelas Sentenças dos Parlamentos, defde 6 de Agofto de 1762 , e 22 de Abril de 1764 , conforme as ditas Sentenças, em execuçaó dellas,

eden. 


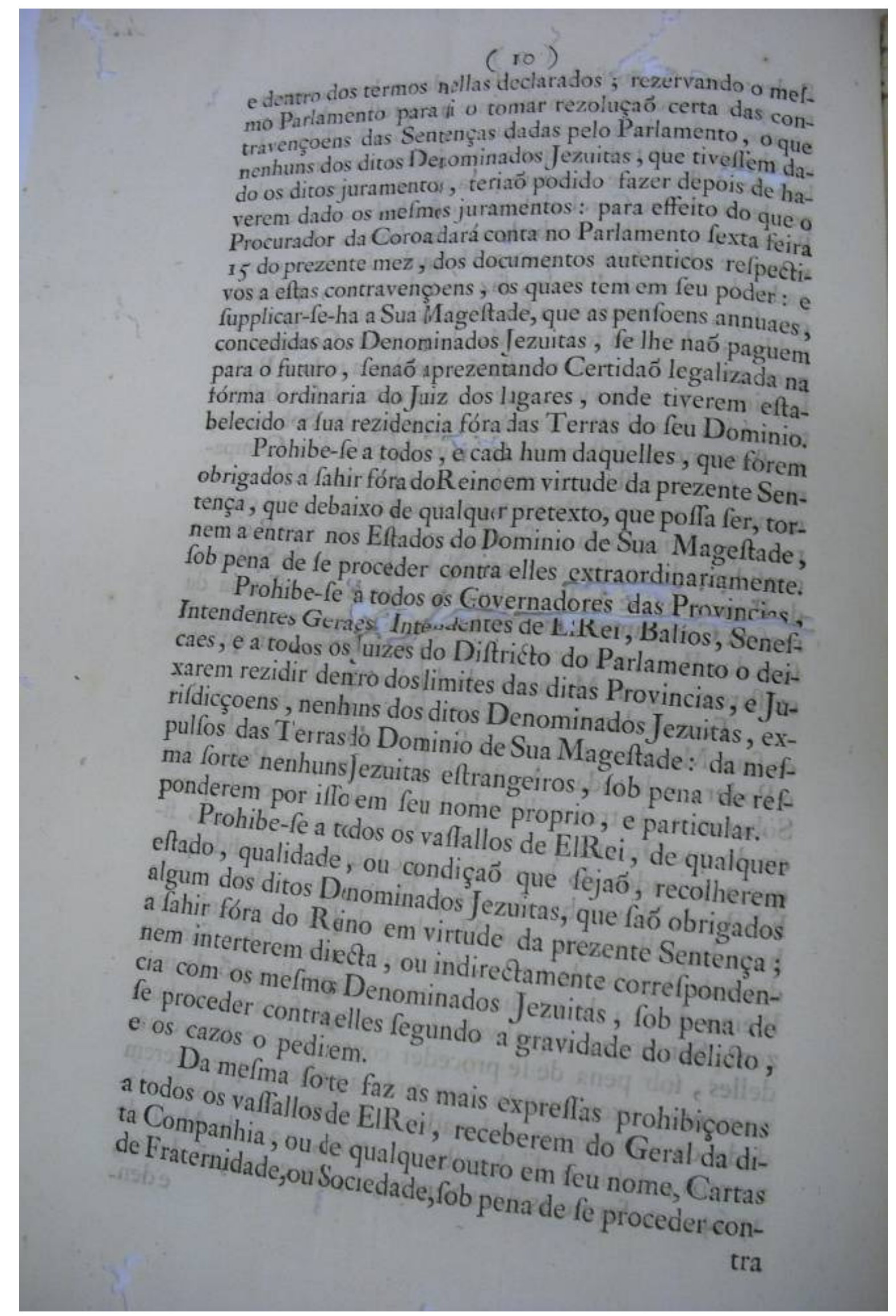




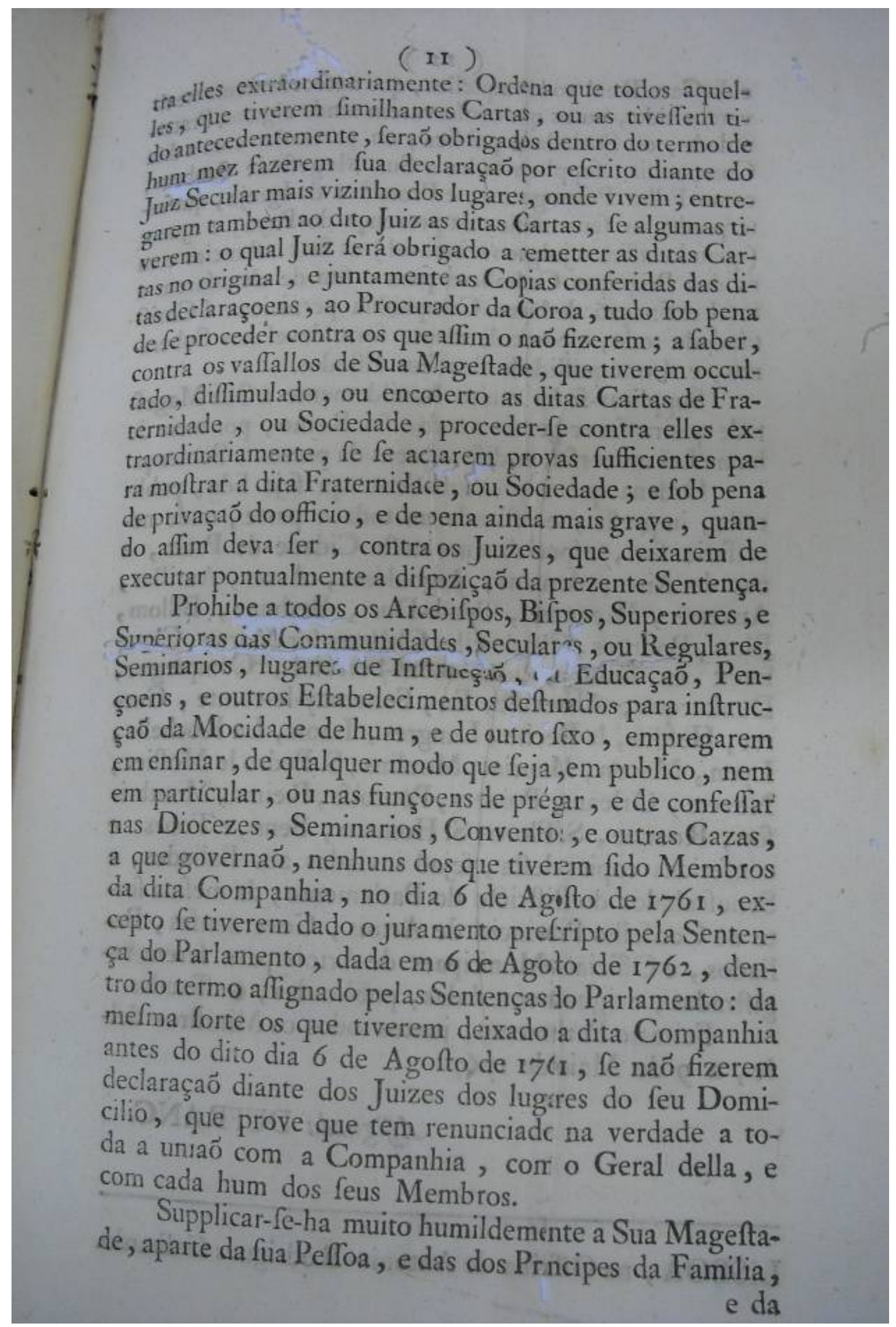




$$
\text { ( } \mathrm{I}_{2} \text { ) }
$$

e da Caza Real todos aquelles, que antecedentemente tiverem tido, ou os que confervarem ainda alguma Fraternidade, ou Sociedade publica, ou particular com a dita Companhia: fupplicir-fo-ha a Sua Mageftade tambem, como Futho Primogenito, e Protector da Igreja, que interponha os feus officios na prezença do Papa; e ajunte (quando affrmo julgie racionavel) as fuas inftancias com as dos Principes Caholicos para o fim de alcanfarem a total extincçá de huma Companhia pernicioza á Chriftandade toda, e partcularmente formidavel aos Soberanos, e á tranquillidade dos feus Eftados.

Supplicar-fe-ha muito lumildemente a Sua Magef tade queira fazer geraes a toco o feu Reino, por meio de huma Lei univerfal, as difpozçoens da prezente Sentença.

Ordena que a prezenti Sentença feja lida, publicada, imprefla, e affixada am toda a parte, onde neceflario for, efpecialmente nefta Cidade de Pariz, e nas de Aire, Amiens, Aıgouléme, Arras, Aurillac, Auxerre, Bapaume, Bar-e-Duc, Bethune, Billom, Blors, Bourges, Charleville. Châlons-fur-Marne, Chaumont en Baligh, Cicrmont-Fel,and, Compregne, Dunkerque, Abevilie, Eu, Fontenay-le-comte, Gueret, Hefdin, la fléche, Langres, Laon, La Rochelle, Lyon, Macon, Mauriac, Moulins, S. Pedro le Moftier, Nevers, Orleani, Poitiers, Pontoife, Reims, Montbrifon, Roanne, S Floro, S. Homero, Sens, e Tours : e conferidas copias defta, fejaó inviadas aos Baliados, e Senefcalados do Diftricto do Parlamento; da mefma forte ao Confelho Povincial de Artois, Governanfas, $\mathrm{Ba}$ giados, e Officiae: Municipaes de Artois para ferem reFeita no Parhmente lidas, publicadas, e affixadas. le, a 9 de Maic de 1767 .

\section{Afgrada DUFRANC.}

\section{LISBO , na Officina de Antonio Rodrigues Galhardo.}



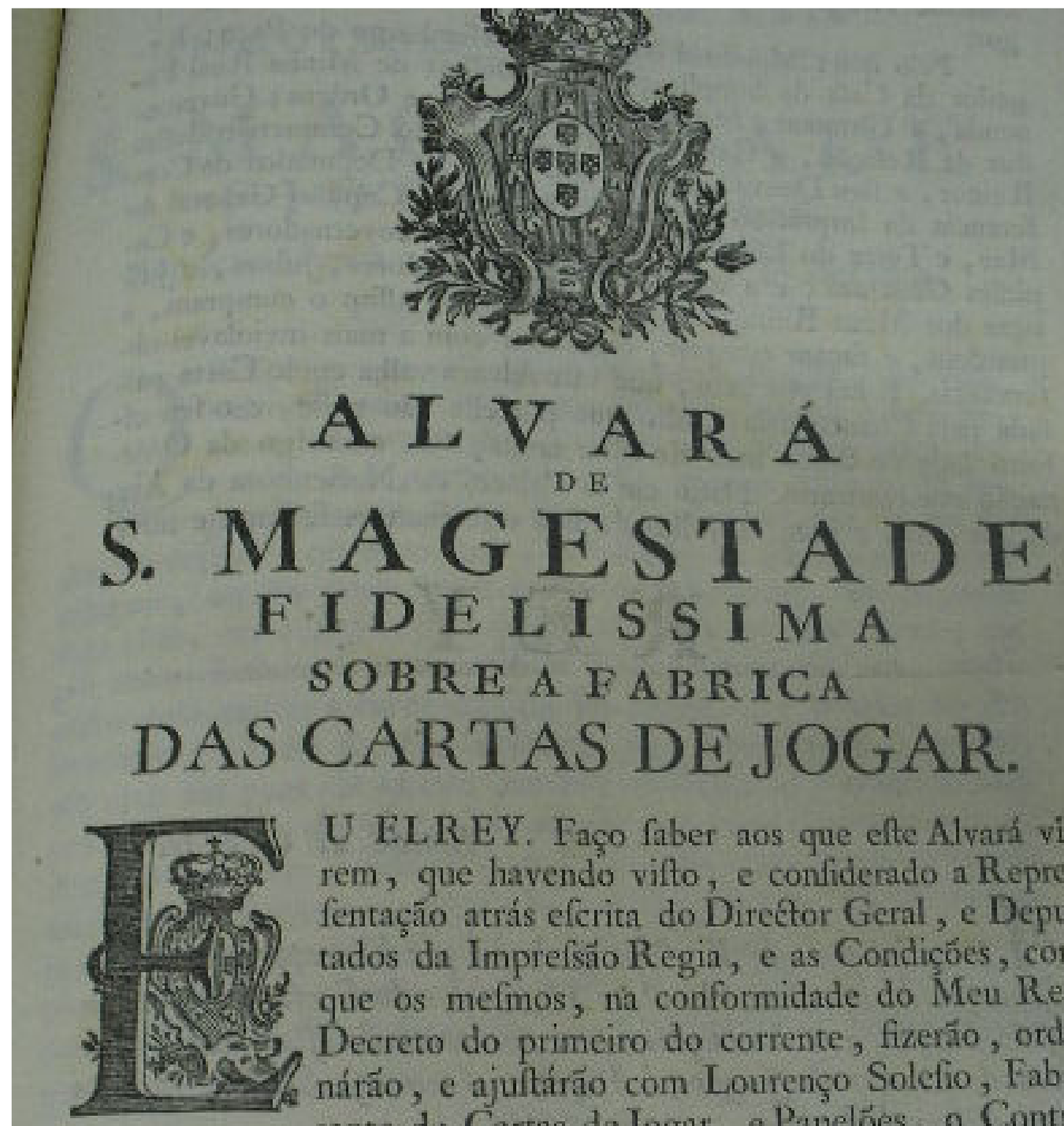

U ELREY. Faço faber aos que efte Alvará virem, que havendo vifto, e confiderado a Reprefentaçáo atrás eferita do Direétor Geral, e Deputados da Imprefsăo Regia, e as Condiçóes, com que os mefmos, na conformidade do Meu Real Decreto do primeiro do corrente, fizerío, ordenáráo, e ajuftárão com Lourenço Solefio, Fabricante de Cartas de Jogar, e Papelóes, o Contrato, com que devia entrar no Meu Real fervico, e eftabelecer as Fabricas das referidas duas Manufacturas: Hei por bem, e me praz de approvar a dita Reprefentaçáo, e de confirmar o referido Contrato conteúdo nas doze Condiçóes, que tudo baixa affinado pelo Conde de Oeyras, Meu Miniftro, e Secretario de Eltado dos Negocios do Reino, as quaes por efte Meu Alvará approvo, e confirmo, e quero fe cumpráo, e guardem, como neillas fe contém, näo obftante quaefquer Leis, Regimentos, Ordenaçóes, ou Provisóes em contrario, que para efte effeito fó- 


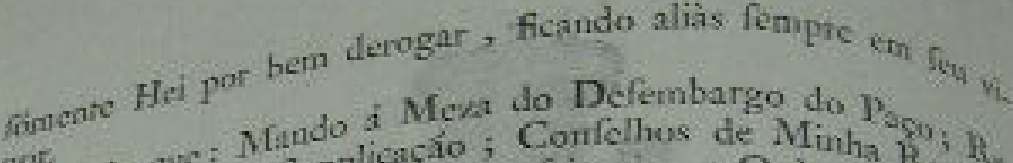

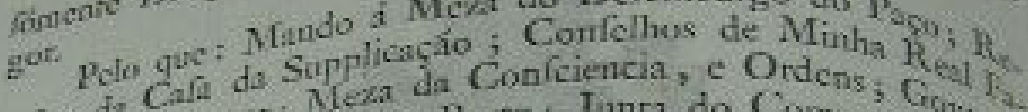

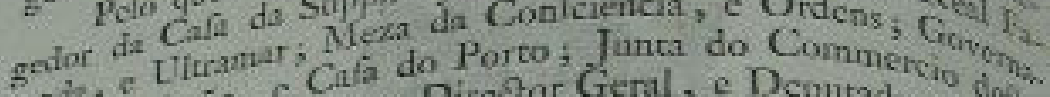

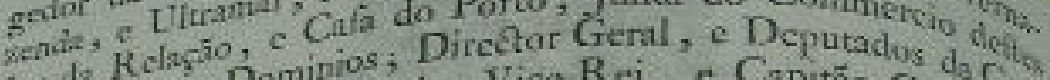
dor da efeus Dominios, Regia; Vica-Rei, e Capităo Ge da Cas? Reinos, ef enprefsio Regia Brazil, e mais Governadoreseral ferencis derra to Eftado dos os Defenbargadores, Juizes, e $\mathrm{C}_{\mathrm{A}}$ Mar, Generaes, e a todo Dominios, que affim o curn, is Jup. pities dos Meus Remos, o guardar com a mais inviolary, e tiças den, e figham cumpris que efte AJvará valha como Cavel of guariem, E hei por bem, que que por ella náo paffe, e orta pac fada pela Chancellaria, mais de hum anno, fem embargo da fef feito haja de durar Dado em o Palacio de N. Senhora drde naçio em contrario. Dullo de mil e ferecentos feffenta da $A_{j}$. do sos erinta e hum de Julho de mil e letecentos lelienta e nove.

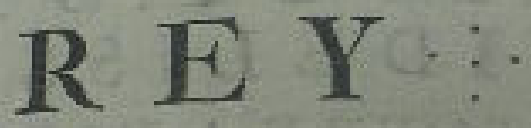

\section{Conde de Oeyras.}

1 Luara, por que V. Magefade ba por bem approvar a Re prefentacăo do Direlor Creral, e Deputados da Conferencia da Iniprofsão Regia, $e$ as Condiçäes, com que pertende efrabelecer as $F_{a}$ bricas de Cartas de Fogar, e Papeloes Lourenço Solefio, tudo na forma alfima declarada.

$$
\text { Para V. Mageftade ver. }
$$

Foapzim $\mathcal{F} 0 f \mathrm{f}$ Borralbo o fez.

Regiftado nefta Secretaria de Eftado dos Negocios do Reino no Livro da Imprefśán Regia a fol. 1 I. verf. N. Senhora da

\section{Goaquim Fofe Borralbo.}




\section{CONDICOOES}

APPROVADAS, E CONFIRMADAS

5. MAGESTADE F I D E L I S S I M A

Por feu Alvará affima, como nelle fe declara.

$$
\text { Condição Setima }
$$

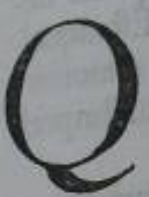

UE logo que principiar efta Adminiftraçáa (que ferá em o primeiro de Janeiro do anno de mil e fetecentos e fetenta) nenhuma peffoa poderá jogar, nem ter em fua cafa, nem fóra della, Cartas algumas de Jogar, que náo forem feitas, e vendidas por ordem da dita Direcçảo; e quem as fizer, ou trouxer de fóra, vender, ou comprar, ou der ajuda, e favor para fe fazerem, ou jogarem con ellas, ou venderem as que forem corridas por pouco, ou cados duas partes a favor da dita Direcçáo, e a terceira ao denunciante : e além da dita condemnaçáo, fendo peóes, incorreráo mais em pena de quatro annos para Angola; e fendo as taes peffoas de outra qualidade, incorreráó em pena de tres annos de degredo fincoenta leguas fóra da Corte. As ditas penas fe aggravaráo nas reincidencias, fendo Juiz o Confervador Geral da Junta do Commercio deftes Reinos, e feus Dominios, com appellaçáo, e aggravo na fórma coftumada, o qual ferá obrigado a ter devafta aberta defte defcaminho, e tomar todas as denunciaçóes, que fe the aprefentarem.

\section{Ortava}

Que nefta Cidade, e mais partes do Reino fe venderáo os baralhos das Cartas a cem reis cada hum; nas Ilhas pelo mefmo preço; e no Brazil, e mais Dominios do Ultramar a cento e fincoenta reis, para o que poderá a dita Adminiftraçáo mandar as que bem the parecer, fem pagarem direitos de fahida. *

$$
\text { NONA }
$$

Quie a mefma Direcçáo poderá mandar dar todos os vare-

- S. Magefade foi fervido declarar, que deixa ao arbitrio do Director geral, e Deputados da Imprejsắ Regia o diminuir os prefos, quando libes parefa jor cosvenicute. 


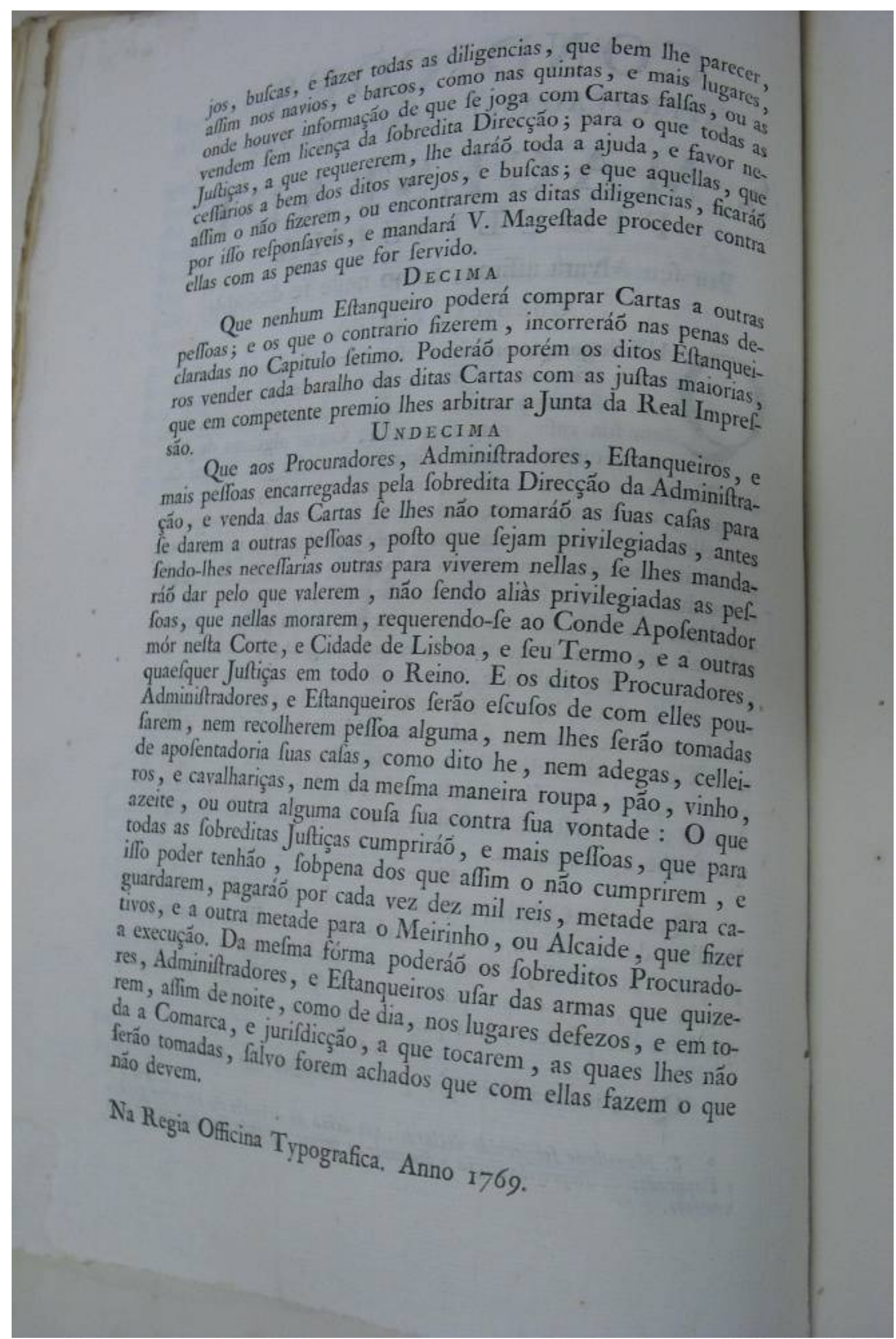




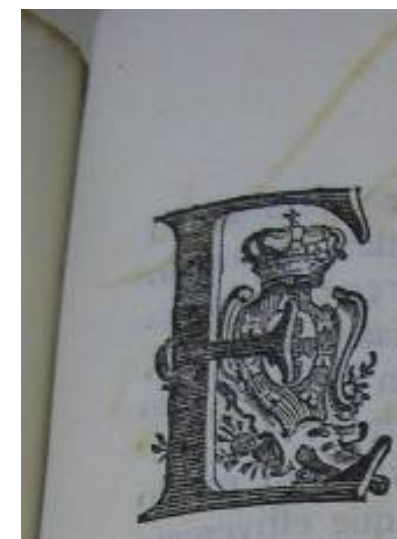

U ELREY. Faço faber ao Vice-Rei, e Capităo General de Mar, e Terra do Eftado do Brazil, a todos os Governadores, e Capitäes Generaes do mefmo Eftado, do do Pará, Reino de Angola, e Ilhas adjacentes a efte Reino, e a todos os mais Governadores dos mefmos Eftados, Miniftros de Juftiça, e Fazenda, e mais Officiaes da Adminiftraçáo della, Fidalgos, Cavalleiros, Gente de Armas, que nas ditas partes tenho, e a todos, e quaefquer Officiaes de qualquer qualidade, eftado, e condiçáo que fejam, que efte Meu Alvará perpetuo de Succefsảo virem, que Eu hei por bem, e mando que todas as vezes, que acontecer faltar qualquer dos fobreditos Vice-Reis, Governadores, e Capitáes Generaes das fobreditas Capitanías, ou Governadores dellas, ou feja por caufa de morte, ou de aufencia dilatada do deftricto das mefmas Capitanías, ou por outro qualquer acontecimento, que requeira de prompta providencia fobre a Succefsáo do mefmo Governo : Succedảo, e entrem nelle o Bifpo da Diocefi, e na fua falta o Deăo; o Chanceller da Relaçăo; e o Official de Guerra de maior Patente, ou que for mais antigo na igualdade dellas. Nas Capitanías, em que náo houver Bifpo, fubftituirá efte lugar o Ouvidor da Comarca, entrando o Vereador mais antigo; e affim, e da mefina forte deverá executar-fe naquellas Capitanías, em que náo houver Chanceller, entrando em feu lugar o Ouvidor. Na falta de alguns dos fobreditos nomeados fuccederá aquelle, ou aquelles, que os fubftituirem nos fobreditos cargos, em quanto Eu nẩo der outra efpecial providencia ; e todos os affima nomeados me ferviráó de commum acordo com o mefmo Poder, Jurifdicção, e Alçada, que compete aos Governadores, e Capităes Generaes das ditas Capitanías, e aos mais Governadores dellas. Notifico-vo-lo affim, e vos mando a todos em geral, e a cada hum em particular, que recebais por Meus Capitảes móres, e Governadores deflas partes aos fobreditos, quando fuccedáo os referidos cafos; e lhes cumprais feus mandados inteiramente, affim como a Meus 
Meus Capitáes móres fois obrigados a fazer, fem a ifto pordes dúvida, ou embargo algum. E elles ufaráó em tứto Governadores, e Capitáes Generaes das ditas Capido aos quando efta Succefsáo aconteça verificar-fe em qualcuer dais, ditas Capitanías, eftando aufentes os fobreditos : Hei outtrofim por bem, e mando, que fe thes leve logo recado com toda a diligencia a qualquer parte, em que eftiverem, por mais remota que feja, fem embargo de quaefquer Lès, Regimentos, ufos, e coftumes, que haja em contrario. E $\log$ o que os ditos receberem recado da fua Succefsão nos referidos Governos, poderáó exercitallos na fórma aflima declarada. Náo eftando porém prefentes mais que duas das ditas Peffoas, effas governaráo até vir a terceira : E nấo eftando prefente mais que huma, effa governará até chegarem as outras duas : E vindo huma das ditas Peffoas primeiro, governaráó ambas até vir a outra : E quando governem duas fómente, fe forem differentes em parecer, tomaráó por terceiro, nos cafos, em que fe náo conformarem, o Miniftro de letras de maior graduaçáo, que lhes ficar mais perto ; e na falta delle, o Provedor de Minha Real Fazer. da ; e na falta deftes, a Vereador da Camara mais antigo. Logo que chegar o Governador, e Capitáo General, que Eu for fervido nomear, năo poderáó mais ufar de Jurifdicçáo alguma as Peffoas, que até a fua chegada governarem, antes lhe entregaráó o Governo. E quero, e me praz, que efte Meu Alvará tenha perpetua força, e vigor, e que fe cumpra inteiramente, como fe foffe Carta principiada en Meu Nome, paffada por Minha Chancellaria, e fellada com o Sello pendente della, fem embargo da Ordenaçáo do Livro fegundo, Titulo quarenta, que diz, que as coufas, cujo effeito houverem de durar mais de hum anno, paffem por Cartas; e paffando por Alvarás, náo, nem fe guardem. Livalerá outrofim, fem embargo da Ordenaçáa do mén E defte vro, Titulo trinta e nove, que o contras os Governos dos Alvará fe remetteráó Exemplares a todos fórma referida fe mefmos Eftados, Reino, e Illas, para na forma rexe- 
cutemos Gara o que fe mandará regiftar nas Secretarias dos mais partes, onde pertencer. Dado no Palacio de Noras, e $n^{2}$, 3 da Ajuda a doze de Dezembro de mil fetecentosta Serenta.

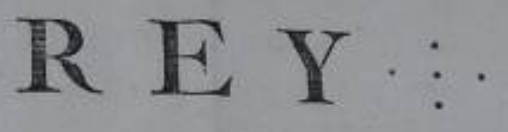

\section{Martinho de Mello e Caftro.}

Luará, por que Voffa Mageftade ba por bem declarar. A as Peffoas, que devem fucceder no cafo de falecerem, ou fe aufentarem alguns dos Governadores, e Capitäes Generaes, ol Governadores dos Eftados do Brazil, e Pará, do Reino de Angola, e Ilbas adjacentes a eftes Reinos, tudo na forma affina declarada.

Para Voffa Mageftade ver.

No Livro, que nefta Secretaria de Eftado dos Negocios da Marinha, e Dominios Ultramarinos ferve de regiftar as Leis, Alvarás, e Patentes, fica efte Alvará lançado. Palacio de Noffa Senhora da Ajuda aos 14 de Dezembro de 1770 ;

$$
\text { Fofé Gomes da Cofta. }
$$

Francifco de Laage o fez.

Na Regia Officina Typografica. 